
Digitized by the Internet Archive in 2007 with funding from Microsoft Corporation 





\title{
A TREATISE
}

\author{
ON
}

\section{INTERNATIONAL PUBLIC LAW}

BY

\section{HANNIS TAYLOR, LL. D.}

late Minister Plenipotentiaky of the United States to Spain; Adthor of "The Origin and Growth of the English Constitution;" a Member of the General Advisory Committee of the American Academy of Political and Social Science.

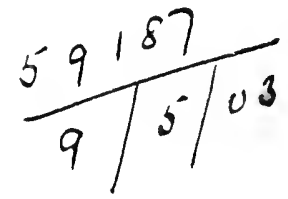

CHICAGO

CALLAGHAN \& COMPANY 
Copyright 1901

BY

HANNIS TAYLOR.

COMPOSITION BY BRoWN-COOPER TYPESETTING Co. CHICAGọ. 


\section{Tavaxd gafayctte $\mathfrak{g}$ gussdu,}

A LAWYER WHO HAS ADVANCED HIMSELF TO THE FRONT RANK OF HIS PROFESSION BY HIS INDUSTRY, LEARNING AND ELOQUENCE;

A MAN OF AFFaIRS Who has MADE HIMSELF A POWER IN THE STATE BY HIS INDOMITABLE WILL AND FORCEFUL PERSONALITY;

A GOOD COMRADE WHO HAS LED CAPTIVE MANY HEARTS BY HIS SYMPATHY AND UNSELFISH LOYALTY, 一THIS BOOK IS INSCLIBED BY HIS OLD FRIEND,

THE AUTHOR. 



\section{PREFACE.}

During the last fifty years international law, as a living and growing organism, has passed through a more marked and rapid development than in any other single epoch in its entire history. Within that time the awakened conscience of the world has drawn the states composing the family of nations into a closer concert, which has been active in its efforts to improve the existing system of international relations through a re-examination and re-statement of the rules by which they are regulated. On its scientific side, this movement has been promoted by a new school of publicists, representing nearly every nationality, whose tireless investigations into every branch of the subject have assumed the systematic form of corporate thought under the guiding hand of the Institute of International Law. On its practical side, this movement has been applying the fruits of that kind of research and reflection to the solution of the vital questions presented in rapid succession to the series of international congresses and conferences which began at Paris in 1856 and ended at The Hague in 1899. When the records of the proceedings of those notable assemblies are read as a connected whole, it is impossible not to hear the outcry for a higher and more stable international life to be based upon some kind of a code more precise and definite than that embodied in existing rules, and for some kind of an international tribunal with a jurisdiction more comprehensive than that usually rested in roluntary courts of arbitration. Whether or no such an ideal is attainable, is purely a tentative question to be solved only by patient and persistent efforts made in the light of actual experience. The hope of even partial success rests not upon the Utopian dream that the passions and self-interest of mankind will grow less acute, but upon the fact that as nations become more perfectly organized they perceive that stability, comfort and economy may be promoted by a transition from the reign of arms to the reign of law.

The re-examination to which the entire system of international law has been thus subjected has been conducted, to a large extent, according to that method of investigating the origin and growth of all law, public and private, which, 
beginning with its germs in prinitive society, attempts to explain its nature and meaning through the record of its development. Only through the application of that method to the entire data to be examined is it possible fully to grasp the nature of the existing angreagation of states viewed as "the result of their historical antecedents,"-antecedents represented by the three great state-systems whose prior histories extend over the immense interval that divides the berimning of anthentic tradition from the beginning of modern times. In order dearly to comprehend all the elements that have entered into the existing state-system, through the interpenetration of principles and ideas thus brought about, it is necessary to make a cursory examination at least of its three predecessors-Greek, Roman and Medieval-whose individual listories constitute only distinct stages in one unbroken and progressive development. ${ }^{1}$

Comparatively recent researches into the history of ancient international law have revealed the fact that very perfect mothods of diplomatic intercourse existed between the independent Greek city-states, acting either under their own constitutions, or through the federal bodies to which the right to such intercourse was surrendered. While it is not possible to prove that there was such a thing as a Greek common law of nations, as that term is now understood, there certainly was an international positive law, composed partly of treaties and partly of conventional usages sanctioned by general acceptance. The dominant idea was that positive international right must rest upon express compact, and under the influence of that idea treaty-making was carried to such perfection that there were eight or ten technical terms in Greek diplomacy to express the different kinds of treatics into which states might enter. To prevent the greater city-states from acquiring abnormal importance by reducing others to a condition of dependence, the weaker and less ormanized communities began at a very early day to gither in confederations. In the effort thus made to preserve the internal equilibrium of Greece a well matured

1 Die Wahrheit, dass das gegenwärtige Recht ein gewordenes und daher wesentlich aus der Vergangenheit $\mathrm{zu}$ erklären ist, bedarf der Ergänzung durch die andere Wahrheit, dass das gegenwärtige Recht zugleich ein verdendes und berufen ist, das fortschreitende Leben der Menschheit zu begleiten.-From the letter of Dr. Bluntschli to Dr. Francis Lieber, written at Heidelberg, September, 1867, and published as a preface to Das Moderne Völkerrecht der Civilisirten Staten. 
treaty system for the maintenance of the balance of power came into full operation. While the aristocratic and agricultural states like Sparta 'were averse to the admission of strangers on any terms, the commercial ones like Athens permitted domiciled aliens to enjoy their laws through a patron, subject to a stranger's tax, and to military service by land and sea. In some of the Greek states individual aliens, or even whole communities, were voted such important civic rights as exempted them from taxation, and enabled them to hold real estate and to intermarry. The most notable feature, however, of this liberal policy was that part embodied in international conventions providing for the mutual administration of justice to resident foreigners, for the establishment of mixed tribunals, or even for the grant of isopolity. While the conception of neutrality as between state and state was very imperfectly developed the $\pi \rho \operatorname{sog}^{g} \varepsilon v \sigma$, -a kind of vice consul whose person and property were sacredly protected in time of war, represented the idea of a neutralized individual as perfectly as any of the medical or clerical staff now guarded during hostilities by the Red Cross conventions.

So long as Rome continued to be simply a state among states there was a normal development of that branch of law pertaining exclusively to the relations of the government of Rome with those of other states. That branch known as the jus fetiale, the law of heralds as agents of negotiation and diplomacy, was the only branch of Roman law that corresponds to the modern conception of a law of nations. The most important function of the collegium fetialium, which regulated the practice and procedure connected with all international questions, related to the forms incident to a declaration of war,-until a formal demand for reparation and a declaration were first made, Cicero tells us that no just war could begin. With that formal and unfruitful branch of Roman jurisprudence the international law of to-day has no definite connection, the most important ceremony embodied in it having become obsolete. In the process through which Rome was transformed from a state among states into a world-power, disdaining relations on terms of equality with other powers, her system of diplomacy first shriveled and then disappeared. Rome's priceless legacy to modern international law is represented by the jus gentium which, as employed by her, was not international law at all. Accord- 
ing to ancient legal ideas the law of one city had no application to the citizens of another'; the jus civile was the embodiment of the immemorial rules and usages which were the special property of homan citizens as such. It was a special law administered by the practor urbanus between Roman and Roman,-it hatd no application between a Roman and a forrigner. As a large colony of resident foreigners finally rathered at Rome, it became necessary to remedy that condition of things through the creation of al practor peregrinus, the prater of foreigners, whose duty it was to administer justice between Roman eitizens and foreigners, between foreigner and foreigner, and between citizens of different cities within the Emprie. As such prator could not rely upon the law of any one city for the criteria of his judgments, he maturally turned his eyes to the codes of all the cities from which came the swarm of litigants before him. In the generalizations necessarily made upon such broad data we have the beginnings of comparative jurisprudence, whose first fruit at Rome was the ascertainment of the fact that there are certain universal and uniform conceptions of justice common to all civilized peoples. Before this new zrowth, watered by the learning of the jurisconsults, reached its maturity the intellectual life of Rome passed nnder the dominion of her subjects in Attica and Peloponnesus, just after they had rielded to the ascendency of the Stoic philosophers who were ever striving to discover in the operations of nature, physical, moral and intellectual, some uniform and universal force pervading all things which conld be designated as the law of nature-the embodiment of unicersal reasonidentical with Zeus, the supreme administrator of the universe. Through the mind of the Roman lawyer that splendid conception entered into the jus gentium as an expanding and enriching force which finally lifted it into a higher sphere. Thus a broad principle of Greek philosophy became so blended with a particular branch of Roman commercial law that the Antonine jurisconsults finally assumed the position that the jus gentium and the jus naturae were identical. Such, in short, was the origin and nature of that branch of Roman private law, whose distinctive feature was its limita. tion to the legal relations of individual foreigners resident at Rome,-it had nothing whaterer to do with the relations of states with states. Only with this fact clearly in view is it possible to estimate the immonse importance of the transition 
which took place when Ayala, Gentilis and Grotius seized upon the jus gentium as the source from which could be drawn rules adequate to determine the jural and moral relations of a group of sovereign, coequal and independent states. Thus it was that a particular branch of Roman commercial law became the philosophic basis of the modern international system.

The state-system of modern Europe is the outcome of "the process of feudalization" through which the Teutonic nations passed, after their settlements within the limits of the Roman Empire. Out of that process arose the modern conception of the state as a nation with fixed geographical boundaries, the state as known to modern international law. The conception of sovereignty which the Teutons brought with them from the forest and the steppe was distinctly tribal or national and not territorial. The idea of sovereignty was not associated in the Teutonic mind with dominion over any particular portion or subdivision of the earth's surface. Alaric was king of the Goths wherever the Goths happened to be, whether upon the banks of the Tiber, the Tagus, or the Danube. The dominant idea that seems to hare prevailed among the conquering nations that settled down on the wreck of Rome was that they were simply encamped upon the land they had won. In the course of time they became tied to the land through a process which, for the want of a better term, has been called "the process of feudalization." In that way the elective chief of the once migratory nation was transformed into the hereditary lord of a giren area of land. The new conception of territorial sovereignty which thus arose did not become established, however, until after the breaking up of the Empire of Charles the Great. The completion of the transition is marked by the accession of the Capetian dynasty in France. Hugh Capet and his descendants were kings in the new territorial sense; they were kings who stood in the same relation to the land over which they ruled as the baron to his estate, the tenant to his freehold. The form thus assumed by the monarchy in France was reproduced in each subsequent dominion established or consolidated, and thus has arisen the state-system of modern Europe in which the idea of territorial sorereignty is the basis of all international relations.

The separate nationalities, each with its own character, language and institutions, which arose out of the ruins of the Empire of Charles the Great, passed through a long childhood under the protecting wings of an institution that illus- 
trated for centuries the enduring power of a political theors. "The two great ideas which expiring antiquity bequeathed to the ages that followed were those of a World-Monarehy and a World-Religion." By those two ideas the Teutonic conquerors of Rome were so overmastered that they came to believe that as the dominion of Rome was universal so must it be eternal. Out of such belief gradually arose the strange creation known as the Holy Roman or Medieval Empire which rested upon the magnificent notion of a rast Christian Monarehy whose sway was absolutely universal. The chiefs of that comprehensive society were the Roman emperor and the Roman pontiff,- the one standing at its head in its temporal character as an empire, and the other standing at its head in its spiritual character as a church. The theory was that each chief in his own sphere ruled by divine right as the viceregent of God, and that each possessed the hearty sympathy and support of the other. The Holy Roman Empire and the Roman Catholic Church were, according to medieval theory, two aspects of a single Christian Monarchy whose mission it was to shelter within its fold all the nations of the earth. Unfortunately after Christianity had substituted for the pagan precept, "Thou shalt hate thy enemy," the novel admonition, "Love your enemies," the new European nationalities continued as of yore to be torn internally by insurrections and bloody civil wars, or to be impelled by race-hatred or the jealousies and ambitions of their sovereigns to perpetual strife with each other. Out of such conditions arose then as now the longing for some acknowledged system of international law, and for some supreme tribunal that could so administer it as to settle all contentions without bloodshed. The highest aspiration of the pope in his struggle with the emperor was so to establish his supremacy over all princes, including the emperor himself, as to enable him to offer to Europe the arbitrating power it demanded. As the supreme international judge of Christendom the pope administered the august scheme of authority embodied in the canon law, designed by its authors to reproduce and riral the Imperial jurisprudence; and, in order to give emphasis to that idea, Gregrory IX, who was the first to condense the canon law into a code, was entitled the church's Justinian. Thus it was that the Roman pontiff assumed the office of supreme judge of appeals in all causes arising in the ecclesiastical courts of

1 Bryce, Holy Roman Empire, p. 87. 
Christendom, especially in matrimonial causes involving the validity of a royal marriage, where the result might affect the legitimacy of the issue, and indirectly the peace of the nation. In that way the pope was called upon to adjudicate in the famous case of the divorce between Catherine and Henry VIII. On the other hand, those who like Dante maintained the independence of the Empire, and who wished to substitute for the canonical system secular Roman jurisprudence, attempted, when it was too late, to find in its temporal head an international judge and mediator who, by reason of his severance from local associations and interests, might, as "Imperator Pacificus," prevent wars between the states of Europe by hearing complaints and redressing injuries inflicted by sovereigns or peoples on each other. As the direct heir of those who from Julius to Justinian had moulded the jurisprudence of Europe, he was to be not only peacemaker but the very embodiment of legality and as such the expounder of justice and the source of positive law. The very extraragance of such pretensions rendered their realization impossible. The wars which such a dominion was designed to check rather increased than diminished in intensity,-the theory of the Empire's political and legal supremacy never ripened into reality. And yet, no matter to what extent the Medieval Empire may have failed as an international power, whether arbitrating on its spiritual side through the pope and the canon law, or on its temporal side through the emperor and the Imperial law, the fact remains that for centuries it was the one bond of cohesion, holding Europe together under the spell of a theory that assumed to provide a complete system of international justice and a supreme tribunal adequate for the settlement of all controversies which could possibly arise between Christian nations. No matter whether the Medieval Empire was a theory or an institution, not until the splendid conception of a united Christendom it embodied was wrecked by the Reformation was the field cleared for the growth of international law as now understood.

The great earthquake which began in Germany struck at the very root of the theory by which the Empire had been created and upheld,- the theory that all Christendom consisted of a single body of the faithful held together under the dominion of the Eterual City, ruling through her spiritual head, the bishop of Rome, and through her temporal head the emperor. From the time of the establishment of the 
world dominion of the Roman Empire the doctrine of the subordination of states to a common superior became so tilmly settled in the minds of men that it seemed a part of the nat niral order that subject nations and their rulers should look for the settlement of all grave disputes, personal and national, to Catesar, at the supreme source of law and political authority. So completely did that idea overshadow the barbarian hordes which finally wreclied the Empire of the IVest that they refused to believe in the reality of their own achievement. In the firm belief that the orerlordship of Rome was destined to be eternal they assisted in the creation of the new fabric known as the Holy Roman Empire which, during the interval that divides the coronation of Charles the Great from the Reformation, grew into an international power so potent that its spiritual head in the person of Gregory VII claimed, in the second excommunication passed upon Henry IV, the right "to give and to take away empires, kingdoms, princedoms, marcinisates, duchies, countships, and the possessions of all men." Not until the collapse of that ancient and imposing theory of a common and irresistible superior did the emancipated nationalities, which had cronched so long at its fect, begin to realize, first, that each state is sovereign and independent, and as such coequal with all the rest; second, that territory and jurisdiction are coextensive. Grotius, clearly comprehending these simple triths, emphasized the fact of the independence of the sorereign states about him by formally repudiating the obsolete doctrine of a temporal and spiritual head of Christendom armed with the right to exact universal obedience. His primary contention was that each state is absolutely independent of all external human authority. Maving thus established a common basis of equality, the difficulty that remained was how to subject sovereign states, through their own volition, to the yoke of legality. No more novel or diffienlt problem was ever presented for solution than that which confronted the publicists of the sixteenth and serenteenth centuries when they were called upon to furnish rules adequate, by virtue of their intrinsic weight and dignity, to compel the obedience of the freshly emancipated European nationalities, without the coercive fore of any recognized central authority. As imitation is always easier than invention it is not strange that every mind which attempted to solve the problem should have turned instinctirely to Roman jurisprudence as the only 
source from which the vacuum could be filled. The most enduring outcome of Roman civilization, surviving the wreck of two empires, was Roman law, whose revired study in the twelfth century in the schools of Italy, Spain, France, and England, caused it to be regarded, in the modern as in the ancient world, as the perfection of human wisdom, the only true and eternal law. A brief account has already been given of the origin and growth of that branch of Roman commercial law known as the jus gentium, and of its blending with the Stoic conception of law in the higher sense, as "right reason, pervading all things," and proceeding "from Zeus and the common Nature." Even in Cicero's time the fusion of the jus gentium and the jus naturae was so complete as to induce him to declare them identical. Nothing could be more clear or vivid than Grotius's definition of natural law as the Antonine jurists had understood it. Following in the footsteps of Suarez and Gentilis he accepted the dominant idea of his age that nature was a law-giver,-as such he placed her upon the vacant Imperial throne, and then undertook to interpret her mandates to nations who would admit no other superior.

The ancient struggle of the German princes for territorial independence, which was greatly advanced by the beginning of the Reformation in A. D. 1521, did not ripen into full triumph until the making of the Peace of Westphalia in 1648, whereby the conflict that had convulsed Germany for more than a century was definitely closed, at the end of the Thirty Years' War, through the two treaties then signed at Münster and Osnabrück. By declaring both Lutherans and Calvinists free from the jurisdiction of the pope or any catholic prelate, and by rendering the states of the Empire practically inde. pendent of the emperor as its federal head, the Peace of Westphalia became a formal abrogation of the sovereignty of Rome, and of the theory of Church and State with which the name of Rome had been for so long a time associated. As an eminent English publicist has recently expressed it: "That peace set the final seal on the disintegration of the World-Empire at once of pope and emperor, and made possible the complete realization of the doctrine of Grotius, the doctrine of the sorereignty of states. The Peace of Westphalia did not create international law, but it made a true science of international law realizable."1 Such, in brief, was the general character of the treaty-settlement made during

${ }^{1}$ Walker, The Science of Int. Law, p. 57. 
the year 1648 in the first body that can be called a diplomatic congress in the modern sense of that term,-a settlement that survived without a break as the public law of Europe down to the French lievolution. The Grotian system,depending upon a full and unqualified recognition of the doctrine of territorial sovereignty, from which flow the corollaries that all states are formally equal, and that territory and jurisdiction are coextensive,-was made the basis of the settlement embodied in the l'eace of Westphalia, so far as the written treaty law was concerned; and upon that basis it has been claimed from that day to this that, before the law of nations, the legal rights of the greatest and smallest states are identical. While such has ever been the legal theory the practice has been far otherwise. Such rights and such equality have always been enjoyed sub modo, - that is, subject to the irresistible power rested by what is called the conventional or higher law in a committee composed of the representatives of a few of the greater states acting in behalf of the whole. That primacy or overlordship, gradually developed outside of the written treaty law since the Peace of Westplialia, represents the common superior who actually succeeded to the place made vacant by the collapse of the Holy Roman Empire as an international director. How to limit and restrain that primacy or overlordship, whether vested in one or more of the greater states, has ever been, as it is to-day, the problem involved in the maintenance of the balance of power. To depress the house of Hapsburg, and to keep Germany disunited were among the leading purposes of the Peace of Westphalia in which the foundations of the system of balance were laid,-a system that proved strong enough to save from annihilation or annexation all of the smaller states down to the partition of Poland begun in 1772 . After only one notable interruption the system of balance thus established, with all its defects, still survives. While it may be true that the tendency manifested at times by Great Britain, during the last century, to assume a position of isolation, and the recent military preponderance of Germany may hare scriously modified the idea of a system of balance as understood in Enrope sixty years ago, such system cannot be said to be obsolete. Nothing is better understood in European diplomacy to-day than the fact that a primacy or overlordship is still rested in the Concert composed of Great Rritain, Russia, France and $A$ ustria, a combination into which 
Italy was admitted in 1867. No student of international law can fully comprehend the nature of that Concert without having in mind an outline, at least, of the history of the more important European treaties made during the long interval which divides the Congress of Westphalia from the Congress of Berlin.

The foundations of the public law of Europe as laid in the treaties made in 1648 at Münster and Osnabrïck were not disturbed until the French Revolution, an event which induced the great powers to interfere in the internal affairs of France when certain revolutionary principles threatened to extend themselves to all other countries. Never before had the principle of the balance of power, in the sense of mutual defense, been asserted on so grand a scale, and in the end the intervention was successful. Napoleon, whose schemes contemplated the overthrow of the European Concert, was crushed, and the throne of France restored to the house of Bourbon. But, before the end came, the ancient diplomatic fabric of Europe was shattered,-old landmarks were swept away, many of the smaller states annihilated, and new ones created. After settling in general terms the basis upon which the European system was to be reestablished, the first peace of Paris provided that "within two months all the powers which had been engaged in the war on either side should send plenipotentiaries to Vienna to settle, at a general congress, the arrangements required to complete the provisions of the Treaty of Peace." On November 1, 1814, the Congress opened; after long delays and serious disagreements the great treaties of Vienna were signed on June 7, 1815; on the 9th, the Final Act; and on the 11th closed the most important diplomatic body that had met since the Peace of Westphalia, a body which relaid the foundations of public law and restored to Europe a peace not seriously disturbed for forty years.

With the advent of the eighteenth century the. European Concert,-made up in the main prior to that time of France, Austria, Spain, Sweden and Holland, with the occasional intervention of Great Britain when her interests were specially involved,- -was widened by the addition of new elements that entirely changed the politics of the world. Such elements were represented by the new empire of Russia built up in the north by the genius of Peter the Great and Catherine; by the powerful and independent kingdom of Prussia, lifted from a secondary place in the German empire by the military 
ambition of Frederick II; by the colonial possessions of Great Britain, France, Spain, Portugal and Holland in the continents of $A$ siat and America and in the eastern and western isles; and by the federal republic of the United States whose birth in the west was proclaimed in the Declaration of Indejendence. Before the close of the American Revolution the Congress of the Uuited States, - which, minder the Articles of Confederation, possessed jurisdiction over all questions arising under the law of nations,-in its Ordinance of December 4 th, 17s1, concerning marine captures, professed obedience to that law "alecording to the general usages of Europe." The new member who thus entered into the family of nations was soon called upon to complete a chapter which has become an intergral part of modern international law. While publicists like Galliani, Lampredi and Azuni were giving scientific form to the growing conceptions of the rights and duties of neutrals considered as a definite part of the international code, and while the Baltic powers were insisting upon the practical enforcement of such rights and duties at the cannon's mouth, the young republic beyond the sea was suddenly compelled to restate with precision and force the very imperfect rules by which the law of nations then attempted to protect the sinctity of nentral territory. The loose practice of the seventeenth century, under which acts of war were so often committed with impunity within nentral lands and waters, after being somewhat improved during the latter part of the (iighteenth, relapsed during the wars of the French Revolution into a condition worse than the first. In the presence of flagrant breaches of neutral right and duty in the old World Washington, as the embodiment of the spirit of legality in the New, said to Congress in his fourth annual address of 1792: "I particularly recommend to your consideration the means of freventing those agreressions by our citizens on the territory of other nations, and other infractions of the law of nations. which, furnishing just subject of complaint, might endanger our peace with them." A year later, as the conflict deepened between the nations engaged in the first greneral European war growing ont of the French Revolution, Waslington issued his famous neutrality proclamation of

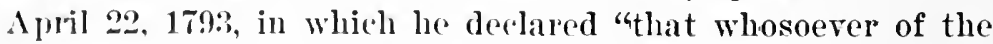
citizens of the United States shall render himself liable to punishment or forfeiture under the law of nations by committing, aiding or abetting hostilities against any of said 
powers, or by carrying to them those articles which are deemed contraband by the modern usages of war, will not receive the protection of the United States." When complaint was made a short time thereafter by the British minister of the fitting out at Charleston under French commissions of two privateers to cruise against British commerce, and of the condemnation of British prizes by a prize-court set up by the French consul at that port, Jefferson, as Secretary of State, replied ou June 5th "that the granting of military commissions within the United States by any other authority than their own is an infringement on their sovereignty, and particularly so when granted to their own citizens to lead them to acts contrary to the duties they owe their own country; that the departure of ressels thus illegally equipped from the ports of the United States will be but an acknowledgment of respect analogous to the breach of it, while it is necessary, on their part, as an evidence of their faithful neutrality." Later on the American cabinet resolved that the dispatch of June 5th should be followed by a circular directed on August 4th to the collector's of customs throughout the United States for the guidance of the revenue officers in their efforts to prevent the arming and equipping of vessels by belligerents in our ports; and, on August 7 th, Jefferson wrote M. Genet that the President considered this government bound to restore all prizes which had been captured by privateers fitted out in the United States, and brought into port after Jume 5th, or make compensation therefor. After the sowing of that crop of principles-the harvest from which the United States reaped in the treaty of Washington of $\mathbf{1 8 7 1}$, and the arbitration at Genera-it is no wonder that the world should be willing to admit, as Hall has lately expressed it, that "the policy of the United States in 1793 constitutes an epoch in the development of the usages of neutrality ** it represented by far the most advanced existing opinions as to what those obligations were." On the substructure thus laid was built up the scheme of legislation for the enforcement of neutral duties provided for in the first American Foreign Enlistment Act of June 5th, 1794, enacted in the first instance for only two years, and made perpetual by the act of April 24, 1800. After the passage of an additional and temporary act on March 3,1817, all prior legislation on the subject was superseded by the act of April 20, 1818, which. after repealing all other acts, consolidated their contents in a definite code $_{2}$ so designed as to prevent or punish erery 
inflaction of neutral duty which could be committed by the issuance of a foreign commission or by the enlistment of land or sea forces within the territorial limits of the United States. As a recognition of the perfection of that neutrality code, there was enacted the British Foreign Enlistment Act of 1819 which, as all the world lnows, was simply a reproduction of the Amerisan acts of 1794 and 1818 , viewed in the light of their diplomatic and judicial histories. Canning, who was an adro"ate of the British act, carried through parliament in the face of strong opposition in 1819, declared, in a notable speech made in the same place in 1832: "If I wished for a guide in a system of neutrality, I should take that laid down by America in the days of the presidency of Washington and the secretaryship of Jefferson." And here the fact should be noted that while the grovernment of the infant republic was thus leading the way to a higher conception of neutral duty, it took the initiative in the establishment of another important prinaiple which has since become a generally accepted rule of international conduct. The European theory that a government's title to recognition is not so much the fact of its ristence as the theoretical legitimacy of its origin received its death-blow when Jefferson, as Secretary of State, declared, in reference to the recognition of the republic proclaimed in France by the National Convention, that "we surely cannot deny to any nation that right whereon our own government is founded, that every one may govern itself according to whatever form it pleases, and change these forms at its own will; and it may trinsact its business with foreign nations through whatever orman it thinks proper, whether king, conrention, assembly, committee, president, or anything else it may choose. The will of the nation is the only thing essential to be regarded." Thus our federal republic emphasized the doctrine, which all states are forced to admit in their dealings with rach other', that all must finally recognize the governmont de facto.

The unusually intimate relations between a few of the greater powers, resulting from their joint intervention in the affairs of France, seem to have sugreseded to the czar the idea of uniting Russia, Austria and Prussia in the mystic bonds of a Holy Alliance, whose primary purpose was to protect the principle of legitimacy against the rising tide of popular freedom by which it was threatened. As a part of that design Austria, at the command of the alliance, crushed the Neapoli- 
$\tan$ revolution of 1820; and France, by the same authority, invaded Spain in 1823 for the purpose of overthrowing the constitution of the cortes and of restoring absolutism in the person of Ferdinand VII. In the summer of that year it was that the Alliance notified Great Britain that, so soon as France should complete the overthrow of the revolutionary govemment of Spain, an international congress would be called for the purpose of terminating the revolutionary governments of South America which had been recognized by the United States but not by Great Britain. In order to defeat that design, full of menace to the English merchants who had built up a large trade with South American countries, Canning, in the summer of 1823 , began to correspond with Mr. Rush, the American minister at London, as to the advantage of a joint declaration by Great Britain and the United States against the proposed intervention of European powers in the affairs of this hemisphere. The ontcome of that correspondence was the definition of the relations of the federal republic of the United States to the nations of the Old World, coupled with a very clear intimation of what its own position was to be in the New. The essence of that epoch-making manifesto, prepared by Jefferson at the request of Monroe, was (1) that the Concert of Europe must never be permitted to interfere in the political affairs of America, North or South; (2) that America must lave a political system of her own entirely distinct from that of Europe. "Our first and fundamental maxim should be never to entangle ourselves in the broils of Europe; our second, never to suffer Europe to intermeddle with cis-Atlantic affairs. America, North and South, has a set of interests distinct from those of Europe, and peculiarly her own. She should, therefore, have a system of her own, separate and apart from that of Europe." The Monroe Doctrine, whose seeds were thus planted by one of the greatest of historio men, like every other institution which has been the result of growth, did not attain its full stature in a night; it did not spring into life fully armed. Its present dimensions are the result of seventy-five years of persistent development worked out by the pens of successive presidents and secretaries of state. It is distinctly a creation of the executive power. By President Polk's protest against future European colonization in this hemisphere, made in the face of possible European intervention on account of the annexation of Texas, President Monroe's original statement was greatly widened; 
and when, in 1865, it became necessary for President Johnson to notify the emperor of the French that this country would no longer tolerate armed intervention in the afrairs of the sister republic of llexico, it was given a deeper meaning and a stronger significance. Not, however, until a resolute and farsighted statesman, who clearly understood that our marvellous national development entitled us to rank as a world power, was given the opportunity by the boundary controversy between Great Britain and the republic of Venezuela, was the inevitabledectaration finally made that the same reasons which impel the Concert of Europe to guard the balance of power in the Old World prompt the government of the United States to maintain alone its primacy in the New. "If the balance of power is justly a cause for jealous anxiety among the goverments of the Old World and a subject for our absolute noninterference, none the less is an observance of the Monroe Doctrine of vital concern to our people and their government."

Thus from the hand of President Cleveland the Monroe Doctrine first received complete and scientific definition; and when the govermment of Great Britain justly and wisely conceded the right of arbitration then asserted by the United States, solely by rirtue of its primacy or overlordship in the New World, a final settlement was made of the place of this republic in the family of nations, and the foundations laid for that close and priceless moral alliance since developed between the two broad divisions of English-speaking peoples. If the Monroe Doctrine as thus expounded is not already a part of the international law of the world, it is rapidly tending inthat direction. As an eminent Engrish publicist has recently expressed it: "The great powers of Europe, as they are called, have gradually obtained such a predominant position as to render untenable the proposition that there is no distinction between them and other sovereign states; and the position they hold in Europe is held by the United States on the American continent. * * The great Republic of the New World stands out like a giant among pigmies. There is no other state in the same hemisphere which ean be compared to her in strength and influence.

* * The supremacy of a Committee of States and the supremacy of a single state can not be exercised in the same manner. What in Europe is done after long and tedious negotiations, and much discussion between representives of no less than six conntries, can be done in America by the 
decision of one Cabinet discussing in secret at Washington."1

The balance of power system, as re-established by the Congress of Vienna, in 1815, was not seriously disturbed until the outbreak of the Crimean War in 1854 , a war under. taken by Great Britain and France primarily to preserve the balance of power in eastern Europe, and incidentally to vest in the European Concert the protection of the Christian peoples subject to Turkey assumed prior to that time by Russia alone. Although not actual belligerents Austria and Prussia were admitted to the Congress which met at P'aris in 1856 to terminate the war, a body in which appeared for the first time in European history ambassadors from the Ottoman Porte. The most important and enduring work of that Congress, in which all the great powers were thus represented, was transacted after the negotiations for peace were terminated. The time had now come when the increasing outcry for the introduction of greater humanity into the rules and practices of war could be disregarded no longer.

In obedience to that demand the question of the maritime rights of belligerents and neutrals was formally presented to the Congress, and the result was the Declaration of Paris, a protocol signed April 16 by all the parties represented, and subsequently accepted as a part of the public law of the world by all powers except the United States, Spain and Mexico.

The first great step thus taken was soon followed by the notable act of President Lincoln who, in 1863, requested Prof. Francis Lieber of Columbia University in the city of New York to undertake the no less novel than humane task of codifying the laws of war. In the very next year, really in response to the appeal made by two citizens of Geneva,-Dunant, a physician, who published a startling story of what he had seen in the hospitals on the battlefield of Solferino, and his friend Moy. nier, who conceived the idea of "neutralizing the sick wagons," -met the famous body composed of the representatives of the fourteen states who signed, on August 22, 1864, the Convention of Genera, regulating the treatment of the sick and wounded, and neutralizing all persons and things employed in their service, such as surgeons, chaplains, nurses, hospitals and ambulances, provided such persons and things are distinguished by a badge or a red cross on a white ground displayed on an arm or on a flag, as the case may be. In order to revise and extend the original provisions another Convention was

1 Lawrence, Principles of Int. Law, pp. 65, 247. Second ed., revised. 
signed at Genera in 1868, but never ratified, whose Additional Articles, including the neutralization of hospital ships, relite chielly though not exclusively to warfare at sea. Less tham two months thereafter a Military Commission at St. Petersburg, composed of delergates from seventeen states, including representatives from Persia and Turliey, agreed as botween thenselves "to renounce the employment of any projectile, on land or the sea, of a weight below four hundred grammes (fourteen ounces), which slould be explosible or loaded with fulminating or inflammable materials." In the Decdaration then made it was said that the object of the use of weapons in war is "to disable the greatest possible number of men, that this object would be exceeded by the employment of ar'ms which needlessly aggravate the sufferings of disabled men, or render their death inevitable, and that the employment of such arms would therefore be contrary to the laws of lumanity." In 1871 met the conference of London which so modified the Treaty of Paris of 1856 as to release Russia from the burdens then assumed as to the Black Sea. In 1874 met the Conference of Brussels, in which appeared the representatives of all the European powers of any importance, in the hope of bringing about the adoption by all civilized states of a common code for the regulation of warfare on land. As the delegates were not plenipotentiaries, the Conference was purely consultative; and the outcome was a series of articles cmbodied in a Declaration which remained as the basis for futme negotiations between the governments concerned. In 1577 met the Conference of Constantinople which vainly endeavored to obtain from the Porte guarantees for the better government of its Christian subjects; in 1884-85, the West Afriean Conference of Berlin, whose purpose was to regulate the affairs of that region, including the boundaries and inde. fendence of the Congo Free State; in 1859 the Marine Conference of Washington, said to have been the first world Conference ever held for purposes of quasi legislation; and, in 1s:90, the Conference of IBrussels, which resulted in the Final $A$ et for the suppression of the Afriean slave trade.

such were the worthy preludes to the meeting of the International Conforence of leace, to the results of whose deliberations, begun in the city of The Hague on the 18th of May, 1s99, sperial considration has been given in the body of this work. Proposed and summoned by the czar of Russia, the Conference was attended by an hundred delegates from 
twenty-six powers,-twenty European, four Asiatic, and two American. It was certainly a hopeful sign for the peace of the world when, at a very early stage in the proceedings of an assembly called by the chief of the great empire of the east of Europe, the first plenipotentiary of the great empire of the West, Sir Julian Pauncefote, formally proposed, in a remarkable mémoire, the question of the creation of a permanent tribunal of arbitration. The delegation of the United States submitted at the sane time a similar proposition, expressing the desire that arbitration might become a normal method of adjusting international disputes. While the delegates of the German Empire objected, and no doubt wisely, to obligatory arbitration, as a step too far in advance of existing conditions, they subsequently expressed the cordial adherence of Germany to an international court of arbitration, Prof. Zorn declaring that his government "fully recognized the importance and the grandeur of the new institution." It is safe to say that all was done that could have been wisely attempted in a meeting necessarily preliminary and tentative. The strength of the Conference was in its patience and moderation. M. Martens, one of the Russian delegates, tells us, "it is a happy token to note, the longer the labors of the Conference at The Hague lasted, the more fully views ware exchanged among the representatires of the different powers, the more pronounced grew the mutual respect, the more friendly grew the personal relations, the more palpable became the desire to do somethiing for the future." That steadfast hope for the future certainly found high-thoughted and eloquent expression when the Hon. Andrew D. White, one of the delegates of the United States, said,-in the notable oration pronounced by him in the midst of the proceedings of the Conference and at the tomb of Grotius,- "from this tomb I seem to hear a voice which says to us as the delegates of the nations: 'Go on with your mighty work: aroid, as you would avoid the germs of pestilence, those exhalations of international hatred which take shape in monstrous fallacies and morbid fictions regarding alleged antagonistic interests. Guard well the treasures of civilization with which each of you is intrusted; but bear in mind you hold a mandate from humanity. Go on with your work. Pseudo-philosophers will prophesy malignantly against you: pessimists will laugh you to scorn: cynics will sneer at you: zealots will abuse you for what you have not done: sublimely unpractical thinkers will revile you for what you have done: ephemeral critics will 
ridicule you as dupes: enthusiasts, blind to the difficulties in your path and to everything outside their little circumscribed fields, will denounce you as traitors to humanity. Heed them not: yo on with your work. Heed not the clamor of zealots. or cynie's, or pessimists, or pseudo-philosopher's, or enthusiasts, or fanlt-finders. Go on with the work of strengthening peace and humanizing war: wive greater seope and strength to provisions which will make war less cruel: perfect those laws which diminish the unmerited sufferings of populations: and, above all, grive to the world at least a beginning of an effective, practical scheme of arbitration."

In the preparation of Part IV, relating to the laws of war, the anthor was fortunate in having the active and able assistance of his friend and fellow-citizen, Peter J. Hamilton, Esq., a rising lawyer and scholar of whom any state might be prond. The son of one of the ablest and most cultured of southern jurists, Mr. Hamilton was trained under his father's eye, and graduated at I'rinceton University in 1879. As a recognition of his distinguished career in that institution he was awarded the highest grade ever given there in political science, and also a fellowship which enabled him to continue his training at the University of Leipzig, where he studied fhilosophy under Wundt and Roman law under Windscheid. The ripe fruit of Mr. Hamilton's researches into French and Spanish history and organization in America was embodied in his notable book published in $1897,{ }^{1}$ which is not so much a local chronicle as a real contribution to the history of the valleys of the Alabama and Mississippi. Grateful acknowledgments must also be made to the Hon. William Wirt Howe of New Orleans, late President of the American Bar Association, for advice frequently given in the domain of Roman law, of which he is a recognized master; and to Rer. W. J. Tyrrell, Iresident of Spring Hill College, Mobile, for valuable assistance in reference to several vexed questions concerning Greek international law. Last but not least the anthor desires to express his thanks for a set of valuable public documents received from the Department of State through the personal lindness of its able and experienced chief, the Hon. John Hay, whose impartial courtesies to his fellow ritizens of all sections and all parties compel them to recognize in him an American who belongs to the country as a whole.

Mobile, Ala., Algit'st 11Th, 1301.

1 "Colonial Mobile." 


\section{CONTENTS.}

\section{INTRODUCTION.}

\$ 1. Analytical and historical methods contrasted.

$\S 2$. Roman theory of a determinable law of nature. What international law really is.

§ 3. Growth of law explained through the record of its development.

$\S$ 4. Comte as founder of the Science of Society.

\&5. Why international law should be re-examined by historical method.

\section{PART I.-ANCIENT AND MEDIEVAL STATE- SYSTEMS.}

\section{CHAPTER I.}

\section{THE ANCIENT STATE AS THE CITY-COMMONWEALTH.}

$\S 6$. The normal international person a state. Greek, Roman and medieval state-systems.

$\S$ 7. Greek city-state an aggregation of village communities.

$\S$ 8. Greek state-system as outlined by Aristotle.

$\S$ 9. Extreme cruelty of laws of war.

$\S 10$. Status of aliens-isopolity and international courts.

$\S 11$. Futile efforts of the Greeks to establish political unity. Primitive conceptions of international law.

$\S$ 12. Athenian Alliance or Empire.

$\S 13$. Achaian League of Peloponnesus.

$\S 14$. Greek contributions to federalism and to the law of nations.

$\S 15$. Italian city-state system.

$\S 16$. Rome and the principle of incorporation.

$\S 17$. Legal science a Roman creation-origin of the Corpus Juris Civilis.

§ 18. Roman jurisprudence the basis of international law. The praetor peregrinus and the jus gentium.

$\S 19$. Relation of jus gentium to jus naturae.

$\S 20$. The jus fetiale the law of negotiation and diplomacy.

\section{CHAPTER II.}

\section{THE MODERN STATE AS THE NATION.}

$\S 21$. The modern state a Teutonic creation.

$\S 22$. Transition from tribal to territorial organization-"process of feudalization."

$\S 23$. Origin of the state-system of modern Europe. 


\section{CHAPTER III.}

\section{THE MEDIEVAL EMPIRE AS AN INTERNATIONAL POWER.}

\$ 24. Theory of the medieval Empire. Pope and emperor as chiefs of the world-monarchy. Belief that Rome and her empire were to be eternal.

§ 25. Limits of the actual authority of the Empire.

$\$ 26$. The pope as an international judge. The canon law.

$\$ 27$. The emperor as international judge and mediator.

$\S 28$. Effects of the Reformation on the Empire.

$\S 29$. Peace of Westphalia a formal abrogation of the sovereignty of Rome.

\section{PART II.-SOURCES AND FOUNDATIONS OF MODERN INTERNATIONAL LAW.}

\section{CHAP'TER I.}

INTERNATIONAL COURTS, CONGRESSES AND CONFERENCES.

$\S 30$. Five sources of international law.

$\$ 31$. Outline of the customary laws of the sea.

\$2. Prize courts as international tribunals.

$\S 33$. Courts of arbitration. Alabama, Bering Sea and other cases.

\$3. International congresses.

$\S 35$. Notable conferences of recent times: Conferences of Geneva, 1864; of St. Petersburg, 1868; of Brusseis, 1874.

\$ 36. The Peace Conference at The Hague-its basic principle: a voluntary system of arbitration; laws and customs of war on sea and land; calling of the Conference; its composition; its results.

\section{CHAPTER II.}

\section{RISE OF THE PUBLICISTS.}

§ 37. Revival of the study of jurisprudence.

$\S 38$. Importance of a knowledge of the publicists-their testimony as experts.

8 39. Spanish and Italian publicists-Gentilis, Suarez, Ayala, Riquelme, Fiore and others.

8 40. German publicists-predecessors of Grotius. Puffendorf a notable disciple of Grotius. Leibnitz and Wolf. Heineccius, Moser, Martens, Klüber, Heffter and others.

§ 41. Dutch publicists-Grotius, Bynkershoek and Huber.

§ 42. English publicists-Zouch, Selden, Rutherforth, Jenkinson, Hobbes and Bentham. Wildman, Manning, Phillimore, Twiss, Hall, Holland, Dicey and others.

§ 43. Swiss publicists-Vattel, Burlamaqui and Bluntschli. 
$\S 44$. French publicists-Valin, Pothier, Foelix, Massé, Ortolan and others.

$\S$ 45. North American publicists and their contributions to law of neutrality-Kent, Wheaton, Story, Woolsey, Halleck, Field, Wharton and others.

$\S 46$. South American and Russian publicists-Calvo, Bello, Martens.

$\S 47$. History and literature of international law.

$\S 48$. Publicists as creators of international rules. Institut de Droit International.

\section{CHAPTER III.}

\section{GROTIUS AND THE AFTERGROWTH OF HIS SYSTEM.}

§ 49. Huig van Groot, known as Hugo Grotius.

$\S 50$. His substitute for the supremacy of the Holy Roman Empire.

$\S 51$. Independent and coequal states-territory and jurisdiction coextensive.

§52. Blended product of jus gentium and jus naturae seized upon by Grotius. Effort to give to it a strained construction unsuccessful.

$\S 53$. The Grotian law of nature. An alternative basis resting on consent alone.

$\S 54$. International law regarded as positive law by transcendental school.

$\S 55$. International law not positive law-Austin, Holland, Wilson.

$\S 56$. International law defined by those who did not regard it as positive law.

$\S 57$. Alternative proposition of Grotius' basis of modern system.

$\S 58$. Author's definition of international law.

$\S 59$. Origin of the phrase "international law."

$\S 60$. Limits of its original sphere.

$\S 61$. How a state may assent to an international rule.

$\S 62$. Original sphere widened by admission of states, new and old.

$\S 63$. All dealings with infidels once deemed unlawful.

\$ 64. Qualified extension of international law to non-Christian states.

\section{CHAPTER IV.}

\section{TREATIES AS SOURCES OF INTERNATIONAL LAW.}

$\S 65$. Treaties as mere agreements affecting special interests. How a special stipulation may grow into a general rule.

$\S 66$. Treaties declaring new general rules or modifying old ones.

$\S 67$. Treaties as bases of concerted action for maintenance of balance of power.

$\S 68$. Peace of Westphalia basis of public law of Europe down to French Revolution.

\$ 69. How a written code may be subordinate to a higher law.

$\S$ 70. System of balance as defined by Gentz, Fénelon and Earl Grey. 
$\S$ 71. Treaties aggrandizing France and Sweden at the expense of Spain and the Empire.

$\S 72$. Treaties of Breda, 1667-Triple Alliance, 1668.

$\S 73$. Peace of Nimeguen, 1678-79-summary of results.

$\S$ 74. League of Augsburg, 1686; Grand Alliance, 1689; Peace of Ryswick, 1697.

$\S 75$. Spanish succession and partition treaties of 1698 and 1700 .

§ 76. Peace of Utrecht, 1713-15-its leading stipulations. Barrier Treaties of 1709,1713 and 1715 .

$\S$ 77. Peace of Carlowitz, 1699.

$\S$ 78. Treaties of Nystadt, 1721; Berlin, 1742; Dresden, 1745; Aix-laChapelle, 1748.

$\S$ 79. Treaty of Naples, 1759-Family Compact, 1761.

$\S 80$. Peace of Paris, 1763-Peace of Hubertsburg, closing Seven Years' War.

\$ 81. Three partitions of Poland, 1772, 1793, 1795.

§ 82. Definitive treaties signed at Versailles, Sept. 3, 1783.

$\S 83$. Intervention of great powers in affairs of France.

$\S 84$. Ancient diplomatic fabric of Europe shattered.

$\S 85$. Work of reconstruction-first Peace of Paris and Congress of Vienna, 1814-1815.

$\S 86$. Result of efforts to restore prior conditions.

$\S 87$. Holy Alliance, 1815-its purposes defined.

$\S 88$. Intervention in affairs of Portugal.

$\S 89$. Intervention in affairs of Greece.

$\S 90$. Intervention in affairs of Belgium.

$\S 91$. Crimean war and treaty of Paris, 1856. Declaration as to maritime rights of belligerents and neutrals.

§ 92. Rise of Prussia. Schleswig-Holstein question.

$\S$ 93. Peace of Prague, 1866. Withdrawal of Austria from Confederation.

§ 94. Treaty between Prussia and France, 1871.

§ 95. Russia and Turkey-Conference of London, 1871. Treaty of San Stefano and Congress of Berlin, 1878. Readjustment of forces.

\section{CHAPTER V.}

\section{EXTENSION OF INTERNATIONAL SYSTEM TO NEW WORLD.}

$\S 96$. Early conflicts as to boundaries. Prior discovery as a basis of title.

$\S 97$. Law of occupatiou as drawn from Roman sources.

$\S 98$. Title to newly-discovered lands under English Constitution.

$\S 99$. General rules as to area appropriated by act of occupation.

\$100. Conflict between U. S. and Spain as to western boundary of Louisiana.

\$101. Conflict with Great Britain as to northeastern boundary.

\$102. Conflict with Great Britain as to northwestern boundary.

\$103. Acceptance of the law of nations by United States.

8104. Jurisdiction over three-mile zone. 


\section{CHAPTER VI.}

MONROE DOCTRINE AND OTHER SOURCES.

\$105. History of Holy Alliance reviewed.

\$106. Jefferson's famous Ietter to Monroe, Oct. 24th, 1823.

$\$ 107$. President Monroe's message of Dec. 2nd, 1823-European system not to be extended in this hemisphere.

\$108. Part of same message relating to unsettled boundaries in nortinwest.

\$109. Meaning of Monroe's phrase, "future colonization."

\$110. Its meaning widened by President Polk.

\$111. Clayton-Bulwer treaty, 1850, an exception to Monroe Doctrine.

\$112. Termination of France's intervention in affairs of Mexico.

\$113. Definition of Monroe Doctrine completed by President Cleveland.

\$114. Instructions given by states for guidance of their own courts and officers.

\$115. History of diplomatic intercourse as a source of international law.

\$116. International private law, or rules to prevent conflict of laws.

\section{PART III.-RIGHTS AND DUTIES OF STATES IN TIME OF PEACE.}

\section{CHAPTER I.}

NATURE AND ATTRIBUTES OF STATES, SOVEREIGN AND PART-SOVEREIGN.

\$117. Territorial sovereignty the basis of all international relations.

\$118. Why the several types of state organization must be examined.

\$119. Sovereign states divided into five classes.

$\$ 120$. Personal unions-relation of Great Britain to Hanover.

§121. Real unions-Austria-Hungary. Prussian and Danish monarchies gesammtstaats; Sweden and Norway a gesammtstaat.

\$122. Incorporate union embodied in British Empire: government of colonial system; treaty-making power vested in crown.

\$123. Federalism prior to making of second constitution of U. S.

§124. Path-breaking idea embodied in second constitution.

\$125. How federal unions are classified-a staatenbund. Right of cantons to make separate treaties.

\$126. The unique federal creation of 1787 a bundesstaat.

§127. Its effect on other systems.

§128. Constitution of North German Confederation.

\$129. Responsibility of federal executive-defect in constitution of U. S.

\$130. No federal control over states in certain cases.

\$131. Case of McLeod.

§132. Part-sovereign states.

§133. Neutralized states only part-sovereign. 
§134. Protected states not persons in international law.

\$135. Republics of Andorra and San Marino.

\$136. Migratory Indian nations.

\$137. Native states of India under British protection. Canada.

\$138. Protected state may preserve international existence. U. S. of Ionian islands.

§139. Neutral city of Cracow and principality of Monaco. Presumption in favor of states originally independent.

\$140. Christian principalities of Ottoman Empire.

\$14. Emancipation of Roumania and Servia.

\$142. Emancipation of Montenegro.

\$143. Bulgaria still dependent.

\$144. Suzerainty of Porte over Egypt. Sultan's nominal control over foreign affairs. Mixed tribunals and Suez Canal.

\$145. Belligerent communities. Internal and external sovereignty contrasted.

\$146. Recognition of belligerency and its effects.

\$147. Indirect recognition-duty of executive.

\$148. Duty of foreign state when recognition of belligerency demanded.

\$149. Reasons for prompt recognition in case of maritime war.

$\$ 150$. Notable recognitions of belligerency.

\$151. Great Britain's recognition of Southern Confederacy.

\$152. Declarations of neutrality and their effects.

\$153. Recognition of independence-when an act of intervention.

\$154. Notable recognitions of independence.

\$155. Channels of intercourse must be kept open.

\$156. Recognition of South American republics by U. S. and Great, Britain.

\$157. Recognition of Texas by U. S.

\$158. All must finally recognize governments de facto.

\$159. Recognitions, formal and informal.

$\$ 160$. Attributes of sovereign states as moral persons.

$\S 161$. Effects of temporary suspension of state life.

\$162. A state's right to reputation.

\$163. How a state may be extinguished through absorption, division or merger.

\$164. Effect of extinction on state obligations.

\$165. Effect of dismemberment on state obligations.

\$166. When severed territory becomes a distinct state-local rights and obligations.

§167. Contention of U. S. with Great Britain after war of 1812.

§168. Summary.

CIIIP'TER II.

SOVEREIGNTY AND JURISDICTION IN RELATION TO PERSONS.

\$169. Territory and jurisdiction coextensive. Legal fiction of exterritoriality. Illustrations.

\$170. Comity the basis of international private law. Result of a strict enforcement of the lex loci. Lex domicilii, how far status depends upon it. Connection between international private law and public. 
\$171. Law of nations deals only with states as corporate persons, and not with individuals composing them. Rights and obligations incident to states as such.

\$172. Who are entitled to a state's protection? Status more important than citizenship.

\$173. Inhabitants of whom every state is usually composed.

\$174. Right of a state to protect its subjects abroad; allegiance; Calvin's case. Natural allegiance originally perpetual. British naturalization acts.

\$175. Rights of English subjects in America. Interstate citizenship. Federal citizenship created by 14 th Amendment.

\$176. Relation of allegiance to citizenship. Former not now perpetual. How British and American citizenship acquired.

$\$ 177$. Feudal rule of citizenship and reaction against it.

$\$ 178$. The old rule in the U. S.

$\$ 179$. Domicile of dependent persons.

$\$ 180$. Nationality of married women.

\$181. Naturalization in U. S.

\$182. English Naturalization Act, 1870. A qualification construed in case of Bourgoise.

§183. Early American doctrine of expatriation. Cases with Prussia in 1840,1853 . A marked departure in 1859; Mr. Cass's declaration. Act of Congress, 1868. Right of every state to settle question for itself.

\$184. Traveling sovereigns-immunities and disabilities abroad.

\$185. Foreign army in a friendly state-other immunities.

\$186. A state's right to receive and expel visitors. Right to exclude obnoxious foreigners defined.

\$187. How far citizens abroad are amenable to local jurisdiction.

§188. Piracy, jure gentium.

\$189. Case of the Huascar. Statutory piracy.

\$190. Slave-trade: Hostile action of Great Britain and other nations, after 1807. Cases of the Amedie, Fortuna, Diana, Lois and Antelope. Great Britain's claim of Right of Visit, 1841, resisted. Reluctance of France and U. S. to concede right of search.

\$191. Territoriality of crime disputed by many nations.

\$192. Cutting's case, 1886 .

\$193. Foreigner can only demand fair trial under local law.

\$194. State's right to punish its citizens for crimes committed abroad.

\$195. British legislation on the subject.

\$196. Like legislation in the U. S.

\$197. Offences punishable by U. S. ministers and consuls in certain countries.

\$198. Duty of a state to protect aliens. Their status in Greece and Rome.

§199. Treatment of aliens in Middle Ages.

\$200. Special policies of England, Germany and France.

\$201. Mere travelers or sojourners.

\$202. Domiciled aliens. What constitutes domicile.

\$203. General rights and duties of aliens. Koszta's case. 
\$204. Letters of denization in England.

\$205. Extradition. Nature and origin of existing system.

$\$ 206$. Extradition treaties between Great Britain, France and U. S. $\$ 207$. Cases of Winslow and Rauscher.

$\$ 208$. U. S. recognizes no obligation to surrender in absence of treaty. Exceptional case of Argüelles.

\$209. A state may impose conditions of surrender.

$\$ 210$. Demand should be limited to treaty offences.

\$211. Fugitive must be tried only for offence specified.

\$212. Political offences-how distinguished from ordinary crimes.

$\S 213$. Responsibility of a state for due execution of its laws.

\$214. No responsibility for erroneous judicial decisions.

$\$ 215$. Duty to prevent mob violence and invasion of neighboring states.

\$216. Responsibility suspended by civil war.

\section{CHAPTER III.}

\section{SOVEREIGNTY AND JURISDICTION IN RELATION TO PROPERTY.}

\$217. State property, teritorial and non-territorial. Servitudes.

\$218. Title by prescription founded on Roman law. Its application to possessions of states. Case of Poland.

\$219. Time necessary to establish international prescription.

\$220. Title by conquest. Case of Electorate of Hesse-Cassel.

\$221. Title by occupation. Effect of recent experienee in Africa.

\$222. Chartered companies as colonizing agents.

\$223. Protectorates-extent of internal control and external obligation.

\$224. Spheres of influence. Prevention of conflicts as to boundaries. Status of native African races.

\$225. Title by accretion. Case of the Anna.

\$226. Right to new formations when rivers are boundaries.

\$27. Title by cession. Just compensation for conquered territory.

$\S 228$. Territorial waters. Exclusive right to use great rivers.

\$229. Bays, gulfs or recesses in coast line. Curtailment of unreason. able claims.

$\S 230$. Straits less than six miles wide-an exception.

$\$ 231$. Territorial waters connecting parts of high seas. Denmark's sound dues.

§232. Rights of war vessels in territorial waters.

§233. Free riverain navigation. Rights of upper states.

\$234. How the great European rivers were emancipated-the Rhine.

\$235. Final act of Vienna Congress. Commercial use of Danube.

$\S 236$. Navigation of Mississippi as regulated by treaties of Paris and San Lorenzo.

§237. Navigation of St. Lawrence as regulated by treaties of 1854 and 1871.

$\S 238$. Opening of South American rivers.

$\$ 239$. Opening of Alaskan and African rivers.

$\$ 240$. Incidental right to use river banks-its limitations.

\$241. Ownership of an entire river. Burden of proof on claimant. 
§242. Emancipation of high seas. Early freedom theoretical.

$\$ 243$. Doctrine of mare clausum. Right to exact tolls and dues.

§244. Claims of Spain and Portugal to newly discovered seas.

§245. Grotius' Mare Liberum.

\$246. Selden's Mare Clausum. Gradual extinction of the doctrine.

§247. The marine league. Grotius, Vattel and Bynkershoek. Necessity for widening the zone.

§248. State legislation extending limit for health and revenue purposes. Its validity.

§249. Right to fish within marine league. Conflicts between Great Britain and U. S.

$\S 250$. Settlements of $1818,1854,1871$ and 1885 .

$\$ 251$. State boundaries-a summary of general rules-burden of proof.

\$252. Servitudes: positive or negative; contractual or customary.

§253. Non-territorial property. Public vessels. Fiction of exterritoriality.

§254. Term "public vessel" defined.

$\S 255$. Immunities of public vessels.

$\S 256$. Their slow growth. Expositions of the earlier doctrine.

§257. New doctrine as defined by Marshall, Cushing and Ortolan.

$\$ 258$. Certain duties and exemptions of public vessels defined.

$\S 259$. Must not harbor criminals and fugitive slaves.

$\$ 260$. When a diplomatic appeal must be made-exception in an extreme case.

\$261. Immunities attach to public vessels as complete organisms.

§262. State's jurisdiction over merchant vessels on high seas.

§263. Fiction of exterritoriality scarcely exists as to merchant vessels.

\$264. How the nationality of a merchant vessel may be established.

$\S 265$. When a merchant vessel must show her papers. Case of the Virginius.

\$266. Right of visitation in time of peace.

$\S 267$. Certain exceptions in favor of the right.

$\S 268$. Immunity of private vessels in territorial waters. Views of Webster and Marshall.

§269. Efforts to secure exemptions through treaties. Cases of Sally and Newton.

$\S 270$. Cases of Jally and Wildenhus.

§271. No right of asylum in merchant vessels. Case of Gomez.

\$272. Goods owned by citizens of one state embarked in ships of another.

\section{CHAPTER IV.}

\section{DIPLOMATIC INTERCOURSE.}

\$273. Envoys, ancient, medieval and modern.

§274. Effort to establish permanent embassies. Views of Grotius, Bynkershoek and Vattel.

$\$ 275$. The several classes of diplomatic representatives.

§276. Growth of diplomatic immunities. Recent legislation.

\$277. Questions of precedence as settled at Vienna and Aix-la-Chapelle. 
§278. Envoys of the first class: the representative character; solemn entry.

\$279. Envoys of the second and third classes.

$\S 280$. Chargés d'affaires ad hoc and ad interim.

$\S 281$. How diplomatic rank is usually determined.

\$282. Theory of equality between sovereign states. Precedence of pope and emperor.

\$2\$3. Significance of royal honors.

$\$ 284$. Right to regulate ceremonials. Courtesy on high seas.

\$25. Right to send and duty to receive envoys.

$\$ 2 S 6$. Difficulties incident to contests for sovereignty.

\$2S7. Effect of revolutionary changes after reception of envoy.

\$2S8. Right of legation retained by certain part-sovereign states.

$\$ 289$. When a particular individual may be rejected without just cause of offence.

\$290. Envoy may be received conditionally. Mr. Keiley's case.

$\$ 291$. Letters of credence and additional full powers.

$\S 292$. Limited full powers. Instructions.

\$293. When right to innocent passage begins. Its extent defined.

\$294. Right of third state to prescribe route. Mr. Soulés case. Rule in U. S.

§295. Necessity for safe-conduct in time of war. Belleisle's case.

$\$ 296$. Inviolability of despatches of a neutral envoy in time of war.

\$297. Ceremonials of arrival and reception.

\$298. Beginning of functions. Ceremonial lex loci.

§299. Diplomatic immunities not unlimited.

$\S 300$. Their duration and extent.

§301. When an envoy may be arrested and expelled. Cases of Gyllenborg and Cellamare.

$\S 302$. When an envoy may be punished by a local tribunal. Wicquefort's case.

$\S 303$. Immunity does not include mere visitors. Sa’s case.

\$304. Minister can not be compelled to appear as a witness.

§305. Exemption from civil jurisdiction. Legislation, English and American.

\$306. Not forfeited by trading.

$\$ 307$. How envoy's personal effects may be subjected.

$\S 308$. How his civil immunity may end.

$\S 309$. Mr. Wheaton's notable case at Berlin. Tacit hypothecation not enforcable.

$\$ 310$. Immunity of minister's hotel and grounds.

\$311. Envoy must not harbor criminals not of his suite.

$\$ 312$. Right of asylum for political refugees in certain countries.

\$313. Immunity of envoy's residence defined.

\$314. Freedom of religious worship.

\$315. Exemption from general taxes. Liability for local dues. Exemption from customs duties.

§316. Immunities of envoy's servants. Practice not uniform.

§317. Envoy's contentious jurisdiction no longer exists.

\$318. Extent of voluntary jurisdiction.

\$19. How accused servants should be dealt with. 
§320. How an envoy's mission may terminate, with or without formal recall.

\$321. Dismissal of envoy before recall. Should not be capriciously sent away.

§322. Notable cases of recall or dismissal. Case of Genet, 1793. Case of Yrujo, 1804. Case of Jackson, 1809. Case of Catacazy, 1871. Case of Lord Sackville, 1888. Case of Bulwer, 1848.

8320. When a mission is terminated by death of envoy.

\$324. Commissioners for special purposes not entitled to immunities

\$25. Judge consuls and consuls d l'etranger.

\$326. A consul's quasi international character.

\$327. His duties in that sphere. Passports.

\$328. Consular organization as a whole. Certain local exemptions.

§329. A consul's local obligations.

§330. Consuls not affected by political changes.

\$331. Consuls clothed with judicial and diplomatic functions by treaty.

\$332. Extension of judicial side of consular office.

\$333. Consular courts in Egypt. Reformed Tribunals of 1875.

\section{CHAPTER V.}

\section{THE TREATY-MAKING POWER.}

§334. Ancient international law conventional. Religious leagues.

$\$ 335$. A fully matured treaty system in Greece.

§336. Collegium Fetialium at Rome.

\$337. Apart from compact, no positive international code.

$\S 338$. The modern common law of nations.

\$339. All treaties void or voidable that conflict with it.

\$340. Treaties and agreements not subjects of international law.

§341. Treaties as classified by Vattel, Martens and Calvo.

\$342. All real treaties divisible into two classes. Executed conventions.

$\S 343$. Executory conventions.

\$344. Executed conventions as defined by Master of the Rolls, 1830 .

\$345. By Supreme Court of the U. S., 1823.

\$346. Revival of permanent servitudes.

\$37. Treaties of alliance, offensive and defensive.

\$38. Conflicting views of Great Britain and Holland, 1756.

\$34. Difference between a treaty of general alliance and one of limited succor.

$\$ 350$. Treaties of guarantee.

$\S 351$. When guarantor can only intervene on demand of beneficiary.

\$352. Collective guarantee to secure a common interest. Lord Derby's view.

§353. Agreements in which guarantees are embodied.

§354. Commercial conventions. Reciprocity.

§355. Treaties establishing special tribunals.

\$356. Treaties of arbitration: their growing popularity; their history, ancient, medieval and modern.

§357. Arbitral courts; their constitution and procedure. 
\$358. Permanent Court of Arbitration provided by Hague Conference; International Bureau and Permanent Administrative Council; how arbitral tribunal shall be constituted; resort to arbitration not compulsory; arbitral procedure; jurisdiction; rehearing.

\$359. Diplomatic negotiation and mediation.

\$360. Preliminary means of settlement invigorated by Hague Conference.

$\S 361$. Power of a state to contract; where it resides.

$\$ 362$. International compacts require only limited freedom of consent.

\$363. Certain limits not to be exceeded.

$\S 364$. When constitutions require that treaties must be ratified.

$\$ 365$. When no right of rejection is reserved. Old and new rule.

\$366. Treaty concluded in due form not to be rejected capriciously.

\$367. Ratifications, express and tacit.

$\$ 368$. When treaties become effective.

$\S 369$. Stipulations to be performed between signature and ratification.

$\S 370$. Legislation to carry treaties into effect.

§371. Controversy of U. S. with France as to treaty of 1831 .

§372. Right of parliament to reject necessary legislation.

$\$ 373$. Claim of House of Representatives as to Alaska purchase.

§374. International agreements may be verbal or written. Languages employed.

§375. Protocols.

§376. Distinction between a "treaty" and a "convention." Use of the alternat.

§377. Construction and interpretation of treaties. Distinction between the two.

§378. General rules. Instrument to be taken as a whole.

§37. When general terms are obscure or equivocal.

$\S 380$. Extrinsic evidence to explain objective obscurity.

§381. When a term used in a treaty between several states has a special meaning in each.

\$382. Technical terms, or terms of art and science.

$\S 383$. When recourse must be had to general spirit and purpose of a treaty.

§384. Clauses in favor of justice and humanity.

\$385. Presumption in favor of a state.

§386. Incidents of substantive rights and obligations.

§387. Rules regulating certain preferences.

§388. Where two meanings are admissible. Interpretation clause.

§389. Special rules: A general permission overcome by imperative provision.

\$390. Precedence between conflicting prohibitive provisions.

\$391. When stipulations so identical that no priority can be assigned.

\$392. When most recent of two treaties takes precedence.

\$393. Prior treaty prevails over subsequent one in conflict with it.

\$394. A treaty may become voidable through subsequent events.

\$95. Russia's contention as to treaty of Paris.

§396. Treaties affected by changes in internal life of a state.

$\S 397$. Dangerous contentions of Heffter and Fiore. 
\$398. When will a breach of conditions by one party render treaty voidable at instance of the other.

§399. Several other circumstances by which a treaty may be extinguished.

$\S 400$. How treaties may be extended or renewed. Difference between the two.

\section{CHAPTER VI.}

\section{RIGHT OF SELF-PRESERVATION.}

\$401. Defensive forms of self-preservation.

$\$ 402$. Invasion of Mexico by U. S., 1836.

$\$ 403$. Invasion of U. S. by British subjects, 1838.

\$404. When a state may defend itself in its own or in non-territorial waters. Case of Virginius.

\$405. Register only prima facie evidence of nationality. Respect due to it as such.

\$406. Liability of Virginius to capture in any event.

$\$ 407$. Right of American and British citizens on board Virginius to lawful trial.

\$408. Great Britain's seizure of Danish fleet as a permissible measure of self-preservation.

\$409. Attack of the U. S. upon Amelia Island, 1817.

$\$ 410$. Notable interventions on religious grounds.

\$11. Notable interventions on political grounds.

\$412. Intervention of France, Great Britain and Spain in Mexico. Ultimate motive of Napoleon III.

\$413. An intervention to end an intervention. Mr. Seward's protest.

$\$ 414$. Intervention of U. S. in affairs of Venezuela.

\$415. Primacy of U. S. as defined by President Cleveland and Prof. Lawrence.

§416. Intervention of U. S. in affairs of Cuba. Community of interests.

§417. Intervention as a contingent necessity. Views of Presidents Grant and Cleveland.

\$418. Intervention precipitated by destruction of Maine.

\$419. Grounds of intervention as defined by President McKinley.

$\$ 420$. Intervention justified by general principles of international law as defined by Great Britain, France and Russia in 1827.

\$421. Can the right to intervene in the affairs of one state be vested in another by a contract of guarantee?

\$422. When intervention is asked by both parties to a conflict, or by one only.

8423. Intervention defined in the light of authoritative precedents.

$\$ 424$. Intervention as a means of preserving the balance of power.

$\$ 425$. Intervention for protection of indirect interests not too remote.

$\$ 426$. Intervention to ward off an imminent danger.

\$427. One state may intervene to prevent or terminate illegal intervention of another.

\$428. Intervention under treaties of guarantee. Case of Belgium.

\$429. Humanitarian interventions to prevent cruelty and tyranny.

\$430. Interventions to end religious persecutions in the Orient. 


\section{PART IV.-RIGHTS AND DUTIES OF STATES IN TIME OF WAR.}

\section{CHAPTER I.}

FORCIBLE MEANS OF REDRESS SHORT OF ACTUAL WAR.

\$431. Preliminary forms of redress classified.

\$432. When an injured foreigner should resort to local courts.

$\$ 433$. Withdrawal of diplomatic agents.

\$434. Embargo and non-intercourse.

\$435. Retorsions: retorsio juris; retorsio facti.

\$436. Reprisals classified.

$\$ 437$. Origin and growth of reprisals.

$\$ 438$. Privateering.

\$39. Privateering virtually abolished.

$\$ 440$. Survival of public reprisals.

\$411. Military and naval demonstrations.

\$42. The Armed Neutralities of 1780 and 1800 .

$\$ 443$. Counter demonstrations. Neutralization of Great Lakes.

\$44. Pacific blockade.

$\$ 445$. Satisfaction.

\$446. Limit of forcible redress.

\section{CHAPTER II.}

\section{COMMENCEMENT OF WAR AND ITS IMMEDIATE CONSE- QUENCES.}

\$447. Arrangement of subjects.

$\$ 448$. Usages called laws of war.

$\$ 449$. The state of war defined.

$\S 450$. Meaning of war in its broader sense.

\$451. How far war is a relation of states and not of individuals.

$\$ 452$. Just causes of war.

\$53. Objects of war, political and military.

\$454. How wars are classified.

\$455. Is a declaration of war necessary; a change in medieval theory and practice; the existing usage.

\$456. A conditional ultimatum.

8457. When a recognition of belligerency should be made.

\$458. Belligerency of Southern Confederacy recognized.

\$459. Closing of ports of New Granada.

$\$ 460$. A civil war a public war.

\$461. Effect of war on private citizens.

\$462. Effect of war on treaties.

$\$ 463$. Effect of war on resident enemies.

\$464. Confiscation of private property. 
\$465. Effect of war on trade.

$\$ 466$. Effect of war on allies.

$\$ 467$. Liability of domiciled aliens to military service.

$\$ 468$. When neutrals become de facto citizens of belligerent state.

\section{CHAPTER III.}

\section{RIGHTS AND DUTIES OF BELLIGERENTS DURING HOSTILITIES}

\section{ON LAND.}

$\S 469$. Instruments of war and their legitimate employment.

$\$ 470$. Evolution of military codes.

\$471. Combatants, lawful and unlawful. Theater of war.

\$72. Regular forces.

§47. Irregular forces: employment of savage against savage.

\$474. Except as against their kind, employment of savages now condemned.

\$475. Guerrillas and banditti.

\$476. Levies en masse.

\$77. Weapons to disable an enemy without unnecessary suffering.

\$78. Unlawful weapons. Efforts to prohibit their use.

$\$ 479$. Recent conferences on the subject of weapons.

\$480. No exemption for crowned heads and officers in actual battle. Pickets and sentinels.

\$481. Devastation as a means of offence.

\$82. Devastation as a means of defence.

§483. Sieges and bombardments. Starvation.

$\$ 484$. Storming and sacking of towns.

$\S 485$. Unjustifiable resistance.

\$486. The giving of quarter.

\$487. Retaliation and reprisals.

§488. How far deceit may be used against an enemy.

$\$ 489$. Assassination or injury by treachery never permissible.

$\S 490$. Bribery.

\$491. Guides.

§492. Spies. Employment of balloons.

$\S 493$. Deserters.

\section{CHAPTER IV.}

\section{RIGHTS AND DUTIES OF BELLIGERENTS DURING HOSTILITIES} AT SEA.

§494. Rules of land war observed at sea so far as they apply.

§495. General object of naval warfare. Armed forces of the state at sea.

§496. Ships with commissions of war. Origin of permanent fleets.

Vessels without commissions.

§497. Rules governing privateers. 
\$498. Neutral territorial waters not to be violated by naval combats. \$499. Bombardments from the sea not limited to fortified places.

\$500. When artifice is permissible at sea. Naval battles between fleets or single vessels.

\$501. Surrender at sea.

\$502. Who are to be regarded as prisoners at sea. Their treatment. \$503. Application of Red Cross conventions to wounded at sea.

\$504. Religious and medical staff.

$\$ 505$. Hospital ships.

\$506. Effect of rescue by a neutral.

$\$ 507$. Naval reprisals.

\section{CHAPTER V.}

\section{LIMITATION, SUSPENSION AND CONCLUSION OF HOSTILITIES.}

\$508. How non-hostile relations are established.

\$509. Cartels; postal and telegraphic communications; cartel ships.

\$510. Flags of truce. Political conferences.

\$511. Safe-conducts, passports and safeguards.

8512. Licences to trade defined; by what authority granted; how

licences are to be construed; course of voyage; time limited

in licence; licences to trade becoming obsolete.

8513. Suspensions of arms, armistices and truces. Revictualling a besieged place.

\$14. Capitulations. Destruction of stores. When surrender is complete.

§515. Sponsions. Capitulation of El Arish in 1800. Capitulation of Gen. Joseph E. Johnston in 1865.

\$516. Hague rules regulating capitulations and armistices.

\section{CHAPTER VI.}

\section{LAWS OF WAR AS TO ENEMY PERSONS.}

\$517. Effect of domicil in an enemy's country.

§518. How far private rights are to be respected by a conquering army.

\$519. Killing and enslaving of prisoners.

\$520. Who arc prisoners of war. Can they ever be slain rightfully? \$521. Treatment of prisoners: wills, burials, employment, pay, escape, ncutral territory, enlistment.

\$522. Bureau of information and relief societies.

\$523. Parole and its obligations.

§524. Exchange of prisoners.

\$525. The giving of liostages.

\$526. Punishment of military offences by martial law.

\$527. Care of the wounded. Neutralization of certain persons and things.

\$528. Geneva Convention of 1864 ; supplemented in 1868 ; inadequate to new conditions. 


\section{CHAPTER VII.}

\section{LAWS OF WAR AS TO ENEMY PROPERTY ON LAND.}

\$529. How far property of the enemy, public and private, may be appropriated during war.

\$30. When title to personal property on land passes.

§51. State personal property subject to seizure as booty.

\$532. Dangers of pillage and its abolition.

\$533. Exemption in favor of holders of public securities.

\$534. Exemption in favor of works of art, libraries and museums.

\$53. Right of occupying army to use state property; its alienation.

\$536. Exemption of churches, cemeteries and the like.

\$537. Exemption of private property.

§538. Requisitions.

\$539. Distinction between requisitions and contributions. Washington.

\$50. Confiscation and sequestration.

\$541. Right of seizure as affected by owner's domicil.

\$542. Right of seizure as affected by situs of the property itself.

\$543. When cotton or other articles may be "constructive contraband."

§544. How a district may be internationalized.

\section{CHAPTER VIII.}

\section{LAWS OF WAR AS TO ENEMY PROPERTY AT SEA.}

\$545. Property liable to capture at sea.

\$546. Property exempt from capture for humanity's sake. Hospital and cartel ships, and fishing boats. Vessels engaged in scientific expedition's. Vessels in distress. Merchant vessels afloat at declaration of war.

\$54. Tendency to exempt all private property not contraband from capture at sea.

§548. Rules defining enemy property at sea. Actual ownership; suum cuique.

\$549. Doctrine of the Consolato first changed by the French. Hostile infection.

\$550. Further variations established by the Dutch. Nationality of ship.

\$551. Declaration of Paris, 1856. Free ships-free goods.

\$552. Nationality of vessel; change of ownership.

\$553. Change of cargo; questions as to consignments.

$\$ 554$. What constitutes capture at sea.

\$55. Naval capture on land.

$\$ 556$. Joint capture.

\$557. Bringing prize in for adjudication. Destruction.

\$55. Ransom; hostage.

\$559. How captor's rights may be lost. Recapture and postliminy. Salvage.

\$560. Exceptions to rule of postliminy.

$\$ 561$. Ownership of the prize. Rule as to privateers. 
§562. Damages for wrongful capture.

\$563. Prize courts.

\$564. Prize jurisdiction, its nature and extent.

\$565. Where prize courts should be held.

$\$ 566$. Procedure in prize cases.

$\$ 567$. Finality of decree.

\section{CHAPTER IX.}

\section{MILITARY OCCUPATION AND ADMINISTRATION.}

\$568. Ancient theory of substituted sovereignty.

$\$ 569$. Modern theory of quasi sovereignty of belligerent occupant.

\$570. Military authority over hostile territory as limited by Hague Conference.

8571. When military occupation begins and ends. Contention of smaller states.

\$572. Contention of great military states. Conclusions reached at Brussels and The Hague.

\$573. Legal relation of subdued inhabitants to occupying state. Suspended sovereignty of prior owner.

\$574. Legal relation of inhabitants of occupied territory to third states.

\$575. When territory may possess at same moment a neutral and belligerent character.

\$576. Duty of occupant to govern. Nature and extent of his authority. \$577. Punishment of crimes in occupied territory.

\$578. Suspension of political and continuance of municipal laws.

\$579. Military occupation under Constitution of the United States.

\section{CHAPTER $\mathrm{X}$. \\ TERMINATION OF WAR.}

$\S 580$. How war may be terminated.

$\$ 581$. General principles affecting treaties of peace.

\$582. Effect of peace on pre-existing treaties.

\$583. Usual bases of peace; status quo; uti possidetis; amnesty.

8584. Cessation of hostilities.

§585. Conquest and its effects.

\$586. Public property after conquest.

\$587. Effects of conquest on laws, municipal and political.

$\$ 588$. Private property unaffected by change of sovereignty.

\$589. Suppression of a rebellion.

$\$ 590$. Treaty of peace.

\$591. Interpretation.

\$592. Indemnity and guarantees.

\$593. Cession perfected by delivery of possession.

\$594. Violation of treaty.

\$595. Postliminy as applied to states or provinces. 


\section{PART V.-RIGHTS AND DUTIES OF NEUTRAL STATES.}

\section{CHAPTER I.}

\section{ORIGIN AND GROWTH OF THE LAW OF NEUTRALITY.}

\$596. Dim conceptions of neutrality in Greek and Roman world.

\$597. Neutrality incompatible with theory of Medieval Empire.

$\$ 598$. Absence of rule as to neutral duty in sixteenth century.

\$599. Growth of the principle of neutrality in seventeenth century. Grotius.

$\$ 600$. Theory of neutrality as defined by the publicists of eighteenth century: Bynkershoek, Wolf, Vattel, Martens.

\$601. Sweden's protest against succor furnished by Denmark to Russia in 1788 .

§602. Conflict between Great Britain and Spain in 1804 .

\$603. Struggle for the freedom of neutral commerce.

$\$ 604$. Rule of War of 1756 .

$\$ 605$. First Armed Neutrality League of 1780 .

$\$ 606$. Second Armed Neutrality League of 1800 .

\$607. Neutral territorial rights vindicated by United States. Proclamation of April 22, 1793.

\$608. Illegal acts of the French Minister Genet. Executive orders of June 5th and August 4th, 1793.

\$609. Trial of Gideon Henfield, July, 1793.

\$610. American Foreign Enlistment Acts of 1794 and 1818.

\$611. British Foreign Enlistment Acts of 1819 and 1870.

§612. Law of neutrality as between state and state.

\$613. Law of neutrality as between states and individuals.

\section{CHAPTER II.}

\section{DUTIES OF NEUTRAL TOWARDS BELLIGERENT STATES.}

§614. General scope of neutral duties defined.

\$615. Standards of neutral duty prior to 1871. Codes of France, Italy, the Netherlands, Austria, Spain, Portugal and Denmark.

\$616. The Three Rules of the Treaty of Washington, 1871: As construed by the counsel of the United States; as construed by the counsel of Great Britain; as construed by the arbitral court.

Criticisms of arbitral definition of "due diligence." Intent as the test of guilt. The character of the ship as the test. Practical value of arbitral decree.

§617. Declarations of neutrality.

\$618. Neither armed assistance nor other aid to be granted under pre-existing treaty.

\$619. No levying of soldiers in neutral territory.

\$620. No passing of belligerent troops through neutral territory. 
\$621. Internment of belligerent soldiers in neutral territory.

\$622. Neither gifts nor loans of money to be made by neutral to belligerent states.

§623. Neutral individuals may lend money to belligerent states.

\$624. Neither arms nor instruments of war can be furnished by a neutral to belligerent state. An exception.

\$625. Neutral individuals may supply instruments and materials of war to belligerent state. Sale of warships.

\$626. Neutral territory not to be used as base of operations for warlike expeditions, military or naval.

\$627. Warlike expeditions organized outside of neutral territory from elements issuing separately from it.

\$628. Neutral states should prevent acceptance of letters of marque by their citizens.

\$29. Power of neutral state to prevent infractions of its neutrality.

$\$ 630$. Reparation by neutral state for failure to perform its obligations as such.

\section{CHAPTER III.}

\section{DUTIES OF BELLIGERENT TOWARDS NEUTRAL STATES.}

\$631. Notice to neutrals of commencement of war.

\$632. Hostilities not to be carried on in neutral territory.

§633. No direct preparation for hostile acts to be made in neutral territory.

\$634. All reasonable regulations for protection of neutrality to be respected.

\$635. Belligerent warships in neutral waters. Hospitality and asylum. Substance of Azuni's rules. Negrin's rules.

\$636. The twenty-four hours rule. Nashville and Tuscarora.

\$637. Sale of a belligerent warship in a neutral port. Case of the Sumpter. Buying and selling of merchant vessels.

§638. Belligerent's right to hold captured persons in neutral territory. $\$ 639$. Belligerent's right to deal with prizes in neutral ports.

$\$ 640$. Attack of one belligerent upon another in neutral waters. Effect of resistance to unlawful attack in neutral waters. Case of the Gen. Armstrong.

\$641. Belligerent right of angary. Right of angary as exercised during the Franco-Prussian War of 1870-71.

8642. Reparation to neutral state for violation of its neutrality.

\section{OHAP'TER IV.}

\section{LEGITIMATE NEUTRAL COMMERCE.}

\$643. Belligerent states and neutral individuals.

\$644. Conflict between neutral and belligerent interests.

$\$ 645$. Rule of the Consolato-ownership of goods as the test.

\$646. French invention of hostile infection.

\$647. Dutch rule-nature of the vehicle as the test. 
§648. British theory and practice.

$\$ 649$. Armed neutralities of 1780 and 1900 .

$\$ 650$. American theory and practice.

Rule of the Consolato adopted by the American judiciary. An exception. Conventional law as to free ships, free goods.

\$651. Declaration of Paris, 1856.

$\$ 652$. Effect of the final clause of the Declaration.

\section{CHAPTER V. CONTRABAND TRADE.}

§653. Ancient and medieval history of contraband.

\$654. Grotian definition of contraband.

$\$ 655$. Articles absolutely contraband-arms and munitions of war.

\$656. Articles which may or may not be contraband-Res ancipitis usus.

§657. Materials and machinery for manufacture of arms and munitions of war.

§658. Materials for naval construction.

\$659. Horses as contraband.

$\$ 660$. Coal as contraband.

\$661. Provisions as contraband.

\$662. Money, metals, cotton, and clothing.

\$663. Power to declare what is contraband. Conditional contraband.

$\$ 664$. State responsibility for individual action.

\$65. Belligerent destination. Deposit.

\$666. Penalty for carrying contraband; modifications by treaty; preemption.

\section{CHAPTER VI.}

\section{NEUTRAL SERVICES, LA WVEL AND UNLAWFUL.}

\$667. Distinction between unneutral service and the carrying of contraband.

§668. Lawful neutral service. Carriage of private, diplomatic and consular correspondence. Should postal vessels and mail bags be exempt from search?

§66. Transport of diplomatic agents. The Trent Affair.

$\$ 670$. Ulawful neutral service. Transmission of signals or messages for a belligerent.

\$671. Carrying of prohibited despatches or persons for a belligerent.

\$672. Neutral vessels engaged as transports in service of belligerent.

\$673. Penalty for the performance of unneutral service.

\section{CHAPTER VII.}

\section{BLOCKADE.}

\$674. Blockades as compromises between belligerent and neutral interests. Armed Neutralities and Declaration of Paris. 
\$675. Classification of blockades-strategic, commercial and pacific.

$\$ 676$. I.aw of blockade as construed by two distinct schools.

\$677. By what authority and within what limits blockades may be instituted. Access to contiguous territory.

$\$ 678$. Blockades to be binding must be effective. Opinions of Continental publicists.

\$679. How knowledge of blockade must be communicated to neutrals. French theory and practice.

\$680. What acts constitute a breach of blockade: English and American rule; case of the Circassian; French rule.

\$681. Right of ingres and egress to and from a blockaded port; period usually allowed for exit; licenses.

$\$ 682$. Effect of the cessation of blockade.

\$683. Doctrine of continuous voyages as applied to breach of blockade. \$684. Penalty for breach or attempted breach of blockade.

\section{CHAPTER VIII.}

\section{RIGHT OF VISIT AND CAPTURE.}

$\$ 685$. Visit and capture in time of peace.

$\$ 686$. Visit and capture in time of war. Nature and scope of the right. $\$ 687$. Formalities of visit.

\$688. Examination of ship's papers.

§689. Effect of resisting visit and search. Conflicting English and American rules.

\$690. Other grounds justifying capture.

$\$ 691$. Duties and liabilities of a captor.

\$692. Burden on captor in prize court.

\$693. Can convoyed ship be visited? Continental practice. English and American practice. Controversy between United States and Denmark as to convoy. 


\section{LIST OF AUTHORITIES CITED.}

Adams, Charles Francis, 1807-1886: Life of, by C. F. Adams, Jr. Boston, 1900 .

Adams, John Quincy, 1767-1848: Memoirs, comprising portions of his diary from 1795 to 1848, edited by C. F. Adams. Phila., 1874-77.

Aguesseau, D'. H. F., 1668-1751: Oeuvres complêtes. Paris, 1819.

Alison, Sir Archibald, 1792-1867: History of Europe from the commencement of the French Revolution to the Restoration of the Bourbons in 1815; History of Europe from the fall of Napoleon in 1815 to the accession of Louis Napoleon in 1852. Blackwood, 1849 and 1856.

Allgemeines Landrecht für die preussischen Staaten.

American State Papers.

American and English Enc. of Law, 2d ed., 1896.

Angeberg, D'.: Recueil des traités, etc., concernant la guerre FrancoAllemande.

Annual Register (The), or a view of history, politics and literature. London, 1758.

Annuaire des Deux Mondes: Histoire général des divers Etats. Paris, 1850-1867.

Annuaire de l'Institut de Droit International.

Aquinas, Thomas, 1224-1274: De Regimine Principum.

Archives Diplomatiques. Recueil de diplomatie et d'histoire. Paris, 1861-1870.

Austin, John, 1790-1859: Province of Jurisprudence Determined. 2d ed., Murray, 1861; Lectures on Jurisprudence (a sequel to the first named), 4th ed., Murray, 1879.

Ayala, Balthazar de, 1548-1584: De jure belli et officiis bellicis et aisciplina militari libri tres. Antwerp, 1597.

Azuni, D. A., 1749-1827: Système universel de principes du droit maritime de l'Europe, traduit de l'italien, avec des additions du même auteur, par J. M. Digeon, 1799. Translated from French into English by William Johnson, New York, 1806.

Bagehot, Walter, 1826-1877: The English Constitution. London, 1896.

Baker, Sir Sherston, b., 1846: Halleck's International Law, 3d ed. London, 1893. First Steps in Int. Law, Boston, 1899.

Bancroft, George, 1800-1891: History of the formation of the Constitution of the United States, 1886.

Barbeyrac, Jean, 1674-1744: Translations in French of the works of Grotius, Puffendorf and Bynkershoek, with dissertations.

Bar, Karl Ludwig von, b., 1836: Das Internationale Privat- und Straf. recht. Translated by G. R. Gillespie, 2d ed., 1892.

Beaconsfield, Earl of, 1805-1881: Collected Speeches.

Bekker-Marquardt: Röm. Alterthüm. 
Bello, Andrès, 1780-1565: Principios de derecho de gentes. Edition, annotated by Sr. Don Carlos M. Silva, Madrid, 1883.

Bemis, G.: American Neutrality, Boston, 1866; Pamphlets on the Recognition of Belligerency, Boston, 1865.

Bentham, Jeremy, 174S-1S32: Works.

Bernard, Montague, 1820-1882: Four lectures on subjects connected with diplomacy, London, 1868; An historical account of the neutrality of Great Britain during the American Civil War, London, 1870 .

Bertodano: Collection de traités de paix, d'alliance, de neutralité. from 1598 to 1700 . Madrid, 1740 .

Bigelow, John, b., 1817: France and the Confederate Navy.

Bisehof, A.: Katechismus des Völkerrechts. Leipzig, 1877.

Blackstone, Sir William, 1723-1780: Commentaries on the Laws of England.

Bloch, J. S.: Future of War, 1899.

Bluntschli, Johann Kaspar, 1808-1881: Das Moderne Vülkerrecht der Civilisirten Staten als Rechtsbueh Dargestellt, 1878; Geschichte des allegemeinen Staatsrecht, etc., 1881; Das Beuterecht im Kriege. 1878 .

Boroughs, Sir John: The Soveraignty of the British Seas. London, 1651.

Bourrienne, L. A. F., 1769-1834: Memoirs of Napoleon Bonaparte.

Bowyer, Sir George, 1811-1883: Commentaries on universal public law. London, 1834.

British Admiralty Manual of Prize Law (Holland), 1888.

British and Foreign State Papers, compiled by E. Hertslet. 1812-1852, London.

Broglie, de, Duc, 1785-1870: Sur la Piraterie. Ecrits.

Brougham, Henry Lord, 1778-1868: Works.

Brunus, Conradus (Conrad Braun), 1493-1563: De legationibus; De seditionibus.

Bryce, James, b., 1838: Holy Roman Empire, 8th ed., 1886; The American Commonwealth, 1889.

Bulmerineq, A., b., 1822: Das Völkerrecht in Marquardsen's Handbuch; Le Droit des Prises Maritimes in Rev. de Droit Int.

Bulwer, W. H. L. E., 1801-1872: Life of Lord Palmerston.

Burlamaqui, Jean Jacques, 1694-1748: Principes du Droit de la Nature et des Gens, 1747. (New ed. by M. Dupin, 1820-1821.) Principes du Droit Politiquc. Genève, 1751.

Bury, La neutralité de la Suisse. Revue de Droit Int. 1870.

Burke, Edmund, 1730-1797: Works.

Bynkershoek, Cornelius van, 1673-1743: De Dominio Maris (1702); De Foro Legatorum (1721); Quaestiones Juris Publici (1737); all contained in the second volume of his Opera Omnia, Leyden, 1767.

Cæsar, Calus Julius, B. C. 100-44: De Bello Gallico.

Calhoun, John C., 1782-1850: Works. 
Calvo, Carlos, b., 1824: Derecho internacional teorico y practico de Europa y America, first published in Spanish, at Paris, in 1868, soon reappeared in French as Le Droit International Théorique et Pratique précédé $a^{*} u n$ exposé historique des progrès de la science du droit des gens. $2 \mathrm{~d}$ ed., 1870, 1872; 3d ed., 1880. Recueil com. plet des traités, etc., depuis l'annće 1493 jusqu'à nos jours, etc. Paris, 1862-1869.

Camden, William, 1551-1623: History of Elizabeth.

Canning, Charles John, Earl, 1812-1862: Speeches.

Caratheodory, Etienne, $D u$ droit international concernant les grands cours deau. Etude thćorique et pratique sur la liberté de la navigation fuviale. Leipzig, 1861.

Carlyle, Thomas, 1795-1881: History of Frederick the Great.

Carnazza-Amari: Traité de Droit International Public. Paris, 1880 . 1882.

Casaregis: Discursus Legalis de Commercio.

Cauchy, Eugène, 1802-1877: Le droit maritime international. Paris, 1862.

Chalmers: Collection of Treaties.

Chemnitz, Philipp Bogislaw, von: De Ratione Status in Imperio nostro Romano-Germanico, about A. D. 1648.

Chrysippus, 280-206 B. C.: apud Plut. de Stoic; apud Diog. Laert.

Cicero, M. T., 106-43, B. C.: De Orat.; De Off.; De Repub.; De Legib.

Clarke, Edward: A treatise upon the law of extradition. London, 1867.

Cleirac: Les Us, et Coutumes de la Mer. Bordeaux, 1647.

Clercq, A. de: Recucil des traités de la France. Paris, 1864-1872.

Coceeius: De postliminio in Pace et Amnestia; Grotius Illustratus.

Cockburn, Alexander J. E., Sir, 1802-1880: On Nationality.

Code Pénal of France.

Coke, Edward, Sir, 1552-1634: Institutes; Reports.

Comte, Auguste, 1798-1857: Positive Philosophy.

Congressional Documents of the United States.

Consolato del Mare. Barcelona, 1494; Venet, 1584.

Constitution of Argentine Confederation.

Cooper, Thomas: Institutes of Justinian.

Correspondence of Napoleon.

Coulanges, Fustel de: The Ancient City. Small's trans. Boston, 1874.

Creasy, Edward S., Sir: First Platform of International Law, 1876.

Croker, John W., 1780-1857: Croker Papers.

Cunningham, W.: The Growth of English Industry and Commerce. Cambridge, 1890, 1892.

Curtis, George Ticknor, 1812-1894: The Case of the Virginius, considered with Reference to the Law of Self-defense.

Dareste, Rudolphe: La Science du Droit en Grèce. Platon, Aristote, Théophraste. Paris, 1893.

Dalloz, D.: Répertoire méthodique et alphabétique de législation, etc. Paris, 1846-1864.

Dante, Alighieri, 1265-1321: De Monarchia.

Daru, Pierre Antoine, Comte de, 1767-1829: Histoire de Venise. Paris, 1821. 
Davis, George B.: Outlines of International Law, 1887.

Davis, J. C. Bancroft, b., 1822: Notes on Treaties of the United States, 1873; Les tribuneaux de prises des Etats-Unis. Paris, 1878.

Demolombe: Cours de Code Napolíon.

Denman, George L.: Broom's Constitutional Law. London, 1885.

Dicey, A. V.: The Conflict of Laws, with notes of American cases, by John Bassett Moore. London, 1896.

Diplomatic Correspondence of the United States.

Duer, John, 1782-1858: A Treatise on Insurance.

Dumont, Jean, 1726: Corps universel diplomatique du droit des gens, contenant un recueil des traités d'alliance, etc. (de 800 a 1731). Amsterdam et La Haye, 1726-1731.

Elliot, J.: The American Diplomatic Code, embracing a collection of treaties, etc., between the United States and foreign powers from 1778 to 1834 . Washington, 1834 .

Emerigon: Traité des assurances et des contrats à la grosse, etc. Nouvelle édition, Rennes, 1827.

Encyclopadia Brittanica, 9th ed.

Engelhard: Du rígime conventionel des feuvres.

Entick: History of the Late War.

Federalist Papers, by Madison, Hamilton and Jay. Dawson ed.

Field, David Dudley, 1805-1894: Outlines of an International Code, 2d ed. New York, 1876.

Fiore, Pasquale: Nouveau droit international public suivant les besoins de la civilization moderne. Paris, 1869. Droit International Codifié, 1890.

Flassan (De): Histoire gínírale et raisonnée de la diplomatie francaise. 2d corrected ed. Paris, 1811.

Flinders' Voyages.

Foelix, Jean Jacques Gaspard, 1791-1853: Traité de droit international prive. First ed. $1843 ; 4$ th revised, Paris, 1866.

Forsyth: Cases and Opinions, etc. London, 1869.

Foster: Crown Law.

Foster, John W.: A Century of American Diplomacy. Boston, 1900.

Frederick II., 1712-1788: Oeuvres de.

Freeman, Edward Augustus, 1823-1892: History of Federal Government, 1863; History of Norman Conquest, 1867-76; Comparative Politics, 1873; Historical Geography of Europe, 1881; Historical Essays, 1872-82.

Fyffe, Charles A., 1845-1892: A History of Modern Europe, 1880-1890.

Gaius, 130-180: Institutes.

Gallatin, Albert, 1761-1849: Works of; edited by Henry Adams, Phila., 1879.

Galiani, Ferdinando, 1728-1786: Dei doveri dei Principi Neutrali verso $i$ Prineipi Guerreggianti e di questo verso $i$ Principi Neutrali. Naples, 1782.

Garden, Comte de: Traité complet de diplomatie, ou théorie génirale des relations extérieures des puissances de l'Europe. Paris, 1833; II istoire des Traití's de Paix, etc., of which fourteen volumes appeared before 1859 , without indication of year. 
Gardiner, Samuel R., b., 1829: England Under the Duke of Buckingham and Charles I.

Gardner: Institutes of American Law.

Gayarré, Charles E. A., 1805-1895: History of Louisiana, 1866.

Geffcken, Friedrich H., 1830-1896: Notes in Heffter's Völkerrecht, 1880.

Geneva Arbitration, 1871: Case of the United States; Case of Great Britain; British counter case, etc.

Gentilis, Albericus (Alberico Gentile), 1552-1608: De Legationibus, libri tres, London, 1585; De Jure Belli commentatio prima, London, 1588; Hispanicae advocationis, libri duo, Hanau, 1613.

Gentz, von, Friedrich, 1764-1832: Fragments Upon the Balance of Power in Europe, 1806.

Gessner, L.; Le Droit des Neutres sur Mer, Berlin, 1865; Zur Reform des Kriegs-Seerechts, Berlin, 1875.

Ghillany, F. G., Manuel Diplomatique, Nordlingen, 1856.

Gibbon, Edward, 1737-1794: Decline and Fall of the Roman Empire, Milman ed., 1839 and 1845.

Glass: Marine International Law.

Glenn, Edwin F.: Hand-Book of International Law. St. Paul, 1895.

Goldschmidt, Dr.: Projet, submitted to the Institut de Droit International, 1874.

Green, John Richard, 1837-1883: History of the English People, 1877-80.

Grote, George, 1794-1871: History of Greece, 1846-1856.

Gravier, Jurien de la: Les Marines du XVe et $d u$ XVIIe sic̀cle.

Greville, Charles C. F., 1794-1865: Memoirs and Diary, 1st series, 4th ed., 1874; 2d series, 1884.

Grotius (Huig van Groot) Hugo, 1583-1645: De jure praedae commentarius, written in 1604 , brought to light and printed at The Hague, under the auspices of Prof. Fruin in 1868; Mare Liberum, nothing more than a chapter-the 12 th-of the $D e$ jure praeda, 1609; De Jure Belli ac Pacis, Libri Tres, Paris, 1625; De Rebus Belgicis, or, the Annals of the Low-Countrey-Warres, published by his sons, Peter and Cornelius, in 1657, and rendered into English by T. M. of the Middle Temple. London, 1665.

Guhl (E.) and Koner (W.): The Life of the Greeks and Romans, translated from the third German edition by F. Hueffer. New York, 1876.

Guicciardini, Francesco, 1482-1540: The History of Italy. Translated by Austin P. Godard, London, 1763.

Guidon de la Mer, 16th century.

Guizot, François P. G., 1787-1874: History of Representative Government.

Günther, Carl Gottlob, 1852-1832: Grundriss eines europäischen Völkerrechts. Ratisbon, 1779.

Gurwood's Selections from Wellington's Despatches. London, 1842.

Hadley, James, 1821-1872: Introduction to Roman Law. New York, 1898.

Hakluyt, Richard, 1553-1616: Hakluyt Society's ed. of the Divers Voyages.

Hale, Matthew, Sir, 1609-1676: History of the Pleas of the Crown, 1739. 
Hall, William Edward, 1835-1894: A Treatise on International Law. 4th ed., Oxford, 1895.

Hallan, Henry, 1777-1859: View of the State of Europe during the Middle Ages. Sth ed., 1841.

Halleck, Gen. Hemry Wager, 1815-1S72: International Law or Rules Regulating the Intercourse of States in Peace and War, San Francisco, 1S61. In 18\%8 Sir Sherston Baker edited the work, "leaving the original text untouched." In $1 \$ 93$ he published a $3 \mathrm{~d}$ ed. (London: Kegan Paul, T. T. \& Co., Ltd.), in which he has "endeavored to make the work more useful to the reader, by omitting all portions of the text which contained incorrect or obsolete law," etc. An edition of Halleck's Elements of International Law and Laws of War appeared at Phila. in $18 \pi 4$.

Hamilton, Alexander, 1757-1S04: Works, edited by H. C. Lodge.

Hamilton, P. J.: Colonial Mobile, Boston, 1897.

Hansard: Parliamentary Debates.

Harcourt, W. G. G. V. V., Sir, b., 1827: Letters of Historicus on some Questions of International Law; reprinted from the Times, with considerable additions. London and Cambridge, 1863.

Hassall, Arthur: Louis XIV.

Hautefeuille, Laurent B., 1805-1875: Les droits et les devoirs des nations neutres en temps de guerre maritime, 1848; Histoire des origines, des progris et des variations du droit maritime international, 1858; Quelques questions du droit international, 1861; Questions de droit maritime international, 1868. Paris.

Hazard's Historical Collections.

Heffter, August Wilhelm, 1796-18\$0: Das Europäische Völkerrecht der Gegenwart auf den bisherigen Grundlagen. Berlin, 1844. Geffcken's Notes, 1880.

Heineccius, Johann Gottlieb, 16\$1-1741: Elementa juris naturae et gentium; Halle, 1738; translated into English, 1742, by G. Turnbull.

Henry's Admiralty Jurisdiction.

Herodotus, 484?-420? B. C.: History. Gaisford ed., Oxford, 1840.

Hertslet, Edward, Sir: The Map of Europe by Treaty, Showing the Political and Territorial Changes since the General Peace of 1814. London, 1875.

Hertslet, Lewis: A complete collection of the treaties, etc., subsisting between Great Britain and foreign powers, etc. London, 18201856.

Hildreth, Richard, 1807-1865: History of the United States. 2d ed., New York, 1851, 1852.

Hobbes, Thomas, 1588-1679: De Cive. Leviathan, 1651.

Höhlbaum, C.: Hansisches Urkundenbuch. Halle, 1876.

Holland, Thomas Erskine, b., 1835: Elements of Jurisprudence, 1880;

The European Concert in the Eastern Question, 1885; Studies of International Law, 1898; Holland's edition of Gentilis, 1877.

Hooker, Richard, 1554-1600: Laws of Ecclesiastical Polity.

Holls, Frederick W.: The Peace Conference at The Hague. New York, 1900.

Holtzendorff, F., von: IIandbuch des Tölkerrechts. Berlin, 1885. 
Homer: Iliad.

Hosack, J.: The Rise and Growth of the Law of Nations, etc. London, 1882.

Howell's State Trials.

Huber, Ulric, 1635-1694: De Conflictu Legum.

Hübner, Martin von, 1723-1795: De la Saisie des Bâtiments neutres. La Haye, 1759.

Hüllmann, Städtewesen des Mittelalters.

Ihering, R. von: Evolution of the Aryan.

Institut de Droit International: Important acts embodied in the documents enumerated in $\S 48$.

Instructions for the Government of the Armies of the United States in the Field, 1863. Dr. Francis Lieber.

Jefferson, Thomas, 1743-1826: Memoir, Correspondence, etc., edited by T. J. Randolph, Charlottesville, 1829; Tucker's Life, Phila., 1837. Jenkins, Leoline, Sir, 1623-1685: Life of by William Wynne. London, 1724.

Jenkinson, Charles (first Earl of Liverpool), 1727-1808: Discourse on the conduct of the Government of Great Britain in respect to neutral nations. London, 1801.

Jenks, Edward: Law and Politics in the Middle Ages. New York, 1898.

Johnston, Gen. Joseph E., 1809-1891: Narrative of Military Operations. New York, 1874.

Jomini, Antoine H., 1779-1869: Précis de l'art de la guerre. 5th ed., Paris, 1838; Des guerres de la Révolution de 1792 à 1801. Paris, 1819-1824.

Journals of the Congress of United States.

Journal de Droit International Privé; publié par M. Ed. Clunet, Paris. Justinian, 483-565: Code, Pandects and Institutes.

Kaltenborn von Stachau (Karl von), 1819-1866: Kritik des Völkerrechts; die Vorlaïfer des Hugo Grotius. Halle, 1848.

Kamarowski: Le Tribunal International.

Kamptz, Karl Albert von, 1769-1849: Neue Litteratur des Völkerrechts. Berlin, 1817.

Kant, ImmanueI, 1724-1804: Rechtslehre.

Kent, James, 1763-1847: Commentaries on American law. Commentary on international law, edited by J. T. Abdy ( $2 \mathrm{~d}$ ed.), London, 1878.

Kleen, M. Richard: Contrebande de Guerre, 1893.

Klüber, Johann Ludwig, 1762-1836: Droit des gens moderne de l'Europe. Nouvelle édition, revue, annotée et complétée par A. Ott, Paris, 1801; Acten des Wiener Congresses in den Jahren 1814 und 1815. Erl., 1815-1830.

Koch, C. G. de: Histoire abrégée des traités de paix, etc. Recast by F. Schöll, Paris, 1817-1818.

Lampredi, Giuseppe Maria, 1732-1793: Del commercio dei popoli neutrali in tempo di guerra. Florence, 1788.

Lanfrey, Pierre, 1828-1877: Histoire de Napoléon. 
Las Siete Partidas, Spanish Code of.

Laurent, F.: Histoire du droit des gens et des relations internationales.

2d corrected ed., Brussels, 1861-1868.

Law Quarterly Review.

Lawrence, T. J.: The Principles of International Law. Boston, 1898.

Lawrence, William Beach, 1800-1881: Commentaire sur les ćlements du droit international et sur lhistoire des progris du droit des gens, par Henry Wheaton. Leipzig, 1868.

Laws of Oléron and of Wisbuy.

Leech, H. Brougham: All Essay on Ancient International Law. Dublin, 1877.

Leibnitz, Gottfried Wilhelm, 1646-1716: Codex juris gentium diplomaticus; Mantissa codicis juris gentium diplomatici. 1693, 1700. Hanover.

Loccenius, Jean: De jure maritimo et navali. Holmiae, 1652.

Locke, Joln, 1632-1704: Essays on Civil Government.

Lodge, H. C.: Life of Alexander Hamilton. Boston, 1882.

Lorimer, James, b., 1818: The Institutes of the Law of Nations. Edinburg and London, 1884.

Liry, Titus, B. C. 59, A. D. 18: History.

Lyman, Theodore: Diplomacy of the United States. 2d ed., 1828.

Mably, Gabriel Bonnot, de, Abbé, 1709-1785: Le droit public de l'Europe, fondé sur les traités; $3 \mathrm{~d}$ revised ed., Genève, 1764; Observations sur l'Histoire de Gréce.

Macaulay, Thomas B., 1800-1859: Essays.

Machiavelli, Niccolò, 1469-1527: The Prince. Translated by N. H. T.; published by Kegan, Paul \& Co.

Mackeldey's Modern Civil Law.

Mackintosh, James, Sir, 1765-1832: Miscellaneous Works. Ed., 1851.

Madison, James, 1751-1836: Examination of the British doctrine which subjects to capture a neutral trade not open in time of peace. London, ed., 1806; Letters and other writings of. Phila., 1865.

Mahan, Capt. A. T., born 1840: The Influence of Sea Power upon History, 1660-1783, 1890; Influence of Sea Power upon the French Revolution and Empire, 1894; Life of Nelson, 1897.

Mahon, Lord, 1805-1875: History of England, 4th ed. London, 1853.

Maine, Henry James Sumner, Sir, 1822-1S88: Ancient Law, 1861; Village Communities in the East and West, 1871; The Early History of Institutions, 1875; International Law, 1888.

Malmesbury, James H. H., Earl of, 1807-1889: Diaries and Correspondence. London, 1844.

Mamiani, Count, Terenzio: Nuova diretto Europeo. Turin, 1859. Translated into English under the title of Rights of Nations. London, 1860.

Manning, Henry Edward, Cardinal, 1808-1892: Monograph entitled The Pope and Magna Charta; reprinted at Baltimore, 1885.

Manning, William Oke, 1809-1878: Commentaries on the Law of Nations; $2 \mathrm{~d}$ ed., by Amos, 1875.

Marquardsen: Der Trentfall. 
Marshall, John, 1755-1835: Life of Washington.

Marshall, S.: A treatise on the law of marine insurance, etc., by W. Shee, London; 5th ed., 1865.

Martens, Baron Ch. de, 1781-1862: Guide Diplomatique, 5th ed., by Geffcken, Leipzig, 1866; Causes célèbres du droit des gens, Leipzig, 1827; Nouvelles causes célèbres du droit des gens, Leipzig, 1843.

Martens (Baron Ch. de, et Cussy): Recueil manuel et pratique de traités et autres actes diplomatiques, etc. Leipzig, 1846.

Martens, G. F., de, 1756-1821: Précis du droit des gens moderne de l'Europe; notes by Pinheiro-Ferreira, and introduction by $\mathrm{Ch}$. Verge, Paris, 1864. The work, which appeared in French at Göttingen in 1789 , was translated into German by the author in 1796 , and into English by Wm. Cobbett, Phila., 1795.

Recueil des principaux traités de paix, d'alliance, etc., depuis 1761 jusqu'à nos jours, reaches down to 1808, with three volumes of supplements. 2d ed., Göttingen, 1817-1835. The Nouveau Recueil, by the same editor, continued by his nephew, Ch. de Martens, by Saalfeld and Murhard, reaches from 1808 to 1839 . The Nouveau Recueil Général, edited by Murhard, and from the 14 th volume by Samwer and Hopf, has been extended onward, since 1839. The Nouveaux supplements, by Murhard, supply deficiencies down to 1839.

Martens, Fedor Fedorovitch, b., 1845: Les consulats et la jurisdiction consulaire en Orient, 1873; La conflict entre la Chine et la Russie, 1881; Traité de droit international, 1883-87.

Martin, Theodore, Sir, b., 1816: Life of the Prince Consort, 1880.

Martin, B. L. H., 1810-1883: Histoire de France.

Massé, M. G.: Le droit commercial dans ses rapports avec le droit des gens et le droit civil. 2d revised ed., Paris, 1861-62.

Meyer, von: Corpus Juris Confoederationis Germanicae.

Messages and Papers of the Presidents: James D. Richardson, editor, Washington, 1899.

Merlin, Phil. Antoine, 1754-1838: Répertoire universel et raisonné de jurisprudence, 1828.

Miles, Gen. Nelson A.: Military Europe.

Militärische Nothwendigkeit und Humanität.

Mill, John S., 1806-1873: Representative Government; Dissertations and Discussions.

Mittermaier, Karl J. A., 1787-1867: Das deutsche Strafverfahren.

Mitford, William, 1744-1827: History of Greece.

Mohl, Robert von, 1799-1875: Geschichte und Literatur des Staatswissenschaften; Staatsrechts, Völkerrecht und Politik.

Molloy, Charles: De Jure Maritimo et Navali; 3d ed., London, 1682.

Mommsen, Theodor, b., 1817: History of Rome.

Montesquieu, de, Chas., Baron 1689-1755: Esprit des Lois.

Moore, John Bassett: Extradition and Interstate Rendition; International Arbitrations; Monograph on Monroe Doctrine.

Morley, John, b., 1838: Life of Cobden.

Moser, Johann Jacob, 1701-1785: Versuch des neuesten europäischẹn Völkerrechts in Friedens- und Kriegszeiten, 
Mosby, John S.: War Reminiscences.

Suirhead, James: Hist. Int. to the Private Law of Rome, 2d ed., by Heury Goudy, London, 1899.

Müller-Jochmus: Geschichte des Völkerrechts im Alterthum. Leipzig, 1848 .

Napier, W. F. P., Sir, 1785-1860: History of the War in the Peninsula, ed. 1851.

anpoleon Bonaparte, 1769-1\$21: Hemoirs of the History of France, dictated by the Emperor, etc.; Correspondence.

:aturalization and Allegiance, Report of the Royal Commission on the Laws of, 1869.

Naval War Corle of the United States (Stockton), 1900.

Negrin, Don Ignacio de: Estudios sobre el derecho internacional maritimo, Madrid, 1862 .

Nelson, H.: Leading Cases on Private International Law, 1889.

Nettleship, H., 1839-1893: Article on Jus Gentium in the Journal of Philology, Vol. XIII., No. 26.

Neumann, L.: Recueil des traitís et conventions conclus par l'Autriche, avec les puissances itrangîres depuis 1663, etc. Leipzig.

Neutrality Law Commissioners, Report of, 1868.

North American Review, April, 1866, Article entitled “A famous diplomatic despatch."

Nys: LHistoire Litteraire et Dogmatique du Droit International en Angleterre.

Oldendorp: Isagoge, seu Elementaria Introductio Juris Naturae, Gentium et Civilis, Cologne, 1539.

Opinions of the Attorneys-General of the United States.

Ortolan, Eugéne: Des moycns dacquérir le domaine international,ou proprieté d'Etat entre les nations, dapris le aroit des gens public. Paris, 1851.

Ortolan, Léon Félicité Théodore, 1808-1874: Rigles internationales et Diplomatie de la mer, 4th ed., Paris, 1864.

Ompteda, D. H. L. von, 1746-1803: Literatur des gesammten, so wohl natïrlichen als positiven Völkerrechts, Ratisbon, 1785.

Osenbrüggen, E.: De Jure Pacis et Belli Romanorum, liber singularis, Leipzig, 1836.

Palgrave, Francis, Sir, 1788-1861: Rise and Progress of the English Comw., London, 1832.

Pando, J. M. de: Elementos del derecho internacional. Madrid, 1843.

Pardessus, Jean Marie, 1772-1853: Collection de lois maritimes antérieures au XVIII siccle, Paris, 1828-1845; Us et coutumes de la mer, 1847.

Parliamentary history of England from the earliest period to the present time.

Parliamentary Papers: Africa, Egypt, France, North America, Turkey. Parsons, Theophilus, 1797-1882: Law of Contracts, 7 th ed., Boston, 1883.

Parton, James: Life of Andrew Jackson, New York, 1860. 
Perels, F.: Das internationale öffentliche Secrecht der Gegenwart, BerIin, 1882.

Pfeiffer: Das Recht der Kricgseroberung in Bezug auf Staats-capitulation, CasseI, 1823.

Phillimore, Robert, Sir, 1810-1885: Commentaries upon Internationa! Law, in three vols., 1854-1857, reprinted in Philadelphia. A fourti volume on Private International Law appeared in London, in 1861. VoIs. i, ii and iii ( $3 \mathrm{~d}$ ed.) 1879-85; Vol. iv ( $2 \mathrm{~d}$ ed.), 1874.

Pinheiro Ferreira, Sylvestre, 1769-1847: Cours de droit public interne: et externe, Paris, 1820-1838; Commentaires sur le "Prícis du droit des gens" de Martens, Paris, 1831.

Pitt, William, 1759-1806: Speeches.

Pitt-Cobbett: Leading Cases and Opinions on International Law, 2d ed., London, 1892.

Pistoye (A. de) et Duverdy (Ch.): Traité des prises maritimes, Paris, 1859.

Plato, B. C. 429-347: The Laws.

Pollock, Frederick, Sir: Introduction to the History of the Science of Politics, London, 1895.

Polybius, B. C. 210?-128: Histories, Hultsch, 1867-71.

Polson, Archer: Principles of the Law of Nations, London, 1848.

Pomeroy, John Norton: Lectures on International Law, Woolsey ed., New York, 1886.

Poore, B. P.: Charters and Constitutions, compiled under order of U. S. Senate.

Post, Dr. Albert Hermann: Grundriss der ethnologischen Jurisprttdence, Oldenburg and Leipzig, 1894.

Pothier, Robert Joseph, 1699-1772: Oeuvres annotées, etc., par M. Bugnet, 2nd ed., Paris, 1861.

Potter's Dwarris on Statutes and Constitutions, Albany, 1873.

Pradier-Fodéré, P.: La Question de l'Alabama et le Droit des Gens.

Puffendorf, Samuel von, 1632-1694: Elementorum Jurisprudentiae Universalis Libri Duo, the Hague, 1660; De Jure Naturae et Gentium Libri Octo, Lund, 1672; De Officiis Hominis et Civis, 1673.

Pütter, K. Th.: Beiträge zur Völkerrechtsgeschichte und Wissenschaft. Leipzig, 1843.

Püttlingen, von: Handbuch, etc.

Quaritsch, Dr.: Compendium des Europäischen Völkerrechts, Berlin, 1895.

Quintilian, 42?-118: Institutes of Oratory.

Rachel, Samuel, 1628-1691: De Jure Naturae et Gentium, Dissertationes Duo, Kiel, 1676.

Randall, H. S.: Life of Thomas Jefferson, New York, 1858.

Randolph, T. J.: Memoir, correspondence, etc., of Thomas Jefferson, Charlottesville, 1829.

Rattigan, Sir W. H.: Article in the Law Quarterly Review (July, 1899), entitled "The Ancient Jus Gentium of the Aryans."

Raynal, G. T., 1713-1796: Histoire, etc., $d u$ Commerce. New ed., Paris, 1820. 
Rayneval, Gerard de: De la liberté des mers, Paris, 1811; Institutions

du droit de la nature et des gens. New ed., Paris, 1832.

Réal, De: La Science du gouvernement, Paris, 1762-64.

Reeves, John, 1752-1829: History of English Law.

Riformateurs et Publicistes de l'Europe, Paris, 1864.

Riglement d'Organization Judiciaire pour les Procis Mixtes en Egypte.

Annuaire de l'Institut de Droit Int., 1877.

Riquelme, Don Antonio: Elementos de derecho publico internacional, Madrid, 1849.

Revuc de droit international et de législation comparće.

Revue des Deux Mondes.

Report of Royal Commission on Fugitive Slaves, 1876.

Rivier: L'Affaire de l'Alabama et le Tribunal Arbitral de Genève.

Robertson, William, 1721-1793: History of America, 1777.

Robinson's Collectanea Maritima.

Roccus: De Navibus et Naulo, Amsterdam, 1708.

Rolin Jaequemyns: La guerre franco-allemande, dans ses rapports avec le droit international, and other productions in Revue dc Droit International.

Romero, Sr. M.: Mexico and the United States. New York and London, 1898.

Romilly, Samuel, Sir, 1757-1818: Life of; edited by his sons, 1840.

Rotteck und Welcher: Staat's Lexikon.

Rouard de Card: Les Destinces de l'Arbitrage International.

Rousseau, J. J., 1712-1778: Contrat Social.

Rutherforth, Thomas: Institutes of Natural Law, London, 1754. Second American ed., Baltimore, 1838.

Rymer, Thomas, 1641-1713: Foedera. Record Commissioners' ed. See prefaces to Sir T. D. Hardy's Syllabus, 1869-86.

Saalfeld, Fried.: Handbuch des Positiven Völkerrechts. Tübingen, 1833.

Sallust, B. C. 86-35: Jugurtha.

Sainte-Croix, de G. E. J., 1746-1809: Des Anciens Gouvernements Fédcratifs et de la Ligislation de Crite. Paris. an. vii.

Sainte-Pierre, Charles J. C. de, 1658-1743: Projet de paix universelic entre les potentats de leurope.

Savigny, Friedrich Karl von, 1779-1861: System des Heutigen Römischen Rechts. Band, viii. Guthrie's trans. with notes and appendix.

Schlegel, Fried., 1772-1829: Staats-Recht des Königreichs Dänemark.

Schmaus, J. J., 1690-1737: Corpus Juris Gentium Academicum. Leipzig, $1730-32$.

Schmelzing, Jul.: Systematischer Grundriss des Praktischen Europäischen Vülkerrechts. Rudolsladt, 1818-1819.

Schmalz, Theodor A. H. von, 1759-1831: Das Europäische Völkerrecht. Berlin, 1817.

Schouler, James: History of the United States under the Constitution, 1880-82.

Schweickart's (F. Ch.) Napoleon und die Kurhessischen Capitalschuldner. Königsberg, 1833. 
Scott, Winfield, Gen., 1786-1866: General Orders.

Selden, John, 1584-1654: Mare Clausum seu de Dominio Maris. London, 1635.

Semmes, Raphael, Admiral, 1809-1877: Memoirs of Service Afloat. Baltimore, 1869.

Sherman, W. T., Gen., 1820-1891: Memoirs, 1875.

Sirey: Recueil général de jurisprudence.

Smith, Adam, 1723-1790: Wealth of Nations.

Smith, F. E.: International Law. London, 1900.

Smith, G., on Recognition by Great Britain of belligerancy of Southern Confederacy in 13 Macmillan's Mag.

Snow, Freeman: Cases and Opinions on International Law. Boston, 1893.

Soto, Dominic, 1494-1560: De Justitia et jure.

Stanhope, Philip H., Earl, 1805-1875: History of England, 1836-54.

Sparks, Jared, 1789-1866: Diplomatic Correspondence of the American Revolution, Boston, 1829-30; Works and Life of Franklin, Boston, 1836-1840.

Spear, Samuel S.: A Treatise on Extradition, 2nd ed., Albany, 1884. Spencer, Herbert, b. 1820: The Study of Sociology. New York, 1883. Statutes at Large of the United States.

Stapleton's Life of Canning.

Stephen, Sir J. F., 1825-1894: History of the Criminal Law of England. London, 1883.

Stephen's Commentaries on the Laws of England. 12th ed.

Stoerk, Option und Plebiscit bei Eroberungen.

Story, Joseph, 1779-1845: Commentaries on the Conflict of Laws. 6th ed. Boston, 1865.

Stubbs, William, 1825-1900: Constitutional History of England. Oxford, 1880.

Suarez, Francisco, 1548-1617: Tractatus de Legibus ac Deo Legislatore.

Tableau Général de l'Institut de Droit International.

Tacitus, Caius Cornelius, B. C. 55?-117?: Germania; Annals.

Taylor, Hannis: The Origin and Growth of the English Constitution. Boston, 1889-98.

Textor, Johann Wolfgang, 1637-1701: Synopsis Juris Gentium. Bâle, 1680.

Thomas's Leading Cases in Constitutional Law.

Thomasius, Christian, 1655-1721: Fundamenta Juris Naturae et Gentium. Halle, 1705.

Thucydides, B. C. 471?-400?: History of the Peloponnesian War. Jowett's trans., Oxford, 1883, with notes.

Thudichum, Prof. F.: Verfassungsgesch. Schleswig-Holsteins von 18061852. Tübingen, 1871 .

Thurloe, John, 1616-1668: State Papers.

Tocqueville, de, Alexis C. H. C., 1805-1859: De la démocratic en Amirique. 15th ed., Paris, 1868.

Todd, Alpheus, 1821-1884: Parliamentary Government in England.

London, new and revised ed., by S. Walpole, 1892.

Torquemada, de, Juan, 1550-1625: Monarquia Indiana. 
Tucker, George: Life of Thomas Jefferson. Phila., 1837.

Treaties and Conventions of the United States, 1889.

Twiss, Travers, Sir, 1810-1897: The Law of Nations considered as independent political communities: on the rights and duties of nations in time of peace. Oxford, 1861. Same in time of war. 2nd ed., London, 1875. Doctrine of Continuous Voyages, etc., 1877. Belligerent Rights on the High Seas. London, 1884. On International Conventions for Maintenance of Sea Lights, 1885.

Valin, René J.: Commentaire sur lordonnance de la marine du mois d'aồt 1681, avec des notes coordonnant l'ordonnance, le commentaire et le code de commerce, par V Bícane. 2d édition, Paris, 1836. Traití des prises, ou principes de la jurisprudence francaise concernant les prises qui se font sur mer. Rochelle et Paris, 1782.

Vangerow, von: Pandekten.

Vattel, Emeric de, 1714-1767: Le droit des gens, ou principes de la loi naturelle appliqués d̀ la conduite et aux affaires des nations et des souverains. Nouvelle édition, par P. Pradier-Fodéré. Paris, 1863.

Victoria, Francisco, de, 1480-1546: Relectiones Theologicae, of which the sixth part is entitled De Jure Belli. Lyons, 1557.

Vidari, Ercole: Del rispetto della proprietá privata fra gli stati in guerra. Pavie, 1867.

Virgil, P. V. M., B. C. 70-19: Eneid.

Voight, Dr. Moritz: Das jus naturale, aequum et bonum, und das jus gentium der Römer. Leipzig, 1856-75.

Walker, Thomas Alfred: The Science of International Law. London, 1893.

Walpole, Spencer: Foreign Relations. Eng. Citizen Series, London, 1882.

Ward, Robert Plumer, 1765-1846: An enquiry into the foundation and history of the law of nations in Europe, from the time of the Greeks and Romans to the age of Grotius. London, 1795. Treatise on the relative rights and duties of belligerents and neutral powers in maritime affairs. London, 1801.

Warnkönig, Leopold A., 1794-1866: Flandrische Staats- und Rechtsgeschichte, 1835.

Washington, George, 1732-1799: Life of, by Chief Justice Marshall, Phila., 1805. The Writings of, edited by J. Sparks, New York, $1847-48$.

Webster, Daniel, 1782-1852: Works of. Boston, 1851.

Webster, Noah, 1758-1843: Sketches of American Policy.

Webster, Pelatiah, 1725-1795: Political Essays.

Welwood, William, end of the sixteenth, beginning of the seventeenth century: De Dominio maris.

Wellesley, Richard C., Marquess, 1760-1842: Memoirs and Correspondence, 1846 .

Wellington, Arthur W., first Duke of, 1769-1852: Selections from the Despatches and General Orders of Field Marshal the Duke of. London, 1842. By Lieut.-Col. Gurwood.

Wenck, F. A. G.: Codex Juris Gentium Recentissimi. Leipzig, 17811795. It embraces the period between 1735 and 1772 , as a continuation of Dumont's Corps Universel Diplomatique. 
Wharton, Francis, 1820-1889: A Digest of the International Law of the U. S. 2nd ed., Washington, 1887. Criminal Law (9th ed.), Phila., 1885. State Trials of the U. S., Phila., 1849.

Wheaton, Henry, 1785-1848: Digest of the Law of Marine Captures or Prizes, New York, 1815. Elements of International Law, 1836, Phila. and London, the preface being dated at Berlin. An edition was prepared by the author in French, which was published at Leipzig and Paris in 1848. An edition, generally known as the sixth edition, appeared at Boston in 1855 with notes by W. B. Lawrence, and a seventh by the same editor in 1863. The eighth edition, with invaluable notes by R. H. Dana, Jr., appeared at Boston in 1866. Wheaton's Histoire du progrìs du droit des gens en Europe, Leipzig, 1841, was afterwards enlarged into the history of the Law of Nations in Europe and America, from the Earliest Times to the Treaty of Washington, 1842. New York, 1845.

White, H. A.: Lee and the Southern Confederacy.

Whiting, Wm.: War Powers.

Wicquefort, Abraham de, 1598-1682: Liambassadeur et ses fonctions, Cologne, 1679; The Hague, 1680, 1681. Translated into English by Mr. Digby. 2nd ed., London, 1740.

Wildman, Richard, 1802-1881: Institutes of International Law. London, 1829.

Williams, George W.: Negro Race in America.

Wilson, Woodrow, b. 1856: The State. Boston, 1892.

Winsor, Justin, 1831-1897: Narrative and Critical History of the U. S. Winckler, Benedict: Principiorum Juris Libri Tres. Leipzig, 1615. Wolf, Christian von, 1679-1754: Jus Gentium Methodo Scientifica Per. tractatum, etc. Halle, 1749. Of that work his Institutiones Juris Naturae et Gentium, which appeared in the following year, is an abridgment.

Woolsey, Theodore D., 1801-1889: Introduction to the Study of International Law. 6th ed., by T. S. Woolsey, New York, 1891.

Würm: Briefe über die Freiheit der Flusschiffahrt.

Wynne's Life of Sir Leoline Jenkins. London, 1724.

Xenophon, B. C. 430?-357?: Cyropaedia. Hellenica.

Zachariæ, Karl Salomo, 1769-1843: Vierzig Bücher vom Staate. Revised ed., Heidelberg, 1841. The fifth volume contains his Völkerrecht.

Zeuss, K.: Die Deutschen und die Nachbarstämme. 1837.

Zouch, Richard, 1590-1660: Juris et Judicii Fetialis, sive Juris inter Gentes et Quaestionum de eodem Explicatio. Oxford, 1650. 



\section{TABLE OF CASES CITED.}

[The References are to the pages.]

Acteon, The, 2 Dodson 53...511 Amitie, L', 6 Rob. Adm. 261...571

Actif, L', Edwards $186 . . \ldots \ldots .576$ Amy Warwick, The, 2 Sprague

Adeline and cargo, The

Schooner, 9 Cranch 244

$\ldots \ldots \ldots \ldots \ldots \ldots . \ldots . \ldots, 580,582$

Adger v. Alston, 15 Wall. 555..603

Adonis, The, 5 Rob. Adm. 258..779

AEolus, The, 1 Dod. Adm. 300..512

Aikman v. Aikman, 3 Macq.

$854 \ldots \ldots \ldots \ldots \ldots \ldots \ldots . .250$

Alabama v. Georgia, 23 How. 505 ................275

Alerta, The Brig, 9 Cranch 359 .............582, 645

Alexander, The, 4 Rob. Adm. 93 .779

Alexander v. Duke of Wellington, 2 Russell \& Mylne 35..540

Alexander's Mrs., Cotton, 2

Wall. 404.......524, 554, 555

Alfred, The, 3 Dallas 307..645, 696

Alliance, The, Blatchf. Pr. C.

186 ................512

Allsop's Case, Forsyth's cases

368 ..................258

Amedie, The, 1 Acton $240 \ldots 237$

Amelia, The, 4 Phila. 417; 1

Fed. Cases 595...........544

Amelia, The, 1 Cranch 1..137, 576

American Ins. Co. v. Bales of

Cotton, 1 Peters 511..267, .........601, 607, 610,613

Amiable Isabella, The, 6

Wheat. 1.....395, 497, 582

Amiable Nancy, The, 1 Paine,

C. C. $111 \ldots \ldots \ldots \ldots \ldots \ldots 440$

Amiable Nancy, The, 3 Wheat.

$546 \ldots \ldots \ldots \ldots \ldots \ldots 440,578$

Amistad de Rues, La, 5

Wheat. $385 \ldots \ldots .582,645,684$

Amistad, The, 15 Peters 518...396
$123 \ldots \ldots \ldots \ldots \ldots \ldots \ldots 456$

Ann, The, 1 Dodson 221......524

Ann, The, 1 Gall. C. C. R. $62 . .434$

Ann Green, The, 1 Gall. 274 ..553, 565, 575, 582

Anna, The, 5 Rob. Adm. 373..

...274, 499, 572, 578, 700, 786

Anna Catharina, The, 4 Rob.

Adm. 107.......632, 553, 559

Anna Maria, The, 2 Wheat. 327 $440,578,787$

Anne, The, 3 Wheat. $447 \ldots . .701$

Anne, Schr., v. United States,

7 Cranch 570.........4434

Anonymous, 9 Opin. Atty. Gen. $518 \ldots \ldots \ldots \ldots \ldots . \ldots 61$

Antelope, The, 10 Wheat. $66 .$. .238, 526, 780

Antonia Johanna, The, 1 Wheat. 159.....553, 554, 565

Apollos, The, Pistoye et $\mathrm{Du}-$

verdy, ii. $81 \ldots \ldots \ldots \ldots .786$

Appollon, The, 9 Wheat. 362..296

Arabella and Madeira, The, 2

Gallison $368 \ldots \ldots \ldots \ldots 698$

Ariadne, The, 2 Wheat. 143...512

Ariel, The, 11 Moore, P. C. 119

.............568, 582

Armstrong v. United States, 182 U. S. $243 \ldots \ldots \ldots \ldots .793$

Arnold v. Insurance Co. 1

Johns. Cas. 363...........358

Arnott v. Groom, Court of Ses-

sion Cases, 9 D. 142......250

Arrogante Barcelones, The, 7

Wheat. $496 \ldots \ldots \ldots \ldots \ldots 645$

Arthur, The, 1 Dodson $423 . \ldots 571$

Astrea, The, 1 Wheat. 125....440 
[the references are to the pages.]

Atalanta, The, 6 Rob. Adm. $440 \ldots \ldots \ldots \ldots .555,744,755$ Atalanta, The, 3 Wheat. 409.. $\ldots \ldots \ldots \ldots \ldots \ldots \ldots 64,717$ Atlas, The, 3 Rob. Adm. 299 ...' 565 Attorney-General v. Wilson, 3

Price $431 \ldots \ldots \ldots \ldots \ldots \ldots 512$ Aurora, The, 8 Cranch 202... 512

Bagaley, The William, 5 Wall. $377 \ldots \ldots \ldots \ldots 524,554,555$ Baigorry, The, 2 Wall. 474 ... 777 Bain v. Schooner Speedwell, 2

Dall. $40 \ldots \ldots \ldots \ldots \ldots \ldots 614$ Baltica, The, Spinks 264......524 Banda \& Kirwee Booty, 1 L.

R. Adm. and Ec. 109......541 Barcelones, The Arrogante, 7

Wheat. 496...........6 645

Bark Springbok v. United

States, 5 Wall. 1..72, 578, 779 Barnes, Ex parte, 1 Sprague

133 ..................1i2

Barrick v. Buba, 2 C. B. (N.

S.) $563 \ldots \ldots \ldots \ldots \ldots \ldots 459$

Bas v. Tingy, 4 Dall. $37 . \ldots \ldots 453$

Batesville Inst. v. Kauffman,

18 Wall. 151............603

Battle, The, 6 Wall. 498.......582

Beck v. McGillis, 9 Barb. (N.

Y.) $35 \ldots \ldots \ldots \ldots \ldots \ldots 222$

Bell v. Kennedy, L. R. 1 S. \&

D. App. $307 \ldots \ldots \ldots \ldots 249$

Bell v. Reid, 1 Maule \& S. 726..524

Bello Corrunes, 6 Wheat. 152..645

Bellona, The, Edward $65 . \ldots .571$

Bentzon v. Boyle, 9 Cranch 191 ..........553, 554, 593

Bermuda, The, 3 Wall. 514. .582, 778 Bernardi v. Motteux, Douglas's

Rep. $581 \ldots \ldots \ldots \ldots \ldots .786$

Bernon, The, 1 Rob. Adm. 102 $.569,696$

Betsey, The, 1 Rob. Adm. 93. .

Betsey, The, 1 Rob. Adm. 332..769 Betsey, The, 3 Dall. 6.580, 581, 645
Betsey Cathcart, The, Bee 282 $\ldots 645,684$

Betsy, The, Bee $67 \ldots \ldots \ldots 6645$

Bilboa, Packet de, 2 Rob. Adm. $133 \ldots \ldots \ldots \ldots \ldots \ldots \ldots 69$

Birtwhistle v. Vardill, $7 \mathrm{Cl}$ \& F. $895 \ldots \ldots \ldots \ldots \ldots \ldots .209$

Blackburne v. Thompson, 15 East $81 \ldots \ldots \ldots \ldots \ldots 457$

Blagge v. N. Y. Ins. Co. 1 Caines Rep. $565 \ldots \ldots \ldots \ldots 786$ Blankard v. Galdy, 2 Salk 411 ...............214, 601

Boedes Lust, The, 5 Rob. Adm. $233 \ldots \ldots \ldots \ldots \ldots \ldots \ldots 433$ Boehm v. Bell, 8 T. R. 154... 581 Bogart, Re, 2 Sawy. 396..... 598 Bolletta, The, Edwards, 173.. 613 Bollman, Ex parte, 4 Cranch.

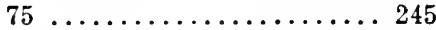

Bourgoise, Re, L. R. 41 Ch. D. $310 \ldots \ldots \ldots \ldots \ldots \ldots \ldots . \ldots \ldots$

Bourse, The, 1 Edwards 370.. 511 Bridges, Ex parte, 2 Woods $428 \ldots \ldots \ldots \ldots \ldots \ldots \ldots . \ldots \ldots 2$

Brig Alberta v. Moran, 9 Cranch 359........582, 645 Brig Penobscot v. United States, 7 Cranch. $356 \ldots . .4434$ Brig William Gray, 1 Paine's C. C. R. $16 \ldots \ldots \ldots \ldots \ldots 434$ Briggs v. The Light Boats, 11 Allen 157 ............ 302 Briscoe, In re, 51 How. Pr. $422 \ldots \ldots \ldots \ldots \ldots \ldots .258$ Brothers, The, Bee 76......645 Brown v. Hiatts, 15 Wall. 177 ................458, 603

Brown v. United States, 8 Cranch $110 \ldots \ldots 462,551,570$ Brunel v. Brunel, L. R. 12 Eq. $298 \ldots \ldots \ldots \ldots \ldots \ldots \ldots . \ldots 249$ Buena Ventura, The, 175 U. S. $384 \ldots \ldots \ldots \ldots \ldots \ldots .463$ Byfield, The, Edwards 188..512, 776

Cabrera, Ex parte, 1 Wash. C.

C. $232 \ldots \ldots \ldots \ldots \ldots .319,339$ 
[THE REFERENCES ARE TO THE PAGES.]

Calais v. Marshfield, $30 \mathrm{Me}$. $511 \ldots \ldots \ldots \ldots \ldots \ldots \ldots 224$

Caledonian, The, 4 Wheat. 100 ..464, 497, 536

Calvin's Case, 7 Rep. 1; 2 State Trials $559 \ldots \ldots .213,600,601$ Calvin's Case, 7 Rep. 28a..... 589 Cambden v. Home, 4 Term 382 ...............570, 579

Campbell v. Hall, 1 Cowp. 204

Campbell v. Hall, 20 State Trials, $322 \ldots \ldots \ldots \ldots \ldots 601$

Capdevielle, In re, 33 L. J. (Ex.) $306 \ldots \ldots \ldots \ldots \ldots 251$

Cape of Good Hope, The, 2

Rob. Adm. 274.....5570, 571

Cargo of Ship Fanny, 9 Cranch, 181 ........... 434

Carlisle v. United States, 16 Wall. 147 ............ 251

Carlotta, The, 5 Rob. Adm. 54.. 576 Carolina, The, 4 Rob. Adm. 256 .........554, 756,758

Carolina, The, 6 Rob. Adm. 336, 507 Caroline, The, 6 Rob. Adm. $461 \ldots \ldots \ldots \ldots \ldots \ldots 750,755$

Carrington v. Merchants Ins.

Co. 8 Peters $495 \ldots \ldots \ldots \ldots 497$

Case v. Woolley, 6 Dana 17... 245 Castioni, Ex parte, L. R. Q. B. Div. 1891, p. $149 \ldots \ldots \ldots 258$

Catharina Elizabeth, The, 5

Rob. Adm. 232......575, 784

Catharina Elizabeth, The, 1 Acton, 309 ........... 786

Ceylon, The, 1 Dodson 105.... $.574,576$

Charlotta, The, Edwards 252.. 774 Charlotte, The, 5 Rob. Adm. $280 \ldots \ldots \ldots \ldots \ldots .439,497$

Charlotte Christine, The, 6 Rob. Adm. 101.......... 772

Charlotte Sophia, 6 Rob. Adm. $204 \mathrm{n}$ 772

Charming Betsy, The, 2 Cranch 64 . $.137,578$
Chavasse, Ex parte, 34 L. J. N.

S. $17 \ldots \ldots \ldots \ldots \ldots \ldots 74$

Cherokee Nation v. State of Georgia, 5 Peters 1..... 176 Cheshire, The, 3 Wall. 231.... ..............554, 772

Chirac v. Chirac, 2 Wheat. 259 ............... 196

Christiana Colbiornsen, La, 13 Merlin, 113 ........... 499 Christopher, The, 2 Rob. Adm. $207 \ldots \ldots \ldots \ldots \ldots . \ldots 51,698$ Church v. Hubbart, 2 Cranch $187 \ldots \ldots \ldots \ldots \ldots \ldots \ldots 295$ Circassian, The, 2 Wallace 135 $.770,773,777$ City of New Orleans v. Armas, 9 Peters $224 \ldots \ldots \ldots \ldots .276$ Clark v. Braden, 16 How. 635.. 389 Clark v. United States, 3 Wash. $101 \ldots \ldots \ldots \ldots \ldots \ldots \ldots 516$ Cohas v. Raisin, 3 Cal. 445... 599 Collett v. Lord Keith, 2 East $260 \ldots \ldots \ldots \ldots \ldots \ldots 601$ Columbia, The, 1 Rob. Adm. $154 \ldots \ldots \ldots \ldots \ldots .769,779$ Comet, The, Edwards $32 \ldots . .779$ Comitis v. Parkinson, 56 Fed. Rep. 556 ............ 222 Commercen, The, 1 Wheat. 382 $\ldots \ldots \ldots \ldots \ldots 726,-37,758,786$ Commonwealth v. Hawes, 13 Bush 697 ............ 254 Compton v. Wilder, 40 Ohio St. $130 \ldots \ldots \ldots \ldots \ldots \ldots 254$ Conception, La, 6 Wheat. 235. 645 Confiscation Cases, The, 20 Wall. $92 \ldots \ldots \ldots \ldots .551,555$ Coolidge v. Guthrie, 8 Am. L. Reg. N. S. $22 \ldots \ldots \ldots \ldots \ldots 540$ Cooper, In re, 143 U. S. 472. 299 Copenhagen, The, 1 Rob. Adm.

289 ................. 565

Coppell v. Hall, 7 Wall. $542 . .358,510$ Cornelia, The, 1 Edwards, 360. 511 Cornu v. Blackburne, 2 Doug-

las, $640 \ldots \ldots \ldots \ldots \ldots 573$ 
[THE REFERENCES ARE TO THE PAGES.]

Corrunes, The Bello, 6 wheat.

$152 \ldots \ldots \ldots \ldots \ldots \ldots 645$

Crane v. Reader, 25 Mich. 303.. 224

Crauford, Lincena v. 3 B. \& P.

Exch. $751 \ldots \ldots \ldots \ldots \ldots 581$

Craw v. Ramsey, 2 vent. 6... 252

Cross v. Harrison, 16 How. 164 600,601

Crossman v. United States, 182

U. S. $221 . \ldots \ldots \ldots \ldots \ldots 793$

Crowell v. M'Fadon, 8 Cranch

94

Daifjie, The, 3 Rob. Adm. 141. 507 Danckebaar Africaan, The, 1

Rob. Adm. 107......... 593

Daniel Frederick, Le, 13 Mer-

lin, $113 \ldots \ldots \ldots \ldots \ldots .499$

Dankbaarheit, The, 1 Dodson's

Adm. 183 ............. 511

Danous, The, 4 Ch. Rob. $256 \mathrm{n}$. .

................524, 553

Dashing Wave, The, 5 Wall.

$170 \ldots \ldots \ldots \ldots \ldots 578,766$

Davison, Re, 22 Blatchf. 473.. 598

De Giacomo, In re, 12 Blatchf. $391 \ldots \ldots \ldots \ldots . . \ldots 257$

De Haber v. The Queen of Portugal, 20 Law J. Q. B. $488 \ldots \ldots \ldots \ldots \ldots \ldots \ldots 228$

De Lima v. Bidwell, 182 U. S.

$1 \ldots \ldots \ldots \ldots \ldots \ldots . \ldots 793$

De Wütz v. Hendricks, 9 Moore

C. P. Rep. $587 \ldots \ldots \ldots \ldots 674$

Dederer v. Del. Ins. Co. 2 Wash.

C. C. $61 \ldots \ldots \ldots \ldots \ldots 575$

Delassus v, United States, 9

Peters $117 \ldots \ldots \ldots \ldots .276$

Del Col v. Arnold, 3 Dall. U.

S. 333

Der Mohr, 4 Rob. Adm. 314.... 787

Despatch, The, 1 Acton $163 \ldots 771$

Despatch, The, 2 Gall. 2..... 571

Dewey v. United States, 178 U.

S. $510 \ldots \ldots \ldots \ldots \ldots \ldots 577$

Dewing v. Perdicarles, 96 U. S.

$193 \ldots \ldots \ldots \ldots \ldots \ldots \ldots 463$

Diana, The, 2 Act. $54 \ldots \ldots \ldots 512$
Diana, The, 1 Dodson's Adm.

Rep. $95 \ldots \ldots \ldots \ldots \ldots .237$

Diana, The, 5 Rob. Adm. 60... 523

Die Fire Damer, 5 Rob. Adm. 357 .............. 787

Direct U. S. Cable Co. v. Anglo-American Tel. Co., 2 App. Cas. $394 \ldots \ldots \ldots \ldots 278$

Divina Pastora, The, 4 Wheat.

$52 \ldots \ldots \ldots \ldots \ldots 188,459,581$

Doe v. Braden, 16 How. 635 .. 389

Dole v. Merchants Ins. Co., 51

Me. $464 \ldots \ldots \ldots \ldots 498,572$

Dole v. N. Eng. Ins. Co., 6

Allen $373 \ldots \ldots \ldots \ldots 498,572$

Don's Estate, Re, 4 Drew. 194. 209

Dooley v. United States, 182

U. S. $222 \ldots \ldots \ldots \ldots \ldots \ldots 793$

Dordrecht, The, 2 Rob. Adm.

$53 \ldots \ldots \ldots \ldots \ldots \ldots \ldots . \ldots \ldots$

Dorr, Ex parte, 3 How. 103... 172

Dos Hermanos, The, 2 Wheat.

$76 \ldots \ldots \ldots \ldots \ldots \ldots . \ldots . \ldots 52$

Dos Hermanos, The, 10 Wheat.

$306 \ldots \ldots \ldots \ldots \ldots \ldots \ldots 77$

Dow v. Johnson, 100 U. S. 158.. 473

Downes v. Bidwell, 182 U. S.

$244 \ldots \ldots \ldots \ldots \ldots \ldots \ldots$

Dred Scott v. Sandford, 19 How.

393 ............216, 794

Dree Gebroeders, The, 4 Rob.

Adm. 235............ 553

Duckworth v. Tucker, 2 Taun-

ton $7 \ldots \ldots \ldots \ldots \ldots \ldots . \ldots 51$

Duncan v. Lawson, $41 \mathrm{Ch}$. D.

$394 \ldots \ldots \ldots \ldots \ldots \ldots 209$

Durand v. Halbach, 1 Miles

(Phila.) $46 \ldots \ldots \ldots \ldots \ldots 358$

Durousseau v. United States, 6

Cranch. 307.......... 433

Earl of Lancaster's Case, 1

Hale's, P. C. $26 \ldots \ldots \ldots \ldots 457$

East India Co. v. Campbell, 1

Ves. Sen. $246 \ldots \ldots \ldots \ldots \ldots 253$

Edward, The, 1 Wheat. $261 \ldots 434$

Edward, The, 4 Rob. Adm. 69.. 737 
[THE REFERENCES ARE TO THE PAGES.]

Edward and Mary, The, 3 Rob.

Adm. $306 . . \ldots \ldots \ldots . . . .570$

Edwards v. Panama, 1 Oreg.

418 .................6 601

Edye v. Robertson, Coll., 112

U. S. $580 \ldots \ldots \ldots \ldots \ldots .232$

Effurth v. Smith, 5 Taunt.

329 ............... 512

El Telegrapho, Newb. 386..... 716

Eleanor, The, 2 Wheat. $345 \ldots 782$

Eliza Ann, The, 1 Dodson's Adm. Rep. 247.......454, 456

Eliza and Katy, The, 6 Rob. Adm. 192............. 786

Eliza Cornish, The, 1 Pistoye et Duverdy, $387 \ldots \ldots \ldots \ldots 774$

Elk v. Wilkins, 112 U. S. $94 \ldots 218$

Elphinstone v. Bedreechund, 1

Knapp, 316........457, 601

Elsebe, The, 5 Rob. Adm. 173

Emily St. Pierre, The, Snow

Cas. $361 \ldots \ldots \ldots \ldots \ldots \ldots . \ldots 75$

Emma, The, Edwards $366 \ldots 512$

Emmens v. Pottle, xvi. Q. B. D.

$358 \ldots \ldots \ldots \ldots \ldots \ldots \ldots . \ldots 749$

Emulous, The, 1 Gall. 563.... 551

Ernst Merck, The, Spinks 98.. 524

Esposito v. Bowden, 7 Ellis \&

B. $763 \ldots \ldots \ldots 459,513,562$

Estrella, The, 4 Wheat. 298

......439, 440, 582, 645, 684

Europa, The, 1 Edwards $341 . .512$

Ex parte Barnes, 1 Sprague 133. 172

Ex parte Bollman, 4 Cranch. 75. 245

Ex parte Bridges, 2 Woods 428. 172

Ex parte Cabrera, 1 Wash. C.

C. $232 \ldots \ldots \ldots \ldots \ldots 319,339$

Ex parte Castioni, L. R. Q. B.

Div. 1891, p. $149 \ldots \ldots \ldots 258$

Ex parte Chavasse (in re Graze-

brook), 34 L. J. N. S. 17... 741

Ex parte Dorr, 3 How. 103.... 172

Ex parte Foss, 102 Cal. 347; 41

Am. St. Rep. 182....... 257

Ex parte Milligan, 4 Wall. 2..
Exchange, The Schooner, v. McFaddon, 7 Cranch. 116.. $206,207,228,303,304,312$, ............6.645, 689, 690

Experiment, The, 8 Wheat. 261. 440 Ezeta, In re, 62 Fed. Rep. 972. . 258

Fairfax v. Hunter, 7 Cranch. $603 \ldots \ldots \ldots \ldots \ldots 249$

Fama, The, 5 Rob. Adm. 113.. .............. 591, 613

Fanny, The, 9 Wheat. $658 \ldots .6646$ Fanny, The, 1 Dodson Adm. $443 \ldots \ldots \ldots \ldots .564,716,785$

Feize v. Thompson, 1 Taunton $121 \ldots \ldots \ldots \ldots \ldots \ldots \ldots . \ldots \ldots 11$

Felicity, The, 2 Dodson Adm. 383 .................. 786 Fenton v. Pearson, 15 East 419. 511 Fifield v. Ins. Co., $47 \mathrm{~Pa}$. St. 166 ...............498, $57_{2}$

Fire Damer, Die, 5 Rob. Adm. 357 ................ 787 First Nat. Bank v. Yankton Co., 101 U. S. $129 \ldots .601,793$ Flad Oyen, The, 1 Rob. Adm. $135 \ldots \ldots \ldots \ldots \ldots \ldots$ 580, 581 Fleming v. Page, 9 Howard 603 .......267, 589, 593. 601, 603 Fletcher v. Peck, 6 Cranch 187. 367 Flora, The, 11 Wheat. 1..... $\ldots \ldots \ldots \ldots 683,779,781,782$ Flore, La, 5 Rob. Adm. 270... 571 Florida, The, 101 U. S. 37..... 577 Foltina, The, 1 Dodson Adm. $450 \ldots \ldots \ldots \ldots \ldots . \ldots 570,591$ Fong Yue Ting v. United States, 149 U. S. $698 \ldots . . .252$ Ford v. Surget, 97 U. S. $594 .$. ............... 459, 498 Fortuna, The, 1 Dodson, Adm. $81 \ldots \ldots \ldots \ldots \ldots \ldots 237$ Foss, Ex parte, 102 Cal. 347; 41 Am. St. Rep. 182 ..... 257 Fostcr v. Neilson, 2 Peters 253. ................136, 299 Frances, The, 8 Cranch $335 .$. ..464, 524 
[THE REFERENCES AIE TO THE PAGES.]

Francis, The, 8 Cranch $354 \ldots 568$ Francis, The, 1 Gall. 614..... 524 Francis and Cargo, The, 1 Gall. 445.............568, 569

Franciska, The, Spink's Prize Cas. $111 \ldots .765,767,768,775$ Frau Ilsabe, The, 4 Rob. Adm. $64 \ldots \ldots \ldots \ldots \ldots \ldots \ldots .765$

Frederick Molke, The, 1 Rob. Adm. 88 774

French Guiana, The, 2 Dodson Adm. 151............. 787 Friendschaft, The, 3 Wheat. 14524 Friendschaft, The, 4 Wheat. $105 \ldots \ldots \ldots \ldots \ldots . .553,554$ Friendship, The, 6 Rob. Adm. 420 $.755,756,758$

Galen, The, 2 Dodson Adm. 19. 571 Garcia v. Lee, 12 Peters $511 \ldots 299$ Gates v. Goodloe, 101 U. S. 612. 524 Geoffroy's Case, Forsyth, Cas. and Opin. 483.......... 599

George, The, 1 Mason $24 . .570,787$ George, The, 1 Wheat. 408... 582 Georgia, The, 7 Wall. $32 \ldots \ldots 696$ Georgia, The, 1 Lowell $96 \ldots 696$ Georgia v. Brailsford, 3 Dall.

$1 \ldots \ldots \ldots \ldots \ldots \ldots \ldots . \ldots 52$

Georgiana, The, 1 Dodson Adm. $401 \ldots \ldots \ldots \ldots \ldots \ldots \ldots 56$

Gibbons, The, $\delta$ Cranch $421 \ldots 440$ Glass v. The Betsey, 3 Dall. 6 ...........580, 581, 645

Gloire, La, 5 Rob. Adm. 192. . . 507 Goetze v. United States, 182 U. S. 221 . 793

Good Catharine, Schr., v. United States, 7 Cranch 349 .

Goss v. Withers, 2 Burr 683.. ..............559, 570

Gran Para, 7 Wheat. $471 \ldots . .645$ Grand Sachem, The, 3 Dall. 333 .................... 578

Grand Terrein, Le, 1 Hay \& Mar. 155
Grapeshot, The, 9 Wall, 129.. 601 Gratitudine, The, 3 Rob. Adm. $258 \ldots \ldots \ldots \ldots \ldots \ldots \ldots 573$

Gray, Brig William, 1 Paine C. C. R. $16 \ldots \ldots \ldots \ldots \ldots 434$ Gray Jacket, The, 5 Wall. 342 ............554, 579, 582

Grigg v. Scott, 4 Campb. 340.. 511 Griswold v. Insurance Co., 3 Johns. $321 \ldots \ldots \ldots \ldots \ldots . \ldots 38$ Groning v. Crockett, 3 Camp. 83 ................ 512 Grotius, The, 9 Cranch. $368 \ldots 570$ Gute Hoffnung, The, 1 Dodson Adm. $251 . \ldots \ldots \ldots \ldots 257,511$

Haabet, The, 2 Rob. Adm. 174. 747 Hampton, The, 5 Wall. $372 . .577,579$ Harcourt v. Gaillard, 12

Wheat. 523......185, 276, 448 Hare, The, 1 Acton $252 \ldots \ldots 776$ Harmony, The, 2 Rob. Adm. $322 \ldots \ldots \ldots \ldots \ldots \ldots \ldots 23$ Hart, The, 3 Wall. $559 \ldots \ldots 555,565$ Hart v. Burnett, 15 Cal. 559... 599 Haven v. Holland, 2 Mason 230. 497 Henrick and Maria, The, 1 Rob.

Adm. 146.............. 765

Henrick and Maria, The, 4 Rob. Adm. 43.........581, 698 Herald, The, 3 Wall. 768..... 774 Hercules, The, 2 Dodson Adm. $353 \ldots \ldots \ldots \ldots \ldots \ldots \ldots 70$ Herstelder, The, 1 Rob. Adm. $114 \ldots \ldots \ldots \ldots \ldots \ldots 581$ Heyer v. Alexander, 108 Ill. 385209 Hiawatha, The, Blatchf. Prize

Cas. 1.........554, 774 Hiawatha, The, 2 Black. 675.. 770 Hiram, The, 1 Wheat. $440 \ldots \ldots 512$ Hobbs v. Henning, 17 C. B. (N. S.) $791 \ldots \ldots \ldots \ldots \ldots \ldots 58$ Hoffnung, The, 6 Rob. Adm. $112 \ldots \ldots \ldots \ldots \ldots \ldots \ldots . \ldots \ldots 76$

Holbrook v. Henderson, 4 Sandford, N. Y. 631....... 331 Hollingsworth v. The Betsey, 2 Pet. Adm. $330 \ldots . . . . . . .578$ 
[THE REFERENCES ARE TO THE PAGES.]

Holmes v. Jennison, 14 Peters

$540 \ldots \ldots \ldots \ldots \ldots \ldots . \ldots 170$

Holyoke v. Haskins, 5 Pick. 20221

Home v. Earl Camden, $2 \mathrm{H}$.

Black. 533........... 577

Hoop, The, 1 Rob. Adm. 196,

.............464, 574

Hope, The, 1 Dodson Adm. 229..510

Hopner v. Appleby, 5 Mason

$71 \ldots \ldots \ldots \ldots \ldots \ldots 69$

Hoppet, Schr., v. United States

7 Cranch $389 \ldots \ldots \ldots \ldots 434$

Horatio, The, 6 Rob. Adm. 320. 576

Hudson v. Guestier, 4 Cranch.

293 ..............581, 698

Hudson v. Guestier, 6 Cranch. $281 \ldots \ldots \ldots \ldots \ldots \ldots 295,683$

Hunter, The, 1 Dodson Adm.

$480 \ldots \ldots \ldots \ldots \ldots \ldots 786$

Hunter v. United States, 5

Peters, $173 . \ldots \ldots \ldots .594,773$

Hurtige Hane, The, 2 Rob.

Adm. 124..........772, 774

Hurtige Hane, The, 3 Rob.

Adm. 324............. 760

Hylton v. Brown, 1 Wash. C.

C. $298 \ldots \ldots \ldots \ldots \ldots 23,614$

Imina, The, 3 Rob. Adm. 167.. 743 Immanuel, The, 2 Rob. Adm.

$186 \ldots \ldots \ldots \ldots .553,632,741$

In re Briscoe, 51 How. Pr. 422 . 258

In re Capdevielle, 33 L. J. (Ex.) 306 251

In re Cooper, 143 U. S. $472 \ldots . .299$

In re Davison, 22 Blatchf. 473. 598

In re de Giacomo, 12 Blatch. 391 257

In re Ezeta, 62 Fed. Rep. 972. . 258 In re Kemp, 16 Wis. $382 \ldots \ldots 601$ In re Metzger, $1 \mathrm{Edw}$. Sel. Cas. (N. Y.) 399 ; 5 How. 176; 1 Barb. 248 ............ 255

In re Meunier, 2 Q. B. 415; 71

L. T. N. S. $403 ; 18$ Cox, C.

C. $15 \ldots \ldots \ldots \ldots \ldots \ldots 258$

In re Ross, 140 U. S. $453 \ldots . .246$
In re Sheazle, 1 Woodb. \& $M$.

$66 \ldots \ldots \ldots \ldots \ldots \ldots 255$

In re Stupp, 12 Blatchf. 501... 257

In re Troutman, 24 N. J. L. $634 \ldots \ldots \ldots \ldots \ldots \ldots \ldots .258$

Indian Chief, 1 Rob. Adm. 26. 358 Indian Chief, The, 3 Rob. Adm. $12 \ldots \ldots \ldots \ldots \ldots \ldots . .624,555$

Invincible, L', 1 Wheat. $238 \ldots .$. $\ldots \ldots \ldots \ldots \ldots 440,582,645,697$ Invincible, The, 2 Gall. $29 \ldots . .581$ Irene, The, 5 Rob. Adm. 76. . 772

Jacobs v. Credit Lyonnais, 12 Q. B. D. (C. A.) $589 \ldots \ldots 209$ James Cook, The, Edwards 261. 772 Jan Frederick, The, 5 Rob. Adm. 128........... 569 Jane Campbell, The, Blatchf. Prize Cas. 101.......578, 582 Jecker v. Montgomery, 13 Howard $505 \ldots \ldots \ldots \ldots \ldots \ldots 787$ Jecker v. Montgomery, 18 How. $110 \ldots \ldots \ldots \ldots \ldots .464,582$

Jenny, The, 5 Wall. 183...... 578 Jeune Voyageur, The, 5 Rob. Adm. 1.............. 574 Johan, The, Edw. Adm. 275... 559 Johanna, The, 1 Wheat. 159. . ..........553, 554, 565

Johanna Emilie, The, Spinks $12 \ldots \ldots \ldots \ldots \ldots \ldots \ldots 462$

Johnson v. McIntosh, 8 Wheat. 543.............129, 606

Jonge Arend, The, 5 Rob. Adm.

14 ................ 511

Jonge Klassina, The, 5 Rob.

Adm. 297.......510, 553, 554 Jonge Margaretha, The, 1 Rob.

Adm. 189 ........... 737

Jonge Tobias, 1 Rob. Adm. 330. 744 Josefa Segunda, The, 5 Wheat.

$338 \ldots \ldots \ldots \ldots \ldots \ldots \ldots 51$

Joseph, The, 8 Cranch. 451. 464, 578 Josephine, The, 4 Rob. Adm. 25. 569 Juffrow Maria Schroeder, The,

3 Rob. Adm. 147.....765, 774 
[THE REFERENCES ARE TO THE PAGES.]

Julia, The, \& Cranch. 181..512, 555 Juliana, The, 4 Rob. Adm. 328. 632 Juno, The, 2 Rob. Adm. 116.. ...........511, 773, 774

Karasan, The, 5 Rob. Adm. 291. 440 Keir v. Andrade, 6 Taunt. 498. 512 Kemp, In re, 16 Wis. $382 \ldots .6601$ Kennett v. Chambers, 14 Howard $38 \ldots \ldots \ldots 137,646,674$

Kensington v. Inglis, 8 East. 273 .............510, 511

King of Spain v. Hullet and Widder, 1 Clark and F. H. of L. $333 \ldots \ldots \ldots \ldots \ldots 230$

Kirk v. Lynd, 106 U. S. 315 ... 555 Klingender v. Bond, 14 East. $484 \ldots \ldots \ldots \ldots \ldots \ldots 510,511$

L' Actif, Edwards $186 \ldots \ldots .576$

L' Amitié, 6 Rob. Adm. 261... 571

L' Invincible, 1 Wheat. $238 . .$. $\ldots \ldots \ldots \ldots 440,582,645,697$

La Amistad de Rues, 5 Wheat. $385 \ldots \ldots \ldots \ldots \ldots 582,645,684$

La Christiana Colbiornsen, 13 Merlin 113............ 499

La Conception, 6 Wheat. 235. . 645 La Flore, 5 Rob. Adm. 268.... 571 La Gloire, 5 Rob. Adm. 192... 507 La Nereyda, 8 Wheat. 108...582, 645 La Satanique v. L' Ary et Maria, 1 Pist. et Duver 191580 Lamar v. Browne, 92 U. S. 187

Lancaster, Earl of, Case, 1 Hale's P. C. $26 \ldots \ldots \ldots \ldots 457$ Lanz v. Randall, 4 Dill. (U. S.) 425

Lattawana, The, 13 Wall. 558. 137

Le Caux v. Eden, Douglas Rep. $595 \ldots \ldots \ldots \ldots \ldots \ldots 570$

Le Cras v. Hughes, 3 Douglas, $81 \ldots \ldots \ldots \ldots \ldots \ldots \ldots . \ldots 51$

Le Louis, The, 2 Dodson's Adm. $238 \ldots \ldots \ldots \ldots 238,780$ Legal Tender, The, Wheaton's

Dig. $302 \ldots \ldots \ldots \ldots \ldots 614$
Leitensdorfer v. Webb, 20 How. ..176, 267

Leucade, The, Spink's Prize Cas. $217 \ldots \ldots \ldots \ldots 177,786$ Lilla, The, 2 Sprague $177 . . .$. ..........186, 459, 583 Lindo v. Rodney, 2 Douglas Rep. 613, 613n......570, 579 Little v. Barreme, 2 Cranch $170 \ldots \ldots \ldots \ldots \ldots \ldots . \ldots 137$ Lively, The, 1 Gall. 315....... 579 Liverpool Packet, The, 1 Gall. $513 \ldots \ldots \ldots \ldots \ldots \ldots . .578$ Livingston $v$. Maryland Ins. Co., 7 Cranch 544...523, 786 Locke v. United States, 7 Cranch $339 . \ldots \ldots \ldots \ldots 787$ London Packet, The, 5 Wheat. $132 \ldots \ldots \ldots \ldots \ldots \ldots \ldots 64$ Louis, The Le, 2 Dodson Adm. $238 \ldots \ldots \ldots \ldots \ldots \ldots 238,780$ Lucena v. Crauford, 3 B. \& P. Exch. $75 \ldots \ldots \ldots \ldots \ldots 581$ Luke v. Calhoun County, 52 Ala. $115 \ldots \ldots \ldots \ldots \ldots .251$ Luke v. Lyde, 2 Burr $882 \ldots . . .42$ Luther v. Borden, 7 How. 1... 536 Lyons v. Cunningham, $66 \mathrm{Cal}$.

$42 \ldots \ldots \ldots \ldots \ldots \ldots \ldots .218$

Macartney v. Garbutt, L. R. 24 Q. B. Div. $368 \ldots \ldots \ldots \ldots 328$ Madison, The, Edwards Adm. $224 \ldots \ldots \ldots \ldots \ldots \ldots \ldots$ Madonna del Burso, The, 4 Rob. Adm. 169........92, 364 Magdalena, The, 3 Dall. $133 \ldots 645$ Magdalena Steam Nav. Co. v. Martin, 2 Ellis and Ellis $111 \ldots \ldots \ldots \ldots \ldots \ldots \ldots . \ldots . \ldots$

Mahoney v. United States, 10 Wall. $62 \ldots \ldots \ldots \ldots \ldots \ldots .92$ Maisonnaire $v$. Keating, 2 Gall. $325 \ldots \ldots \ldots \ldots .573,578$ Maley v. Shattuck, 3 Cranch. $458 \ldots \ldots \ldots \ldots \ldots \ldots \ldots 78$ Manly, The, 1 Dodson Adm. $257 \ldots \ldots \ldots \ldots \ldots \ldots .512$ 
[THE REFERENCES ARE TO THE PAGES.]

Marbury v. Madison, 1 Cranch $176 \ldots \ldots \ldots \ldots \ldots \ldots \ldots \ldots$

Maria, The, 1 Rob. Adm. 340... $\ldots \ldots \ldots \ldots 42,636,731,781,784$ Maria, The, 5 Rob. Adm. 365.. 778 Maria, The, 6 Rob. Adm. 201... 772 Mariamne, The, 5 Rob. Adm. 9. 440 Marianna, The, 6 Rob. Adm.

$24 \ldots \ldots \ldots \ldots \ldots \ldots 56,582$

Marianna Flora, The,11 Wheat.

$1 . \ldots \ldots 683,779,780,781,782$

Marquis de Somerueles, The, Stewart's V. Ad. 445 (Nov.

Sco.) ............... 544

Mars, The, 6 Rob. Adm. 79... 786 Martin v. Lessee of Waddell,

16 Peters $409 \ldots \ldots \ldots \ldots .130$

Martin v. Mott, 12 Wheat. 19.. 596

Mary, The, 5 Rob. Adm. 200.. 507

Mary, The, 9 Cranch. $126 \ldots . .554$

Mary Clinton, The, Blatchford

Pr. Cas. 556.........187, 554

Mary Ford, The, 3 Dall. 188... $. .574,575,582$

Mary and Susan, The, 1 Wheat. 46 .............4439, 554

Masterson v. Howard, 18 Wall. 99

Mauran v. Ins. Co., 6 Wall. 1 ............498, 570, 572

M'Donough v. Dannery, 3 Dall. $188 \ldots \ldots \ldots \ldots 574,575,582$

M'Ilvaine v. Coxe's Lessee, 4 Cranch. 212 ........... 185

McKay v. Campbell, 2 Sawyer $118 \ldots \ldots \ldots \ldots \ldots .218$

Melomane, The, 5 Rob. Adm. $42 \ldots \ldots \ldots \ldots \ldots \ldots \ldots 497$

Mentor, The, 1 Rob. Adm. 179. 614

Metzger, In re, 1 Edw. Sel. Cas.

(N. Y.) 399 ; 5 How. 176;

1 Barb. 248.............255

Meunier, In re, 2 Q. B. $415 ; 71$

L. T., U. S. $403 ; 18 \operatorname{Cox}$, C,

C. $15 \ldots \ldots \ldots \ldots \ldots \ldots 258$

Miller v. Resolution, 2 Dall. 1.
Miller v. United States, 11 Wall. 268... 198, 551, 553, 555 Milligan, Ex parte, 4 Wall. 2. ..........457, 599, 601

Minerva, The, 1 Edward $375 \ldots 512$ Minerva, The, 6 Rob. Adm. 396. 568 Minor v. Happersett, 21 Wall.

167 ................ 218

Mitchell v. Harmony, 13 How.

115 .................. 557

Mitchel v. United States, 9

Peters $711 . . \ldots \ldots \ldots \ldots 276$

Montgomery v. United States,

15 Wall. 395............4 460

Moodie v. The Alfred, 3 Dall.

$307 \ldots \ldots \ldots \ldots \ldots 645,696$

Moodie v. The Ship Brothers,

Bee $76 \ldots \ldots \ldots \ldots \ldots \ldots 645$

Moodie v. The Ship Phoebe

Anne, 3 Dall. 319....... 645

Morgan v. French, Journal de

Droit Int. Privé, 1874, p.

$72 \ldots \ldots \ldots \ldots \ldots \ldots \ldots \ldots \ldots \ldots \ldots$

Mostyn v. Fabrigas, 1 Cowp.

165 ..................6 601

Mure v. Kaye, 4 Taunt. 34... 253

Murray v. Charming Betsy, 2

Cranch 64....137, 553, 578 Musurus Bey v. Gadhan, L. R.

1 Q. B. $535 \ldots \ldots \ldots \ldots \ldots 340$

Nancy, The, 1 Acton 58...... 776

Nancy, The, 3 Rob. Adm. 122.. 743

Nancy, The, Bee $73 . \ldots \ldots \ldots 645$

National Bank v. Yankton, 101

U. S. $129 \ldots \ldots \ldots \ldots 601,793$

Nayade, The, Newb. Adm. 366. 578

Naylor v. Taylor, 4 Manning \&

Ryland $531 . \ldots \ldots \ldots \ldots \ldots 769$

Nemesis, The, Edward $50 \ldots 581$

Neptunus, The, 1 Rob. Adm. $170 \ldots \ldots \ldots \ldots 773,774,777$

Neptunus, The, 2 Rob. Adm.

110 ................... 769

Nereide, The, 9 Cranch. 388 ...

$\ldots 137,555,566,716,717$,

$\ldots \ldots \ldots \ldots \ldots 769,785,789$

Nereyda, La, 8 Wheat. 108..582, 645 


\section{[THE REFERENCES ARE TO THE PAGES.]}

Nuestra Senora, The, 4 Wheat. $497 \ldots \ldots \ldots \ldots \ldots \ldots 188,440$

Neutralitet, The, 3 Rob. Adm. $295 \ldots \ldots \ldots \ldots \ldots \ldots 555,744$

New Orleans v. Armas, 9 Peters $224 \ldots \ldots \ldots \ldots \ldots 276$

New Orleans v. S. S. Co., 20 Wall. $387 \ldots \ldots \ldots \ldots \ldots .616$

Norwich v. Wright, 13 Wall. $104 \ldots \ldots \ldots \ldots \ldots \ldots \ldots \ldots$

Oakes v. United States, 174 U.

S. $778 \ldots \ldots \ldots \ldots \ldots \ldots 574$

Ocean, The, 5 Rob. Adm. 91... 524

Odessa, The, Spinks $208 \ldots \ldots .513$

Odin, The, 1 Rob. Adm. 248... 571

Olinde Rodrigues, The, $174 \mathrm{U}$.

S. $510 \ldots \ldots \ldots \ldots \ldots \ldots . \ldots 78$

Orion, The, Stewart Rep. 506... 776 Orozembo, The, 6 Rob. Adm. $430 \ldots \ldots \ldots \ldots \ldots \ldots 756,758$ Osborn v. United States Bauk,

9 Wheat. $738 \ldots \ldots \ldots \ldots .224$

Otis v. Walter, 11 Wheat. 192.. 433

Otto and Olaf, The, Spinks 259. 774

Paeket de Bilboa, The, 2 Rob.

Adm. 133 ........... 569

Palmyra, The, 12 Wheat $1 . .582,787$

Panaghia Rhomba, The, 12

Moore, P. C. $180 \ldots \ldots \ldots .779$

Paquete Habana, The, 175 U.

S. $677 \ldots \ldots \ldots \ldots \ldots \ldots 59$

Parlement Belge, The, L. R. 5

P. D. 197 .............. 302

Peacock, The, 4 Rob. Adm. 187. 490

Pearl, The, 5 Wall. 574...... 578

Pedro, The, 175 U. S. $354 \ldots \ldots 463$

Peggy, The, 1 Cranch 103..134, 611

Pelham Burke's Case, 1 Ed-

ward's App. Div......... 457

Pelham v. Rose, 9 Wall. 103... 555

Penusylvania v. Ravenel, 21

How. 103

Pequignot v. Detroit, 16 Fed.

Rep. $211 \ldots \ldots \ldots \ldots \ldots . .222$

Perdicaries v. Charleston Gas

Lt. Co., 1 Hughes $69 . . . .463$
Peterhoff, The, 5 Wall. 28..... $\ldots \ldots \ldots \ldots 726,739,751,766$ Phillips v. Eyre, L. R., 6 Q. B 1. 599 Phillips v. Hateh, 1 Dill. 571.. $.460,464$

Phoebe Anne, The, 3 Dall. 319. 645 Phoenix, The, 5 Rob. Adm. 20. 553 Phoenix Ins. Co. v. Pratt, 2 Binney $308 \ldots \ldots \ldots \ldots \ldots 786$ Pizarro, 'The, 2 Wheat. 227..582, 786 Polka, The, 1 Spinks' Eceles \&

Adm. Rep. $447 \ldots \ldots \ldots \ldots .698$

Portlaud, The, 3 Rob. Adm. 41. 554

Postilion, The, Hay \& Marriott

245 ................ 524

Potinger v. Wightman, 3 Mer.

$67 \ldots \ldots \ldots \ldots \ldots \ldots \ldots 221$

Potsdam, The, 4 Rob. Adm. 89. 774

Potts v. Bell, 8 T. R. $548 \ldots . . .464$

Praris v. Captain Martine, 2

Stair $239 \ldots \ldots \ldots \ldots \ldots \ldots 440$

President, The, 5 Rob. Adm. 277523

Princessa, The, 2 Rob. Adm. $49 \ldots \ldots \ldots \ldots \ldots \ldots .632$

Prize Cases, The, 2 Black. 635.

187, 212, 454, 457, 459, 524, $\ldots \ldots \ldots 554,555,556,559,775$

Protector, The, 12 Wall. 700.. $.458,603$

Ranger, The, 6 Rob. Adm. 125 ..........511, 737, 738

Rapid, The, 8 Cranch. $155 \ldots 460,463$ Re Bogart, 2 Sawy. 402...... 598

Re Bourgoise, Infants, L. R. 41

Ch. D. $310 \ldots \ldots \ldots \ldots \ldots 225$

Re Davison, 22 Blatch. 475.... 598

Re Don's Estate, 4 Drew 194... 209

Rebeckah, The, 1 Rob. Adm. $227 \ldots \ldots \ldots \ldots \ldots \ldots . \ldots 47$

Regina v. Cunningham, Bell's Crown Cas. 72....... 27s

Regina v. Keyn, L. R. 2 Exch. Div. $63 \ldots \ldots \ldots .80,84,88$

Regina v. Zulueta, 1 Car. \& Kir. 215 .............. 244

Rendsborg, The, 4 Rob. Admr. $121 \ldots \ldots \ldots \ldots .553,569,632$ 
[THE REFERENCES ARE TO THE PAGES.]

Resolution, The, 2 Dall. 1..573, 577 Resolution, The, 6 Rob. Adm.

$13 \ldots \ldots \ldots \ldots \ldots \ldots \ldots . \ldots . \ldots 5$

Rhode Island v. Massachusetts,

4 How. 639 ............ 265

Richardson v. Ins. Co., 6 Mass. $113 \ldots \ldots \ldots \ldots \ldots \ldots \ldots .741$

Ricord v. Bettenham, 3 Burr. 1734 ............... 573

Ringende Jacob, 1 Rob. Adm. $89 \ldots \ldots \ldots \ldots \ldots \ldots \ldots 745$

Rising Sun, The, 2 Rob. Adm. 106 ................ 786

Roberts v. Hartley, 1 Douglas $311 \ldots \ldots \ldots \ldots \ldots \ldots . \ldots 57$

Robinson v. Morris, 5 Taunt. 720 .

Rolla, The, 6 Rob. Adm. 364.. $765,773,776$

Rosalie and Betty, The, 2 Rob. Adm. $343 \ldots \ldots \ldots \ldots \ldots \ldots 743$

Rose v. Himely, 4 Cranch. 240. $.295,581,683$

Rose in Bloom, The, 1 Dodson Adm. 58 ............ 774

Ross, In re, 140 U. S. $453 \ldots . .246$

Rover, The, 2 Gall. 240...... 578

Rugen, The, 1 Wheat. 62....565

Ryall v. Kennedy, 40 N. Y. (S.

C.) $347 \ldots \ldots \ldots \ldots \ldots \ldots$

St. Jozé Indiano, The, 1 Wheat. 208........... 569

St. Lawrence, The, 9 Cranch. $120 \ldots \ldots \ldots \ldots \ldots \ldots \ldots$.

St. Nicholas, The, 1 Wheat. 417. .............565, 786

St. Volante, The, 13 Merlin 94. 499 Sally, The, 1 Gall. C. C. R. 58. 434 Sally Magee, The, 3 Wall. 451. 582 San José Indiano, The, 2 Gall. 268 ............... 554

San Juan Baptista, The, 5 Rob. Adm. 33............ 787

Santa Brigada, The, 3 Rob. Adm. 52 ........... 571

Santa Cruz, The, 1 Rob. Adm. $50 \ldots \ldots \ldots \ldots 434,575,579$
Santissima Trinidad, 1 Brockenbrough $470 \ldots \ldots \ldots \ldots 645$ Santissima Trinidad, The, 7 Wheat. 283....302, 305, 577, .........582, 645, 684, 741 Santos v. Illidge, 8 C. B. (N. S.) $861 \ldots \ldots \ldots \ldots \ldots 244$ Sarah Christina, The, 1 Rob. Adm. 237............ 746 Sarah Maria, The, 1 Edwards $361 \ldots \ldots \ldots \ldots \ldots . \ldots 511,512$ Satanique, La, v. L' Ary et Maria, 1 Pist. et Duver. 191580 Schooner Adeline, The, 9 Cranch. 244......576, 580, 582 Schooner Anne v. United States, 7 Cranch. $570 \ldots . .444$ Schooner Exchange v. M'Faddon, 7 Cranch. $116 . . . .$. . $206,207,228,303,304,312$, .........6.645, 689, 690

Schooner Good Catharine v. United States, 7 Cranch. 349 ............... 433 Schooner Hoppet v. United States, 7 Cranch. 389.... 434 Schooner Peggy, The, 1 Cranch. $103 \ldots \ldots \ldots \ldots \ldots \ldots 134,611$ Schooner Speedwell, 2 Dallas $40 \ldots \ldots \ldots \ldots \ldots \ldots 614$ Schwartz v. Insurance Co., 3

Wash. C. C. $117 \ldots \ldots \ldots \ldots 565$ Science, The, 5 Wall. 178..... 766 Scotia, The, 14 Wall. $170 \ldots . .137$ Scotland, The, 105 U. S. 24... 137 Scott v. Billgerry, 40 Miss. 119. 601 Sea Lion, The, 5 Wall. 630.... 510 Sechs Geschwistern, The, 4 Rob. Adm. $100 \ldots \ldots \ldots \ldots 696$ Shanks v. Dupont, 3 Peters 246. 586 Sheazle, In re, 1 Woodb. \& M.

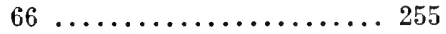
Ship Richmond v. United States, 9 Cranch. 102..... 434 Ships Taken at Genoa, 4 Rob. Adm. $388 \ldots \ldots \ldots \ldots \ldots .787$ Short Staple v. United States, 9 Cranch. 55.......575, 576 
[THE REFERENCES ARE TO THE PAGEs.]

Sidgreaves v. Myatt, 22 Ala.

$617 \ldots \ldots \ldots \ldots \ldots \ldots . \ldots 251$

Siffkin v. Glover, 4 Taunt. 717. 512

Siren, The, 13 Wall, 389..... 571

Slaughter House Cases, 16

Wall. $78 \ldots \ldots \ldots \ldots \ldots 216,218$

Stert, The, 4 Rob. Adm. 65... 766

Sloop Betsey, The, 3 Dall. 6.

..........580, 581, 645

Smart v. Wolff, 3 T. R. $323.570,581$

Smith v. Turner, 7 How. 283.. 223

Society, Etc., v. New Haven, 8

Wheat. 464.........369, 461

Soglasie, The, Spinks Prize

Cas. 104.............. 568

Somerville v. Somerville, 5

Ves. $750 a \ldots \ldots \ldots \ldots 221,250$

Sommersett's Case, 20 St. Tr.

79; 1 Evans Decis. 95... 697

Sophie, The, 6 Rob. Adm. 138. 614

Sorensen v. The Queen, 11

Moore Priv. C. Cas. 119..

...............568, 582

Sottomayor v. De Barros, L. R.

3 P. D. (C. A.) 1; $37 \mathrm{~L}$.

T., N. S., $415 \ldots . \ldots \ldots \ldots .209$

Speculation, The, 1 Edwards

$344 \ldots \ldots \ldots \ldots \ldots \ldots . \ldots 511$

Spratt v. Spratt, 4 Pet. $393 \ldots 223$

Springbok, The, 5 Wall. 1... $72,578,779$

Staadt Embden, The, 1 Rob.

Adm. 26.............. 745

Star, The, 3 Wheat. $78 \ldots \ldots .576$

Stark v. Chesapeake Ins. Co., 7

Cranch. $420 \ldots \ldots \ldots \ldots .223$

State v. Allen, 2 Humph. 258.. 258

State v. Penney, 10 Ark. 621.. 224

State v. Vanderpool, 39 Ohio

St. $273 \ldots \ldots \ldots \ldots \ldots \ldots 254$

Strother v. Lucas, 12 Peters

$410 \ldots \ldots \ldots \ldots \ldots .276,610$

Stupp, In re, 12 Blatchf. 501.. 257

Succession of Larendon, 39 La.

An. 952 ............. 209

Susa, The, 2 Rob. Adm. 251..
Susan, The, 6 Rob. Adm. $461 n$. $749 \mathrm{n}$.

Sutton v. Sutton, 1 Russ \&

Mylne 663..........368, 461

Talbot v. Janson, 3 Dall. 133 .. $\ldots 440,473,645,684$

Talbot v. Seeman, 1 Cranch 1 $.137,576$

Taylor v. Best, 14 C. B. $487 \ldots 339$

Taylor v. Taintor, 16 Wall.

$366 \ldots \ldots \ldots \ldots \ldots \ldots 258$

Teresita, The, 5 Wall $180 \ldots 578$

Teutonia, The, L. R. 3 Adm. \& Eccl. 394; L. R. 4 P. C.

App. $171 \ldots \ldots \ldots \ldots \ldots$......45

Thirty Hogheads of Sugar v.

Boyle, 9 Cranch $191 \ldots .$.

$\ldots \ldots \ldots \ldots \ldots$ 553, 554, 593

Thomas Gibbons, The, 8

Cranch. 421 ..........4440

Thomasson v. State, 15 Ind.

$449 \ldots \ldots \ldots \ldots \ldots \ldots . \ldots 218$

Thompson, The, 3 Wall. 155.. 578

Thorington v. Smith, 8 Wall. 1. 459

Thrasher's Case 6 Webster's

Works $526 \ldots \ldots \ldots \ldots . .251$

Thurlow v. Com. 5 How. 504.. 223 Tobago, The, 5 Rob. Adm. 218. 582 Trende Sostre, The, 6 Rob.

Adm. 390n.............. 743

Triheten, The, 6 Rob. Adm. 65. 777 Troutman, In re, 24 小. J. L.

$634 \ldots \ldots \ldots \ldots \ldots \ldots . \ldots 25 s$

Tulip, The, 3 Wash. 181..... 757

Turner v. Bank of North Amer-

ica, 4 Dall. 10......... 245

Twee Gebroeders, 3 Rob. Adm.

$162 \ldots \ldots \ldots \ldots 678,684,697$

Twee Gebroeders, The, 1 Ed-

wards $95 \ldots \ldots \ldots \ldots \ldots .612$

Twilling Riget, The, 5 Rob.

Adm. $82 \ldots \ldots \ldots \ldots \ldots \ldots .565$

Two Friends, The, 1 Rob. Adm.

$271 \ldots \ldots \ldots \ldots \ldots 575,576$

Tyler v. Defrees, 11 Wall. 331.. 551 
[THE REFERENCES ARE TO THE PAGES.]

Udny v. Udny, L. R. 1 Sc. App. $441 \ldots \ldots \ldots \ldots . .209,249,250$

United States v. Alberty, 1 Hemp. 444........... 245

United States v. Amistad, 15 Peters $518 \ldots \ldots \ldots \ldots \ldots . . .396$

United States v. Arjona, 120 U. S. $488 . \ldots \ldots \ldots \ldots \ldots \ldots 137$

United States v. Arredondo, 6 Peters 691........... 136

United States v. Arwo, 19 Wall. 486

United States v. Baker, 5 Blatchf. 6.......235, 245, 498

United States v. Bales of Cotton, 1 Woolworth $236 \ldots$. ...........555,570,571

United States v. Bird, 1 Sprague 299........... 245

United States v. Cargo of Ship Fanny, 9 Cranch 181..... 434

United States v. Corrie, 23 Law Rep. 145.............. 245

United States v. Cruikshank, 92 U. S. $542 \ldots \ldots \ldots \ldots \ldots \ldots . . \ldots 218$

United States v. D'Auterive, 10 How. $609 . \ldots \ldots \ldots \ldots \ldots . . .390$

United States v. Gordon, 7 Cranch. 287.

United States v. Hall, 2 Wash. C. C. $366 \ldots \ldots \ldots \ldots \ldots \ldots . \ldots 44$

United States v. Hall and Worth, 6 Cranch 171.....433

United States v. Hayward, 2 Gall. 485 . 582,593

United States $v$. Holmes, 5 Wheat. 412............234

United States v. Jackalow, 1 Black. 484.............. 245

United States v. Klintock, 5 Wheat. 152..

United States $\nabla$. Lafontaine, 4 Cranch C. C. 173....319, 339 United States v. Lumsden, 1 Bond. 5..............680

United States v. Magill, 1 Wash. C. C. 463.......2 245
United States v. McRae, L. R. 8 Equity 69........... 609 United States v. Mingo, 2 Curt. $1 \ldots \ldots \ldots \ldots \ldots \ldots \ldots . . \ldots 245$

United States v. Moreno, 1 Wal. 400 ................ 608

United States v. Padelford, 9 Wall. 540 ............. 540

United States v. Palmer, 3 Wheat. 610...188, 234, 439, 459

United States v. Payne, 2 McCrary, 289; 8 Fed. Rep. $883 \ldots \ldots \ldots \ldots \ldots \ldots . \ldots . \ldots 397$

United States v. Percheman, 7 Peters 51......136, 610, 613 United States v. Peters, 3 Dall. 121 645

United States v. Pillerin, 13 How. 9............ 276

United States v. Pirates, 5 Wheat. $185 . . . \ldots \ldots \ldots \ldots . .234$

United States v. Quincy, 6 Peters, $445 \ldots . . \ldots \ldots \ldots 646$ United States v. Rauscher, 119 U. S. $407 \ldots \ldots \ldots .254,255$ United States v. Reading, 18 How. $10 \ldots . . . \ldots \ldots . . .494$

United States v. Repentigny, 5 Wall. 211..............6 610

United States v. Reynes, 9 How. 127..........299, 60s United States v. Rice, 4 Wheat. 246............... 593

United States v. Schooner Peggy, 1 Cranch 103..134, 611 United States v. Smith, 1 Hughes $347 \ldots \ldots \ldots . . . .608$

United States v. Ta-wan-ga-ca, Hemp. 304............. 245

United States v. Thompson 1 Sum. 168............. 245

United States v. Tract of Land, 1 Woods $475 \ldots . . . . . .6608$ United States v. Villato, 2 Dall. $370 \ldots \ldots \ldots \ldots \ldots \ldots . \ldots 223$

United States v. Walsh, 22 Fed. Rep. 644........... 223 
[TIE REFERENCES ARE TO THE PAGES.]

United States v. Watts, S Sawyer 370 .

United States v. Winchester, 99

U. S. $372 \ldots \ldots \ldots \ldots \ldots .555$

United States v. Wright, 2

Pitts. R. $440 \ldots \ldots \ldots \ldots .506$

United States v. Wright, $15 \mathrm{~L}$.

Rep. N. S. $459 \ldots \ldots \ldots \ldots .532$

Usparicha v. Noble, 13 East

232 510

Vavasseur v. Krupp, L. R. 9

Ch. D. $351 \ldots \ldots \ldots \ldots \ldots 228$

Venice, The, 2 Wall. 258..... 524

Venus, The, 4 Rob. Adm. 355.. 507

Venus, The, 8 Cranch. 253....

$\ldots \ldots \ldots 523,524,553,554,564$

Venus, The, 5 Wheat. $127 \ldots . .578$

Victoria, The, Edwards $97 \ldots 698$

Vigilantia, The, 1 Rob. Adm. 1 .........553, 554, 696

Virginie, La, 5 Rob. Adm. 124

................. 571

Volant, The, 5 Wall. 179..... 766

Vriendschap, The, 4 Rob. Adm. 98 510

Vrou Judith, The, 1 Rob. Adm. $150 \ldots \ldots \ldots 769,773,774,779$

Vrow Anna Catharina, The, 6

Rob. Adm. 269......... 553

Vrow Anna Catharina, The, 5

Rob. Adm. 15..........6632

Vrow Cornelia, The, 1 Ed-

wards $360 \ldots \ldots \ldots \ldots \ldots 511$

Vrow Johanna, The, 2 Rob.

Adm. 109............. 769

Vrow Johanna, The, 4 Rob.

Adm. 351............. 787

Vrow Margaretha, The, 1 Rob.

Adm. $337 \ldots \ldots \ldots \ldots \ldots . .568$

Wagner v. The Juanita, Newb.

Adm. 352 .
Ware v. Hylton, 3 Dall. 199.... $\ldots \ldots \ldots \ldots 136,249,462,612$ Warin v. Scott, 4 Taunt. 605.. 511 Warrender v. Warrender, $2 \mathrm{Cl}$.

\& F. $488 \ldots \ldots \ldots \ldots \ldots .221$

Welch v. Adams, 152 Mass. 74. 209 Welch v. Sullivan, 8 Cal. 165.. 599 Wheelwright v. Depeyster, 1 Johns. 472 ........... 581 White v. Burnley, 20 How. 249. 460 Wildenhus, Case of, 120 U. S. $1 \ldots \ldots \ldots \ldots \ldots \ldots \ldots .313$ Wilhelmsberg, The, 5 Rob. Adm. $143 \ldots \ldots \ldots \ldots \ldots .786$ William, The, 5 Rob. Adm. 385. 778 William \& Mary, The, 4 Rob. Adm. $381 \ldots \ldots \ldots \ldots \ldots .571$

William Bagaley, The, 5 wall. $377 \ldots \ldots \ldots \ldots 524,554,555$ William King, The, 2 Wheat. $148 \ldots \ldots \ldots \ldots \ldots \ldots \ldots .433$

Williams v. Armroyd, 7 Cranch. 423 ................ 583

Williams v. Marshall, 6 Taunt. $390 \ldots \ldots \ldots \ldots \ldots \ldots . \ldots 512$

Wiliams v. Suffolk Ins. Co., 13 Peters $415 \ldots \ldots \ldots \ldots \ldots .299$

Williamson v. Brig Betsy, Bee $67 . \ldots \ldots \ldots \ldots \ldots 645$ Wolff v. Oxholm, 6 M. \& S. $92 . .463$ Woods v. Wilder, 43 N. Y. 164 ..............510, 553 Worcester v. State of Georgia, 6 Peters 575.......... 136

Yates v. Hall, 1 T. R. 73..... 573

Young v. United States, 97 U. S. $39 \ldots \ldots \ldots \ldots . \ldots 40,555$ Young Jacob, etc., 1 Rob. Adm. $20 \ldots \ldots \ldots \ldots \ldots \ldots \ldots 59$

Zavalla, The, Blatchf. Prize Cas. $173 \ldots \ldots \ldots \ldots \ldots . \ldots 52$ 462 Zee Star, The, 4 Rob. Adm. 71. 786 


\section{INTRODUCTION.}

§1. Analytical and historical methods contrasted.-The expounders of jurisprudence are now divided into two distinct schools whose methods of investigation and demonstration are radically different from each other. To a student of the older or analytical school a constitution, a code of laws or customs present themselves as things that have existed from the very beginning in their present form. His primary duty therefore involves only such an analysis of their various provisions as will reveal the existing rules under which rights and duties are defined and remedies administered. With the history of the processes through which such constitutions or codes came into existence he has nothing directly to do,-in his view the history of law is really no part of jurisprudence, it is simply a side-light which may or may not be used as an aid to interpretation. From the utterly false assumption upon which this method proceeds have necessarily resulted many serious misconceptions as to the origin of government, and as to the nature and development of law, both public and private. Chief among these may be mentioned the fanciful theory, long upheld by the names of Hooker, Hobbes, Locke and Rousseau, that man, in order to escape from the ills incident to the imperfect operations of the law of nature in a "state of nature," consciously and deliberately entered into a "social contract." Hooker tells us that "this was the cause of men uniting themselves first in political societies;" and to that Locke adds that in order to escape from a condition that was practically a state of war men agreed "together mutually to enter into one community and make one body politic." Investigations of the historical school into the early history of institutions have Iong ago revealed the fact that not only does such assumption lack any historical foundation whatever, but that the very contrary was the truth. Through recent research the fact has been established that individualism was unknown to ancient politics; that status and not contract was the basis of primitive society. At the outset the individual counted for nothing,

1 Ecclesiastical Polity; the Le- ernment; the Contrat Social. viathan; the Essays on Civil Gov- 
the state, society for everything. As Aristotle has stated it, "man is born to be a citizen." By the aecident of birth he was assigned his grade in primitive society from which he was not expected to depart.

\$2. Roman theory of a determinable law of nature.-The theory thus exploded by means of the historical method began with the assumption that over and above the laws of men there is a law of nature, an abstract standard of human conduet to which all earthly laws should conform, and to which all mankind should be made to assent through the dictates of universal reason. When the time came for Ayala, Gentilis and Grotius to lay the foundations for the set of understandings now generally known as international law, the main difficulty was to settle upon a source from which rules could be drawn adecquate to determine the jural and moral relations of a group of sovereign, coequal and independent states. In the effort to supply the vacuum Grotius and his suecessors revived the Roman theory that there is really such a thing as a determinable law of nature; and so the conclusion was reached that the natural law is binding on states inter se; and that that law and the jus gentium are identical. Thus it became the fashion to attribute the origin of international law to some transcendental source, such as nature, reason, and the Divine W'ill,-a source that was supposed to impart to it an intrinsic and substantive authority over all the nations of the earth. To give color to such fictions it was held that the usage of nations was not the origin of the law, but only the evidence of it; as Sir Robert Phillimore has expressed it such usage expresses "the consent of nations to things which are naturally, that is, by the law of God, binding upon them.",

What international law really is.-In order to disentangle the subject from such fanciful and unscientific theories the historical school made another of its prosy inquisitions into the actual historical facts, and the outcome is the statement that what is now called international law is simply a body of rules accepted by civilized nations as binding and obligatory in

2 "A really city-less man *** this $\not{\alpha} \pi \circ \lambda i s$, the clanless and masterless man whom Aristotle regards as a kind of Monster, is identical with the natural man of Hobbes and Rousseau. He is the unit out of whom, if there be only enough of them, theorists of the Social Contract school undertake to build up the State." Sir.F. Pollock, Hist. Science of Politics, p. 20.

3 Preface to Com. on Int. Law, vol. i, p. 5. 
their mutual dealings with each other. In the words of Dr. Bulmerineq such law "is the totality of legal rules and institutions which have developed themselves touching the relations of states to one another." ${ }_{4}$ Thus the historical school, ever opposed to all á priori assumptious, has clearly demonstrated, that the primitive organization of individual states never was, and never could have been, based upon conscious and deliberate contract among its members; that as between sovereign and coequal states, refusing to admit any common superior, no set of understandings, expressed or implied, could possibly rest upon any other basis.

§3. Growth of law explained through the record of its development.-The historical method of investigating the origin and growth of law, public and private, beginning with its germs in primitive society, attempts to explain its nature and meaning through the record of its development. The main difficulty in the way of complete denonstration is the fragmentary character of the evidence as to the initial forms of law in the early periods. Only by a comparison of such fragments as have been preserved in the survivals of ancient law or custom, in the usages of savage tribes and stagnant nations, or in the annals of a few ancient historians, is it possible to reconstruct primitive society as a complete organism. 'The same process of thought that gave birth to comparative anatomy and comparative philology, at a little later day, brought forth comparative politics and comparative jurisprudence. ${ }^{5}$ These new branches of knowledge are simply parts of the gen. eral result of the transition that has taken place since the end of the last century from the old or artistic method of historical investigation to the new or sociological. The cause of the transition was the consciousness that the system of permanent, uniform and universal law that regulates growth and decay in the physical world applies as well to the growth and decay of societies as to other phenomena. The French Revolution gave a strong impulse to the new idea, and the French scholars, who were nearest to the upheaval that brought suddenly into view the underlying social forces that had lain

\Das Völkerrecht (in Marquardsen's Handbuch, vol. i), sec. 1 of the monograph.

- As an illustration of the advance that has been made in Germany in the study of Comparative
Jurisprudence under the influence of the historical school of jurists, see the volumes of Dr. Albert Hermann Post, entitled, Grundriss der ethnologeschen Jurisprudenz, Oldenburg und Leipzig, 1894. 
ominously silent during the drealful calm of the latter days of the ancient regime, were the first to undertake, after the Peace of 1815 , the mighty task of rewriting the history of the world from a new point of view. Michand, the Thierrys, Sismondi, Nichelet and Ginizot led the way, and upon their heels came Augiste Comte who raised limself to the level of Leibnitz and bescartes by pereceiving that social organization must be viewed and explored ats a whole because of the connection between each leading group of social phemomena and every other leading group so intimate as to make a change in one result in a corresponding modification in all the rest.

$\S 4$. Comte as founder of the science of society.-By withdrawing the collective facts of society and history from the recrion of external volition, and placing them in the region of law, Comte made possible the social scienc shat now describes how men becane grouped in political communities, how they separated into high and low, rich and poor, how they formed casts and guilds, how they recognized property, and how they constituted government and liaw. To use his own language "Not only must political institutions and social manners, on the one hand, and manners and ideas, on the other, be always mutually connected; but further, this consolidated whole must be always connected by its nature with the corresponding state of the integral development of humanity, considered in all its aspects of intellectual, moral, and physical activity." So industrious have been the popular historians in rewriting the general history of mankind, in the light of the new revelation, that Mr. Freeman declared not long ago that all historical writings anterior in date to the end of the eighteenth century have been entirely superseded, with the exception perhaps of Gibbon alone. The time is near at hand when the same thing may be sald with equal truth of all, or nearly all, of the older treatises specially devoted to the origin and growth of government and law.

- See J. Cotter Morison's article on History, Enc. Brit., vol. xii, p. 19.

i Herbert Spencer admits that to Conte "is duc the credit of having set forth with comparative definiteness the connection between the Science of Life and the Science of Society." The Study of Sociology, p. 328 . s "Judge O. W. Holmes recently observed that the tendency of our age to 'explain thin 3 ' by stating the conditions under which they came into being, and noting their growth under the influence of a varying environment from age to age, is as strongly marked in the field of law as in other departments of intellectual activity. This 
$\S 5$. Why international law should be re-examined by historical method.-The entire field of international law should be re-examined in the light of the historical method, because the two great elements involved are the outcome of a gradual and complicated process of historic development. The first element is represented by the high contracting parties upon whose consent the entire fabric depends for existence,-the sovereign, coequal and independent commonwealths that constitute collectively the state-system of modern times. Not until the era of the Reformation did that state-system assume its present form; prior to that time the political relations of the European states as members of the shadowy Christian commonwealth known as the Holy Roman Empire precluded the idea of independent nationalities. It may be true that the Empire was far more of a doctrine or theory than an institution, and get not until that theory or phantom of a united Christendom vanished was it possible for the independent nationalities that emerged to begin the building up, bit by bit, of the existing system of understandings that has no real counterpart in the ancient or medieval world. The student of interuational law must therefore ascertain, in the first place, how it was that the existing state-system with which he has constantly to deal came into existence,-an inquiry that necessarily involves a somewhat careful examination of the ancient and medieval state-systems that preceded it. Not until the first branch of the subject has been fully mastered can a clear and definite understanding be had of the process through which the emancipated nationalities were forced by the rery necessities of their situation gradually to construct a modus vivendi under which they could dwell together in some kind of peace and concord. Thus will the effort be made to unfold, with the aid of the historical method, the several stages of growth through which the system of international law came into existence. When that point has been reached the aid of the analytical method will be invoked, in order that the intent and meaning of the various and complicated rules embodied in that system may be clearly expounded.

method of legal study has done and is doing a great work for English and American law; placing particular doctrines in their proper places, making plainer the relations of one part of the law to another, sweeping away cobwebs of tradition, and separating the essential from the accidental in respect to institutions." Law Notes, June, 1899, p. 54. 



\section{PAFT I.}

\section{Ancient and Medieval State-Systenls.}

\section{CHAPTER I.}

THE ANCIENT STATE AS THE CITY-COMMONWEAL'TH.

§6. The normal international person a state.-Holland, in his Elements of Jurisprudence, defines international law to be "the body of rules regulating those rights in which both of the personal factors are states. * * The normal international person is a state which not only enjoys full external sovereignty, but also is a recognized member of the family of nations, - * * an aggregate of states which, as the result of their historical antecedents, have inherited a common civilization, and are at a similar level of moral and political opinion." In order fully to grasp the nature of the existing aggregate of states viewed as "the result of their historical antecedents," it will be necessary to examine, to some extent at least, the three great state-systems whose prior histories extend over the immense interval that divides the beginning of authentic tradition from the beginning of modern times.

Greek, Roman and medieval state-systems.-The first of such systems was that embodied in the relations, religious and political, existing between the Greek city-states which persistently refused to be merged in any single aggregation that could be called, in any proper political sense, a nation. The second was that embodied in the relations existing between the sovereignty of Rome and the nations beyond the limits of her authority. The third was that embodied in the relations existing between the states bound up for centuries in the strange political fabric known as the Holy Roman Empire. The germs of international comity and morality first appear in a clearly developed form in the Delplic Amphictyony, to the responses of whose oracle not only the

1 Pp. 345, 349. 
Greeks but the Romans-eren the Romans of the time of the Empire often listened with respeet. There can be no doubt that Greek ideas as to the proper relations of states to each other were impressed, to a greater or less extent, upon that system of Imperial law whose influence las been so far reaching and so permanent. The magniticent conception of a unirersal Christian Commonwealth embodied in the Medieval Empire rested upon principles drawn almost exclusively from Roman soures; and when upon the actual dissolution of that fabric at the time of the Reformation the modern state-system of independent nationalities emerured, the jurists who attempted to construct a new set of understandings among them turned instinctively to the same source for their materials. By reason of this interpenetration of principles and ideas, it is impossible to comprehend all the elements that enter into the existing state-system without a eursory examination at least of its three predecessors whose individual histories constitute only distinct stages in one unbroken and progressive derelopment.

$\S 7$. Greek city-state an aggregation of village communities.-The most important single result so far attained by the application of the comparative method to the study of political institutions is embodied in the discovery that the unit of organization in all the Aryan nations, from Ireland to Hindoostan, was the naturally organized association of kindred-the family swelled into the elan-which in a settled state assumed the form of a village community. When we have firmly taken hold of that fact, when we elearly understand that the original unit of organization was the same in all the Aryan nations, whether situated on the shores of the Mediterranean or the Baltic, we have possessed ourselves of the atom or unit that, in different forms and different combinations, everrwhere enters into the structure of the state,--a term that has represented radically diflerent conceptions at different periods of the world's history" For the earliest illustration of the an. cient conception of the state as the city-commonwealth we must go to the Hellenic world in which the seience of polities was born. The dominant political idea we there encounter is embodied in the independent city standing towards all other cities as a sovereign state whose internal affairs are regulated br its own domestic constitution. When the municipal organization

2 For a more complete statement English Constitution, vol. i, pp.1-3. see The Origin and Growth of the. 
of such a state is examined the fact is revealed that the eitycommonmealth is a composite whole that has arisen out of the aggregation of village communities. The first stage is represented by the gathering of a group of village communities or clans $\left(\gamma^{\prime} v \varepsilon \alpha\right)$ into a brotherhood ( $\left.\rho \rho \alpha \tau \rho i \alpha\right)$; the second by the gathering of brotherhoods into a tribe; the last by the wathering of tribes into a city. "Several families formed the phratry; several phratries the tribe, several tribes the city. Family, phratry, tribe, city, were, moreover, sorieties exactly similar to each other, which were formed one after the other by at series of federations." ${ }^{3}$ Internal changes that afterwards took place in the primitive constitution of the independent city do not touch the fact that it represented the only practical conception of the state that existed in the Hellenic world. To the Greek mind the state, the city-commonwealth, was an organized society of men dwelling in a walled city with a surrounding territory not too large to allow its free inhabitants habitually to assemble within its limits to discharge the duties of citizens. ${ }^{4}$ During the earlier and more brilliant days of Greek history the city and nothing higher or lower was the one acknowledged political unit.

§ 8. Greek state-system as outlined by Aristotle.-In this șstem of free cities, internally organized at the ontset after one general model, were contained the political conditions with which Aristotle, the acknowledged founder of political science, was brought into contact; and, in obedience to his practical temper, he begins his political speculations with a description of the forms of government actually existing around him. It is probable that in order to collect sufficient data to support the statements and conclusions contained in his politics, he made, as a preparatory study thereto, the collection called the Constitutions, which is said to have contained a description of the organization, manners, and customs of one hundred and fiftyeight city-states. ${ }^{5}$ In that rast collection were embraced, no doubt, examples of every varying shade of political constitution. In one city sorereignty was vested in a pure democracy, electing magistrates, enacting laws and ratifying treaties in

3 De Coulanges, The Ancient City (Small's trans.), p. 168. See also Freeman's Comparative Politics, p. 104.

4 Aristotle thought that a state should not be so large as to deny to its citizens the opportunity to become familiar with each cther. Politics, vii, c. iv. 13 .

5 The main body of materials thus collected has been lost, but the fragments that remain have 
an assembly in which every free citizen had an equal voice; in another all the power was vested in a narrow oligarchy; while in a third the supreme authority was confided to a tyrant whose attributes raried widely according to circumstances. And ret despite such internal variations the idea was universal that every Greek city was entitled to a perfectly independent existence, with the full right to regulate its external relations with other states through its own ambassadors. As the master of the history of Greek federalism has expressed it: "Each city is either sovereign or deems itself wronged by being shorn of sovereignty. At a few miles from the gates of one independent city, we may find another, spealing the same tongue, worshipping the same gods, sharing the same national festivities, but living under different municipal laws, different political constitutions, with a different coinage, different weights and measures, different names, it may be, for the rery months of the rear, lerying duties at its frontiers, making war, making peace, sending forth its ambassadors under the protection of the laws of nitions, and investing the bands which wage its border warfare with all the rights of the armies and the commanders of belligerent empires." The citizens of each "aultonomous city-conmmnity" thus ciremstanced looked upon its narrow limits as his comtry $\left(\pi \alpha \tau \rho \rho^{\prime}\right)^{7}$; within its walls his selfcentered patriotism was confined; and thus he was taught to regard limself not as a Greek or an Italian, but as an Athenian or Roman. The intense love for one's own city thus engendered was more than equaled, however, by the bitter late that grew ont of the ever eonflicting interests and jealousies arising between neighboring states whose pride it was to deny any common superior.

\$ 9. Extreme cruelty of laws of war.-The natural outcome of such conditions was a state of almost perpetual war carried on under laws cruel almost beyond modern conception. Outside the limits of Hellas, a term that applied to every place where Greeks dwelt, all mankind were barbarians or enemies, and as such without claim to any lind of humane consideration. ${ }^{8}$ Within the limits of Hellas, while there was a feeling

been collected and annotated by Neumann, and are contained in Bekker's Oxford edition of Aristotle.

- Freeman, Hist. of Federal Government, vol. i, pp. 35-36.
7 The same use of the word is common in modern Greek.

8 Aristotle calmly argued that barbarians were intended by nature to be slaves of the Greeks. Politics, I., II., VI. He further 
that common blood constituted a local and exceptional tie, between Greek and Greek in a state of war, the laws seem to have been almost if not equally severe. No matter whether we look for the rule to the Greece of Thucydides or to that of Polybios, death or slavery was the state to be expected by the conquered, unless there was an express stipulation to the contrary. The life of a prisoner was not sacred unless the conqueror bound himself by express stipulation to preserve it; and in the same way inlabitants of a conquered city, even when no special provocation had been given, were legally liable to sale in the absence of any personal claim upon their captors. $^{10}$ To kill the men and sell the women and children of a conquered Greek city, while it might be an extreme act of severity, was no breach certainly of the letter of the Greek law of nations when no contrary stipulation had been entered into. The perils thus attending war upon land were fully equaled by those of the sea. Piracy, unblushingly practiced by the most civilized nations of antiquity, subjected the peaceful merchant not only to plunder and capture by men with whom his country had no quarrel, but also to the contingency of sale to some barbarian master. ${ }^{11}$ Such in brief were the distinguishing features which marked the relations existing in time of war between the numberless independent communities of Greece, that spread themselves first over the European peninsula bearing that name, then along the Egean coasts of Asia Minor, and finally around the borders of the greater sea in such a way as to justify Cicero's notable declaration that an Hellenic hem was woven about the barbarian lands of the Mediterranean.

$\S 10$. Status of aliens; isopolity and international courts.And yet relentless as was the policy of Greek city-states when contended that it was both natural and honorable to acquire wealth by making war in order to reduce to slavery those who had been thus predestined by nature to that condition. Ibid., I., viii. In the beginning of the Laws Plato declares war to be natural between all

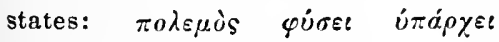

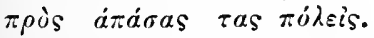

9 Thucydides, i. 30 et passim.

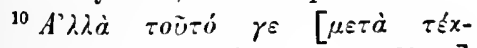

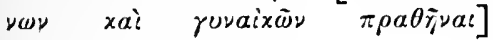

$x \alpha \grave{\imath} \tau 0 \tilde{t} \mathrm{~S} \quad \mu \eta \theta \dot{\varepsilon} \nu \quad \grave{\alpha} \sigma \varepsilon \beta \dot{\varepsilon} S \quad \varepsilon \pi t \tau \varepsilon$

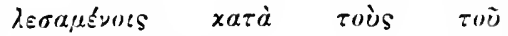

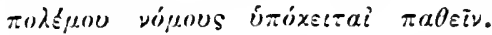
Polyb. II., 57.

11 Prof. H. Brougham Leech, in his very able Essay on "Ancient International Law” (Dublin,1877), after a careful review of the authorities, concludes that the usual statements as to the cruelty of the Greeks in war are exaggerations. "To pronounce them insensible to any moral laws," he says, "or to any reciprocal obli- 
hostilities were in progress, the more enlightened of them were not unfriendly to peaceful foreigners who eame to dwell permanently within their walls. While the aristocratic and agricultural states were arerse to the admission of strangers on any terms, the commereial ones favored their introduction. On the one hand sparta in her earlier and severer days forbade leer citizens to gro abroad and refused to permit strangers to reside within her bounds; ;2 on the other, $A$ thens allowed her domiciled aliens ( $\mu \varepsilon \tau o z \chi^{\circ}$ ) ) to enjoy her laws through the

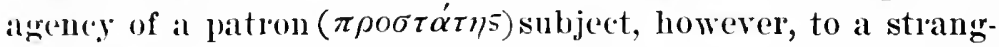
er's tax, and to military service by land and sea. ${ }^{13}$ In some of the Greek states individual aliens, or even whole communities, were roted such important civic rights as exempted them from taxation, and enabled them to hold real estate and to intermarry. Oecasionally, by vote of the community, an alien was endowed with full citizenship. The most notable feature of this liberal policy was that part of it embodied in international conventions providing for the mutual administration of justice to resident foreigners, for the establishment of mixed tribunals, or "ven for the grant or isopolity. ${ }^{14}$ As Laurent ${ }^{15}$ has expressed it: "Lorsque deux cités roulaient s'unir intimément, elles convenaient que ceux de leurs membres qui s'établiraient dans la république alliée $y$ jouiraient de tous les droits du citoyen, nềme du droit de suffrage et de l'admissibilité aux fonctions publiques. On alppelait cette alliance étroite ispolitie. * * * La justice était le plus profond, le plus légitime des besoins, et les villes commercantes etaient aussi intéressées à assurer ce bienfait aux étrangers, que ceux-ci à le demander. Des conventions spéciales pourvurent a cette nécessité. On y déterminait les règles d’apres lesquelles les contestations devaitent être jugées; parfois on convenait que les juges seraient pris ágalement chez les deux peuples et formeraient ainsi une espéce de cour internationale; on se promettait

gations, except such as were enjoined by treaties, is, even with regard to their relations with nonHellenic states, and in a much greater degree as between themselves, a libel of the grossest kind." P. 16.

12 Plut. Ages, 10. Plut. Lycurg., c. 27. Thuc., I, 144.

13 Thuc., III, 16. Cf. Plut., c. 37. 14 Arist. Polit., III. 1, 3. Ibid.,

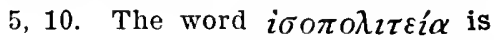
also used by Plutarch (II, 300) and means "equality of civic rights."

15 Histoire du Droit des Gens, II, 114 seq.; citing Niebuhr, Histoire romaine, II, 95 seq. (traduct. fr. ćdit de Brux); Demost. de Coron. $\S 90$ seq., p. 225 seq.; Xenoph. (Hellen, I, 1, 26) ; Sainte-Croix, Legislation de Crite, p. 357-360; 
bonne et prompte justice; l'étranger pourait souteuir ses prétentions devant ces tribunaux, sans avoir besoin d'un patron." Such privileges, extended to barbarians as well as Greeks, swelled the ranks of domiciled strangers at Athens until they equaled one-half of the citizens.

$\S$ 11. Futile efforts of the Greeks to establish political unity.The spirit of isolation, of exclusiveness that made impossible anything like a fusion through incorporation of the Greek cities of the main land, despite the eflorts to establish an interstate citizenship, extended itself in full force to the colonial system. Although each mother city sent out the colonizing group that left her as a part of herself, the parent state retained no political control whatever over its offspring, and the new communities that thus reappeared far from home refused as a general rule to enter into any common system of gorernment even with other Greek settlements upon the same coast. The single unirersal tie that seems to have impressed these disconnected entities with a sense of their oneness was that which arose out of the consciousness that all Hellas was bound together by a common blood, a common civilization, a common tradition, and last, and most of all, by a common religion. The longing for union first manifested itself in the creation of the several religious leagues formed between neighboring cities encircling some famous shrine which they desired to enrich upon the one hand and to defend upon the other. ${ }^{16}$ The mostfamous and powerful of such associations was that which gathered alternately about the temple of Apollo at Delphi and about the shrine of Demeter Amphictyonis at Thermopylæ, including, at one time, almost all the tribes of central Greece and, in its latter dass, members from Dorian states of Peloponnesus. The once prevalent idea that the Delphic $\mathbf{~} \mathrm{m}$ phictyony embodied a real federal govermment of all Greece has given way long ago to the conclusion that its primary purpose was purely religious and its political action purely incidental. ${ }^{17}$ To preserve the sacred independence of the oracle at Delphi by guarding the surrounding territory from in-

Polyb., XVI, 26, 9; Liv. XXXI, 15; V. Hullmann, Handelsgeschichte der Griechen, p. 193-196.

16 "A league in its simplest form was but the extension of the religlous obligation, under which fellow citizens stood towards one another, as votaries of the same gods." Twiss, Law of Nations, $\S 209$.

17 For an early statement as to the true nature of the League see Sainte Croix, Des Anciens Gouvernemens Fédératifs, Paris, an. vii. 
vasion and to superintend the common worship of Apollo were the primary purposes of the league; to forbid, while it was thus assembled, any extreme measures of hostility against any city sharing in the common Amphictyonic worship, such as razing it to the ground or cutting off its water supply, were incidental political acts that became blended with its religious functions. ${ }^{1 s}$

Primitive conceptions of international law.-As a part of these primitive conceptions of international law, arising out of the conscionsness that all Hellenic peoples were of the same race and religion,may also be noted the general understanding that those who died in battle were to receive burial; that the lives of those who took refuge in the sanctuaries of a conquered city were to be spared; and that those who were journeying to the common seats of Hellenic worship or to the public games ${ }^{19}$ were under the protection of what has been termed an early Truce of God. As the only deliberative body in which members from the greater part of Greece habitually assembled it is not strange if, on a few occasions, the Amplictyonic Council did attempt to speak with real dignity as the monthpiece of a common national feeling. Upon such data rests the statement that the "Council was not exactly a Diplomatic Congress, but it was much more like a Diplomatic Congress than it was like the goveruing assembly of any commonwealth, kingdom or federation. The pylagoroi and hieromnêmones were not exactly ambassadors, but they were more like ambassadors than they were like members of a British parliament or even an American congress. The business of the Conncil was not to govern or to legislate, either for a single state or for a league of states; its duty was simply to manage a single class of affairs, in which a number of independent commonwealths were alike interested, but which did not come within the individual competence of any one of their number." 20

$\S$ 12. Athenian Alliance or Empire.-For political associations pure and simple, whose primary purpose was to regulate the external relations of as many independent cities as would enter into them, we must look to the Greek federal leagues

18 The old Amphictyonic oath forbade all such extreme measures against any city sharing in the common worship. Asch. Fals. Leg. $\$ 121$.
10 Grote, Hist. of Greece, Pt. II, ch. ii.

20 Freeman, Hist. of Federal Govt., vol. i, p. 140. 
whose beginnings, like those of the purely religious associations, often antedate authentic tradition. The earlier and more brilliant period in the history of the Greek commonwealths is that occupied by the supremacy of a few great cities which extended their dominion by reducing other selfgoverning commonwealths to a state of dependence. Foremost among that class stood the city-state of Athens, which extended her overlordship by reducing her dependent allies to a condition in which they were permitited to enjoy local autonony under their own constitutions, including the right, in some instances, to retain their own fleets and armies, without the right to participate in any way in the political affairs of the ruling state by whose assembly the foreign relations of the alliance, if alliance it may be called, were absolutely controlled. The most favored members of the Athenian Alliance or Empire, even Chios or Mitylênê, could not be given a voice in the general direction of the Confederacy for the simple reason that Greek exclusiveness rejected to the last the idea of a fusion of any large number of cities into a single body with equal rights common to all. ${ }^{21}$ Athens was the ruling state, and her supreme power was vested in an assembly in which no one except an Athenian citizen could possibly appear. The principle of representation was unknown, and the Greek instinct of separateness firmly refused to admit either subjects or allies to a common franchise. By reason of that principle, whose rejection became the corner stone of Roman dominion, the independent cities of Greece were nerer merged in any larger aggregate that could be called in any proper political sense a nation. The independent city was the Greek ideal, and because the Athenian supremacy cast a shadow upon it, her rival Sparta rose against her with the popular war cry that all Greece must be made autonomous. ${ }^{22}$

$\S 13$. Achaian League of Peloponnesus.-Toprevent the greater cities from acquiring abnormal importance by reducing

21 "Some of them combined from time to time, generally for defensive purposes, in which case the hegemony was assigned to one by express consent or silent recognition; but the system of a central government, though indications of such a tendency appear in the development of Athenian Empire, had not been worked out, and the individual independence of the several states was never so far infringed upon as to render inaccurate the application of the word 'international' to their relations with one another." Prof. H. Brougham Leech's Essay on "Ancient Int. Law," p. 5.

22 Thucydides, i, 139, et al. 
others to a state of dependence, the wealier and less strictly organized communities began at a very early day to draw together in more or less perfect confederations, whose history, beginning with the minor northern leagues of Phocis, Akarnanial, Eprires and Thessaly, "ulninated in that of the famous Achiain league of Peloponnesus, revired, about B. C. $280,{ }^{23}$ in order to unite the greatest possible number of Greek cities in opposition to the designs of Macedonia to reduce all Greece under lere direct sovereignty or indirect influence. In the eflorts thus made to preserve the internal equilibrium of Greece a fully matured treaty system for the maintenance of the balance of power appears in full operation. So perfect was the organization of the Acliaian League that it has been classed as a Ierfect national govermment,-in German technical language as a bundesstat and not as a mere staatenbund.24 Ilowever that may be, the fact is clear that it possessed one attribute vital to the existence of such a government in that frovision of its constitution that reserved to the federal head complete supremacy in its relations with other states as to matters affecting the Achaian body as a whole; no single eity could, of its own authority, make war or peace or send ambassadors to foreign powers.

$\S 14$. Greek contributions to federalism and to the law of nations.-When the Greek political system is thus viewed as a whole it appears to have contained, apart from its highly developed forms of independent city life, many of the more important elements that have entered into federalism and into the law of nations as matured in later times. The point at which the "alacity of the Greek for the highest type of political organization failed is marked by his inability to fuse the coherent mass of self-governing communities, bound together by the ties of a common language, a common civilization and a common religion. into a single aggregate whose concentrated powcrs could lave been wielded under the name of a Greek

23 Cf. Polyb., ii, 41.

24 Helwing, p. 237; Heffter, Das Europäische Vïlicrecht, \$\$ 20, 21. Such knowledge of the constitution of the League as the framers of the Federal Constitution of the United States possessed seems to have been drawn from the Obserrations sur $l$ Historie de la Grece of the Abbe Mlably. From the Fed- eralist (No. xviii), we learn that "Could the interior structure and regular operation of the Achaian League be ascertained, it is probable that more light might be thrown by it on the science of Federal Government, than by any of the like experiments with which we are acquainted." 
nation or empire. In the domain of jurisprudence tlere is a corresponding lack of perfect development. The growth of law began, no doubt, in Greece earlier than in Italy, and up to a certain point it may have developed more brilliantly. If Greece had succeeded in building up an extensive and powerful empire, the outcome might have been a great codification that would have rendered unnecessary the compilations of Justinian. But the fact is that no such thing happened. The Greeks left behind them no complete or imposing legal monuments. Of their conceptions of law and legal procedure we can only catch glimpses from the Homeric poems, from the fragments that remain of the Hellenic codes, from the details of law and practice found in the orations of Demosthenes and other Greek orators, from what Plato tells us in the Dialogues, the Republic, and the Laws, from the outlines of public law to be traced in the politics of Aristotle, and from the fragments of a legal treatise by Theophrastus, referred to in the first book of the Digest of Justinian. ${ }^{25}$ With the aid of all that can be drawn from these imperfect survivals, distinguished by a lack of order and by an inability to sever law from morality and religion, it is hard to negative the assertion that neither the Greeks themselves, nor any society thinking or speaking in their language, ever developed the smallest capacity for producing anything like a philosophic system of jurisprudence. ${ }^{26}$ And yet after all that has been said the fact remains that the very perfect methods of diplomatic intercourse matured between the independent Greek city-states, acting either under their own constitutions, or through the federal bodies to which the right to such intercourse was surrendered; the system for the maintenance, mainly through federal compacts, of the international balance of power, ${ }^{27}$ or for concert of action against a foreign foe; the clear distinctions between the rights of peace and war; the efforts of the Amphictyonic bodies to mitigate the horrors of war,- - give color at least to the assertion that there was really such a thing as a Greek law 25 of nations to which the peculiar organization of the Hellenic world offered a specially inviting field for development.

25 Upon the whole subject, see La Science du Droit en Grice. Platon, Aristote, Thíophraste. Par Rodolphe Dareste, membre ale $l$ ' Institut Conseiller a la Cour de Cassation, Paris, 1893.
26 Maine, Ancient Law, p. 343.

$2 \pi$ Polyb., i, 83.

is "The pages of Thucydides contain frequent and definite allusions to a recognized public law in Greece-an International Positive 
\$ 15. Italian city-state system.-When we pass from the Greek to the Italian peninsula we there find the idea of the independent eity to be the leading political idea; and we also find the Italian city to be the resultant of the process of aggregation heretofore described in which the village community was the unit or starting point. In their earlier stages the rescmblance between the Greek and Latin city-state was complete,-not until the time of the Empire did the government of kome become radically unlike the governments of Greece. In Italy the village-community appears as the gens; out of the union of gentes arose the tribe; out of the union of tribes arose the state or city-commonwealth. ${ }^{29}$ But the idea of the state as an independent city was never carried out with the same completeness in Italy as in Greece, for the reason that the Italian cities, generally smaller than those of Greece, manifested a greater willingness to join together in confederations. In that way the history of ancient Italy taken as a whole is far more a history of confederations than of single cities.

$\S 16$. Rome and the principle of incorporation.-And yet, as an exception to the general rule, it was upon the soil of Italy that a group of village communities grew into a single vast and independent city ${ }^{30}$ that centralized within its walls the political power of the world. The way in which Rome accomplished that marvelons result was by departing from the exchusive policy of the Greek cities that persistently refused to incorporate dependent cities by extending to them their own framclise. As it was beneath the dignity of the sovereign rity to confoderate with her dependents, and as the expedient of representation was unlnown, Rome entered upon a policy of incorporation carried out by the extension of her franchise first to Italy, then to Gaul and spain, and finally to the whole Roman world. ${ }^{31}$ In the end a right so widely

Law-composed partly of treaties, which are referred to as binding documents, and partly of conventional usages, sanctioned by time and general acceptance." Prof. H. Brougham Leech's Essay on Ancient Int. Law, p. 7.

29 De Coulanges, The Ancient City, pp. 131-146, 154-177.
30 Maine, Early Hist. of Inst., p. 84.

31 Guizot, Hist. Rep. Govt., pp. 181, 182. As to the edict of Antoninus Caracalla, extending the privilege of Roman citizenship to all the free inhabitants of the empire, see Maine, Ancient Law, p. 139; Gibbon, Decline and Fall, vol. i, pp. 185, 193, 194. 
bestowed became of course utterly worthless; but the theory upon which the right was conferred was never for a moment lost sight of. The freeman who received the franchise of the Roman city could only exercise it within her own walls; it was only within the local limits of the ruling city that the supreme power's of the state could be exercised. ${ }^{32}$ And so, whether we take for illustration the exclusive Greek city, or the great Latin city extending its franchise to all the world, the ancient conception of the state as the city-commonwealth stands forth clearly and distinctly defined.

\section{\$ 17. Legal science a Roman creation-origin of the Corpus} Juris Civilis.-When the Roman political system is viewed as a whole just criticism can scarcely deny that it was only within the domains of jurisprudence and military organization that the Latin genius produced original and enduring monuments for imitation. Legal science is a Roman creation, an evolution from a code which, in its primitive form, was merely an enunciation in words of the customs of the Roman people, put forth before Roman society had finally emerged from that condition in which religious duty and civil obligation are inevitably confounded. ${ }^{33}$ It has been said that Roman law begins with a code and ends with a code. The Corpus Juris Civilis was the final outcome of the process of evolution that began with the decemviral code of the Twelve Tables, four centuries and a half before Christ, and ended with the compilations made in the reign of Justinian, more than five centuries after Christ. During that period of nearly a thousand years, during which Roman law was in the process of constant change and development, its expositors consistently adhered to the theory that the entire system rested on the Twelve Tables and therefore upon a basis of written law, just as English lawyers have always assumed that their entire system has been derived from immemorial tradition. With the creation of the primitive code the spontaneous development of Roman law ceased; and then the question of questions that arose was as to the means of adapting an unelastic system of strict and highly formal law, originally confined to a single

32 "Within the walls of Rome alone could be consummated all the acts of a Roman citizen." Guizot, Hist. Rep. Govt., p. 184.

33 "For the period preceding the compilation of the Twelve Tables, the only law which prevailed was that which was under the special protection of the Roman priesthood, which represented the rule of God and of reason, and which derived its force and authority 
city, to the ever increasing wants of a society expanding into an empire. That marvelous result was slowly and silently accomplished by the employment in their natural order of Legal Fictions, Equity and Legislation. ${ }^{34}$ To the second, as embodied in the equitable jurisdiction of the praetor, Roman society was chiefly indebted for the supplementing of the meager and inadequate provisions of the Twelve Tables, for the mitigation of its harshness and rigor, for the extension of its principles, for the removal of its ambiguities, and for its adaptation to the erer widening requirements of justice. In the discharge of their duties the praetors depended, as a general rule, for counsel upon the jurisconsults who condensed into their learned and subtile opinions, known as responsa prudentium, the fruits of the most exhaustive research into almost every branch of human knowledge. In that way was built up an artificial body of equitable jurisprudence, a scientific law literature, whose growth occupies a period beginning 100 B. C. and ending 250 A. D., ${ }^{35}$ a period enriched by the works of Capito, Labeo, Papinian, Paulus, Gaius, Ulpian and Modestinus. With the reign of Serverus Alexander that learned and splendid age of creative jurisprudence drew to a close; and then followed a period during which Gibbon tells us, "the oracles of jurisprudence were almost mute." During the creative period in which the jurisconsults were putting forth their wonderful treatises it was that the power of legislation passed from the people to the senate and then through a gradual process of usurpation from the senate to the emperor. When Justinian came to the throne of the Eastern Empire it was with the settled purpose of collecting, revising, and systematizing the entire aftergrowth of Roman law superimposed upon the primitive system during the ten centuries that had intervened between his time (A. D. 527-565) and the adoption of the Twelve Tables (B. C. 450). The outcome was the famous Code of Justinian, the Pandects, and Institutes, which, with the later Constitutions of Justinian, known as Novels, constitute the Corpus Juris Civilis Romani.

$\S 18$. Roman jurisprudence the basis of international law.It is impossible to comprehend what is now known as interna-

from tradition and custom." Sir W. H. Rattigan's article entitled, The Ancient Jus Gentium of the Aryans, in The Law Quarterly Review for July, 1899 , p. 313 . 
tional law without some understanding of Roman jurisprudence for the simple reason that it is the philosophic basis of the entire system. Therefore for the benefit of those who are not civilians the brief statement just made will be supplemented by a few details that are indispensable. What the Romans called jus civile was the embodiment of the immemorial rules and usages, based upon the tribal customs and upon religious sanctions, which were the special property of those who shared in the Roman tradition and worship. In other words the jus civile was the special law administered by the practor urbanus between Roman and Roman,-it could not apply as between a Roman and a foreigner. ${ }^{36}$ The general rule was that the law of one city had no application to the citizens of another. For that reason Rome permitted the Latin and Italian cities subject to her dominion to retain their own laws for the benefit of their own residents, so far at least as their retention did not contravene her policy and authority. ${ }^{37}$

The praetor peregrinus and the jus gentium.-As there was a large body of resident foreigner's at Rome, who would have been entirely without the benefits of law if they had been forced to rely upon the praetor urbanus, it was necessary to constitute a praetor peregrinus, the praetor of foreigners, whose duty it was to administer justice between Roman citizens and foreigners, between foreigner and foreigner, and between citizens of different cities within the empire. ${ }^{3 s}$ As such praetor could not rely upon the law of any one city for the criteria of his judgments, he finally turned his eres to the codes of all the cities from which came the swarm of litigants before him. In the gen-

36 It could only be extended to members of allied states to which commercium and recuperatio were guaranteed by treaty. Just. Inst. i. 2, 1. Cf. Muirhead, Roman Law, pp. 103, 225. "The early law of Rome was essentially personal,not territorial." Ibid. p. 103. "From the period that a jus gentium began to be administered by Roman magistrates the stricter jus civile of the Roman citizens commenced to experience innovatious which gradually changed its whole character, and moulded it to the requirements of a more progressive age." Sir W. H. Rattigan's article entitled, "The Ancient Jus Gentium of the Aryans," cited above.

37 Cf. Woodrow Wilson, The State, p. 133.

38 As early as 247 B. C. a praetor peregrinus was appointed at Rome to administer justice in such cases. Hadley, Introd. to Roman Law, p. 91. 
eralizations necessarily made npon such data we have the beginnings of comparative jurisprudence whose first fruit at Rome was the ascertaimment of the fact that there are certain universal and uniform conceptions of justice common to all civilized peoples.39 As Muirhead ${ }^{40}$ has expressed it in greater detail: "In the earliest staces of its recognition it (jus gentium) was "an independent international private law, which, as such, regrulated intercourse between peregrins, or between leregrins and citizens, on the basis of their common libertas; which during the republic was purely empirical and free from the influence of scientific theory, but whose extensions in the early empire were a creation of the jurists, - a combination of comparative jurisprudence and rational speculation. To say that it was de facto in observance everywhere is inaccurate; on the contrary, it was Roman law, built up by Roman jurists, though called into existence through the necessities of intercourse with and among non-Romans."

$\S$ 19. Relation of jus gentium to jus naturae.-Before this new growth, watered by the learning of the jurisconsults, reached its maturity the intellectual life of Rome passed under the dominion of her subjects in Attica and Peloponnesus just after they had yielded to the ascendency of the Stoic Philosophers who were ever striving to discover in the operations of nature, physical, moral and intellectual, some uniform and universal force pervading all things that could be designated as the law of nature-the embodiment of universal reasonidentical with Zeus, the supreme administrator of the universe. $^{41}$ Through the mind of the Roman lawyer that splendid conception entered into the jus gentium as an expanding and enriching force which finally lifted it into a higher sphere. In that way a broad principle of Greek philosophy became so blended with a particular branch of Roman commercial law that the Antonine jurisconsults finally assumed the position

39 It seems to be clear that such a conception was well defined as early as the second century B. C. Cic. de Off, iii, 69. Cf. Prof. Nettleship, Journal of Philology, xii, p. 169; Voigt, Das Jus Naturale, passim.

40 Roman Law, p. 226, citing Voight (Jus. Nat., vol. ii, p. 661) . who distinguishes the jus civile, jus gentium, and jus naturale as the systems that applied respectively to the citizen, the freeman and the man. Comp. Cic. De Orat. i, $13, \S 56$. See also Voigt, vol. i, pp. 399,400 .

41 Cf. Chrysippus, apud Plut. de Stoic. Rep. 9; Ibid. apud Diog. Laert, vii, 88; Holland, Elements of Jurisprudence, pp. 30-31. 
that the jus gentium and the jus naturae were identical.4. Long before their time Cicero had recognized the fact, and had declared that the fruit of the union was not one law for Rome and another law for Athens, one law to-day and another law to-morrow, but one eternal and immortal law for all time and for all nations, just as God the common master and ruler of all is one. ${ }^{43}$ The ligher authority, the more philosophic dignity thus imparted to the blended product should be viewed, however, rather in the narrower sense given to it by the Antonine jurist Gaius ${ }^{44}$ than in the wider and more extravagant sense given to the jus naturae by Ulpian ${ }^{45}$ who extended it not only to men but to animals. As we shall see hereafter, when the time came for Ayala, Gentilis, Oldendorp and Grotius to discover a source from which could be drawn such rules of justice and right as would command the general acceptance of men's consciences as a voluntary law of conduct between states considered as moral persons with a free will to do right or wrong, they instinctively turned to the blended product of the jus gentium and the jus naturae, and revived it in the narrower sense in which Gaius and others of his school had expounded it. Thus it was that a branch of Roman private and commercial law, called by Voigt "an independent international private law," originally administered between Romans and foreigners and between foreigner and foreigner at Rome, was set up as the reservoir, midway between the province of morals and that of positive law, from

42 Maine, Ancient Law, p. 96.

43 Non erit alia lex Romae, alia Athenis, alia nunc, alia posthac; sed et omnes gentes et omni tempore una lex, et sempiterna, et immortalis, continebit, unusque erit communis quasi magister et imperator omnium Deus. Fragm. $l i b$. iii, de Repub.

44 "Omnes populi qui legibus et moribus reguntur partim suo proprio, partim communi omnium hominum jure utuntur: nam quod quisque populus ipse sibi jus constituit, id ipsius proprium est vocaturque jus civile, quasi jus proprium ipsius civitatis; quod vero naturalis ratio inter omnes homines constituit, id apud omnes populos peræque custoditur vocaturque jus gentium, quasi quo jure omnes gentes utuntur. ropulus itaque Romanus partim suo proprio, partim communi omnium hominum jure utitur. Quæ singula qualia sint, suis locis proponemus." Inst. i, I. See also Inst. Just. i, 2, § 2.

45 Just. Inst. i, 2. “Ulpian's extravagantly wide application of the term never seems to have gained currency." Holland, Elements of Jurisprudence, p. 33 . Ulpian's definition of the Laws of Nature and of Nations appears, however, in the Spanish Code of Las siete Partidas. 
which has been drawn the rules that now define the rights and obligations of all civilized nations.

$\S 20$. The jus fetiale, the law of negotiation and diplomacy.The only branch of Roman law that pertained exclusively to the relations of the govermment of Rome with those of other powers, and consequently the only branch that corresponds to the modern conception of the law of nations, was that known as the jus fetiale, the law of heralds as agents of negotiation and diplomacy between different states. The eivilized nations of intipuity were very punctilious in making a formal declaration of wal before entering upon actual hostilities. With the Greels the custom was to send a herald, whose person was silcred, to express the hostile intent, either alone or as the companion of an ambassador charged with that duty.46 At Ronce that important function belonged to a college of heralds (collegium fetialium) originally composed of twenty patricians, whose duty it was to regulate the practice and procedure connected with all international questions. ${ }^{47}$ Until a formal demand for reparation (res repetere) and a declaration were first made, Cicero tells us that no just war could begin. ${ }^{48}$ In order to exhaust every effort to obtain redress three or four of the college crossed the limits of the offending state, and there through their prolocutor, the pater patratus for the time, demanded in a solemn and oft repeated formula the restitution of what was due to Rome. Not until justice had been withheld for three and thirty days, did the king consult the senate, and then, if war was decreed, the pater patratus again risited the offending country with a bloody lance which he threw across the border as a visible token that hostilities had actually begun. This custom, that survived until the earlier times of the republic, gave way as the theater of war widened, to the more convenient practice of hurling a lance

46 Even in the midst of hostilities the Greeks generally respected the herald and the trophy, and truces were fairly kept. Thuc. I, 23, 54; II, 12, 22, 79; III, 24 . The slaughter of the envoys of Persia by the Athenians and Spartans was clearly a breach of the general rule. Herod, viii. 136; Thuc. I, 67 .

47 Livy, i, 32; ix, 5; xxxvi, 3.

48 De Officiis, I, 11. As to the
Greeks, see Schömann, Antiq. Juris Publici. As to the Romans, Osenbrüggen, pp. 27-84; BekkerMarquardt, Röm. Alterthüm., iv, 380-388; Guhl and Koner's Greeks and Romans, p. 541. As to declarations of war in the Middle Ages, see Ward's Foundation and His. of the Law of Nations in Europe (London, 1795), vol. ii, p. 211 et seq.; Woolsey, Int. Law, pp. 188-189. 
from a pillar near the temple of Bellona towards the offending state,- the actual declaration of war then being made by the military commander of a contiguous province through an ambassador. With that formal and unfruitful branch of Roman jurisprudence the international law of to-day has no definite connection, the most important ceremony embodied in it having become obsolete.

When the difference, both as to origin and character, between the jus fetiale and the jus gentium is taken into account, it is strange, indeed, to find Wheaton confusing the one with the other. He says, "When the Romans called their fecial law the law of nations, jus gentium, we are not to understand that it was a positive law, . . . the design of it was to direct them how they should conduct themselves towards other nations in the hostile intercourse of war." ${ }^{49}$ It is stranger still that at this late day Calvo should have repeated Wheaton's error in the declaration that "Les Romains donnaient a cette partie du droit le nom de droit des gons, parce qu'elle avait pour objet de dèterminer la conduite de Rome à l'égard des autres nations en cas de guerre." 50 Sir Sherston Baker makes the same mistake when he says the jus gentium "was simply a civil law of their own for the purposes of war." 51 It is hardly necessary to repeat that the jus gentium, as a branch of Roman private law, had nothing whatever to do with the conduct of war.

49 Hist. of the Law of Nations, 51 First Steps in Int. Law p. 26 . (1899), pp. 2-3.

50 Droit International, I, p. 4. 


\section{CHAPTER II.}

\section{THE MODERN STATE AS THE NATION.}

$\S 21$. The modern state a Teutonic creation.-Out of the settlements made by the Teutonic nations upon the wreck of the Roman Empire has gradually arisen the modern conception of the state as a nation occupying a definite area of territory with fixed geographical boundaries,-the state as known to modern International Law. In the Germania of Tacitus we have the contemporaneous observations of one of the greatest and most accurate of historians upon the social and political oryanization of the Teutonie race while yet in its childhood. By the aid of his invaluable sketch it is possible to establish by direct and positive evidence the existence of those primitive elements of or anination, common to the whole Aryan world, whose existence in the Greek and Italian peninsulas can only be inferred from traces and survivals. According to his account the race now called Teutonic, although of the same physical type, and speaking the same language, and although possessed of a common mythology, and a common system of social, political and military institutions, did not possess in its own tongue a common name by which to describe the race as a whole, nol any form of central political organization. ${ }^{1}$ This homogeneous race was broken up into an endless number of political communities or tribes which stood to each other in a state of complete political isolation, except when united in temporary confederacies. The typical Teutonic tribe, the civitas of Calesill and Tacitus,-represented an aggregation of hundreds while the hundred represented an aggregation of village communities. ${ }^{2}$ 'The parallel between the Tentonic, the Greek and the Latin tribe seems to be complete. But there the parallel ceases. In the Mediterranean peninsulas the resultant of a union of tribes was the city-commonwealth,-in Teutonic lands the resultant of a union of tribes was not a city at all but a nation. ${ }^{3}$ In ancient Grecce and Italy the city became the heart, the center of social and politi-

1 Tac, Germania, cc. 1-4.

2 For a more complete statement with the authorities, see The Origin and Growth of the English
Constitution, vol. i, pp. 7, 95-116.

3 The Origin and Growth of the Eng. Const., vol. i, p. 8. 
cal life, while in countries inhabited by the Teutonic race the idea of the eity never beeame dominant. The Teutonic city, if it were to be found at all, was simply the dwelling-place of a part of the nation who were in nowise privileged above those who dwelt beyond its bounds. At the time Tacitus wrote the typical Teutonic tribe (civitas) was a distinct commonwealth, the largest and highest politieal aggregate. Not until nearly a hundred years later were these scattered tribes gathered into larger wholes-into nations. ${ }^{*}$ When that stage was reached, when tribes were fused into the higher political unit-the nation-the primitive Teutonic conception of the state or commonwealth widened into its full and final develop. ment.

§ 22. Transition from tribal to territorial organization"process of feudalization."-But another stage of growth had yet to be passed before the new unit that thus arose out of the aggregation of tribes reached the full modern conception of the state as a nation possessing a definite portion of the earth's surface with fixed geographieal boundaries. The fact must be borne steadily in mind that the primary bond that united the people who composed a Teutonic nation was a personal one,-the national king was first among the people, the embodiment of the national being, but not the king of a particular area or region of territory. The idea of sovereignty was not associated in the Teutonic mind with dominion over a particular portion or subdivision of the earth's surface. The Merovingian line of ehieftains were not kings of France, they were kings of the Franks; Alaric was king of the Goths wherever the Goths happened to be, whetlee upon the banks of the Tiber, the Tagus, or the Danube. ${ }^{5}$ The dominant idea which seems to hare prevailed among the eonquering nations that settled down upon the wreck of Rome was that they were simply encamped upon the land they had won. The conception of sovereignty which the Teutons brought with them from the forest and steppe was distinctly tribal or national and not territorial. The general nature of the transition whereby the primitive notion of tribal sovereignty was gradually superseded by that of territorial sovereignty has been described as a movement from personal to territorial organization; ${ }^{6}$ from a state of things in which personal freedom and

4 Zeuss, Die Deutschen und die Nachbarstämme, pp. 303, 304.

5 Maine, Ancient Law, p. 100 seq.
6 Palgrave, Eng. Commonw., pt. i, p. 62 . 
political right were the dominant ideas to a state of things in which those ideas have become bound up with and subservient to the possession of land. The most striking single result of the transition,-which, for the want of a better term, has been called "the process of feudalization," - is that the elective chief of the nation, the primitive embodiment of the tribal sovereignty, is cradually transformed into the hereditary lord of a given areal of land.

$\$ 23$. Origin of the state system of modern Europe.-The new conception of territorial sorereignty which thus grew out of "the proress of feudalization" did not become established, howerel, until after the breaking up of the empire of Charles the Great. Inring the reign of his son Louis its dismemberment really hegan, but it was not until the third year after his death (A43) that the partition was finally accomplished under the famous Treaty of Verdun, by whose terms the empire was divided into three kingdoms. The western, roughly corresponding in geographical area with modern France, was assigned to Charles the Bald; the eastern, Germany, to Louis the Bavarian; Italy, and a long, narrow debatable land between Germany and France, known as Lotharingia, to Lothar who, immediately upon his father's death, had assumed the imperial title. Thus was broken up the empire of Charles the Grealt, and out of its framents have arisen most of the states of modern Europe. The completion of the transition from personal to territorial sovereignty is marked by the accession of the Capetian dyalsty in France. When the hundred years' struggle between the Dukes of Paris and the descendants of Charles the Great ended in the triumph of Hugh Capet, he not only assumed the dyuastic title of King of the French, but he also styled himself King of France. ${ }^{9}$ Hugh Capet and his descendants were kings in the new territorial sense; they were lings who stoot in the same relation to the land over

7 Stubbs, Const. Hist., vol. i. p. Rex Franciae was other than right 166.

s Maine, Village-Communities, lecture v, entitled "The Process of Feudalization."

s Maine, Ancient Law, p. 104. Mr. Freeman was once inclined to challenge Maine's statement, but he afterwarls wrote me: "I should not say that what Maine says about Rex Francorum and in a general way. Those things came in gradually. Roi de France comes in pretty early, as early as Wace. I doubt whether Rex Franciae is ever used, till Hen. iv.'s Rex. Franciae et Navarrae, as a formal Latin title." See also Norm. Conq., vol. i. Appendix, note M, p. 395. 
which they ruled as the baron to his estate, the tenant to his freehold. The form thus assumed by the monarchy in France was reproduced in each subsequent dominion established or consolidated, and thus has arisen the state-system of modem Europe in which the idea of territorial sovereignty is the basis of all international relations. ${ }^{10}$ And so it may be said that the modern conception of the state as the nation is the outcome of "the process of fendalization" through which the Tentonic nations passed after their settlements within the limits of the Roman Empire. ${ }^{11}$

10 Ancient Law, 99-108.

11 Cf. Edward Jenks, Law and Politics in the Middle Ages, chapter iii, "The State." "It is, in fact, only in England, and, possibly in Scandinavia, that the state, 96 even at the close of the Middle Ages, at all approaches that condition of sovereign omnipotence described by Hobbes, and elaborated by Bentham and Austin." p. 96. 
THE MEDIEVAL EMPIRE AS AN INTERNATIONAL POWER.

$\S 24$. Theory of the medieval Empire-CThe separate nationalities, each with its own character, language and institutions, which arose out of the wreck of the Empire of Charles the Great passed through a long childhood under the protecting wings of an institution that illustrated for centuries the enduring power of a political theory. The differences of race, which were supposed to be natural and immovable barriers to political union prior to the conquests of Rome, were gradually eliminated by the extension of Roman citizenship, by the equalizing effects of Roman law, by the eren pressure of government upon all classes, and by the movements of population stimulated by commerce and the traffic in slares. The unity of the Empire and the ease of communication thus brought about paved the way for the rapid dissemination of a religion destined to abolish, by its universality, the host of purely local divinities in whose name the people of one nation were taught to look upon all others as unclean beings, natural foes. Thus it was that political exclusiveness was greatly mitigated on the one hand by a dominion that gave a common citizenship, a common speech and a common law to many nations, while on the other endless local pantheons were forced to yield to the worship of one God before whom all men were equal. "The two great ideas which expiring antiquity bequeathed to the ages that followed were those of a World-Monarchy and a World-Religion." By those two ideas the Teutonic conquerors of Rome were so orermastered that they came to believe that as the dominion of Rome was universal so must it be eternal. Out of such belief gradually arose the strange creation known as the Holy Roman Empire which rested upon the magnificent notion of a vast Christian Monarchy whose sway was absolutely universal.

Pope and Emperor as chiefs of the world-monarchy.-The chiefs of that comprehensive society were the Roman emperor and the Roman pontiff,- - the one standing at its head in its tem-

1 Bryce, The Holy Roman Em- Freeman's brilliant review of that pire, p. 87. See also Mr. E. A. work reprinted in his Essays. 
poral character as an empire, and the other standing at its head in its spiritual character as a church. The theory was that each chief in his own sphere ruled by divine right as the direct vicegerent of God, and that each possessed the hearty sympathy and support of the other. The Roman Empire and the Roman Catholic Church were, according to medieval theory, two aspects of a single Christian Monarchy whose mission it was to shelter beneath its wings all the nations of the earth. The creation of such a fabric was made possible by the fact that as the advancing influence of Christianity widened through a vast and varied sphere of action it became both necessary and expedient to model the ecclesiastical machinery upon the basis of the secular administration. Thus it was that the ecclesiastical organization became the counterpart of the civil,-its provinces and dioceses usually corresponding to the administrative divisions of the Empire with whose boundaries it finally became coterminous.

Belief that Rome and her empire were to be eternal.-Such was the political and religious structure of the society upon which the Teutons descended rather as imitators than as mere destroyers. ${ }^{2}$ Everywhere their effort was to identify themselves with the system they overthrew. Their belief that Rome and her empire were to be eternal was not destroyed even when the last Caesar of the West yielded to his Eastern brother at Byzantium the sole headship of the Roman world. ${ }^{3}$ But when Italy thus passed again, in 476, nominally under the control of the Emperor at Constantinople, she did not carry the rest of Western Europe with her; and during the three centuries and a quarter that followed there survived in the West a longing for unity and guidance under a revived Roman Empire as a necessary part of the world's order. In that longing no one came to participate with more sincerity than the Roman pontiff; the spiritual head of Christendom conld not dispense with the temporal; according to the belief of that age, without a Roman Empire there could hardly be a Roman Catholic and Apostolic Church. Under the influence of that idea, accentuated by the pressure of local disorder, Pope Leo III

2 Cf. The Origin and Growth of the Eng. Const., vol. i, p. 83 .

3 At the bidding of Odoacer the boy, Romulus Augustulus, resigned his power into the hands of the senate; and then a deputa- tion from that body proceeded to the Eastern court and laid the insignia of royalty at the feet of Zeno because, as they declared, the West no longer required an emperor. 
resolved to talke the tinal step, and on Christmas day, A. D. s00, placed upon the brow of the mighty chief of the Franks, Chatres the cireat, the muguestioned lord of Western Europe, the diadem of the ('ilesirs. From that time the theory of the dual fabric, supposed to cmbody a perfect alceord between the papal and imprerial powers, was gradnally developed in the coun'se of conlliets which clearly demonstrated the utterly imprateticable dhatrater of such a mion. Whether the supreme temporal ruler, who was admitted into his high office through conseceration at the halnds of the spiritual chief of Christendom, was in the last resort subordinate to the latter as the lesser to the greater light, or whether their dignities were co-ordinate, and rooqual, were the questions orer which was fonght the great battle between pope and emperor in the diys of the world's wonder Frederick II.*

$\S 25$. Limits of the actual authority of the Empire.-The theory of the Hedieval Empire fatiled not only in the require ment that the pole and the emperor should exercise their concurrent sway withont conflict of jurisdiction, but also in the idea that their dual overlordship represented Rome's universal dominion. The Empire was never able to extend its authority over the whole of Christendom, much less over the whole world. At the highest point reached by the Hohenstanfen the territories over which they clamed more or less jurisdiction may be gromped under four heads:

Finst, the (isimin lands within the actual boundaries of the Inoly limpine, in which the emperor alone down to the death of Fredericl: Il, was the effective sovereign,--embracing Germany, the northern half of Italy, the kingdom of Burgundy or Arles, louraine, Alsalce and a portion of Flanders.

second, the nom-dierman districts of the Empire in which the emperos was in theory sole monareh,-but in practice little reanded,-embrateing Bolemia, the Slavic principalities of Mecklenberwa and Pomerania, and the pagan Lithuanians or

4 See Pollock's Hist. of the Science of Politics, p. 34. The contention Fredrick left unconcluded was continued in the next age by two famous disputants. St. Thomas of Aquin, in his treatise, "Of the Government of Princes," defended the supremacy of the papacy on the one hand; while Dante, in his "De Monarchia," maintained the independence of the empire on the other. As to the authorship of the $D e$ Regimine Prineipum, see Reformateurs et Publicistes de l'Europe, Paris, 1864. 
Prussians, free prior to the establishment among them of the Teutonic knights.

Third, certain outlying countries, governed by kings of their own, over which the emperor's sovereignty had been at some time asserted,--embracing Hungary, Poland, Denmark, France, Sweden and Spain.

Fourth, other European states whose independent rulers generally admitted the emperor's superior rank without yielding to him any actual allegiance,-embracing England, scotland, Naples and Sicily, Venice, and those remote eastern lands over which Frederick Barbarossa had asserted the rights of Rome as mistress of the world. The Byzantine princes refused of course to admit the emperor's claims in any form whatsoever. ${ }^{5}$

$\S 26$. The pope as an international judge.-After Christianity had substituted for the pagan precept: "Thou shalt hate thy enemy," the novel admonition: "Love your enemies," the new European nationalities continued as of yore to be torm internally by insurrections and bloody civil wars, or to be im. pelled by race-hatred or the jealousies and ambitions of their sovereigns to perpetual strife with each other. Out of such conditions arose the longing then as now for some acknowledged system of international law and for some supreme tribunal that could so administer it as to settle all contentions without bloodshed. The highest aspiration of the pope in his struggle with the emperor was so to establish his supremacy

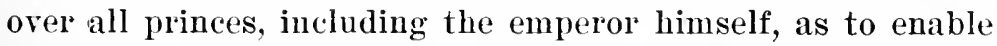
him to offer to Europe the arbitrating power it demanded. The medieval claim of papal supremacy, as restated in our own time by a great English cardinal, was that "The supreme civil power of Christendom was dependent on the supreme spiritual authority. The pontiffs created the Empire of the West; they conferred the imperial dignity by consecration; they were the ultimate judges of the emperor's acts, with power of deprivation and deposition."' That judicial suprenacy which the pope claimed not only over the emperor but over all other Christian princes, taking its color from the

5 Bryce, The Holy Roman Empire, chap. xii.

6 See the Monograph by Cardinal Manning entitled The Pope and Magna Charta, first published in England, and reprinted in Bal- timore in 1885. As to the pope's influence for good as an arbitrator between states, see J. S. Mill, Dissertations and Discussions, II, 152 . 158. 
dominant political idea of that age, naturally assumed a feudal shape. The theory was that all Christian princes stood to the Roman pontiff as great vassals to a supreme lord or sovereign, and as such supreme lord the pope claimed the right to enforce the duties due to him from his feudal subordinates through an ascending scale of penalties that culminated at last in the absolution of the subject from the bonds of allegiance, and in the deposition of the sorereign himself. such were the claims of the papal power and such its resources when King Joln of England found it expedient to kneel at the feet of Innocent III.

The canon law.-The august scheme of papal authority was (mbodied in the canon law, designed by its authors to reproduce and rival the Imperial jurisprudence; ${ }^{7}$ and in order to give emphasis to that idea Gregory IX, who was the first to condense the canon law into a code, was entitled the church's Justinian. Thus it was that the Roman pontiff assumed the oflice of supreme judge of appeals in all causes arising in the ecelesiastical courts of Christendom, especially in matrimonial causes involving the validity of a royal marriage where the result might effect the legitimacy of the issue, and indirectly the peace of a nation. In that way the pope was called upon to arbitrate in the famous case of the divorce between Catherine and Henry VIII.

$\S 27$. The emperor as international judge and mediator.-On the other hand those who like Dante maintained the independence of the Empire, and who wished to substitute for the canonical system secular Roman jurisprudence, attempted, when it was too late, to find in its temporal head an international judge and mediator who, by reason of his severance from local associations and interests, might as "Imperator" Pacificus," prevent wars between the states of Europe by hearing complaints and redressing injuries inflicted by sovereigns or peoples upon each other. As a direct heir of those who from Julius to Justinian had moulded the jurisprudence of Europe, he was to be not only peacemaker but the rery embodiment of legality $y^{9}$ and as such the expounder of justice and the source of positive law. The very extravagance of such

7 For its history, see The Origin and Growth of the Eng. Const., vol. I, pp. 261, 339 .

8 Ibid., vol. ii, pp. 54-74.

9 "Imperator est animata lex in terris." Von Raumer, v. 81, quoting from a letter of the bishop of Salzburg and Regensburg to Pope Gregory IX. 
pretensions rendered their realization impossible. The wars which such a dominion was designed to check rather increased than diminished in intensity,-the theory of the Empire's political and legal supremacy never ripened into reality. ${ }^{10}$

$\S 28$. Effects of the Reformation on the Empire.-And yet no matter to what extent the Holy Roman Empire may have failed as an international power, whether arbitrating on its spiritual side through the pope and the canon law, or on its temporal side through the emperor and Imperial law, the fact remains that for centuries it was the one bond of cohesion holding Europe together under the spell of a theory that assumed to provide a complete system of international justice and a supreme tribunal adequate for the settlement of all controversies which could possibly arise between Christian nations. Nomatter whether the Holy Empire was a theory or an institution, not until the splendid conception of a united Christendom it embodied was wrecked by the Reformation, was the field cleared for the growth of international law as now understood. Many sided as it was in its nature and consequences the great earthquake which began in Germany need be considered here only as a political movement that struck at the very root of the theory by which the Empire had been created and upheld,- the theory that all Christendom consisted of a single body of the faithful held together under the dominion of the Eternal City, ruling through her spiritual head, the bishop of Rome, and through her temporal head, the emperor. The growing spirit of nationality which impelled the Teutonic nations, along with other causes, tobreak with Rome suggested, as a substitute for the medieval form of a universal faith spreading over vast dominions bound up in a single temporal government, the new theory that the political and religious life of each nation should be one, and that the religion of the people should follow the faith of the prince. For the older form of a universal faith uniting Christians of all nations under the convertible terms, Roman and Catholic, the Lutheran states substituted the principle of territorial religion which acknowledged the right of each nation to determine the form of belief that should prevail within its bounds. ${ }^{11}$ So com-

10 "It can hardly be said that upon any occasion, except the gathering of the council of Constance by Sigismund, did the Emperor appear filling a truly inter- national place." Holy Roman Empire, p. 244. See also p. 239.

11 This is well put by Green, Hist. of the English People, vol. ii, p. 181: "For the principle of 
pletely did the establishment of the new doctrine overthrow the pretensions of the Empire in northern Europe, that the Protestant jurists of the serenteenth century scoffed at its lordship of the world, and declared it to be nothing more than a German monarehy." Such it became in fact through the results of the Reformation, while in theory it lingered on as a shadow in the hands of the Hapsburg emperors, until August 6,1806 , when the Imperial dignity, by a formal deed, ${ }^{13}$ was finally resigned by Francis II, who, after releasing from their allegiance the states that had formed the Empire, retired to his hereditary dominions under the title of "Emperor of Austria."

$\S 29$. Peace of Westphalia a formal abrogation of the sovereignty of Rome.-The ancient struggle of the German princes for territorial independence, which was greatly advanced by the beginning of the Reformation in $\mathrm{A}$. D. 1521, did not ripen into full triumph until the making of the Peace of Westphalia in 1648, whereby the conflict that had convulsed Germany for more than a century was definitely closed, at the end of the Thirty Years' War, through the two treaties then made,-one signed by the emperor and the French at Minster in October, and the other by the Swedes and the emperor at Osnabriick in August, ${ }^{14}$ the Dutch and Spaniards having made peace at Ifinster during the preceding January. ${ }^{15}$ By declaring both Lutherans and Calvinists free from the jurisdiction of the pope or any Catholic prelate, and by rendering the states of the Empire practically indejendent of the emperor as its federal head, the Peace of Westphalia became a formal abrogation of the sovereignty of Rome, and of the theory of Church and state, with which the name of Rome had been for so long a time associated. As a recent English writer has

Catholicism, of a universal form of faith overspreading all temporal dominions, the Lutheran states had substituted the principle of territorial religion, of the right of each sovereign or people to determine the form of belief which should be held within their bounds." See also Ibid., p. 274 .

$12 \mathrm{Cf}$. De Ratione status in Imperio nostro Romano-Germanico written by Philipp Bogislaw von Chemnitz under the pseudonym of
“Hippolytus a Lapide." That was followed in 1667 by Puffendorf's keenly sarcastic tract De statu imperii germanici liber unus, said to be the most important production of that epoch in Germany as to public law and polities.

13 The original may be found in Meyer's Corpus Juris Confoederationis Germanicae, vol. i, p. 70. See also Histoire des Traités, vol. viii. 14 Dumont, vi, 1, 450, 469.

15 Ibid., vi, 1, 429. 
well expressed it: "That peace set the final seal on the disintegration of the World-Empire at once of pope and emperor. and made possible the complete realization of the doctrine of Grotius, the doctrine of the Sovereignty of States. The Peace of Westphalia did not create international law, but it made a true science of international law realizable."16

16 Walker, The Science of International Law, p. 57. 



\section{PAFT II.}

\section{SOURCES AND FOUNDATIONS OF MODERN INTERNATIONAL LAW.}

\section{CHAPTER I.}

INTERNATIONAL COURTS, CONGRESSES AND CONFERENCES.

$\S 30$. Five sources of international law.-The rules that regulate the conduct of civilized nations in their intercourse with each other, known in the aggregate as international law, have been slowly drawn from sources which may be conveniently grouped under five distinct heads:

1. Decisions of prize courts, awards of courts of arbitration, and acts of international congresses and conferences.

2 . The works of great publicists, who perform the double function of rerifying the existence of old rules and of creating new ones.

3. Treaties of alliance, peace, commerce and others defining, declaring or modifying pre-existing international law.

4. Instructions giren by states for the guidance of their own courts and officers.

5. The history of diplomatic intercourse.

$\S 31$. Outline of the customary laws of the sea.-It is impossible to understand the position of prize courts as international tribunals without some prior knowledge of the history of the customary law of the sea out of which their jurisdiction arose. The mighty forces that finally swept away the Holy Roman Empire as an international power gradually crystallized the elements out of which its successor grew. The Crusades gave an immense impetus to trade, and the Italian cities of Genoa, Pisa, Florence and Venice, through which flowed the swelling stream of intercourse eastward, rose suddenly into greatuess. The new commercial activity thus 
imparted to the south was rivaled in the north by a movement that drew together about A. D. 1260 a few Baltic towns in the Hanseatic League, gradually extended to no less than ninety cities, whose trade found its way to the Mediterranean through the League of the Rhine formed about A. D. 1250, and through the Swabian League formed $A . D .1376 .{ }^{1}$ The influence thus exerted by the Crusades upon commerce and commercial unions upon land extended itself in due time to trade upon the sea, and the outcone was the "Sea Laws," a term employed by writers on maritime law in the sixteenth century to designate collections of usages of the sea that had been recognized as having the force of customary law, either through the decrees of a maritime conrt, or through the resolutions of a congress of merchants and shipmasters. ${ }^{2}$ To the first class belong the usages of the mariners of the Atlantio known as the Laws of Oleron, to the second the customs of the mariners of the North Sea and of the Baltic lnown as the Laws of Wisbuy. ${ }^{3}$ It is believed that the judgments of the marine court of Oleron were drawn up as early as the twelfth century; and it is probable that a record of such judgments was brought into England and published as law by Richard I, upon his return from the Holy Land. ${ }^{4}$ At whatever date re. ceived such usages and judgments of the sea were entered in

I Hallam, View of State of Europe during the Middle Ages, iv; Höhlbaum, Hansisches Urkundenuuch, I, No. 4, 5, 6; Warnkönig, Flandrische staats-und Rechtsgeschichte, I, 315; Cunningham, Growth of English Ind. and Com., vol. i, pp. 138, 141, 146, 174, 184.

2 As to the causes which brought about the collection of the judgments of the maritime court of Oléron, see Cleirac's introduction to his work on Les Us et Coustumes de la Mer, first printed in Bordeaux in 1647 . The first part is devoted to the Laws of Oléron, of Wisbuy and to the Ordinances of the Hanse towns; the second to Le Guidon; the third to various ordinances of France, Spain and the Netherlands as to the jurisdic. tion of the admiralty.
3 While the first laws of Wisbuy and the customs of Amsterdam should be assigned to the fourteenth century, the sea-code of Wisbuy, borrowed in part from the laws of Oléron and Amsterdam, belongs to the next century. Cf. Hüllman, Städtewesen des Mittelalters, i, 182.

4 Such is the statement of Cleirac. The earliest known text is contained in the Liber Memor. andorum to be found in the archives of the Guildhall of the corporation of London. To the same century belong the judgments of Damm, the port of Bruges, which began to be of importance before the close of the twelfth century. For the old and true text, see Warnkönig, Flandrische Staats-und Rechtsgeschichte, I. Appendix, No. XLI. 
the Black Book of the Admiralty as the Laws of Oleron, and thus became "a national code of maritime law for the direction of the admiral; and whatever was defective therein was supplied from that great fountain of jurisprudence, the ciril law, which was generally adopted to fill up the chasms that appeared in any of the municipal codes of modern European nations." So great was the authority of the Laws of Oleron in most of the Atlantic ports of France that portions of them were incorporated into that model of marine legislation known as the Ordonnance de la Marine of Louis XIV, published in 1681, and expounded less than a century later by Valin in the famous commentary from which English and American jurists and text writers have drawn without stint. ${ }^{6}$ The $O r$ donnance of Louis was also enriched from the Consolato del Mare, whose authorship is contested by both Spain and Italy. The most probable theory of its origin seems to be that which regards it as a gradual collection of the early maritime customs of the commercial cities of the Mediterranean made between the twelfth and fourteenth centuries. ${ }^{7}$ The first edition was that published in the Catalonian dialect at Barcelona in 1494, but by common consent the best is that of Pardessus contained in his Collection of Maritime Laws. ${ }^{8}$ The greatest importance has been attached to its chapters on marine captures in war, embodying the leading rrinciples of prize law, in regard to which it has in recent times exercised an important influence. ${ }^{9}$ Of a more comprehensive character than the Consolato del Mare, and of a considerably later date, is the Guidon de la Mer, drawn up toward the close of the sixteenth century, ${ }^{10}$ probably at the instance of the merchants of Rouen. Far more ancient, however, than all such compilations, and the starting point no doubt of them all are the rubrics relating to ships and shipping contained in the Roman civil law,

5 Reeves, Hist. of Eng. Law, iii, 389.

6 The Commentaire sur l'Ordonnance de la Marine was published in 1760; the Traité des Prises in 1763 .

7 Grotius refers to it as containing the constitutions of Spain, France, Cyprus, Syria, the Balearic Isles, Genoa, and Venice.

8 Collection des Lois Maritimcs antérieurs au XVIIIe siècle, (Paris, 1828-1845, 6 vol.), II, c. XII.

9 "They agree at present with the maritime code of Europe, notwithstanding many attempts to revise their regulations." Manning, Law of Nations, p. 15.

10 The laws of the Hanseatic League belong in the main to the fourteenth and fifteenth centuries. 
especially the rubric de lege Rhodia de jactu, ${ }^{11}$ quoting and confirming the Rhodian law as to jettison. When the time came for English judges to realize that the doctrines of the common law were not equal to the growing exigencies of English commerce by land and sea, they were not slow to expand their simple code by the introduction of new principles drawn from foreign sources. Foremost in the good work was Lord Mansfield, a well-trained civilian, who, in lis opinion in the case of Luke rs. Lyde, ${ }^{12}$ involving the important question of freight pro rata, eites the laws of Rhodes, the Digest, the Consolato del Mare, the laws of Oléron and of Wisbuy, Roccus de Navibus et Naulo, and the Marine Ordinance of Louis XIV.

$\S 32$. Prize courts as international tribunals.-The only maritime court with which international law is directly concerned is the prize court, a municipal tribunal set up by belligerent states for the purpose of passing upon the validity of captures made by their eruisers. While so engaged the prize court is not supposed to administer the law of the state to which it belongs, but the gencrally accepted law of nations, which has no locality. In the case of The Maria ${ }^{13}$ Lord stowell declared it to be lis duty "to administer with indifference that justice which the law of nations holds out, without distinction, to independent states, some happening to be neutral, and some to be belligrerent. The seat of judicial authority is, indeed, locally here, in the belligerent country, according to the known law and practice of nations; but the law itself has no locality. It is the duty of the person who sits liere to determine the question exactly as he would determine the same question if sitting at Stockholm; to assert no pretensions on the part of Great Britain which he would not allow to Sweden in the same circumstances, and to impose no duties on Sweden, as a neutral country, which he would not admit to belong to Great Britain in the same character." The decrees of prize courts hare thus become acknowledged sources of international law,-the greater or less weight to be given to any particular deliverance depending in each ease upon the learning, impartiality

11 Dig. 14, 2. There are, however, many other rubrics of the Roman law relating to shipping. See Dig. 4, $9 ; 22,2 ; 47,5,9$.

122 Burr., 882. Roccus, a Neapolitan lawyer, published a large work on maritime law in 1655 , from which was compiled a smaller work published in Amsterdam in 1708, entitled De Navibus et Naulo. Cf. Parsons, Marjtime Law, vol. I, pp. 8-13.

13 Robinson, Admiralty Reports, I, 340,350 . 
and independence of the tribunal from which it emanates. And as such courts are the outcome of maritime usages that represent the very earliest agreement of civilized nations as to mutual rights and interests-antedating by centuries any general understanding as to the principles that should regulate intercourse on land-their decisions may be justly regarded as the earliest sources of international law, or, as Austin has expressed it, the places where its rules are first found. ${ }^{14}$

$\S 33$. Courts of arbitration-Alabama, Bering Sea and other cases.-It has been well said that the judgments of mixed tribunals appointed by the joint consent of contending nations should be considered as higher sources of international law than those of mere admiralty counts ${ }^{15}$ dependent upon the power and authority of a single state and subject to a certain extent to direction from its executive. ${ }^{16}$ The mention of such tribunals brings at once to the minds of all English-speaking people the Alabama and Bering Sea controversies recently settled between Great Britain and the United States by courts of that character. In the case first named the contending states submitted to the Arbitral Tribunal that sat at Genera in 1872 the question whether or no Great Britain had fully discharged her duty as a neutral power when the same should be riewed in the light of the famous "Three Rules," agreed upon in the Treaty of Washington of $1871,{ }^{17}$ taken in

14 Jurisprudence, II, 526-528. 15 Wheaton, Elements, Dana ed., p. 26.

16 En Europe, les tribunaux de prises relèvent généralement de l'initiative et de l'action directe du pouvoir exécutif: ce qui tend peutêtre à affaiblir la force de leurs dècisions comme source du droit international. Aux Etats-Unis, ces tribunaux sont composés de juges indépendants inamovibles, si ce n'est en cas de prévarication, nommés à vie par le président de la république et confirmés par le sénat. Calvo, \$23. Even Lord Stowell, who, in deciding the famous case of The Maria in 1799 , proclaimed, "It is the duty of the judge to administer that justice which the law of nations holds out without distinction to independent states, some happening to be neutral, and some to be belligerent," declared in 1812: "It is strictly true that the king in council possesses legislative powers over this court, and may issue orders and instructions which it is bound to obey and enforce: and these constitute the written law of this court. These two propositions, that the court is bound to administer the law of nations, and that it is bound to enforce the king's orders in council, are not at all inconsistent with each other."

17 For a brief and convenient statement, see Wharton, Int. Law Dig., $\$ \S 150$ g, 396. For a complete 
connection with the "principles of international law not inconsistent therewith." The judgment was that she had not. In the Bering sea case the same parties submitted to a like tribunal that met at I'aris in 1893 a question which arose out of the contention of the United states that it had exclusive rights over certain portions of the open sea under a treaty made with Russia in 1567. That treaty ceded to the United states all the rights which had accrued to Russia by rirtue of a certain ukase issued by the Tzar in 1821, claiming the l'acific north of latitude $51^{\circ}$ as a mare clausum, on the ground of first discovery and the possession of both its shores. ${ }^{18}$ It was adjudged that as international law never gave to Russia the riglit to make a mare clausum moler such eireumstances she could not convey it as such to the United States, whose territorial rights in Mlaskan waters were thus confined to its bays and gulfs and the marine league along its shores. Berond those limits it is to have no special property in fur-seals upon the theory that they are semi-domestic animals. ${ }^{19}$ In the same category may be mentioned the submission of Great Britain and Portugal of the controversy involving the application of the law of occupation to the case of Delagoa Bay, decided by Marshal MacMahon in $1875 ;^{20}$ and the submission by Great Britain and Venezuela of the controversy as to their respective boundaries decided in 1900 . These cases may be taken as typical illustrations of the advance made in international arbitration by special tribunals, prior to the meeting of the Peace Conference at The Hague in $\mathbf{1 8 9 9 .}$

$\$ 34$. International Congresses.-The most augustassemblies in which nations meet together for the purpose of quasi legislation are known as congresses, the more famous being those that closed their labors at Westphalia in 1648, at Nimeguen in 1678 , at Ryswick in 1697 , at Utrecht in 1712 , at Rastadt in $\mathbf{1 7 9 9}$, at Vienna in 1815, at Verona in 1823 , at Paris in $\mathbf{1 8 5 6}$ and at Berlin in 1879. So slight is the difference that divides a congress from a conference that Lord

statement, the British and American Cases and Counter-cases presented to the Arbitral Tribunal.

18 As to Mr. John Quincy Adams' protest against Russia's claim, see below; and also British and Foreign State Papers, IX, 483.
19 See the Award of the Arbitrators rendered in August, 1893; and consult also for the antecedents, Wharton, Int. Law Dig., $\S \S 29,159,309$.

20 Pitt-Cobbett, Leading Cases in International Law, pp. 262-263. 
Beaconsfield confessed in the House of Lords:"1 "I really can not explain the difference between a congress and a conference, because I do not recognize any difference between them. There is a common idea that a congress consists of sorereigns, and a conference of plenipotentiaries; but there is no foundition for this distinction. The Congress of Rastadt, at the beginning of the last century, was composed of plenipotentiaries, and so was the Congress of Paris, 1856." On supreme occasions when treaty settlements are to be made affecting the balance of power and the peace of the world it is usual to dignify the assembly with the title of congress, regardless of the character of the elements that compose it. Only by virtue of a superior dignity of that character can a congress be dis. tinguished from a conference. By far the most splendid and important congress that has assembled in modern times was that of Vienna, composed of both sovereigns and ministers, about a hundred in number. The whole body never met in council, nor was there ever a formal exchange of credentials. The entire business of the congress was transacted by conmittees of the great powers-Great Britain, France, Austria, Russia and Prussia-to which were added for certain purposes the ministers of Sweden, Spain and Portugal. The task assayed by the publicists and statesmen who met at Vienna inrolved no less than the reconstruction of the ancient diplomatic fabric of Europe which the Napoleonic wars had shattered,-a task so executed as to restore peace, not seriously disturbed for forty years, upon the basis of new understandings for a long time held sacred by every member of the family of nations. The resistless tide of change has, however, so far obliterated the rearrangements of political interests and territorial rights then made that the only fragments of the work of the Vienna Congress that survive as elements in existing international law are embodied in a tew provisions regulating the navigation of international streams, and declaring the slave trade forever abolished.

$\S 35$. Notable Conferences of recent times.-Of the conferences of recent times the most notable are the Conference of St. Petersburg in 1825, which pared the way for the independence of Greece; the Conference of London in 1831, which arranged the separation of the Kingdom of Belgium from Holland; the Conference of Geneva in 1864, which gave direction

21 Feb. 25, 1878. 
to the first European effort to introduce greater humanity into the rules and practices of war; the Conference of St. Petersburg in 1868, which resulted in a Declaration prohibiting the use, on land or sea, of projectiles below a certain weight; the Conference of London in 1871, which modified the treaty of I'aris of 1856 ; the Conference of Brussels of 1874 , which met to discuss the laws of warfare on land; the Conference of Constantinople in $18 \pi 7$, which vainly endearored to obtain from the Porte guarantees for the better government of its Cluristian subjects; the West Ifrican Conference of Berlin in $1884-85$, which met to regulate the affairs of that region, including the boundaries and independence of the Congo Free State; the Marine Conference of Washington in 1859. which is said to have been the first world conference ever held for purposes of quasi legislation; the Conference of Brussels in 1890, which resulted in a Final Act for the suppression of the African slave trade; and the Conference of Peace at The Hague in 1899, which embodied the results of its labors in three treaties to be considered more fully hereafter.

Conferences of Geneva, 1864; of St. Petersburg, 1868; of Brussels, 1874.-The most enduring part of the work of the Congress of Paris of 1856 is that embodied in the Declaration of new maritime rules as to privateering, blockades, and the seizure of goods at sea. The earnest effort then made to diminish throngh concerted action the evils of war was soon seconded by the representatives of the fourteen states, which acceded, in the first instance, to the Convention of Geneva of 1864 regulating the treatment of the sick and wounded, and neutralizing all persons and things employed in their service, snch as surgeons, chaplains, nurses, hospitals and ambulances, provided such persons and things are distinguished by a badge of a red cross on a white ground displayed on an arm or on a flag, as the case may be. In order to revise and extend the original provisions another Convention was signed at Geneva in 1868 , but never ratified, whose Additional Articles, including the neutralization of hospital ships, relate chiefly though not exclusively to warfare at sea. Less than two months thereafter a Military Commission at St. Petersburg, composed of delegates from seventeen states, including representatives from Persia and Turkey, agreed "as between the parties in their wars with one another,-but not in wars with other powers, or in which other powers had a share,-to renonnee the employment of any projectile, on the land or the sea, of a 
weight below four hundred grammes (fourteen ounces), which should be explosible or Ioaded with fulminating or inflammable materials." 22 In the Declaration in which the right to use such projectiles was renounced the parties in interest took occasion to say that the object of the use of weapons in war is "to disable the greatest possible number of men, that this object would be exceeded by the employment of arms which needlessly aggravate the sufferings of disabled men, or render their death inevitable, and that the employment of such arms would therefore be contrary to the laws of humanity." In 1874, at the invitation of the Emperor of Russia, met the Conference of Brussels, in which appeared the representatives of all the European powers of any importance in the hope of bringing about the adoption by all civilized states of a common code for the regulation of warfare on land. As the delegates were not plenipotentiaries the conference was purely consultative; and the outcome was a series of articles embodied in a Declaration which remained as the basis for future negotiations between the governments concerned. The first effort to codify the rules of war was that made by Dr. Lieber in 1863, at the instance of the government of the United States, the outcome of which exercised as marked an influence upon the proposals agreed to at Brussels as have those proposals on the Manuals for the guidance of their armies subsequently issued by the European states, and on the codeadopted in 1880 by the Institut de Droit International. ${ }^{23}$ That Institution reached the conclusion that "the project of a declaration agreed upon at Brussels, although having much resemblance to the American instructions of President Lincoln, has the advantage orer them of extending to international relations a regulation made for one state, and of containing new requirements at once practical, humane, and progressive." It is also important to note that the work of the Geneva Conference of 1864 is connected with that of the Brussels Conference of 1874 by the statement embodied in the proposed code of the latter that the duties of belligerents with regard to the sick and wounded are to be regulated by the stipulations of the former. ${ }^{24}$

\section{$\S 36$. The Peace Conference at The Hague-its basic principle.}

22 Martens (N. R. G.) xviii, 607629 , and $450-476$ for text of conventions.
${ }_{23}$ Tableau Général de l'Institut, 173-190.

24 British State Papers, Miscellaneous, No. 1 (1875), pp. 322, 324. 
-Among all the conferences of the nineteenth century, vitally important as many of them were, by far the most fruitful in the intellectual order was the last. There are substantial grounds for the hope that the results of its deliberations will mark a turning point in the international relations of the world, just as the malking of the second constitution of the Cnited states marked a turning point in its political history. The master builder's who accomplished that mighty task seem to have been overeome at its close by the grandeur of their achicrement, and when the masses of the people had the opportunity to examine the details of the work, and to feel the practical benefits it wrought in their political condition, they, too, became imbued with a splirit of intense admiration; they put it upon a pedestal and made it a popular idol; as a German historian has expressed it, the new constitution passed thromgh a process of canonization. ${ }^{25}$ The uncritical enthusiasts who thus looked upen the framers of the unique federal experiment as demigods and not as men, and who held up their work as a spontaneous creation produced under the effects of intellectual inspiration, unwittingly put upon it the gravest reproach to which it conld possibly have been subjected. Just because it was no such thing, it has been able to survive all the trials and ricissitudes through which it has passed. "If the brilliant success of the American constitution provesanything, it does not prove that a viable constitution can ever be "struck off at a given time by the brain and purpose of man." ${ }_{26}$ Epon the contraly all political history proves that Sir James Macintosh was right when he said that "constitutions ar" not made; they grow." Every viable constitution must be the natural outcome of progressive history; it must be the result of the wolding together of pre-existing elements just at the moment when such elements are being impelled towats union ly their own momentum. Only because the statesmen and publicists who met at The Hague for the purpose of laying the foundations of a federal constitution for the Enited states of the World were guided by that all-important truth, is there ans hope whatever that the results of their labors will endure as a permanent and cohesive force.

A voluntary system of arbitration.-Clearly perceiving that the enestion of questions to be solved was that in rolved in the

25 Von Holst, vol. I, pp. 64-70.

${ }^{26}$ Prof. Alexander Johnston in The New Princeton Review, Sept., 1887, p. 186. 
constiuction of just such an arbitral tribunal as would embody the advance so far made in that direction by sovereign states unwilling to bow absolutely to any common superior capable of subjecting them to positive law, the delegates wisely resolved to attempt only a voluntary system of arbitration depending upon the moral sentiment of the world for coercive authority. "Tine only other alternative to a voluntary system of arbitration must necessarily include a sanction, in the shape of an executive power or authority with sufficient force to compel adherence to an agreement for arbitration. * * * They were careful to leave the sovereignty of each state absolutely unimpaired, and trusted exclusively to the force of public opinion and the public conscience for a sanction to enforce the mandates of the newly-established court." ${ }_{27}$ Mr. Seth Low was clearly right when he said: "The convention at once gives to arbitration a place among the recognized means of preserving the peace of the world. It is hoped, and it is expected, that it will more and more serve this high function. For this reason, among others, the resort to arbitration, like the resort to good offices and mediation and to international commissions of inquiry, is left wholly voluntary. This, in the judgment of the writer, is the strength, not the weakness, of the plan." 28 In organizing the Permanent Court upon a purely voluntary basis the Conference simply systematized and supplemented the results of the world's experience on that subject. Apart from the establishment of the court itself, the two notable additions made were in the form of a definite code of procedure,- the lack of which was recognized as a serious drawback to international arbitration as early as 1874 by the Institut de Droit International,- -and in the statement in that code of the principle that "the tribunal is authorized to determine its own jurisdiction." 20

Laws and customs of war on sea and land.-In the same conservative spirit the Conference proceeded to systematize and supplement the results of international efforts previously made to regulate the laws and customs of war on sea and land. In order to render the sequence of development more obvious

27 Holls, The Peace Conference at The Hague, p. 356 .

28 See his excellent exposition of the results of the conference in North American Review for November, 1899 .
29 First convention, Art. XLVIII. The conventions and other interesting documents are printed in the appendices to Mr. Holls's lucid and attractive work cited above. 
a brief account was given in the preceding section of the attempts to humanize the laws of maritime war embodied in the Declaration of Paris, and in the Geneva Convention of 1864 , as amended in 1868. The "Additional Articles" adopted in the year last named, extending to sick and wounded combatants at sea the same humane provisions guaranteed by the Genera Convention of 1864 to soldiers on land, did not receive positive sanction until the Conference at The Hague completed its third eonvention "for the adaptation to maritime warfare of the principles of the Genera Convention of August 22, 1864." As M. de Martens of Russia las expressed it: "It was this Conference that caused the final adoption by sixteen powers of Europe of the principle whereby the wounded in times of naval warfare shall have the same right to have their person. their life, their health and property respected, as the wounded in case of warfare on land." ${ }^{30}$ In the same way the second convention framed by the Conference "concerning the laws and customs of war on land" was simply a development of such laws and customs as had been adopted in 1874 by the Conference of Brussels, but never ratified,-laws and customs first formulated, as stated alrealy, during the American Civil War, at the request of President Lincoln, by Prof. Francis Lieber of Columbia University in the city of New York.

Calling of the Conference-its composition-its results.-The original rescript of August 24, 1898, in which the Emperor of Russia initiated the Peace Conference, was supplemented by a circular letter of Count Mouravieff, dated January 11, 1899, defining more precisely the several subjects to be submitted for international deliberation. Foremost among such subjects were those involving agreements among the powers, "not to increase for a fixed period the present effective of the armed military and naval forces, and at the same time not to increase the budgets pertaining thereto;" "to apply to naval warfare the stipulations of the Geneva Convention of 1864, on the basis of the additional articles of 18tis;" "to revise the Declaration concerning the laws and customs of war elaborated in $1874 \mathrm{by}$ the Conference of Rrussels, which has remained unlatified to the present day;" "to accept in principle the employment of good offices, of mediation and facultative arbitration in ases lending themselves thereto, with the object of preventing armed conflicts between nations." After

30 See article in North American Review for November, 1899. 
The Hague had been selected as a meeting-place the Netherlands government, on April 7, 1899, issued a formal invitation to each of the invited powers" requesting it "to be good enough to be represented at the above mentioned Conference, in order to discuss the questions indicated in the second Russian Circular of the 30th December, 1898 (11 January, 1899), as well as all other questions connected with the ideas set forth in the Circular of the 12th (2tth) August, 1898, excluding, however, from the deliberations everything which refers to the political relations of states, or the order of things established by treaties." In response to that invitation more than one hundred delegates from twenty-six powers assembled in the "House in the Woods," May 18, 1899, of which twenty were European, four Asiatic and two American, each power having one vote. After permanent organization had been completed President de Staal stated in his opening address: "We shall also undertake in a special manner to generalize and codify the practice of arbitration, of mediation, and of good offices. These ideas constitute, so to speak, the very essence of our task." The first place was therefore given to that subject in the Final Act of the 29th of July, 1899, reciting that the Conference has prepared for submission to the plenipotentiaries of the powers (1) three conrentions, (2) three Declarations; that it has unanimously adopted a resolution to the effect that "The Conference is of the opinion that the restriction of military charges, which are at present a heary burden on the world, is extremely desirable for the increase of the material and moral welfare of mankind;" and that it las passed, with differing degrees of unanimity six other resolutions, referring various questions for other and later consideration. The constructive work of the Conference was embodied, however, in the three conventions first named, entitled as follows:

(1) Convention for the peaceful adjustment of international differences.

(2) Conrention with respect to the laws and customs of war on land.

(3) Convention for the adaptation to maritime warfare of the principles of the Genera Convention of August 22, 1864.

The contents of each of these conventions will be considered hereafter in connection with the subject to which it specially relates.

31 No invitations were sent to the Holy See and the South AfriSouth American republics were can republics. The Central and

not represented. Holls, pp. 34-35. 


\section{CHAPTER II.}

\section{RISE OF THE PUBLICISTS,}

$\S 37$. Revival of the study of jurisprudence, -During the centuries in which the European nations were actively engaged by land and sea in the establishment of commerce in material things, there began a new kind of commerce in intellectual and spiritual things, in ideas, that changed the face of the world. The twelfth century witnessed the enthusiastic revival of the study of Roman law; the thirteenth, the spread of the scholastic philosophy; the fourteenth, the appearance in Italy of a new literature adorned first by the name of Dante, then by that of Petrarch. Along with this literary revival there came a general uprising throughout Europe of the human mind against the entire system of authority, spiritual and temporal,.by which men were governed, an uprising that manifested a tendency to apply thought to practical ends through,the reorganization of society upon fixed and definite principles. Under these new influences the Middle Ages, essentially unpolitical, gave birth at the close to Polities, and with them appeared "the first of a class of persons whom friends and enemies may both, though with different meanings, call idleal politicians." ${ }^{1}$ Hard as it may be to apply that term in any except a bad sense to Machiarelli, to that epoch he belongs, and with him the modern study of politics begins. Ronssean said that when Tacitus wrote the Germania, he intended it as a satire upon Roman manners. Gentilis, one of the founders of intermational law, who followed upon the heels of Machiavelli, defended him upon the ground that his "Irince" was only a veiled satire upon the vices of princes intended as an exposition of their tyranny and as an admonition to the people. From that point of view the "Prince" may be justly regarded as an outery for some great deliverer, even for a powerful despot, who might purge Italy of the detestable dissimulation, crime and corruption through which she was misgoverned, and who might build up her unity after driving out the French, German and Spanish invaders who were despoiling and rrining her. It can not be proven that Machiavelli really sanctioned either frand or treachery. For the first

1 Bryce, The Holy Roman Empire, p. 232. 
time since Aristotle we find in lim the passionless spirit of a man of science attempting to establish the groundwork of his reasoning through the reviral of the neglected separation of ethics from politics in a form so extreme as to reach "even to the point of apparent paradox and scandal." A branch of the Science of Politics thus revived was jurisprudence. ${ }^{2}$

$\S 38$. Importance of a knowledge of the publicists-their testimony as experts.-It is of paramount importance that students of international law should be familiar with the entire line of publicists for the reason that often by their testimony alone can the existence of its rules be established. As Sir Robert Phillimore has well expressed it, "The consent of nations is further evidenced by the concurrent testimony of great writers upon international jurisprudence. The works of some of them have become recognized digests of the principles of that science, and to them every cirilized country yields great, if not implicit, homage." 3 In other words, the existence of any rule as to which the nations have actually agreed as a basis of intercourse must be proven in each case by the consensus of publicists who depose as experts to the fact. Each witness has his own character and his own place in the hierarchy, fixed in advance by his learning, his reputation for impartiality or maybe by his antiquity. ${ }^{*}$ In some cases importance is attached to the fact of nationality. For instance, the conduct of any nation could be justly considered specially reprehensible if it should refuse to accept a rule established by a consensus of opinion in which its own publicists had joined. Upon the Continent where the common basis of law is Roman, and where the weight of precedents in the form of actual adjudications has never been the same as within the domain of English law, the tendency is and has been to give greater importance to the dicta of publicists when well supported than the judgments even of prize courts.

2 Pollock, Hist. of the Science of Politics, pp. $32,42$.

3 Int. Law, vol. i, p. 58.

4 "Regarding jurists, then, in the light of witnesses, it is their competency rather than their ability which most concerns us. We find a number of men of education, of many different nations, most of them quite uninterested in maintaining any particular thesis as to the matter now in question, agreeing generally for nearly three centuries in the proposition that the territory of a maritime country extends beyond low-water mark." Coleridge, J., in The Queen v. Keyn, Law Reports, Exchequer Division, vol. II, p. 154 (1876).

5 See the views of Hautefeuille on that subject in Des Droits et des Devoirs des Nations Neutres. 
On the other hand, in Encrand and America, where it is a habit of life for lawyers and publicists to look to the decisions of judicial tribunals as the most authoritative sources of law, the tendency is in the opposite direction. Such are the leading considerations that must be keft steadily in view when the weinht of the testimony of any publicist is under consideration, such weight increasing, of course, with every invocation of his authority by statesmen or jurists, and with every rear that passes without dissent from the rules he has solemnly promulgated. It is therefore indispensable for all who attempt either to expound or administer international law to have a thorough personal acquaintance with the character of the witnesses upon whose testimony the facts of its existence depends. For the purpose of facilitating such acquaintance, the leading publicists of the world who have written formal treatises on the subject will be grouped upon the basis of nationality,--the name of the work of each being given with its proper date, and in some instances with an indication of the standing of the author not only in his own country but in the world at large.

§ 39. Spanish and Italian publicists-Gentilis, Suarez, Ayala, Riquelme, Fiore and others.-Albericus Gentilis, just mentioned as the defender of Machiavelli, is regarded by many as the real founder of modern international law. He was born at Sanginesio, July 14, 1552; and after taking his degree in law at the University of P'erugia he returned to his native city, whenee, while engaged in recasting its statutes, he was forced to flee with his father on account of Protestant opinions common to both. After sojourning in Austria, Albericus arrived at Oxford in the fall of 1580, and seven years thereafter he was appointed Regius professor of civil law. His fame rests upon his application of that part of the Imperial jurisprudence embodied in the jus naturac to the new questions that arose out of the relations of modern states resting upon territorial sovereignty. While regarding with great deference the entire body of Roman law, secular and canonical, he adopted as his real guide the jus naturae, as the best epitome of the philosophy of law. In order to make a direct application of it to the laws of war he selected that theme as the subject of the law disputations that took place in July, 158s, and in the fall of that year he published at London his De Jure Belli commentatio prima. Upon that treatise it was that Grotius founded his De Jure Belli ac Pacis (Paris, 1625), whose method and 
arrangement, as well as its illustrative erudition, is largely drawn from the earlier source. ${ }^{6}$ And yet it is equally true that Gentilis upon his part was dependent upon a group of Spanish scholars dereloped just before his time at the University of Salamanca, founded in 1243 by Ferdinand III of Castile. In that institution, for a long time devoted chiefly to the study of the ciril and canon law, were trained the Jesuit, Francisco Suarez (1548-1617); Francisco de Victoria, a professor at Salamanca about 1546, who published at Lyons in 1557 his Relectiones Theologicae, of which the sixth part is entitled De Jure Belli; and Dominic Soto, ${ }^{7}$ the pupil and successor of Victoria, who published in 1560 the subject matter of his leetures in an elaborate treatise of Justice and Law. The most distinguished member of the group was Suarez, whose extensive work, Tractatus de Legibus ac Deo Legislatore, surreys in a general was, and in a method thoroughly scholastic, the field afterwards occupied by Gentilis and Grotius. Side by side with the Jesuit, if not above him, must be ranked another Spaniard, Balthazar Ayala, a judge advocate of the Spanish army in the Netherlands, who published at Antwerp in 1597 his De Jure et Officiis Bellicis et Disciplina Libri Tres. Gentilis greatly improved upon the work of his Spanish predecessors, and then transmitted the result as embodied in lis De Jure Belli to Grotius. From that time both Spanish and Italian publicists seem to have abandoned the field to writers of other nations until the long silence was broken at last by Bertodano who published at Madrid in $\mathbf{1 7 4 0}$ a Collection de traités de paix, d'alliance, de nentralité, from 1598 to 1700 . Not until 1830 did Pinheiro-Ferreira, who annotated Vattel and Martens, publish his radical work entitled Cours de Droit Public Interne et Externe, in which the first part of the second volume is deroted to international law. In 1849 Don Antonio Riquelme published at Madrid his Elementos de derecho publico internacional, con explicacion de todas las reglas que constituyen el derecho international espanol. In 1859 Count Terenzio Mamiani della Rovere, then professor of

6 Of Gentilis Grotius says: $C u$ jus diligentîa sicut alios adjuvari posse scio et me adjutum profiteor. Prolegomena, § 39 . A new edition of his work, edited by Professor Holland, appeared in 1878 .

7 Soto was appointed arbitrator by Charles $\mathrm{V}$ to decide between
Sepnlveda, representing the Spanish-American colonists, and Las Casas, representing the natives, in a controversy as to the lawfulness of enslaving them. Upon his decision in their favor was based the edict of Reform of 1543 . 
the philosophy of history in the University of Turin, published his Nuoro diretto Europeo which, after being condemned by the Index, was translated into English under the title, Rights of Nations, London, 1860. In 1s6z that was followed by the Estudios sobre el derecho internacional maritimo; exposition razonada de sus principios fundamentales by Don Ignacio de Negrin, of the administrative corps of the spanish Marine. In 1867 Ercole Vidari, professor of Commercial law in the University of I'avia, published his Del rispetto della proprietá privata fra gli stati in guerra; and in 1868 appeared at Paris a translation from the Italian of the work of Pasquale Fiore, professor of international law in the University of Pisa, entitled,-le Nouveau droit inlernalional public suivant les besoins de la civilization moderne. The most important Italian works since that time are Carnazza-Amari's Traité de Droit International Public, a French translation of which appeared at Paris in 1850-18s2, and Fiore's Droit Int. Codifié, 1890.

$\S 40$. German publicists-predecessors of Grotius.-As early as 15:39, some years before the appearance of the works of Suarez, Victoria and Ayala, Oldendorp, a professor at Marburg, published at Cologne his Isagoge, seu Elementaria Introductio Juris Naturae, Gentium et Civilis; and in 1548 Conrad Brunus, a German civilian, published at Mainz his elaborate treatise in five books entitled De Legalionibus, in which he contends, contrary to the opinions of Ayala, ${ }^{8}$ that all wars by Christians against infidels are just if undertaken to recover dominions that may be made useful to all Christendom. ${ }^{9}$ The only remaining German predecessor ${ }^{10}$ of Grotius was Benedict Winckler, first professor of law at Leipzig, then syndic of Luibeck, whose Principiorum Juris Libri Tres appeared at Leipzig in 1615.

Puffendorf, a notable disciple of Grotius.-The most notable German among the immediate successors of Grotius was his disciple Samuel ron Puffendorf, a native of Saxony, who came into notice through the publication at The Hague in 1660 of

8 Ayala was bold enough to declare that, Bellum adversus infideles, ex eo solum quod infideles sunt, ne quidem auctoritate imperatoris vel summi pontificis indici potest, infidelitas enim non privat infideles dominio quod habent jure gentium; nam non fidelibus tantum rerum dominia, sed omni rationabili creaturæ data sunt.

9 Lib. IV, c. 5 .

10 As to all of them see Von Kaltenborn, Die Vorlaüfer des Hugo Grotius. Halle, 1848. 
his Elementorum Jurisprudentiae Universalis Libri Duo, a youthful production based upon the principles of Grotius and Hobbes, in which he reached the conclusions that there is no voluntary or positive law of nations except that of nature; that the usages nations generally observe in war are of no binding force, and therefore that by their infraction no duties, properly so called, are really violated. Charles Louis, eleetor palatine, to whom his work was dedicated, created for him at Heidelberg a new chair of the law of nature and of nations (1661); and in 1670 Puffendorf was called to the Unirersity of Lund where in 1672 appeared the mature work of his life, entitled De Jure Naturae et Gentium Libri Octo, a resumé of which, under the title De Officiis Hominis et Civis, appeared in 1675. In his later work Puffendorf simply widened and systematized his earlier thoughts in such a way as to enable him to derice law from reason, from the ciril law, and from divine revelation, and in that way to establish three "dise $i$ plines,"-natural law, ciril law and moral theology. After" clearly subscribing to the declaration made by Hobbes in his De Cive $e^{11}$ that the law of nature and of nations are identical, Puffendorf declared that "there is no other voluntary or positive law of nations properly invested with a true and legal force, and binding as the command of a superior." 12 Realizing the imperfection in the Grotian theory of a law of nature, the persistent effort of Puffendorf was to remedy the defect by demonstrating the inseparable connection between natural and positive law. The Grotian theory thus completed by Puffendorf, with the aid of Hobbes, was shirply and prompty combated by Samuel Rachel, a professor first at Helmstadt, then at Kiel, whose De Jure Naturae et Gentium Dissertationes Duo appeared at the place last named in 1676 . Thus it was that "This controversy abont the origin and obligation of international law gave rise to two conflicting sects among German public jurists of the latter part of the seventeenth century. The one, adhering to Puffendorf, denied altogether the existence of any other law of nations than the law of

$11 *$ * lex, quam loquentes de hominum singulorum officio naturalem dicimus, applicata totis civitatibus, nationibus sive gentibus, vocatur jus gentium, c. xiv, §4. See also Leviathan, p. 63. 12 De Jure Naturae et Gentium, lib. II, c. $3, \S 23$. It seems to be customary to quote Leibnitz's statement that Puffendorf was a Vir parum jurisconsultus, et minime philosophus, - the words of a bitter rival. 
nature applied to independent communities; whilst the latter - adopted the doctrine of Rachel, founding the law of nations upon the law of nature as moditicd by usage and express compact." 13

Leibnitz and Wolf.-Passing over the work of J. W. Textor, a defender of the views of Rilchel, who published his Synopsis Juris Gentium at bitle in 16so), and that of Christian Thonasius, a learned disciple of l'utfendorf, who put forth his Fundamenta Juris Naturae et Gentium at Halle in 1705, mention must be made of the collection of treaties and other diplomatic alts that appeared in 1693 with a preface by Leibnitz, intended as a commentary upon the principles of international law. The most notalle name that next occurs is that of Christian F. von Wolf (1679-1754), a disciple of Leibnitz both in philosophy and jurisprudence who, upon the recommendation of his master, was made a professor at Halle, where the Leibnitzian philosophy survived in a Wolfian form until it was superseded by that of kiant. The last of his nine quarto rolumes upon the law of nature is devoted to the law of nations,-a work followed in 1749, when he was seventy years old, by his Jus Gentium Methodo Scientifica P'ertractulum, in quo jus gentium naturale, ab eo quod rolunlarii. pactitii et consuetudinarii est, accurate distinguitur, of which his Institutiones Juris Naturae et Gentium, that appeared in the following year, was an abridgment. After declaring in the preface to his Jus Gentium that "in the great society of nations it becomes necessary to establish a law of positive institutions more or less varying from the natural law of nations," he concludes that such law, "the voluntary law of nations, derives its force from the presumed consent of nations, the conventional from their express consent; and the consuetudinary from their tacit consent." 14 All such artificial distinctions would have been forgotten long ago, along with their anthor and his philosophy, had it not been for the fact that Wolf's materials were skilfully worked orer and popularized by his disciple Vattel, a Swiss publicist of note, of whom more will be said hereafter.

Heineccius, Moser, Martens, Klüber, Heffter and others.-In 17:38 J. G. Heineccius, a professor at Halle, published at that

13 Wheaton, Hist. of the Law of Nations, p. 105.

14 Proleg. $\S \S 3,25$. The presumed assent of nations to the voluntary law is based upon the fiction that Nature herself has established a great commonwealth of which all nations are members. 
place his Elementa Juris Nalurac et Gentium, in which jus gentium is viewed as the sum of rights that find their applicattion to societies of every sort; and in 1777-81 were published at Frankfort-on-Main and Tübingen the more important works of the publicist John J. Moser: Versuch des Neuesten Europäischen Völkerrechts in Friedens-und-Kriegszciten, elc., and Beyträge zu dem Neuesten Europäischen Völlerrechls in Fricdenszeiten und in Kriegszeiten. Moser, uswally called the father of the positive school,manifested his eminently practical tendency by disclaiming all intention to write either a scholastic or philosophical exposition based upon the application of natural law to the relations of states. International law was, he said, only a collection of rules established by the practice of nations, whose intrinsic force rested entirely upon treaties and usage; and his primary purpose was to illustrate their meaning through modern examples. In 1785 George Frederick von Martens, a professor at Göttingen, published at that place his Primae Liniae Juris Gentium Europearum Practici, a syllabus of his lectures, afterwards enlarged into the sum. mary of the European law of nations that appeared in 1788 as Précis du Droit des Gens Moderne de l'Europe fondé sur les Traités et l'Usage. ${ }^{15}$ Martens believed, with Vattel, that Wolf was right, when he said that,as the mere law of nature is insufficient to regulate the intercourse of states, it must be modified and supplemented by mutual consent, out of which arises the positive or special law of nations, resting either upon compact, express or implied, or upon mere usage. Upon that basis he reasoned out a general theory of a positive European law of nations that had great weight in its time. He also began to publish in 1791 the Recueil des Principaux Traités de Paix, d'Alliance, etc., depuis 1701 jusqu'à nos jours, - a work continued by C. de Martens, Saalfeld, Murhard, Samwer, Hopf, and Stoerk, until the series in 1887 extended to sixty-four volumes. ${ }^{16}$ In 1779 appeared the com-

15 Published in German at Göt- Recueil, a general collection of tingen in 1788 , with a 2 nd ed. in treaties was published by Leibnitz French in 1801. In 1831 a fourth in 1693, entitled Codex Juris Genedition appeared in French with tium, and containing documents notes by Pinheiro-Felreira, and in from 1097 to 1497 ; followed in 1700 1855 a fifth by Pinheiro and Vergel. by the Mantissa; in 1726-39 was It was also translated into English published Dumont's Corps Univerby Cobbett and printed at Phila- sel Diplomatique du Droit des delphia in 1795.

Gens, continued by Barbeyrac and

16 Prior to the appearance of the Rousset, and containing treaties 
pleted work of Günther entitled, Grundriss eines Europ. Völkerrechts, nach Vermunf, Terträgen, Herkommen, etc.; in 1819, J. L. Klüber's Droit des Gens Moderne de l'Europe; soon republished, in a modified form, in his own tongue as Europäisches Völlerrecht; in 1818-1819, at Rudolstadt, J. Schmelzing's Systematischer Grundriss des Pralitischen Europ. Völkerrechts; in 1s17, at Berlin, T. Schmalz's Europ. Völlerrecht; in 18\%3, at Trübingeu, F. Saalfeld's IIandbuch des Positiven Völerrechts; in 1841, at Heidelber' C. S. Zachariae's seven volumes entitled, Vierzig Böcher rom staate; the fifth volume of which contains his lölkerrecht; in 1844, at Berlin, the great work of August W. Hefrter, of the highest authority in Germany, entitled Das Europäische Töllerecht der Gegenwart; translated into French by 11 . Jules Bergson ; ${ }^{17}$ in 1877, at Leipzig, A. Bischof's Katechismus des Tölherrechts; and in 1895, at Berlin, Dr. Quaritsch's Compendium des Europäischen Völkerrechts.

\section{§41. Dutch publicists-Grotius, Bynkershoek and Huber.-} The work of Huig van Groot, generally known as Hugo Grotius, who stands not only at the head of the Dutch publicists, but at the head of all, as the father of modern international law, will subsequently be made the subject of special consideration by reason of its paramount importance. The Dutch publicist next in fame is Cornelius van Bynkershoek, born at Middleburg in Zeeland in 1673, who became an advocate, and settled at The Hague, where he published, in 1702, his De Dominio Maris; and in the following year was made a member, and afterwards president, of the supreme appellate court for the provinces of Holland, Zeeland and West Friesland. In 1710 appeared his Observationes Juris Romani; in 1721 his De Foro Legatorum; and in 1737 his Questiones Juris Publici, - dissertations that placed him in the front rank of publicists despite the fact that he wrote no systematic work.

from 838 A. D. to 1738 ; in 1781-95 was published Wenck's Corpus Juris Gentium Recentissimi, containing treaties from 1735 to 1772 . Besides these each nation has its own collection.

17 This standard work was, after Heffter's death, re-edited by Dr. F. Heinrich Geffcken in a seventh edition, 1880. While Geffcken left the text unaltered, in valuable notes [bracketed with a G], he has brought the work up to date, omitting in the 8th edition, 1888 , some sections deemed antiquated. Geffcken's notes are for all present purposes of greater value than Heffter's text. What Dana was to Wheaton, Geffcken was to Heffter. 
After his death complete editions of his writings were published at Geneva in 1761, and at Leyden in 1766, and translated into French by Duponceau. The most important part of his work, so far as international law is concerned, is the first book of his Questiones Juris Publici entitled, De Rebus Bellicis, in which he enters, for the first time, into a critical and systematic exposition of the rules that should regulate maritime commerce between neutral and belligerent states. Therein he dissents from Grotius as to the application and extent of the ancient law of France as to neutral ships and goods. ${ }^{18}$ In his De Dominio Maris (c. v.) he admits that certain portions of the sea may be susceptible of exclusive dominion, that is to the extent of a cannon shot from shore, a rule he extends to such seas as are completely surrounded by the adjacent territories of any particular state. As to the general foundation of international law, he derives it from reason and usage (ex ratione et $u s u$ ), and usage he bases on the evidence of treaties and ordinances made in harmony with general custom. ${ }^{19}$ Another Dutch publicist, standing in between Grotius and Bynkershoek, was Ulric Huber, a lawyer, historian and philologer, born at Dockum in Dutch territories, in 1635. His treatise, De Conflictu Legum, is to be found in his Prelectiones Juris Civilis. He died in $\mathbf{1 6 9 4 .}$

\section{$\S$ 42. English publioists-Zouch, Selden, Rutherforth, Jenkin-} son.-In the order of time the English publicists must next be considered, because as early as 1650 appeared the Juris et Judicii Fetialis, sive Juris inter Gentes et Qucestionum de eodem Explicatio of Dr. Zouch, the distinguished English civilian, who succeeded Albericus Gentilis as professor of Roman law at Oxford, and who was in 1641 judge of the High Court of Admiralty. In Zouch's work, which is a mere abridgment of that of Grotius, is emphasized the master's fundamental distinction between natural law and the law established by general consent, which governs, or should govern, all independent communities. It is likely that Zouch would never have been remembered at all if it had not occurred to him to describe the kind of law last named as jus inter gentes, in contradistinction to the jus gentium of the Roman lawyers, which had become the equivalent of jus naturae. Ten years prior to the appearance of Zouch's work, John Selden, a jurist and oriental scholar, had published his De Jure Naturali et Gentium juxta

18 Q. J. Pub., lib. i, c. xiv.

19 Ibid., lib. i, c. $x$. 
Disciplinam Ebracorum, a work of monstrous erudition, in which is described the peculiar institutions of the Jews, with an exposition of their understanding of jus gentium, and of their international usages in wal and peace. While he makes no direct reference to the doctrines of Grotius, he adopts his basic principle, dividing the laws of nations into the primitive or matural, and the secondary, derived from convention and custom. Selden is, however, far better known as the author of the Mare Clausum, published in 1635 as a counter blast to Grotius's Mare Liberum.20 It had been written sixteen or seventeen year's before, and dedicated to James I, who prohibited its publication for political reasons. It was finally put forth by his successor as a lind of state paper, in which the sorereignty of Great Britain orer the surrounding seas was asserted in such a way as to deny to the Dutch the right to fish off the coasts. In 1754 Thomas Rutherforth, a Cambridge professor, published his lectures upon Grotius as Institutes of Natural Law; and in $\mathbf{1 7 5 7}$ Charles Jenkinson, first earl of Liverpool, issued a Discourse on the Conduct of Great Britain in respect to Ncutral Nations.

Hobbes and Bentham.-In the same general way in which German students of international law regard Leibnitz and Saviøny, French students Montesquieu and the Abbe Mably, English and American students regard Hobbes and Bentbam, as publicists who in their explorations of the entire field of jurisprudence have shed light incidentally upon that branch in which they are specially concerned. Beginning with the postulate that man's natural state is a state of war, Hobbes applies the principle, not only to men in their individual relations, but to states in their political relations, thus reaching the conclusion that every state has the right to do whaterer it pleases to all other states. He divides the natural law "into the natural law of men, and the natural law of states, commonly called the Law of Nations. The precepts of both are the same ** that law, which when spealing of individual men we call the Law of Nature, is called the Law of Nations when applied to whole states, nations, or people."21 His droidful rered of perpetual wall was mitigated, however, by the admission that "rinson sugresteth convenient Articles of

20 First published anonymously rights in the Atlantic and Pacific at Leyden in 1609 , as a protest oceans by virtue of the decree of against the extravigant claims of Pope Alexander VI, made in 1493. Spain and Portugal to exclusive $: 1$ De Cive, c. xiv, § 4. 
Peace, upon which men may be drawn to agreement. These Articles are they which otherwise are called the Laws of Nature." 22 Whenever either men or states may find it conrenient and useful to substitute peace for war through contract, the right to do so is eonceded to them. The same utilitarian idea of convenience underlies Bentham's incomplete essay on international law, in which, after reviewing its general character, especially in relation to the causes and consequences of war, he attempts to formulate a plan to secure universal and perpetual peace through a league of European states to be governed by laws enacted by a federal legislature, and enforced through a federal judicature. The motive, he contends, that should prompt men to set up an international code is embodied in the idea of general utility in so far as nations may abstain from injuring other nations, and may do actual good to them, without any special detriment to their own well being. In the event of inevitable wars the code was so to proride as to mitigate as far as possible the evils necessarily resulting from them. ${ }^{23}$ Thus "the formula of the greatest happiness is made a hook to put in the nostrils of Leviathan, that he may be tamed and harnessed to the chariot of utility."24

Wildman, Manning, Phillimore, Twiss, Hall, Dicey and others.In 1829 were published Richard Wildman's Institutes of International Law; in 1839 William Oke Manning's Commentarics on the Law of Nations, in which special consideration is given to the rights of neutrals in maritime war; in $1848 \mathrm{Archer}$ Polson's Principles of the Law of Nations, with practical notes and supplementary essars on the law of blockade and on contraband of war; in 1854-61 sir Robert Phillimore's notable and comprehensive Commentaries upon International Law; in 1858 John Westlake's Treatise on Private International Law or the Conflict of Lau's; in 1861. Sir Trarers Twiss's (Regius Professor of Civil Law at Oxford) The Law of Nations, considered as Independent Political Communities, and in 186:: Rights and Duties of Nations in Time of War: in $1876 \mathrm{Sil}^{\circ}$ Edward S. Creasy's First Platform of International Lau; in 1884 James Lorimer's Institutes of the Lau of Nations; in the

22 Leviathan, p. 63.

23 Bentham's Works (Bowring ed.), Pt. viii, pp. 537-554. As to the resemblance of Bentlam's project of perpetual peace to those suggested by Saint Pierre and Rousseau, see Wheaton, History, p. 343 .

24 Pollock, Hist. of the Science of Politics, p. 101. 
same year W. E. Hall's masterful Treatise on International Law; in $18 S 9$ H. Nelson's Private International Law; in 1893 Thomas A. Walker's Science of International Law; in $\mathbf{1 8 9 5}$ 'T. J. Lawrence's thoroughly digested and brilliant volume entitled The Principles of International Law; in $1896 \mathrm{~A} . \mathrm{V}$. Dicey's Conflict of Laus; in 1899 Sir Sherston Baker's First Steps in International Law; and in 1900 F. E. Smith's International Law.

Special reference should be made not only to Prof. T. E. Holland's Studies of International Law (1898), but also to the invaluable expositions of that subject contained in his Elements of Jurisprudence, declared by an eminent critic to be "the first work of pure scientific jurisprudence which has appeared in England-that is, of the general seience of law distinctly separated from the ethical part of politics." $24 a$

\section{43. Swiss publicists-Vattel, Burlamaqui and Bluntschli.-} The short yet notable line of Swiss publicists was founded by Emeric de Vattel, who was born at Couret in the principality of Neuchatel in 1714. Turning from theology to philosophy he became a disciple of Leibnitz, whose system he defended against Crousat in a publication that appeared at Geneva in 1741. Thus it was that Vattel was drawn to Wolf, another and stronger disciple whom Leibnitz had installed as his expounder at IIalle, and of whose work on international law a brief deseription has been given already. We learn from Vattel himself that "The treatise of the philosopher of Halle on the latw of Nations is dependent on all those of the same author on philosoplyy and the law of nature. In order to read and monderstand it, it is necessary to have previously studied sixteen or serenteen quato volumes which precede it. Besides, it is witten in the mamner and even in the formal method of geometrical works."." As Wolf thus spoke in an unknown tongue, Vattel dermed it neressary "that some brother having the gift of interpretation should expound the invaluable jargon." 26 So it was that he became to Wolf what Dumont was to Buntham,--an interpreter who, after condensing and systematizing the materials of his principal, reproduced the refined product in such neat, clear and precise French as to command universal attention and admiration. By such means the skillful editor suceeded in making a popular abridgment

24a Pollock. Hist. of the Science of Politics, p. 63.

25 Droit acs Gens. Préface, xii.
26 Macaulay, on Dumont's Memoir of Mirabeau, Essays, vol. i, p. 757 . 
which has sared not only his own fame, but that of his master, from oblivion. In the hope of clothing himself with some lind of originality, Vattel attempted to differ from Wolf as to the process through which should be established the foundations of the voluntary law of nations, based by the latter upon the fiction of a great republic set up by nature herself to shelter within its fold all the nations of the earth. ${ }^{27} \mathrm{~A}$ gainst that assumption Vattel formulated the simple rule, that "the Law of Nations is originally no other than the Law of Nature applied to nations." Although the application of that law to states differs from its application to individuals, both Wolf and Vattel agreed that its precepts were equally binding upon both, and for that reason both termed it the necessary law of nations, because all were necessarily bound to observe it. Like the law of nature herself this necessary law could neither be changed nor dispensed with by any state, in the forum of conscience, by treaty or by any less formal act. To obviate practical difficulties the necessary law thus defined was subdivided into an internal law, or law of conscience, and an external law, or law of action. A treaty might be void under the precepts of the former, and yet perfectly valid under the terms of the latter. Proceeding from different premises, master and disciple both reached the conclusion, that there was $a$ voluntary law of nations, and in addition thereto a conventional law, resulting from compacts, and a customary law resulting from usage. ${ }^{29}$ All flowed from a common source, the will of nations, - as Wolf has expressed it, the voluntary, from their" "presumed consent, the conventional from their express consent, and the consuetudinary, from their tacit consent." Wo Then all such unfruitful distinctions have been entirely forgotten, Vattel will still be remembered by reason of the fact that he really did original work in advancing the growth of the law of neutrality, which was in so imperfect a state in the time of Grotius that even he declared that when two states are members of a league one may defend a third power from the attack of its ally without a breach of the general peace between them. The good work of developing the law of neutrality, greatly accelerated by Bynkershoek, was

27 See above, p. 58 , note 14 .

28 Préliminaires, § 5 .

29 Droit des Gens, Préliminaires, $\S \S 17,21,24,25$. "These three kinds of Law of Nations, the
Voluntary, the Conventional, and the Customary, together constitute the Positive Law of Nations," $\S 27$.

30 Proleg., § 25. 
carried on twenty years later by Vattel, who added many rules to the growing doctrine, that in order to secure all the advantages of neutrality, a nentral nation "must in all things show a strict impartiulity towards the belligerent powers." 31

A contemporary of Tattel was Jean J. Burlamaqui, the famous writer upon the law of nature and of nations born at Geneva in 1694, whose chief works are Principes du Droit Naturel et des Gens, 1747; and Principes du Droit Politique, 1751.

In our own time the name of another Swiss publicist has become as familiar throughout the world as that of Vattel. Reference is made to Johann Kaspar Bluntschli ${ }^{32}$ of Zurich, who was for a long time a professor at Zurich, Munich and Heidelberg. His principal works are Das moderne Völkerrecht der civilisirten Staaten als Rechtsbach dargestellt, Nordlingen, 187s; Das Beuterecht ün Kricge, 187S; and Geschichte des allgemeinen Staatsrecht, 1881.

$\S$ 44. French publicists-Valin, Pothier, Foelix, Massé, Ortolan and others.-French publicists, who were not among the first to devote themselves to the special study of international law, have by the general excellence of their subsequent contributions more than balanced the original deficit. In 1762-64 appeared at Paris De Real's work in eight rolumes entitled La Scionce duGourcmement-the fifth of which embraces the Law of Nations. The first great name, however, connected with the subject is that of Rene J. Valin, who published at Rochelle in 1760 his Commentaire sur l ordonnance de la marine du mois d'aout 1681; and in 176:3 his Traité des Prises, ou principes de la jurisprudence francaise concernant les Prises qui se font sur mer, -a subject also considered by Pothier in his Traité de Propricté. In 1811 appeared Gérard de Rayneval's De la liberté des mers; and in $18: 32$ a new edition of his Institulions du droit de la nature et des gens. In 1838 appeared the Traité complet de la diplomatie, ou Théoric générale des relations cxtérieures des puissances de l' Europe of comte de Gauden; in 1843 the Traité alu droit international privé of the Parisian advocate Folix; in 1844 Le droit commercial dans ses rapports arec les droits des gens et le droit civil of M. G. Massé, a counsclop of the Court of Cassation; in 1845 the notable liègles intemationales ct Diplomatie de la mer of Theodore Ortolin; in 1 sts the Droits et devoirs des

s1 Droit des Gens, p. 332 .

$32 \mathrm{He}$ was born in 1808 and died in 1881 . 
nations neutres en temps de guerre maritime of L. B. Hautefeuille, who also published in 1858 his Histoire des origines, des progrès et des variations du droit maritime international, and in 1868 a book entitled Questions de droit maritime international. In 1851 appeared the Des Moyens d' acquérir le domaine international ou propriété d'Etat entre les nations, d'après le droit des gens public of Eugene Ortolan; in 1858 the Traité des prises maritimes of M M. Pistoye et Duverdy; and in 1862 Le droit maritime international considéré dans ses origines et dans ses rapports avec les progrès de la civilization of Eugène Cauchy, a work crowned by the Academy of Moral and Political Sciences.

$\S 45$. North American publicists-contributions to law of neutrality.-While American publicists were necessarily the last to make contributions to international law, by common consent they have rendered already invaluable services in developing the law of neutrality, and international private law, or conflict of laws. An eminent British statesman once said in parliament, while a minister of the crown, "that if he wished for a guide in a system of neutrality he should take that laid down by America in the days of Washington and the secretaryship of Jefferson," ${ }_{33}$ - a statement strengthened by Sir Robert Phillimore ${ }^{34}$ who said that when the United States were sorely tried during the war of the first French Revolution, "in 1793 under the presidency of Washington, they put forth a proclamation of neutrality, and resisting both the threats and the blandishments of their recent ally, took their stand upon sound principles of international law, and passed their first neutrality statute of 1794. The same spirit induced the Government of these states, at that important crisis when the Spanish colonies in America threw off their allegiance to the mother country, to pass the amended foreign enlistment statute of 1818; in accordance with which, during the next year, the British statute, after a severe struggle, and mainly by the great powers of Mr. Canning, was carried through parliament." Such was the general character of the work performed by the early publicists of the United States in the official conduct of its foreign affairs prior to the advent of those who have expounded the principles of international law in formal treatises.

33 Cf. Wharton, Int. Law Dig., vol. i, Preliminary Remarks.

34 Int. Law, vol. i, p. 559, 3ed, 1879. 
James Kent.-It the head of that line stands James Kent, who, after ably assisting in laying the foundations of American equity jurisprudence as a chancellor of the State of New York, resigned in order to accept, at the age of sixty, the professorship of law in Columbia College. Out of the lectures there delivered grew the famous Commentaries on American Law published in 1826-30, the first part of which is devoted to a brief yet luminous exposition of the principles of the "Law of Nations" as then accepted in this country. Chancellor Kent also published a separate Commentary on International Law, a second edition of which, edited by J. T. Abdy, appeared in London in 1878.

Henry Wheaton.-The greatest of American expounders of international law was Henry Wheaton, a lawyer, diplomat, and historical scholar who was born in the State of Rhode Island in 1785. After thorough academic and linguistic training, he removed to the city of New York, where he published, in 1815, his work on the Law of Marine Captures, which brought at once genuine reputation. After haring filled the office of reporter of the Supreme Court of the United States from 1816 to 1827 he was appointed in the year last named as Chargé d'Affaires at Copenhagen, where he remained until his transfer in 1835 to Berlin, first as Minister Resident, and finally as Minister Plenipotentiary. From Berlin came, in 1836, his Elements of International Law, the notable work which has passed through so many editions, augmented and improred as it has been by the voluminous notes of Richard Henry Dana, Jr., and William B. Lawrence, who thus became incolred in prolonged litigation. The work, howerer, upon which Wheaton's fame chiefly depends is his History of the Law of Nations in Europe and America, to be noted hereafter in its proper place.

Joseph Story.-Next to John Marshall, Joseph Story, born in the State of Massachusetts in 1769 , is the most famous of the group of notable judges who defined the powers of the federal judiciary of the United States in the series of formatice decisions and opinions that extends from 1812 to 1832. To Story, more than to any other one, is due the upbuilding and defining of our admiralty jurisdiction. As a prize court judge he made such contributions to international law as associate his name with the English Stowell, and the French Portalis. His most notable contribution to that subject is, howerer, his Confict of Laws, which appeared in 1834 at a time when, as he tells us in his preface, "There existed no treatise upon it in the English 
language; and not the slightest effort has been made, except by $\mathrm{Mr}$. Chancellor Kent, to arrange in any general order even the more familiar maxims of the Common Law in regard to it. The subject has been discussed with much more fullness, learning, and ability by the foreign jurists of continental Europe. But even among them there exists no systematical treatise embracing all the general topics." Thus story was the first to place the study of international private law upon a systematic and scientific basis.

Woolsey, Halleck, Field, Wharton and others.-In 1860 appeared Dr. Theodore D. Woolsey's well known and rery. useful Introduction to the Study of International Law; and in 1861 Henry W. Halleck, a general in the army of the United States, published a work on International Law, or Rules Regulating the Intercourse of States in Peace and War, which has receired rery decided recognition. In 1872 Darid Dudley Field made an important move in the right direction when he published Outlines of an Intcrnational Code-a scheme "embracing not only a codification of existing rules of international law, but the suggestion of such modifications and improvements as the more matured cirilization of the present age should seem to require." In 1873 Dr. Francis Wharton, favorably known as a writer on other branches of law, published his Conflict of Laws, and in 1886 his exhaustive Digest of the International Law of the United States. In the same year appeared John Norton I'omeroy's Lectures on International Law in Time of Peace; in 1887 George B. Davis's Outlines of International Law; in 1895 Gleun's International Law; and in 1Ś9s Freemin Snow's International Lau.

§ 46. South American and Russian publicists-Calvo, Bello, Martens.-In 1868 South America did honor to the New World through the rery notable contribution of M. Carlos Calvo which, after a first appearance in Spanish under the title of Derecho International Teorico y Practico de Europa y America, was translated into French as Le Droit International Théorique et Pratique, the title by which it is now generally known. Calvo, who came to this country as minister from Paraguay, speaks in the lighest terms of his compatriot Andre Bello (born in Caracas in 1780), the author of Principios de derecho de gentes. According to Calvo "Bello est le premier" qui ait signalé l'insuffisance des principes émis dans l'ouvrage de Vattel et ait tenté d’y suppléer." 35

35 Droit Internationat. vol. i, p. 86. 
No account of the leading publicists of the world would be at all complete that omitted the name of Fedor Fedorovitch Martens, the eminent Russian, born at Pernau in 1s45, and aducated at st. Petersburg, where he was appointed professor of international law at the age of twenly-five. On the death of Prince Gortschakof he was matde a permanent member of the Council of Foreign $A$ fílirs, and as such lae has represented his government at various international conferences. Many of his works on international law have been translated into French, the most important of which are Les Consulats et la Jurisdiction Consulaire en Orienl, 1873; La Conflict entre la Chine et la Russie, 1881; Traité de Iroil Internationale, 3 vols. 1883-87. To these must be added his collection of treaties and conventions concluded by Russia with foreign powers, of which eleven volumes or more have been published, beginning in 1874. By his honorable services as arbitrator in several international controversies he has won from his friends the sonbriquet of "Lord Chief Justice of Christendom."

$\S 47$. History and literature of international law.-Having now grouped the principal expounders of international law according to their origin, brief mention must be made of the more important works of those who have specially devoted themselves to its history and literature. To Germaily belong Von Omptedi's Literatur des gesammlen, so wohl natïrlichen. als positiven, Töllierrechts, Ratisbon, 1785, continued by Von Kamptz, Neue Literatur des Volkerrechts seit dem Jahre 1\%S4, Berlin, 1s17; E. Osenbrïggen's De Jure Pacis ct Belli Romanorum, liber singularis, Leipzig, 1836; K. Th. Pütter's Beiträge zur Völlerrechtsgeschichte und Wissenschaft, Leipzi⿺尢, 1843; Müllep-Jochmus's Geschichte des Völkerrechts im Alterthum, Leiprig, 184s; and Robert V. Mohl's Die Geschichte und Lilcratur der Staatswissenschaften, Erlangen, 1855-1858, in the first volume of which is contained an excellent monograph, with criticisms upon the more recent literature tonching the subject. 'To England belong Robert Ward's Enquiry into the Foundation and History of the Law of Nations in Europe. from the Time of the Grects and Romans to the Age of Grotius, London, 1795; and J. Hosack's Rise and Growth of the Law of Nations as Established by General Usage and by Treaties from the Earlicst Time to the Treaty of Utrecht, London, 1ss2. To Belgium belongs F. Laurent's Itistoire du droit des gens et des relations internationales, Ghent, 1850, Paris, 1851, Bruxelles, 1861-68. To the United 
States belongs Henry Wheaton's History of the Law of Nations in Europe and America from the Earliest Times to the Treaty of Washington, 1S42, a work originally written and published in French as a Mémoire in answer to the following prize question proposed by the Academy of Aloral and Political Sciences in the Institute of France: Quels sont les progrès qu'a fait le droit des gens on Europe depuis la Paix de Westphatie? In $18+1$ Wheaton published as an answer to that question an essay entitled Histoire du progrès du droit des gens on Europe, which, in being rendered into English, was expanded into the work in question. ${ }^{36}$

$\S 48$. Publicists as creators of international rules.-Publicists nust be viewed, however, not only as witnesses to the existence of rules laid down by others, but as creators of rules erolved from their mere sense of law, which have won their way through their own merits to general acceptance. Reference has been made already to the splendid age of creative jurisprudence in the history of Roman law that ended with the reign of Severus Alexander,-an age in which the responsa prudentium of the jurisconsults, enriched from nearly every branch of human knowledge, laid the foundations of a scientific law literature adorned by the names of Papinian, Gaius, Ulpian and Modestinus. ${ }^{37}$ The foundations of modern international law were laid in the same way through the successive efforts of Suarez, Ayala, Gentilis, Grotius, Puffendorf, Wolf, Bynkershoek and Vattel, and of the other less notable authorities of that epoch who worked with them. It is certain that the greater part of the present law of Occupation and Jurisdiction was derived from the application made by the Spanish casuists and Protestant civilians of the rules of Roman law to the momentous international problems presented by the discovery of the New World. ${ }^{38}$ In the chapters in which Grotius pleads on account of his temperamenta belli may be found stated, perhaps for the first time, many humane rules which have become the undisputed basis of belligerent theory and practice. ${ }^{39}$ To the views of Brnkershoek are largely due the rules that now govern as to the extent of a state's territorial waters, ${ }^{40}$ while to Vattel must be given special credit for an amplification of the rules through which he has-

36 I am indebted for a knowledge of a few of the works named in this and preceding sections to Calvo, Le Droit International, vol. i, pp. 81-91, and to Woolsey, Introd. to Int. Law, Appendix 1.
37 See above, p. 20.

38 See below, p. 127 et seq.

39 De Jure Belli ac Pacis, III. c. $x i, \S 14$.

40 See above, p. 61. 
tened the growth of the then rapidly developing law of nentrality. ${ }^{41}$ There is no adequate foundation for the assumption that the formative period of international law has ended. It is "a living organism," ${ }^{42}$ growing with the growth of nations, and as such it develops new rules to meet new conditions as they arise out of advancing civilization. Its formative period cannot end until it has evolved an international code, and an international tribunal to interpret it.

Institut de Droit International.- If it be true that individual publicists, acting in isolation, may, evolve from their mere sense of law new rules capable of winning general acceptance, certainly greater importance still should attacli to such as are formulated, after patient and exhaustive deliberation, by a collegiate body of those expounders of international law the world over who have attiined the greatest celebrity. Such is the constitution of the Institut de Droit International whose annual meetings and weighty publications are doing so much to lead the thoughts of publicists and statesmen into those paths in which progress is most possible. The more notable recommendations so far made by the Institut may be summarized as follows: Its resolutions adopted in 1875 as to the duties of neutrals, founded upon the three rules of the Treaty of Washington, and its declarations as to the inviolability of private property at sea; its code of procedure of the same year for the use of tribunals of arbitration; its proposal of 1877 that neutral governments shall be charged with the duty of preventing shipments of contraband goods from their ports to a belligerent destination; its resolution of 1879 defining the scope of the assumed right of a state to punish foreigners for acts done outside of its jurisdiction; its assent in 1880 to the Manuel des Lois de la Gucre sur Terre; its proposed Règlement des Prises Maritimes of 18S2, and its condemnation in that year of the decision in the Springbok case ${ }^{43}$ its declaration in 1887 as to pacific blockade; its project of 1888 designed to temper the practical application of the right of expelling foreigners; and its resolution of 1894 as to the extension of the three-mile limit. While recommendations thus made have no intrinsic authority, they are entitled to the deference and consideration due to disinterested efforts to reach the wisest conclusions made by those who are able to unite the greatest learning with the widest experience.

41 Ibid., p. 65.

42 For that phrase I am indebted to Lawrence. Preface to Principles of Int. Law.
43 The Bark Springbok v. The United States, 5 Walls., 1-28. This case will be considered fully in its proper place. 
CHAPTER III.

GROTIUS AND THE AFTERGROWTH OF HIS SYSTEM.

$\S$ 49. Huig van Groot, known as Hugo Grotius.-At the lead of the array of publicists just grouped according to nationality there stands one who has passed through a process of canonization as "the Father of the Law of Nations," an epithet which has become almost a part of the name of Huig ran Groot, generally known as Hugo Grotius, born at Delft, in the Prorince of Holland, April 10, 1583. The historical school strives neither to make nor unmake heroes; its business is so to place each actor in the line of causation as to make it possible fairly to estimate his thoughts, and their influence, with just reference to those of his predecessors and successors in the same field of activity. It appears from what has been said already as to the works of the predecessors of Grotius-Oldendorp, Suarez, Victoria, Soto, Ayala, Gentilis, and Winckler-that he was not the first to perceive or to declare that some fresh understanding between the sovereign states of Europe should be substituted for the international power of the Holy Roman Enpire, finally swept away in the storm of the Reformation. It is not necessary for the fame of Grotius that his predeces. sors should be deprived of their due meed of praise. Eren the stingy spirit in which he himself acknowledged the merits of Ayala and Gentilis should be a rebuke to his adulators. ${ }^{1}$ Coming upon the scene at a turning point in European history, Grotius was by his faith and nationality, by his special training as jurist, historian, theologian and man of letters, and above all by his insight, specially qualified for the execution of a task whose scope and necessity were clearly indicated by the political conditions actually existing around him. When the nature of his achievement is riewed in the light of his environment, the origin of his two fundamental conceptions may be traced to sources which are by no means veiled in mystery.

$\S 50$. His substitute for the supremacy of the Holy Roman Empire.-From the time of the establishment of the world dominion of the Roman Empire, the doctrine of subordination of

1 De Jure Belli ac Pacis, Proleg., § 39. 
states to a common superior, became so firmly settled in the minds of men, that it seemed a part of the natural order that subject nations and their rulers should look for the settlement of all grave disputes, personal and national, to Caesar, as the supreme sourer of law and political authority. So completely did that idea overshadow the barbarian hordes which finally wrecked the Enupire of the West that they refused to believe in the reality of their own achievement. In the firm belief that the overlordship of Rome was destined to be eternal they assisted in the creation of the new fabric lnown as the Holy Roman Empire, which, during the interval that divides the coronation of charles the Great from the Reformation, grew into an international power so potent that its spiritual head in the person of Gregory VII claimed, in the second excommunication passed npon Henry IV, the right "to give and to take away empires, kingdoms, princedoms, marquisates, duchies, countships, and the possessions of all men." 2 While that mannificent conception of a common superior, before whom all states and princes were expected to bow, was passing forever away in the midst of political and social disorder and perpetual war, there developed a longing for the ereation of some new eentral force, which could take the place of the old and perform the mission of peare it had so signally failed to discharge. The first ontery which came from Machiavelli ${ }^{3}$ was repeated a century later by Grotius, who was impelled to write, as he tells us himself, because he "observed throughout the Christian world a licentiousuess in regard to war, which even barbarous nations ought to be ashamed of; a running to arms upon rery frivolous or rather no occasion; which being once taken up, there remained no longer any reverence for right either divine or humin, just as if from that time men were authorized and firmly resolved to commit all manner of crimes without restraint." 4 We know now that the dream of impressing upon his contemporaries the necessity for the establishment of a "dirine and human law," as a substitute for the obsolete overlordship of the Holy Empire, entered into the mind of Grotius at a rely early age. The discovery in 1868 by I'rofessor Fruin of the De jure pracdae, written by Grotius in 1604 , settles the fact that the prineiples and plan of the

2 Bryce, Holy Roman Empire, p. 155. As to the belief of the barbarians in the eternity of the Empire, see p. 18.
3 See above, p. 52.

4 De Jure Belli ac Pacis, Proleg., $\S 39$, Eng. trans., with notes by Barbeyrac, London, 1738. 
De Jure Belli ac Pacis, published in 1625, were clearly con. ceived by an abnormally precocious youth of twenty-one, who had made good Latin verses at nine, and who was ripe for the university at twelve. ${ }^{5}$ Such was the natural aptitude and training, such the environment, of the author of a work which has been made the subject of extravagant praise upon the one hand, and of unjust depreciation upon the other. ${ }^{6}$ Its merits rest in the main upon the presentation of two funda. mental conceptions that will be considered separately.

$\S 51$. Independent and coequal states-territory and jurisdiction coextensive.-All publicists who have written recently admit that the corner-stone of the Grotian system, if such it may be called, was laid when its author made a full and frank admission of the obvious historical fact, that, with the passing of the Holy Empire, the typical modern state, resting upon the idea of territorial sovereignty, reached its full and final development. The effort has been made already to explain how it was that the personal and tribal organizations of the conquering hordes that settled down upon the wreck of the Roman Empire finally became tied to the land through "the process of feudalization," a process that contributed to the modern world only one new element through the conversion of tribal into territorial sovereignty. In that way the elective king of the migratory nation was gradually transformed into the hereditary lord of a given area of land to which he stood as the baron to his estate, the tenant to his freehold. ${ }^{7}$ As soon as the new states thus organized were deprived of a common superior through the collapse of the theory of a universal supremacy, two corollaries became irresistible: first, that each state is independent, and as such coequal with all the rest; second, that territory and jurisdiction are coextensive. Grotius, clearly comprehending these simple truths, emphasized

5 Cf. Mark Pattison's article on Grotius in Enc. Brit. (9 ed.), vol. $x i$, p. 218 . The De jure praedae was printed at The Hague under the auspices of Prof. Fruin.

6 De Quincey said that the work of Grotius is equally divided between "empty truisms and timeserving Dutch falsehoods." On the other hand Adam Smith declared it to be: "A monument which can only perish with the civilized intercourse of nations, of which it has laid down the master principles with a master's hand. Grotius first awakened the conscience of governments to the Christian sense of international duty." For Mackintosh's estimate, see Miscell. Works, p. 166; for Bluntschli's, Geschichte des allgemeinen staatsrechts (Munich, 1864).

7 See above, pp. 28-29. 
the fact of the independence of the sovereign states about him by formally repudiating the obsolete doctrine of a temporal and spiritual head of Christendom, ${ }^{8}$ armed with the right to exact universal obedience. His primary contention was that each state is absolutely independent of all external human authority. ${ }^{9}$ Having thus established a common basis of equality, the difficulty that remained was how to subject sovereign states, through their own volition, to the yoke of legality.

§ 52. Blended product of jus gentium and jus naturae seized upon by Grotius.-No more novel or difficult problem was ever presented for solution than that which confronted the publicists of the sixteenth and seventeenth centuries when they were called upon to furuish rules adeguate, by virtue of their intrinsic weight and dignity, to compel the obedience of the freshly emancipated European nationalities, without the coercive force of any recognized central authority. As imitation is always easier than invention, it is not strange that every mind which attempted to solve the problem should have turned instinctively to Roman jurisprudence as the only source from which the vacuum could be filled. The most enduring outcome of Roman civilization, surviving the wreck of two empires, was Roman law, whose revived study during the twelfth century, in the schools of Italy, Spain, France and England, caused it to be regarded, in the modern as in the ancient world, as the perfection of human wisdom, the only true and eternal law. A special effort has heretofore been made to draw out in some detail the process through which a particular branch of Roman private law, administered by the praetor peregrinus, and known as the jus gentium, was blended with the Stoic conception of law in the higher sense, as "right reason, pervading all things," and proceeding "from Zeus and the common Nature." 10 Even in Cicero's time the fusion of the jus gentium with the jus naturae was so complete as to induce him to declare them identical. ${ }^{11}$ In that way the jus gentium was clothed with a higher authority, a philosophic dignity which tends to obscure its lumble origin as a mere division of

${ }^{8}$ De Jure Belli ac Pacis, II, State immortal? Ibid., II, c. ix, $\S 3$. c. xxii, $\S \S 13,14$.

9 Can parts of a state be alienated without their own consent? See De Jure Belli ac Pacis. II, c. vi, \& 4. In what sense is a How it may die or cease to be. Ibid., II, c. ix, $\S 4$.

10 See above, p. 22.

11 Lege naturæ, id est gentium, De off. i, 23. 
private law. To this cause may be attributed the fact that the term jus gentium was, in a few exceptional cases, ${ }^{12}$ used out of its normal and proper sense to indicate a branch of law binding on all nations in the direction of their international relations as jus commune gentibus. And so it may be true that "there floated also always before the eyes of the later Roman jurists a vision of a 'jus naturale'; a universal code, from which all particular systems are derived, or to which they all tend, at least, to approximate: a set of rules, the matter, or contents, of which is of universal application." 13

Effort to give to it a strained construction unsuccessful. - The effort to give to the blended product of jus gentium and jus naturae a strained construction was never successful. It was not the extravagant interpretation of Ulpian, but the more restricted and more reasonable one of Gaius, that finally determined its meaning in the time of the Antonines. ${ }^{14}$ As Sir Henry Maine has expressed it: "At last, at a peculiarly felicitous conjuncture, Ayala and Grotius were able to obtain for it the enthusiastic assent of Europe, an assent which has been over and over again renewed in every variety of solemn engagement. * * * Having adopted from the Antonine jurisconsults the position that the jus gentium and the jus naturae were identical, Grotius, with his immediate predecessors and his immediate successors, attributed to the law of nature an authority which would never perhaps have been claimed for it, if 'law of nations' had not in that age been an ambiguous expression. They laid down unreservedly that natural law is the code of states, and thus put in operation a process which has continued almost down to our own day, the process of engrafting on the international system rules which are supposed to have been evolved from the unassisted contemplation of the conception of nature." ${ }^{15}$ As Grotius and his predecessors were well trained civilians, there is no basis for the assumption that they were befogged as to the true nature of jus gentium and jus naturae as convertible terms. The fact that the jus gentium was only a branch of Roman private law, and not a system of rules which had been preriously

12 Hoc vos, Feciales, juris gentibus dicitis? Livy ix, II. Populum Romanum neque recte neque pro bono facturum, si ab jure gentium se prohibuerit, Sallust, Bell. Jug., c. xxii. Cf. Prof. Nettleship's arti- cle on Jus Gentium in the Journal of Philology, vol. xiii, No. 26.

13 Holland, Elements of Jurisprudence, p. 6.

14 See above, p. 23.

15 Ancient Law, pp. 95-96. 
applied to the relations of states, was no reason why it should not have been lifted into a higher spliere. Before Grotins appeared upon the scene his Spanish and Italian predecessors had surveyed the whole field,-Gentilis in particular having specially emphasized the fact that the jus naturae was the highest embodiment of human reason, by which all historical precedents were to be tested, and, if necessary, set aside. ${ }^{10}$ And yet, acute and learned as they were, the predecessors of Grotins were not able to catch the ear of the world. It was his good fortune "to come along behind them and pick up their brains," and to fuse, through his rare art of exposition, their scattered and fragmentary thoughts into one coherent whole which appealed in due time to all mankind, and thus "first awakened the conscience of governments to the Christian sense of international duty."

$\S 53$. The Grotian law of nature-an alternative basis resting on consent alone.-Nothing could be more clear or vivid than Grotius's definition of natural law as the Antonine jurist had understood it. In lis prologomen ${ }^{17}$ he declares that "the principles of that law, if you rightly consider, are manifest and self-evident, almost after the same manner as those things are that we perceive with our outward senses, which do not deceive us, if the organs are rightly disposed, and if other things necessary are not wanting." And in the body of his work he adds: "Natural right is the rule and dictate of right reason, slowing the moral deformity or moral necessity there is in any act, according to its suitableness or unsuitableness to a reasonable nature, and consequently, that such an act is either forbid or commanded by God, the author of nature." ${ }^{1.3}$ One can almost imagine that he hears the great Stoic Chrysippus speaking of the natural law as "the right reason, pervading all things," 19 and "proceeding from Zeus and the common nature." ${ }^{20}$ Grotius, following in the footsteps of Suarez and Gentilis, accepted the dominant idea of the age that nature was a lawgiver. His dream was to place her as such upon the vacant Imperial throne, and then to interpret her mandates

16 See above, p. 54.

17 De Jure Belli ac Pacis, § XL.

18 De Jure Bclli ac Pacis, I, c. i, $\S 10$.

19 See above, p. 22.

20 Grotius declared in so many words: "And in this sense Chrys- sippus and the Stoics said, that the original of right is to be derived from no other than Jupiter himself; from which word Jupiter it is probable the Latins gave it the name jus." Proleg., § XII. 
to nations who would admit no other superior. "The law of nature is," he says, "so unalterable that God himself cannot change it. For though the power of God be immense, yet may we say, that there are some things unto which this infinite power does not extend. * * * For instance then, as twice two should not be four, God himself cannot affect; so neither can He, that what is intrinsically evil should not be evil." The practical difficulty inherent in this splendid conception was its vagueness, the same difficulty that beset Comte's system of religion, in which Humanity as a concrete conception was exalted to the throne occupied by the Supreme Being under monotheistic systems. Eternal and unalterable as the Grotian law of nature was said to be, it was in fact indeterminable, although in theory it might be assumed to be otherwise. Interpreted by one mind, it meant one thing, by another, something quite the opposite. Therefore, without some kind of common consent as to what its precepts were, it was nothing more than a glittering abstraction. Clearly perceiving that difficulty, Grotius very discreetly formulated an alternative basis for the new system which enabled it to rest upon consent alone. Alongside of the law natural, he said, there was a law voluntary whose nature was twofold, divine and human. While the former could never conflict with the law natural, the latter might. This human voluntary law he divided into three parts; first the law made for the benefit of a single society, the civil law; second, the law of the particular condition; third, the law made for the benefit of all societies, the law of nations. ${ }^{21}$ The authority of that law he said was derived from the approval of all, or at least of many nations,-the proof of it consisting of continued usage and the testimony of experts. ${ }^{22}$ Thus it was that Grotius reached the common sense basis upon which the law of nations now reposes,-the abstract and transcendental foundation embodied in his first postulate having been finally swept away.

$\S 54$. International law regarded as positive law by transcendental school.-False and unhistorical as the obsolete theory of natural law really is, there can be no doubt that it served a useful purpose in its day, in giving moral dignity to

21 De Jure Belli ac Pacis, I, c. i, $\S \S 13,14,15$.

22 Latius autem patens est jus gentium, id est quod gentium omnium aut multarum voluntate vim obligandi accepit. * * Probatur autem hoc jus gentium pari modo quo jus scriptum civile, usu continuo et testimonio peritorum. Jbid., § 14. 
the new system by reason of the then prevalent idea, that it was the hirhest and most sacred of all law, and, as such, binding upon all who aspired to stand above the brute creation. The original force of the idea must certainly have been great, if it maly be estimated by the permanency of its influence. It is marelous to see how a large majority of the best writers upon international law, even down to our own time, have persisted in deriving its principles from a transcendental source; such as Nature, Reason, and the Divine Will. While each nember of that school has striven, through some ingenuity of his own, to make the old doctrines more manageable or reasonible, beneath it all there is a common undertone that cannot be mistalien. The general assumption is that not only does international law flow from a transcendental source, but that it has all the cualities of positive law imparted by a lawgiver,-command, and the power to enforce the command. In mitigation of the conclusion that such law is binding upon all nations, proprio rigore, ingenious refinements are indulged in by one sect to prove that it must be adopted by the conscious act of each independent community, while another claims that a tacit assent may be presumed from the acts of governments in their mutual dealings. ${ }^{23}$ The following extracts from wellknown authors will be given as typical expositions of the general theory, withont the special qualifications through which some of them have attempted to limit it or explain it away. Puffentlorf, a disciple of Grotius who went beyond his master, assuming that the natural jus gentium is included in the wider science of jus naturac, accepted Hobbes's statement that "the natural law may be divided into the natural law of men, and the natural law of states, commonly called the law of nations." 24 lieyond that Puffendorf declares "there is no other voluntary or positive law of nations properly invested with a true and legal force, and binding as the command of a superior power." 25 Vattel, the disciple of Wolf, who beliered that the law of nations was the natural law applied to international affairs, avers that "we call that the necessary law of nations which consists in the application of the law of nature to nations. It is necessary because nations are abso-

23 See the elaborate opinions of Lord Coleridge, C. J., and of Cockburn, C. J., in The Queen v. Keyn, Law Rep. 2. Exchequer Division, pp. 63-239.
24 De Cive, c. xiv, $\S 4$.

${ }_{25}$ De Jure Naturae et Gentium. II, c. iii, § 23. 
lutely bound to observe it. This law contains the precepts prescribed by the law of nature to states, on whom the law is not less obligatory than on individuals. * * * This is the law which Grotius, and those who follow him, call the internal law of nations, on account of its being obligatory upon nations in point of conscience." 26 Hautefeuille declares that "international law, then, has its foundation in the divine or primitive law; it is from this source that it entirely flows. By the help of this law alone, I firmly believe that it is not only possible, but easy to regulate all the relations which exist, or which can exist, between the peoples of the world. This common and positive law contains all the rules of justice; it exists independently of all legislation, of all human institutions. It rules peace and war, and traces out, in every position of affairs, their rights and duties." ${ }^{27}$ Sir Robert Phillimore believed that "moral persons are governed partly by Dirine law (leges divinae), which includesnatural law-partly, by positive instituted human law, which includes written and unwritten law or customs (jus scriptum, non scriptum consuctudo). States, it has been said, are reciprocally recognized as moral persons. States are therefore gorerned, in their mutual relations, partly by Divine, and partly by positive law. Divine law is either (1) that which is written by the finger of God on the heart of man, when it is called natural law, or (2) that which has been miraculously made known to him, when it is called revealed or Christian law. The primary source, then, of international jurisprudence is divine law."2s To the mind of Sir Robert the usage of nations was the evidence of, but not the origin of, that law,-usage only expressed "the consent of nations to things which are naturally, that is, by the law of God, biuding upon them." 29 Even_Bluntschli declared that "the law of nations is that recognized universal law of nature which binds different states together in a humane jural society, and which also secures to the members of different states a common protection of law for their general human and international rights." 30

$\S 55$. International law not positive law-Austin, Holland, Wilson.-The foregoing are fair examples of the formulas in which the old transcendental school has been accustomed to

26 Droit des Gens, Préliminaires, $\S 7$.

27 Des Droits et des Devoirs des Nations Neutres, introd. ch.
28 Int. Law, vol. i, p 15.

29 Ibid, preface, p. v.

30 Das Völkerrecht, § 1. 
arer, (1) that international law tinds its origin in some superhuman source; (2) that by virtue of its origin it is really positive law, unchangeable, and binding upon all nations without any expressed or implied assent upon their part. The tirst assmution, whose vital infirmity has been pointed ont already, has been assailed both by the analytical and historical schools, and has been rejected by both because it is at once unnecessary, unscientitic and unhistorical. The second assumption, that international law is positive law, has broken down long ago under the principles latd down by Austin, who defines law, "in the most general and comprehensive acceptation in which the term, in its literal meaning. is employed," to be rules of conduct "laid down for the gruidance of an intelligent being by an intelligent being having power over him." Under that detinition are embraced (a) Lalws set by God to Men, styled Lalws of God, or Divine Law, and (b) Laws set by Men to Men." Laws of the latter class are set by authors, determinate or indeterminate, and are aceosdingly laws propel or improper. A law set by a determinate anthor is styled a law proper, and to that class belong the laws of God and also certain of the laws set by men to men. To the small division of law proper set to men by men, being political superiors aleting as such, Austin applies the term positive law, in order to distinguish it from divine law, positive morality, and law metaphorical. "The matter of jurisprudence is positive law: law. simply and strictly so called: or law set by political superiors to political inferiors." 31 The essence of Austin's quaint and pedantic description of positive law is that it must be a command, armed with a definite sanction, issuing from a determinate author.-a " iaw set by political superiors to political inferiors." International law is thus excluded from the domain of positive law because its mandates do not issue from a common superior almed with power to enforce obedience. "It diflers from ordinary law in being unsupported by the authority of a state. It differs from ordinary morality in being a rule for states and not for individuals. It is the ranishing point of jurisprudences: since it lacks any arbiter of disputed questions, save public opinion, beyond and above the disputant parties themselves, and since. in proportion as it tends to become assimilated to true law by the agrregation of states into a larrer societr, it ceases to be itself, and is

31 The Province of Jurisprudence Determined, lecture 1. 
transmuted into the public law of a federal government." 32 Because international law is only enforceable through the public opinion of civilized states, it is set by an indeterminate author, and is therefore law improper, that is, no law at all. For that reason it has been assigned by Austin a place in his positive morality, alongside of those customary rules observed among mankind for whose breach no authoritative punishment can be inflicted. As an eminent publicist of our own has recently stated it: "The province of international law may be described as a province half way between the province of morals and the province of positive law. It is law without a forceful sanction." ${ }^{33}$ While international law must thus be content to abide for a time in the borderland to which recent classification has assigned it, there is no reason to believe

- that current classifications and definitions of law are destined to be final. Already the Austinian system is under a fire that may sweep it away before the incoming of the next genera. tion.

$\S 56$. International law defined by those who do not regard it as positive law.-To illustrate the actual result of the rejection of the theories that international law originates in a transcendental source, and that it is really positive law, it will be necessary to place in juxtaposition the definitions of such representatives of the new school as ignore both assumptions. Austin says that "international law is founded on the opinions generally receiced among civilized nations, and its duties are enforced only by moral sanctions: by fear on the part of nations, or by fear on the part of sovereigns, of provoking general hostility and incurring its probable erils, in case they shoudd riolate maxims generally received and respected;" ${ }^{3}$ Holland, ${ }^{35}$ that "the body of rules regulating those rights in which both of the personal factors are states is loosely called 'the law of nations', but more appropriately 'jus inter gentes,' or international law;" ${ }^{36}$ Lawrence, that "international law may be defined as the rules which determine the conduct of the general bods of civilized states in their dealings with one another;" Hall, that "international law consists in certain rules of conduct which modern civilized states regard as

32 Holland, Elements of Jurisprudence, pp. 345-346.

33 Woodrow Wilson, The State, p. 628 .
34 Province of Jurisprudence Determined, pp. 147-148.

35 Elements of Jurisprudence, $\mathbf{p}$. 345 .

36 Principles of Int. Law, p. 1. 
being binding on them in their relations with one another with a force comparable in nature and degree to that binding the conscientious person to obey the laws of his country, and which they also regard as being enforceable by appropriate means in case of inf ringement;" ${ }^{37}$ Bulmerincq, ${ }^{38}$ that international law "is the totality of legal rules and institutions which have developed themselves touching the relations of states to one another;" Prof. Cairns, that "international law is the formal expression of the public opinion of the civilized world respecting the rules of conduct which ought to govern the relations of independent nations, and is, consequently, derived from the source from which all public opinion flows,-the moral and intellectual convictions of mankind;" ${ }^{39}$ Calyo, that "the law of nations or international law should be understood to be the sum of the rules of conduct observed by the different nations in their relations with each other; in other words, the totality of mutual obligations of states,-that is to say, of the duties they ought to fulfil, and the rights they ought to defend in regard to each other";"40 Lord Coleridge, that "the law of nations is that collection of usages which civilized states have agreed to observe in their dealing with one another;" ${ }^{41}$ Sir Travers Twiss, that "the science of the law of nations may be accordingly defined to be the science of the rules which govern the international life of states." ${ }_{22}$ Not only is there an entire absence from these definitions of any reference to the origin of international law in a transcendental souree, but in all of them such understandings or customs as actually exist between civilized nations are carefully designated as "rules" or "usaces" in order to emphasize the fact that they are not laws in the current acceptation of that term. And yet while that fact is perfectly understood by all special students of the subject, the term "internationil law," in the limited and technical sense that has been given it, is univer. sally used by all publicists as a convenient phrase in the absence of a more perfect designation.

$\S 57$. Alternative proposition of Grotius basis of modern system.- By the sweeping a way of the transcendental theory of

37 Int. Law, p. 1.

38 Das Vilkerrect (in Marquardsen's Handbuch, vol. i), § I of the monograph.

39 Quoted in Dana's notes to Wheaton's Elements, p. 23.
40 Le Droit International, vol. i, p. 93 .

41 The Queen v. Keyn, Law Rep.

2 Exchequer Division, p. 154.

42 Law of Nations, vol. i, p. 2. 
the origin of international law, and by the consequent severance of its connection with what is generally known as divine law, the existing system of rules now regulating the intercourse of nations can find no other basis upon which to rest than that embodied in the alternative proposition of Grotius, which declares that the law of nations derives its authority from the unanimous approbation of all, or, at least, of many nations; its proofs are continued usage and the testimony of the jurisperiti. ${ }^{3}$ The fact must be remembered, however, that when Grotius formulated that alternative, his primary assumption stood above it as a reservoir full of the moral force and dignity inherent in the jus gentium as the equivalent of jus naturae. "The habit of identifying the Roman law with the law of nature, for the purpose of giving it dignity, was of old date in Europe. When a clergyman or a lawyer of an early age wishes to quote Roman law in a country in which its authority was not recognized, or in a case to which Roman law was not allowed to apply, he calls it 'natural' law." ${ }_{4+}$ Since the old reserroir has been remored, to what source can we go for a moral force adequate to the task of sustaining a system of mere rules that do not rise to the dignity of laws, and which apply only to states as such? The obvious answer is, that such states are in their corporate capacity moral beings, clothed with all the rights and duties that pertain to the individual members of which they are composed. As PinheiroFerreira has well expressed it: "The sole difference there is between citizens united in a single state and the different peoples of the earth is that for a settlement of their differences the first resort to the decisions of their legislators and judges, while the second rarely submit to such methods, preferring to adjust their conflicts by an appeal to force. And yet as no one will maintain that might makes right, it must be admitted that, prior to the employment of force, there were rights on the one hand and duties on the other. It is these rights and duties, outside the sphere of force and legislation, that constitute what is called the law of nations." modern international law fancied they had discorered infallible criteria for the definition of all such rights and duties in what they called laws of nature;-"precepts, obedience to which, whether it be $\mathrm{or}^{\circ}$ be not commanded by the state, is

43 See above, p. 79. ${ }^{45} \mathrm{Cf}$. Calvo, Le Droit Interna-

44 Maine, International Law, p. tional, pp. 93-94. 20. 
insisted upon by a deep rooted public sentiment. Resting essentially upon public sentiment, they are rules of morality; but having reference only to such ontward actions as are thought fit for political enforcement, they form only one class of such rules." ${ }^{46}$

$\S 58$. Author's definition of international law.-Public sentiment is really the reservoir from which the rules now regulating the mutual relations of states have been slowly drawn through the experience, the usage of nations. Usage or "custom is, as it were, the filter-bed through which all that comes from the fountains must pass before it reaches the main stream." ${ }^{\prime 7}$ Or to borrow a stronger simile from the astronomers, that vast and unicersal conception of morality and legality constituting the public opinion of the civilized world is the central light, which, like the sun, has thrown off the nebulous envelopes or rings that have gradually hardened into the compact international rules which rise almost to the dignity of positive laws. The hope this simile suggests is embodied in the fact that no matter how much it may have thrown off, the original nucleus of light remains unimpaired. For that reason the statement has heretofore been made that there is no adequate basis for the assumption that the formative period of international law has closed. With that fact clearly in riew, international law may be defined to be the aggregate of rules regulating the intercourse of states, which have been gradually evolved out of the moral and intellectual convictions of the civilized world as the necessity for their existence has been demonstrated by experience. In the light of such a definition the relation of international to natural law loses its importance, while the ancient and arbitrary divisions of the former into a natural and voluntary, or into a natural or necessary, voluntary, conventional, and customary law of nations fade into mere archaisms.

$\S 59$. Origin of the phrase, "international law."-It is not strange that the close connection between international and Roman law should have caused it to be occasionally called civil law, jus civile. It was so described by Bishop Ridley in a speech made as Visitor to the unirersity of Cambridge in the reign of Edward VI; and about a century and a half

46 Holland, Elements of Jurisprudence, p. 29.

47 Lawrence, Principles of Int. Law, p. 91. 
later it was so designated by Locke in his work on Education. ${ }^{48}$ The title given by Gentilis to his book was De Jure Belli (1588), to which Grotius so added as to make the title of his work, De Jure Belli ac Pacis (1625). Then followed the work of Zouch, the English admiralty judge, entitled Juris et Judicii Fecialis, sive Juris inter Gentes ${ }^{\mathbf{9}}$ (1650). In the same way in which Zouch attempted to identify the new system with Roman Fetial law, Puffendorf attempted to identify it with the jus naturae by entitling his work De Jure Naturae et Gentium (1672). Nearly a century later Vattel added to the difficulty by naming his production Droit des gens (1758), the French equivalent of the Latin jus gentium. In order to diminish the confusion thus increased by the suggestion that jus gentium was that part of the law of Rome that regulated her relations with other independent states, Jeremy Bentham, ${ }^{50}$ in 1780 , coined the phrase "international law," which still survives as the only available description of a set of rules excluded by the current method of classification from the domain of positive law.

$\S 60$. Limits of its original sphere.-The original sphere of international law was defined by the boundaries of those states which belonged to the new European system brought into being through the Peace of Westphalia,-a system admitting in theory the absolute independence and equality of every state upon the basis of territorial sovereignts while limiting in fact such independence by an assumption, for a long time considered axiomatic, that the leading European states should possess only such a nicely adjusted proportion of power as would make it impossible for any one of them ever to acquire a preponderating influence. That system, whose primary purpose it was to preserve the balance of power, originally embraced only the Christian states of Europe,-it did not extend either to the New World, or to the civilized yet nonChristian nations recently received into the fold. How the New World was in due time added to the domain of international law, and how a new principle has been here established as the equivalent of the Old World doctrine of a balance of

48 Nys, L'Histoire Litteraire et Dogmatique du Droit International en Angleterre, p. 27; Lawrence, pp. 8-9.

49 Chancellor D'Aguesseau con- verted Zouch's new term into Droit entre les Gens, Oeuvres, iv, p. 267.

50 Works. Morals and Legislation, Pt. 1, p. 149, Bowring ed. 
power, will hereafter be made the subject of special consideration. ${ }^{51}$

$\$ 61$. How a state may assent to an international rule.-If the question be asked,as to the manner in which the older European states originally acknowledged the binding force of thr. new international system, the answer must be given,that many of them were initiated at its birth without formal ceremony, and that since that time they have confirmed their membership in the family of nations by a series of acts which constitute the long history of their mutual intercourse. The relation Great Britain bears to the system was thus expressed by Sir Alexander Cockburn in his judgment given in the famous Alabama Controversy settled at Genera in 1872: "As Great Britain forms part of the great fraternity of nations, the English common law adopts the fundamental principles of international law and the obligations and duties they impose; so that it becomes, by force of the municipal law, the duty of every man, so far as in him lies, to observe them, by reason of which any act done in contravention of such obligations becomes an offense against the law of his country." Four years thereafter the English Court of Criminal Appeal decided the notable case of the Queen rs. Keyn ${ }^{52}$ (popularly called the "Franconia" case) which arose out of the conviction for manslaughter of a German captain of a German ship who, within two miles and a half from the beach at Dover, through negligence, as the jury found, ran into a British ship, sank her, and caused the death of one of her passengers. The great question on appeal was whether or no the English criminal courts of common law had jurisdiction orer such crimes committed within the three mile zone. Certainly there was no jurisdiction unless such zone (learing out of riew its exact width), was British territory; and, as the common law nerer extended itself so far from shore, it could only have become such by virtue of Great Britain's adoption of the general rule of international law on that subject. As Lord Chief Justice Cocliburn stated it: "It thus appearing, as it seems to me, that the littoral sea beyond low-water did not, as distinguished from the rest of the high seas, originally form part of the territory of the realm, the question again presents itself, when and how did it become so? Can a portion of that which

\$1 See below, p. 127 seg.

52 Law Rep., 2 Exchequer Division, pp. 63-239. 
was before high sea have been converted into British territory without any action on the part of the British government or legislature-by the mere assertions of writers on public lawor even by the assent of other nations? And when in support of this position, or of the theory of the three-mile zone in general, the statements of the writers on international law are relied on, the question may be asked, upon what authority are these statements founded? When and in what manner have the nations, who are to be affected by such a rule as these writers, following one another, have laid down, signify their assent to it? To say nothing of the difficulty which might be found in saying to which of these conflicting opinions such assent had been given." The Court by a majority of one only, including the Chief Justice, held that the assent of a nation to such a rule of international law, as the one in question, must be manifested by some formal act performed by it in its sovereign capacity-such, for instance, in the case of Great Britain, as an act of parliament or the judgment of a competent tribunal. The result was that the conviction was quashed,upon the ground that the court which tried the prisoner had no jurisdiction; and two years thereafter parliament enacted the 'Territorial Waters Jurisdiction Act'53 by which the jurisdiction of the English courts that had succeeded to the jurisdiction of the Admiral of England was declared to extend, according to the international rule prevailing everywhere else, over the three-mile zone. Thus was Great Britain saved from the inconvenience of a judgment, declared to be unsound by one of the greatest English jurists since Bentham, ${ }^{54}$ that would have placed her in conflict with the whole civilized world as to the form in which the assent of a nation to the rules of international law should be manifested. Lord Coleridge, in his dissenting opinion, stated the general rule correctly when he said, in substance, that while a nation could only become subject to international law through its assent. in the case of Great Britain and all other cirilized powers such assent has been given already, either by express action or declaration, or at all events by a non-dissent.

$\S 62$. Original sphere widened by admission of siates, new and old.-The original sphere of international law has been con-

53 40 and 41 Vic. c. 73 . Cf. Sir J. F. Stephen, Hist. of the Crim. tional Law, pp. 39-44.

Law, vol. ii, p. 29 et seq. 
siderably widened through its extension to new states which hare come into existence since its foundations were laid, and to a few old non-Christian states received recently into the family of nations. In the first classare included such states as have been constituted during the present century by eirilized men in heretofore uncivilized countries. As an illustration reference may be made to the Republic of Liberia, which grew out of the efforts of The American Colonization Society, that obtained in 1821 from native $\lambda$ frican chiefs a cession of territory on the coast of Upper Guinea upon which a community was formed that established its independence, and, in 1847, assumed the name of the Republic of Liberia. Through the formal recognition of the new state by Great Britain in a treaty made in $1848,{ }^{55}$ and by like acts upon the part of other nations, the national existence of the negro republic has been clearly established. In 18.35 a company of Dutch farmers left Cape Colony and settled first in what was known as the Colony. of Natal, whence, upon its annexation to the British Empire, they removed beyond the river Vaal into a new country, in which they established the Transwaal or South African Repub. lie, recognized in 1852 by Great Britain as an independent state, and in due time by other nations. Although deprived through subsequent erents of a part of its external sovereignty, the Transvaal continued to exist as a distinct political community down to its recent subjugation. A philanthropic society directed by the King of the Belgians, and known as the International Association of the Congo, ${ }^{56}$ founded in the basin of that river civilized communities for the purpose of breaking down the slare trade and for opening up the country to commerce and peaceful settlement. After acquiring for itself vast territories through treaties made with many native tribes, the boundaries of the Association were clearly defined in a series of declarations and conrentions negotiated in 1884 and 1885 with the several states represented at the West African Conference at Berlin, which there recognized the new community founded by the Association as an independent nation, and its flag as that of a friendly power. ${ }^{57}$ To states thus organized must be added such as have established a

55 Twiss, Law of Nations, preface to 2 nd ed.

se In 1876 Leopold II invited representative geographers to his palace for a conference to discuss the exploration and civilization of Africa through the development of commerce and the abolition of the slave trade.

57 See above, p. 46. 
distinct political existence through successful revolt from the mother state and subsequent recognition of their independence by other nations. At the head of that class stands the federal republic of the United States, whose successful revolt from Great Britain and subsequent recognition by the nations of the earth pared the way for the emancipation of the Latin communities in South America which broke away from Spain and Portugal, and for the emancipation of Texas from Mexico.

$\S 63$. All dealings with infidels once deemed unlawful.-The original theory of the Christian states that founded the international system was that all dealings, whether by treaty or otherwise, with heathen or infidel nations were unlawful. It was, however, no crime to make war upon them or to deprive them of their territories. ${ }^{5 s}$ Not until 1720 was a Russian minister permitted to reside at Constantinople, and not until after the beginning of the present century did it become the custom for the European states to admit the Sultan into treaty relations. Thus by degrees ancient prejudice gave way before the conriction that heathen communities should become entitled eren to formal admission into the family of nations whenever they are found to possess stable and organized governments recognizing to some extent at least the fundamental principles of European civilization. Under these changed conditions Turkey was received in $\mathbf{1 8 5 6}$ through the Treaty of Paris, whose seventh article declared "the Sublime Porte admitted to participate in the adrantages of the public law of Europe and the system of concert attached to it;" and since then China, Japan, Persia and Siam hare been with adequate formality accorded like recognitions. In that way the sphere of the international ssstem, widening beyond the limits of Christian states, has become practically coterminous with cirilization.

$\S 64$. Qualified extension of international law to non-Christian states.-And yet it would be erroneous to assume that the reciprocity existing between Christian states has been extended absolutely to such as are non-Christian; or that the former have been disposed to force the ethical rules recognized among themselves in all their severity upon those who have not reached the same stage of advancement. In 1804 when Lord Stowell was called upon to enforce the public law

58 For the then current opinions as expressed by Conrad Brunus, see above, p. 56. 
of Europe against Turks he said, in the case of The Madonna del Burso,59 that "The inhabitants of the Ottoman Empire are not possessor's of exactly the same law of nations with ourselves. In consideration of the peculiarities of their situation and character, the cont has repeatedly expressed its disposition not to hold them bound to the ntmost rigonr of that system of public law, on which European states lave so long acted in their intercourse with one another." $\Lambda$ nd in the case of Mahoney v. The United States ${ }^{60}(1870)$,- -in which it was held that upon Algiers becoming a French province, the functions of an American consul previously accredited to that country were ipso facto changed,-the court said: "The full reciprocity, which, by the general rule of international law, prevails between Christian states in the exercise of jurisdiction over the subjects or citizens of each other in their respective territories, is not admitted between a Christian state and a Mohammedan state in the same circumstances; and in our treaties with Mahometan powers, express stipulations are made for the enjoyment by our citizens of certain extra territorial rights with respect to their persons and property." And to that may be added the declaration of Mr. David Dudley Field, who said that as a general rule "it may be considered certain that the law of nations, as understood in Christendom, is not yet extended in its plenitude to the rest of the world. The reason is obrious. That law was first planted in Europe, and has been cultivated only in Europe and America. Its object is the intercourse and community of nations. The object of all people outside of Christendom has been conquest or isolation and non-intercomse." ${ }^{\prime}$ The limited reciprocity thus extended to non-Christian states is usually defined in treaties in which, so far as the United States is concerned, it is usually provided that American consuls shall have exclusive jurisdiction over civil controversies between American citizens.

5946 Robinson's Adm., p. 172.

6010 Wallace, p. 62 .

61 Paper presented to the Institute of Int. Law, and entitled "Ap- plicability of Int. Law to Oriental Nations." Printed in Appendix to his Int. Code, pp. 663-670. 


\section{CHAPTER IV.}

TREATIES AS SOURCES OF INTERNATIONAL LAW.

$\S 65$. Treaties as mere agreements affecting special interests. -If international law, ancient, nedieval and modern, may be justly regarded as one unbroken development, treaties should be ranked among the primary sources from which its rules have been drawn. In "Greek diplomacy, which, considering the ground it covers is rastly fuller than that of modern times, * * * there were eight or ten technical terms to express the different sorts of treaties into which nations might enter."1 As sources of modern international law, treaties appear in onl three aspects, each of which will be considered in the order of its importance. In their humblest and narrowest aspect treaties are mere agreements between states for the settlement of their current interests or controversies, made either with a tacit admission of the existence of a common law of nations, or with an express stipulation that some principle of that law shall be changed or modified in a particular case. As Madison expressed it: "They may be considered as simply repeating or affirming the general law; they may be considered as making exceptions to the general law, which are to be a particular law between the parties themselves." As an example of a treaty between two nations for the establishment of a special rule peculiar to themselves, reference may be made to that executed between Prussia and the United States in 1785 , in which it was agreed that in case one was at war while the other was at peace, the belligerent would be content simply to detain contraband goods found upon a neutral vessel in lieu of the manifest right of confiscation. ${ }^{3}$

How a special stipulation may grow into a general rule.-While nothing could be, per se, more unlike a source of international law than such a stipulation, it is perfectly possible even for such an exception to grow into a general rule, if, in the process of time, its wisdom and convenience are demonstrated by

1 Prof. H. B. Leech's Essay on Ancient International Law, p. 22.
2 Examination of the British Doctrine, etc., p. 39.

3 Treaties of the U. S., p. 903 . 
experience. Such a special rule may work so well in practice that nation after nation will adopt it until in the end all will accept it as a part of what is generally known as the common law of nations. In such a case the first treaty in which the special stipulation oceured must be regarded as the somree from which the new general rule has been drawn. A notable illustration of the working of such a process may be found in the history of the famous rule that free ships make free goods, a rule that has slowly worked its way, through its own merits. into general acceptance during the long interval that has elapsed since 1650 , when, for the first time, it was introduced into a treaty between Christian powers through a negotiation concluded in that year between Spain and the Netherlands. ${ }^{*}$

$\S 66$. Treaties declaring new general rules or modifying old ones.-A second and higher relation in which treaties are usually considered as sources of international law is that assumed when their makers deliberately and arowedly lay down new rules or modify old ones. In that aspect, Madison says, that "treaties may be considered a voluntary or positive law of nations." Certainly they cannot become such until assent is manifested according to the Grotian rule which requires the approbation of all, or at least of many nations. In theory, no state, however small, ean be bound by a new rule until it has accepted it; in fact it becomes morally subject to it after many of the greater nations have, during a considerable period of time, actually observed it. An ideal treaty of the kind in question would be one in which all nations, great and small, should explicitly agree upon all the precepts necessary to determine their mutual relations, with a permanent tribumal to construc and apply them. In the absence of such an ideal, groups of nations have from time to time striven to approach it by themaking of new rules binding upon themselves in the hope that they will ultimately win universal acceptance. The practical value of such efforts necessarily depends upon the weight and number of the signatories, and upon the length of time during which the new rules continue in force. A hopeful example of treaties of that class may be found in the Declaration of Paris made in $1856^{6}$ by France, Great Imitain, Russia, Sardinia, Austria, Irussia, and the Ottoman Porte,-without

4 Dumont, Corps Diplomatique, vol. vi, Pt. I, p. 571; Laurence, p. 99.
5 Examination of the British Doctrine, etc., p. 39.

6 Martens (N. R. G.), XV, 791. 
the signature of the United States, Spain and Mexico, ${ }^{7}-$ wherein new maritime rules were laid down as to privateering, blockades, and the seizure of goods at sea. Despite the lack of unanimity privateering has been practically abolished as a result of the agreement actually made. In the Treaty of Washington of 1S71, the United States and Great Britain agreed upon three rules to be taken as applicable to the international cause célèbre, generally linown as the Alabama case,-rules which were to govern the arbitrators in their decision, along with the "principles of international law not inconsistent therewith." As the United States contended that all three rules were in force when the acts in question were committed, the treaty was, as to her, purely declaratory; while as to Great Britain, who denied that assumption, it was creative of new rules by which she agreed to be judged in that case. In contrast with the assent thus giren by only two nations to rules, admitted to be new by only one of them, may be cited the assent of the civilized world to the Final Act of the Brussels Conference of 1890 for the suppression of the African Slave Trade,-a conference, called by Belgium at the instance of Great Britain, whose work was crowned with the assent of all upon its ratification by France in January and by the United States in February, 1892. ${ }^{\circ}$ The three conventions signed at the Peace Conference at The Hague in 1899 are, however, by far the most important illustration that has so far occurred of a successful effort upon the part of many nations to agree upon a system of rules to determine their mutual rights and duties in reference to certain vital concerns.

$\S 67$. Treaties as bases of concerted action for maintenance of balance of power.- A third and higher relation still in which treaties stand to international law, is that assumed when, as bases of some great concerted action between all or nearly all of the states of Europe, they have been made so to ehange the status of territories, and so to determine the fate of drnasties, as to preserve the balance of power which the Concert of Europe is supposed specially to guard. Since the Peace of Westphalia the general treaty system then established, whose

7 The United States declined because the principles in question were not so extended as to secure from capture all private property at sea. See Mr. Marcy, Sec. of State, to M. de Sartiges, Minister of France, Wharton, Int. Law Dig., vol. iii, § 385 .

8 Treaties of the U. S., p. 481.

9 British State Papers, Africa, No. 7 (1890) ; Ibid., Treaty Series, No. 7 (1892). 
primary purpose was to preserve the balance of power then established, has been inseparable from its offspring. In order, therefore, fully to grasp the development of the public law of Europe since that time the two systems must be considered together. The underlying motive which shaped the results of the effort made in 164s to rebuild the state-system of Europe by the aid of diplomatey, must be found in the fact that when Richelien flung France into the Thirty Years' War the essence of his poliey was to break the power of the house of Hapsburg, and to render impossible the unity of Germany under its leadership. While he did not live to see the triumph of his plan, it was fully realized when upon the exhaustion of all the combatants France and sweden, who had borne the brunt of the battle against Ferdinand II and his son, were able to dictate the treaties of Münster and Osnabrück which became the basis of the new Germanic constitution. ${ }^{10}$

$\S 68$. Peace of Westphalia basis of public law of Europe down to French Revolution.-In the preliminaries signed in 1641 it was agreed that Congresses should be held at Münster and at Osnabriick in Westphalia. Meeting simultaneously in both of those towns in July, 1643, the French mediating minister represented the Catholic party at Münster, and the Swedish minister represented the Protestants at Osnabrück. The Empire, the Pope, spain and Venice were also represented. After much delay and conflict, the outcome of the complicated negotiations was the two famous treaties of $164 \mathrm{~S}^{11}$ that established the religious equality of the Catholic, Lutheran and Reformed churches in Germany by confirming to the Lutherans, and extending to the Reformed or Calvinistic churches the religious frerdom guaranteed by the Treaty of Passau ${ }^{12}$ and by the religious peace of Augsburg. ${ }^{13}$ In order to make the settlement permanent it was provided that if any territorial sovereign should change his religion, or acquire sovereignty over a land where a creed other than his own was established, he should not have the power to force his faith upon his people. Thus was the attempt made to check further religious inmovations and serularizations of ecclesiastical property. To stay the progress of Germany towards national unity three

10 Cf. Bryce, Holy Roman Empire, p. 324.

11 For the original Latin see Gillany, Manual Diplom., i, 1-100; for the French, Dumont, vi, 1 . $450,469$.

12 Aug. 2, 1552; Dumont, iv, 3, 42. 13 Sept. 25, 1555; Ibid., iv. 3, 88 . 
hundred and fifty German princes were made almost independent of the Emperor, their federal chief, and the blow thus struck at the house of Austria, as the temporal head of the Catholic body, was made more effective by measures that paved the way for the growth of Prussia, its predestined rival, as the natural leader of the Protestant party. To narrow the limits of the Empire, two countries, Holland and Switzerland, ${ }^{14}$ once integral parts of Germany, were during the year $164 \mathrm{~S}$ declared independent. As a means of upholding the provisions of the settlement, France and Sweden, the chief beneficiaries, were given the right to intervene in the internal affairs of Germany, a right that greatly encouraged the aggressive policy of Louis XIV, so fruitful of future complications. In January, 1648, nine months before the Peace of Westphalia was consummated, Spain and Holland made a separate peace at Münster wherein the freedom and sovereignty of the United Provinces was recognized, ${ }^{15}$ and the Scheldt with certain water-courses connected with it closed,each party retaining the places in its possession, and Spain renouncing all claim to such as had been won by the Dutch from Portugal. ${ }^{16}$ Such, in brief, was the general character of the treaty settlement made during the year 1648 in the first body that can be called a diplomatic congress, in the modern sense of that term,-a settlement that survired without a break as the basis of the public law of Europe down to the French Revolution.

$\S 69$. How a written code may be subordinate to a higher law. -In tracing the growth of institutions it often becomes necessary to describe a phase of development in which a well defined and accepted theory is found to be in open conflict with actual conditions. As a familiar illustration reference may be made to the unwritten and conventional code of tacit understandings-out of which the English ministerial system has been slowly evolved, and from which it derives moral and political, as distinguished from legal, authority-that has grown up during the last two centuries alongside of the older code of written constitutional law, from which it must be

14 Switzerland had long been in fact independent. The Peace of Westphalia formally recognized that fact.

15 Nearly seventy-five years before that time the Netherlands had declared their independence, which in the meantime was recognized by all the states of Europe except Austria. Dumont, v, 507; vi, 429; Mackintosh's Works, iii, 444. 16 Dumont, vi, 1, 429. 
sharply distinguished. ${ }^{17}$ Under the written code, all of the legal prerogatives vested in the English crown at the end of the Revolution of 1688 remain intact; under the unwritten or conrentional code, the exereise of all such prerogatives is vested in a body of ministers known as the cabinet, which is nothing more nor less than a committee of the majority of the house of commons. Thus in theors, and under the terms of the written law, the sovereignty of England is rested in an hereditary king; in fact, it is vested by virtue of the conventional constitution in the majority of an elective assembly. With that illustration of a witten code, alongside of which there is a higher law embodied in a set of tacit understandings, clearly in riew, it will be easier to explain how it is that the legal rights of the theoretically equal European states are held subject to the higher or conventional law upon whose authority rests the primacy or overlordship rested in the few great states that constitute the Concert of Europe. As heretofore explained, the Grotian system depends upon a full and unqualified recognition of the doctrine of territorial sorereignty from which flow the corollaries that all states are formally equal, and that territory and jurisdiction are coextensive. ${ }^{18}$ Such was the basis of the settlement embodied in the Peace of Westphalia, so far as the written treaty law was concerned, and upon that basis it has been claimed from that day to this that, before the law of nations, the legal rights of the greatest and smallest states are identical. But such rights and such equality have always been enjoyed sub modo, -that is, subject to the irresistible power vested by the conventional or higher law in a committee composed of the representatives of a few of the greater states acting in behalf of the whole. 'That primacy or overlordship, gradually developed outside of the written treaty law since the Peace of Westphalia, represents the common superior who actually succeeded to the place made vacant by the collapse of the Holy Roman Empire as international director. How to limit and restrain that prinacy or overlordship, whether vested in one or more of the greater states, has ever been and is to-day the problem involved in the maintenance of the balance of power.

$\S 70$. System of balance as defined by Gentz, Fénelon, and Earl Grey.-Chevalier von Gentz, who published in 1806 his Frag- 
ments Upon the Balance of Power in Europe, ${ }^{19}$ after defining such balance to be "a constitution subsisting between neiglboring states more or less connected with one another, by virtue of which no one among them can injure the independence or essential rights of another, without meeting with effectual resistance on some side, and consequently exposing itself to danger," suggested the maintenance of four conditions as the necessary basis of such an equilibrium: (1) that no state must ever become so powerful as to coerce all the rest; (2) that every state which infringes the conditions is liable to be coerced by others; (3) that the fear of coercion should keep all within the bounds of moderation; and (4) that a state having attained a degree of power to defy the union should be treated as a common enemy. The idea of a "union" thus expressed is more fully developed in the Instructions, drawn up by Fénelon for the guidance of the Duc de Bourgogne, who was told that "Christendom is a kind of universal republic, which has its interests, its fears, and its precautions to be taken. All the members of this great body owe it to one another for the common good, and owe it to themselves for the security of their country, to prevent the progress of any other members who should seek to overthrow this balance, which would turn to the certain ruin of all the other members of the same bods." 20 To repress the house of Hapsburg, and to keep Germany disunited, were among the leading purposes of the Peace of Westphalia in which the foundations of the system of balance were laid,--a system that proved strong enough to save from annihilation or annexation all of the smaller states down to the partition of Poland begun in 1772 by three great powers, jealous of each other, and indifferent to the rights of sovereignty and nationality, and to the good opinion of the world. With only one notable interruption the system of balance thus established has, with all its defects, continued down to our own time. Even so recent a statesman as Earl Grey declared that "the poorest peasant in England is interested in the balance of power, and that this country ought to interfere whenever that balance appeared to be really in danger." Upon that principle Great Britain joined with France in the Cri-

19 In the same year he published War Between Spain and England. In 1814 he was made first secretary to the Congress of Vienna, of whose secret proceedings he has left a curious account. He, in fact, drafted the treaties finally signed by all the powers.

20 Cf. Henry Reeves' excellent article on Balance of Power in Enc. Brit., vol. iii, pp. 267-272, 9th ed. 
mean War of 185t, whose primary purpose was to preserve the balance of power in Eastern Europe, by preventing the aggrandizement of Russia through the dismemberment of the Ottoman empire and the capture of Constantinople. While it may be true that the tendency manifested at times by Great Britain during the present century to assume a position of isolation, and the recent military preponderance of Germany, may have seriously modified the idea of a system of balance as understood in Europe fifty years ago, such system can not be said to be obsolete. Nothing is better understood in European diplomaey to-day than the fact that a primacy or overlordship is still vested in the Concert composed of Great Britain, Germany, Russia, France and Iustria, a combination into which Italy was invited in 186it. No student of international law can fully comprehend the nature of that Concert withont having in mind an outline, at least, of the history of the more important European treaties made during the long interval that divides the Peace of Westphalia from the Treaty of Beplin.

§ 71. Treaties aggrandizing France and Sweden at the expense of Spain and the Empire.-From the Peace of Westphalia to that of Utrecht the central figure ever moving upon the stage of European politics was Louis XIV, the prime object of whose policy was to make permanent the triumph of France over both branches of the house of Austria,--a triumph made possible when, in the midst of the exhaustion and dissension incident to the religious wars, Richelien turned the scale against that honse through alliances with Sweden, the United Provinces, and the Protestant princes of Germany. The first fruits of that triumph,--reaped jointly by France and Sweden through the treaties of Münster and Osnabrück in which Mazarin closed the Thirty Years' War,-were greatly aud mented, so far as France was concerned, when in 1659 the Peace of the lyrenees ${ }^{21}$ ended a twenty years' war between that power and Spain, through stipulations which, apart from large additions of territory to France and some restitutions to Spain, arranged a marriage compact between Louis XIV and the infanta Maria Theresa, who renounced, in consideration of a dowry never paid, all her rights to the Spanish crown and to the possessions incident thereto. While Louis was thus settled upon his throne as the most powerful monarch in Christendom, the king of Sweden was careful to enlarge his

21 Dumont, vi, 2, 264-293. 
possessions through the Treaty of Oliva, executed May 3, 1660, with the king of Poland, who was induced to renounce for himself and his line all claims to Sweden and Finland, to give up to Sweden the greater parts of Esthonia and Livonia, and entirely to sever the duchy of Prussia from the suzerainty of Poland in favor of the Elector of Brandenburg. ${ }^{22}$ On the 6th of June followed the Treaty of Copenhagen $^{23}$ between the lings of Denmark and sweden which, after securing the provinces of Halland, Schonen, Bleckingen, the isle of Hween, Bahus and its precinct to Sweden, and after restoring the island of Bornholn and Drontheim in Norway to Denmark, arranged as to the right of passage through the Sound and Belt. Thus did France and Sweden continue to add to the advintages originally secured through treaties that left the Empire depressed and disorganized, and Spain sady weakened through a series of misfortunes, chief among which may be noted the independence of Holland, the revolt of Portugal, the ruin of her fleet by the Dutch, and the annihilation of her infantry by Condés victory at Rocroi. ${ }^{24}$

$\S$ 72. Treaties of Breda, 1667-Triple Alliance, 1668.-The growing commercial prosperity of Holland soon brought her into a rivalyy with England, which culminated in 1651 in the passage of the memorable Navigation Act of that year designed to destroy the carrying trade of the Provinces by prohibiting the importation in foreign vessels of any but the products of the countries to which they belonged. The struggle for the lordship of the sea thus begun soon ripened into a conflict which was closed by the Treaties of Breda, ${ }^{25}$ executed July 31, 1667, between Englind and Holland, England and France, and England and Denmark. Between the two first named it was agreed that each should hold what it had won in the war, and in that way England retained the settlement of New Amsterdam on the Hudson, soon to be better known as the colony of New York, and Holland Surinam, in addition to a gain of the isle of Polaroon on the coast of Bombay. It was also stipulated in favor of Holland that the Narigation Act of 1651, reënacted by Charles II, should be so modified as to permit merchandise coming down the, Rhine to be imported into England in Dutch ressels. In exchange for

22 Dumont, vi, 2, 303, 319.

23 Confirming in part that of Roetskild, March 8, 1558. Ibid., vi, 2,205 .
24 Cf. Green, Hist. of the Eng.

People, iii, p. 348 .

25 Dumont, vii, 1, 40-56. 
Acadia (Nova Scotia), England received from France, Antigua, Montserrat, and the English part of St. Christopher's in the West Indies.

Such was the condition of things on January 23, 1668, when Sir William 'Temple succeeded in forming the Triple Alliance ${ }^{25}$ between England, Holland and Sweden, in order to check the aggressive policy of Louis XIV, whose purpose to invade the Netherlands was then manifest. On February 23, through the mediation of England, wals executed the Treaty of Lisbon'T between spain and l'ortugal, wherein the independence of the country last nimed was virtually acknowledged, and all territory, except Ceuta in Africa, restored. In May of the same year followed the treaty of peace concluded at Aix-la-Chapelle between France and Spain, which provided for the restoration of Franche Comte to the latter and the retention by the former of the places taken by her in the Spanish Netherlands. ${ }^{28}$ The steady aim of French diplomacy from that moment was to break up the Triple Alliance, and so to isolate the United Provinces as to secure the long contemplated French in rasion against outside interference. In that, however, Louis was disappointed. Enemies finally rose against him on every side, and in 1674 the English parliament forced Charles II to make peace with the Dutch, an adrantage sealed by the marriage in November, 167t, of William of Orange with Mary, daughter of the duke of York, and presumptive heiress of the English crown.

$\S$ 73. Peace of Nimeguen, 1678-79-summary of results.Shortly after that event was made the Peace of Nimeguen, 1675-79, a general pacification that ended the Dutch war, to which England, France, Sweden and some of the smaller states of the Empire were parties on the one hand, and Holland, Spain, the Elector of Brandenburg, Denmark, and some of the smaller German states on the other. On account of her interest in Holland, England was represented for the first time in a continental congress, whose results were embodied in a

26 Dumont, vii, 68-70. "The diplomatic history of England in its modern sense dates from this period; and the foundations of British foreign policy were laid by Sir W. Temple. ** Louis XIV. was extending French territory on every side at the expense of Spain; and France, under his rule, was rap- idly becoming supreme on the Continent." Spencer Walpole's Foreign Relations, p. 14.

27 Ibid., 1, 70.

$2 s$ Ath, Armentıères, Binche, Bruges, Charleroi, Courtray, Douay Furnes, Lille, Oudenarde, Tournay, and the fort of Scarpe. 
series of treaties of which the following were made at Nimeguen: that made by France with Holland, August 10, 1678; that made by France with Spain, September 17 of same year; that made by the Emperor with France, and also with Sweden, February 5, 1679; and that made by Holland with Sweden, October 12, of that year. Denmark made a treaty with France September 2, 1679, at Fontainebleau, and with Sweden September 26 of the same year, at Lund..$^{29}$ The general results of the pacification thus brought about may be thus summarized: (1) France gained greatly on her eastern border at the expense of Spain, while the Emperor ceded to her Freiburg in the Breisgau, he recovering Phillipsburg for the Empire, and procuring on very onerous conditions the restoration of the duke of Lorraine to his duchy and estates. (2) To Holland France was required to restore all places taken from her during the war, while by a special stipulation she restored to the Prince of Orange, Orange and other estates within her dominions. (3) To Spain were returned important possessions in the Netherlands, the town and duchy of Limburg, the towns of Leuve and St. Ghilain, and the town of Puycerda in Catalonia. (4) From Denmark Sweden recovered what the former had conquered, including Wismar and the isle of Rïgen; from the Elector of Brandenburg what he had taken from her in Hither Pomerania, upon the surrender of the lands beyond the Oder, except the towns of Dam and Golnow.

$\S$ 74. League of Augsburg, 1686; Grand Alliance, 1689; Peace of Ryswick, 1697.- While Holland, the original cause of the war, was saved by the Peace of Nimeguen, that peace made Louis XIV, despite his concessions, the arbiter of Europe; and against him all were soon forced to combine in order to check his aggressive policy of "reunions," as they were called, through which he applied old feudal rules to the acquisition of territories and towns in time of peace. Thus it was that he seized Strasburg in 1681. Aroused by that event, and by subsequent menaces still more serious, the German princes for mutual protection drew together in $\mathbf{1 6 8 6}$ in the great League of Augsburg, ${ }^{30}$ whose making marks the beginning of the long struggle between France and the rest of Europe. In February, 1689, William and Mary, under the Declaration of Right, were seated upon the English throne, whereupon the exiled

29 Dumont, vii, 1, 351 seq. On June 29, 1679, the Elector of Brandenburg made a treaty with
France and Sweden at St. Germain-en-Laye.

30 Signed at Vienna in 1687. 
James was graciously received at St. Germain as if he were still the king of England. Thus defied, William completed in the summer of that year the Grand Alliance ${ }^{31}$ which soon girt France on every side, save that of Switzerland, with a ring of foes. To close the war that ensued of nearly ten year's' duration was made the Peace of Ryswick (so called from a castle near The Hague), embodied in treaties signed on September 20 and October 30, 1697, by France with England, Holland, Spain, and the Emperor and the Empire. ${ }^{32}$ Louis's great concession to William was embodied in an acknowledgment that he was the lawful king of England, coupled with a promise not to help his enemies, meaning of course James II. England and France then mutually restored what each had taken from the other in the war. In consideration of the return of Pondicherry in India to the French East India Company, Holland received from France many valuable commercial privileges, in addition to the right to maintain a Dutch garrison in each of the Spanish Netherland barrier-fortresses. With eightytwo places excepted, France restored to Spain all the "reunions" made since the Peace of Nimeguen. The Emperor had less cause to be satisfied. William had pledged himself that Strasburg should be restored, but, as neither England nor Holland would support him, it was given up in express terms to France. In restoring the "reunions" gained from the Empire, an exception was likewise made of Alsace, which thus ceased all connection with the imperial system and became an integral part of the territory of France. On the other hand Breisach and Freiburg were ceded to the Emperor, Phillipsburg to the Empire, the duchy of Zweibrïcken (Deuxponts) to the king of Sweden, as Count Palatine of the Rhine, and Mumpelgard to Würtemburg, while among other stipulations of less importance a declaration was made in faror of the free navigation of the Rhine.

$\S 75$. Spanish succession and partition treaties of 1698 and 1700.-Exhausted as he was by a long war and its great sacrifices, it is quite clear that Louis would never have made the concessions embraced in the Peace of Ryswick, if he had not been eager to free his hands for the contest ineritable upon the approaching death of the childless Charles II, the last of

31 England and Spain acceded to the alliance, originally concluded between Holland, the Emperor and Empire at Vienna, May
12, 1689. Dumont, vii, 2, 229-230, $241,267$.

32 Dumont, vii, 2, 399 seq. 
the male line of the Austrian sovereigns who had occupied the throne of Spain for two centuries. At that moment the claimants of the Spanish succession-nations were then considered as the private inheritance of princes-were the Emperor Leopold, head of the house of Austria, and a son of Charles's aunt; the French Dauphin, Philip, the grandson of Maria Theresa, half sister to Charles; and the Electoral I'rince of Bavaria, the only male cousin of the spanish ling, and his nearest male relation. ${ }^{33}$ Such was the menace to the peace of Europe that forced mutual concessions from the signatories of the treaties at Ryswick; and on October 11, 1698, England, Holland and France, in the hope of removing that menace, concluded at The Hague the first Partition Treaty, ${ }^{34}$ in which the succession of the Electoral Prince of Bavaria was recognized on condition that the Italian possessions of Spain should pass to his two rivals,-the duchy of Milan to Archalue Charles, the second son of the Emperor, the two Sicilies with the border province of Guipuzcoa to the French Dauphin. Upon the death of the Electoral Prince, the chief beneficiary, early in 1699, the first settlement became void; whereupon a second Partition Treat ${ }^{35}$ was concluded between the same parties in the next year (London, March 13, The Hague, March 25, 1700), wherein it was provided in general terms that spain, the Netherlands, and the Indies were to pass to the drehduke Charles of Austria, and the whole of the Spanish territories in Italy to the Dauphin,--it being also provided that Milan should be exchanged for Lorraine, wlose duke was to be transferred summarily to the new duchy. To such a settlement Austria refused to assent, while the resentment excited at Madrid by the proposed dismemberment of the monarchy finally induced Charles II to sign another will in which he bequeathed the whole of his great inleritance to the second son of the Dauphin, Philip, duke of Anjou. Louis's rash resolve then made to place his grandson on the throne of Spain, and to unite the two crowns in the house of Bourbon raised anew the whole question of the balance of power in Europe, while it was generally conceded that such a union would be fatal to the independence of all other states, would replace the Stuarts upon the throne of England, and would give to France at the

33 All three claimants derived their titles through females, who, according to the ancient law of
Spain, could neither inherit nor transmit the inheritance.

34 Dumont, vii, 2, 442.

35 Ibid., n. s., 477. 
lead of the Catholic party an undue religious preponderance. To prevent sucl results William, who was the soul of the opposition to France, in September, 1701, drew Great Britain, Holland and the Empile into the Grand Alliance, soon joined by Denmark, sweden, the Palatinate, Portugal, Savoy and the bulk of the German states. After the power of France had been greatly reduced, the long war carried on against her by the Alliance was concluded by the P'eace of Utrecht embodied in separate treaties made by France with Great Britain, Holland, Prussia, Portugal and Savoy (April 11, 1713); by Spain with Great Britain (July 1:3), with savoy (August 13), and with Holland (June 26, 1714); by Spain with Portugal (February 6, 1715). Thus deserted by his allies, the Emperor was forced to make peace with France for himself and the Empire at Rastadt (Nareh 6,1714 ) in a treaty finally concluded at Baden in switzerland on the 7 th of the following September. ${ }^{36}$

$\S 76$. Peace of Utrecht, 1713-14 -its leading stipulations.By the Peace of Utrecht, denounced by the English parliament as an inglorious end of a glorious war, Philip was left in possession of the Spanish throne, upon his renunciation of all right to the crown of France, coupled with like renunciations by the dukes of Berry and Orleans of their claims to that of Spain. Thus it was declared to be the inviolable law that the two crowns slonld never be united on the same head. In addition to that assurance Great Britain received from France an express recognition of the Hanoverian succession as settled by parliament, consent to the expulsion of the Pretender from her soil, a fromise that Dunkirk should be dismantled and the larbor filled up, in addition to a cession or restoration of Hudson's Bay and Straits, St. Kitts, Nova Scotia, and Newfoundland with the adjacent islands,-France reserving, however, Cape Rreton and the islands at the mouth of the St. Lawrence. with the right to catch and dry fish on certain parts of the Newfomdland coast. So far as the Continental powers were concerned, the Peace of Itrecht, adopting the principle embodied in the earlier lartition Treaties, stripped Spain of even more than they had originally proposed to take from her. While Philip was permitted to retain Spain and the Indies, lee was recpuiled to cede to Charles of Austria, who had now become Emperor, his possessions in Italy, the Spanish Netherlands and the island of Sardinia in satisfaction of his elaims. At the same time the isle of Sicily was handed over to the 36 Dumont, viii, 1, 339, seq., 345, 353, 366, 393, 401, 415, 436, 444. 
duke of Savoy. To Great Britain Spain was required to cede Gibraltar and Minorea with Port Mahon, strongholds that secured to the former the command of the Mediterranean. ${ }^{37}$

Barrier Treaties of 1709,1713 , and 1715.-France, who purchased peace upon easier terms than Spain, in addition to her concessions already mentioned to Great Britain, was required to consent to the reëstablishment of the Dutch barrier upon a grander scale than ever before,-a subject that ean only be fully mastered by a study of the three barrier treaties made October 29, 1709; January 30, 1713, and November $15,1715^{38}$ The result was to erect a barrier in favor of Holland against France by the transfer of the Spanish Netherlands to Austria. Such in general terms were the leading features of the Peace of Utrecht which secured the repose of Europe for thirty years, despite the fact that it made no treaty arrangements between the Emperor and Spain,- - the former failing to recognize his Bourbon rival, Philip V, and the latter refusing to ratify the dismemberment of its dominions through which the Emperor was so largely benefited.

$\S$ 77. Peace of Carlowitz, 1699.-At this point mention may be conveniently made of the Peace of Carlowitz, which followed the annihilation by Prince Eugene of the Turkish army at Zentha, September 11, 1697,--a peace consisting of treaties concluded January $26,1699,{ }^{39}$ by the Sultan with the Emperor, with the king of Poland, and with Venice. In addition to a stipulation for a twenty-five years' truce with the Emperor, the Sultan surrendered his suzerainty over Transylvania, acknowledged it to be an Austrian province, and agreed that the southern bank of the Danube should mark the line between his dominions, and Hungary,--Venice retaining possession of what it held in Greece except Lepanto, and of Castelnuovo and Risano in Dalmatia.

$\S$ 78. Treaties of Nystadt, 1721; Berlin, 1742; Dresden, 1745; Aix-la-Chapelle, 1748. - With the advent of the eighteenth century the European Concert,-made up in the main prior to that time of France, Spain, A ustria, Sweden and Holland, with the occasional intervention of Great Britain when her interests were specially involved,--was widened by the addition of new elements that entirely changed the polities of the world.

37 Upon condition that neither Moors nor Jews were to reside there.
38 Dumont, viii, 1, 243, 322, 458. 39 Ibid., vii, 2, 448-458. 
Such elements were represented by the new empire of Russia built up in the north by the grenius of Peter the Great and Catharine; by the powerful and independent lingdom of Prussia, lifted from a secondary place in the German empire by the militiry ambition of Frederick II; by the colonial possessions of Great Britain, France, Spain, Portugal and Hol. lind in the continents of $A$ sia and America, and in the eastern and western isles; and by the federal republic whose birth in the west was proclaimed in the Declaration of Independence. One of the first important treaties following that of Utrecht was that known as the Peace of Nystadt, ${ }^{+0}$ concluded August 30, 1721, in Finland, between the Tzar and Sweden, wherein the latter, in consideration of two million rix dollars and the return of certain parts of Finland which Peter had conquered, ceded to Russia Livonia, Esthonia, Ingermanland, part of Carelia, Riga, Rivel, Wiborg, the isle of Oesel, along with certain other towns and forts. Prussia then comes prominently into riew in the preliminary Peace of Breslau, June 11, 1742 , and in the definitive Peace of Berlin, July 28,41 made between Frederick II and Maria Theresa, who had been confirmed in her rights as heir to her father Charles VI by the famous Pragmatic Sanction constituting her the inheritor of the entire mass of the Austrian monarehy. Although that sanction was guaranteed by France in the preliminary treaty of Vienna, definitely signed November $18,1738,{ }^{42}$ and at different times by most of the other European powers, in the confusion that followed the death of Charles in October, 1740, the ling of I'russia marehed suddenly into Silesia and took possession of that country. As a settlement of the contest the Peace of Breslan ceded to Prussia upper and lower Silesia (excepting the mountains and the towns of Troppau and Iigrerndorf) and the country of Glatz. By the Peace of Dresden, December 25,1745 , Frederick confirmed that of Breslau, and acknowledged the grand duke of Tuscany, the husband of Maria Theresa, as Emperor. By the definitive Peace of Aix-la-Chapelle, October $18, \mathbf{1 7} 48,{ }^{43}$ between France, Great Britain, and Holland.-Spain. Austria, Genoa and Modena being accessories, - the general war growing ont of the Austrian succession was closed by a general restitution of con-

40 Dumont, viii, 36.

42 Ibid., i, pp. 1.88.

41 Wenck's Corpus Juris Gen-

43 Ibid., ii, 310 seq.

tium, 1, 734 seq.; ii, 191 seq. 
quests, and a renewal of treaties that placed the combatants in nearly the same position occupied when the struggle began.

§ 79. Treaty of Naples, 1759-Family Compact, 1761.-The Treaty of Naples, October 3, 1759,4 between Charles III of Spain, Austria, and the Two Sicilies, specifying the conditions under which the last named might be united to the Spanish crown, was followed by the treaty known as the Family Compact, August 15, 1761, ${ }^{45}$ between France and Spain, and such other members of the house of Bourbon as might be invited to join it. The purpose of the Compact was so to bind the French and Spanish branches in an offensive and defensive alliance as wonld guarantee not only their own dominions but those of the two other Bourbon sovereigns.

$\S 80$. Peace of Paris, 1763-Peace of Hubertsburg, closing Seven Years' War.-The famous Peace of Paris, February 10, $1763,{ }^{46}$ - which closed between Great Britain, France, Spain and Portugal the world-wide contest, made possible by reason of their colonial dominions, greatly to the advantage of the first named,-marked the transition from a condition of things in which the relative weight of European states had depended entirely upon their possessions within Europe itself. The world had learned already that wars begun within the original limits of the European Concert might have to be fought out on the banks of the Ganges and the St. Lawrence. By England's triumph on the heights of Abraham France's dream of empire in the west was broken; she was forced to give up her priceless possessions and to retire from Nortl America. Among the fragments retained by France may be mentioned the right of fishery on the Newfoundland coast as defined in the Treaty of Utrecht, and also the same right in the Gulf of St. Lawrence three leagues from British coasts, and at a distance of fifteen leagues from Cape Breton. The middle of the Mississippi was to separate the territories of the two nations, east of which only the Isle of New Orleans was to remain a French possession. France had, however, by the secret treaty of November 3, 1762, already ceded Louisiana, including New Orleans, to Spain, ${ }^{47}$ but possession was not taken until 1769. In the West Indies France ceded to Great Britain the islands of Granada,

44 Wenck, iii, 206.

45 Ibid., iii, 278 seq.; Martens (R), i, 16-18.

46 Wenck, iii, 329; Martens, (R), i, 104-166.
47 "Thus old Louisiana was dismembered, and the Mobile District was to go to England." P. J. Hamilton's Colonial Mobile, p. 176. By the Treaty of St. Ildefonso, Octo- 
St. Vincent, Dominique, and Tobago, in addition to the restoration of Minorca. In return she recovered Guadaloupe, Desirade, Mariegalante, Martinique, Melleisle and St. Lucia, and also Pondicherry and a certain district on the coast of India. The cession of Florida by Spain to Great Britain, ${ }^{48}$ already agreed upon, was completed by that treaty. The month that witnessed the conclusion of the Peace of Paris witnessed also the conclusion of the Peace of Hubertsburg between Prussia, Austria and Saxony, elosing, without loss of territory upon the part of Prussia, the Seven Years' War, a turning point in the world's history.

$\S$ 81. Three partitions of Poland, 1772, 1793, 1795.-So far the European Concert, resting upon a recognition of territorial sovereignty, and the consequent right of every state to maintain an independent existence, had been able to preserve the weakest of its members from amnihilation and aumexation,even the little republics of Geneva and san Marino had survived as distinct nationalities. The basic principle conceding to each state the equal right to live, was first violated by the revolutionary proceeding that ended in the First Partition of Poland, arlanged July 15, 1772, ${ }^{49}$ in treaties between Russia and Austria, and Russia and Prussia, three jealous powers whose declared reason for their act was the security of neighboring nations against the internal discords of the smaller state. In that way a third of the territory of Poland,with five millions of its inhabitants, passed to the three powers named in proportions agreed upon among themselves; and to the dismemberment thus begun the Diet of Poland, in August, 1773, was forced to assent through a committee appointed for that purpose. The Second Partition appears in the form of treaties made between Russia and the king and Republic of Poland, July 13 and October 16, 1793, and of a treaty between Prussia and Poland, September 25 of the same year. After the insurrection of $\mathbf{1 7 8 4}$ had ended with the fall of Warsaw, what remained of Poland was finally divided between Prussia, Austria and Russia, who settled the boundaries of their respective acquisitions by a convention dated St. Petersburg, January 3 , and October 24, 1795. Prussia held the capital with the

ber 1, 1800, Louisiana was retroceded to France. For the treaties of 1762 and 1800 see De Garden, Histoire des Traités de Paix, viii, 50.
48 In consideration of the return of Cuba and Philippines.

49 Martens (R), ii, 89 seq. 
territory as far as the Niemen; Austria, Cracow, with the comntry between the Pilica, the Vistula and the Bug; the rest went to Russia. ${ }^{50}$

$\S$ 82. Definitive treaties signed at Versailles, Sept. 3, 1783.While Poland was thus passing from the malp of Europe, a new member came into the family of nations through the preliminary articles of peace settled at Paris, Norember 30, 1782, between Great Britain and the United States. Owing to the delay incident to contentions as to boundaries, as to fishing rights on the banks of Newfoundland, and as to the collection - of debts incurred before the war,-a delay increased by the efforts of France and Spain to postpone the final settlement until their own claims against Great Britain could be adjusted,-the definitive treaty in which the independence of the United States was recognized, with certain concessions as to fishing rights and boundaries, was not signed until September $3,1783 .{ }^{51}$ On that day were also signed the definitive treaties of Versailles, ${ }^{52}$ between Great Britain, France and. Spain, in which France, who had borne herself brilliantly in the war by protecting Holland on the one hand and aiding the United States on the other, received important restitutions of territory both in the East and West Indies, in addition to a reaffirmance of her rights of fishery near and on Newfoundland and a recognition that she held the islands of St. Pierre and Miquelon in full sorereignty. The articles of the treaty of Utrecht and of subsequent treaties as to Dunkirk were at the same time abrogated. To Spain Great Britain ceded Florida and Minorea in consideration of the return of Providence Island and the Bahamas, with a reaffirmance of the right of the British to cut logwood within limits clearly defined. Not until May 20, 1784, was a final peace made between Great Britain and Holland, in which the former returned to the Dutch nearly all of the conquests made during the war.

$\S 83$. Intervention of great powers in affairs of France.-The right of intervention, so mercilessly applied by Austria, Russia and Prussia in the case of Poland,stood as a precedent to guide those states that deemed it their duty to interfere with the internal affairs of France when the principles of the French Revolution threatened to extend themselves to all other countries. As early as July 6, 1791, the emperor of

50 Martens (R), v, 531 seq.; vi, 168 seq.
51 Ibid. (R), iii, 495, 553.

52 Ibid. (R), iii, 503 seq. 
Germany invited the great powers of Europe to inform the Frencl nation that the sovereigns "would unite to avenge any further offenses against the liberty, the honor, and safety of the king and his family; that they would consider as constitutional laws only those to which the ling should have given his free assent; finally that they would employ every means of terminating the scandal of a usurpation founded on rebellion, and of which the example was dangerous to every government;" 53 and on the 27th of the next month Leopold of Austria and Fredtrick William of Prussia, in the conventions of l'ilnit\%,invited the same sovereigns to join with them in applyind "fle most efticacious means to put the king of France in a state to enable lim with perfect freedom to lay the foundations of a monardical govermment, equally consistent with the rights of sorerejgis and the welfare of the French nation; in which case the Emperor and the king of Prussia were resolved to act prompily, and with necessary forces to obtain the proposed common object." $5+$ Difficult as it was for England,who had within the century and a half preceding that time brought one ling to the block and sent another into exile as incidents to revolutionary changes in her own constitution,to join in the declaration that foreign powers have the right to intervene and prevent such changes, she was finally impelled by the work of French emissaries, sent to foment disturlaness within her borders, to enter in 1793 the general coalition formed to carry on against France what Pitt happily termed "the wal of armed opinion." Never before had the principle of the balance of power, in the sense of mutual defense, been asserted on so grand a scale, and in the end the intervention was effective. Napoleon, whose schemes contemplated the orerthrow of the European Concert, was wushed, and the throne of France restored to the house of Bourbon.

\section{\$ 84. Ancient diplomatic fabric of Europe shattered.-Before} the end came the ancient diplomatic fabric of Europe was shattered,-old landmarks were swept away, many of the smaller states annililated,and new ones created. As we have seen already the Holy Enipire was finally dissolved in $1806 ;^{55}$ a new league known as the Confederation of the Rhine was formed of its lesser members; the ancient republics of Venice,

53 Wheaton, History, etc., pp. 347-348, citing Schoel, vol. iv, p. 185 . st Ibid., p. 348.

55 See above, p. 36 . 
Genoa and Holland were overthrown; the house of Braganza was expelled from Portugal, and the two branches of the house of Bourbon in Spain and Naples subverted; the final partition made of Poland by Russia, Prussia and Austria was ignored; and the Spanish and Portuguese colonies in America emancipated. In the mighty struggle with his enemies Napoleon's primary purpose was to force them to withdraw, one by one, from the coalitions against him. In the Peace of Basel made between France and Prussia, April 5, 1795, ${ }^{56}$ the latter promised to give neither aid nor comfort to the enemies of the French Republic, and to forbid their passage through her territories; in the treaty made May $15,1796,{ }^{57}$ between France and the king of Sardinia, the latter renounced the coalition and ceded to France the counties of Nice; in the treaty of St. Ildefons $0^{58}$ made August the 19th of the same year, Spain became the ally of France; in the treaty made between France and the. Pope, February 19, 1797, ${ }^{59}$ the latter renounced the coalition, in addition to many serious grants and concessions; the treaties made between France and the Emperor at Campo Formio, October 17, 1797, at Lunéville February 9, 1801, at Presburg December 26, 1805, ${ }^{60}$ and at Vienna, October 14, 1809, ${ }^{61} \mathrm{em}$ bodied successive humiliations and sacrifices for Austria, while with the triumphant Peace of Tilsit made with Russia and Prussia, July 7 and 9, 1807, ${ }^{62}$ Napoleon may be said to have reached the highest point of his fortunes. As early as 1795 Holland had been conqueled and, under a new constitution in harmony with that at Paris, had emerged as the Bata. vian Republic in close alliance with France. The one great enemy Napoleon could neither cajole nor conquer was England, by whose sea power the fleets of Holland and Spain were annihilated, and both Holland and France stripped of their foreign possessions. To save Louisiana from the grasp of England, Napoleon, with a clear comprehension of its value, threw it into our lap for a song in the treaty made at Paris between the French Republic and the United States, April $30,1803 .{ }^{63}$

56 Martens (R), vi, 45-52.

57 Ibid. (R), vi, 211.

58 Spain had made peace with France in 1795 . The treaty of San Ildefonso was virtually a renewal of the Family Compact of 1761.
59 Martens (R), vi, 239 seq.

60 Martens (R), vi, 385, 420; vii, 296; viii, 388 .

61 Ibid. (N. R.), i, 210.

62 Ibid. (R.), viii, 637, 661.

63 Ibid. (R.), vii, at the close. The sacrifice must have been a 
$\S 85$. Work of reconstruction-first Peace of Paris and Congress of Vienna, 1814-1815.-On April 11, 1814, Napoleon abdicated, and on May 30 the first Peace of Paris ${ }^{6 *}$ was embodied in treaties almost identical between Louis XVIII and each of the four great powers, in which France, after renouncing her sovereignty over all parts of Europe outside of her own limits, agreed that those limits should be reëstablished, with some additions to her eastern and northern frontiers, as they had existed in 1792. After settling in general terms the basis upon which the European system was to be reëstablished, the $32 d$ article of the Peace provided that "within two months all the powers which had been engaged in the war on either side should send plenipotentiaries to Vienna to settle, at a general Congress, the arrangements required to complete the provisions of the Treaty of Peace." On November 1, 1814, the Congress opened; after long delays and serious disagreements the great treaties of Viennal were signed on June 7, 1815; on the 9 th, the Final Act $^{65}$ and on the 11 th closed the most important diplomatic body that had met since the Peace of Westphalia-a body which relaid the foundations of public law and restored to Europe a peace that was not seriously disturbed for forty years.

$\S 86$. Result of efforts to restore prior conditions.-France although vanquished secured equal consideration through the consummate art of her ambassador, Talleyrand, who admonished the Congress in his note of December 12, 1814, that when the treaty of May 30 stipulated that "the labors of the Congress should form a real and permanent balance of power, it did not intend to throw into a common mass all territories and allnations, to be afterwards divided in certain proportions. It intended that every legitimate dynasty should be preserved or restored, that every legitimate right should be respected, and that the vacant territories, that is to say, those destitnte of sovereigns, should be distributed according to the principles of the political balance, or, what is the same thing, according to the conservative principles of the rights of each hard one for Napoleon, who declared that "America is a fortunate country; she grows by the follies of European nations."

6* Martens, (N. R.), ii, 1-18. For the secret treaty entered into at the same time between certain of the allied powers for the disposal of the territories surrendered by France, and for the reëstablishment of the European system without reference to her, see Murhard's Nouv. Suppl., i, 329.

65 Klüber, Acten des Wiener Congresses: Martens (N. R.), ii, 379 ; Martens and Cussy, iii, 61. 
and the repose of all." ${ }^{66}$ While it was well understood that it would be impossible to recreate exactly that older European system of which independent Poland had been a part, Talleyrand's effort was to bring about as close an approximation to prior conditions as altered circumstances would permit. And that general result was in the end aecomplished. France shrank to her normal dimensions; Austria regained what she had ceded to her; to Prussia was restored in a general way what she had possessed before the Peace of Tilsit; Ferdinand IV was reëstablished upon the throne of Naples and recognized as the king of the Two Sicilies; a new Germanic Confederation was formed, whose constitution was incorporated in the Final Act of the Congress ${ }^{67}$ the effort failed to reconstruct Poland as a constitutional Kingdom subject to the Tzar, and the fragments as distributed at Vienna were finally vested in Russia, Austria and Prussia; Genoa was united to Sardinia; Venice to Austria; Norway to Sweden; Belgium and the grand duchy of Luxembourg to Holland under the king of Netherlands; a part of Saxony to Prussia; the Swiss Confederation was reorganized and neutralized; the navigation of all the great rivers of Europe, except the Danube, ${ }^{68}$ was regulated; and, in order to remove conflicts that had long existed as to precedence, a elear definition was given of the relative rank of ambassadors and ministers. Thus the Final Act of this Congress, ${ }^{69}$ to which were annexed many of the special compacts necessarily executed in advance of it, became the most

co Klüber, Acten des Wiener Congresses, vii, B'd., § 48. Talleyrand's bold and artful protest thus made against the designs of the allies who had entered into the secret treaty of May 30th, 1814 (see above, p. 114, note 64 ), really frustrated their plans, and secured for France, in the midst of their divided counsels, a very substantial influence.

67 The powers then conferred upon the Diet were more clearly defined by an additional act signed at Vienna, in May, 1820, and ratified by the Diet at Frankfort in June of that year. For the Federal Act of 1815 , see Martens (N. R.), ii, p. 353 ; for the Schluss Act of 1820 , Ibid., v, p. 466 .
68 The regulations made at Vienna were extended to the Danube by the Treaty of Paris, 1856, with the additional provision that the duty of keeping it open to navigation should be conferred upon a permanent board of seven commissioners. Five articles of the Treaty (15-19) were devoted to the subject. It was provided by the treaty of Bucharest (1812) and by that of Adrianople (1829) that the use of the Danube for commercial purposes was to be enjoyed in common by the subjects of Russia and Turkey.

${ }^{69}$ Nine days thereafter began the battle of Waterloo. Not until November 20, 1815, was concluded the second Treaty of Paris, con- 
important international document of modern times, because never before had the territorial possessions and frontiers of the continental states been defined in a single instrument to which all had an equal right to appeal, and upon the performance of whose conditions each had an equal right to insist.

§ 87. Holy Alliance, 1815-its purposes defined.-The successful intervention of the allied powers in the affairs of France, involving as it did unusually intimate relations between a few of the greater ones, seems to have suggested to the Emperor of Russia the idea of uniting Austria, Prussia and Russia in the mystic bonds of the Holy Alliance ${ }^{\text {i0 }}$ formed at Paris in September, 1815, in which it was provided that as their interests were one and indivisible they should act together as a unit, lending "one another, on every occasion, and in erery place, assistance, aid, and support." To this new combination France gave her adhesion in the Congress of Aix-la-Chapelle in $1818 ;^{71}$ in that which met at Troppau in 1820 , the growing designs of the confederates widened into a declaration that in order to prevent the "crime" of revolt they "had an undoubted right to take a hostile attitude in regard to those states in which the overthrow of the government might operate as an example;" and in a circular issued from Laybach, to which place the Congress of Troppau was remored, they branded "as equally null, and disallowed by the public law of Europe, any pretended reform effected by revolt and open violence." Meeting again at Verona in October, 1822, in the hope of checking the growing spirit of freedom and independence then manifesting itself throughout Europe, and especially for the purpose of crushing the revolutionary government of Spain, the allies expressed the results of their deliberations in a circular declaring their intention "to repel the maxim of rebellion, in whatever place and under whatever form it might show itself;"

sisting of four separate documents of the same tenor between France and each of the four great powers, rounding out and completing what had been agreed upon more than a year before. Martens, ii, 632 seq.

70 It was signed in triplicate by the three sovereigns personally, without ministerial countersignatures, with the words $A u$ nom de la tris sainte et indivisible Trin- ité prefixed. It was published at St. Petersburg on Christmas Day. 1815, with a manifesto announcing that the object of the alliance was to establish a Christian fraternity among the European nations. For an English version of the compact see Manning, pp. 82-84, 1 st ed.

i1 Martens, (N. R.), iv, 549-566. 
and by a secret treaty their ultimate object was embodied in a mutual agreement not only "to put an end to the system of representative goveruments" in Europe, but also to destroy "the liberty of the press." 72 Such was the nature of the. league, really formed for the protection of the principle of legitimacy against the then rising tide of popular freedom, which authorized Austria to check constitutional progress in Italy by suppressing the Neapolitan revolution of 1820, and commissioned France to invade Spain in 1823 in order to overthrow the Spanish constitution of the cortes and restore absolutism in the person of Ferdiuand VII. Encouraged by such successes, the allies notified Great Britain during the summer of 1823 that so soon as the army of France should complete the suppression of the revolutionary government of Spain, a Congress would be called for the purpose of terminating the revolutionary goveruments in Spauish America, already recognized by the United States, but not by Great Britain, who had, however, clearly indicated to the allies at the Congress of Verona, through her representative, the duke of Wellington, that she preferred isolation to their extreme and dangerous policy of intervention. ${ }^{73}$ When the Holy Alliance attempted to extend that policy to the New World the resist. ance opposed to it by the United States was embodied in what is generally known as The Monroe Doctrine, of which more will be said hereafter. ${ }^{74}$

$\S 88$. Intervention in affairs of Portugal--Hostile as Great Britain was to general and indiscriminate intervention, she felt compelled to interfere in the affairs of Portugal upon the death in 1826 of John VI, whose heir was his son Dom Pedro $I V$, the ruler of Brazil. As the constitution of that country provided that its crown should never be united on the same head with that of Portugal, Pedro resigned the latter to his infant daughter Donna Maria, appointing a regency to govern during her minority under a moderate system of parliamentary government embodied in a constitutional charter. When Spain attempted to orerthrow that settlement by giving aid and comfort to the absolutist pretender Dom Miguel, Great Britain gave to the regency armed assistance, and thereupon followed the civil war and the armed interference of Spain,-

72 See the excellent monograph of Prof. John Bassett Moore of Columbia University, entitled The Monroe Doctrine, pp. 5-6.
${ }^{73}$ Cf. Alison, Hist. of Europe from the Fall of Napoleon, ii, $p$. $629 \mathrm{seq}$.

$7 \pm$ See below, pp. 140-152. 
a situation composed at last by the quadruple alliance entered into April 22, 1834, between France, Great Britain, Spain and Portugal.

\$ 89. Intervention in affairs of Greece.-The year 1827 witnessed the intervention of Great Britain, Russia and France in the affairs of Greece in order to deliver that country from the dominion of the Ottoman Porte. On the 6th of July a treaty ${ }^{75}$ was entered into between the mediating powers setting forth the grrounds of intervention; on the 20 th of October the Turkish fleet was annihilated in the Bay of Navarino by the combined fleets of the allies; and in a short time thereafter Greece was practically independent. After a period of anarchy Otto of Bavaria was made king, and on May 7, 1832, the protecting powers signed a convention ${ }^{76}$ in which it was agreed that the limits of the new kingdom should be fixed in a treaty with Turkey according to the protocol made in the preceding September. The Bavarian family having been expelled by a revolution in 1862 , a new sovereign was found in the person of the son of the ling of Denmark, who ascended the throne as George I, under the protection of a treaty made July 13, 186:, ${ }^{77}$ between Denmark on the one hand and Great Britain, France and Russia on the other. In this it was stipulated among other things that the Ionian Islands should become a part of Greece whenerer the consent of the Ionian parliament should be sanctioned by the courts of France, Russia, Austria and Prussia,-an arrangement finally consummated by the treaty of March 29, 1864, between Great Britain, France and Russia on the one hand and Greece on the other, Austria and Prussia assenting. In the treaty last named the islands of Corfu and Paxo with their dependencies were endowed with perpetual neutrality. ${ }^{i 8}$

$\S 90$. Intervention in affairs of Belgium.- The jear 1830 witnessed the intervention of the five great powers for the purpose of composing the Belgic revolution, whose object was to dissolve the union of Belgium with Holland brought about at the Congress of Vienna in 1815. The king of the Netherlands having requested their mediation, the representatives of Great Britain, France, Russia, Austria, and Prussia met in conference at London in November, 1830, and after assigning

75 Martens (N. R.), vii, 282, 463.

76 Ibid. (N. R.) , x, 550 .

78 Annuaire des Deux Mondes,

77 Martens (N. R. G.), xvii, 2, 79. xii., 1000-1004. 
to Holland all territory belonging to her prior to 1790 , and to belgium what remained of the Kingdom of the Netherlands except the grand duchy of Luxembourg, entered finally into the international compact of November $15,1831,{ }^{79}$ which provided for the definitive separation of Belgium from Holland, and for the existence of the latter as a perpetually neutral state. When the king of the Netherlands attempted to resist the settlement, Great Britain and France coërced him by enbargo blockade, and the taking of the citadel of Antwerp in 1832. At length the king of the Netherlands agreed to accept the treaty of 1831, and a fresh negotiation followed resulting in the convention between Belgium and Holland of the 18th of April, 1839, confirmed by the five powers, whose 7 th article repeated the declaration that Belgium should remain an independent and perpetually neutral state, and bound to observe such neutrality towards all other states. ${ }^{80}$ When in 1870 that neutrality was threatened during the Franco-Prussian war, Great Britain was quick to defend it, and the result was two fresh treaties,-one between herself, France and Belgium, the other between herself, Prussia and Belgium,-in the first of which she stipulated that in the event Prussia should vio. late the neutrality she would join with France and Belgium in protecting it; in the second, that in the event France should violate it, she would join with Prussia and Belgium in protecting it. ${ }^{81}$

$\S$ 91. Crimean war and treaty of Paris, 1856.-The Crimean War,-undertaken by Great Britain and France primarily to preserve the balance of power in eastern Europe, and incidentally to vest in the European Concert the protection of the Christian peoples subject to Turkey, assumed prior to that time by Russia alone,-was terminated in the Congress that met at Paris in 1856, the first in which ambassadors of the Sultan ever appeared. The more important articles of the treaty of peace signed, March $30,{ }^{82}$ between Great Britain, France, Russia, Austria, Sardinia and the Ottoman Porte, Prussia being also invited to participate, provided (1) that the independence and territorial integrity of the Ottoman Empire should be preserved, each of the six powers guaranteeing a strict observance of the engagement; $(2)$ that the places cap-

79 Martens, (N. R.), xi, 390.

so Wheaton, History, Pt. iv, § 26 ;

Hertslet, Map of Europe by Treaty, ii, 859-884, 996-998.
81 Hertslet, Map of Europe by Treaty, iii, 1886-1891.

s2 Martens (N. R. G.), xv, 770. 
tured from Russia during the war should be restored, a tract being taken from Russian Bessarabia and added to Moldavia in such a way as to deprive Russia of the command of the mouths of the Daunbe; (3) that Moldaria and Wallachia, as states under the suzerainty of the Porte, should be confirmed in their privileges, it being further provided that the same guarantee should be extended to Servia, with its privileges and burdens, ${ }^{83}$ and that there should be a reorganization of such principalities, for the carrying out of which another couvention was signed at Paris, Angust 19,$1858 ;^{84}$ (4) that the Black Sea should be neutralized and opened to the commerce of all nations; all war vessels to be excluded, excepting certain armed ressels for police purposes under a separate conrention made between Russia and the Porte, who agreed to maintain no naval arsenals on its coasts,-it being further stipulated, according to "the ancient rule ${ }^{85}$ of the Ottoman Empire," that the straits of the Bosphorus and the passage of the Dardanelles should be closed to foreign ships of war while the Porte is at peace with other nations, excepting only the light draught ressels in the service of the legations of friendly powers, and certain ressels of like character of the powers having the right under the treaty to station them at the mouths of the Danube; (5) that that river, which had not been included in the regulations made in $\mathbf{1 8 1 5}$ at Vienna for the navigation of the great rivers of Europe, should be thrown open to commerce; (6) that Turkey should be admitted into the family of nations.

Declaration as to maritime rights of belligerents and neutrals. -After the peace negotiations were thus concluded the question of the maritime rights of belligerents and neutrals was formally presented to the Congress as a body representing all the great powers of Europe, and the outcome was the famous

83 The Sultan's right to maintain garrisons there was not taken away.

84 Martens, (N. R. G.), xvi, 2, 50.

85 In 1774 Russia compelled Turkey to open the Black Sea and the straits leading to it from the Mediterranean to merchant vessels, it having been the custom of the Porte prior to that time, regardless of the public law of Europe, to forbid the passage of the Dar- danelles and Bosphorus to all ships of other powers. After 1774 Turkey continued the exclusion as to ships of war, and in 1809 Great Britain recognized the practice as "the ancient rule of the Ottoman Empire," and in 1840 a like recognition was made by Russia, Austria and Prussia, who signed with her the Quadruple Treaty of London made in that year with the Porte for the pacifi- 
Declaration of Paris, ${ }^{86}$ a protocol signed April 16 by all of the parties represented, and subsequently accepted as a part of the public law of the world by all powers except the United States, ${ }^{87}$ Spain, and Mexico. The four propositions agreed upon by the plenipotentiaries were expressed in the following terms:

1. Privateering is and remains abolished.

2. The neutral flag covers enemy's goods, with the exception of contraband of war.

3. Neutral goods, with the exception of contraband of war, are not liable to capture under an enemy's flag.

4. Blockades, in order to be binding, must be effective,that is to say, maintained by force sufficient to prevent access to the coast of the enemy.

§ 92. Rise of Prussia. Schleswig-Holstein question.-The time had now come for the balance of power in Europe to be seriously disturbed by the assertion of the military strength of Prussia, whose designs resulted in the overthrow of the Germanic Confederation and the expulsion of Austria from that body. By the death of Frederick VII of Denmark in November, 1863, was precipitated the conclusion of the long delayed struggle between the Danes and the Germans as to their respective rights orer the duchies of Holstein and Schleswig. Holstein, always a part of Germany, and Schleswig, by law indissolubly united to Holstein, had been incorporated with Denmark under her constitution of 1855. After protesting against that act as a riolation of its rights, the Federal Diet finally decreed federal execution against Denmark in October, 1863. Such was the condition of things when Christian IX succeeded, a few weeks later, to the Danish throne under the arrangements his father had been authorized to make by the Treaty of London, May 8, 1852. ${ }^{\text {ss }}$ When the new king, with a disputed title, formally accepted the constitution incorporating the duchies with Denmark, he found himself confronted by prince Frederick of Augustenburg who claimed both

cation of the Levant. Cf. Holland, The European Concert in the Eastern Question, pp. 92, 95, 99, 246.

86 Martens (N. R. G.), xv, 791. For the special guarantee entered into between Great Britain, France and Austria to insure the integrity and independence of the Ottoman Empire, a breach of which was made a casus belli, see Ibid., 790 .

si For the reasons that prompted the United States to withhold its assent, see above, p. 95 , note 7 .

$8 s$ Martens (N. R. G.), xvii, 2 , 313 seq. Cf. also Prof. F. Thu- 
Schleswig and flolstein, backed not only by strong followings in both duchies but by the approving sentiment of the Germans, who saw in lis aspinations a chance of rescuing the duchies frem the banes. Cnder the pressure of that sentiment the Fecleral l)iet in locenber, 186:3, sent a body of troops to ocenpy Inolstrin. It that peint Prussia intervened, ancl, after seroring the coupleration of Iustria, their united armies, early in 1s6t. (rushed Demmark, who was thus forced to exerute, October :30, 1s6it, the Peace of Vienna, ${ }^{\text {s9 }}$ wherein she ceded Schleswig, Holstein, and Lauenburg to the emperor of Austria and the king of I'russia, with a promise to consent to such arrangements as they might make. The quarrel that ensued between Austria and Prussia as to the final disposition of their joint acquisition was composed for a moment by the Convention of Gastein, August $14,1865,{ }^{90}$ wherein it was agreed that Schleswig should be controlled provisionally by Pruscia, and Holstein by Austria, - the latter agreeing to sell her rights over Lauenburg to Prussia for 2,500,000 rix dollars.

s 93. Peace of Prague, 1866-withdrawal of Austria from Confederation. - That hollow truce only gave time to the combatants to provide allies and to arm for the final struggle precipitated by Austria's motion in the last sittings of the Diet of the 11th and 14 th of June, 1866 , to mobilize the federal forces for the purpose of enforcing execution against Prussia. After the fact was disclosed that Austria was supported by saxony, Bavaria, Würtemberg, Hanover, HessenCassel, Hessen-Darmstadt, and several of the minor states, Prussia withdrew from the Confederation, and before the end of the month declared war mpon Hanover, Saxony and Austria. $^{91}$ Prussials military superiority, backed by her allegiance with Italy, made the struggle so short that the preliminaries of peace, embodied in the Conrention of Nikolsburg, July 26 , 1866, were made final in the Peace of Prague on the $23 \mathrm{~d}$ of Angust." The great ontcome was the withdrawal of Austria from the Confederation, thus leaving Prussia free to form a new one in which she could be supreme. Under the constitution ${ }^{93}$ of the new league, known as the North German Con-

dichum's Terfassungsgesch. Schlesuig-Holsteins von 1806-1852, Tübing, 1871.

s9 Martens (N. R. G.), xvii, 2, $474-486$.

oo Annuaire des Deux Iondes, vol. xiii, 971 (1864-1865).
91 For a more complete statement see Bryce, Holy Roman Empire, pp. 407-416.

92 Annuaire, xiv, 363,367 , (for 1866, 1867).

93 Adopted April 17, 1867. 
federation, at whose head Prussia placed herself, the military forces of all the federal states were fused and placed under the command of the king of Prussia, who, as permanent president of the Confederation, was authorized to control its foreign policy, although a nominal independence was left to the minor princes, who were permitted to send and receive diplomatic agents, to summon their local legislative bodies, and to levy local taxes. By conquest and by treaty Prussia about that time increased and consolidated her dominions by incorporating Hanover, Hessen-Cassel, Nassau, Franlfort, Schleswig. Holstein and Lauenburg. ${ }^{94}$

$\S$ 94. Treaty between Prussia and France, 1871.-In the Peace of Prague it was stipulated that the South German States should maintain an independent national existence in a league of their own, with the clear right to enter into treaty relations with the Northern league, which embraced only the states north of the river Main. When the fact was revealed that within a few months after the conclusion of the war of 1866 some of the Southern states ${ }^{95}$ had actually entered into secret military conventions with the North German Confederation, a critical condition of things arose between France and Prussia, which was greatly aggravated by the triumph in 1867 of the latter over the former in the diplomatic struggle for the possession of the grand-duchy of Luxemburg. At the outbreak of the ineritable conflict, precipitated by the rash action of France in July, 1870,96 Prussia was able to marshal under her leadership the combined forces of Germany inspired by an enthusiasm so intense and unirersal as to make them irresistible. At Versailles, on January 18th, 1871, after the necessary legislation in the various states, the king of Prussia assumed the title of German Emperor, thus welding Germany together as a single state under a new constitution ${ }^{97}$ sixty-fice years after the final dissolution of the ancient body

94 The Convention of Gastein secured Lauenburg, the Peace of Prague, Schleswig-Holstein.

95 Bavaria, Würtemburg and Baden.

96 On July 15, 1870, Olivier, French minister of foreign affairs, in asking a credit of the Corps Legislatif, declared that a refusal to give audience was a casus belli. For another view see Benedetti's
Mission en Prusse and Studies in Diplomacy.

97 "The constitution of the new Empire is in its main features that of the North German Confederation, modified by the treaties whereby Baden, Würtemburg and Bavaria, respectively, entered the pre-existing body." Bryce, pp. 417-418. 
known as the Holy Roman Empire. On the 28th Paris eapitulated, and the preliminary peace of February 26th was confirmed by the definitive treaty concluded at Frankfort on May 10th, under which Germany gained from France Alsace and Lorraine, together with a great indemnity to cover the cost of the war. $^{98}$

$\S 95$. Prussia and Turkey. Conference of London, 1871.While Prussia was thus building up her hegemony in central Europe, the steady growth of Russia in the east was drawing her nearer to the realization of her plans for the dismemberment of Turkey and the capture of Constantinople, checked for a time by the results of the Crimean War and the treaty of 1856 , in which those results were embodied. The two great humiliations to which Russia was then subjected consisted of the forced surrender of her protectorate over the Eastern Christians, and of the abrogation of her rights to keep war ressels in the Black sea and to maintain naval arsenals on its coasts. So keenly did Russia feel the restraints placed upon her sovereignty by the stipulations last named, that the moment the ally who had aided England in imposing them upon her was stricken down, she notified the other signatory powers, in a circular issued in October, 1870, shortly after the fall of the second empire, that it was impossible for her to be longer bound either by the objectionable articles of the treaty of 1856 or by the Convention of the Straits really a part of it. To save appearances England deemed it best to eall a Conference in which the demands of Russia could be duly ratified. The representatives of the powers who met in London in January, 1871, after declaring that no state can break or modify a treaty without the voluntary assent of the other contracting parties, ${ }^{99}$ finally annulled on March 13th articles XI, XIII and XIV of the Treaty of Paris, while Russia and Turkey by a separate agreement abrogated the special convention made between them at that time as to the size and number of armed vessels the two riparian proprietors might maintain for police purposes. In lieu of the articles annulled the following was submitted: "The principle of the closure of the Straits of the Dardanelles and the Bosphorus estab-

98 Martens (N. R. G.), xix, 653, 688.

99 The exact language employed was this: "It is an essential principle of the law of nations that no power can liberate itself from the engagements of a treaty, nor modify the stipulations thereof, unless with the consent of the contracting powers by means of an amica- 
lished by the special convention of March 30, 1856, is maintained, with the right, on the part of His Imperial Majesty the Sultan, of opening said Straits in time of peace to ships of war of friendly and allied powers, in case the Sublime Porte should find it necessary in order to secure the Treaty of Paris of March 30th, 1856.1" In that way Russia regained her full sovereignty over the Black Sea and its coasts, subject to the right of the Sultan to invite into the Straits at any moment such powers as may be willing to join with him in order to check any naval aggression Russia may make.

Treaty of San Stefano, and Congress of Berlin, 1878.-The fresh complications in which the Slavonic Christians became involved with the Porte in 1877 gave to Russia another opportunity for a war, which she concluded in a separate treaty with the Ottoman Porte at San Stefano, March 17th, 1878, after having advanced to the very suburbs of Constantinople. That treaty Great Britain, with her fleet at the Dardanelles and with her Indian troops at Malta, sternly refused to recognize because the separate peace itself, apart from its special stipulations, was in open riolation of the terms of the treaties of 1856 and 1871.2 Under such conditions Russia, who could no Ionger count upon the neutrality of Austria, consented to submit her treaty with Turkey to a European Congress that sat at Berlin from June 13 to July 13, 1878. In the definitive treaty signed on the day last named and ratified August 3 , the settlement made at San Stefano was modified in several particulars, the chief being a reduction of the territory of Bulgaria, and the division of that state into two parts. That part north of the Balkans was to constitute an autonomous principality under the suzerainty of the Sultan, with a Christian gorernment and national militia, while that south of the Balkans was to be made into the province of East Roumelia subject to the direct authority of the Sultan, but with administrative autonomy and a Christian governor-general. To Austria-Hungary passed in the final settlement Bosnia and Herzegovina, while the concessions of territory made to Servia and Monte-

ble arrangement." British State Papers, Protocols of London Conference, 1871, p. 7; Hertslet's Map of Europe by Treaty, 1256-7, 1892-8, 1904.

1 For the text of the treaties, see
Holland, The European Concert, pp. 272-276.

2 Martens (N. R. G.), 2nd Ser., iii, 246 and 259; Holland, pp. 335348. 
negro, and to Russia in Asia, by the treaty of San Stefano were slightly diminished. Montenegro and Roumania were recognized as fully independent,--Servia also under certain conditions. ${ }^{3}$ The Sultan, under the pressure of advice, made some concessions to Greece which subsequently so extended her frontiers as to give her Janina as well as Thessaly, while to Great Britain he assigned the island of Cyprus to be occupied and administered by her. ${ }^{4}$

Readjustment of forces.- When the immense changes that have taken place since $\mathbf{1 8 1 5}$ in Poland, in Belgium, in Italy, in Germany, in Denmark, in France, and in Turkey are taken into account, it can hardly be maintained that any substantial part of the work of the great Congress of Vienna still survives. The system of balance then established was finally shattered by the rise of Prussia and the reörganization of Germany in such a way as to make its military power more than a match for any single European state. The readjustment of forces thus brought about has taken the form of the triple alliance between Germany, Austria and Italy on the one hand, and the dual alliance of Russia and France on the other, with Great Britain guarding against isolation through closer relations with the United States.

3 With the consent of the pow- 4 Great Britain went into posers Servia was declared a King- session in 1881. dom in 1882. 


\section{CHAPTER V.}

\section{EXTENSION OF INTERNATIONAL SYSTEM TO NEW WORLD.}

\section{$\S 96$. Early conflicts as to boundaries-prior discovery as a}

basis of title.- In account must now be giren of the process through which the system of international law, founded and nurtured by the European nations, ${ }^{1}$ was extended to the New World. The struggle for the possession of rast and undefined territories in the East and West inaugurated by the discoreries of the Spanish and Portuguese narigators, who took the lead during the 15th and 16th centuries, presented questions beyond the resources of the medieval international code, for the reason that the new conditions involved were without a parallel in medieval European experience. The only authorities that could be invoked were the Holy Roman Empire and the principles of Roman law which formed the basis of its judicature. On the very threshold of the struggle Christendom wascalled upon to pass on the rights of the native though infidel inhabitants of the territories of which the European discoverers wished to possess themselves. Despite Ayala's bold declarations that war against infidels simply because they were such could not be justly authorized by either Pope or Emperor, that infidelity did not of itself forfeit their right to sovereignty under the law of nations, for the reason that dominion over the earth was originally given not to the faithful alone but to all rational creatures, ${ }^{2}$ - the conclusion was generally and firmly established that the rights of the native infidel occupants were entirely subordinate to the paramount claims of the first Christian discoverers. With that question thus disposed of, the Pope, as the bestower of kingdoms and the final judge between Christian nations, was soon called upon by Spain and Portugal to adjust the grave conflict which had arisen between them in the New World as to the

1 "It is scarcely necessary to point out that as international law is a product of the special civilization of modern Europe, and forms a highly artificial system of which the principles cannot be supposed to be understood or recognized by countries differently civilized, such states only can be presumed to be subject to it as are inheritors of that civilization." Hall, Int. Law, p. 42 .

2 See above, p. 56 . 
relative extent of their freshly discovered possessions. As a settlement of that controversy Alexander VI published in 1493 his famous lull granting to Ferdinand and Isabella, and to their successors to the united crown of Castile and Aragon, with certain rescrvations, all lands discovered and to be discovered to the west of an imaginary line to be drawn from pole to fole an hundred leagues west from the Azores and Cape De Verde Islands. ${ }^{3}$ So nnjust did that division prove to I'ortugal that on .June 4th, 1494 , a convention was made with Spain at Tordesillas moving the meridian line to a point thres hundred and seventy leagues west of the Cape Verde Islands, a change which gave to Portugal Brazil, the Moluccas, the l'hilippines and half of New Guinea. ${ }^{4}$ Finally, to compose the bloody conflicts that arose when Great Britain, France and llolland entirely ignored the extraragant claims set up under the papal grant by spain and Portugal not only to the lands but to the seas of the New World, another basis of division was adopted whose fundamental principle was prior discovery. All agreed to subordinate the rights of the native Indians to those of the first Christian discoverers, whose conflicting clains could only be settled through an appeal to the meager and inadequate rules provided by the Roman lawyers for the acequisition of res mullius through occupatio.

$\S 97$. Law of occupation as drawn from Roman sources.Under the Roman law anything without an owner, res nullius, might be taken possession of by anyone who desired to keep it, and such "taking possession," as a mode of acquisition, was known as occupatio." If the thing thus acquired had once had an owner it was necessary to show that he had roluntarily abandoned it, while the new possessor was also required to manifest his purpose to retain it,-_apprehension must be aceompanied by an animus possidendi, or rem sibi habendi." As res nullius the Romans counted a new island formed in the middle of a river, divisible between the riparian owners by a line drawn midway hetween the banks; or what is more to the point a new island rising in the sea through volcanic action

a For the text of the bull, see Calvo's Recueil, i, pp. 1-15. Cf. also Torquemada, Hon. ind., lib. 18, c. 3 ; Robertson, i, pp. 14S-150; Cauchy. I, pp. 3is-3s1.

4. Jurien de la Gravièr, Les Marines du XTe et du XVIIe sircle,
1, 86; Nar. and Crit. Hist., 11, pp. 14-15.

s Hadley, Introduction to Roman Law, p. 164.

6 Mackeldey's Modern Civil Law (Kaufmann's ed.), vol. i, p. 249. 7 Insula quae in mari est (quod 
to which Italy was no stranger. Such was the source to which Grotius turned for the rules that were to regulate, to some extent at least, the process of discorery and settlement applied by the European nations to the partition of the New World. ${ }^{8}$ By discovery, eacl nation was supposed to take possession of what it desired as res nullius; by settlement, to manifest its intention to keep it as its own. The claim of the English crown to the territories upon which the English settlements in America were made rested upon the voyages of the Cabots (1497-98), to whom was issued a patent-the oldest surviving document connecting the old land with the new ${ }^{3}$-authorizing them "to seek out and discover all islands, regions, and provinces whatsoever that may belong to the heathens and infidels," and to set up the royal banner therein. The inchoate right thus acquired by discovery at the close of the fifteenth century did not ripen into a perfect title until early in the seventeenth when the permanent English settlements in America were made. In order to regulate the competition for the possession of the New World, to a void conflicting settlements, and consequent war with each other, the European nations agreed, as Chief Justice Marshall has expressed it, "to establish a principle which all should acknowledge as the law by which the right of acquisition, which they all asserted, should be regulated between themselves. This principle was that discovery gave title to the government by whose subject, or by whose authority, it was made against all other European governments, which title might be consummated by possession. * * While the different nations of Europe respected the rights of the natives as occupants, they asserted the ultimate dominion to be in themselves." 10

$\S 98$. Title to newly-discovered lands under English Constitution.- According to the theory of the English constitution the title to all newly discovered lands accrued to the king in his public and royal character,and the exclusive right to grant them resided in him as a part of the royal prerogative. "Upon these principles rest the various charters and grants of terri-

raro accidit) occupantis fit: nullius enim esse creditur. Institutes, II, i, $\$ 22$.

8 Cf. De Jure Belli ac Pacis, II, c. iii, entitled De acquisitione originaria rerum, ubi de mari et fuminibus.
9 Dated March 5, 1495 (1496, new style), and printed in the Hakluyt Society's edition of the Divers Voyages, and in Rymer's Foedera. 10 Johnson vs. McIntosh, 8 Wheat., 573. 
tory made on this continent."11 The great title deed under which the English settlers in America took actual and permanent possession was James I's charter of April 10th, 1606, creating the London and Plymouth companies as distinct corporations. After their dissolution, out of the vast territories originally granted to them were carved the domains finally distributed between the five southern colonies of Virginia, Maryland, North Carolina, South Carolina and Georgia, and the four northern colonies of Massachusetts, Connecticut, Rhode Island and New Hampshire,- the border lands between the two being assigned to New York, New Jersey and Pennsylvania, from the last of which was clipped the state of Delaware. ${ }^{12}$ Many of these colonial charters attempted to convey rights from ocean to ocean despite the fact that the English settlers had entered only into possession of the narrow slip of country between the Alleghanies and the Atlantic. Upon the ground that a state cannot acquire a whole continent by making settlements on one of its coasts, the British negotiators contended, at the conference held in London in 1826-27 as to the Oregon boundary dispute, that such colonial charters have no international validity; that the grantees under them only received exclusive rights as against their fellow-subjects. ${ }^{13}$ By that contention was exposed the fatal defect inherent in the old doctrine of discovery and settlement, a doctrine that furnished no adequate or practical rule by which the extent of territory constructively incident to actual settlements can be precisely determined.

$\S 99$. General rules as to area appropriated by an act of occupation.-As to the area appropriated by an act of occupation nothing more definite has ever been formulated than the general rule, that when a settlement is made by duly authorized persons the state to whose benefit it accrues is entitled, not only to all lands occupied and controlled by it, but also to such unoccupied regions beyond as are necessary to its safety and legitimate development. As first settlements are usually made upon coasts, questions have often arisen as to their extension inland. Is the English colonial charters show it was the custom of that country to claim in North America, as Mr. Calhoun has expressed it, "specific limits along the

11 Taney, C. J., in Martin et al. vs. The Lessee of Waddell, 16 Peters, 409.
12 Cf. The Origin and Growth of the Eng. Const., vol. i, pp. 17-19.

13 Twiss, Law of Nations, vol. i, $\S \S 117,118$. 
coast, and generally a region of corresponding width extending across the entire continent to the Pacific Ocean." 1 Against that extravagant claim prevailed, however, the more reasonable rule that the rights of a coast settlement do not extend inland further than the watershed. ${ }^{15}$ While the rules for the division of continents are equally applicable to great islands like Australia, it is admitted that an island of moderate size, or even a group of small islands, may be acquired by one formal act of annexation and one settlement. In that way Great Britain and Germany took possession, respectively, in 1855, of the Louisiade Archipelago and the Marshall Islands, groups situated off the eastern end of New Guinea. ${ }^{16}$ As to lateral boundaries the general rule is that when two states have established settlements upon a coast, and the extent of their respective territories is uncertain, a line should be drawn midway between the last posts on either side without regard to the natural features of the intervening country. ${ }^{17}$ It has been claimed that the entire basin of a great river and its tributaries is so appurtenant to the land at its mouth that the whole may be acquired through the possession there of a fort or settlement extending no considerable distance on either side. $^{18}$ The sounder view is that such a claim must be limited (1) by the reservation that the extent of coast occupied must bear some reasonable relation to the extent of the river basin claimed to be appurtenant to it; (2) by the fact that the occupation of one bank of a river does not necessarily confer a right to the opposite bank, still less to extensive territories beyond it. $^{19}$ In order that the original occupation may be

$14 \mathrm{Mr}$. Calhoun, Sec. of State, to Pakenham, Sept. 3, 1844. Ms. Notes, Great Britain; Calhoun's Works, vol. v, p. 432.

15 Such was the rule laid down by the American commissioners at Madrid in the controversy of 1803-5 as to the boundaries of Louisiana. See below, p. 133.

16 Annual Register for 1884, pp. 433-434. For Vattel's rule as to the acquisition of sovereignty over "islands or other lands in a desert state," see I., c. xviii, §§ 206, 207.

17 Phillimore, i, § cexxxii-viii; Twiss, i, $\S 115-9,124$; The Ore- gon Question, 249; Bluntschli, $\S \S 278,279$; Hall, $\S 32$. In that way was fixed the boundary line between Spain and the United States on the Gulf of Mexico. Treaties of the U. S., p. 1017.

18 Such was the contention of Mr. Rush in 1824, and of Mr. Gallatin in the Conference held at London in 1827 between the Commissioners of Great Britain and the United States. Cf. British and Foreign State Papers, 1825-26, p. 506.

19 Twiss, i, §§ 118, 119, 143; Hall, $\S 32$. 
legally effective it is necessary that the person or persons making the settlement shall possess either specific or general authority to appropriate unoccupied lands from the state in whose name they act. When a duly commissioned officer takes possession of territory in the name of his state his act is its act, indicating for the moment at least a union of fact and intention. If, however, a navigator without authority takes possession in the name of his state and then sails away without actually founding a settlement, the fact of possession ceases, and with it the basis for subsequent ratification. When unauthorized persons enter unippropriated country, and actually make a settlement there in the name of the state to which they belong, a simple adoption or ratification of their act by such state will cure the original want of authority, without prejudice to the rights of any other state. ${ }^{20}$

$\S 100$. Conflict between U. S. and Spain as to Western boundary of La.- Such were the leading general rules into which the meager materials to be drawn from Roman law were expanded when the time came for the European nations to perform a task that stood without a precedent in history. So inadequate did such rules prore to be when actually applied to the partition of the New World that wars were only prevented in the settlement of the greater boundary controversies through compromises and special agreements in each particular ease. That course was pursued in the three notable disputes, composed since the beginning of the present century, as to the territorial limits of the United States. After the purchase of Louisiana from France in 1803, a conflict arose between the United States and Spain as to the western boundary of the eeded territory, the former claiming that it should be the Rio Grande, the latter, that it should be a line drawn between the Red River and the Sabine. As assignees of the French title the United States rested upon the acts of La Salle in 1681-85 at the mouth of the Mississippi and in the Bay of Espiritu Santo. The Spaniards relied upon the prior explorations made by Spanish officers on the northern shores of the Gulf of Mexico in 1518 and 1561, and upon long and uninterrupted subseruent possession of the whole country. Upon that basis Spain demanded that the frontier should be fixed midway between the posts which had been permanently occupied by themselves and the French respectively. The American com-

20 Martens, Prícis, § 37; Philli- §§ 111, 114, 120; Bluntschli, more, i, § cc. xxvi-viii; Twiss, i, $\S \S 279-9$; Hall, § 32. 
missioners contended in the conference held upon the subject with the commissioners of Spain that it was "erident that by discovery and possession of the River Mississippi in its whole length, and the coast adjoining it, the United States are entitled to the whole country dependent on that river, the waters which empty into it, and their sereral branches, within the limits on that coast;" and in support of their claim they relied upon a few principles which they said were "simple, intelligible, and at the same time founded in strict justice. The first of these is that, when any European nation takes possession of any extent of seacoast, that possession is understood as extending into the interior country, to the sources of the rivers emptying within that coast, to all their branches, and the country they cover, and to give it a right in exclusion of all other nations to the same." In other words the contention was that the discovery and occupation of a line of seacoast by a state entitles it to the interior country as far back as the crest of the watershed, a claim in perfect accord with the general principles of the law of nations. ${ }^{22}$ The matter was finally compromised and settled in the treaty of 1819 by fixing the frontier not very far from the line for which Spain had contended at the outset. ${ }^{23}$

$\S 101$. Conflict with Great Britain as to northeastern boundary.-The treaty signed at Washington, August 9, 1842, by Lord Ashburton and Mr. Webster closed the ancient strife as to the northeast boundary between Canada and the state of Maine growing out of loose and inadequate definitions contained in the treaty of 1783 . In the course of the long discussion which really began in $182 \tau^{24}$ it was maintained upon the part of the Cnited States that a treaty of partition between a mother state and a new one born of it should not be considered as a treaty of cession from the former to the latter, but as an acknowledgment that certain territory was under a pre-existing title, in the possession of the state which established its independence. $^{25}$ As the disputed region was nearly if not

116.

21 Mémoire de l'Amerique, p.

22 Twiss, i, § 117; Lawrence, § 94.

23 Cf. British and Foreign State - Papers, 1817-18.

24 In 1833 the matter was submitted to the arbitration of the King of Holland, whose award was rejected by the United States "because he was so notoriously under our (British) influence, and because he had lost his independence with the loss of Belgium." Lord Aberdeen to Mr. Croker, Feb. 25th, 1843. Croker Papers, ii, p. 398.

25 British and Foreign State $\mathrm{Pa}$ pers, 1827-28, 490-585. 
entirely unoceupied in 1783 , and only partially settled after 1790 , the difficulty was to determine who was in possession at any given time. As to the exercise of proprietary or sovereign rights over such region pending a definite settlement of the real controversy, Lord Aberdeen elained that it was "an acknowledged rule of law that when a doubt (as to the right of sovereignty) exists, the party who has once clearly had a right,and who has retained actual possession, shall continue to loold it until the question at issue may be decided."' As the United States admitted that Great Britain had a right to a "de facto jurisdiction" over all territory, if any, inlabited before 1783 , the problem was limited to the proper mode of dealing with the portions settled after 1790. The solution of the problem embodied in the compromise treaty of August, 1842, although denounced by Lord Palmerston as "a capitulation," was generally accepted and applauded by both nations. ${ }^{27}$

$\S 102$. Conflict with Great Britain as to northwestern boundary.- In the making of the Ashburton Treaty the lonis standing dispute between Great Britain and the United States as to the claim of the latter to the territory between the Rocky Mountains and the Pacific Ocean, and between the $42 \mathrm{~d}$ degree and 54th degree and 40 minutes of north latitude, was left out of consideration altogether. No claim could have possibly presented in a more perplexing form two sets of acts of discovery and settlement in direct conflict with each other. The main questions at issue involved disputed facts both as to the priority of the alleged discoveries, and as to the subsequent acts of occupation, scattered over long interrals of time, confirming them. At the outset the United States, claiming only the basin of the Columbia River by right of discovery and settlement, rested its case (1) upon the fact that Capt. Gray of Boston, an uncommissioned navigator, had in 1792 discorered the mouth of the river, sailing up some fifteen miles until the channel he was in ceased to be navigable; (2) upon the fact

$28 \mathrm{Cf}$. Hall, Int, Law, pp. 102-104.

27 Greville's Memoirs, Sept. 17, 1842, vol. i, 2nd ser. From the fact that the government of the United States saw fit to obtain the consent of Massachusetts and Maine to the treaty before it was concluded, it can not be conclusively inferred that the former did not possess perfect power to deal with the subject without such consent. Opinions of Attorneys-General, vi, 756; Kent. Comm., i, 166, 167; Webster's Works, vi, 272, 289; Halleck's Int. Law, p. 848; The schooner Peggy, 1 Cranch, 103. 
that Captains Lewis and Clark, who were the first to discover the sources of the river, had explored its course to the sea; and (3) upon the further fact that the first posts and settlements in the disputed territory had been founded by citizens of the United States. The general contention, it was claimed, had been greatly strengthened by Great Britain's restitution in the treaty of Ghent, 1814, without reservation or exception, of the settlement of Astoria or Ft. George, founded at the mouth of the Columbia river by Americans in 1811, and captured by the British during the late war. The counter case of Great Britain rested, (1) upon an alleged discovery of the river, four years before Capt. Gray entered it, by Lieut. Meares, of the royal nary; (2) upon the acts of Capt. Vancouver, a surveyor of the coast, who entered shortly after Gray, and fiuding the true channel explored the river for a hundred miles or more and took formal possession of the country in the name of the King. The claim of the discovery of the sources of the river by Americans was offset by the statement that prior to or contemporaneously with their acts the agents of the British Northwest Company had made like explorations, establishing posts on the head waters or main branches of the river. The contention of the United States was then so widened as to embrace the whole territory originally described by virtue of the boundary treaty made with Spain in 1819, which conveyed to the former whatever rights were vested in the latter north of the 42d parallel by reason of acts of certain Spanish navigators who were supposed to have discovered the coasts of the region in question prior to the coming of either British or Americans. Great Britain at once rejoined that the original discoverers of the coast were really Sir Francis Drake in 1579 and Capt. Cook in 1778; and that so far as the treaty with Spain was concerned, it could not convey in any event more than the joint right of occupancy secured to her equally with Spain by the convention of the Escorial, 1790, usually known as the Nootka Sound Convention. In reply to the claim set up by the United States under the colonial charters running from ocean to ocean, Great Britain denied that they possessed any international ralidity, or that the grantees under them held exclusive rights against any one, except fellow subjects. As a final and saving clause the United States contended that she had the best right to the region in question by reason of contiguity of settlement,-a right which Mr. Gallatin said "must depend, in a considerable degree, on the magnitude and 
population of that settlement." "As As anything like a scientific solution of such a perplexing controversy was out of the question,an appeal was wisely made, after the two countries had drifted to the rerere of war, to compromise, the result of which was the treaty of $1816,2^{-9}$ in whose first article it was stipulated that from the point on the 49 th parallel of north latitude where the boundary laid down in the then existing treaties terminated, the frontier should be continued westward along said 49th parallel to the middle of the channel separating the continent from Vancouver"s Island, and thence southerly through the middle of silid channel, and of Fucas straits, to the Pacific Ocean, the navigation of the whole of such channel and straits, south of the 49th parallel, remaining free and open to both parties.

\section{$\S 103$. Acceptance of the law of nations by the U. S.-Before} the close of the American revolution the Congress of the United States,-which under the Articles of Confederation possessed jurisdiction orer all questions arising under the law of nations,-in its Ordinance of December 4th, 1781, concerning marine captures, professed obedience to that law "according to the general usages of Europe;"'30 and by the terms of the second federal constitution treaties were made the supreme law of the land,binding the nation as a whole and all subordinate authorities and judges of every state. ${ }^{31}$ After ratification a treaty becomes the equivalent of an act of Congress whenerer it is self-executing; and whenever a treaty conflicts with such an act the latest in date must control. ${ }^{32}$ By the judgments of the Supreme Court of the United States the common law of nations has been placed upon as high a plane as the conventional. It has been there declared that the federal courts must respect the law of nations as a part of the law of

28 For the English and American views, and for the facts of the ease in its later form, see De Garden, Histoire des Traitís de Paix, v., 95; Parl. Papers, Iii, 1846; Oregon Corresp., 34 and 39; Twiss, Oregon Question, 379; Dana's Wheaton, pp. 250-255; Hall, § 33.

29 U. S. Laws and Treaties, ix, 109,869 .

30 Journals of Congress, vol. vii,
185; Kent's Commentaries, vol. i, p. 1.

31 Ware vs. Hylton, 2 Dall., 199; Marbury vs. Madison, 1 Cranch, 176 ; Worcester vs. George, 6 Peters, 575.

32 Foster vs. Neilson, 2 Peters, 314; U. S. vs. Arredondo, 6 Peters, 691 ; U. S. vs. Percheman, 7 Peters, 51. 
the land $;^{33}$ that such law, unlike foreign municipal laws, need not be proved as a fact; ${ }^{34}$ that even as to municipal matters the lex fori should be so construed as to conform to such law unless the contrary be expressly preseribed $;^{35}$ that as the conduct of the foreign relations of the United States is placed in the lands of the federal government, its decisions upon all such subjects are binding on every citizen of the Union. ${ }^{36}$ American statesmen have been no less pronounced than the jurists as to the binding force of international law. Mr. Jefferson, when Secretary of State, wrote to M. Genet that "the law of nations makes an integral part * * of the laws of the land," ${ }^{3 i}$ and $\mathrm{Mr}$. Webster, when in the same office, wrote to Mr. Thompson that "every nation, on being received, at her own request, into the circle of civilized gorernments, must understand that she not only attains rights of sovereignty and the dignity of a national character, but that she binds herself also to the strict and faithful observance of all those principles, laws and usages which have obtained currency among civilized states." 38 It has been held, however, that maritime law, not a part of international law, is only so far operative in any country as it is adopted by the laws and usages of that country. ${ }^{39}$

$\S 104$. Jurisdiction over three mile zone.-At the very outset the government of the United States adopted provisionally that rule of international law which extends the jurisdiction of a nation over the littoral seas surrounding it to the extent

33 The Nereide, 9 Cranch, 388. "In England, the position that the law of nations is a part of the municipal law was first, so far as is disclosed by the reports of decided cases, asserted from the bench by Lord Talbot, in 1736. (Triquet v. Bath, 3 Burrow's Reports, 1480.) He found no warrant for it in the earlier institutional writers of his country, although many of them were civilians. * * The principle thus declared was received without question in America, and remained unshaken by the Revolution." Inaugural Address delivered by Judge Simeon E. Baldwin, as President of the International Law Association, at Rouen, Aug. 21,
1900. See also Holland's Studies of Int. Law, p. 193; Respublica v. De Longchamps, 1 Dallas Reports, 111, 114; United States v. Arona, 120 U. S. Reports, 488.

34 The Scotia, 14 Wallace, 170.

35 The Amelia, 1 Cranch, 1; 4 Dall., 34; Murray vs. The Charming Betsy, 2 Cranch, 64, 118; Little et al. vs. Barreme, 2 Cranch, 170.

36 Kennett vs. Chambers, 14 Howard, 38.

37 June 5, 1793, 1 Am. St. Pap. F. R., 150.

38 April 15, 1842, Webster's Works, vi, 437.

39 Norwich Co. vs. Wright, 13 Wall., 104; The Lottawana, Ibid., 558; The Scotland, 105 U. S., 24. 
of three miles from low water mark; $;^{40}$ and at a little later day it was declared that "our jurisdiction has been fixed (at least for the purpose of regulating the conduct of the Government in regard to any events arising out of the present European war) to extend three geographical miles (or nearly three and a half English miles) from oul shores, with the exception of any water's or bays which are so land-locked as to be unquestionably within the jurisdiction of the United States, be their extent what they may."41 And in order to remove all ambiguity it was finally declared that it may be regarded "as settled, that so far as concerus the eastern coast of North America, the position of this department has uniformly been that the sovercignty of the shore does not, so far as territorial authority is concerned, extend beyond three miles from low water mark, and that the seaward boundary of this zone of territorial waters follows the coast of the mainland, extending where there are islands so as to place round such islands the same belt. This necessarily excludes the position that the seaward boundary is to be drawn from headland to headland, and makes it follow closely, at a distance of three niles, the boundary of the shore of the continent or of adjacent islands belonging to the continental sovereign." 42 While, within such limits, the sovereign of the shore may arrest, by due process of law, persons charged with crime on board foreign merchant ships, and may require that nothing be done by ships of friendly powers by which the peace of the shore may be disturbed, the claim to teritorial jurisdiction within the three mile zone cannot be extended to ships using the ocean as a highway, and not bound for a port within such jurisdiction. ${ }^{43}$ It is asserted by a few publicists that with the increasing range of great guns states should have the right of their own motion to extend the limits of their jurisdiction over littoral seas.

$40 \mathrm{Mr}$. Jefferson, Sec. of State, to the Minister of Great Britain, Nov. 8, 1793. Wharton, Int. Law Dig., vol. i, § 32 .

41 Mr. Pickering, Sec. of State, to Governor of Virginia, Sept. 2, 1796.

42 Mr. Bayard, Sec. of State, to Mr. Manning, Sec. of the Treasury, May 28, 1886: “The exclusive jurisdiction of a nation extends to the ports, harbors, bays, mouths of rivers, and adjacent parts of the sea inclosed by headlands, and, also, to the distance of a marine league, or as far as a cannon-shot will reach from the shore along its coasts." Mr. Buchanan, Sec. of State, to Mr. Jordan, Jan. 23, 1849. Wharton, Int. Law Dig., vol. i, $\S 32$, pp. 101, 107, 108.

43 Henry on Adm. Jur. (1885), $\S$ 89; Martens, Précis, i, p. 144; Bluntschli, § 302; Heffter, §75; Klüber, § 130; Ortolan, i, p. 133. 
As Hall has expressed it: "It is probably safe to say that a state has the right to extend its territorial waters from time to time at its will, with the now increasing range of its guns, though it would undoubtedly be more satisfactory than au arrangement upon the subject should be arrived at by common consent." ${ }^{4}$ It is very difficult to conceive upon what theory or by what authority any state acting alone could do any such thing, as the existing jurisdiction rests solely upon common consent as manifested by usage. In the Franconia case it was expressly held that Great Britain could only acquire jurisdiction over the three mile zone encircling her coasts through the adoption of the general rule of international law by which it is conferred. ${ }^{45}$

44 Int. Law, p. 127, ed. 1880. See made in Hall's text. See p. 160, 32 Alb. Law Jour., p. 101. A slight 4th ed.

modification was subsequently 45 See above, p. 88 seq. 


\section{CHAPTER VI.}

\section{MONROE DOCTRINE AND OTHER SOURCES.}

$\S$ 105. History of Holy Alliance reviewed.-In the account heretofore given of the growth of the European treaty system from the Peace of Westphalia to the Treaty of Berlin,an effort was made to draw out the process through which a primacy or overlordship was vested, by a set of tacit understandings, outside of and above the ordinary rules of international law, in that combination of the great powers, now six in number, usually known as the Concert of Europe. An account was also given of the circumstances under which an inner circle of that Concert, known as the Holy Alliance, undertook to intervene in the internal affairs of certain European states in order to protect the principle of legitimacy against the then rising tide of popular freedom, as a result of which Austria, at the command of the Alliance, crushed the Neapolitan revolution of 1820 , and France, by the same authority, invaded Spain in 182:3 for the purpose of overthrowing the constitution of the Cortes and of restoring absolutism in the person of Ferdinand VII. In the summer of that year it was that the Alliance notified Great Britain that, so soon as France should complete the overthrow of the revolutionary government of Spain, a congress would be called for the purpose of terminating the revolutionary governments in South America, which had then been recognized by the United States but not by Great Britain. ${ }^{1}$ The attempt thus made by those who claimed the right to exercise a primacy or overlordship in the affairs, external and internal, of European states to extend that system of interference to American Republics forced the government of the United States, as the dominant political power in this hemisphere, to assert that in itself alone resides a primacy or overlordship, which has gradually become as well defined in the New World as that of the Concert of Europe in the Old. Like every other institution that has been the result of growth

1 See above, p. $116 \mathrm{seq}$. When in 1825 Canning formally recognized the independence of such governments his intention is said to have been to seek compensation for the preponderance of France in the
Peninsula by "calling the New World into existence to redress the balance of the Old." Alison, Hist. of Europe from the Fall of Napoleon, ii, p. 715 seq. 
it did not attain its full stature in a night; it did not spring into life fully armed. Therefore, in order clearly to explain the nature and extent of the hegemony of the United States in this hemisphere, it will be necessary to trace, step by step, the process through which the doctrine as originally announced has reached its present state of maturity. Castlereagh, who was regarded as too much in sympathy with the Holy Alliance, yielded the direction of England's foreign affairs to Canning, who came forward as an advocate of the universal right of self-government, and as an opponent to France's invasion of Spain, just in time to deal with the momentous question presented by the threat of the Alliance to extend its interference to Spain's relations with her colonies in South America. In order to defeat that design, full of menace to the interests of English merchants who had built up a large trade with South American countries, Canning, in the summer of 1823 , began to correspond with Mr. Rush, the American Minister at London, as to the advantages of a joint declaration by Great Britain and the United States against the proposed European intervention.

$\S$ 106. Jefferson's famous letter to Monroe, Oct. 24th, 1823.As soon as President Monroe received that correspondence he submitted it to Mr. Jefferson, then in retirement, with the request that he would advise him in the matter. On the 24 th of October Jefferson in his letter from Monticello said, among other things, that "the question presented by the letters yoi have sent me is the most momentous which has been offered to my contemplation since that of Independence. That made us a nation; this sets our compass and points the course which we are to steer through the ocean of time opening on us. And never could we embark upon it under circumstances more auspicious. Our first and fundamental maxim should be never to entangle ourselves in the broils of Europe; our second, never to suffer Europe to intermeddle with cis-Atlantic affairs. America, North and South, has a set of interests distinct from those of Europe, and peculiarly her own. She should, therefore, have a system of her own, separate and apart from that of Europe. * * * One nation, most of all, could disturb us in this pursuit; she now offers to lead, aid, and accompany us in it. By acceding to her proposition we detach her from the bands, bring her mighty weight into the scale of free government, and emancipate a continent at one stroke, which might otherwise linger in doubt and difficulty. 
Great Britain is the nation which can do us the most harm of any one or all on earth, and with her on our side we need not fear the whole world. With her, then, we should most sedulously cherish a cordial friendship, and nothing would tend more to knit our affections than to be fighting once more side by side in the same cause. * * But we have first to ask ourselves a question. Do we wish to acquire to our own confederacy any one or more of the Spanish provinces? I candidly confess that I have ever looked on Cuba as the most interesting addition which could ever be made to our system of States. The control which, with Florida I'oint, this island would give us over the Gulf of Mexico and the countries and isthmus bordering on it, as well as all those whose waters flow into it, would fill up the measure of our political well-being. Yet, as I am sensible that this can never be obtained, even with her own consent, but by war, and its independence, which is our second interest (and especially its independence of England), can be secured without it, I have no hesitation in abandoning my first wish to future clances, and accepting its independence, with peace and the friendship of England, rather than its association at the expense of war and her enmity." Madison, who was consulted at the same time through Jefferson, gave his cordial approval to Canning's suggestion, ${ }^{3}$ and Calhoun, who was Secretary of War at the time, declared that he believed that the Alliance "had an ultimate eye to us; that they would, if not resisted, subdue South America. * * Violent parties would arise in this country, one for and one against them, and we should have to fight upon our own shores for our institutions."

$\S 107$. President Monroe's message of Dec. 2nd, 1823-European system not to be extended in this hemisphere.-Thus advised President Monroe, in his seventh annual message, delivered December 2d, 1823, said to Congress that "in the wars of the European powers, in matters relating to themselves, we have never taken any part, nor does it comport with our policy to do so. It is only when our rights are invaded or seriously menaced that we resent injuries or make preparation for our defense. With the movements in this hemisphere we are of necessity more immediately connected, and by causes which must be obvious to all enlightened and impartial observers. The political system of the allied powers is essentially dif- 
ferent in this respect from that of America. This difference proceeds from that which exists in their respective governments. And to the defense of our own, which lias been achieved by the loss of so much blood and treasure, and matured by the wisdom of their most enlightened citizens, and under which we have enjoyed unexampled felicity, this whole nation is devoted. We owe it, therefore, to candor and to the amicable relations existing between the United States and those powers to declare that we should consider any attempt on their part to extend their system to any portion of this hemisphere as dangerous to our peace and safety. With the existing colonies or dependencies of any European power we have not interfered, and shall not interfere. But with the governments who have declared their independence and maintained it, and whose independence we have, on great consideration and on just principles, acknowledged, we could not view any interposition for the purpose of oppressing them, or controlling in any other manner their destiny, by any European power, in any other light than as the manifestation of an unfriendly disposition toward the United States. * * Our policy in regard to Europe, which was adopted at an early stage of the wars which have so long agitated that quarter of the globe, nevertheless remains the same, which is not to interfere in the internal concerns of any of its powers; to consider the government de facto as the legitimate government for us; to cultivate friendly relations with it, and to preserve those relations by a frank, firm, and manly policy; meeting, in all instances, the just claims of every power, submitting to injuries from none. But in regard to these continents, circumstances are eminently and conspicuously different. It is impossible that the allied powers should extend their political system to any portion of either continent without endangering our peace and happiness; nor can any one believe that our southern brethren, if left to themselves, would adopt it of their own accord. It is equally impossible, therefore, that we should behold such interposition, in any form, with indifference. If we look to the comparative strength and resources of Spain and those new governments, and their distance from each other, it must be obvious that she can never subdue them."

$\S 108$. Part of same message relating to unsettled boundaries in northwest.- At an earlier stage of his message, in a paragraph (7) far removed from the two (4S and 49) from which 
the foregoing extracts have been taken, President Monroe had expressed himself in the same general way in reference to a subject having no connection whatever with the intervention of the Ioly Alliance in the affairs of South America. The first declaration,-relating to fresh acquisitions of territory by European powers in any portion of the American continents by occupation or colonization,- - was prompted by a controversy as to unsettled boundaries in the Northwest that grew out of a ukase issued by the Czar of Russia in September, 1821, in which lie had asserted exclusive territorial rights from the extreme northern limit of the continent to the 51st parallel of north latitude, by attempting to exclude foreigners from fishing and navigation for the purposes of commerce within an bundred Italian miles of the coast down to that parallel. Against that nkase both Great Britain and the United States protested because an unsettled controversy was then pending between them as to the very territory to which the Czar thus laid claim. When Russia proposed an amicable settlement of the matter Mr. John Quiney Adams, then Secretary of State, said to the Russian minister at a conference held on July 17th, 1823, "that we should contest the right of Russia to any territorial establishment on this continent, and that we should assume distinctly the principle that the American continents are no longer subjects for any new colonial establishments." Mr. Rush, our minister at London, enclosing copies of his instructions to Mr. Middleton, our minister at St. Petersburg, and directing him to confer freely with the British government on the sulject. In his letter to Mr. Rush Mr. Adams said, that a "necessary consequence of this state of things will be, that the Imerican continents henceforth will no longer be subject to colonization. Occupied by civilized nations, they will be accessible to Europeans and each other on. that footing alone; and the Pacific Ocean, in every part of it, will remain open to the navigation of all nations in like manner with the Atlantic. Incidental to the condition to national independence and soveignty, the rights of interior navigation of their rivers will belong to each of the American nations within its own territories." Just five months thereafter President Monroe, in para-

4 J. Q. Adams's Memoirs, VI, ly denied the correctness of the 163. position, and that 'Great Britain

5 "When Mr. Rush made known Mr. Adams's letter to the British Cabinet, he asserts that they totalconsidered the whole of the $u n$ occupied parts of America as being open to her future settlements in 
graph seven of his message of December 2 nd mentioned above, informed Congress that "at the proposal of the Russian Imperial Government, made through the minister of the Emperor residing here, a full power and instructions have been transmitted to the minister of the United States at St. Petersburg to arrange, by anicable negotiation, the respective rights and interests of the two nations on the nortlwest coast of this continent. A similar proposal had been made by his Imperial Majesty to the Government of Great Britain, which has likewise been acceded to. * * In the discussions to which this interest has given rise and in the arrangenents by which they may terminate, the occasion has been judged proper for asserting, as a principle in which the rights and interests of the United states are involved, that the American continents, by the free and independent condition which they have assumed and maintain, are henceforth not to be considered as subjects forfuture colonization by any European powers."

$\S 109$. Meaning of Monroe's phrase, "future colonization." When serious discussion afterwards arose as to the meaning of President Monroe's phrase "future colonization," reference was made to the letter of $\mathrm{Mr}$. Adams, who is credited with laying the foundations of this part of the Monroe Doctrine when he said that these continents are "occupied by civilized nations," and are "accessible to Europeans and each other on that footing alone." After Mr. Adans became president he threw further light on the subject in his special message to the Senate of December 26th, 1825, when, speaking of meas. ures which might be adopted by the Panama Congress, he suggested that "an agreement between all the parties represented at the meeting, that each will guard by its own means against the establishment of any future European colony within its borders, nay be found advisable. This was more than two years since announced by my predecessor, as a principle resulting from the emancipation of both the American continents." In the light of that declaration it secms to be clear that Mr. Monroe only intended to say that no future colonization by European nations comld be permitted within the limits already claimed by civilized powers; and that he did not have in mind the vast unoccupied regions still unsettled by such powers. ${ }^{6}$

like manner as heretofore;' that is, 'by priority of discovery and occupation." Dana's notes to Wheaton's Elements, p. 99.
6"It was by no means generally admitted that the American continents were then wholly occupied by civilized nations. There were 
His declaration that, "with the existing colonies or dependencies of any European power we have not interfered, and shall not interfere," relieved that part of the subject from all ambiguity. Such are the two foundations, relating to two entirely distinct subject matters, of what is generally linown as the Monroe Doctrine, a doctrine which has gradually reached its present dimensions through seventy-five years of persistent development.

$\S 110$. Its meaning widened by President Polk.-Pending the controversy with Great Britain as to the Oregon territory, and in the face of possible intervention by the European powers on account of the annexation of Texas, President Polk, in his message of December 2nd, 1845, greatly widened the protest of President Monroe against "future colonization by any European powers" when he said that "it should be distinctly announced to the world as our settled policy, that no future European colony or dominion shall, with our consent, be planted or established on any part of the North American continent." That enlarged declaration, unfettered by any implication that European settlements might be made in North America outside the boundaries of eivilized nations, was evidently intended by the use of the word "dominion" to forbid the acquisition by conquest or purchase of any territory already occupied. ${ }^{8}$ In obedience to that principle Great Britain and France were more than once notified that the United States could not witness with indifference the transfer of Cuba by Spain to any other European power ; while in the ClaytonBulwer Treaty of 1850 Great Britain expressly bound lerself not to exercise dominion over "any part of Central America,"

vast regions of territory not actually settled by the subjects of civilized powers. Neither Russia nor Great Britain admitted the claim put forth by Mr. Adams." Prof. John B. Moore's Monograph, The Monroe Doctrine, p. 4.

7 In his special message to congress of April 29, 1848, concerning Yucatan, Mr. Polk went still farther when,-after stating that the authorities of that country, in the face of an Indian insurrection, had offered to transfer "the dominion and sovereignty of the peninsula" to the United States,
Great Britain or Spain,-he declared that "we could not consent to a transfer of this 'dominion and sovereignty' to either Spain, Great Britain, or any other European power."

8 "This doctrine of Mr. Polk would require our consent to any acquisition of dominion by a European power, whether by voluntary cession or transfer, or by conquest." Dana's notes to Wheaton's Elements, p. 102.

9 "You will now add that we could not consent to the occupation of those islands (Cuba and 
a provision under which she was finally induced to give up the protectorate, acquired long before the treaty was made, over the Indians of the Mosquito Coast. ${ }^{10}$

\section{$\S$ 111. Clayton-Bulwer treaty, 1850-an exception to Monroe} Doctrine.-The Clayton-Bulwer treaty ${ }^{11}$ is specially notable as the only exception to the rule that the government of the United States will decline to enter into any alliances or combinations with European powers for the settlement of questions connected with its interests in this hemisphere. In defiance of that fundamental principle as embodied in the Monroe Doctrine, the treaty in question,- - after declaring in the preamble that the United States and Her Britannic Majesty are "desirous of consolidating the relations of amity which so happily subsist between them by setting forth and fixing in a convention their views and intentions with reference to any means of communication by ship-canal which may be constructed between the Atlantic and Pacific Oceans by way of the river San Juan de Nicaragua, and either or both of the lakes of Nicaragua or Managua to any port or place on the Pacific Ocean,"-provides (art. I) that "the govermments of the United States and of Great Britain hereby declare that neither the one nor the other will ever obtain or maintain for itself any exclusive control over the said ship-canal; agreeing that neither will ever erect or maintain any fortifications commanding the same, or in the vicinity thereof, or occupy or fortify, or colonize, or assume or exercise any dominion over Nicaragua. Costa Rica, the Mosquito Coast, or any part of Central America; nor will either make use of any protection which either affords, or may afford, or any alliance which either has or may have to or with any state or people, for the purpose of erecting or maintaining any such fortifications, or of occupying, fortifying, or colonizing Nicaragua, Costa Rica, the Mosquito Coast,

Porto Rico) by any other European power than Spain under any contingency whatever." Mr. Clay, Sec. of State, to Mr. Brown, Oct. 25, 1825. Mss. Inst. to Ministers.

10 Cf. Martens (N. R. G), ii, 210-6. The United States "will not consent to the subjugation of any of the independent states of this continent to European powers, nor to the exercise of a protectorate over them, nor to any other direct political influences to control their policy or institutions." Mr. Cass, Sec. of State, to Mr. Dodge, Oct. 21,1858 . By a treaty concluded with Honduras, Nov. 28, 1859, and with Nicaragua, Aug. 28, 1860, Great Britain finally relinquished the Mosquito Protectorate. See President Buchanan's Fourth Annual message, 1860.

11 Treaties of the United States, p. 441. 
or any part of Central America, or of assuming or exercising dominion over the same. * * * Article $\Pi$. Vessels of the United States or Great Britain traversing the said canal shall in case of war between the contracting parties, be exempt from blockage, detention, or capture by either of the belligerents." The treaty as a whole rested upon two clearly defined conditions: first, that the canal should be built at once by private persons or companies, - "it being desirable that no time should be unnecessarily lost in commencing and constructing the said canal, the governments of the United States and Great Britain determine to give their support and encouragement to such persons or company as may first offer to commence the same, with the necessary capital, the consent of the local authorities, and on such principles as accord with the spirit and intention of this convention;" second, that the compact should not be a dual but an international one,- "the contracting parties in this convention engage to invite every state with which both or either have friendly intercourse to enter into stipulations with them similar to those which they have entered into with each other, to the end that all other states may share in the honor and advantage of having contributed to a work of such general interest and importance as the canal herein contemplated." Now that a half century has passed by without any effort whatever upon the part of the private persons who were to construct the canal promptly, and after the failure during that time of any other power to become a party to the arrangement, it is hard to understand how any publicist can contend that the treaty is not "voidable" under the well settled principle that neitler party to an international compact "can make its binding effect dependent at his will upon conditions other than those contemplated at the moment when the contract was entered into, and on the other hand a contract ceases to be binding so soon as anything which formed an implied condition of its obligatory force at the time of its conclusion is essentially altered." 12

Whether it will be wise for the government of the United States to avail itself unconditionally of the legal right thus vested in it to anuul the treaty in question; whether it will be to its ultimate interest to assume alone the defense of the pro-

12 Hall, §116. For a more extended consideration of that doctrine, see below, Sec. 394. A summary of the conflicting views of
English and American statesmen as to its application to the Clayton-Bulwer treaty may be found in Wharton, Int. Law Dig., § $150 \mathrm{f}$. 
posed canal and to relinquish many advantages that would certainly flow from its neutralization, ${ }^{12 a}$-are questions of American statesmanship that lie beyond the domain of international law. It is to be hoped, however, that such a wise and conservative solution of these vexed questions may be reached as will satisfy the reasonable aspirations of the two great branches of the English speaking people.

$\S$ 112. Termination of France's intervention in affairs of Mexico.- The step backward taken at the making of the Clayton-Bulwer treaty was more than regained when in December, 1865 , it became necessary for the government of the United States to terminate the intervention of France in the internal affairs of Mexico. Notice was then given that friendship with that country must cease, "unless France could deem it consistent with her interest and honor to desist from the prosecution of armed intervention in Mexico to overthrow the domestic republican government existing there, and to establish upon its ruins the foreign monarchy which has been attempted to be inaugurated in the capital of that country."13 Five years later a full and final expression was given to the aspirations of the United States upon that subject by Mr. Fish,-in his Report of July 14th, 1870, to President Grant, accompanying the President's message of the same date,when he said: "This policy is not a policy of aggression; but it opposes the creation of European dominion on American soil, or its transfer to other European powers, and it looks hopefully to the time, when, by the voluntary departure of European governments from this continent and the adjacent islands, America shall be wholly American." And then that very able Secretary of State placed, perhaps for the first time, the rapidly developing primacy upon a broad philosophic and historic basis when he said that, "the United States, by the priority of their independence, by the stability of their institutions, by the regard of their people for the forms of law, by their resources as a government, by their naval power, by their commercial enterprise, by the attractions which they offer to European immigration, by the prodigious internal development of their resources and wealth, and by the intellectual life of their population, occupy of necessity a prominent position on this continent, which they neither can nor should abdicate, which entitles them to a leading voice, and which imposes on

12a David Dudley Field favored the plan of neutralization. Int. Code, p. 373 , second ed.
$13 \mathrm{Mr}$. Seward, Sec. of State, to Mr. Bigelow, Dec. 16, 1865; Mss. Inst., France. 
them duties of right and of honor regarding $A$ merican questions, whether those questions affect emancipated colonies, or colonists still subject to European dominion."

$\S$ 113. Definition of Monroe doctrine completed by President Cleveland.-Not, however, until a resolute and far-sighted statesman, who clearly understood that our marvelous national development entitled us to rank as a world-power, was given the opportunity by the boundary controversy between Great Britain and the Republic of Venezuela, was the inevitable declaration finally made that the same reasons that impel the Concert of Europe to guard the balance of power in the Old World prompt the government of the United States to maintain alone its primacy in the New. In his special message $^{14}$ to Congress of December 17th, 1895, President Cleveland, after referring to the contention of the British Prime Minister that the Monroe Doctrine had been given "a new and strange extension and development," said that "without attempting extended argument in reply to these positions, it may not be amiss to suggest that the doctrine upon which we stand is strong and sound, because its enforcement is important to our peace and safety as a nation and is essential to the integrity of our free institutions and the tranquil maintenance of our distinctive form of government. It was intended to apply to every stage of our national life and cannot become obsolete while our Republic endures. If the balance of power is justly a cause for jealous anxiety among the governments of the Old World and a subject for our absolute non-interference, none the less is an observance of the Monroe Doctrine of vital concern to our people and their government. ** The Monroe Doctrine finds its recognition in those principles of international law which are based upon the theory that every nation shall have its rights protected and its just claims enforced." When the government of Great Britain justly and wisely conceded the right of arbitration thus asserted by the United States, solely by virtue of its ${ }^{15}$ primacy or overlordship

14 Messages and Papers of the Presidents, ix, 655 .

15 That the statesmen of Great Britain perfectly understood at the time the nature of the concession clearly appears from the following: "From the point of view of the United States the arrangement is a concession by Great Britain of

the most far-reaching kind. It admits a principle that in respect of South American republics the United States may not only intervene in disputes, but may entirely supersede the original disputant and assume exclusive control of the negotiations. Great Britain can not, of course, bind any other 
in the New World, enduring foundations were laid for that close moral alliance since developed between the two broad divisions of English-speaking peoples. In the light of an examination of that primacy as it exists to-day it is folly to contend that it is just what it was when originally formulated by President Monroe. As "it was intended to apply to every stage of our national life and cannot become obselete while our Republic endures," it has grown with our growth, and now stands ready to adapt itself to all future developments. The change that has taken place has, however, been less in its outward form than in its inner spirit. To use the words of Bagehot, it "is like an old man who still wears with attached fondness clothes in the fashion of his youth; what you see of him is still the same; what you do not see is wholly altered."16 The marvel to students of the American constitution is that the upbuilding of the primacy of the United States in the New World has been worked out by the pens of Presidents and Secretaries of State,-it is purely a creation of the executive power.

$\S 114$. Instructions given by states for guidance of their own courts and officers.-The Monroe Doctrine must, therefore, be classed with those sources of international law which rest upon instructions given by states for the guidance of their own courts and officers. All such national acts are in their inception nothing more than expressions of opinion by particular states that certain rules are so just and equitable that they are willing to bow to their authority. Not until a new rule thus announced has, through its own merits, won general acceptance can it become a part of the general body of international law. In that event the first announcement should be considered as the source from which the general rule was drawn. A familiar illustration of this principle is to be found in the famous marine ordinance of Louis XIV, which was nothing more than a set of instructions issued to the prize courts and naval commanders of France directing them how to proceed in prize cases, the conduct of which was greatly embarrassed by the fact that the usage of nations on that subject had not then been clearly established. That beautiful model of legislation, through its intrinsic merit, aided by the excellent commentary of Valin nearly a century later,

nation by her action, but she has set up a precedent which may in future be quoted with great effect against herself." London Times,

Nov. 14, 1896.

16 The Eng. Const., p. 2. 
finally became the general basis of law upon that subject. ${ }^{17}$ As sir William Grant expressed it, "When Louis XIV published his famsus ordinance of 1681, nobody thought that he was undertaking to legislate for Europe, merely because he collected together and reduced into the sliape of an ordinance, the principles of marine law as then understood and received in Fiance." ${ }^{18}$ In the same way the Instructions for the Guidance of the Army of the Luited states in the Field ${ }^{10}$ - an anticipation of the attempt made at the Brussels Conference of 1874 to form a code for the regulation of land war-give promise of winning generil acceptance, as like manuals have been adopted by several states, and as they have already been commended in the works of two eminent publicists. ${ }^{20}$ The fact has just been emphasized that what is generally known as the Monroe Doctrine-that new page which is being rapidly incorporated into the general body of the law of nationsrests only upon a series of purely national documents formulated from time to time by the Presidents of the United States or by Secretaries of State. As soon as the entire family of nations, or all of its members directly interested in the subject, acquiesce in that doctrine as Great Britain and France have done, the new rule establishing the hegemony of the United States in these continents will become a part of the public law of the world, if it is not so already.

\section{$\S 115$. History of diplomatic intercourse as a source of inter-} national law.- The fifth and final source of International law is to be found in the general history of diplomatic intercourse embodied in the mass of materials contained in the archives of the departments of foreign affairs of the several countries, including the histories of the negotiations through which wars have been begrun and ended and treaties made and ummade, the official opinions of jurists given publicly or confidentially to their governments expounding the law in particular cases,

17 See above, p. 41.

$18 \mathrm{Cf}$. Marshall on Insurance, $\mathrm{i}$, p. 425 .

19 A Code of War for the Government of the Armies of the United States in the Field was prepared during the great civil war (186165) upon the requisition of the President by the eminent publicist Francis Lieber. It was adopted and promulgated by the War Department in General Orders, No. 100. It is evident that that was the model which suggested to Bluntschli his codification of the Law of War. See the preface to his Droit International Codifié.

20 Maine, Int. Law, p. 24; Lawrence, Principles of Int. Law, $p$. 105. 
as well as the records of the numberless miscellaneous transactions embraced in what are generally known as state papers. Reference has been made already to the works of great publicists who have created sources of international law through their individual effort in a purely private capacity. ${ }^{21}$ When experts of that class become the representatives of states charged with the conduct of their foreign affairs, their official utterances in state papers often become of exceptional importance. In that category may be placed the utterances of the early publicists of the United states who gare such an impetus to the more perfect development of the laws of neutrality, ${ }^{22}$ and also such official opinions of the Attorneys General as relate to the law of nations. While new rules thus laid down may sometimes become sources through general acceptance, ordinarily precedents contained in state papers, if precedents they may be called, are looked to rather as evidences of what the practice or usage of nations really is than as sources of it.

\section{\$116. International private law, or conflict of laws.-} In what has so far been said as to the sources and foundations of international public law no reference has been made to that kindred branch designated by some writers as private international law, by others as conflict of laws. ${ }^{23}$ While serious objections may be urged against both terms for their failure perfectly to express the idea they are intended to convey, the former seems to be gaining in general acceptance, despite the fact that both Story and Dicey have given the weight of their names to the latter. As early as 1826 Chancellor Kent, in the

21 See above, p. 71.

22 See above, p. 67.

23 "In 1840 Felix began a series of articles ' $d u$ conflit des lois de différentes nations, ou du droit in. ternational,' and republished them in 1843 as the 'Traité du droit international privé, ou du confit des lois en matière de droit privé.' Mr. Westlake followed in 1858 , 1880 and 1891 with his 'Private International Law, or the Conflict of Laws;' M. Fiore in 1869, with his 'Diritto internazionale privato, o principii per risolvere $i$ conflitti tra legislazione diverse in materia di diritto civile e commerciale;' $\mathbf{M}$. Haus with 'Le droit privé qui régit les étrangers en Belgique, ou du droit des gens privé considéré dans ses principes fondamentaux et dans ses rapports avec les lois civiles des Belges,' 1874; M. Brocher with his 'Nouveau traité du droit international privé, 1876; and Mr. Foote with his 'Private International Jurisprudence,' 1878. In 1874 M. Clunet estab. lished at Paris the 'Journal $d u$ droit international privé.", Holland, Elements of Jurisprudence, p. 369 . 
first volume of his Commentaries, ${ }^{24}$ said that "a recent French writer (M. Tictor Foucher) divides the law of nations into two branches, (1) public international law, which regulates the political relation of nation to nation; and (2) private international law, which, though based upon the first, regulates the reciprocal and personal relations of the inhabitants of different states." It may well be said that the second is based upon the first because it is impossible by fanciful refinements to overturn the fact that the laws of one state cannot be enforeed within the limits of another except through "comity,"-that term being understood to mean not mere courtesy, but that reciprocal obligation which arises out of the necessity for every nation to recognize and enforce, under certain conditions, the laws of every other nation in order to prevent gross inconvenience and injustice to litigants (ex comitate ob reciprocam utilitatcm). ${ }^{25}$ Little, if any, improvement can be made upon the axioms of Huber, the third of which is that the rulers of every empire from comity admit, that the laws of every people, in force within its own limits, ought to have the same force everywhere, so far as they do not prejudice the powers or rights of other governments, or of their citizens, ${ }^{26}$ because it appears that this matter is to be determined, not simply by the civil laws, but by the convenience and tacit consent of different people. If then the enforcement of the laws of one state affecting a private individual within another, depends upon "the convenience and tacit consent of different people," the conclusion is irresistible that such tacit consent is one of the rules regulating the intercourse of nations. The law of the state actually enforced within another is a national law; the rule by virtue of which it is so enforced is an international rule. There is therefore an absolute necessity for the use of the word international as an apt term to describe this system of international obligation resting upon international convenience. The only real question is as to the form in which

24 Page 2, note a. David Dud- itur agunt, ut jura cujusque populi ley Field in his International intra terminos ejus exercita tenCode (1876) uses the terms Public eant ubique suam vim, quatenus International Law and Private In- nihil potestati aut juri alterius ternational Law just as Kent did imperantis ejusque civium praein 1826 . 10.

25 Cf. Dicey, Conflict of Laws, p.

26 Rectores imperiorum id com-

judicetur. Lib. 1, tit. 3, de Conflictu Legum, § 2, p. 538. Story, Conflict of Laws, $\S 29$. 
the word international should be so combined with other words as to express the exact idea. Prof. Holland favors such a transposition of the current term as will make it read international private law, ${ }^{27}$ which is far more definite than $A n$ wendung der Gesetze (Ap $^{8}$ (Aplication of Law). And yet even against a slight change for the better stands the usage of more than fifty years, during which time a majority of the best writers have employed the term private international law in contradistinction to public international law. If any change is to be made in the first of these titles the substituted term should certainly express the true state of the case. It is hard to conceive of alything more misleading than the term Conflict of Laws, when employed to describe the international rules established to remove such conflicts,-rules, as Sir Henry Maine ${ }^{29}$ has expressed it, "plescribing the conditions on which one community will recognize and apply the jurisdiction of another." If that be their real character, the body of law in question should be entitled: International Private Law, a system of rules established by the comity of nations for the prevention of conflict of laws. For like reasons that part of the subject treated in the present work has been entitled International Public Law. Within a reasonable time the author hopes to publish another to be entitled International Private Law.

27 Elements of Jurisprudence, pp. 368-373. Such a change, which Prof. Holland says does not fully remedy the difficulty, finds support in the names of the following works: Schäffner's die Entwickelung des internationalen Privatrechts, 1841; Pfeiffer's das Princip des internationalen Privatrechts, 1851; von Bar's das internationale Privat- und strafrecht, 1862; von Püttlingen's Handbuch des in Oesterreich-Ungarn geltenden internationalen Privatrechts, 1878. The Zéitschrift fïr internationales Privat-und strafrecht was founded by $\mathrm{F}$. Böhm in 1890 .

28 For an illustration of the use of that term, see Struve's ïber das positive Rechtsgesetz in seiner Beziehung auf räumliche Verhältnisse und über die Anwendung der Gesetze verschiedener Oerter, 1834. 29 Int. Law, p. 17. 



\title{
PAFT III.
}

\section{RIGHTS ANd Duties OF States in TIME OF PEACE.}

CHAPTER I.

\begin{abstract}
NATURE AND ATTRIBUTES OF STATES, SOVEREIGN AND PART-SOVEREIGN.
\end{abstract}

$\S 117$. Territorial sovereignty the basis of all international relations.-By what has so far been said two conclusions have been clearly established: first, that what is now known as international law is a system of rules created by civilized nations, since the beginning of the Reformation, to regulate their intercourse with each other; second, that such system was founded in the first instance by the states that gradually arose ont of the settlements made by the migratory hordes who settled down permanently npon the wreck of the Roman Empire. ${ }^{1}$ The vitally important outcome of the process through which such migratory hordes were tied to the landthe "process of feudalization"-was the principle of territorial sovereignty which has become the basis of all international relations. $^{2}$ Upon that basis rests the modern conception of the state as a nation with fixed geographical boundaries,-a conception radically different from the ancient conception of the state as a city-commonwealth. ${ }^{3}$ When, therefore, publicists attempt to describe the state as it exists to-day by means of definitions drawn from Aristotle ${ }^{4}$ and Cicero ${ }^{5}$ they should remember that the corporate entity now known as the state is something of which no statesman of the ancient world ever dreamed,-it is a new creation at which both Aristotle and

1 See above p. 26.

2 Ibid., p. 27.

3 Ibid., p. 18.

4 Pol,, bk. vii, c. iv, 13.
5 Respublica est cœtus multitudinis, juris consensu et utilitatis communione societas, De Rep. 1. i. $\$ 25$. 
Cicero would have stared and gasped. Out of the modern conception of the state has grown the fundamental principle of territorial sovereignty, and from it flow, naturally and necessarily, the corollaries that every state is coequal with every other, and that teritory and jurisdiction are coextensive.

$\S 118$. Why the several types of state organization must be examined.-Each sorereign state is supreme within its territorial limits; with its internal political constitution no other state has the normal right to interfere. International law deals solely with a state's external relations and not with its internal organization. Each state as a corporate body binds itself through the acts of the governmental agents established and authorized by its own constitution. No other state has the right to dictate who such agents shall be or how they shall be constituted; it can only satisf $y$ itself as to the fact that such agents have been duly constituted and that they are acting within the limits of their authority. Thus the administrators of every state are forced for their own protection to examine the constitutions of all other states with which they deal so as to be sure that those who represent them are not acting ultra vires. ${ }^{6}$ For that reason it will be necessary briefly to review the several typical forms of state organization existing in the world to-day.

$\S 119$. Sovereign states divided into five classes.-The tendency which has manifested itself in Europe during the last thirty years to build up great nationalities, through the incorporation of smaller states in more strictly organized wholes. has brought about some notable internal political changes, especially in the constitutions of Germany, Italy and AustriaHungary. With such changes clearly in view the statement may be made, that the corporate entities known to international law, which act as independent units when dealing with other states, are (1) single or organic bodies like France and Russia; (2) such states, otherwise entirely separate and distinct, as happen to be temporarily or accidentally united in a personal union under a single sovereign, (3) aggregates arising ont of real unions like that uniting Hungary with Austria; (4) incorporate unions such as that existing between England and

o "It is the business of the state with which a contract is made to take reasonable care to inform itself as to the competency of those with whom it negotiates." Hall, p. 348. 
Scotland, and between Great Britain and Ireland; (5) federal unions of the kind embodied in the constitutions of Switzerland, Germany and the United States.

$\S 120$. Personal unions-relation of Great Britain to Hanover. -Of the unions into which states may enter without formingr confederations, those known as personal unions are the least important because, so far as international law is concerned, states thus joined still retain complete independence. The illustration usually given of such a union, is that which accidentally bound the United Kingdom of Great Britain and Ireland to that of Hanover from the accession of George $I$ down to the death of William IV, during the five successive reigns in which the king of England was the Elector of Hanover. ${ }^{7}$ The coincidence which thus placed the two crowns on the same head by the civil law of succession in each country, did not place either in such a relation to foreign powers that war with the one necessarily involved war with the other, while in treaty engagements with such powers no attempt was made to involve the one with the other. For a long time prior to $1857^{\circ}$ the Swiss canton of Neuchatel was united through a personal union to the Prussian monarchs, by reason of the fact that the king of Prussia was sorereign prince of Neuchâtel, which held at the same time a recognized place in the Swiss Confederacy as the only non-republican canton.

$\S 121$. Real unions-Austria-Hungary.-When states with an independent existence are permanently united to each other under a single sovereign in such a way as to make them, for the purposes of international law, a single corporate body, the tie between them becomes a real union as distinguished from a personal one. ${ }^{9}$ A typical illustration of a real union is that embodied in the dual monarchy of Austria-Hungary, the final outcome of an agglomeration of various nationalities in which each has striven to preserve its ancient constitution from destruction by the overwhelming force of the central authority. As a partial recognition of that aspiration the constitution of February 18th, 1867, reorganized the composite whole as the joint kingdom of Austria-Hungary, a "real union" of

7 Cf. Phillimore, § i, lxxvi; Halleck, i, 68; Heffter, $\S 20$; Twiss, i, 46.

8 In that year the independence of Neuchâtel was recognized by Prussia when the sovereign prince relinquished all his rights, except his title, which his successor (the German emperor) has dropped.

9 Unio civitatum, sive perpetua sit, sive temporaria, fit jure (1) vel societatis (systema civitatum 
two states, constitutionally and administratively independent, under the supreme direction of the emperor of Austria, also king of Bohemia and "A postolic" ling of Hungary, who stands at the head of the whole government in all its branches. In the direction of the common concerns of the two lingdoms the emperor-king is assisted by three ministries, the first being that of foreign affairs, to which is committed all international functions, diplomatic and commercial. ${ }^{10}$

Prussian and Danish monarchies gesammtstaats.-The single political community which thus deals with other states has been described by German publicists as a gesammtstaat or joint-state in order clearly to define its international character. ${ }^{11}$ When the emperor of the Holy Roman Empire finally consented that Frederick, son of the Great Elector, might assume (January 18tl, 1701) the title of king of Prussia, he was influenced by the fact that Prussia was then beyond the bounds of the Empire. ${ }^{12}$ In his new capacity Frederick thus became an independent monareh, while as elector of Brandenburg he was a subject of the Empire. And so under the constitution of the Germanic Confederation, as settled by the Congress of Vienna, ${ }^{13}$ the head of the house of Hohenzollern, as the chief of a Prussian monarchy composed of Germanic and non-Germanic states, possessed the right to enter into the treaty engagements in three distinct capacities: First, in belalf of the entire Prussian monarchy as a gesammtstaat or joint-state; second, in behalf of the Germanic portion of it; third, in behalf of the non-Germanic portion of it. At the same epoch the ling of Denmark could treat in belialf of the entire Danish monarchy as a gesammtstaat or joint-state; or in behalf of the two Germanic duchies of Holstein and Lanenburg alone; or in behalf of the Danish provinces alone. ${ }^{14}$

fœderatarum) (2) vel imperii (sub eodem imperante). Hœc est vel personalis vel realis. Klüber, I, § 27.

$10 \mathrm{For}$ the details of the existing constitutions and the organization of the common ministries, ef. Woodrow WiIson, The State, $\$ § 592$, $593,594,595,597$.

11 "The political unity of the states which compose the Austrian Empire forms what the German publicists call a community of states (gesammtstaat); a community which reposes on historical antecedents." Dana's Wheaton, p. 61.

12 Bryce, The Holy Roman Empire, p. 388. The title was taken from the name of the duchy of East Prussia, so called from its situation next to Russia-po Russia.

13 Twiss, i, p. 48.

14 As to the effect of the Final Act of 1820 in defining the warmaking and treaty-making powers, 
Sweden and Norway a gesammtstaats.-It thus appear's that a gesammtstaat may be a greater whole in which the states composing it have lost their international existence, as in the ease of Austria-Hungars, or it may be a greater whole in which such states enjoy both a separate and common international existence, as in the cases of Prussia and Denmark as once organized. There should therefore be no difficulty in classing the aggregate arising out of the union of sweden and Norway as a gesammtstaat or real union, ${ }^{15}$ because, howerer distinct the two kingdoms may be in their internal relations, the fact remains that they possess a single international system, at whose head stands the common king acting exclusively through the Swedish minister of foreign affairs, as Norway has no such functionary. While war can only be made after consultation with a joint council of the two kingdoms, the common king must himself assume the full responsibility of the decision, and war or peace thus made necessarily involves both kingdoms. And yet it is not eorrect to say that "Norway has not any international existence apart from sweden," because the common king may make a treaty binding one king. dom only. There is not a complete merger of "Sweden and Norway as regards international relations: they retain their separateness and individuality in the family of nations; and the ling may, and of ten does, conclude treaties affecting one of his kingdoms only." 16

$\S 122$. Incorporate union embodied in British Empire.-The term incorporate union is usually employed to describe the mighty aggregate which has arisen out of the process through which the little Teutonic kingdom called "Wessex has grown into England, England into Great Britain, Great Britain into the United Kingdom, the United Kingdom into the British Empire," the fourteen centuries that have elapsed since the Teutonic conquest and settlement of Britain began. The history of that

both of the confederation itself and of its several members, see Wheaton's Hist. Law of Nations, $447-48,457-60$.

$15 \mathrm{It}$ is so classed by Klüber (§27), and by Heffter (\$26). Wheaton and Phillimore, however, class the union between Sweden and Norway as a personal one. Twiss, while denying that position. says, "it is not identical with the real union which exists between the independent states which compose a gesammtstaat, as Norway has not any international existence, apart from sweden." i, pp. 51-52.

16 Wilson, The State, $\$ 628$.

17 Freeman, Norm. Conq., vol. i, p. 16 . 
process breaks itself naturally into two parts: the first embracing the making of England itself and the subsequent drawing together by force of its authority of the whole of the British Isles under the legal title of the United Kingdom of Great Britain and Ireland (449-1861); the second embracing the acquisition of all the territories possessed by the United Kingdom outside of the original group (1606-1899).

Government of colonial system.-The distinguishing feature of the elastic system through which England's colonial empire is now governed,is embodied in the application to each of its widely divergent parts of that kind of administration which seems best adapted to its special stage of development and to its local wants and traditions. The English colonial system thus embraces almost every form of government from the autocratic high commissioner, who legislates for savage Basutoland by the issuance of proclamations merely, up to the complex federal union under which the self-governing communities of Canada control their own destinies with scarcely any interference whatever from the parent state. ${ }^{18}$ The sovereignty, internal and external, of each of the original home kingdoms has been completely merged in the United Kingdom formed by their successive unions, while the ultimate power over the entire integrated mass resides in the imperial and omnipotent parliament at Westminster, or rather in its popular chamber, which carries on the executive government in the name of the crown through ministers really responsible to itself alone. ${ }^{\text {* }}$

Treaty-making power vested in crown.-The sole and exclusive power to make treaties, leagues and alliances with foreign states and princes, binding upon the British Empire, is rested in the crown, acting under the advice of its responsible ministers. $^{20}$ In order to insure secrecy and dispatch in the conduct of foreign affairs, parliament permits ministers to initiate a foreign policy and to carry it out in secret at their peril, it being understood that they will be subjected to punishment in the event they conclude any treaty derogatory to the honor or interest of the Empire. As Lord Palmerston expressed it in tendering a seat in the cabinet to Mr. Cobden: "You and

18 See the author's article entitled England's Colonial Empire, in The North American Review for June, 1896.
$19 \mathrm{Cf}$. The Origin and Growth of the Eng. Const., vol. ii, ch. iii.

20 Bowyer Const. Law, p. 160; Blackstone, vol. i, ch. vii; Palmerston, Hansard, vol. iv. pp. $174,787$. 
your friends complain of a secret diplomacy and that wars are entered into without consulting the people. Now, it is in the cabinet alone that questions of foreign policy are settled. We never consult parliament till after they are settled. If, therefore, you wish to have a roice in these questions, you can only do so in the cabinet." ${ }_{21}$ For that reason "it is neither regular to ask, nor is it convenient to answer, questions relative to treaties which are yet pending;" ${ }^{22}$ and when a treaty is made in the name of the crown, acting through a responsible minister, it requires no formal sanction or ratification by parliament as a condition precedent to its ralidity. ${ }^{23}$ Parliament can only give or withhold its sanction to such parts of a treaty as require legislation at its hands to give them force and effect. $^{24}$ It is clear that the crown may acquire additional territory from foreign powers without the consent of parliament, provided it is not acquired by purchase $;^{25}$ it is, however, a doubtful and disputed question whether the crown can alienate British territory without such consent. ${ }^{26}$

$\S 123$. Federalism, prior to making of second constitution of U. S.-Down to the making of the second constitution of the United States (1787) the Confederation of Swiss Cantons, the United Provinces of the Netherlands, the Germanic Confederation and our Articles of Confederation represented the total advance which the modern world had made in the structure of federal governments. Such advance was embodied in the idea of a federal system made up of a union of states, cities, or districts, representatives from which composed a single federal assembly, whose supreme power could be brought to bear not upon individual eitizens, but only upon districts, cities or states as such. ${ }^{27}$ The fundamental principle upon which all such fabrics rested was the requisition system, under

21 Morley's Life of Cobden, vol. ii, p. 231; Spencer Walpole's Foreign Relations, p. 117. "It is for parliament to inquire, to criticise, to support, to condemn, in questions of foreign policy, but it is not for parliament to initiate a foreign policy." Beaconsfield's Collected Speeches, vol. ii, p. 125.

22 Mir. of Parl. 1841, p. 1032; Todd's Parl. Govt. of Eng., vol. i, p. 134 seq.
23 Hansard, vol. 156, p. 1361; Ib., vol. 201, p. 174.

2* See Gladstone in Hansard, vol. 71 , p. 548 .

25 Dutch Guinea, Hansard, vol. 205 , p. 657 ; vol. 211 , p. 287 . Amos, Fifty Years of Eng. Const., p. 403. 26 See digest of cases in Forsyth, Const. Law, pp. 182-186; Todd, Parl. Govt. in England, vol. i, p. 136.

27 Freeman, Hist. of Federal Govt., vol. i, ch 1 . 
which the federal head was endowed only with the power to make requisitions for men and money upon the states or cities composing the league for federal purposes, while the states or eities, alone, in their corporate capacity, possessed the power to execute and enforce them. The first serious effort made by the English colonies in America towards federal union ended with the making of the first constitution of the United States, embodied in what is known as the Artieles of Confederation. Up to that point nothing new had been achieved; the fruit of the first attempt was simply a confederation upon the old plan, with the federal power rested in a single assembly which could only deal through the requisition system with states as states. $^{29}$ During the war of the Revolution American experi. ence demonstrated the fact that a league based upon the requisition system was a mere rope of sand; and yet every other federal commonwealth that had ever existed down to that time had rested upon that impotent expedient.

$\$ 124$. Path-breaking idea embodied in second constitution.Under such conditions necessity became the mother of invention. After a painful travail America gave birth to a novel and irresistible political idea,-what the Germans would call a path-breaking idea, bahnbrechende Idee. In February, 1783, Pelatiah Webster published at Philadelphia a tract entitled "A Dissertation on the Political Union and Constitution of the thirteen United States of North America," in which he not only advocated permanent courts of law and equity, and a stricter organization of the executive power, but also a national assembly of two chambers instead of one, with power not only to enact laws, but to enforce them on individuals as well as on states. $^{29}$ A year later this tract was followed by another of the same tenor from Noah Webster of Hartford,in which he proposed "a new system of government which should act, not on the states, but directly on individuals, and rest in congress full power to carry its laws into effect." 30 This brand-new idea which the Websters were the first to express, - the ide:i of giving to a federal government the power to execute its laws not on states in their corporate capacity, but directly on individuals,-embodied the most important and far-reaching principle to which our career as a nation has so far given birth.

28 The Origin and Growth of the Eng. Const., vol. i, pp. 48-58.

29 See P. Webster's Political Essays, p. 228.
30 Madison Papers, vol. ii, p. 708. See also Noah Webster's Sketches of American Policy, pp. 32-38. 
As soon as it was settled that this new idea was to be made the basis of the work of the Convention of $\mathbf{1 7 8 7}$, it became iner. itable that the new fabric should be endowed with a strictly organized constitution with the usual branches, executive, legislative, and judicial, with all the usual machinery of govermment bearing directly upon every citizen of the Union without reference to the governments of the several states. Thus it was that the states of the American Union were finally welded together in a perfect federal government which is but a single state in all matters concerning the federal body as a whole, and yet a group of states perfectly independent in all matters which concern each member of the group as a local self-governing community.

$\S$ 125. How federal unions are classified-a staatenbund.With this preface clearly in view it will be easier to explain the principles upon which federal states are classified by writers on international law. The less strictly organized union or league resting upon the requisition system,- of the type prevailing prior to the maling of the present constitution of the United States,-is usually styled a confederated state, or in German technical language a staatenbund. ${ }^{31}$ The leading characteristic of such a confederation, so far as its internal relations are concerned, is that the state does not entirely surrender to the central power its right of dealing directly with other states. Only after reserving to itself the right thus to dispose of a certain part of its foreign affairs is the control over the remainder surrendered to the central authority. Originally both the Swiss and German confederations belonged to that class. While the final outcome of the struggle of the Swiss cantons to emancipate themselves from the toils of the feudal system, begun early in the fourteenth century, was assured by the accession to the league in 1513 of the last of those thirteen German cantons which were to constitute its central membership down to the French Revolution, it was not until its recognition by the great powers in the treaty of Westphalia in 1648 that the Swiss Confederation became in the eye of the public law a sovereign state. ${ }^{32}$

31 As to the distinction between the two classes see J. S. Mill, Rep. Govt., p. 301; Prof. Bernard's Lectures on American War, Oxford, 1861, pp. 68-72; Tocqueville, Dimocracy in America, vol. i, pp. 250 ,
265 seq.; Freeman, Hist. of Fed. Govt, vol. i, pp. 11 and 12 , and notes; Heffter, § 20.

32 Wilson, The State, $\S \S 379,507$, 508 . 
Right of cantons or states to make separate treaties.-Under the constitution of the leagne as it existed prior to 1798 the several cantons retained the right to make separate treaties with foreign powers and with each other; and under the new act of confederation concluded in August, 1815, between twenty-two cantons, the right of each was reserved to conclude any alliance which was not prejudicial to the rights of the general confederation or of any of its members. In the same way the Germanic constitution as modified at the Peace of Westphalia, which converted the empire into a confederation of the loosest sort, ${ }^{33}$ gave to the members of the diet, by whose votes the emperor was to be governed, the right not only to contract alliances among themselves but with foreign princes, provided no prejudice resulted thereby to the emperor and the empire. Under the constitution of the new German confederation, embraced in the Federal Aet of the Congress of Vienna (1815), the right was still retained by each state to declare and carry on war and to negotiate peace with any power foreign to the confederation, and to make its own alliances, provided no injury was thereby inflicted upon the confederation itself, or upon any of its members. ${ }^{34}$

$\S 126$. The unique federal creation of 1787 a bundesstaat.By the adoption of the second federal constitution of the United states an entirely new type of federal government was created, which writers upon public law have designated a composite state, or supreme federal government, in German technical language a bundesstaat. As Tocqueville ${ }^{35}$ has expressed it: "This constitution, which may at first be confounded with federal constitutions which have preceded it, rests in truth upon a wholly novel theory which may be considered a great diseovery in modern political science. In all the confederations which preceded the American constitution of 1789 the allied states, for a common object, agreed to obey the injunc-

33 See above, p. 36.

34 Each state also retained its rights of legislation as to foreign powers and to its co-states. Klüber, Oeffentliehes Reeht des Deutschen Bundes, $\$ 137-143$. As to the effects of the Final Act of 1820 , consisting of sixty-five articles, on the treaty-making power, see above, p. 115 , note. A good com- mentary on the Final Act may be found in Twiss, vol. i, pp. 71-74.

35 Democracy in America, vol. $i$, pp. 198, 199, Bowen ed. "It is a commonwealth as well as a union of commonwealths, because it claims directly the obedience of every citizen and acts immediately upon him through its courts and executive officers." Bryce, The Am. Com., vol. i, p. 13. 
tions of a federal government; but they reserved to themselves the right of ordaining and enforcing the execution of the laws of the union. The American states, which combined in 1789, agreed that the federal government should not only dictate, but should execute its own enactments. In both cases the right is the same, but the exercise of the right is different; and this difference produced the most momentous consequences." The federal system now existing in the United States has no prototype in history, unless Mr. Freeman has been able to maintain his somewhat difficult contention, that the Achaian League should be classed among "composite states" 36 by virtue of the fact that its national government acted directly, as a general rule, upon the citizen, although it does not seem to have passed from the requisition stage to that in which a supreme federal government collects its taxes through the direct agency of its own officers. ${ }^{37}$ It seems to be clear that there was a common citizenship; that every Achaian citizen owed a direct allegiance to the central authority as a citizen of the league itself, and not merely of one of the cities composing it. Whatever may have been the constitution of the league, it is clear that the makers of the existing constitution of the United States derived no real guidance from that source because, as they tell us in the Federalist, ${ }^{38}$ "could the interior structure and regular operation of the Achaian League be known, it is probable that more light might be thrown by it on the science of federal government, than by any other like experiments with which we are acquainted."

$\S 127$. Its effect upon other state systems.-The new federal creation which arose out of the deliberations of the convention of 1787 was both unique and original, and its success has abolished from the world the pre-existing type of federal league (staatenbund) superseded by it. The entire state-system of

36 "The Achaian League was, in German technical language, a bundesstaat and not a mere staatenbund." Hist. of Fed. Govt., p. 259, citing Helwing, p. 237.

37 There were undoubtedly fed-

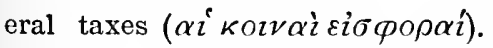
Pol. iv, 60. But there is no evidence that they were gathered directly by federal collectors.

38 No. xviii. Such knowledge as the framers did possess of Greek federalism seems to have been drawn chiefly from the work of the Abbé Mably, Observations sur l'Histoire de Grèce. Federalist, xxiii, p. 117. They were familiar only with the leagues that had grown up between the Low-Dutch communities at the mouth of the Rhine, and between the HighDutch communities in the moun- 
Central and South America has been formed on the North American plan. The outer shell of the republican states then organized upon soil once belonging to Spain and Portugal is invariably on that plan, with representative institutions and public law, constitutional and criminal, ${ }^{39}$ drawn from English sources, while the private law which dominates within the shell is almost purely Roman. When such states draw together in federal unions they simply adopt, with eertain changes in details, the present constitution of the United States. ${ }^{40}$ The success of the Ameriean experiment has also intluenced in a way that is unmistakable the confederacies of the European world. In 1847, - after the seven cantons which had united foul years before in the separate leagne known as the Sonderbund had been driven back to their allegiance,-Switzerland finally awoke to the fact that the old and discordant confederatey (staatenbund) embodied in the piact of 1815 should be transformed into a supreme federal government (bundesstaat). such was the result of the adoption of the new constitution of 1848 which made Switzerland a composite state with a legislature consisting, like our own, of two houses, one representative of the people, the other of the states or cantons. To that was added by the important revision of 1874 a federal supreme court, which in many departments of jurisdiction is the highest tribunal in the land. By the new constitution the control of the international relations of the cantons was rested absolutely in the federal executive, a collegiate body or council divided into seven departments, the first of which is that of foreign affairs. In order to secure greater continuity in all departments that last named has been separated from the presidency with which it was formerly associated. ${ }^{11}$

$\S 128$. Constitution of North German Confederation.-As explained heretofore, the great outcome of the war of 1866 between Prussia and Austria was the expulsion of the latter from the old confederation of 1815 , thus leaving the former free to form an new one in which she could be supreme. ${ }^{42}$ Under

tains of Switzerland and upon the plains of Germany. Federalist, Nos. xix, xx.

39 See Señor Matias Romero's essay on The Anglo-Saxon and Roman systems of Criminal Jurisprudence, in his work, Mexico and the United States, pp. 409-428.
40 Les Provinces conservent tout le pouvoir non délégué par cette constitution au gouvernement fédéral. Constitution of Argentine Confederation.

41 See Wilson, The State, §509513.

42 See above, p. 122. 
the constitution of the new league known as the North German Confederation, ${ }^{43}$ at whose head Prussia placed herself, the military forces of all the federal states north of the Main were fused and placed under the command of the ling of l'russia, who, as permanent president of the confederation, was authorized to control its foreign policy, although a nominal independence was left to the minor princes who were permitted to send and receive diplomatic agents, to summon their local legislative bodies, and to levy local taxes. While the siege of Paris was in progress a proposition was accepted so to reorganize the confederation as to unite all the states, except Austria, in a German empire with the king of Prussia as its head; and, after the necessary legislation in the various states, that sovereign assumed at Versailles in January, 1871, the title of German emperor, thus welding Germany together as a single state under a new federal constitution, which is nothing more than that of the North German Confederation modified by the treaties whereby Bavaria, Würtemberg and Baden respectively entered the pre-existing body. ${ }^{44}$ By the new constitution, which bears date April 16th, 1871, complete jurisdiction over the foreign affairs of the empire is rested in the imperial gorernment, with the reservation that certain of the states shall retain the right to deal independently with foreign courts in reference to such of their affairs as do not involve imperial interests. When such states do not send special representatives for that purpose, their separate interests are looked after by the representatives of the empire. While the reservation thus made of a limited right of diplomatic intercourse in favor of certain states causes the new fabric to be still designated, in a purely technical sense, a staatenbund, everybody knows that it is really a supreme federal government, a bundesstaat, in the highest sense of that term. ${ }^{45}$

$\S 129$. Responsibility of federal executive-defect in constitution of U. S.-As the staatenbund has thus been superseded

43 Adopted April 17, in 1867, Annuaire, xiv., 810; Lawrence's Commentary on Wheaton, vol. ii, 1-76.

44 "Each of these states obtained its due representation in the federal council and federal assembly, and each reserved for itself certain powers or immunities beyond those enjoyed by the North German States." Bryce, Holy Roman Empire, pp. 417-418.

45 The supreme federal government really transacts all of the external business of the empire. Cf. Statesman's Year Book for 1894, pp. 531-534. 
everywhere by the bundesstaat, international law has only to deal with supreme federal governments which for all international purposes appear as single states, representing the nationality of the entire federal body. The executive power of such a body charged with the conduct of its foreign affairs is necessarily the only anthority of which foreign nations take cognizance. For that reason the constitution of every federal system should supply its executive with resources adequate to every international demand that can rightfully be made upon it. Unfortunately the constitution of the United States is not perfect in that respect. Foreign nations are denied the right to hold diplomatic intercourse with the several states, ${ }^{46}$ and yet the supreme federal government is under no constitutional or legal obligation to assume the settlement of such damages as foreigners may suffer through the failure of the local anthorities of such states to extend to them complete police protection. The position assumed by the federal government of the United States in such cases has been defined as follows: "The system of government which prevails in the United States, and which their public written constitution has made known to the government of China at the time of our entering into treaties with that country, creates several departments, distinct in function, yet all tending to secure justice and to maintain order.* * * The government of the United States recognizes in the fullest sense the honorable obligation of its treaty stipulations, the duties of international amity and the potentiality of justice and equity, not trammeled by technical lulings nor limited by statute. But among such obligations are not the reparation of injuries or the satisfaction by indemnity of wrongs inflicted by individuals npon other individuals in violation of the law of the land. Such remedies must be pursued in the proper quarter and through the arenues of justice marked out for the reparation of such wrongs." 47

\section{$\S 130$. No federal control over states in certain cases. $-\mathrm{A}$ gov-}

46 "No state shall enter into any treaty, alliance, or confederation; * * * No state shall, without the consent of Congress, ** enter into any agreement or compact with another state, or with a foreign state." Art. 1, sec. 10. The right and duty to protect the interests of the states is vested in the general government. Florida v. Georgia, 17 How. 478. As to the scope of the term "agreement," see Holmes v. Jennison, 14 Peters, 540. $47 \mathrm{Mr}$. Bayard, Sec. of State, to Mr. Cheng Tsao Ju, Feb. 18, 1886, Mss. Notes, China. House Ex. Doc. 102, 49th Cong. 1st sess. For. Rel. 1886. 
ernment is liable internationally for damages done to alien residents by a mob which by due diligence it could have. repressed. ${ }^{48}$ When in 1880 British subjects were injured by a mob in Texas, it was held by the secretary, after consulting the attorney-general, that as the offense "was against the peace and dignity of Texas," it was "cognizable only by the authorities of that state. So far as their legal remedy against the assailants is concerned, the Dows (the parties injured) stand as to their natural and ciril rights in precisely the same condition as to recourse to the state tribunals as the citizens of that state; and, in their capacity of British subjects, they can resort also to the courts of the United States at their option for ciril redress and indemnity." 49 In other words if a state of the American union becomes liable for damages done to an alien resident by mob riolence, which it failed to prevent by due diligence, such state cannot be held responsible internationally because as to foreign powers it does not exist. And yet the federal executive, with whom alone such foreign powers can deal, can do no more than offer the injured parties such redress as they may find in private suits to be conducted against their assailants in the state and federal tribunals. To mitigate extreme hardships often arising out of this unfortunate condition of things, the federal executive, while disclaiming "any sense of obligation on the part of this government under the law of nations," ${ }^{50}$ has of its own motion called upon congress in a few exceptional cases to provide a just indemnity.

$\S 131$. Case of McLeod.-The inability of the federal goverument of the United States to respond in all cases to its international obligations, by reason of its powerlessness to control the action of the states when moring within the sphere of their sovereign authority, was strikingly illustrated in the case of McLeod, a British subject,tried in the state of New York in 1841, for the murder in 1838 of a person killed in the attack made in a port of that state on the steamer Caroline, employed by Canadian insurgents for the conveyance of passengers and munitions of war from the American to the Canadian shore. The British gorernment assumed responsi-

$48 \mathrm{Mr}$. Evarts, Sec. of State, to Sir E. Thornton, May 22, 1880. Mr. Gibbs, May 28, 1878. Mss. Mss. Notes, Great Britain.

Inst., Peru.

$50 \mathrm{Mr}$. Fish, Sec. of State, to Mr.

$49 \mathrm{Mr}$. Evarts, Sec. of State, to Partridge, Mar. 5, 1875. Mss. Inst., Brazil. 
bility for the acts of MeLeod and demanded that the government of the United States should deliver him upon the ground that it was "well known that the destruction of the steamboat Caroline was a public act of persons in Her Majesty's service, obeying the orders of the superior authorities. That act, therefore, according to the usages of nations, can only be the subject of discussion between the two national governments." In the course of the correspondence Mr. Webster, then secretary of state, said: "That an individual forming part of a public force and acting under the authority of his government, is not to be held answerable as a private trespasser or malefactor, is a principle of public law sanctioned by the usages of all cirilized nations, and which the government of the United States has no inclination to dispute." 51 Despite that admission, MreLeod, whose release was denied by the state judge on habeas corpus, ${ }^{52}$ was subjected to trial in a New York court, which resulted in his acquittal. It thus became impossible to revise the state's proceedings in the federal tribunals; and in the hope of removing such difficulties in the future Congress passed an act in 1842 pointing out a way in which the federal courts may acquire exclusive jurisdietion over such cases. It is now provided in our Revised Statutes (sec. 75:3) that the writ of habeas corpus from a federal judge may run when "a subject or citizen of a foreign state, and domiciled therein, is in custody for an act done or omitted under any alleged right, title, authority, privilege, protection or exemption claimed under the commission, or order, $\mathrm{Or}^{2}$ sanction of any foreign state, or under color thereof, the validity and effect whereof depend upon the law of nations." 53

$\S 132$. Part-sovereign states.-Any state, no matter what the form of its internal constitution, may, through a voluntary convention or through external pressure it cannot resist, be placed

51 Mr. Webster, Sec. of State, to Mr. Crittenden, March 15, 1841. Mss. Dom. Let.

52 In a speech made in the Senate (April 6, 1846,) on the Treaty of Washington, Mr. Webster said: "I was utterly surprised at the decision of that court on the habeas corpus. On the peril and risk of my professional reputation, I now say that the opinion of the court of New York in that case is not a respectable opinion, either on account of the result at which it arrives, or the reasoning on which it proceeds." Webster's Works, vol. v, p. 129. Webster's view of the case is approved by Phillimore, Int. Law, vol. iii (3rd ed. 1880), p. 60 , and by Hall, Int. Law, $\$ 102$.

53 See lix parte Dorr, 3 How. 103; Ex parte Barnes, 1 Sprague, 133; Ex parte Bridges, 2 Woods, 428 . 
in such a relation of dependence to another state as to be deprived of a part of its external sovereignty or have the same for a time entirely suspended. In either event such a state would descend to the class usually designated as partsovereign, ${ }^{54}$ and as such continue to be a subject of international law. Even an absolute surrender of the national will, if it be temporary or revocable, will not deprice a state of its international existence. ${ }^{55}$ An illustration of the nature of part-sovereign states may be found in the persons of such as have united themselves in that kind of an imperfect federal union known as a statenbund. In the older Germanic and Swiss confederations, which belonged to that class, the several states reserved to themselres the right to deal with foreign powers in matters not expressly transferred by the terms of the act to the exclusive control of the federal authority. ${ }^{56} \mathrm{As}$ a necessary result complete external sovereignty was rested neither in the central gorermment nor in the states out of whose union it arose. It is, therefore, correct to say that the central as well as the local governments in such a system are only part-sovereign. When, however, a staatenbund is transformed into a bundesstaat of the kind now embodied in the present constitutions of Switzerland and the United States, which deal with foreign powers as single states, neither the central nor local governments remain part-sorereign. Through the acquisition of complete jurisdiction orer the foreign affair's of the combinations they represent, the former become fully sovereign; while the latter, by being entirely deprived of such control, lose all exterual sorereignty whatsoerer,-they cease to be subjects of international law. The perfect external sorereignty thus centered in the bundesstaat is for just the opposite reason rested in such states as are united in a personal union of the kind that joined Great Britain to Hanover from 1714 to 1837 . The union that binds Sweden to Norway, despite what has already been said as to its peculiar nature, ${ }^{57}$ does not leave either kingdom part-sorereign,but unites both in a single state completely sovereign so far as other nations are con-

54 The term part-sovereign has been adopted as more accurate than the term semi-sovereign, which implies an equal division of the powers of sovereignty between the local and foreign rulers. The latter term seems to have been introduced by J. J. Moser in his
Beyträge zum Völkerrecht in Friedenzeiten, vol. i, p. 508. Cf. Twiss, vol. i, p. 25; Heffter, § 19; Martens, Précis, § 20; Klüber, § 1; Lawrence, p. 68 .

55 Hall, § 4.

56 See above, p. 156.

57 See above, p. 161. 
cerned. All other states bound together in real unions stand, of course, in the same category. The same thing may be said of the German empire as now constituted, despite the fact that certain of the states composing it retain the formal or complimentary privilege of dealing with foreign affairs not committed to the imperial government. ${ }^{58}$

$\S 133$. Neutralized states only part-sovereign.-Permanently neutralized states such as Switzerland and Belgium cannot, howerer, be said to possess complete external sovereignty because under the conventions securing their integrity they are deprived of a part of their independence by being denied the right to engage in any except strictly defensive warfare, and to enter into any compacts that might involve them in hostilities for other than purely defensive purposes. In the same way the Transval Republic, originally independent, ${ }^{59}$ impaired its sorereignty when it agreed, in article 4 of the convention of February 27,1884 , to make "no treaty with any other state, other than the Orange Free State, nor with any native tribe east or west of the republic, without the approval of Great Britain." "so And yet all such states are entitled to all the privileges, and are bound by all the obligations, of international law, with complete liberty of action, except as to the particular attributes of sovereignty surrendered.

$\S 134$. Protected states not persons in international law.-Not until a state is placed by its own act, or by external pressure which it cannot resist, in such a permanent and irrevocable position of dependence upon another as to vest in the controlling state the entire direction of its foreign affairs, does it cease to be a person in international law. Such communities are usually termed protected states, because by reason of their inability to defend themselves they have been placed under a protectorate, constituted either by a voluntary stipulation between themselves and the protecting power, or by an arrangement made without their consent between other powers interested in the disposition of their territory. In

58 See above, p. 169.

59 The independence of the Transvaal was recognized by Great Britain in 1852 , and by other powers thereafter.

60"As the rulers of the Transvaal are bound to obtain the assent of Great Britain before they can take effective action in a most important sphere, the Boer Republic can not, in strictness, be said to possess the full rights of independence, though it is called an independent state in treaties and despatches." Lawrence, pp. 112113. 
cases in which the international existence of protected states ceases entirely they may still enjoy, so far as their internal affairs are concerned, almost entire independence of the controlling state. In such cases the iuternal relations involved belong exclusively to the domain of public or constitutional law.

$\S$ 135. Republics of Andorra and San Marino.-The two protected states now existing in Europe that make the nearest approach to the definition given above, are the little republics of Andorra and San Marino. The former, situated between the Pyrenees of Arrièze in France and the Pyrenees of Catalonia in Spain, holds within its territorial limits, about thirty miles in length and twenty in breadth, a small pastoral population who administer their domestic affairs under the joint protection of the French Republic and the Spanish Bishop of Urgel,-the final appeal in civil cases being either to the Court of Cassation at Paris or to the Episcopal College at Urgel. To each of the protecting powers a nominal annual tribute is paid, while the general expenses of government are defrayed by a kind of rent drawn from the occupiers of pastoral lands. ${ }^{61}$ The latter, styled by Italian writers La Republichetta, ${ }^{62}$ is an "intermational atom" which for many centuries enjoyed as an independent republic all the rights of local self-government under the protection of the Holy See, a duty to which the king of Italy succeeded in 1862 . It may be true that as late as 1834 Andorra negotiated a treaty with Spain, and yet for all practical purposes the fact remains that neither of these miniature states has any international affairs or any real international existence.

\$136. Migratory Indian nations.-In the same category must be placed the migratory Indian nations occupying lands whose ultimate title is rested in the United States. While that power in the many treaties made with such communities has recognized their political existence and their capacity to maintain the relations of peace and war, it was nevertheless decided by the Supreme Court in 1831 that the Cherokee nation dwelling within the limits of the state of Georgia was not a "foreign state," in the sense in which that term is used

61 See Historia de la Republica d'Andorra, Barcelona, 1848; The Edinburg Review, No. 230; Twiss, vol. $i$, pp. $42-43$.
62 Günther, Europäisches Völker. recht, i, c. i, § 19. 
in the constitution, but a "domestic dependent nation." The relation thus existing is a unique one. As the court, speaking through Chief Justice Marshall, has expressed it: "They look to our government for protection; rely upon its kindness and its power; appeal to it for relief to their wants; and address the President as their great father. They and their country are considered by foreign nations, as well as by ourselves, as being so completely under the sovereignty of the United States, that any attempt to acquire their lands, or to perform a political connection with them, would be considered by all as an invasion of our territory, and an act of hostility." ${ }_{63}$

\$137. Native states of India under British protection-Canada.-In order, however, to view dependent protected states, not the subjects of international law, upon the largest scale we must turn to the British Empire, which exercises absolute extermal control over the native states of India that enjoy more or less internal sovereignty under a system of treaties in which the imperial power has agreed to respect certain limitations upon itself in favor of local rights and privileges. such guarantees, under the "residuary jurisdiction" that embraces all matters not expressly provided for in treaties. are, however, more imaginary than real. All of the states admit the absolute supremacy of the British government; some of them recognize its right to interfere in their internal affairs; while none of them elaim the right of diplomatic intercourse with each other or with foreign powers. Despite the fact that it is a perfectly organized federal commonwealth, with almost complete power to regulate its internal affairs without interference from the parent state, Canada must likewise be classed, so far as international law is concerned, as a dependent protected state.

$\S 138$. Protected state may preserve international existenceU. S. of Ionian islands.-In some cases protected communities have been subjected to external control under circumstances permitting them to retain an international existence as partsovereign states. As Hall (sec. 4) has well expressed it, in order to secure that status to such a state, it is necessary that "its members must owe no allegiance except to the community itself, and its international liberty must be restrained in those matters only in which the control of the protecting power tends to prevent hostile contact with other states, or to secure

${ }_{63}$ The Cherokee Nation v. The State of Georgia, 5 Peters, 1. 
safety if hostilities arise." A happy illustration of such a case was that presented by the United States of the Ionian Islands prior to their cession by Great Britain to Greece. These islands, which had formed a part of the maritime possessions of Venice, and which passed under the sovereignty of the French republic in $1797,{ }^{6+}$ were finally, by treaties made in Norember, 1815, between Great Britain, and her three allies, Russia, Prussia and Austria, respectively, placed under the immediate and exclusive protection of the first named, because the Emperor Alexander had promised that the islands should neither be incorporated in any other state nor made the vassal of any suzerain. The ling of Great Britain and Ireland thus assumed as sovereign protector the entire control of the foreign diplomatic relations of a single free and independent state, which was permitted to retain a trading flag of its own, and to receive commercial agents or consuls, subject to such regulations as are observed by such agents in other independent states, without the power, however, to acredit like agents on its own account. While the British government practically controlled the entire executive power in the protected state, it never attempted to bind it in any of its treaties except those made as its protector; and during the Crimean War the position of neutrality which it assumed, although denied at first by the executire, was judicially recognized by a British admiralty court. ${ }^{65}$ By the external control reluctantly assumed by Great Britain, and voluntarily surrendered by her in $1864,{ }^{66}$ -in both instances under international compacts-Ionian subjects were not converted into subjects of the British crown; they retained their nationality under circumstances which made it possible for them to maintain their neutrality even during a war begun by the protecting state itself.

\section{$\S 139$. Neutral city of Cracow and principality of Monaco.-}

64 Subsequently they were occupied by the joint forces of Russia and the Ottoman Porte, and by the treaty of Constantinople (March 21,1800 ), they were made tributaries of the Sultan, as their protector and suzerain. Martens ( R) vii, p. 41. Under the treaty of Amiens (1802) the Seven Islands were recognized as an independent republic. Martens (N. R.) iii, p. 13. Under the treaty of Tilsit the
Emperor of Russia, ignoring the Porte, transferred them in full sovereignty to France, and during the subsequent course of the war six of them passed to Great Britain by conquest. Only Corfu remained in the hands of France down to 1814, when it was ceded by the treaty of Paris to the Allied Powers.

65 The Leucade. Admiralty Prize Cases, 1854-56, p. 217.

${ }^{6} \mathrm{~A}$ Annuaire, xiii, 1000-1004. 
In May, 1815, the eity of Cracow,-which upon the dissolution of Poland had been assigned (October 13th, 1795) to Austria by the conrention of St. Petersburg, ${ }^{67}$-was, after many interrening vicissitudes, declared in a treaty then made between Russia, Austria and I'russia to be (sera encisagée) forever a free, independent and strictly neutral city, under the protection of the three high contracting powers. ${ }^{68}$ As the triple treaty was annulled and the republic of Cracow suppressed, upon the ground that it had failed to preserve the neutrality upon which its existence depended, ${ }^{69}$ it is now unnecessary to re-examine the intricate and interesting question once involved in its peculiar status as a dependent community. There seems to be some doubt whether the principality of Monaco,-which, by the treat $y^{\text {io }}$ of I'eronne in 1641, placed itself under the protection of France, a protection transferred in the great settlement of $1815^{71}$ to Sardinia,-is now a part-sovereign or fully independent state. It can hardly be denied that Monaco was a protected state under the superior power of Italy, which succeeded to the rights given to Sardinia under the treaties of 1815 and 1817, until after the cession of Nice to France by Italy in 1860. The difficulty arises out of the fact that in February, 1861, the Prince of Monaco, without the concurrence of Italy, definitely ceded to the emperor of the French the communes of Mentone and Rocabruna, which were thus interposed between what remained of the principality and the Italian frontier. As Italy did not protest against the open repudiation of her protectorate, and as France has never attempted to assume one, it is hard to resist the conclusion that Monaco is now a sovereign political community.

Presumption in favor of states originally independent.-In the case of all states imperfectly independent, including such as are member's of confederacies, the legal presumption is that

G7 Martens (R.) vi, p. 171. It was severed from Austria by Napoleon, and by the subsequent treaty of Vienna (Oct. 14, 1809) was attached to the Duchy of Warsaw, then belonging to the King of Saxony. The results of the campaign of 1812 placed the Emperor Alexander in possession of the various portions of territory which had constituted the Duchy of Warsaw (a new state created by
Napoleon), and which were redistributed between Russia, Austria and Prussia under the treaties of May, 1815. Martens (N. R.) ii, p. 225.

Gs Martens (N. R.) ii, p. 251.

69 See Twiss, vol. i, pp. 36-41.

70 Schmauss, Corpus Jur. Gentium Academicum, i, p. 521.

71 Treaty of Paris, Nov. 20, 1815. Martens (N. R.) ii, p. 687. See the subsequent treaty of Turin, 
they are in the full possession of all rights and privileges which they have not expressly resigned. Prima facic they are independent because such was their original condition. ${ }^{72}$

$\S 140$. Christian principalities of 0ttoman empire.-For a diametrically opposite reason the presumption is, that those states have not an international character which have gradually acquired a limited independence ${ }^{73}$ under the suzerainty of the mother state, from whose complete control they have been partially emancipated either by its own voluntary act, or through successful revolt. Leaving out of view the commonwealths once under the suzerainty of the Holy Roman Empire,-an overlordship abolished in substance through the Peace of Westphalia in 1648, and formally surrendered at the dissolution of the empire in $1806,{ }^{74}$ - the best modern illustrations of the relation in question are to be found in the cases of those Christian principalities that have won first partial, and then complete, independence of the Ottoman Empire. The struggles of the oppressed Christian populations to emancipate themselves have been systematically advanced first by Russia, then by the European Concert, in such a way as to secure them under European guaranties, first, local self government under the suzerainty of the Porte, and finally complete sovereignty.

\section{$\S 141$. Emancipation of Roumania and Servia.-The statement}

Nov. 17, 1817, (Nouveau Supplément, ii, p. 343), completing the arrangement of 1815 .

72 "A member of a confederation or a protected state is prima facie independent, and consequently possesses all rights which it has not expressly resigned; a state under the suzerainty of another, being confessedly a part of another state, has those rights only which have been expressly granted to it." Hall, p. 31.

73 "The assumption of a collective authority on the part of the powers to supervise the solution of the Eastern question-in other words, to regulate the disintegration of Turkey-has been gradual. Such an authority has been exercised tentatively since 1826, systematically since 1856 . It has been applied successively to Greece, to Egypt, to Syria, to the Danubian principalities and the Balkan peninsula generally, to certain other of the European provinces of Turkey, to the Asiatic boundaries of Turkey and Russia, and to the treatment of the Armenians." Holland, The European Concert, p. 2. M. Rolin Jacquemyns, in speaking of the action of the powers in connection with the Greco-Turkish contest of 1885-6, has said that within the limits of Ottoman Empire and the small states adjoining there exists "une autorité collective, historiquement et juridiquement établie; e'est celle des grandes puissances." Rev. de Droit Int. xviii, 603.

${ }^{74}$ See above, p. 36. 
has heretofore been made that at the Peace of Carlowitz (1699) the Porte acknowledged the suzerainty of Leopold I of Austria over Transylvania. ${ }^{75}$ By the treaty of Kutschauk-Kainardji made between Russia and Turkey in July, 1774, ${ }^{\text {i6 }}$ the principalities of Moldavia and Wallachia and the province of Bessarabia, which had been overrun by the armies of the Empress Catharine, were restored to the Porte upon condition that their inhabitants should be permitted to exercise the Christian religion, and that the prince of each principality should be permitted to maintain at Constantinople a chargé d' affaircs to be entitled to the prisileges accorded to such by the law of nations. By the treaty of Adrianople, ${ }^{77}$ made in September, 18.9, which declared that the principalities were under the suzerainty of the Porte and the guarantee of Russia, they were given the right to a national administration, with all the privileges of complete commercial intercourse. As heretofore pointed out the Peace of Paris (1856) substituted a European for a Russian guarantee. $^{i 8}$ In 1861 the Porte, in concert with the guaranteeing powers, consented to the union of the principalities under Prince Couza, who was succeded in $1866 \mathrm{by}$ Charles of Hohenzollern as Prince of the United Principalities; and by the treaty of Berlin (1878) the fruit of the union, Roumania, was acknowledged as independent, Irince Charles assuming the title of ling in March, 1881.99 Servia, which became a Turkish provinee after the disastrons battle of Kossovo in June, 1389, did not win the right of Christian worship and an independent internal administration until the making of the treaty of Adrianople ${ }^{80}$ between Russia and Turkey in September, 1829; a concession followed in 1838 by an organic statute conferring the sovereignty of the province, under the suzerainty of the Porte, upon Prince Milosch, in whose family it was made hereditary. By the treaty of Paris ${ }^{81}$ the relations thus established were placed under the guarantee of all the powers, and that condition of things continued down to the

75 See above, p. 107.

i6 Martens (R.) ii, p. 286.

is By the fifth article it was provided that the hospódar should hold his office for life under certain provisions contained in a separate act annexed to the treaty; and in other respects subject to the regulations of the separate act of the convention of Ackerman (Oct. 7, 1826). Martens (N. R.) viii, p. 143; Ibid., vi, p. 1053.

is See above, p. 119.

79 On May the 27th of the same year he was crowned with Euro. pean sanction.

so Martens (N. R.) viii, p. 116.

81 Ibid. (N. R. G.) Xv, p. 770 . 
treaty of Berlin, through which Servia became entirely independent.

\$142. Emancipation of Montenegro.-Montenegro,-originally a district of Servia governed by a prince dependent upon the king of that country,-maintained its independence from the time of the Ottoman conquest of Servia (1389) down to 1516, when its prince, George Tzernoievich, with the consent of the people, transferred his office to the bishop and retired to Venice. The office of prince bishop (Vladika) ${ }^{\text {s2 }}$ thus created, in which the spiritual and temporal powers were merged, although by law elective became in practice hereditary in the family of Petrovich after the close of the seventeenth century. Not until 16:2: was the Porte ever able, by force of arms, to establish even a nominal supremacy over Montenegro; and from that time a continued resistance to such supremacy was carried on with varying fortunes down to 1706 when the Montenegrins attempted to give strength to their cause by placing themselves under the protection of Peter the Great of Russia. After that event it became the custom for the successor of each Vladika to receive consecration at St. Petersburg, the same being considered as a virtual investiture of the office of prince or ruler. $^{83}$ This act of homage to Russia failed, however, to end the strife between Turkey and Montenegro, the former continuing its efforts to subdue the principality down to 1852 , when it was advised by two of the powers to recognize Montenegro's de facto independence without the surrender of its de jure title. Thus it was that in the Treaty of Paris (1856) the declaration was made that "the Sublime Porte considers Montenegro to be an integral part of the Ottoman Empire, but that it has no intention to alter the actual state of things in that country." st Not until the malking of the treaty of Berlin (1878) was Montenegro recognized by the Porte and all the contracting powers as an independent state.

$\S$ 143. Bulgaria still dependent.-Roumania, Servia and Montenegro, which thus became sovereign states after abiding for a long time under the suzerainty of the Ottoman Empire, left behind them Bulgaria, a Danubian principality which has not yet been able to secure its independence. The treaty of Berruler.

82 The word signifies prince or

$83 \mathrm{As}$ to the statement that the vladika who succeeded in 1830 refused the episcopal dignity, see
Phillimore, Int. Law, vol. i, § 94; Twiss, vol. i, p. 108.

84 Martens (N. R. G.) xv, pp. 736, 738. Protocol of conference 25 and 26 March, 1856. 
lin, by which the three first named were finally emancipated, only provided that Bulgaria should be "an autonomous and tributaly principality under the suzerainty of His Imperial Majesty, the Sultan," with a Christian government and a national militia; and that another province bounded on the north and west by liulgaria should be constituted under the name of Eastern Roumelia, ${ }^{85}$ subject to the direct authority of the sultan, with a Christian grovernor-general and administrative antonomy. In 1879 Alexander of Battenberg was elected prince of Bulgaria, and in 1885 he excited a revolution in Eastel'n Roumelia which resulted in its union with Bulgaria and with the proclamation of himself as sovereign. Upon his forced abdication in 1887 he was succeeded by Prince Ferdinand, of saxe-Coburg, despite Russia's opposition unsupported by any other European state. The power's have neither recog. nized the union brought about by the successful revolution of 1885, nor the election of Prince Ferdinand in 1887, and yet they have not attempted to undo either. While in 1883 the representative of the principality was denied the privilege of signing a treaty concerning the navigation of the Danube, upon the ground that the signature of the Porte was sufficient, the fact remains that its rulers are pressing so agrgressively their right to control its affairs, internal and external, as to leave but little doubt that in the near future such efforts will be followed by complete independence.

$\S 144$. Suzerainty of Porte over Egypt.-The suzerainty of the Porte over Egypt, which for centuries was a vassal state of the Ottoman Empire, administered through a Turkish pasha, -was placed in imminent peril when Melemet $\mathrm{Ali}$, who, after the annihilation of the Mamelukes, became the undisputed master of the country, attempted in 1831 to win from the Sultan entire independence. ${ }^{\mathrm{s}}$ After a series of brilliant military successes he advanced so near to Constantinople that Russia was forced to prevent its capture by sending her fleet to the IBosphorus in February, 1833. In the following May the convention of Kutayah, brought about through the mediation of France and Great Britain, secured the peace of the Levant for a time by a cession to Mehemet Ali of the whole of Syria, and to his son Ibrahim the collectorship of Adana. When the

85 For the details as to Bulgaria and Eastern Roumelia, see Holland, The European Concert, pp. $238-40$.
86 In November, 1831, Mehemet invaded Syria, and the Turks were defeated at the decisive battle of Konieh on December 21, 1832. 
former renewed his attempt to impair the integrity of the empire, he was met by the intervention of Great Britain, Russia, Austria and Prussia, who, in the interest of the peace of Europe, made with the Porte in July, 1840, the Quadruple Treaty of London, ${ }^{87}$ whose terms the power's agreed to enforce against Mehemet, to whom was given, upon the payment of an annual tribute, the administration of Egypt, with the reversion of it to his descendants in the direct line. By virtue of that treaty, and the Sultan's firman of June, 1841, Egypt was erected into an hereditary paschalic under Mehemet Ali and his descendants, who were authorized to maintain a limited army, contract loans and make non-political conventions with foreign powers.

Sultan's nominal control over foreign affairs.-The local authority thus granted was subject, however, to the suzerainty of the Sultan, who retained the right to grant exequaturs to foreign consuls resident at Alexandria or Cairo, to give operation to treaties of commerce concerning Egypt by his firman addressed to the pasha, and to direct generally the external affairs of the country as the overlord to whom foreign nations must address themselves in the first instance. This conventional arrangement, which became a part of the public law of Europe, and which still exists in theory, has been set aside in fact as the result of the political and financial difficulties which forced Great Britain and France in 1879 to appoint controllers-general of their own, with the rank of Egyptian ministers, with power to inquire into every financial branch of the public service. In order to rid Egypt of that kind of foreign control Arabi Pasha created the revolt in 1882 which Great Britain, owing to the lack of co-operation from France, was forced to crush alone. ${ }^{s s}$ Since that time her army of occupation has remained under the pledge that it will be withdrawn so soon as the finances of the country can be reorganized and stable authority secured under a reliable and permanent native administration. In the meantime, government is carried on

87 For the text, see Holland, The European Concert, pp. 90-93. While France was not a party to the treaty she gave the settlement her moral influence. Memorandum of Mr. Thiers, Minister of Foreign Affairs (Oct. 5, 1840). Martens (N. R. G.) i, p. 183; Twiss, vol. i, p. 94 . 8s "In December England agreed, though France demurred, to the abolition of the Dual Control which was effected by a decree of 18th of January, 1883." Holland, Concert of Europe, p. 108, citing Parl. Papers, 1883, Egypt, No. 6, p. 32. 
under the direction and advice of Great Britain as the real suzerain.

Mixed tribunals and Suez Canal.-In the hope of securing a more perfect administration of justice, mixed tribunals were established in 1875, consisting of courts of first instance with a mixed stafr of judges, subject to al court of appeals composed of four native and six European members, the latter being drawn from the several countries specially interested. In October, 18s7, Great Britain and France entered into a convention for the neutralization of the Snez Canal, ${ }^{59}$ which, under the terms of the treaty, is to be free to shipes of all nations even in tine of war, subject only to the proviso that the belligerents shall neither embark nor disembark troops or materials of wal along the canal or in its ports of access. The stipulation that the nentrality of the canal shall be guarded in the first instance by the Khedive, and in case of his inability by the I'orte in conjunction with the powers, was promptly agreed to by Germany, Austria, Italy and Spain; and, after some objections from Russia and Turkey, by the last named in $1888^{90}$

\section{$\$ 145$. Belligerent communities-internal and external sov-} ereignty contrasted.-It is proper to reckon among part-sovereign states those communities which in their effort to separate from the mother state and to establish a distinct political existence of their own have won, through a recognition of their belligerency, a temporary or inchoate sorereignty which may ripen into a perfect one with the final recognition of their independence. Whether such an effort shall be made, for what reason, and in what form, are internal and domestic questions which are purely national; whether such a community shall be admitted into the family of nations, and upon what terms, are questions purely international. In that way every state possesses two kinds of sorereignty: first, an intei-

89 As to the negotiations and disagreements concerning the international status of the canal that took place between its opening in 1869 and the settlement of 1888 , see Lawrence's Essay on Some Disputed Questions in Modern International Law, ii.

90 In November, 1875 , the Khedive sold his canal shares to the
British Government; in a circular dispatch of Jan. 3, 1883, Lord Granville proposed that the canal should be neutralized; and during negotiations with France in 1884 he proposed that that process should be extended to Egypt as a whole. Holland, Concert of Europe, pp. 103,109 and note 4. 
nal sovereignty, inherent in the people as a whole, whose exercise is vested in its rulers by virtue of its constitutional law (droit public interne); second, an external sovereignty consisting of its right as an independent political community to deal with all others of its class npon equal terms under the rules of internationel law (droit public cxtcrne). In the case of an older state such sorereignty was acquired when the organization of civil society began; in the case of a younger one it dates from the time when it finally makes good its independence against the community from which it has separated itself. That process of separation is usually broken into two distinct stages: first, that which is marked by a recognition of belligerency; second, that which is marked by a recognition of independence. The starting point is the effort made by the revolting community to establish internal sovereignty which depends upou its own acts alone, and not upon the subsequent recognition of other states. It was therefore held by the Supreme Court of the United States to be "a principle which is believed to be undeniable, that the several states which compose this union, so far at least as regards their municipal regulations, became entitled, from the time when they declared themselves independent, to all the rights and powers of sovereign states, and that they did not derive them from concessions made by the British king. The treaty of peace contains a recognition of their independence, not a grant of it. From hence it results, that the laws of the several state governments were the laws of sovereign states, and as such were obligatory upon the people of such state, from the time they were enacted." 1

$\$ 146$. Recognition of belligerency and its effects.-After the struggle for sovereignty has begun, a recognition of belligerency may come either from the parent state or from foreign states, or from both. It is not to be expected that either will consider whether or no it will make such recognition until the revolting community has made such a show of force, -by subjecting a definite area of territory to the control of an organized gorernment through the maintenance of armies fighting under the rules of cirilized warfare, or by the equifment of cruisers, if the struggle is in whole or part maritime, -as to establish beyond question the existence of war, as now

1 McIlvaine v. Coxe's Lessee, 4 et al. v. Gaillard et al., 12 Wheat., Cranch, p. 212. See also Harcourt 524. 
understood, as a fact. ${ }^{2}$ The new organization thus set up is expected to have such a de facto political existence and such resources as to enable it, if left alone, to constitute a state capable of maintaining a permanent place in the family of nations. The power first called upon to deal with the new condition of things is necessarily the parent state itself, who must, if it refuses to recognize the insurgents as belligerents, regard them as rebels on land and pirates at sea, and their acts in taking supplies from the invaded territory as robbery. With that purely internal question of municipal law between a recognized state and a part of its revolted subjects foreign states have nothing whatever to do, so long as the state of war thus existing does not affect their interests. While as a general rule the parent state is not swift to extend a recognition of belligerency to those in arms against it, motives of humanity, coupled with the desire to protect its forces from military reprisals, usually force it to that result so soon as the struggle assumes serious proportions.

$\$ 147$. Indirect recognition-duty of executive.-It cannot be expected, however, that the parent state will volunteer a direct and formal recognition; it hardly ever does more than perform certain acts from which its indirect recognition may be inferred. During the war between the American colonies and the mother country, Denmark, who had not recognized their belligerency, delivered to Great Britain in 1779 some merchant ressels sent by Paul Jones as prizes into Norwegian ports. The United States afterwards made claim upon Denmark upon the ground that the conclusion by England and the American insurgents of cartels and the like anounted to an: indirect recognition of the latter as belligerents, and consequently east upon Denmark and other foreign nations the duties of neutrality. ${ }^{3}$ In an indirect manner a recognition of

2 "It is certain that the state of things between the parent state and insurgents must amount in fact to a war, in the sense of international law; that is, powers and rights of war must be in actual exercise; otherwise the recognition is falsified, for the recognition is of a fact." Dana's Wheaton, p. 35. As to the general question involved in a recognition of belligerency, see Bluntschli, $§ 512$, and in the Revue de Droit International, ii, 452; Calvo, $\S 68-70$; Bernard, Historical Account of the Neutrality of Great Britain during the American Civil War, ch. 5 and 7 ; Lawrence, pp. 77-79; Hall, § 5; The Lilla, 2 Sprague, p. 177; Halleck, p. 73 seq.; Walker, pp. 115-118.

3 See Sparks's Dip. Corr., iii, p. 121; Sparks's Life of Franklin, viii, 407-462; State Papers, iii, 4; Lawrence's Wheaton, Introd., 
belligerency was extended by the government of the United States to those of its citizens who combined against it under the perfectly organized de facto government of the Southern Confederacy. When the question, whether or no such recognition had in fact been indirectly extended, was presented for judicial review, the Supreme Court said: "As a civil war is never publicly proclaimed, eo nomine, against insurgents, its actual existence is a fact in our domestic history which the court is bound to notice and to know. * * Whether the President is fulfilling his duties, as commander-in-chief, in suppressing an insurrection, has met with such armed hostile resistance, and a civil walr of such alarming proportions as will compel him to accord to them the character of belligerents, is a question to be decided by him, and this court must be governed by the decisions and acts of the political department of the government to which this power' was intrusted. 'He must determine what degree of force the crisis demands.' The proclamation of blockade is, itself, official and conclusive evidence to the court that a state of war existed which demanded and authorized a recourse to such a measure, under the circumstances peculiar to the case. The correspondence of Lord Lyons with the secretary of state admits the facts and concludes the question."

\section{$\S 148$. Duty of foreign state when recognition of belligerency} demanded.-Has a revolted community, after it has arrayed a considerable population in arms under an organized government occupying a definite area of territory, a legal right to demand recognition of its belligerency of foreign nations; or must such recognition be sought at their hands as a matter of pure grace and favor? While there are anthorities that support the affirmative as to the legal right, ${ }^{5}$ the sounder view seems to be that as the belligerent community is not a legal person, and as the only ground upon which it can rest its demand is that of humanity, it has nothing ligher than a moral claim to such recognition. ${ }^{6}$ From the standpoint of

cxxxiv; Mr. Wheaton's dispatch to Mr. Upshur, Nov. 10, 1843. "The claim against Denmark was kept alive by intermittent action until 1844, and does not appear to have been ever formally dropped." Hall. p. 34 , note.
699. Proclamation of blockade is conclusive evidence of war. The Mary Clinton, Blatchf. Pr. 556.

5 Bluntschli ( $\$ 512)$ maintains the right directly, and Vattel (III, ch. xviii, $\S 293-4)$ by implication. 6 Hall, pp. 32-35.

4 Prize Cases, 67 U. S., 635- 
international law a foreign state has no right to recognize the belligerent character of those in insurrection against a parent state, until its own interests become so involred, or so threatened as to make such recognition a necessary measure of self protection. $^{7}$ Before a foreign state attempts to influence the result of the contest, by extending recognition to insurgents against a firmly established government to which it owes legal and friendly duties, it must maturely consider whether from the peculiar nature of the contest its interests are so involved as to make such action upon its part really necessary. It is not within the province of the private citizens of a foreign state, or of its judicial or naval officer's, at home or abroad, to pass upon that question, which belongs exclusively to the executive department of the government armed with the right to prescribe the rule for the guidance of all. ${ }^{8}$ While such rule should not be proclaimed with precipitation, every state foreign to the contest "owes it to its own citizens, to the contending parties, and to the peace of the world, to make that decision seasonably. If it issues a formal declaration of belligerent rights prematurely, or in a contest with which it has no complicity, it is a gratuitous and unfriendly act. If the parent government complains of it, the complaint must be upon one of these grounds. To decide whether the recognition was uncalled for and premature, requires something more than a consideration of proximate facts, and the overt and formal acts of the contending parties. The foreign state is bound and entitled to consider the preceding history of the parties; the magnitude and completeness of the political and military organization and preparations on each side; the probable extent of the conflict, by sea and land; the probable extent and rapidity of its development; and, abore all, the probability that its own merchant ressels, naval officers and consuls may be precipitated into sudden and difficult complications abroad. The best that can be said is that the foreign state may protect. itself by a seasonable decision either upon a test case that arises, or by a general prospective decision; while, on the other hand, if it makes the recognition prematurely, it is liable

7 Le seul motif vraiment ration- la reconnaissance du titre de belnel et légitime pour qu'un êtat ligêrant, définit la position qu'il attribue le caractére de belligérent entend assumer à l'égard des comaux factions d'un autre état, c'est que la lutte de ces factions compromet les droits et les intérésts du gouvernement étranger, qui par

battants. Calvo i, $\S 68$.

s U. S. v. Palmer, 3 Wheat. 610; The Divina Pastora, 4 Wheat. 52; The Nuestra Senora, Ibid., 497. 
to the suspicion of an unfriendly purpose to the parent state."

$\S 149$. Reasons for prompt recognition in case of maritime war. -If a land war is in question, and the insurrection is confined to the interior of a country surrounded by loyal provinces, and in that way isolated from foreign states, it is not the custom for such states to act at all, because as their interests are not likely to be involved they have no reason for self-protection. If, however, the revolted district be so near to the frontier of a foreign state as to force upon it the decision of the question whether or no war actually exists, it is within its province alone to determine that question in the light of the special facts involved upon which it must rely for the, rindication of its conduct. ${ }^{10}$ In the case of a maritime war, states interested in commerce upon the sea have a greater right to take prompt and decided action, without suspicion of bad faith, because. at any moment they may be called upon to pass upon the status of cruisers, the question of prize, or the legality of blockades. If it is war, the commissioned cruisers of either side may search or capture foreign merchant vessels; if it is not, such ressels can resist all such attempts. If it is war, the prize courts of either side can adjudicate questions properly brought before them; if it is not, they cannot lawfully exist. If it is war, foreigner's must respect the blockades by which the parent states close insurgent ports jure gentium; if it is not, they will not respect paper decrees closing such ports, in any erent.

$\$ 150$. Notable recognitions of belligerency.-In order to determine the circumstances under which a recognition of belligerency is permissible, it is helpful to study the cases in which such recognition has been actually extended by conscientious and important foreign states. When in 1825 England recognized the belligerent rights of the provisional govermment of Greece, and Turkey complained that no national character could properly belong to subjects in rebellion, Canning's reply was that "the character of belligerency was not so much a principle as a fact, that a certain degree of force and consistency acquired by a mass of population engaged in war entitled that population to be treated as a belligerent, and, eren if this title were questionable, rendered it the interest well understood of all civilized nations so to treat them." ${ }_{11}$ A

9 Dana's Wheaton, pp. 36-37.

10 Hall, p. 36.

11 Hansard, vol, clxii, p. 1566. See also Abdy's Kent (1878), 94; Lord Russell's speech, May 6, 1861; Stapleton's Life of Canning, 476. 
profitable study may also be made of the fact involved in the recognition of belligerency by France and Holland during the American Revolution $;^{12}$ of those involved in a like recognition by the United States in favor of the South American colonies of Spain during the civil war between them and the parent state; and of those involved in a like recognition by the United States in favor of Texas during the eivil war between that state and Mexico. ${ }^{13}$

\section{$\S 151$. Great Britain's recognition of Southern Confederacy.-} The most inportant and exhaustive recent diseussion of the circumstances under which a foreign state may properly extend a recognition of belligerency was that which ensued between Mr. Adams and Earl Russell (April 7 to September $18,1865)$, in the course of which the former contended that Great Britain's recognition of the belligerent rights of the Sonthern Confederacy was "mnprecedented and precipitate." Earl Russell contended in reply that, while the facts involyed were withont an exact parallel, his government was in duty bound to pass upon them promptly under circumstances that forced it to decide on the one hand whether it would permit the right of search and blockade as acts of war; and on the other whether those commanding the ships of the Confederates, appearing in every part of the world under their letters of marque, should be treated as pirates or as lawful belligerents. ${ }^{14}$ There was no dispute as to the two controlling facts. On April 19th, 1861, President Lincoln put forth his proclamation blockading the ports of the seceded states, an act which he said was performed "in pursuance of the laws of the United States and of the law of nations in such case provided." 15 In the prize cases heretofore eited ${ }^{16}$ it was held by the Supreme Court of the United States that the I'resident had

12 Annual Register, 1776, pp. 182, 183, 1779, p. 249; Martens' Causes Célibres, i, 113; correspondence between Mr. Adams and Earl Russell (April 7th to Sept. 18th, 1865).

13 Wharton, Int. Law Dig., \$ 69; Opinions of Attorneys-General, iii, 120; Canning's Life, 399; British Annual Register, 1823, 146; Mr. Forsyth to the Mexican Minister, Sept. 20, 1836.

14 Sec Lawrence's Wheaton (ed.
1863), 44; an article entitled "A famous diplomatic dispatch," in North American Review for April, 1886; Goldwin Smith on the recognition by Great Britain of Southern belligerency in 13 Macmillan's Mag., 168; Bemis's pamphlets on the recognition of belligerency, Boston, 1865.

15 Extract from the proclamation.

16 See above, p. 187. 
a right jure belli to institute such a blockade, which neutrals were bound to regard; that the proclamation of blockade was, itself, official and conclusive evidence to the comrt that a state of war existed which demanded and authorized a recourse to such a measure under the circumstances peculiar to the case. Not until May 13, more than three weeks after the issuance of such proclamation by the President, did the queen proclaim her neutrality between the two belligerents. As the propriety of that act had been indirectly affirmed by our own Supreme Court, ${ }^{17}$ it is unnecessary to make farther reference to a contention which drew its only real support from passions that have happily passed away long ago.

§152. Recognition should be formal.-When a foreign state deems it necessary to protect itself by a recognition of belligerency, it should always render its intention perfectly clear by making it in a formal way so that all may know the date from which its neutrality begins. ${ }^{18}$ After such a step has been taken it is irrevocable,except by agreement, so long as the circumstances exist under which it was granted, because, while it may be a revocable concession as between grantor and grantee, as to third parties it creates new legal relations which cannot be arbitrarily determined so long as a state of war actually continues. ${ }^{19}$ A proof of that assertion may be found in the fact that such declarations do not benefit the insurgents only. While they gain a recognized status, conferring on them the right to commission cruisers at sea, to make loans, and to enjoy all the protection incident to civilized warfare on land, the parent state is at the same time entitled to have the blockades of its own ports respected, to assert against neutral commerce all the powers of a party to a maritime war, and at the same time to be exempt from responsi-

17 "Yt would seem, then, that if the British Government erred in thinking that the war began as early as Mr. Lincoln's proclamation in question, they erred in company with our Supreme Court." Woolsey, Int. Law, § 180 . See also Bernard's British Neutrality, chaps. iv-vii; M. Bluntschli's summing up of the controversy in Rev. de Droit, Int. ii, 462.
18 On April 22, 1793, President Washington issued his celebrated proclamation of neutrality, recognizing the existence of war between France on the one part, and Great Britain and other powers on the other, and declaring the purpose of the U. S. to observe a course "friendly and impartial towards the belligerent powers." 19 Hall, pp. 37-38. 
bility for the acts of its revolted subjects in the insurgent territory. ${ }^{20}$

$\S 153$. Recognition of independence-when an act of intervention.-When one state signifies its assent to the admission of another into the family of nations by a recognition of its indefendence, the propriety and timeliness of such an act must be tested by substantially the same principles that govern when a recognition of belligerency is in question. A distinction must be kept steadily in view in both cases between an act of recogrnition performed by the parent state, and a like act when performed by a foreign one. ${ }^{21}$ Whether performed by the one or the other, it is supposed to be simply an acknowledgment of a pre-existing fact, an admission the former is not likely to make until forced by necessity to abandon all hope of subduing the community in revolt analinst it. When, therefore, the party mainly interested makes such an admission, no doubt should remain in the minds of other govermments as to their course in the premises. ${ }^{22}$ Difficulty often arises when a foreign state desires to recognize the independence of the struggling community before the parent state is ready to do so, because a premature or unjustifiable recognition either of belligerency or independence is really an act of interrention which the parent state may meet by a declaration of war. If the parent state and the foreign state differ, as they often do, as to the rircumstances justifying recognition, each must decide for itself,and it there is a conflict the only arbiter is arms.

$\$ 154$. Notable recognitions of independence.-A pointed illustration of the two contingencies may be found in the circumstances attending the recognition of the independence of the Cnited States by foreign powers. After Great Britain herself had recognized their independence in the preliminaries of 1782 ,

20 See declaration of Mr. Adams, June 14,1861 , as to effect of concession of belligerent rights to Confederate States. Papers relating to Foreign Affairs, etc., p. 89 ; Dana's Wheaton, p. 37.

21 The word "recognition" does not have the same meaning in the one case as in the other. Such was the contention of Sir James Mackintosh in his spech on the recognition of South Am. States, and Canning held a similar view.
See Mackintosh's Miscellaneous Works (ed. 1851), p. 749; Hansard, N. S. xi, 1397.

22 "When a state has itself recognized the independence of a revolted province it cannot pretend that recognition by other states is premature." Hall, p. 88. It was nearly seventy years after the declaration of independence by the Netherlands that it was recognized by Spain in the treaty of Münster, 1648. 
she did not consider it as an unfriendly act for other powers to follow her example. But when at an early stage in the struggle (1778) France and Holland extended such recognition she made it the cause of war against both. ${ }^{23} \mathrm{Mr}$. John Quincy Adams, when writing to President Monroe ${ }^{24}$ in 1816 upon a kindred subject, contested the grounds upon which Great Britain had acted. He said "there is a stage in such (revolutionary) contests when the party struggling for independence has, as I conceive, a right to demand its acknowledgment by neutral parties, and when the acknowledgment may be granted without departure from the obligations of neutral. ity. The neutral nation must, of course, judge for itself when this period has arrived; and as the belligerent nation has the same right to judge for itself, it is very likely to judge differently from the neutral, and to make it a canse or pretext for war, as Great Britain did expressly against France in our revolution, and substantially against IIolland."

$\S 155$. Channels of intercourse must be kept open.-While political sympathies generally influence the time at which such recognitions are made, the commercial interests of nations forbid that they shall close their eyes very long to accomplished facts. All states owe it as a duty totheir citizens tokeep open the channels of intercourse so that they may trade with and sojourn in every state having a de facto existence. Thus by necessity states are compelled to establish relations with all new communities as soon as that may be done without iujury to the parent state from which they liare revolted. Such state can, however, justly claim injury if a recognition of independence occurs while it is making a substantial struggle for the recovery of its authority, regardless of the fact whether the war is just or unjust. On the other hand, it has no right to complain after its efforts in that direction have become so feeble and inadequate as to afford no reasonable hope of ultimate success.

$\S 156$. Recognitions of South American republics by U. S. and Great Britian.-Such were the principles clearly defined during the course of the long discussion which preceded the recognition by the United States and Great Britain of the indepen-

23 Martens, Causes Célibres, i, hand, admits that, under the cir370-498; Wheaton, Hist. Law of cumstances, the act of France was Nations, pt. iii, §12, 220-294.

24 Mss. Monroe Pap., Dept. of sion."

State. Wheaton, on the other 
dence of the South American republics. Of the insurrections which broke out through the whole of South America in $\mathbf{1 8 1 0}$, that which oceurred in Buenos Ayres $^{25}$ was immediately successful; and in due time like success followed the efforts made by Chile, Venezuela and the provinces north of La Plata. And yet so cautions was the government of the United States that when Mr. Clay proposed in Congress in 1818 a sympathetic mission to the revolted provinces his motion was rejected by a large majority. ${ }^{26}$ President Monroe in his message of December, 1819, while recommending a revision and improvement of neutrality laws, manifested, lowerer, a somewhat different spirit when he said that "the steadiness, consistency, and success, with which they have pursued their object, as evidenced more particularly by the undisputed sovereignty which Buenos Ayres has so long enjoyed, evidently give them a strong claim to the farorable consideration of other nations. These sentiments on the part of the Cnited States have not been withheld from other powers with whom it is desirable to act in concert." In his message of December, 1820 , he gave emphasis to that statement by expressing the hope that a change of government in the parent state would bring about a recognition of independence in view of the fact that "in no part of Sonth America has spain made any impression on the colonies." Nerertheless the senate refused to pass Mr. Clay's fresh resolution for the recognition of their independence. brought forward in the House of Representatives February, 1821, after its adoption by that body. Not until January, 1822, did Congress conclude to adopt, by an almost unanimous vote, the Iresident's recommendation that the independence of Mexico and the Spanish provinces of South America should be acknowledged, and that diplomatic relations should be estab. lished with them. ${ }^{27}$ On the 6th of $A$ pril $M r^{2}$. Adams, secretary of state, in explaining to Mr. Anduaga, the minister of Spain, ${ }^{2}$ the motives that prompted the final act said: "In every question relating to the independence of a nation two principles

25 It formally declared its independence in 1816 .

26115 nays to 45 yeas. 2 Annals, 1st sess. 15th Cong., 1655. See also, as to the entire transaction, J. C. Bancroft Davis's notes to Treaties of the U. S.

27 On the 4th of May, 1822, Congress made an appropriation "to defray the expenses of missions to the independent nations on the American continent." 3 St. at L., 678.

2 Mss. For. Leg. Notes. As to the reception of the action of the U. S. in England, see Gallatin's Writings, vol. ii, p. 240. 
are incolved, one of right and the other of fact; the former exclusively depending upon the determination of the nation itself, and the latter resulting from the successful execution of that determination. $* *$ This recognition is neither intended to invalidate any right of Spain, nor to affect the employment of any means which she may yet be disposed or enabled to use with the view of reuniting those provinces to the rest of her dominions. It is the mere acknowledgment of existing facts with the view to the regular establishment with the nations newly formed of those relations, political and commercial, which is the moral obligation of civilized and Christian nations to entertain reciprocally with one another." Not until 1825 did did Great Britain resolve to make a like acknowledgment, the reason for which as stated by Lord Liverpool-the head of a govermment in which Camning was foreign secretary-was "that there was no right while the contest was actually going on. * * The question ought to be-was the contest going on? He for one could not reconcile it to his mind to take any such step so long as the struggle in arms continued undecided. And while he made that declaration he meant that it should be a bona fide contest." ${ }^{9}$ Great Britain thus refused to act until it was absolutely clear that Spain had really given up the contest, and that the South American republics had in fact gained their independence.

$\S 157$. Recognition of Texas by U. S.-The United States acted with equal deliberation in the recognition of the independence of Texas, which, after a year of warfare, made its declaration in December, 1835. Although the revolted Texans really ended the war in the decisive battle of San Jacinto in April, 1836, and took the Mexican president prisoner, President Jackson in his message ${ }^{30}$ of December of that year counseled delay because, he said, "a premature recognition under these circumstances, if not looked upon as a justifiable cause of war, is always liable to be regarded as a proof of an unfriendly spirit to one of the contending parties. All questions relative to the govermment of foreign nations, whether of the Old $\mathrm{or}^{*}$ New World, have been treated by the United States as questions of fact only." Not until March, 1837, was the independence of Texas recognized by the United States, when Mr. Forsyth, secretary of state, said: "The indepen-

29 Hansard, N. S. $x, 974$; Martens (N. R.) vi, 148, 154 .
30 Messages of the Presidents, vol. iii, p. 266 . 
dence of other nations has alway's been regarded by the United States as a question of fact merely, and that of every peopie has been invariably recognized by them whenever the actual enjoyment of it was accompanied by satisfactory evidence of their power and determination permanently and effectually to maintain it. This was the course pursued by the United States in acknowledging the independence of Mexico and the other American states, formerly under the dominion of Spain. The United States, in recognizing Texas, acted in perfect accordance with their ordinary and settled policy." 31

$\S 158$. All must finally recognize governments de facto.-Thus has our federal republic enphasized the doctrine, which all states are forced to accept in their actual dealings with each other, that all must finally recognize the govermment de facto. Even in monarchical countries in which ideas of legitimacy and divine right are at the root of state institutions, while there is a greater prejudice against the acceptance of a new regime founded on revolution, it is practically impossible for their administrators to hold ont against accomplished facts. While the European governments refused to recognize the French Republic of 1792 because of its instability and its objectionable character, they found it convenient to recognize successively the revolutionary governments of Louis Phillippe in 1830, of the Republic in 1848, and of the Empire in 1852.

$\S 159$. Recognitions, formal and informal.-While any act which clearly indicates the intention to recognize independence is sufficient, the most formal way to express it is by a separate declaration to that effect addressed to the new state, or by a like declaration embodied in a treaty with it. In the manner first named Great Britain chose to recognize the Congo Free State. In a declaration made in a treaty of alliauce dated February 6, 1778, France set forth the fact that the "essential and direct end of the present defensive alliance" is to maintain the sovereignty and independence of the United States.32 Great Britain, France and Russia, after having indirectly recognized the independence of Greece by the making of consular

$31 \mathrm{Mr}$. Forsyth, Sec. of State, to Mr. Castillo, Mch. 17, 1837. Mss. Notes, Mex. In 1840 the independence of Texas was recognized by Great Britain and France.

32 As to the obligations imposed on the U. S. by that treaty, see
Phillimore, Int. Law (3 ed.), vol. iii, p. 228; Lyman's Diplomacy of the U. S., 38; Randall's Jefferson, vol. 1, chap. xiv; Chirac v. Chirac, 2 Wheat., 259; Lodge's Hamilton, 49. 
and commercial agreements with her in $182 \bar{\tau}$, formally recognized it in a protocol in 1832; and in that form the German Empire was recognized by the plenipotentiaries of the great powers who met in the conference held at London in January, 1871. The independence of Belgium was promptly recognized by the great powers in 18:30, without the consent of Holland, by admitting her as a party to a treaty in which her boundaries were defined and her neutral character established. And yet the fact must be borne in mind that the cases of Greece and Belgium are rather illustrations of foreible intervention than of mere recognition. Indirect recognition may result by implication from the sending of a diplonatic representative to a new state, or from receiving one from it, or even from the grant of an exequatur to one of its consuls. ${ }^{33}$

$\S 160$. Attributes of sovereign states as moral persons.-As soon as a political community which has set up a separate national existence of its own receives recognition of its independence, it enters at once into the full enjoyment of sovereignty as a corporate person endowed not only with the right to perpetuate its existence as such by an unbroken succession of new members, but with the attributes and responsibilities incident to "moral persons, having a public will, capable and free to do right and wrong, inasmuch as they are collections of individuals, each of whom carries with him into the service of the community the same binding law of morality and religion which ought to control his conduct in private life." 34 Such a sovereign has the right to claim independence of and equality with all others of its class, and to exercise jurisdiction throughont its territory. The postulate is fundamental that jurisdiction and territory are co-extensive. ${ }^{35}$ With a few exceptions, which will be explained when the ${ }^{36}$ two broad divisions of the subjects are examined in detail, a sorereign state has jurisdiction over all persons and things within its territorial limits, and in some instances such jurisdiction orer both extends beyond its limits and thus becomes exterritorial. Among its several attributes of sovereignty may also be noted the rights of a state to maintain diplomatic intercourse with other states; to make treaties with them; and, under certain

33 Hertslet's Map of Europe by Treaty, Nos. 149, 152 and 441; Parl. Papers, Africa, No. 4, 1885; Wharton's Int. Law Dig., §115; Hall, § 26 .
34 Maine, Int. Law, p. 33.

35 Walker, Science of Int. Law, p. 112 seq.

$36 \mathrm{Cf}$. the two following chapters. 
exceptional conditions, to intervene in their internal affairs. ${ }^{37}$ $A$ gainst the exceptional and extraordinary right of interven. tion stands the normal right of every state to manage its own affairs, internal and external, without outside interference. It is the privilege of every state to adopt any form of government it deems best suited to its internal wants and conditions, and its identity is never lost so long as its corporate existence survives. While that is preserved neither internal revolutions, nor alienations of parts of its territory can diminish any of its rights or discharge it from any of its obligations. ${ }^{38}$

$\S 161$. Effects of temporary suspension of state life.-The life of a state is not necessarily extinguished even by the temporary suspension during a civil war of its authority over those who owe it allegiance. Neither a change in the person of its ruler nor a complete transformation in the internal organization of its government can affect the treaties ${ }^{39}$ or pub- $^{-}$ lic debts of a state so long as the corporate identity remains. As the people as a whole were bound at their creation by the acts of authorized agents, each new grovernment succeeds not only to the fiscal rights but to the fiscal obligations of its predecessor. The obligation to pay all debts previously contracted endows each new government of course with the public domain and all other property to which the state is entitled. ${ }^{+0}$ A transfer of the public property through revolution to a new government does not necessarily work any change in the prop. erty rights of private individuals. The dominant party can, however, if possessed of the supreme powers of the state, appropriate the whole or a part of the property of such individuals through a system of confiscation. ${ }^{* 1}$ A revolutionary

37 See chapters iv, $v$ and $v i$ of this part.

38 "The identity of a state, therefore, is considered to subsist so long as a party of the territory which can be recognized as the essential portion through the preservation of the capital or of the original territorial nucleus, or which represents the state by continuity of government, remains either as an independent residuum or as the core of an enlarged organization." Hall, p. 24. Twiss, vol. i, pp. 20-21. 39 "The treaty relating to national objects remains in force so long as the nation exists as an independent state." Dana's Wheaton, p. 46 "There may be exceptions, however, to this rule with respect to certain treaty engagements, which come under the general division of personal as contradistinguished from real treaties." Twiss, vol. i, p. 21, citing Vattel, II, ch. 12, § 183; Wolf, Jus Gentium, \& 414.

40 Heffter, Völkerrecht, § 24.

41 The right to confiscate exists in full force, when the war is domestic or civil. Page v. U. S., 11 Wallace, pp. 268-331. 
government may also during the period of its authority alienate the whole or $^{*}$ a part of the public domain. Upon a return to the ancient regime all private property not confiscated, and the public domain not alienated, revert to their former owners just as in the case of conquest they revert upon the evacuation of territory occupied by a public enemy. ${ }^{42}$ The validity of all intervening transfers and all acts of confiscation are then subject to contest under municipal law as administered in state tribunals. Where foreign governments or their subjects treat with the actual lead of the state, or a government de facto acquiesced in by the nation, and thus acquire a part of the public domain or private confiscated property, the lawful sorereign after his restoration should, as a general rule, recognize such transactions as valid, although they were consummated by those whom he considered usurpers. $^{43}$ On the other hand where such alienations have been made to the subjects of the state itself, such restored sovereign is generally conceded the right to annul or confirm them according to the dictates of policy, special consideration being given to the rights of bona fide purchasers of such alienations. ${ }^{44}$

$\$ 162$. A state's right to reputation.-As a state is a moral person with susceptibilities and with a character as such to maintain, it is claimed that another one of its attributes is the right of reputation, which no one should attempt by deed or word to injure or take away. For that reason it is said that no state through its officials or through its public documents has the right to wound the feelings or injure the good name of another, by asserting its inferiority or by reflecting upon the character of its social or political institutions, - a deliberate insult to one of its functionaries being considered the same as

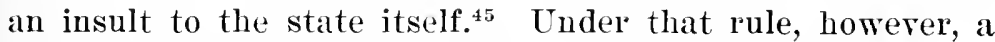
state is not bound to take away from the press or private citizens the right to criticise both foreign states and their sorereigns,- those who abuse that right being subject to responsibility accordiug to the laws of the state to which they belong. ${ }^{* 6}$

$\S 163$. How a state may be extinguished through absorption,

42 "If the revolution fails, the chap. 1, §258; Dana's Wheaton, status ante revives." Twiss, vol. $\$ 31$.

i, p. 21 .

43 Grotius, de Jur. Bel. ac Pac.,

45 Woolsey, Int. Law, $\S 82$.

46 In 1799 certain English subII, c. $14, \S 16$.

jects, prosecuted for libel on Paul

44 Klüber, Droit des Gens, sec. il, I of Russia, were punished by fine 
division, or merger.-Having now defined the process through which a new political community may win a place in the fam. ily of nations, and the cardinal rights of such as enjoy that privilege, an indication must be given of the methods through which any state, young or old, may lose its place and disaypear from the map of the world. The formost attribute of sovereignty is the right of self-preservation, a right which entitles every state to maintain a continuous intemational existence. Unless it gives adequate provocation by its own acts, no state or combination of states laas the right to dismember or eliminate it. In the absence of such provocation its international life can be legally determined only by its own will. For that reason every independent community is expected to put itself in a position to protect its territory, and the persons and property of its members against unjust aggressions. As Vattel has expressed it: "The nation ought to put itself in such a state as to be able to repel and humble an unjust enemy. This is an important duty which the care of its own perfection and even its self-preservation imposes both on the state and its conductor." 47 Thus every state holds its life subject to the contingency of destruction at the hands of any other state or states which may be powerful enough to make good the contention that its annihilation is necessary for their protection. The three powers who finally absorbed Poland, in proportions agreed upon among themselres, gave as a justification for that act their security as neighboring nations against the internal discords of the smaller state. While one state may thus be broken up, and its fragments distributed among its neighbors, another may be so divided as to originate two or more new states. In explanation has been given already of the circumstances under which the great powers were called upon to intervene in the affairs of the kingdom of the Netherlands, finally converted by their anthority int o the entirely distinct and independent lingdoms of Holland and Belgium. ${ }^{48}$ Upon the same principle the ancient kingdom of New spain disappeared, and out of its fragments arose the several independent republies of Central America. In such cases the process of transformation cannot be considered complete until the independence thus claimed by the new com-

and imprisonment; and in 1803 the English court convicted Jean Peltier, a French refugee, for libel- ling Napoleon, then First Consul. See Phillimore, i, p. 447.

${ }^{47}$ Droit de Gens, I, ch. 14, § 177. 48 See above, p. 118 . 
munities has been duly recognized by other states. ${ }^{49}$ Single commonwealths may also disappear by being merged in federal unions which assume the entire control of their international affairs. Such was the case when in 1815 the republic of Valais and the principality of Nenchatel were admitted into the Helvetie Confederation ; ${ }^{50}$ and in 1845 when the republic of Texas was by a resolution of Congress admitted as a state of the American Union. Thus through the application of external force it eamnot resist, or through its own voluntary act, a state may cease to exist absolutely, as in the case of Poland, or lose only its international existence, as in the case of Texals. In either event it ceases to be a subject of international law.

$\S 164$. Effect of extinction on state obligations.-In order to determine the status of the obligations of a state which has passed through any of the vicissitudes already deseribed, it is necessary to distinguish between the case of one that has lost its corporate identity, and one which has simply suffered dismemberment without the loss of such identity. It is also necessary to distinguish between the general personal obligations of a state, and its special and local obligations which may be said to "run with the land." Whenever an entire state loses its identity by being absorbed into another, the absorbing power as the heir to its whole property naturally becomes liable for its entire debt, and at the same time extends its treaty obligations to the ammexed territory. After the incorporation of Naples in the kingdom of Italy, it was decided by the courts of both France and Italy that a treaty made in 1760 between France and Sardinia, relative to the execution of judgments of the courts of one within the limits of the other, applied to every part of the new Italian state into which Sardinia had expanded. ${ }^{51}$ When a state is annihilated, as in the case of the kingdom of the Netherlands, and two entirely new and distinct states are created ont of its fragments, neither of which represents the defunct nationality, what then becomes of its obligations? From Grotins ${ }^{52}$ we learn that

49 Twiss, vol. i, p. 19.

50 Martens (N. R.), iv, p. 173.

51 "There is this difference, however, between the effect of acquisition by cession and by absorption of an entire state, that in the latter case, the annexing power being heir to the whole property of the incorporated state, it is liable for the whole debts of the latter, and not merely for those contracted for local objects or secured upon special revenues." Hall, $\$ 29$.

52 De Jure Belli ac Pacis, II. c. ix, $\$ 10$. 
where a state is divided "anything which may have been held in common by the parts separating from each other must either be administered in common or be ratably divided." Clancellor Kent ${ }^{53}$ made that vague rule a little more definite when he said that "if a state should be divided in respect to territory, its rights and obligations are not impaired; and if they have not been apportioned by special agreement, those rights are to be enjoyed, and those obligations fulfilled, by all the parts in common." "st Phillimore, after quoting both Grotius and Kent, declared that "if a nation be divided into various distinct socicties, the obligations which had accrued to the whole, before the division, are, nnless they have been the subject of a special anreement, ratably binding upon the different parts." So far as Phillmore is concerned there is no basis for Hall's statement ${ }^{55}$ that "it is difficult to be sure whether these writers only contemplate the rare case of a state so splitting up that the original state person is represented by no one of the factions into which it is divided," because he limits his comments to a case in which a nation is "divided into various distinct societics." In that event he says that prior obligations, in the absence of special agreement, are "ratably binding upon the different parts." Or as Heffter (\$25) has expressed it: "Property rights and duties of an entirely extinguished state survive its dissolution, subject only to a change in their administration; in cases of partition they devolve proportionately upon each of the dismembered parts. To that extent it may be said that the treasury of the absorbing state succeeds absoIntely to the rights and duties of the extinguished one." It may be true that new creations arising out of the annihilation of an older state, which they do not represent, are not legally bound to assume ratably a part of its general indebtedness,that such obligation is purely a moral one. Whether moral or legal, the obligation of Holland and Belgium to bear ratably the general debt of the defunct kingdom of the Netherlands was distinctly recognized and enforced in the treaty of 1839 in which the European Concert made an equitable settlement of all the interests involved.

$\$ 165$. Effect of dismemberment on state obligations.-It is far more usual, however, for such questions to arise when a state, without a loss of its corporate identity has a portion of its territory and population taken from it by conquest to form an

53 Com., i, p. 25.

54 Vol. i, § exxxvii.

5s P. 99, note. 
integral part of another state; or when the severed territory is erected into a new and entirely independent state. Three recent precedents justify the statement that when a conquering state seizes a part of the territory of another and adds it to its own, it is in duty bound to assume not only the local and special obligations that "run with the land," but a ratable part of the general debt of the state suffering dismemberment. In that way a part of the debt of Denmark was apportioned to Schleswig-Holstein ${ }^{56}$ when those provinces became Prussian in 1866. In the same year the emperor of Austria consented to the union of the Lombardo-Venetian kingdom with that of Italy, ${ }^{5 T}$ on condition of the liquidation of the debts chargeable to the ceded territory in conformity with the treaty of $\mathrm{Zur}$ ich; and Italy, in a convention with France, agreed to assume so much of the Papal debt as was proportionate to the revenues of the Papal provinces appropriated by it." "If the cession or alienation consist of a portion of the territory, the charges which weigh upon the whole will be apportioned (unless something to the contrary is stipulated) among the various divided parts formed, except such indivisible charges as the so-called guaranteed loans recognized as such by diplomatic usage." The same author in explaining what he means by "guaranteed loans" says that "international usages have replaced that species of obligation by the special dedication of certain properties or rents to the payment of loans contracted by the state, loans which in order to be valid must have been made in accordance with the laws of the state contracting them. Diplomatic language recognizes also under the denomination of guaranteed loans those contracted for the benefit of a country or special region, and it is understood that an obli gation rests upon them, without adding to them in any way the significance of a civil mortgage." 59

$\S 166$. When severed territory becomes a distinct state-local rights and obligations. $-A$ narrower and more technical rule prevails when the parent state is deprived of a portion of its territory which is erected into an entirely distinct political community. The cogent reasoning in such a case is that as a

56 Martens (N. R. G.), xvii, ii, 474-486.

57 Peace of Prague, Article II. Annuaire des Deux Mondes, xiv, p. 804 .

58 Lawrence's Wheaton, vol. i, p. i, p. 369 , 214.

59 Heffter, p. 72. See also, D. Haas, Division of the Debts of States, Bonn, 1831; Leonhardi and Emminghaus, Digest of Germanic Law; F. de Martens, Int. Law, vol. , p. 369 
man who loses an arm or leg in battle is not thereby relieved of any part of his obligations, so a state that is so dismembered as to suffer no loss of identity remains bound as before for its entire general indebtedness. "Such a change," Halleek ${ }^{60}$ says, "no more affects its rights and duties, than a change in its internal organization, or in the person of its rulers. This doctrine applies to debts due to as well as from the state, and to its rights of property and treaty obligations, except so far as such obligations may have particular reference to the revolted or dismembered territory or province." In other words as the old state continues its corporate life without interruption, it retains all general state property, and all general benefits resulting from treaties, with full liability for all general obligations with which the new creation taken from its side may disavow all legal connection. The new state on its part carries with it only local obligations, whether contracted for local objects or secured by a lien on local revenues, and such local duties as arise out of agreements to maintain the channel of a river, or to levy no more than certain tolls along its course. As a compensation for such burdens the new state is entitled to property within it of a local character, or to such, not within it, as belongs to state institutions localized there, and to the privileges arising from treaties specially contracted for the benefit of its territory, such for instance as contain demareations of its boundaries, and such as secure to its inhabitants, or a part of them, the right to navigate streams running through other countries from its frontiers. ${ }^{61}$

\section{$\S 167$. Contention of U. S. with Great Britain after war of 1812.}

-In the treaty of 1783 , severing the United States from Great Britain and defining their respective boundaries, the citizens of the former were secured certain fishing rights upon the coasts of Newfoundand, Nova Seotia and Labrador. After the war of 1812 the question arose whether such rights had been only suspended by the war or whether they had been entirely abrogated. Upon the part of the United States the former contention was maintained upon the ground that its inhabitants derived the fishing privileges in question not from the article in the treaty of 1783 , which merely recognized them, but from the fact that the sererance from the mother country did not take away from the people of the United States the right to their common enjoyment as it had existed before that 
event. Great Britain upon her part contended "that the claim of an independent state to occupy and use at its discretion any part of the territory of another without compensation $\mathrm{or}^{\circ}$ corresponding indulgence cannot rest on any other foundation than conventional stipulation." 62 That view of the matter, which finally prevailed, was the basis of the settlement of the controversy made by treaty in $1818 .^{63}$

$\S 168$. Summary.-After a careful review of all the authorities the general statement may be made (1) that no matter whether a state is entirely extinguished by a division into two or more distinct states, or (2) whether it loses its identity by being absorbed into another state, or (3) whether a state without a loss of its identity has a portion of its territory taken from it to form an integral part of another state, or (4) whether such severed part is erected into an entirely new and independent state, all local charges, and guaranteed debts to which certain domains and their revenues are dedicated, survive as charges upon the localities to wlich they relate, with their equities unimpaired. In the case first named the general debt of the state should certainly be ratably binding, morally, if not legally, on its sereral parts; in the second it passes as a whole to the absorbing state; in the third the acquiring state should assume a ratable proportion of it; and in the fourth, every principle of equity and good conseience requires that it should be provided for out of the common state property and the residue divided in proportion to the revenues of the two distinct commonwealths. In the notable case of West Virginia that obligation, though formally recognized, ${ }^{64}$ has never been discharged.

62 British and Foreign State for the assumption of a just share Papers, vii, 79-97.

63 See below, $\S 344,345$.

64 "Even in the throes of revolution declaring separation from the mother state provision was made of the old state debt, though its adjustment has never yet been reached." Art. "West Virginia" in Enc. Brit., 9th ed., vol. xxiv, p. 520. 


\section{CHAPTER $\Pi$.}

SOVEREIGNTY AND JURISDICTION IN RELATION TO PERSONS.

$\S 169$. Territory and jurisdiction coextensive.-From the fundamental doctrine of territorial sovereignty, upon which the modern international system reposes, flows the corollary that territory and jurisdiction are coextensive. ${ }^{1}$ Jurisdiction is in fact an attribute inherent in sovereignty that follows it whereever it goes. As Chief Justice Marshall has expressed it: "The jurisdiction of the nation within its own territory is necessarily exclusive and absolute. It is susceptible of no limitation not imposed by itself." ${ }^{2}$ Or in the ampler phrase of Folix "every state possesses the power of regulating the conditions on which the real or personal property, within its territory, may be held or transmitted; and of determining the state and eapacity of all persons therein, as well as the validity of the contracts and other acts which arise there, and the rights and obligations which result from them; and, finally, of prescribing the conditions on which suits at law may be commenced and carried on within its territory."3 From this general right of control results the exclusice power of erery state to fix by legislation the personal and civil status of its citizens and the status and condition of all real and personal property situated within its limits whether belonging to citizens or aliens. Upon that basis rest two of the three maxims of Huber: ${ }^{4}$ first, that the laws of every empire have force only within the limits of its own government, and bind all who are subjects thereof, but not beyond them; second, that all persons who are found within the limits of a gorernment, whether their residence is permanent or temporary, are to be deemed subjects thereof.

1 "The whole space over which a nation extends its government becomes the seat of its jurisdiction, and is called its territory." Vattel, Droit des Gens, i, c. $18 ; \S 205$. Si gens quaedam regionem vacuam occupat, imperium in ea simul occupat. Wolf, Jus Gentium, § 85 . "The right of empire or jurisdic- tion is distinguished from the right of dominion or property." Twiss, i, § 139 .

2 The Schooner Exchange v. McFaddon et al., 7 Cranch, p. 136.

3 Droit Int. Privé, § 9.

4 De Confictu Legum, Lib. 1, tit. $3, \S 2$, p. 538 . 
Legal fiction of exterritoriality-illustrations.-Necessity and convenience have, however, forced the incorporation into international public law of the doctrine, that in reference to cerrtain persons and certain kinds of property the jurisdiction of a state may be extended beyond its actual territorial limits; and, in order to uphold the theory that territory and jurisdiction are coextensive, the legal fiction" has been invented, that in certain cases a detached portion of a state may become migratory with the eapacity to float on the sea, or to superimpose itself upon the territory of another state with its municipal institntions in full force upon it. Such is the fiction when a foreign sovereign goes in his public capacity within the limits of another state; or when the army of one state marches over the territory of another with which it is at peace; or when the ambassadors or other public ministers of one state go upon a diplomatic mission to another and establish a residence there. The fiction is that such residence is a jart of the state from which the envoys have come, with all of its domestic institutions, including its special forms of religious worship, in full force; and with perfect immunity from the jurisdiction, both civil and eriminal, of the country to which it has been temporarily transferred. A still more striking illustration of the fiction may be found in the case of a public ship of state sailing over the seas free from the right of search, or in a friendly port which it may enter without express permission, and there enjoy "an exemption from the jurisdiction of the sovereign within whose territory she claims the rights of hospitality," "excepting only necessary sanitary rules and ordinary harbor regulations. ${ }^{7}$

$\S 170$. Comity the basis of international private law.-Whenever a state desires to give an exterritorial effect to its laws within that wide and difficult domain occupied by international private law it resorts to an entirely different expedient.

5 Par une espèce de fiction légale, commandée en quelque sorte par la situation élevée qu'elles occupent, les personnes qui représentent un État au dehors sont généralement regardées comme n'ayant pas quitté le territoire de leur nation et comme devant à ce titre échap- per à la jurisdiction du pays où elles se trouvent, pour rester exclusivement soumises aux lois de leur propre pays. Calvo, § 503.

6 The Schooner Exchange v. McFaddon et al., 7 Cranch, 117.

7 See below, § 258 . 
It then falls back upon the third axiom of Huber, "that the rulers of every empire from comity admit that the laws of every people, in force within its own limits, ought to have the same force everywhere, so far as they do not prejudice the powers or rights of other governments, or of their citizens." This expedient has prospered through the willingness upon the part of states to modify their exclusive rights of sorereignty in order to prevent "gross inconvenience and injustice to litigants, whether natives or foreigners."

Result of a strict enforcement of the lex loci.-In the absence of that disposition to relax sovereign rights the mutual conressions which civilized nations have made for such reasons would have been impossible. If each state in the full exercise of its sovereignty had simply insisted that its courts shall apply the lex loci to all jural relations coming before them there could have been no such thing as international private law, whose province it is to determine which of two conflicting systems of law shall prevail in a given case. In that event the intercourse between nations would have been continually rexed with inconveniences and injustices arising out of conditions in which a right duly acquired under the laws of one country could be annulled by contrary laws prevailing in another. In order to prevent as far as possible that general result there has been growing up among civilized states, since the middle of the seventeenth century, a body of rules ${ }^{10}$ touching the purely private relations of individuals, whose aim is to secure the recognition and enforcenent in the courts of every state of any right which has been duly acquired under the laws of another. It has not been found convenient, however, to relax the exclusive sovereign right of erery state to determine the status and disposition of immovable property. All rights

8 De Conflictu Legum, Lib. 1, tit. $3, \S 2$, p. 538 .

9 Dicey, Conflict of Laws, p. 10.

10 Savigny, writing in 1849 , says, "one can say that this branch of science has already become a common property of civilized nations, not through possession already gained of fixed, universally acknowledged principles, but through a community in scientific in- quiries which reaches after such possession. A vivid picture of this unripe but hopeful condition is furnished by the excellent work of Story, which is also in a high degree useful to every investigator, as a rich collection of material." A Treatise on the Conflict of Laws, forming the Sth vol. of his System des Heutigen Romischen Rechts. See W. Guthrie's trans. 
in immovablesare, as a general rule, regulated by the lex situs. ${ }^{11}$ This growing system of mutual concessions has therefore been limited to the regulation of rights in movables upon the basis principle that the personal status and jural capacity of a person is to be determined by the law of his domicil. In that way this branch of law has been mainly occupied with the application of the lex domicilii to questions of marriage, divorce, succession, wills, citizenship, minority, legitimacy, lunacy, gaurdianship, and administrations, foreign judgments and contracts, bankruptcy and the like. By Savigny ${ }^{12}$ and many other foreign jurists, it has been held that a person's status, subject to certain exceptions, depends entirely upon the law of his domicil, or as Lord Westbury expressed it in Udny $v$. Udny, ${ }^{13}$ a person's civil status ought to be "governed universally by one single principle, namely, that of domicil, which is the criterion established by law for the purpose of determining civil status." Hence the general rules, subject to certain exceptions, that the assignment of movables, wherever situated, in accordance with the law of the owner's domicil is valid; that a person's capacity to enter into a contract is governed by the law of his domicil at the time of its making; that a marriage is valid when each of the parties has, according to the law of his or ler respective domicil, the capacity to enter into that relation; that a will of movables is to be interpreted with reference to the law of the testator's domicil at the time when it was made; and that the distributable residue of the movables of a deceased person is governed by the law of his domicil at the time of his death.

Connection between international private law and public.-As all such rules concern the purely private relations of individuals, and as they all relate to rights depending upon the law of one state whose enforcement may be forbidden in the courts of another, they can only be connected with international law

11 Birtwhistle v. Vardill, $7 \mathrm{Cl}$. \& F. $895 ;$ Re Don's Estate, 4 Drew, 194; Duncan v. Lawson, 41 Ch. D. 394; Heyer v. Alexander, 108 Ill. 385; Succession of Larendon, 39 La. An. 952; Welch v. Adams, 152 Mass. 74. Cf. Story, Conflict of Laws, $\S \S 431-463$; Nelson, Private Int. Law, p. 277, commenting on Ja- cobs v. Crédit Lyonnais, 12 Q. B. D. (C. A.) 589, 603, per curiam; Westlake (3rd ed.), p. 261.

12 Conflict of Laws, $\$ 362$, Gutherie's trans. (2nd ed., 1880), p. 148. 13 L. R. 1 Sc. App. 441, 457. See also Sottomayor v. De Barros, 3 P. D. (C. A.) 1; Dicey, Conflict of Laws, pp. 79 , seq., 479,728 seq. 
proper by rirtue of the fact that the tacit consent ${ }^{14}$ which upholds the system of reciprocal concessions is a part of the code regulating the intercourse of nations. The law of the state actually enforced within the territory of another is national law; the rule by virtue of which it is so enforced is an international rule. In that way only is international private law, whose province it is to prevent conflict in matters of purely individual right, connected with international public law which is strictly confined to the relation of states with states.

$\S 171$. Law of nations deals only with states as corporate persons, and not with individuals composing them.-The fact has more than once been emphasized that the persons who compose the family of nations are corporate persons, states, which must be eitluer sovereign or part-sovereign, because, when a state is entirely deprived of its external sovereignty, it reaches the vanishing point at which it disappears from international law. The family of nations may, therefore, be compared in a general way to that kind of a federal league heretofore described as a stactenbund for the reason that in both eases the law that constitutes the union operates only upon states as such and not upon the individuals of whom they are composed. ${ }^{15}$ The independent state is a collective person, with a moral nature, into whose corporate being are absorbed, so far as international law is concerned, all the citizens that compose it. $A \mathrm{~s}$ an Oxford scholar has recently expressed it: "By a state, or political society, we understand, at the present day, a community (1) of considerable size (2) occupying a clearly defined territory,(3) owing direct and complete allegiance to a common anthority, and (4) invested with a personality which enables it to act more or less as an individual." 16

Rights and obligations incident to states as such.-International rights and obligations belong to the corporate person of the state as an individual; its citizens as such possess neither. Their obligations are to their own state which in turn guarantees them protection under the terms of its domes-

14 "It is of course a merely voluntary act on the part of any state when it gives effect to foreign law." Holland, Elements of Jurisprudence, p. 368 .
15 See above, p. 165.

16 Edward Jenks's Law and Politics in the Middle Ages, p. 68. 
tic constitution, a protection which they can demand from their own state as a matter of municipal law. But in their relations with other states they lave in their citizen capacity neither rights nor duties which they can sustain as such. As against other states a citizen can only assert his rights through the agency of his own state, which is consequently responsible to them for his acts. "If his throat is eut as a prisoner of war taken in the serrice of the state, it is his state that is internationally outraged; if he cuts the throat of a prisoner that he has taken, it is his state that has committed a breach of the law of nations. Intemationally the jural existence of the citizen is thus wholly sunk in the jural existence of the state; or, in other words, the state is a jural unity of the component elements of which the law of nations takes no account." 17

$\S 172$. Who are entitled to a state's protection? Status more important than citizenship.-International law proper, to whose consideration this work will be limited, knows nothing of the component elements of states until one of them assumes in its corporate capacity the enforcement of the rights or the settlement of the obligations of citizens or subjects standing in such a relation to it as to warrant its representation of them. In that way it becomes a matter of prime importance to ascertain who are the component elements of a state whose rights it must enforce and for whose wrongful acts it must give satisfaction. In other words, this question must be asked and answered: In what relation must a person stand to a state in order so to clothe himself with its nationality that it will be bound to assume his rights and obligations in his dealings with other states? Primarily the question who is or is not a citizen or subject of a particular state is a question of municipal law; and when that has been answered, international law has no right to inquire into the manner in which a state's sovereignty is exercised over such subject or citizen within its jurisdiction, whether the same is territorial or such as is exercised in unappropriated places. A person without being clothed with the full citizenship of a state, under its municipal law, may, however, still bear such relations to it that his status will compel it to assume responsibility for him. The right of a state to protect a subject abroad may, therefore, rest upon a relation far short of full citizenship. A foreigner may by

17 Lorimer's Institutes of the Law of Nations, vol. ii, p. 131. 
virtue of his domicil acquire the national character of a state to such an extent as to secure its protection beyond its bounds. In the famous case of Koszta, who based his claim to protection upon domicil, Mr. Marcy said: "It is a maxim of international law that domicil confers a national character; it does not allow any one who has a domicil to decline the national character thus conferred; it forces it upon him often very much against his will and to his great detriment. Internaltional law looks only to the national character in determiniug what country has the right to protect." 18 Therefore, whenever the question is asked whether or no a state is in duty bound to enforce the rights or answer for the acts of any individual, the response must depend upon the relation he bears to the state which assumes or is called upon to speak for him, and that relation is one rather of status than of citizenship. "The rule fixing citizenship upon an individual,-the rule, that is, ascribing nationality,-is matter for municipal law. In international law locality, not nationality, is the all-important test of character."

$\S 173$. Inhabitants of whom every state is usually composed.The inhabitants of whom every state is usually composed may be roughly divided into natural born citizens; naturalized eitizens; denizens; domiciled aliens; and mere casual visitors or travelers passing through the country, to all of whom certain duties are due. The persons who bear such relations to a state, perfect or imperfect, as will authorize or require it to exercise jurisdiction over them may therefore be grouped under the following heads:

1. Persons as to whose nationality no real question can exist, such as have been born upon its soil of native parents

$18 \mathrm{Mr}$. Marcy, Sec. of State, to Mr. Hülsemann, Sept. 26, 1853. Mss. Notes, Austria; Wharton Int. Law Dig., vol. ii, §§ 175,198 . See also 3 Lawrence Com. sur droit int. 138; 4 ibid. 179, 180 . While Mr. Marcy's position is sustained by Calvo, Droit International (3rd ed.), ii, p. 96 , it has been assailed by Hall ( $\$ 72$ ), who says, "Domicil no doubt imparts national character for certain purposes; but those purposes, so far as they have to do with public international law, are connected with the rules of war alone, and Mr. Marcy's contention was wholly destitute of foundation." However extreme Mr. Marcy's view may appear to foreign jurists, its tendency was followed by the Supreme Court of the U. S. in the Prize Cases (2 Black, 635) in which it was held, "First, that if a place was in the firm possession and under the control of the rebel enemies, it was, for the time, and in the technical sense of the prize law, enemy's territory; second, that the property of a person domiciled in that 
who have never thrown off their allegiance, and foundlings who, in the absence of a known father or mother, must be attributed to the soil upon which they are born or found.

2. Persons as to whose nationality there may be a question, such as children born of the subjects of one power within the territory of another; legitimate minors whose fathers are dead; illegitimate minors whose nationality depends upon that of the mother where national character is of a personal and not of a local origin; married women whose nationality, with certain notable exceptions, is merged in that of foreign husbands whose subsequent change of nationality carries with it a like change as to them; naturalized persons, who can only be controlled or protected to a limited extent outside of the jurisdiction of the new state whose citizenship they have assumed; and the children of such naturalized persons who are minors at the date of the naturalization of their parents.

3. To citizens either by birth, marriage or naturalization must be added (1) such foreigners resident as enjoy special privileges as denizens without being full citizens; (2) such domiciled aliens, not being denizens, as have acquired by virtue of their domicil certain rights and privileges; (3) mere travelers passing through or visiting the country temporarily.

$\S 174$. Right of a state to protect its subjects abroad; allegiance; Calvin's case.-A part of the general right of self-preserration possessed by erery state is the special right to protect its subjects abroad which is correlative to its liability to respond for injuries inflicted upon aliens within its own limits. ${ }^{19}$ Foremost among those who have the right to call upon a state to stand as their representative and protector as to other states are such as have been clothed with its nationality through birth upon its soil of native parents who have never surrendered their natural allegiance. In the famous case of Calvin or Colvill ${ }^{20}$ decided in 1608 , after argument in the exchequer chamber before the chancellor and the twelve judges, the entire doctrine of allegiance was exhaustively

place at the time of the capture was liable to condemnation as enemy's property in the sense of the prize courts." Dana's note, 160 , to Wheaton's Elements.

19 Hall, § 87. "Finally the right of protecting subjects abroad falls under the head of self-preservation." Ibid., $\$ 73$.

207 Rep. 1; 2 State Trials, 559

(e) (6 Jac. 1, A. D. 1608). See also notes of the judgments in State Papers, Dom. $\mathrm{xxx}, 40$, and xxxiv, 10. Cf. Denman's Broom's Const. Law, 1885, pp. 4-59. 
reviewed as to the post-nati, as those subjects were called who were born in Scotland after the accession of James $I$. The contention was that they were no more aliens than those born upon the soil of England. All of the judges, except two, declared that Calvin, an infant born in Edinburgh in 1605, was no alien; that allegiance is the "true and faithful obedience of the subject due to the sovereign;" and that persons born in the allegiance of the king are his natural subjects, regardless of locality. As allegiance was due by both kingdoms to one sovereign, ${ }^{21}$ it was held for that reason that internaturalization followed, although each kingdom has its own parliament and its own laws. It thus became a settled doctrine of English law that any one is entitled to English nationality by birth who could prove that he came into life upon English soil of parents under actual allegiance to the sovereign, ${ }^{22}$ eren when the place of birth was within limits held for the king by a mere temporary right of forcible occupation. ${ }^{23}$ Then foreign territory previously uninhabited is occupied by English settlers, the laws of England go into immediate operation, as in the colonies founded by such settlers in America. On the other hand, when a conquest is made of inhabited territory English law does not operate until it is expressly proclaimed. ${ }^{24}$

Natural allegiance originally perpetual. British naturalization acts.-Natural allegiance acquired by birth upon English soil was, at an early day, held to be neither local nor temporary but perpetual and indissoluble, imposing upon the subject for his whole life the duty to render military service to the crown whenerer required to do so. ${ }^{25}$ Those who were alien-born could, under the old system, acquire British eitizenship only by an act of parliament, by letters patent or through the results of conquest. The whole subject has, however, during the last reign been thoroughly reviewed in a series of stat-

21 See Excursus III, Thomas' Leading Cases in Const. Law, p. 37. 22 "All persons born within the United Kingdom, or in the colonies, fall within [the] description [of natural-born British subjects]. And this extends even to those born of aliens residing in this country, provided their parents were not at the time in enmity with our sovereign." 2 Steph. Com., 12th ed., p. 405 . See also
Cockburn, Nationality, p. 7; Dicey, Conflict of Laws, pp. 175 et seq., 740 .

232 Dyer, 224 a.

24 Blankard v. Galdy, 2 Salk. 411.

25 In the United States the courts have been inclined to follow the rule of the English common law, and to hold that neither a native nor a naturalized citizen can throw off his allegiance without the consent of the state. Kent. 
utes (regulating the acquisition of national character, expatriation and the status of aliens), which ends with the Naturalization Act, 1870 ( 33 and 34 Vict.). By that act the ancient doctrine of perpetual allegiance has been renounced and provision made for the naturalization of British subjects in foreign states, for their resumption of British nationality and also for the neutralization of aliens, who are permitted not only to acquire and hold real and personal property like natural born British subjects, but to acquire title to the same through an alien as through a natural born British subject. ${ }^{26}$ Great Britain has thus placed herself in full accord with the modern tendency to extend to the stranger every privilege not in conflict with the duty of self-protection, by conceding to the naturalized alien nearly all of the rights of full citizenship.

$\$$ 175. Rights of English subjects in America.-In the great title deed $^{2 \pi}$ under which the English settlers in America took actual and permanent possession of the best part of the Atlantic seaboard it was provided "that all and every persons being our subjects which shall go and inhabit within the said colony and plantation, and eren their children and posterity, which shall happen to be born within any of the limits thereof, shall have and enjoy all liberties, franchises, and immunities of free denizens and natural subjects within any of our other dominions, to all intents and purposes as if they had been abiding and born within this one realm of England, or in any other of our dominions."

Interstate citizenship.- When the colonies declared their independence of the mother country they drew together in a federal league based upon the old and ineffectual system of requisitions upon states as states. The only feature that lifted the first federal constitution above others of its class was the new system of interstate citizenship embodied in the rule that any one might at will transfer his membership from one state to another. ${ }^{2}$ In the second federal constitution

Comm., ii. 49; 8 Opinions of Atty.General, 157; Story on the Constitution, iii, 3, n. 1; Wharton, State Trials, 654.

$26 \mathrm{Cf}$. The Origin and Growth of the Eng. Const., vol. ii, pp. 229, 424.

27 Charter granted by James I, April 10, 1606, contained in Charters and Constitutions compiled under order of U. S. Senate by B. P. Poore, part ii, p. 1888. See also Hazard's His. Collections.

28 "The principle of inter-citizenship infused itself neither into the constitution of the old German Empire, nor of Switzerland, nor of Holland." Bancroft, Hist. of Const., vol. i, p. 118. 
of 1787 ,-based upon the new and fundamental idea that the federal power shall operate directly upon the citizen and not upon the states as such, - the original provision as to interstate citizenship was reproduced in section two of article four, which provides that, "The citizens of each state shall be entitled to all privileges and immunities of eitizens in the sereral states." There was, however, no attempt made either in the second constitution itself, or in any act of congress passed after its adoption, to establish or define ditizenship of the United states as such, as a distinct and independent thing from state citizenship, 29

Federal citizenship created by fourteenth amendment.-Federal citizenship was first created by section 1 of the Fourteenth Amendment, which provides that " $\Lambda$ ll persons born or naturalized in the United States, and subject to the jurisdiction thereof, are citizens of the United States and of the state wherein they reside." In the weighty judgment in which the effect of that provision was reviewed the fact was recognized that the order of eitizenship had been reversed; that under the amendment the primary citizenship in this country is to the United States; and the secondary to the state of the citizen's lesidence. It was further held that the two citizenships are separate and distinct from each other. In the words of the court, "It is quite clear, then, that there is a citizenship of the United States and a eitizenship of the state, which are distinct from each other, and which depend upon different characteristics or circumstances in the individual." ${ }^{30}$ A person may be a eitizen of the United States without being a citizen of a state. He cannot, howerer, be a citizen of a state withont being a citizen of the United States. The former may be acquired through birth or naturalization; the latter, only through residence. So far as international law is concerned the most important declaration contained in the judgment quoted above is that "Another" privilege of a citizen of the United States is to demand the eare and protection of the Federal Government over his life, liberty and property when on the high seas or within the jurisdiction of a foreign goverument.

29 "That the constitution itself has defined citizenship of the United States by declaring what persons, born within the several states, shall or shall not be citizens of the United States, will not be pretended. It contains no such declaration." Mr. Justice Curtis in Dred S,cott v. Sandford, 19 Howard, 575 .

30 The Slaughter-House Cases, 16 Wallace, 78 . 
Of this there can be no doubt, nor that the right depends upon his character as a citizen of the United States." It is, therefore, by virtue of his national citizenship that every citizen of the United States now has the right to call upon the federal government to stand for him as to foreign states.

$\$ 176$. Relation of allegiance to citizenship. Former not now perpetual. - With the indications now given as to the nature of allegiance and citizenship, as those terms are understood throughout the English-spealking world, clearly in view, it will be easier to explain their relation to each other. The acquisitiun of national character through birth has ever depended under English practice not simply on the fact of birth upon English soil, but on the further fact of birth within the allegiance, that is within the king's dominions, of parents under actual obedience to him. ${ }^{31}$ If the question be asked, what is allegiance? the answer may be given that it is the true and faithful obedience which the subject of every state owes to the state or its head in return for the protection which the state affords him. If the question be asked, how many kinds of allegiance are there? the answer is (1) natural allegiance (alta ligeantia) of the subject borm; (2) acquired allegiance (ligeantia acquisita), growing out of some act or circumstance other than birth, such as denization or naturalization; (3) local allegiance(ligeantia localis), resulting from the protection given to an alien friend residing within the state no matter for how short a time; (4) legal allegiance (ligeantia legalis), resulting from an actual personal oath taken by the subject, an oath which by the common law could be tendered to every one who had attained the age of twelve years. ${ }^{32}$ As stated heretofore it was once a fundamental tenet of the English common law that natural allegiance was perpetual and could not be renounced without the consent of the sovereign; and the same doctrine was maintained in the United States during the earliel period of our national history. ${ }^{33}$ Both countries have, however, expressly repudiated it by statute. An act of congress adopted July 27,1868 , declared that "the right of expatriation is a natural and inherent right of all people, indispensa-

31 The three conditions to be considered were the time of birth, the place of birth, and the actual obedience of the parents. 7 Rep. 18.
32 Coke, Lit. 129a; Brown's Law Dict. (Sprague's ed.); 8 Opin. Atty.-Gen., 139; 9 Ibid. 356.

33 See above, p. 214. 
ble to the enjoyment of the right of life, liberty, and the pursuit of happiness,"-principles distinctly recognized in the British Naturalization Aet, $15 \%$, providing for the naturalization of British subjects in foreign states, and for the enjoy. ment of the same privilege within British jurisdiction by the subjects of such states. ${ }^{3 *}$

How British and American citizenship acquired,-British national character, which is ipso facto lost by naturalization within a foreign state, ${ }^{35}$ may now be acquired by birth within the allegiance, or by naturalization in the prescribed forms. In identically the same way the national eitizenship of the United states may be alcquired under the Fourteenth Amend. ment, which provides that a person may become such a citizen, first, by birth in the United states "subject to the jurisdiction thereof," second, by naturalization therein. ${ }^{36}$ The old common law idea of birth within the allegiance was thus perpetuated in the phrase as to jurisdiction, which excludes from the operation of the amendment children of ambassadors, ministers, consuls, and eitizens or subjects of foreign states born within the United States. ${ }^{37}$ One who is endowed with the citizenship of a state by birth, naturalization, or otherwise, may as a member of the body politic become subject to its laws and entitled to its protection, and to the enjoyment of civil or private rights, without being clothed with political rights. Political privileges are not essential to citizenship, there is no necessary connection between citizenship and the right to vote. ${ }^{3 \mathrm{~s}}$

$\$ 177$. Feudal rule of citizenship and reaction against it.-According to Roman ideas a person was a citizen who had the freedom of a city with the right to participate in the exercise of all its privileges, civil and political. ${ }^{39}$ His city was his country ${ }^{40}$ and his countrymen were those who shared with him the benefits of a municipal constitution. Under that system, resting upon personal rights inherent in the individual, the

3* U. S. Rev. Stat., §1999; St. 33 Vict., c. 14, May 10, 1870.

$35 \mathrm{i}$. e., after the date of the Naturalization Act of 1870 .

36 Elk v. Wilkins, 112 U. S. 94; Mckay v. Campbell, 2 Sawy. (U. S.) 118; Minor v. Happersett, 21 Wallace, 167 .

3 Slaughter-House Cases, Wallace, 73 .
38 U. S. v. Cruikshank, 92 U. S. 542 ; Minor v. Happersett, 21 Wall. 162; Lyons v. Cunningham, 66 Cal. 42; Lanx v. Randall, 4 Dill. (U. S.), 425, judgment of $\mathrm{Mr}$. Justice Miller in the circuit court. $39 \mathrm{Cf}$. $6 \mathrm{Am}$. and Eng. Enc. of Law, p. 15, note 2, citing Thomasson v. State, 15 Ind. 449.

to See above, p. 10. 
national character of a child depended primarily upon the national character of the parents, and not upon the place of birth. With the growth of feudalism, which brought about a far more intimate connection between the individual and the soil upon which he was born, the Roman theory was so far modified by the idea of locality that it became "the rule of Europe" ${ }^{* 1}$ for states, within whose limits children were born to subjects of foreign powers, to consider such children as natives solely by virtue of the place of their birth. The reaction against that doctrine, which has finally established as a general rule the principle that children of aliens remain aliens by virtue of the status of their parents, dates from the establishment of the Code Napoleon providing that the nationality of a child shall follow that of its parents. The new doctrine thus announced has gradually worked its way into the codes of most civilized states, either in its entirety or with such modifications as protect children against the effects of the old rule by arming them with the power to choose their own nationality. ${ }^{22}$ Austria-Hungary, Belgium, Costa Rica, Denmark, Germany, Greece, Norway, Roumania, Russia, Servia, Spain, Sweden, Switzerland and Salvador, which claim children of their subjects as subjects wherever born, admit the corresponding principle that the national character of a child depends upon that of his parents and not upon the place of his birth. The greater number of the South American states cling to the old rule, while England, France, the Netherlands, Portugal and the United States, which uphold to a greater or less extent its theory, avoid its effects by giving in various forms to children born of aliens the right to elect on attaining their majority either the nationality of their parents or that of the country in which they were born. So generally has that just principle been recognized by the more important states that it may now be regarded as the prevailing rule upon the subject.

$\S 178$. The old rule in the U. S.-Few states hare done less to abrogate the old rule than the United States. The Fourteenth Amendment provides that "all persons born or naturalized in the United States, and subject to the jurisdiction thereof, are citizens of the United States and of the state

41 Demolombe, Cours de Code see Pothier, Des Personnes et des Napoléon, liv. i, tit. i, ch. i, No. Choses, pt. i, tit. ii, sec. i.

146. For the old law of France, 42 Hall, pp. 234-238. 
wherein they reside." By section 1992 of the Revised Statutes "all persons born in the United States and not subject to any foreign power, excluding Indians not taxed, are declared to be citizens of the United States." It is therefore clear that Indians not taxed and all persons who fall within the clauses italicized are not citizens within the terms either of the constitution or statute. It appears, therefore, that children born in the United States to foreigners here on trausient residence are not citizens, because by the law of nations they were not at the time of their birth "subject to the jurisdiction." ${ }^{43}$ When the question is asked as to the status of ehildren born here to domiciled aliens, the only answer that can be made-in the absence of an aftirmative statute giving them the right of election upon attaining their majority-is that they are provisionally citizens of the United States, until they voluntarily renounce that eharacter after they have become of full age. It has been held by the department of state that minor children, born in this country to naturalized citizens, after visiting Germany temporarily, are entitled to passports to return to this country upon the eve of their majority; ${ }^{44}$ and that a person born here, although he was immediately carried abroad by his parents, has the right to elect the nationality of the United States when he arrives at full age. ${ }^{45}$ On the other hand it has been declared by the same authority that a child born here to French parents, who goes during his minority to France, and there remains voluntarily after he attains his majority, will be held to have abjured his American nationality, ${ }^{46}$ - and that a child born here to a foreign father, when taken by him abroad, acquires his domicil and nationality. ${ }^{47}$

$\$ 179$. Domicil of dependent persons.-During the lifetime of the father his domicil remains that of his legitimate or legitimated minor child; after the father's death the domicil of such minor is that of the mother while he lives with her'; after the death of both parents the domicil of such minor, or of an illegitimate minor after his mother's death, is probably that of the

43 Cf. Wharton, Int. Law Dig. vol. ii, $\S 183$.

+4 Mr. Evarts, Sec. of State, to Mr. White, April 23, 1880, Mss. Inst. Germ.

$45 \mathrm{Mr}$. Evarts, Sec. of State, to Mr. Cramer, Nov. 12, 1880, Mss. Inst. Denmark; and the same to
Mr. Hitt, Feb. 10, 1880, Mss. Inst., France.

46 Mr. Evarts, Sec. of State, to Mr. Noyes, Dec. 31, 1878, Mss. Inst., France.

$47 \mathrm{Mr}$. Frelinghuysen, Sec. of State, to Mr. Cramer, June 4, 1883, Mss. Inst., Switz. 
guardian and may be changed by him. ${ }^{48}$ As the paternity of an illegitimate child must always be a matter of doubt, the domicil of origin is the domicil of his mother at the time of his birth, and her nationality thus becomes as a general rule his nationality. A notable exception, however, exists in the case of the illegitimate issue of an English woman born abroad, by reason of the fact that it is only by statute, in which illegitimates are not included, that children born out of the kingdom are admit. ted to be British subjects. On the other hand the illegitimate issue of foreign mothers born on British soil are British ${ }^{49}$ because "any person who, whatever the nationality of his parents, is born within the British dominions, acquires British nationality at birth, and is a natural-born British subject. This principle is not affected by the Naturalization Act, 1870 . The son of French citizens, born in London or in Calcutta, is from the moment of his birth a British subject. The only respect in which his position, in regard to nationality, differs from that of a son of English parents, who is born in London, is that he can, when he has attained full age, renounce British nationality and by making a declaration of alienage become thereupon in the eye of Englislr law an alien." so All children, legitimate and illegitimate, fall within the general rule if born upon British soil, no matter whether their parents be natives or aliens. British nationality. is fixed by the place of birth and when thus acquired it can be lost only (1) by naturalization in a foreign state; (2) by a declaration of alienage; (3) by the combined effect of descent and place of residence during infancy; (4) by marriage, in the case of a woman. ${ }^{51}$

$\S 180$. Nationality of married women.-While marriage never affects the nationality of a man, as a general rule the wife's nationality is merged in that of the husband. If he is a foreigner she becomes so; and any subsequent change of nationality on his part involves a like change as to her. ${ }^{52}$ So it is that a woman is deemed to be a subject of the state of which

48 Somerville v. Somerville, 5 Ves. 749a; Potinger v. Wightman, 3 Mer. 67; Holyoke v. Hoskins, 5 Pick. 20; Ryall v. Kennedy, 40 N. Y. (S. C.) 347, 361; Westlake, 3rd ed., pp. 300, 301.

49 Hall, § 69 ; Bluntschli, § 366 .

50 Dicey, Conflict of Laws, p. 741, quoting Naturalization Act, 1870 , s. 4 .

51 Naturalization Act, 1870, ss. 6, 4,10 .

¿2 Warrender v. Warrender, 2 Cl. \& F. 488; Westlake, 3rd ed., p. 302 , s. 253 ; Story, Conflict of Laws, s. 46 ; Savigny, s. 357 . 
her husband is for the time being a subject; and after his death she continues in that relation until she changes her nationalit ${ }^{53}$ The English common law, which did not admit that marriatge affected a woman's nationality, has been made to conform to the general principle by the Naturalization Act, 1870, sec. 10. While the United states has always held "that, inrespective of the time or place of marriage, or the residence of the parties, any free white woman, not an alien enemy, marrifed to a citizen of this country, is to be taken and deemed a citizen of the United States," 54 it was for a long time undisputed law that a female citizen of the United States did not lose her nationality by marriage with an alien husband. By the law department of the government it was declared that an Ameriean woman whomaried a spanish subject residing here, and who died in Spain after her removal to that country with her hushand and child, was at the time of her death an American citizen. ${ }^{55}$ Judicial interpretation, however, is now pointing in the opposite direction. "Since the right of expatriation has been so fully recognized, and since the converse proposition that an alien woman, by marriage with an American citizen, becomes a citizen, has been declared by statute, it appears that a woman's marriage with a foreigner should be regarded as an act of expatriation, at least when accompanied with residence abroad." 56 Such was the new doctrine announced by Judge Brown, ${ }^{5 \tau}$ now of the Supreme Court, who,-after quoting the act declaring that an alien who married a citizen shall be deemed a citizen, and also section 1999 of the Rerised Statutes dofining the right of expatriation,--said: "It seems to me that we should regard the sections above quoted as announcing the vicws of congress upon this branch of international law, and ought to apply the same rule of decision to a case where a female American citizen marries an alien husbamd that we should to a case where an alien woman marries an American citizen. * * * It will be noticed that legislation upon the subject of naturalization is constantly advancing toward the idea that the husband, as the head of the family, is to be considered its political representative, at least for

¿3 Pennsylvania v. Ravenel, 21 Howard, 103.

st Wharton, Int. Law Dig., vol. ii, p. 421 .

$\therefore 19$ Opinions, Atty.-General, 321. See also Comitis v. Parker- son, 56 Fed. Rep. 556; Beck v. McGillis, 9 Barb. (N. Y.) 35. $506 \mathrm{Am}$. and Eng. Enc. of Law. p. 31.

57 Pequignot v. Detroit, 16 Fed. Rep. 211. 
the purposes of citizenship, and that the wife and minor children owe their allegiance to the same sovereign power." It is to be hoped that, with section 10 of the British Naturalization Act, 1870 , clearly in view, congress will soon convert the wise deliverance of Mr. Justice Brown into statute law.

$\S 181$. Naturalization in U. S.-International law does not attempt to say who are natural born subjects, as the right to define their character is purely a matter of municipal law. The former, after conceding the right to each state to exercise complete jurisdiction over such subjects within its territory and to protect them when beyond its limits, simply accepts as conclusive any authoritative designation it may make of such as are entitled to stand to it in that relation. No such absolute concession is made, however, as to those adopted citizens who are united to a state artificially through the tie of allegiance resulting from the legal process of naturalization. In such a case the rights of the adopting state are to a certain extent subject to the pre-existing right of control rested in the state of birth. When the state of nativity concedes to a subject the right of expatriation there can be no conflict; and that is generally true so long as the naturalized citizen remains within the jurisdiction of the state of his adoption. But whether with or without the consent of the native state, naturalization is complete and conclusive as between the naturalizing state and any third state. The congress of the United States has the exclusive power to establish a uniform rule of naturalization, ${ }^{58}$ and it vests the function not only in the federal courts but in such courts of record in the states as have common law jurisdiction, a seal and a clerk. The alien who seeks the privilege must declare upon oath before a competent court, at least two years prior to his admission to eitizenship, that it is his bona fide intention to become a citizen, and renounce his allegiance to any prince, potentate or state, and particularly by name to the prince or state whereof he is at the time a subject or citizen $;^{59}$ and when the judgment of naturalization, which cannot be collaterally impeached, ${ }^{60}$ is made, the applicant is endowed with all the privileges belonging to natural-born citizens of the United States, excepting only such as are withheld

58 U. S. v. Villato, 2 Dall. 373; Thurlow v. Com. 5 How. 504; Smith v. Turner, 7 How. 283. 59 Rev. Stat. U. S., §§ 2165, 2167. Fed. Rep. 644.
60 Spratt V. Spratt, 4 Pet. 393 ; Stark v. Chesapeake Ins. Co., 7 Cranch, 420 ; U. S. v. Walsh, 22 
by the federal constitution. ${ }^{61}$ The child of an alien thus natmalized partakes of his father's naturalization eren if he was born abroad, provided his father emigrated to this country with him and was naturalized during his minority. ${ }^{62}$ Artificial citiz'nship thus gained maly be lost by emigration and other acts, manifesting an intention voluntarily to abandon such nationality and allegiance.

§ 182. English Naturalization Act, 1870.-Formerly in England naturalization could be granted only by an act of parliament. Now, under the Naturalization Act, $1870,{ }^{63}$ it may be granted at the discretion of the secretary of state for the home department to any alien who resides in the United Kingdom or who has been in the service of the crown for five years, prorided he continues to reside or serve as before. After he has taken the oath of allegiance and obtained the certificate, he becomes a British subject within the United Kingdom, with the right to sit in either house of parliament, and to be a member of the privy council. India and the colonies have their own laws regulating naturalization within their borders. To British eitizenship thus granted there is annexed, however, a serious limitation. The certificate declares the naturalized alien to be entitled to all the privileges and subject to all the obligations of a natural born subject of the United Kingdom "with this qualification-that he shall not, when within the limits of a foreign state of which he was a subject previons to his obtaining his certificate of naturalization, be deemed to be a British subject unless he has ceased to be a subject of that state in pursuance of the laws thereof, or in pursuance of a treaty to that effect."

A qualification construed in case of Bourgoise.-Such qualification is a recognition by the English parliament that the ancient maxim of nemo potest exuere patriam is still in force in all states; and that the right of expatriation does not exist where it has not heen expressly granted by the state of nativity. As stated lieretofore the Nituralization Act, 1870, in theory, does not change that principle so far as Great Britain is concerned. ${ }^{64}$ Through the provisions of that act the doctrine of perpetual allegiance is simply modified by a consent that British nation-

61 Osborn v. U. S. Bank, 9 Wheat. 738 .

6210 Opinions of Atty.-Genl., 329. See also U. S. Rev. Stat., §2172; State v. Penney, 10 Ark. 621;
Crane v. Reeder, 25 Mich. 303;

Calais v. Marshfield, 30 Me. 511. 6333 and 34 Vic., c. 14. 64 See above, p. 219. 
ality may be lost or relinquished througl naturalization in a foreign state by a declaration of alienage; by marriage, in the case of a woman; or by the combined effects of descent and place of residence during infancy. A striking illustration of the British doctrine may be found in the case of Bourgroise, ${ }^{65}$ a Frenchman, who, after obtaining in 1871 a certificate of naturalization with the usual qualification, married an English lady; and in 1880 returned with her to France, where two children were born to them and their births duly registered in the Euglish embassy at Paris. After his death in France in 1886, and the appointment there of a guardian for his children. application was made to the English court of chancery to make a like appointment. The question thus arose whether or no the naturalization of Bourgoise was effective in France, whose laws provide that the French national character can only be lost through an absolute naturalization abroad. ${ }^{66}$ The English court held that it had no jurisdiction to appoint a guardian for the children of Bourgoise, who died a subject of France, because, under his qualified British naturalization, he had not "ceased to be a subject of that state in pursuance of the laws thereof."

$\S 183$. Early American doctrine of expatriation. Cases with Prussia in 1840, 1853.-We have seen that in our earlier history the American doctrine as to the right of expatriation was identical with the British.67 Story, among others, declared "the general doctrine" to be "that no persons can, by any act of their own, without the consent of the government, put off their allegiance and become aliens," although the government of the United States had in its controversies with Great Britain at an earlier day claimed the right to protect persons who had been naturalized by it, despite the fact that the state of their nativity had either forbidden a reunciation of its allegiance or had attempted to subject it to certain conditions. When, in 1840 a Prussian, who had been naturalized in the United States, was required after his return to his native country to perform military service, he called upon Mr. Wheaton, then

${ }^{65} \mathrm{Re}$ Bourgoise, Infants, $\mathrm{L} . \mathrm{R}$. 41 Ch. D. 310.

66 "Article 17 of the Code Civile laid it down, that 'La qualité de Français se perdra par la naturalisation acquise en pays étranger;' but this clearly referred to an ab- solute naturalization, and did not touch the question whether a qualified naturalization operates to deprive a natural-born French subject of his status." Walker, Science of Int. Law, p. 213.

o7 See above, p. 217. 
American minister at Berlin, for protection. He was told that "having returned to the country of your birth, your native domicil and natural character revert, so long as you remain in the Prussian dominions, and you are bound in all respects to obey the laws exactly as if you had never emigrated." 68 And when in 1853 another I'ussian, who had obtained the naturali. zation of this country, chaimed its protection after his return to that country, the declaration was made that, "If a Prussian subject chooses to emigrate to a foreign country without obtaining the certificate which alone can discharge him from the obligations of military service, he takes that step at his own risk. He elects to go abroad under the burden of a duty le owes his government. His departure is in the nature of an escape from her laws; and, if at any subsequent period, he is indiscreet enough to return to his native country he cannot complain if those laws are executed to his disadvantage." ${ }^{69}$

A marked departure in 1859; Mr. Cass's declaration.-A marked departure from such views took place when in 1859), during a controversy between the United States and Prussia as to conscription laws, Mr. Cass declared that "the moment a foreignel" becomes naturalized his allegiance to his native country is severed forever. He experiences a new political birth. $A$ broad and impassable line separates him from his native country. ** Should he return to his native country he returns as an American citizen, and in no other character." тo The contention was then made that the country of naturalization has the right to protect its citizen in the land of his nativity from punishment for any crime not complete before expatriation. "The offense must have been complete before his expatriation. It must have been of such a character that he might have been tried and pumished for it at the moment of his departure." 71 While the Prussian government refused to admit that distinction between inchoate and perfect obligation it ended the contro-

$68 \mathrm{Mr}$. Wheaton to Mr. Forsyth, July 29, 1840.

$69 \mathrm{Mr}$. Everett, Sec. of State, to Mr. Barnard, Jan. 14, 1853. Mss. Inst., Prussia. See also as to the foregoing documents Senate Ex. Doc. No. 37, 36th Cong., 1st Sess., pp. $7,49,54,135,167$.

70 "From that time onwards the successive governments of the United States have shown a disposition to carry the right of expatriation to the furthest practicable point." Hall, p. 244.

71 Mr. Cass, Sec. of State, to Mr. Wright, July 8, 1859. Mss. Inst., Prussia. 
versy by discharging the party in question from the army as an act of courtesy to the United States. ${ }^{72}$

Act of Congress, 1868. Right of every state to settle question for itself.-The disposition thus manifested to press the right of expatriation to the greatest possible extent culminated in the act of $1868,{ }^{33}$ in which Congress took the final step, so far as this country is concerned, by declaring that "the right of expatriation is a natural and inherent right of all people, indispensable to the enjoyment of the rights of life, liberty, and the pursuit of happiness." In accordance with that declaration, which is made binding upon every officer of the government, our department of state holds that the right of expatriation is absolute, and that conditions imposed by goremment of origin have no exterritorial force. Such was the position of Mr. Evarts who, in 1879, wrote that "it is noticed with regret that the Swiss local authorities, at least, are disposed to maintain the doctrine of perpetual allegiance by denying the right of a native of that country to become naturalized elsewhere without their consent. This pretension has always been regarded here as extraragant, and as such has been resisted, so that sereral of the most important European countries with monarchial governments, which were most strenuous in supporting it, have receded from their claims and have concluded naturalization treaties with the United States." it As every state is equally entitled to its own views as to the nature and extent of the right of expatriation, and as no general understanding has been reached on the subject, no one state can do more than settle the question for itself by its own action, and as to others by express treaty stipulations. Since the declaratory act of 1868 the gorernment of the United States has been steadily working in that direction, and the result has been a series of treaties in which it is generally provided that a naturalized citizen of one country upon his return to the land of his birth can be tried there only for offenses against its laws complete before his emigration. When military service is specially mentioned, the stipulation usually is that it cannot be imposed upon the naturalized citizen after his return, nor can punishment be inflicted for its neglect, unless the obligation to perform it had actually matured before his departure. 359.

72 Halleck (Baker's ed.), i, 357-

73 Rev. Stat. § 1999. it Mr. Evarts, Sec. of State, to Mr. Fish, Nov. 12, 1879. Mss. Inst., Switz.; For. Rel. 1879. 
A possibility of future service is not sufficient, the call must actually have been made. ${ }^{i 5}$

$\S 184$. Traveling sovereigns-immunities and disabilities abroad.-Having now lefined the eharacter of persons who may claim to be citizens of a state by birth, marriage or naturalization, and who are subject as such to its jurisdiction at home and specially entitled to its protection abroad, an inquiry must be made as to the rights a state may lawfully claim in behalf of such citizens when they desire to enter into and abide for a time in a foreign state. At the outset a sharp distinction must be drawn between those who go abroad in a public and those who go in a private capacity, because the former are clothed with that immunity from local jurisdiction as to their persons, and in the case of sovereigns and their diplomatie representatives as to their retinues, which is embodied in the legal fiction of exterritoriality. The necessity and convenience of that fiction in the case of a sorereign, who as the head of the state represents not only its dignity but its independence and equality as a corporate person, is too obrious to require demonstration. And ret eren a sovereign has no right to enter upon foreign territory except through the permission of its governing power who, for grave reasons of state, may withhold in an exceptional case the comity or courtesy usually extended. ${ }^{i 6}$ When, howerer, the pririlege has been granted, such sovereign enters with an immunity or exemption from the local jurisdiction of the foreign state so long as he remains there in his sovereign capacity. ${ }^{7 \pi}$ No dues or taxes can be exacted of him; his home, which is his sanctuary, cannot be invaled by police or admin-

75 See Art. II of the Baden Treaty of 1868. Treaties of the U. S., p. 43; Lawrence, p. 196.

76 A refusal of such a courtesy without grave cause would no doubt be considered as a very serious offense.

77Bynkershoek, De Foro Legat. c. iii, § 13, and c. ix, § 10; Marshall, C. J., in Schooner Exchange v. McFaddon, 7 Cranch, 136. "The immunity of a sovereign as the representative of his state for anything done or omitted to be done by him in his public capacity has been affirmed by the English courts in De Haber v. the Queen of Portugal (XX Law Journal, 2, B. 488); and the French courts gave effect to the same principle in the cases of actions brought by a M. Masser against the Emperor of Russia, and by a M. Solon against the Viceroy of Egypt." Hall, p. 176, note 1. "Where a foreign sovereign has his name added as defendant in a suit against his agents, in order to be in a position to thus claim his property, he does not thereby subject himself to the jurisdiction of the court." Vavasseur v. Krupp, L. R. 9 Ch. D. 351. 
istrative officers; he cannot be subjected to the jurisdiction, ordinary or extraordinary, of civil or criminal tribunals; and such immunities extend equally to every member of his suite. If, forgetful of the obligations thus imposed, he commits acts against the peace or order of the community which exempts him from all punishment, or permits his attendants to commit such acts, the only redress that remains to the offended state is to expel him with his retinue from its territory.

It seems to be clear that there was a time when visiting sovereigns could exercise within their dwellings and orer their own subjects a complete jurisdiction both civil and criminal. $^{78}$ When, however, Queen Christina of Sweden iu 1657, after her abdication, hid her favorite, Monaldeschi, put to death in Paris by the captain of her guard, ${ }^{79}$ public indignation was so intense as to compel her expulsion. According to modern usage the risiting sovereign is not expected to exercise his sovereignty actively even over his own suite within the foreign jurisdiction. If one of them commits a crime it is expected that he will be sent home for trial; and if civil controversies arise among them, or between one of them and subjects of the foreign power, neither the sovereign nor his judges should attempt to act away from home, because in any event any decision they might render could not be enforced outside of their own country. It has been held that a visiting sorereign becomes justly liable to expulsion in the erent he attempts to make his house a refuge for accused persons, not of his suite, who are pursued by the local authorities. ${ }^{\text {so }}$ Whenever a sovereign puts aside his public capacity by traveling incognito, or by entering the military service of a foreign state, he becomes for the time being a private individual and subject as such to the jurisdiction of the sorereignty in which he happens to be until he sees fit to resume his privilege, which he may do at any time. It may happen that a person who is a sorereign over one state may be a subject in another, as in the case of the Duke of Cumberland who, after his accession to the

787 Co. 15. Mare Clausum, p. 326.

79 Cf. Hosack, Rise and Growth of the Law of Nations, Appendix, v.

80 Bynkershoek, De Foro Legatorum, c. iii; Phillimore, ii, § civviii; Bluntschli, $\S \S 129,136-42$, 150-3; Heffter, $\S 42$ and 53-4; Calvo,
§ 530-2; Klüber, § 49; Martens, Précis, \& 172. The last named seems to concede to the visiting sovereign both civil and criminal jurisdiction over his suite, while Phillimore and Klüber concede to him only the civil. Cf. Hall, p. 176 and note 1. 
throne of Hanover, took the oath of allegiance in England, and sat as an English peer by hereditary right. In such a case when permanent privileges are assumed with the consequent liability to punishment for an abuse of them, it is not clear that the recipient should have the right to shield himself by resuming at will his inviolability as a sovereign elsewhere. When a sovereign as a private individual holds property in a foreign state the better opinion is that its courts have the right to bind it by proceedings taken in them, whether it be real or personal ;1 and when a sovereign roluntarily enters the courts of a foreign state, or accepts their jurisdiction, he has no special privileges whatever. ${ }^{82}$

\section{$\S 185$. Foreign army in a friendly state-other immunities.-} It may be stated as a general rule that a foreign army passing over the territory of a friendly state, whether as an ally in a common cause or not, is entirely exempt from its civil and criminal jurisdiction, ${ }^{83}$ for the reason that any other rule would be destructive of discipline. If the passing soldiers commit offenses against the inhabitants they are to be dealt with by their officers under the military anthority of the state to which they belong. If such culprits are handed over to the civil courts of the country traversed, it must be as an act of concession and as an expression of confidence upon the part of their officers. If an exception to this general rule exists, it is in faror of the local jurisdiction over an offending member of the force found entirely outside of its lines. When states bear such relations to each other that the passage of troops is frequent, it is usual to regulate the line of march and the method in which offenders against peaceful inhabitants shall be punished by special conventions, such as those made

81 Bynkershoek, De Foro Legatorum, c. xvi; Klüber, $\S 49$; Martens, Précis, \& 172-3. Bluntschli $\S \S 129,134,136-142,150-3$; Calvo, $\S 547-9$; Fiore, $\S \S 492,498-9$.

82 "He brings with him no priv. ileges that can displace the practice as applying to other suitors." The King of Spain v. Hullet and Widder, 1 Clark and F. H. of L. 333; the Newbattle L. R. P. D. 33 ; Calvo, § 549.

83 In the seventeenth century Zouch only mentioned the immun- ity in his Dissertation concerning the punishment of Ambassadors (Trans. by D. J., p. 26); and in the eighteenth Casaregis concedes exclusive jurisdiction to a sovereign over his military and naval forces and over his ships wherever they may be: Libere jurisdictionem sive voluntariam aive contentiosam, sive civilem, sive criminalem; quod occupant tanquam in suo proprio, exercere possunt, etc. Discoursus de Commercio, 136, 174. 
between Prussia and Hanover in 1816, and between Prussia and Brunswick in $1835 .^{84}$ The immunities of public ressels and fleets when on the high seas or in the territorial water's of foreign states can be treated more conveniently in the forlowing chapter, to be deroted to the consideration of sorereignty and jurisdiction in relation to property,-a chapter in which an examination will also be made of the partial immunities enjoyed under like circumstances by prirate merchant ressels. In the same way it will be more convenient to treat in the chapter to be specially devoted to diplomatic intercourse the immunities incident to the persons, families and suites of diplomatic representatives, and the partial immunities to which consuls are likewise entitled.

\section{$\$ 186$. A state's right to receive and expel visitors.-A general} description must next be given of the rights which a state may lawfully claim in faror of such of its citizens as desire to enter foreign territory in a purely private capacity. If the sovereign himself cannot visit a foreign state without its permission expressed or implied it is not reasonable to suppose that his subjects are clothed with a higher privilege. Erery independent state possesses, certainly in theory, the right to grant or refuse hospitality. ${ }^{85}$ Undoubtedly such a state possesses the power to close the door to all foreigners whom for social, political or economic reasons it deems it expedient to exclude; and for like reasons it may subject a resident foreigner or a group of them to expulsion, ${ }^{86}$ subject of course to such retaliatory measures as an abuse of the excluding or expelling power may provoke. At the very beginning of our national life the government of the United States recognized the fact that "Every society possesses the undoubted right to determine who shall compose its members, and it is exercised by all nations in peace and war. A memorable example of the exercise of this power in time of peace was the passage of the alien law of the United States in the year 179s. * * It may

84 Martens (N. R.) iv, 321; (N. R. G.) vii, i, 60; Hall, p. 206 and note 1. The rule now universally recognized is that a state must obtain express permission before its troops can pass through the territory of another state; a rule established by modern publicists who have finally overcome the contrary opinion held by
Grotius. See De Jure Belli ac Pacis, ii, c. 2, xiii.

85 As against that right stands the claim that every state at peace with another has a certain right of intercourse. For the maxims underlying that supposed right, see Heffter, Völker, $\S 33$, 5th ed.

s6 Sometimes called the Droit de Renvoi. 
always be questionable whether a resort to this power is warranted by the circumstances, or what department of the government is empowered to exert it; but there can be no doubt that it is possessed by all nations, and that each may decide for itself when the occasion arises demanding its exercise." 87

Right to exclude obnoxious foreigners defined.-Not long ago this government became impressed with the fact that the occasion had arisen for the exclusion of Chinamen and alien paupers, and in 1882 Congress passed an act entitled "An Act to Regulate Immigration," ss in which it was provided among other things that the commissioners at the various ports should prohibit the landing on these shores of "any convict, lunatic, idiot or any person unable to take care of himself or herself without becoming a public charge." When in a case ${ }^{89}$ made under the act it was contended before the Supreme Court "that the framers of the constitution have so worded that remarkable instrument, that the ships of all nations, including our own, can, without restraint or regulation, deposit here, if they find it to their interest to do so, the entire European population of criminals, paupers, and diseased persons, without making any provision to preserve them from starvation, and its concomitant sufferings even for the first few days after they have left the vessel," the answer was that such contention is entirely untenable. The political department of the government has asserted with equal emphasis that "the power of expelling obnoxious foreigners is one incident to so $\mathrm{F}$ ereignty." "Do "During the revolutionary period of 1848 , "an act of parliament (11 and 12 Vict., c. 20) was passed in Great Britain, * * by which power was given to the executive in England and Ireland to remove aliens from the realm; and in the United States it was declared by an order, dated 19th Angust, 1861, that no person, if a foreigner, should be allowed to land in the United States, without a passport from his own govermment, countersigned by a minister or consul of the United States." ${ }^{91}$ It is, however, often a delicate question to

8i Mr. Marcy, Sec. of State, to Mr. Fay, Mar. 22, 1856. Mss. Inst., Switz.

8822 Stat. at L., 214.

89 Edye v. Robertson, Coll., 112 U. S. $580-600$.

$90 \mathrm{Mr}$. Fish, Sec. of State, to
Mr. Foster, Oct. 17, 1873. Mss. Inst., Mex.

91 Abdy's Kent, 110. The order in question which grew out of the exigencies of the civil war is no longer in force. 
determine when the right of expulsion may be exercised without giving just offense to the state whose citizen or citizens are thus cast out. The Institut de Droit International, while recognizing the right of expulsion to the full extent, has adopted a project designed to temper its practical application. $^{92}$

$\S 187$. How far citizens abroad are amenable to local jurisdiction.-What degree of protection can a state demand for such of its citizens as have been voluntarily received by another as acceptable sojourners? The fundamental condition upon which such persons accept the hospitality of a foreign state is that they will be amenable to its laws, both civil and criminal. "Every nation, whenever its laws are violated by any one owing obedience to them, whether he be a citizen or stranger, has a right to inflict the penalties incurred upon the transgressor if found within its jurisdiction. The case is not altered by the character of the laws unless they are in derogation of the well-established international code. No nation has a right to supervise the municipal code of another nation or claim that its citizens or subjects shall be exempted from the operation of such code, if they have voluntarily placed themselves under it." It may be said that the exclusive territorial jurisdiction of every state gives it complete control over all foreigners not protected by special immunities. While they remain upon its soil, subject to the generally received limitation, that, in the absence of express agreements to the contrary, no state can arrest or punish citizens of another for offenses committed outside of its jurisdiction, even though they are regarded as such by the law of the state to which the offender belongs. When a state demands the right to punish a foreigner for a criminal act committed within the limits of another sovereignty before his arrival, it asserts a claim to concurrent jurisdiction which, if valid, would overthrow the fundamental assumption upon which the present state-system is founded. And yet self-evident as that principle would seem to be, the rule that a state can only punish crimes committed within

$92 \mathrm{As}$ to the project of International Declaration adopted in 1888 , see Annuaire de l'Institut, 1888-9, 245. M. Rolin Jacquemyns (Rev. de Droit Int., $\mathrm{xx}, 498)$, in his scheme of restriction, declares that "en l'absence d'un état de guerre," "l'expulsion en masse de tous les étrangers appertenant à une ou plusieurs nationalités determinées ne se justifierait qu'à titre de représailles." Hall very properly concludes that such ought to be the law, p. 224, note 1 . 
its territorial jurisdiction is subject to serious exceptions aris. ing $^{1}$ (1) out of the general consent of nations that one crime committed on the high seas against all mankind may be punished by any state into whose hands the offender may fall; (2) out of the refusal of certain states to admit that their right to punish crime rests upon considerations purely territorial. $^{2}$

$\S$ 188. Piracy, jure gentium.-It is a settled rule of international law that erery state possesses jurisdiction orer all pirates seized by its ressels or officers because their crime is one necessarily committed outside of the territorial jurisdiction of any civilized state against the entire body of civilized states considered as a single community. As the offense is against all mankind it may be punished in the proper tribunal of any country in which the offender may be found, or into which he may be carried, although committed on a foreign ressel on the high seas. That is only true, however, as to the jurisdiction over such acts as constitute piracy jure gentium. ${ }^{3}$ In contemplation of that law "Piracy is robbery or forcible deprivation on the high seas, without lawful authority, and done animo furandi, and in the spirit and intention of universal hostility. It is the same offense on sea as robbery is on land." A single act of violence, if adequate in degree,- - such, for instance, as a successful revolt of a crew who, after killing the captain, ${ }^{5}$ take a ship out of the hands of its officers and make depredations on other shipping,-may constitute the offense if committed on the sea outside the jurisdiction of any state, without anthorization from any recognized political community. Many acts perfectly legal when committed with such organization become piratical when committed without it. For that reason every belligerent community is eager to secure recognition as such in order that its commission may save its cruisers from being ranked as pirates. ${ }^{6}$ If such a

1 Mr. Marcy, Sec. of State, to Mr. Jackson, Jan. 10, 1854. Mss. Inst., Prussia.

2 See below, p. 240.

3 Bynkershoek, Quaest. Jus. Pub., lib. i, cap. 17; Howell's State Trials, xii, 1271-2; Blackst. Comm., iv, 286; Phillimore, i, 394, 406; Le duc de Broglie, "Sur la Piraterie," Ecrits, iii, 335-375; Kent, i, 184-6; Wildman's Int. Law, ii, 150; U. S. v. Palmer, 3 Wheat. 610 ; U. S. v.
Kintock, 5 Wheat. 152; U. S. v. Pirates, Ib. 185; U. S. v. Holmes, Ib. 412; Bluntschli, § 343; Calvo, vol. i, § 485 .

4 Am. and Eng. Enc. of Law, 18, p. 461 .

$5 \mathrm{Mr}$. Marcy, Sec. of State, to Mr. Starkweather, Sep. 18, 1854. Mss. Inst., Chili. A pirate must, however, be in the predicament of an outlaw, hostis humani generis.

${ }^{6}$ For a statement of the circum. 
community goes down in the struggle, the protection of its commission ends with its de facto existence. ${ }^{7}$ If, however, a commission has been lawfully granted, captures made under it, although unauthorized by the laws of war, are not piratical so long as the commissioned state survives to answer to other states for miscleeds committed in its name. ${ }^{8}$

$\S 189$. Case of the Huascar. Statutory piracy.-In 1877 a revolutionary movement took place in Per'u whose only visible result was the seizure, at Callao, of the ironclad Huascar by her crew and some of her officers, who began a roving career without any kind of a commission and without any kind of a political organization behind them capable of granting one. After stopping two British ressels, from one of which a supply of coal was taken without payment, the admiral commanding the English squadron in the Pacific, who justly regarded the Huascar as "piratical against British subjects, ships and property," fought an inconclusive engagement with her, after which she surrendered to a Peruvian squadron. It is hard to understand why any one should question the correctness of the position of the English admiral whose conduct was approved by his government, after the law officers of the crown had reported that the acts of the Huascar were piratical. ${ }^{9}$ As conflicting authorizations are supposed to be void, a vessel is considered a pirate which, under commissions from different sovereigns at war with each other, depredates impartially upon the commerce of them all. ${ }^{10}$ A general description has thus been given of the crime of piracy as defined by the law of nations, so that

stances under which insurgents can not be considered pirates, see U. S. v. Baker, 5 Blatch., p. 6 ; (Proceedings published in full in separate volume entitled Trial of Officers, etc., of the privateer Savannah, N. Y., 1862;) Wharton, Int Law Dig., vol. iii, pp. 464-75.

7 When the Southern Confederacy fell in the spring of 1865 , the cruiser Shenandoah was in the Antarctic seas, and, in ignorance of that event, continued her depredations upon American vessels around Cape Horn until Aug. 2, when her captain, hearing of the extinction of his government, desisted from further hostilities. Upon that statement the British government, when the Shenandoah was given up at Liverpool in November, permitted the captain and crew to go free, while the ship was turned over to the United States. British State Papers, British Case presented to the Geneva Arbitrators, 156-60.

8 Lawrence, Principles of Int. Law, pp. 210-11.

9 Parl. Papers, Peru, No. I, 1877. Hall, pp. 277-8.

10 A commission, however, to a private armed vessel from either of the belligerents affords a defense, according to the law of nations. U. S. v. Baker, 5 Blatch., 11-13. 
it may not be confused with that kind of piracy which is ereated by the statute law of particular states, and which ean only be punished by them when committed by their own subjects and foreigners within their jurisdiction. In its legislation on the subject the United States has not only embraced the erime of piracy as defined by the law of nations, but has also decelared certain acts to be piracy which are not so under that law.

$\$ 190$. Slave-trade: Hostile action of Great Britain and other nations, after 1807. - When the slave-trade, at one time considered as perfectly legitimate commerce, came to be regarded as an odious crime which all civilized nations should aid in suppressing, the question arose as to the most practical means to be employed to secure that end. As there was no international rule justifying interference with it in any form, and as no general consent could be obtained adequate to create such a rule, it only remained for such states as desired to suppress it to make it the subject of hostile municipal legislation. As early as 1792 Denmark led the way by prohibiting the importation of slaves from abroad into her colonies after 1802; and by the second constitution of the United States Congress was empowered to prohibit their importation after 1808,-a provision supplemented by a series of statutes ${ }^{11}$ which culminated in the act of Mareh 3,1820, providing that all persons over whom the jurisdiction of the United States extended who were concerned in the slave-trade, or in lidnaping negroes or mulattoes, were to be considered as pirates punishable by death. In 1807 Great Britain passed the first act declaring the slave trade illegal; in 1814 the treaties of Paris, Kiel and Ghent provided for its final abolition; in 1815 that provision was repeated in the declaration of the Congress of Viemna; in 1815 and 1817 , in treaties made by Great Britain with Spain and Portugal those counties agreed that the trade should be abolisleed; and in 1527 , in a convention concluded by Great Britain with Brazil it was made piratical for the subjects of that coun. try to engage in it after 1830. In 18.3 the House of Representatives instructed the President of the United States to enter into such negotiations with the maritime powers of

11 In 1807 the importation of slaves was made to cease after Jan. 1, 1808; in 1818 the penalties for participation in it by citizens of the United States were in- creased; and in 1819 the vessels and effects of all citizens found to have been engaged in it were made subject to seizure and confiscation. 
Europe and America as would secure "the effectual abolition of the African slave-trade, and its ultimate denunciation as piracy under the law of nations by consent of the civilized world." While Great Britain was induced to pass an act in March of the following year declaring the slave-trade to be piracy, the attempt then made to have it declared to be so, jure gentium, by the general consent of nations, was signally unsuccessful.

Cases of the Amedie, Fortuna, Diana, Louis and Antelope.Equally so was the attempt made at an earlier day to have the traffic pronounced illegal everywlere through judicial interpretation. In the case of the American ressel, ${ }^{12}$ The Amedie, the Lords of Appeal in prize cases delivered a hostile judgment in 1807 , through Sir William Grant, after Great Britain had declared the traffic unlawful and after the United States had forbidden all citizens and residents to carry slaves from this country to a foreign one, or from one foreign country to another. Sir William's effort was to create out of the acts of certain nations, without the concmrence of the rest, the international rule that the slave-trade was at least prima facie illegal jure gentium. No matter if it be true, as Mr. Dana contends, ${ }^{13}$ that that question was unnecessary to the decision of the case, it was in fact argued and passed upon by the judges who declared through their spokesman that "we can now assert that this trade cannot, abstractly speaking, have a legitimate existence, ** we have now a right to affirm that prima facie the trade is illegal, and thus to throw on claimants the burden of proof that, in respect of them, by the authority of their own laws, it is otherwise. ** In this case, the laws of the claimant's country allow no property such as he claims." While Lord Stowell permitted himself to be bound by this new invention in the case of The Fortuna, ${ }^{14}$ decided in 1811 in the High Conrt of Admiralty, he exempted from its operation the subsequent case of The Diana ${ }^{15}$ - a Swedish ressel captured by a British cruiser while actually carrying slaves to the possessions of Sweden in West India-upon the ground that that country which had not prohibited the traffic by treaty 240.

121 Acton's Admiralty Reports,

13 "The proceeding, from beginning to end, was one of prize of war solely; and her condemnation had nothing to do with her being engaged in the slave trade." Dana's Wheaton, note 86, p. 208. 14 Dodson's Admiralty reports, 81.

15 Ibid, 95. 
or statute, still continued to uphold it in practice. And in the case of The Louis, ${ }^{16}$ decided in 1817 , he finally repudiated the general principle announced in the case of The Amedie by deeiding that even if the laws of France had prohibited the traffic, which was doubtful, the light of visitation and search, purely a belligerent right, could not under the law of nations be exercised in time of peace to enforce that prohibition through a British court upon the property of Frencl subjects. He held that the slave-trade could only become piracy, in the absence of a general convention, when so treated in practice by all civilized nations. Such was the doctrine laid down by the Supreme Court of the United States in 1825 in the case of The Antelope ${ }^{17}$ in which Chief Justice Marshall, speaking for the court, held that while the African slave-trade is contrary to the law of nature, it is not prohibited by the law of nations; that although prohibited by some nations, it may still be earried on by the subjects of such as have not prohibited it by statute or treaty; that it is not piracy unless made so by the statutes or treaties of the state to which the trader belongs; that the right of visitation and search does not exist in time of peace; that a ressel engaged in the slave-trade, even when it is prohibited by the laws of the country to which it belongs, cannot, for that cause alone, be seized on the high seas, and brought in for adjudication, in time of peace, in the courts of another country; that only where the laws of another country are violated, or where there is a treaty providing for the mutual right of search and capture, can that right be lawfully exercised.

Great Britain's claim of right of visit, 1841, resisted.-When, in 1841, British cruisers attempted to stop American vessels suspected of being engaged in the traffic, the British foreign office, disclaiming the right of search in time of peace, claimed the right of visit in order to discorer "whether the ressel pretending to be American and hoisting the American flag be bona fide American,"-a right which Mr. Webster resisted upon the ground that there is no distinction between the right of visit and the right of search, because the former really includes the latter. In the next year the controversy was composed for a time by that article of the Treaty of Washing. ton, which provided that each nation should maintain on the coast of Africa a naval contingent adequate "to enforce, separately and respectively, the laws, rights and obligations of

162 Dodson Admr. Rep., 210.

1710 Wheat. 66-132. 
each of the two countries." 1 s Great Britain's more practical policy was to remove the difficulties in the way of suppressing the traffic through treaty engagements mutually conceding the right of search so that the cruisers of each of the contrating powers might have the right to examine and if necessary seize and bring to trial ressels of otler nations suspected of the offense. As early as 1817 she inaugurated that policy in a treaty with Portugal; in the same year the mutual right of search was secured in the Treaty of Madrid made with Spain; in 1818 in a treaty with the Netherlands; in 1831 and 18.3 .3 in treaties with France; and in 1841 in a treaty with Austria, Prussia and Russia.

Reluctance of France and U. S. to concede right of search.France, who refused to accede to that quintuple arrangement. held on to her agreements of 1831 and 1833 until 1845, when the prejudices of her people against the right of search in any form induced her to renounce both, as she had the right to do under their terms. After that time, while France agreed to maintain a squadron on the African coast to co-operate with the British cruisers in suppressing the traftic, it really flourished under the protection of her flag by reason of the fact that Arab dhows could easily obtain from a French consul a license conferring upon them French nationality with its consequent exemption from search and seizure. ${ }^{19}$ It was almost equally hard for Great Britain to induce the United states to consent to the mutual right of search of ressels supposed to be slavers. The temporary suspension of the question by the Treaty of Washington in 1842 did not prevent a sharp remonstrance on the subject by the Senate of the United States in $1858 ;^{20}$ and

18 Treaties of the United States, p. 436 .

19 "They were then safe from capture even if their decks were crowded with slaves. The utmost a British officer could do, and this rather on sufferance than by right, was to send a boat and to demand to have the ship's papers shown over the side of the ves. sel." Lawrence, p. 215. For practice under the treaty of Washing. ton, see Foote's Africa and the American Flag.

20 When in that year the British government stationed cruisers near the island of Cuba for the purpose of preventing the slave trade, the Senate resolved "that American vessels on the high seas in time of peace, bearing the American flag, remain under the jurisdiction of the country to which they belong; and, therefore, any visitation, molestation, or detention of such vessel by force, or by the exhibition of force on the part of a foreign power, is in derogation of the sovereignty of the United States." 
not until 186: did the two countries finally agree upon a treaty $^{21}$ in which the mutual right of search was conceded to public ressels, specially provided with instructions for that purpose, which were authorized to visit merchant ressels suspected of trading in slaves within two hundred miles of the African coast south of parallel thirty-two, and within thirty leagues of Cuba. The abolition of slavery in that island as well as in the several Ameriean Republics has, however, put an end to the tratic on the western coast of Africa, while that which still thrives on the eastern is yielding to the measures taken in recent years to suppress it,-chief among which may be mentioned the Final Act of the Brussels Conference, ${ }^{22}$ 1890 , explained alrealy.

$\$ 191$. Territoriality of crime disputed by many nations.-Despite the general rule "that the criminal jurisdiction of a nation is limited to its own dominions and to vessels under its llag on the high seas, and that it cannot extend it to acts committed within the dominion of another without violating its sovereignty and independence," ${ }^{23}$ the territoriality of crime is disputed by a formidable group of nations who claim that their tribunals have the right to take cognizance of offenses committed by foreigners in foreign territory. ${ }^{24}$ Some of the group in question limit their efforts to the punishment of foreigners found on their soil who have committed acts abroad against the safoty or high prerogative of the state as a sorereign, while others include foreigners who have committed crimes abroad against their citizens as private individuals. Under the first head may be mentioned France, Germany, Aus. tria, Italy, spain, Belgium, and Switzerland; under the second, Russia, the Netherlands and Greece. Austria and Italy claim only the right to punish conditionally offenses committed abroad against their citizens, after extradition has been offered to and refused by the state in which the crime was com-

21 Negotiated by Mr. Seward and Lord Lyons. Treaties of the United States, p. 455 .

22 See above, p. 95.

23 Mr. Calhoun, Sec. of State, to Mr. Everett, Sep. 25, 1844. Mss. Inst. Great Britain.

24 For the older authorities for and against the validity of such laws, see Foelix, liv. ii, tit. ix, ch. iii. See also Fiore, Delits commis à l'etranger, Rev. de Droit Int., xi, 302; Von Bar, § 138; Progetto del Codice Penale del Regno d'Italia, p. 263; Martens, Précis, $\S 100$; Phillimore, i, § cccxxxiii; Hall, $\S 62$. As illustrations of the views of those who deny the doctrine of the territoriality of crime, see Massé, §524; Woolsey, § 76. 
mitted. ${ }^{25}$ The French law, which is typical of the class to which it belongs, provides for the punishment of those who in other countries have offended the sovereignty of France by criminal acts against the safety of the state, by counterfeiting its seal or coin having actual currency, or by the forgery of paper money. In the varying lists of offenses committed abroad against private individuals, for which certain states attempt to punish foreigners within their limits, are usually included murder, arson and forgery, and sometimes libel.

$\S$ 192. Cutting's case, 1886.-An exhaustive exposition of that aspect of the subject may be found in the recent case of Mr. Cutting, which maly be stated as follows: "On June 18th last (1856) A. K. Cutting, a citizen of the United States, who for the preceding eighteen months had been a resident 'off and on,' of Paso del Norte, Mexico, * * published in a newspaper of El Paso, Tex., a card commenting on certain proceedings of Emigdio Medina, a citizen of Mexico, with whom Mr. Cutting had been in controversy. For this publication $\mathrm{Mr}$. Cutting was imprisoned on the 22nd of June last, at El Paso del Norte, in Mexico. * * But the paper was not published in Mexico, and the proposition that Mexico can take jurisdiction of its author on account of its publication in Texas is wholly inadmissible and is peremptorily denied by this gorernment. If Mr. Cutting can be tried and imprisoned in Mexico for publishing in the United States a criticism on a Mexican business transaction in which he was concerned, there is not an editor or publisher of a newspaper in the United States who could not, were he found in Mexico, be subjected to like indignities and injuries on the same ground. To an assumption of such jurisdietion by Mexico neither the government of the United States nor the governments of our several states will submit." 26 On behalf of Mexico Mr. Romero produced

25 On Nov. 15,1899 , the department of state (U. S.) received a telegram from the chargi at Rome, stating that Diblassi had been sentenced to six years imprisonment. Diblassi fled to Italy after killing Ellis, a health officer in Boston. owing to Ellis' attempt to enforce sanitary regulations. Instead of demanding extradition the Italian court was permitted to proceed upon evidence supplied by the
Massachusetts authorities. As to the punishment of such criminals in Austria, when extradition is declined by the offended state, see the essay on the doctrine of asylum, by $R$. von Mohl, in his staatsr. Völkerr. u Politik, vol. i, 644-649.

$26 \mathrm{Mr}$. Bayard, Sec. of State, to Mr. Jackson, July 20, 1886. Mss. Inst., Mex.; Senate Ex. Doc. 224, 49th Cong., 1st sess.; For. Rel., 
"the Mexican laws, article 186, whereby jurisdiction is assumed by Mexico over crime committed against Mexicans within the United States or any other foreign country; and under this he maintained the publication of a libel in Texas was made eognizable and punishable in Mexico." 27 The contention of the United States which prevailed in that case embodies a clear and positive statement of the views of those who are prepared to maintain the ancient principle as to the territoriality of crime $^{2 s}$ against the dangerous innovation which assumes "that the principle is not founded on reason, and that as interconrse. grows closer in the world nations will the more readily aid general justice." 29

\section{$\$$ 193. Foreigner can only demand fair trial under local law.} -Such is the general nature of the criminal jurisdiction which may be asserted against any one who goes beyond the limits of his own nation. Whenerer it is properly asserted by a foraign tribunal having jurisdiction over the offense charged, the state to which the accused belongs can only demand that he be fairly tried under the municipal law of the formm, provided such law is "in conformity with those sanctions of justice which all civilized nations hold in common," ${ }^{30}$ and does not contravene some special right acquired by treaty by the country whose protection is invoked. It is the duty of a state to construe and administer its own laws, and if that be done, promptly and impartially, and with a just regard to the rights of a foreigner within its bounds, his state has no right to complain. There is no ground for interference except in case of refusal of justice or of palpable injustice; or where "summary, sanguinary, or undue punishment" 31 has been inflicted. There must be "arbitrary acts of oppression or deprivation of property as contradistinguished from penalties and punishments, incurred by the infliction of the laws of the count?y within whose jurisdiction the sufferers have placed them-

1886. For an exhaustive review of the whole subject, sce Mr. Moore's Report on extra-territorial erime and the Cutting case, issued by the Dept. of State of the United States in 1877, and the article upon the report by Mr. Albéric Rolin in the Revue de Droit Int., 18s8, p. 559.

27 Mr. Bayard, Sec. of State, to
Mr. Jaekson, July 27, 18s6. Mss. Inst., Mex.

2s See Dana's Wheaton, pp. 189 . 190.

29 Woolsey, $\$ 76$.

$30 \mathrm{Mr}$. Bayard, Sec. of State, to Mr. Jackson, July 20, 18s6, quoted above.

31 Mr. Webster, Sec. of State, to Mr. Ellis, Jan. 3, 1842. Mss. Inst., Mex. 
selves." ${ }^{\prime}$ While it is not to be anticipated that proceedings in a foreign "jurisdiction will be conducted otherwise than in strict conformity to law with every constitutional guarantee for the fair trial and defense of the accused, yet it is the clear right and duty of * * any government to satisfy itself that its citizens enjoy whilst temporarily in foreign lands, every right and privilege before the bar of justice, and to see that they are allowed the fullest means of defense." ${ }^{33}$ If a suitor applies to a foreign tribunal for justice, he must submit of course to the rules by which that tribunal is gorerned. Submission to the laws of a foreign state is the condition upon which its hospitality is extended. Every state has the right to prescribe the reasonable conditions upon which a foreigner may reside within its territory. ${ }^{34}$

$\S 194$. State's right to punish its citizens for crimes committed abroad.-In connection with the duty of states to protect their citizens against injustice from foreign tribunals must be considered the jurisdiction claimed by most of them to punish such citizens, by virtue of the tie of personal allegiance, for certain heinous crimes committed by them in foreign territory. As the jurisdiction is personal it cannot generally be exercised until the offender comes again within the jurisdiction, territorial or maritime, of the country to which he belongs. The right to punish then becomes purely a question of municipal law whose provisions must regulate the conditions under which a trial may be had. Russia, many of the German states, Italy, Austria, some of the Swiss cantons, and Norway enforce their donestic criminal law against all of their subjects who hare committed offenses abroad either against the state itself, their fellow subjects or foreign subjects. ${ }^{35}$

$\S 195$. British legislation on the subject.-Owing to differences in their constitutional systems a more limited control

32 Mr. Marcy, Sec. of State, to Mr. Jackson, Jan. 10, 1854. Mss. Inst., Austria.

$33 \mathrm{Mr}$. Bayard, Sec. of State, to Mr. Lowell, Apr. 10, 1885. Mss. Inst., Gr. Brit.

34 "The government of the United States recognizes the right of Mexico to prescribe the reasonable conditions upon which foreigners may reside within her territory, and the duty of American citizens there to obey the municipal laws." Mr. Frelinghuysen, Sec. of State, to Mr. Morgan, Feb. 17, 1885. Mss. Inst., Mex.

35 "France notices no crimes of Frenehmen against foreigners; nor' 'delits' of one Frenchman against another on foreign soil; nor 'crimes' of Frenchman against Frenchman, except on complaint of the injured party." Woolsey, $\$ 76$. 
is asserted by Great Britain and the United States, whose criminal jurisprudence rests upon the general principle common to both that crimes are territorial, and justiciable only in the courts of the country where committed. From that general rule both countries have, however, made serious departures through positive legislation. By 35 Hen. VIII., c. 2 , all offenses declared to be treason, misprision of treason or concealment of treason committed by any person out of the realm of England were made triable in the Court of King's Bench by a jury of the shire in which the court sits or before commissioner's assigned for the purpose in any shire; and in a series of statutes as to murder, beginning with 33 Henry VIII., c. 23 , and ending with 24 and 25 Vic. c. 100 s. 9 , it was finally provided that where any murder or manslaughter is committed on land out of the United Kingdom, whether within the queen's dominions or without, and whether the persons killed were subjects of her majesty or not, the offense may be dealt with in all respects as if it had been committed in England in the county or place in which the suspected person is apprehended or in custody. To these offenses must be added such as are created by the Foreign Enlistment Act, ${ }^{36}$ most of which can be committed either within or without her majesty's dominions; offenses created by the acts prohibiting the slavetrade $;^{37}$ offenses which may be committed abroad by certain (ivil and military officers of colonies and other British possessions in the discharge of or under color of their official powers; and finally such offenses as may be defined by the queen legislating through Orders in Council by virtne of the authority conferred by the Foreign Jurisdiction Acts. ${ }^{38}$ The act of 1875 authorizes the queen to exercise "power and jurisdiction over her subjects witlin any islands and places in the Pacific Ocean not being within her majesty's dominions nor within the jurisdiction of any eivilized power," while that of 1878 gives to her power to legislate for her subjects in any place where they are resident or resort "which is not subject to any government from whom her majesty might obtain power and jurisdiction by treaty" or any of the other means mentioned in the act of 1843 whose first recital is that the queen has "by treaty,

3633 and 34 Vic., c. 90.

37 See R. v. Zulueta, 1 C. and K., 226-27; Santos v. Illidge, 8 C. B. (N. S.), 861. It is doubtful whether such acts are locally confined to the queen's dominions. 386 and 7 Vic., c. 94 (1843), 29 and 30 Vic., c. $87(1886), 38$ and 39 Vic., c. $85(1875), 41$ and 42 Vic., c. 67 (1878). 
capitulation, grant, usage, sufferance, and other lawful meaus, power and jurisdiction within divers countries and places out of her majesty's dominions." 39 No crime committed abroad can now be tried in England unless an express statutory provision has been made to that effect.

$\$$ 196. Like legislation in the U. S.-The constitution of the United States (art. I, $\$$ ) provides that Congress shall have power "to define and punish piracies and felonies committed on the high seas, and offenses against the law of nations;" and (art. III, 52 ) that "the trial of all crimes, except in the case of impeachment, shall be by jury; and such trial shall be held in the state where the said crimes shall have been committed; but when not committed within any state, the trial shall be at such place or places as the Congress may by law have directed." A crime committed against the laws of the United States upon the high seas or elsewhere, out of the limits of a state, is not local, and may be tried at such place as Congress may designate. It has therefore been provided that the trial of all persons who commit such crimes, out of the jurisdiction of any particular state or district, shall be had in the district where the offender is found, or into which he is first brought. ${ }^{40}$ As the states of the American union, as such, are unknown in our intercourse with foreign nations, the entire jurisdiction over crimes committed beyond theil limits has been vested in the federal government, whose criminal jurisdiction is purely statutory. ${ }^{41}$ As heretofore explained penalties are imposed by statute not only upon piracy, jure gentium, but upon other like acts which would not constitute piracy under that law.

39 "A variety of Orders in Coun. cil have been made under the authority of these acts for regulating the proceedings to be taken before various courts to which they apply. I may mention in particular the orders which apply to the courts in China, the courts in various parts of the Turkish Empire, particularly in the courts at Constantinople and in Egypt, and the order relating to the Western Pacific Islands dated August 13, 1877." Sir J. F. Stephen, Hist. of the Criminal Law of Eng., vol. ii, p. 59. See also, Ibid. 13-16. 40 Rev. Stat., $\$ 730$. For the construction of that section, see U. S. v. Alberty, Hemp. 444; U. S. v. Thompson, 1 Sum. 168; U. S. v. Corrie, 23 Law Rep. 145; U. S. v. Mingo, 2 Curt. 1; U. S. v. Magill, 1 Wash. 463; U. 'S. v. Bird, 1 Sprague, 299; U. S. v. Baker, 5 Blatch. 6; U. S. v. Arwo, 19 Wall. 486; U. S. v. Jackalow, 1 Black. 484.

41 The U. S. courts have no jurisdiction of offenses at common law. Ex parte Bollman, 4 Cranch, 75; Turner v. Bank of N. A., 4 Dal. 10; U. S. v. Ta-wan-ga-ca, Hemp. 304; Case v. Woolley, 6 Dana, 17. 
An explanation has also been given of such statutes as attempt to assimilate slave-trading to that crime. ${ }^{42}$

$\$ 197$. Offenses punishable by U. S. ministers and consuls incertain countries.-Learing out of riew piracy and slave-trading and such other crimes as may be committed against the laws of the United states upon the high seas, reference need be made only to such offenses as may be punished abroad by United states ministers and consuls in certain countries. The Revised statutes ${ }^{43}$ ordain that in order to carry into full effect the provisions of the treaties of the United States with China, Japan, Siam, and Madagasear, respectively, the minister and the consuls appointed to reside in each of those countries shall "be invested with the judicial anthority herein described, which shall appertain to the office of minister and consul, and be a part of the duties belonging thereto, wherein, and so far as, the same is allowed by treaty, "-subject to the limitation that "jurisdiction in botl eriminal and eivil matters shall, in all cases, be exercised and enforced in conformity with the laws of the United States, which are hereby, so farr as is necessary to execute such treaties, respectively, and so far as they are suitable to carry the same into effect, extended over all citizens of the United states in those countries; and over all others to the extent that the terms of the treaties respectively justify or require." 43 a

\section{$\$ 198$. Duty of a state to protect aliens. Their status in Greece} and Rome.-While it may be theoretieally true that a state in the extreme exercise of its sovereignty may exclude all foreigners from its limits, such a policy would at once deprive it of a place in the family of nations and of the consequent benefits of international law. Nations must hold intereourse with each other, and the right of a state to protect its subjects abroad imposes the reciprocal duty upon it to answer for injuries unlawfully inflicted upon foreigners within its territory and jurisdiction. ${ }^{44}$ In order to illustrate the fact that that obligation is as old as civilization an account has been given of the status of aliens and of the privileges accorded them in the Greek city-states whose policies were liberal or exclusive according as they were commercial or non-commercial. ${ }^{45}$ So important did the foreign colony become at Rome that the tribunal of the protor peregrinus had to be established

4: Sce above, p. 236 .

43 Secs. $4083,4086$.

43a Constitution of U. S. does not guarantee right of trial by jury in such cases. In re Ross, 140 U. S., 453.

44 See above, p. 213.

45 See above, p. 11. 
for their special benefit, out of whose procedure arose the jus gentium, "an independent international private law, which, as such, regulated intercourse between peregrins, or between peregrins and citizens, on the basis of their common libertas." ${ }_{4}$ While the connubium and commercium as well as the suffragium and honores of the citizen were denied to the alien friend, ${ }^{47}$ even the jus civile, the special law administered between Roman and Roman, could be extended to members of allied states to which commercium and recuperatio were granted by treaty. ${ }^{48}$

$\$ 199$. Treatment of aliens in middle ages.-In the states that arose upon the wreck of the Roman Empire aliens were treated throughout the middle ages with more or less liberality, according as the policy of each particular state tended to foster or exclude foreign merchants and artisans. Such commercial cities as Genoa, Venice and Pisa obtained even from the Sultan special quarters and privileges for their traders in the cities of the Asiatic seaboard. ${ }^{49}$ Some states permitted merchants and artisans to enter and to ply their vocations with the right to acquire personal property and to sue and be sued in the ordinary civil courts with due protection to life and limb. Sometimes they were placed under the care of a special host $;^{50}$ and sometimes as suitors they were granted the boon of a jury de medietate lingua..$^{51}$ As a return for such privileges the foreign merchant was expected to bear heary taxation in addition to many special exactions. If he desired to withdraw from the realm he was liable to be amerced of a part of his goods, movable or immovable, through the gabelle d'emigration,${ }^{22}$ if he desired to remove from one state to another property derived from a deceased ancestor, he was expected to pay for the privilege through the royal fine imposed as the droit de détraction, or droit de retraite. ${ }^{53}$

$\S 200$. Special policies of England, Germany and France.-As a general rule the alien was prohibited by the municipal laws of all states from holding real property, and to that rule English law formed no exception. And yet prior to the disabling

46 See above, p. 22.

47 Walker, p. 215.

48 Muirhead, Roman Law, p. 225. 392.

49 Hallam, Middle Ages, vol. ii,

50 Cf. Stat. 5 Hen. iv. c. 9.

51 Cf. Stat., 28 Edw. 3 c. 13.
52 Originally no one had the right to quit his country except under such conditions as its government saw fit to impose. Martens, Prícis, §§ 90, 91; Heffter, §§ 15,33 ; Vattel, i, 69, $\$ 220$.

53 Vattel, ii. 8, § 113. 
legislation ${ }^{54}$ against aliens brought about by Britislı jealousy of the Dutch followers of William III, England encouraged the coming of foreign merchants and artisans, who, except in time of war, were permitted to come and go freely.55 They were permitted to buy and sell with but few restrictions; ${ }^{56}$ they were provided with special facilities for the recovery of debts, ${ }^{57}$ in addition to the right of trial by a jury de mediate lingue. ${ }^{5 s}$ The most rigorous folicy agalinst aliens was no doubt that which prevaled in the German states and in France, where the more perfect development of the feudal system rested in the local mignate, or seigneur, despotic rights over foreigners known in the aggregate as jus albinagii or droit d'aubaine. This general right of pillage, which finally passed from the local milguates to the sovereign himself, was usmally enforced (1) in the form of extraordinary taxation levied upon foreigners upon special occasions; ( $(z)$ in the form of confiscations to the use of the crown of all property of a deceased foreigner to the exclusion of his representatives, whether claiming by descent or under a will.58a The reaction against such barbarous usages has resulted in a general policy in favor of aliens which las finally secured for them in all advanced states a civil status almost as farorable as that of citizens. Prior to the Freuch Revolution of 1789 the droit d'aubaine had been abolished or modified as to certain states, as in the treaty of $17 \tau \mathrm{s}$ between France and the United states stipulating for the mutual abolition of both the droit d'aubaine and the droit de détraction; and by a decree of the Constituent Assembly in 1791 the former was entirely abrogated as to all nations without regard to reciprocity. ${ }^{59}$ The narrow and jealous policy against aliens S. 5 .

54 Stat. 12 and 13, Will. III, c. 2,

55 Stat. 9 Hen. III, st. 1 , c. 30 .

56 9 Edw. III, st. 1, c. 1; 25 Edw. III, st. 4, c. 2 ; 2 Rich. II, st. 1 , c. 1 ; Stat. 2, Edw. III, c. 9 ; St. 3, Car. I, c. 4 .

75 Statutum de Mercatoribus, 11 or 13 , Edw. I.

58 27 Edw. III, st. 2, c. 24 . Stat. 28, Edw. III, c. 13; Stat. 3 and 4 , Will. IV, c. 91 , s. 37 . Cf. Cunningham, English Commerce (Modern Times), pp. 47, 111, 119, 178, 287.

5saGrotius, De Jure Belli ac
Pacis, lib. ii, cap. vi, $\S 14$; Vattel, ii, 8, § 112 .

59 That concession was retracted, however, and the subject restored to the basis of reciprocity by the Code Napoléon in 1803. Finally that part of the code was repealed by the Ordinance of July 14, 1819, permitting foreigners to possess both real and personal property in France, and to take by succession $a b$ intestato, or by will, equally with native subjects. In 1853 a treaty was made between the United States and France which 
contained in the disabling clause of the Act of Settlement yielded in England, after nearly a century and a half, to more liberal ideas embodied in a series of statutes beginning with 7 and 8 Victoria, c. 66 (1844) and ending with 33 and 34 Vict., c. $14(1870)$. By the act last named real and personal property may be acquired, held and disposed of, by aliens as by nativeborn British subjects; and within the United Kingdom an alien enjoys all the privileges of a British subject, except that of owning a British ship, and the right to office, or to any municipal parliamentary or other franchise. ${ }^{60}$

$\S 201$. Mere travelers or sojourners.-International law is concerned in the first place with the alien, who, without a domicil, in a foreign state, simply passes through its territory as at mere traveler or sojourner. As such he is entitled to the full protection of its laws, and amenable to its criminal jurisdic. tion for any breaches of the peace or other offenses he may commit against the person or property of other's.

$\S 202$. Domiciled aliens; what constitutes domicil.-Far more interest attaches, however, in the second place, to the domiciled alien, who goes into a foreign country and resides there with the intention of remaining permanently, or for an indefinite period. He need not become a citizen in order to acquire a domicil; ${ }^{61}$ and the residence necessary to constitute it need not be long in point of time. "If the intention of permanently residing in a place exists, a residence in pursuance of that intention, howerer short, will establish a domicil." ${ }^{62}$ On the other hand mere length of residence will not of itself

was intended to authorize citizens of each country to hold real and personal property in the other, equally with its own citizens. As the treaty admitted the right of each state of the Union to regulate the subject for itself, the President undertook only to recommend to each state to enact the necessary legislation, France reserving the right to govern herself by rules of reciprocity. U. S. Laws, x, 992 . It is claimed, however, on high authority, that the treaty-making power under our constitution is adequate to establish by federal authority alone such a rule of law in each state, without the aid of state legislation. Fairfax v. Hunter, 7 Cranch, 627 ; Ware v. Hylton, 3 Dallas, 242; 8 Opinions of Atty Gen., 415; Halleck, § 157; Kent. Comm. iv, 420; Jefferson's Works, iii, 365; Dana's Wheaton, § 82 and note 47 .

$602 \mathrm{Cf}$. The Origin and Growth of the Eng. Const., vol. ii, pp. 229, 424 .

61 Udny v. Udny, L. R. 1 Sc. App. 441; Bumel v. Bumel, L. R. 12 Eq. 298; Dicey, Conflict of Laws, p. 111.

62 Bell v. Kennedy, L. R. 1 Sc. App. 307, 319, per Lord Cran. worth. 
constitute domicil. There must be not only the physical fact of residence but the mental fact of purpose or intention to reside (animus manendi). "We are all agreed that to constitute a domicil there must be the fact of residence. * * and also a purpose on the part of [D] to have continued that residence. While I say that both must concur, I say it with equal confidence that nothing else is necessary." ${ }^{63}$ Interuational law recognizes two kinds of domicil: (1) domicil of origin, such as children, legitimate or illegitimate, acquired by an absolute rule or fiction of law at the time of birth by reason of the domicil at that time of the person upon whom they are dependent, usually the father or mother; $;^{64}(2)$ domicil of choice, such as every independent person may acquire through the proper combination of the fact of residence with the intention of a permanent or indefinite prolongation of it. ${ }^{65}$ "Every man's domicil of origin must be presumed to continue, until he has acquired another sole domicil by actual residence, with the intention of abandoning his domicil of origin. This change must be animo et facto, and the burden of proof unquestionably lies on the party who asserts that change." "6 As dependent persons, such as minors and married women, lack the power of legal volition, their domicils are the same as, and change, if at all, with the domicil of those upon whom they are legally dependent. A person on attaining his majority retains the last domicil which he had during his minority until he changes it by some independent act of his own. ${ }^{67}$ In determining the nature of domicil so far as it depends upon choice the main difficulty is to ascertain the necessary intention or animus. As Lord Westbury has expressed it, "Domicil of choice is a conclusion or inference which the law derives from the fact of a man fixing voluntarily his sole or chief residence in a particular place, with an intention of continuing to reside there for an unlimited time." ${ }^{8 s}$ While no person can be without a domicil, no one can, for the same purpose, have at the same time more

63 Arnott v. Groom, Court of Session Cases, 9 D. 142. 149-52.

61 "It is a settled principle that no man shall be without a domicil, and to secure this result the law attributes to every individual as soon as he is born the domicil of his father, if the child be legiti. mate, and the domicil of the mother, if illegitimate." Udny v. 441,458 .
Udny, L. R. 1 Sc. App. 441, 575. 65 Cf. Westlake, Private Int. Law, §§ 243, 253.

66 Aikman v. Aikman, 3 Macq. 854,877 .

67 Dicey, Conflict of Laws, pp. 120-130. See also Somerville v. Somerville, 5 Ves. 749a, 787.

6. Udny v. Udny, L. R. 1 Sc. App. 
than one domicil. It is contended, however, by high authorities that a person may have different domicils for different purposes. ${ }^{66}$

$\S 203$. General rights and duties of aliens-Koszta's case.Leaving out of view those questions of private right and obligation arising out of the lex domicilii which belong solely to the domain of international private law, and such as arise out of the war-burdens, personal and pecuniary, a domiciled alien may be called upon to bear, and such as arise out of the adop. tion of a belligerent domicil by a neutral, the general statement may be made that the law of nations considers an alien while domiciled in a country entitled to the protection of its laws, ${ }^{70}$ in return for which he owes a temporary and local allegiance which continues during the period of his residence. ${ }^{i 1}$ He is so far subject to the laws of the land as to crime that he may be guilty of treason in giving aid and comfort to the enemies of the country in which he resides. ${ }^{71 a}$ On the other hand if he be domiciled in the United States he is entitled "to our care and consideration, and in most circumstances may be regarded as underour protection," because, as stated in the case of Koszta, "i2 "it is a maxim of international law that domicil confers a national character. International law looks only to the national character in determining what country has the right to protect." Therefore "every foreigner boru, residing in a country, owes to that country allegiance and obedience to the laws as long as he remains in it, as a duty imposed upon him by the mere fact of residence, and the temporary protection which he enjoys, and is as much bound to obey its laws as native subjects or citizens. This is the universal understanding of all civilized nations, and nowhere a more established doctrine than in this country." 73

60 "I apprehend," says Pollock, C. B., "that a peer of England who is also a peer of Scotland, and has estates in both countries, who comes to parliament to discharge a public duty, and returns to Scotland to enjoy the country, is domiciled both in England and Scotland." In re Capdevielle, 33 L. J. (Eq.) 306,316 . Cf. Dicey, Conflict of Laws, pp. 95-97.

703 Opinions Atty-Genl., 253; Sidgreaves v. Myatt, 22 Ala. 617;
Luke v. Calhoun County, 52 Ala. 115.

711 East P. C., c. 2, § 4; 1 Hale P. C., c. 10 ; Thrasher's Case, 6 Webster's Works, 526.

71a Carlisle v. U. S., 16 Wallace, 147; Foster's Crown Law, Discourse, i, § 2 .

$72 \mathrm{Mr}$. Hülsemann's letter to $\mathrm{Mr}$. Marcy, and his reply in Senate documents, 33d Congress, 1st Sess., vol. i.

${ }_{73}$ Mr. Webster, Sec. of State, re- 
$\$ 204$. Letters of denization in England.-The sovereigu still has the power in England to grant letters of denization whereby a domiciled alien, ex donatio regis, may be made a British subject. "A denizen is in a kind of middle state between an alien and a natural born subject, and partakes of both of them. He maly talie lands by purchase or devise, which an alien may not; but cannot take by inheritance, for his parent, through whom he must claim, being an alien, had no inheritable blood, and therefore could convey none to the son. * * * $\quad$ A denizen is not excused from paying the alien's duty and some other mercantile burdens. And no denizen ean be of the privg commcil, or either house of parliament, or have any office of trust, etc." 74

$\S 205$. Extradition-nature and origin of existing system.The doctrine is undoubtedly ancient that it is the duty of every state to refuse an asylum to fugitives from justice from other states,not only for its own peace and security but for that of society as a whole; and in order to discharge that duty every state has the undoubted right of its own motion to expel such persons from its limits through agencies provided by its own municipal laws. ${ }^{75}$ As to the nature of the obligation of a state to deliver up a person accused of the commission of a crine in another upon the demand of its government, there has always been a difference of opinion among publicists,-one class holding that such an obligation is positively imposed by the law and usage of nations $;^{76}$ the other, that it is so imperfect as to depend purely upon comity and convenience, in the absence of express compact. ${ }^{77}$

port to the President, Dec. 23, 1851. 6 Webster's Works, 524.

74 Blackst. Comm. 374. See also Fong Yue Ting v. U. S., 149 U. S. 698, 736; Craw v. Ramsey, 2 Vent. 6.

75 "The power of expelling obnoxious foreigners is one incident to sovereignty." Mr. Fish, Sec. of State, to Mr. Foster, Oct. 17, 1873. Mss. Inst., Mex.

76 Chief among the first class may be mentioned Grotius, $D e J u r$. Bel. ac. Pae. lib. ii, cap. xi, $\S \S$ 3-5; Heineccius, Praeleet. in Grot. pt. Burlamaqui, tom. ii. Part iv, ch. $3, \S \S 23-29$; Vattel, liv. ii, ch. 6 ,
The existing system of extradi-

§ 76-77; Rutherforth, Int. of Nat. Law, ii, ch. 9, p. 12; Schmelzing, systematischer Grundriss des praktischen europäischen Völkerrechts, $\S 61$; Kent's Comm., i, 36, 37, 5th ed.

77 Chief among the second, may be mentioned Puffendorf, Elementa, lib. viii, cap. $3, \S 23,24$; Martens, Droit des Gens, liv. iii, ch. 3, § 101; Klüber, Droit des Gens. Part ii, tit. 1, ch. 2, § 66; Saalfeld, IIandluch des positiven Välkerrechts, § 40; Heffter, Europäische Völkerrecht, \$ 63; Sir R. Phillimore, i, §ccclxiv, Blunt. schli, § 395; Fiore, Trattato di 
tion is the outcome of the greatly increased intercourse that has grown up among nations in very recent times,-by far the greater part of the numberless treaties in which it is embodied dating from the nineteenth century or rather from the last half of it. $^{78}$ While various writers upon international law have expressed their views as to the principles involved, no two nations have followed the same practice, and for that reason it has been found necessary to regulate the entire subject by treaty. It is certainly the opinion of a majority of modern publicists that a state is under no absolute obligation to surrender fugitive criminals unless it has expressly contracted to do so. While France has held the contrary view, England and the United States have from the beginning maintained that doctrine.

\section{$\S 206$. Extradition treaties between Great Britain, France and} U. S.-There are only two English cases at all old in which the right of extradition was asserted, and in neither of them was it decided that the crown possesses, by virtue of the com. mon law, the power to deliver to a foreign nation a person accused by it of the commission of crime. ${ }^{79}$ Upon the contrary it is maintained that the common law gives the executive no right to arrest an alien and deliver him to a foreign state. ${ }^{80}$ While Great Britain made the first extradition treaty with the United States in 1794, and an agreement of the same kind with France in the treaty of Amiens in 1802, Mr. Clarke says, in view no doubt of the fact that both were of limited duration, that "The history of the subject in England begins with the treaties made with the United States in October, 1842, and with France in 1843." ${ }^{81}$ As British extradition treaties can only be put into effect through statutory regulations, 6 and 7 Vic., c. 75, was passed to enforce the treaty with France; and

Diritto Internazionale Publico, § 611; Hall, § 13; Wheaton, Elements, § 13. For a more complete list of the chief authorities on either side, see Fœlix, Droit International Privé, liv. ii, tit. ix, ch. vii, and Von Bar, Des Internationale Privat-und-strafrecht, § 148.

78 Mittermaier wisely concludes that the existence of so many special treaties upon the subject is conclusive of the fact that there is no general usage recognized among nations. Deutsches strafverfahren, Theil i, § 59, pp. 314319. For a full account of the treaties, and of the practice independently of them, see Calvo, liv. $\mathrm{xv}$, Sect. ii.

79 East India Co. v. Campbell, 1 Ves. Sen. 246; Mure v. Kays, 4 Taunt. 34. Cf. Sir J. F. Stephen, Hist. of the Crim. Law, vol. ii, p. 66.

so Clarke, Extradition, ch. $\nabla$. 81 Ibid., p. 109, 2d ed. 
6 and 7 Vic., 76 , to enforce that with the United States; and when both proved ineffectual in practice ${ }^{82}$ the existing law was substituted which is embodied in two acts known as the Extradition Acts, 1870 and $1873 .{ }^{83}$

$\$ 207$. Cases of Winslow and Rauscher. $-\Lambda$ serious controversy arose between the governments of Great liritain and the United States in 1876 when the former refused to surrender the forger Winslow and other fugitives, unless the latter would make an express stipulation that they should not be tried for any oflense other than that for which their extradition was demanded. ${ }^{s t}$ While no such condition or limitation was contained in the treaty of 1842 such a provision had been inserted in the British Extradition Act of 1870 , and that prevision the British government attempted to enforce just as if it had been written in the treaty itself. After the government of the United States refused to make stipulations that of Great Britain receded from its position; whereupon the former clearly indicated its unwillingness to try oflenders for any crime except that for which they are extradited, ${ }^{85}$ a rule embodied in a clear and final form in the convention entered into between the two countries in $1890 .^{86}$ There is every reason why the United States should make such a rule an element in all of its extradition engagements in view of the decision of the Supreme Court in the case of Rauscher, ${ }^{8 \pi}$ an officer of an American vessel who was extradited under the treaty with Great Britain of 1842 upon a charge of murder on the high seas of one of his ship's crew. The court held that a man extradited under such cireumstances could not be tried upon

82 "Between 1843 and 1865 the French obtained the extradition of one prisoner only, though they made upwards of twenty demands, for the most part during the earlier years of the period. Extraditions to America were a little less uncommon." Sir J. F. Stephen, Hist. of the Crim. Law, vol. ii, p. 67.

8333 and 34 Vic., c. 52 , and 36 and 37 Vic., c. 60 .

84 For a full statement of the case, see Wharton, Int. Law Dig., $\S 270$.

8: The following authorities maintain that rule as a matter of international law. W. B. Lawrence, 14 Alb. Law Journal, 96; 19 Ibid. 329 ; Cairns, Chancellor, as quoted in U. S. For. Rel., 1876, 286, 296; Spear on Extrad., chap. vi; Lowell, J., in 10 Am. Law Journal, 617, 620. U. S. v. Watts, 8 Sawyer, 370,14 Fell. Rep. 130; Com. v. Hawes, 13 Bush, 697; State v. Vanderpool, 39 Ohio St. 273; Compton v. Wilder, 40 Ohio St. 130.

86 Treaties of the United States, p. 437; British State Papers, United States, No. 1 (1890).

sĩ U. S. v. Rauscher, 119 U. S.. 407. 
an indictment charging him with cruel and unusual punishment of the deceased, although such punishment resulted from the identical acts proved in the extradition proceeding. He could not be tried, the court said, for a minor offense not included in the treaty of extradition.

$\S 208$. U. S. recognizes no obligation to surrender in absence of treaty.-It has been the settled law of the United states from the outset, through a consensus of opinion between the executive and judicial departments of the government, that, in the absence of treaties, there is no obligation upon a state to surrender to auother upon its demand persons who, after having committed offenses within the former, have sought an asylum in the latter. ${ }^{s s}$ "The law of nations embraces no prorision for the surrender of persons who are fugitives from the offended laws of one country to the territory of another. It is only by treaty that such surrender can take place." s9 "The practice of nations tolerates no right of extradition. Whatever elementary authors may say to the contrary, one nation is not bound to deliver up persons accused of crimes who have escaped into its territories on the demand of another nation against whose laws the alleged crime was committed. The govermment of the United States has fron the beginning acted on this principle." ${ }^{90}$ While there is a decision to the contrary, ${ }^{91}$ the better doctrine is that in the absence of legislative authority the President has no right to surrender a fugitive upon the authority of a treaty alone. ${ }^{92}$

Exceptional case of Arguelles.-Ind yet in defiance of all precedent, and in the absence of treaties and statutes, Mr. Seward, with the sanction of the President, ordered in 1864 as a purely executive act, the arrest and delivery to spain of

ss Mr. Rush, Sec. of State, to Mir. Hyde de Neuville, April 9, 1817; Mss. Notes For. Leg. Cf. Wharton, Conflict of Laws, $\S 941$.

89 "Apart from the provisions of treaties on the subject, there exists no well-defined obligation on one independent nation to deliver to another fugitives from its justice; and though such delivery has often been made, it was upon the principle of comity. The right to demand it has not been recognized as among the duties of one govern- ment to another which rest upon established principles of international law." U. S. v. Rauscher, 119 U. S. 407.

$90 \mathrm{Mr}$. Buchanan, Sec. of State, to Mr. Wise, Sept. 27, 1845. Mss. Inst., Brazil.

91 In re Sheazle, 1 Woodb. \& M. 66.

92 In re Metzger, $1 \mathrm{Edw}$. Sel. Cas. (N. Y.) $399 ; 5$ Howard, 176; 1 Barb. 248; Spear on Extradition ( 2 d ed.), 57. 
Argüelles, a governor of a district of Cuba who had escaped to New York, after laving sold into slavery, while in his charge, a cargo of Africans landed from a slave-ship in that island and declared to be free by the proper authorities. When the President was called upon by the Senate to explain under what law or treaty he had acted, he presented the report of Mr. Seward, who said that "there being no treaty of extradition between the United States and Spain, nor any act of Congress directing how fugitives from justice in Spanish dominions shall be delivered, the extradition in this case is understood by this department to have been made in virtue of the law of nations and the Constitution of the United States. * * * Although it may be conceded that there is no national obligation to make such a surrender upon a demand thereof, unless it is acknowledged by treaty or statute, yet a nation is never bound to furnish asylum to dangerous criminals who are offenders against the human race; and yet it is believed that if in any case the comity could with propriety be practiced, the one which is understood to have called forth the resolution furnished a just occasion for its exercise." ${ }^{93}$ This illegal transaction was never subjected to judicial review, as the accused was delivered by the marshal to the Cuban agents of Spain before a petition could be filed for habeas corpus. ${ }^{94}$ However, when the notorious Tweed escaped to Spain an exact return was made of our illegal courtesy $;^{95}$ and in 1877 an extradition treaty was entered into with that country, which was amended in 1882 .

$\S 209$. A state may impose conditions of surrender.-While there may be differences of view as to the real character of the obligation binding one state to deliver fugitive criminals to another, and disputes as to the limits of executive authority in particular cases, it seems to be generally admitted that

93 For a full statement of the case, see Wharton Int. Law Dig., $\S$ 268.

94 "There is no doubt, we believe, of the high criminality of the man, and as little that no law or exigency authorized the transaction." Woolsey, $\$ 78$, note. The "higl criminality of the man" has, however, induced one authority to applaud the grossly illegal proceeding through which he was de- livered up. “A splendid example of such a recognition of international obligation was afforded by the action of the U. S. Government in the case of the scoundrel Arguelles in 1864, U. S. Diplomatic Correspondence, 1864, Part ii, pp. 60-74." Walker, Science of Int. Law. 236, note 1 .

95 See Wharton, Conflict of Laws, $\S 835$, note. 
every state has the right to define the conditions upon which the surrender shall be made. As to what those conditions should be something like a consensus of opinion has been brought about through the making of the mass of extradition treaties by which the subject is now actually regulated.

$\S 210$. Demand should be limited to treaty offenses.-It is generally understood that the demand must be confined to treaty offenses,-as to extradition treaties the rule expressio unius est exclusio alterius is in full force. ${ }^{96}$ If an extraordinary case arises, not within the list of enumerated offenses, the only hope is an appeal not to the treaty but to that courtesy or comity which a state may extend, beyond the domain of law, wherever it is to its interest to do so. ${ }^{97}$ In order to obviate that necessity, the tendency is steadily to increase the list of crimes for which surrender may be demanded. To the seven offenses of that kind described in the extradition clauses of the treaty of 1842 between the United States and Great Britain twenty more were added by the convention of 1890 .

$\S 211$. Fugitive must be tried only for offense specified.-It is firmly settled, certainly so far as Great Britain and the United States are concerned, that the fugitive is not to be tried for an offense other than that for which he is extradited, until a reasonable time and opportunity has been given him after his release or trial to return to the country from which he was taken. It has been held that a person extradited upon a particular charge cannot be convicted on a lesser charge included in it. ${ }^{98}$ Some treaties expressly provide that they shall not apply to crimes committed before their date, while others either include all anterior crimes or certain ones expressly designated. ${ }^{9}$ The better opinion seems to be that a subject charged with the commission of an offense within the "jurisdiction" of the demanding state cannot properly be tried for a crime committed within the territory of a third independent state from which he has escaped to the state upon which the

96 See Mr. Jefferson's reasons, in instructions of March 22, 1792, in 1 Am. St. Papers (For. Rel.), 258; $12 \mathrm{Am}$. and Eng. Enc. of Law, p. 594.

97 Ex parte Foss, 102 Cal. 347, 41 Am. St. Rep. 182.

9s See above, p. 254.
99 It has been held that prior crimes are included within the operation of a treaty where its language will admit of such a construction, unless they are expressly excepted. Cf. In re De Giacomo, 12 Blatch. 391; In re Stupp, Ibid. 501. 
demand is made. ${ }^{1}$ And no state can be expected to deliver up a fugitive criminal while he is in custody on account of an offense committed therein, until the pending charge has been disposed of, or until punishment has been duly inflicted. ${ }^{2}$

$\S 212$. Political offenses-how distinguished from ordinary crimes.-It is generally provided that no surrender will be made if the offense with which the accused is charged is of a political character. Grave and difficult questions continually arise out of the construction of that exception because neither statesmen nor jurists have yet been able to agree upon a definition that will clearly distinguish political offenses from ordinary crimes. In sone cases the motive has been held to be the chief ingredient. When that has been purely political it has been permitted to stamp that character upon an act which otherwise would have been private assassination. The sounder view, however, is that to give to an act a political character it must be incidental to or form a part of a political movement or disturbance. Such was the ground upon which the Court of Queen's Bench refused, in 1890, to deliver up ${ }^{3}$ Castioni, a Swiss engaged in an insurrection against the authorities of the canton of Ticino, who, during the progress of such disturbance, shot a fellow-citizen in the attack upon the town hall at Bellinzona. As it is necessary, however, in order to constitute such a political movement or disturbance as the law of nations contemplates that there shall be two parties in the state, each striving to impose its own government upon the other, it has been held that a mere explosion caused by an anarchist in the absence of such conditions does not constitute a political offense. ${ }^{4}$ And yet the fact remains that the tentative efforts so far made to define offenses "of a political character" for which extradition will not be granted are both

1 The accepted doctrine seems to be that the provisions of an extradition treaty do not extend to such a case. Allsop's Case, Forsyth's Cas. 368; $12 \mathrm{Am}$. and Eng. Enc. of Law, p. 595 .

2 Taylor v. Taintor, 16 Wallace, 366; In re Briscoe, 51 How. Pr. (N. Y. Supreme Ct.) 422; In re Troutman, 24 N. J. L. 634; State v. Allen, 2 Hump. (Tenn.) 258.

3 Ex parte Castioni, Law Reports, Queen's Bench Division,
1891, pp. 149-168. “Great Britain will decline to deliver up to justice the excited politician who, in the course of a revolutionary émeute, shoots down a defenseless statesman of the ruling party." Walker, Science of Int. Law, p. 237.

4 In re Meunier [1894], 2 Q. B. 415, 71 L. T. N. S. 403,18 Cox C. C. 15. As an example of a political offense, see In re Ezeta, 62 Fed. Rep. 972 . 
vague and inadequate. Sir J. F. Stephen pared the way for a rational and practical definition when he suggested that the character of the act should be made to depend chiefly upon the belligerent or non-belligerent condition of the doer. ${ }^{5}$ Guided by that suggestion, ${ }^{6}$ Prof. T. J. Lawrence has well said that, "if political offenses were defined as acts done for political objects, which would be allowed by the laws of war were the relation of belligereney established between the doer's of them and the state against wlich they are done, we should be able to distinguish between those crimes which shock the conscience of humanity, though the perpetrators of them are actuated by political motives, and acts which bring down upon the doers no strong noral condemnation, though we may think them violent and foolish."

$\S 213$. Responsibility of a state for due execution of its laws.The fiction that a state is a person subject to obligations, both moral and legal, is vividly illustrated by the rule which provides that if from a lack of due diligence in the enforcement of its legal machinery it fails to protect another state against breaches of international law, it becomes itself responsible to the injured state or to its citizens for the direct results of its default. Every state possesses the inherent right as a sovereign to choose whatever form of constitution it deems best, and to enforce it through whatever kind of a code it chooses to enact, prorided only that such constitution and code are collectively adequate to the discharge of its international obligations. ${ }^{7}$ One state cannot dictate to another as to the form of its internal polity, but it lias the right to demand that it shall be adequate to the end in view, and that it shall be enforced with due diligence when its interests are involved. Because the doctrine of territorial sovereignty gives to every state the right, with a few exceptions, to enforce its laws, ciril and criminal, against all persons and property within its jurisdiction, the rule is a just one that, "prima facie a state is, of

5 Hist. of the Criminal Law, pp. 70,71 .

6 Principles of Int. Law, pp. 238239.

7 The best expositions of the subject of state responsibility which has not yet been perfectly defined, are to be found in Bluntschli, §§ 466-469; Halleck, i, 397;
Phillimore, i, § ccxviii, and preface to $2 d$ ed., pp. xxi-ii; Reasons of Sir A. Cockburn for dissenting from the Award of the Tribunal of Arb. at Geneva, Parl. Papers, North Am. No. 2, 1873, pp. 31-8; Hansard, cci, 1123; Calvo, \$\$ 357-8, $3 d$ ed.; Fiore, $\S 390-4$ and $\S \S 646$ 64, 2d ed.; Hall, § 65 . 
course, responsible for all acts or omissions taking place within its territory by which another state or the subjects of the latter are injuriously affected." 8 When acts of omission or commission are ehargeable to the administrative, naval or military agents of a state while under the direct control of its executive, whereby another state or its citizens are injured, the dnty of the offending state to disavow such acts, or in a case sufficiently grave to make prompt reparation by the infliction of adequate pmishment, is too obvious for special considera. tion.

$\S 214$. No responsibility for erroneous judicial decisions.-The responsibility of a state for the conduct os its judicial officers rests upon an entirely different basis. In all highly organized modern state-systems such officer's are placed in positions of greater or less independence so as to protect them, except in the cuse of high misdemeanors, from all responsibility to the other departments of power. International law presupposes that the tribunals of every state are open for the impartial administration of justice between natives and foreigners, and only when there has been a palpable denial of it, after the foreigner has made an adequate alpeal to such tribunals, does the ocrasion arise for diplomatic intervention. "It is not necessars to affirm that a government is not responsible in any case to a foreign government for an alleged erroneous judicial decision rendered to the prejudice of a subject of said foreign government. But it may be safely asserted that this responsibility can only arise in a jroceeding when the foreigner, being duly notified, shall have made a full and bona fide, though unavaling defense, and, if necessary, shall have carried his case to the tribunal of last resort. If, after having made such defense and prosecuted such appeal, he shall have been unable to obtain justice, then, and then only, an a demind be with propriety made upon the government." 9 Redress must be denied on some fral pably unjust gromud, ${ }^{10}$ such as discrimination on account of alienage, ${ }^{11}$ or there must be arbitrary acts of oppression or deprivation of property as contradistinguished from penalties and the punishments incurred through the ordinary infraction of law, ${ }^{12}$ before the administration of a state's justice can be subjected to diplomatic inquisition.

8 Hall, § 65 .

- Mr. Clay, Sec. of State, to Mr. Tacon, Feb. 5, 1828. Mss. Notes. For. Leg.
$11 \mathrm{Mr}$. Bayard, Sec. of State, to Mr. Phelps, June 4, 1885. Mss. Inst., Peru.

12 Mr. Marcy, Sec. of State, to

101 Opinions Atty-General, 53. 
$\S 215$. Duty to prevent mob violence and invasion of neighboring states.-Of far more practical importance, however, is the duty imposed upon a state so to administer its laws in time of peace as to prevent private persons from inflicting injuries upon foreigners within its limits through mob riolence; and also to prevent private persons from organizing and arming upon its soil for the purpose of invading neighboring states. There can be no question that a state is liable internationally for damages done to alien residents by a mob which it could, by due diligence, have repressed. ${ }^{13}$ While the gorernment of the United States frankly admits that rule, it qualifies it with the proviso that when a remedy is given in the judicial tribunals against the individuals by whom such violence is inflicted it must be exhausted, if possible, before the state as such can be called upon for redress. ${ }^{14}$ Whenever border raiders gather upon the frontiers of a country with the view of making incursions into a neighboring friendly state, it is the plain duty of the former to use due diligence for their apprehension; or, in default of it, to answer for the damages the marauders inflict. Such was the position assumed by the government of the United States when, in $\mathbf{1 8 7 0}$, it said, that "the accountability of the Mexican government for the losses sustained by citizens of the United States from the robbery and exactions committed at Guaymas, in May last, by the armed force under the command of Fortino Viscaino, seems to be unquestionable;" ${ }^{15}$ and nine years later when a body of Indians under Sitting Bull, who had taken refuge in Canada, were about to make hostile incursions into the United States the government of Great Britain was notified of the fact and requested to "recognize the importance of being prepared upon the frontier with a sufficient force either to compel their surrender to our forces as prisoners of war, or to disarm and disable them from further hostilities, and subject them to such constraints of surveillance and subjection as will preclude any further disturbance of the peace on the frontier." 16

\section{$\S 216$. Responsibility suspended by civil war.-The obli-}

Mr. Jackson, Jan. 10, 1854 . Mss. Inst., Austria.

$13 \mathrm{Mr}$. Evarts, Sec. of State, to Mr. Gibbs, May 28, 1878. Mss. Inst., Peru.

14 See above, p. 170.

$15 \mathrm{Mr}$. Fish, Sec. of State, to Mr,
Nelson, Nov. 16, 1870. Mss. Inst., Mex., For. Rel., 1871.

$16 \mathrm{Mr}$. Evarts, Sec. of State, to Sir E. Thornton, May 27, 1879. Mss. Notes, Gr. Brit. For. Rel., 1879. 
gation thus imposed upon a state in time of peace to protect other states and their citizens from injuries resulting from a failure upon its part to insure a diligent execution of its laws ceases when the normal operation of such laws is temporarily suspended by insurrections or civil commotions beyond its control. ${ }^{17}$ As a foreigner cannot expect better treatment than a state guarantees to its own citizens he must accept its hospitality subject to all the contingencies resulting not only from intestine but from international war. ${ }^{18}$ As no state is expected to compensate its own citizens for losses sustained through civil commotion beyond its control, a foreigner camnot claim indemnity for injuries inflicted either upon himself or property during the progress thereof, either through acts of insurgents reconnized as belligerents, or through measures necessarily taken by the state itself to re-establish its anthority. Upon that ground Great Britain, during the American Ciril War, refused to demand compensation for injuries inflicted on the property of her subjects by the military forces of the United States. The claimants were informed that they must be content with such remedies as were provided for its citizens. ${ }^{19}$

The famous case of the Alabama, involring the most recent discussion of the obligations of a neutral to a belligerent for a diligent execution of its laws, will be duly considered in that part of the work to be specially devoted to the rights and duties of neutral states.

${ }_{17}$ Les gouvernements sont-ils ou non responsables des pertes et des préjudices éprouvés par des étrangers en temps de troubles intérieurs ou de guerres civiles? Cette question a été longuement discutée et finalement résolvé par la négative. Calvo, $\S 292$. See also Bluntschli, $\$ 380$.

18 "It is believed that it is a received principle of public law that the subjects of foreign powers domiciled in a country in a state of war are not entitled to greater privileges or immunities than the other inhabitants of the insurrectionary district." Mr. Seward, Sec. of State, to Mr. Wydenbruck, Nov.

19 "That the British loyalists who suffered pecuniary loss through the casualties of war during the American Revolution had no claim on the United States, under the law of nations, for redress, was admitted by Mr. Pitt, June 3, 1785 , in the House of Commons (27 Hansard's Parl. Hist., 610, $618)$. The same point was determined by the British American Claims Commission. (See House Rep. 262, 43d Cong., 1st Sess.)" Wharton, Int. Law Dig., §224. As to the obligation of aliens to submit to martial law, see 1 Halleck, Int. Law (Baker's ed.) 351; 2 id., 455 .

16, 1865. Mss. Notes, Austria. 


\section{CHAPTER III.}

\section{SOVEREIGNTY AND JURISDICTION IN RELATION TO PROPERTY.}

\$217. State property, territorial and non-territorial-Servitudes.-A state as a colporate person may possess property, movable and immovable, either within its own limits or beyond them. The territorial property of a state consists of all the land and water within its geographical boundaries, including all rivers, lakes, bays, gulfs and straits lying wholly within them. As incidents to such territorial possessions must be added a state's jurisdiction over its marginal waters when its territory abuts upon the sea, and the right of its people to navigate such rivers as form boundaries between two or more states, or such as rising within one state traverse the territories of others on their way to the sea. The legal title to such territorial property may rest either upon (1) prescription, (2) conquest, (3) occupation, ( 4 ) accretion, or (5) cession. The non-territorial property of a state consists of such possessions as it may hold in its public capacity beyond its own limits, whether within or without the jurisdiction of other states; of such as it may hold as a private individual within the jurisdiction of another state; of its public ressels; of its private ressels, covered by the national flag; and of the goods of its subjects embarked in foreign ships. From their very nature and situation the right to use and enjoy certain classes of state property depends exclusively upon municipal law, while for a like reason the right to use and enjoy certain other classes depends entirely upon international law. A state may limit or qualify its sorereignty and jurisdiction over its territorial property by permitting a foreign state to perform within its bounds certain acts otherwise prohibited; or by surrendering the right to exercise certain parts of its domestic jurisdiction as a protection to others. Restrictions thus imposed upon the sovereignty of a state are known as servitudes ${ }^{1}$ which may be either positive or negative.

1 The term servitude is borrowed from Roman law wherein it signifies an innocent use as distinguished from a right. In order to convert the former into the latter some kind of contract or stipulation was necessary. Si quis velit vicino aliquod jus constituere, pac- 
\$218. Title by prescription founded on Roman law.-The original group of European states, out of whose assent modern international law grew, could, as a general rule, put forward no higher title than preseription to the territories of which they had been immemorially possessed. It is not strange therefore that Grotius should hare found a uthority for it in Roman jurisprudence,, 2 and that Heineccius, Woltr, Bynkershoek, Mably, Vattel, Rutherford and Burke should lave accepted his conclusions. ${ }^{3}$ Cnder the jus civile one of the means by which property could be aequired was the eftlux of time (usucaptione, prescriplione"). Vattel says that "after having shown that usucaption and prescription are founded on the law of nature, it is easy to prove that they are equally a part of the law of nations, and ought to take place between different states. * * * And so far is the nature of the parties from affording them an exemption in the ease, that usucaption and preseription are much more necessary between sovereign states, than between individuals. Their quarrels are of much greater consequence; their disputes are usually terminated only by bloody wars; and consequently the peace and happiness of mankind much more powerfully require that possession on the part of sovereigns should not be easily disturbed." 5

Its application to possessions of states-Case of Poland.-In order to impart additional force to the presumption arising ont of lapse of time English jurists invented the legal fiction that a title so established originally rested on a grant. ${ }^{6}$ Disregarding that narrow assumption Burke founded the right to all territory "on the solid rock of prescription; the soundest, the most general, the most recognized title between man and

tionibus atque stipulationibus id officere debet. Justinian Inst. II, tit. ii. De Servitutibus.

2 Sic qui rem suam ab alio teneri scit, nec quicquam contradicit multo tempore, is nisi causa alia manifeste appareat, non videtur id alio fecisse animo, quam quod rem ilIam in suaram rerum numero esse nollet. De Jure Belli ac Pacis, II, cap. 4.

3 Cf. Phillimore (i, $\S \S 255-260$ ), who considers the question at great length. See also Heffter, $\S 12$; Bluntschli, § 290; Riquelme, i, 28; Calvo, $\$ 212$; Wheaton, Elements, \& 164 .
4 Muirhead, Roman Law, pp. 138 , 251, 393.

5 Droit des Gens, II, § 147.

- In English law prescription is used in a comparatively narrow sense, and a title thus acquired is limited to incorporeal hereditaments. It may, however, have borne at one time a wider meaning. A title by prescription to land is mentioned in 32 Hen. VIII, C. 2 ; and it seems that tenants in common may still make title to land by prescription. Littleton's Tenures, § 310 . See also Williams, Rights of Common, 3. 
man that is known in municipal or in public jurisprudence; a title in which not arbitrary institutions but the eternal order of things gives judgment; a title which is not the creature, but the master of positive law; a title whieh, though not fixed in its term, is rooted in its principles in the law of nature itself, and is, indeed, the original ground of all known property; for all property in soil will always be traced back to that source, and will rest there." 7 The loctrine of preseription incorporated in every municipal code in orter to quiet the title of individuals is applied, subject to certain modifications, to the possessions of states in order to secure stability in international affairs and that freedom from strife which would be perpetual, if every nation could rise in arms to assert obsolete legal rights. From the very necessity of the case the quieting influence of prescription has been extended not only to cases of long-continued possession where no original source of property right can be shown to have existed, but also to cases in which the rightful proprietor, wrongfully dispossessed, has been unable or unwilling to re-establish his possession. In the notable case of the dismemberment of Poland titles to the appropriated territory, based upon acts generally armitted to have been immoral, have through the lapse of time and general acquiescence become permanent simply because it is as necessary to end disputes between nations as to territory as it is to cut off litigation between individuals. But as the rule does not extend beyond its reason, a title thus acquired by prescription is only good internationally, and does not bar any right which the inhabitants of appropriated territory may have to free themselves from a foreign yoke. Lampredi, ${ }^{9}$ Martens ${ }^{10}$ and Klüber ${ }^{11}$ have even denied that the doctrine has any place whatever in the law of nations, because it is not a principle of what is called natural law; and some color has recently been given to their contention by the mildness of the

7 Works, ix, 449, letter to $R$. denies the existence of internaBurke, Esq.

8 Prescription is applicable to the title to national property. Rhode Island v. Massachusetts, 4 Howard, 639.

9 Jur. Pub. Univ. Theorem, p. iii, cap. VIII.

10 Précis, § 70-1.

$11 \S$ 6, 125. “Mamiani (p. 24) tional prescription, because it cannot exist in faccia ai diritti essenziali ed irremovibili della persona umana,' but, as the words quoted may suggest, he is thinking only of the relations of a dominant state to a subject population." Hall, p. 125, note. 
protest made against the annexation in 1871 of Alsace and Lorraine by Germany, acting under the influence of the growing sense of nationality which in that particular is clearly retrogressive.

\section{$\$ 219$. Time necessary to establish international prescription.-} As there is no common law giver to enforce his authority upon all states it is impossible to fix the time necessary to establish international prescription with that exactness with which it is defined in municipal codes. In the absence of a general rule nothing more definite exists than the statement that a reasonable time must clapse before an adverse possession based upon prescription can ripen into a perfect title. Is Vattel expressed it: "It is impossible to determine by the law of nature the number of years required to found prescription: this depends on the nature of the property in dispute and the circumstances of the case." 12 In his outlines of an international code (\$5) Field has proposed a positive rule requiring fifty years as the necessary period of a national prescription. In the absence of such a rule the lapse of time necessary for a generation to be born, educated and to come into possession of the powers and duties of the state has been suggested as a negative limit.

$\$ 220$. Title by conquest-Case of electorate of Hesse-Cassel.As title by preseription rests upon the single fact of long continued possession, so title by conquest rests upon the single fact that conquest in the military sense has ripened into conquest in the legal sense, without the aid of cession or transfer from the vanquished state. Conquest in the first sense is complete when the armies of one of the belligerent states, after having subdued those of the other, establish a control based on actual force. Conquest in the last sense is complete when the victorious state proclaims in a formal way the fact that it intends to add the conquered territory to its own dominions, and then for a sufficient length of time continues to exercise all the powers of sovereignty over it. As title by conquest thus consists in the appropriation of property through one act or a series of contimous acts, it is often difficult to determine when conquest in the legal sense has become so complete as to give to the doings of the new sovereign international validity. That difficulty, which the career of Napoleon presented in various forms, was fully discussed by the learned

12 Droit des Gens, II, § 142. 
in the famous case of the Electorate of Hesse-Cassel occupied by his troops in 1806, and transferred, after having been governed by him directly for about a year, to the newly formed kingdom of Westphalia that lasted until 1813, after having been expressly recognized by Prussia and Russia in the treaty of Tilsit, in 1807. Before the transfer Napoleon as sovereign confiscated the private property of the elector who, having taken service in the Prussian army, was proceeded against as a person in arms against the legitimate ruler of the state. In a suit subsequently brought by him in order to contest the validity of a discharge giren by Napoleon of a certain debt due to him by mortgage, the question arose whether, at the date of the confiscation, Napoleon had in fact effected such a conquest as would uphold the exercise of that sovereign right. After the case, which began in the courts of Mecklenburg, had been appealed first to the University of Breslau, and then to two other German universities, it was finally held, (1) that the restored government of the elector could not be considered as a continuation of his former government because the kingdom of Westphalia had been recognized as its successor, and the electorate as politically extinct; (2) that the confiscation was legal because Napoleon had in fact effected such a conquest as authorized that sovereign act; (3) that eren if the elector's property did revert with the conclusion of peace, as a restored owner, "according to the letter of Roman law," he had only the right to take it as he found it without compensation for damages suffered in the interval. ${ }^{13}$ The government of the United States holds that a mere military conquest does not enlarge its boundaries $;^{14}$ such a possession of conquered territory is a purely military occupation until determined by treaty; $;^{15}$ and not until its confirmation does the acquisition made under it become a part of the national domain. ${ }^{16}$

$\S 221$. Title by occupation-Effect of recent experience in Africa.-An effort has been made heretofore to explain the process through which the European nations attempted to reg-

13 Schweickart, Napoleon und die Kurh., pp. 8-104; Heffter, Europ. Välker., §§ 186-188; Pfeiffer, Das Recht der Kriegseroberung, pp. 240-252; Rotteck und Welcker, Staat's Lexikon. tit., DomainenKïufer; Zachariae, ueber die Verpflichtung; Phillimore, vol. iii, \$
568-572; Halleck, Int. Law, p. 842. 14 Fleming v. Page, 9 Howard, 603.

15 American Ins. Co. v. Canter, 1 Peters, 542.

16 Ibid. 542; Leitersdorfer v. Webb, 20 Howard, 176. 
ulate the partition of the New World through the application to their conflicting claims of the meagre and inadequate rules provided by Roman law for the acquisition of res nullius through occupatio. The conclusion reached was that the fatal defect inherent in the old doctrine of discovery and settlement consisted of its inability to provide any adequate or practical rule by which the extent of territory, constructively incident to actual settlements, could be precisely determined. The absence of any generally admitted criterion by which, the area appropriated by an act of occupation could be defined necessarily precipitated boundary disputes which assumed gigantic proportions. ${ }^{17}$ With the results of American experience clearly before their eyes the nations now participating in the partition of the continent of Africa have made a novel and far-reaching addition to the law of occupation which promises to remove its greatest defect. As the undiscovered portions of the earth's surface have become more and more circumscribed, the ancient contention that the discovery of previously unknown lands confers an absolute title upon the state under whose authority it is made has dwindled down into the doctrine, that, while discovery alone confers no proprietary right, it does confer upon the discoverer for a reasonable time an exclusive right of oceupancy, and the inchoate title thus acquired is strengthened by the fact that it is based upon prior discovery. ${ }^{1 \mathrm{~s}}$ According to modern practice the corner stones of effective international oecupation are settlement and amexation; ${ }^{19}$ and the questions of paramount importance concerning them are those involving the definitions of boundaries and the right of political incorporation.

$\S 222$. Chartered companies as colonizing agents.-There was nothing novel in the means employed for the appropriation and

17 See above, p. 127 seq.

18 "In the early days of European exploration it was held, or at least every state maintained with respect to territories discovered by itself, that the discovery of previously unknown land conferred an absolute title to it upon the state by whose agents the discovery was made. But it has now been long settled that the bare fact of discovery is an insufficient ground of proprietary right. It is only so far useful that it gives additional value to acts in themselves doubtful or inadequate." Hall, $\S 32$.

19 "The best modern practice, and the views of the most acute and thoughtful publicists, give authority to the doctrine that effective international occupation is made up of two inseparable elements - annexation and settlement." Lawrence, Principles of Int. Law, § 93 . 
settlement of African soil. "Under the last of the Tudors and the first of the Stuarts, two trading charters were issued to two companies of English adventurers. One of these charters is the root of English title to the East, and the other to the West. One of these companies has grown into the Empire of India; the other into the United States of North America." 20 Just as Great Britain sent out the Virginia and East India companies in the early days of discovery and settlement, she has recently sent to Africa on a like mission the British East Africa Company, the British South Africa Company, and the Royal Niger Company. In the same way went forth the German East Africa Company, and the International Association of the Congo, which, under the direction of the king of the Belgians, undertook the philanthropic task of introducing commerce and abolishing the slave trade in the vast basin of that river. These quasi political bodies, to which their creators have delegated powers but little removed from those of sovereignty, are to a certain extent subjects of international law, (1) because vast areas of territory are committed to their control within which all forms of legislation and administration are carried on with only a nominal supervision from the parent state; (2) becanse to a limited extent they are permitted by the parent state to have certain "dealings" with foreign states. As an illustration, in 1889 the Queen in Council granted a royal charter of incorporation to the British Sonth Africa Company conferring upon it-subject to the approval of the Secretary of State for the colonies, and the requirements of the High Commissioner in those parts-large powers of administration, with the right to promote emigration and colonization, trade and. commerce, and to acquire by grant from the native inhabitants "any rights, interests, authorities, jurisdictions, and powers of any kind or nature whatever, including powers necessary for the purposes of gorernment." 21 While the Colonial Secretary possesses the right to disapprove of "any of the dealings of the company with any foreign power," and to compel it to perform under his direction all obligations contracted by the Imperial Goverument with foreign powers, so far as they relate to its territory and activities, such safeguards have not always been sufficient to save the Imperial Government from the necessity of sending its own agents into

20 Bryce, The American Com- Statesman's Year Book for 1894, monw., vol. i, p. 416. pp. 193-195.

21 London Gazette, Dec. 20, 1889; 
the country to restore peace and order through the assumption of a large measure of control over the affairs of such companies.22

\section{\$223. Protectorates-Extent of internal control and external} obligation.-In order to insure to appropriated and uncivilized regions a degree of peace and order which chartered companies can hardly be expected permanently to supply many goveruments have supplemented or superseded their control by the establishment of protectorates, a rather vague and indefinite form of political organization which differs from a colony in that the protected community neither becomes an integral part of the protecting state nor surrenders, except to a certain extent, the right to exereise internal sovereignty. As a general rule the power establishing a protectorate strives to secure such a limited right of control over the internal affairs of the dependent community as will enable it to discharge the external obligations assumed to foreign states. How far such obligations should extend is a matter of serious controversy. If the protecting state is under obligation to answer to other states for injuries inflicted upon their citizens by those under its protection, it certainly seems reasonable that it should be armed with jurisdiction to administer justice over all, whether subjects of other civilized states or not. That general right, believed to have been affirmed by all the states represented at the Berlin Conference of 18s4-5 except Great Britain, and recognized, certainly by implication, in the General Act of the Brussels Conference of July, 1890, was expressly aftirmed by imperial decree in $1885,{ }^{3}$ so far as the

22 It has, therefore, been well said, by one who has done most to make this subject clear, that such a company, like Janus of old, has two faces. "On that which looks towards the native tribes all the lineaments and attributes of sovereignty are majestically outlined. On that which is turned towards the United Kingdom is written subordination and submission. We may extend the simile and make it apply to all the other chartered companies of which we spoke. They are sovereign in relation to the barbarous or semibarbarous inhabitants of the dis- tricts in which they bear sway. They are subject as regards the governments of their own states." Lawrence, Principles of Int. Law, p. 82 . See also pp. $80-81 ; 166-167$. 23 Reichs-Gesetzblatt of March 15, 1888. From a decision of the Court of Cassation made Oct. 27th, 1893 (Affaire Magny. et autres), it may be inferred that that jurisdiction will be exercised as a matter of course in all French protectorates. "In all protectorates which are covered by the Africa Order in Council of 1889 jurisdiction can be taken over subjects of the powers which adhered to the 
German protectorates are concerned, and by the I'acific Order in Council of 1893, and the South African Orders in Council of 1891 and 1894 in the districts to which they relate. As a compensation for the burden thus imposed noon the protecting state to guard other states against acts of lostility and depredation upon the part of its wards, and to secure to foreign subjects and their property a reasonable degree of security within the protected territory, it has the right to demand that all states which feel aggrieved by acts committed by those under its protection must appeal to it for redress and not attempt to exact it by force from the native rulers or peoples. Over the territorial waters of the protected state the protecting power has as between itself and foreign countries the right to exercise a control commensurate with the general scope of its jurisdiction and responsibility. It has been said that there is now a tendency to regard the inhabitants of protected districts as subjects of the protecting state for international purposes; and that when that point is reached protectorates will differ in no wise from ordinary provinces or colonies. During the intervening period of transition they certainly may be regarded as training schools for those who, if they fail to establish complete political independence, must expect to submit to complete political incorporation.

$\S 224$. Spheres of influence-Prevention of conflicts as to boundaries.-The one new and hopeful expedient in the interest of peace which the partition of Africa has added to the law of occupation is embodied in the derice recently acreed upon in various forms by Great Britain, Germany, France, Italy, Portugal and other nations for the prevention of future conflicts as to boundaries. With the history of such conflicts in America to guide them a systematic effort has been made by many powers to prevent their recurrence in Africa through international treaties of delimitation which define in adrance the "sphere of influence" through which the growing settlements of any given state may extend. From the sphere thus defined the dominant state has the right to exclude other European states through their own consent, thus leaving the field clear for the free development of its chartered companies and protectorates. The power thus confered over a given area is an excluding power and not one of entire and direct

General Acts of the Conferences of Berlin and Brussels." Hall, § 38, note 1. 
control over the affairs of the sphere, either internal or external. The foundations of the new system were outlined when the states represented ${ }^{2+}$ in the West African Conference at berlin declared in 1885 that "any power which henceforth takes possession of a tract of land on the coasts of the African continent outside of its present possessions, or which being hitherto without such possessions shall acquire them, as well as the l'ower" which assumes a Protectorate there, shall accompany the respective act with a notification thereof, addressed to the other Signatory Powers of the present act, in order to enable them, if need le, to make good any claims of their own;" and "the signatory Powers of the present Let recognize the obligation to insure the establishment of authority in the regions occupied by them on the coasts of the African continent sufficient to protect existing rights, and as the case may be, frecelom of trade and transit under the conditions agreed upon." In the next year conventions were concluded between Portugal and Germany and Portugal and France; and in .July, 1890, when Great Britain and Germany entered into important agreements as to the extent of their respective possessions it was expressly stipulated, that "one power will not in the sphere of the other make acquisitions, conclude treaties, accept sovereign rights or protectorates, nor hinder the extension of the intluence of the other." In 1891 like arrangements were concluded between Great Britain and Portugal and between Great Britain and Italy, and in 1893 between Great Pritain and (icmany.26 The nations colonizing on the coasts of $A$ frica, ${ }^{27}$ whichl lave thus reduced to a minimum the chances of conflicts as to boundaries, when the growing populations

24 Austria, Belgium, Denmark. France, Germany, Great Britain, Italy, the Netherlands, Portugal, Russia, Spain, Sweden and Norway, Turkey and the United States.

25 General Act of the Berlin Conference, Arts. 34, 35; Parl. Papers, Africa, No. 4, 1885.

$26 \mathrm{Cf}$. Lawrence, Principles of Int. Law, § 95, and also Walker, Science of Int. Law, p. 161.

27 As the treaty stipulations in question apply only to the African coasts, questions as to the extent of interior occupations, even on that continent, will have to be determined by the customary law of nations as heretofore. "Prince Bismarck's conception of the customary law is shown by an expression of wish uttered by him at the opening of the Berlin Conference. 'Pour qu'une occupation soit considérée comme effective, il est à désirer que l'acquéreur manifeste, dans un délai raisonnable, par des institutions positives, la volonté et le pouvoir d'y exercer ses droits et de remplir les devoirs qui en résultent.' (Parl. Papers, Africa, No. 4,1885 , p. 3.)" 
within their respective spheres shall eventually touch each other, have of course no power to bind those states that have not made themselves parties to sucl stipulations. And yet the new rule thus established by all who have actually participated in the partition of Africa possesses a growing moral force which will no doubt develop it there, as the Monroe doctrine has been developed here, into a positive canon of international law. ${ }^{2 s}$

Status of native African races.-In dealing with the native races of Africa, the European nations have, in one respect, simply repeated the history of their dealings with like races in this hemisphere. In their partition treaties with each other the natives are ignored as persons whose rights are entirely subordinate to those of the Christian invaders. Despite the assumption, however, that undereloped conmunities possess no status which international law can recognize, the states now colonizing Africa are generally careful to make treaties with the native states or tribes, or to obtain concessions from their chiefs before entering into possession of their territories. When technical rules fail, considerations of morality and justice suggest that the new paternal regime shall not only be founded on some show of right but shall be conducted with fairness and consideration.

§225. Title by accretions-Case of the Anna.-When the territory of a state abuts upon the sea, or when it is bounded by a river, the action of water may create new formations the titles to which are determined by rules drawn in the main from Roman jurisprudence. ${ }^{29}$ Where islands are formed off the coast of a state by allurion, volcanic action or other cause, they become a part of the state to which the coast belongs, although formed ontside of prior territorial limits. The coast line is thus moved out into the sea, and from the limits of the new formation the extent of teritorial waters must be esti-

28 Hall, p. 120 , note 1 . $\mathrm{He}$ is clearly right in characterizing as premature Holtzendorff's statement (1887, Handbuch, ii, \& 55) that "Der grundsätzlich entscheidende Gesichtspunkt ist dieser: Kein Staat kann durch einen Occupationsact mehr Gebiet ergreifen, als er mit seinen effectiven Herrschafttsmitteln an
Ort und Stelle ständig in Friedenszeiten zu regieren vermag." The strict application of that principle, Hall says, would deprive Germany of the larger part of the territory which she claims in Southwest Africa and New Guinea.

29 Justinian, Inst., II., i, 20-24; Digest, XLI., i., 7, 29, 65. 
mated. Such was the judgment of Lord Stowell in the famous case of the Anna, ${ }^{30}$ seized off the mouth of the Mississippi, within three miles of certain low mud islands formed from the alluvial wash and debris of that river, which were uninhabited and uninhabitable, but more than three miles from the Belize, the extreme point of the main land. "It is argued that the line of territory is to be taken only from the Belize, which is a fort raised on made land by the former Spanish possessors. I am of a different opinion. I think that the protection of territory is to be reckoned from these islands, and that they are the natural appendages of the coast on which they border, and from which, indeed, they are formed." One of the main reasons given for the conclusion reached was that if the islands in question "do not belong to the United States of America, any other power might occupy them; they might be embanked and fortified." That line of reasoning gives great cogency to the suggestion that the same rule should be employed in determining the limits of territorial waters off the coasts of Florida, among the Bahamas, along the shores of Cuba, and in the Pacific where "are to be found groups of numerous islands and islets rising out of vast banks, which are covered with rery shoal water, and either form a line more or less parallel with land or compose systems of their own, in both cases enclosing considerable sheets of water, which are sometimes also shoal and sometimes relatively deep. $* *^{*}{ }^{*}$ There can be little doubt that the whole Archipiélago de los Canariosis a mere salt water lake, and that the boundary of the land of Cuba runs along the exterior edge of the banks." 31

$\$ 226$. Right to new formations when rivers are boundaries.Where a river constitutes the boundary between two states questions may arise as to the right to new formations either when deposits are made upon the banks or in the bed of the river. or when it entirely changes its course. In such cases the just rules of Roman law defining the effect of such changes upon private riparian ownership have been adopted as rules of public law applicable to states. If lands of two riparian owners, no matter whether states or private individuals, lie npon opposite sides of a stream their ownership extends to the midchannel or thalweg. 32 All gradual alluvial deposits on either

305 C. Rob. Adm. 373. See also Snow, Cases, p. 393.

31 Hall, pp. 129-30.

32 "Pour ce qui est des fleuves et lacs frontières, dont la rive oppossée est également occupée, leur milieu, y compris les îles que traverse la ligne du milieu, sépare ordi- 
bank belong to its owner; and if a mass of one river bank be violently torn away the original proprietor does not lose his right to it unless it is immovably fixed to the bank on the other side. If a river forming a boundary between two states gradually and silently changes its course its bed ${ }^{33}$ continues to mark the dividing line, the exposed soil accruing to the owner of the bank to which it is annexed. If such a river suddenly changes its course and forms a new channel wholly within the territory of one of the states, no change of ownership occurs because the deserted bed is apportioned equally between the former riparian owners. And the same thing is true of a lake belonging wholly to one state which suddenly overflows into the lowlands belonging to another. The new land belongs to the nearest state regardless of the nature of its soil, as the right to dominion does not depend upon that fact. Where the bed of a river belongs equally to bordering states, an island formed wholly on one side of the deepest channel belongs to the state owning the nearest shore. If it arises in the middle of the stream, it is divided between the two proprietor's by a line of separation following the original center of the channel. When a fixed line constitutes the boundary between two states each is entitled to the accretions made on its side of such line. ${ }^{34}$

$\S 227$. Title by cession-Just compensation for conquered territory.-No matter whether territory of a state is acquired

nairement les territoires. Au lieu de cette ligne ou a nouvellement choisi pour frontièr le thalweg, c' est à dire le chemin variable que prennent les bateliers, quand ils vont aval, ou plutôt le milieu de ce chemin." Kluber, Droit des Gens, $\S 133$. The mole accurate and more equitable boundary of the midchannel or thalweg employed by modern publicists is to be preferred as a line of demarcation to that described by the older writers as the midale of the river. See Grotius, II. c. $3, \S 18$; Vattel, I. c. 22 , $\S 266$.

33 In the disputed boundary case of the State of Alabama v. State of Georgia (23 Howard, 505), in which a State was held to have ownership of soil and jurisdiction in the bed of a river, such bed was so defined as to include "that portion of its soil which is alternately covered and left bare as there may be an increase or diminution in the supply of water, and which is adequate to contain it at its average and mean stage during the entire year, without reference to the extraordinary freshets of the winter or spring, or the extreme droughts of the summer or autumn." It was also held that "in such places on the river where the western bank is not defined, it must be continued up the river on the line of its bed, as that is made by the average and mean stage of the water," as defined above.

${ }^{34}$ Grotius, II. c. $3, \S 16$; Vattel, I. c. $22, \S 268-269$; Phillimore, I. $\$$ 
by prescription, conquest, oceupation or accretion it may be given a way, sold or exchanged by means of a treaty of cession in which is usually embodied all of the speetal stipulations and conditions incident to the transfer. While such cessions are not common, nations anxious to conciliate others bave sometimes made gifts of territory as manifestations of good will. In that way the colony of Louisiana was ceded by France to Spain in 1762 as indemnity for the loss of Florida transferred to England by the treaty of Paris $;^{35}$ and in 1850 Great Britain ceded to the United states a part of the Horseshoe reef in Lake Eric for lighthouse purposes. ${ }^{36}$ As instances of cessions for valuable considerations reference may be made to the transfers to the United States of Louisiana from France in 1803; of Florida from Spain in 1819; and of Alaska from Russia in 1867.37 In the treaty of Berlin, 1878, Roumania returned to Russia that portion of Bessarabia secured at her expense through the treaty of Paris, 1856 , in exchange for the Dobrontehil taken from Turley. It is far more usual, however, for cessions of territory to be made from one state to

238-40; Halleck, I, 146; Calvo, § 294; BIuntschli, §§ 295-299; Creasy lnt. Law, 241, 249; Martens, Prícis, $\S 39$; Twiss, $1, \S 147$; 8 Opinions of Atty. Gen'l, 175.

35 See above, p. 109.

36 Treaties of the United States, p. 444 .

37 The Supreme Court of the United States has laid down the following rules for the construction and interpretation of treaties of cession:

The laws applicable to treaties of cession do not apply to treaties for the recognition of independence, such as that of 1783 , with Great Britain. Harcourt v. Gaillard, 12 Wheaton, 523.

The stipulation in the treaty of cession of Louisiana for the protection of the inhabitants of the ceded territory in the enforcement of their liberty, property, and religion ceased when Louisiana became a member of the Union and its inhabitants were "admitted to the enjoyment of all the rights, advantages and immunities of citizens of the United States." City of New Orleans v. Armas, 9 Peters, 224.

A treaty of cession is to be construed in accordance with the state of things existing at the time. Strother v. Lucas, 12 Peters, 410.

A treaty of cession is a deed or grant by one sovereign to another, which transfers nothing to which he had no right of property, and only such right as he owned and could convey to the grantee. Mitchel v. U. S., 9 Peters, 711.

A guarantee in a treaty of cession of vested rights in the ceded territory covers only rights which emanated from a prior rightful sovereign. U. S. v. Pillerin, 13 Howard, 9. Such a guarantee covers inchoate as well as matured rights. Delassus v. U. S. 9 Peters, 117; Strother v. Lucas, 12 Peters, 410.

3. Holland, European Concert in the Eastern Question, p. 302. For a more extended list of cessions 
another at the end of a war in which the victor profits at the expense of the ranquished. Such was the nature of the cession in 1871 of Alsace and part of Lorraine by France to Germany. ${ }^{39}$ At the close of the Mexican war, in 1847, the government of the United states inaugurated a new policy which should certainly commend itself to all humane and justiceloving nations. The sum of fifteen millions of dollitrs was voluntarily paid to the conquered state as fair compensation for the cession of territory exacted of it. ${ }^{40}$ The stipulations contained in treaties of cession vary of course with each particular case, but in such arrangements it is usual to provide for the transfer along with the ceded district of its proportionate share of the public debt of the dismembered state; and also for such guarantees as can be obtained in favor of the rights to be enjoyed by the inhabitants under the new regime to which they are committed. ${ }^{41}$

\section{$\S 228$. Territorial waters-Exclusive right to use great rivers.} -The public domain of every state is made up in part of its territorial waters, a term used to describe such rivers, bays, gulfs and straits as are wholly within its limits and subject to its exclusive jurisdiction. A notable instance of the assertion of the right of a state to enjoy the exclusive use of a great river entirely within its bounds, and to prohibit such use to all other states, is that embodied in the claims of the United States over the Mississippi after the cessions of Louisiana and Florida had placed it in the midst of the territory of

by sale, gift, exchange and will, see Phillimore, i, § cclxviii-lxx and cclxxv; Calvo, $\S 225-8$.

39 Treaty of Frankfurt, Hertslet, Map of Europe by Treaty, III., 1955. Treaties of the U. S., p. 681 .

40 Art. XII of the Treaty of Guadalupe Hidalgo, proclaimed July 4, 1848, provides that "in consideration of the extension acquired by the boundaries of the United States, as defined in the fifth article of the present treaty, the government of the United States engages to pay to that of the Mexican Republic the sum of fifteen millions of dollars."

11 It is usual in modern treaties, and in some of the old ones (e. g., those of Ryswick and Utrecht), to secure to the inhabitants of the ceded territory liberty to keep their nationality of origin, coupled with the condition that within a certain time adequate for the settlement of their affairs they shall retire within the territory remaining to their state of origin. See Treaties of Vienna in 1809 (Martens (N. R.) i, 214), of Paris in 1814 (id. ii, 9), of Vienna in 1864 (N. R. G. xvii, ii), of Zurich in 1859 (id. xxvi. ii), of Turin in 1860 (id. 540), and of Frankfort in 1871 (id. xix, 689). The limits of time range from one to six years. 
the Union. "Since then the exclusive control of the river by the United States, so far as concer'ns foreign states, has been conceded internationally; though, subject to police supervision and to the right to impose pilotage and quarantine regulations, the free navigation of this and of other navigable rivers within the United States is, by the law of nations, accepted by the United States, open to all ships of foreign sovereigns." 42

$\$ 229$. Bays, gulfs or recesses in coast line-Curtailment of unreasonable claims.-In the absence of any generally acknowledged standard as to their size and conformation it is difficult to determine in any given case whether or no a bay, gulf, or recess in a coast line can be justly regarded as territorial water. England once claimed the inclosed parts of the sea along her coasts known as the King's Chambers, including the waters within lines drawn from headland to headland; ${ }^{43}$ the entire Bristol Channel between somerset and Glamorgan is probably considered British territory $;^{44}$ and the I'rivy Council has lately held that the Bay of Conception, which is fifteen miles wide and which penetrates forty miles into the interior, is a part of the territorial waters of Newfoundland. ${ }^{45}$ Germany and France are inclined to linit their claims to such bays, gulfs and recesses as are not more than ten miles wide at their entrance, measured in a straight line from headland to headland. The latter claims, however, the whole of the oyster-beds in the Bay of Cancale, the entrance to which is seventeen miles wide,-the cultivation of such beds by local French fishermen making the case exceptional. At an earlier day the United States was inclined to claim dominion over a wide extent of the adjacent ocean. "Considering." says Chancellor Kent, "the great extent of the line of the American

42 Wharton, Int. Law Dig., § 30 . See also Lawrence's Wheaton, $\mathrm{n}$. 114, p. 361; Twiss, i, § 141.

43 James I made a proclamation as to these chambers in 1604 , and their limits, including considerable areas, were "arrived at by a jury of twelve sworn for the purpose, and their finding was presented to Sir Julius Cæsar, Judge of the Admiralty, on March 4, 1604." Walker, Science of Int. Law, p. 170, note 3 . While the ancient claim of Great
Britain within such limits has been forgotten, it has never been formally withdrawn.

44 Such seems to have been the decision in Reg. v. Cunningham, Bell's Crown Cases, 86. "Possibly, however, the court intended to refer only to that portion of the channel which lies within Steepholm and Flatholm." Hall, p. 162, note 2.

45 Direct U. S. Cable Co. v. Anglo. American Tel. Co., 2 App. Cas. 394. 
coasts, we have a right to claim for fiscal and defensive regulations a liberal extension of maritime jurisdiction; and it would not be unreasonable, as I apprehend, to assume for domestic purposes connected with our safety and welfare the control of waters on our coasts, though included within lines stretching from quite distant headlands,-as, for instance, from Cape Ann to Cape Cod, and from Nantucket to Montauk Point, and from that point to the capes of the Delaware, and from the south cape of Florida to the Mississippi." ${ }^{46}$ While Chesapeake and Delaware bays and other inlets of a like character are still considered as territorial water $s,{ }^{47}$ the general policy of this goverument, conforming itself to the opinion of the civilized world, clearly tends towards the curtailment of any unreasonable claim to jurisdiction outside of the marine league. ${ }^{48}$

$\S 230$. Straits less than six miles wide an exception.-There is a general disposition to regard all straits only or less than six miles wide as wholly within the territory of the state or states to which their shores belong. When they have more than that width the space in the center outside of the marine league limits is considered as open sea. As a notable exception, howerer, to the general rule that territorial rights cannot be extended over straits more than six miles wide reference may be made to the final settlement of the northwest boundary line between Great Britain and the United States orisinally provided for in the treaty of 1846,49 which declared that such line should follow the forty-ninth parallel of latitude to the middle of the strait separating Vancouver's Island from the continent, and thence down the middle of the Strait of Fuca to the Pacific. When disputes as to the title to certain islands arose the boundary question was submitted under the treaty of $1871^{50}$ to the arbitration of the German emperor; and in 1873 a protocol, signed for the purpose of carrying out his decision, extended the line for fifty miles to the Pacific through the middle of a strait fifteen miles wide, after passing it across a body of water thirty-five miles long and twenty miles wide. 51

46 Comm, i, 30.

47 Wharton, Int. Law Dig., $\S \S 27$, 28. When in 1793 the English ship Grange was captured by a French vessel, in Delaware Bay, it was restored upon the ground of the territoriality of its waters. Am. State Papers, i, 73.
48 See above, p. 137.

49 Treaties of the U. S., p. 438.

50 Treaties of the U. S., p. 478 .

51 For the award and protocol, see Compilation of Treaties in force, 1899, pp. 255-258. See also. Parl. Papers, North Am., No. 10, 1873. 
$\S 231$. Territorial waters connecting parts of high seas-Denmark's "Sound dues."-When the territorial waters of a state, no matter whether an appropriated strait or marginal waters, form a channel of communication between two parts of the high seas, they are subject to the right of innocent passage in faror of all mankind for the purposes of necessary or convenient commercial navigation. In the days when the principle was admitted that the sea was subject to appropriation certain powers that owned narrow waterways claimed the right to exact tolls from foreign vessels passing up and down the straits. The most ancient and the most notable of such claims was that of Denmark, which enforced the prescriptive right to collect what were known as "Sound dues" upon the vessels of other powers passing to and fro from the North Sea to the Baltic through the sound or the two Belts.52 During the Middle $A$ ges those who were subjected to such exactions often negotiated treaties with her to regulate their amount, and when they were increased to an excessive point, Sweden, Holland and the Hanse Towns went to war on that account.53 Finally, under the growing pressure for free passage through all territorial waters that are channels of communication, Denmark, despite her prescription of five centuries, was forced in 1857 to surrender the Sound dues through the treaty of Copenhagen,in exchange for which the leading maritime states of Europe paid her a large pecuniary indemnity, received in the form of compensation for the future maintenance of buoys and lights. ${ }^{53 a}$ In the same year the United States, by a separate

52 As early as 1319 a charter regulated the dues to be paid by the Dutch; in a treaty made in 1490 with Henry VII English vessels were forbidden to pass the Great Belt as well as the Sound, except in case of necessity, and then only upon the payment of certain dues; and in the treaty concluded in 1544 with the Emperor Charles V it was stipulated that merchants of the low countries visiting Danish ports should pay the same dues as formerly.

53 The result was that in 1645 , through the treaty of Christianstadt, Sweden was exempted from the tolls, the amount of which was for the first time definitely ascertained for the benefit of those who remained liable to them. In another treaty made between Denmark and the United Provinces of the Netherlands in 1701 all remaining obscurities were removed. These two treaties of 1645 and 1701 continued as the standards by which the rates due from privileged and non-privileged nations were measured. Wheaton, Hist. Law of Nations, 158-161; Schlegel, Staats-Recht des Königreichs Dänemark, 1 Th. Kap. 7, §§ 27-29. 53a Martens (N. R. G.) xvi, 331. 345 . 
convention, became a party to the general settlement by agreeing to pay three hundred and ninety-three thousand and eleven dollars in consideration of Denmark's declaration that the Baltic should be open to American ships. ${ }^{54}$

\$232. Rights of war vessels in territorial waters.-There seems to be no good reason to doubt that the right of innocent passage, when claimed by ressels of states at peace with the territorial power,extends as well to vessels of war as to merchantmen, when the former are content to abstain from all illegal acts and to observe all reasonable regulations. The same principle that regulates the treatment of ambassadors applies to the reception of foreign men-of-war within territorial waters. No state has the right to forbid their passage through its straits from sea to sea even when they purpose to attack an enemy's ressel, or to bombard or blockade his ports. It has been held that the passage of a belligerent manof-war over neutral territorial waters in nowise vitiates a capture subsequently made on the high seas or in seas under belligerent control. So long as they commit no hostile acts within territorial waters, or so near them as to endanger the peace and security of the people of the state to which they belong, their passage is "innocent,"-since that word, as used in the phrase "right of innocent passage," refers to the character of the passage and not to the nature of the ship.

$\S 233$. Free riverain navigation-Rights of upper states.The tendency to relieve modern commerce from all restrictions upon the right to free navigation of the seas, which forced the abolition of the Sound dues, has been for a long time steadily demanding the free navigation of all rivers separating or passing through different states. One extreme school denies that the right of ricerain navigation ever existed at all upon the general principle that a state possesses such absolute proprietary rights over its own territory that it may exclude the ressels of all other powers from its own section of a waterway. ${ }^{55}$ Another declares that in time of peace all

54 Treaties of the U. S., p. 238 . The government of the U. S. refused to become a party to the general convention signed by the five powers on the Baltic and North Sea (1) because it did not care to recognize the right of Denmark to levy the Sound dues;
(2) because it did not care to involve itself in a question of purely European policy, a question involving "the balance of power among the governments of Europe."

55 e. g. Twiss, I, § 141 . When the river is wholly within the territory of a single state undoubt- 
navigable rivers in communication with the sea are open to the navies of all nations. ${ }^{56}$ Between the two stands a third, which holds that when a navigable river flows in part of its course through the territory of one state and in part throngh that of another, those who live upon its upper waters have an imperfect or moral right to use that portion of it beyond their own bounds. ${ }^{57}$ In other words no matter how great the wants or necessities of the upper state, or how moral its action might be, international law, from the standpoint of strict legal right, is forced to regard any attenut upon its part to force a passage to the sea atross the territory of another state as a trespass becaluse that other has the legal right to open or close its part of the river at will, or to tax or otherwise regulate transit over it as its policy may dictate.

$\$ 234$. How the Great European rivers were emancipated-the Rhine.-Upon that theory the navigation of all the great Eurolean rivers, running through the territories of more than one state, was subjected to tolls and other dues down to the beginning of the present century. Such were the conditions under which the attempt was made to regulate the use of the navigable rivers of the continent through the establishment of a conventional law by which all tolls and dues were either to be abolished or reduced by common consent to a uniform system. ${ }^{5 s}$ At the very beginning of modern international law edly "il est considére comme se trouvant sous la souverainté exclusive de ce même état." Calvo, § 229. See also Holtzendorff, Enc., 1223, citing Wurm, Briefe über die Freiheit der Flusschiffahrt, 1858; Caratheodory, $D u$ droit int. concernant les grands cours d'eau, 1861; Engelhard, Du regime conrentional des fleuves, 1870.

56 e. g. Bluntschli, who says (\$ $314)$ "les fleuves et rìvières navigables qui sout en communication avec une mer libre sont ouverts en temps de paix aux navires de toutes les nations."

57 Grotius, De Jure Bcl. ac Pac., II, cap. 2 , $\S \S 12,14$; cap. 3 , $\S ~ 7-12$; Vattel, Droit des Gens, II, cap. 9, $\S \S 126-130$; Puffendorf, De Jur. Naturae et Gentium, III, cap. 3 , § $\mathrm{S}$; Martens, Précis, § 84 ; Heffter, §

77; Calvo, § 230; Fiore, §§ 758, 768; Wheaton, § 193.

58 It seems to be generally ad. mitted that the common right of navigation, even if it exists, is subject to certain rights in the local proprietor: "sauf entente amiable entre eux, par voie de stipulations conventionnelles, pour l'exercise de ce même droit, qui peut, suivant les circonstances, affecter la sécurité du pays en possession des deux rives de l'embouchure." Calvo, §230. Halleck says that the common right of commercial navigation is subject to such provisions as are necessary to secure "the safety and convenience" of the several states interested, i, 147-8. See also "Conventional Law of Europe as to the Great Rivers," Twiss, I, $\S$ 145. 
the fact was recognized that all such matters should be made the subject of convention, and for that reason in the treaty of Westphalia, 1648, the navigation of the river Scheldt was closed to the Spanish Netherlands in favor of the Dutch, and so remained until it was foreibly opened upon the oceupation of Belgium by the French in 1792.59 At the instance of the French government it was that the first step towards the freeing of river traffic was taken when, in 1804 , the various Rhine tolls were abolished at the Congress of Rastatt by the convention. The good work thus begun was greatly advanced by a declaration in the treaty of Paris, 1814, that the navigation of the Rhine should be free to all the world, and that the then approaching congress to be held at Vienna should examine and determine how the navigation of other rivers should be opened and regulated.

\section{$\$ 235$. Final act of Vienna Congress-Commercial use of Dan-} ube.-Thus it was that, by an Annexe (xvi) to the Final Act of that congress, the free navigation of the Rhine was confirmed "in its whole course, from the point where it becomes navigable to the sea, ascending or descending;" and like provisions were made for the narigation of the Neckar, the Moselle, the Main, the Scheldt, and the Meuse, subject only to police rules and such moderate dues as would compensate the several riparian states for their expenditures upon such waterways. ${ }^{60}$ Beyond such conventional arrangements the Congress of Vienna did not go; no general declaration was made in favor of the abstract right of free navigation of all ricers separating or traversing the territories of different states. ${ }^{61}$ Through the efforts of a mixed commission, which completed its work in 1821 , the free navigation of the Elbe was established among

59 For the subsequent arrangements for the free navigation of the Scheldt made in the treaties of Vienna, and in the treaty of 1831 for the separation of Holland from Belgium, see Wheaton, Hist. Law of Nations, $282-285,552$.

60 For a list of conventions regulating the navigation of rivers separating or passing through different states, see Heffter, Appendix viii.

81 Neither was the principle of free navigation applied to rivers lying wholly within one state. Martens (R.) viii, 261 and (N. R.) ii, 427, 434. For the real intention of the treaties of Paris and Vienna as to the freedom of river navigation, see $M$. Englehardt, in the Revue de Droit International (xi. 363-81), who says "les libertês fluviales, telles qu'on les pratique anjourd'hui, sout essentiellement conventionnelles." 
the states interested in the commerce of that river. ${ }^{62}$ By the treaty of Bucharest, 1812, and that of Adrianople, 1829, it was provided that the commercial use of the Danube should be enjoyed in common by the subjects of Russia and Turkey; and, in 1856 , by the treaty of Paris, this, the last of the great European rivers to be emancipated, was brought under the general system established by the Congress of Vienna, and a commission established for the execution of necessary engineering works at its mouth, the expense of which was to be paid out of a levy of tolls to be imposed for that purpose. ${ }^{63}$

\$236. Navigation of Mississippi as regulated by treaties of Paris and San Lorenzo.-The navigation of the greatest arterial river of the North American continent was made the subject of conventional regulation in the treaty of Paris, 1763, wherein the province of Camada was ceded to Great Britain by France, and that of Florida to the same power by spain, and the boundary between the British and French possessions declared to be a line drawn through the channel of the Mississippi from its source to the Iberville, and thence through the latter and the lakes Maurepas and Ponchartrain to the sea. In that treaty the right to narigate the border river from its source to the sea through the passages at its mouth was secured to British subjects free from the right of visit or the payment of any dues whatsoever. That condition of things was entirely changed when, in 1769, Spain took possession of Louisiana and New Orleans, ceded to her by France in the secret treaty of November 3, 1762, and of Florida retroceded to her by Great Britain in the treaty of Versatiles, $1783 .{ }^{64}$ Spain thus possessed of both banks of the Mississippi for some distance above its mouth set up in full force against the United States after its independence the European doctrine that the upper inhabitants of a river have no perfect legal right to insist upon a passage to the sea if the state in entire possession of the intervening district sees fit to withloold it. In order to answer that contention American publicists were forced to fall back upon the abstract reasoning by which Grotius ${ }^{65}$ and some of his successors had attempted to

62 Neumann, iv, 613; Martens (N. R.), v, 714 .

63 Holland, European Concert in the Eastern Question, 248-250, 308.

64 See above, pp. 109,111 . See also Calvo, Recueil complet des traités,
II, p. 363; Ch. de Martens (R.), I, p. 33 .

65 De Jur. Bel. ac Pacis, II, cap. 2 , $\S 11-13$; cap. $3, \S \S 7-12$; Puffendorf, III, cap. $3, \S \S 3-6$; Wolf, Just., $\S \S 310-312$; Vattel, I, § 292; II, §§ 
establish the right of passage over territory, whether by land or water, as one of the natural rights reserved for the general advantage of all mankind when separate property was originally established. While that cogent argument had never received positive sanction in European experience, either medieval or modern, it proved effective; and in 1795 the treaty of San Lorenzo el Real ${ }^{66}$ was concluded wherein Spain conceded the free navigation of the Mississippi from its source to the ocean to the citizens of the United States, who were permitted to deposit their goods at the port of New Orleans, and to export them subject to no other duty or demand except the hire of warehouses.

$\S 237$. Navigation of St. Lawrence as regulated by treaties of 1854 and 1871.-A second radical change of conditions occurred when, through the acquisition of Louisiana in 1803 and Florida in 1819, the United States became possessed of both banks of the Mississippi, thus transfered to that class of rivers over which a single state may exercise exclusive control. So nearly was that result reached by the purchase of Louisiana alone that the treaty of Ghent, ${ }^{67} 1814$, omitted all reference to the right of British subjects to navigate it, - a right which article 8 of the treaty of Versailles, 1783, had secured for the equal benefit of "the subjects of Great Britain and the citizens of the United States." Despite the fact that the former power, when she possessed only a small district in which the Mississippi took its rise, had claimed the right to navigate its entire course to the sea, sle contended when the right to navigate the st. Lawrence was in question that although the United States was in possession of the southern shores of the great lakes and the river to the point at which the boundary line intersects the same, it had no right to navigate its lower waters embraced entirely within its territory. "On the ground that she possessed both banks of the st.

123-139. The Roman jurists considered certain things incapable of appropriation by their very nature. Et quidem naturali jure communia sunt omnium hæc, aer, aqua profluens, et mare, et per hoc litora maris. Justinian, Inst. II. tit. l, $\S 1$.

66 Martens (R.), VI, p. 561. La libre navigation du Mississipi est
un fait consummé depuis 1795; cependant les débats auxquels elle a donné lieu entre le gouvernement de l'Espagne et celui des EtatsUnis constituent un des précédents les plus précieux relatifs à la navigation des fleuves." Calvo, Le Droit Int., $\S 223$.

6i Hertslet, Map of Europe by Treaty, II, p. 378; Martens (N. R.) II, p. 76 . 
Lawrence where it disembogues itself into the sea, she denied to the United States the right to narigation, though about onehalf of the waters of Lakes Ontario, Erie, Huron and Superior, and the whole of Lake Michigan, through which the river flows, were the property of the United States." 68 Thus did Great Britain change places with spain by the assertion of an exclusive right over the lower waters of the St. Lawrence against the immediate interests of a growing population inhabiting at least eight states of the American Union, and the territory of Michigan besides. The pressure of such great interests gave a fresh force to the argument that the claim of exclusive control over lower waters was opposed to natural right; and in that way the controversy, actively in progress in 1826 , was adjusted by the reciprocity treaty ${ }^{69}$ of 1854, which opened the navigation of the river, as well as the canals of Canada, to the United States on the same conditions imposed on British subjects, in exchange for a concession in favor of such subjects to narigate Lake Michigan. Although that treaty ceased to exist March 17, 1866, under resolution of Congress of January 18, 1865, Great Britain did not, after that time, insist on the exclusive right of narigation, and finally by treaty of Washington, ${ }^{70} 1871$ (art. xxxi), that right, so far as the British portion of the river is concerned, was secured "forerer" to citizens of the United States.

$\$ 238$. Opening of South American rivers.-The South American rivers, which as a general rule were subject to the old principle of exclusion, have been gradually opened to narigation through conventions. The La Plata river system, closed to foreign ships until 1853, was opened as to the Parana and Paraguay, in so far as they lie in Argentine territory, to the ships of all nations by treaties made in that year with England, France, and the United States; and by another treaty made in 1855 the free navigation of the Parana and Uruguay was conceded "to the merchint vessels of all nations"-a declaration repeated as to all three rivers, from their entrance into the La Plata to interior ports, in a convention made with lirazil, 185. In 1853 Uruguay opened its rivers to all nations, and granted to England and France the free navigation of the Paraguay as far as Assumption,-stipulations repeated

6. President Grant's second an- p. 448; Hertslet, IX, p. 998; Marnual message, 1870 . See also Phil- tens-Samiver, III, pt. 1, p. 498.

limore, Int. Law, $3 d$ ed., 245.

70 Treaties of the United States,

69 Treaties of the United States, 478. 
by Paraguay in treaties made in the same year with the same powers, and in 1859 with the United States. Before the opening of the La Plata river system began Brazil agreed, in a treaty with Peru in 1851, to extend to the navigation of the Amazon the principles of river regulation laid down by the Congress of Vienna. But even that limited arrangement was suspended for some years, and the great river remained elosed not only to non-riparian states but to Ecuador down to 1867 when, under a decree made by the emperor of Brazil, the Amazon, the Tocantins and the San Francisco, so far as he had power to regulate the subject, were opened to the merchant vessels of all nations. ${ }^{71}$

$\S 239$. Opening of Alaskan and African rivers.-By the treaty of Washington, 1871, the rivers of Alaska, rising in British territory and running into our own, were opened to both nations $;^{72}$ and by the Final Act of the West African Conference, 1884-85, it was provided that the Congo and Niger and their tributaries should be free to all, under an international commission, without exception or discrimination. ${ }^{73}$ So completely has the narrow doctrine of earlier times given way during the present century to the necessities of commerce and free intercourse that Field has been able to state the rule for the future as follows: "A nation and its members, through the territories of which runs a narigable river, have the right to navigate the river to and from the high seas, even though passing through the territory of another nation, subject, however, to the right of the latter nation, to make necessary or reasonable police regulations for its own peace and safety." 74

$\$ 240$. Incidental right to use river banks.-The right to navigate a river carries with it as an incident the right to use the shores, so far as that may be necessary to the enjoyment of

$\mathbf{7 1}$ Hertslet, Map of Europe by Treaty, IX, p. 191, 601; De Clercq., IV, p. 303; Martens-Samiver, IV, pt. 1, p. 249 ; Calvo, $\S \S 227,228$. 229 ; Wharton, Int. Law Dig., $\$ \S$ $30,40,157,321$. In the authorities cited are contained the details as to like conventions made about the same time by Bolivia and Peru. See also Dip. Corresp. of the U. S. for 1867, 1868, ii, 256. The Tapajos, the Madeira and the Rio Grande, tributaries of the Amazon, were also opened, but not through the upper part of their course, where only one bank belongs to Brazil.

72 Treaties of U. S., p. 478 . See Art. XXVI as to Yukon, Porcupine and Stikine.

73 British State Papers, Africa, No. 4 (1885), pp. $308,311$.

74 Outlines of an International Code, $\$ 55$, citing message of President Grant to Congress of the U. S., Dec., 1870, and treaties therein enumerated. 
the primary right, in obedience to that principle of Roman law which, assuming that navigable streams are public or common property, gare a free passage over them, with the incidental right to use the banks to lade or unlade cargoes, to moor ressels and the like. ${ }^{75}$ As the primary right is itself limited so is the incidental, whose exercise must be enjoyed subjeet to the mutual convenience of both parties. ${ }^{76}$ That principle of Roman municipal law declaring the use of rivers and their shores to be vested, according to the abstract principles of national right, in all Roman eitizens, was applied by the publicists to like interests between nations. ${ }^{77}$

\section{$\S 241$. Ownership of an entire river. Burden of proof on claim-} ant.-When a river forms the boundary between two states one of them may, through prescription or convention, be possessed of the entire chinnel without the opposite bank, ${ }^{78}$ or it maly possess the entire liver and both banks. ${ }^{79}$ As Grotius has expressed it: "But though, as I have said in case of any doubt, the jurisdictions on each side reach to the middle of the river that rons between them, yet it may be, and in some places it has actually happened, that the river belongs wholly to one party, either because the other nation had not yet possession of the other bank till later, when their neighbors were already in possession of the whole river, or else because matters were so stipulated by some treaty."so In the treaty of st. Germain en Lay, 1679, the king of Sweden ceded to the elector of Brandenbures the right bank of the river Oder, withont the right to ereet fortifieations upon it, the grantor retaining jurisdiction over the entire channel together with the left bank. An After sweden had received from the emperor of

75 As to the jus littoris, see Justinian Inst. II, tit. 1, $\S \S 1-5$; Grotius, II, cap. 2, $\$ 15$; Vattel, II, cap. 9, \$ 129; Puffendorf, V, cap. 3, 8 ; Caratheodory, Du droit international concernant les grands cours deau, p. 59. Phillimore, I, §§ 157-161; Polson, sec. 5; Wheaton, Hist. of the Law of Nat., 510.

76 "The great weight of authority since Vattel is that the state througl which a river flows is to be the sole judge of the right of foreigners to the use of the river. Wheat. Int. Law, i, 229; Vattel I,
1, § 292." Wharton, Int. Law Dig., $\S 30$.

77 Calvo, § 234.

is Wolf, Jus Gentium, §106; VatteI, I, $\$ 266$.

${ }_{79}$ "A nation having physical possession of both banks of a river is held to be in juridical possession of the stream of water contained within its banks." 1. Phillimore, $\S 170$.

so De Jur. Bel. ac Pac., II, cap. $3, \S 18$.

\&1 Dumont, Corps Diplomatique, XIII, p. 408. 
Germany under the treaty of Osnabrück, 1648, a cession of the entire river Oder it was held that she had acquired possession of a margin on the further bank of two German miles as an incident inseparable from the grant. On that principle of construction Prussia, after she lad received from Poland under the treaty of Warsaw, 1773 , a cession of the entire river Netze, maintained the contention that such a cession carries with it the entire stream and both its banks. ${ }^{82}$ The burden of proof is, however, upon the state claiming to own an entire stream or lake; and, if a title so set up cannot be maintained either by prescription or convention, the rule is that the use is in common, the boundary in the case of non-navigable rivers being the middle of the stream, and in the case of navigable ones, the 'thalweg' or center of the deepest channel. ${ }^{83}$ In the treaty ${ }^{84}$ concluded in 1808 between the Grand Duchy of Baden and the Helvetic Canton of Argovie, the water-frontier line or thalweg was defined to be "the line drawn along the greatest depth of the stream," and so far as bridges are concerned, "the line across the middle of each bridge."

$\$ 242$. Emancipation of high seas-Early freedom theoretical. -The process through which the navigable rivers of the world have finally been opened to the commerce of all nations is simply the consummation of that wider movement through which the high seas have likewise been emancipated from the ancient claim that they, too, were subject to appropriation. Ulpian and other classic jurists of his school, ignoring the actual practice of antiquity, contended that the sea was free and open to all; and in the Institutes the doctrine is clearly defined that air, running water and the sea cannot be appropriated because they are not susceptible of detention, ${ }^{85}$ of physical possession, without which there can be no basis for the permanent relation involved in the juridical conception of property. According to Roman theory the seas were res communes; navigable rivers, res publica. ${ }^{86}$ There can be no doubt, however, that from the earliest times the theoretical

82 Twiss, I, $\$ 144$, citing Gunther (II, § 14), who held that Prussia's claim to all such portions of the opposite bank as the waters of the river in a state of inundation overflowed, as well as the marshes caused by such inundations, was in conformity to usage.
83 8 Opinions Attys. Genl., 175.

8. Martens (N. R.) I, p. 140.

85 See above, p. 284, note.

86 The same distinction was recognized by Grotius, II, cap. ii, §12. Cf. Wharton, Com. Am. Law, § 191; Hadley, Int. to Roman Jaw, pp. 156-57. 
freedom of the seas could only be enjoyed subject to the perils imposed by the nests of pirates that infested all of them. ${ }^{57}$ After the northern rovers had reduced piracy to a system, the maritime nations were forced to police the seas, and to preserve peace and security upon them, through the exercise of territorial sovereignty over such portions as were adjacent to their coasts,-or, to use a very modern term, specially within their spluere of influence. ${ }^{8 s}$

$\$ 243$. Doctrine of mare clausum. Right to exact tolls and dues.-Out of that condition of things the doctrine of mare clausum had necessarily emerged prior to the advent of modern international law, which was forced to recognize the fact that property could be acquired in seas, for the obvious reason that most of them had been actually appropriated. The control that arose out of such appropriations did not involve, however, the right to exclude vessels of other nations from protected waters, but only the right to exact of them tolls and dues as compensation for the security guaranteed to them. ${ }^{89}$ Upon that general basis rested the claim of Venice to the Adriatic; the claim of Genoa to the Ligurian sea; the claim of France to an indefinite extent of waters stretching outwardly from the coast; the claim of England to seas surrounding her shores and extending from Stadland in Norway to Cape Finisterre in Spain; and the claim of Denmark, on the one hand, to the entire space between Iceland and Norway, and, on the other, to the Baltic in joint sovereignty with Sweden. ${ }^{90}$

87 "Piratical leagues flourished for ages in every corner of the Mediterranean, and even the merchant princes of Tyre and Sidon were not too proud to blend a little piracy with more legitimate operations." Walker, Science of Int. Law, p. 164.

88 "In the thirteenth and fourteenth centuries a rich vessel was never secure from attack; and neither restitution nor punishment of the criminals was to be obtained from governments, who sometimes feared the plunderer, and sometimes connived at the offense." Hallam, M. A. II, p. 397.

so Venice, which in 1269 began to exact heavy tolls from all vesse!s navigating the Northern Adriatic, based her claim to dominion over that sea upon an asserted grant of Alexander IV made in recognition of her sacrifices in ridding the gulf of pirates and Saracens. Guicc. IV, p. 360.

90 Selden, Mare Clausum. II, c. 30 2; Daru, Hist. de Venise, V, § 21; Loccenius, De Jure Marit. I, c. 4. "In 1485 it was agreed in a treaty between John II of Denmark and Henry VII that English vessels should fish in and sail over the seas between Norway and Iceland on taking out licenses, which required to be renewed every seven years." Hall, $\$ 40$, citing Mare Clausum, II, c. 32 . 
There were, of course, special territorial reasons why the Baltic should be considered as a mare clausum, reasons that applied equally to the Black Sea so long as it was entirely encircled by Turkish territory.

\section{$\S 244$. Claims of Spain and Portugal to newly discovered seas.} -It is not therefore strange that when spain and Portugal took the lead in the great work of discovery and conquest in two hemispheres that the former should have attempted to appropriate the Pacific and the Gulf of Mexico and the latter the Indian Ocean and the newly discovered route around the Cape of Good Hope. It was the preposterous claim thus asserted by these powers, involving no less than the exclusion of the ships of other nations from what they were pleased to call their waters, just at the moment when the discovery of America gave a fresh impetus to trade and commerce, that provolied the counter blast,in the form of a protest from the excluded, denying the whole theory upon which the right of appropriation rested." When Mendoza, the envoy of spain at the English court, complained to Elizabeth of the intrusion of English ressels into the waters of the Indies, she admonished him that "the nse of the sea and air is common to all; neither can a title to the ocean belong to any people or private persons, for as much as neither nature nor public use and custom permitted any possession thereof." 92

$\S 245$. Grotius's Mare Liberum. - When Grotius was called upon, a short time thereafter, to deal with the theoretical side of the question, he gave sanction to Elizabeth's declaration by reviving in his Mare Liberum (c. 5), published in 1609, the old doctrine of Roman law that there can be no property in anything without occupation, to which the vagrant waters of the ocean cannot be subjected. ${ }^{93}$ Upon that ground he asserted the common right of mankind to the free navigation, commerce, and fisheries of the Pacific and Atlantic oceans, against the exclusive claims of Spain and Portugal whether founded on prior discovery or the grant of Pope Alexander VI. The broad statement that the sea could not be made the subject of property he qualified at a later day by the necessary admission that such linited portions of it may be as gulfs and marginal waters when bearing the proper relation to the adjacent

91 See above, p. 128. 93 See also De Jure Belli ac Pacis, 92 Camden, Hist. of Eliz., year II, c. 2, §§ 2, 3. 1580 . 
land. ${ }^{94}$ As thus modified the Grotian doctrine has become the rule of modern intermational law. But that result was not reached without a struggle in faror of the prescriptive right of appropriation. Even the countrymen of Grotius resisted the right of the spiniands to go to the Philippines by the way of the cape of Good Hope, while the elaims of the sovereigns of England over the British seas were brought forward by Gentilis in his Adrocalio IIispanica in 1613.

\section{$\$ 246$. Selden's Mare Clausum. Gradual extinction of the doc-} trine.-A wider importance was given to that contention by Selden's Marc Clausum, first published in 16:35, as stated heretofore, ${ }^{95}$ as a kind of state $\left.1 \mathrm{al}\right) \mathrm{pe}^{\mathrm{r}}$ in which the sovereignty of Great liritain over the surrounding seas was so asserted as to deny the right of the Dutch to fish ofl the coasts.96 The first successful resistance to these wide pretensions of Great Britain eame from the rising power of that maritime people. And yet despite all opposition she clung to them so persistently that when the negotiation for the settement of the right of search, which had nearly reached a successful conclusion in 1803 , was about to be consummated with the United States, it was broken off at the last moment because her government could not be induced to concede freedom from it within the British seas. ${ }^{97}$ As a general rule, howerer, such claims to dominion began to dwindle from the middle of the serenteenth century, and by the beginning of the nineteenth they had practically disappeared. Great Britain, long after she had giren $u_{p}$ the substance of what she claimed as her rights, contented herself with a shadow in the form of ceremonial honor's to her flag within certain areas; while Denmark, after reducing her pretensions to an attempt to retain a wide belt around Iceland and Greenland for the exclusive use of her fishermen, finally gave up the struggrle in 1872 , and voluntarily accepted the three-mile limit. The special jurisdiction for so long a time asserted by spain orer the waters surrounding Cuba disappeared, of conrse, if it ever existed, with her loss of dominion in that quarter.9s The last important attempt to assert exclusive claims over a portion of the open sea was that made by

${ }^{9} 4$ De Jure Belli ac Pacis, II, c. $3, \S 8$.

95 See above, p. 62.

$96 \mathrm{Sir}$ John Boroughs, The Soveraignty of the British Seas (London, 1651), p. 115 seq.; Mare Clausum, p. 472 seq. 9i Mr. King to Mr. Madison, British and Foreign State Papers, 181214, p. 1404.

9 The last formal discussion of Spain's claim to a special jurisdiction over the waters surrounding 
the United States, as the assignee of Russia, in the matter of the Bering Sea, a controversy settled by an arbitration to which reference has been made already. ${ }^{1}$ Even in that case "the proprietary or territorial claim was tacitly dropped at an early stage of the proceedings," and another "to jurisdictional rights of control for certain purposes, resting on a totally different basis, was substituted for it, or was at least insisted upon in its place."

\section{$\S 247$. The marine league. Grotius, Vattel and Bynkershoek.--} Under the Grotian doctrine of free navigation special claims of dominion over whole seas have vanished, leaving as survivals only the jurisdiction over bays, gulfs, mouths of rivers, parts of sea inclosed by leadlands, and certain straits heretofore described as territorial water's. When to such waters are added, under the general usage of nations, the marine league, once the distance measured by a cannon shot from the shore, a definite and complete idea may be formed of the entire extent of a state's maritime territorial jurisdiction. The attempt has been made to establish the fact that the jurisdiction which each state possesses over its marginal waters (leaving out of view the exact width of the zone) is a creation of international and not municipal law. It is a right flowing from a general rule to which all nations are supposed to have given either an express or implied assent. ${ }^{3}$ As to the right itself there can be neither cavil nor question, (1) because each state must possess it for the protection of the lives and property of its citizens on land against the violent acts of other's whose states could not be held responsible without the recognition of the right of pursuit and capture; ( $(2)$ because it is necessary to each state as an indespensable means for the effective execution of its revenue laws; (3) because without it no state can retain and protect the natural products of the sea for the exclusive benefit of its own citizens. And yet cogent as such reasons are the right was not defined in Roman law; and Grotius himself

the island of Cuba took place at Madrid in March, 1895, between the Duke of Tetuan, one of the noblest and wisest of Spanish statesmen, and the author, then United States minister to Spain, in the matter of the U. S. mail steamer, Alliança, fired on by a Spanish gunboat off Cape Maysi, six miles from the Cuban coast. See Foreign Relations of the U. S., 1895 , pt. II, pp. 1177-1185. As to the nature and extent of Spain's claim, see Wharton, Int. Law Dig., § 327.

1 See above, p. 44.

2 Hall, p. 155. That statement must stand upon its own merits.

${ }^{3}$ See above, p. $8 \&$ seq. 
recognized it only in a vague and general way in the statement, relating evidently to gulfs and bays, in which he admits that a state possessing the land on either side should possess a portion of the sea, provided it is not such a portion "as is too large to alpear part of the land." Vattel," in discussing the same subject, only rentured to say that "the dominion of the state orer the neighboring sca extends as far as her safety renders it necessary and her power is able to assert it; since, on the one hand, she cannot appropriate to herself a thing that is common to all mankind, such as the sea, except so far als she has need of it for some lawful end, and, on the other, it would be a vain and ridiculous pretension to claim a right which she was wholly unable to assert." In order to reduce such general statements to a definite and usable basis the pratical Binkershoek ${ }^{6}$ defined the marginal water necessary for the safety of a state to be such a space as could be covered by a cannon shot from the coast, that being considered in his day as substantially equivalent to the zone within a marine league of low-water mark.

Necessity for widening the zone.-With the substitution of the long-range guns now in use the conviction is growing that the old rule, so far as the width of the zone is concerned, should cease with its reason. In 1894 the Institut de Droit International indulged in an exhanstive discussion of the question, and there was no divisien of opinion as to the necessity of griving a greater breadth to the zone,-a decided majority favoring a zone six marine miles from low-water mark as territorial for all purposes, with the right in a nentral state to extend it in time of war for all the purposes of neutrality, after due notice, to a distance from shore equal to the longest range of modern guns. It is idle, howerer, to talk of the substitution of a new rule without some kind of international con(erit. ${ }^{\mathrm{T}}$

$\$ 248$. State legislation extending limit for health and revenue purposes. Its validity.-The conviction that the three-mile limit is too narrow for health and revenue purposes prompted Great Britain to enact 26 Geo. II, providing that all vessels

+De Jure Belli ac Pacis, ii, c. 3, vis." De Domin. Mar. c. 2. See $\S 8$. also Ortolan, Diplom. de la Mer, i,

"Droit des Gens, I, c. xxxiii, § c. 8 ; Phillimore, i, c. 8 ; Twiss 1. 289.

$\S 172$; Heffter, $\S 75$; Martens, Pri-

"His maxim was, "Terræ potestas finitur ubi finitur armorum cis. § 158 .

i See above, p. 138. 
liable to quarantine-shall be required to make signals to other ships within four leagues under a penalty; and 9 Geo. II, c. 35, and 24 Geo. III, c. 47 (Horering Acts), assuming for certain revenue purposes a jurisdiction of four leagues from the coasts. The Congress of the United States by acts passed in 1797,1799 and 1807 has authorized in the same way the seizure of ressels laden with certain cargoes within four leagues of the American coasts; $;$ and many other maritime nations have made like enactments. Are such statutes, so far as they exceed the generally recognized limit, valid under the laws of nations? Wheaton contended that they were; but his annotator, Dana, after a careful review of the authorities cited to support that statement, concludes that "it may be said that the principle is settled, that municipal seizures cannot be made, for any purpose, beyond the territorial waters. It is also settled, that the limit of these waters is, in the absence of treaty, the marine league or the cannon-shot. It cannot now be successfully maintained, either that municipal visits and search may be made beyond the territorial waters for special purposes, or that there are different bounds of that territory for different objects." Dana's assumption that the text of his principal is not sustained by the decisions of the Supreme Court of the United States is clearly untenable. Leaving out of riew Church v. Hubbard ${ }^{10}$ as inconclusive, and admitting that Rose $\mathrm{r}$. Himel $\mathrm{y}^{11}$ is in conflict with the text, there is no good reason to doubt that that case was overruled by Hudson v. Guestier,12 in which it was held that "a seizure, beyond the limits of the territorial jurisdiction, for breach of a municipal regulation, is warranted by the law of nations." It does not follow, howerer, that the conclusion reached by Dana is untenable. No matter what the riew taken by the highest court of any one nation may be, the fact remains that a rule to bind all must have the assent of all or nearly all. If the powers to which they belong object, upon what ground can any state, in matters of trade and health, "venture to enforce any portion of her civil law against foreign vessels which have not as yet come within the limits of her maritime jurisdiction? A state exercises in matters of trade for the protection of her marine

\section{s Cf. Wharton, Int. Law Dig., $\$ 32$.}

9 Note No. 108 entitled "Munici. pal seizures beyond the marine league or cannon-shot."
102 Cranch, 187.

114 Cranch, 241.

126 Cranch, pp. 282-285. The quotation in the text is the language of the head note. 
revenue, and in matters of health for the protection of the lives of her people, a permissive jurisdiction, the extent of which does not appear to be limited within any certain marked boundaries, further than that it camot be excrcised within the jurisdictional waters of any other state, and that it can only be exereised over her own ressels and over such foreign res. sels as are bound to her ports." 13

$\S 249$. Right to fish within marine league. Conflicts between Great Britain and U. S.-While the people of all nations have an equal right to fish in the high seas and on banks and shoal places in them, the state that owns the shore has the exclusive right of fishing within the three-mile marine belt following the simusities and indentations of the coast. The application of that rule to the littoral conformation of North America has from the ontset given rise to conflicts between the governments of Great Britain and the Lnited states which have been composed from time to time by special conventions. The conchusion of the treaty of $178 \%$, in which the independence of the latter was recognized, was delayed by discussions resulting at last in concessions to its citizens of the right to continue the enjoyment of fishing privileges on the banks of Newfoundland without that of drying and curing on that island. ${ }^{14}$ To that was added the liberty to fish enjoyed by British seamen along the coasts of Newfoundland, in the Gulf of St. Lawrence, and on the coasts, bays and creeks of all other British dominions in America, with the privilege of curing and drying fish in any of the unsettled harbors, bays, and creeks of Nora Scotia, the Magdalen Islands, and Labrador so long as they should remain in that condition. After the war of 1812 it became a grave question whether such privileges, as to which the treaty of Ghent was silent, had been merely suspended by that event or entirely abrogated. The United States rested the first contention upon the theory that the articles in question were only regulations of fishing privileges enjoged in common by all the subjects of the British possessions prior to the separation which, it was claimed, did not take from the inhabitants of the territory of the new state their loeal rights of property within the territory remaining to the old. Great Britain ${ }^{15}$ rested the

13 Twiss, $1, \S 181$, citing The Apollo, 9 Wheaton, 371; Kent's Comm. tit. $1, \S 31$.

14 Treaties of the U. S., p. 377 . See above, p. 111.
15 "In other words, it was denied that the separation of a new state from an old one involves the loss, on the part of the inhabitants of the territory of the new state, of 
second on the assumption that "the claim of an independent state to occupy and use at its discretion any part of the territory of another without compensation or corresponding indulgence, cannot rest on any other foundation than conventional stipulation."16

$\S 250$. Settlements of $1818,1854,1871$, and 1885 .- In the settlement of the matter made for a time in the treaty of $181 \mathrm{~s}^{17}$ perpetual fishing rights were guaranteed to the United States on the basis of contract, ${ }^{18}$ this government renouncing forever the right "to take, dry or cure fish on, or within three marine miles of any of the coasts, bays, creeks or harbors of his Britannic Majesty's dominions" in America not included within the limits specified. When a controversy subsequently arose as to the meaning of the terms in italics it was held by the Mixed Commission under the convention of 1853 that the Bay of Fundy, over sixty miles wide and about a hundred and forty long, with one of its headlands in the United States, was not an exclusively British bay within the meaning of the treaty. Consequently the "coast" of Great Britain could not be measured from its headlands. ${ }^{19}$ By the Reciproeity Treaty ${ }^{20}$ of 1854 the whole subject of the northeastern fisheries was readjusted upon the basis of the right of the United states to take all kinds of fish, except shell-fish, "on the sea-coast and shores, and in the bays, harbors, and creeks of Canada, Nora Scotia, Prince Edward's Island, and of the several islands thereto adjacent, without being restricted to any distance from the shore, with permission to land upon the coasts and shores of those colonies and the islands thereof, and also upon the Magdalen Islands, for the purpose of drying their nets and curing their fish;" in exchange for a concession

local rights of property within the territory remaining to the old state." Hall, p. 100.

16 British and Foreign Papers, vii, 79-97.

17 Such was the admission of $\mathrm{Mr}$. Dana, as agent for the U. S., before the Halifax Fishery Commission in 1878. Parl. Papers, North America, No. 1, 1878, p. 183 . If $\mathrm{Mr}$. Dana did not in fact make such an admission, as Hall (p. 100, note 2) claims he did, he should have made it.
18 Treaties of the U. S., pp. 415 , 416.

19 The case arose out of the forfeiture in a British port of the American fishing schooner Washington, seized while fishing in the Bay of Fundy, ten miles from the shore. Compensation was awarded the owners 1or an illegal condemnation. The Schooner Washington: Report of the commissioners under the convention of 1853 , pp. 170-186. 20 Treaties of the U. S., p. 448453. 
of reciprocal rights to British fishermen on the eastern coasts of the Cnited states from the 36 th degree northwards. After that treaty, terminable in ten rears, hat been brought to an end in $1866^{21}$ by the action of the United States, a new reciprocity agreement was embodied in the treaty of Washington,22 $18 \pi 1$, conceding to the parties free trade in fish and free fishing with a stipulation that a cash balance should be struck between the values of the privileges thus granted;-a balance fixed in $1877 \mathrm{by}$ the Halifax Commission at five and a half millions of dollar's in faror of Great Britain. When the last reciprocity arrangement expired in $1885^{23}$ a return was made to the basis of 1818 , inadequate in itself to prevent constant frietion between American fishermen and the Canadian authorities.2- In dealing with questions growing out of the local laws of the maritine provinces, and the action of the provincial authorities deemed to be in derogation of the rights secured by treaties to its fishermen, the United States holds that Great Britain and not the provinces is the sovereign to be dealt with, and that British rights under such treaties may be restricted but not expanded by provincial legislation. ${ }^{25}$

$\S 251$. State boundaries - a summary of general rules-burden of proof.-In defining the elements of land and water that go to make up the territorial domain of a state it has been necessary to anticipate nealy all of the difficult questions involved in state boundaries, which consist either of such natural features as momtains, rivers, and lakes, or of arbitrary lines connecting natural or artificial points. Where there is real doubt ol ignorance as to a frontier, and no express agreement concerning it, certain general rules have been accepted which may be summatrized as follows: Where two states are separated by ranges of mountains or hills the water-divide marks

21 The two powers were thus thrown back for a time upon the treaty of 1818 .

22 Treaties of the U. S., p. 478.

23 In consequence of a notice given by the President of the U. S. in 1883 .

24 In the hope of terminating all differences plenipotentiaries of the two powers met in Washington, in 1S57, and agreed upon a new fishery treaty, which the Senate of the U. S. failed to confirm. For the de- tails agreed upon, see British State Papers, U. S. No. 1 (1888).

25 "This government conceives that the fishery rights of the United States, conceded by the treaty of Washington, are to be exercised wholly free from the restraints and regulations of the statutes of Newfoundland." Mr. Evarts, Sec. of State, to Mr. Welsh, Feb. 17, 1879. MSS. Inst., Gr. Britain. Cf. Wharton, Int. Law Dig., $\S \S 299-308$. 
the boundary line or frontier. When the separation is made by a river, not the exclusive property of either of the riparian states, the boundary is the middle of the stream, if it is nonnarigable; if it is so, the thalweg, or center of the deepest channel. When the separation is made by a lake, a line rum through the middle of it constitutes the boundary, in the absence of another established by usage or treaty. Such normal and reasonable rules of equality must yield, however, when one state is able to establish its right to an entire lake or stream by prior occupation before the opposite bank is appropriated, or by a treaty made for the purpose of establishing a political frontier. When the whole of the bordering waters is thus acquired the title seems to carry with it not only the opposite banks of the river or lake, but also perhaps a sufficient margin besides for defensive or rerenue purposes. The state that asserts such extensive claims, either by occupation or treaty, must so clearly prove them as to overcome the just and natural presumption in faror of equal rights. That presumption will prerail where opposite shores have been occupied at the same time by riparian states, or where neither can clearly prove the priority of its occupancy. ${ }^{26}$ In the United States all conflicts as to boundaries with foreign states pertain to the political departments of the government, whose solutions of them will be accepted as final by the judiciary. ${ }^{27}$

$\S 252$. Servitudes. Positive or negative; contractual or customary.-At the beginning of this chapter the averment was made that a state mas limit or qualify its sovereignty and jurisdiction over its territorial property by permitting a foreign state to perform within its bounds certain acts otherwise prohibited; or by surrendering the right to exercise certain parts of such sovereignty and jurisdiction as a protection to others.28 Restrictions thus imposed are known as servitudes, a term borrowed from Roman law, which, in respect to their nature, are either positive or negative;29 and in respect to their origin, are contractual or customary. The last named, resting on immemorial prescription, are embodied in the right

26 See above, pp. 288-9, and au. thorities there cited.

27 Foster v. Neilson, 2 Peters, 253; Garcia v. Lee, 12 id., 511; Williams v. Suffolk Ins. Co., 13 id., 415; U. S. v. Reynes, 9 Howard, 127; in re Cooper, 143, U. S., 472.
28 See above, p. 263.

29 "Servitudes may be classified in various ways. They may be 'positive,' consisting 'in patiendo,' or 'negative,' consisting 'in non faciendo ;' 'apparent' or non-apparent.' " Holland, Elements of Juris- 
of innocent passage over territorial waters so situated as to render their free navigation conrenient or necessary to the use of the open seas; in customary rights over waters, pastures and forests which seem to exist in some places for the benefit of persons living near a frontier; and in the right of military passage through a foreign state to ontlying territory, if any such right has survired the rearrangement and simplification of the map of Central Europe. ${ }^{30}$ While all of the customary servitudes are from their nature positive, other servitudes of that class may be created by treaty, such for example as the right of a state to occupy with its troops a part of the territory of another state under certain circumstances; the right to exercise police power or to collect taxes within certain parts of foreign territory; the right to there establish and maintain custom-liouses, and to take the necessary steps for the discovery of smuggling and the like; and the right to organize and maintain postal services. Negative servitudes are from their nature invariably the results not of customary law but of contract. As they embody positive agreements not to exercise certain attributes of sovereignty, their existence must be proved by treaty or equivalent agreement. Such are the obligations of a state to abstain from all exercise of jurisdiction over those under the protection of another state; to maintain no more than a certain number of soldiers, or to construct no war vessels, except of a certain pattern, or to keep up only a certain number of fortified places; to embody certain exceptions in its laws concerning religious worship for the benefit of the citizens of foreign states; to exempt certain classes of foreigners and foreign corporations from taxation; and to refrain from the establishment of custom-houses along the frontier of a foreign state. ${ }^{31}$ Familiar illustrations of such servitudes may be found in that part of the l'eace of Utrecht, 1713-15, wherein France bound herself to England not to permit the Stuart pretenders to reside in French territory; in that part of the same Peace in which the possession of Gibraltar was confirmed to England on eondition that she would not permit either Moors or Jews to reside there; and in that part of

prudence, pp. 195-96, citing Dig. viii, I, 1; Von Vangerow, Pandekten, iii, § 338 .

30 Hall (p. $166 \mathrm{n}$ ) says: "It is somewhat more than doubtful whether any instances of a right of military passage have survived the simplification of the map of Central Europe." See also § 21 .

31 For a clear statement of negative and positive servitudes, see Bluntschli, $\S \S 356,357$. 
the treaty of Paris, 1814, providing that Antwerp should always be maintained as an exclusively commercial port. ${ }^{32}$ Such international servitudes may of course be brought to an end at any time by treaty to that effect between the doninant and servient state. They may also perish when the former waives its right to exercise the privilege within a reasonable time, or when the liability of the latter is no longer compatible with the development of international law or with the development of its internal constitution and the maintenance of public order. ${ }^{33}$

$\S 253$. Non-territorial property. Public vessels. Fiction of exterritoriality.-The non-territorial property of a state may consist (1) of its public vessels; $(2)$ of private vessels covered by the national flag; and (3) of goods owned by its citizens but embarked in the ships of other states. Such property may be held by a state in its corporate capacity beyond its own limits, within or without the jurisdiction of other states. Whether upon the high seas or in a foreign port the jurisdiction of a state over one of its public ressels is so complete that, in order to give intensity to the idea, the legal fiction has been invented that such vessel is simply a detached and floating portion of the state to which it belongs. ${ }^{34}$ Like all other similes this one may in some particulars fail to present an exact parallel, and yet it is undoubtedly more forcible than the alternate phrase that a public ressel by virtue of its character is clothed with an immunity which exempts it to a certiin extent from all foreign control. Nomatter in what form the idea of exterritoriality may be expressed, the privileges with which it surrounds a public ressel are so important and so serious that such a definition should be given as will clearly distinguish such as are entitled to stand in that category.

\$254. Term "public vessel" defined.-The general statement may be made that the term public vessel embraces not only such as are armed for war, but such unarmed craft as despatch

32 See above, pp. 106, 114 seq.

33 Bluntschli, § 359; Holland, Elements of Jurisprudence, pp. 197, 200.

34 "Such vessels have been regarded by many writers, especially by French writers, as being invested with the character of what they have called 'ex territoriality.'
It has been said that a ship of war is a floating part of the nation to which it belongs, and that when in the harbor of a foreign state the law of that state does not extend to it." Sir J. F. Stephen, Hist. of the Crim. Law, vol. ii, p. 43 . This doctrine that a ship is "a floating part of the nation," a "con- 
boats, store ships, transports, and the like, employed temporarily for public purposes only, commanded by an officer holding sucha commission as his state requires for ressels of that class, and satisfying such other conditions as may be required by law. When a doubt arises as to the character of a publie ressel, generally evidenced by the than and pennant she carries, or by the firing of a gun, it is usual, as a matter of conltesy, to accept the word of honor of her commander as to the fact that she is public. The commission under which the commander acts must be aceepted as conclusive, 36a subject to the condition expressed below ${ }^{36}$ and the declaration of the sovereign himself was held to be alssolutely so by the Euglish Court of Appeal in the case of a Bolgian mail packet,-commanded by officers of the royal nary of that country, but carrying mereluandise and passengers,-when, in a suit for damages, the ling of the Belgians stated that the ressel was in his possession as sovereign, and was a public vessel of the state. ${ }^{37}$

$\$ 255$. Immunities of public vessels.-The Supreme Court of Massachusetts has held that a vessel, owned and employed by the govermment of the United States, as an instrument for the performance of its public duties, cannot be proceeded against by a citizen, even for the enforcement of a lien that attached before she assumed that character. ${ }^{38}$ Upon the high seas the jurisdiction of a state over its public commissioned ressels is absolute,-their entire immunity from the right of search in

tinuation or prolongation" of territory is no older, Hall avers $(\$ 76)$, than the "Exposition des Motifs," put forth by the Prussian government in 1752 in justification of its conduct in confiscating the funds payable to its English creditors in respect of the Silesian Loan. Cf. Martens, Causes Cél., ii, 117.

35 Ortolan, Dip. de la Mer, i, 18186; Calvo, $\$ \$ 876-84$.

30 "It is true that when there is probable ground to believe that the flag is assumed for piratical purposes, this will excuse the arrest and search of the vessel. But unless there be such probable cause the vessel must be assumed by foreign cruisers to be entitled to the flag she flies." Wharton, Int.
Law Dig., \& 408. There is, however, a presumption in favor of the innocence of a public vessel doing acts prima facie piratical, so long as it appears to act under the authority of the state to which it once belonged. Cf. Hall, pp. 27576.

36a The Santissima Trinidad, 7 Wheaton, 283.

37 The Parlement Belge, L. R. 5, P.D. 197. The court refused to consider whether or no her public character was affected by the fact that she was partly employed in the carrying of passengers and merchandise.

3s Briggs v. The Light-Ships, 11 Allen, p. 157. 
any form or for any purpose being generally conceded. ${ }^{39}$ Not until such ressels pass into the territorial water's of a forcign state is there any abridgment whatever of that sweeping privilege. Unlike private ressels they have no absolute right to enter without notiee or permission into the ports of friendly powers. "If, for reasons of state, the ports of a nation geelerally, or any particular ports be closed against vessels of war generally, or the vessels of any partieular nation, notice is usually given of such determination. If there be no prohilsition, the ports of a friendly nation are considered as open to the public ships of all powers with whom it is at peace." 10

$\$ 256$. Their slow growth. Expositions of the earlier doctrine. -A great revolution in opinion has taken place since the beginning of the present century as to the extent to which the local sovereigu waives jurisdiction over a public vessel admitted to his ports by his express or implied assent. So lightly was the immunity of such a vessel regarded in the seventeenth century that Bynkershoek ${ }^{41}$ in his attempt to demonstrate that the property of a foreign sovereign is not distinguishable, by any legal exemption, from that of a private individual, refers to the case of Spanish ships of war seized in Flushing in 1668 by a private individual for a debt due from the king of Spain; and as late as 1794 Attorney-General Bradford,-in a case in which six American citizens were taken out of a British sloop of war by the local authorities while she was lying in the harbor of Newport, Rhode Island,- - gave it as his opinion that "the laws of nations invest the commander of a foreign ship of war with no exemption from the jurisdiction of the country into which he comes." ${ }_{22}$ Fire years later a like declaration was made by Attorney-General Lee, who held, in the case of the British packet Chesterfield, that, "it is lawful to serve civil or criminal process upon a person on board a Brit-

39 The only possible exception is in the case of piracy explained already.

40 Marshall, C. J., in The Schooner Exchange v. McFaddon et al., 7 Cranch, 141.

41 De Foro Legat., c iv. "In that case the States-General interposed; and there is reason to believe, from the manner in which the transaction is stated, that either by the interference of government, or by the decision of the tribunal, the vessels were released." Wheaton, Elements, $\S 101$.

421 Opinions of Attys. Genl. U. S., p. 47. It was held "that a writ of habeas corpus might be legally awarded in such a case, although the respect due to the foreign so:ereign may require that a clear case be made out before the writ may be directed to issue." 
ish ship of war lying in the harbor of New York." 43 Such views, in full faror on the other side of the Atlantic, received still more emplatic expression in 1820 from Lord Stowell himself when he was asked by his govermment for an opinion in the case of Brown, a British subject who, after escaping from a Spanish prison, took refuge on a British ship of war lying in the harbor of Callao. After saying that the British captain had no right to protect Brown, he added: "I am led to think that the Spaniards would not have been chargeable with ille. aral violence, if they had, thought proper to employ force in taking this person out of the vessel." 4

\section{$\$ 257$. New doctrine as defined by Marshall, Cushing and Orto-} lan.-The opposing tide of opinion which finally overthrew such dangerous and untenable doctrine found emphatic and anthoritative expression in 1812 in the case of the Exchange, a ressel belonging originally to an American citizen which. after having been scized and confiscated at San Sebastian, in Spain, was converted into a public armed ressel by Napoleon in 1810. When her original owner attempted to reclaim her after her peaceful entry into the port of Philadelphia as a public ressel of the Emperor of the French, the Supreme Court of the United States, speaking through Chief Justice Marshall, held that a warship of a foreign sovereign at peace with the United States coming into our ports, and demeaning herself in a friendly manner, is exempt from the jurisdiction of the country. It was beld that "the implied license, therefore, under which such ressel enters a friendly port, may reasonalily be construed, and it seems to the court ought to be construed, as containing an excmption from the jurisdiction of the sovereign within whose territory she claims the rights of hospitality." 45 That sound doctrines repeated by Attorney-general Cushing, ${ }^{46}$ in the case of the sitka,-a Rus-

431 Opinions of Attys. Genl. U. S., p. 87. Sce as to these cases Report of the Royal Commission on Fugitive Slaves, 1876 , pp. lxxiii, Ixxy. Also Phillimore, i, § cecxlvi.

44 Report of Royal Commission on Fugitive Slaves, p. lxxvi. See Halleck, 1, 188, Baker ed. Law. rence, p. 224.

45 The Schooner Exchange v. McFaddon et al., 7 Cranch. 144.

467 Opinions of Attys. Genl. U. S., p. 122. Mr. Cushing declared that the courts of the U. S. have "adopted unequivocally the doctrine that a public ship of war of a foreign sovereign, at peace with the United States, coming into our ports and demeaning herself in a friendly manner, is exempt from the jurisdiction of the country. She remains a part of the territory of her sovereign." 
sian vessel captured by a British cruiser during the Crimean war and brought into the harbor of San Francisco with a prize erew on board,-and specially emphasized by Ortolan ${ }^{47}$ and by the publicists of Europe and America generally, was re-defined by the arbitral tribunal at Geneva in the following form: "The privilege of exterritoriality, accorded to vessels of war, has been admitted into the law of nations; not as an absolute right, but solely as a proceeding founded on the principles of courtesy and mutual deference between different nations." 48

\section{$\S 258$. Certain duties and exemptions of public vessels defined.} -It would be folly to contend that the immunity from local jurisdiction thus granted a public vessel in a foreign port is absolute. It is universally admitted that such a vessel must observe all reasonable health regulations, local revenue laws, and the administrative rules of the port as to lights, anchorage and harbor police. ${ }^{49}$ If she is a belligerent, the local authorities, in enforcing the observance of neutrality laws, may even detain and try any prizes brought in where there is good reason to believe that the captures were made in riolation of the neutrality of the state they represent.50 The primary object of the immunity is to exempt as far as possible the discipline and internal government of the ship, her officers and crew from interference from local law. "The essence of the privilege of ships of war in foreign territorial waters is, that the commanding officer is permitted to exercise freely, and without interference on board his ship, the authority which, by the law of his own country, he has orer the ship's company." 51 In order to secure that result public vessels in foreign waters are exempt from all forms of process in private suits $;^{52}$ and from all judicial proceedings or seizures in the name of a foreign state for the punishment of violations of public law. If such state feels aggrieved it must apply for

47 Dip. de la Mer, II, c. x. See also Foelix, II, tit. ix, c. i, $\S 544$; Hautefeuille, tit. vi, c. i, $\S 1$; Heffter, $\S 79$; Bluntschli, $\S 321$; Negrin, tit. i, c. iv; Riquelme, i, 228.

48 For a review of the practice of the U. S., see Wharton, Int. Law Dig. $\S 36$.

49 Hall, § 55; Lawrence, Principles of Int. Law, $\S 129$.

50 The Santissima Trinidad, 7 Wheaton, 285.
51 Sir J. F. Stephen, Hist. of the Crim. Law, vol. ii, p. 49.

52 In January, 1879, the U. S. frigate Constitution, when returning from France laden with machinery taken to the Paris Exposition, at the expense of this government, went aground on the English coast near Swanage where it became necessary to secure the assistance of a tug, as to the value of whose services a dispute arose 
redress directly to the sovereign to whom such vessel belongs.

$\$ 259$. Must not harbor criminals and fugitive slaves. $-A$ public ressel clothed with immunity in a foreign port must not commit any acts of aggression against the peace and security of the state whose hospitality is asked by bringing in conspirators intent upon civil war, or by harboring criminals or persons charged with non-political crimes. Custom seems, however, to have established the right of such a vessel to grant simple hospitality to a political refugee if he appeal's at the side of the ship without invitation and seeks protection. Asylum conceded under such circumstances gives to the territorial power neither the right to demand the surrender of such refugee nor to expel the ship on account of his retention aboard of her. It is, howerer, undoubtedly the duty of the commander of a public ship to surrender to the local anthorities all persons clarged with ordinary crimes. In 1876 a serious discussion arose whether or no an exception should be made to that rule when a slave contrives to get on board a British ship of war in a foreign harbor, belonging to a country where slavery is recognized by law. A very able commission ${ }^{53}$ was appointed to examine the question, and six of its members concluded that in such a case international law required that the fugitive slave should be surrendered, but that "a rigid adherence to that theory by the commanding officers of British ships in foreign territorial waters in all cases whatever would be neither practical nor desirable." Sir James F. Stephen was honest enough, however, to admit in his separate opinion that whenever such an exception to the general rule shall be made, "it should be done openly and arowedly as an act of power, as an invasion on moral grounds of the sovereignty of independent nations." $5+$

between the owners of the tug and the representatives of the ship. When application was made for the issuance of a warrant for the arrest of the ship and her cargo, objection was made not only on behalf of the American government, but on behalf of the crown, and the writ was refused on the ground that the vessel, "being a war frigate of the United States navy, and having on board a cargo for national purposes, was not amenable to the civil jurisdiction of this country." L. R. 4, P. D., 156.

53 Composed of the duke of Somerset, Lord Chief Justice Cockburn, Sir Robert Phillimore, Sir James F. Stephen, Mr. Montague Bernard, Mr. Justice Archibald, Mr. (afterwards Lord Justice) Thesiger, Sir Henry Holland, Admiral Sir Leo. pold Heath, Sir Henry Maine, Sir George Campbell, and Mr. Rothery.

$54 \operatorname{Sir}$ J. F. Stephen, Hist. of the Crim. Law, vol. ii, p. 55. 
$\S 260$. When a diplomatic appeal must be made.-When the commander of a public vessel wrongfully refuses to surrender either a political refugee or an ordinary criminal to the authorities of the territorial state, it can look for redress only through a direct diplomatic appeal to the sovereign to whom the vessel belongs. No invasion of the ship can be made for any purpose. To that general rule no exception can be recognized except, perhaps, in an extreme case requiring the prompt expulsion of the vessel; such, for instance, as would arise if she should be made a focus of intrigue, or an instrument of conspiracy against the territorial power through the harboring by her captain of political refugees in communication with the shore.

$\S 261$. Immunities attach to public vessels as complete organisms.-Immunities attaching to public vessels belong to them only as complete organisms, composite wholes made up of ship and crew combined. Therefore, when such a vessel is found at sea without a crew the abandoned hulk is mere property and nothing more. And in the same way when the crew go ashore the privilege of exterritoriality no longer protects them. Officers and crew, including the captain, when he is not acting in his official capacity as the agent of his state, are then subject to the local law; and when crimes are committed on shore the local tribunals may assume jurisdiction of them or they may be made the subject of diplomatic complaint to the government of the state to which the ship belongs.

$\$ 262$. State's jurisdiction over merchant vessels on high seas.The jurisdiction of a state over all of its vessels, public and private, when on the high seas outside the territorial waters of any other state is complete. ${ }^{55}$ As applied to merchant vessels it extends to all persons and things aboard, including foreigners, whether passengers or seamen. On its criminal and administrative side such jurisdiction embraces all acts that may be classed under either head whether committed by eitizens or foreigners; and the same may be punished in state tribunals, if in violation of the system of discipline established by state law. On its civil side it embraces all matters of that character affecting subjects on board; or foreigners, not par-

55 "The ocean is the sphere of the law of nations, and any merchant vessel on the seas is, by that law, under the protection of the laws of her own nation, and may claim immunity unless in cases in which the law allows her to be entered or visited. ${ }^{\star}$ Mr. Webster, 
tially exempted by the municipal law of the state while in transit, to the extent and for the purposes for which they are subject to such civil jurisdiction when on land. On its protective side it involves the guarding of all merchant craft from any kind of interference from other powers, except when the ressel of the protecting state has given such powers the right to deal with it, either by reason of some act of hostility against one or more of them, or against all mankind; or by the commission in time of war of some act that belligerents have the right to punish; or by an escape to the high seas after an infraction by such vessel, or by some one on board, of the laws of a foreign state while within its territorial waters. By reason of such control over its merchant vessels a state is subjected to a corresponding responsibility which renders it liable for all hostile acts committed by them on the high seas arainst other states; and requires it to open its courts for redress to foreigners who have suffered by reason of wrongful acts committed by such ressels or by those on board of them.

$\S 263$. Fiction of exterritoriality scarcely exists as to merchant vessels.-If a state owning merchant ressels possessed the exclusive jurisdiction to administer redress in every case in which foreign states or their subjects could ask it, the fiction of exterritoriality as applied to them would be complete. It can hardly be said to exist, ${ }^{56}$ however, (1) because all states claim the right to enforce their jurisdiction to a certain extent over the merchant vessels of all other states even upon the high seas; $(2)$ because every state into whose territorial waters a foreign ship comes claims the right to subject it almost absolutely to the loeal jurisdiction, both civil and criminal. Only after the immunity to which a merchant vessel is entitled, upon the theory that it is merely an extension of the territory of the state to which it belongs, has been reduced by the subtraction of those comuter claims to jurisdiction asserted by all other states, is it possible to understand how little privilege really remains.

$\$ 264$. How the nationality of a merchant vessel may be established.-Before attempting to define the extent to which a merchint ressel may be subjected on the high seas to the jurisdiction of a foreign state, it will be necessary to explain Sec. of State, to Lord Ashburton, Aug. 8, 1842. MSS. Notes, Great Britain; 6 Webster's Works, 317. 56 The extreme view expressed Mer.

upon this subject by M. Hautefeuille has been ably opposed by $\mathrm{M}$. Ortolan in his Diplomatie de la 
what constitutes such a vessel, and the means by which her nationality may be established. As the property of a private owner the apparent sign of her nationality is her flag, the right to fly which depends upon the law of the state to which she elaims to belong; and that law may confer the right by reason of the place of construction, ownership, the nationality of the eaptain, or the composition of the crew. A vessel owned by a citizen of the United States may carry its flag and enjoy the protection of its government on the high seas, although from the fact that she is foreign built or for some other cause she cannot become a registered vessel of this country. Protection thus given to non-registered vessels is analogous to that given to persons of foreign birth not naturalized but domiciled in the United States. ${ }^{57}$

$\S 265$. When a merchant vessel must show her papers-Case of Virginius.-When the nationality of a private vessel is challenged her commander, who is not the agent of the state to which she belongs, cannot offer his word of honor in proof of the fact. He must strengthen the prima facic presumption raised by the flag he carries by showing his papers, which should prove his right to carry it under the law of the state represented by such flag. When a state has the right to inquire, in war or peace, into the national character of a merchant ressel claiming to belong to another state, it cannot be concluded by the Hags or papers used. It can pass behind both to the actual facts upon which national character depends. If the inquiring state finds it to its advantage to accept the fact as established by such flags and papers it may do so, and use it, in war or peace, as an estoppel against the parties in interest. On the other hand, if it elects to press the inquiry, and finds that such papers have been fraudulently issued in order to give a spurious national character to the ressel possessing them, it may, as between itself and the owner, ascertain the real nationality and act accordingly. ${ }^{5 s}$ In that event, if the state issuing the papers sees fit to intervene, the question of their validity becomes a political one between the two powers thus involved. In the matter of the Virginius the government of the United States took the position that ship's papers, certifying under its authority that the ressel holding them is entitled to its protection, cannot be tested as to alleged fraudulency by foreign powers. This gov-

57 Wharton, Int. Law Dig., § 410. 58 Dana's Wheaton, Note 163. 
ernment thus assumed to be the sole judge of the validity of such papers, so far as proceedings on the high seas are concerned; and at the same time recognized its duty to punish all parties forging or wrongfully using them, and to see that they should not be employed as the basis of claims against foreign states. ${ }^{59}$

$\$ 266$. Right of visitation in time of peace.-No state can effectively inquire into the nationality of a merchant vessel "arrying the flag of another on the high seas without exercising at least the right of visitation, in the absence of which neither the sufficiency or regularity of her papers, nor the leagality of the undertaking in which she is engaged ean be ascertained. To justify the exercise of that right the inquiling state must employ it to enforce some kind of jurisdiction lawfully belonging to it. For instance, as the erime of piracy is an offense against all uations, every state has jurisdiction to punish it. And yet even in that ease the right to search on suspicion of piracy is like a right to arrest a suspected felon, and carries with it a liability for damages if the charge is not substantiated, provided there was no probable ground to believe that the flag was assumed for piratical purposes. "The right of visitation is by the law of nature an intercourse of mutual benefit, like that of strangers meeting in the wilderness. The right of search is for pirates in peace and for enemies in war." 60

$\$ 267$. Certain exceptions in favor of the right.-Apart from the case of piracy the right to visit merchant vessels in time of peace is confined to the execution of revenue laws, when asserted within the territorial waters of the offended state; and to a proper case of self-defense. ${ }^{61}$ In the exercise of the latter, it is claimed that a state may visit and capture a vessel on the high seas, or in its own waters, when it has a reasonable ground to believe that it is engaged in a hostile expedition against it. In the same way a state, in whose territorial waters a private vessel, or some one on board of her, has committed an offense against its laws, may pursue her into

59 For a complete statement, see Wharton, Int. Law Dig., $\S \S 315$, 337.

6011 J. Q. Adams' Mem., 142.

61 Subject to these exceptions the right of visit in time of peace may be said to have ended when in 1858 Great Britain abandoned it even when there was a necessity to discover the real nationality of vessels suspected of being engaged in the slave trade. See above, p. 239. 
the open sea and there arrest her, provided the pursuit was begun while the vessel was still in such waters, or just after her escape from them. ${ }^{2}$ The right of visit and search is, however, primarily a war right, and by the common law of nations belongs to belligerents only. ${ }^{63}$ Therefore not until that branch of the subject is reached will it be made the subject of special consideration.

$\S 268$. Immunity of private vessels in territorial waters-Views of Webster and Marshall.-When a private merchant vessel passes into the territorial waters of a foreign state immunity from local jurisdiction, as an incident of the doctrine of exterritoriality, is reduced to a minimum by reason of the fact that the jurisdiction of the state to which the vessel belongs is forced to yield in a greater or less degree to that of the local sovereign. And yet as experience has demonstrated long ago that it is beneficial to commerce for the former to regulate everywhere the internal discipline of the ship, and the rights and duties of the officers and crew towards the vessel or among themselves, the tendency is for the latter to abstain as far as possible from interfering with such internal concerns. ${ }^{64}$ It is clear that the ship's company is not a mere collection of isolated strangers, but an organized body of men governed internally by the laws of the country to which the ship belongs. As Mr. Webster said in the case of the Creole, "the rule of law and the comity and practice of nations allow a merchant vessel coming into any open port of another country voluntarily, for the purpose of lawful trade, to bring with her and keep over her to a very considerable extent the jurisdiction and authority of the laws of her own country. A ship, say the publicists, though at anchor in a foreign harbor, possesses its jurisdiction and its laws. *** It is true that the jurisdiction of a nation over a vessel belonging to it, while lying in the port of another, is not necessarily wholly exclusive. We

62 Bluntschli, § 342; Woolsey, § 58; Hall, $\S 77,80$.

63 As Judge Story expressed it in the case of The Marianna Flora (11 Wheaton, p. 42), "this right is strictly a belligerent right, allowed by the general consent of nations in time of war, and limited to those occasions." The qualification then follows "that American ships offending against our laws, and foreign ships, in like manner, offending within our jurisdictions may, afterwards, be pursued and seized upon the ocean, and rightfully brought into our ports for adjudication."

64 Cf. Ortolan, Diplomatie de la Mer, liv, ii, ch. xiii, as to the tendency in France. 
do not consider, or so assert it. For any unlawful acts done by her while thus lying in port, and for all contracts entered into while there, by her master or owners, she and they must donbtless be answerable to the laws of the place. Nor if the master and erew while on board in such port break the peace of the commmity by the commission of crimes can exemption be claimed for them." ${ }^{\circ}$ As Clief Justice Marshall said in The Exchange case, "when merchant vessels enter for the purposes of trade, it would be obviously inconvenient and dangerous to society and would subject the laws to continual infraction, and the govermment to degradation, if such individuals or merchants did not owe temporary and local allegiance, and were not amenable to the jurisdiction of the country.",66

\section{$\$ 269$. Efforts to secure exemptions through treaties. Cases of} Sally and Newton.-The general statement may therefore be made that merchant vessels entering a foreign port for purposes of trade, if not exempted by treaty, are subject while they remain to the local law ${ }^{67}$ To obviate inconveniences necessarily arising ont of conflicting jurisdictions, an effort has long been in progress to secure through conventions in favor of such vessels a certain and elearly defined degree of exemption from such law. The first of such conventions so entered into by the United States was with France, 1788, "for" the purpose of defining and establishing the functions and privileges of their respective consuls and vice-consuls;"6s and while it was in force the cases of The Sally and The Newton ${ }^{69}$ arose, in each of which the proper consul of the United States elaimed exclusive jurisdiction of the offense, and so did the local anthorities of the port. The French Council of State, to which the matter was referred, pronounced against the local tribunals, "considering that one of these eases was that of an assault committed in the boat of the American ship Newton, by one of the crew upon another, and the other was that of a severe wound inflicted by the mate of the American ship Sally upon one of the seamen, for having made use of the boat

$65 \mathrm{Mr}$. Webster to Lord Ashburton, Aug. 1st, 1842. State Papers, 1843, 1xi, 35; 6 Webster's Works, pp. $303-318$.

66 The Schooner Exchange v. McFadion, et al., 7 Cranch, 144.

oi A merchant vessel, except under some treaty stipulation, has no exemption from the territorial jurisdiction of the harbor in which she is lying. 15 Opinions of Attys. Genl. U. S., p. 178.

688 Stat. at Large, p. 106.

6 See the accounts given in 1 Phillimore (3d ed.), 484, and (2d ed.), 407; Dana's Wheaton, § 103. 
without leave."70 In speaking of these cases M. Massé, after referring to crimes by which the peace of the port is broken, says: "It is otherwise in case of offenses committed on board of the foreign vessel by a man of the crew against another man of the same crew because it concerns the internal discipline of the vessel-[parce qu' il s'agit alors de la discipline intéricure du vaisseau]-in which the local anthority should not interfere when its assistance is not called for, or the tranquillity of the port is not broken."

\$270. Cases of Jally and Wildenhus.-After another convention had been concluded with France (1853) there arose in 1859) the case of Jally, the mate of an American merchantman who had killed one of the crew and severely wounded another on board ship in the port of Havre. In that case the Court of Cassation held that merchant vessels are fully under the local jurisdiction whenever the state sees fit to exercise it, and that it should be exercised "whenever the act is of a nature to compromise the tranquillity of the port, or the intervention of the local authority is invoked, or the act constitutes a crime by common law, the gravity of which does not permit any nation to leave it unpunished, without impugning the rights of jurisdiction and territorial sovereignty."72 After a treaty had been proclaimed on this subject between the United States and Belgium" (1881), in which it was provided that "the local authorities shall not interfere, except when the disorder that has arisen is of such a nature as to disturb tranquillity and public order on shore, or in the port," arose the case of Wildenhus, ${ }^{74}$ involving an affray in which one member of the crew of the Belgian steamship Noordland stabbed another between decks, while the vessel was moored at the dock in the port of Jersey City, state of New Jersey. Although exclusive jurisdiction was claimed for the king of Belgium (1) under the general rules of international law, to which the practice of the United States conforms; and (2) by virtue of treaties

70 Upon that state of facts the Council was of "opinion that the jurisdiction claimed by the American consuls ought to be allowed, and the French tribunals prohibited from taking cognizance of these cases." Ortolan, Rigles Internationales de la Mer, tom. i, pp. 293298. Appendice, Annexe H, p. 441.
71 Droit Commercial, 421, 423.

72 Case of the Tempest, Dalloz, Jurisprudence Générale, Annce 1859 , p. 92 . See also 1 Ortolan, Diplomatie de la Mer (4th ed.). pp. 455, 456; Sirey (N. S.), 1859 , p. 189 .

7321 Stat. $776,781$.

74120 U. S., 1 . 
between the two conntries, the Supreme Court of the United States upheld the local jurisdiction in accordance with the general doctriue recognized by the French government and courts that there is a distinction between acts relating solely to the internal discipline of the ressel, or even crimes aud lesser offenses committed by one of the crew against another, when the peace of the port is not affected, on the one hand, and, on the other, crimes or lesser offenses committed upon or by persons not belonging to the crew, or even by members of it upon cach other, provided in the latter case that the peace of the port is compromised. Upon that wise and reasonable basis many nations have attempted to regulate this difficult sulject ly conventions, and these "numerous conventions, and the roluntary abstention from the exercise of jurisdiction which creywhere more or less prevails, point towards the proximate formation of a uniform eustom which would be reasonable in the abstract and singularly little open to practical objections."

$\$ 271$. No right of asylum in merchant vessels. $-A$ s no discussion would be proper here of the extent to which a merchant vessel in a foreign port is subject in a private suit to ordinary almiralty jurisdiction, the fact need only be added that such a ressel has no right of asylum even for a political refugee in the ports of the refugee's country. Such was the doctrine clearly recognized in the case of Sotelo, a Spanish political refugee, surreptitiously embarlied at Valencia on the French Packet boat l'Ocean, who was seized and imprisoned by the local authorities of Alicante after he had traversed the open sea on his way to that port; ${ }^{76}$ and in the case of Gomez, a political refugee from Nicaragua, in regard to whose proposed arrest Mr. Bayard, in his instructions to Mr. Hall, Mareh 12,1855, conceded the jurisdiction of the local authorities orer a merchant vessel so long as it remains in the ports of the country. ${ }^{77}$

75 Hall, $\$ 58$.

io Calvo, $\$ 470$. "There is no stipulation in existing treaties between this country (Great Britain) and Spain which can be deemed sufficient to debar the Spanish government from exercising the right which, in his Lordship's opinion, appertains to that government of claiming its own subjects when they may be found in a Spanish port as passengers on board vessels hired to convey the mails between this country and the peninsula." Rep. Fugitive Slave Commission, p. 154.

77 MSS. Inst. Cent. Am. For. Rel, 1885. Mr. Bayard informed $\mathrm{Mr}$. 
$\S 272$. Goods owned by citizens of one state embarked in ships of another.-In the classification lieretofore made of the nonterritorial property of which a state may be possessed, was included goods owned by its citizens or subjects, but embarked in foreign ships. As it is only through the national character of the owners that such goods can be considered the property of the state, they ean only remain such so long as such owners do not acquire a foreign character, which they may through domicil or services to another state, without ceasing to be ritizens or subjects of the state of origin. As we shall see hereafter, when that branch of the subject is reached, enemy character may attach to the persons of neutrals and through them to their property as an effect of domicil, or to property owned by neutrals by reason of its origin, or of the use to which it is applied.

Hall that "any exemption or immunity from local jurisdiction must be derived from the consent of that country." Such is the law as recognized by this government despite Mr. Blaine's attempt to establish a contrary rule in instructions issued in 1890 concerning the case of Barrundia. 


\section{CHAPTER IV.}

\section{DIPLOMATIC INTERCOURSE.}

\$273. Envoys, ancient, medieval and modern.-The system of diplomatic intercourse that prevailed in the ancient world rested on three clearly defined conditions. In the first place, ats such intercourse was limited and occasional, the intermediaries who were sent only on special errands were expected to return as soon as the business in hand was concluded; in the second, the heralds or ambassadors thus employed were not divided into different classes or orders; in the third, as a general rule, the persons of envoys were held to be sacred and inviolate even in the midst of hostilities. When there was a departure from that rule, as in the case of the slaughter of the Persian enroys by the Athenians and Spartans, the act was regarded as an ontrage against "the laws of all mankind."1 such continued to be the general sentiment of all civilized communities after the primitive system lad passed from the ancient to the medieval world. ${ }^{2}$ The Turks alone among the European nations were habitually careless of the general usage; and the ill fame thus acquired by Constantinople, by reason of the practice there existing of committing to prison diplomatic agents of the country with which war was imminent, ${ }^{3}$ continued down to the early years of the present century, when the Porte gave formal notice to the ministers of Austria and Prussia that the Seven Towers no longer existed.

$\$ 274$. Effort to establish permanent embassies.-Not until near the close of the fifteenth century did Lonis XI of France attempt to supersede that part of the ancient practice permitting the sending of temporary agents for special oceasions only by maintaining ambassadors at foreign courts as permanent residents. ${ }^{*}$ The motive for the innovation thus made seems

\begin{abstract}
1 Herod. VIII, 136; cf. Thuc. I, 67.

2 As to the lack of protection to ambassadors, during that period, in the states through which they passed on the way, see Bernard, Lectures on Diplomacy, pp. 121, 122.
\end{abstract}

3 As late as 1806 the British min- ister found it necessary to withdraw secretly from Constantinople to avoid torture and death which Turkish traditions rendered imm:nent. Rt. Hon. Charles Arbuthnot to Lord Howick, Feb. 3, 1807. Papers relating to the Expedition to the Dardanelles, 1807.

${ }_{4}$ "If they lie to you, lie still 
to have commended itself "to Ferdinand the Catholic, whose policy led him to entertain [ambassadors] at various courts, as a kind of honorable spies." Coke praises the cautious and suspicious Henry VII for having set lis face against the practice. He was "a wise and politique king," because he "would not in his time, suffer lieger ambassadors of any foreign king or prince within his realm, or he with them, but upon occasion used ambassadours;" ${ }^{\prime 6}$ and as late as 1660 a French envoy was given to understand by the Polish Diet that if he did not return home he would be treated as a spy.7

Views of Grotius, Bynkershoek and Vattel.-Eren after the Peace of Westphalia, 1648, through which the modern international system was founded, had made jermanent diplomatic missions a necessity, the prevailing prejudice against them was strong enough to prompt Grotius to declare that they could be rejected, without an infringement of right, because contrary to ancient practice. While he admitted that they are "now common," he claimed that they were not "necessary." And nearly a century later Bynkershoek" manifested something of the same spirit when he defined ordinary legates as those who "are maintained at friendly courts not for special but for general purposes, even for the sake of what they can find out." But despite all such prejudices permament legations had become a fixed institution by the middle of the serenteenth century, and from the pages of Bynkershoek and Vattel a very definite idea can be derived of their character. From the latter we learn that "several orders of ministers being established, more or less dignity was annexed to their character, and proportionate honors were required of them. *** Custom has established three principal degrees. What is, by way of pre-eminence, called the representative character, is the faculty possessed by the ininister, of representing his master even in his very person and dignity." 10

$\S 275$. The several classes of diplomatic representatives.-Only the right to represent the person and dignity of the sovereign

more to them," was the exhortation of Louis XI to his ambassadors. Flassan, Diplomatie Francaise, I, 247.

5 Ward, Hist. of the Law of Nations in Europe, ii, p. 290; ibid, ii, p. 484 .

6 Fourth Institute, Ch. xxvi.
7 Ch. de Martens, Guide Diplomatique, § 23.

s De Jure Belli ac Pacis, II, c. xviii, $\$ 3$.

${ }^{9}$ De For. Leg., $\$ 1$.

10 Droit des Gens, iv, c. vi, $\$ 89$, 70 . 
conferred the representative character, and those who possessed it were of the first class and bore the title of ambassadors, ordinary or extraordinary. No matter which, they stood without question above the second class, who did not possess the representative character, because their functions related solely to the sovereign's affairs, as distinct from his person and dignity. Such agents of the second class were known as envoys, either ordinary or extraordinary. Since the beginning of the eighteenth century "the name of residents has been confined to minister's of a third order, to whose character general custom has annexed a lesser degree of respectability. * * His representation is in reality of the same nature as that of the envoy."11 So bitter became the disputes as to precedence between the three classes of diplomats that it became necessary during the century last named to create a fourth, "ealled simply ministers, to indicate that they are invested with the general quality of a sovereign's mandatories, without any particular assignment of rank and character. * * In order to aroid all contest on certain occasions when there might be room to apprehend it, the expedient was adopted of sending ministers not invested with any of the three characters. Hence, they are not subjected to any settled ceremonial, and can pretend to no particular treatment."12 In order to add to the dignity of such a minister, who took rank immediately after an ambassador, he was sometimes given the title of minister plenipotentiar $y^{13}$ an office gradually united with that of enroy extraordinary and placed in the same rank with it. ${ }^{14}$

\$276. Growth of diplomatic immunities. Recent legislation. -While questions as to official precedence were thus giving rise to endless conflicts, the still graver question involving the inviolability conferred by the legatine character was still the sulject of serious controversy. Coke, who opposed any wide immmity, held that an envoy who should commit in England any crime contra jus gentium, such as "treason, felony, alultery," should thereby forfeit his privilege and become

11 Vattel, Droit des Gens, IV, c. ters ehargís d'affaires shortly afvi, § 73 .

12 Ibid. IV, c. vi, § 74.

13 Hertslet, Map of Europe by Treaty, I, 62, 63. 14 "Ministers resident and minis- 188. terwards completed the catalogue, which we find in general acceptance at the commencement of the nineteenth century." Twiss, I, $\S$ 
liable to punishment like any other private foreigner, ${ }^{15}$ and in 1708an ambassador from Peter the Great was actually arrested and taken out of his coach in London for a debt of fifty pounds there contracted. As Queen Ame conld not cut off the head of the sheriff of Middlesex, as the Czar demanded, she sent him instead an engrossed and illuminated copy of an act ${ }^{16}$ passed to prevent such an outrage in the future by declaring according to English ideas the privileges to which diplomatic agents should be entitled under the laws of nations. In 1789 the in riolability of ambassadors was declared in France by an act of the Constituent Assembly; and in April, 1790, a declaratory act ${ }^{17}$ was passed on the same subject by the Congress of the United States. Like legislation by the leading European nations either defines specifically the immunities which each recognizes, or declares generally that all members of foreign legations "shall enjoy the privileges conferred upon them by the principles of international law and public treaties."1s

\section{$\$ 27 \%$. Questions of precedence as settled at Vienna and Aix-} la-Chapelle.-Such was the general nature of the adrance that had been made when the powers assembled in the Congress of Vienna undertook to hush the endless controversies as to precedence by a common understanding establishing the three following classes of diplomatic agents:

1. Ambassadors, legates or nuncios.

2. Envoys, ministers, and others accredited to sovereigns.

3. Chargés d'affaires accredited to ministers of foreign affair's.

To that classification was annexed the conditions: First, that only ambassadors, legates or nuncios should possess the representative character; second, that diplomatic agents on an extraordinary mission should not by reason thereof (it ce titre) enjoy any superiority of rank; third, that within any class, precedence should depend upon priority in the date of the official notification of arrival. ${ }^{9}$ is the latter condition made it possible for the ministers of the second class of the

15 Institutes, c. 26, 152-157.

16 Stat. 7 Anne, c. 12.

17 Rev. St. U. S., $\$ 4063$. Opinions of Attys. Genl. U. S., p. 26; Ex parte Cabrera, 1 Wash. C. C. 232 ; U. S. v. Lafontaine, 4 Cranch, C. C., 173.

18 Phillimore, ii, pp. 228 sq.
19 "Art. 1. Les employés diplomatiques sout partagés en trois classes:

Celle des ambassadeurs, légats ou nonces;

Celle des envoyés, ministres, ou autres accrédités auprès des souverains; 
great continental powers to be outranked by ministers of the same class representing the minor powers of Germany, the Congress of Aix-la-Chapelle (November, 1S18), was ealled upon to regulate the difficulty by interpolation between the second and third classes, as arranged at Vienna, another class known as ministers resident accedited to sovereigns. ${ }^{20}$ The minor states could thus be represented by ministers without being forced to struggrle for precedence over like representatives from the great powers. The acceptance of that modification completed the final arrangement dividing the diplomatic body into four distinct classes,-all in one class ranking before any of the class below it, with precedence in each class depending upon length of residence of each individual diplomat at the court to which he is accredited.

$\$ 278$. Envoys of the first class-the representative character. -First in the lierarchy stands the ambassador, legate or nuncio, accredited from sovereign to sovereign, who is supposed to represent not only the personal dignity of his principal, but the public affair's of the state over which he presides. For that reason, to representatives of the first class only was given the representative character. Originally the superior importance aceorded to ambassadors rested mainly upon their right to have personal audience of the sovereign to whom they were accredited, a right which has become a mere shadow with the growth of constitutional government, under which no important act can bind the state unless performed by a responsible minister. The rule eeasing with its reason the right of personal audience with the sovereign was gradually extended

Celle des chargés d'affaires accrêdités auprès des ministres chargés des affaires étrangères.

Art. 2. Les ambassadeurs, légats ou nonces, ont seuls le caractère représentatif.

Art. 3. Les employés diplomatiques en mission extraordinaire, n'ont, à ce titre, aucune supćriorité de rang.

Art. 4. Les employés diplomatiques prendront rang. entre eux, dans chaque classe, d'après la date de la notification officielle de leur arrivée." From the recez of the Congress of Vienna of the 19th of March, 1815.
20 "Pour éviter les discussions désagréables qui pourraient avoir lieu à l'avenir sur un point d'étiquette diplomatique, que l'annexe du recez de Vienne, par lequel les questions de rang ont été réglées, ne parait pas avoir prévu, il est arrêté entres les cinq cours, que les ministres résidens, accrédités auprès d'elles formeront, par rapport à leur rang, une classe intermédiaire entre les ministres du second ordre et les chargés d'affaires."

Protocol of the Congress of Aixla-Chapelle of the 21st November, 1818. See also Hertslet, Map of Europe by Treaty, I, 575. 
on proper occasions to all diplomatie agents. In order further to obliterate all real distinctions between the higher classes of such agents the right of solemn entry, once enjoyed by ambassadors at the beginning of their missions, resulting sometimes in armed confliets, has been permitted to bccome obsolete. 21

\$279. Envoys of the second and third classes.-To the second class of diplomatit agents belong envoys, envoys extratordinary, ministers plenipotentiary, envoys extraordinary and ministers plenipotentiary, and intermuncios who, while accredited from sovereign to sovereign, represent only the aflatirs of the state to which they belong.2 To the third class belong ministers, ministers resident, residents, and minister's chargés d'affaires accredited to sovereigns. Unless a chargé is thus accredited he cannot rank in the third class. His sovereign must accredit him as minister in the first instance, as in the case of the minister chargé d'affaires of the king of Sweden accredited to the Padischah of the Ottoman in 1784.23

\$280. Charges d'affaires ad hoc, and ad interim.-To the fourth class belong chargés d'affaires, accredited to the minister of foreign affairs, who are either sent ont originally with express credentials as such, or promoted temporarily to that position, as members of an embassy or legation, during the absence or inability of their chief. In the first case they are known as chargés d'affaires ad hoc; in the last, as chargés d'affaires ad interim. ${ }^{24}$

\section{§281. How diplomatic rank is usually determined.-While}

21 For an account of the armed conflict that took place on Tower Hill, London, in 1661, between the retinues of the French and Spanish ambassadors by reason of the attempt of each to follow next to the king in the procession formed for the solemn entry of the representative of Sweden, see Ward, Hist. of the Law of Nations, ii, 458-462. The ceremonial is still observed on a small scale at Madrid, where the author has several times witnessed it.

22 Martens, Prćcis, vii, c. 2, § 198. As to the position once taken by the Austrian Internuncio at Constantinople, by special treaty ar- rangement, see $\mathrm{Ch}$. de Martens, Guide Diplomatique, c. 10, §65.

23 Martens, Précis, vii, c. 2, § 194.

24 Martens, Guide Diplomatique, c. I, § 11. Wheaton (Elements, p. III, c. I, $\S 6$ ) cites an instance in which the Secretary of State of the U. S. formally notified the charge d'affaires of an European power of the highest rank, that "he courd hold official intercourse only with a department of state; that he had no right to converse with the President on matters of business, and might consider it a liberal courtesy if he was presented to him at all." 
every state may determine for itself the character in which it will accredit its diplomatic representatives, it is usual for that matter to be settled by agreement that in any given case the agent received will be of the same rank as the one sent. The definite and final arrangement of the classes or orders in the diplomatic hierarchy by the Congresses of Vienna and Aix-laClapelle, and the definitions that have been given, either by the positive cnactments or judicial decisions of particular states, of the immunities and exemptions belonging to diplomatic agents have finally placed the right of embassy or legation upon a basis so firm and so well understood that its several branches may now be defined almost with the accuracy and precision of municipal law.

$\S 282$. Theory of equality between sovereign states. Precedence of pope and emperor.-The corner stone of the existing international system is the idea of equality between sovereign states regardless of their relative geographical extent or physical power. Each has the same natural right to do any lawful act that may be rightfully performed by any other. "Power" or weakness does not in this respect produce any difference. $A$ dwarf is as much a man as is a giant; a small republic is no less a sovereign state than the most powerful kingdom." And yet despite the theory of equality, powerful states, like powerful individuals, so assert their personality as to secure a precedence over the less powerful. In the family of nations the superior ranks, titles and other ceremonial distinctions thus secured by the greater states have either been tacitly recognized by constant usage, or by express compacts voluntarily entered into. As the spiritual head of the Holy Roman Empire the pope claimed for his ambassadors or nuncios precedence over the representatives of all temporal princes, and in the Catholic countries of France, Spain, Austria-Hungary, and Portugal such precedence is still conceded them. ${ }^{20}$ As the temporal head of that empire the successor of Charlemagne and the Casars likewise claimed, as "emperor," precedence over all other temporal princes. ${ }^{27}$ That title, once considered from its historical associations more eminent than all others, dwindled, however, with the importance of the

25 Vattel, Droit des Gens, Príliminares, $\$ 18$.

26 The recez of the Congress of Vienna of March the 19th, 1815, expressly provided that "le pré- sent règlement n'apportera aucune innovation relativement aux représentans du Pape."

27 Bryce, Holy Roman Empire, Ch. VII. 
empire itself until it came to signify no more than that of "king."

$\S 283$. Significance of royal honors.-To the chiefs of certain states were conceded by the customary laws of Europe what were called royal honors, entitling their possessors not only to precedence orer all princes not so endowed, but also to the exclusive privilege of accrediting ambassadors to other powers. ${ }^{28}$ Such regulations originally made for the special benefit of monarchical states, at a time when the European republics were too feeble to maintain their equality, gare way at last when the republics of Venice and the United Provinces grew strong enough to assume the honors of crown heads, and Cromwell demanded that no mark of respect that had been paid to the enroys of the monarchy should be withheld from the representatives of the English commonwealth. The first French republic in its treaties with other European powers was eareful to stipulate for the same ceremonial as to rank and etiquette that had been observed between them and France prior to the Revolution, ${ }^{29}$ and that rule is now observed between the monarchical states of Europe and the present Republic of France, the United States of North America and Switzerland.

$\S 284$. Right to regulate ceremonials. Courtesy on high seas. -Every state has by virtue of its sorereignty the exclusire right to regulate all questions of precedence, and all ceremonials within its territorial jurisdiction, ${ }^{30}$ including the ceremonies with which its forts and ships of war are to be approached or passed within its recognized sea-limits. The disputes that once arose out of the refusal of certain states to pay to the flags of certain territorial powers marks of homage within what were known as the narrow seas grew, as a general rule, out of a denial of the pretensions of such powers to supremacy within them. The real domain of international courtesy in this regard is to be found on the high seas ${ }^{31}$ and in foreign

28 Vattel, Droit des Gens, II, § 38; Klüber, Droit des Gens Moderne, Pt. II, tit. I, c. $3, \S \S 91,92$; Heffter, $\S 28$.

29 See treaties of Campo Formio (Art. 23), and of Luneville (Art. 17), with Austria, and treaties of Basel with Prussia and Spain. Schoell, Histoire des Traités de Paix, i, p. 610, ed. Bruxelles.
30 By the fifth article of the recez of the Congress of Vienna it was provided that "il sera déterminé dans chaque état un mode uniforme pour la réception des employés diplomatiques de chaque classe."

31 "Inter ea refero, si quis minor dignitate majorem, in publico sibi obviam factum, salutet vel non 
ports where the commanders of the ressels of all civilized nations are or should be instructed to perform certain ceremonial acts, "as honors paid to the independence of nations, as a public anthorized recognition that the sovereignties of the world are entitled to mutual respect." 32 The tendency to assimilate all municipal laws and ordinances regulating salutes to a uniform standard, through international agreement, has resulted in eertain rules upon that subject, which were put in force by various maritime powers July 1st, $18 \pi T$.

$\S 285$. Right to send and duty to receive envoys.-Passing from form to substance, the statement may be made that the very essence of equality is embodied in the right of every sorereign power to communicate and negotiate on equal terms with every other. The right of embassy or legation is now a normal and necessary condition of international intercourse, and it is unnecessary to inquire whether it rests upon mere comity, or upon the positive rules of international law. ${ }^{33}$ While no state is bound to send ambassadors to another, it may do so if it sees fit, and the state to whom they are accredited is bound under the existing nsage to receive them, subject to the right to reject certain persons for good cause to be determined, not by an arbitrary discretion, but with reference to certain recognized standards. It cannot be doubted that every independent state has the right to send diplomatic agents to any other power through the action of that department of its government to which such power is committed by its own constitution. The form of such constitution it las the right to settle for itself, and after it is so settled foreign states must recognize it. The right to send envoys is an attribute of sorereignty, no matter whether the same is vested in a ling, a president or in a senate or council acting in conjunction with such king or president.

\$286. Difficulties incident to contests for sovereignty.-Grave diplomatic difficulties often arise during revolutions or civil wars involving contests for the sovereignty itself. In such a

salutet, et si qua minorum principum navis, in mari extero, navibus majorum principum, quaqua etiam dignitate sint, salutem dicat vel neget." Bynkershoek, Quaest. J. P., II, § 24.

32 Ortolan, Diplom. de la Mer. vol. i, bk. 2 , c. 15 .
$33 \mathrm{As}$ to the general nature of the obligation of a state to send and receive envoys, see Grotius, $D e$ Jure Belli ac Pacis, II, c. 18, \& 1; Vattel, Droit des Gens, iv, c. 5, \$\$ 55-65; Martens, Précis, vii, c. 1 , $\S$ 187-190; Rutherforth's Inst.; vol. ii, b. ii, c. $9, \S 20$; Hall, $\S 98$. 
case every prudent government is careful not to decide prematurely, by a formal reception of envoys from a de facto power, whether or no the real sovereignty has actually passed to such power. ${ }^{34}$ In order to relieve the state to which such enroys are sent from making any formal or positive decision on that subject, they sometimes go in the anomolous character of agents clothed with the powers and immunities of ministers, without being invested with the representative character, or entitled to diplomatic honors. ${ }^{35}$ In reference to sucl agents Mr. Seward said in memoranda of March 13 and July 17, 1865, touching the affairs of Mexico: "It is a fixed habit of this government to hold no official intercourse with agents of parties in any country which stand in an attitude of revolution antagonistic to the sovereign authority in the same country with which the United States are on terms of friendly diplomatic intercourse. It is equally a fixed habit of this government to hold no inofficial or private interviews with persons with whom it cannot hold official intercourse." 36

\section{\$287. Effect of revolutionary changes after reception of envoy.} -If, after a minister has been accredited to a country and received by it, a revolutionary change takes place in the government of the state from which he comes, his functions are rather suspended than terminated; and during such suspension he is entitled to the immunities and respect due to his station. And on the other hand if, after he has been duly received, the government to which he is accredited is forcibly overthrown and another substituted in its place, which his own fails to recognize, it is usual for him to continue to enjoy the immunities originally belonging to him, although it is a grave question whether his state could claim for him such immunities as a right, while it refuses to "invest him with the representative character," or to recognize the lawfulness of the government upon which such claim would have to be made.37

$34 \mathrm{As}$ to the question of expediency involved, see Merlin, Rípertoire, tit., Ministre Publique, Sect. ii, $\S 6$.

35 During the civil war in the United States the Confederate government sent such agents to Europe, who conferred in an unoficial manner with the Emperor of the French and with members of the
British government. The reception of such private agents can not be construed into an act of recognition.

${ }^{36}$ Ex. Doc. No. 20, 39th Cong., 1 st Sess.

37 En tout cas, malgré la cessation de sa mission pour l'une ou l'autre des causes que nous venons d'énumérer, le ministre conserve 
$\S 288$. Right of legation retained by certain part-sovereign states.-The right of embassy or legation does not belong exclusively to such states as are absolutely sovereign and independent. It may be claimed by those classed as part-sovereign, provided that in partially surrendering their right to control their external affairs the $y$ have not lost the essence of nationality.38 Whether the right has been entirely surrendered must depend in any given case upon the special relations existing between the dominant and dependent states. Convenient illustrations of such relations may be found in what has been said already as to such protected communities as have been permitted to retain an international existence, special reference being made to the Christian principalities of the Ottoman Empire. ${ }^{39}$ Whether in the case of a federal union the several units composing it have retained the right of diplomatic representation on their own account, independently of the federal head, depends of course upon the terms of each particular compact. Such reservations made in the ancient constitutions of the Germanic and Swiss Confederations hare practically disappeared from the present constitution of the German Empire and absolutely from the existing federal constitution of Switzerland.40 In like manner the entire control of the foreign affairs of the United States is rested in a supreme federal government under a constitution which expressly forbids any state from entering without the consent of Congress into any agreement or compact with another state, or with a foreign power. ${ }^{41}$ The right to send or receive public ministers, thus taken away from the states by implication, was withheld in express terms by the Articles of Confederation ( $(6)$. which provided that "no state, without the consent of the United States in Congress assembled, shall send any

jusqu' au retour dans son pays toutes les immunités et tous les droits inhérents à son caractère public." Calvo, § 466. See also Dana's Wheaton. $\S 209$, and Note 121; Martens, Précis, $\S 238$; Vattel, Droit des Gens, iv, c. $9, \S \S 123$, 126; Heffter, § 223; Phillimore, ii, $\S 240$; Klüber, $\S 228$; Martens, Guide, § 56; Twiss, I, § 200.

38 It can not be said, without qualification, that "this right belongs only to states which are independent, ‘qui summi imperii sunt compotes inter se." Twiss, I, § 184.

39 See above, pp. 179 seq. As to the right of Egypt to negotiate commercial and postal conventions with foreign powers under the Sultan's Firmans of 1866 and 1867, provided they do not contain political arrangements, see Holland, European Concert in the Eastern Question, pp. 116-128.

40 See above, pp. 168 seq.

41 Art. 1, § 10. 
embassy to, or receive any embassy from, or enter into any conference, agreement, alliance, or treaty with any king, prince or state."

$\S 289$. When a particular individual may be rejected without just cause of offense.-The fact that foreign governments are sometimes asked in advance whether or no a particular individual will be acceptable as an envoy is a clear and practical admission of the right of rejection when confined within the limits which usage has prescribed. ${ }^{42}$ By the authority of such usage a state may, without giving a just cause of offense, refuse to receive a particular individual (1) when a recognition of the special character in which he comes would be a menace to the interests or dignity of the receiving power; or when such character conflicts with the constitution of such power. On the first ground Queen Elizabeth refused to receive the nuncio of Pius IV, sent to invite her to appear at the Council of Trent, because she feared that his mission might result in the creation of disaffection among her subjects $;^{43}$ on the second, the pope refused in 1875 to receive Prince Hohenlohe because, being a cardinal, he was $c x$-officio a member of the curia. The right to reject a particular individual may be justly exercised (2) when he is known to be politically hostile either to the state or its sovereign; or when he is of notoriously bad character or personally obnoxious to the sorereign or state to which he is sent. Francis I refused to receive Cardinal l'ole as legate because he was an arowed enemy of his ally, Henry VIII; and Richelieu rejected the Duke of Buckingham as ambassador extraordinary from Charles $I$, because on a previous visit to France he had rentured to profess an ardent love for the queen herself.44 "It must be borne in mind that an envoy is a person as well as the abstract representative of his government, and that it is the prerogative of every government to require that those with whom he deals be personae gratae, and to decide the question for itself." 45 A state has also the right (3) to refuse to receive as an envoy one of its own citizens for the obvious reason that it is desirable to prevent a conflict between the

42 It is not usual, however, to ask as to acceptability in advance. As to the practice of the goveriment of the U. S. see Wharton, Int. Law Dig., § 82a.

43 Green, Hist. of the Eng. People, ii, pp. 327-28.
44 Gardiner, England Under the Duke of Buckingham and Charles I., i, pp. 182, 183, 329 .

${ }_{45} \mathrm{Mr}$. Frelinghuysen, Sec. of State, to Mr. Morgan, Dec. 30, 1884. MSS. Inst., Mex. 
interuational immunities of a minister and the civil liabilities of a native-born subject. For that reason it has become a maxim of government with many European states not to receive one of its own citizens as a permanent diplomatic representative of a foreign power.46 It has, howerer, been held in sereral notable cases that the objection should not be insisted upon if the envoy comes as a naturalized eitizen or subject of the state he represents. ${ }^{47}$ In any event, if a sorereign sees fit to receive a natural-born subject as an envoy, without any express reservation of his jurisdiction over him, it seems to be clear that he thereby waives all authority he might otherwise exercise by reason of his origin, and clothes such enroy with the complete jus legationis.48

$\$ 290$. Envoy may be received conditionally. Mr. Keiley's case. - Is the duty to receive is not absolute, it may be coupled with conditions, provided they are expressed before or at the time of the reception, and are not derogatory to the dignity of the accrediting govermment. The United States held at an arly day in its dealings with France that a conditional offer to accept a minister" should not "be expressed in terms which may comtenance the inadmissible pretension of a right to prescribe the qualifications which a minister from the United States should possess;" 49 and when in 1885 the goverument of Austria-Hungary intimated in advance that the usual honors could not be accorded to Mr. Keiley, because of his marriage to a lady of the Hebrew faith by civil contract only, the Secretary of State replied "that the ground npon which it is announced that the usual ceremonial courtesy and formal

46 Such was the rule of the French and Swedish courts, and likewise of the United Provinces. Twiss, I, § 186. "This government objects to receiving a citizen of the United States as a diplomatic representative of a foreign power. Such citizens, however, are frequently recognized as consular officers of other nations, and this policy is not known to have hitherto occasioned any inconvenience." Mr. Evarts, Sec. of State, to Mr. Logan, Sept. 19, 1879. MSS. Inst. Cent. Am.

"Ch. de Martens, Guide Diplomatique, I, c. II, $\S 6$, referring to the cases of Count Pozzo di Borgo and Count de Bray, two French subjects, received in their native country, the first as Minister of Russia, the second as Minister of Bavaria, after having been naturalized in the countries which they respectively represented.

4s Phillimore, II, c. 135; Wheaton, Elements, pt. III, c. I, § 15. For Vattel's view, see iroit des Gens, iv, c. 8, § 112. For the English view, as affirmed by judicial decision, see Macartney v. Garbutt, L. R. 24. Q. B. D. 368 .

49 President John Adams, Second Annual Address, 1798. 
respect are to be withheld from this enroy of the United states to your government, that is to say, because his wife is alleged or supposed by your govermment to entertain a certain religious faith, and to be a nember of a certain religious sect, eannot be assented to by the executive of the government of the American people, but is and must be emphatically and promptly denied." "so When an enroy lats been once received unconditionally, he is of course entitled to all immunities and honors incident to his office free from the possibility of subsequent abridgment.

$\$ 291$. Letters of credence and additional full powers.-Ifter the rank of an envoy has been settled by the state appointing him, he must be armed with a letter of credence, in order that he may enjoy in the state to which he is sent the immunities and honors incident to the same. Such letter of crederee, in the case of an ambassador or minister entitled to rank in either of the three first classes, is addressed by the soreroign or chief magistrate of the sending to the corresponding chicf of the receiving state. Such letter, which usually states the general object of the mission and the oflicial character of the agent bearing it, for whose acts full faith and credit is asked, is written either in the first person as a cabinet letter (lettre de cabinet); or in the third person as a letter of council (lettre de chancellerie. $^{51}$ In the case of a chargé d'affaires and other agents of that class the letter is addressed by the minister charged with foreign affairs to the corresponding minister of the other government. While letters of tredence imply general full powers to transact all such political business as falls legitimately within the seope of the mission, it is, nevertheless, usual, if any special treaty or convention is to be negotiated, to arm the agent with an additional full power to negotiate, which may be inserted in the letter of credence or embodied

$50 \mathrm{Mr}$. Bayard, Sec. of State, to Baron Schaeffer, May 18, 1885. MSS. Notes, Austria. See also President Cleveland's First Annual Message, 1885; Senate Ex. Doc. No. 4, 49th Cong., 1st sess; Geffeken in Holtzendorff's Handbuch, iii, 632. President Cleveland declined to cancel Mr. Keiley's appointment, intrusting the interests of the American government at $\mathrm{Vi}$ enna to the care of a secretary of legation, acting as chargé d'affaires ad interim.

51 Martens, Précis, vii, c. $3, \S$ 202 ; Wicquefort, de l'Ambassadeur, i, § 15. "Great Britain has, of late, set examples to other states of simplifying, as much as possible, the ceremonial of credentials, but several of the great European powers, Russia for instance, still continue to employ the lettre de chancellerie for the credentials of 
separately in letters-patent. In additional full power thus given may be a mandate ad hoc, limited to the particular negotiation or treaty in question (pouroirs spéciaux); or it may be a general mandate to treat with the ministers of all the powers within the dominion of the sovereign to whom the envoy is sent (poucoirs généranx); or it may be an unlimited mandate to treat with all powers or states (pouroirs illimités).

$\$ 292$. Limited full powers-Instructions.-It is usual to provide envoys sent to congresses not with letters of credence, but with limited full powers ${ }^{52}$ of the second class, as it is not always certain what powers or states will participate in the same. When the congress assembles, such envoys reciprocally exchange copies of their mandates with each other, or deposit them in the hands of the mediating power or presiding min. ister. ${ }^{53}$ For his personal guidance in the conduct of the business intrusted to him, every diplomatic agent is furnished by his government with instructions, generally given in writing, which he must keep secret, unless he is specially anthorized to divulge their contents either in whole or in part. If a proposition or overture is made to lim beyond the scope of such instructions, he should only receive it ad referendum.

$\$ 293$. When right to innocent passage begins. Its extent defined.- Mlthough a permanent diplomatic mission does not commence until the credentials of the enroy have been acknowledged by the government to which he is sent, from the time of their reception he is so far under the protection of the law of nations as to be entitled to a right of innocent passalge through a friendly third state, in going to and returning from that to which he is accredited.5t Cnder such circumstances he need only be armed with a passport from his own govelnment establishing his official character. It the outset this just privilege does not seem to have been recognized as

her diplomatic agents of the three first orders." Twiss, I, § 195.

52 General full powers are extremely rare at the present day, if not entirely obsolete. "Il n'est plus d'usage de munir un ministre du plein pouvoir, qui l'autorisait à traiter avec toutes les puissances, et que l'on appelait 'actus ad omnes populos.", Ch. de Martens, Guide Diplomatique, I, c.
4. Cf. also Phillimore, xi, § 230 . And for instances in which full powers were actually granted, see Twiss, I, § 196.

53 Wicquefort, de l'A mbassadeur. i, § 16; Ch. de Martens, Guide Diplomatique, II, $\$ 17$.

54 Phillimore, ii, 210, 211 (2d ed.) holds that "in time of peace the ambassador is of right inviolable in his transit through a third 
an absolute right, and instances are not wanting of seizures inade in other days by third powers of ambassadors passing to and from friendly states. While from Grotins ${ }^{55}$ we can only learn that "the law respecting the inviolability of ambassadors is to be understood as binding upon the nation to whom the embassy is sent," Bynkershoek rebuts the presumption that it is binding on any other by a positive declaration that the privilege is operative only within the state to which the enroy is accredited.56 So rapid, however, was the growth of all immunities incident to the legatine character, after the establishment of permanent missions, that Vattel was able to say: "It is true that the prince alone to whom the minister" is sent is obliged and specially engaged to secure to him the enjorment of all the rights attached to his character; but the other's, over whose territory he passes, cannot refuse him that to which the minister of a sovereign is entitled, and which nations owe reciprocally to one another. They owe to him above all things perfect personal security."

$\S 294$. Right of third state to prescribe route-Mr. Soule's case-Rule in U. S.-The immunity thus established is subject, however, to the right of the third state to prescribe the route to be traveled, ${ }^{57}$ and to insist that there shall be no unnecessary delays on the way.5s In 1854 the government of France refused to permit $\mathrm{Mr}$. Soule, the minister of the United States to Spain to make a stay (séjour) at Paris on his return to his post at Madrid from which he had been temporarily absent. The French minister of foreign affairs in defining the position of his government said that "the Emperor has not wished, as you appear to think, to prevent an en roy of the United States crossing the French territory to go to his post to acquit himself of the commission with which he was charged by his government; but between this simple passage and the sojourn of a foreigner whose antecedents have awakened, I regret to say, the attention of the anthorities invested with the duty of securing the public order of the country, there exists a difference, which the minister of the interior had to appre-

country, but cannot claim the Gentilis, Zouch, Huber and privileges of exterritoriality as a Wicquefort.

matter of tacit compact."

57 Droit des Gens, iv, c. vii, § 84.

55 De Jure Belli ac Pacis, II, c. $18, \S 5$.

5s Phillimore ii, 186-189; Halleck, 234; Holbrook v. Henderson,

"6 De Foro Legatorum, ix, § 7. 4 Sandford's (N. Y.) Rep., 631; Citing in support of his position, Field's Code, Int. Law, $\S 136$. 
ciate. If Mr. Soule was going immediately and direct to Madrid, the ronte of France was open to him; if he was about coming to Paris to sojourn there, that privilege was not accorded him." 59 In reaching that conclusion the French authorities were largely influenced, however, by the fact that Mr. Soulé, a native-born subject of France, was only a naturalized citizen of the Cnited States. The point was made that it would have required "a special agreement to have enabled him to represent, in his native land, the country of his adoption." In an official opinion of Attorney-General Cushing the rule was laid down that "a person coming into the United States as the diplomatic representative of a foreign state, with eredentials from governing powers not recognized by this gorermment, is accorded diplomatic privileges merely of transit, and this of courtesy, not of right, and such privileges may be withdrawn whenever there shall be cause to believe that he is engaged in, or contemplates, any act not consonant with the laws, peace and public honor of the United States." 60

$\$ 295$. Necessity for safe-conduct in time of war-Belleisle's case.-In time of war an envoy has no right to enter the territory of a state hostile to his own without its safe-conduct, ${ }^{61}$ a refusal to grant which is a virtual refusal to receive him. Even though accredited to a friendly state, if he is found upon the soil of another at war with his own without a safe-conduct, he can be seized without offense to the law of nations. Maréchal de Belleisle, an ambassador from the French to the Irussian court, did not complain when he was transferred to England as a frisoner of war, after his arrest on his way to Berlin, in an outlying possession of Hanover, that country being at the time engaged with England in war against his own. Envoys 62 assembled in a congress or conference, while not accerdited to the government of the state in which it is held, are considered as directly representing their states, and

¿T The correspondence between Mr. Mason, U. S. Minister to Paris, and Mr. Drouyn de L'Huys, the French Minister of Foreign Affairs, as to the refusal of the French government to permit Mr. Soule to enter France, is printed in Senate Ex. Doc. No. 1, 33d Congress, 2d sess. See also Lawrence's Wheaton (ed. 1863), 422.
608 Opinions of Attys. Genl. U. S. 1855 .

61 Vattel, Droit des Gens, iv, c. 7 , § 85; Ch. de Marten's Guille Diplomatique. II, § 19.

62 Ibid. Droit des Gens, iv, c. 7, § 85; Martens, Prícis, § 247; Martens, Causes Cól., ii, I; Heffter, § 207; Moser, Versuch, iv, 120; Car- 
as such they are entitled to the usual immunity throughout. ${ }^{63}$

$\$ 296$. Inviolability of despatches of a neutral envoy in time of war.-During the siege of Paris, 1870, when the German military authorities declined to permit a messenger with dispatches from the United states minister at that capital to pass through their lines, except upon condition that the contents of the pouch should be left unsealed, a question arose as to the rights of legation of a neutral state under such eircumstances. In complaining of the act as a discourteous one which the United States could not acquiesce in, Secretary Fish propounded this question: "When, howerer, the blockaded fortress happens to be the capital of the country where the diplomatic representative of a neutral state resides, has the blockading force a right to cut him off from all intercourse by letter with the outer world, and even with his own gorernment? No such right is either expressly recognized by public law, or is even alluded to in any treatise on the subject. The right of legation, however, is fully aclinowledged, and, as incident to that right, the privilege of sending and receiring messages. *** $*$ Indeed, the rights of legation under such circumstances must be regarded as paramount to any belligerent right. They ought not to be questioned or curtailed, unless the attacking party has good reason to believe that they will be abused, or unless some military necessity, which upon proper statement must be regarded as obrious, shall require the curtailment." 64 After an explanation from Count Bismarck that "the delay occurring now and then in the transmission of your dispatch-bag is not occasioned by any doubt as to the right of your government to correspond with you, but by obstacles it was out of my power to remove," Mr. Fish closed the incident by expressing the hope that the interruptions "were the unavoidable incidents of the then pending" military strife. In the absence of any recurrence, we are content with the recognition so fully made by Connt Bismarck of the right which we claim." 65

lyle, History of Frederick the Washburne, Feb. 24, 1871. MSS. Great, iv, p. 60. 63 Phillimore, ii, 210, 211; Hall, $\S 99$. Inst., France. Documents attached to President Hayes's message of Feb. 6, 1878. See also D'Angeberg, $6 \pm \mathrm{Mr}$. Fish, Sec. of State, to Mr. Recueil des Traités, etc., concernBancroft, Nov. 11, 1870. MSS. Inst. ant la guerre Franco-Allemande, Germ.; For. Rel., 1870. Nos. 756 and 783 ; Wharton, Int. 65 Mr. Fish, Sec. of State, to Mr. Law Dig., § 97. 
$\$ 297$. Ceremonials of arrival and reception.-It is the duty of every enroy on his arrival at his post promptly to notify the minister of foreign affairs of the fact. If the former is of the first class the notification should be made through some official of the embassy or legation who should present to the latter his principal's letters of credence, asking for him at the same time an audience with the sorereign. When the enroy is of the second or third class he is expected to notify the minister of foreign affairs of his arrival by note, asking for a time to be fixed at which he himself may present his letters of credence to the sovereign. Chargés l'affaires and other agents of the fourth class, accredited to the minister of foreign affairs, notify him by letter of theirarrival, asking at the same time an audience for the purpose of presenting to him their credentials.

$\$ 298$. Beginning of functions-Ceremonial lex loci.-While the enroy's immunity commences with his entry into the territory of the state to which he is sent, he does not begin to exercise his functions until his reception by the sovereign has taken place; 66 and from that time he should be careful to remember that every court has its own etiquette and ceremonials regulated by rules which it has an exclusive right to make, and that generally there is a functionary known as an introducer of ambassadors, or by some equivalent title, whose duty it is to explain such rules and direct their application. ${ }^{6 \tau}$ With the ceremonial lex loci the new comer should be most careful to conform, so far as instructions from his own state will permit. 68 If he has lived at another court he should be careful not to infer that rules with which he has long been familiar are of universal application; and, if he is an ambassador, he should not trust too implicitly to the statements generally contained in the text books that public audiences and solemn entries are everywhere obsolete. ${ }^{69}$

$\$ 299$. Diplomatic immunities not unlimited.-It would be impossible for an enroy efficiently to discharge the duties of his mission if his liberty of action was restrained like that of any other foreign sojourner by obedience to the local jurisdic-

66 As to the usual ceremonial at. tending the presentation of letters of credence, see Ch. de Martens, Guide Diplomatique, iv, $\S 33-36$; Twiss, I, § 198.

67 Ibid. Guide Diplomatique, iv. $\S 37$.
68 Diplomatic Representatives of the U. S. are subject to certain restrictions as to the dress they may wear at foreign courts. Cf. Wharton, Int. Law Dig., § 107b, "Court Dress."

69 See above, p. 321 . 
tion. In order, therefore, to secure a free and fearless disrharge of diplomatic functions a consensus of nations lats established the right of erery envoy to enjoy for himself, his family and his suite a certain excmption from such jurisdirtion. While such privilege continues the envoy remains subject to the laws of his own state whirh govern his persomal status and rights of property according to the fiction that althongh de facto resident in a foreign country he is de jure resident within the territory of his own. Such is the nature of the fiction of exterritorialityzo invented to give intensity to the idea that the envoy, his family and his snite are exempt from all local control. If that were absolutely true, if there was no conflict between the fiction and the fact, the task incolved in framing a general definition of theimmunity would not be a difficult one. The fact is, howerer, that such inmmnity is neither unqualified nor mulimited, and comld not be so without grave inconvenience to the state granting it. In effort will, therefore, be made to define its general scope and character, and then to state the sereral limitations br which it is curtailed.

$\S 300$. Their duration and extent.-The exemption, which is supposed to rest upon a tacit compact between the sending and receiving state, ${ }^{71}$ begins the moment the envor enters the territory of the latter, and continues not only during his entire residence but until he loses his official character or leares the countre, even when prior to his departure war has broken out between his own state and that to which he is accredited. ${ }^{2}$ While the privilege continues it exempts the enroy, his hotel and moreable effects from the local juristiction, civil and criminal, and through him it is extended to those of his suite

70 Grotius defined his idea of the fiction when, speaking of legates, he said: "fictione quadam habentur pro personis mittentium, ita etiam fictione simili constituerentur quasi extra territorium." $D e$ Jure Belli ac Pacis, II, c. 18, §§ 4, 5 .

71 Martens has stated the matter clearly when he says that the "extension of exterritoriality pertains only to the positive law of nations, to treaties or nsage, and is susceptible of modifications, which, in fact, it undergoes; whence it is not enough always to appeal to exterritoriality in order to enjoy those rights which may be derived from the extended notion given to the word." Précis, vii, c. 5, § 215. See also to the same effect, Rutherforth's Inst. ii, b. ii, c. $9, \S 20$; Wicquefort, de l'Ambassadeur, i, 27; Bynkershoek, De Foro Legatorum, c. 5, 8; Klüber, Droit des Gens Hoderne de IEurope. Pt. II, tit. 2, p. 203; Wheaton. Hist. Law of Nations, $287-243$.

ז See above, p. 325 , note 37 . 
possessing a diplomatic character; and in a lesser degree to his wife, children, chaplain, private secretary and servants, persons necessary to his comfort and convenience, but not a part of the diplomatic corps of his comntry. To the first class belong secletaries of embassies and legations who, like the minister himself, hold commissions from the sovereign; and the messengers and couriers who, while bearing dispatches, are exempt from seizure on the high seas and upon land when passing through friendly third states.

$\$ 301$. When an envoy may be arrested and expelled-Cases of Gyllenborg and Cellamare.-The exemption of a diplomatic agent frem the eriminal side of the local juristiction can only be susperuded in an extreme case when, by actually plotting or conspiring against the state to which he is accedited, such agent forees its police anthorities to arrest him in self-defense. such action was taken by the government of Great Britain, in 1717, when count Gyllenborg, the ambassador of Sweden, was arrested and his diplomatic documents seized because "vidence had been obtained that he was one of the moving spirits in a conspiraley then on foot to overthrow George I, and to set the old I'retender on the throne. When the reasons were explained all the diplomats present, except the ambassador of spain, expressed themselves as satisfied; and the count was detained as a prisoner nutil exchanged for the English ambassador to sweden, who had been arrested in retaliation.73 In the next rear the Spanish ambassidor at l'aris, Prince (ellamare, was arrested and conducted ateross the frontier because he had engaged in a conspiraley to seize the duke of Orleans and proclain the king of spain regent of France in his stead, with the duke of Maine as deputy. ${ }^{74}$ As there was 110 protest from other prowers this case and the meceeling are generally acesped as settling the right to arrest and expel an enroy detected in actual conspiracy against the ancemment to whith he is alceredited.5 While such government cannot punish him even under such eiremustances, it may foreibly resist him, and if necessary foreibly eject him from

7: Ch. de Martens, Causes Célibres, I, 75-138; Ward, Hist. Law of Nations, II, 548-550; Lord Mahon, Hist. of Eng., I, ch. viii. As to the rase of Lesley, Bishop of Ross, who claimed immunity from the criminal jurisdiction upon the ground that he was an ambassador of Mary Queen of Scots, see PittCobbett, Cas. Int. Law, pp. 65, 104 105.

it Ch. de Martens, Causes Célìbres, I, 139-173.

75 Klüber, § 211; Heffter, § 42; 
the country. ${ }^{76}$ In ordinary cases of a violation by a diplomatic agent of the local criminal law the correct and usual course is to ask his recall; or, if the case is serious, to expel him without that formality, thus casting upon his own state the duty of punishing his offense. 77

$\S 302$. When an envoy may be punished by a local tribunalWicquefort's case.-Such an agent cannot be subjected to trial and punishment in a local tribunal,78 unless his state should voluntarily withdraw the immunity after the commission of the offense; or, where it has been actually waired beforehand by his being received under conditions amounting to a consent that he shall submit to such jurisdiction, as in the case of a subject received as a foreign minister on that express condition. $^{79}$ In 1675 Wicquefort, a native of Amsterdam, was convicted and sentenced to imprisonment for life with confiscation of goods for betraying state secrets to foreigners while holding office under the states-General, although he was then aeting at the Hague as the resident diplomatic agent of the Duke of Lüneburg. ${ }^{80}$ As Wicquefort was a public official of his own country when he assumed the diplomatic character his case does not necessarily conflict with the doctrine that when a state receives one of its private citizens as a foreign minister, without any express reservation of its jurisdiction, it thereby concedes to him the full diplomatic immunity.

$\S 303$. Immunity does not include mere visitors-Sa's case.Such immunity from criminal process certainly extends to the minister, the official members of the legation, his wife and children, and to such other persons as are in good faith permanent members of his family, not including mere visitors. In extreme application of that exception occurred in the case of Don Pantaleon Sa, the brother of the Portuguese ambassador at London, who was tried, convicted and hung by permission of Cromwell for having committed a murder of special atrocity in that city. His claim of diplonatic exemption was ignored, although he averred that he was a member of his brother's

Phillimore, ii, §§ cliv-viii; Bluntschli, § 209; Hall, § 50 .

76 Grotius, De Jure Belli ac Pacis, II, c. 18, § 4; Bynkershoek, De Foro Legat., c. 17, 18, 19; Vattel, iv, c. vii, $\S$ 94-95; Martens, Prícis, vii, c. $5, \S 218$; Ward, Hist. Law of Nations, ii, c. 17, 291-334.
$7 \pi$ Walker, Science of Int. Law, p. 226 .

78 Vattel, iv, c. 7, § 94; Phillimore, ii, §§ 157-170; Bluntschli, §§ 209, 210; Pitt-Cobbett, Cas. Int. Law, pp. 108-110.

${ }^{79}$ See above, p. 328.

so Bynkershoek, De For. Leg., 11 
suite, and waiting under a promise from his sovereign to succeed him upon his recall then momentarily expected. ${ }^{\mathrm{s}}$

$\$ 304$. Minister caunot be compelled to appear as a witness.As a minister cannot be subjected to restraint by process from a court, he can neither be compelled to appear as a witness nor to give a deposition before a magistrate in a proceeding requiring him to submit to cross examination. ${ }^{\text {s2 }}$ He can be requested to waire his privilege and roluntarily appear but he cannot be compelled to do so. In the event of such a request the state in question must determine whether the right to make the waiver is rested in the minister or only in the gorernment he represents. ${ }^{83}$ When, in 1856 , the Dutch minister at Washington, who was a material witness in a case of homicide, refused to appear in open court, although willing to make a deposition on oath, his government refused to order him to give evidence publicly. In consequence of such refusal the United States, arailing itself of the only recognized expedient, demanded his recall. ${ }^{84}$

$\S 305$. Exemption from civil jurisdiction-Legislation, English and American.--The general immunity which exempts an envoy from the civil side of the local jurisdiction is also subject to certain qualifications. The English act ( 7 Anne, c. 12) heretofore referred to, declaratory of the common law, of which the law of nations must be deemed a part, provided that "all writs and processes whereby the goods or chattels of a diplomatic agent may be seized, distrained, or attached shall be

and 18; Wheaton, Hist. of the Law of Nations, p. 234.

81 Ward, Hist. of the Law of $\mathrm{Na}$ tions, ii, 535-546. As to Hale's untenable contention that an ambassador may be tried for murder, see Pleas of the Crown, I, 99. Nearly twenty years later the case of Pantaleon was quoted as a precedent to justify the arrest by the Emperor of the Prince von Fürsten. burg, envoy of the Elector of $\mathrm{Col}$ ogne. Welwood's Memoirs, p. 112. 82 "But where by the laws of the country, evidence must be given orally before the court, and in the presence of the accused, it is proper for the minister or the member of the mission whose testi- mony is needed to submit himself for examination in the usual manner." Hall, § 53. That was the course pursued by Señor Camacho, minister from Venezuela, in the case of Guiteau, the assassin of President Garfield. See Guiteau's Trial, I, 136.

s3 When a diplomatic representative of the U. S. is called upon to waive his privilege and give testimony, "he should not do so without the consent of the President, obtained through the Secretary of State." Printed Pers. Inst. Dip. Agents, 1885. Wharton, Int. Law Dig.. \$ 98 .

s. For the correspondence of the government of the Netherlands 
deemed and adjudged to be utterly null and void to all intents, constructions, and purposes whatsoever. * * * Prorided, and be it declared, that no merchant or other trader whatsoever, within the description of any of the statutes against bankrupts, who hath or shall put himself into the service of any such ambassador or public minister, shall have or take any manner of benefit by this act." The corresponding statute of the United States prorides that "whenever any writ or process is sued out or prosecuted by any person in any court of the United States, or of a state, or by any judge or justice, whereby the person of any public minister of a foreign state or prince, authorized and received as such by the President, or any domestic servant of any such minister, is arrested or imprisoned, or his goods or chattels are distrained, seized or attached, such writ or process shall be deemed roid." 85 The object of all such legislation is to secure to diplomatic agents in foreign countries immunity from every kind of writ process employed for the purpose of forcing them to pay their debts out of any property there employed as a means or instrumentality in the exercise of their diplomatic functions. As Grotius has expressed it: "As to what respects the personal effects (mobilia) of an ambassador, which are considered as belonging to his person, they are not liable to seizure, neither for the payment nor for security of a debt, either by order of a court of justice, or, as some pretend, by command of the sovereign. This, in my judgment, is the soundest opinion; for an ambassador, in order to enjoy complete security, ought to be exempt from erery species of restraint, both as to his person, and as to those things which are necessary for his use. If, then, he has contracted debts, and if, which is usually the case, he has no real property (immobilia) in the country, he should be politely requested to pay, and if he refuses, resort must be had to his sovereign." 86

$\S 306$. Not forfeited by trading.-While a diplomatic agent should not be permitted to engage in mercantile transactions, it has been held that such a breach of propriety on his part does not work a forfeiture of his privilege. In deciding the case of Taylor $\mathbf{}$. Best, 1854, 87 the lord chief justice said, "If

in refusing to permit its agent to testify, see Senate Ex. Doc. No. 21. 34th Congress, 3d sess. See also Halleck, i, 294; Calvo, §§ 583-4.

85 Rev. St. U. S., § 4063 ; Ex parte
Cabura, 1 Wash. C. C. 232 ; U. S. v. Lafontaine, 4 Cranch, C. C. 173. s6 De Jure Belli ac Pacis, II, c. $18, \S 9$.

8714 C. B. 487. 
an ambassador or public minister, during his residence in England, riolates the character in which he is accredited to that court, by engaging in commereial transactions that may raise a question between the govermment of Great Britain and that of the country by which he is sent, he does not thereby lose the general privilege which the law of nations has conferred upon persons filling that high character-the proviso in the statute of Anne limiting the privilege in cases of trading applying only to the servants of the embassy." In order that the conclusion thus reached should not be given too wide a construction Lord Campbell, in deciding the case of the Magdalena Steam Navigation Company v. Martin, 1859, 88 after upholding the doctrine laid down in Taylor $v$. Best, said "it certainly has not hitherto been expressly decided that a public minister duly accredited to the queen by a foreign state is privileged from all liability to be sued here in civil action."

$\S 307$. How envoy's personal effects may be subjected.-If the question be asked under what circumstances a civil liability may be enforced in the local courts against a public minister duly accredited, the answer can be made that while no such proceeding can bind the official property of the embassy or legation, including the hotel itself, its furniture and appurtenances, and the envoy's personal effects, carriages and the like, a proceeding taken in the proper form may bind other property held in the country by the minister in his private capacity. Such, for instance, as real property there held other than his hotel or dwelling; or such personal property as he may own as a private person or merchant engaged in trade or other business, or in a private fiduciary character as executor or trustee. ${ }^{99}$ As the minister does not hold such lands and groods by virtue of his office, and as they are in nowise necessary to its exercise, there is no reason why his diplomatic immunity should shelter them. Isut in any suit or seizure intended to bind them through the action of the local courts the fiction of the minister's exterritoriality must be kept up by proceeding against him in the form usually employed against any other absent person reputed to be out of the country. ${ }^{90}$

88 Ellis and Ellis, 111. See also Calvo, $\S 592$; Halleck, i, 285-7; Musurus Bey v. Gadhan, L. R. Hall, §50; Dana's Wheaton, Note (1894), 1 Q. B. 535.

*o Martens, Pricis, 216-7; Klüber, is exempt from arrest."

$\S 210$; Woolsey, $\S \S 91,92,96 ; 90$ "At the least, according to Heff- 
§308. How his civil immunity may end.-A minister's immunity from civil jurisdiction vanishes, of course, (1) when he waives it at the time of his reception; (2) when, with the consent of his government, he subsequently clothes the local courts with jurisdiction over him by voluntarily appearing before them either as plaintiff or defendant.91 In that event, if judgment is rendered against him, even on a counter claim, he must pay it. If judgment is rendered in his favor, and the other party appeals, he must submit to the appellate jurisdiction. A final judgment against him can be satisfied, however, only out of property which he possesses separate and apart from that exempt by virtue of his diplomatic character. $^{92}$

$\S 309$. Mr. Wheaton's notable case at Berlin. Tacit hypothecation not enforceable.-While the famous American publicist, Wheaton, was minister at the court of Berlin, the proprietor of the house in which he resided claimed the right to detain his goods found on the premises at the expiration of the lease, in order to secure the payment of damages alleged to be due, on account of injuries done to the house during the contract. The proprietor relied upon a section in the Prussian Civil Code, declaring that "the lessor" is entitled, as security for the rent and other demands arising under the contract, to the rights of a pfandgläubiger, upon the goods brought by the tenant upon the premises, and there remaining at the expiration of the lease." In the same code a right so secured was thus defined: "A real right, as to a thing belonging to another, assigned to any person as security for a debt, and in virtue of which he may demand to be satisfied out of the substance of the thing itself, is called unterpfandsrecht."93 If Mr. Wheaton had been a subject of the country there could not have been a

ter, no step can be taken towards an ambassador which can not be taken towards an absent stranger." Woolsey, § 91 . See, to the same effect, Bluntschli, $\S \S 138-140$; Vattel, iv, c. viii, § 115.

91 Vattel, iv, c. viii, § 111; Phillimore, ii, pp. 180, 217. With the consent of his government he may bring suit, and become responsible for costs.

92 When in 1720 the envoy of the Duke of Holstein was sued in Hol- land for a debt contracted in trade, a decree of arrest was granted against him, and all his goods within the jurisdiction subjected : $u$ the decree, except the movables belonging to him as ambassador, which were held to be exempt. Bynkershoek, De Foro Legatorum, c. xvi.

${ }^{93}$ Allgemeines Landrecht für die preussischen Staaten, Part 1 , tit. $21, \S 395$; tit. $30, \S 1$. 
moment's doubt as to the right of the landlord to seize and detain the goods either for unpaid rent or for damages, under the municipal law. The real question was as to the right of the proprietor as against a foreign minister who, as a general rule, can only be compelled to perform his contracts through an appeal to his own govermment. After an amicable settlement had been made of the damages claimed, and the goods returned, a discussion of the right in rolved took place between the two governments, in the course of which the United States distinctly admitted that if there had been an express hypothecation by a formal giving in pledge, implying a transfer of possession as security for a debt, there could be no doubt that the pawnee would have possessed such a real right as the Prussian Code contemplated, untrammeled by any diplomatic immunity whatever. In that event the privilege would have been waived. On the other hand, it was confidently maintained that where there is only an implied contract, or tacit hypothecation purely by operation of law, as in the case in question, the unwaived diplomatic immunity would prevent a distress for rent under the local municipal law. ${ }^{1}$ Bynkershoek, on the authority of Grotius, states that the goods of foreign ministers cannot be taken by way of distress or pledge $;^{2}$ and the act of Congress of 1790 expressly inchudes distress for rent among the legal remedies denied creditors of such ministers. ${ }^{3}$

$\S 310$. Immunity of minister's hotel and grounds.-The immunity that protects an envoy's residence, usually called his hotel, together with its grounds and ontbuildings, applies, no matter whether it is owned or rented by his government or himself or furnished by the state to which he is accredited. ${ }^{4}$ It is supposed to be his sanctuary within whose curtilege his family and suite, his diplomatic papers, his personal effects and equipages are beyond local interference or control. And yet despite the fiction of exterritoriality, more perfectly developed perhaps in this instance than any other, the fact remains that in certain particulars even the hotel is subject to local law. The state granting immunity necessarily reserves the power of self-defense, which it may rightfully exercise in the crent the enroy is implicated in actual conspiracy against it, either by ejecting him forcibly from the country, or by foreibly

1 For a complete statement of the matter, see Dana's Wheaton, $\S \S 228-240$.

2 De Jure Belli ac Pacis, II, c. 18,
$\S 19 ;$ De Foro Legatorum, c. viii.

3 See above, p. 339.

* Klüber, § 192, note. 
entering and searching his official abode.5 In the presence of such an emergency the personal and local immunities both disappear.

$\S 311$. Envoy must not harbor criminals not of his suite.Despite the practice that existed during the seventeenth and eighteenth centuries of misusing the hotels of diplomatic agents as asylums for criminals, through an extension to them of the right attached during the Middle $A$ ges to many sacred places, it is now settled in European countries that its abolition is the only rational answer to Bynkershoek's question:6 "Are ambassadors sent to harbor thieves?" If a criminal, not a member of the enroy's family or suite, takes refuge in his hotel the local authorities can demand that he be delivered up; and if the envoy refuses to comply the local sovereign has a clear right to ask his recall. Such was the course pursued by the Swedish king when the British ambassador at Stockholm, Mr. Guidekens, asserted the absolute right of asylum in favor of a merchant accused of crime who had escaped to his hotel.7 With so convenient and efficacious a remedy always at hand, it should not be claimed that in case of a refusal to deliver a criminal the local authorities have a right to make a forcible search and seizure within the hotel by the breaking down of doors and the like. ${ }^{8}$ Where a demand is made for the surrender of one over whose person or offense the envoy's country claims exclusive jurisdiction such enroy should, in case of refusal, either send the accused home for trial, or try him himself, provided he has jurisdiction to do so under the laws of his own state, coupled with the consent of the local sovereign that he may exercise it within his territory.

\$312. Right of asylum for political refugees in certain countries.-While the barbarous treatment often inflicted upon political offenders in Oriental countries, and the frequent revolutions that occur in the South and Central American states, seem to have established in those parts a custom in favor of

5 "It is equally agreed that this immunity ceases to hold in those cases in which a government is justified in arresting an ambassador and in searching his papers." Hall, § 52. See, to the same effect, Dana's Wheaton, Note No. 129, II.

6 De For. Leg., § 21.

7 Martens, Erzählungen, etc. i, 217-235. s Such, however, is clearly the law. Vattel, iv, c. ix, § 118; Klüber, § 208; Martens, Précis, § 220; Phillimore, ii, § cciv-v; Bluntschli, $\S 200$. As to the notable case of the Duke of Ripperda, who was taken by force in 1726 from the house of the English Ambassador at Madrid, under an order from the Council of Castile deciding "that 
the right of asylum for political refugees, the government of the United States has deemed it its duty to say, that, "though the privilege of asylum in Mohammedan states, as well as in South America, are more liberally dispensed than in the leading European states, they should be in all cases carefully guarded."

$\$ 313$. Immunity of envoy's residence defined.-Subject to the foregoing exceptions the general statement mat be made that while the exact limits of the inviolability of the hotel are not perfectly defined, a fair result of reasoning on principle and of a comparison of authorities is that the residence of the minister should enjoy absolute immunity from the execution of all compulsory process within its limits, and from all forcible intrusions. "If it can be rightfully entered at all without the consent of its occupant, it can only be so entered in consequence of an order emanating from the supreme authority of the country in which the minister resides, and for which it will be held responsible by his government."10

$\S 314$. Freedom of religious worship.-No matter what may be the creed of the state to which the envoy is accredited, he is entitled to freedom of religious worship in a private chapel in his own house, according to the forms peculiar to his nation, provided he makes no public manifestation of it, nor attracts attention to it by the ringing of bells, processions or other external rites. ${ }^{11}$ Since the time of the Reformation the Catholic and Protestant nations have mutually recognized this privilege either by convention or usage; and by like means it has been secured to ministers and consuls in Turkey and other Oriental states. ${ }^{2}$ In most countries the growing spirit of religious toleration has so widened the privileges as to permit cmbassies and legations to maintain public chapels, in which

he might be taken out of it, even by force," see Vattel, u. s., and Martens, Causes Cćl., i, 178, and ii, 52 .

9 Mr. Clayton, Sec. of State, to Mr. McCauley, May 31, 1849, MSS. Inst. Barb. Powers.

$10 \mathrm{Mr}$. Buchanan, Sec. of State, to Mr. Shields, Mar. 22, 1848. MSS. Inst., Venez.

11 Martens, Précis, \& 222-226; Klüber, $\S 215,216$; Ch. de Martens, Guide Diplomatique, $\S 35$.
12 There is no significance in the silence of Grotius upon this subject, because in his day a resident embassy was a novelty; it had not the sanction of ancient custom. Vattel was able to speak of the right, however, as one belonging to a public minister "by established custom in almost every country." Droit des Gens, iv, § 104 . He says "that a minister, and especially a resident minister, should enjoy the full exercise of his religion within 
natives of the same religion may freely unite with foreigners in the celebration of a common faith. ${ }^{13}$

$\S 315$. Exemption from general taxes. Liability for local dues. -It is usual to assert that the person of the envoy, his movables, and the property belonging to him as the representative of his sovereign are not subject to taxation. A far more exact idea of the exemption can be drawn, however, from the statement of Twiss, who says that "a foreign minister is privileged from being called upon to contribute personally to general taxes of a country; that is, to such taxes as are levied by the government, and which are available for the general purposes of the state, in which the ambassador is not interested. But a foreign minister is not exempt from the payment of local dues, which are raised for purposes of local administration, and which are expended on local objects, from which he himself, in common with his neighbors, derives immediate benefit. Thus he is liable to pay local rates assessed upon his hotel, or its site, for sewerage, lighting, watching and similar objects. He is also liable to pay tolls for the use of roads and bridges, and also for the carriage of his letters, if they are conveyed to him by the local post."14 Even the exemption from general taxes as thus formulated is not universally recognized. "When a foreign legation occupies rented property in this country, the owner of the premises is not exempted from all lawful taxes;" and "the rule observed by this government with respect to the taxation of property owned by a foreign government and occupied as its legation, is to accord reciprocity in regard to general taxation, but not to specially exempt it from local assessments, such as water rent and the like, unless it were definitely understood that these taxes would also be exempted by the foreign government upon a piece of property belonging to the United States and used for a like purpose by our minister."15

his own house, for himself and suite."

13 Calvo, i, p. 665; Dana's Wheaton, $\S 248$.

14 Law of Nations, I, § 203.

$15 \mathrm{Mr}$. Bayard, Sec. of State, to Mr. Woolsey, Apr. 15, 1886 . MSS. Dom. Let. Wheaton claims, too broadly, no doubt, that "the hotel in which he resides, though exempted from the quartering of troops, is subject to taxation in common with the other real property of the country, whether it belongs to him or to his government." Dana's ed., § 242. Phillimore (ii, 214) states the rule more reasonably when he says "the fiction of exterritoriality can not be applied to immovable possessions, and there is no doubt that they, with their incidents, remain sub- 
Exemption from customs dues.-As to immunity from customs dues, it is the usage of nearly all nations to permit the heads of all missions, temporary or permanent, of whatever rank, to import free of duty such articles as are intended for their private use or consmmption. While in some countries the privilege is limited to a certain amount, such amount is usually so liberal as to preclude the idea that any restriction is really intended.

\section{$\S 316$. Immunities of envoy's servants. Practice not uniform.} -As domestics and servants permanently employed about the person $\mathrm{or}^{*}$ premises of the envoy are to a certain extent exempt from the local jurisdiction, the municipal law often requires that a list of them be furnished the minister of foreign affairs so that the privileges to which they are entitled may be understood and respected by the local police. ${ }^{16}$ There is, however, no uniform practice among nations defining the precise extent to which such privileges ought to be recognized. Although the statute of Anne declares that all civil process against the servints of ministers, unless they are traders, shall be void, in criminal matters the British authorities claim the right of jurisdiction over them, if the offense with which they are charged is committed outside of the minister's residence. When, in 1827, a coachman of Mr. Gallatin, American minister at London, was charged before a magistrate with assault committed outside the legation, a warrant was issued under which the accused was arrested in his stable on the premises. After informal complaint had been made the British Foreign Office replied that the statute could not be so construed as "to protect the mere servants of ambassadors from arrest, upon criminal charges," and, in substance, that the premises of ministers are not entitled to inviolability. Nothing more was admitted than the fact "that comrtesy requires that their houses should not be entered without permission being first solicited in cases where no urgent necessity presses for the immediate capture of the offender." For that reason the magistrate was rebuked only for "the mode in which the warrant was executed in the

ject to the jurisdiction of the country in which they are situate. . . From this rule with regard to real property is to be exempted the actual dwelling-house of the ambassador, which is intimately connected with his personal invio- lability." That view is supported by Hall, ( $\$ 63$ ), and Calvo ( $\$ 529$ ). 16 Bynkershoek refers to the custom as one generally neglected in his time. Foro. Legat., c. 16 . The same statement would not be far from the truth at the present day. 
present instance."17 While the English practice is exceptional, it is entirely in line, with an attempt made at Munich in 1790 to draw a distinction between the actual members of a mission and those only in attendance on them, and to assert local jurisdiction over the latter as a matter of right. ${ }^{18}$ Before protection can be secured for a servant of a minister, in any event, the fact must be proven that he is not a mere appointee, but a bona fide nember of a diplomatic household, because it is only lis character as such that entitles him to immunity.19 Where the immunity is recognized, who can punish such a servant for crimes committed against the local law?

\section{$\$ 317$. Envoy's contentious jurisdiction no longer exists.-} There was a time when publicists claimed that an envoy possessed jurisdiction, both civil and criminal, over his suite; and upon that theory, in 1603, Sully, then Marquis of Rosny, French ambassador at London, assembled a council or jury of Frenchmen for the trial of one of his people who had killed an Englishman in a brothel. After the accused had been thus condemned to death and delivered to the English authorities for execution he was pardoned by James I.20 The voluntary side of such jurisdiction remains, but the contention has passed away, if it ever really existed. As Heffter has well expressed it: "The right of contentious jurisdiction is nowhere, within my knowledge, conceded to ambassadors at Christian courts, even for the persons of their suite; but they here simply execute requisitions directed to them, especially in regard to the hearing of witnesses, and all this according to the laws of their own country."

$\S 318$. Extent of voluntary jurisdiction.-By virtue of his voluntary jurisdiction, a diplomatic agent may still, in accordance with the forms prescribed by the laws of his own state, authenticate and legalize wills and other unilateral acts and contracts, affixing his seal and the like. It seems to be clear

17 Wharton, Int. Law Dig., § 94; Lawrence's, Wheaton (ed. 1863) 1006, 1007.

18 Martens (Précis, 219, and Causes Cél., iv, 20) regarded the distinction inadmissible, and it seems to have been inconsistent with usage.

19 It is not the minister who gives "protection;" it is the law that clothes his servants and domestics with a public character. 20 As the accused had been condemned by a tribunal constituted under the authority of his own country, the French claimed that the pardon was unauthorized. Ward, Hist. of the Law of Nations, ii, 527.

21 Völkerrecht, § 216. 
that such an agent may legalize contracts of marriage between members of his suite; and some writers claim that he may also legalize marriages between subjects of his state, other than members of his suite, when specially anthorized to do so by his sovereign. There is, however, no general custom compelling other states to recognize such marriages. Even in countries where the marriage of two foreigners may be solemnized, it seems that the marriage of a subject of the state with a foreigner in the house of his ambassador, according to the law of the foreign state, would not, as a general rule, be upheld. As evidence of the tendency in that direction reference may be made to the case of Morgan v. French, in which a marriage between an Englishman and a French subject, celebrated at the English embassy at Paris, was declared void by the Tribunal Civil de la Seine, ${ }^{22}$ and to the case of a marriage between an Austrian and an English woman. celebrated in English form at the English embassy at Vienna, annulled by the Supreme Court of Austria in $1880 .{ }^{23}$ There is, however, no well-defined rule upon the subject, which is involved in great confusion and uncertainty. ${ }^{24}$

$\S 319$. How accused servants should be dealt with.-Despite the general principle that the servant of an enroy cannot be made defendant in a civil suit or arrested on a criminal charge without his master's consent, when the local criminal law is broken the enroy must either arrest the offender and send him home for trial, or, what is the better course, if the case is not exceptional, surrender him to the local authorities for trial and punishment. In 1867 the Czar permitted a French court to try one of his subjects who had entered the Russian embassy at Paris and there wounded one of its attachés. ${ }^{25}$

$\S 320$. How an envoy's mission may terminate, with or without formal recall.-An enroy's mission may terminate through circumstances which may cause him to enter upon a new career at the same post, without a return to his own country. Such

22 Journal de Droit Int. Privé., 1874 , p. 72 .

23 Note to Gillespie's translation of Von Bar, p. 493.

24 For a more complete statement of the whole subject, see Lawrence, Commentaire, iii, 357-78; Stocquardt, in the Rív. de Dr. Int., 1888, pp. 260-300; Hall, p. 192, note 1 .
25 The French government refused to surrender the criminal upon the ground that the fiction of exterritoriality did not apply (1) because the accused Russian was not in the employ of the ambassador; (2) because the calling in of the local police was a waiver of the immunities of the residence. 
is the case when there is a change in his diplomatic rank; or when the death or abdication of his own sovereign, or of the sovereign to whom he is accredited, makes it necessary that he should be armed with fresh credentials corresponding with changed conditions. If there is a mere change of rank there must be a letter of recall to close the old career and a fresh letter of credence to define the new; if the envoy's sovereign dies or abdicates, it is usual, in monarchical countries, for a letter of notification ${ }^{27}$ of a continuance of his appointment to be sent by the successor of the deceased or deposed sovereign to the prince at whose court he resides; if the prince to whom he is accredited dies, new letters of credentials must be sent for presentation to his successor. ${ }^{28}$ In the United States, and other countries governed under republican systems, no change or interruption takes place in the functions of diplomatic agents either upon the death of the president, or at the expiration of his term of office and the inauguration of his successor. ${ }^{29}$ In the following cases the termination of the envoy's mission is absolute: (1) When the period fixed for the duration of the mission expires, or, when the return of the ordinary. minister to his post ends the term of a minister ad interim. In neither case is a formal recall necessary. Under this head may be classed special missions, whose objects have been attained or have failed; and mere missions of ceremony, when their purpose has been fulfilled. (2) When the envoy is recalled either through the voluntary action of his own government or at the special request of that to which he is accredited. In the first case, no matter whether the object of the mission has been

27 Calvo claims that while the accredited agent can be thus authorized to continue his functions, "he most assuredly needs new letters of credence to define and establish his position. It is by this fact relating to their representative character that ministers are always distinguished from consuls." Vol. 1, §§ 466, 470.

28 Martens, Précis, §§ 238-42; Heffter, § 223; Phillimore, ii, § ccxl; Dana's Wheaton, $\$ \$$ 250-251; Bluntschli, § 227-43; C. de Martens, Guide Diplomatique, c. ix. There is a difference of opinion as to the termination of a diplomatic mission by a change of government through revolution. On the one hand, it is claimed that the relations between the diplomatic agent and the new government may be regarded as informal or official at the choice of the parties without a fresh letter of credence. On the other, it is maintained that such a letter is specially necessary as a means of emphasizing the difference between a diplomatic agent and a consul. Practice appears to favor the latter view. Hall, p. 318. s9 The same is true in the event of the election of a new pope. Calvo, § 1367; Halleck, i, 304. 
accomplished or has failed, or whether the recall is the result of motives not affecting the friendly relations of the two governments, formal letters of recall must be sent to the enroy by his grovernment, copies of which he must present to the minister of foreign aflairs, asking at the same time an audience with the sovereign for the purpose of taking leave. At such audience it is expected that the envoy will present to the sovereign the original of his letters of recall with a formal address, or with informal remarlis appropriate to the occasion. If the recall is the result of a misunderstanding between the two governments, the circumstances of each case must determine whether or no a formal letter of recall is to be sent to the envoy; or whether he may quit the residence without waiting for it; or whether he is to demand of the sovereign an andience of leave. If, however, the recall is at the request of the government to which he is accredited, it is clear that the envoy would neither ask nor receive such an audience. ${ }^{30}$

$\S 321$. Dismissal of envoy before recall. Should not be capriciously sent away.-A sovereign at whose court an enroy resides may send him away without waiting for his recall, either by reason of acts of his govermment, or on account of his own misconduct. In the first event, it is usual for such sovereign to inform him by note that he desires to end all diplomatic intercourse with his government, at the same time presenting him with his passports. In the second, not only the dignity of the enroy, but that of his state is so involred that justice and courtesy alike demand that reasons should be given sufficient to warrant a proceeding of such gravity. In justice to itself the dismissing state should formulate the grounds upon which its action is based,-in justice to its agent the accrediting state should ascertain whether such grounds rest upon adequate proof. There is no reasonable foundation for the position assumed by Halleck, ${ }^{31}$ and reproduced by

30 No matter in what manner a mission is terminated, or the functions of its incumbent suspended, the diplomatic agent continues in possession of all his immunities until his return to his own country. Vattel, iv, c. $9, \S 126$; Martens, Précis, vii c. $9, \S 239$; Ch. de Martens, Guide Diplomatique, vii, $\S 59$, c. ii, § 15.
31 Int. Law, i, 307, resting mainly upon an opinion of AttorneyGeneral Cushing, which does not sustain the position. He also refers to Merlin, who merely says that "le souverain êtranger ile peut s'offenser si l'on prie son ministre de se retirer quand il a terminé les affaires qui l'avaient amené." 
Calvo, ${ }^{32}$ that a state is in duty bound to recall an envoy who has become unacceptable to the government to which he is accredited simply upon its statement that he is so; and that such state has no right to ask for reasons to be assigned why such enroy has become unacceptable since his reception as persona grata. Dana also falls into obvious confusion when he assumes that a dismissal or demand for recall may be rested upon the identical grounds upon which a state may object to receive a particular person in the first instance. ${ }^{33}$ After all special objections to the personality of an envoy have been waived by his reception, it is obviously unjust that he should be expelled and disgraced without a reasonable and provable cause. As Hall has fairly expressed it: "Courtesy to a friendly state exacts that the representative of its sovereignty shall not be lightly or capriciously sent away; if no cause is assigned, or the cause given is inadequate, deficient regard is shown to the personal dignity of his state; if the cause is grossly inadequate or false, there may be ground for believing that a covert insult to it is intended. A country, therefore, need not recall its agent, or acquiesce in his dismissal, unless it is satisfied that the reasons alleged are of sufficient grarity in themselves." 34 No more just or reasonable rule can be formulated as a standard by which the merits of particular cases of dismissal or forced recall, past or present, may be tested.

\$322. Notable cases of recall or dismissal. Case of Genet, 1793. -Washington gave an admirable example of the patience and moderation which should characterize such a proceeding when in 1793 the French minister, Genet, attempted to violate the neutrality of the United States by granting commissions to

\section{Droit International, § 439.}

33 "Although there be no misconduct that entitles the sovereign to dismiss him, still it is no just cause of offence if he object to a particular person as ambassador, on grounds short of misconduct, and merely for the reason that he is a person with whom, for whatever cause, diplomatic or personal relations can not be agreeably or advantageously maintained." Dana's Wheaton, Note 137.

${ }^{34}$ Int. Law, pp. 318-19. The government of the U. S. has, however, given its sanction to the view maintained by Halleck, Calvo and Dana. "The official or authorized statement that a minister has made himself unacceptable, or even that he has ceased to be 'persona grata, to the government to which he is accredited, is sufficient to invoke the deference of a friendly power and the observance of the courtesy and the practice regulating the diplomatic intercourse of the powers of Christendom for the recall of an objectionable minister." Mr. Fish, Sec. of State, to Mr. Curtin, Nov. 16, 1871. MSS. Inst. Russia. 
Ameriean citizens who fitted ont privateers manned by Americans to cruise against English commerce. Despite such proceedings, anglavated by an insolent correspondence in which the minister attempted to stir np Congress and the people ayainst him, the mesident did not insist upon Genet's recall until it becalne a necessity, in recognition of which the Provisory Council of the French liepublic demanded "the arrest of Mr. Cienet and all the other agents who may have participated in his faults and sentiments." 35

Case of Yrujo, 1804.-When in 1804 the recall of the Spanish minister, Yrujo, was demanded on account of an attempt made by him to bribe a I'hiladelphia newspaper to advocate the spanish view of the boundary question then in controversy with the United States, and his government consented with the proviso that he should be permitted to depart on the footing of a minister going home on leave, he was permitted to hover around Washington until $180 \pi^{36}$

Case of Jackson, 1809.-In 1809 the United States demanded the recall of the British minister, Jackson, primarily beeause he charged that the secretary of state, as an act of falsehood and duplicity, had conchded an agreement with his predecessor, Erskine, "in violation of that gentleman's instructions," which "were at the time, in substance, made known to you;" and, secondarily, because of continued offenses in the form of "toasts given by him at the public dimners at Boston." As the grovernment of the offending minister was not satisfied with the evidence offered to sustain the charge of misconduct, it only consented to the demand for recall, after recording the fact that "Ilis Majesty has not marked with any expression of his displeasure the conduct of Mr. Jackson, * * * who does not alyuar, on the present occasion, to have committed any intentional offense against the government of the United States." 37

Case in 1855.-In 1855 it was held by this government that a foreign minister who engages in the enlistment of troops here for his govermment is subject to be summarily expelled

35 Fauchet's letter to Mr. Randolpl, Sec. of State, Feb. 21st, 1794. Cf. Hildreth's Hist. of the U. S., iv, 439; Wharton, Int. Law Dig., $\S 84$.

36 Schouler's U. S. ii, 108; Whar- ton, St. Tr., 322; Int. Law Dig., $\S \S 84,106$.

37 Lord Wellesley's reply to Mr. Pinkney, 3 American State Papers (Foreign Relations), 355, ff; Lyman's Diplomacy of U. S., ch. i; 
from the country, or, after demand of recall, dismissed by the president. ${ }^{38}$

Case of Catacazy, 1871.- In 1871, "the conduct of Mr. Catacazy, the Russian minister at Washington, having been for some time past such as materially to impair his usefuluess to his own government, and to render intercourse with him for either business or social purposes highly disagreeable," an intimation was made to his govermment that "under the cilcumstances the president is of the opinion that the interests of both countries would be promoted and those relations of cordiality with the government of the Czar, of the importance of which he is well aware, would be plated upon a much surer footing, if the head of the Russian legation here was to be changed."39 As there was hesitation and delay in acceding to the request, upon the eve of the visit of a Russian grand duke, a second communication was sent saying "the president cannot be expected to receive as the principal attendant of his highness one who has been abusive of him and is personally unacceptable." $\neq 0$ Before the offending minister was finally withdrawn this government felt called upon to say that after it "has requested the recall of a foreign minister, if there be delay or difficulty in obtaining such recall, his passports, in case of continued misconduct on his part, may be sent to him forth with." +1

Case of Lord Sackville, 1888. - Shortly before the presidential election of 18s8, a person professing to be a British-born subject wrote to the British minister at Washington, Lord Sackville, asking him to adrise the writer "privately and confidentially" how he should vote, and to inform him whether in his opinion Mr. Cleveland would, if re-elected, pursue a policy friendly to England. Lord Sackville fell into the trap, and replied in a letter, promptly published, which made him at least technically liable to the charge of interfering in the internal affairs of the country. The further charge that he had spoken insultingly of the president and Senate to a newspaper reporter he repudiated entirely in a letter to the Secretary of State. Upon that state of facts his recall was demanded; and

Alison's Hist. of Europe, 10, 651. 387 Opinions of Attys. Genl. U. S., 367 .

$39 \mathrm{Mr}$. Fish, Sec. of State, to $\mathrm{Mr}^{2}$. Curtin, June 16, 1871. MSS. Inst. Russia.
40 Mr. Fish, Sec. of State, to Mr. Curtin, Aug. 18, 1871. MSS. Inst. Russia.

$41 \mathrm{Mr}$. Fish, Sec. of State, to Mr. Catacazy, Nov. 10, 16, 1871. MSS. Notes, Russia. 
when his govermment failed to comply, before it lad time to receive any explanation from him, he was given his passports and dismissed within three days. ${ }^{22}$

Case of Bulwer, 1848.-Equally precipitate action, but on far graver provocation perhaps, marked the dismissal of Mr. Bulwer, British minister to Spain, who, in 1848 , was given his passports by the reactionary government of Narvaez, with an intimation that he should quit Madrid within forty-eight hours, upon the ground that he had interfered with the internal affairs of the country, not only by involving himself with the opposing party, but by complicity in actual revolt. When the Spanish government failed to justify its charges Lord Palmerston responded by dismissing the Spanish minister at London. ${ }^{43}$

$\$ 323$. When mission is terminated by death of envoy.- When a mission is terminated by the deatl of an enroy, it becomes the dut $y$ of the first official of the embassy or legation to place seals upon his effects, and to make arrangements for the interment of tle body, or for sending it home, after all proper ceremonials and honors have been observed according to the custom of the place. Except in case of necessity the local authorities are not expected to interfere. While the personal immunities of the envoy necessarily end at his death, the courtesy of nations entitles his widow and family, together with their domestics, to the enjoyment for a limited time of the same immunities possessed by them during his lifetime. All questions as to the validity of the envoy's testament, as well as those respecting the succession ab intestato to his movable property, remain, of course, to be determined by the laws of his own country of which he dies a de jure resident. ${ }^{44}$

$\S 324$. Commissioners for special purposes not entitled to immunities.-Despite Heffter's views ${ }^{45}$ to the contrary commission-

42 Martens (N. R. G.) 2e Ser. xvi, 649; Parl. Papers, U. S. No. 4 (1888) and No. 1 (1889).

43 Calvo ( $\$ 581$ ) charges that $\mathrm{Mr}$. Bulwer was actually implicated in the insurrectionary movement; but Hall (p. 321, note 1) clain:s that the State Papers, 1848, entirely disprove the accusation.

44 Phillimore, ii, \$ 242. The envoy continues subject to the laws of his own country as to all that concerns his personal status and property. Grotius, De Jure Belli ac Pacis, II, c. $18, \S \S 4,5$. He preserves his domicil in his own country as a necessary consequence of the fact that his functions are determinable at the will of his sovereign. He can not, therefore, have the intention of residence.

${ }_{45} \mathrm{He}$ claims that they have $\mathrm{a}$ right to the "prérogatives essen- 
ers appointed under treaty stipulations for special purposes, such as the arrangement of a military evacuation or the delimination of a frontier, are not entitled to diplomatic immunities. So distinctly is that fact recognized that when a commissioner of Great Britain, under the sixth article of the treaty of amity, commerce and navigation, made between that power and the United States in 1794, was tried for an offense against the local law by a court sitting at Philadelphia, his government made no complaint whatever. ${ }^{46}$ Such functionaries are, however, entitled to special protection and courtesy, and perhaps to something more, if circumstances should arise demanding it. No very distinct practice has been developed as to their treatment. ${ }^{47}$

$\S 325$. Judge consuls and consuls a l'etranger.-The judge consul, whose office was reproduced in the chief maritime cities of South Europe after its first appearance at Barcelona, in 1279 , was originally a local officer annually elected by the mercantile community to settle disputes between such community and foreign merchants in matters of commerce and navigation. ${ }^{48}$ As the interests of commerce widened, the primitive system of domestic consuls gave place to the existing system of consuls à l'étranger, appointed not by the resident body of merchants in each city but by foreign states, who commis. sioned them to look after the commercial interests of their citizens. Consuls of the new type, whose existence dates from the sixteenth century, were never charged with the conduct of foreign affairs,and for that reason were never endowed with a diplomatic character.

$\S 326$. A consul's quasi-international character.-And yet while a consul is thus primarily a state officer sent abroad to look after such interests of its citizens as affect foreign states only, remotely and indirectly, the fact that his functions are performed on foreign soil in an official house over whose portals he may place the arms of his country, and that any outrage upon him in his official capacity is a violation of international law, certainly clothes him with at least a quasi-interna-

tielles dues aux ministres publics." $§ 222$.

$4 \mathrm{Mr}$. Monroe, Sec. of State, to Mr. Harris, July 31, 1816. Wharton, Int. Law Dig., 93a.

${ }^{47}$ De Garden, Traité de Dip., ii, 13; Bluntschli, § 243; Hall, § 104.
48 The Consolato del Mare, one of the earliest compilations of rules for the decision of maritime and commercial questions, is considered to have been so called, as em. bodying the rules according to which the judge-consuls, estab- 
tional character. A copy of the commission he receives from lis own state is forwarded to the minister of state in the country in which he is to officiate, in order that an exequatur may be obtained for him, without which he cannot enter officially upon the exercise of his consular duties. From the time he is thus recognized he receives to a certain limited extent the protection of the law of nations. ${ }^{4 !}$

$\S 327$. His duties in that sphere-Passports- - is the chief duties of a consul as a state officer necessarily involve matters of a purely domestic character, with which international law has no concern whatever, reference need be mide only to such as bring him into direct or indirect relations with the officials of foreign states. Under that head may be classed the consular duties which make it the business of the commercial agent to collect information of an economic, commercial or political character; to use unofficially with the authorities of the country such influence as he mily have in behalf of his fellow citizens in need of it; to see that the laws of the state in which he officiates are properly administered when the rights or interests of such fellow citizens are involved, and to report to his own government through the proper diplomatic channel any failure in that regard; and to perform all necessary acts in relation to passports. As a general rule a citizen leaving his own country obtains from its government a passport which, so far as other states are concerned, is really no more than a certificate of citizenship with a description of his person, usually substantiated by his autograph. When such a document is presented at the frontier of a friendly foreign state it is usual for it to grant to the bearer the right of passing through in the form of a visé entered upon the document itself, in order to obviate the inconvenience which would result if an entirely new passport were demanded at the border's of every nationality.50 Each state determines, of

lished in the maritime cities of Spain, proceeded in determining the questions submitted to their decision." Twiss, I, § 206. See also Pardessus, Lois Maritimes, iv, 256, v, 108, 116 seq.

49 The rights and privileges cf consults rest on the general law of nations and on treaty. 1 Opinions of Attys. Genl. U. S., 378. The fiction of exterritoriality does not extend to them. Ibid., 7, 18. so "The theory and practice respecting passports to private citizens in time of peace seems to be this: each nation, as a part of its internal system, may withhold the right of transit through its territory. Permissions to foreigners to pass through are properly passports." Dana's Wheaton, note 124 . 
course, who shall give or receive its passports, and designates the officials at home or abroad, who shall have the authority to issue them. It is usual to grant to consuls the right to issue passports only to subjects of their own country living within the spheres of their consulates, and to put their visé upon the passports of foreigners going from such spheres to the countries to which such consuls belong. 51

\section{$\S 328$. Consular organization as a whole-Certain local exemp-} tions.-The consular organization as a whole is usually made up of consuls-general, consuls, vice-consuls, and commercial agents, who have no right to any foreign ceremonial or mark of respect, and no right to precedence except among themselves, according to the rank of the several states to which they belong. As mere commercial agents they possess neither the diplomatic character nor its consequent immunities either for themselves, their families, their houses or their property.52 And yet by comity they enjoy certain exemptions from local and political obligations as privileges incident to their official character as the duly appointed and recognized officers of foreign states. A consul cannot be arrested for political reasons; he is exempt from any personal tax and from having soldiers quartered in his house; he cannot be burdened with. such local obligations as might conflict with the discharge of his consular duties, such as service on juries, in the militia or even in a municipal guard. While his house, over whose door he may place the arms of his nation, is liable to domiciliary visit and search, the papers and archives of the consulate are, as a general rule, exempt from seizure or detention. ${ }^{53}$ If, in time of war, his house is in the midst of actual hostilities, it is usual for the combatants not to injure it by their fire, except in cases of urgent and manifest military necessity.

51 As to the functions and privileges of consuls, see Martens, Précis, iii, c. $3, \S 84$; De Garden, Traité de Dip., i, 315; Pinheiro-Ferrera, title, "Passport;" Heffter, §§ 244-8; Bluntschli, $\S \S 245-75$; Calvo, $\$ \S$ 442-500; Lawrence, Commentaire, i, $1-103$.

52 "Consuls are not diplomatic characters, and have no immunities whatever against the laws of the land, and hence they can be prosecuted for breach of neutrality laws." Mr. Jefferson, Sec. of State, to Mr. Gore, Sep. 2, 1793 . MSS. Dom. Let.

53 Calvo ( $\$ 484$ ) states that not many years ago the archives of the French consulate at London were seized and sold for arrears of house tax due from the landlord of the house occupied by the consulate. Lawrence (Rev. de Droit Int. $\mathrm{x}, 317$ ) states that in 1857 the archives of the $U$. S. consulate at Manchester, including flag, seal, 
$\$ 329$. A consul's local obligations.-Such privileges, conceded to consuls with the view of enabling them efficiently and safely to discharge their official duties, do not withdraw them either from the civil or criminal jurisdiction of the courts of the country in which they officiate. Leaving such privileges out of view, even consuls who owe no allegiance to the state in which they reside, and the sole object of whose residence is the discharge of their consular functions, possess only the ordinary personal exemptions and disabilities incident to aliens who are mere sojourners.54 If such consuls hold real property, engage in business and have a fixed residence in the country neither their consular privileges nor their official status so affect their property or trade as to change its national character.55 In the event a citizen of the country is commissioned by a foreign state as its consul he, like a nativeborn minister, accepted without conditions, is no doubt entitled from the time he receives his exequatur to the privileges necessary for the proper performance of lis official duties. He would not be entitled, of course, like an alien consul to exemptions incident to his personal status as an alien.

If a consul misbehaves himself by meddling in the political affairs of the country in which he resides, or by attempting to violate its neutrality, or by refusing to appear and give evidence before a court, or the like, his exequatur may be revoked, and he may be punished or sent out of the country at the option of the offended state. ${ }^{56}$

$\S 330$. Consuls not affected by political changes. - As a consul is not a diplomatic representative his official position is not supposed to be affected by political changes in the state in which he is acting. The sending of a person for the perform-

and arms, were seized for a private debt of the consul, and would have been sold if the amount due had not been paid by the American minister at London. Hall (p. 335, note 2) says there is no foundation for either story.

542 Opinions of Attys. Genl. U. S., 725. A foreign consul in the U. S. possesses, however, the privilege of being sued only in a Federal court, a privilege which belongs not to him personally but to the sovereign he represents. Du- rand v. Halbach, 1 Miles (Phila.), 46.

55 Consular privilege cannot protect a consul as to mercantile affairs engaged in by him outside of his official business. Kent, i, 44, 62; Phillimore, ii, 335; Arnold v. Ins. Co., 1 Johns., 363; Griswold v. Ins. Co., 16 Johns., 346; Indian Chief, 1 C. Rob. (Admr.), 26; Wharton, Int. Law Dig., § 120.

56 Coppell v. Hall, 7 Wallace, 542; 2 Opinions of the Attys. Genl. U. S., 725. 
ance of consular duties into a given territory does not necessarily imply a recognition of the govermment of such territory, if its legitimacy is at the time in question. If the form of governmeut of a state is changed, or if that part of it in which the consul resides is annexed to another, no new exequatur is required. No such demand was made of consuls within the limits of the Confederate States, appointed before the outbreak of the civil war, who continued to exercise their functions during its continuance. ${ }^{57}$

$\S 331$. Consuls clothed with judicial and diplomatic functions by treaty.-Within the last forty years a long series of treaties has been concluded between states recognized as members of the family of nations for the purpose of re-defining and somewhat enlarging the privileges and duties with which consuls were originally clothed by custom, especially such as relate to the manner in which their evidence is to be procured by courts, and to the infractions of territorial law for which they may be tried in local tribunals. ${ }^{58}$ In their efforts to withdraw their citizens from the jurisdiction of local magistrates in Mohammedan and other non-Christian states, not fully within the pale of international law, the civilized nations have so extended and developed the office of consul, by special conventions, as to give it in those parts a dignity and importance entirely abnormal. The general purpose of such arrangements may be defined to be the clothing of consuls with both diplomatic and judicial functions where exceptional powers and immunities are made necessary by the absence of stable and responsible local government. For instance, "all Christian nations refuse to the gorernment of Horocco any right, power, or control whatever, in any circumstances, over the persons or property of Christians, or Franks, as they are called, residing in that empire." 59 While in Morocco every

57 In 1823 consuls were appointed by Great Britain to the South American Republics, and their governments informed that such appointments were made for the protection of British subjects, and for the collection of information that might lead to the establishment of friendly relations. Not until eighteen months thereafter was any one of such republics recognized as a state.
58 As examples, see the treaties made between France and Italy, 1862 (Martens, N. R. G., 2e, Ser. i, 631), North German Confederation and Spain, 1870 (N. R. G., xix, 21), Germany and the United States, 1872 (N. R. G., xix, 21), Germany and Russia, 1874 (N. R. G., 2e, Ser. i. 233), United States and Italy, 1878 (Id., iv, 272).

$59 \mathrm{Mr}$. Seward, Sec. of State, to 
citizen of the United States is required to seek from the consul a certificate showing that he is under his protection. Is the several conventions differ as to details a special study must be made in order to ascertain just what provisions prerail in any given district. Looking at the matter from a diplomatic point of view, whenever a consul is appointed chargé d'affaires he has a double politieal capacity; and thongh invested with full diplomatic privikeges, he becomes so inrested as chargé, ${ }^{60}$ not as cousul, the consular character beingr necessarily subordinate to the diplomatic.

$\$ 332$. Extension of judicial side of consular office.-It is, however, on the judicial side that the consular office has received the widest extension through the new system of conventions. Reference has been made already to the judicial powers vested in British consuls and ofher officers in the East under the Foreign Jurisdiction Acts, enacted to give effect to the "power and jurisdiction within divers countries and places out of Her Majesty's dominions," secured "by treaty, capitulation, grant, usage, sufferance, and other lawful means." 61 A variety of Orders in Council have been made nnder the authority of these acts regulating the procedure in such exterritorial courts, special reference being male to those existing in China, in the Western Pacific Islands, and in various parts of the Turkish Empire, including the courts at Constantinople and in Egypt.62

\section{\$333. Consular courts in Egypt-Reformed Tribunals of 1875.} --The creation of such courts in the country last named went on until there were sixteen or seventeen consulates exercising jurisdiction, civil and criminal, over the subjects of their respective nations, in addition to the native tribunals. In all civil and commercial matters the general rule was that the defendant should be bronght, before his own tribunal in accordance with the maxim actor sequitur forum rei,-the native before the native tribunal, the foreigner before the tribunal of his consulate. In criminal matters it was also the general rule that the subjects of the local sovereign who rommitted crimes against those of a foreign state were to be dealt with by the local tribunals, while the subjects of each

Mr. McMath, Apr. 28, 1862. MSS.

Inst. Barb. Powers.

60 7 Opinions of Attys. Genl. U. the Crim. Law, ii, 59. S., 342 . 
foreign state committing crimes against natives had the right of trial in, or protection from, the consular courts of their own nation. When a foreigner committed a crime the local police had no authority to arrest him unless he was caught in the act; and after his arrest the investigation was made before his consul, who, if the erime was grave, was bonnd to send him lome for trial. In order to remove the confusion and police demoralization resulting from such a condition of things ${ }^{63}$ an International Commission, in which were represented Great Britain, France, the United States, the North German Confederation, Russia, Austria-Hungary, Italy and Esypt, met at Cairo, in October, 1869, to consider certain reforms in the administration of justice proposed by the gorernment of the last named; and, after prolonged negotiations, the old consular system was finally superseded by the Reformed Tribunals established by order of the Khedive in June, 1875, with a mixed staff of judges composed partly of natives and partly of foreigners, the latter being always in the majority. The new arrangement, to which all of the more important powers, including the United States, have assented, consists of three courts of first instance at Alexandria, Cairo, and Zagazig, with a superior court of appeal at Alexandria, the jurisdiction and procedure of them all being regulated by codes drawn up for that purpose. ${ }^{64}$

63 The inefficiency of the then existing system was explained in a report drawn up in 1876 by Nubar Pasha, and communicated to the Powers.

64 "The institution of these courts is indeed the turning-point of recent Egyptian history. . . New Codes, to be administered by the courts came into operation on the 18th October, 1875, and the courts themselves were opened for business on 1st January, 1876. The powers of the courts, originally granted for five years, have been prolonged, by a series of decrees, to 1st February, 1882, to the 1st February, 1883, to 1st February, 1884, and lastly to 1st February, 1889." Holland, European Concert in the Eastern Question, pp. 102-3. Like decrees have been made since the last date given. For the text of "Réglement d'organisation judiciare pour les procès mixtes en Égypte," see Annuire de l'Institut de Droit International, 1877, $\mathrm{p}$. 321. 


\section{CHAPTER V.}

TIE TREATY-MAKING POWER.

§334. Ancient international law conventional-Religious leagues.-The weight of learned opinion upholds the conclusion that there existed in the ancient world no clearly defined or generally reconnized law of nations apart from that derived from prositive conventions. As Mitford has expressed it: "It appears to have been very generally held among the Greeks of that age, that men were bound to no duties to each other without an express compact." 1 Death or slavery was to be expected by the conquered unless there was an express stipulation to the contrary. ${ }^{2}$ Such was the natural outcome of a condition of political and religions exclusiveness in which first the tribe and then the state taught each of its members to believe that the natives of other states who worshipped unknown gods were unclean beings, natural foes. ${ }^{3}$ The first effort to admit the stranger into political fellowship was through the making of leagues recognizing a common divinity in whose honor a libation of mixed wines was poured out by the contracting parties with the prayer that he who first violated the compact might have his blood poured out in like manner.* To that class of leagues, whose primary purpose was purely religious, belonged the early compacts providing incidentally for freedom of commerce and for hospitality to strangers."

$\$ 335$. A fully matured treaty system in Greece.-An effort has been made already to emphasize the fact that the commerrial communities in Greece so far farored the admission of peaceful aliens within their walls as to enter into international conventions providing for the mutual administration

1 Hist. of Greece, i, c. 15 , § 7.

2 See above, p. 11.

3 "The Roman dominion, giving to many nations a common speech and law, smote this feeling on the political side; Christianity more effectually banished it from the soul by substituting for the variety of local pantheons the belief in one God, before whom all men are equal." Bryce, Holy Roman Empire, 88 .
4 Homer, Il., III, 300.

5 As to the real nature of the Delphic Amphictyony, whose primary purpose was religious, and whose political action was incidental, see above, p. 13. At a later time the advocate of King Perseus declared to the Achæn Assembly that "no person seeks to induce you to enter into any new alliance which will embarrass us, but only into an agreement which will se- 
of justice to resident foreigner's, for the establishment of mixed tribunals, or even for the grant of isopolity. ${ }^{6}$ The outcome of such efforts to provide for closer relations between the members of its various communities, and to preserve the internal equilibrium of Greece was a fully matured treatysystem which, for a long period of time, was in full operation. In that way the art of treaty-making was highly developed in Greece, and there can be but little doubt that the respect entertained for obligations imposed by intermational agreements was quite as great as that existing in modern times.

\$336. Collegium Fetialium at Rome.-The principal duties inposed upon the Collegium Fetialium at Rome related to the solemnities with which war was proclaimed and concluded, and to the process through which treaties and alliances were entered into, and general negotiations conducted. ${ }^{7}$ By the Roman lawyers all international compacts were dirided into three classes: 1 , pactiones; 2 , sponsiones; and 3 , fadera. ${ }^{\mathrm{S}}$ At a

cure to each party freedom of commerce and reciprocity of right."

6 See above, pp. 11-12.

7 See above, p. 24 . The Collegi$u \mathrm{~m}$ is "said to have been founded by Numa, and to have derived its origin from the Egyptians through the Greek colonies." Prof. H. Brougham Leech, Essay on Ancient Int. Law, p. 18. The oldest text of a treaty now in existence is that of a treaty entered into between Ramses II., King of Egypt, and the Prince of the Kheta.

8 " (1) Those of the first order (Polyb. iii. 22; Liv. xxxviii. 38) provided that the two states should, if possible, not engage in war with one another, and contained regulations as to the sojourn of the citizens of each on the territory of the other (Liv. xxx. 37, xxxvii. 30, xxxviii. 38 ). (2) Treaties of the second class bargained for greater intimacy between the two states, and bound the superior power to give aid if called upon (Caes. B. G. i. 31). Those (3) providing for military assistance sometimes placed the parties on an absolute equality
(Liv. 34,57 , xxviii. 45, xxvi. 24 ) ; in other cases the socius was subordinated to Rome (Cic. Balb. 16, 35 ) ; it remained free, but practically was at Rome's orders, as a client at those of his patron, though the Romans admitted their obligation to afford full protection (Liv. $\mathrm{xxx}$. 42; Caes. B. G. i. 43), and included the socius in their own treaties with neighboring peoples (Liv. xxx. 37, xxxviii. 11, 38)." See "Concise Dictionary of Greek and Roman Antiquities," based on Sir Wm. Smith's larger Dictionary. Henry Holt \& Co., 1898. See also MacKensie's Roman Law, 6th ed., p. 205; Salkowski's Roman Private Law, Whitfield's trans. It may be said that pactiones were merely agreements more or less formal; that sponsiones were treaties formed by ceremonies of a religious character and having the sanction of an oath; that foedera were leagues or treaties of alliance under which the allied community could acquire some rights that even the Romans would feel bound to respect. 
very early day it became the special business of the College of Heralds to determine the conditions, and to prescribe the forms, under which the Roman people could denounce treaties and declare war without incurring the anger of the gods. The statement may, therefore, be made without exaggeration that certainly the most solemn and potent part of ancient international law was that which rested upon positive compacts or conventions.

$\S 337$. Apart from compact, no positive international code.While it is undoubtedly true that the pares of Thucydides and Cicero clearly recognize the fact that, outside of such binding documents as treaties, there were certain usages and customs, sanctioned by time and general acceptance, and tending in the direction of justice and humanity, the fact remains that they were too vague and ill-defined to constitute a positive code of international morality. ${ }^{9}$ Down to the end of the eighteenth century the Mohammedan world in its dealings with the Christian nations of Europe likewise proceeded upon the principle that there was no other law of nations than that derived from positive compacts or conrentions. ${ }^{10}$

$\S 338$. The modern common law of nations.-Modern international law has been defined to be the aggregate of rules regulating the intercourse of states which have been gradually evolved out of the moral and intellectual convictions of the civilized world as the necessity for their existence has been demonstrated by experience.11 In that mass of rules, occupying a province half way between the province of morals and that of positive law, such as are expressly defined by treaty are only an element, and in fact a subordinate element,for the reason that their stipulations are void whenever they conflict with that higher law lecognized by the consensus of nations as the embodiment of certain fundamental principles with which no treaty can be in conflict. That higher law, upon which the validity of all treaties depends, is generally known as the common law of nations, to distinguish it from the more precise rules defined in particnlar conventions. The attempt has been made heretofore to describe the sources from which that higher ol common law has been draw wh, and the processes through which the elements thus derived have been blended

9 See above, pp. 16-17.

10 "At the commencement of the present century it would not have been incorrect to have described those relations as resting solely on compact." Twiss, I, $\S 61$, citing Lord Stowell's judgment in the Madonna del Burso (1804), 4 C. Robinson's Adm. Reports, 172. 11 See above, p. 86. 
in the existing international system which the Peace of Westphalia made possible. ${ }^{12}$

$\S 339$. All treaties void or voidable that conflict with it.-In the light of the foregoing statement it will be less difficult to understand how it is that every treaty is void, or at least voidable, that conflicts with certain principles which established usage has fixed as the foundation stones of modern international polity. Such principles are those which forbid the domination of the entire world by a single power; the acquisition of proprietary rights over the open sea; the subjugation or partition of a state, unless its existence is entirely incompatible with the general security; the imposition by treaty of conditions inconsistent with the existence or development of a state, and the acquisition by treaty of rights previously vested in other states. As international law regards states as moral beings, subject to all the obligations ineident to them as such, a compact for the establishment of the slave trade would also be void, because in conflict with the general principle in favor of human freedom which the consensus of civilized states has recently recognized. As the tendency is to apply as far as possible the analogies of private law, when the validity or construction of international compacts are in question, it may be said that just as private contracts are void when contrary to public policy as defined in municipal law, so are the first named when in conflict with public morality as defined in international law.

$\S 340$. Treaties and agreements not subjects of international law.-Before attempting to classify such treaties and agreements as are admitted to be subjects of the law of nations, it will be convenient to eliminate such as are excluded from that category, although a state,or one of its organs, may be a party thereto in an individual capacity. Only those compacts can be considered interuational which are entered into by one independent state with another, or others of its class, in conformity with law. Tested by that rule the following agreements cannot be considered as international: (1) Contracts entered into between a state and a private individual for a loan or the like; (2) agreements entered into between a state and the church for the regulation of matters religious or political, such as the concordats of certain states with the pope, who executes them not as a temporal prince, but as the head of the Catholic Church; (3) agrecments between reigning families or

12 Part II, entitled "Sources and Foundations of Modern International Law." 
dynasties regulating matters of succession or the like. ${ }^{13}$ For instance, a family compact for mutual support, or a special agreement to seat a prarticular prince upon the throne and to guarantee his possession as a safeguard against internal revolution, the motive being the advancement of personal as dis. tinct from strictly international interests. Such arrangements, which expire with the deatle of the sovereign or the extinction of his family, if not sooner ended by their own terms, are often described by the text-writers as personal treaties in contradistinction to real ones ${ }^{14}$ that continue to bind the state regardless of changes in its internal constitution or in the persons of its rulers.

$\$ 341$. Treaties as classified by Vattel, Martens and Calvo.Despite the various forms of classification to which treaties and conventions have been subjected by the leading publicists, it is difficult to find one at once simple, comprehensive and practical. Vattel, for example, divides them into personal treaties, expiring with him who contracts them, and real treaties, binding the state permanently; and into equal treaties "in which the contracting parties promise the same thing or things that are equivalent," and unequal, "in which the allies do not reciprocally promise to each other the same things, or things equivalent." 15 Martens, after repeating such divisions, speaks of transitory conventions, perpetual in their effects; treaties properly so called, stipulating for the performance of successive acts dependent on the continued life of the state and other contingencies; and mixed treaties, partaking of the nature of both. ${ }^{16}$ Calvo,-after dividing treaties with reference to their nature into personal and real, in reference to their form into transitory and permanent, and in reference to their effects into equal and unequal, simple and conditional,--finally classifies them with reference to their objects into treaties of guarantee, alliance, neutrality, boundary, cession, jurisdiction, commerce, extradition. ${ }^{17}$

13 Bluntschli, § 443 ; Hall, p. 339 , note 1 ; Dana's Wheaton, $\$ \S 29,275$.

14 Grotius, De Jure Belli ae Pa. cis, II, c. $16, \S 16$. "The former," says Puffendorf, "are such as are made with the prince purely with relation to his person, and expire with him; the latter are such as are made with the kingdoms or commonwealths, rather than the prince or government, and these outlive the ministry and the government itself, under which they were first made." De Jure Naturae et Gentium, VIII, c. $9, \S 6$.

15 Droit des Gens, II, c. XII, \$\$ 183, 172, 175.

16 Précis, § 58-62.

17 Droit International, $\S \S 643-68$. 
\$342. All real treaties divisible into two classes. Executed conventions.-As personal treaties have been excluded already from the domain of international law proper, the task of classification is limited to real ones which bind states as such. If the artificial and unfruitful terms, "equal," "mnequal," and "mixed" are then discarded as confusing, all treaties properly so-called, binding states in their corporate capacity, may be divided into two classes: First, those which, having been executed once for all, are intended to be perpetual in their effects, regardless of changes in the sovereignty and form of government of the contracting parties, because their objects are fully attained. While the operation of such peruanent settlements may be suspended during war, they revive upon the return of peace, proprio vigore. To that class belong treaties containing recoguitions of independence, settlements of boundaries, cessions, exchanges of territory, and grants of permanent servitudes ${ }^{18}$ in favor of one nation within the territory of another. The perversely inapt and misleading term, "transitory," generally used to describe perpetual treaties of the class in question, should be discarded for the term "executed," which, when taken in the sense given it in English private law, perfectly expresses the idea.

$\S 343$. Executory conventions.-A private contract, as defined by Chief Justice Marshall, "is a compact between two or more parties, and is either executory or executed. An executory contract is one in which a party binds himself to do, or not to do, a particular thing. ** A contract executed is one in which the object of the contract is performed; and this, says Blackstone, differs in nothing from a grant."19 After such treaties as have been carried into immediate effect and their objects so performed as to leave nothing for future action are grouped in the first class, as executed conventions, all that remain may be ranged in the second, as executory, because they stipulate for the performance of successive acts to be continued through a period of time, limited or unlimited. All such agreements as thus fall in the second class may be conveniently described with reference to their objects as treaties of alliance, neutrality, guarantee, commerce, extradition and the like. While it of ten happens in practice that a single compact between two or more states embraces articles belongSee also Heffter, $\S 89$; Twiss, I, 12, § 192; Martens, Précis, II, c. 2, §§ 228-232.

$\S 58$.

18 Vattel, Droit des Gens, II, c. ${ }_{19}$ Fletcher v. Peck, 6 Cranch, 136. 
ing to both classes, there is no reason why confusion should thereby result. The validity and construction of each article must be tested by the rules relating to the class to which it belongs, regardless of the fact that it happens to be united in the same paper with others of a different eharacter.

$\$ 344$. Executed conventions as defined by Master of the Rolls, 1830.-The permanent character of executed conventions was clearly recognized by the English and American courts in cases involving the effects of the war of 1812 upon the treaty of peace of 1783 between Great Britain and the United States, in which the independence of the latter was acknowledged, and future confiscations prohibited; and upon that of $\mathbf{1 7 9 4}$, between the same parties, in which the titles of American eitizens holding lands in Great Britain and of British subjects holding lands in the United states, that might otherwise have been forfeited for alienage, were confirmed. When the question arose in the Rolls Court in 1830 whether or no the rights of American citizens who held lands in Great Britain on the 28th day of October, 1795,-rights expressly guaranteed by article nine of the treaty of $1794^{20}$ declared to be permanent,had been affected by the war of 1812, the Master of the Rolls held that "the privileges of natives being reciprocally given, not only to the actual possessor's of lands, but to their heirs and assigns, it is a reasonable construction that it was the intention of the treaty that the operation of the treaty should be permanent, and not depend upon the continuance of a state of peace. The Act of 57 Geo. III, c. 95, gives full effect to this article of the treaty in the strongest and clearest terms."'21

$\$ 345$. By Supreme Court of U. S., 1823.-When in 1823 the same question came before the Supreme Court of the United States, in the case of a certain foreign corporation whose right to hold lands in Vermont was denied "on the ground of alienage, and that its rights are not protected by the treaty of peace," the court said it was "not inclined to admit the doctrine urged at the bar, that treaties became extinguished, ipso facto, by war between the two governments, unless they should be revived by an express or implied renewal on the return of peace. * * There may be treaties of such a nature, as to their object and import, as that war will put an end to them; but where treaties contemplate a permanent arrangement of territorial and other national rights, or which, in their terms, are meant to provide for the event of an interven-

20 Martens (R.), V, p. 662.

21 Sutton v. Sutton, 1 Russell \& Mylne, 663. 
ing war, it would be against every principle of just interpretation to hold them extinguished by the event of war. If such were the law, even the treaty of 1783 , so far as it fixed our limits, and acknowledged our independence, would be gone, and we should have had again to struggle for both upon original revolutionary principles. * * We think, therefore, that treaties stipulating for permanent rights, and general arrangements, and professing to aim at perpetuity, and to deal with the case of war as well as of peace, do not cease on the occurrence of war, but are, at most, only suspended while it lasts; and unless they are waived by the parties, or new and repugnant stipulations are made, they revive in their operation at the return of peace." 22

$\S 346$. Revival of permanent servitudes.-While executed conventions creating permanent servitudes in faror of one state within the territory of another, such, for instance, as a right of way over its territors, are suspended during war, they also revive with the return of peace without the aid of a new agreement. The term servitude, borrowed from the Roman law, signifies only an innocent use as distinguished from a right. To convert the former into the latter the jurists held that it was necessary to obtain a compact or stipulation to that effect. ${ }^{23}$

$\$ 347$. Treaties of alliance-offensive and defensive.-By the provisions of executory conventions, such as treaties of alliance, guarantee, neutrality, commerce, jurisdiction, arbitration, extradition and the like, involving the performance of successive and neutral acts, the intercourse of states is now chiefly regulated. First on the list requiring special notice are treaties of alliance, which may be either offensive or defensive, or both. ${ }^{24}$ In the first, the ally usually agrees generally to

22 The Society for the Propagation of the Gospel in Foreign Parts v. The Town of New Haven, 8 Wheaton, 464. The weight of authority supports the conclusion that, as a general rule, treaties at most are only suspended by war, unless their terms imply a continuance of peace, or the reason for their existence is destroyed by war. Cf. Kent, Com. I, 176; Phillimore, pt. XII, c. 11 ; Kluber, $\S 165$; Halleck, 371, 862; Heffter, $\S \S 122$ and 180-1; Calvo, § 1687; Bluntschli, §
538; Hall, § 124-5. However, Twiss (I, § 234) says "that Great Britain in practice admits of no exception to the rule that all treaties, as such, are put an end to by a subsequent war between the contracting parties." Citing Lord Bathurst's letter of Oct. 30,1815 , to Mr. J. Q. Adams. American State Papers, 1834; iv, 354.

23 See above, p. 263 . For Klüber's interpretation of a servitude, see Droit des Gens, §§ 137-138. 2* Vattel, Droit des Gens, III, § 79 . 
co-operate in hostilities against some power specially named, or against any power with whom the other party may become involved in actual war. In the second, the ally is expected, as a general rule, only to co-operate in the defense of the other contracting power in a war really and truly defensive,-a war actually commenced by the common foe in the first instance. According to Grotius ${ }^{25}$ and other text writers the casus foderis of a defensive alliance does not arise in the case of an unjust war, that is, a war of aggression begun by the power who lias only stipulated for aid in another contingency. It is said a tacit condition is annexed to every treaty made in time of peace for co-operation in time of war that succor can only be expected in a just war, for the reason that the common law of nations forbids both parties to be accessory to acts either of injustice or bad faith. The difficulty in such cases is to determine what constitutes a just or defensice war, since certain wars, offensive in form, are actually defensive both in spirit and substance. 26

$\S 348$. Conflicting views of Great Britain and Holland, 1756.An elaborate discussion of that question arose ont of the conflicting views of Great Britain and Holland, during the war of 1756 , as to the true construction of the treaties of 1678 , 1709,1713 , and 1717 , - the last named having been renewed by the Quadruple Alliance of 1718 , and by the treaty of Aixla-Chapelle of 1748 . In these treaties each state guaranteed to the other all of their possessions and rights in Europe against "all kings, princes, republics and states," with a stipulation that each should give to the other certain specially defined succor in the event either should "be attacked or" molested by hostile act, or open war, or in any other manner disturbed in the possession of its states, territories, rights, immunities and freedom of commerce."27 After Great

${ }_{25}$ De Jure Belli ac Pacis, II, c. dangerous wrong is manifestly $15, \S 13$; c. $25, \S 4$; Bynkershoek, meditated, may prevent it by strikQuaest. Jur. Pub., I, c. 9; Vattel, Droit des Gens, II, c. 12, § 168; III, c. $6, \S 86-96$.

26 "Where attack is the best mode of providing for the defence of a state, the war is defensive in principle though the operations are offensive. Where the war is unnecessary to safety its offensive character is not altered because the wrong-doer is reduced to defensive warfare. So a state against which ing the first blow, without thereby waging a war in its principle offensive." Wheaton, § 285 . Dana in his comments on the text (Note 147) says, "this reasoning makes the words 'defensive war' substantially synonymous with justifiable war, or necessary war."

27 Charles, Earl of Liverpool's Discourse on the Conduct of the Government of Great Britain in respect to Neutral Nations, 1st ed., 
Britain's European possession of Minorca had been attacked by France the States-General refused the stipulated succor upon the ground that the casus foderis had not arisen, as the former was in fact the real aggressor. Holland, while admitting that France had been the aggressor in Europe, contended that that act was merely a consequence of hostilities previously begun in America, to which the treaties did not apply. The elder Lord Liverpool in replying to such reasoning contended (1) that, while the treaties in question were called defensive, they were not really such in substance when given that "fair and liberal construction, such as might be expected from friends, whose interests these treaties were supposed to have forever united;" that the framers of them knew "that an injured nation might be necessitated to commit even a preventive hostility, before the danger which caused it could be publicly known;" (2) that "the treaties above mentioned promise the defense of the dominions of each party in Europe, simply and absolutely, whenever they are attacked or molested. If, in the present war the first attack was made out of Europe, it is manifest that long ago an attack hath been made in Europe; and that is, beyond a doubt, the case of these guaranties." As the Dutch were unwilling to be convinced the English argument, cogent as it was, was entirely unavailing.

$\S 349$. Difference between a treaty of general alliance and one of limited succor.-At this point the distinction should be emphasized between a general alliance and one of limited succor and subsidy, in which one power, without binding itself to engage in general hostilities, engages to furnish to another a certain limited number of troops, ships of war, money or provisions. ${ }^{28}$ There was a time when a state could supply such auxiliary forces to one of the belligerents and still, in all other respects, remain neutral. Such was the attitude of the Swiss Confederation during the period in which it habitually supplied military contingents to the other European powers. ${ }^{29}$

$\S 350$. Treaties of guarantee.-Treaties of guarantee vary widely both as to their form and substance. In their simplest form they are mutual agreements in which one party for a consideration to the advantage of himself makes an assurance 1757. See also Dana's Wheaton, $\S \S$ $281,282,283$.

28 Vattel, Droit des Gens, III, c. $\mathrm{V}, \S \S 80,81,82$.

29 Both Great Britain and France at one time relied upon treaties of subsidy with certain of the Ger-

man powers in order to procure troops to carry on their wars. In 1793 the former concluded a treaty of subsidy with the Landgrave of Hesse-Darmstadt, who undertook to furnish for three years a corps of 3,000 troops of all arms for 
to the advantage of another, as in the treaty of Tilsit, 30 whereby France and Russia guaranteed to each other the integrity of their respective possessions. In the same way all the contracting powers gave mutual guarantees at the peace of $\mathrm{Aix}$ la-Chapelle, in $1748,{ }^{31}$ and at that of Paris, in 1763.32 In the second place, guarantees mal be given by one or more parties for the benefit of a third, such as that entered into by France, England and Austria, April 15th, 1856, guaranteeing, "jointly and severally the independence of the Ottoman Empire recorded in the treaty concluded at Paris on the 30 th March." 33 In the same way the sorereignty and independence of Greece were guaranteed by Great Britain, France, Russia and Bavaria in a treaty entered into in $1832,{ }^{34}$ and the Protestant succession to the throne of England by the Dutch at the Peace $^{35}$ of Utrecht in 1715.

$\$ 351$. When guarantor can only intervene on demand of beneficiary.--When such a gluarantee is given by a single state, or by two or more severally, or jointly and severally, a guarantor can only intervene on the demand of the party or parties for whose benefit or protection the guarantee has been given, for the obrious reason that the beneficiary primarily interested in the arrangement is the best judge of his own interests. Only after the initiative has been taken by the beneficiary is the obligation cast upon the guarantor to render the stipmlated assistance; and then only when it does not conflict with the just rights of third parties, with prior treaty stipulations, or with the miversally recognized principles of international morality. ${ }^{36}$ If the promised assistance prove insufficient, the beneficiary has no right to call upon the guarantor for indemnity ${ }^{37}$ Such gruarantees are also limited to rights and possessions existing at the tine they were made. Upon that ground ${ }^{38}$ it was that Louis XV declared in 1741 against Maria Theresa and in faror of the Elector of Bavaria, despite the fact that in the treaty of Vienna, definitely signed service in any part of Europe, in accepted by Greece and the Ottoconsideration of an annual subsidy. man Empire.

Martens (R.), V, 524.

30 Martens (R.), VIII, 607, 661.

21 Wenck, ii, 310 seq.

32 Wenck, iii, 329 ; Martens (R.),

I, 104-166.

33 Martens (N. R. G.), xv, 770.

34 Martens (N. R.) . x, 550. According to the terms of a protocol signed by them, Feb. $3 d, 1830$, and
35. Second treaty of barrier ( 30 Jan. 1713). Schmauss, Corpus Jur., p. 1287.

36 Vattel, II, c. XVI, $\$ \S 236-9$; Klüber, §§ 157-9; Phillimore, ii, c. VII; Bluntschli, §430-41; Hall,.§113. 37 Dana's Wheaton, p. 355. ${ }_{38}$ "This reasoll is incontestably a good one, in the general view of it, and the only question at that 
in November, 1738, France had guaranteed the pragmatic sanction of Charles VI. constituting his eldest daughter the heir of the entire mass of the Austrian heritage. Like all other obligations of suretyship, such guarantees are strictly construed.

$\$ 352$. Collective guarantee to secure a common interest. Lord Derby's view.-In the third place, a guarantee may be given collectively by several powers in order to secure some general arrangement in which they have a common interest,-such, for instance, as that embodied in the treaties of 1831 and 1839 constituting Belgium an independent and neutral state. The guarantee given to Belgium was that she should be permitted to maintain that status, in consideration of which she bound herself to remain so for the common benefit of the contracting parties. In such a case one high authority maintains that when complaint is made it becomes the duty of all guarantors to examine the matter in common in order to ascertain whether or no there is good ground for intervention, so that a single conclusion may be supported by united action. If no such conclusion can be reached, then it is claimed that each guarantor has not only the right, but is charged with the duty, of taling alone such action as his judgment may dictate. ${ }^{39} \mathrm{~A}$ more limited view of the duties imposed by such a collective guarantee was taken by Lord Derby, who, when expressing the opinion of the English government as to the extent of the obligation assumed by it in signing the Luxemburg convention of 1867 , said in that year in the house of commons, "that in the event of a violation of neutrality all the powers who have signed the treaty may be called upon for their collective action. No one of those powers is liable to be called upon to act singly or separately. It is a case, so to speak, of limited liability. We-are bound in honour-you cannot place a legal construction upon it-to see in concert with others that these arrangements are maintained. But if other powers join with us it is certain that there will be no violation of neutrality. If they, situated exactly as we are, decline to join, we are not bound single-handed to make up the deficiency. Such a guaranty has obviously rather the character of a moral sanction to the arrangements which it defends than that of a contingent liability to make war. It would no doubt give a right to time was, whether the court of also Flassan, Histoire de la DiploFrance made a just application of it." Vattel, II, c. XVI, § 238 . See

matie Francaise, VII, 195.

39 Bluntschli, § 440. 
make war, but would not necessarily impose the obligation." 40

$\S 353$. Agreements in which guarantees are embodied.-Agreements in which guarantees are embodied appear either in primary and independent treaties specially made to maintain a certain state of things, or in auxiliary treaties; or in provisions accessory to a treaty so framed as to secure the performance of the stipulations of the principal engagement. Sometimes the faithful performance of treaties is guaranteed by the hypothecation of territories or fortresses; ${ }^{41}$ and formerly it was secured by the giving of hostages, the last example of which, apart from the giving of such security for the performance of military conventions, oceurred after the making of the Peace of Aix-la-Chapelle, 174s, when two British peers remained on parole at Paris until Cape Breton was restored to the French. ${ }^{42}$ Another ancient mode of confirming the faith of treaties, that by solemn oaths, intensified by certain religious ceremonies, is entirely obsolete. ${ }^{43}$

$\$ 354$. Commercial conventions. Reciprocity.-The treatymaking power now finds a wide field for its operation in the conclusion of conventions regulating the conditions of reciprocal trade, and defining the rights and duties of commercial intercourse. Such arrangements embrace not only the exchange of raw materials and manufactured articles, but also compacts for the reciprocal exchange of correspondence by post (such as that embodied in the Universal Postal Union entered into between the leading civilized states by virtue of article 18 of the treaty of Berne, 187-1); for the regulation of trade-marks; for the prevention of collisions at sea; and for the protection of the rights of anthors and artists in their literary works by means of international copyright. The prin-

40 Hansard, 3d Ser., clxxxvii, 1822. In criticising that statement Hall (pp. 361-2) says that "the only objects of a guarantee are to secure that action shall be taken under circumstances in which a state might not move for its own sake, and to prevent other states from disregarding the arrangement, or attacking the territory guaranteed, by holding up to them the certainty that the force of the guaranteeing powers will be employed to check them. On the con- struction given to a collective guarantee by Lord Derby neither end would be attained. Whichever view be adopted the word collective is inconvenient."

41 Klüber, $\$ 156$.

42 Vattel, II, c. XVI, \& 247; Ward, Hist. of the Law of Nations, i, 172175.

43 The most modern example, perhaps of the use of an oath for such a purpose occurred in connection with the alliance between France and Switzerland, 1777. 
ciple of reciprocity is, as a general rule, the dominating force in such agreements; and, in order to give effect to that principle, the most farored nation clause is usually inserted not only in commercial treaties but in literary and art conventions. It does not follow, however, that the mutual benefits stipulated are always equivalent. "The rule of the most favored nation may not be, and scarcely ever is, equal in its operation between two contracting parties. It could only be equal if the measure of roluntary concession by each of them to the most farored third power were precisely the same; but as that rarely happens, by referring the citizens of two contracting powers to such a rule, the fair competition between them, which always ought to be a primary object, is not secured, but, on the contrary, those who belong to the nation which has shown least liberality to other nations are enabled to engross almost the entire commerce and narigation carried on between the two contracting powers. The rule of the most farored nation is not so simple as the proposed substitute (that of a treaty of reciprocity, which Mr. Poinsett was instructed to negotiate)." 44 It has been held that a corenant to give pririleges granted to the "most farored nation" only refers to gratuitous privileges, and does not corer privileges granted on the condition of a reciprocal advantage. ${ }^{45}$

$\$ 355$. Treaties establishing special tribunals.-As explained heretofore the treaty-system of Greece embraced international conventions proriding for the administration of justice to the sojourning foreigner, and for the establishment of mixed tribunals. ${ }^{46}$ Such treaties of jurisdiction as have been made in modern times generally provide for the establishment of special courts for the settlement of such questions as may arise between foreigners not domiciled (transcuntes); or between such foreigners and the subjects of the country in which they reside; or for the exercise of jurisdiction orer the same classes of persons by consuls or commercial agents. Special courts of the type referred to existed at an early day under conventions entered into between Great Britain and Portugal ${ }^{47}$

$44 \mathrm{Mr}$. Clay, Sec. of State, to Mr. Poinsett, Mar. 26, 1825.

$45 \mathrm{Mr}$. Livingston, Sec. of State, to President Jackson, Jan. 6, 1832. Wharton, Int. Law Dig., § 134. 46 See above, p. 12.

47 "There was an analogous treaty of a later date between France and Portugal in regard to French subjects. But in case of a suit of a French subject against a British subject, the privilege granted to the British nation being the most ancient, the judge-conservator 
(1654), between Great Britain and Spain and between France and Spain; and the judge-conservator appointed to settle in them all questions arising out of commercial controversies between subjects of the respective states was required to administer the foreign law when it was specially involied. When, howerer, a natural-born subject of Great Britain or France acquired a domicil in Spain or Portugal he passed under the control of the local tribunals. Such special courts are the prototypes of the many foreign tribunals existing by treaty in Oriental lands, other than those which are strictly consular: ${ }^{4}$ Everywhere the consular court is now a recognized institution whose influence is being widened by an everswelling list of conventions whose tendency is to define with precision not only the exceptional powers, purely contractual, rested in consuls for the special protection of their countrymen in states outside the pale of international law, but also the older and more limited powers with which they were originally invested by custom in states within it. ${ }^{49}$

$\$ 356$. Treaties of arbitration; their growing popularity.Treaties of jurisdiction reach their ligher point when they embody agreements between sovereign states to submit their differences to arbitral tribunals, to whose final awards they bind themselres to bow with perfect loyalty. The constitution of every independent state embraces three factors known to national law as legislation, jurisdiction and execution. It has been well said that the ultimate problem of international jurisprudence is how to find in that sphere equivalents for those three factor's without which there can never be either an authoritative international code, or an international tribunal armed with power to assume jurisdiction over all disputes between states, and to enforce its decrees against such as are refractory. The only serious efrorts so far made to approatch such an ideal have been embodied in treaties of arbi-

of the British nation was held to be the competent julge." Twiss, I, § 157, citing Gazette des Tribunaux of 16 and 17 Oct., 1843 , cited by Fœlix, Traité du Droit International, I, \& 148. Reference has been made heretofore to the establishment at Rome of the court of the praetor peregrinus whose special duty it was to administer justice between resident foreigners not domiciled at Rome, and between resident foreigners and Roman citizens. See above, p. 21.

4. The international courts of Egypt, heretofore described, may be cited as an illustration.

49 See above, p. 359.

so Lorimer's Institutes of the Jaw of Nations, ii, 186 seq. 
tration whose growing popularity in our own time is certainly a hopeful indication. While the history of diplomatic intercourse discloses the fact that that method of settling international disputes was often resorted to before the present century began, it has been within that time that it has developed into real importance.

Their history-Ancient, medieval and modern.-When the high state of development to which the Greek treaty-system attained is taken into account, it would be strange, indeed, if we failed to find that states which constituted, through international agreements, such tribunals as have been heretofore described $^{51}$ for the settlement of disputes between their respective eitizens, should have failed to provide like tribunals for the settlement of disputes between themselves as corporate persons. While the data underlying such a conclusion is scanty, it is at least probable that all or nearly all of the political unions had courts of that character. Both Grote and Schömann believe that, from the beginning, the Athenian symmarehy had a common tribunal at Delos; and in the project of the fifty years' truce (B. C. 421) it was provided that the parties to the new alliance should be such independent states as would submit their disputes to arbitration. It is, therefore, maintained that between Greek states thus closely united, it was a rule of public law that war was not to be waged until after an unsuccessful attempt to arrive at a settlement by judicial means; and that, after the restoration of peace, all questions of interpretation were to be submitted to some individual or state on whom the parties could agree. ${ }^{52}$ Passing over the annals of the Roman Empire,-whose private law, as it stood in the time of Justinian, ${ }^{53}$ has supplied the form of arbitration and rules of procedure since adopted by sorereign and independent states,-we find Gerohus, at the beginning of the twelfth century, suggesting the application of that method of settlement to international controversies; and Leibnitz, at the end of the seventeenth, proposing the pope and the emperor as joint public arbitrators. In 1713 the Abbe St. Pierre came forward with a project to secure perpetual peace between the European powers, which was circulated shortly after the conferences that led to the Peace of Utrecht,

51 See above, p. 12.

52 See article on Arbitration in International Review for 1874; Schömann's Gr. Alterth., ii, 5.
53 The parties had then ceased to bind themselves by the penalty, at first the essence of the transac. tion. 
at which conference the Abbe was present. The aim of that project, more fully developed in 1729 , was to perpetuate the settlement embodied in the treaties of Utrecht through an alliance or league of Enropean states, which should renounce the right of war, and submit their differences to the arbitration of a diet representing twenty votes, three-fourths of which was to be final.it In 17si-89 followed the scheme of Jeremy Bentham, leretofore explained ${ }^{55}$ and in 1795 Immanuel Kant published his essay "touching perpetual peace" 56 in which he maintained that international law should rest upon a confederation of free states which should guarantee untrammelled intercommunication through the establishment of a world citizenship, under the direction of a congress to be called and dissolved at the pleasure of the members of the confederation. In 1838 the New York Peace Society, in a petition to the House of Representatives of the United States, proposed a board of international arbitration; and in 1842 James Mill went a step further by insisting, in a treatise, that delegates from the several governments should not only constitute an arbitral court, but should formulate a code for its guidance. In order to give practical effect to that idea, Darid Dudley Field published in 1872 "Outlines of an International Code," defining the constitution of "a High Tribunal of Arbitration;" Dr. Goldschmidt drafted in 1874 a complete code of "proposed rules for international tribunals of arbitration;" and the Institute of International Law, at its meeting at The Hague in 185, adopted a scheme of arbitral procedure. ${ }^{5 \pi}$ The efforts thus made to advance the cause of arbitration on its theoretical side have been more than equaled during recent years by the efforts to give to principles thus defined practical application. A special student of the subject declares in an estimate recently made that,--after subtracting numerous cases of mediation, ordinary boundary survess, domestic commissions, direct treaty settlements, and pure diplomatic negotiations, often improperly included in sucli estimates,--the whole number of international arbitrations during the present century, exclusive of cases now pending and incomplete, is one hundred

54 See Wheaton, Hist. of Law of Nations, Pt. ii. In order to gain favor for his scheme, St. Pierre attributed it to Henry IV. of France and his minister sully.
5.5 See above, p. 63.

56 For his Zum Ewigen Frieden, see Works, vol. v, pp. 411-466. Wheaton, Pt. iv, $\$ \S 36,37$.

5 i See Annuaire for 1877 , p. 123- 
and thirty-six. ${ }^{58}$ of that number fifty-seven are credited to the United States (all but four since 1800); thirty-three to Great Britain; and twelve to France.

$\S 357$. Arbitral courts; their constitution and procedure.-The basis of the entire arbitral proceeding is, of course, the treaty itself in which the parties are expected to define the precise scope of the submission, the constitution of the special tribunal, and the method of its procedure. It often happens that the litigating states choose the pope, a temporal sovereign, or other head of a state 59 as sole arbitrator, who may escape the personal labor of an exanination by committing the whole matter to some learned coadjutor whose award he adopts as his own. It is more usual, however, for the opposing parties to agree upon private persons to act as arbitrators; or to commit their selection, in whole or in part, to foreign states. In that erent an nneven number should be chosen, or a referee appointed, as an arbitration falls to the ground when there is an equal dirision of rotes, or upon the death of an arbitrator where no provision for the appointment of a successor has been made. Such arbitrators, who cannot delegate their functions, constitute a real tribunal which may prescribe its own rules of procedure when the preliminary treaty has failed to define them. In that event it is expected that the principles of the eivil law will govern unless the parties agree to be bound by special rules framed by themselves. If they deem proper the arbitrators may submit to the parties equitable propositions as the basis of settlement. If that expedient fails then a definite award should be rendered, which has all the moral force of a judgment at law, provided that the procedure of which it is the culmination has been justly and legally conducted. It is "generally admitted that the arbitral decision or award may be honorably disregarded when the tribunal has exceeded the powers conferred upon it by the articles of submission; when the award has been

58 Harvard Law Review, Nov., 1900, p. 182 . Note on arbitration to Mr. J. B. Moore's article, “A Hundred Years of American Diplomacy." For other estimates, see Calvo's ( $\$ 1489-1510$ ) list of disputes settled by arbitration since 1794; Rev. de Droit Int. xix, 196 and $\mathrm{xx}$, 511; and a short pamphlet published by the Peace Society en- titled The Proved Practicability of International Arbitration.

59 Since 1869 the President of the U. S. has acted as arbitrator in five cases, and since 1859 ministers of the U. S. have acted either as arbitrator or umpire in six. See also Moore's Int. Arbitrations in 6 Vols. 
procured throngh fraud or corruption; when there has been a flagrant denial of justice; or when the terms of the award are equirocal. Bluntschli claims that it may also be disregarded, "if the arbitral decision is contrary to international law. But the decision of the arbitrators cannot be attacked under the pretext that it is erroneous or contrary to equity, save for errors of calculation." 60

$\S 358$. Permanent court of arbitration provided by Hague conference.-In the outline heretofore drawn of the results of the Peace Conference at The Hague the fact was emphasized that the delegates, in dealing with the subject of arbitration, clearly understood that its practical application has been hindered by three obstacles: first, by the necessity of constituting a special court in each particular case; second, by the lack of power in such a court to define its own jurisdiction; third, by the lack of a settled code to regulate its procedure. ${ }^{61}$ In the effort to remove the first of such obstacles the Conference undertook "to organize a permanent Court of Arbitration accessible at all times, and acting, unless otherwise stipulated by the parties, in accordance with the rules of procedure included in the present convention." ${ }_{62}$ In furtherance of that design it was agreed that "each Signatory Power shall select not more than four persons, of recognized competence in questions of international law, enjoying the highest moral reputation, and disposed to accept the duties of arbitrators. The persons thus selected shall be enrolled as members of the court, upon a list which shall be communicated by the Bureau to all the Signatory Powers. Any alteration in the list of arbitrators shall be brought to the knowledge of the signatory Powers by the Bureau. Two or more Powers may mite in the selection of one or more members of the court. The same person may be selected by different Powers. The members of the cont shall be appointed for a term of six years, and their appointment may be renewed." "63

\section{International Bureau and Permanent Administrative Council.-}

60 Vïlkerrecht, § 495: "If, however, the arbitrators, by pronouncing a sentence evidently unjust and unreasonable, should forfeit the character with which they are invested, their judgment would deserve no attention; the parties had appealed to it only with a view to the decision of doubtful questions." Vattel, II, c. xviii, § 329 . See also Heffter, $\S 109$; Phillimore, iii, § iii; Calvo, $\S 1512-32$; Fiore, $\S \S 1478-91$; Hall, § 119.

61 See above, p. 49.

62 First Convention, Art. xx.

(i) Ibid., Art. xxiii. 
In order to provide the Court with an administrative organ it was stipulated that "an International Bureau shall be established at The Hague, and shall serve as the record office for the Court. This Bureau shall be the medium of all communications relating to the court. It shall have the custody of the archives and shall conduct all the administrative business. The Signatory Powers agree to furnish the Bureau at The Hague with a certified copy of every agreement of arbitration arrived at between them, and of any award therein rendered by a special tribunal." ${ }_{64}$ As a means of establishing such a Bureau, and of directing and controlling its action, it was further" provided that "a permanent administrative Council composed of the diplomatic representatives of the Signatory Powers accredited to The Hague, and of the Netherlands Minister of Foreign Affairs, who shall act as President, shall be constituted in that city as soon as possible after the ratification of the present $A$ ct by at least nine Powers. This Council shall be charged with the establishment and organization of the International Bureau, which shall remain under its direction and control. It shall notify the Powers of the constitution of the Court and provide for its installation." 65

How arbitral tribunal shall be constituted-Resort to arbitration not compulsory. - "Whenever the Signatory Powers wish to have recourse to the permanent Court for the settlement of a difference that has risen between them, the arbitrator; selected to constitute the Tribmal which shall have jurisdiction to determine such differences, shall be chosen from the general list of members of the Court. If such arbitral Tribunal be not constituted by special agreement of the parties, it shall be formed in the following manner: Each party shall name two arbitrators, and these together shall choose an umpire. If the votes shall be equal, the choice of the umpire shall be intrusted to a third Power selected by the parties by common accord. If an agreement is not arrived at on this subject, each party shall select a different Power, and the choice of the umpire shall be made by the united action of the Powers thus selected. The tribunal being thus constituted, the parties shall communicate to the Bureau their decision to have recourse to the Court, and the names of the arbitrators. The Tribunal of arbitration shall meet at the time fixed by the parties. The nembers of the Court, in the discharge of their 
duties, and outside of their own comtry shall enjoy diplomatic privileges and immunities." 60 It thus appears that the members of the permanent Court constitute a general staff of judges, under the protection of intermational law, out of which an arbitral tribunal can be constituted in each particular case by any one of the methods indicated. As explained heretofore the Conference was careful to leave the resort to arbitration purely voluntary, unless a kind of moral coercion was contemplated by the following provisions: "The Signatory Powers consider it their duty in case a serions dispute threatens to break out between two or more of them, to remind these latter that the permanent court of arbitration is open to them. Consequently, they declare that the fact of reminding the parties in controversy of the provisions of the present convention, and the advice given to them, in the higher interests of peace, to have recourse to the permanent Court, can only be considered as an exercise of good offices." 67

Arbitral procedure: Jurisdiction; Rehearing.-The arbitral tribunal at Geneva, which finally settled the famous controversy between Great Britain and the United States, came to the very verge of failure, after the two governments had stated their "eases," because of the lack of a clearly recognized power to define its own jurisdiction under the terms of submission. It may therefore be said that all other regulations made at The Hague as to arbitral procedure become comparatively nnimportant in the presence of that one which declares that, "the Tribunal is authorized to determine its own jurisdiction, by interpreting the agreement of arbitration or other treaties which may be quoted in point, and by the application of the principles of international law." 68 Learing that vitally important matter out of view, the remaining provisions rest upon a recognition of the fact that all forms of procedure in arbitration should be so designed as to facilitate two distinct objects-instruction and debate. The former consists of the transmission by the agents of the litigating powers to the opposite party, and to the members of the Tribunal itself, of all records and other documents, whether written or printed; the latter, of verbal claborations of the contentions lield. After the conclusion of debate, and after deliberation behind closed

66 First Convention, Art. xxiv.

68 Ibid., Art. xlviii.

o7 Ibid., Art. xxvii. 
doors, "the award shall be made by a majority of rotes, and shall be accompanied by a statement of the reasons upon which it is based. It must be drawn up in writing and signed by each of the members of the Tribunal. **** The award duly pronounced and notified to the agents of the parties in litigation shall decide the dispute finally and without appeal." 69 The parties may, however, reserve in the agreement of arbitration the right to demand a rehearing of the case. In that event, "and in the absence of any stipulation to the contrary, the demand shall be addressed to the Tribunal which has pronounced the judgment; but it shall be based only on the discovery of new facts, of such a character to exercise a decisive influence upon the judgment, and which at the time of the judgment were unknown to the Tribunal itself and to the parties demanding the rehearing. ${ }^{70}$ The Conference wisely refused to accept the proposal that, in the absence of any special stipulation, every decree of arbitration shall be subject to rerision if, within three months after the announcement of it, there shall be discorered a new fact which, in the judgment of the Tribunal, is of a nature to exercise a decisive influence upon it. ${ }^{71}$

§359. Diplomatic negotiation and mediation.-Two methods of amicable settlement are generally involed before there is an appeal to arbitration. In case of conflict contending states are expected to resort in the first instance to diplomatic negotiation in the hope of adjusting by mutual concession and compromise pending differences. In that way Great Britain and the United States settled their notable boundary controversies, and the prolonged disputes as to the rights of fishery on the banks of Newfoundland and in the Gulf of St. Lawrence, in the treaties of 1818,1854 and $1871 .^{2}$ When the parties themselres cannot agree some common friend often interposes his good offices in the spirit of mediation so as to bring about a friendly understanding by reconciling conflicting claims and opinions. ${ }^{73}$ In the hope of promoting that

69 First Convention, Arts. lii, liv. 7o Ibid., Art. lv.

71 For the debate upon the proposition, and the adoption of $M$. Asser's amendment, see Holls, The Peace Conference at The Hague, pp. 286, 287, 303.

72 See above, p. 133 seq.
73 In its first stage mediation is a mere offer of advice or assistance in the settlement of a controversy which either party has a perfect right to refuse. After the offer has been accepted, however, by both parties, it becomes both the right and the duty of the mediat- 
method of settlement the plenipotentiaries who united in the making of the Protocol of the Treaty of Paris, 1856, declared that they did "not hesitate to express, in the name of their" goremments, the wish that states between which any serious misunderstanding may arise should, before appealing to arms, have reconrse, as far as cireumstances might allow, to the good oflices of a friendly power."

$\$ 360$. Preliminary means of settlement invigorated by Hague conference.-Title 1 of the first Hague convention, "On the maintenance of the general peace," declares that "with a view to obviating, as far as possible, perourse to force in the relations between states, the Signatory Powers agree to use their best efforts to insure the pacific settlement of international disputes." As means to that end Title II provides for "Good Offices and Mediation;" Title III for "International Commissions of Inquiry;" Title IV for "Intermational Arbitration." After redefining and supplementing general mediation as heretofore practiced, the Conference, on motion of Mr. Holls, undertook to give to it a new and broader significance by declaring that "the Signatory Powers are agreed in recommending the applieation, when circumstances allow, of special mediation in the following form:

"In case of a serious difference endangering the peace, the states at variance shall each choose a Power, to whom they intrust the mission of entering into direct communication with the Power chosen on the other side, with the object of preventing the rupture of pacific relations. During the period of this mandate, the ter'n of which, unless otherwise stipulated, cammot exceed thirty days, the states in conflict shall caise from all direct communication on the subject of the dispute, which is regarded as having been referred exclusirely to the mediating Powers, who shall use their best efforts to settle the controversy. In case of a definite rupture of pacific relitions, these Powers remain charged with the joint duty of taking advantage of every opportunity to restore peace." it

ing power to interpose its advice with a view to the settlement of the difficulty. As a party to the negotiation it then has the right to go that far, although without the authority to constrain either contestant to accept its opinion. While it is under no obligation ro guar- antee the performance of the treaty concluded under its influence, in point of fact, it frequently does so. Klüber, Droit des Gens, pt. ii, tit. $2, \S 1$; c. $2, \S 160$; Dana's Wheaton, \& 288 .

it First Convention, Art. viii. 
$\$ 361$. Power of a state to contract; where it resides.-Every sovereign state is capable of entering into a contract with another to do any acts not forbidden, or to refrain from any acts not enjoined by the law regulating its international relations. When a state is only part-sorereign its contracting power is further limited to the extent to which it has been deprived of its full capacity by being confederated with, protected by, or subordinated to another state or states. ${ }^{i 5}$ All contracts entered into in excess of such limitations are void. In any event the fundamental law of each state nust determine in whom is rested the power of negotiating and contrating treaties with foreign states. ${ }^{6}$ In absolute monarchies like Russia, or even in constitutional systems like that of Great Britain, such power is usually vested in the ruling sovereign; in republics, in a single chief magistrate, or in a council, subject or not, as the case may be, to ratification by some other Power. The agents appointed by a sovereign or chief magistrate to negotiate or contract in his name must be duly empowered in some one of the several forms heretofore set forth.

$\$ 362$. International compacts require only limited freedom of consent.-While it may be true in a certain sense that compacts between states in order to be valid must be executed with freedom of consent, such freedom is far removed from that required by private law when engagements are entered into between private individuals. From the very necessities of the case international law is often obliged to admit the validity of treaties eren when the suffering party has been compelled to execute them through the application of force and intimidation. Otherwise treaties made to end wars or to avert them could seldom be consummated. As Phillimore has well expressed it compacts thus entered into must be upheld in the same way that private law upholds contracts entered into to aroid or end litigation, althongh executed under the dread of a certain expense and an uncertain issue. ${ }^{i 7}$

$\S 363$. Certain limits not to be exceeded.-And yet, if certain limits are exceeded, force and intimidation may vitiate the agreement. When, for instance, a state is coerced in that way

75 Vattel, II, c. XII, § 155; Grotius, De Jure Belli ac Pacis. II, Bluntschli, § 403; Calvo, $\$ 681$.

76 See above, p. 197.

$7 \pi$ Int. Law, ii, 62, 63. See also on, 267. 
into parting with its independence, it will be assumed that it did not voluntarily commit suicide as a means of reparation or as a measure of protection to another. In any event a treaty is roid if the sovereign of a state, a commander or an agent authorized to negotiate a treaty, is forced through personal fear to enter into it. While a state lying at the mercy of another cannot avail itself of that condition of things, its representative may, if he is subjected to violence or intimidation. Upon that ground was repudiated the cession extorted from Ferdinand VII by Napoleon at Bayoune, in 1808.78 Neither does freedom of consent exist where the contract is concluded under false impressions produced by the fraud of the party benefited, as in the case of a boundary treaty in which one of the parties was indueed to agree to the adoption of a certain line through the use of a map that turned out to be a forgery. ${ }^{9}$

$\S 364$. When constitutions require that treaties must be ratified.-When the constitution of a state, like that of the United States, provides that any treaty or convention made by its diplomatic agents cannot become binding mitil it has been ratified by a senate or a similar body, there can be no question that an express ratification is necessary, because the other contracting party is charged with the duty of informing himself of the extent of the powers of those with whom lie negotiates. $^{\text {so }}$ In such a case the ratifying power has the right to reject the provisional compact as a whole, or to amend it by the addition of new proposals. ${ }^{s 1}$ It then remains for the other party to assent or not to what is really a new treaty.

$\$ 365$. When no right of rejection is reserved-0ld and new rule.-A different state of things exists when the executive, armed with the entire treaty-making power, is called upon to ratify a convention made in his name by diplomatic agents acting under full powers, in which is reserved no right of rejection whatever. In that event the older writers, such as Grotius, Puffendorfse and Vattel, proceeding upon the analogies

78 Fyffe, Modern Europe, I, 367370 ; Hall, § 10 .

79 Heffter, § 85; Klüber, § 143; Bluntschli, $\$ 408-9$. For the controversy as to the map of Northeastern Territory used by Commissioners of 1783 , see Wharton, Int. Law

Dig., § $150 \mathrm{e}$.

80 See above, p. 158. s1 Bluntschli, § 413; Calvo, §§ 707-8; Wharton, Int. Law Dig., $\S$ 131.

s2 Grotius, De Jure Belli ac Pacis, II, c. 11, § 12; Puffendorf, De Jure Naturae et Gentium, III, c. 9 . $\S 2$. 
of the Roman law respecting the contract of mandate or commission, held that so long as the plenipotentiary did not exceed the limits of his credentials, "every promise which he makes, within the terms of his commission, and within the extent of his powers, binds his constitnent;" 84 and that view has received a certain amount of support from a few modern anthorities. ${ }^{85}$ But the obvious lack of analogy between international conventions and private contracts, and the immense risk of injury to vast and complicated interests entailed by such a rule, gave rise to a usige, clearly recognized by Bynkershoek, to the effect that a ratification by the sovereign is necessary in every instance to give validity to treaties concluded in his name, exeept in the very rare case where the entire instructions are contained in the patent fullpower. ${ }^{86}$ Such usage has gradually developed into the modern rule that express ratification, in the absence of special agreement to the contrary, is requisite in every case in which a treaty is concluded by negotiations in the name of another no matter how ample their powers.s7

$\S 366$. Treaty concluded in due form not to be rejected capriciously.-It must not be assumed, however, that any school of publicists has ever held that the ratification of a treaty, concluded in conformity with a full power, can be honorably rejected by one of the contracting parties from mere caprice, in the absence of cogent or substantial reasons. As Vattel has expressed it, "before a sovereign can honorably refuse to ratify that which has been concluded in virtue of a full-power, 156.

84 Droit des Gens, II, c. 12, §

85 Klüber, § 142; Phillimore, ii, $\S$ lii; Heffter, § 87. The last named thinks a state is morally bound under such circumstances.

86 "Sed rarum est, quod publica mandata sint specialia; rarius, quod arcanum mandatum publico sit contrarium; rarissimum verò, quod legatus arcanum posterius spernat, et ex publico priori rem agat. Quaest. Jur. Pub., lib. ii, c. 7. Bynkershoek is careful to criticise Wicquefort's condemnation of the conduct of princes who had refused to ratify the acts of ministers on the ground of their contra- vening secret instructions ( $L$ 'Ambassadeur, ii, § 15 ).

87 Marten's Précis, § 48; Dana's Wheaton, § 259; Hall, § 110; Schmalz, Vökerrecht, c. iii, 53; Ortolan, Diplomatie de la Mer, I, c. v; Calvo, \$ 697. Vattel (II, c. 12, $\S 156$ ) admits that "it is customary te place no dependence on their (princes') treaties till they have agreed to and ratified them." The statement made in the text does not include of course a treaty directly and personally concluded by a sovereign or other person exercising the sole treaty-making power of a state. 
he must have strong and solid reasons, and in particular he must show that his minister has deviated from his instruetions." In defining the grounds upon which a state may justly withloold its ratification, M. Guizot, in defending the refusal of the French government to ratify a treaty made in 1841 for the suppression of the slave trade, went so far as to say that "ratification is a real and substantial right; no treaty is eomplete without being ratified; and if, between the conclusion and the latification, inportant facts cone into existence-new and evident facts-which change the relations of the two powers and the ciremstances amidst which the treaty is concluded, a full right of refusal exists." ss scarcely less ample is Bluntsehli's subsequent declaration that "the refusal, even without cause, to ratify a treaty, can, under certain circumstances, be regarded as contrary to propricety, affecting very gravely the credit of the state, and jeopardizing the relations of friendship existing between the contracting parties; but this refusal should never be considered as a riolation of law, even when the person charged with the negotiations has acted within the limits of his powers and has executed the treaty in conformity with the instructions that he has received." $s 9$ To prevent all controversy it is now usual for sovereigns to expressly reserve the right to ratify whatever is concluded by their agents in their names, either in the full power or in the treaty itself.

$\$ 367$. Ratifications, express and tacit.-In express ratification is completed through the exchange of written instruments identical in form signed by the persons clothed with the supreme treaty-making power; or, where that power resides in a body of persons, by their duly authorized agent. In such ratifications, if the provisions of the treaty are not recited textually, the title, the preamble, the date and names of the plenipotentiaries should be set forth so clearly as to leave no doubt that the agreement embodied in the text of the treaty is that referred to. ${ }^{90}$ When a minister, who usually acts under

88 Moniteur, Feb. 1, 1843.

s9 Vülerrecht, § 420 .

${ }^{90}$ The ratification should not embody a new condition or any modification of the treaty as agreed on. If, however, one of the parties to a treaty annexes, at the time of its ratification, a written declaration explaining ambiguous language in the instrument or adding a new and distinct stipulation, and the treaty is afterwards constitutionally ratified by the other party, and the ratifications duly exchanged, the declaration thus annexed is a part of the treaty, and 
the immediate orders $O r^{\circ}$ as the monthpiece of the treaty. making power, enters, while within the limits of his authority, into agreements in notes or in any other informal way for which express ratification is not required by custom, tacit ratification may take place, if the supreme power capable of binding the state fails to repudiate such algreements as soon as it acquires knowledge of them.11

$\$ 368$. When treaties become effective.-Not until the formality of ratification las been completed does the treaty come into full operation; and then, unless there is an express agreement to the contrary, it becomes effective between the parties from the time it is signed, and not from the time of latification. Is an exception to the first rule may be cited the convention concluded at London, July 15th, 1840 , for the pacification of the Levant, in which it was provided in a reserved protocol of the same date that certain prelininary measures should be put into execution immediately (tout de suite), without waiting for the exchange of ratifications.92 As an exception to the second, may be cited the treaty of Paris, 1856, in which it was agreed that it should come into force from the moment of its ratification. ${ }^{93}$

$\S 369$. Stipulations to be performed between signature and ratification.-When stipulations are entered into to be performed between the signature and the ratification of a treaty, the rights and obligations of the parties cannot be fully determined until the fact is settled whether $\mathrm{or}^{2}$ no the ratification is to take place. If it does, the prarty who has failed to exe-

as binding and obligatory as if it, were inserted in the body of the instrument. Clark v. Braden, 16 Howal'd, 635.

91 Hall, § 110 , citing Wheaton, Elem., pt. iii, ch. ii, $\S 4$; Halleck, i, 230. This statement can have no application, of course, to treaties negotiated by the agents of a state whose constitution vests the power of ratification in a senate. If such notes affect the treaty in any way they must be communicated to the senate as a part of the compact. For that reason the diplomatic agents of the United States are not willing to sign or receive declara- tions or other notes in connection with a treaty. See discussion of the subject in connection with Clayton-Bulwer Treaty, where the British Minister, in exchanging ratifications, sent a note of explanation to Mr. Clayton, to which the latter replied. Cf. Dana's note, No. 138 , to Wheaton.

92 Martens (N. R. G.) I, 156.

93 Holland, European Concert in the Eastern Question, p. 241. Treaties of cession are also an exception to the general rule, because they only take full effect from the actual cession (traditio) of the territory itself. Twiss, I, $\S 233$. 
cute such intermediate stipulations is already guilty of an infraction of the treaty; if it does not, then a party who has performed in whole or in part is entitled to be put in his original position, or to receive an equivalent compensation. ${ }^{94}$

$\$ 370$. Legislation to carry treaties into effect.-When the treaty-making power of a state has concluded a convention within its province to make, what is the nature of the obligation thus imposed upon the legislature to enact all laws neeessary to carry its provisions into full effect? The constitution of the United states (art. vi, $\$ 1$ ) provides that "all treaties made, or which shall be made, under the authority of the United States, shall be the supreme law of the land;" and Washington, in his special message of March 3, 1796, declared "it is perfectly elear to my understanding that the assent of the House of Representatives is not necessary to the validity of a treaty." 95 If that is the true nature of the treaty-maling power in this country, when a convention has been concluded and ratified by the proper authorities, it becomes obligatory upon the state as a whole, and upon each and every department of its government, including the legislature, whose duty it is to enact all laws, and to make all appropriations necessary to carry it into complete effect. The obligation, moral and legal, is complete; and it is no sufficient answer to another state, in the event of a breach of the contract, to aver that one department of the government has refused to perform its legal duty. ${ }^{96}$

$\$ 371$. Controversy with France as to treaty of 1831.—Such was the principle asserted by the grovernment of the United States agrinst France, when the Chamber of Deputies refused to make appropriations to carry out the treaty of 1831 providing for the payment of the spoliation claims, whose settlement brought the two countries to the verge of war. ${ }^{97}$ In express-

94 Bluntschli, \& 421; Heffter, § 87; Hall, § 110 . As to acts performed in the interim, in contravention of the stipulations of the compact, see case of U. S. v. D'Auterive, 10 Howard, 609.

${ }_{95}$ Special message on Jay's treaty.

96 Despite a contrary contention, as old as the government itself, Congress has almost invariably acted upon the principle that it is bound to carry into effect all treaties duly executed by the President and Senate,-notably in 1796, with respect to the treaty of 1794 with Great Britain; in 1816, as to the commercial convention with the same power; in 1842-43 with respect to the treaty of Washington; and, in 1853-54, with respect to the convention with Mexico.

9 i Wharton, Int. Law Dig., \$§ 131a, 318. 
ing himself on that subject Mr. Wheaton, then United States minister" at Copenhagen, said: "Neither government has anything to do with the auxiliary legislative measures necessary, on the part of the other state, to give effect to the treaty. The nation is responsible to the government of the other nation for its non-execution, whether the failure to fulfill it proceeds from the omission of one or the other of the departments of its goverument to perform its duty in respect to it. The omission here is on the part of the legislature; but it might have been on the part of the judicial department-the court of cassation might have refused to render some judgment necessary to give effect to the treaty. The king cannot compel the Chambers, neither can he compel the courts; but the nation is not the less responsible for the breach of faith thus arising out of the discordant action of the international machinery of its constitution." 1

\section{$\$ 372$. Right of Parliament to reject necessary legislation.-In} the English constitutional system the treaty-making power is rested in the crown alone. After that organ of the Empire, acting through a responsible minister, has executed a convention it requires no formal sanction or ratification by Parliament as a condition precedent to its validity.2 And yet there was a time when Parliament claimed the right to reject legislation necessary for the purpose of so modifying existing laws of trade and navigation as to adapt them to the stipulations of treaties. $^{3}$ Out of that condition of things grew, no doubt, the practice of stipulating in treaties requiring auxiliary legislation,that they shall not be binding until the necessary laws are passed or the necessary appropriations made to carry them into effect. ${ }^{*}$

$1 \mathrm{Mr}$. Wheaton, Minister at Copenhagen, to Mr. Butler, Attorney General, Jan. 20, 1835, and quoted with approval in Meier's Ueber den Abschluss von staatsverträgen, Leipzig, 1874, p. 168. See also Lawrence's Wheaton (1863), 459; Kent, Com., I, 285; Heffter, § 84; Halleck, 854; Bello, Derecho International, pt. 2 , c. $9, \S 6$.

2 See above, p. 162, and authorities cited.

3 Todd, Parl. Govt., i, 133; Forsyth, Const. Law, p. 369; Hertslet,
Map of Europe by Treaty, ix, p. 1064 seq.; Lord Mahon, Hist. of England, i, p. 24. "Thus, the commercial treaty of Utrecht, between France and Great Britain, was never carried into effect, the British parliament having rejected the bill," etc. Halleck, 191.

4 Where it appears on the face of a treaty that its operation, in whole or in part, depends upon legislation as a prerequisite, it does not bind as to such provisions, until the requisite legislation 
$\$ 373$. Claim of House of Representatives as to Alaska purchase.-Inimated by that idea the House of Representatives,when the time eame to make the necessary appropriation to carry out the purchase of Alaslia perfected in the treaty with Russia ratified by the Senate, May 28, 1867,-attempted to revire its ancient pretensions by coupling with its grant a reservation of its right to approve or disapprove in all cases in which its action is necessiry for the excention of a treaty. such raim was embodied in the following terms in the amended act making the apropriation: "Whereas, the subjects thus embraced in the stipulations of said treaty are among the subjects which by the constitution of the United States are submitted to the power of Congress, and over which Congress has jurisdiction; and it being for suele reason necessary that the consent of Congless shall be given to the said treaty before the same shall have full foree and effect, having taken into consideration the said treaty, and approving of the stipulations therein to the end that the same may be carried into effect, therefore, sec. 1. Be it enacted by the Senate and House of Representatives of the Cnited States of America in Congress assembled, that the assent of Congress is hereby given to the stipulations of said treaty." After the Senate had restored the bill to its original form by rejecting the clauses asserting the claim of the House that the consent of Congress as a legislative body is necessary to the payment of money and the incorporation of territory, when provided for in a treaty, the contention was hushed by the substitution in conference of a colorless preamble reciting that "Whereas, said stipulations camnot be carried into full foree and effect except by legislation to which the consent of both houses of Congress is necessary, therefore, Be it resolved, etc." 5 The perfecting

takes place, though, from the time it is proclaimed, it may take effect as a national compact. 8 Opinions of Attys. Genl. U. S. 750 .

5 Congressional Globe for 1867, 4031, 4159, 4392. "This measure, which was adopted in the House by a vote of 91 to 48 , has the features of compromise strongly impressed upon it.

The question, therefore, which was agitated in 1796, whether Congress can, unde: the Constitution, refuse, in its legislative capacity, to pass acts for the execution of treaties duly ratified, remains still open. Yet two positions may be regarded is accepted in the practical working of our government. One is that without a Congressional vote there can be no appropriation of money which a treaty requires to be paid. The other is that it should require a very strong case to justify Congress in refusing to pass an appropriation which is called for by a 
of the English ministerial system, through the transfer of the treaty-making power of the crown to a majority of the House of Commons, has practically eliminated from English politics such unseemly conflicts of authority as those in question. ${ }^{6}$ Led it be hoped that a more mature and enlightened ninderstanding of our federal constitution will eliminate them in future from the politics of the United States.

$\S 374$. International agreements may be verbal or written.Languages employed.-Intermational agreements, like private contracts, may be either verbal or written; and as custom has prescribed no set forms, their meaning may be expressed either by words or signs which clearly indicate the concurrence of two or more minds as to one and the same thing. No matter what the means employed the moment that consent on both sides is clearly established a convention exists whose binding force is complete. ${ }^{7}$ Thus in time of war certain signs, having a well understood meaning, are often employed in the making of military conventions. By the exhibition of white flags, for example, by two opposing armies a truce may be established. ${ }^{8}$ Usually, however, such agreenents are reduced to writing in solemn form, and signed by the contracting parties, or by persons duly anthorized to act for them. Until about the beginning of the eighteenth century treaties between the European powers were, as a general rule, written in Latin. Since that time it has become customary for the representatives of countries speaking different languages to prepare treaties in the tongue of each of the contrating parties in parallel columns. As an exception to the general rule most of the treaties of the United States with Russia are written in French. Those with Great Britain are signed in the English language only. ${ }^{8 a}$

$\S 375$. Protocols.-Negotiations, more or less prolonged, necessarily precede the conclusion of international agreements, and, to the end that an enduring memorial may be preserved of the results of each discussion as the negotiation proceeds, it is usual to record the several resolutions arrived at in a document called a protocol, which. if the subject under discussion is specially important, is generally signed by

treaty duly ratified." Wharton. Int. Law Dig., § 131a.

${ }^{6} \mathrm{Cf}$. The Origin and Growth of the Eng. Const., ii, 548 seq.

7 Martens, Précis; Klüber, $\S 143$; Heffter, § 87; Phillimore, ii, § 1 .
8 Martens, Prícis, § 65, Bluntschli, § 422; Hall, § 109.

8a Mr. Fish. Sec. of State, to Miss Fraser, Nov. 18, 1874. Wharton, Int. Law Dig., $\$ 130$. 
the negotiators themselves. The record thus made of the effort to arrive at an algreement has, of course, no binding effect if no conchusion is reached, as its obligation in law depends upon the ultimate success of the negotiation as a whole.

$\$ 376$. Distinction between a "treaty" and a "convention"Use of the alternat.-Leaving out of riew such military arrangements as cartels, truces, capitulations and sponsions, the compacts that remain are known either as treaties or conventions, - the former term being usually employed to describe the more serious political and commercial contracts, the latter, those of more linited scope or of lesser dignity. When the rank of contracting states is equal or undetermined, in order to prevent controversy as to precedence in the execution of treaties and conventions, it has become the practice to vary the order of naming the parties in the preamble, and of affixing the signatures of the plenipotentiaries themselves in the several counterparts of the same agreement. The signers thus alternate in a regular order, or in one determined by lot. In that way each state may be first named, and its plenipotentiaries may sign first in the copy possessed and published by itself.9 Such controversies as to precedence are sometimes avoided by another expedient consisting of the signing in the order of the French alphabet of the names of the representatives of the several contracting states. ${ }^{10}$

$\$ 377$. Construction and interpretation of treaties-Distinction between the two.-In view of the fact that some of the most serious wars in history have arisen out of conflicting opinions as to the real meaning of treaty stipulations, it is not strange that publicists and jurists, from the time of Grotius down to our own. should have made every effort to formulate a set of rules designed to remore, at least in part, the difficulties incident to their construction and interpretation. While it seems to be universally aldmitted that it is next to impossible "to prescribe any system of rules of interpretation for cases of ambiguity in witten language that will really avail to guide the mind in the decision of doubt," 11 the conviction is

Annex xvii to the Vienna Congress Treaty of June 9,1815 , provides that in acts or treaties between those powers which admit the alternity, the order to be observed in the signatures of ministers shall be decided by ballot.
Hertslet, Map of Europe by Treaty, I, pp. 62,63 .

${ }_{10}$ Klüber, Uebersicht der Diplomatischen Verhandlungen des Wiener Congresses, \$ 164.

11 Potter's Dwarris on Stat. and Const.. p. 176. 
equally well established that such principles of construction as are generally recognized have done much to remove the chaos that would have existed if an unfettered and arbitrary discretion had been permitted to preside in each particular case. The only real advance made in that direction has been by those who, disregarding metaphysical distinctions, arbitrary formulas and minute and confusing subdivisions, have contented themselves with simply adapting to the purposes of international law, as far as applicable, such general principles as have been developed and approved by experience in the construction of statutes and private contracts. And here reference should be made to the important distinction between "construction," the process through which the general sense of a treaty is derived by the application of the rules of logic to what appears upon its face, and "interpretation," the process through which the meaning of particular terms is explained by reference to local circumstances and idioms the framers had in the mind at the time. ${ }^{12}$ Only to that extent can matters aliunde the treaty be employed to explain its meaning. No court or other expounder can supply a casus omissus in a treaty any more than in a law. ${ }^{13}$ With this preface clearly in view, the attempt will be made to formulate such of the rules $^{14}$ in question as are most general in their application.

§378. General rules: Instrument to be taken as a whole.-As the primary object of all construction is to discover the common thought in which the minds of the contracting parties met, the entire instrument containing the agreement, no matter whether a contract between individuals or a treaty between nations, must be taken as a whole, and construed according to the natural, fair, and received acceptation of the

12 See Dr. Lieber's Legal and Political Hermeneutics, c. $1, \S 8$; ch. $3, \S 2,4$ and c. 5 ; Parsons on Contracts (7th ed.), ii, p. 623 (a).

13 The Amiable Isabella, 6 Wheaton, 1.

14 The foundations of the existing system of rules for the interpretation of treaties were laid by Grotius, ii, c. xvi. After his day they were revised and reproduced by Puffendorf (v, c. xii), by Domat (Cushing's ed., I, p. 108), by Vattel (ii, c. xvii), and by Ruther- forth (ii, c. 7). For a convenient restatement of the best parts of the work of each, see Potter's Dwarris on Statutes and Constitutions, pp. 121-146; and also Wildman's Institutes of Int. Law, i, 176-186. For the best recent expositions, see Heffter, § 95; Phillimore, ii, c. viii; Calvo, §§713-22; Fiore, \$\$111731 ; Hall, $\S \S 111,112$; and Savigny's exposition of "fundamental rules of interpretation" in his $R \dot{0}-$ mischen Rechts (vol. i, ch. iv, § $\mathrm{xxxiii).}$ 
terms in which it is expressed. Despite Cicero's sugryestion, quoted by Grotius, that "when you promise, we must conside" rather what you mean, than what you say," it is only from the words actually used that such meaning can be drawn. And yet, in the effort to discover the common intention the spirit rather than the letter should govern,-in the words of Dr. Paley, "where the terms of promise admit of more senses than one, the promise is to be performed in that sense in which the promisor appreliended at the time the promisee received it." 15

When the language of a treaty, each word being accorded its ordinary meaning, yields a plain and reasonable sense, it must be taken in that sense, provided that the same does not involve an absurdity, or draw the contract into confiict with fundamental principles of settled law. A treaty must be so construed as to exclude frand and to make its operation consistent with good faith. ${ }^{16} \quad M y^{\circ}$ construction that would render it null and void should be rejected.

$\$ 379$. When general terms are obscure or equivocal.-If general terms are used which are obscure or equivocal they must be given the sense most suitable to the subject or matter to which they relate. If, howerer, he who has expressed himself in such a manner in one place has expressed himself more clearly elsewhere on the same subject, he is the best interpreter of himself. And yet a word or phrase mas be used in a treaty several times without requiring the same meaning to be attached to it each time, the sense corresponding with the end sought to be attained in each case.

$\$ 380$. Extrinsic evidence to explain objective obscurity.-If special terms are used which are obscure or equivocal because they must be explained by local circumstances and by idioms the framer of the instrument had in mind when they were used, interpretation may be invoked in order that extrinsic evidence may be taken for the purpose of explaining objective obscurity:

$\$ 381$. When a term used in a treaty between several states has a special meaning in each.-When a term used in a treaty between two or more states has in each a special and local legal meaning, it must be applied to the afrairs of each in the sense given it by its national law. Such was the rule applied 
to the construction of the word "inhabitant" used in the treaty" of 1866 between Austria and Italy, -in the former, the word signifying such persons only as are domiciled according to Austrian law; in the latter, every person living in a commune and registered as a resident. ${ }^{17}$

$\S 382$. Technical terms, or terms of art and science-Technical terms, or terms of art and science, should be construed according to the definitions given them by the masters of the several branches of knowledge or art or science to which they belong.

$\S 383$. When recourse must be had to general spirit and purpose of a treaty.- When the language of a treaty, each word being accorded its ordinary meaning, fails to yield a plain and reasonable sense, recourse must be had to its general spirit and purpose as manifested by the provisions of the instrument as a whole, or by the context of the ambiguous, improper, incomplete or obscure passages. The dominant and controlling principle then is that the treaty was not made to perish through inherent defects, but to stand as a harmonious whole ${ }^{18}$ and when such a general result is once attained nothing short of convincing proof of intention will give to any particular provision a construction in conflict with the rest.

$\S 384$. Clauses in favor of justice and humanity.-Clauses which faror justice, equity and humanity are to be construed broadly. While odious clauses, involving cruelty or hard conditions for one parte, are to be construed so strictly as to confine their operation to the narrowest limits.

$\S 385$. Presumption in favor of a state-As it will not be presumed that any state desires to divest itself of its sovereignty, its property or its right of self-preservation, no such result can be established by implication. It must be clearly expressed.

$\S 386$. Incidents of substantive rights and obligations.-As the valid grant of a substantive right, or the assumption of a substantive obligation, is supposed to carry with it all the incidents necessary to the enjoyment of the one or the performance of the other, such incidents will be presumed to have followed tacitly whenever such substantive right or obligation has been given or imposed by treaty.

17 Fiore, § 1121.

18 That construction most favorable to its execution, as designed by the parties, will be preferred. U. S. v. Payne, 2 McCrary, 289; 8 Fed. Rep., 883. 
$\$ 387$. Rules regulating certain preferences.-What will suffer no delay ought to be preferred to what may be done at another time; and in all cases where a thing only permitted is found incompatible with what is prescribed, the latter should have the adrantage.

$\$ 388$. Where two meanings are admissible-Interpretation clause.-Where two meanings are admissible that is to be preferred which is least for the advantage of the party for whose benefit the clause is inserted, the presumption being that he who secures a special privilege will see that it is expressed as fully as it was intended. Any special advantage conceded by a party under any one article is supposed to be in consideration of all the advantages enjoyed by the same party under that and all other articles. ${ }^{19}$ A well founded distrust of the practical efficacy of the foregoing rules often prompts the insertion into treaties, prior to their ratification, of an interpretation clause in which the contracting parties agree to remore any ambiguity that may have occurred in the original text.

$\$ 389$. Special rules: A general permission overcome by imperative provision.-In addition to the difficulties already enumerated, which the general rules of construction and interpretation are designed to remove, there is a special class arising out of conflicting clauses of the same treaty, or out of conflicts between different treaties, for whose reconcilement the following special rules have been made: A general permission is overcome or limited by an imperative provision. general or specific. For example, a concession of a right of fishing in certain territorial waters, to which the right of curing and drying on the spot is an essential incident, must yield to a prohibition forbidding the persons to whom the substantive right is granted to enjoy the incidental. On the same principle a special permission overeomes a general imperative provision,- the latter being taken as a general rule to which the former is an exception.

$\$ 390$. Precedence between conflicting prohibitive provisions. -As penal sanctions are supposed to give additional force to obligations, when prohibitive provisions conflict, and there is a penalty attached to the one and not to the other, the former takes precedence; or, when a more severe penalty attaches to the one than the other', the former takes precedence. When

196 Opinions of Attys. Genl. U. S. 148. 
there is no penalty attached to either, that one takes precedence which is most precise in its commands.

$\S 391$. When stipulations so identical that no priority can be assigned.-When stipulations are so identical in their nature and sanctions that no priority can be assigned to either, the most important must be discharged by the party bound, unless the promisee, who has the right of selection, sees fit to demand the performance of the less important.

$\S 392$. When most recent of two treaties takes precedence.When two treaties between the same states conflict, the one of most recent date takes precedence, because the supposition is that it was intended as a substitute for its predecessor. If, however, the later of two conflicting treaties is made by an inferior though competent authority, it must yield to a prior one executed by a higher authority. ${ }^{20}$

$\S 393$. Prior treaty prevails over subsequent one in conflict with it.-As it is unlawful after a compact has been made with one party to attempt to divest the rights vested under it, without the consent of the beneficiary, a prior treaty made with one state or states will prevail over any subsequent convention with another in conflict with its provisions. Upon that elementary principle was resisted the preliminary treaty of peace signed by Russia and Turkey at San Stefano, March 17, 1878. As Prince Bismarck expressed it at the opening of the Berlin Congress, the plenipotentiaries there assembled met for the purpose of submitting that treaty "to the free discussion of the cabinets, signatories of the treaties of 1850 and 1871 ," because it attempted to modify without their consent "the state of things as fixed by former European conventions." 21

20 This apparent exception rests upon an admission of precedence due to a prior convention made under the following circumstances: In 1800 Piacenza with its garrison was surrendered, at three in the afternoon, to the French by the Austrian commandant, who from the nature of his command, had the right to make such a capitulation. At eight o'clock in the morning of the same day Generals Berthier and Melas had concluded a convention, providing for the re- tirement of the entire Austrian force behind the Mincio, and for the surrender of Piacenza to the French, but with its garrison withdrawn. Upon the ground that the prior agreement was concluded by a higher authority, it was claimed and at once admitted that it should have precedence. Corresp. de Nap.. i, vi, 365. Hall, § 112.

21 Holland, European Concert in the Eastern Question, pp. 221-22, quoting Count Schouvaloff's admission that the treaty in question 


\section{$\$ 394$. A treaty may become voidable through subsequent} events.-In effort has been made heretofore to explain the antecedent conditions upon which the validity of a treaty depends, consisting in the main of the capacity of the parties to contract, of the anthority of the agents acting in their name, of consent freely given, of ratification, and, last and most of all, of conformity of the objects of the treaty with the fundamental principles of the law of nations. After the validity of an international agreement has been firmly established, by the concullence of such antecedents, it may become voidable through the operation of subsequent events, which might not have surch an effect in the case of private contract."2 so unstable are the conditions of international existence, and so diffirnlt is it to enforere a contratet between states after the state of facts upon which it was founded has substantially rhanged, that all such agreements are necessarily made subject to the general understanding that they shall cease to be obligatory so soon as the conditions upon which they were executed are essentially altered.

\$395. Russia's contention as to treaty of Paris.-In 1870, when Russia determined to repudiate some of the vital provisions of the Treaty of Paris relating to the Black Sea, ${ }^{23}-b y$ which she hat been fettered at the close of the Crimean War, and which her subsequent development had rendered unbearable.2-2-she rested her case, in part, upon that ground in the "ircular addressed to the powers assereting that "the treaty of the 18/30 Malch, 1856, had not escaped the modification to which most dimropean transactions have been exposed, and in the face of which it would be difficult to mantain that the written law, founded upon the respect for treaties as the basis of public right and regulating the relations between states. retains the moral validity which it may have possessed at other times." This instance is given simply as an illustration

was "a preliminary convention, having obligatory force only on the contracting parties, by which Russia intended to let the Turkish government know beforehand the demands she would formulate later before Europe." See Parl. Papers, 1878, Turkey, No. 39, pp. 12, 137, 242.

22 For the leading distinctions between treaties and private con- tracts, see Wharton, Com. Am. Law, § 157.

23 See above, p. 124.

24 Bluntschli ( $\$ \$ 415$ and 456) maintains that a state may hold any treaty to be null, if incompatible with its development; and he seems to regard the propriety of Russia's action in denouncing the treaty of 1856 as an open question. 
of what the general nature and seope of the doctrine in question is, and not as an expression of opinion that Russia was right in her contention that essential modifications of original conditions had actually been brought about in that particular case, (1) by the aequiescence of the great powers in the union of the Danubian provinces through "a series of revolutions aqually at variance with the spirit and letter" of the treaty; (2) through the opening of the Straits to foreign ressels of war in violation of the terms of the treaty; and (3) through changes in naval warfare incident to the use of ironclads which exposed the Russian ports in the sea to sudden attacks from enemies foreing a passage through the straits. Russia contended not only that the natural course of erents had worked a material change in the conditions which were in contemplation when the treaty of 1856 was made, but that it had been violated through the positive failure of the parties to observe some of the essentials. ${ }^{25}$

$\S 396$. Treaties affected by changes in internal life of a state. -If a treaty is consistent at the outset with the right of selfpreservation it is an implied condition that it shall remain so. While a state may surrender by compact its natural right to independence, such an intention will never be inferred, it must be clearly expressed. Therefore a treaty, which was not intended to be a menace to the life or independence of a state at the time of its execution, beeomes voidable the moment subsequent events invest it with that character. In the same way if a compact is made in contemplation of the continuance of a particular form of government in one or both of the contracting states, either may terminate it whenever internal constitutional changes render it inapplicable to the new circumstances. It is also an implied condition of the continuing obligation of a treaty that the parties to it shall retain their freedom of will with respect to its subject-matter. For example, if a state, independent at the time of the execution of a convention, subsequently becomes subordinate to anotler through the fortunes of war or enters into a confederation whose constitution restrains its liberty of action, its obligation to per-

25 For the best statements of the matter, including the text of the treaty of London, of March 13. 1871, see Holland, European Concert in the Eastern Question, pp. 220-276; and Hertslet's Map of
Europe by Treaty, 1256-7, 1892-8. 1904. For the protocols of the conferences held at London from Jan. 17th to March 4th, 1871, see Martens (N. R. G.) xviii, 273; British State Papers, 1871, p. 7. 
form the prior agreement becomes subordinate to its restraints and obligations involved in its new relations. Such a case constitutes an exception to the general rule that a prior treaty takes precedence of a subsequent one. 26

\$397. Dangerous contentions of Heffter and Fiore.-The foregoing recognized and legitimate grounds upon which a valid treaty may become voidable through subsequent erents, are too ample to justify the effort to open wider the door of temptation through such contentions as that of Heliter, who says that a state may repudiate a treaty, where it conflicts with "the rights and welfare of its people ;" 27 or that of Fiore, who maintains that "all treaties are to be looked upon as null, which are in any way opposed to the development of the free activity of a nation, or which hinder the exercise of its natural rights." 2 If such dangerous assumptions were tenable it would be difficult to understand why treaties of a certain lind should be made at all.

$\$ 398$. When will a breach of conditions by one party render treaty voidable at instance of the other.-It is a difficult matter to determine what kind of a breach in the conditions of a treaty by one party will render it voidable at the instance of the other. It is undoubtedly true that the binding force of every international compact rests upon the implied condition that it shall be observed by both parties to it, and some authorities hold that its stipulations are inseparable and consequently that they must stand or fall together ;9: while others, after distinguishing between principal and secondary articles, maintain that only infractions of the former are sufficient to destroy its binding force. ${ }^{30}$ As erery promise made in a treaty by one party enters into the consideration in return for which essential parts of the agreement are undertaken by the other, who shall say that one of the contracting parties shall be armed with the power to determine what is or is not essential in the eyes of the other? In the midst of such difficulties, from

26 Martens, Prícis, $\$ \S 52,56$; Dana's Wheaton, $\S 275$; Bluntschii, $\S \S 458,460$; Hall, pp. 373-4; Phillimore, iii, 661 .

27 V̈̈lkerrecht, $\$ 98$.

2s Nouv. Droit Int. I, p. ch. IV.

29 Vattel (II, c. xiii, § 202 maintains that the violation of an arti- cle in a treaty may cancel the whole, citing Grotius, II, c. xv, § 15. To the same effect, Heffter, $\S$ 98; Calvo ( $\$ 729$ ), assents to the doctrine, but with a qualification. See also Klüber. § 155.

so Wolf, Jus Gentium, § 432; Martens, Prícis, $\$ 59$. 
which there is no escape, "all that can be done is to try to find a test which shall enable a candid mind to judge whether the right of repudiating a treaty has arisen in a given case. Such a test may be found in the main object of a treaty. There can be no question that the breach of a stipulation which is material to the main object, or, if there are several, to one of the main objects, liberates the party other than that committing the breach from the obligations of the contract; but, it would be seldom that the infraction of an article which is either disconnected from the main object or is unimportant, whether originally or by change of circumstances, with respect to it, could in fairness absolve the other party from performance of his share of the rest of the agreement, though if he had suffered any appreciable harm through the breach he would have a right to exact reparation, and an end might be put to thetreaty as respects the subject-matter of the broken stipulation." 31 The failure of one of the strongest and most original minds which has of late years grappled with the vexed questions of international law to offer anything more definite or more practical as a rule to determine what kind of a breach will render a treaty voidable, is perhaps conclusive of the fact that all that can be said is that when a breach occurs the party availing himself of it, if he fails to demonstrate that he has been deprived of something really material to at least one of the main objects he had in view, exposes himself to the suspicion of bad faith. ${ }^{32}$

$\S 399$. Several other circumstances by which a treaty may be extinguished.-Apart from the grounds already enumerated a treaty may be extinguished by the expiration of the term to which its existence was originally limited; by the complete destruction of the thing which constituted its subject-matter; by the completion of every obligation contained therein if an executory convention; by the performance of a condition upon which its existence was made to depend, such, for instance, as the payment of a definite sum of money; by the express renunciation of one of the parties in interest; by mutual agreement of the contracting parties; $b y$ the execution of a new treaty, inconsistent with a previous one; by circumstances

31 Hall, pp. 368-9.

32 Lawrence (Principles of Int. Law, p. 288) holds that "when, and under what conditions, it is justifiable to disregard a treaty, is a question of morality rather than of law." 
rendering its execution impossible; or by a declaration of war suspending or entirely destroying its effect. ${ }^{33}$

$\S 400$. How treaties may be extended or renewed. Difference between the two.-Treaties once extinguished may be either extended or renewed by express or tacit consent. Unless they are thus extended or renewed they expire at the end of the term for which they were contracted. At the close of a war it is usual to renew expressly the treaties in force at the time of its beginning; and when a treaty is thus expressly renewed it is the same as if a new one were concluded in all resperts similar to the former. If a treaty is renewed or extended tacitly the acts from which the purpose to do either is inferred must place the intention of the parties beyond question or mistake. ${ }^{34}$ As Vattel $^{35}$ has well expressed it: "According to the circumstances and nature of the acts in question, they may prove nothing more than a simple continuation or extension of the treaty, which is very different from a renewal, especially as to the term of duration. For instance, England has entered into a subsidiary treaty with a German prince, who is to keep on foot, during ten years, a stated number of troops at the disposal of that country, on condition of recciving from her a certain yearly sum. The ten years being expired, the king of England causes the sum stipulated for one year to be paid; the ally receives it; thus the treaty is indeed tacitly continued for one year; but it cannot be said to be renewed; for the transaction of that year does not impose an obligation of doing the same thing for ten rears successively. But, supposing a sovereign has, in consequence of an agreement with a neighboring state, paid her a million of money for permission to keep a garrison in one of her strongholds during ten years, if, at the expiration of that term, the sovereign, instead of withdrawing his garrison, makes his ally a tender of another million, and the latter accepts it, the treaty is, in this case, tacitly renewed."

33 Klüber, § 164; Bluntschli, $\$ \S$ 450, 454; Calvo, $\$ 610$; Creasy, Int. Law, pp. 40-43; Halleck, I, pp. 242, 268; Davis, Int. Law, pp. 179-80;
Wharton, Int. Law Dig., § 137a. :4 Heffter, \& 99; Calvo, $\$ 616$; Fiore, $\S$ 1133-5.

35 Drout des Gens, § 199. 


\section{CHAPTER VI.}

\section{RIGHT OF SELF-PRESERVATION.}

$\S 401$. Defensive forms of self-preservation.-In the corporate person of every state is vested the inherent right of self-preservation which, when exercised in a defensive form, embraces not only all those means through which each independent political community guards its territory from actual invasion, and the person and property of its citizens, at home and abroad, from injustice and violence, but also those permissible measures through which such a community may take defensive action either within foreign territory or in non-territorial waters when either is unlawfully employed as a starting point for attacks against it.

$\$ 402$. Invasion of Mexico by U. S., 1836.-It is the duty of every state so to administer its laws in time of peace as to prevent private persons from organizing and arming upon its soil for the purpose of invading a neighboring state. When the government of a state in which such an enterprise is pending fails after warning to prevent it, or when the exigencies of the case are such as to compel action without warning, the government of the threatened state may send troops across the border in order to check the invasion; or, after it has been actually made, it may pursue the offenders and punish them within the territory of the state from which they came. ${ }^{1}$ "Temporary invasion of the territory of an adjoining country, when necessary to prevent and check crime, 'rests upon principles of the law of nations entirely distinct from those on which war is justified-upon the immutable principles of self-defense-upon the principles which justify decisive measures of precaution to prevent irreparable evil to our own or to a neighboring people." 2

$\S 403$. Invasion of $\mathrm{U}$. $\mathrm{S}$. by British subjects, 1838.-It was

1 Vattel, III, c. $3, \S \S 44,49,50$; c. $7, \S 133$; Phillimore, i, $\S 213$; Klüber, § 44; Twiss, i, § 102; Hall, 84. Some other writers, while admitting the right of self-preservation by means of acts violating the sovereignty of another state, deny that it is a pacific right. They regard any invasion of a state's territory as "imperfect war." See Halleck, i, 95; Calvo, §§ 203-4.

2 Mr. Forsyth, Sec. of State, to Mr. Ellis, Dec. 10, 1836. MSS. Inst. Mexico. 
this plain right of self-defense so emphatically asserted by the United States against Mexico in 1836, that Great Britain invoked to justify the acts of those of her subjects who, during the Canadian rebellion of 1838 , crossed by her command the American frontier, boarded a steamer called the Caroline and sent her adrift down the falls of Niagara in order to prevent her use by insurgents armed upon Imerican soil for the invasion of British territory. Under such circumstances the United States called upon Great Britain "to show a necessity of self-defense, instant, overwhelming, leaving no choice of meansand nomoment for deliberation." 3 In the Senate Mr. Calhoun said: "It is a fundamental principle in the law of nations that every state or nation has full and complete jurisdiction over its own territory to the exclusion of all others, a principle essential to independence, and therefore held most sacred. It is accordingly laid down by all writers on those laws who treat of the subject, that nothing short of extreme necessity can justify a belligerent in entering with an armed force on the territory of a neutral power, and, when entered, in doing any act which is not forced on him by the like necessity which justified the entering." ${ }^{4}$ As invasion was imminent Great Britain found no difficulty in making a case of self-defense forced upon her by "instant, overwhelming" necessity; and so the matter ended with an admission from her that although the invasion was justifiable, an apology was due for it. ${ }^{5}$ While it is undoubtedly true that a state may treat any violation of its territory as an act of war, when such riolation occurs without any hostile intention, and with the purpose of preventing erents which might lead to war, the invaded state should under such circumstances regard such preventice measures rather as friendly than as hostile acts.

$\S 404$. When a state may defend itself in its own or in nonterritorial waters. Case of Virginius. When the intent is erident and the emergency great, a state threatened with an attack from the sea by persons on board a vessel sailing under the flag of another state may, as an act of self-defense, search and capture such ressel either in its own waters or in nonterritorial waters, despite the general rule which denies the

3 See Mr. Webster's report of Jan. 7,1843 , giving correspondence to that date in regard to the steamer Caroline, contained in Senate Doc. No. 99, 27th Cong., 3d sess.; and also Parl. Papers, 1843, 1xi, 4651.

4 Works, iii, 625.

s See President Tyler's message, transmitting the treaty of Wash- 
right of risiting and seizing upon the ligh seas in time of peace vessels of a friendly power. Such right became the subject of serious discussion in the famons case of the Virginius, a steamer duly registered at the port of New York as a part of our commercial marine on the 26th day of September, 1870. After receiving, on the fourth of the following month, a certificate of the register in the usual form, the steamer sailed from the port of New York, and did not thereafter return to the territorial jurisdiction of the United States. Early in November, 1873, while sailing under the flag of the United States, the Virginius was captured by the Spanish war steamer Tornado in waters claimed by the Spanish authorities to be territorial, and conducted with her crew and passengers, amounting in all to nearly two hundred persons, into the port of Santiago de Cuba, where the prisoners were charged with. piracy and connection with certain Cuban insurgents. The Attorney-General of the United States in a communication to the Secretary of State, dated December 17, 1873, admitted that, "Spain, no doubt, has a right to capture a vessel, with an American register, and carrying the American flag, found in her own waters assisting, or endeavoring to assist, the insurrection in Cuba, but she has no right to capture such a vessel on the high seas upon an apprehension that, in violation of the neutrality or navigation laws of the United States, she was on the way to assist said rebellion. Spain may defend her territory and people from the hostile attack of what is, or appears to be, an American vessel; but she has no jurisdiction whatever over the question as to whether or not such vessel is on the high seas in violation of any law of the United States." 6 Assuming the fact to be beyond all question that the Virginius was seized upon the high seas the gravamen of the American contention, at the outset, was that "American vessels on the high seas in time of peace, bearing the American flag, remain under the jurisdiction of the country to which they belong; and therefore any visitation, molestation, or detention of such vessel by force, or by the exhibition of force, on the part of a foreign power, is in derogation of the sovereignty of the United States." 7 Spain's reply was that the captured ressel really belonged not to American citizens, but

ington to the Senate, Aug. 11, 1842;

Webster's Works, vi, 355.

614 Opinions of Attys. Genl. U.
S., p. 340. See also Parl. Papers. lxxvi, 1874,65 .

7 See President Grant's fifth annual message, 1873. 
to certain Cuban insurgent leaders who had fraudulently obtained, in riolation of the municipal laws of the United States, a register which did not legally invest the ship with an American national character. The Attorney-General's rejoinder was that "Spain cannot rightfully raise that question as to the Virginius, but the United States may, and, as I understand the protocol, they hare agreed to do it, and, governed by that agreement and without admitting that spain would otherwise have any interest in the question, I decide that the Virginius, at the time of her capture, was without right and imploperly carrying the American flag." s Upon that basis the matter was compromised, so far as the capture of the ship was concerned, and the Virginius, with the American flag flying, was delivered to the nary of the United States subject to an agreement which provided "that, should it be shown to the satisfaction of this government that the Virginius was improperly bearing the flag, proceedings should be instituted in our courts for the punishment of the offense committed against the United States. On her part, Spain undertook to proceed against those who had offended the sovereignty of the United States, or who had violated their treaty rights." 9

\section{$\$ 405$. Register only prima facie evidence of nationality. $R$ -} spect due to it as such.-The terms of a compromise entered into under circumstances of passion and excitement, naturally incident to the unlawful execntion by the Spanish authorities of American citizens and British subjects found on board of the Virginius, should not mislead the minds of publicists as to the real issues involved in the capture of the ship itself, which are entirely separate and distinct from those in rolred in the subsequent proceedings under which many of the captured suffered death. ${ }^{10}$ The decision of the Attorney-General of the United States, that the Virginius was fraudulently carrying its llag at the time of her capture upon the high seas, should certainly go far to discredit the unreasonable contention that the possession even of a fraudnlent register is conchusice evidence toall the world of national character,as to which no state can inquire,except that one whose lawsare violated through its procurement. The true doctrine is that such a register is only prima facie evidence of nationality, which any state may chal-

814 Opinions of Attys. Genl. U. S., p. 340 .

2 President Grant's special message, Jan. $5,1874$.
10 Fifty-three of the passengers and crew of the Virginius were put to death. Those who were American citizens were certainly ex- 
lenge at its peril when its interests are involred. ${ }^{11} \mathrm{As} \mathrm{Mr}$. R. H. Dana, Jr., the able editor of Wheaton, well concluded at the time: "Nations laving cause to arrest a vessel, would go behind such a document to ascertain the jurisdictional fact which gives character to the document, and not the document to the fact. * * The register of a foreign nation is not, and by the laws of nations is not, recognized as being a national voucher and guarantee of national character to all the world." 12 And yet such prima facic evidence should be treated with the greatest respect, and any attempt to overturn it should be attended with the greatest caution, and with a full consciousness of the fact that, in the event of its verity, full satisfaction must be given for any and all damages resulting from any unwarranted attack upon its genuineness.

$\S 406$. Liability of Virginius to capture in any event.-It must not be assumed, however, that a lawful American register would have shielded the Virginius from visit and capture on the high seas, provided the Spanish commander had a reasonable ground to believe that the vessel was then engaged in a hostile expedition against the territory of his country, and that the danger was pressing and imminent. Under such circumstances Spain had a clear "right of self-defense, which, springing from the law of nature, is as thoroughly incorporated into the law of nations as any right can be. No state of belligerency is needful to bring the right of self-defense into operation. It existed at all times-in peace as well as in war. The only questions that can arise about it relate to the modes and places of its exercise." 13 That positive exposition of the right made at the time by an eminent American jurist has been confirmed by another who, in defining the rules of international law illustrated by the case of the Virginius, has said: "That the right of self-defense authorizes a nation to visit and capture a vessel as well on the high seas as in its own waters, when there is reasonable ground to believe it to be engaged in a hostile expedition against the territory of such nation." 14

\$407. Right of American and British citizens on board Virginius to lawful trial.-Admitting that the Virginius was

ecuted without due process of law.

11 See above, p. 310.

12 In a Boston Journal of January 6, 1874.
$13 \mathrm{Mr}$. George T. Curtis's examination of "The Case of the Virginius, Considered with Reference to the Law of Self-Defense."

14 Woolsey, § 214. 
legally captured on the high seas as a precautionary defensive measure, the fact remains that the right of Spain either to try or punish the American citizens on board of her was subject to all the limitations imposed by the general rules of international law, and by the special provisions of the treaty of 1795 , guaranteeing that the courts of justice shall be open alike to citizens of each power, with all the privileges of counsel and trial according to the ordinary forms of law. ${ }^{15}$ While the expedition may have been illegal, it cannot be maintained that any piratical acts had been committed prior to the moment of capture; and, even if the ressel and crew had been taken in territorial waters while in the act of landing the passengers, that act could not liave been considered piratical in the absence of all means of enforcing invasion with riolence. ${ }^{16}$ Spain did not therefore attempt to defend the summary proceedings of her officials for whose illegalities she responded with a prompt indemnity. The British government, which likewise received compensation for the families of British subjects executed under the same circumstances, while it did not complain of the seizure of the ressel, or of the detention of the passengers and erew, claimed that after that precaution had been talien "no pretense of imminent necessity of selfdefense could be alleged; and it was the duty of the Spanish authorities to prosecute the offenders in proper form of law, and to have instituted regular proceedings on a definite charge before the execution of the prisoners." It was further claimed that, in that event, it would have been found that "there was no charge either known to the law of nations or to any municipal law, under which persons in the situation of the British

15 The treaty of 1795 (Art. 7) provided "the courts of justice should be open alike to citizens of each power; that seizures of the persons of its citizens of one power by the authorities of the other, within its jurisdiction, were to be made and prosecuted under the ordinary forms of law, and that the persons so arrested were to have the right to employ such adrocates or attorneys as they pleased, who were to have the right of access to them, and of being present at all examinations and trials, all of which engagements have since been entered into with other powers." J. C. Bancroft Davis, Notes on Treaties of the U. S., 1873.

16 "She offered, and was capable of offering no resistance to search or capture. Her passengers, at thes instant of capture, were not armed or organized, and so were incapable of levying war against the authority of Spain, whatever may have been their ultimate intention." Davis, Int. Law, pp. 391-2. 
crew of the Virginius could have been justifiably condemned to death." 17

$\$ 408$. Great Britain's seizure of Danish fleet as a permissible measure of self-preservation.-As a permissible measure of selfpreservation, Great Britain justified her action in demanding that the Danish fleet should be delivered into her custody when, in 1807, Napoleon threatened to force Denmark to take part in the war against her. By secret articles in the Treaty of Tilsit, of which the British government was cognizant, it was provided that France should be at liberty to take possession of the Danish fleet and use it against Great Britain, in which event the former "would have been placed in a commanding position for the attack of the vulnerable parts of Ireland and for a descent upon the coasts of England and Scotland." As the Danes were possessed of no military force capable of resisting an attack from the French army then massed in the north of Germanc, Great Britain felt compelled to prevent the use against her of the naral power of a neutral state, which had been deprived of its free agency, by despatching to the Baltic both a fleet and an army capable of checking the designs of the French. Not until she had offered means of defense against France and a guarantee of the whole Danish possessions, did Great Britain demand the custody of the Danish fleet under the following conditions: "We ask deposit -we have not looked for capture; so far from it, the most solemn pledge has been offered to your government, and it is hereby renewed, that, if our demand be acceded to, every ship in the nary of Denmark shall, at the conclusion of a general peace, be restored to her in the same condition and state of equipment as when receired under the protection of the British flag." When Denmark refused to accede to the demand, even in that form, upon the ground that she was both able and willing to maintain her neutrality, an English army landed at Copenhagen and laid siege to the city, and in that way compelled the Danish government to surrender its entire naval force as the price of safety. The result of the seizure was such exasperation upon the part of the Danes that they threw themselves completely into the

17 Parl. Papers, lxxvi, 1874. "it is clear from this language that the mere capture of the vessel was an act which the British govern- ment did not look upon as beins improper, supposing an imminent necessity of self-defence to exist." Hall, § 86 . 
arms of the French, and at once declared war against England. ${ }^{18}$

$\S 409$. Attack of the U. S. upon Amelia Island, 1817.-The goverument of the United States likewise appealed to the right of self-preservation as a justification for its attack upon Amelia Island, situated at the mouth of St. Mary's River, and a part of the territory of spain, when it became necessary to expel a band of buceaneers that had seized it in 1817 under the direction of an aldventurer named McGregor, who, in the name of the insurgent colonies of Buenos Ayres and Venezuela, undertook to prey indiscriminately upon the commerce of Spain and the United states. When the govermment of the former proved eitler unable or unwilling to suppress the nuisance, Iresident Honroe directed a vessel of wall to drive out the marauder's and to destroy their ressels and works. ${ }^{19}$

\section{$\$ 410$. Notable interventions on religious grounds.-Having} now reviewed the several defensive forms of the right of selfpreservation, the attempt will be made to describe its one offensive form generally known as intervention, a term difficult to confine within the limits of a precise and exhanstive definition. In view of that fact an outline has been heretofore drawn of its origin and growth in the European system, with the belief that illustrations of the manner in which intervention has been actually applied in notable cases will be found to be the most reliable and helpful indications of its real character. $^{20}$ From what has thus been said it appears that in the Peace of Westphalia, for so long a time the basis of the modern public law of Europe, was embodied a provision that France and sweden, its chief beneficiaries, should be given the right to interrene in the internal afficirs of Germany, as a means of upholding the prorisions of a settlement whose primary purpose was to secure the religious

1s Alison, Hist. of Europe, vi, 474-5; De Garden, Hist. des Traite's de Paix, $\mathrm{x}, 238-43$, and 325-31; Lanfrey, Hist. de Napolion Ier, iv, 146-9; Mahan's Influence of Sea Power Upon the French Revolution and Empire, ii, 277.

19 See President Nonroe's first annual message, 1817; Parton's Life of Jackson, ii, 421 ff. "When an island is occupied by a nest of pirates, harassing the commerce of the United States, they may be pursued and driven from it by authority of the United States, even though such island were nominally under the jurisdiction of Spain, Spain not exercising over it any control." Mr. Adams, Sec. of State, to Mr. Hyde De Neuville, Jan. 27, 1\$18; MSS. For. Leg. notes. 20 See above, pp. 110, 111,117,118. 
equality of the Catholic, Lutheran and Reformed churches, as originally guaranteed by the Treaty of Passan, and by the religious Peace of Augsburg. It thus became a recognized principle from the very beginning that the Great Catholic and Protestant powers could legitimately intervene for the protection of their co-religionists in the bosom of rival states. Upon that basis it was that Austria and Spain repeatedly interfered in favor of the Catholic party in France, Germany and England, while the Protestant powers were equally watchful of their adherents in France, Germany and the Netherlands. ${ }^{21}$

$\S 411$. Notable interventions on political grounds.-The right to intervene in the internal affairs of a state on religious grounds became a convenient precedent for the right to intervene on political grounds when, in 1772 , Russia, Austria and Prussia resolved to interfere in the internal affairs of Poland, ostensibly to protect neighboring nations against the internal discords of the smaller state. The right of political intervention so mercilessly applied in the case of Poland was then taken as a precedent to guide those states that deemed it their duty to interfere in the internal affairs of France when the principles of the French Revolution threatened to extend themselves to all other European countries. The successful intervention of the allied powers in the affairs of France, involving as it did unusually intimate relations between a few of the greater ones, seems to have suggested to the Emperor of Russia the idea of uniting Austria, Prussia and Russia in the mystic bonds of the Holy Alliance, formed not only for the purpose of intervention in the affairs of those European states in which the cause of legitimacy was endangered by the rising tide of popular freedom, but also for the suppression of the republican governments that had arisen upon what had once been Spanish soil in Central and South America. No sooner was that attempt frustrated by the joint action of Great Britain and the United States than the former intervened in the affairs of Portugal, whose internal disorders, beginning in 1826 with the death of John VI., were composed by the Quadruple Alliance concluded in 1834. Before that result was reached Great Britain, France and Russia felt called upon by the erents of 1827 to interrene in the affairs of Greece, in order to deliver that country from the dominion

21 Cf. Wheaton, Hist. Law of Nations, Part I, §§ 2, 3, pp. 80-88. 
of the Ottoman Porte. The rear 1830 witnessed the beginning of the intervention of the five great powers for the purpose of composing the Belgic revolution, whose object was to dissolve the union of Belgium with Holland brought about at the Congress of Viema in 1815. In 1.54 Great Britain and France intervened in the affairs of Turkey, primarily to preserve the balance of power in Eastern Europe, and incidentally to rest in the European Concert the protection of the Christian peoples subject to Turkey assumed prior to that time by Russia alone. In 1863 Prussia intervened in the affairs of Denmark; and, after the co-operation of Austria had been secured, their united armies, early in the next sear, crushed that country and forced her to execute the Peace of Vienna, wherein Schleswig-Holstein and Lanenburg were ceded to the victors, subject to such arrangements as they might make with each other. To the foregoing summary of the European history of the right of intervention will be added a few notable and recent illustrations drawn from the history of the New World, before any attempt will be made to deduce from the data thus presented, such general principles regulating the exercise of this right as may be said to have been established by usage.

\$412. Intervention of France, Great Britain and Spain in Mexico. Ultimate motive of Napoleon III.-A notable intervention of three monarchical European powers in the internal affairs of a republican American state was provided for in a convention ${ }^{22}$ made at London, October 31st, 1861, between Great Britain, France and Spain for the declared purpose of enforcing the parment of certain claims against Mexico held by citizens of the contracting powers, and of securing for the future more perfect protection for their persons and property. While the allies disavowed any purpose to acquire territory, or "to exercise in the internal affairs of Mexico any influence of a nature to prejudice the right of the Mexican nation to thoose and constitute the form of its government," plain provision was made for a war of conquest and for a military occupation subject only to the limitation that the conquered should be permitted ultimately to set up such a civil regime as they might deem best. In December of 1861 the army of the allies ocenpied Vera Cruz; and on the sod of the following July the Emperor of the French, in a letter commanding General Forey to march upon the Mexican capital, disclosed the 
fact that his real and ultimate motive in intervening was to prevent the United States from becoming the sole dispenser of the products of the New World by checking her extension southward through the restoration of the prestige of the Latin races in America. The interests and influence of France were to be advanced.through the gratitude and sympathy which would be extended to her by any new government that might be established in Mexico nnder her patronage. ${ }^{23}$ A shrewd Frencluman admitted at the time that the probable expectation of all three of the allies was "the overthrow of the system of govermment established in Mexico since its independence, and the substitution of a monarchical system." 24 The orereagerness of France to attain that end soon deprived her of both her coadjutors. At a conference held at Orazaba, April 9th, 1862, the English and Spanish commissioners refused further co-operation upon the ground that the French had exceeded the terms of the convention in extending military aid to the faction in favor of the establishment of an imperial government. Thus left alone Napoleon protected that faction in their effort to create an Assembly of Notables, selected even without the pretence of a general rote of the Mexican people, which undertook to establish an imperial government by offer ${ }^{2}$ ing the throne to Maximilian, an archduke of Austria, whose authority France at once acknowledged in a convention guaranteeing military aid. The new emperor arrived at Vera Cruz at the end of May, 1864.25 So far the intervention of the allied powers in the affairs of Mexico has been considered from the point of view of their interests only. When thus considered its justification must rest upon the specific grounds set up in the terms of the original convention, and in its general declaration that the object of the contracting parties was "to demand more efficacious protection for the persons and property of their subjects, as well as a fulfilment of the obligations contracted towards their majesties."

23 Archives Dipl., 1863, II, pp. 328-330.

$2+\mathrm{M}$. Chevalier in Révue des Deux Mondes, April, 1862. Despite the Emperor's disclaimer of any intention to force a government on Mexico, he instructed General Forey "to establish either a monarchy, if it be not incompatible with the national sentiment of the country, or, at all events, a government which promises some stability."

25 On April 8th, 1864, before leaving Europe, Maximilian signed the treaty of Miramar in which France undertook to furnish certain military aid upon certain pecuniary considerations. De Clercq, ix, p. 18. 
$\S 413$. An intervention to end an intervention. Mr. Seward's protest.-When such intervention is considered in reference to the interests of the United States a new principle comes into view,-a principle which permits one state to intervene in order to prevent or terminate the intervention of another state or states when the same is illegal or unjustifiable. By virtue of the primaty or overlordship orer the New World rested in it through the growth of the Monroe Doctrine, the government of the United states, so soon as its freedom of action was assured by the successful termination of the civil war, nndertook to indicate to France that there existed profound national discontent by reason of the fact "that the French army which is now in Mexico is invalding a domestic republican gorerument there, which was established by her people, and with whom the United States sympathized most profoundly, for the arowed purpose of suppressing it, and establishing upon its rnins a foreign monarchical government, whose presence there, so long as it shall cndure, could not but be regarded by the people of the United States as injurious and menacing to their own chosen and endeared republican institutions." 26 So efficacious was this intervention, interposed to terminate an intervention, that an arreement was soon arrived at "between this government and the Emperor of France, to the effect that he will withdraw his expeditionary military forces from Mexico in three parts: the first of which shall leave Mexico in Norember next, the second in March next, and the third in Yovember, 1867 , and that upon the eracuation being thus completed, the French government will immediately come upon the ground of non-intervention in regard to Mexico, which is held by the United States." 27

$\$ 414$. Intervention of $U$. $S$. in affairs of Venezuela.-When near the close of $18 \% 5$ it became necessary for the government of the Inited States to intervene in the boundary controversy then pending between Great Britain and the Republic of Venezuela, the Iresident declared in a special message to Con-

$26 \mathrm{Mr}$. Seward, Sec. of State, to Mr. de Montholon, Dec. 6, 1865. MSS. Notes, France. For the preceding correspondence, beginning in 1861 with the refusal of the United States to take part with France, Spain and Great Britain, against Mexico, see Wharton, Int.
Law Dig., \$58; British and Foreign State Papers for 1861-2, vol. 52. Cf. also Calvo, $\$ \S 118-126$; Dana's Wheaton, note 41.

$2 \pi \mathrm{Mr}$. Sewarl, Sec. of State, to Mr. Campbell, Oct. 25, 1866. MSS. Inst., Mex. 
gress28 that, "if a European power by an extension of its boundaries takes possession of the territory of one of our neighboring republics against its will and in derogation of its rights, it is difficult to see why to that extent such European power does not thereby attempt to extend its systen of government to that portion of this continent which is thus taken. This is the precise action which President Monroe declared to be 'dangerous to our peace and safety' and it can make no difference whether the European system is extended by an adrance of frontier or otherwise." Is the right of intervention was thus made to rest upon the Monroe Doctrine, and as Great Britain had contended in her reply ${ }^{29}$ to the original suggestion of arbitration, that that doctrine does not embody any principle of international law which "is founded on the general consent of nations," and that "no statesman, however eminent, and no nation, however powerful, are competent to insert into the code of international law a novel principle which was never recognized before and which has not since been accepted by the government of any other country," it became necessary for the President to declare that, "practically the principle for which we contend has peculiar, if not exclusice, relation to the United States. It may not have been admitted in so many words to the code of international law, but since in international councils every nation is entitled to the rights belonging to it, if the enforcement of the Monroe Doctrine is something we may justly claim, it has its place in the code of international law as certainly and as securely as if it were specifically mentioned; and when the United States is a suitor before the high tribunal that administers international law the question to be determined is whether or not we present claims which the justice of that code of law can find to be right and ralid."

\section{\$415. Primacy of U. S. as defined by President Cleveland and} Prof. Lawrence.-When that point was reached the only remaining difficulty was that involved in the restatement of the Monroe Doctrine in such a form as to warrant the contelltion that the United States, by virtue of its primacy or orerlordship in the New World, has the right to act as final arbiter and to carry out its decrees by force, if necessary, whenever a

28 Dec. 17, 1895. Messages and Papers of the Presidents, ix, 655.

29 Such reply was embodied in two communications addressed by the British Prime Minister to Sir Julian Pauncefote, British ambassador at Washington. 
controversy is pending between a European power and an American state, whose consequences threaten an extension of the European system in this hemisphere. In order fully to derelop that idea the President maintained that "if the balance of power is justly a cause for jealous anxiety among the governments of the Old World, and a subject for our absolute noninterference, none the less is an observance of the Monroe Doctrine of vital concern to our people and their government." Thus, in a clear and consistent form was finally reached the conclusion that the same supreme directing and arbitrating power, which in the Old World is rested in the Concert of Europe, is, in the New, vested in the government of the United States acting alone. While Great Britain, whose interests in these Continents are far vaster than any otler European power, frankly admitted, as a matter of fact, that such a primacy is rested in the United States by accepting the arbitration upon which its government insisted, one of the most notable of English publicists has recently admitted, as a matter of theory, that "the Great Powers of Europe, as they are called, have gradually obtained such a predominant position as to render untenable the proposition that there is no distinction between them and other sorereign states; and the position they hold in Europe is held by the United States on the American continent. * * International law gives the Great Pow. ers no more right in their individual capacity than the smallest and weakest of their fellows. But collectively they act in the questions over which they have gained control pretty much as the committee of a club would act in matters left to it by the rules of the club. * * If it be true that there is a primacy in America comparable in any way with that which exists in Europe, it must be wielded by her (the United States), and by her alone. There is no room for that machinery of conferences, congresses, and diplomatic communications which play so large a part in the proceedings of the great powers. The supremacy of a committee of states and the supremacy of a single state cannot be exercised in the same manner. What in Europe is done after long and tedious negotiations, and much discussion between representatives of no less than six countries. can be done in America by the decision of one cabinet discussing in secret at Washington." 30

30 Lawrence, Principles of Int.Law, pp. 65, 66, 247. 
$\S 416$. Intervention of U. S. in affairs of Cuba. Community of interests.-In the famous letter ${ }^{31}$ directed by Mr. Jefferson to President Monroe, October 24, 1823, in which the former laid the foundations of the doctrine which has since borne the name of the latter, the following passage occurs: "But we have first to ask ourselves a question. Do we wish to acquire to our own confederacy any one or more of the Spanish provinces? I candidly confess that I have ever looked on Cuba as the most interesting addition which could ever be made to our system of states. The control which, with Florida Point, this island would give us orel the Gulf of Mexico and the countries and isthmuses bordering on it, as well as all those whose waters flow into it, would fill up the measure of our political well-being." Since that time every American Secretary of State has kept clearly before his eyes the fact that the geographical position of Cuba places that island in such special relations to the United States as to preclude the idea of its transfer, either by purchase or conquest, to any one of the more powerful of the European nations. On October 25, 1825, Mr. Clay, Secretary of State, wrote to Mr. Brown that "you will now add that we could not consent to the occupation of those islands (Cuba and Porto Rico) by any other European power than Spain under any contingency whatever;" and, on October 2, 1829, Mr. Van Buren, Secretary of State, wrote to Mr. Van Ness that "the government has always looked with the deepest interest upon the fate of those islands, but particularly of Cuba. Its geographical position, which places it almost in sight of our southern shores, and, as it were, gives it the command of the Gulf of Mexico and the West Indian seas, its safe and capacions harbors, its rich productions, the exchange of which for our surplus agricultural products and manufactures constitutes one of the most extensive and valuable branches of our foreign trade, render it of the utmost importance to the United States that no change should take place in its condition which might injuriously affect our political and commercial standing in that quarter." 32 With such interests to protect the United States necessarily became deeply concerned in the successive insurrections in Cuba against the dominion of Spain, extending over a period of nearly fifty years, during which time the government of the former was subjected to great expense through the enforce31 See above, p. 142.

32 MSS. Inst. Ministers, 1825 and 1829 . 
ment of neutrality laws, while its people, shocked by the speotacle of almost incessant strife, were forced to bear enormous pecuniary losses incident to the interruption of trade and com. merce.

$\S 417$. Intervention as a contingent necessity. Views of Presidents Grant and Cleveland.-The condition of things brought about by the great war, which began at Yara in 1868 and ended ten years later with the Treaty of Zanjon, prompted Mr. Fish to direct $\mathrm{Mr}$. Schenck, November 27,1875 , to explain to Great Britain "that intervention is not contemplated as an immediate resort, but as a contingent necessity in ease the contest be prosceuted and satisfactory adjustment of existing griefs be not reached;" 33 and in his seventh aunual message directed to Congress in the same year President Grant said that "in such event, I am of opinion that other nations will be compelled to assume the responsibility which devolves upon them, and to seriously considel the only remaining measures possible, mediation and intervention." 34 During the final rerolt, which began in February, 1895, the devastation incident to the policy of concentration, inaugurated by the Captain General's bando of October 21, 1896, became so destructive of American interests, that President Cleveland, in his fourth annual message, informed Congress "that it cannot be reasonably assumed that the hitherto expectant attitude of the Cnited States will be indefinitely maintained. While we are anxious to accord all due respect to the sovereignty of Spain, we cannot riew the pending conflict in all its features, and properly apprehend our ineritably close relations to it and its possible results, without considering that by the course of events we may be drawn into such an unusual and unprecedented condition as will fix a limit to our patient waiting for Spain to end the contest, either alone and in her own way, or with our friendly co-operation." 35

$\S 418$. Precipitated by destruction of Maine.-After the destruction of the Maine at Havana during the night of the 15th of February, 1898, had demonstrated the fact that the government of Spain could no longer assure the safety and security of a ressel of the American nary visiting that port on a mission of peace, President MeKinley was called upon

33 MSS. Inst., Gr. Brit. 35 Messages and Papers of the

34 Messages and Papers of the Presidents, ix, p. 721.

Presidents, vii, p. 339 . 
to determine whether or no the time had arrived for the forcible intervention of the United States. President Cleveland, in the message just referred to, had said that "when the inability of Spain to deal successfully with the insurrection has become nanifest and it is demonstrated that her sovereignty is extinct in Cuba for all purposes of its rightful existence, and when a hopeless struggle for its re-establishment has degenerated into a strife which means nothing nore than the useless sacrifice of human life and the utter destruction of the very subject-matter of the conflict, a situation will be presented in which our obligations to the sovereignty of Spain will be superseded by higher obligations, which we can hardly hesitate to recognize and discharge." After quoting that passage President McKinley in his special message of April 11, 1898, informed Congress that in his judgment the time had come for forcible intervention, and requested authority "to use the military and naval forces of the United States for these purposes."

\section{$\S 419$. Grounds of intervention as defined by President} McKinley.-In defining the grounds of such proposed action he said: "The forcible intervention of the United States as a neutral to stop the war, according to the large dictates of humanity and following many historical precedents where neighboring states have intervened to check the hopeless sacrifices of life by internecine conflicts beyond their borders, is justifiable on rational grounds. It involves, however, hostile constraint upon both the parties to the contest, as well to enforce a truce as to guide the erentual settlement. The grounds for such intervention may be briefly summarized as follows: First. In the cause of humanity and to put an end to the barbarities, bloodshed, starvation, and horrible miseries now existing there, and which the parties to the conflict are either unable or un willing to stop or mitigate. It is no answer to say this is all in another country belonging to another nation, and is therefore none of our business. It is specially our duty for it is right at our door. Second. We owe it to our citizens in Cuba to afford them that protection and indemnity for life and property which no government there can or will afford, and to that cnd to terminate the conditions that deprive them of legal protection. Third. The right to intervene mas be justified by the very serions injury to the commerce, trade and business of our people and by the wanton destruction of property and devastation of the island. Fourth, and which is of 
the most importance. The present condition of affairs in Cuba is a constant menace to our peace and entails upon this government an enormous expense." 36

$\S 420$. Intervention justified by general principles of international law.-Lea ving the Honroe Doctrine entirely out of view, the foregoing grounds justified the intervention of the United States under the generally recognized principles of international law. "The right of self-defense incident to every state may in certain circumstances carry with it the necessity of interrening in the relations, and to a certain extent of controlling the conduct of another state; and this where the interest of the intervener is not immediately and directly but mediately and indireetly affected. This remark brings us to the consideration of the doctrine of intervention." 37 While Great Britain protested in connection with the Neapolitan Revolution of 1820 against the improper exereise of the right, in that case, she at the same time stated that "no government could be more prepared than the British government was to uphold the right of any state or states to interfere where their own immediate security or essential interests are seriously endangered by the internal transactions of another state," provided the exercise of such right is "justified by the strongest necessity, and to be limited and regulated thereby." 38 In $\mathbf{1 8 2 7}$ the right of intervention in favor of Greece as against Turkey was emphatically asserted in a treat ${ }^{39}$ signed on the 6 th of July of that year, between Great Britain, France and Russia, whose preamble declared that the three contracting parties were "penetrated with the necessity of putting an end to the sanguinary contest which, by delivering up the Greek provinces and the isles of the Archipelago to all the disorders of anarchy, produces daily fresh impediments to the commerce of the European states, and gives occasion to piracies, which not only expose the high contracting parties to considerable losses, but, besides, render necessary burdensome measures of protection and repression." A more graplic description could hardly have been drawn of the intolerable conditions imposed by the anarehy in Cuba upon the people of the United States.

36 Messages and Papers of the Presidents, x, p. 147.

3 i Phillimore, i, p. 554.

38 Circular Despatch of Lord Castlereagh, Jan. 19, 1821. British and Foreign State Papers, 1820-21, p. 1160; Hertslet's Map of Europe by Treaty, i, pp. 664-666; Ghillany, ii, 253.

$$
39 \text { Martens (N. R.), vii, } 282 \text { and }
$$
463. 
$\$ 421$. Can the right to intervene in the affairs of one state be vested in another by a contract of guarantee?-Having now considered the leading cases in which intervention is authorized by the general principles of international law, the question must be asked, whether or no the right or duty of intervention in the internal affairs of one sovereign state can be lawfully vested in another state or $^{2}$ states by virtue of an express contract in the form of a guarantee that certain internal conditions shall remain unimpaired. As stated heretofore, when the foundations of the modern international system were laid in the provisions of the Peace of Westplaalia, as a means of upholding or guaranteeing them, the right was rested in France and sweden of perpetual interference in the internal affairs of the German Empire; and in the treaties in which the Peace of Utrecht was embodied sixty-five years later guaranties were given that the crowns of France and Spain should never be united on the same head, and that the Protestant successionasestablished by law in England should be maintained and defended. ${ }^{+0}$ By such compacts a state undoubtedly surrenders certain attributes of sorereignty, as in the case of engagements not to maintain fortifications upon certain parts of the territory and the like. ${ }^{1}$ If the latter are valid, why not the former?+2 In any event such guaranties when given by sovereign or part-sovereign states come within the purview of international law, and for that reason must be distinguished from the constitutional guaranties given by a federal state to the members composing it, which do not come within its purview, because such protected states are not such persons as international law can recognize.

$\S 422$. When intervention is asked by both parties to a conflict, or by one only.-In the erent of civil war, if both parties to the conflict ask the intervention of one or $^{2}$ more powers as a means of settlement, certainly no objection can be urged against the

40 See above, pp. 97, 106.

$41 \mathrm{As}$ to negative servitudes of that class, see above, p. 299.

42 The right of intervention under a treaty of guarantee is upheld by Martens (Précis, $\S 78$ ), Klüber $(\S 51)$, and Heffter $(\S 45)$. Hall ( 93 ), on the other hand, makes the very forcible suggestion that "the doctrine that intervention on this ground is either due or per- missive, involves the assumption that independent states have not the right to change their government at will, and is really a relic of the exploded notion of ownership on the part of the sovereign." Twiss ( $I, \S 231$ ), and Halleck (i, $85)$, maintain the same view. Vattel (II, c. xii), and Phillimore (ii, $\S 56$ ), are too doubtful to be ranged on either side. 
justice or legality of such a proceeding. If, however, the invitation comes from one only of the contestants, can such an invitation of itself in any ease legalize the intervention? De. spite Phillimore's declaration that intervention under such circumstances "ean harlly be asserted to be at variance with any abstract principle of international law, while it must be admitted to have received continual sanction from the practice of nations," 43 the only view logifally consistent with the theory of the right of every state to independence seems to be that embodied in IIalleck's contention, that "if the invitation be from one only of the contestants, it can, by itself, confer 110 rights whaterer against the other party." ${ }_{44}$ The obvious answer to Bluntschli's claimt5 that a state has the right to intervene in a civil war in behalf of an established government so long as it remains the real organ of the state, and to Heffter's, ${ }^{46}$ that a state may intervene in favor of whichever contestant appears to be in the right, is that whenever a state undertakes to intervene on either ground it should do so subject to the same considerations that would govern its action in the event of a recognition of belligerency or independence. As stated heretofore, when a forcign power desires to recognize the independence of a community struggling to free itself from a parent state, before it is ready to do so, cantion should be exereised, for the reason that a premature or unjustifiable recognition either of belligerency or independence is really an act of intervention, which the parent state may meet by a declaration of war. ${ }^{47}$

$\$ 423$. Intervention defined in the light of authoritative precedents.-Intervention, when riewed in the light of the leading alses that have taken place in the Old World and the New since the modern international system began, may be defined to be the right of a single state or a group of states forcibly to interfere in the affairs, internal or external, of one or more states, irrespective of their consent, in order to maintain or alter actual conditions, whenever the intervening power or powers determine that such action is necessary under the principle of self-preservation. As interrention is a hostile act, which the state interfered with may treat as an act of war, the intervening power must neces-

43 Int. Law, i, § 395 .

44 Int. Law, i, 87.

45 Völkerrecht, $\S$ 476-7.
46 Völkerrecht, § 46.

47 See above, pp. 188, 192. 
sarily assume the right of final judgment and the burden of proving that such judgment is justified by the facts of the particular case. The fundamental difficulty in the matter arises out of the necessity of reconciling two apparently irreconcilable principles. The theologian or metaphysician who is called upon to harmonize the doctrines of freewill and predestination is confronted with a dilemma scarcely more perplexing than that imposed upon the publicist when he attempts to reconcile the right of independence, which confers upon every sovereign member of the family of nations complete liberty to live its own life and to manage its aflairs in its own was, with that higher law which authorizes one or more states, under certain conditions, to compel another to do something which, if left to itself, it would not do, or refrain from doing something which, if left to itself, it would do. Against the theoretical difficulty stands, howerer, the fact that the higher law actually exists, and has been enforced during a long period of time in a series of cases, some of which are now generally accepted as authoritative precedents. Therefore when the question is asked upon what grounds can one state or a group of states legally intervene in the affairs of another, the only answer that can be given is that, in the light of such precedents, a state or group of states may in the fol. lowing cases resort to intervention as a branch of the general right of self-preservation:

$\S 424$. Intervention as a means of preserving the balance of power.-In the modern international system, whose primary purpose has ever been the maintenance of the balance of power, was embedded at the outset the right of intervention as a means of preserving such balance; and, from the middle of the seventeenth century down to the Congress of Berlin, that means has been invoked whenever the scrstem of balance has been threatened by a disturbance of the international equilibrium of forces. ${ }^{48}$ It is hard to reconcile the fact that the Concert of Europe, or a combination of several of its

48 While the outlines of the sys$t \in m$ of balance were drawn in the terms of the Peace of Westphalia (1648), its express recognition, as a de facto system, dates from the Peace of Utrecht (1713) concluded expressly, according to the recital in the treaty between Great
Britain and Spain, "Ad formandam stabiliendamque pacem ac tranquillitatem Christiani orbis Justo Potentiæ Aequilibro." Schmauss, Corp. Jur. Gent. Academicum, p. 1419; Twiss, I, $\S 104$; Lawrence, Essays on Some Disputed Questions, etc., No. 5. 
greater members, intervened in the affairs of Greece in $182 \pi$; in the affairs of Belgium in 1830; in the afrairs of Turley in 1556 ; in the aflairs of Denmark in 1864; and in the affairs of Russia and Turliey in 18\%, with the statement that "of late rears it (intervention for the preservation of the balance of power) has fallen into disrepute, and those who still maintain it sef it forth in a greatly modified form." 49 Certainly no such observation is likely to be made as to the corresponding overlordship asserted of late years in the New World by the goverument of the United states. Ind, so fal as the Concert of Europe is concermed, present indications give no reason for the belief that its existence will become less necessary for the future maintenance of the greneral peace; or that there will be a disposition to take a way from it a range of intervention somewhat wider than that possessed by individual states.

$\S 425$. Intervention for protection of indirect interests not too remote.-A state may intervene for its own protection in the affairs of another when by acts of omission or commission the offending state actually interferes with or threatens the institutions, good order, or safety, intermal or external, of the interrening state,- "and this where the interest of the intervenor is not immediately and directly but mediately and indirectly affected." 50 Austria, Russia and Prussia interrened in the afrairs of Poland upon the ground that their security was imperiled by the internal discords of the smaller state; and that precedent guided all of the European states that deemed it their duty to interfere with the internal affairs of France when the principles of the French Revolution tlreatened to disturb the institutions of all monarchical countries.51 While intervention may thus be justified by the indirect consequences of certain acts of omission or commission upon the part of the offending state, it cannot be extended so far as to embrace merely the indirect consequences of a certain form of government. or the prevalence of ideas opposed to those of the intervening state. 52

49 Lawrence, Principles of Int. Mamiani, 100-1; Fiore, i, 421-55; Law, pp. 126-7.

" Phillimore, i, p. 554.

51 See above, p. 111.

52 Martens, Pricis, \& 74; Phillimore, i, \$387-88; Dana's Wheaton, Pt. ii, ch. 1; Halleck, i, 83.465 ; Bluntschli, $\$ 474$, note, and 478; Hall, §91. The right of one state to interfere in the affairs of another is confined to narrower limits by Vattel (II, c. iv, \$ 54), Heffter ( $\$ \$ 30-1$ and 44-5), and Calvo ( $\S 141-2$ ). 
$\S 426$. Intervention to ward off an imminent danger.-The most obvious ground of intervention, and the one least exposed to criticism, is of course that presented by the necessity which impels a state to ward off an imminent and pressing danger. Thus when in 1804 the English government discovered that Spain was preparing a naval armament at Ferrol, in order to carry out an agreement to assist France, then at war with Great Britain, hostilities were begun against the offending state after the remonstrances of the intervening state were disregarded. ${ }^{53}$

$\$ 42 \%$. One state may intervene to prevent or terminate illegal intervention of another.-One state may intervene in order to prevent or terminate the illegal intervention of another state or of a combination of states in the affairs of a neighbor or friend, so as to secure to it its freedom of action. ${ }^{54}$ In that event the power intervening to terminate such intervention must justify its action upon some ground justifiable as between itself and the power or powers against whom it is asserted. A convenient and recent illustration is presented by the action of the government of the United States in terminating the intervention of France in the internal affairs of Mexico upon grounds which have been fully explained already. ${ }^{55}$

$\S 428$. Intervention under treaties of guarantee. Case of Belgium.-As a state may undoubtedly contract itself out of some of its common law rights, it may part with certain attributes of sovereignty in treaties of guarantee binding it to maintain a particular dynasty or a particular form of government; or granting the reversion to another dynasty in the event of the extinction of its own $;^{56}$ or stipulating for its permanent neutralization. When during the Franco-Prussian war of 1870 it was suspected that both France and Prussia contemplated a violation of the neutrality of Belgium, Great Britain at once

53 Annual Register for 1805, pp. 20-27.

54 Heffter, § 96; Bluntschli, § 479;

Mamiani, 104.

55 See above, p. 414.

56 Martens, Précis, § 75; Heffter, § 45; Phillimore, i, $\S 400$; Bluntschli, $\S 479$. "The latest occasions on which any question of intervention on the above ground seems to have arisen were in 1849 , when, according to Phillimore, Austria meditated, but did not carry out, an intervention in Tuscany; and in 1860 , when Spain appears to have intervened diplomatically, on behalf of the Duchess of Parma, on the occasion of the annexation of Parma to the kingdom of Italy by a popular vote." Hall, p. 301, note 1 . 
intervened by concluding two conventions, the first between Belgium, Prussia and herself, the second, between Belgimm, France and herself,-each stipulating for joint action to uphold the guarantee in the event of its infraction by either belligerent. 57

$\$ 429$. Humanitarian interventions to prevent cruelty and tyranny,-The foregoing are generally described as legal grounds $\mathrm{s}^{58}$ of intervention in contradistinction to those which rest upon a moral basis only. As international public law professes to deal solely with the relation of states to each other, and as such immoral acts of a particular state in its internal dealings with its own subjects as result in massalcres, brutalities, and religious persecutions do not fall within the scope of such relations, many contend that the right of intervention cannot be legally in roked for their redress or repression. The jurisdiction of international law over what are known as humanitarian interventions rests upon no stronger foundation than the theory that as each state composing the family of nations is a moral being, and as such clothed with moral duties and responsibilities, any act upon its part so grossly immoral as to amount to a public scandal may be dealt with as an offense against the entire body of states considered as a single society. Such right of intervention when approved by the whole body of civilized nations should therefore stand upon a far firmer foundation than in the case of its assertion by one state only. From the incomplete treatment of the subject by modern publicists, whose opinions are conflicting, it is difficult to draw precise and definite conclusions as to the circumstances and conditions under which an intervention for the prevention of cruelty and tyranny may be properly undertaken. Vattel holds

57 Hertslet, Map of Europe by Treaty, III, 1886-1891. The British guarantee of the neutrality of Belgium had been given in the treaties of 1831 and 1839 .

5. Some authorities maintain that all interventions belong properly to the domain of politics, and not to that of international law. Sir Wm. Vernon Harcourt, in the letters published originally in the London Times under the title of "Historicus," and afterwarls in a separate form over his own name, says (p. 14), "it (intervention) is above and beyond the domain of law, and when wisely and equitably handled by those who have the power to give effect to it, may be the highest policy of justice and humanity." And again (41) he says, "nevertheless it must be admitted that in the case of in. tervention, as in that of revolution, its essence is its illegality, and its justification its success." See also Pomeroy, Int. Law, p. 244 ; Lorimer, Institutes, ii, ch. viii, 
Intervention permissible for the succor of a people oppressed

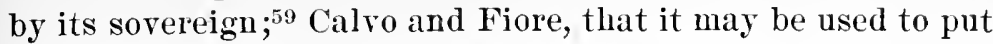
an end to crimes and slaughter $; 60$ Mamiani, Bluntschli and Wheaton, that it may be applied as the means of aiding an oppressed race. ${ }^{61}$ On the other hand, Heffter denies that it can be rightfully involied for the repression of tyranny. When France and England suspended diplomatic relations with Naples, in consequence of the inhumanity with which the kingdom was ruled, the Russian government issued a circular declaring "that as a consequence of friendly forethought one government should give advice to anothè in a benevolent spirit, that such adrice might even assume the character of exhortation; but we believe that to be the furthest limit allowable. * * To endearor to obtain from the king of Naples concessions as concerns the internal government of his state by threats, or by a menacing demonstration, is a violent usurpation of his authority, an attempt to govern in his stead; it is an open declaration of the right of the strong over the weak." 62 Against that effort to limit the right to a mere exhortation may be balanced the claim that "should the cruelty be so long continued and so revolting that the best instincts of human nature are outraged by it, and should an opportunity arise for bringing it to an end, removing its cause without adding fuel to the flame of the contest, there is nothing in the law of nations which will condemn as a wrong-doer the state which steps forward and undertakes the necessary interrention." 63

$\S 430$. Interventions to end religious persecutions in the Orient. -Despite the fact that interventions for the purpose of putting an end to religious persecutions within civilized states are not generally sanctioned by publicists, they seem to be regarded as legitimate when employed by Europe as a means of protecting Christians within the limits of the Orient, upon the general ground that the Eastern Question constitutes an exception, a case apart. ${ }^{64}$ One of the motives of the interven-

59 Droit des Gens, I, c. 4, §51.

60 Droit Int. \$166; Nouveau Droit Int., i, 446. Mamiani (112) denies that intervention may be employed for that purpose.

61 Nuovo diretto, p. 86; Völker. recht, § 478; Elements, §69, Dana ed.
62 Martin, Life of the Prince Consort, iii, 510.

63 Lawrence, Principles of Int. Law, p. 120.

64 See the views of M. Rolin Jaequemyns expressed in regard to the Greco-Turkish conflict of 18856 in Rev. de Droit Int., xviii, 603. 
tion that resulted in the Crimean War was to rest in the European Concert the protection of the Christian peoples subject to Turkey, assumed prior to that time by Russia alone; and by virtue of the authority thus assumed the Great Powers intervened to stop the persecution and massacre of Christians in the Mount Lebanon district in $1860 .^{65}$ In commenting upon such an intervention, undertaken for the purpose of preventing and terminating barbarous and scandalous cruelty, it is usual for text writers to declare that it is "a higl act of policy above and beyond the domain of law;" 66 or that "from the point of riew of law, it is always to be remembered that states so intercening are going beyond their legal powers. Their excuse or their justification can only be a moral one." 67 How vague and unmeaning such artificial distinctions really become when the fact is remembered that international law is not positive law at all,-only a body of rules that dominate "a province half way between the province of morals and the province of positive law." 68

65 For the two protocols signed on August 3, 1860, in the conference of the representatives of the Five Powers held at Paris, see Holland, European Concert in the Eastern Question, pp. 207-8.
66 The Letters of Historicus on some Questions of Internationl Law, I.

67 Hall, p. 308.

68 See above, p. 83 . 


\section{PAFT IV.}

\section{Rights and Duties of States in Tine OF WAR.}

\section{CHAP'TER I.}

FORCIBLE MEANS OF REDRESS SHORT OF ACTUAL WAR.

$\S 431$. Preliminary forms of redress classified.-Before attempting to define what war really is or to discuss its consequences, a brief consideration should be given to the forcible means of redress sometimes employed in the effort to terminate differences between nations without a resort to actual hostilities. When one state injures another either directly or by injuring or permitting an injury to a citizen of the other, and fails or refuses to grant redress in the amicable methods heretofore discussed, the offended state may pursue one of several courses not necessarily in rolving acknowledged war. Such methods of peaceable redress have been variously classified. Wheaton's application of the generic name of reprisals to all forms of redress short of actual war is confusing because that term is generally associated, in a narrower sense, with certain well known procedures to which it is limited by usage. It is more convenient to divide the remedies in question into such as are negative, expressing rather displeasure than exacting redress; and into such as are positive, threatening retaliation or asserting force closely akin to that employed in actual war. To the first division belong severance of diplomatic connection and other like expressions of national displeasure; to the second, embargoes and non-intercourse, retorsions, reprisals, sequestrations, military and naval demonstrations and pacific blockades. In no event should force be used until all other means have been exhausted. ${ }^{1}$

1 Wheaton, Elements, 210; 1 Opin. Attys. Genl., p. 30; Heffter, $\$ 111$, G. n. 6 . 
$\$ 432$. When an injured foreigner should resort to local courts. - An injured foreigner is expected to resort to the remedies provided by the local courts before appealing to his government, unless there is a state of anarchy or the condition of the courts for other reasons renders their procedure a mockery of justice. Eren then the grovernment appealed to should, in ordinary cases, protest (protestatio facto contraria) before interrening. ${ }^{2}$

$\$ 433$. Withdrawal of diplomatic agents._. Is permanent minister's and ambassador's are maintained as the best mediums through which views may be exchanged and business amicably adjusted between nations, a refusal to settle just claims within a reasonable time may become a snfficient cause for the withdrawal of a diplomatic agent from the offending capital. Under such cireumstances the representative may retire, leaving the business of his embassy or legation in the hands of a chargé d'affaires; or the mission may be entirely closed, and the enroy of some friendly power requested to look after the interests of citizens. Thus in 1827 the American chargé at Rio de Janeiro, when "his representations in behalf of the rights and interests of his countrymen were disregarded and useless, deemed it his duty, without waiting for instructions to terminate his official functions, to demand his passports and return to the United States." Not until the Brazilian gorernment promised "that indemnity should be promptly made for all injuries inflicted on citizens of the United States, or their property, contrary to the laws of nations," did President Adams authorize the renewal of diplomatic intercourse. In 1834 when France failed to pay the indemmity due under the spoliation treaty like pressure was applied; and when in 1858 a tax was inposed by Mexico, which nnduly discriminated against eitizens of the United States, it was deemed such an unfriendly act that the American minister, under instructions, suspended diplomatic relations with that country ${ }^{3}$ A notable repetition of the same procedure recently occurred during the boundary controversy between Great Britain and Venezuela. Mild as this remedy appears to be, it is often efficacious, especially when the injury results from mere delay rather than from hostile intention.

$\S 434$. Embargo and non-intercourse.-A more decided step is taken when there is a suspension of commercial intercourse 
with the offending nation. This breaks the bond which unites nations most strongly and enlists that influential class, the merchants, in securing an adjustment of the point in controversy. It may assume either or both of two forms,- -an entbargo which prevents our own shipping, and perhaps that of the other state, from leaving our ports, or a non-intercourse law, prohibiting eitizens of the offending state from coming to our country or trading with our citizens. Both forms have appeared in Imerican history, and, as often happens in practice, the two have sometimes run into each other in their effects. Embargo (a Spanish law term meaning sequestration) may be domestic, applying only to the shipping of the state imposing it, or it may be hostile, having for its object the prerention of the exit of the enemy's ressels. Eren the former may injure the enemy by preventing export to him of food or other necessary articles. When his ressels are seized, it is by way of attachment or sequestration, and they are held, not condemned. Should war result, they become subject to prize jurisdiction as of the date of the original seizure; otherwise they will be released on adjustment of the matters in dispute. ${ }^{*}$ In an extreme case they might be confiscated at once, a course formerly usual at the outbreak of war; but under modern tendencies as to exemption of private property that is unlikely now. In no erent can compensation be claimed when the right of detention really exists. ${ }^{5}$ Passing over the temporary embargo of the United States in 1794 , special reference must be made to the pacific or domestic one of $1807 .{ }^{6}$ Stung by the British claim and practice of search and impressment of seamen, the attack on the Chesapeake, and Napoleon's continental policy, America kept her ships at home for the double purpose of protecting her commerce from British and French aggressions, and, by cutting off supplies, of coercing both of those gigantic belligerents. ${ }^{7}$ More domestic than foreign suffering

4 The Boedes Lust, (1804), 5 Rob. 233; Twiss, War, $\S \S 12,59$; Wharton, Int. L. D., $\S 320$.

5 Geffcken, in note 4 , contradicting the text of Heffter, $\S 112$.

6 Under the act of December 22 , 1807; 2 U. S. Statute at Large 451, with sundry amendments in succeeding years.

i 2 Schouler's U. S., 186; 2 Gallatin Writings, 492. The principal decisions under the embargo laws are as follows: United States vs. Hall and Worth, 6 Cranch, 176; Durousseau vs. The United States, 6 Cranch, 307; The Schooner Good Catharine vs. The United States, 7 Cranch, 349; Crowell et al. vs. McFaddon, 8 Cranch, 94; United States vs. Gordon et al., 7 Cranch, 287; The William King, 2 Wheat. 148; Otis vs. Walter, 11 Wheat. 
resulted, however, from that expedient, which was followed, March 1, 1809, by a non-intercourse act directed against Great Britain alone. As war with that country resulted from such measures, Gallatin was convinced that they are per se ineficient. In 1839) England placed a hostile embirgo upon the shipping of the Two sicilies, and when that kingdom retaliated the embargo galve way to reprisals. Although many ressels were captured and sicilian vessels detained at Malta, the British minister did not withdraw from Naples. The matter was finally adjusted through the mediation of France, and the offensive sulphur monopoly, granted by the Italian authorities to Taix, Aycard, and Cie., was rescinded. Thereupon all ships were released. Had war followed they would have been considered captured from the date of seizure, and condemned or not according as the enemy did or did not condemn." There is perhaps a third form of embargo, a general one, detaining all shipping to prevent information from getting out, or for some other military reason. That form is, however, peculiar to a state of war or to circumstances indicating its approach. ${ }^{10}$

$\$ 435$. Retorsions: retorsio juris.-Retaliation in a broad sense covers any and all positive acts in return for unfriendly acts of another country. It relates more specifically, howerer, to the return by one state in substantially the same form of an injury done to it by another. Such retaliations in lind, or retorsions, have been varionsly and perhaps fancifully subdivided. Retorsio juris, or retorsio de droit, is generally applied to a negative form of retaliation used after a violation of comity. It is the name for acts placing eitizens of the offending state under the same disabilities as those to which it subjects the eitizens of the retorting state. It is a hostile reciprocity, applicable to tariffs, conity, imperfect obligations and general policy.11 If China should put Imericans under the

192; The Sally, 1 Gallis, C. C. R. 58; The Ann, 1 Gallis, C. C. R. 62 ; The Brig William Gray, Paine's C. C. R. 16; United States vs. Hall et al., 2 Wash. C. C. R. 366 .

82 U. S. Statutes at Large, 528; 379 ; Wharton Int. Law Dig., \$ 319. The principal decisions under the non-intercourse laws are as follows: The Brig Penobscot vs. The United States, 7 Cranch, 356; The Schooner Hoppet vs. The United
States, 7 Cranch, 389; The Schooner Anne vs. The United States, 7 Cranch, 570; The Ship Richmond vs. The United States, 9 Cranch, 102; The cargo of the ship Fanny, 9 Cranch, 181; The Edward, 1 Wheat. 261; The Sally and cargo, 1 Gallis, C. C. R. 58.

9 The Santa Cruz, 1 Rob. 42.

10 Geffcken, in Heffter, Völkerrecht. $\$ 112$, note 3 .

11 Hall, § 120; Martens, § 254; 
same disabilities that her subjects suffer in the United States, there would be an example. Illustrations of what are called tariff wars, not infrequent in modern times, may be found in recent dealings of Germany with Russia and of Canada with the United States. That kind of retaliation seldom if ever leads to war between civilized countries, even when it does not bring the offending state to terms,- the principle being clearly recognized that each state has the fullest right to regulate its internal and foreign commerce as it pleases, short, perhaps, of a total prohibition of it. It is odd to find Grotius declaring the contrary rule for his day of restricted intercourse. ${ }^{2}$

Retorsio facti, as Klüber has it, is the positive form ${ }^{13}$ of retaliation, and in one sense embraces all species of active punishment of an offending state, short of war. An extreme instance of the exercise of this right was Napoleon's imprisonment of English travelers in France in 1802 in retaliation for captures of French ressels without a declaration of war. There is some eridence that this was intended to be limited to British soldiers and officials; but as carried out it affected others, and some of the thousands imprisoned are said to have been still in confinement when the Allies entered Paris in 1814. Personal retaliation was also practiced by Frederick II, after the imprisonment of the Prussian Stackelberg by the Empress of Russia. Such acts, when legitimate, should, lowever, be classed as reprisals. To lessen the confusion often arising out of the use of identical terms in different senses, it will be well to confine retorsion to the return in kind of wrongs done to us. If it be necessary to indicate degrees, retaliation of violations of comity should be called retorsio juris; retaliations of violations of rights retorsio facti. ${ }^{14}$

$\$ 436$. Reprisals classified.-Reprisals (old French, reprisalles, later represailles, Latin pignoratio, repressaliae, clarigatio) extend to persons and property, and are a kind of international set-off. ${ }^{5}$ 'They have been divided by Klüber, Wheaton and Phillimore, according to their origin, into negative, when

Bluntschli, §505; Martens, Précis. viii, ch. 1, §2; Heffter, Völkerrecht, §110, and n. 111, opposing Wurm's contention.

12 Grotius, De Jure Belli ac Pacis, Bk. II, ch. 2, sec. 13, 18; Martens, Précis, III, ch. 2, §1.
13 Wheaton, Elements of Int. Law, p. 210.

14 Heffter, $\$ 110$, n.

15 Twiss, supra, $\S 20$; Wharton, Commentaries on Am. Law, § 206; Vattel, Droit, etc., II, ch. $18, \S 342$. 
due to refusal of a right, and positive, when due to an injury. Or as Field has expressed it, basing the distinction upon character rather than origin, "a reprisal which consists in the refusal to perform a perfect obligation, or to permit the enjoyment of a right, is termed a negative reprisal. A reprisal which involves the seizure or detention of persons or property in violation of the provisions of this Code, or without authority of law, is termed a positive reprisal." Grotius, Wolf, Vattel and Heffter limit reprisals to acts of force, and classify the negative kind as retorsions. Retorsions are, however, properly retaliation in kind, and reprisals are attachments by way of set-off. In 1834, during the controversy between France and the United States as to the payment of the spoliation claims, President Jackson, in his sixtl annual message, said: "It is my conviction that the United States ought to insist on a prompt execution of the treaty, and, in case it be refused, or longer delayed, take redress into their hands. *** $*$ It is a well settled principle of the international code that where one nation owes another a liquidated debt, which it refuses or neglects to pay, the aggrieved party may seize on the property belonging to the other, its citizens or subjects, sufficient to pay the debt, without giving just cause of war. This remedy has been repeatedly resorted to, and recently by France herself toward Portugal under circumstances less unquestionable."

$\S 437$. Origin and growth of reprisals.-The origin of reprisals, which should never be resorted to except in case of a palpable denial of justice, ${ }^{16}$ is to be found in the right of individuals to exact reparation for private debts or wrongs. Such hostile action is not confined to the individual wrong-doer, as in the common law process of Withernam; it is permitted against any and all persons, and property of the offending nation, on the idea that the state, in which all its members are merged, is responsible in solidum for wrongful acts for which it does not make reparation. When goods are thus seized they are sold and the proceeds applied to the indemnification of the injured party, as Cromwell did with the proceeds of Freneh ships sold to pay for a Quaker's ressel confiscated in France, and the States General for debts due their citizens by the Venetian minister at Naples. ${ }^{17}$ Such reprisals were once as

16 Grotius, DeJure B. ac Paeis, III, c. $2, \S 14$; Bynkershoek, Quaest. Jur. Pub., I, ch. 24; Vattel, Droit des Gens, II, c. $18, \S 343$.
17 Twiss, Law of Nations, War, $\S \S 11,21$; Vattel, Droit des Gens, II, ch. $18, \S 346$ et seq.; Valin, Traití des Prises, p. 321; Pres. 
common on sea as private wars on land, and have an interesting history which connects them with the ancient procedure in which the plaintiff himself arrested the defendant and exacted his due, and with the almost equally ancient practice of piracy. Self-help is the first impulse of all who are wronged and was the natural recourse of man in primeral times when there was no recognized superior, or when such superior was too weak to guarantee adequate redress. Private reprisals, for public and private injuries, were known to the Greeks, and were common in the middle ages. ${ }^{18}$ It is said that in 1292 at Bayonne an Englishman stabbed a Norman sailor and escaped, which led to reprisals on an English ship, and this to counter-reprisals. In the end, thousands of lives were lost and the result was a public war between France and England. In France the right to authorize reprisals was rested in the parliament until, in 1484, it was confined to the king, the earliest letters being of 1596 . Its exercise was finally regulated by the Ordinance of the Marine of Louis XIV, in 1681. This directed that a person injured should have his damage estimated by a court of admiralty before petitioning for letters, and that these should not be granted until security was given by petitioner and application to the offending sovereign had proved fruitless. ${ }^{19}$ Reprisals really gave rise to the prize court, and became a leading subject of its jurisdiction. The anthorities concede the right to exist even after a prize adjudication, if that be plainly unjust,-in re minime dubia, as Grotius has it. ${ }^{20}$ The authorization to commit reprisals is embodied in what is called letters of marque and reprisal from the sovereign; although, as a general rule, a capture without a commission is good against the enemy, leaving the captor liable to punishment by his own government. Great Britain, however, treats such conduct in an enemy as piracy. The word marque, though French in form, is probably akin to the German mark, English march, and indicates the right to pass the boundaries. While it does not occur in treaties until the 14th century, the propriety of reprisals is fully recognized by them up to the last century.

Jackson's 6th Annual Message, prisals, Iliad XI, 697, and Livy II, 1834; 2 Azuni, II, ch. iv, art. II.

18 The oldest Greek form was $\alpha \nu \partial \operatorname{eo\lambda } \eta \psi_{i}^{\prime} \alpha$, seizure of hostages. Geffcken, in Heffter, Völkerrecht, $\S 111$, n. 2. See for classic re-

c. $34, \S 4$.

19 Ordonnance de la Marine, August, 1681, 1, 3, tit. 10; 2 Azuni, II, ch. v, art. II, note.

${ }^{20}$ De Jure B. ac Pacis, III, ch. 2, sec. 5 . 
The division of reprisals into public and private must be kept steadily in view. Thus, the right may be granted to persons who have been injured to infliet special reprisals; while general reprisals, as Grand Pensionary De Witt is said to have observed, amount practically to open war.21 Technically they do not constitute war, for none is declared and battles do not occur" but, as Lord Hale says, they "many times in process of time grow into a very formal war." 22 Jefferson thought that general letters of marque and reprisal had an advantage over formal war, beeause their" "revocation restores peace without the delins, difficulties and ceremonies of treaties." 23 Clay, on the other hand, has declared that such a procedure never failed to resnlt in war when the state assailed dares to engage in it.24 Reprisals cannot properly be made in any form for injuries done to a third nation not an ally.25

$\S 438$. Privateering.-A privateer ${ }^{26}$ (armateur, la course, corsare, haperschiff) is a private vessel acting under a government commission or letter of marque (not of reprisal) to capture ressels of the enemy. As regular troops antedate standing armies, so privateering antedates regular navies. The practice can be traced back to the troubled era after the fall of the Roman Empire, and received some regulation by the 13th century. Ducange even quotes a commission of 1152. Privateering was much relied on for several centuries and is closely connected with the subject of reprisals. In the 14th century it was settled that the privateer must have the authorization of his sorereign; by the next that he must bring his captures intoanadmiralty court for adjudication; and in the latter part of that century treaties provide for exacting sureties (idoneam cautionem) from the masters or owners. ${ }^{27}$ Such provisions are explicitly set ont in Queen Elizabeth's proclamation of $\mathbf{1 6 0 2}$, and the existing rules are largely those compiled by Jenkins and others under the Order of Conncil of 1664. In 1761 the prizes of two uncommissioned French vessels were confiscated. ${ }^{2 s}$

21 Twiss, Law of Nations, War, $\S 17$ and note; Vattel, Droit des Gens, II, ch. 18, 3346 .

22 Pleas of the Crown, 1623. Geffcken accordingly denies that there can be any "état de représailles" such as France tried to establish against China. Heffter, \& 111, n. 235 Jefferson's Works, 387.
24 Wharton, Int. Law Dig., § 318. 25 Heffter, § 111 and $n$.

26 The word is English and apparently first used by Sir Leoline Jenkins in 1665. (Twiss, Law of Nations, War, §187, §14.)

27 Twiss, supra, $\$ 188$, Martens, Précis, VIII, ch. i, $\$ 6$.

$2 s 2$ Azuni, II, ch. v, art. III, note. 
During the colonial wars over four hundred American privateers roved the West Indies and even the French coast, and in the Seven Years' War French privateers from Martinique took 1,400 English merchantmen, and French privateers the world over took 2,500.29 In 1776 New England privateers captured 342 British ressels, and by 1778 the prizes were nearly 1,000, valued at $£ 2,000,000$. In the war of 1812 Americans fitted out some five hundred, and the Edinburgh Review estimates their prizes at over 1,700. Mexico in 1845 and the Confederate States in 1861 proclaimed their readiness to grant letters of marque against the United States, but in neither case did a neutral apply. It is doubtful whether a neutral so acting would not be a pirate. ${ }^{30}$ While during the civil war there were a few vessels on the Confederate side like the Savannah, the Alabama, Sumter, and Florida were regular ships of war. Privateers were in general use by the French and English in the Napoleonic wars, against the protest of Nelson and Codrington. The latter declared their proceedings nothing short of piracy, and that they hoisted either flag to make a capture. ${ }^{31}$ Many states now treat privateers as pirates, but this has not become an international rule, except where they act under commission from both sides. ${ }^{32}$

Commission and bond.-The commander of a privateer is commissioned and the owners must gire bond, the American law to that effect dating from the hostilities with France in 1789. Even an enemy may be commissioned to act against his own country. ${ }^{33}$ While there is no international rule on the subject, the British law requires privateers to carry a special jack; the American does not. ${ }^{34}$ The commander must be on board at the time a capture is made, although it seems the lieutenant may act when the captain is dead. ${ }^{35}$ If the commission be not on board the capture is void, although its loss after that event is not material if the fact be satisfactorily shown and explained. ${ }^{36}$ In a civil war a commission issued by

29 Mahan's Sea Power, 314, 317. 30 Heffter, §124a, and G. n. 6 .

31 Napier, Penins. War, App. 497; Mahan's Nelson, 610.

32 Field, Int. Code, § 742 ; Wharton, Int. Law Dig., § 385; Heffter, $\S 124 \mathrm{a}$.

33 The Mary \& Susan, 1 Wheaton, 57. The American instructions in the War of 1812 are given in
Wharton, Int. Law Dig., § 385.

342 Wheaton, App., p. 80, 112; Twiss, Law of Nations, War, § 197. 35 The Charlotte, 5 Ch. Rob. 280 ; Twiss, Law of Nations, War, § 195 , note 43.

36 Twiss, Law of Nations, War, $\S 190$; United States vs. Palmer, 3 Wheaton, 644; The Estrella, 6 Wheaton, 304. 
either side will be recognized by foreign states. ${ }^{37}$ It will be revoked by proceedings in a court of admiralty if the commander offends against the law of nations. If fraudulently obtained this avoids a capture, and its misuse will render the owners liable, jointly and severally. The bond is the limit of liability of the sureties, but not of the owner, except in the case of unauthorized piratical acts. In general, privateers are not within the law limiting recoverable damages to the ship and freight. ${ }^{38}$ Unless, as in France, municipal law otherwise declares, liability is commensurate with the injury, and each owner is liable not pro tanto, but for all. ${ }^{39}$

\section{$\$ 439$. Privateering virtually abolished.-As privateering is} liable to abuse, it has gradually fallen into disfavor; and since the formation of regular naries the necessity for it his decreased. As early as 1675 Sweden and Holland concluded a treaty which not only abolished the practice as between those countries, but bound them to endeavor to persuade their respective allies to abandon it. The next effort in that direction was embodied in the treaty made in 1785, largely through the efforts of Franklin, between Prussia and the United States, securing exemption of private property from capture at sea, followed by the effort of France during its Revolution to abolish privateering. From that time the govermment of the United States has been striving to secure for that rule of exemption the approval of all nations. ${ }^{40}$ of the subsequent treaties abolishing privateering as between particular countries, the most important is the Declaration of Paris, 1856, in which "La course est el demeure abolic." The parties to that agreement were Great Britain, France, Austria, Prussia, Italy and Turker, the United States declining to accede unless it was also provided that private property be

373 Opinions Attys. Genl., 120.

38 The Mariamne, $5 \mathrm{Ch}$. Rob. 10; The Gibbons, 8 Cranch, 428; Tht; Karasan, 5 Ch. Rob. 292; Praris vs. Captain Martine (1675), 2 Stair, 239; The Experiment, 8 Wheat. 261.

39 Del Col vs. Arnold, 3 Dallas, 333; 1 Wheaton, 259; 1 Paine, 111; The Karasan, 5 Rob. 291; the Anna Maria, 2 Wheaton, 327; Bynkershoek, Q. J. P. 151. As to other points decided on privateer- ing see Talbot vs. Janson, 3 Dall. 133; The Thos. Gibbons, 8 Cranch, 421; The Astrea, 1 Wheaton, 125; The Amiable Nancy, 3 Wheat. 546; The Estrella, 4 Wheat. 29s; The Nuestra Senora, 4 Wheat. 497 . As to commissions by unrecognized insurgents, see subject of Pirates. 40 The capture of the Spanish Santa Yago by the French privateer Dumourier, and her recapture by the British sloop Edgar in 1793 ler to 'Iartens' celebrated es- 
exempt from capture at sea. While France, Prussia, Italy and Russia were willing to assent to that amendment, England was not. In 1861-2 a bill was introduced in the Congress of the United States to authorize the president to issue letters of marque, but it failed through the fear that it might be construed to be a recoguition of the Southern Confederacy as a foreign power. ${ }^{41}$ During the recent Spanish-American war, although between parties not bound by the Declaration, the United States expressly adopted all of its rules, while Spain adopted all except that as to privateering. As a matter of fact neither side issued letters of marque. The French insisted during the Franco-Prussian war that the ressels composing the Prussian Volunteer Navy were no more than privateers in disguise, but the British government decided otherwise upon report of Sir Travers Twiss and its other law officers. Such vessels, to be supplied by private citizens, were to be regularly officered, commissioned and regulated.42 Although this German "Seewehr" was never actually organized, a similar fleet was equipped in Russia during the threatened war with England in 1877 and still exists. No nary, however provided, which is to be manned and officered by the state, can offend against the rule forbidding privateering. Nor can just objection be made to the subrention system, under which Great Britain in 1887 agreed with the Cunard and White Star lines to pay an annual subsidy as compensation for the right to buy or lease their vessels in the event of war. The United States made a similar arrangement in 1892 with the American Line, and under it acquired and used, without objection, during the war with Spain, the Paris, New York, and St. Paul as war vessels.

$\S 440$. Survival of public reprisals.-It must not be understood, however, that the virtual abolition of privateering, and of letters of marque and reprisal has resulted in the extinction of public reprisals. It is still open to a state acting through its own agents on its own waters, on the high seas or on foreign soil, to enforce satisfaction of claims out of goods of another country. The best recent illustration occurred when Nicaragua refused to pay a claim of Great Britain's and the latter power, after seizing the seaport of Corinto, collected

say on Privateers. As to U. S. (670), etc.; Wharton, Int. Law policy, see documents in Wharton, Dig., $\S 385$.

Int. Law Dig., § 385 .

42 Hall, Int. Law, §547; Whar-

41 Bluntschli, Mod. Kr. secs. 170 ton, Int. Law Dig., § 384. 
the customs in order to satisfy herself. While that expedient produced the desired result in that case, there is no reason to believe that it will be often resorted to except as a means of ending disputes between nations of unequal strength. And yet such a proceeding may be perfectly legitimate, and, as an orert act revocable withont the formalities of treaty-making, has some theoretical advantages at least. ${ }^{43}$

A public debt not the subject of reprisal.-A public debt is not the subject of reprisal; it is inviolable, and interest cannot be stopped on it as a means of redress. Frederick II threatened, in 1753, as retaliation for seizure by England of Prussian ships engaged in prohibited trade, to confiscate English interests in a silesian loan which he had guaranteed; and in opposition to this was presented with an admirable memorial of English jurists, penned principally by Murray, afterwards Lord Mansfield. Although Montesquieu characterized the famous paper as réponse sans replique, it seems to be frequently overlooked that Frederick did not yield to the English contention until he had received $£ 20.000$ sterling indemnity for the confiscated ressels. Bluntschli has been charged with sanctioning the seizure and Geffckin clearly does. It is more correct to say that the former was less inclined to approve Frederick's action than to criticise the English seizures which led up to it. It is now generally conceded, as a matter of policy, if not of principle, that a public debt is secure against reprisals in peace and war. ${ }^{44}$

$\$ 441$. Military and naval demonstrations.-Consideration must next be given to such forcible means of redress as are involved in the use of the armed forces of an injured nation in or about the territory of the offending state. Such demonstrations are usually made by naval forces, and are frequently effective. They consist in the appearance and deploying of war ressels before the capital, or a seaport of the offending country, with or without instructions to bombard in case of further refusal of redress. I display of force of this character was made by the United States against the Barbary Powers in the early part of the last century, and against Japan in 1552. The same kind of pressure has been several times applied during recent pears to Turkey when she was derelict. In fact, it is usually the first step taken by a state when injury

435 Jefferson Works, 164, 387.

44 Many of the papers on the sub- ject are given in 2 Martens' Causes Célibres, Droit des Gens, 1. 
is threatened to its subjects at any foreign port. Thus a German ship was recently sent to Hayti to protect German interests; and the Vixen to Bluefields to protect American interests. The Maine was dispatched to Havana harbor on a like errand, although present there ostensibly as a courtesy. Greytown or San Juan was actually bombarded by the United States sloop Cyane in 1854, because of the impossibility of otherwise obtaining satisfaction for injuries inflicted on American citizens. ${ }^{45}$

$\S 442$. The armed neutralities of 1780 and 1800 .-An interesting form of naval demonstration, of more than ordinary historic interest, grew out of the Armed Neutralities of 1780 and 1800, a term usually employed to describe certain alliances entered into between the northern powers in opposition to maritime claims then asserted by Great Britain in derogation of the rights of neutral nations. As these alliances contributed no little to the development of the laws of neutrality they will be made the subject of further consideration under that head. They deserve, however, a passing mention here because the outcome of them was a series of joint naval demonstrations on the high seas which were to a certain extent successful. In order to guarantee to their merchant marine the protection they claimed for them, the allies prepared extensive fleets and sent them to sea, in the Baltic and elsewhere, with instructions to go, as the Empress Catharine expressed it, "wherever honor, interest and need require," without failing to maintain a strict neutrality between England and her enemies.

$\S 443$. Counter demonstrations. Neutralization of Great Lakes.-Whenever there appears to be unusual military or naval preparation near its borders, a state is perfectly justified in inquiring into the cause, and, in the event of an unsatisfactory reply, in making corresponding preparations. When Spain complained not long ago of the massing of an American fleet at Key West, in striking distance of Cuba, the fleet was promptly recalled despite the then strained relations between the two countries. In order to prevent such demonstrations on either side of the Canadian border, was made the agreement of 1817 , a happy arrangement originally suggested perhaps by the instructions of Castlereagh to the British commissioners at the Ghent treaty negotiations. The immediate

45 Calvo, vol. ii, p. 131; Wharton, Int. Law Dig., \$\$50d, 224a, 321. 
proposal of the disarmament came, however, from James Monroe when Secretary of state under Madison. That proposal finally matured into the agreement ratified by the United States Senate April 16, 1818, limiting the naval force of each country to one ressel on Lake Ontario, two upon the upper lakes, and one on Lake Champlain, each not to exceed 100 tons burthen, and to carry only one 18-pound cannon. ${ }^{46}$ Apart from the prevention of the expense and hostile feeling generally incident to rival armaments, this arrangement, although not applying in terms to forts, has actually prevented the erection of fortifications on any large scale. The neutralization of the great lakes was the earliest of such agreements, and has had much to do with the preservation of friendly relations between Canada and the United States.

$\$ 444$. Pacific blockade.-Blockade is a step in advance of demonstration. It goes beyond forcible menace and is generally designed to suspend the commerce of the offending state. Whether neutral trade can thus be suspended depends largely upon the temper of the neutral, as there can be no legal blockade as to neutrals except in war. The English government realizing that its own conduct at the La Plata. was incorrect, refused to permit the French fleet to coal at Hong Kong during the later Formosan blockade, on the assumption that the French proceedings really amounted to war with China. The so-called Pacific Blockades of the nineteenth century, during which they originated, may be summarized in order of date as follows: In 1827 came the first, in which the Greek provinces of Turkey were blockaded by the combined fleets of Great Britain, France and Russia, as a means of compelling concessions. This resulted in the battle of Navarino and open war. Then in 1831 occurred France's blockade of the Tagus in order to coerce Portugal; and, in 1833, that of Holland by France and Great Britain in order to compel the recognition of lielgimm. In the New World there occurred in 18:36 the pacific blockade of New Granada by England, and in 1838that of Mexico by Flance, resulting finaly in war. The blockade of La Plata by France lasted from 1838 to 1840 , followed, from 1845 to 1848 , by like action by both France and England. In 1850 Greece was blockaded by England; and in 1860 Sicily by Sardinia and the revolutionists of Naples. In 18ti2 Rio de Janciro was blockaded by England;

46 J. M. Callahan, Neutrality of American Lakes, 84; Wharton, Int. Law Digest, $\S \S 31,40,150$. 
and in 1879 Chili by Bolivia, a proceeding resulting in war between the two republics. In 1880 Dulcigno was blockiaded by the powers in order to compel Turkey to execute a treaty; and in 1884 pacific blockade assumed a new form in the hands of France who went so far as to bombard the arsenal of Foo Chow on Formosa as a part of policy called by Ferry "intelligent destruction." Finally, in 1886, Greece was blockaded by all the great powers except France and Spain; and in 1897 Crete was subjected to a like discipline by the Powers, who used cannon vigorously. As a general rule such blockades have been instituted by stronger countries against weaker ones, and amount certainly to a threat of war. Woolsey, who opposed the practice, considered it neither more nor less than $\mathrm{war}^{47}$ and in 1874 the Institut de droit international condemned it. It is now generally admitted, however, that neutral commerce is not to be disturbed during pacific blockades; and, in that form, approved by Fiore, it may be said that this substitute for embargo has become a part of international law. ${ }^{48}$ In no event can there be a confiscation in connection with a pacifio blockade, as that is an incident peculiar to war alone.

$\S 445$. Satisfaction.-When clearly in the wrong no civilized state should refuse satisfaction. Great Britain apologized promptly for the attack on the Prometheus in 1851 when attention was called to the matter. ${ }^{49}$ On the other hand, afte' ${ }^{\circ}$ President Jackson's message of 1834 adrocating reprisals against France for not paying an agreed elaim, it required the active mediation of Great Britain to prevent a rupture. ${ }^{50}$ The form of satisfaction to be rendered, varying with the offense, has been treated under other heads. As a general rule, it may be said to consist of a disavowal or apology, with a salute to the flag; and, when possible, of a restoration of affairs to their original condition, or of compensation to the sufferers from the wrong in question. Thus after an affront in 1854 to the French consul at San Francisco, the French flag was saluted; and in like manner the Brazilian after the American seizure of the Florida at Rio Janeiro. In the Trent affair the Confederate commissioners were restored to English protection,

47 Int. Law, $\$ 118$. It has been approved (Sept. 7, 1887) by tne Institut de droit international, provided neutrals are not affected.
48 Heffter, Völkerrecht, § 112 and note.

49 Wharton, Int. Law Dig., § 315d.

50 Ib. $\$ 318$. 
just as the British government in 1811 restored the seamen taken from the Chesapeake in 1807,51 with compensation to the wounded and to families of the sailors killed in the action. The Virginius, restored to the United States in 1873 at Bahia Honda, sank on her homeward voyage off Cape Fear.52 When it is impracticable to restore the status quo ante, as in case of loss of life, satisfaction generally embraces a salute and payment of an indemnity, either in money or in the slape of a cession of territory.

$\$ 446$. Limits of forcible redress.-It must be confessed that most, if not all, of the above mentioned methods of forcible redress are not, strictly speaking, international remedies because international law presupposes equality between the states affected. The greater part of the proceedings cited oecurred between a powerful and a weak state, or between a concert or league and a small country. Such was the case with most of the pacific blockades. Could a blockade of Liverpool by a French fleet for any purpose, or of Hamburg by English ships possibly result in anything but war? While honor, which has caused almost as much bloodshed as ambition, may be a misleading term, in the form of national selfrespect it must be mpheld at any cost. No nation can yield to menace without loss of prestige abroad, and without national humiliation at home,- a result declared by President Cleveland in his Venezuelan message to be worse than war with all its horrors. As between equal nations there can be no peaceful remedies which involve force. Remonstrance, withdrawal of representatives, embargo and non-interconrse may occur withont brealking the peace; but retorsions and reprisals involving force will inevitably bring nations of equal power to the very verge of hostilities, while demonstrations, blockades and sequestrations will be held tantamount to a declaration of war. National sensitiveness, which did not exist to the same extent perdalps a century ago, has grown with the intensifica. tion of nationality itself. Measures saroring of force must therefore be reserved, in the present state of public opinion, for the coercion of inferior powers who cannot resent them. And ret unjust as the enployment of such remedies may seem to be they ale certainly more humane than actual bloodshed. when it beeomes necessary for greater states to coerce or discipline weaker ones.

51 Wharton, Int. Law Dig., §§ 27, 52 Wharton, Int. Law Dig., § 327 . $315,315 \mathrm{~b}, 325,328,374$. 


\section{CHAPTER II.}

\section{COMMENCEMENT OF WAR, AND ITS IMMEDIATE CONSE- QUENCES.}

$\S 447$. Arrangement of subjects.-According to Talleyrand and Montesquieu international law is founded on the principle that in peace nations should do each other as much good and in war as little harm as possible. ${ }^{1}$ Since then the idea has certainly gained ground that in war the primary object is to disable the enemy with as little human suffering as practicable. But, no matter whether its conduct be humane or inhumane, acknowledged war must be considered from three points of view. The first relates to active hostilities, and covers forces, instruments, captures, intercourse and methods. The second, to the persons of the enemy, and embraces prisoners, non-combatants and neutralized foes. The third, to property of the enemy, whether public or private, and its administration under martial law. As a matter of convenience naval warfare will be treated separately, because of the rules peculiar to it. In addition to these four subjects special consideration will be given to the commencement of war and its consequences; to the limitations, suspension and conclusion of hostilities; to military occupation and administration, and to the termination of war by treaty or otherwise. While a number of questions arise incidentally, logically the main divisions of the laws of war fall under these heads which will be treated in corresponding chapters.

$\$ 448$. Usages called Laws of War.--The parties to a war are called belligerents, and among civilized nations they conduct hostilities in accordance with usages called laws of war which are based on certain very ancient principles. Even Polybius speaks of oi zov $\pi \circ \lambda \varepsilon \mu o v$ rouor, and Livy of quaedam belli jura. ${ }^{2}$ At this late day few will follow the German General Von Hartmann and possibly Von Moltke in saying that there are no laws of war, only foree tempered by custom. ${ }^{3}$ Sir James Mackintosh stated the matter correctly when he said

1 Moniteur, Dec. 5, 1806; Esprit des Lois, I, ch. 3.

2 Polybius, $\mathrm{V}$

12, XXXI, 30.
3 Militärische Nothwendigkeit und Humanität, 1877; Heffter, $\S 113$, Geffcken, note 2 . 
that "in the present century a slow and silent, but very substantial mitigation has taken place in the practice of war, and in proportion as that mitigated practice has received the sanction of time, it is raised from the rank of mere usage and becomes part of the law of nations." 4 Before entering upon the special examination of such laws or usages, the attempt. will first be made to consider in this chapter what war really is,-its nature, causes, and linds; how it is begun and announced; and what are its effects.

$\S 449$. The state of war defined.-The greatest masters of the art of war, such as C'alesar, Napoleon and Frederick, have left memoirs and descriptions of warfare, strategy and tactics, but no clear-cut definition of the relations of states to each other while their generals are in the field. War as defined by Cicero is a dispute by force, and the United States Supreme Court has called it a suit prosecuted by the sword,-an idea also advanced by Bluntschli, but slarply criticised by Von Hartmann and cieffeken. Such in effect is the view advocated by Grotius, who, after so extending the idea as to embrace the whole relation of the actors, defines war to be the state of those who dispute by force of arms. ${ }^{5}$ He includes, however, individual and private hostility, called feud or vendetta, now under the ban of civilization. Bynkershoek declares war to be the state of things incident to a contest between independent persons striving by force or fraud to assert their rights. Vattel defines war as that state in which nations prosecute their rights by force, and Bacon calls it a high trial of right between nations. ${ }^{6}$ David Dudley Field in his proposed international code designates it as a hostile contest at arms between nations or communities claiming sovereign rights. Bluntschli calls it armed self-help of political powers, and so does Ifefiter after him. The latest writer, Lawrence, regards it as a contest carried on by public force between states ${ }^{7}$ or quasi-states, which is in effect a translation of the armorum publicorum justa contentio of Alberico Gentilis, almost the

41 Miscellaneous Works, 360.

" De Off.. Bk. 1, ch. II; De Jure Belli ac Pacis, Bk. I, ch. 1, sec. II: Harcourt vs. Gaillard, 12 Wheaton, 523, 528, (per Justice Johnson) ; Heffter, $\S 113$, Geffcken, note 2 .

B Droit des Gens, Bk. III, ch. 1; Twiss, Int. Law, War, $\S \S 27,99$, and preface; Bynkershoek, Quaestiones Juris Publici, ch. 1.

7 Int. Code, section 704, edition of 1876; Lawrence, Int. Law, $\$ 155$; BIuntschli, Mod. Kriegsrecht, sec. 1; Grotius, De Jure Belli, I, ch. II; Heffter, §113. 
earliest publicist. The British Manual (compiled by Lord Thring), and Clausewitz, likewise define it as an armed contest between independent nations. ${ }^{8}$

$\$ 450$. Meaning of war in its broader sense.-The foregoing definitions, excepting those of Bynkershoek and Grotius, are defective in limiting the term war to the acts of belligerents. While such acts constitute warfare, war has a broader meaning. ${ }^{9}$ It embraces warfare, its effects and incidents,-it is the whole state or condition of a contest of nations by arms. This is indicated by Burlamaqui and in Woolsey's rather ner. ative definition of war as an interruption of a state of peace for the purpose of attempting to procure good or prevent evil by force. ${ }^{10}$ A modern definition of war might be the condition accompanying an armed contest between belligerent communities neither of which recognize de facto any political superior. ${ }^{11}$ Such a definition excludes private hostilities and includes civil war. In all cases war can be made (jus belli in the subjective sense) only by the supreme power of the community or state. ${ }^{2}$ While a mere horde of pirates cannot be considered as such a community, the Barbary powers are recognized as states for many purposes. ${ }^{13}$ The state need not necessarily have a fixed territory, for the Romans constantly considered the wandering German tribes as entitled to the rights of civilized war. ${ }^{14}$ Every association claiming to be a state should, however, have a land basis of some kind. When, in 1893, the Brazilian fleet without any such basis revolted and attempted to blockade Rio, it was prevented by the war ships of the United States and other powers. Such precarious and short-lived associations have no right to ask recognition as states.

$\S 451$. How far war is a relation of states and not of individuals.-The theories of international law vary from decade to decade, and practice differs of course somewhat from theory. As this is a mark of progress, it camnot be a subject of regret.

8 Maine, Int. Law, 131; Heffter, $\S 115 \mathrm{n}$.

9 Rutherforth distinguishes the acts from the state of war in Institutes, Bk. II, ch. 9, § 22 .

10 Martens, Précis, VIII, ch. 2, $\S 1$; Woolsey, Int. Law, $\S 115 ; 2$ Burlamaqui Nat. and Pol. Law, IV, ch. 1 .
11 See Twiss, Law of Nations, War, § 191.

12 Wheaton, Elements Int. Law, 212.

13 Bluntschli, Mod. Friegsrecht, sec. 4 (514).

14 Bluntschli, Mod. Kriegsrecht, sec. 3. (512). 
So far as war is concerned, much depends on the interpretation of its definitions. In the wars of ancient times every citizen was expected to do all the harm he could to erery citizen of the hostile country. In modern times, since the adrent of standing armies, there has been a differentiation between combatants and non-combatants, not as the result of any theory but because of the cruel and inconclusive results of the older practice. Vattel, in his time, could say that it had become the practice for "the troops alone to carre on the war, while the rest of the nation remain in peace." 15 The theory of war was then so changed as to explain what had become the practice. Rousseau said war was a relation of states, ${ }^{16}$ and Portalis startled all thinkers by his declaration, in almost the same words, on opening the French prize court in 1801 (14 Flor., Year VIII) that it is the relation of things, not persons,- "a relation of state to state, not of individual to indiridual. The private persons thereof are only enemies by accident; not as men, not even as citizens, but only so far as they are soldiers." Talleyrand in a Napoleonic state paper of Norember 20th, 1806 , uses almost the same language. declaring that three centuries of civilization had given Europe an international law to which that continent owed its prosperity, and according to which war did not extend to private persons or property. This may hare been written according to the maxim attributed to this distinguished turncoat, that speech was given man to disguise thought, for Napoleon's practice was to make war pay for itself as long as he was in the enemy's country. The present British manual states both principles,- - the old, that war makes the citizens of the respective states enemies, and the new, that the are enemies only as soldiers. ${ }^{17}$ This is characteristic of English thought. Despite the inconsistency, the new does not at once drive out the old. The gradual increase of humanitarian feeling has led to the general adoption of the latter principle by publicists, and the trend of their teaching is to consider war as the affair of armies, which private citizens may regard with little personal interest. While the Romans distinguished hostis from inimicus, a public from a private foe, it is certainly true that the eitizen is now differentiated from his state as he nerer was in ancient times. ${ }^{18}$ As the American Regulations express it,- "protee-

15 Droit des Gens, III, ch. 15, \& 17 Moniteur, Dec. 5, 1806; Maine, 226. Int. Law, 132.

16 Contrat Social, I, ch. 4.

1. Bluntschli, Kod. Friegsrecht. 
tion of the inoffensive citizen of the hostile country is the rule; privation, and disturbance of private relations, are the exceptions." 19 Although he may have failed to carry the principle fully into practice, Wilhelm proclaimed, in 1870 , that he made war only on French soldiers and would protect French citizens. International practice has so far ameliorated the conditions of war as to induce many to believe that we are approaching the quasi-millennial time when the unarmed population of traders, peasants and workmen shall go on undisturbed in their occupations; when private cargoes may be transported anywhere withont risk, learing armies and navies to carry on their work of injuring each other as little as possible. Can the new theory ultimately prevail against the fact that states and their gorernments are merely representatives of the people? Calvo ${ }^{20}$ cogently opposes to Pinheiro-Ferreira's elaboration of the new idea the "absolute solidarity of government and nation." As an illustration it may be said that during the recent conflict between France and Germany not only were the two gorernments at war, but all Frenchmen as such, and all Germans as such, represented by them, although as mere men they were not. Under the new conception as thus stated proper scope will remain to humanity for the alleviation of the horrors of war, and to patriotism, which no theory should attempt to annihilate.

$\S 452$. Just causes of war.-Grotius, quoting Camillus's declaration against the Gauls, adopts as just causes of war defense, recovery of one's own, and punishment of an enemy,omnia quae defendi, repetique, et ulcisci fas est. This Grotius condenses and says the only reasonable cause of war is an injury received, or, as Heffter expresses it, an injury received or threatened. Bluntschli widens the riew so as to embrace any hindrance to the true development of the state, but not mere con renience or interest. ${ }^{21}$ Vattel has a great deal to say about a just war, 22 and its justice will undoubtedly attract the sympathy of the civilized world. When society disapproves of a man's conduct it makes him feel it in one way or another. But this is forbidden to states as such. Although a war is unjust, all states not engaged must ordinarily treat the

sec. 21 (530), et seq; Field, Int. Code, $\$ 705$.

10 American Regulations, 24-25.

20 Calvo, Droit Int. II, 109. 21 De Jure Belli ac Pacis, II, 40; ch. 12, § 190, etc. c. $1, \S \S$ I-II; Bluntschli, Mod. Kriegsrecht, sec. 7, (516), sec. 9, (518); Heffter, § 113.

22 Droit des Gens, III, ch. 3, \& 
aggressor and injured in the same way. While public opinion is apt to express itself through the usual channels, the gorernments must remain strictly neutral. This does not mean, however, that all wars are just. It must be a very flagrant case that will lead to an official interference or even remonstrance. Morally the motives as well as causes should be commendable, but the independence and equality of nations usually compel all besides the combatants to consider any public war as just on each side, and in general neither will be found entirely wrong.

$\S 453$. Objects of war, political and military.-The political object of a just war is forcible redress or prevention of a national injury and security against its repetition. The ultimate end in view is a better peace, as peace is the normal condition of states, war the exception. ${ }^{23}$ The pretext for war often differs of course from the real reason. ${ }^{24}$ A war offensice in fact may be defensive in right, and many of the wars of Europe to prevent one country from becoming too powerful, as leretofore discussed under the head of Balance of Power, were justifiable and defensive. Grotius, Vattel and Kent adrocate alliances to prevent such danger, and the Dreibund and Franco-Russian cntente in our own day have that object. From a military point of view the object of war, according to the British manual, is to procure the complete submission of the enemy at the earliest possible period with the least possible expenditure of men and money. ${ }^{25}$ The attainment of that end should indicate or influence the means and methods of warfare. War for redress consists principally of reprisals against property of the enemy, but, unlike the reprisals heretofore discussed, does not stop with full satisfaction of the wrong and expenses. War uses similar methods with the view of erippling the enemy, but may go further than simple damages and include punishment or exemplary damages, even severe enough to prevent repetition of the wrong. ${ }^{26}$

$\$ 454$. How wars are classified.-The classifications of war, so far as international law is concerned, are descriptive rather than fundamental.27 The variations depend largely on the

23 Heffter, §130; American Regulations, 29; Woolsey, $\S 114$, etc.; 2 Burlamaqui Nat. \& Pol. Law, IV, ch. 2 .

242 Burlamaqui, Nat. \& Pol. Law, IV, ch. 2.
25 Vattel, Droit des Gens, III, ch. 3, 42 ; Livy, V, c. 49 ; Maine, Int. Law, 132; 1 Kent, Comm. 165. 26 Twiss, Law of Nations, War, $\S 73$.

27 Calvo, Droit International, \& 689 et seq. 
point of view. Thus, military writers discuss offensive and defensive wars in relation to operations in the field, while historians consider rather the political objects in riew. Publicists think generally of the status of the combatants and write of public, perfect, and solemn wars and their opposites. So from one point of view we lave offensive, defensive, and auxiliary wars, the last being where allies aid. A war defensive in fact may be offensive in form because, as Geffcken truly says, he causes war who makes it unavoidable, whether he strikes the first blow or not. ${ }^{2 s}$ A gain, war's have been divided into private, public, and mixed, but as private wars-between subordinate parts of one state-are not now recognized, the distinction is without practical ralue. Where hostilities are localized or otherwise restricted as to time, place, and methods, the conflict is often called an imperfect war, as that of 1798-9 between the United States and France, wherein, without a declaration, captures were made and prisoners exchanged. An imperfect or quasi war also existed between the United States and Spain on the Mississippi River in 1793.29 When wars are classified according to their motives or objects they are known as wars of independence, conquest, religion, intervention and the like. A war to recover independent nationality is often designated as a political or national war, while the term civil war is applied to a contest in which two parties strive for the possession of one government, or to such a conflict as occurred in America in 1861-65 in which one party strove to form an independent state and the other to keep the whole country united. Religious or civil wars are apt to be more cruel than foreign wars, but otherwise the variations involve questions rather of ethics or of strategy and tactics than of law. "A civil war," says Vattel, "produces in the nation two independent parties, who consider each other as enemies, and acknowledge no common judge: constituting, at least for a time, two separate bodies, two distinct societies. On earth they have no common superior. They stand therefore in precisely the same predicament as two nations who engage in a contest, and, being unable to come to an agreement, have recourse to arms." 30 The old sovereign is apt to deny belligerent rights, to fine and punish occupied

28 Heffter, $\S 113$, Geffcken, note 335; Bas vs. Tingy, 4 Dall., 37, 4; 2 Burlamaqui, Nat. \& Pol. Law, 40. IV, ch. iii.

30 Droit des Gens, III, ch. 18, § 20 Wharton, Int. Law Dig., $\S \S 333$, 293-4, and note, 
districts, and exact useless oaths of allegiance, ${ }^{31}$ but, as in the religious wars in France and the Netherlands, retaliation of his cruelty will generally bring him to terms. Such distinctions are in fact merely matters of convenience. Origin and object do not affect war lights or duties. The right of search, the treatment of prisoner's and all else is the same in a just as in an unjust war, one of independence or religion. The nature of the conflict may arouse patriotism at home and even intervention from abroald. That is a political matter for each state to solve. But increase of number of combatants from these or any other causes does not change the laws gorerning the conduct of the war itself. It is all war, whatever its cause or object, and should all be conducted in a civilized way.32 By claiming civilization a state agrees to live on friendly terms with all others making a similar claim, and that peace shall be the rule and war the exception. If this could be expressed in legal phrase, it would call for a liberal construction of everything relating to this general rule and for strict construction of everything relating to the exception.

$\$ 455$. Is a declaration of war necessary?-According to modern usage a declallation of war is not necessary. ${ }^{33}$ A state of war may exist without any formal declaration of it by either party and that is true of wars both foreign and civil. Calvo and Hautefeuille maintain that some solemn act is necessary to begin any war not of defense, and the former is disposed to reproach England and the United States for numerous examples of wars begun simply by the perpetration of acts of hostility. ${ }^{34}$ There is never a formal declaration in a civil war. It has been held that the great civil conflict in the United States begun with the I'resident's proclamation of blockade of April 27, $1861 .^{35}$ In 1846 President Pierce stated in his famous message that "war exists by the act of Mexico." Congress roted men and money, but it never declared war, and even the act of Congress came after the battles of Palo Alto and Resaca de la Palma. The United states did declare war against Great Britain in 1812 and agaiust spain on April 25.

31 American Regulations, 156.

32 Wheaton, Elements Int. Law,

p. 213; Bluntschli, Mod. Kriegsrecht, sec. 6 (515), sec. 10 (519), sec. $20(529)$.

${ }^{33}$ Sir Wm. Scott in the Eliza Ann; The Teutonia (1871), L. R.
3 Adm. \& Eccl. 394; L. R. 4 P. C. 171.

34 Calvo, Droit Int., II, 30, 33.

35 Prize Cases, 2 Black, 635, 667. The dissenting opinions date it from the act of Congress of July 13,1861 . 
1898: but in the first instance the United States began active hostilities before the news could eross the ocean; and in the second, the declaration recognized that war had existed since April 21. England captured New York in 1664 before declaring war against Holland; and, before the Seren Year's' War was declared, captured hundreds of ships and thousands of prisoners from France. Since the peace of 1763 the European practice has been even more irregular, and the necessity of a declaration is generally denied. ${ }^{36}$ In 1870 the representatives of France at Berlin handed the German government a note simply declaring that "le gouvemement de S. M. Imp. se considère dès-ì-présent comme étant en état de guerre avec la Prusse," and in 1877 a dispatch to the same effect was delivered to the representative of Turkey at St. Petersburg. Such are the survivals of the medieral practice according to which knightly honor forbade an attack until after full notice. In the 12th century letters of defiance (literae diffidacionis) under seal were exchanged, a form prescribed for private warfare in the Holy Roman Empire, as by the Golden bull of 1356. Later on heralds at arms were employed, the last examples of which practice occurred when French heralds declared war at Brussels against Spain in 1635 , and in 1657 when Sweden sent a herald to Copenhagen for the same purpose. ${ }^{37}$ Chivalry drew its r'ules from the Roman custom of sending the fetiales to demand redress, and these, when that was refused, threw a lance across the boundary, or, at a later time, in the direction of it. Hostes hi sunt qui nobis aut quibus nos publice bellum decrevimus. Caeteri latrones aut praedones sunt. The Romans were generally strict in the observance of forms, and to that Vattel attributes much of their subsequent greatness. ${ }^{38}$ The Romans practice, however, was exceptional. Dion Chrysostom says that as a general rule war was not declared.

A change in medieval theory and practice.-The international development due to the Thirty Years' War, and the institution of permanent embassies about the time of Richelieu, wrought a great change in medieval theory and practice. A manifesto to neutral nations became as important as a declaration of war against the enemy. No declaration preceded Gustarus Adolphus' invasion of Germany, none the Spanish Armada,

\footnotetext{
36 Martens, Précis, VIII, ch. 2, Bynkershoek, Quaest. Jur. Pub., $\S 4$. ch. II.

37 Twiss, Int. Law, War, § $32 ; \quad 38$ Droit des Gens, III, 4, §51;
} 
none Buckingham's deseent on Spain, none the war between England and France when the latter aided the American revolt. While happily the action of Frederick II in seizing Silesia before his messenger could reach Vienna has found no adrocates, nations for the last century and a half have generally contented themselves with a proclamation to their own citizens of the existence of war and a formal notice to neutral states. In the time of Queen Mary even the home proclamation was by herald. In these days of easy communication a declaration is an empty form. ${ }^{39}$

The existing usage.-Negotiations precede war and their nature warns the parties in interest of the probable outcome. The recall or dismissil of diplomatic representatives is generally the last step before actual hostilities, although this may oceur without war. While the first act of hostility determines the commencement of the war so far as third parties or states are concerned, it has become usual for each government to issue a proclamation, or manifesto, in which it endeavors to show its own good faith and to expose the bad faith of the adversary. ${ }^{40}$ Such manifestoes are loosely spoken of as declarations of war, ${ }^{41}$ and usually fix the duties of neutrals. On account of the provision in its constitution giving power to Congress to declare war, formal declarations will probably remain usual with the United States and other nations with like institutions. The short-lived constitution under which Napoleon proposed to reign after his re-ascension in 1815 contained a similar provision. It thus appears that war may begin with a manifesto, declaration, or the first act of military force against the opposing state. ${ }^{2}$ While a war de facto may arise without proclamation, declaration or notice of any lind, the beginning of hostilities is usually followed by some kind of notice or recognition. If war be notorious, neutral states and ritizens are bound to take cognizance of it. The existence of war vel non was once said to depend on whether or no the courts were open; but, as war is the act of the political powers, it is now held to depend on the acts or declarations of the govermment and courts camnot adjudicate the question on any

Livy, I, ch. 21; Bynkershoek, Q. J. P., ch. II.

39 Bluntschli, Mod. Kriegsrecht, sec. 13 (522); Twiss, supra, §32; To the same effect Lord Stowell in The Eliza Ann, 1 Dodson R. 247; The Amy Warwick, 2 Sprague, 123.
40 Wheaton, Elements, 213; Vattel, V, III, ch. $2, \S 64$.

$41 \mathrm{As}$ by Geffcken in note 1 to Heffter, $\S 120$.

4: Bluntschli, Mod. Kriegsrecht, s $1 S$ (527). 
other eridence. ${ }^{33}$ As war is two-sided it is necessiry that the declaration or manifesto be accepted by the opponent, who may do so by acts without a counter declaration $\mathrm{or}^{\circ}$ manifesto. ${ }^{4}$

$\$ 456$. A conditional ultimatum.-One form of declaration is the conditional ultimatum in writing setting forth the essential demands succinctly and giving some certain limited time for compliance. If such terms are not alceded to within the time prescribed, war begins, as in the recent conflict between the Boer government and Great Britain. By what authority the declaration or manifesto shall be issued is purely a matter of municipal law. It must proceed, however, from functionaries wielding the supreme power of the state, a power which the state constitution may vest either in the executive or leg. islative department of the government.

$\S 457$. When a recognition of belligerency should be made.A civil war presents some peculiar features. There cannot well be a declaration, because generally neither side recognizes the other as the true govermment, and for that reason embarrassing questions are presented to foreign states,-questions, as Canning has stated it, not so much of principle as of fact. If the disturbance is in the interior and of local importance, it should not be officially noticed except for the purpose of holding the general govermment liable for all damages to foreigners and their intrests. If the revolt reaches the border, especially a seaport, the case is altered. Foreign interests, particularly of the neighboring state, are apt to be so involved as to force the sendirg of warships by different states for the protection of their citizens. In that event, if the insurrection is formidable and so organized and continued as to affect such interests, a recognition of belligerency should follow. ${ }^{45}$ Such action places the two sides upon an equality so far as actual warfare is concerned, although it is not a rec-

43 Earl of Lancaster's case, 1 Pacis, III, c. 3 , § VIII. BurlamHale's Pleas of the Crown, C. 26, aqui correctly distinguishes a 344; Co. Litt. 249 b; Elphinstone vs. Bedreechund, Knapp, 316; Pelham Burke's case, 1 Edwards, App. D; 3 Camp. 62, 66; Blackburne vs. Thompson, 15 East 90 ; Milligan's case, 4 Wall. 2; Prize Cases, 2 Black, 667.

44 Vattel, Droit des Gens, III, ch. 4, § 57; Grotius, De Jure Belli ac declaration from a publication or manifesto, 2 Nat. \& Pol. Law, IV, ch. iv.

45 Field's Int. Code, §§ 707-8; Message of Pres. Grant as to Cuba Dec. 7, 1875, in 7 Messages of Presidents, p. 64; later messages of Presidents Cleveland and McKinley, 
ognition of independence or in any sense a prejudgment of the right of the case. By relieving the general or old government of responsibility for damages by the insurgents, and by griving it the right of search of foreign vessels, belligerency is a distinct alvantage for it. While such recognition is generally resented ly the farent state, its advantages are never repudiated.t6 Cpon the insurgents it confers the right to eapture contraband on a ressel belonging to the state which has recognized their belligerency, a principle illustrated by the aase of the brigr laacket in the Texan Revolution. ${ }^{4}$ In a civil war each party practically recognizes the belligereney of the other by treating them as lawful enemies, but such recognition is not to be construed as an acknowledgment of independence.ts

\section{$\$ 458$. Belligerency of Southern Confederacy recognized.-} I'robably the most famous recognition of belligerency was that by England during the American civil war,-a contest not a (ivil war in the ordinary sense, with two parties struggling for possession of the general government, but an actual geographical severance for a time of one country into two parts, the larger of which elaimed to retain the sovereignty. The smaller section, composed of seven states at first, organized a government, complete in all its parts and undisputed in its operation. A military force was put in the field and, on April 11, 1861, they attacked the Federal post Fort Sumter, and captured it. On April 15th $\mathrm{Mr}$. Lincoln called for 75,000 men in the northern states, and on $\mathrm{April} 17 \mathrm{Mr}$. Daris invited applications for letters of marque and reprisal. Then on $A$ pril $19,{ }^{49} \mathrm{Mr}$. Lincoln issued his proclamation declaring a blockade of the ports within the revolted states "in pursuance of the laws of the United States and of the law of nations." War existed, and appeal had eren been made to international law. ${ }^{50}$ England derived the bulk of her raw cotton from the seceding states, and at this very time millions of dollars of her cargoes were in the Southern ports. The British proclamation of neutrality issued May 14 th was therefore proper. The courts have leed that in Virginia, for instance, the war began with Mr. Lincoln's proclamation April $2 \pi, 1861$, of the intended blockade. Its beginning and ending differed according to proclamations applicable to the several states respectively. ${ }^{51}$

46 Wharton, Int. Law Dig., $\$ 333$.

472 Opinions Attys. Genl., 1066.

4s Martens, Prícis, VIII, ch. 2, § $3, \mathrm{n}$.
496 Pres. Messages, pp. 13, 14.

50 Heffter, $\S 115$, Geffcken n. 4.

51 Brown vs. Hiatts, 15 Wall. 
$\$ 459$. Closing of the ports of New Granada._- I similar question had just been settled as to certain ports of New Granada. In consequence of civil war that government had attempted to close by order rebellious ports to the outside world. Lord John Russell considered such action an infringement of international law, saying that while in peace a nation could open or close its ports, it could not do so in war as to ports in hostile occupation, unless the closing was by the means of an effective blocliade. The same principle has since been recognized by the United States in connection with the Colombian civil war of 1885 , and may be regarded as accepted law. ${ }^{52}$

$\$ 460$. A civil war a public war.-A civil war is a public war and must be carried on as such. Either belligerent may blockade the ports of the other ${ }^{53}$ prisoners are to be exchanged; and officer's recognized by their titles. There is no distinction, from a military point of riew, between a civil and a foreign war until after the final decisive battle. When the rebellion is subdued the rebels, if their terms of surrender do not forbid, may be proceeded against for treason, ${ }^{54}$ as a matter of internal policy, not of international law. The United States courts have not been consistent as to the light in which they regard the Confederate government, probably the most de facto government that did not survive a war. Despite that fact, however, the courts have been unwilling to admit that the federal government did not exist in the South for any purpose. Probably the point of reconciliation of the decisions is that as to completed transactions the Confederate was a de facto government, but as to matters executory it was not. ${ }^{55}$

$\$ 461$. Effect of war on private citizens.-From the standpoint of law war still places the private citizens of a contending state in hostility to those of the other, according to the old proclamation commanding every subject to attack the enemy, courir sus aux ennemis. Despite the modifications made in that rule by a more humane practice, war still breaks up all intercourse, in the way of trade or otherwise, between the combatants; 56 no contracts can be made that are enforceable during

52 Hall, International Law, $p$. $37 \mathrm{n}$.

53 Prize cases, 2 Black, 635; U. S. vs. Palmer, 3 Wheaton, 610 ; Divina Pastura, 4 Wheaton, 52.

54 Instructions for United States Army in Field, 152-4.
55 Prize cases, 2 Black, 635, 673. 674; The Lilla, 2 Sprague, 177; 2 Clifford, 169; Thorington vs. Smith, 8 Wall. 1, 7, 9, 10; Ford vs. Surget, 97 U. S. 594, 604, 605.

58 Barrick vs. Buber, 2 C. B. (N. S.) 563 ; Esposito vs. Bowden, 7 
or after the war, with the exception of ransom bills and the like. Heffter denies that war suspends trade, but Sir Wm. Scott's declaration in The Hoop that "a state in which contracts cannot be enforced cannot be a state of legal commerce" is sounder in principle and practice. That subject, howerer, concerns international private law rather than public. The old theory and practice regarded war as a state of force in which each nation and each man did as he saw fit,- - a return to a Hobbeslike condition of strife, with survival of the strongest. Social development has, however, improved states as well as individuals. Civilization means that peace is the rule and that war is the exception. It means perhaps even more,--that war is a legal procedure, a rechtshïlfe, for the purpose of securing a better peace.57 Except in self defense, no one without a commission of some lind from the sovereign can now attack the enemy. We are thus returning to the rule of Cicer ${ }^{58}$ and departing from that of Solon and the self-help of medieval times. But even now important questions arise after declaration of war as to effect on treaties, resident enemies and neutral states. The interests of neutrals have so expanded within a century by the increase of commerce and growth of nations as to deserve a separate title of equal importance even with those of War and Peace.

\$462. Effect of war on treaties.-During a debate in the British House of Commons a minister said that it was unnecessary to consider the provisions of the Treaty of Paris of $\mathbf{1 8 5 6}$ because in the event of war it would be abrogated. He was promptly contradicted, even by his colleagues, but the incident shows a not uncommon mental confusion on the subject. While war does abrogate treaties, so far as they relate to the matter in dispute, it clearly does not abrogate treaties relating to weapons and methods of warfare. It is not a complete lapse into barbarism. War does not break every bond of lumanity, says Vattel,-all agree that people at war do not cease to be men. ${ }^{59}$ There are, however, a vast number of cases

\section{Ellis and B. 763; Phillips vs.} Hatch, 1 Dillon, 192. According to Bynkershoek, Quamvis autem nulla specialis sit commerciorum prohibitio ipse tamen jure belli commercia sunt vetita. Quaest. Jur. Pub., 1, 3; Am. Regulations, 86; The Rapid, 8 Cranch, 155; Wharton, Int. Law Dig., \$ 337 ;
Montgomery vs. U. S., 15 Wall. 395; White vs. Burnley, 20 How. 249.

$5 \tau$ Bluntschli, Mod. Kriegsrecht, sec. 20 (529).

${ }_{58}$ De Officiis, lib. I, c. II.

59 Droit des Gens, II, ch. 15; III, ch. $10, \S 174$. 
between the two extremes, as to some of which we have no judicial decisions, and as to others text books are not all iil accord. The following may be accepted as general rules: (1) that war abrogates treaties, so far as they relate to the subject matter in dispute; (2) that it suspends those relating to the commereial intereourse of combatants; (3) that it does not affect those made to regulate war itself, (t) or which on their face are intended to be permanent. ${ }^{60}$ It is often difficult of course to determine whether or no particular provisions fall within the one class or the other. The general principle is that all provisions are permanent except those which would conflict with rights and duties of a state of war or evidently relate only to a state of peace. ${ }^{61}$ From one point of view war may be regarded as a means for compelling the offending state to a fulfilment of its treaty obligations. ${ }^{62}$

$\S 463$. Effect of war on resident enemies.-The effects of war on resident enemies have varied at different times. Magna Charta provided that foreign merchants in England should be attached, without harm to body or goods, until it was known how English merchants were to be treated by the enemy, when the same treatment was to be extended them. Edward III allowed forty days for merchants to leave, and a reasonable time has generally been given since in civilized countries. But aliens have sometimes been imprisoned, sometimes expelled and their property confiscated. Even during the late war with Spain President If Kinley, acting under powers originally conferred by a statute of 1798 , warned them by proclamation that they were objects of suspicion, and at the beginning of the Boer war many British were expelled from the Transvaal. Grotius, followed by Kent, holds that a state has the right to imprison all subjects of the enemy who are within its power until the end of hostilities. Thus, at the sudden outbreak of war after the Peace of Amiens, Napoleon imprisoned all the British in France, as retaliation, however, for the British seizure of French ships that had come during peace into English ports. ${ }^{63}$ Tattel's view ${ }^{6+}$ has prevailed that as such foreigners are in rited to the country, it is implied they

60 Socy. Propagation vs. New Haven, 8 Wheaton, 494; Sutton vs. Sutton, 1 Russ. \& Mylne, 663. See Wharton, Int.Law Dig., $\S \S 135,302$. 61 Heffter, § 122.

62 Bluntschli, Mod. Kr., Sec. 29
(538), 213 (712); American Army Regulations, 15.

63 De Jure Belli ac Pac., III, c. 9, IV, 1, 3; Kent's Commentaries I, § 56; Calvo, Droit Int., II, 37. 64 Droit des Geṇs, III, ch. $4, \S 63$. 
shall be permitted to leare with their property. Such was the prorision of a treaty of Utrecht with Muyden and Teesp in 1463, and of a Hanse treaty with France twenty years later. During the next century, under the lead of France, such treaties became common. In 17.56 French subjects were invited to remain in England despite the war'; and that practice, repeated in the declaration arainst spain six rears later, has become more and more prevalent, with or without treaty provisions therefor. Calvo, howerer, admits an exception in the ease of active soldiers, who may be detained in order to prevent their return for military purposes.65 And yet during the Franco-I'russian war even German soldiers were permitted to retire, despite the fact that permission might have been refused beanse they were a part of the enemy's amy.60 Later on Germans were expelled from the department in which Paris lies, but that was an incident of the state of siege then imminent, and, as a military measure, ean hardly be condemned, whaterel may be said of the methods employed.it The alien and sedition laws, passed in the Cuited States during the undeclared war with France in 1798, were unpopular, and probably led to the orerthrow of the Federalists, the dominant political party at that time. The detention or expulsion of eitizens of the enemy nation can be justified only for military reasons, and when expelled they must have safe conduct through the lines.

$\$ 464$. Confiscation of private property.-It is not likels that any eivilized nation would now confiscate the property of private enemies within its limits on the outbreak of war. Alexander Hamilton justly said that "whenerer a government rrants permission to foreigners to acquire property within its territories, or to bring and deposit it there, it tacitly promises protection and security." The Roman law declared quae res hostiles apud nos sunt, non publicae sed oecupantium fiunt,assigning them to the first taker. ${ }^{6}$ The Cuited states supreme Court has indeed declared confiseation to be a war right, not effectire, howerer, until Congress enacts a statute for the purpose ${ }^{69}$ - something Congress has been eareful never to do

65 Calvo, Droit Int., II, 37.

66 Heffter, $\$ 121$, Geffeken, note 2. ken.

6 - Heffter, $\S 121$, note 4 , Geffc-

68 L. $51, \S 1$ D, De acq. res, etc.

69 Letters of Camillus: Brown

vs. U. S., 8 Cranch, 123. The opin- ion is by Marshall; that of Story

dissenting held the right to exist without legislation. Wagner vs. The Juanita, Newb. Adm. 352; Ware rs. Hylton, 3 Cranch. 199; The Johanna Emilie, Spinks 14. 
except during the ciril war. The same rule prevails in England, where confiscation is a right of the crown which may be exercised without the aid of additional legislation. There they attempt to distinguish between debts and other property, contending that private debts cannot be confiscated, although property can. When France seized both in 1793, Great Britain retaliated, and at last, in April, 1814, compelled the removal of sequestrations and the liquidation of claims. In 1807, in retaliation for condemnation of Danish property in British ports as droits of the admiralty, $£ 1,265,000$ in value, Denmark sequestered debts due from Danish to British subjects hardly amounting to $£ 300,000$. The court of King's Bench denied the validity of the Danish sequestration, endearoring to distinguish between debts and other property, ${ }^{70}$ in a decision by Lord Ellenborough, which has been justly criticised. The only recent instance of such confiscation was the act of the Confederate Congress of August, 1861, declaring that "property of whatever nature, except public stocks and securities held by an alien enemy since the 21 st of Mas, 1861, shall be sequestered and appropriated," under which receivers were appointed and even land sold. While the act was probably within war powers, it was condemned at home and abroad, and the sales made under it have been held void. ${ }^{71}$ Modern practice does not go beyond sequestrating during the war the income of real property owned by private enemies within our limits, in deference to the principle that after encouraging persons to buy land it is not honorable to take adrantage of war to deprive them of it. ${ }^{2}$ Ships in port were formerly confiscated, but the universal rule now is to allow them time to finish loading and reach their home ports, if they do not contain contraband. ${ }^{73}$ A declaration of war by one state against another does not per se affect residents and citizens of the former, except so far as it involves their right to remove their property from the enemy state within a reasonable time,-a right upheld by the courts of New York, and denied by the lower Federal Courts. ${ }^{73 a}$

$\S 465$. Effect of war on trade.-War suspends civil inter-

70 Wolf vs. Oxholm, 6 M. \& S. 5, $§ 76$; Bynkershoek, Quaest. Jur. 92; Wheaton, Elements of International Law, IV, 1, § 12 .

Pub., I, c. 7 .

73 Heffter, $\S 121$, note 1 ; The

71 Dewing vs. Perdicaries, 96 U. Pedro, 175 U. S. 354; The Buena

S. $193 ; 1$ Hughes, 69 .

Ventura, ib. p. 384 .

72 Vattel, Droit des Gens, III, c. 73a The Rapid, 8 Cranch, 155. 
course of all kinds between the belligerent nations and between their respective citizens. Thus a Berlin banker (Güterbock) was punished for dealing in securities issued by the Gambetta government; and insurance on a cargo from an enemy country cannot be collected. ${ }^{7 t}$ It has even been held that a ressel can be condemned after she has left her cargo at an intermediate enemy port and is on her way home. ${ }^{75}$ If the theory ever prevails that the governments only are at war, trade and other intercourse across the lines will be lawful. But eren then that practice will remain much the same, because such intercourse als a whole is contrary to military necessities. Now it is forbidden by law ${ }^{76}{ }^{6}$ - under the new theory it would be forbidden by proclamation. Intercourse with neutrals is not affected by war, neither is domestic trade, except so far as either interferes with military operations.

$\$ 466$. Effect of war on allies. - A declaration of war or its equiralent does not conclude an ally, who can always appeal to the tacit clause implied in every treaty of alliance, under which he has the right to determine for himself whether or no the casus foederis has actually taken place. If the war is clearly and obriously unjust the co-ally is not bound, no matter whether the alliance be offensive, defensive, or both. ${ }^{77}$ In determining that question, however, the co-ally should gire to his friend the benefit of all doubts; in the absence of proof to the contrary he should presume that his ally has just cause of war. When an alliance purely defensive is entered into the co-ally is expected, as a general rule, only to co-operate in defense of his ally in a war really and truly defensire. How difficult it often is to determine what constitutes a just or defensive war, since certain wars offensive in form are actually defensive both in spirit and substance, was fully illustrated by the serious conflict of views between Great Britain and Holland in 1756, to which reference has been made already. ${ }^{78}$

\section{Conflict between France and the United States as to alliance of}

$7+$ Potts vs. Bell, 8 Term R. 548; Heffter, § 123, Geffcken, n. 2.

75 The Joseph, 8 Cranch, 451; The Caledonian, 4 wheat. 100.

76 Phillips vs. Hatch, 1 Dillon, 191; The Hoop, 1 Rob. 196; The
Frances, 8 Cranch, 335; Jecker vs. Montgomery, 18 How. 112.

77 Vattel, Droit des Gens, III, ch. 6 , $\S 83,86$; Wheaton, Elements Int. Law, III, ch. 2, 115; Halleck, Int. Law, pp. 416-417.

78 See above, p. 369 . 
1778.-Further illustration may be found in the conflict that arose between the United States and the rerolutionary government of France in 1793 as to the duty of the former under the treaty of alliance of February $6,1768,79$ which, after reciting that in the then pending war with Great Britain, France and the United States were allies, provided that the "essential and direct end of the present defensive alliance" was to maintain the sovereignty and independence of the United States, in return for which the latter guaranteed to the crown of France all its then possessions in the West India Islands. It was further agreed "that in case of rupture between France and England the reciprocal guarantee declared in the said article shall have full force and effect the moment such war shall break out." After calling on the members of his cabinet for their opinions in writing as to the binding force of the treaty in question, under conditions then existing, Washington, in the midst of divided counsels, issued his famous neutrality proclamation, ${ }^{80}$ which a recent writer declares "has had a greater influence in molding international law than any single document of the last hundred years." 81 The ostensible ground upon which the binding force of the alliance was denied was, as stated by Hamilton ${ }^{82}$ in the essays of Pacificus, that the "guarantee" clause between the United States and France was personal to Louis XVI, and did not apply to the revolutionary government that succeeded the deposition of that monarch. That such a contention was entirely untenable was clearly demonstrated by Madison, ${ }^{83}$ who, under the name of Helvidius, said that "a nation, by exereising the right of changing the organ of its will, can neither disengageitself from the obligations, nor forfeit the benefit of its treaties. This is a truth of vast importance, and happily rests with sufficient firmness on its own authority. To silence or prevent cavil I insert, howerer, the following extract: 'Since then, such a treaty (a treaty not personal to the sovereign) directly relates to the body of the state, it subsists though the form of the republic happens to be changed, and though it should be even transformed into a monarchy-for the state and the nation are

79 Treaties and Conventions of the U. S., p. 307 .

80 Messages of the Pres., vol. I, pp. $156-8$.

81 Foster, A Century of Am. Diplomacy, p. 154.
82 Works, vol. IV. (ed. 1885), p. 362 seq.

83 Writings, vol. I, 614 ff. See also Tucker's Life of Jefferson, vol. I, pp. 414, 421 . 
always the same, whatever changes are made in the form of goverument - and the treaty concluded with the nation remains in force as long as the nation exists. Vattel, B. II, \$5." "Even if it be true, however, that the ostensible ground upon which Washington ignored the "guarantee" clause in question was inconsistent with acknowledged principles of international law, there can hardly be a doubt that the United States was entirely released by the real ground, which was that the propaganda of the French Revolution, challenging the hostility of all Europe by the declaration of an offensive crusade against its ancient institution: did not make a casus foederis under an alliance purely defensive.

Other illustrations; another tacit condition of alliances.-When in 1826 the Princess Regent of Portugal called for the assistance of Great Britain against Spain by virtue of the tripartite treaty of 1703 between England, Portugal and Holland, Canning, who admitted the existence of the treaty, argued in the House of Commons that it was necessary that the casus foederis should be shown. Another tacit condition of every alliance is that the ally can be called upon to furnish only such assistance as is possible at the time. ${ }^{84}$ Had the treaty provisions been even stronger in their terms, Great Britain could hardly have expected France while in her death struggle with Germany in 1871 to aid in punishing Russia for violating the regulations of $\mathbf{1 8 5 6}$ as to warships in the Black Sea. Neither France, Austria nor Great Britain stirred to aid Turkey when Russia attacked her in 1871,-non-action which seems to have been a violation of their treaty engagements. ${ }^{85}$ The same principles apply to qualified alliances, (partie auxiliaire, nebenpartei), such as those for subsidy, auxiliaries, and the like.

Warlike alliances made after the outbreak of war.-No serious difficulty should ever attend the ascertainment of the casus foederis of a warlike alliance made at the commencement of, or during a war, because all parties are then expected to understand the exact nature of the obligations they assume. By the making of such compacts third parties are called upon to determine whether or no they are of such a nature as to make the signatories also parties to the war. If so, their making is tantamount to a declaration of war and justify immediate hostilities. Great Britain so regarded the alliance made

84 Vattel, Droit des Gens, III, c. ss Heffter, § 116, Geffcken, note 8 . $6, \S 92$. 
by France with her revolted colonies in North America during the American revolution. ${ }^{86}$

$\S 467$. Liability of domiciled aliens to military service.- $\mathrm{As}$ stated heretofore the law of nations considers an alien while domiciled in a country entitled to the protection of its laws, in return for which he owes a temporary and local allegiance that continues during the period of his residence. ${ }^{87}$ In time of peace, such a domiciled alien may be called upon to perform such police or military service as may be necessary for the maintenance of the social order of the state from which he is deriving advantage; in time of war, he may be called upon under certain conditions of emergency to render military service in protecting such a state against external dangers. The extent of this liability to police and military duty upon the outbreak of war has never been precisely defined. When the question arose at New Orleans, during the war of 1812, as to French subjects who, after serving efficiently in the hour of danger, attempted to leave the ranks and return to their business, Consul Tousard was quite active in supplying certificates to avoid service. The difficulty thus presented Andrew Jackson finally solved by compelling those who claimed to be foreigners to leave the city until he considered all danger passed. While there was a great stir at the time, no legal objection could be made to that method of expelling non-combatants from military lines. ${ }^{8 s}$ During the American civil war the same question was presented more directly in the conscriptions imposed by the Southern Confederacy, and by the government of the United States under the act of March 3, 1863 , the President's proclamation of May the 8th of that year, and section 18 of the act of February 24th, 1864, providing "that no person of foreign birth shall, on account of alienage, be exempted from enrollment or drait under the provisions of this act, or the act to which it is an amendment, who has at any time assumed the rights of a citizen by voting at any election under the authority of the laws of any state or territory, or of the United States, or who has held any office under such laws or any of them; but the fact that any such person of foreign birth has roted or held, or shall vote or hold, office as aforesaid, shall be taken as conclusive eridence that he is not entitled to exemption from military service on account of

86 Bynkershoek, Quaest. Jur. Pub. 1, c. ix; Phillimore, iii, $\S 73$; Requelme, Derecho Pub. Int. i, tit. 1, c. xi.
87 See above, p. 251.

88 Gayarré, La. vol. iv., p. 579. 
alienage." During the general discussion of the subject with Great Britain, which began as early as 1861, that power, after objecting to English subjects being compelled "to serve in the armies in a civil war, where besides the ordinary incidents of battle they might be exposed to be treated as rebels and traitors in a quarrel in which, as aliens, they would have no concern," admitted that its gorernment "might well be content to leave British subjects voluntarily domiciled in a foreign country, liable to all the obligations ordinarily incident to such foreign domicil, including, when imposed by the municipal law of such country, service in the militia or national guard, or local police, for the maintenance of internal peace and order, or even, to a limited extent, for the defense of the territory from invasion." While that admission was in perfect aceord with Lord Lyous' declaration "that there is no rule or principle of international law which prohibits the gorernment of any country from requiring aliens, resident withiu its territories, to serve in the militia or police of the country or to contribute to the support of such establishments," so Hall, after eliminating the distinction between residents and mere sojourners, was undoubtedly right in suggesting that "the concession made to local authority seems unnecessarily large." 90 Bluntschli states the rule more correctly when he says that resident aliens cannot be compelled to enroll themselves in a force to be used for ordinary national or political objects; that they cannot be compelled to aid in maintaining the social order except as a part of the police as distinguished from the political power; and that they can only be compelled to defend the state or a part of it against invasion when that is threatened by savages or uncivilized nations. ${ }^{91}$

$\$ 468$. When neutrals become de facto citizens of belligerent state.-While it would be a violation of nentrality to seek to enlist soldiers in a neutral country, it is not improper to accept the military service of all neutrals who may come to the belligerent and offer themselves. In such case these cease to be neutrals and for the purposes of the war become de facto citizens of the belligerent state. ${ }^{92}$ The same theory was acted on by the Germans during their oceupation of Paris in 1871,

89 Naturalization Commission, Append. to the Report, 42.

90 Int. Law, 217.

91 Völkerr., \& 391.
92 Twiss, Law of Nations, War, $\S$ 42; Grotius, De Jure Belli ac Pacis, III, c. $4, \S \S$ vi, vii. 
COMMENCEMENT OF WAR-ITS CONSEQUENCES. 469

when they billeted soldiers in apartments occupied by Americans and protected by certificates and flags of the United States. Bismarck declined to admit such rights of enclave, so to speak, and the United States did not press the point. ${ }^{93}$

93 Foreign Relations U. S. 1871, p. 307. 


\section{CHAPTER III.}

\section{RIGHTS AND DUTIES OF BELLIGEREN'TS DURING HOSTILI- TIES ON LAND.}

\section{$\$ 469$. Instruments of war and their legitimate employment.}

- The conduct of active hostilities, of the operations of armies in the field, is regulated by what is generally known as military law, which may be regarded from three points of view. The first involves the instruments of warfare, such as forces and weapons; the second, the methods of warfare and the degree of foree to be employed; the third, the extent to which the use of fraud or artifice against an enemy is permissible. Although war is the extreme self-help of nations, such a use of force is permissible, and no more, as is necessary for the accomplishment of its legitimate ends. ${ }^{1}$ In the practice of the ancient world almost any means could be used for coereing the enemy, although by the time of Sallust the conduct of Marius in putting to the sword some inlabitants of the Numidian town of Capsa and enslaving the rest was recognized as contrary to the law of war, contra jus belli. ${ }^{2}$ Killing, enslaring, rapine, poison, frand were the usual methods of the earlier ages, and even Bynkershoek and Wolf in the eighteenth century advocated a return to such practices, ${ }^{3}$ the former declaring that everything is lawful against an enemy except perfidy. Fortunately, Grotius before and the humane Tattel after them inculcated different rules. While relapses from their standards sometimes occurred, they were at least recognized as relapses. The growth of modern methods has resulted in a great gain for humanity, which Heffter says is the "regulative" of the law of war. The general principle may be stated to be that everything is prohibited which is not of a nature to contribute to the military operations, and

1 Wheaton, Elements Int. Law, p. 250 ; Heffter, $\S 119, \S 113$; Grotius, De Jure Belli ac. Pacis, III, ch. 4, secs. 5-7; Vattel, Droit des Gens, III, ch. 8. This division is preferable to Heffter's Kriegsmanier and Kriegsraison.
2 Sallust, Jugurtha, c. 91. See Livy, II, 12, XXXI, 30, also.

3 Wolf, Jis Gent., § 878; Bynk., Quaest.Jur. Pub., I, chs. 1, 3. Even Burlamaqui says that by a state of war that of society is abolished. 2 Nat. \& Pol. Law, IV, ch. v; but see also ch. $\mathbf{x}$. 
everything permitted shall be done only in the manmer and circumstances reasonably calculated to forward them.*

$\S 470$. Evolution of military codes.-Reference has been made already to the influence of the pioneer manual prepared in 1863 by Francis Lieber for the government of the United States armies in the field, and revised by a board of officers presided over by Major-General E. A. Hitchcock, a work styled by Calvo the codification of the laws of war." Many of the best principles thus put together are to be found in the Swedish army regulations of Gustarus Adolphus, which presented so marked a contrast to the general practice of armies in the Thirty Years' War'. Is Lieber's dominant idea was the repression of what he deemed a rebellion, his Manual is in some particulars too severe, especially so in regard to occupied territory, its residents and their property. ${ }^{6}$ The good work thus begun, necessarily in an imperfect form, was gradually developed by the Red Cross Conrentions of 1864 and 1868; by the Declaration of St. Petersburg, 1868; by the Brussels project of 1874; and by the code adopted at Oxford by the Institute of International Law in 1880. The most important of these progressive eflorts was the Brussels project, based in the main on the labors of Lieber and Bluntschli, which remained as a mere project, a guide to jurists and a beacon to such nations as chose to follow, down to its adoption, with only a few changes, by The Hague Conference of 1899 . The conrention into which it was then incorporated provides that each of the signatory powers shall issue to its armed forces corresponding instructions or manuals to govern in wars between themselves in which non-assenting states do not intervene. "Iu cases not provided for in the articles, populations and belligerents remain under the safeguards and gorermment of the principles of international law resulting from the customs established between civilized nations, the laws of humanity, and the demands of public conscience. 7 "

\$471. Combatants, lawful and unlawful. Theatre of war.Legally all residents of countries at war are enemies; and no matter whether we adopt the new rule that only the governments are at war, or the theory that only a part of the citizens are delegated to conduct it for all, the result is the same,some of the respective populations carry on hostilities and

4 Westlake, Int. Law, 236.

5 Calvo, Droit Int., II, 282.

${ }^{\circ}$ Davis, Int. Law, 397.
7 Hague Second Convention, Art. I and II. 
others do not. The former are termed active enemies, the latter passive. Of active enemies some are lawful combatants and others not. The lawful combatants are those impressed with military character by the belligerent state. ${ }^{8}$ Such as are connected with the military or official service whose positions do not call for hostile acts, like the medical, judicial and commissary departments, are exposed to the dangers of hostilities, but cannot be separately attacked so lonig as they do not take part in actual hostilities. They are sometimes called special combatants; or, as in The Hague second Convention, are included among non-combatants. Unlawful combatants are those who carry on hostilities without state authority, those who give aid and comfort to the enemy, and also spies and pirates. Active enemies or combatants may be killed while resisting with arms, but must be taken if unarmed, or when they offer to surrender. While unlawful combatants may be summarily dealt with, after capture lawful combatants are prisoners of war. The theatre of war can be only our own country, that of the enemy, or the territory of no one,- of which almost the only example now known is the high seas. To wage war on neutral territory, by land or sea, is to invade it and justify war by the invaded country.

\$472. Regular forces.-While a declaration of war in the usual form calls upon all citizens to proceed to hostilities against the enemy, in practice this duty is limited to those persons who are impressed with military character by the national authority, to such, in short, as constitute the regular army and navy. Cato adrocated the necessity of regular enrollment to make a soldier, ${ }^{9}$ but generally in ancient times the whole male population made up the military forces, a usage that survived for some time after the Teutonic conquests. During the Middle Ages war became a trade, carried on by highly trained mercenaries, who sold their services wherever required. Upon the formation of large states, however, that plan became unreliable and unsatisfactory. The growth of the Spanish power in the fifteenth century was accompanied by that of a disciplined national army under Ferdinand, Charles and Philip. ${ }^{10}$ Thus was necessitated simi-

8 Calvo's division into ennemis forcés, volontaires, et passifs is the same, remembering that his first and second classes are included under active enemies above: Droit
Int., II, 107; Am. Regulations, 57; Hague Second Convention, Article 111.

${ }^{9}$ Cic. De Off., c. II.

10 As to the Spanish and other 
lar organizations in France, under Francis I and Louis XIV, and in Prussia under Frederick II. Standing armies thus came in and grew with the growth of kingship, a process certainly not interrupted by the French Revolution, resulting in a military system which gave to them a still wider expansion. The nationalization of Europe has also increased standing armies by making service general and compulsory, apart from calling attention to the necessity for the employment of irregular forces. At present European armies amount even in time of peace to sereral hundred thousand men for each of the great powers, and in war perhaps a million can be called out by each. Regular forces, uniformed and officered, are governed by military law; and, when properly disciplined, move like huge machines, doing comparatively little damage to their own citizens or to non-combatant enemies and their property. They are impressed with the military character of the nation and are only too well known and recognized in international law. They and they only are the war power, the nation at war, the national authority, under the rule requiring offensive hostilities to be committed only by lawful authority. All such acts are unlawful except when so committed under authority of a belligerent or in self-defense. ${ }^{11}$ The forcible acts of a soldier become those of the state by which he is commissioned; he is not responsible to the local courts, or to any other except his military superiors. ${ }^{12}$ Chaos would come again on land and sea if the old theory dominated the modern practice; if all the citizens of one country engaged in actual hostilities with all those of the other. All persons not in military and naval forces are now considered only as passive enemies in contradistinction to fighting men. ${ }^{13}$

$\$ 473$. Irregular forces: employment of savage against savage. -It is the common practice for civilized states to employ savages as allies or subordinates in wars with other savages. In America the Choctaws under Pushmataha acted with Andrew Jackson in the great Creek War; and the same kind of allies have often been employed since in operations against the Modocs, Apaches and other western Indians. During the war

armies, see Robertson's Charles V, section II.

11 Field, Int. Code, § 734; Talbot vs. Jansen, 3 Dallas 133, 160 ; Halleck, Int. Law, § 391. See also
Jefferson and Webster in Wharton, Int. Law Dig. $\S 350$.

12 Dow vs. Johnson, 100 U. S. 158. 13 Heffıer, § 124; Wheaton, Elements, 255 . 
in Tonquin the French used the Yellow Flags against the native Black Flags, and in Africa and India the British habitually employ the native peoples. It seems that in no other way can white troops, trained in a different school, so learn the methods of their salvage foes as to grapple with them effectually. Such a platetice necessarily sanctions many barbarities, but only agalinst races outside the palle of international law, who do not consider such acts as barbarities when committed by themselves. If war is to be carried on against salvages, it must be, to some extent at least, on a plane and in a manner which they can appreciate and understand. "A war against hordes and bands who recognize no law of humanity, "silys Ileffter, ${ }^{1+}$ "is necessallily lawless." The disturbances in Clima in 1900 constitute a case in point. International law is based on reciprocity, even of evil, if that be practiced by the enems. While the governmental announcement in parliament that the Zulus if attacked by Boers would be armed and encouraged to defend themselves, came as a painful surprise, it was only a threat of a lawful and necessary expedient, which fortunately the non-action of the Boers in that direction made it unnecessary to execute.

$\$ 474$. Except as against their kind, employment of savages now condemned.-Except as arainst their kind, the employment of sarages is now condemned. ${ }^{15}$ Through a long course of development certain races have ripened into what are called civilized communities, with many customs and traits in common; and so bound together by ties of intercourse that war is regareled as an abnormal condition. ${ }^{16}$ While it is true that all may have started from the same savage state, those who have passed throngh it differ widely from those who remain in it. The solemn formula of the Ver sacrum of the Romans was a survival of the ammual wandering of the early Aryans; but could those who took part in it (sacrani) have met their own ancestors with whom it originated they would have disowned these as barbarians. The Catholic Pontiff (pontifex-bridgehuilder) is the lineal successor of the bridge-builders of those same wandering tribes, but the rope represents an international power which would frown on such warfare as those car-

$14 \S 119$.

15 Bluntschli, Mod. Kriegsrecht, sec. 53 (559).

16 See Ihering's Aryans, passim; and the works of L. H. Morgan, H. S. Maine, J. F. McLennan, Sir John Lubbock and others. 
penters aided. In war cruelty of all kinds, now universally condemned by civilized peoples, was and is characteristic of uncivilized races, ancient and modern. Can war be waged more eruelly than by turning savages against civilized communities? The employment of Turkos in the Franco-German war was therefore justly condemned by Bluntschli; and the sending of Circassians into Hungary by Russia in 1848, and of Bashi Bazooks into Bulgaria in 1877 was equally reprehensible. Nevertheless, towards the end of the Crimean War Russia was preparing to arm some of her savage races; and in the threatening time of 1878 Lord Beaconsfield brought Indian troops through the Suez Canal and quietly stationed them at Malta. On the one hand that act was regarded as a master stroke of policy, showing what resources Great Britain could muster; on the other, it was decried as a fresh invasion by barbarians. As these men were uniformed and disciplined, the outery was probably unjustifiable. Their organization certainly marked an advance on what had been witnessed in the American Revolution, and in the earlier French-English wars for the possession of this continent, when much of the fighting was done by the redskins. Even in the Anglo-American war of 1812 Tecumseh was in British pay; savages were attached to British armies; from the Lakes to the Gulf warfare was waged between Americans and Indians. The fact that no such thing would be tolerated now represents a distinct gain for civilization. While the participation of Indians in the American civil war is interesting, it is not so important, because their hostilities were confined to their Indian Territory and were directed against their own races. Arming slaves to fight against their old masters in that struggle was perhaps an inevitable result of the exalted enthusiasm for what was deemed by the one side a war for human freedom, not unlike the call of the French Republic in 1793 to the nations of Europe to throw off the yoke of kings and princes. And yet was not such arming an international wrong? Incentives to a servile insurrection would probably appear to a calm observer now in a different light. If slavery is brutalizing, slaves for that very reason are unfit for soldiers. While it is true that Lee favored their use on the Southern side, it was only after all other defensire means were well nigh exhansted. ${ }^{18}$ Although the freeing of slaves as a matter of war 
policy is now considered permissible, ${ }^{19}$ it was declared by $\mathrm{Mr}$. Adams when Secretary of State in 1820 not to be among the acts of legitimate war. ${ }^{20}$

$\S 475$. Guerrillas and banditti.-Whether guerrillas or partisans can be legitimately employed in war is less clear. Marion, in the American Revolution, and Mosby, in the civil war, were, according to their lights, as truly patriotic as Andreas Hofer in the Tyrol. The propriety and ralue of scout and partisan service when properly guarded can scarcely be doubted. "It is just as legitimate to fight an enemy in the rear as in the front. The only difference is in the danger" to those who thus strive to capture supply trains, and despatches, and isolate an army from its base. The American regulations speak of such bands as armed and uniformed, but acting in detached corps or bodies. ${ }^{21}$ While the history of every country reveals the existence of like forces, the great military powers have always been hostile to them. When South German peasants mutilated his stragglers, the soldiers of Gustavus Adolphus burned their villages. Napoleon was equally severe in Germany and in Spain, for which he has since been commended by Bismarek. Wellington issued a proclamation in southwest France that guerrillas must join the regulars under Soult or be shot and have their villages burned. During the Franco-Prussian war the Germans treated as banditti the Franc-tireurs who harassed their outposts, and picked off their sentinels; and they would not recognize the "garde national mobile," although that force was by law of 1870 made part of the army. British severity in South Africa is similarly defended.22 The ground of complaint is, that, since distinction is made in the treatment of combatants and non-combatants, there must be a distinction in the dress and behavior of these two classes. The man with the hoe must not by day enjoy the protection of the occupying army and by night burn its stores or assassinate the sentinels. ${ }^{23}$ The matter was thoroughly discussed at the Conference of Brussels in 1874, shortly after the Franco-Prussian war, and also at The Hague.

19 Bluntschli, Mod. Kriegsrecht, § 58 (564).

20 Wharton, Int. Law. Dig., $\S 338$.

21 Mosby's Reminiscences, 44;
Am. Regulations, 81; 3 Bourrienne, ch. 18.

22 Calvo, Droit Int., II, 117, 119.

23 Vattel, Droit des Gens, §271. III, c. $15, \S 226$; Martens, Précis, $\S 271$. 
At Brussels the German delegate endeavored to have warfare limited to regular forces, while the smaller states contended that this would leave them at the mercy of neighbors, who, unlike them, could and did maintain large standing armies. The conclusion finally reached at Brussels and affirmed at The Hague was that militia and volunteers should be treated the same as the army, when " 1 . Having at their head a person responsible for his subordinates; 2. Having a distinctive sign, fixed and recognizable at a distance; 3 . Carrying arms openly; and, 4. Complying in their operations with the laws and customs of war. In those countries where the militia or corps of volunteers constitute the army, or make part of it, they are comprised under the denomination of army." That provision is now part of the Second Convention of The Hague, ${ }^{24}$ and covers militia like the Landsturm of Norway, and the Ordenanza of Portugal, un-uniformed forces which are or may be officered. In 1810 Wellington used the Ordenanza to harass Masséna, who called them assassins and highway robbers, and ordered all that were captured to be shot. When the former remonstrated, pointing out that they were real militia. and that Masséna himself had "augmented the glory of French arms" while in command of un-uniformed levies, the order was not carried out.25 Bluntschli, writing before the Conference at Brussels, boldly contends that the right and duty of patriotism cannot be made dependent on the cut and color of one's clothes. Uniform is a matter of discipline, not of international law. ${ }^{26}$ Volunteers from abroad may aid the contending parties, as in the case of-Garibaldi in Italy, and later in France, ${ }^{27}$ even without express authority from the state. Such authority, however, must be presumed, as it is that which distinguishes soldiers from freebooters. The other requirements consist in the main of marks to indicate the same. A notable instance of irregular warfare occurred in 1602 when the Sarovards attempted to capture Genera by escalade, on the failure of which the Genevans hanged all their prisoners as robbers who had attacked them without cause. ${ }^{28}$ Napoleon, in 1796, shot the leaders of the

24 Hague Second Convention, Article I, to be found in Holls' Peace Conference at The Hague. The Brussels Project (in English) will be found in the appendix to Field's Int. Code, second edition. 25 Lanfrey, 1 Hist. de Napolćon,
V, 386: Wellington, Despatches.

26 Bluntschli, Mod. Kriegsrecht, sec. $65(570 \mathrm{a})$.

27 Id., sec. 64 (570).

28 Vattel, Droit des Gens, III, ch. $4, \S 68$. 
Pavian rerolt, magistrates and peasants alike; and in the next year he not only shot the Venetian revolutionists who killed the French wounded in Verona and massacred the garrison at Chinsa, but levied contributions besides. One of the most atrocious proclamations in history is that of the allied army which in vaded the Lower Valais in 1799 , by reason of its disregard of the recognized distinction between partisans and banditti. The former are irregular but lawful troops, while the latter are raiders without commission, robbers, assassins and all others who are beyond the pale of law. ${ }^{29}$

$\$ 476$. Levies en masse.-The status of levies en masse is defined in identical terms by the Brussels Project and The Hague Convention, as follows: "The population of an unocenpied territory, who, on the approach of the enemy, spontineously take up arms to combat the invading troops, without having had time to organize themselves in conformity with Article 9 (or Article 1 of the Convention), shall be considered as belligerent if they respect the laws and eustoms of war." During the Franco-Prussian War, after the army was dispersed, captured, or besieged in Paris, and government nonexistent, all France was in a ferment, and in many places "the population spontaneously took up arms to combat the invading troops." The same thing has many times occurred elsewhere; as the Belgian delegate said at Brussels, the records of such risings make up the most glorious pages in the history of every country. It is difficult, if not impossible, to reconcile the interests of invaders, who need security, with those of the invaded, whom patriotism urges to arms. ${ }^{30}$ At the same time Bluntschli is correct in saying that such risings in the rear of an occupying army present other questions, and may be treated with great severity, unless they assume such proportions as to make the occupation nominal. Is the German delegate at The Hague, General schwarzhoff remarled, soldiers deserve consideration on the ground of humanity as well as inhabitants, and when exhausted by march and battle have a right to protection against treacherous uprisings after oecupation. ${ }^{31}$ The lirussels l'roject, as confirmed at The Hagne, now dispenses with both uniform and anthorization in the atse of such levies.

29 Am. Regulations, 82.

30 Maine, Int. Law, 172; Hague Second Convention, Article II.
31 Mod. Kriegsrecht, sec. 96 (598); Holls' Peace Conference, 144. 
$\S 477$. Weapons to disable an enemy without unnecessary suffering.-Turning now from forces to their weapons, including arms, projectiles and material, the general rule is that ouly those shall be used which will disable the enemy with as little suffering as practicable. ${ }^{2}$ "All unnecessary cruelty," says Bluntschli, "is barbarity;" and on that ground the Brussels Project prohibited the use of all arms, projectiles and substances which may cause unnecessary suffering. Perhajs the principle involved may be said to forbid every method of warfare which aims at injuries which cannot be obriated by surgery. From that point of view instruments of war and surgery become correlative. For definite applications of the principle reference must be made to certain details agreed on in international conferences. Thus at St. Petersburg, in 1868 , it was agreed that no projectile should be used on land or sea of less than 400 grammes (or 14 ounces) in weight, charged either with fulminating or inflammable material. At The Hague it was declared that "the contracting parties agree to abstain from the use of bullets which expand or flatten easily in the human body, such as bullets with a hard envelope which does not entirely cover the core, or is pierced with incisions." 33 It was understood that this was aimed at the Dumdum bullet, originally manufactured for the British army in India, claimed on the continent to be cruel, and in England defended as humane. The British and American delegates did not sign this declaration because, amongst other reasons, it forbids a particular specification in bullets instead of establishing a principle. All nations represented, however, in view of the newness of the practice and danger of injury to other than combatants, agreed "to prohibit, for a term of five years, the launching of projectiles and explosives from balloons, or by other new methods of a similar nature." 34 Another special declaration or convention was that "the contracting powers agree to abstain from the use of projectiles the object of which is the diffusion of asphyxiating or deleterious gases," although that attempt to limit inventiveness was dissented from by the British and American delegates. ${ }^{35}$ At The Hague Capt. Crozier proposed the adoption of the principle "that the use of bullets inflicting wounds of useless cruelty, such as

32 Lord Stowell, in the Flad Oyen, $1 \mathrm{Ch}$. Robinson, 140.

33 Holls' Peace Conference, 459.

For discussion, see page 98 .
34 Holls' Peace Conference, 455. For discussion, see page 95 .

35 Holls' Peace Conference, 461. For discussion, see page 119 . 
explosive bullets, and in general every kind of bullets which exceeds the limit necessary for placing a man hors de combat, should be forbidden." "3t "While that proposal did not come to a rote, it probably embodies good law not requiring special endorsement. Excepting the prohibitions above named, which apply only between the signatory powers, every nation can arail itself of inventions to disable or destroy, by wholesale if preferied. Torpedoes, mines and great guns may be used to destroy whole ships and hundreds of meen at one time, provided no unusual suffering is inflicted upon the victims.

\section{$\S 478$. Uniawful weapons. Efforts to prohibit their use.-} l'oison has been forbidden from the laws of Manu to the conventions of The Hague, whether applied to weapons in battle or to the water used by the enemy. ${ }^{37}$ Nails, scrap iron and other forms of langridge eannot be used in guus, ${ }^{38}$ and some anthorities contend that chain and bar shot, 39 and red hot balls (first used in 1574 at the siege of Dantzic) are also prohibited. ${ }^{40}$ The last prohibition is, however, not apt to be material now, as the use of rifled camnon has dispensed with such missiles. Bombshells are allowed, but fire grenades not. Broken glass. lime, double or half bullets and the like are unlawful, and bloodhounds and wild animals are forbidden. Such prohibitions are subject to change, and vary with each epoch. Although Innocent III's attempt to prohibit the use of all missilesamong Christians failed, the crossbow was anathematized to some effect in 11:39 by the Lateran Council as artem Deo odibilem. To that fact England's fortunate reversion to the long bow is attributed. Firearms were held by Chevalier Bayard to be an unfair innovation, and in his last days he thanked God that he had slain without mercy all musketeers falling into his hands. Cannon were first used only to batter down walls, and not against soldiers, for it was considered barbarous to subject a brave man to death at the hands of a coward who remained at a distance. The English at Crecy first used firearms against the foe, and their suc-

36 Holls' Peace Conference, 103.

3 i Bluntschli, Kriegsrecht, sec. 50 (557) et seq.; Martens, Pricis, VIII, cli. III, \$3, n.; Vattel, Droit les Gcus, \$156; Halleck, Int. Law, 339; Hague Second Convertion, Article 23. Wolf held otherwise. Jus Gent., § 878 .
3* Hall, Int. Law, $\$ 185$; Martens, Prícis. VIII, ch. $3, \S 3, \mathrm{n}$.

39 Klüber, Int. Law, $\$ 244$; Bluntschli, Mod. Kr., $\$ 54$ (560); Martens, supra.

to Heffter, Vïlkerr., § 125; Bluntschli, §54 (560); Martens, supra. 
cesses compelled other nations to adopt their methods. And ret as late as 1759 the French vice-admiral Conflans forbade the use of hollow shot because he did not deem the practice honorable. The first users of the rifle wore green the better to escape capture and death, and for fear of similar treatment the bayonet was not much used until Frederick the Great adopted it. The torpedo, invented as the American Turtle during the revolt of the colonies from the mother country and perfected during the American civil war, although execrated at first. has, like firearms and the bayonet, won a permaneut place in war. The same is true of the ram. first used with effect by the Virginia during the American civil war, although existing in the French nars in the Solferino and Magenta since 1859.41 At The Hague Russia rainly endeavored to secure its prohibition.

$\S 479$. Recent conferences on the subject of weapons.-Civilized nations have during recent years held several conferences on the subject of weapons, and as between themselres the matter has now approximated an agreement. As heretofore explained, those of St. Petersburg in 1868 and of The Hague in 1899, both due to the initiative of Czars of Russia, have been the most important. The former on December 11, 1868 , declared that in war it is sufficient to "disable the greatest number of soldiers possible; and that this end would be exceeded by employing arms needlessle aggravating the sufferings of the disabled or making death ineritable; and that, therefore, the emplorment of such arms is contrars to the laws of humanity." +2 The importance of that declaration depends not so much upon a description of weapons as upon the fact that it announces a general principle of international law. Prussia endearored to list the forbidden weapons, but was thwarted by England. who feared that a check would thereby be given to inventiveness. ${ }^{+3}$ Although the passions of the Franco-Prussian War had not sufficiently subsided to permit the immediate and formal adoption of its recommendations, the moral effects of the Brussels Conference manifested themselves in varying degrees in the more humane manuals for army use since then adopted by different countries, following the model promulgated by the United States during the civil

41 See Maine, Int. Law, lectures VII and VIII; Mahan, Influence of Sea Power, 117.
42 Martens, 18 Nouv. Rec. Gen., 474.

43 Bluntschli, Mod. Kriegsrecht, sec. 52 (558a). 
war. ${ }^{44}$ The Brussels rules were approved by the Institute of International Law and substantially embodied in its military code. Russia endeavored to observe them during her war with Turkey in 1877 and expounded them in a military catechism distributed among her troops. With but slight revision they were adopted at The Hague.

$\$ 480$. No exemption for crowned heads and officers in actual battle. Pickets and sentinels.-The practice of picking off officers of the enemy, common during the Franco-I'russian War, has been specially emplasized by the Boer War. In 1870-1 twice as many officers were killed and three times as many wounded in proportion as soldiers in the ranks. In the future the relative loss of the former will probably increase now that modem guns witl smokeless powder enable sharpshooters to kill officers at 800 paces with ease and safety ${ }^{45}$ While crowned heads have sometimes claimed exemption from the dangers of battle which they often manage to bring on, ${ }^{46}$ Charles XII said the cannoneers of Thorn were right in firing at him, because by his death they might end the war. Although officers, like crowned heads, have no exemption above other men, they should as far as possible keep themselves out of danger, and the old Confederate cry in the Wilderness of "Lee to the rear" recognized the duty not less than the danger" of the commander. It is also contended in many quarters that pickets and sentinels should not be fired on except to drive them in; but, considering how important their remoral is in order to effect a surprise, this requirement is too exactingti and cannot be considered as an established rule of international law.

$\$ 481$. Devastation as a means of offense.-Devastation of an enemy's country must be viewed first as a means of reducing the foe to submission by inflicting distress upon him; second, as a necessary incident to military operations. While Grotius, regarding it mainly in its first aspect, expressly tolerates it, ${ }^{48}$ it was not generally regarded, even in his time, as permissible. The harrying of the Palatinate by Louis XIV in 1689, and the savage wasting of Bavaria by Marlborough in 1704 called forth the execrations of that age as well as of

44 Maine, Int. Law, 129.

45 Bloch, Future of War, 41, 332, 336. 4 ' Vattel, Droit des Gens, III, ch. sec. 1.
$4 \pi$ Am. Regulations, 69; Davis Int. Law, 223.

48 De Jure Belli ac Pacis, III, 11,

\section{$8, \S 159$.}


posterity. The severity of the French minister Louvois, of which a monument still remains in the ruins of Heidelberg castle, was indirectly a blessing, because, while it desolated the country, it rendered a like occurrence impossible for the future. The only form of offensive devastation really permissible is that occurring as a necessary part of military operations, involving the laying waste of the country in order to form a "barrier," as Vattel has expressed it.9 While the cutting of the Dutch dikes by Vendome, from Ostend to Ghent, may possibly have been permissible, such conduct surely injures non-combatants while its effect on combatants is uncertain. The tendency of civilized opinion is therefore to restrict such operations as much as possible. Although the history of Cuba shows that derastation was for a long time employed as a regulal method of war by both Spaniards and insurgents, it was left for Gen. Weyler while governor-general to give to it a new and terrible significance. In order to make the country untenable for insurgents, an official bando of October 21, 1896, forbade cultivation and drove the peasantry into towns or within the military lines. That policy was called "reconcentration," and resulted in the miserable death of fifty per cent. of the 300,000 reconcentrados. This as much as any other one thing led to the intervention of the United States, for, as President McKinley declared, "it was not civilized warfare; it was extermination. The only peace it conld beget was that of the wilderness and the grave." 50 Fortunately the disastrous result of the experiment, to its anthors as well as to its victims, is likely to make a repetition impossible.

$\$ 482$. Devastation as a means of defense.-While what may be done in one's own country to harass the enemy is important as a matter of strategy, it is not so much a question of international as of municipal law, or rather of the military law of the state interested. When the Dutch cut their dikes to flood out the French, it was regarded as an act of heroism, the fulminations of Louis XIV to the contrary notwithstanding. Peter ravaged eighty leagues of his own empire to check Charles XII, and reaped the results at Pultowa.51 The burning of Moscow was certainly as patriotic as it was effective

49 Droit des Gens, III, 9, § 167-8; Wheaton, Int. Law, p. 253. As to the Palatinate, see Hassall's Louis XIV, pp. 263-6.
5010 Messages of the Presidents, 141.

51 Vattel, III, 9, § 167. 
against Napoleon. Is such means are generally employed before the enemy"s power is firmly fixed, they must be distingnished from revolts designed to destroy it after occupation, which are governed by different principles elsewhere discussed.

$\$ 483$. Sieges and bombardments. Starvation.-When an army besieges a place several interesting questions arise. While polluting and poisoning streams that supply the garrison is of course forbidden now as it was in Greece, it is lawful to cut off the water itself and all provisions. It is lawful to starve the enemy into submission, ${ }^{52}$ a result almost accomplished at Ladysmith by the Boers. It is also lawful, as an extreme measure, to bombard the fortifications when it is impossible to reduce the place otherwise; if private property is thereby injured, no blame attaches to any one. It is even allowable to bombard a city protected by forts in order that private distress may compel the military to capitulate. Such was the Prussian practice in France during the twenty-two sieges in which they made no assaults.53 The same means were employed in the American civil war, and by the Versailles troops against the Paris Commune. Such a practice, sharply opposed as it is to the humanitarian drift of modern thought, does not justify, howerer, the bombardment of the residence quarter of a city as such in order to force residents to urge a surrender. "Such moral pressure," says Bluntschli, "would be thoroughly immoral." The only attempt at a remedy made at The Hagne was in the form of a prohibition against an attack or bombardment of undefended towns, villages, habitations, or buildings. A fortress may be attacked without warning, but the bombardment of a town should be resorted to only after reasonable notice, sar twenty-four hours, so that non-combatants may retire to a place of safety, unless surprise, assault or other pressing military reasons prevent.55 Although that right was insisted on in vain by the representatives of neutral powers at Paris in 1871, a truce of seceral days was allowed at Santiago on demand of the consuls, in order that foreigners might retire beyond the Ameriean lines. When reasonable notice was given by Dewey and

52 Bluntschli, Mod. Kriegsrecht, $\S 50$ (557).

53 Calvo II, $123,125$.

54 Mod. Kriegsrecht, sec. (554a). s. Bluntschli, Mod. Kriegsrecht, sec. 44 (552) et seq.; American Regulations, 19; Calvo, Droit Int. 47 II, 126; Hague Second Convention, Article 26. 
Merritt at Manila, the commandant, surrounded by the insurgents, had no place of safety for non-combatants. Buildings dedicated to religion, art, science, or benevolence, hospitals, and public buildings not in military use are to be spared if recognized as such, and to that end the besieged are expected to designate them by some specially visible signs previously indicated to the assailants. ${ }^{56}$ While a white flag or any other clear indication is sufficient, the American regulations mention a yellow flag as used for hospitals; and during the Spanish-American War the flag of the Red Cross Society was largely used for that purpose. In Corsica, in Nelson's time, even black flags were so employed. ${ }^{57}$ If such a flag is misused, the besieged cannot complain if it should be subsequently disregarded; it will not even protect churches if they are devoted to military purposes. Bismarck said "museums ought not to be placed in fortresses," and for that reason he would not hare hesitated to bombard any part of Paris. In fact, hospitals, schools and a museum of natural history were not spared at Paris, nor a library and cathedral spire at Strasburg. As to the last, the excuse was that it was used by the French for the purpose of observation. ${ }^{58}$ During the siege non-combatants may be expelled, subject to a recognized though harsh rule of war authorizing the besieger to refuse exit and thus force the garrison of the city to readmit them if he thinks such a course will hasten the surrender of the place through a more rapid consumption of its supplies ${ }^{59}$ At the siege of Jerusalem Titus at first thought of thus turning fugitives back, but finally yielded to compassion and let them pass; and such was the conduct of Henry IV at his siege of Paris. In our own day the Germans twice permitted non-combatants to retire from Strasburg, but refused to allow "useless mouths" to leave Paris, because they had determined to reduce the capital by famine. 60

$\S 484$. Storming and sacking of towns.-No matter how des. perate the fighting may be, after a fortified place is taken by storm the enemy is to be treated as in other battles, and civilian persons and property are to be respected as in other cases. When the practice has been otherwise, the excuse has been made that it is difficult to prevent the indulgence in lust and

$$
56 \text { Hague Second Convention, Ar- }
$$
ticle 27.

57 Am. Regulations, 115; Mahan's Nelson, 124. ss Calvo, II, 128-9.

$59 \mathrm{Am}$. Regulations, 18.

60 Heffter, § 126 and note 9

(Geffcken); Am. Regulations, 18. 
rapine of troops maddened by hand-to-hand encounters. Grotius says that in order to remove the danger of surprises the rule was established by mutual consent, about the time of Prince Maurice's attempt upon Venloo in 1597, that prisoners should be put to death. ${ }^{61}$ Ifter Tilly's siege and storming of Magdeburg it was discovered that the population of twentyfive thousand had been reduced to twenty-seven hundred, and that largely by throat-eutting. While that was undoubtedly an extreme case, the massacres of garrisons and populations were common during the Thirty Years' War, and have oceurred often since. A recent parallel may be found in the burning of Bazeilles near Sedan in 1870, where it is said women and children were deliberately murdered, only three hundred surviving out of a population of two thousand. The excuse given was that some of the people there had massacred wounded Germans. $^{62}$ All text writers unite in condemning the sacking of towns; and eren soldiers declare it subversive of military discipline. At The Hague it was specially prohibited eren when a place is assaulted. ${ }^{63}$ Unless an officer, says Halleck, "can control his soldiers, he is unfit to command them;" 64 and after recounting the horrible scenes in Spain at the capture of Ciudad Rodrigo, Badajos, and San Sebastian, Napier declares that soldiers can be controlled if taught that such conduct is criminal, immoral and contrary to military honor, and punishable by death, if necessary. "With such regulations," he observes, "the storming of towns would not produce more military disorders than the gaining of battles in the field." ${ }^{65}$ Although pillage is still sanctioned by some authorities in extraordinary cases, as by way of punishment for violation of the laws of war, the propricty of its employment is always questionable. Such reprisals should be inflicted only on the guilty few, not on a whole community. ${ }^{66}$

$\$ 485$. Unjustifiable resistance.-It was anciently maintained that a garrison resisting an overwhelming force should be punished by massacre for the reason that an obstinate and hopeless defense unnecessarily causes the death of the besiegers. The rule may have grown out of the Roman practice that

61 Vattel, Droit des Gens, III, ch. $10, \S 178 \mathrm{n}$.

62 Calvo, II, 121-2; Heffter, 278, G. n. 6 .

63 Hague Second Convention, Art. 28.
${ }^{64}$ Halleck, 442-3; Martens, Précis, VIII, ch. $3, \S 17$.

65 Peninsular War, XXII, ch. 2;

3 Alison's Europe, ch. 63.

66 Halleck, Int. Law, XIX, §§ $13-$

14; Martens, Précis, $\S 280$, and 
the besieged could expect quarter only before the battering rams were put into actunl operation. Even Wellington writing in 1820 says "it has always been understood that the defenders of a fortress stormed have no right to quarter." 6 i He did not, however, follow that rule himself, which is moribund, if not dead. As a recognition of the fact that bravery should always be respected Alexander ordered the Milesians spared because of their resistance; nothing can be more cruel, says Brnkershoek, than to punish an enewy for his courage. ${ }^{68}$ Davoust's long defense of Hamburg in 181t, when he even refused to hear of French reverses elsewhere, is a striking illustration of that stern sense of duty which inspired those who held out at Mafeking, Kimberley and Ladysmith against the besiegers during the Boer War. When Galrez, who appeared before Mobile in 1780, summoned the garrison to surrender under threat of less farorable terms after resistance, Durnford replied, "was I to gire up the Fort on demand, I would be regarded as a traitor to my ling and country. A heart full of generosity and valor will ever consider brave men fighting for their country as objects of esteem and not revenge." Lawrence, who, in 181t, bravely defended Fort Bowyer against three ressels, did not surrender it until the next sear upon the attack of the whole British fleet and army after the battle of New Orleans. ${ }^{69}$ In the American civil war General Page fought the whole Federal fleet under Farragut until the same fort (then called Morgan) was practically in ruins, while on the opposite side of the channel Colonel Anderson gare up Fort Gaines on demand. In 1877 Osman Pasha with the spade converted open Plerna into a fortress which thrice withstood the fiercest Russian attack and greatly raised the prestige of Turkish arms, while Toral surrendered Santiago in 1898 , by consent of his superior's, rather than have it taken by storm. Each of these brave and skilled officers acted according to his convictions of duty, under circum. stances that differed widely from each other.

$\S 486$. The giving of quarter.-Quarter should be given an enemy when he offers to surreuder or when by wounds or other circumstances he is rendered incapable of further resistance. ${ }^{70}$ Being placed hors de combat, he ceases to be a combat-

Pinheiro-Ferreira's note to it; Calvo, Droit Int., II, 182.

67 Calvo, Droit Int.. II, 141: Caesar, Bell. Gall. II, 32; Cicero De Off, I. 21 .
68 Quaest Jur. Pub., ch. III. ${ }^{69}$ Colonial Mobile, pp. 254, 379, 382.

70 Second Hague Convention, Article 23 (c) (d). 
ant, and from that time no one has the right to treat him as a foe. War, says Calro, camnot silence conscience. The only exception now recognized is where a combatant has committed some flagrant breach of the laws of war, as by fighting in his enemy's uniform, or by refusing quarter himself. ${ }^{i 1}$ in such case, says Lieber, he may be executed if the fact of his guilt is discovered within three days after his surrender. The American regulations mention another exception, which is so contrary to humanity that it cannot be recognized as international law, and this is, that troops may refuse quarter when they are in such straits as to render it impossible that they should encumber themselves with prisoners. ${ }^{2}$ Instances of no quarter were frequent in the wars of the Vendee and Commune, and sometimes still oceur in the heat of action. Formerly the exception was almost the rule. Even as late as the Revolt of the Netherlands war was earried on at sea with unrelenting cruelty. On the capture of a spanish expedition in the Strait of Calais, the Duteh drowned every Spaniard captured; and in 1593 the Comncil of the Netherlands resolved to give the Dutch no quarter on land, an order revoked only because of complaints of the military, who saw that they would be the sufferer's through retaliation. ${ }^{73}$ Louis XIV declared that he would grant no quarter to the Dutch cities; and nearer our own times Radetsky in Lombardy, Haynau in Hungary, and Muravieff in Poland refused quarter to thousands of their opponents, because, forsooth, they were rebels. ${ }^{74}$ The only theory upon which the German threat at St. Menehould of death to all concealing arms can be justified is that in such cases resistance constructively continues. It may be said that quarter can seldom, if ever, be properly refused except by way of retaliation on soldiers who have themselves denied it.

$\$ 487$. Retaliation and reprisals.-Retaliation, or military rengeance, may justify some acts of force which would otherwise be condemned. The colden Rule has litte international application, for "the whole international code," observes Wheaton, "is founded upon reciprocity." is If an enemy violates the established usages of war, it may become the duty as well as the right of his adversary to retaliate in order to

71 Vattel, III, ch. $8 ; \$ 141$.

72 Am. Regulations, 60, 68 .

73 Grotius, Annals of the Low Countries, XIV. p. 550; Id. book III. 253.
74 Calvo, Droit Int., II, 143, 144; Heffter, 278, Geffcken, n. 7.

i. Wheaton, Elements Int. Law, 
prevent further excesses on his part. In any event retaliation should consist of a repetition of the same or similar acts, and, so far as possible, it should be inflicted, not vicariously, but on the actual wrongdoer. Alexander sent word to Darrius that if the latter continued to wage war without quarter he would himself be refused quarter; and scipio told the spanish princes that they themselves and not hostages would be held responsible for their acts. While the destruction of Corinth because of injury to Roman ambassadors has been justly condemned as excessive retaliation, the same can hardly be said of Lysander's execution of Athenian prisoners for Athenian cruelty. In 1813 there was the possibility of the enforcenent of a very aggravated form of reprisal and counter reprisal growing out of the British threat, afterwards abandoned, to try for treason twenty-three naturalized Irishmen captured in American ressels. ${ }^{76}$ During the American ciril war Lee disapproved of Early's burning of Chambersburg, despite the fact that it was done by way of retaliation for Hunter's destruction of property in the valley of Virginia. 75 When, in the course of that war, the Union government liberated Sonthern slaves and enrolled them in the army, the Confederates, refusing to recognize them as soldiers, treated them as revolted slaves, and as such refused to grant them quarter. Whereupon President Lincoln, July 30, 186:3, threatened the execution of prisoners as retaliation in kind. ${ }^{78}$ However improper the arming of such slaves may have been, the flag and commission under which they acted, as in the case of warships, should have protected them by cutting off all question as to their original character. As they were not deserters in any proper sense, the Union authorities, after having adopted them as soldiers, could hardly have done less than protect them by retaliation. While reprisals on helpless prisoners is the most cruel and objectionable form of vengeance, sometimes it may present itself as the only arailable method. ${ }^{79}$ The question often arises in conflicts between communities standing on different planes of civilization. Even then reprisals by a civilized country can only be tolerated in a clear and grave case of barbarity. The better opinion forbids inhumanity. If torturing captives to death is to be punished, execution

76 Wharton, Int. Law Dig., § America, 350, etc.; Am. Regula$348 \mathrm{~b}$.

77 White's Lee, $408 \mathrm{n}$. tions, 58 .

is Williams, Negro Race in 79 Heffter, § 129. 
without cruelty is sufficient. Field justly declares for death alone rather than any barbarity in retaliation. ${ }^{80}$ The sacking and burning of the Emperor's palaee in 1860 in retaliation for Chinese cruelty to Europeans captured in ambush was unjustifiable. 81

$\S 488$. How far deceit may be used against an enemy.-When we pass from the question of open Force to that of Deceit, involving the employment of secret means, still more debatable ground is reached. Roman law considered as innocent all fraud used against an enemy; and Angustine, although the author of the phrase fides etiam hosti servanda, said as much. Chrysostom commended most those generals who conquer by subtlety, ${ }^{82}$ on the theory that anything is preferable to bloodshed, a view largely adopted in modern thought and practice. $^{83}$ According to that practice, deceit, even during hostilities, must be confined within eertain limits. While it may be used as a part of the secret play for position in the preparation for battle, when fire is aetually delivered it must be under the true flag distinctive of the countries of the belligerents. According to Hantefeuille, and the ordinances of 1696 and 1704 , the first summons to stop at sea should likewise be fired under the national colors, a claim, however, not universally admitted. A false uniform or flag, permissible on land or sea as a means of bringing on or escaping a conflict, must be abandoned just before the delivery of fire; and captured uniforms must have in battle some distinguishing mark. ${ }^{34}$ False information may be allowed to fall into the hands of an enemy and feints, surprises, ruses, and stratagems of all kinds are permissible in actual hostilities, ${ }^{85}$ but not in negotiations. Vattel, followed by Halleck and others, holds that deceit is not allowable "whenever we have expressly or tacitly engalged to speak the truth to an enemy;" s6 and Bynkershoek admits that we must keep our promises to an enemy. Acepting such statements as truisms. when does the perfect

80 Bluntschli, Mod. Kr., Sec. 61 (567), 75 (580), etc.; Maine Int. Law, 174; Field, Int. Code, \$759.

s1 Calvo II, 111. For the papers in Asgill's case during the American Revolution, see 2 Martens, Causes Cólibres du Droit des Gens, 169.

s2 Quoted in Grotius, De Jure Belli ac Pacis., III, ch. $1, \S 3$. s3 Vattel, Droit des Gens, III, ch. $10, \S \S 178,180$.

st The Peacock, 4 Rob. Rep., 187; Bluntschli, Mod. Kr., § 59 (565); Am. Regulations, 64. See Field's Int. Code, $\S 764$.

s. Hague Second Convention, Article 24.

so Vattel, Droit des Gens, III, ch. $10, \S 177$. 
good faith implied by peaceful negotiation begin and end? A little consideration will clear up the point. Deceit and fraud are lawful only in war, and war suspends intercourse. To the extent that intercourse is resumed, by truce or otherwise, there is a return pro tanto to peaceful methods,- - from that time the good faith of peace may be rightfully expected. As Bynkershoek expresses it, the opponents then cease, pro hac vice, to be enemies. ${ }^{87}$ All official intercourse must therefore be truthful; on no other basis can there be any mitigation of the horrors of war or even a cessation of hostilities. There must be some common ground on which to meet; some time when artifice in every form is inadmissible.

$\$ 489$. Assassination, or injury by treachery never permissible. -Assassination or injury by treachery is never permissible ${ }^{88}$ such methods have no place in an honorable contest of arms. If a general can be captured by a charge, no rule is violated; if a soldier in uniform breaks through the enemy's lines in battle, or even into a camp, and kills the commander, his life may be sacrificed, but not as a penalty for the breach of military law. Porsenna commended the courage of Mucius Scaevola who tried thus to kill him. ${ }^{89}$ The putting of a price npon an enemy's head and the gaining of admission within his lines by false pretenses $0 r^{\circ}$ by disguises, are, however, forbidden. ${ }^{90}$ The true spirit was manifested when the Romans warned Pyrrhus that his physician had offered to poison him, and when eren Tiberius rejected a similar proposal as to Arminius. Mr. Fox earned the lasting respect of Napoleon by notifying him, upon the part of the British cabinet, of an attempt projected by fanatics against his life. On the other hand, the atrocious assassination of William of Orange has done much to perpetuate the horror erer since entertained for such conduct. It is now generally admitted that all such unnecessary acts are mistakes as well as crimes. While the abnormal state callerl war opens the door to deception, it closes the door to perfidy. As the American regulations put it, men do not cease to be moral beings because battling with arms.91 "Every nation," says Webster, "on being received at her own request into the circle of civilized governments must understand that she

si Quaest Jur. Pub., ch. I.

88 Heffter, § 125 , note 9 (Geffcken); Hague Second Convention. Article 23 (b).

89 Livy, II, ch. 12.
90 Halleck, Int. Law, 400; Bluntschli, Mod. Kr., § 54 (561).

91 Halleck, Int. Law, 402; Bynkershoek, Quaest. Jur. Pub., I, ch. I; Heffter, § 141; Am. Regulations, $15,16$. 
binds herself to the strict and faithful observance of all those principles, laws and usages which have obtained currency among eivilized states and which have for their object the mitigation of the miseries of war." 92

$\$ 490$. Bribery.-It is unlawful to bribe or otherwise seduce generals, soldiers or people of the opposing belligerent. Thus, death is the penalty for attempting to bribe an ofticer or to make a soldier desert. At the same time, it is lawful to accept the services of traitors when tendered. ${ }^{93}$ Usage anthorizes aiding and perluaps instigating a rebellion or other political movement in the enemy state.94 History is full of examples, the latest being that of $\triangle$ guinaldo in the Plilippines, for which, however, the United States have paid dearly.

$\$ 491$. Guides.-A belligerent may compel any inhabitant to act as a guide to the military, and for that reason any one acting under such compulsion is exempt from the rule providing that a person who voluntarily guides the enemy of his country is punishable by death. A guide who intentionally misleads, even when acting under compulsion, may be punished by death $;^{95}$ and as the same harsh rule is applied when a district is occupied by an enemy, an active guide misleading the occupying army is punishable in the same way. The deatl penalty is likewise inflicted upon a war traitor for offering to guide the army of his old country. In each instance such service is regarded as perfidy, not patriotism.

\$492. Spies. Employment of balloons.-A spy is one who with disguise or other deception goes peaceably among the enemy forces to discover and report their condition. The Hague Conference declared that "an individual can only be considered a spy if, acting clandestinely, or on false pretenses, he obtains, or seeks to obtain, information within the zone of operations of a belligerent, with the intention of communicating it to the hostile party." 96 Although captured spies are, as a general rule, liable to be hanged, regardless of the fact that they are anthorized by their commanders, The Hague conventions require a trial before punishment, even when they are taken in the act. While all generals employ spies, Vattel

92 Letter to Thompson, Apr. 15, Klüber, Droit des Gens, § 244. 1842 ( 6 Works, 437).

93 Woolsey, Int. Law, § 127 ; Vattel, Droit des Gens, III, c. 10 , § 180-1; Halleck, Int. Law, § 27; Bluntschli, Droit Int. Cod, $\$ 564$; : + Heffter, \$ 125 , G. n. 7 . 95 Am. Regulations, 93-7; Bluntschli, §§ 634-6.

96 Hague Second Convention, Art. 29-30. 
says that none boast of them. ${ }^{1}$ Frederick II redueed their use to a science; Wellington employed them constantly in Spain ; and Wolseley frankly adrocates them. Information about the enemy from some source is necessary, and reconnoitering in uniform, which is permitted, reveals only external conditions. Spies, who are the detectives of war, may be men of high patriotism, as they certainly are of unusual bravery. André was of a higher type than Arnold; and Capt. Natlian Hale, shot by the British as an American spy, was an honorable man. ${ }^{3}$ And yet the enterprise has a dishonest side, because the spy must disguise himself and play friend to acquire information to be used by him as an enemy. The principle of selfpreservation demands that every army shall punish spies with death; the business must be made too hazardous to have many practitioners. For that reason spies must be volunteers; no commander can detach a soldier for such service. ${ }^{4}$ And yet the criminality is limited to the special expedition; after the spy has rejoined his army, he ceases to be such, and if subsequently captured is to be treated as other prisoners of war. ${ }^{5}$ Communication of information, fairly acquired, to the army of one's own country when it reëstablishes its occupation of a captured place, is not punishable. Reconnoissance in uniform, such as Lieutenant Rowan's daring expedition to Cuba for the purpose of communicating with the insurgent Garcia, is legitimate; and so is the carrying of dispatehes openly, even by civilians. As disguise and secrecy are the essential characteristics of a spy, there seems to be no just ground for regarding soldiers reconnoitering from balloons as such, despite the contrary contention made by the Germans at the siege of Paris, during which sixty-four balloons were sent up. Gambetta was able to organize resistance in the provinces after escaping in that manner. ${ }^{6}$ Balloons, used by the French as early as the battle of Fleurus in 1794, and by the Russians in 1812, were employed by the Federal troops in Virginia, by the British in

1 Field's Int. Code, $\$ 767$; Droit des Gens, III, ch. 10, $\$ \$ 179,180$, 182; Am. Regulations, $88-90$; Bluntschli, Mod. Kr., § 126 (628), etc.

24 Napier, Penin. War, XIV, 220-1.

3 See 3 Phillimore, 153, for the British side.

4 Halleck, Int. Law, p. 407.
- 5 Hall, Int. Law, 561; Am. Reg., 633; Bluntschli, Mod. Kr., § 131 (632a); Brussels Code, Articles 19-21; Second Hague Convention, Article 31.

${ }^{6}$ Hall, Int. Law, 560; Bluntschli, Mod. Kr., $\$ 129$ (631); Calvo, Droit Int., II, 133; Heffter, $\S 128$, n. 2 ; Second Hague Convention, Article 29. 
the Boer war, and, along with telephones, are a regular part of the German manoeurres. ${ }^{7}$ It is not, therefore, strange that messengers by balloon should have been recognized at The Hague Conference as a legitimate means of reconnoissance. ${ }^{8}$ Persons so traveling are to be regarded when captured as prisoners of war, as legitimate aids to military operations.

$\$ 493$. Deserters.-Deserters from the enemy may be accepted and enlisted, ${ }^{9}$ but when recaptured they may be shot. International law has nothing to oppose to so salutary a military rule, because such persons have forfeited all right to be regarded as soldiers. ${ }^{10}$ When taken by their former sovereign they are not treated as prisoners of war, although regularly uniformed and enrolled as members of the opposing army. It is unlawful to incite the enemy's soldiers to desert or to betray their cause, just as it is to encourage crime of any kind in the enemy's country. ${ }^{11}$ The general interest of civilization demands that the military oath should be respected, and for that reason France in 1859 and Prussia in 1866 committed wrongs when they raised Hungarian regiments against Austria. While volunteers from the enemy's country may be accepted and enrolled, at least until conquest is complete, inhabitants of the enemy's country cannot be compelled to serve against their old sorereign in the army or otherwise.12 Although not deserters unless they have abandoned their country's army, such rolunteers by breaking their oaths of allegiance become traitors; and, unless protected by retaliation, they may justly expect civil trial for treason.

7 Miles, Military Europe, 103.

8 White's Lee, 255; Second Convention Hague, Article 29.

9 U. S. v. Reading, 18 How., 10. 10 Am. Reg., 1, 48; Bluntschli, Mod. Kr., \& 125 (627); Vattel,
Droit des Gens, III, ch. $8, \S 144$; Woolsey, Int. Law, 220.

11 Bluntschli, Mod. Kriegsrecht, $\S 58$ (564).

12 Ib., § 71 (576). 


\section{CHAPTER IV.}

\section{'RIGHTS AND DUTIES OF BELLIGERENTS DURING HOSTILI- TIES AT SEA.}

$\$ 494$. Rules of land war observed at sea so far as they apply.So far as they apply the rules regulating the conduct of hostilities on land are observed during hostilities at sea. When the rast importance of the subject is considered it is strange indeed that during a period in which such great and successful efforts have been made to codify the rules of land war so little should hare been done to codify the rules of sea war. It is safe to predict that in the near future naral warfare must proceed upon a gigantic scale when the fact is recalled that the war fleet of Great Britain alone numbers orer five hnndred ships of all classes, costing upwards of $\$ 400,000,000$, and manned by orer 100,000 men; ${ }^{1}$ and that the sea power of the other leading maritime states is undergoing a correspondingly rapid development. And yet when search is made for an international naval war code to direct the conduct of such rast forces it cannot be found, save so far as its beginnings may be indicated in The Hague third "conrention for the adaptation to maritime warfare of the principles of the Geneva conrention of August 22, 1864," and in a few national regulations. Since the Spanish-American war the Secretary of the Nary of the United States has prescribed, with the President's approval, for the use of that branch of the service, a Naval War Code, ${ }^{2}$ purporting to embody the laws and usages of war at sea, which should be considered in connection with otherattempts to accomplish the same result. ${ }^{3}$ In the light of the imperfect rules and usages now regulating the subject, brief consideration will be given, first, to belligerents at sea, and the limits within which they may act; second, to naral hostilities on the sea and shore; third, to the care of the wounded and prisoners at sea.

$\S 495$. General object of naval warfare. Armed forces of the state at sea.-The special objects of maritime war, according to

1 Miles, Military Europe, 69.

2 Prepared by Capt. Chas. $\mathrm{H}$ Stockton, U. S. N., president of the Naval War College.

3 As to foreign naval codes, see
Das Internationale öffentliche seereeht der Gegenuart, by F. Perels, Berlin, 1882; Guide International du Commandant de Bati. ment de Guerre, by $\mathbf{E}$. Rosse, 
the American Naval War Code, are the capture or destruction of the military and naral forees of the enemy; of his fortifications, arsenals, drydocks and dockyards; of his various military and naval establishments, and of his maritime commerce; to prevent his procuring war material from neutral sources; to aid and assist military operations on land; and to protect and defend the national territory, property, and sea-borne commerce. Military necessity permits measures that are indispensable for seeming the ends of the war and that are in accordance with modern laws and usages of war. It does not permit wanton devastation, the use of poison, or the doing of any hostile act that would make the return of peace unnecessalrily difficult. Non-combatants are to be spared in person and property during hostilities, as much as the necessities of war and the conduct of such non-combatants will permit." To effect such objects is the purpose of naval organization. In the United states the following are recognized as armed forces of the state at sea:

(1) The officer's and men of the nary, naval reserve, naval militia, and their anxiliaries.

(2) The officers and men of all other armed ressels cruising under lawful authority. ${ }^{5}$

$\$ 496$. Ships with commissions of war. Origin of permanent fleets.-The right to give battle at sea is in general confined to ships with commissions of war. The fighting force at sea is the nary, now as well organized as the army, composed of war vessels, which represent the nation in arms on the sea. Permanent and organized fleets of that character have been gradually developed out of voluntary forces composed of ships belonging to private individuals. "The beginnings of the English nay can be faintly traced in the fleets which were raised in the latter part of the pre-Norman period for the protection of the kingdom against the incursions of the Danes. Under the scheme then employed each shire was required to furnish slips in proportion to the number of its hundreds, -an arrangement which applied to the inland shires as well as to those on the seaboard. Each shire sent its quota of ships to the fleet, as it sent its quota of fighting men to the host. This primitive system, whieh did not long survive the Norman conquest, was succeeded after that event by a new arrange-

Paris, 1891; Almanach fïr die $k$. 4 Am. Naval Code, Art. 1. $u$. $k$. Kriegs Marine, 1900, II Theil, 5 Ib., Art. 9.

Pola, Austria. 
ment based upon different principles. In order to supply the lack of a regular nary, and to protect the sonthern seaboard against attack, the Conqueror incorporated the Cinque Ports and endowed them with certain privileges, upon condition that they would furnish a given number of ships and men for si many dass in case of an emergency. The naval force thus contributed by the privileged towns for local defense was angmented, when the crusades created a necessity for a large number of ships for foreign expeditions, by fleets of mercenaries, which were maintained, like the mercenary element in the army, out of the royal exchequer. In the naval force of mercenaries thus raised and maintained out of the roval revenue the permanent fleet finds its origin. The organization and gorernment of the fleet, thus dependent upon the king's bounty, derolred during the medieval period upon the admiral, the king's lieutenant and highest naval representative."6 In Holland also the nary was originally composed of private ships which received a kind of subsidy. ${ }^{7}$

Vessels without commissions.-In accordance with the theory that all citizens of one belligerent state are at war with all citizens of the other, practice still permits private vessels withont commissions of any lind to defend themselves, and even to attack ressels of the enemy,-captures by such ships being now reserved as droits of the admiralty. ${ }^{8}$ In the absence of a commission, a right of search and capture does not exist as against neutrals. ${ }^{9}$

$\$ 497$. Rules governing privateers.-Privatcers may make captures wherever the Declaration of Paris does not prevail. No matter what prejudice still exists against privateering, it is not to be confounded in any sense with piracy. Its conduct is the subject of regular rules, which many treaties have defined from the fourteenth century, when letters of marque became common, down to the nineteenth. On one occasion the British confiscated a French privateer for exceeding her commission. ${ }^{10}$ Cruisers of a de facto government or belligerent are

${ }^{6}$ Origin and Growth of the Eng. Caledonian, 4 Wheat. 100; The Const., vol. I, pp. 348-549.

? Bynkershoek, Quaest. Jur. Pub., ch. XVIII.

8 The Grand Terrein, 1 Hay \& Mar. 155.

${ }^{9}$ Haven v. Holland, 2 Mason, 230; The Rebeckah, 1 Ch. Rob. 227 ; The Melomane, 5 Ch. Rob. 42; The Amiable Isabella, 6 Wheat. 1; Carrington v. Mercht. Ins. Co., 8 Pet. 495; Bynkershoek, contra, Quaest. Jur. Pub., ch. XX; the Charlotte, 5 Ch. Rob. 280.

10 Leoline Jenkins, 714, 754; 2 Wooddeson, 425; Du Ponceau's Bynkershoek, 134, n. 
not pirates. for it is immaterial whether the govermment be rightful or not. ${ }^{11}$ In 1776 the British parliament declared that acts of treason and piracy had been committed on the high seas from the colonies, and enacted that all persons arrested therefor should be imprisoned but not tried. This provision was continued from year to year and was aimed at American privateersmen. Those so captured were ultimately exchanged or released. The same result followed the attempt made during the American civil war to carry out President Lincoln's order of April 19, 1861, declaring that Confederates molesting commerce of the United states would be treated as pirates. The crew of the captured savamal, under Judge Nelson's charge at New York, were not convicted; while those convicted at Philadelphia in Smith's case were not sentenced, but treated as prisoners of war when a threat of retaliation was made. ${ }^{22}$ A privateer may be visited to ascertain its character, but as in the case of a public war ressel it is exempt from search. Hautefenille even contends that it is exempt from visitation, but he also holds the doubtful riew that a merchant ressel mar resist the visitation of a privateer unless a commission is first shown. ${ }^{13}$ Privateers are not always allowed the same privileges in neutral ports as public war vessels. Some states do not admit them at all except in cases of necessity, while others even permit them to sell their prizes. The same rules apply, howerer, to privateers as to public war ressels when once admitted to a port. Since the Declaration of Paris, the subject has necessarily lost much of its importance, for the reason that captures have since been made almost exclusively by public ressels of war.

$\$ 498$. Neutral territorial waters not to be violated by naval combats.-The operations of war ressels are necessarily confined to the waters of their own country, those of the enemy, or the high seas, which are free to belligerents and nentrals alike. The extent of sea embraced within the territorial limits of a state has been already defined. While l'hilip II

11 Mauran v. Ins. Co., 6 Wall. 1; Dole v. N. E. Ins. Co., 6 Allen, 373; Same v. Merchts. Co., 51 Me. 464; Fifield v. Ins. Co., $47 \mathrm{~Pa}$. St., 166; U. S. v. Baker, 5 Blatchford 6 ; Ford v. Surget, 97 U. S. 619.

12 Whiting's War Powers, 215, note; U. S. v. Baker, 5 Blatch. 6 ;
Wharton, Int. Law Dig., \$ 381 . The case of the Savannah was printed separately, and in full, by Baker \& Godwin, 1862 .

13 The St. Juan, 2 Causes Célibres du Droit des Gens, 183; 3 Droits et Devoirs des Nat. Neut., XI, $1, \S 1$. 
claimed so much as was within sight from land, Bynkershoek's view has prevailed that the dominion of the state ends where the power of its' arms terminates. Terrae dominium finitur ubi finitur armorum vis. "According to the code of laws and usages of war at sea adopted by the United States the area of maritime warfare comprises the high seas or other waters that are under no jurisdiction, and the territorial waters of belligerents. Neither hostilities nor any belligerent right, such as that of visitation and search, shall be exercised in the territorial waters of neutral states. The territorial waters of a state extend seaward to the distance of a marine league from the low water mark of its coast line. They also include, to a reasonable extent, which is in many cases determined by usage, adjacent parts of the sea, such as bays, gulfs, and estuaries inclosed within headlands; and where the territory by which they are inclosed belongs to two or more states the marine limits of such states are usually defined by conventional lines." 14 At the month of the Mississippi, for instance, the marine league runs from the mud islands dotting the gulf. ${ }^{15}$ Within these limits the area covered by the territorial waters of a neutral state is as sacred as its soil. Thus in 1793 when the British ship Grange was captured by the French L'Ambuscade on the water's of Delaware Bay, the United States compelled its restitution. Although Brnkershoek says that pursuit begun outside may be continued and finished within the limit, dum fervet opus. such is not the practice. The territorial waters of a neutral, says Azuni, constitute a sacred asylum. ${ }^{16}$

$\S 499$. Bombardments from the sea not limited to fortified places.-Sometimes land forces have an opportunity to attack war ressels when the latter attempt to pass through a narrow channel, as at Vicksburg and Mobile during the American civil war. Such conflicts oceur more often, however, through the employment of sea forces for the bombardment of coast defenses, or undefended platees, an important and unsettled subject, remitted at The Hague for discussion by future conferences. There is no law or practice which

14 Bynkershoek, De Dom. Maris, 2 Azuni, II, ch. IV, Art. 1. Among ch. II; Quaest. Jur. Pub., ch. VIII; French cases.may be mentioned Il Am. Naval Code, Art. 2.

15 The Anna, $5 \mathrm{Ch}$. Robinson, 373,385 .

Volante, in 13 Merlin, Repertoire

16 Quaest. Jur. Pub., ch. VIII; ick, ib. 11:. 
limits bombardments from the sea to fortified places as on land. In 1866 Valparaiso was hombarded by the Spanish admiral Jendes Nunez; and recently a French naval officer, Adurial Aube shortly afterwards aupointed minister of marine) advocated the use of hombardment, together with the lery of heary contributions, in case of watr with Great Britain. Nelson's bombardment of Copenhagen is searcely a case in point, as that was only or mainly incidental to the battle with the Danish fleet stationed in front of the city. In the American naral code bombardment, by uaral force, of unfortified and undefended towns, villages, or buildings is forbidden, except when it is incidental to the destruction of military or naval establishments, public depots of munitions of war, or ressels of war in port, or unless reasonable requisitions for provisions and supplies essential, at the time, to such naval ressel or ressels are foreibly witheld, in which case due notice of bombardment shall be given. The bombardment of unfortified and undefended towus and places for the non-payment of ransom is forbidden. ${ }^{17}$

$\$ 500$. When artifice is permissible at sea. Naval battles between fleets or single vessels. - It sea as on land the use of fialse colors in war is forbidden. When a ressel is summoned to lie to, or before a gun is fired in action, the national colors should be displayed. And yet it is lawful to use false colors as a ruse, as Nelson did while he lay off Barcelona for a long time showing the French flaw, with the object of drawing out the ships of spain, then allied with France. ${ }^{18}$ When such preliminaries are over and naval combat actually begins between fleets or single ressels, war assumes its most terrible form, involving as it does not only the destruction of the crew by missiles from all the elunines of war, but also the danger of destruction of the ship itself by shot and shell, rams, mines, torpedoes and magazine explosions. As to the conduct of such engagements nothing more specific ean be said than that the general rules of land war must be observed so far as they apply, subject to certain modifications resulting from special frovisions as to hospital ships and the like to be separately considered hereafter. The use of chain and bar shot and red hot balls meets with less objection at sea than on land because the former were designed to cut away the rigging and the 
Iatter to fire wooden ships, and to that extent they are as legifimate as fireships. Even boiling water may be used as a permissible means of defense against boarding parties, but pitch cannot be thrown. While there are fewer conventional restrictions on weapons and projectiles than on land, fighting at sea is subject to the general principle forbidding the infliction of injury beyond what is actually necessary to compel submission, ${ }^{19}$ a principle whose application leaves a wide range of discretion to each commander. Thus before Trafalgar Nelson declared annihilation his object, and his fleet was ordered, in the event of danger of the escape of the enemy, not to desist from destruction in order to save ships or men. ${ }^{20}$ On the other hand, during Farragut's passage of Fort Morgan, the Confederate Gen. Page chivalrously refused to fire on a ship's boat pushing off to rescue the struggling survirors from the Tecumseh, sunk by a torpedo, even though the oarsmen defiantly raised the Union colors instead of the usual flag of truce.

$\S 501$. Surrender at sea.-At sea the question of surrender of the crew is complicated with that of the ship. As she is manned by the crew, when she surrenders, they must. Therefore while they cannot run the ship away after an offer of surrender is made, if it is not accepted in a reasonable time, or circumstances put acceptance out of the power of the conquering ship, the offer is avoided. The crew are not bound to sink with the ship; they are not required to drown, because the flag is struck. They can save themselves in any way possible, and they do not then become prisoners unless they pass under the control of the enemy. Thus when Admiral Ganteaume was picked up by a French boat after the Lorient exploded, and when Captain Semmes escaped to a British pleasure yacht after the Alabama sank, both were free men. Mr. Seward's shocking contention in the latter case that it was the right of the Kearsarge to claim the advantage that would have resulted from the lawful destruction of the crew of the Alabama, Lord Russell promptly and justly rejected.21 At the battle of the Nile, when fire was seen on the L'Orient, the British directed their aim to that spot and thus prevented its extinguishment. But, when the destruction of the ship became inevitable, Nelson sent boats and men to aid in saving the

19 Am. Naval Code, Art. 1.

20 Mahan's Nelson, 302.
21 Semmes' Service Afloat, 766; Wharton, Int. Law Dig., $\S 394$. 
crew. 22 During the battle off Santiago, when the Vizcaya, on fire all over, ran up a white flag. the Iowa not only refrained from a finishing broadside but lowered her boats and saved hundreds of the erew. When Phillips of the Texas in the same battle kept his men even from cheering, because "the poor devils are dying," he expressed the true spirit of modern international law, which regards a disabled opponent as no longer a foe, but a fellow man in distress, who is to be helped, not injured.

\$502. Who are to be regarded as prisoners at sea. Their treatment.-The American Naval Code declares, in accordance with the general practice, that in case of capture, the personnel of the armed forces or armed ressels of the enemy, whether combatants or non-combatants, are entitled to receive the humane treatment due to prisoners of war. The personnel of all public unarmed ressels of the enemy, either owned or in his service as auxiliaries, and of merchant vessels who, in self-defense and in protection of the ressel placed in their charge, resist an attack, are entitled, if captured, to the status of prisoners of war. The personnel of a merchant ressel of an enemy captured as a prize can be held, at the discretion of the captor, as witnesses, or als prisoners of war, when by training or enrollment they are immediately avalable for the naval serviee of the enemy, or they may be released from detention or confinement. They are entitled to their personal effects and to such individual property, not contraband of war, as is not held as part of the ressel, its equipment, or as money, plate, or cargo contained therein. All passengers not in the service of the enemy and all women and ehiltren on board such ressel shonld be released and landed at a convenient port, at the first opportunity. Any person in the naval service who pillages or maltreats, in any manner, any person found on board a merchant vessel captured as a prize, shall be severely punished.23

\section{$\$ 503$. Application of Red Cross Conventions to wounded at sea.} - As explained heretofore, while warfare on land has been regulated from time to time by conferences of the great powers, no binding agreement was ever reached designed to regulate even in fart warfare at sea prior to the P'eace Conference at The Hague, whose third convention extended the rules of the Red Cross Conventions of 1864 and 1868 , with some modifications, to such warfare. By their own terms such rules are 
binding on the contracting powers only in ease of war between two or more of them; and from the time when one of the belligerents is joined by a non-contracting power they cease to bind even the former.24 Such rules, relating mainly to the wounded and to hospital ships, may be summarized as follows:- the shipwrecked, wounded, or sick of one of the belligerents, who fall into the hands of the other, are prisoners of war. The captor must decide, according to circumstances, if it is best to lieep them, or to send them to a port of his own country, to a neutral port, or eren to a hostile port. In the last case, prisoners thus repatriated cannot serve as long as the war lasts. ${ }^{25}$ Sailors and soldiers who are taken on board when sick or wounded, to whatever nation they belong, shall be protected and looked after by the captors. ${ }^{26}$

\$504. Religious and medical staff.-The religious, medical, or hospital staff of any captured ship is inviolable, and its members cannot be made prisoners of war. On learing the ship they take with them the objects and surgical instruments which are their own private property. They may continue to discharge their duties while necessary, and can afterwards leave when the commander-in-chief considers it possible. Betligerents must guarantee to members of such staffs falling into their hands the enjoyment of their salaries intact. ${ }^{27}$

$\S 505$. Hospital Ships.-Military hospital ships,-that is to say ships dedicated by states specially and solely to the purpose of assisting the wounded, sick, or shipwrecked,-shall be respected, and cannot be captured while hostilities last, provided the names of such ships shall have been communicated to the belligerent powers at the commencement or during the course of hostilities, or in any event before they are employed. So far as regards their stay in a neutral port, such ships are not, however, on the same footing as men-of-war. 2 Hospital ships, equipped wholly or in part at the cost of private individuals or officially recognized relief societies, shall likewise be respected and exempt from capture, provided the belligerent power to whom they belong has given them an official commission and has notified their names to the hostile power at the commencement of or during hostilities, and in XI.

24 Hague Third Convention, Art.

${ }^{25}$ Hague Third Convention, Art.

26 Ib., Art. VIII.

$2 \tau$ Ib., Art. VII.

28 Ib., Art. I.

IX. 
any ease before they are employed. Such ships should bear a certificate from the competent authorities, declaring that they were under their control while fitting ont and at their final departure. ${ }^{29}$ Hospital ships, equipped wholly or in part at the cost of private individuals or officially recognized societies of neutral countries, shall be respected and exempt from capture, if the neutral power to whom they belong has given them an official commission and notified their names to the belligerent powers at the commencement of or during hostilities, and in any case before they are employed. ${ }^{30}$ Military hospital ships shall be distinguished by being painted white outside, with a horizontal band of green about a metre and a half in breadth. The private or neutral ships above mentioned shall be distinguished by being painted white outside, with a horizontal band of red about a metre and a half in breadth. Boats belonging to such ships as well as small craft employed in hospital work, shall be distinguished by similar painting. All hospital ships are required to make themselves known by hoisting, together with their national flag, the white flag with a red cross provided by the Geneva Convention. ${ }^{31}$ Such ships which cannot be used by the governments concerned for any warlike purpose shall afford relief and assistance to the wounded, sick, and shipwrecked of the belligerents independently of their nationality. During and after an engagement they act at their own risk and peril; and they must not in any way hamper the movements of the combatants. The belligerents have the right to control and risit them; they can refuse their assistance; order them off; make them take a certain course; put a commissioner on board; and they can even detain them if important circumstances require it. As far as possible the belligerents shall inscribe on the sailing paper's of the hospital ships the orders which they give them. ${ }^{32}$

$\$ 506$. Effect of rescue by a neutral.-While under the rules adopted at The Hague Conference neutral merchantmen, yachts, or ressels, having, or taking on board, sick, wounded, or shipwrecked of the belligerents, camiot be captured for so doing, they are liable to capture for any violation of neutrality they may have committed. ${ }^{33}$ No attempt was made, howerer, to determine the fate of belligerents so reseued. The Amerian delegates at The Hague endeavored to secure the adoption

29 Hague Third Convention, Art. II.

30 Ib., Art. III.
31 Ib., Art. V.

32 Ib., Art. IV.

33 Holls' Peace Conference, 469. 
of certain articles making such rescued men prisoners on demand of either belligerent, but this never came to a vote. ${ }^{44}$ Article 10, as adopted, provided for the internment of those landed in a neutral country, but from the convention as rat $\mathrm{i}$ fied that article was omitted. ${ }^{35}$ The American naval code provides that merchant vessels, yachts, or neutral vessels, that happen to be in the vicinity of active maritime hostilities, may gather up the wounded, sick, or shipwrecked of the belligerents. Such vessels, after this service has been performed, shall report to the belligerent commander controlling the water's thereabouts, for future directions, and while accompanying a belligerent will be, in all cases, under his orders; and, if a neutral, shall be designated by the national flag of that belligerent carried at the foremasthead, with the red cross flag flying immediatey under it. These vessels are subject to capture for any violation of nentrality that they may commit, and any attempt to carry off such wounded, sick, and shipwrecked, without permission, is a violation of neutrality. ${ }^{36}$ It should be noted that this provision is stronger than the American proposal at The Hague in that it compels the neutral rescuer to surrender his guest to the stronger belligerent. Whether a neutral can be required to make a surrender under such circumstances is an unsettled question. A notable case was that of Captain Semmes of the Alabama, rescued by the British pleasure yacht Deerhound, whom Great Britain declined to surrender to the United States. ${ }^{37}$

\$07. Naval reprisals.-According to the American naval code, in the event of an enemy failing to observe the laws and usages of war, resort may be had to reprisals, when the offender is beyond reach, if such action should be considered a necessity; but due regard must always be had to the duties of humanity. Reprisals should not exceed in sererity the offense committed, and must not be resorted to when the injury complained of has been repaired. If the offender is within the power of the United States, he can be punished, after due trial, by a properly constituted military or naval tribunal. Such offenders are liable to the punishments specified by the criminal law. ${ }^{38}$

34 Holls' Peace Conference, 131.

35 Ib., 127-130.

36 Am. Naval Code, Art. 25.
37 Semmes' Service Afloat, 766.

38 Am. Naval Code, Art. 8. 


\section{CHAPTER V.}

\section{LIMITATION, SUSPENSION AND CONCLUSION OF HOSTILITIES.}

\$508. How non-hostile relations are established.-In the statements contained in the two preceding chapters as to the laws of war regulating the rights and duties of belligerents during hostilities on land and sea, no reference was made to those expedients through which particular individuals are protected against the operation of general rules by flags of truce, passports, safe-conducts, or licenses to trade; or to those wider meins, such as cartels, suspensions of arms, armistices, truces and agreements for capitulation through which hostilities are entirely suspended for a time as to a part or the whole of the armed forces of the enemy. All such arrangements, substituting non-hostile for hostile relations, rest upon the alssumption that they will be carried ont with perfect good faith, under rules requiring a strict construction of all special permissions, and such a construction of all general stipulations as will secure to each belligerent the full benefit of their expressed or implied intention, without permitting either to use them als a cover for acts not contemplated by them.

$\$ 509$. Cartels: postal and telegraphic communications; cartel ships.-Cartels really represent the first step taken in the establishment of that kind of non-hostile intercourse called by Vergil commercia belli, ${ }^{1}$ because as agreements entered into during war, or in anticipation of it, they determine not only the extent to which hostile relations shall be suspended but also the mode in which such direct intercourse as may be permitted shall be conducted. While in contemplation of the constitution of the United States they are not treaties, cartels are of such force that the sovereign power cannot annul them. Every belligerent is bound to observe such contracts, 2 and it is their province to prescribe the rules regulating the reception of bearers of flaws of truce, the treatment of the wounded and

1 Eneid X, 432; Tacitus, Ann. XIV, 33. See 6 Webster's Works, 438 .
2 Dana's Wheaton, $\S \S 254,344$; Halleck, Int. Law, II, p. 326 seq.; Martens, Pricis, $\S 275$; U. S. v. Wright, 2 Pitts. R. 440. 
prisoners of war, the exchange of prisoners by land and sea, the interchange of postal and telegraphic communications and the like. Whether such communications are to be permitted at all is a matter to be determined in each case by the belligerents themselves, who likewise regulate the method of their exchange whenever an agreement is made to that effect. As each of the other subjects involved can be more conveniently treated elsewhere, it will only be necessary to consider here the special regulations concerning cartel ships employed in the conveyance of prisoners to and from the place of exchange. Such vessels usually sail under a safe-conduct issued by an officer called a commissary of prisoners, who resides in the enemy country, although, when the bona fides of the employment has been clear, the immunities of a cartel ship lave been accorded to vessels sailing under an agreement with a commanding officer, not authenticated by formal documents. When properly authorized such a vessel is exempt from belligerent capture or molestation while actually engaged in the work of exchanging prisoners, whether she has prisoners on board or not. Such protection does not extend, however, to a voyage undertaken from one port to another of the state to which the cartel ship belongs for the purpose of transporting prisoners from the latter place to the lostile territory. Such a ship forfeits her privileges if she departs from the strict line of the special business to which she is assigned, or gives good reason for the suspicion that she intends to do so. No fraudulent use must be made of her to acquire information, and she cannot carry either merchandise or passengers for hire. While belligerents may employ ressels, either public or private, in their cartel service, these must not be in a condition to carry on hostilities; they are permitted only one gun for the purposes of salutes. ${ }^{3}$

$\$ 510$. Flags of truce.-When a belligerent desires to negotiate with the enemy he is expected to send a negotiator accompanied by a person bearing a white flag, and a drummer or a bugler. While such a flag of truce (parlamentärflagge) must not be fired upon intentionally under ordinary circumstances, the bearer may be refused admittance or not parleyed with,

3 The Daifje, 3 Rob. 141-3; the Venus, 4 Rob. 357-8; La Gloire, 5 Rob. 192; The Mary, Ibid., 200; The Carolina, 6 Rob. 336; Calvo,
§ 2117-9; Admiralty Manual of Prize Law (Holland), 1888, p. 1112; Duer, On Ins., vol. 1, pp. 539 seq. 
provided a contrary course would be inconsistent with military conditions. If the flag is sent during an engagement, the sending detachment should cease firing, and so should the other if willing to receive it. A flag per se asks no cessation of hostilities except as to the party bearing it, for instance, the boat crew bringing it, if it be sent at sea. ${ }^{*}$ Although firing need not always cease, "for the decisive moment of rictory might pass," it would be very hard to justify an attack upon an enemy who, after ceasing his fire, slows his wish to parley.5 At Carite Arsenal Sostoa hoisted a white flag for a while in order to gain time to remove non-combatants. The Americans went ashore next day under the false impression that it meant surrender. When persons under the protection of a flag of truce are received by the enemy "the right of inviolability" attaches to them; they must be protected from personal injury, and permitted to return to their own lines. Every precaution can be taken, howerer, to prevent them from using their mission as a means of acquiring information. To that end they may be stopped at the outposts and their communieations received from that point; they may be temporarily detained and shut off from all communication with persons other than those designated; or they may be subjected to blindfolding or any other necessary and reasonable precaution. While a person under a flag of truce may communicate to his chief any information he may have obtained without effort upon his part during his stay within the enemy's lines, any attempt to acquire knowledge surreptitiously makes him liable to punishment as a spy. ${ }^{6}$ A flag of truce does not protect deserters whether they bear it or go in attendance upon it. They may be seized and executed, notice being gicen to the enemy of the reason of their execution.

Political conferences.-Sometimes political authorities meet under a flag of truce for purposes which may or may not be of a military nature. Thus Napoleon and Alexander met on the raft at Tilsit as sorereigns rather than as generals. One of the most notable recent instances of the kind occurred at Hampton Roads, February 3, 1865, near the close of the American civil war, when President Lincoln, Secretary of State Seward and other federal officials met Vice-President Steph-

4 Mahan's Nelson, 486.

"Maine, Int. Law, 189; Heffter, p. 278 , G. n. 5 .
6 Bluntschli, Mod. Kr., \& 181 (681) et seq.; Am. Reg. 111, 113, 116. etc. 
ens, and the other Confederate commissioners, by special agreement, in order to discuss the means of securing a permanent peace. During the hours in which the negotiators steamed about the roadstead in earnest conference, war did not cease on land or sea. On that day, from the Potomac to the Rio Grande, hostilities were suspended only upon the deck of the little vessel covered by the white flag.

$\$$ 511. Safe-conducts, passports, and safeguards. $-A$ safe-conduct (sauvegarde) or passport is a document given by a commander authorizing certain designated persons to pass within the limits occupied by his force. Its extent, therefore, varies with and follows the jurisdiction of such commander. While the term passport is usually limited to persons, safe-conduct extends to persons and things. One may be implied from circumstances, as when M. Schnabele, a Frenchman, was invited over the frontier by German officials. It was held that such an inritation implied the right to return. ${ }^{7}$ A safeconduct to go may, therefore, imply the right to return, and in all cases implies protection so far as it extends. If granted to a person by name, it covers his equipage, but not his family; if to a class, it covers all degrees of that class, as in the case of the clergy. ${ }^{8}$ Neither passport nor safe-conduct is of value outside the district of the officer granting it. To be general, therefore, either must be given or confirmed by commanders-in-chief or their deputies ad hoc. A safeguard is a protection granted to institutions or to specially farored persons or property during military occupation. ${ }^{9}$ It may cover a particular person, place or thing, and is usually granted for the protection of archices, libraries, museums and buildings of a like nature against injury by soldiery after an assault or battle. The concessions first named can be revoked only by an authority equal to that by which they are granted. ${ }^{10}$ The death or suspension of the officer granting them does not ipso facto affect them. ${ }^{11}$ While soldiers given as a safeguard cannot be attacked by the enemy, they can resort to the severest measures in punishing any violation of the safety of their trust.

\section{§512. Licenses to trade defined; by what authority granted.-}

7 Maine, Int. Law, 190; 1 Kent Comm. 162; Vattel, III, ch. 17.

8 These rules are attributed to Grotius in 2 Wildman Int. Law, 29.
${ }^{3}$ Martens, Précis, VIII, ch. 3, § 13.

10 Calvo, Droit Int., II, 273-5.

11 Heffter, § 142, Geffcken, n. 1. 
Licenses to trade are permissions or safe-conducts to carry on commerce forbidden by the ordinary laws of war or by the municipal laws of the grantor; and are either general or special. They are general when granted by a state to all of its own subjects, or to all neutral or enemy subjects, as authority to trade in particular articles or at particular places; special, when given only to particular individuals as authority to trade in the manner prescribed by their terms. In either case all disabilities of the enemy are removed within the scope of the permission, by virtue of which the recipient can contract with the subjects of the hostile state and enforce his contracts in its courts. ${ }^{12}$ Licenses may be granted directly by the belligerent goverument, or by a general in the field, with its sanction. If a license is granted by such an office in excess of his authority, it is, as a general rule, valid as to the forces under his command. ${ }^{13}$ It was held, however, by the Supreme Court of the United States that the act of Congress of July 13, 1861, authorizing the President to license certain commercial intercourse with the Confederate States, did not contemplate the exereise of that authority by subordinate officers without the express order of the executive. Therefore, when a certain firm in New Orleans obtained from an agent of the treasury department in that city a special permit, "approved" by Admiral Farragut, commanding the blockading force on that coast, as a license for the shipment of cotton from the port of Mobile, the ship and cargo were condemmed as prize of war, after the seizure by the blockading squadron of which Admiral Farragut was the chief.1t $A$ s the issuance of a lieense is a high act of sovereign power, depending upon an exact knowledge of the special circumstances, it is an implied condition of its validity that the application for it shall not be attended by misrepresentation of material facts. As Lord Stowell has expressed it a licence "is a thing stricti juris, to be obtained by a fair and eandid representation and to be fairly pursued." A misrepresentation or suppression will invalidate it, although not made with the intent to deceive. ${ }^{15}$

12 Usparicha v. Noble, 13 East, 341. In Kensington v. Ingles, 8 East, 290, Lord Ellenborough held, however, that an enemy trader in England can not sue in his own name, though he can through a British agent or trustee. Halleck, i1, 343 seq.; Hall, § 196.
13 The Hope, 1 Dodson, 229; Woods v. Wilder, 43 N. Y. 164.

14 The Sea Lion, 5 Wall. 630 . See also Coppell v. Hall, 7 Wall. 542.

15 The Vriendschap, 4 Rob. 98; Klingender v. Bond, 14 East, 484; the Jonge Klassina, 5 Rob. 297. 
How licenses are to be construed.-The general rule is that at license to trade is to be given a reasonable construction, with reference as well to the general conditions attending its issuance as to the special circumstances of the particular case. While it may not be to the interest of the grantor to construe it too literally, it should be so construed as to carry out his real intention entertained at the time. So where a license is granted to a particular person by name, or to a particular person and other's, he may act either as principal or agent, although without interest in the property in which the trade is carried on under it. If a license is made negotiable, the transferee will be protected, although, as a general rule, it is not transferable. ${ }^{16}$ For that reason when granted to a particular person, he cannot act under it as an agent for others, and in that way make his personal privilege a subject of transfer and sale. As to the character of the ship in which the goods are to be transported, it may be said that, as a general rule, her national character as described in the license is a necessary condition to be fulfilled. It is probable, lowever, that such condition would not be violated if, for the ressel of a particular nation specified, the ressel of another neutral should be substituted; or, if the terms of the license refer only to one ressel, the employment of two, provided both bear the same national character and there be no variation in the quantity or quality of the goods described in the license. As to the goods themselves in favor of which a license is given, limiting their quantity or specifying their character, there can be no condemnation when there is a reasonable general correspondence between the cargo convered and the terms of the license by which it is covered. If a permission, authorizing the importation of goods from an enemy's ship, is confined in terms to the goods, by a just legal construction it will be extended to the ressel also. ${ }^{17}$

$A$ neutral operating under a

16 Feize v. Thompson, 1 Taunton, 121; Warin v. Scott, 4 Taunton, 605; Robinson v. Morris, 5 Taunton, 740. The privilege to trade under a license can be sold when it is perfectly general in its terms and not granted to specific individuals. The Acteon, 1 Dodson, 53. See also Fenton v. Pearson, 15 East. 419; Grigg v. Scott, 4 Campb. 340; The Juno, 2 C. Rob.
116; Klingender v. Bond, 14 East 484; The Sarah Maria, Edwards, 361; The Ranger, 6 Ch. Rob. 125.

17 Kensington v. Inglis, 9 East, 273; the Dankbaarheit, 1 Dodson, 183; the Vrow Cornelia, 1 Edw. 340 ; the Jonge Arend, 5 Rob. 14; the Goede Hoffnung, 1 Dod. 257; the Bourse, 1 Edw. 369; the Speculation. $1 \mathrm{Edw}$. 344; the Hoffnung. 2 Rob. 162. "A privilege given by 
license thereby becomes liable to capture by the other belligerent, even if the license is in fact unauthorized. ${ }^{18} \mathrm{As}$ between the belligerents themselves, the ship of a person narigating under an enemy's license is subject to condemnation by the state to which its possessor belongs. ${ }^{19}$ Where a trade is licensed insurance on cargo is lawful as an incident to it.20 To be effective the license must be on board at the time of the visitation.

Course of voyage; time limited in license.-The requirements of the license as to the port of shipment or delivery, of departure or destination, must be followed strictly; and the same may be said as to a direction that the ship shall stop at a particular port for convoy. If she touches for orders at an interdicted port, the license is forfeited, a result which would not follow an unathorized deviation, for the same purpose, to a nentral or other port not forbidden, or a deviation from the prescribed course produced by stress of weather, or other unavoidable accident. Such are the leading exceptions to the general rule that deviation from the prescribed course entails confiscation. A limitation as to the time a voyage shall begin for the exportation of goods to an enemy's port is subject to a much more rigid construction than a limitation as to the importation of goods within a designated time. In the first ease, where the license requires that the goods covered by it shall be exported on or hefore a certain day, a delay of a single day beyond the limit will render the license wholly void. In the second, when a date is fixed before which the ressel must arrive, allowance will be made for delays caused by stress of weather, the acts of hostile governments, or other like causes over which the holder of the license has no control. ${ }^{21}$

act of Parliament to ships belonging to any state in amity with Great Britain and manned with foreigners, to import merchandise, otberwise prohibited, does not extend to foreign built ships, British owned. (Attorney-General v. Wilson, 3 Price, 431.)" Halleck, ii, p. 351 , note 1 . See Keir v. Andrade, 6 Taunt. 498.

18 The Julia, \& Cranch. 181; the Aurora. Ib. 203, 444; the Alliance, Blatchf. Pr. C. 262.

19 The Hiram, 1 Wheat. 440 ; the
Ariadne, 2 Wheat. 143; the Julia, 1 Gall. 233, 8 Cranch 181.

20 The Europa, 1 Edw., 341; the Minerva, Ib. 375; the Emma, Ib. 366; the Twee Gebroeders, Ib. 97; the Byfield, Ib., 188; the Manly, 1 Dod. 257. But see the Emma, Edwards, 366 .

21 The Sarah Maria, 1 Edw. 361; the Diana, 2 Act., 34; the Eolus, 1 Dod. 300; Williams v. Marshall, 6 Taunt. 390; Effurth v. Smith, 5 Taunt. 329 ; Siffken v. Glover, 4 Taunt. 77; Groning v. Crockatt, 3 Camp. 55. 
Licenses to trade becoming obsolete.-The complicated system of judicial rules thus laid down by the prize courts as to the construction of licenses was an outcome of the conflict between France and England for commercial supremacy at the end of the eighteenth and the beginning of the nineteenth century, during which a very large number were granted by both belligerents. Despite such relaxations, however, unfortunate neutrals, chief among whom was the United States, found their commerce seriously restricted by both sides. The right of neutrals to hold commereial intercourse with belligerents was almost denied by the efforts of each, under the guise of blockades which existed only on paper, to prevent all trades that could not be made subservient to its own interests. To prevent a repetition of such a condition of things, the Declaration of Paris, 1856, provided that blockades, in order to be binding, must be effective; and that enemy goods not contraband of war might be freely carried on neutral ships; "and it is quite certain that in future maritime struggles neutral powers will not again submit to such treatment as they received from France and England in the crisis of their great conflict for commercial supremacy." 22 Licenses to trade were not issued during the Crimean War. Instead, Great Britain declared by an Order in Council of April 15, 1854, ${ }^{23}$ that "all vessels under a neutral or friendly flag, being neutral or friendly property, shall be permitted to import into any port or place in Her Majesty's dominions all goods and merchandise whatsoever, to whomsoever the same may belong; and to export from any port or place in Her Majesty's dominions to any port not blockaded any cargo or goods, not being contraband of war, or not requiring special permission, to whomsoever the same may belong." Like permission was granted to both subjects and neutrals by the governments of France and Russia.

$\S$ 513. Suspensions of arms, armistices, and truces.-The word truce is a generic term which, in its broader sense, covers all cessations of military operation regardless of their extent as to time or place. In that sense it embraces a parley, a brief intermission confined to the immediate combatants; a suspension of arms, longer in duration but limited to a particular place; an armistice, a still longer cessation between larger

22 Lawrence, Principles, p. 451.

23 As to the effect of that and like orders on the trade of a British subject with the enemy, see Espo- sito v. Bowden, 7 E. and B. 763 ; and the Odessa, Spinks Pr. R. 208. 
bodies; and a truce proper between entire armies or countries for a general purpose, which may be political. The Truce of God in the tenth century affected all of Europe, while that between Holland and Spain in the seventeenth lasted twelre years.- The various terms are often used, however, interchangeably. Such arrangements for military purposes are within the power of every independent officer so far as concerns the troops commanded by him. The object being temporary, everything at the end should be in the same position as at the beginning of the armistice, ${ }^{24}$ and each army must refrain from repairing or strengthening works or making disposition of troops which could have been commanded by the enemy's guns if hostilities had continued. Thus the besieged cannot repair a breach and the besiegers cannot push troops to unoccupied points, although deserters may be received. ${ }^{25}$ Either side may drill, bring up recruits and stores, and do any other thing by means of routes not occupied or commanded by the enemy when the armistice was declared. ${ }^{26}$ According to Livy, Plilip violated this rule by retreating while under a flag of truce, ${ }^{2 \pi}$ and Arabi Pasha, who did the same thing at Alexandria in 1882, was afterwards tried and condemned for it. On the other hand, it was perfectly proper for Sherman to repair railroads during the armistice with Johnston, although the prime object was to use them for attack in the event the convention was not approved by the Federal government. Much depends, howerer, in each particular case upon the actual terms of the agreement, which are usually dictated by the stronger party. ${ }^{28}$ While an intentional breach of truce authorizes the opposing commander to recommence hostilities without more, its violation by particular acts may be prevented by force by the other side without a general renewal of hostilities. When soldiers break an armistice and are captured, they are only prisoners of war. The officer giving the orders under which they act is alone responsible, ${ }^{29}$ and redress must therefore be sought at headquarters. When a truce is to extend from such a day to

${ }^{24}$ Chaudordy, in D'Angeberg, Rec. No. 758; 1 Kent Comm. 159; Vattel, Droit des Gens, § 209.

${ }^{25}$ Am. Regulations, 143; Calvo, Droit Int., II, 284, considers receiving deserters as a hostile act and therefore forbidden. Catching rain for a thirsty garrison is as reprehensible!
26 Bluntschli, Mod. Kr., \$§ 188 (688), 191 (691), etc.; Vattel, Droit des Gens, III, ch. 16, § 239260.

27 Livy, lib. XXXI, c. 38 .

28 Calvo, Droit Int., II, 285-7. See Thiers, French Revolution. $29 \mathrm{Am}$. Regulations, 146. 
another, it is often difficult to determine whether the term is inclusive or exclusive of the dates named. Puffendorf and Vattel maintain that both are included, while an English commission in 1831 held that the last was included and the first excluded,-thus requiring troops to continue fighting on the day they agree to cease. ${ }^{30}$ When ambiguous, the terms of such an agreement are to be construed liberally. ${ }^{31}$ Although they bind indiriduals only from the time they learn of them, the government responsible for a breach should make good to the other any injury inflicted in the meantime..$^{32}$ A truce according to some authorities authorizes private trade between opponents within the limits affected.

Revictualling a besieged place--Because there has been no settled general rule as to the right of revictualling a besieged place during a truce, conventions have often been made to remove the difficulty in particular cases. Under the Armistice of Treviso in 1801 Mantua was to receive a fixed amount of provisions for the garrison from ten days to ten dass,-the inhabitants being permitted at the same time to bring in supplies for themselves, subject to the supervision of the French military authorities, who resersed the right to prevent the quantity exceeding the daily consumption. ${ }^{33}$ Under the Armistice of Pleiswitz in 1813 the commanders of the inresting troops were to revictual the fortresses held by the French every five days, a commissary named by the commandant of each of the besieged places being charged with the duty of watching over the exactness of the supply.34 These conventions recognized the right of revictualment, at short intervals, under the supervision of the besieger; and that should be the general rule in the absence of contrary stipulations, because, if that right is not allowed to the besieged, the general principle that at the end of a truce the state of things shall be unchanged in those matters which an enemy can influence will be set aside in a vital particular. As provisions are an exhaustible weapon of defense, the consumption of which cannot be suspended, the mere continuance of a truce must soon crush the besieged if they are not permitted to maintain the conditions existing at its beginning. And yet, despite that cogent

30 Bluntschli, Mod. Kr., 195 (695) ; Calvo, Droit Int., II, 288; Halleck, Int. Law, 658.

312 Wildman, Int. Law, 27; Vattel, Droit des Gens, III, § 244.
32 Heffter, § 142 . See, however

Am. Regulations, 141, contra.

33 Martens (R.) vii, 294.

34 Martens (N. R.) i, 584. 
contention, the weight of opinion seems to favor the idea that in case the besieging army is in a position to prevent the introduction of supplies into a besieged place in the absence of truce, their introduction during its continuance is inadmissible unless authorized by an express permission to that effect. Upon that basis P'rince Bismarek, during the Franco-Prussian war, refused to permit the introduction of supplies eren in limited quantities. In November, 1870, he even refused to permit l'aris to receive sufficient food for the subsistence of the population during a twenty-five days' armistice which it was then proposed to conclude in order that an assembly might be elected competent to decide the questions involved in the making of peace. In a circuliar addressed to the French diplomatic agents abroad, denouncing such conduct as a violation of the spirit of the armistice, M. de Chaudordy clearly defined, not what the settled rule of law is, but what it should be in all such cases. 35

$\$$ 514. Capitulations.-Capitulation or surrender is frequently the result of an armistice. Of the two words capitulation, whose terms vary with the generosity or strength of the conquering army, is generally regarded as the more creditable. Sometimes the besieged surrender without conditions, as Cronje to Roberts in the Boer war; sometimes they march out with honors of war, that is, with flags and drums, and ground their arms. ${ }^{36}$ Sometimes they are allowed to withdraw to their own lines, as when Galvez in 1781 permitted Campbell to sail from Pensacola to New York; or as the Spaniards, who surrendered at Santiago to the Americans in 1898, were permitted to embark for Europe as soon as vessels were provided by their own country. The surrender of a town carries only so much territory as submits with it. ${ }^{37}$ During the FrancoPrussian war, in the earlier capitulations, such as those of Sedan, Strasburg and Metz, the troops were sent prisoners of war to Germany, but in the later ones the officers were released on parole with their arms, horses, and effects. The gardes nationals and mobiles, who belonged to the respective places, were not made prisoners, although all other soldier's

35 "Pour tous les peuples en effet, la condition du ravitaillement est implicitement contenue dans le principe de l'armistice, puisque chaque belligérant doit se trouver. à la fin de la suspension (l'hostili- tés, dans l'état où il se trouvait au commencement." D'Angeberg, Rec. No. 758. Hall, § 192.

36 Halleck, 660.

3 i Clark v. U. S., 3 Wash., 101. 
were. The military equipment and the like was of course taken possession of by the conquerors. ${ }^{38}$ Sometimes the surrender is on condition of parole for all the army, as in the case of Lee at Appomattox. In fact, capitulations and truces may assume any form that may be agreed on, provided no political conditions are inserted.

Destruction of stores.-Capitulation carries with it the tacit agreement not to destroy munitions then on hand, or otherwise alter the condition of the works surrendered. Nothing, however, prevents a commander when capitulation becomes inevitable from destroying everything possible beforehand, in order to minimize the success of the enemy. ${ }^{39}$ Thus, in 1865, during the American Civil War, Gen. Page destroyed all the ammunition and stores he conld before surrendering Fort Morgan, near Mobile, and a court martial of the enemy sustained him. Sarrazin's criticism of the attion of the French at Almeida in 1811 in destroying stores and even fortifications before retreating seems to be groundless.

When surrender is complete.-Surrender is not complete until accepted, a fact usually but not necessarily evidenced by the tender and receipt of the sword of the conquered. While Washington received the sword of Cornwallis at Yorktown, Capt. Erans refused to accept that of the wounded Eulate when brought aboard the Iowa, and Shafter that of Toral tendered at Santiago. Such a ceremony may now be regarded as an archaism, departing with other srmbolic forms of primitive law. It was not necessary for Lee to tender his sword to Grant; in point of fact he did not tender it, and Grant did not refuse it. Their minds met in a written capitulation which, by its terms, allowed the conquered to retain their side arms; nothing more was necessary. Pulling down the flag, or hoisting a white flag, is an offer to surrender, consummated when control, actual or symbolical, is assumed by the conqueror. After such an offer the conquered are bound to wait a reasonable time before renewing battle or attempting to escape; otherwise their action might be regarded merely as a trick to secure some advantage. If, however, the flag is immediately recalled before it is acted on, no law is violated, as in the case of the Santissima Trinidad in the battle of Cape St. Vincent. ${ }^{+0}$ If the offer is not accepted, the fight may be renewed, of course 
under colors, or escape may be effected. Acceptance is not a matter of course. The conqueror may not desire prisoners; he may not be in condition to consummate the matter; or he may be prevented by new cireumstances from doing so. If the enemy is satisfied with a victory and marches off when the flag is shown, the weaker party cannot be considered prisoners, as their offer has in effect been rejected. If a relieving force routs the conquerors, prior to the acceptance of the white flatg of their comrades, the offer of surrender is a roided, and there is no question of prisoners. In capitulations, as in all other agreements, the minds of both parties must meet; and if the forms appropriate to the particular occasion are not carried into effect, there is no contract.

$\$ 515$. Sponsions.-In time of war certain conventions may be concluded without special authority by virtue of the implied powers incident to the offices of certain persons in high command. Such, for example, as truces made by generals and admirals suspending or limiting hostilities within the limits of their respective commands; cartels for the exchange of prisoners; or capitulations for the surrender of a city, province, or fortress. Unless there is a special reserration in the act itself, compacts of that kind do not generally require a ratifieation by the supreme power of the state to which the officer belongs. ${ }^{42}$ The state is not bound, however, if its representative exceeds the limits of his authority, express or implied; or if he includes political conditions among the articles agreed to. Such engagements, when made without express authority, or beyond the limits of such as may be reasonably inferred, are called sponsions, and are not binding until confirmed either by express or tacit ratification. As Martens has expressed it: "Whatever the chief or the inferior promises beyond the limits of the authority intrusted to him is only a simple sponsion which nothing but a subsequent ratification, either express or implied on the part of the nation, can render obligatory." 43 As the ratification of neither party can be inferred, in the case of conventions concluded in excess of specific powers, from mere silence, ${ }^{44}$ good faith requires that

42 Grotius, De Jure Belli ac either by its representative or by Pacis, III, c. 22, $\S$ 6-8; Vattel, a voluntary agent, they not havDroit des Gens, II, c. $14, \S 207$.

43 Précis, II, c. 11, $\$ 48$. "A simple sponsion, that is an agreement formed in the name of a state ing been authorized, is only obligatory when it is ratified by the state." Klüber, $\S 142$.

44 Dana's Wheaton, § 255; Hal- 
the party who resolves to dissent from what has been done in its name should promptly indicate the fact to the other party so as to prevent the carrying of its part of the agreement into effect. And in the event that a state repudiating the act of its agent received some benefit or advantage as a result of the unauthorized agreement, or in the event that the other state has performed acts in accordance with it, it is the duty of the former either to give to the latter compensation, or at least to restore it to its original status. ${ }^{45}$

Capitulation of El Arish in 1800.-Passing over the examples of sponsions embodied in the capitulation made by the commanders of the Roman army while inclosed in the defiles of the Caudine Forks, repudiated by the Roman senate ${ }^{46}$ in the convention concluded at Closter-Seven, during the Seren Year's War, between the Duke of Cumberland, commanding the British forces in Hanover, and Marshal Richelieu, commanding the French army, for a suspension of arms in the north of Germany, annulled by the King of England in his capacity of Elector of Hanover; in the armistice and capitulation, granting ammesty to their revolted subjects under which the king and queen of Naples reëntered their capital in 1799, set aside as "infamous" by Lord Nelson, who compelled the rebels to surrender at discretion ${ }^{47}$ in the capitulation of the French under Rapp at Dantzic in 1814, on condition that they should return to France, disregarded by the Czar, who held them as prisoners of war; and in the convention ratified by General Butler in March, 1848, during the Mexican war, providing that the Mexican civil authorities were to be reëstablished in their respective offices, ignored by the American commander of the separate military department of California, special reference must be made to the capitulation of El Arish, notable as an illustration of an agreement made by a military commander contrary to his instructions, although, as it happened, in

leck, i, p. 277. Hall ( $\$ 110$ ) well says that "the writers who say that ratification cannot be inferred from silence are evidently thinking of conventions concluded in excess of specific powers, and not of agreements which are practically within the powers of the persons making them, but which are not technically binding from the moment of their conclusion, owing to the signatories not being the persons in whom the treaty-making power of the state is theoretically lodged by constitutional law."

${ }^{45}$ Grotius, De Jure Belli ac Pacis, II, c. $15, \S 16$; III, c. 22 , $\S$ 1-3; Vattel, II, c. 14, §§ 209-212;

Rutherforth's Inst. II, c. 9, § 21.

461 Mommsen's Rome, 471. 47 Mahan's Nelson, 367. 
innorance of their terms. When in December, 1799, General Kleber, the commander of the French army in Egypt, perceived that he could not maintain himself permanently in the country, he made a proposal of capitulation to the Grand Vizier who was advaneing through syria, and to Sir Sidney Smitl. acting on the coast as commodore, under the orders of Lord Keith, the admiral commanding the English fleet in the Hediterranean. Under such conditions Sir Sidney Smith assumed the responsibility of signing an agreement with General Kleber, on January 24, 1800, conceding to the French army in Egypt the right to evacuate the country, and to return to France through their own ports with their arms, baggange and other property. On February 22, 1800, a month after the signing of the capitulation, and after Kleber had already restored certain places to the Turks moler its provisions, Sir sidney Smith received orders from Lord Keith instructing him not to consent to any terms not involving the surrender of the French troops as prisoner's of war. Such orders were based on instructions sent from London to Lord Keith on the previous 17th of December. When the French commander was thus informed that what Sir Sidney Smith had done was repudiated by his superior officer, under orders from his gorermment, he renewed hostilities so vigorously as to gain a great rictory over the Turks at Heliopolis on March $20,1800$. Before the news of these changed conditions reached England, the British cabinet resolved to ratify the capitulation which Sir Sidney Smith had made; but General Menou, who sucreeded Kleber in June, believing that he could hold the country, refused to renew the agreement, which thus fell to the ground. Not until hostilities had been prolonged for more than a year did the remains of the French army surrender on substantially the same terms as those originally agreed upon at El Arish. ${ }^{4}$ These facts demonstrate beyond question that there is no basis for a charge of bad faith against the British government, which simply exercised its undoubted right to refuse to ratify an aureement made by a subordinate com. mander beyond the limits of his authority.

Capitulation of Gen. Joseph E. Johnston in 1865.-After the Ameriean civil war had been brought nearly to a close by reason of the surrender of Gell. Lee to Gen. Grant, on April

48 Martens (R.) vii, 1; De Garden, Hist. des Traités de Paix. vi. 210-14, 288; Parliamentary His- tory, XXXV, 587-97; Fyffe, Modern Europe, I, 224-227. 
9th, 1865, Gen. Joseph E. Johnston, who was still at the lhead of an army, addressed, on April 13th, to Gen. W. T. Sherman, a commander subordinate to Gen. Grant, a letter inquiring "whether, to stop the further effusion of blood and the derastation of property, you are willing to make a temporary suspension of active operations, * * the object being to permit the civil authorities to enter into the needful arrangements to terminate the existing war." On the next diy Gen. Sherman replied: "I am fully empowered to arrange with you any ter'ms for the suspension of hostilities between the armies commanded by you and those commanded by myself, and will be willing to confer with you to that end." From statements made by Gen. Sherman in his Memoirs ${ }^{49}$ it may be inferred that his prior conversations with President Lincoln upon this very subject authorized him to say to Gen. Johnston that "I am fully empowered to arrange with you any terms for the suspension of hostilities." However that may have been, before the two generals actually met for conference the fateful assassination of President Lincoln occurred. As Gen. Jolnston himself has expressed it: "Is soon as we were without witnesses in the room assigned to us, General Sherman showed me a telegram from Mr. Stanton, announcing the assassination of the President of the United States." 50 Under these circumstances, on April 18, General sherman offered and General Johnston accepted terms of capitulation embratcing serious and far-reaching political conditions, and ending with the statement: "Not being fully empowered by our respective principals to fulfil these terms, we individually and officially pledge ourselves to promptly obtain the necessiry authority, and to carry out the above programme." 51 Leaving that declaration entirely ont of view, the successor of President Lincoln had a clear legal right to refuse to ratify the sponsion in question because a subordinate commander had incorporated in its articles political conditions entirely beyond the limits even of his implied anthority. A new convention was arranged on the basis of Lee's capitulation.

\section{§516. Hague rules regulating Capitulations and Armistices.} -Having now defined the general principles of international

49 Memoirs of General W. T. of Agreement," is printed in full Sherman, vol. ii, pp. 327, 330, 346, in Johnston's Narrative, pp. 405-7. 347.

50 Johnston's Narrative, p. 402.

51 The "Memorandum, or Basis See also Grant's Narrative, ii, 514; Davis's Rise and Fall of the Confederate Gov., ii, 684 seq. 
law relating to capitulations and armistices as the existed prior to the Peace Conference at The Hague, it will be conrenient to place in juxtaposition with them the rules there adopted on both subjects:

"Capitulations agreed on between the contracting parties must be in accordance with the rules of military honor. When once settled, they must be scrupulously observed by both the parties.

"An almistice suspends military operations by mutual agreement between the belligerent parties. If its duration is not fixed, the belligerent parties ean resume operations at any time, provided always the enemy is warned within the time agreed upon, in accordance with the terms of the armistice.

"In armistice may be general or local. The first suspends all military operations of the belligerent states; the second, only those between certain fractions of the belligerent armies and in a fixed radius.

"In armistice must be notified officially, and in good time, to the competent authorities and the troops. Hostilities are suspended immediately after the notification, or at a fixed date.

"It is for the contracting parties to settle, in the terms of the armistice, what communications may be held, on the theatre of war, with the population and with each other.

"Any serious violation of the armistice by one of the parties gives the other party the right to denounce it, and even, in case of uraency, to recommence hostilities at once.

"A violation of the ter"ms of the armistice by private individuals acting on their own initiative, only confers the right of demanding the punishment of the offenders, and, if necessary, indemnity for the losses sustained." 52

52 Second Convention, chapters The Peace Conference at the IV and V, Articles XXXV-XLI, Hague, 155 seq.

both inclusive. See also Holls, 


\section{CHAPTER VI.}

\section{LAWS OF WAR AS TO ENEMY PERSONS.}

\$517. Effect of domicil in an enemy's country.-Having now considered the relations of belligerents during actual hostilities by land and sea, reference must next be made to the laws of war as to enemy persons originally non-combatant, and to such combatants as are placed hors de combat. In the first elass are embraced private, unarmed residents of the belligerent country; in the second, prisoners, the wounded and their attendants. Upon the outbreak of war the status of every resident of a hostile state is seriously affected by the event. In war as in peace the national character of a person is for many purposes determined by his domicil, that is, by his actual residence as qualified by his intention of there remaining. As to such intention actions speak louder than words. That is to say, as actual residence is a fact, any intention of changing it should be shown by other facts rather than by mere statements which may be varied to suit interest. ${ }^{1}$ The intention is to be derived from all the circumstances of the case, particularly from the occupation engaged in. Long continued residence raises such a strong presumption of intention to remain, that Lord Stowell says that "time is the grand ingredient in constituting domicil. In most cases it is unaroidably conclusive." 2 While that statement may gire undue importance to mere length of residence, the fact is always very persuasive as an indication of the intention to remain, which, rather than the time evidencing it, when duly proved, is the grand ingredient of domicil. ${ }^{3}$ The same eminent judge lars the proper stress on intention in citing the case of Whitehill, a British subject of that name who settled permanently in St. Eustatius only a day or two before the arrival of Admiral Rodney and the forces that conquered the island for England.* Lord Camden held that under those circumstances Whitehill had already acquired a foreign domicil before the British

1 Wheaton's Elements international Law, 245; Livingston $v$ Md. Co., 7 Cranch, 506. 2 The Harmony, 2 Rob. Adm., 277.
3 The Venus, 8 Cranch Rep., 253; Hylton v. Brown, 1 Wash. C. C. 312; The President, $5 \mathrm{Ch}$. Rob.,

4 The Diana, 5 Rob. Adm., 60. 
capture, and therefore that he, together with others who intended to remain there "ought to be considered resident subjects" of the Republic of the United Netherlands. From these cases it appears that time and intent are the two great elements that determine domicil. Enemy character attaches to all persons domiciled in the enemy's country, although they may be neutrals in fact, or even loyal citizens of the country to which they belong. Their enemy residence makes them for war purposes enemies de facton no matter whether the war be civil or foreign. In like manner a citizen residing in a neutral state may lawfully trade with a country at war with his native country. ${ }^{6}$ The "adventitious character" gained by residence alone ceases, howerer, from the moment a person puts himself in motion to leave permanently; such character being gained by residence, ceases with residence. When once in itinere for his own country, he becomes immediately its citizen again, ${ }^{7}$ provided the return is not a mere casual visit, which does not alter domicil." Is Lord Stowell expressed it: "The character" that is gained by residence ceases by non-residence. It is an adventitious character, and no longer adheres to him from the moment that he juts himself in motion bona fide to quit the country sine animo revertendi."

$\$ 518$. How far private rights are to be respected by a conquering army.-The ancient principle and practice of consideringr an enemy as without any rights which the conqueror is bound to respect has been discarded. Asit was still in force in the time of Grotius, he pleaded against it as unjust though lawful; ${ }^{9}$ and since the Peace of Westphalia his view has gradually ripened into the now clearly recognized distinction between combatants and non-combatants. If the Duc de Grammont is correctly reported as saying to the Baden ambassador that in the war with Prussia not even women would be spared by

5 Twiss, Law of Nations, War, § 152; Prize Cases, 2 Black, 635; The Venice, 2 Wallace, 258; Mrs. Alexander's Cotton, 2 Wallace, 419; The Wm. Bagaley, 5 Wall. 377; Gates v. Goodloe, 101 U. S., 612.

6 The Danous, 4 Ch. Rob. 256, n.; The Ann, 1 Dodson 221; Notes in 2 Knapp, 301, 365; The Postilion, Hay \& Marriott, 245; Bell v. Reid, 1 Maule \& S., 727,
7 The Indian Chief, $3 \mathrm{Ch}$. Rob. 12, 20; and note to p. 21; The Ocean, 5 Ch. Rob. 291; The Venus, 8 Cranch, 253; The Frances, 2 Gallison, 616; see also the Baltica, Spinks, 264; The Ernest Merck, Spinks, 89.

$\mathrm{s}$ The Friendschaft, 3 Wheat. 14; The Frances. 8 Cranch. 335.

口 De Jure Belli ac Pacis, III, IV, VI-XIV. 
the French, ${ }^{10}$ his statement may be accepted as an extreme exposition of the ancient rule, under which Frederick II claimed the right even to increase his army in the invaded country by conscription. The modern rule is that private citizens who are non-combatant are to be protected in the exercise of all rights and privileges which do not conflict with the war necessities of the invader. ${ }^{11}$ Such necessities justify a denial of the right of assembly, of freedom of speech, and of intercourse with the other portions of the country, as well as any occupation aiding the old sovereign or injuring the invader. Even women and children may be imprisoned when necessity requires it. In the absence of such necessity, however, mechanics, merchants and all other passive enemies engaged in peaceful pursuits are to be encouraged and protected in their business, according to the lumane practice of Cyrus who did not disturb cultivators of the soil in his invasions. ${ }^{2}$ While it is true that the absolute and despotic right of violence orer the persons of all the inhabitants of a hostile country is still rested, as a physical fact, in the conqueror, its application is limited in practice by the mitigating principle now generally recognized that such right shall not be extended beyond the reasonable necessities of war. And in order that such necessities may not be made the equiralent for convenience, the civilized nations of the world have been for some time striving to agree upon a war code regulating the entire subject, a result at least partially attained in the second Hague convention. Under the laws of war now existing religion, speech, education, trades, and the honor of the conquered are, as far as possible, to be respected. ${ }^{13}$ Although for special reasons, rules somewhat more stringent prevail as to private property at sea, the French went too far in 1870 in imprisoning merchant seamen because they might become of value to the German wary. The contrary contention of Napoleon I was the more reasonable $;^{14}$ and the American regulations (39) properly except from imprisonment all not directly promoting the objects of war.

\$519. Killing and enslaving of prisoners-Ransom.-While Polybius says that the killing of eaptives was an old Roman custom, employed to inspire dread, it was not universal among ken).

${ }^{10}$ Heffter, § 126 note 7 (Geffc-

11 Am. Regulations, 25.

13 Bluntschli, Mod. Kriegsrecht,

12 Cyropaedia, book V, ch. 4. 
the Greeks, whose later practice was to regard them as slares. Is explained heretofore the Greeks thought of non-Greeks or barbarians as having no rights whatever, and Aristotle eren adrocated war for the purpose of acquiring slares. ${ }^{15}$ Slavery itself was certainly a humane improvement on the sarage pactice of killing enemies, the Digest deriving "servus" from the humane selling of captives by the emperors, who thus "servare solent." 16 It was a rule of Edward III, during his wars in France, to reserve for execution a certain number of the inhabitants of besieged towns, and he was among the first to take important prisoners away from the actual captors. Less than a century later Henry $V$, after Agincourt, lilled his prisoners in what he deemed self-defense, although he protected the peaceful population; as did the Chevalier Bayard, always lumane in his invasions. The third Lateran Council in 1179, as well as the Eastern Church somewhat later, forbade the sale of Christian prisoners, under decrees not always obeyed. During the middle ages, when a knight could be slain but not enslared, enslarement generally assumed the form of sending to the galleys, and that in turn gave way to ransom in favor of the indiridual captors, and then, after the institution of amies paid by the sorereign, to ransom in his favor,-the final transition being marked by the campaigns of Gustarus. As the abolition of slarery and ransom gave the (aptor less pecuniary interest in his captives, the change led for a time to an increase of bloodshed. Grotius, even before the Thirty Years' War, averred that "when arms were once taken up all reverence for law, divine and hmman, was abandoned, als if men were authorized to commit all forms of crime without restraint;" in 1690 a British commander threatened to send prisoners as slaves to America $;^{17}$ and throughout the seventeenth century treaties and state papers speak of galleys and ransom during the war and release at its close. In a cartel at Frankfort in 1743 a marshal's ransom was fixed at 32,000 florins. ${ }^{15}$ The last instance of ransom oceurred in 1780 , between the French and English, when a marshal or admiral was

15 Politics I, VIII; Livy XXXI, c. 29 ; Justinian Inst. I, iii, 3 ; Herod. VI, 30; Xen. Hellen. V, 4; Livy IX, 4; Tacitus, Annals II, 21. See the Antelope, 10 Wheat. 120. 16 L. 239,1 D. L. 19 de verb. sig. 17 Grotius, De Jure Belli ac Pa- cis, Prolegomena; Id. III, ch. 7, $\S 1-2$, ch. $7, \S 9,2$; Maine, Int. Law, 134; Hall, Int. Law, 427; Calvo, Droit Int., II, 139; Bynkershoek, Quaest. Jur. Pub., ch. 3; Heffter, \& 129 and note.

181 Causes Cel. du Droit des Gens, Martens, 285. 
valued at sixty men and a private soldier at one pound sterling. So firmly had the custom of taking prisoners become established by the time of the French Revolution, that after the convention in 1794, on motion of Barère, had decreed that no quarter should be given to the English, Hanoverians and Spaniards, the French soldiers nevertheless took prisoners from a sense of military honor and excused it to the government on the pretext that the men were descrters. The infamous decree was soon revolied, ${ }^{19}$ even without a threat of retaliation. Ransom is not now exacted except for prisoners remaining after a general exchange, and then only by special national authorization. 20

$\$ 520$. Who are prisoners of war. Can they ever be slain rightfully?-All soldiers and sailors, public officials and other's actively aiding the progress of war by word or act, and not criminals, coming into the hands of a combatant, are prisoners of war. They are in the power of the hostile gorernment, but not in that of the individuals or corps capturing them. ${ }^{21}$ Sovereigns are also treated as prisoners, as John of France at Poitiers, Napoleon III after Sedan, and Napoleon I after coming aboard the Bellerophon. The latter always denied that he had surrendered and claimed that in any event his subsequent detention at St. Helena was improper, because there was then no war. His treatment, in some respects unnecessarily harsh, was certainly due to fear of his influence. ${ }^{22}$ The release of Napoleon III after the Franco-Prussian war was more in accord with modern thought and practice. Prisoners constitute a somewhat broader class than combatants, or enemies who may be killed in battle. Reporters, sutlers, contractors, and others accompanying an army, whom the conqueror sees fit to detain, have a right to be treated as prisoners of war if provided with a certificate from the commander of their army..$^{23}$ Every prisoner of war, if questioned, is bound to declare his true name and rank, and, if he disregards this rule. he is liable to a curtailment of the advantages accorded to

19 Twiss, Law of Nations, War, $\S 66,177$; 3 Ch. Rob., App. A; Vattel, Droit des Gens, III, ch. 17, 278; Macaulay, essay on Barère; Calvo, Droit Int. II, 144, note (1); 3 Phillimore 156.

20Am. Regulations, 74, 108.

22 See Lord Roseberry's Napoleon, the Last Phase, (1900) for an incisive arraignment of the English government's treatment of their captive.

23 Hague Second Convention, Art. XIII.

21 Hague Second Convention, Art. IV. 
the prisoners of war of his class.24 While it is conceivable that prisoners may be slain under exceptional eircumstanees, such circumstances present, as Burke expressed it, cases "at which morality is perplexed and reason staggered." Henry V, as stated above, lilled his prisoners after $A$ gincourt to free the hatuds of all his men, and Napoleon in 1799 shot three or four thousand Turks captured at Jaffa, who would not respect parole, 25 because he could not feed or escort them. On the other hand Charles XII, after Narva, released hiș captives, under similar cireumstances.

$\$ 521$. Treatment of prisoners: Wills, burials, employment, pay, escape, neutral territory, enlistment.-Prisoner's are to be supported and cared for by their captors, in sickness and health, a rule grossly riolated by the Spaniards in 1809 when they placed seven thousand on Cabrera Island, where twothirds of them died like beasts. The Hagne rules provide that prisoners of war must be humanely treated, and that the govermment into whose hands they fall is bound to maintain them. In the absence of a special agreement between the belligerents, prisoners of war are to be supplied with food, quarters, and clothing on the same footing with the troops of the government which has captured them. ${ }^{26}$ They cannot of course expect to receive better food or accommodations than the captors themselves, or to enjoy privileges which imperil their conquerors. Thus, when Admiral Anson found himself with more prisoners than crew, he had to keep them in the hold, despite their sufferings there. While prisoners of war may be detained in a town, fortress, camp, or any other locality, and bound not to go beyond certain fixed limits, they can only be confined as an indispensable measure of safety. ${ }^{27}$ They are subject to the laws, regulations, and orders of the army of the state into whose latuds they liave fallen. Any act of insubordination warants the adoption as regards them of such measures of sererity as may be necessary, ${ }^{28}$ but in general they shall enjoy every latitude, even in the exercise of their religion, including attendance at their own chureh service, provided only they comply with the regulations for order and the police ordinances issued by the military authorities. Prisoners shall be

24 Ib. Art. IX.

"See passim, 1 Bourrienne, ch. Art. V. XVIII.

2т Hague Second Convention,

${ }^{26}$ Hague Second Convention,

28 Ib. Art. VIII.

Art. IV, VII. 
kept in restraint, with as little constraint as is consistent with their safety, until the end of the war or until exchanged. ${ }^{29}$ Although all their personal belongings, except arms, horses and military papers, are regarded as private, some writers say that if valuable these may be kept from them until release. ${ }^{30}$ The wills of prisoners of war shall be received or drawn up on the same conditions as for soldiers of the national army; and the same rules shall be observed regarding their death certificates and burials, due regiard being paid to their grade and rank. They may be employed at work not unsuited to their condition and not directly hostile to their own army and country, and this Bluntschli and Calvo construe into an authorization for their employment on distant fortifications, a claim properly condemned by Geffcken on principle. If they desert and proffer information, it may be received; but they cannot be compelled to give it or be punished for false information when given. ${ }^{31}$ Prisoners should not be emplosed to strengthen their captor's military position, for this tends to release a corresponding number of his soldiers for service at the front. The more modern practice confines their labor to what contributes to their own welfare. The Hague rules authorize a state to utilize the labor of prisoners of war according to their rank and aptitude. Their tasks shall not be excessive, and shall have nothing to do with military operations. Prisoners may be authorized to work for the public serrice, for private persons, or on their own account; and work done for the state shall be paid for according to the tariffs in force for soldiers of the national army employed on similar tasks. When the work is for the other branches of the public service or for private persons, the conditions shall be settled by agreement with the military authorities. The wages of the prisoners shall go toward improving their position, and the balance shall be paid them at the time of their release, after deducting the cost of their maintenance. ${ }^{32}$ It has been sometimes the practice, now sanctioned by The Hague Conference, for officers to receive their regular pay, or some proper pay,

29 Ib. Art. XVIII.

30 Brussels Project, Art. 23; Am. Reg. 50, 53, 72; Bluntschli, $\S 601 ;$ Heffter, $\S 121$, Geffcken, n; Hague Second Convention. Art. IV. 31 Bluntschli, Nod. Kr., § 91 (593), 608, etc.; Calvo, § 1853;
Heffter, $\S 129$, n. 3 ; 6 Webster's Works, 437; Am. Regulations, 80, 76 ; Halleck, Int. Law, 436; Wharton. Int. Law Dig., § 348d.

32 Davis, Int. Law, p.235n; Calvo, Droit Int.. II, 145; Hague Second Convention, Art. VI. 
from their captors, who in their turn balance accounts on this score with the enemy. Thus in 1870-1 the Germans paid French officers, and the French paid captive officers and men al so. ${ }^{33}$ As the object of imprisonment is security, not punishment, Peter's conduct in exiling his prisoners to siberia after Pultowa is indefensible. I'unishment may be inflicted for breaches of rules; and for conspiracy for a joint escape even the death penalty may be imposed. ${ }^{34}$ It is not legal, however, to imprison the companions left behind as a deter'ent to $\mathrm{fur}^{-}$ ther attempts, as the Prussians did in 1870 . When a prisoner attempting to escape is recaptured before rejoining his own army he is liable to disciplinary punishment, and he may be killed while escaping. If he suceeds in rejoining his army, he cannot be punished for such escape when made prisoner subsequently, even if in escaping he has killed his guard.35 While imprisomment is lawful, it is equally so to escape if opportunity offers. In 1870 the Government of National Defense offered a reward of seven hundred and fifty francs to each officer who should escape from German imprisonment. A person seized by way of reprisals is entitled to be treated like a hostage, whose life is sacred. ${ }^{36}$ Captivity is not like imprisonment for crime, and does not affect civil rights. A will, for instance, is valid although the testator be a prisoner of war. Prisoners set ashore in a neutral port, though under guard, become free, a result which does not follow if with an army having the right of transit. If retained on the ship, however, prisoners are not affected by the neutrality of the port, Bynkershoek to the contrary notwithstanding..37 The question has been much debated as to the enlistment of prisoners, formerly customary. After Breitenfeld, Gustarus Adolphus was able not only to fill up the gaps in his ranks, but even to create new regiments out of his numerous captives. While enlistment, if voluntary, is no more objectionable than the acceptance of deserters, such recruits ean expect no quarter if they fall into the hands of their old sovereign.

$\$ 522$. Bureau of information and relief societies.-The Hagne

33 Hall, Int. Law, $424 \mathrm{n}$; Calvo, Droit Int. II, 145; Hague Second Convention, Art. 17.

34 Bluntschli, Mod. Kr., $§ 109$ (611) ; Halleck, Int. Law, 430; Am. Regulations, 39, 77, 78; Calvo, Droit Int. II, 146.
35 Hague Second Convention, Art. VIII.

36 Vattel, Droit des Gens, II, c. 18 , 351 ; III, c. 14, $\$ 220$; Bluntschli, Droit Int. Cod., § 738; Hague Second Convention, Art. 19.

3т Bynkershoek, Quaest. Jur. Pub., ch. XV. 
rules provide that a Bureau of Information for the benefit of prisoners of war shall be instituted at the commencement of lostilities in eacl of the belligerent states, and, when necessary, in the neutral countries on whose territory belligerents have been received. This bureau is intended to answer all inquiries about prisoners of war, and shall be furnished by the various services concerned with all the necessary information to enable it to keep an individual return for each prisoner of war, including intermments and changes, admissions into hospital and deaths. It is also the duty of the bureau to receive and collect all objects of personal use, valuables, letters, and the like found on battlefields or left by prisoners who have died in hospital or ambulance, and to transmit them to those interested. The bureau shall have the privilege of free postage, and all letters, money orders, and valuables, as well as postal parcels destined for prisoners of war or dispatched by them, shall be free of all postal duties, both in the countries of origin and destination, as well as in those they pass through. Gifts and relief in kind for prisoners of war shall likewise bo admitted free of all duties and charges, including payments for carriage by government railways. ${ }^{38}$ Relief societies for prisoners of war, regularly constituted in accordance with the law of the country for the purpose of serving as intermediaries for charity, shall receive from the belligerents, for themselves and their duly accredited agents, every facility, within the bounds of military requirements and administrative regulations, for the effective accomplishment of their humane task. Delegates of such societies may be admitted to places of internment for the distribution of relief, as also to the halting places of repatriated prisoners, if furnished with a personal permit by the military authorities, on giving engagements in writing to comply with all their regulations for order and police..$^{39}$

\$23. Parole and its obligations.-Captured troops may at the option of the captor be released on their written parole or agreement to do or not to do certain things after discharge, including, as a general rule, a promise not to serve against the captor $0^{2}$ his allies for a reasonable time, not to exceed the duration of the existing war. The parole, which must be given by commissioned officers, if any, for their soldiers, when in due form consists of the exchange of two documents giving

38 Second Hague Convention, 39 Ib. Art. XV. Articles XIV, XVI. 
name, rank, and the like. Paroles cannot be forced; they must rest on the free consent of the prisoners. A mere declaration that prisoners are free on parole is an unconditional release; ${ }^{40}$ and there can be no paroling during battle or in masses inmediately afterwards. ${ }^{41}$ The Hague rules proride that prisoners of war may be set at liberty on parole if the laws of their country authorize it; and, in that event they are bound on their personal honor serupulously to fulfill, both as regard their own government and the government by whom they were made prisoners, the engagements they have contracted. Their own govermment shall not then require or accept of them any service incompatible with the parole given. ${ }^{42}$ While a prisoner caunot be forced to accept his liberty on parole, on the other hand the hostile government is not obliged to assent to his request to be set at liberty in that manner. ${ }^{43}$ Any prisoner of war liberated on parole and recaptured, bearing arms against the government to whom he has pledged his honor, or against the allies of that government, forfeits his right to be treated as a prisoner of war, and can be brought before the courts. ${ }^{44}$ Parole does not, however, deny to the released soldier the right to drill recruits, to accepting civil employment, or to fight other enemies, or to perform any other act except service in the field against the combatant releasing him. ${ }^{45}$ While Geffeken may be right on principle in declaring that such released prisoners should remain neutral and do nothing that would release other troops for active service, practice does not go so far. If the government to which the prisoner belongs refuses to assent to the terms of the parole, he must surrender himself and become a prisoner again; and, if the enemy then refuses to receive him back, he is free without parole or conditions. ${ }^{46}$ The national faith is sacredly pledged to fulfilment of the obligations of parole, unless the nation to which the released prisoners belong has forbidden acceptance of such release, and at the same time provides for their support luring imprisonment..7

40 Bluntschli, Mod. Kr., $\$ 116$ (618) et seq.; Maine, Int. Law, 165, etc.; Field Int. Code, $\S \S 816,822$; Heffter, $\$ 129$, n. 2 (Geffcken); Am. Regulations, 119-134.

41 Am. Regulations, 128; Bluntschli, sup., § 120 (622).

42 Hague Second Convention, Art. $\mathrm{X}$.
43 Ib. Art. XI.

44 Ib. Art. XII.

45 Am. Regulations, 130.

46 Am. Reg., 130-1; Bluntschli, sup., § 122 (624) et seq.; Heffter, § 129, n. 2; Maine, Int. Law, 167.

47 U. S. v. Wright, 15 L. Repr. N. S. 459 ; Halleck, 438 . 
The Germans complained that French officers violated their paroles in 1870 and that their government put them in active service again. ${ }^{48}$ In every war, however, there are accusations of bad faith, and it is generally difficult to be certain as to the facts. Napoleon assuming that many of the defenders of Jaffa were Turks whom he had just paroled at El Arish, beheaded then after recapture. This extreme penalty is allowable for breach of parole, after the fact has been ascertained and declared by a court martial. ${ }^{49}$

\$24. Exchange of prisoners.-Exchange of prisoners, the agreement for which is called a cartel, is customary and proper, but not compulsory. The contention that if exchange is refused by one side the other may put his prisoners to labor in order to pay for their maintenance, or treat them with any unnecessary severity, is unsupported by international law. Thus Grant was within his strict rights when he refused to exchange with Lee, in order thereby to prevent reinforcing the Southern army, ${ }^{50}$ a conrse pursued by the British with the same motive during the recent Boer War. The cartel may be made before or during the war, the first known dating, according to Dumont, from 1673. While Gustavus and Wallenstein and other early commanders exchanged prisoners, it was only late in the eighteenth century that we find exchange employed (by the Dutch) as a regular system. Unless otherwise agreed, exchanges are made on the basis of man for man, rank for rank, in equal health, excluding spies, traitors and war rebels. If there is a disparity in rank, it is usual to agree on so many privates for particular ranks of officers. During the FrancoPrussian War, as the Germans held nearly three hundred and fifty thousand prisoners against a few thousands in the hands of the French, there could be no equal exchange. Whether, after exchange, there shall be further service during the war or not is a matter to be settled by agreement in each case. In the absence of an express agreement that those exchanged may serve, Bluntschli holds that it is implied that they shall not. ${ }^{51}$ In order to facilitate exchanges it is usual for each combatant to have one or more commissioners within the lines of the enemy, who are treated as neutrals so long as they do

48 Heffter, $\S 129$, n. 6.

49 Am. Regulations, 124.

50 Bluntschli, Mod. Kr., $\S 110$ (612), 112 (614) et seq.; Maine, Int. Law, 165; Field, Int. Code, $\S \S$
827-828. As to health of prisoners, see Washington's Works, IV, 439, 454, App. XIII, XIV; White's Lee, 393, 444; Calvo, Droit Int. II, 146. 51 Mod. Völk., § 613. 
not attempt to aid their principals by departing from the line of their duty. Yapoleon did not facilitate exchanges with the English, because they at first refused to exchange Frenchmen for any prisoner's not English; and when they finally agreed he distrusted their intentions.52 He won the enthusiastic friendship of the Empelor Iaul by sending back without any equivalent ten thousand Russian soldiers captured while acting witl the armies of England and Austria, after those countries had refused to receive them in exchange for French prisoners. ${ }^{53}$ There were cartels during the American Revolution, as in 177s. And a cartel entered into in 1813, covering equivalents for unequal ranks, provided that British agents might reside in American towns, and American agents in Halifax and elsewhere.

$\$ 525$. The giving of hostages.- While the exaction of hostages is not farored, the may be given as pledges for the fulfillment of any agreement between belligerents, or as security for the payment of indemnity. It is not lawful to take prominent citizens as hostages in order to insure the tranquillity of a district, because in that way the innocent may be punished without securing the desired result. Neither is it permissible to put prominent people of the country on railroad trains in ordel to insure the safety of traftic, as was done during the war of $1870-1$, in the case of the "notables" who were forced to ride on the locomotive from Nancy to Toul, from Toul to Commercy, and from Commercy to Bar-le-Duc. The Germans also took forty persons from Dijon, Gray and Vesoul by way of reprisals for the imprisonment at Clermont. Ferrand of as many captains of merchant ressels captured by the French. ${ }^{54}$ When outrages oceur the better plan is to fine the district responsible therefor. An extreme case occurred when Bacon during his Virginia rebellion stationed the wives of his enemies on entrenchments he was building so as to protect his own men from the fire of the gorernment troops. Hostages are to be treated as well as the prisoners of war, excepting only the right to exchange. They are not liable to death or personal injury, but merely to detention by such means as are necessary for enforcing the pledge. If a hostage die, the giver, in the absence of express agreement, is not bound to supply another. ${ }^{55}$ During recent years, the

52 Calvo, Droit Int., II, 148.

531 Bourrienne, ch. III.

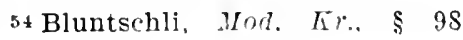

(600) ; Calvo, Droit Int., II, 151, 152; Heffter, § 128, Geffcken, n. 2. i.) 3 Phillimore, Int. Law, 68; 
growth of good faith between enemies has rendered the exaction of hostages practically obsolete. The special status of hostages on a ransomed ship will be discussed elsewhere.

526. Punishment of military offenses by martial law.-Robbers, marauders, guides misleading the army, insurgents after occupancy (sometimes called war rebels), persons giving information after such occupancy to their old govermment (wai traitors) and all others injuring the invading army or the peace of the occupied territory, are subject to martial law and punishable even by death. ${ }^{56}$ While patriotism may inspire some of these deeds, the safety of the army requires serere repression of all. Heffter classifies those who are beyond the protection of the laws of war as, (1) those who make war on their own account, unauthorized by the sovereign; (2) courbatants or noncombatants who themselves violate such laws, such as maranders; (3) those who commit treason or hostilities against the enemy in occupancy; (4) deserters and spies. ${ }^{57}$ The treatment of such persons may be rigorous beyond the ordinary rules; they are denied exchange, and mas be tried and punished, always provided the terms of their surrender do not forbid, as faith must be kept eren with traitors. ${ }^{58}$ Pirates are hung because they are enemies of the human race, and spies when caught in the act, to prevent a recurrence of their risits. Napoleon, while a republican general, approved the detention of an emigré who had been sent by the enemy as the bearer of a flag of truce, but no further harm was done him, although Frenchmen considered the prisoner as a parricide. ${ }^{59}$ The British government acquiesced in General Jackson's execution of Arbuthnot and Ambrister, two Englishmen who were condemned by a court martial in $181 \mathrm{~s}$ because they had incited savages to ruthless warfare. Ordinary treason is not a military but a civil offense, and as such triable by due process of law after the conclusion of hostilities. That it is a wise policy to conciliate rather than exasperate the ranquished by such prosecutions was happily illustrated at the close of the great ciril war in the United States. Despite the assassination of President Lincoln and the conflict of his successor with Congress, General Grant was able to hush the attempt made

Field, Int. Code, §§ $824-826$; Am. schli, Mod. Kr., § 139 (640), etc.;

Regulations, 54, 55 .

56 American Regulations, 52, 84, $85,90-2,95,101$, etc.; Blunt-
Calvo, Droit Int.. II, 158-160.

57 Heffter, § 126, IV.

58 Heffter, $\S 128$.

591 Bourrienne, ch. IV. 
to arrest Gencral Lee for treason, and successfully to maintain that the Confederate commander was protected by the terms of his surrender. When there has been what can be properly styled a rebellion, there is, however, no question as to the principle authorizing the rightful sovereign to punish all active rebels whose terms of surrender do not guarantee immunity. ${ }^{60}$ The fact that communities larboring eriminals or abetting their deeds may be punisleed by fine or otherwise, does not justify the practice of mulcting an innocent district because it happens to be their place of abode. Such an offense as that of syying may be extinguished by a suceessful return of its anthor to his own army, while others, like those of assassination, poisoning, perfidy, and eruelty to prisoners, are not so purged or limited.61 As the delictum of sailing under the enemy's pass is not purged by the voyage, both vessel and cargo may be seized after arrival in the United States. ${ }^{62}$ Sex does not enter into the question of guilt or punishment. ${ }^{63}$ Detention of suspected persons by the military is justifiable. ${ }^{64}$ In an extreme case, branding is still permissible among military punishments.

$\$ 527$. Care of the wounded. Neutralization of certain persons and things.-There is a class of combatants whose fate calls for even more eare and sympathy than that of prisoners. While they need only to be gnarded, wonnded soldiers must be removed from the battlefield for surgical aid and nursing, a service often performed during hostilities under a flag of truce. The duty thus begun does not cease with the battle and is not limited to the soldiers of one side. The wounded regardless of nationality are to be cared for by the victor, that is, by him who remains master of the field ${ }^{65}$ and in order to facilitate the work of humanity, physicians, surgeons, nurses, hospitals, ambulances and their attendants and equipments are rexarded as quasi neutral when properly distinguished, as by a red cross on a white ground. Such is the beneficent result of the Genera Convention of 1864 , said to be the outgrowth of "Souvenir de Solferino,"-an article by the Genevan physician Dunant ${ }^{65 a}$ describing the horrors of the battlefield and its hospitals,--just

60 Wharton, Int. Law Dig., § 348a.

61 First Steps Int. Law, 225.

62 The Caledonian, 4 Wheat. 100.

63 Am. Regulations, 102.

64 Luther v. Borden, 7 How. 1.
65 Martens, Précis, VIII, ch. 3, § 15.

65a This is the statement of Bluntschli (Völkk. § 586) who adds that "the first incentive to this treaty, one of the noblest achieve- 
as the organization of the Tentonic Knights for care of the wounded was the ontgrowth of the siege of Acre in $1190 \mathrm{dur}$ ing the Third Crusade. The growing tendency upon the part of combatants to provide for the wounded, and to some extent for suffering prisoners,-especially noticeable since the days of Gustavus Adolphus, himself a pioneer in his care for his soldiers,-has in our own time transformed the Roman maxim, hostes dum vulnerati fratres, into a positire system of recognized duty. The spirit of humanity which is attempting to set limits to weapons and hostilities, and to protect the unarmed residents of the seat of war, is equally careful to cover with the agis of neutralization all who now minister to the physical and spiritual needs of combatants on land and sea. Chaplains, physicians, druggists and nurses are not to be made prisoners so long as they take no part in active warfare, although they may be compelled to aid the wounded of either side if necessary. ${ }^{66}$ By a converse process to that by which munitions of war are enemized, these agents of mercy are neutralized whenever engaged in the noble work for which they have been specially prepared.

$\$ 528$. Geneva Convention of 1864 , supplemented in 1868 , inadequate to new conditions.-The general meaning and intent of the Geneva Convention is always noble, although its wording is sometimes obscure. Under its provisions the wounded may, when practicable, be delivered to the outposts of their army, and, even when cure leaves them nnfit for war, must be sent back home. The provision for paroling them when cure has made them fit for service has, however, proven unwise in practice, and during the Franco-Prussian war was disregarded by both sides. Hospitals and their equipment may be retained by the captors, but ambulances and their equipment and all sanitary officials must be restored to their own army. People giving shelter to the wounded are under special protection and

ments of progressive humanity, was given by an article of Dunant, the Genevan physician, under the title Souvenir de Solferino, wherein he painted the horrible impressions which had been given him by a visit to the battlefield of Solferino and the military hospitals. Moynier, President of the Geneva Society of Public Utility, took up the thought that ambulances should be neutralized; and both friends of humanity applied then to different governments in order to attract their attention to this important question. Everywhere sprang up voluntary associations for the benefit of wounded soldiers and their support."

66 Geneva Convention; Bluntschli, Mod. Kr., § 90 (592a). 
are exempted from military contributions. ${ }^{67}$ The sick and wounded captured at sea are to be similarly treated and sent home on parole, in the absence of some special and imperative reason to the contrary.68 And yet, no matter how humane the intentions of the civilized nations may be, it is to be feared that future wars will involve at least as much suffering as has been witnessed in the past, for the reason that improvement in weapons has exceded that in hospital equipment. To the increase of range, accuracy and rapidity of fire, and the greater numbers under arms, must be added the fact that a single bullet or shell will disable many more people now than formerly. While some authorities consider the new bullet as more humane because it more often wounds than kills, others observe that its greater velocity scatters the liquids of the body in such a way as to produce a result more damaging than that of the tabooed explosive missiles. The increase in the number of the wounded will render it still more difficult to provide sufficient attendants and safe places for hospitals. Even during the Franco-Prussian war thousands were forced to lie on the fields for days; and in the Turkish war of 1877-8, and in the American-Spanish and the Boer wars like conditions prevailed. If every increase in range or other improvement in firearms shall heighten the difficulty, Prof. Bilroth mas be correct when he says that in order to be perfectly efficient the sanitary corps must equal the combatants,-which is of course impracticable. Should future wars between wellarmed nations become more and more bloody ${ }^{69}$ international law must improve upon existing remedies. That the Convention of Geneva is already inadequate to the new conditions is evidenced by the fact that its adoption at The Hague was coupled with a iall for its revision. ${ }^{70}$ The vital principle has, however, been firmly settled. It will never more be necessary, unless in the far East, to debate as Napoleon did in Syria the propriety of poisoning the wounded rather than leave them to the merey of the enemy. ${ }^{i 1}$

67 Geneva conventions; given in Wharton, § 348; Davis, Int. Law, 429 , seq. See also Bluntschli, Mod. Kr., § 81 (586), et seq.; Maine, Int. Law, 156.

6s Id.; see also Bluntschli, Mod. Er., $\S 90$ (592a).
69 Bloch's Future of War, Part 1 , chapter VII.

70 Hague Second Convention, Art. XXI; Holls' Peace Conference, 377.

711 Bourrienne, ch. XIX. 


\section{LAWS OF WAR AS TO ENEMY PROPERTY ON LAND.}

$\$ 529$. How far property of the enemy, public and private, may be appropriated during war.-As belligerents apply force to each other in order to exact damages for and security against wrongs, real or assumed, the seizure of the enemy's territory or other property is an effectual means to that end. In fact it may be said that war implies primarily the direct exercise of force against property, while it ealls for force against indiriduals only incidentally, so far as they resist its application to the former. ${ }^{1}$ It will be necessary, therefore, to consider here how far property of the enemy, public and private, may be used or appropriated during war. The general principle is that only such property is affected as is susceptible of military use, or capable of 'strengthening the enemy, a principle whose application involves distinctions not only between property of the state and that of the subject, but also between different classes of subjects, and between different kinds of property, even though belonging perhaps to the same person. Consideration will be given, first, to the method of seizure or capture; second, to the property subject to such appropriation, with reference to the class to which it belongs. The administration of captured property, when it assumes the form of a district or territory, will be treated in the chapter specially deroted to military occupation and administration.

$\$ 530$. When title to personal property captured on land passes. - The title to personal property captured on land is now supposed to pass from the moment of capture. Under the Romans it was not complete, on land or sea, until the goods were brought into a safe place, perductio infra presidia, locum tutum; en loch salvo, according to the Consolato. Only then did it become proof against recapture. While it is generally stated that from the sixteenth century the rule has been that title passed after twenty-four hour's' possession, Bynkershoek ${ }^{2}$ denies that such a rule ever existed anywhere except in the imagination of Grotius. As to ships it was adopted, however,

1 Twiss, Law of Nations, War, III, c. $6, \S 3$, n. 1 and 2 ; BynkerPreface. shoek, Quaest. Jur. Pub., c. IV;

2 Grotius, De Jure Belli ac Pacis, Goss v. Withers, 2 Burr. 683. 
by the French ordinance of. 1799 ; and it is a part of the present Irussian law as to personal property on land. The Code Sapoleon established or reaftirmed the principle of actual detention as determining title; and then, if not before, the twenty-four hours rule ceased to prevail except on sea. ${ }^{3} \quad$ land capture is perfect, therefore, as soon as the property is seized or taken from hostile possession under order's of a commanding officer and reduced to firm possession; and a subsequent sale is good even against the former owner." While reduction to possession of a city or district involves a more complicated process than the seizure of a musket, each case is governed by the same principle, analogous to that involved in adverse possession, which, although varying with the object in question, must in all cases be suited to the particular property. In that respect, it makes no difference whether the property is public or private, real or personal. As a general rule public property passes instantly to the conqueror as the result of his victory, while private property does not until its proprietor is ousted by forcible acts in his individual case. The principle thus remains unaffected that whatever divests the possession of the original owner and substitutes the military in his place is a good capture.

\$531. State personal property subject to seizure as booty.When we consider what property is subject to valid capture, and what disposition is to be made of it after it has been reduced to possession, the nature of the object becomes important. As to personal or movable property belonging to the opposing state as such, it may be said that everything may be appropriated or destroyed by the invading army so far as it is useful for military operations. Money, arms, stores, supplies, ships, means of transportation or communication, and everything else directly serviceable in warfare is regarded as booty (pradia bellica, kriegsbeute) which may be used, destroyed, $\mathrm{or}^{\mathrm{P}}$ otherwise disposed of at will. Because of their public character, railroads, rolling stock, steamers, telegraph and other means of communication are dealt with in the same way even though owned by citizens and not by the state, subject to the

3 Calvo, Droit Int., II, 174; Martens, Précis, VIII, ch. $3, \S 11$; Hall, Int. Law, 472; Bynkershoek, Quaest. Jur. Pub., ch. IV.

4 Alexander v. Duke of Wellington, 2 Russell \& Mylne, 35; U. S. v. Padelford, 9 Wall. 540; Lamar v. Browne, 92 U. S. 195; Young v. U. S., 97 U. S. 39; Coolidge v. Guthrie, 8 Am. L. Reg., N. S., 22. See Field, Int. Code, $\S 843$; Heffter, $\S 136$. 
owner's right to have them restored at the end of the war with indemnity for their use. ${ }^{5}$ Telegraphs and cables within mili. tary zones may also be seized, operated, or destroyed, or their business subjected to military supervision or censorship, even though owned by neutrals, so far as necessary for war operations. The Manila cable was cut during the recent war, and the Americans even attempted to isolate Cuba by severing all cables leading from that island. ${ }^{6}$ Postoffices may be seized, and as in Napoleon's time mails may be opened at will to gain information. Taxes, dues, tolls and other regular or special revenues may be collected and used, although, under existing rules, they must be first applied, as far as possible, to the administration of government on substantially the same scale as under the prior legal gorernment. ${ }^{7}$ Arms, horses, and the like may be appropriated from enemy soldiers, but not money or personal property, except that the dead may be despoiled when such goods would have to be buried or otherwise lost. Flags, cannon, munitions, military chests and all other military articles become the property of the army or state, according to Grotian maxim, bello parta cedunt reipublica. The ownership in captured articles the Roman Law gave to him who first took possession; "quod maxime," says Gaius, "sua esse credebant quae ex hostibus cepissent." When the right to take booty, now strictly limited by the necessities of military operations, is exercised at all, the fruit usually becomes the property of the state or the army as an organism. While such is the general rule, an exception still exists in faror of the indiridual captors as to moner, clothing, ntensils and the like found on the battlefield, but not as to money or valuables on prisoners, ${ }^{8}$ nor as to bells, which under a curious old rule used to go to the chief of the besieging artillery. ${ }^{9}$ In Great Britain, by the terms of 3 and 4 Vict., ch. 65 , sec. 22 , booty, like prize, is within the jurisdiction of the Admiralty Court, which passes on questions of co-operation on land as on those of joint cavture at sea. ${ }^{10}$

532. Dangers of pillage and its abolition.-At Waterloo Napoleon owed his escape to the fact that the Prussians nearest to him were so busy pillaging camp equipages that they 53.

5 Hague Second Convention, Art. $\S 1$, etc.; Heffter, $\S 130$; Gaius, IV,

6 See Am. Naval Code, Art. 5.

7 Ib. Art. $48,49$.

8 Calvo, II, 184; Digest, Lib. I,
16; Am. Regulations, 72 .

9 Heffter, § 135 and note.

10 Construed in Banda \& Kir-

wee Booty (1866), 1 L. R. Adm. \& Ec. 109. 
did not see him. Even in the Franco-Prussian, the last great war between civilized powers, there was much ground of complaint. While the Germans claim that the "Recneil de documents sur les exactions" is exaggerated, Geffclien admits that the "Retten und Rollen" of the second half of the war was a great wrong, similar to the excesses of the Prussians about Paris in 1815. Much must be attributed, however, to a spirit of revenge against the French growing out of their conduct in Prussia under Davoust and Clarke. Although in the RussoTurkish war of 1877 , which was to some extent, as Thier's expressed it, a war between two barbarians, no advance was made; in the Boer war, particularly on the British side, private property was more respected. That such respect is no less in the interest of policy than of morals elearly appears from the terms of Napoleon's proclamation before landing in Egrpt, in which he wisely said that "pillage will only destroy our resources, for it converts into enemies the people whom it is our interest to have for friends." ${ }^{11}$ By The Hague Conference pillage was absolutely prohibited $i_{2}^{12}$ and it is to be hoped, despite discouraging instances to the contrary occurring during international expeditions into China in 1900 , that it will soon disappear from the practice of civilized nations.

$\$ 533$. Exemption in favor of holders of public securities.While war acts as a suspension of the right of private citizens of one country to sue citizens of another, states, on grounds of public faith and policy, do not permit war to interfere with the parment of their own public debt, even to enemies. When in 1854 Great Britain was asked because of war with Russia to repudiate the moiety of a Russian-Duteh loan, assumed on the fall of Napoleon in consideration of retaining the Dutch colonies, a motion to that effect was emphatically negatived in Parliament. ${ }^{3}$ Such a guarantee in favor of public funds has caused much surplus capital to be thus invested the world over. Although the capture of the evidence of debt does not give to the captor as assignee the right to collect, possession of both evidence and owner would accomplish that result after the final subjection of such owner had made the conqueror its universal successor. ${ }^{14}$ Unless there is annexation or other

111 Bourrienne, ch. XIII.

12 Hague Second Convention, Art. 47.

${ }_{13}$ Twiss, Law of Nations, War,

$\S 58$; Maine, Int. Law, 203, 206;
Vattel, Droit des Gens, III, ch. 5, §

77. As to the Silesian loan, see above, p. 442 .

1+ Vattel, Droit des Gens, III, c. 11, § 112; 3 Phill. Int. Law, § 561-2; 
full and permanent conquest there is no power atequired to remit a public debt. ${ }^{15}$ There must be something more than mere temporary occupation to create that right. On the other hand, if the legal government has sold public property on installments, the oceupying state camnot appropriate the payments as they mature, representing as they do the principal, that is, the property which when in specie was exempt from appropriation. ${ }^{16}$

$\S 534$. Exemption in favor of works of art, libraries and museums.-It is now generally conceded that worls of art and the contents of museums, even though public property, are not to be seized as booty. They must be protected, not removed. ${ }^{17}$ This very modern view is not recognized, however, by the American Regulations, which provide for the seizure and removal of such objects if practicable, when they are the property of the government. While the Romans recognized a still more stringent rule in their earlier practice, as many articles eren now in Italian collections witness, they were so far converted to the more civilized view, that, when the time came for their own territories to be orerrun, Belisarius endearored, though in rain, to restrain the destroring hand of Totila. Venice in her glory was adorned with foreign spoil; and Napoleon during his campaigns accumulated in the Lourre the choicest treasures of Europe, particularly of Italy, which the pasquinade said should have been sculptured by Canova not as draped but stripped. The treaty which restored Louis XVIII left these articles undisturbed, and the Allies do not seem to have thought of them until the second oceupation of Paris in 1815, when Napoleon, the only one who could have resisted their reappropriation, was a prisoner. Then it was that Wellington declared this "spoil to be contrary to the practice of civilized warfare," and with Blïcher held that the Allies should restore all such acquisitions to their original owners. ${ }^{18}$ But when the effort was made to give effect to that resolve by the forcible remoral of such articles from the Louvre, a doctrine kindred to cy pres was invoked in order to

Halleck, Int. Law, 451-3. As to Alexander and the Thessalian debt, see post, Termination of War.

15 Grotius, De Jure Belli ae Pacis. III, ch. VIII, $\S 4$; Calvo gives several instances in point, Droit Int., II, 205, etc.
16 Heffter, § 133, Geffcken, n. 3.

17 Halleck, Int. Law, 439, 454. 456; Am. Regulations, 36.

18 Wellington's Despatch, September $23,1815$. 
enable any one of the Allies who had then absorbed the original owner to appropriate on return all works of art belonging to him,-a rule under which the Vatican aequired many treasures which had been in abolished or changed religious houses. A restoration to true owners of such things as had been acquired as booty would have been fair enough, especially if the Allies hatd been willing to release all their own acquisitions of a similar nature, except for facts peculiar to this case explained in part by Romilly.19 Not only had many of the articles in question been acquired by express treaties; but there was not a country represented among the Allies that had not at some time concluded treaties with Napoleon expressly or impliedly recognizing the identical or like acquisitions. Those treaties should have been respected and only such objects removed, if any, as now became legitimate booty of the Allies ontside of their terms. If such treaties were made under duress, so is almost every one concluding a war. The fact is that Wellington seems to have rested the removal more upon the ground of giving France a "great moral lesson" of the strength of united Europe than on principle of any kind. ${ }^{20}$ On the other hand the Germans during their occupation of Versailles in 1871 set a noble example, not only by not taking anything away, but by keeping everything under guard. ${ }^{21}$ In America at a much earlier day Dr. Croke, of the vice-admiralty court at Halifax, restored to the Philadelphia Academy of Arts the Italian paintings and prints captured by a British cruiser in the war of 1812,22 and, as the same rule now applies to libraries and museums of all kinds, a like decision was rendered by a United states District Court in Pennsylvania during the civil war as to two cases of books consigned to the University of North Carolina. ${ }^{23}$ Before such a rule existed the love of literature often led to the appropriation of libraries by the conqueror. In the Thirty Years' War even Gustarus Adolihus after Würzburg was stormed sent the cathedral library to Cpsala by way of reprisals for the taking of the more precious library of Heidelberg to the Vatican; and at a later day he made Oxenstiern a present of that at Mayence,

19 Romilly's Life, 404; 32 Hansard, 759,760 .

20 See the despatch, No. 997, p. 897 in Gurwood's collection.

$\because 1$ Bluntschli, Mod. Kr.. $\$ 150$ $(650)$, etc.
22 The Marquis de Somerueles, Stewart's V. Ad. 445, 482 (Nov. Sco.).

23 The Amelia, 4 Phila. 417, 1 Fed. Cases, 595. 
with the result that it was lost in the Baltic with the ship in which it was embarked. In the sack of Prague by Königsmarck, after the King's death, Ulfilas' famous Gothic manuscript of the Gospels was taken from the Jesuit college and sent to the library of Cpsala, where it still remains.

\$35. Right of occupying army to use state property. Its alienation.-Public lands and buildings, with their incomes, are subject to use for public purposes by the occupying army, but not to injury or destruction,- - use in their case being a different thing from capture. Parks, monuments, arehives and the like, which are not prize of war, are to be guarded and administered. According to the rule adopted at The Hague, the occupving state shall only be regarded as administrator and usufructuary of the public buildings, real property, forests, and agricultural works belonging to the hostile government, and situated in the occupied country. Such state must protect the corpus of these properties, and administer it according to the rules of trusteeship.st When in the fall of 1814 the British general Ross, acting under strict orders from home, occupied Washington and destroyed the capitol, president's home and nary yard, as Admiral Cochrane had burned Havre de Grace and Georgetown on Chesapeake Bay the year before, the excuse was that the American troops had burned Newark, Long Point and St. David in Canada. As retaliation in kind was not justifiable even if the United States had not disavowed such acts and punished their authors, the occmrence was reprobated by Englishmen, as well as by Americans. ${ }^{25}$ On April 11, 1815, Sir James Mackintosh called the attention of Parliament to the fact that while during the preceding twenty-five years every capital on the continent of Europe had been occupied without injury to state property, it had been reserved for Great Britain to destroy in the capitai of the United States objects exempt among civilized nations from the ravages of war. ${ }^{26}$ About the same time Blücher. if he had not been restrained by the Allies, would hare committed a like atrocity by blowing up the Bridge of Jena and the Column of Austerlitz. In striking contrast stands the notable

24 Hague Second Convention, shameful acts are recorded in our Art. 55. history," and even Alison admits

25 Twiss, Law of Nations, War, \& 69; Calvo, Droit Int.. II, 178 . 180; Green says in his History of the English people: "Few more it tarnished the luster of the victory. See also Maine, Int. Law, 19s; Wharton, Int. Law Dig., 31s, 249. 2630 Hansard, Debates, 526-7. 
example of Emperor Francis, who, when he ordered the execution of Napoleon's designs for the Simplon arch, despite the fact that one of them showed Napoleon at Vienna, contented himself with simply adding another showing him also at Fontainebleau. In somewhat the same spirit, after the French had erected a fountain at Coblenz with a boastful inscription as to the invasion of Russia then begun, the Russian general Priest, crossing two years later in the opposite direction, added "Vu et approuve," with his name and office,-thus bringing history up to date. ${ }^{27}$ Prussians in France in 1870-1 and English and French at an earlier date in China were less considerate. When after the close of the Franco-I'russian war, the French stopped the contractors to whom the Germans had sold for cash during their occupancy the right to cut from the public forests near Nancy, the latter assented to the correctness of the French position. All rules designed to prevent devastation are most often violated during civil wars, because of hatreds engendered by counter accusations of treason and oppression. During the American civil war, which constitutes no exception, many acts of vandalism occurred, especially in the South, the main seat of hostilities.28 The same humanity should, however, be exacted in all wars; and the difficulty of securing it only makes the duty the more imperative.

While it is sometimes denied that lands and other property in the hands of the conqueror can be sold or otherwise alienated, it is probably more correct to say that such alienation is inchoate until the issue of the war settles the ownership. If confirmed to the alienor, his disposition of it is ratified; if otherwise, it is invalid. In neither event can the subject of the original owner become the purchaser unless his allegiance be also changed.

\$536. Exemption of churches, cemeteries and the like.Churches, hospitals, schools, and charitable institutions of all kinds are entitled to protection. The buildings may be used temporarily for needs of the conqueror, although alien to their purposes, but the property must not be injured, and shall either remain in custody of the owners or be ultimately returned to them in good order after its temporary use has

27 Baedeker's Rhine, p. 95.

28 See White's Lee, 289, 397 n., 408; and Calvo, Droit Int.. II, 177, 182 , where he speaks of "les exces sanglants qui ont marqué les luttes de la Pologne contre la Russie, ainsi que la guerre de secession aux Etats-Unis." 
ended. ${ }^{29}$ While to Christianized Rome sepulcra hostium nob is religiosa non sunt, ${ }^{30}$ cemeteries and their monuments are now sacred. It is to be hoped that the Royalist desecration of Cromwell's remains and the Republican violation of the tombs of St. Denis will never have a parallel. In the hope of prerenting such excesses, more characteristic of race wars than of those between civilized nations, The Hague Conference declared that the property of the municipalities, that of religious, charitable, and educational institutions, and that of art and science, eren when state property, shall be treated as private property. All seizure, destruction, or intentional damage done to such institutions, to historital monuments, works of art or science, is prohibited, and should be prosecuted. $^{31}$

\$53. Exemption of private property.-Private property according to existing rules is treated even more favorably than that of the public. Except in extreme cases, to be mentioned hereafter, it is both respected and protected. At The Hague it was declared that family honor and rights, individual lives and private property, as well as religious liberty and worship, must be respected. Private property cannot be confiscated. ${ }^{32}$ Such regard for private property is, however, of modern date. The Greeks, unlike the Hindoos, sometimes eut down even olive vineyards, and the agreement of Maréchal Brisac with the Spanish general in 1552 to spare forests is famous because exceptional. ${ }^{33}$ Grotius did not rise higher than the Roman principle that, as an enemy had no rights, property formerly his can be appropriated because without an owner. "Gustarus Adolphus, who kept a copy of Grotius by him in camp, did not act on that theory, preferring to set his face against "pilfering and spoiling," while his contemporary Wallenstein was earning the title of prince of plunderers. All private property, even that of the individual sovereign, is now respected, at least in theory, and booty therein is not permitted. ${ }^{34} \mathrm{As}$ ' $/ \mathrm{ach}$ ariä expresses it, private property of the enemy can be touched only so far as the necessities of war require, for it is part of

29 Am. Reg. 34; Bluntschli, Mod. $K r ., 148$ (648), etc.; Maine, Int. Law, 195.

${ }^{30}$ L. 4 D. de sep. viol.; L. 36 D. de relig.

31 Hague Second Convention, Art. 56 .
32 Second Convention, Art. 46.

33 Bluntschli, Mod. Kr., §§ 161 (661), 163 (663).

34 Am. Reg. 88; Bluntschli, secs. 152 (652), 157 (657); Frederick II, Oeuvres, XXVIII, 91; White's Lee, 200, 228, 286, 289. 
the wall power of its country only so far as that country could itself exercise dominion over it. ${ }^{35}$

$\S 538$. Requisitions.-Quarters, food, forage, supplies, clothing, fuel, arms, horses, draft animals, transportation, cattle, and similar necessities may under the name of requisitions be taken by an army from private citizens. Inhabitants, such as carpenters, smiths, drivers, tradesmen and laborers, may be compelled to work for military purposes, and soldiers may be billeted in private houses. While nothing not a military necessity should be taken, if the army chest runs low, even money in banks is sometimes appropriated, as in the notable example given by Daroust at Hamburg in 1814. It was the practice of Frederick II to direct that such supplies should be contributed gratis, ${ }^{36}$ and that has been the general rule, to which the Mexican and Crimean wars present exceptions, the former, however, only through the exercise of General Scott's personal influence. ${ }^{37}$ Although a state may decline during war to pay any money to its opponent, it should do so if it is due citizens, because in that form it is impressed with the character of private property. ${ }^{38}$ In accordance with that idea, the theory, at least, is now settled that requisitions shall be paid for or that vouchers (bons de requisition), signed by proper officers, shall be given to the owners of the property so appropriated, ${ }^{39}$ entitling them to future remuneration by the enemy or their own country. Heffter, Bluntschli, De Garden and Calvo hold ${ }^{40}$ that international law requires such payment, and The Hague Conference has sanctioned this riew by declaring that neither requisitions in kind nor services can be demanded from communes or inhabitants except for the necessities of the army of occupation. They must be in proportion to the resources of the country, and of such a nature as not to involve the population in the obligation of taking part in military operations against their country. These requisitions and

35 See Heffter, $\S 130$, n. 7 .

36 Oeuvres 28, p. 91.

37 General Orders, No. 358, Nov. 25 , and Dec. 31,1847 . While the American generals were permitted to use their discretion in the enforcement of the right of requisition, its existence was expressly affirmed in the instructions under which they acted. See Mr. Marcy's Instructions to Gen. Taylor quoted by Halleck, ii, 112. The Treaty of Guadalupe Hidalgo provided that in future hostilities requisitions shall be paid for "at an equitable price if necessity arise to take anything for the use of the armed forces."

38 Bluntschli, sec. 158 (658).

39 Am. Regulations, 38 .

40 Calvo, Droit Int., II, 189-190.

Marcy in the Mexican War denied 
services shall only be demanded on the authority of the commander in the locality occupied. The contributions in kind shall, as far as possible, be paid for in ready money; if not, their receipt shall be acknowledged. ${ }^{41}$ Wellington gave such receipts after Waterloo, not as guarantees of future payment, but as evidence that requisitions had already been made upon their holders for provisions and forage. Napoleon was guilty of excessive requisitions, and he lived to attribute his reverses in spain to such conduct there. ${ }^{2}$ The daily supplies requisitioned by the Germans at Versailles are said to have been 120,000 loaves, 80,000 pounds of meat, 90,000 pounds of oats, 27,000 pounds of rice, 7,000 pounds of roast coffee, 4,000 pounds of salt, besides 20,000 litres of wine and 500,000 cigars. ${ }^{43}$ From official reports it appears that in the thirtyfour invaded departments damages proven amounted to 141,000,000 francs from fire and the like, and $264,000,000$ francs from the loss of personal property taken without requisition, say $\$ 80,000,000$ in all lost without remuneration. Wine and cigars were almost always exacted as a part of such requisitions, especially champagne for the officers, articles which can scarcely be classed as necessities for the support of the invader.

$\S 539$. Distinction between requisitions and contributions. Washington.--There is a distinction between requisitions and contributions, the former being levied in kind, as supplies or services for the army, the latter as gifts really exacted as much by force as requisitions, with the advantage to the invader that they are never to be accounted for. In their origin contributions were a substitute for plundering,mutation for booty, generally but not necessarily in money. ${ }^{44}$ Although Gustavus Adolphus, exceptionally mild for his time, punished plunderers with death, he did not hesitate to lery forced contributions, as at the surrender of Mayence, where he imposed a contribution of $\$ 160,000$, of which half was paid by the clergy. At Munich and elsewhere he was equally exacting. Bluntschli's contention that contributions were

that international law required payment.

41 Hague Second Convention, Art. 52 .

42 Calvo, Droit, Int., II, 183, 187. On page 194 Calvo states that the French contributions in 1870-1 were 39 million, imposts 49 million, requisitions 327 million francs, making the same total of 415 millions. See also Hall, $444 \mathrm{n}$.

${ }^{43}$ Halleck (Baker ed.) ii, p. 73, note.

44 Calvo, II, pp. 188, 194. 
abolished with the booty for which it is a substitute was not sustained by the Brussels Conference, which, after his book was published, sanctioned them with the proviso that they should be levied by commanding generals only. The same lim. itation was imposed by The Hague Conference, whose rule provides that if, besides the taxes mentioned, the occupant levies other money contributions in the oceupied territory, this can only be for military necessities or the administration of such territory. No contribution shall be collected except under a written order and on the responsibility of a commander-inchief. ${ }^{45}$ This collection shall only take place, as far as possible, in accordance with the rules in existence and the assessment of taxes in force. For every contribution a receipt shall be given to the person paying. ${ }^{46}$ By the irony of history the origin of the word "requisition" has been attributed to that most considerate of generals, Washington, ${ }^{47}$ although the practice is as old as war itself. In his time requisitions were first employed by the Assembly of Massachusetts, for the purposc of regularly supplying his army around Boston with firewood and hay from the towns not more than twenty miles distant. ${ }^{48}$ The word generally used by Washington is "contribution," as when in 1767 he directs Hamilton to procure from the inhabitants of Philadelphia "contributions of blankets and clothing * * in proportion to the ability of each." 49 It is true that he does speak repeatedly of "specific requisitions," the constitutional phrase then employed to describe the requisitions of Congress on the several states for provisions, - a phrase applicable to demands for supplies made bs the general on local gorernments, but not to forced supplies exacted by military chicfs from the countrr. ${ }^{50}$ He seems to have used the term "forage" oftener than any other to indicate the process of collecting supplies, such as hay, grain, cattle, hogs, sheep, and horses, for which he directed receipts to be given. ${ }^{51}$ When referring to its application to his own people he speals of it as "assessinga proportion of the productions of the earth," and he

45 Bluntschli, $\$ \S 154-5(654-5)$; tions is provided for in Art. 48. Twiss, War, $\$ 64$.

46 Hague Second Convention, Arts. 49 and 51. Mr. Holls (p. 449) has fallen into an error, which is liable to create confusion, by translating "contributions" as "taxes." Their collection as distinguished from that of contribu47 Halleck, pp. 459-460; Hall, $443 \mathrm{n}$; Calvo, II, pp. 188. 48 Washington Works (Sparks), III, p. 190, n. 49 Ib. V, 67. 50 Ib. VII, 158 and often. 51 Ib. VII, 173, in 1780. 
condemns it as ineffectual, burdensome and oppressive. ${ }^{52} \mathrm{~A}$ different yet very effective kind of contribution was that levied by the United States military authorities during the Mexican war on imports, neutral and even American, into Mexican ports. $^{53}$ Scott's lery of $\$ 150,000$ for his soldiers on occupying the City of Mexico was, however, of the older type, and the fund resulting therefrom was devoted afterwards to the founding of a Soldiers' Home at Washington. ${ }^{54}$

$\$ 540$. Confiscation and sequestration.-The right of confiscation has been fully upheld by the United states supreme court, whether it be applied to property on land or to cargoes afloat in American ports, ${ }^{55}$ when authorized by an act of Congress. Such legislation as that of July 13, 1861, A ugust 6, 1861, July 17,1862 , and March 3,1863 , is not objectionable eren when it confiscates the property of loyal adherents of the United States, their residence in the enemy's country making them enemies also. ${ }^{56}$ While these acts contain some provisions subject to constitutional limitations because enforcible under the municipal powers in the Constitution, the general right of confiscation flows from the war powers of Congress, which have no limitations except those recognized by international law. Confiscation of property or stocks, as well as the freeing of slaves, are war rights conferred by those acts.57 If the invader is a slave-holding state, its occupation makes no difference in the condition of slaves. If, on the other hand, the invader does not recognize slavery, his occupation puts slaves in an intermediate position, amounting to emancipation only in the event the territory is permanently retained. The Czar of Russia thus solred the question submitted to him as arbitrator between England and the United States after the war of independence. ${ }^{58}$ The American Regulations go further, however, and provide that fugitive and captive slaves become free and are beyond any question of postliminy. The freeing of slaves by proclamation of President Lincoln has been justified as a war measure on the ground that slaves are contra-

52 Ib. VII, 369 (1781).

53 Wharton, Int. Law Dig., § 339 .

549 Stat. Large, 596.

55 Brown v. U. S. 8 Cranch, 110 , and 228, 229; The Emulous, 1 Gallison, 563; Kent, Commentaries, 56-60.

56 U. S. Stat. Large, 255, 319, 589, 762; Miller v. U. S. 11 Wall. 268.
57 Miller v. U. S. 11 Wall. 268, 305, 309, 311; Tyler v. Defrus, Id. 331. The Confiscation Cases, 20 Wall. 92 , and a number of others deal more with procedure than principle.

$5 s$ Calvo, Droit Int., II, 170; Am. Regulations, 43 . 
band, and the result was clothed with legality by the subsequent amendment of the Constitution declaring that neither slavery nor involuntary servitude, except for crime, shall exist in the United states. If the Southern Confederacy had triumphed the proclamation would have been of no effect, of course, in law or fact. Debts between individuals of belligerent states may be confiscated by special legislation, as by both grovernments during the American civil war, and such action will be sustained to the extent parment has been actually compelled. Confiscation during mere military oceupation of the enemy's conntry is so far upheld as to excuse the debtor from second payment when he shows vis major, but not otherwise.59 The requisites are (1) proof of parment, (2) that the debt was due, (3) that payment was not delayed by the debtor, and (4) that there was compulsion, either by actual force or by threatened punishment.60 Although it was declared in 180T, in Wolffe r. Oxholm, that the confiscation of private debts is invalid, story held in 1814 just the contrary. Confiscation is now confined almost exchusively to civil wars, involying the question of allegiance. ${ }^{61}$ The principle underlying the right of confiscation must not be confused with that which justifies the destruction or seizure of buildings for military use; or with the rule providing, that, if non-combatants fire on troops from dwellings or otherwise use them for hostile purposes, these may be demolished as a punishment. Confiseation is usually enforced not as a penalty but a supposed military necessity. While its employment can never be justified as a means of extinguishing the title to real property simpiy becanse it belongs to an alien enemy, the income of such property may be sequestrated to prevent its remittance to the enemy's country.62 sequestration differs from confiscation in that it does not divest property, and only suspends remedies during the war. ${ }^{63}$ It may, therefore, be said that the three exceptions to the rule commanding that private property shall be respected are embodied in the toleration (1) of booty, in the limited form in which it survives, (2) of contributions and requisitions, and (:3) of penalties and confiseations.

$\S 541$. Right of seizure as affected by owner's domicil. - Is

a Bynkershoek, Quaest. Jur. Pub. ch. VIII; Calvo, Droit Int., II, 206.

60 First Steps Int. Law, 352.

61 Maine Int. Jaw, 202; See Hamilton's Camillus Letters.
62 Vattel, Droit des Gens, III, ch. 5 , $\$ 76$; III, ch. $13, \S 200$.

63 Georgia v. Brailsford, 3 Dallas 
stated heretofore domicil is so important in distinguishing friend from foe that a neutral domiciled in one belligerent country thereby becomes the foc of the other belligerent. In the matter of the Laurents, who had money in the Mexican treasury to pay for confiseated church property for which that government had not delivered a deed, General scott confiscated the fund as public property, and it was held by arbitrators that it was rightfully subjected, because its owners were pro hac vice Mexicans. ${ }^{64}$ The rule may be so extended as to make a subject or citizen an enemy even of his own country for certain purposes. While such domicil does not necessarily change his eitizenship or his permanent allegiance, or affect him criminally at all, it may make him an enemy so far as concerns his property connected with his residence. It may stamp enemy character upon such property, and in that way subject it to the treatment awarded to that of an enemy, ${ }^{65}$ a rule extensively applied by the Federal authorities during the American civil war. In that struggle neither the neutrality nor loyalty of cotton owners prevented the military seizure of their property, howerer strongly such facts may have appealed to the legislature for compensation afterwards. ${ }^{66}$ On the other hand, so long as he does not forfeit his privileges of neutrality by participating in active hostilities, even an enemy domiciled in a neutral country is a neutral, and his property there is also neutral. Thus an American residing in the Danish island of St. Thomas, who traded with the French colonies while France and United States were hostile, was protected by his neutral residence. ${ }^{67}$ The share of an enemy in a partnership, doing business in a neutral country is, howerer, subject to seizure. ${ }^{68}$ On the continent of Europe, where the nationality of the owner controls rather than his domicil or the accidental location of the property itself, ${ }^{69}$ different principles prevail.

64 Calvo, Droit Int. II, 210. The Ann Green, 1 Gallison, 274.

65 The Venus, 8 Cranch, p. 253; 2 Wheaton Rep., App. Note I, p. 27; The Danous, 4 Rob. 225, n.; Miller v. U. S., 11 Wall. 268; Woods v. Wilder, 43 N. Y. 164.

66 The Vigilantia, 1 Ch. Rob. 1; The Immanual, 2 Ch. Rob. 148; The Anna Catherina, $4 \mathrm{Ch}$. Rob. 107; The Rendsborg, 4 Ch. Rob. 121; The Vrow Anna Catherina, 6 Ch. Rob. 269; The Dree Gebroed- ers, 4 Ch. Rob. 235; The Phoenix, 5 Ch. Rob. 20; The Jonge Klassina, 5 Ch. Rob. 299, 303; Hhd. v. Boyle, 9 Cranch, 191, 197; See also Calvo, Droit Int., II, 48 et seq.; Wharton, Int. Law Dig., §§ 203, 224-8, 353, 373.

67 Murray v. Charming Betsy, 2 Cranch, 120.

68 The Antonia Johanna, 1 Wheat. 159; The Friendschaft, 4 Wheat. 109.

69 Calvo, Droit Int., II, 59; Heff- 


\section{$\$ 542$. Right of seizure as affected by situs of the property} itself.-As property situated in the enemy state is so far personified as to be treated as enemy property, even though the owner is friendly or a neutral and resides in his own country, ${ }^{70}$ it appears that the situs of the property itself must sometimes be considered independently of the domicil of the owner. The reason of such a rule is to be found in the fact that as the wealth of a nation is made up of the property of all its residents, everything permanently within its bounds is liable through taxation or otherwise to support the government carrying on hostilities. Justice requires that all property should be equally subject to the fortunes of war, regardless of the actual allegiance or residence of the owners, whether belligerent, neutral or loyal, and that the products of the soil should be placed in the same category as the soil itself. ${ }^{71}$ While in the case of a neutral confiscation relates only to property in the enemy domicil, in the case of an enemy by domicil all his property is liable, wherever it can be seized. Because citizens wishing to withdraw their property from an enemy's country must do so seasonably, ${ }^{2}$ it might be inferred that conversely an enemy's property in a neutral country would be protected. Upon the contrary, whenever it can be reached it is captured; its neutral location does not make it neutral. ${ }^{3}$ Even the hostile use by the enemy of neutral property makes it subject. to capture, although the owner or master derotes it to such use only while acting under duress. Neither state courts nor prize courts can enter into such questions between individuals and the other country; when they ascertain that certain property was used by or for the enemy state, they must act accordingly. And so in the case of the transport of an official or dispatches from an enemy port $;^{74}$ of a neutral sailing under

ter, $\$ 124$, Geffcken note 1 ; Bynkershoek holds to the English rule in Quaest. Jur. Pub. ch. III.

70 The Vigilantia, 1 Rob. Adm. p. 1; The Susa, 2 Id. p. 255; The Portland, 3 Id. p. 41; The Jonge Klassina, 5 Id. pp. 297, 302; The Johanna, 1 Wheat. p. 159; The Friendschaft, 4 Id. p. 105; Mrs. Alexander's Cotton, 2 Wall. 404; The Venus, 8 Cranch, 253; The Hiawatha, Blatchford, Pr. Cases, 1. 16; The Mary Clinton, Id. 556; The Anna Catherina, 4 Rob. 119;
The Gray Jacket, 5 Wall. 342; The Mary and Susan, 1 Wheat. 46; Calvo, II, p. 54; Bentzon v. Boyle, 9 Cranch, 191.

71 Vattel, Droit des Gens, I, ch. 14, sec. 182; Prize Cases, 2 Black, 635; The Cheshire, 3 Wall. 231; The San José Indians, 2 Gall. 268. 72 The St. Lawrence, 9 Cranch, 120; The Mary, Ib. 126; The Gray Jacket, 5 Wall. 342; The Wm. Bagaley, 5 Wall. 377.

73 The Venus, 8 Cranch, p. 253; Calvo, Droit Int. II, 54.

74 The Carolina, 4 Ch. Rob. 261; 
the enemy's license or conroy, or otherwise identifying himself with the enemy; or even in the case of citizens of a belligerent country allowing their property to be found under an enemy's flag. ${ }^{75}$ Such rules apply equally to merchants who are consuls of neutral states. ${ }^{6}$ Although France and Russia recognize the sale of a ship to a neutral only when complete before declaration of war, England and America uphold it at any time if bona fide and absolute. ${ }^{77}$

$\S 543$. When cotton or other articles may be "constructive contraband."-Striking instances of property personified as an enemy, eren by both sides, occurred during the American civil war, in which cotton, and in a lesser degree sugar, rice, and tobacco, although privately owned and without a military character, were treated as subject to capture by the Federals and to destruction by the Confederates themselves whenerer such capture seemed probable. The legality of such a proceeding was recognized by legislation on the one side, ${ }^{78}$ and by practice on the other. Rather than permit cotton, the chief reliance of the Confederacy for the purchase in Europe of munitions of war, to fall into the hands of the Union forces, the Southern armies devoted it, however owned, to destruction. It is estimated that a stock, to the value of $\$ 80,000,000$ was destroyed in that way at New Orleans just before its capture by the Federal forces. When captured by such forces, it was appropriated and sold, regardless of ownership, by the government; the soldiery could not le'gally seize it as booty or for the sake of gain. ${ }^{79}$ While, in a popular sense, cotton thus came to be known as "contraband," it was, under the circumstances surrounding it, rather enemy property of such an exceptional character as to justify its distinction under a

The Atalanta, $6 \mathrm{Ch}$. Rob. 460 ; The Julia, 8 Cranch, 189; The Nereid, 9 Cranch, 388; The Neutralitet, 3 Ch. Rob. 296; The Hart, 3 Wall. 559.

75 The Wm. Bagaley, 5 Wall. 377.

76 The Indian Chief, $3 \mathrm{Ch}$. Rob. 27, and citations.

77 Heffter, $\S 124$, Geffcken note, 1. 78 See Acts of confiscation of Aug. 6, 1861, designed to weaken the enemy, not to punish the owner (12 Statutes at Large, 319); and of July 17,1862 , designed to punish disloyal owners (Id. 591); and that of March 12, 1863 (Id. 820), for the collection of abandoned property. See also Kirk v. Lynd, $10 \mathrm{G}$ U. S. 315; Confiscation Cases, 20 Wall. 92, 109; and U. S. v. Winchester, 99 U. S. 372, 376, which seem to conflict with Pelham v. Rose, 9 Wall. 103, and Miller v. U. S., 11 Wall. 268; U. S. v. Bales of Cotton, Woolworth, 236.

i9 1 Kent's Commentaries, 92, 93; Prize Cases, 2 Black, 687; Mrs. Alexander's Cotton, 2 Wall., 404, 420, 422 ; Young v. U. S., 97 U. S. 39. 
special rule, dictated, according to Kent, by the necessary operations of war. Although such cotton as the produce of enemy soil was enemy property, and although, strietly speaking, residence in the encmy's country made its owners enemies, Federal legislation, distinguishing between "rebel" and "Ioyal," provided for payment to the latter by the government of the net proceeds of sale. ${ }^{80}$ European writers have, however, sharply questioned the American extension to private property on land of the well-settled principle that produce, used to maintain the enemy's cause, is at sea subject to confiscation or destruction. ${ }^{\text {s1 }}$ The argument is that if cotton or wheat may be treated, under the special conditions of war in the United States, as "constructive contraband," any other article may be so treated under the special conditions of war elsewhere. The unusual severity with which cotton and certain other articles were treated during the American civil war does not accord with the theories and tendencies of modern international law.

$\S 544$. How a district may be internationalized.-While under ordinary conditions international law concedes to national or municipal law the exclusive right to regulate the conduct of military anthorities within the limits of their own country, a suspension of that principle sometimes occurs, especially during an invasion, in which a district of country becomes in a measure enemized, or hostilized, by the force of circumstances. When, for instance, civil government is suspended and military occupation ensues temporarily, with all its consequences, in a certain part of one's own country, such part is treated as hostile, and private property is necessarily appropriated for the army or to prevent its falling into the hands of the enemy. ${ }^{82}$ In England and America there is no law to cover such a condition of things, occurring not infrequently on the continent of Europe, where it is called a state of siege. As military rights and duties are practically the same under such abuormal conditions as in the erent of a hostile invasion, they need not be discussed separately. For instance, private property may be appropriated for public use, or, what is the same thing, destroyed to prevent its falling into the enemy's hands for his use. During the Anglo-Boer war such appropriation was generally called "commandering." The exercise of

80 Act of March 12,1863 , sec. 6

(12 Statutes at Large, 821).

«1 Heffter, $\$ 135$, Geffcken note 2 .
82 Prize Cases, 2 Black, 635, 674 (Justice Grier). 
this despotic war power can be justified, however, only by extreme and pressing necessity. Thus while dike-cutting by the Dutch, and the burning of Moscow by its inhabitants cannot be condemned, because justified by sound military reasons, the threatened destruction of the Johannesburg mines would have been criminal. As a general rule, for all purposes of this chapter, the opposing parties in a civil war are to be considered as enemies of each other; and where "the boundary is marked by lines of bayonets, which can be crossed only by force," either side of it is enemy's territory to the other, with all the rights and duties which the laws of war impose. ${ }^{83} \mathrm{As}$ an exception to that rule, whenever any district is so affected by hostilities as to place it in the abnormal condition defined in this section, it may be said to be internationalized so long as such condition continues.

83 Mitchell v. Harmony, 13 Howard, 115. 


\section{CHAPTER VIII.}

\section{LAWS OF WAR AS TO ENEMY PROPERTY AT SEA.}

$\$$ 545. Property liable to capture at sea.-The only property liable to capture at sea is personalty, either public or private. The former embraces all public ressels and their appurtenances and war supplies on board designed for naval use, or in the course of trausportation to fortified places; the latter, with certain exceptions, all vessels and cargoes belonging to an enemy. From the decisions of the prize courts it appears, however, that the laws of war are much more concerned with private property than public, that is, with its violent appropriation or capture by belligerents. Whatever belongs to an enemy, except certain craft exempt for humanity's sake, and property, not contraband, under a neutral flag, may be violently taken by his opponent, with the result that the captor becomes actual owner thenceforth jure belli. The present chapter therefore relates mainly to captures, whose consideration involves, in the first place, the question, what property is subject to capture and what is not; in the second, what constitutes a ralid capture, including both the acts of possession by the captor, and the acts of the prize court recognizing and ralidating the change of ownership. While that method of treatment reverses the order pursued in regard to captures on land, the change is desirable here because of the consideration which must be given to prize courts in connection with sea captures.

$\S 546$. Property exempt from capture for humanity's sake. Hospital and cartel ships, and fishing boats.-There are but few exceptions to the rule that all enemy property afloat is subject ' to the fate of war. The first place on the list of such ressels as are exempt from liability to capture should be given to hospital and cartel ships, neutralized by common consent and now protected by The Hague rules, on account of their humane missions. The same spirit has for a long time guaranteed more or less perfect protection to other harmless or specially useful craft, such as coastwise fishing boats, which, with their crews and appurtenances, are exempt from capture during war so long as they confine themselves strictly to their legitimate pursuit. The exemption so far as concerns France and England dates back at least to 1403 ; and as to France and Hol- 
land to the arrangement regulating the herring fishery made in 1536. France declined to recognize it for a short time after 1692 because certain persons claiming to be fishermen were regarded as spies; and in the time of Napoleon England also captured fishermen on the charge that their boats trimsported military stores. ${ }^{1}$ And so during the American Revolution Paul Jones in his warship the Providence and the American privateers generally captured fisling boats off the banks of Newfoundland, ${ }^{2}$-an example that would not be followed now. When in 1854 the British destroyed boats and dwellings of fishermen in the sea of Azof, they daimed that such action was necessary for military purposes. Although Lord stowell speaks of the exemption in question as existing "by a rule of comity only and not of legal decision," the supreme Court of the United States has recently declared, in a notable judgment heretofore referred to, that 'the word 'comity' was apparently used by that great judge as synonymous with couptesy or good will. But the period of a hundred years which has since elapsed is amply sufficient to have enabled what originally may have rested on custom or comity, courtesy or concession, to grow, by the general assent of civilized nations, into a settled rule of international law." 3 The exception does not apply, however, to ressels engaged in whaling or other deep sea fisheries or to those in which the catch is for salting and commercial use. ${ }^{4}$

Vessels engaged in scientific expeditions.-Tne exemption in favor of ressels engaged in scientific expeditions is of "more recent growth. Probably the first prominent instance occurred when the French naval authorities issued orders for the protection of the English explorer, Captain Cook, during his circumnavigation of the world in 1776,5 the principle of which has

1 Bynkershoek, Quaest. Jur. Pub. ch. III; Halleck, Int. Law, p. 493; Bluntschli, Mod. Kr., §§ 165 (665), 173 ( 673 ), etc.; Young Jacob, etc.; 1 Rob. Adm. Rep. 20; 2 Azuni, I, ch. I, Art. V.

2 Cooper.

3 The Paquete Habaña, 175 U. S. 677.

4 Hall, § 148; The Susa, 2 Ch. Rob. 251; The Johan, Edw. Adm. R. 275 \& App. L. The American naval code expresses the excep- tions as follows: "All public vessels of the enemy are subject to capture, except those engaged in purely charitable or scientific pursuits, in voyages of discovery, or as hospital ships under the regulations hereinafter mentioned. Cartel and other vessels of the enemy, furnished with a proper safe-conduct, are exempt from capture, unless engaged in trade or belliger. ent operations."-Art. 13.

"Halleck. Int. Law, p. 493. 
been recognized sereral times since. Flinders lad a different experience at Mauritius in 1803 , because the passport on which he relied, expressly covering the ship Investigator, was held by the French authorities not to embrace the Cumberland, for which the Investigat or had been exchanged. ${ }^{6}$ Great Britain and France, by a convention made in 184:3 and extended in 1856, hare likewise exempted mail packets until notification; an exemption of no great importance, as the exchange of mail must necessarily cease at an early day in every war.

Vessels in distress.-Is the precedents on the subject are conflicting it is going too far to say as some writers do that interuational law exempts from capture vessels driven into an enemy port by stress of weather, or entering there in ignorance of the existence of war. The commendable course was certainly that pursued by the governor of Havana who in 1746, after refusing to accept the surrender of the shattered British warship Elisabeth, aided her to refit. ${ }^{7}$ There is, however, a more distinct agreement that ships and cargoes wrecked on an enemy coast shall be exempt from capture. ${ }^{8}$ As such a rule of comity rests upon the best impulses of honor and humanity it is to be hoped that, as in the case of fishing boats, it will soon ripen into law. Such an exemption of shipwrecks would represent a notable departure from the primitive notion which regarded them as treasure trove, if not direct gifts of God to the dwellers of the inhospitable coast. ${ }^{9}$

Merchant vessels afloat at declaration of war.-As heretofore observed, merchant vessels of the enemy that have sailed from a port within the jurisdiction of the belligerent, prior to the declaration of war, shall be allowed to proceed to their destination, unless they are engaged in carrying contraband of war or are in the military service of the enemy. Merchant vessels of the enemy, in ports within the jurisdiction of the belligerent at the outbreak of war, are generally allowed some reasonable period after war has begun to load their cargoes and depart, and shall thereafter be permitted to proceed to their destination, unless they are engaged in carrying contraband of war or are in the military service of the enemy. Merchant vessels

62 Flinders Voyages, ch. 3-9.

7 Lawrence, Int. Law, 381; as to neutrals, see the Hurtige Hane, 3 Rob. 326; Raynal's Hist. du Commerce, XIV, ch. 17; 2 Azuni, II, ch. IV, Art. I, note. s Bluntschli, Mod. Kr., $\S \mathbf{1 6 5}$ (665), 173 (673), etc.; Halleck, Int. Law, p. 494.

91 Kent's Commentaries, 8, 13. 
of the enemy which have sailed from any foreign port for any port within the jurisdiction of the belligerent before the declaration of war, are likewise generally permitted to enter and discharge their cargoes and thereafter to proceed to any port not blockaded. The American naval code thus states these principles, the substance of which is now generally recognized and acted on. ${ }^{10}$

$\$ 547$. Tendency to exempt all private property not contraband from capture at sea.-There has been for a long time a persistent effort upon the part of certain states to exempt all private property, not contraband, from capture at sea. While eridence of preceding attempts in the same direction are to be found, the most definite early enunciation of the principle occurs in the American-Prussian treaty of $\mathbf{1 7 8 5}$, in which Frederick II and Franklin attempted to establish for their respective countries a rule which has not been generally observed, even in subsequent treaties between such countries. In 1823 Secretary J. Q. Adams tried to induce England, France and Russia to adopt it; and in $1856 \mathrm{Mr}$. Marcs urged the powers to incorporate it in the Declaration of Paris along with the abolition of privateering. Then in 1859 the Bremen Chamber of Commerce declared that the exemption in question is demanded by the legal conscience of the age, it gare expression to the spirit in which the freedom of commerce should be adrocated, a spirit firmly upheld by the United States in its consistent efforts to give permanent and final effect to Franklin's initiative. As it is now even beyond the power of the fleets of Great Britain to guard her world-wide commerce, Hall wisely contends that the time has come for that power to withdraw her long-continued opposition to the adoption of a rule that proposes to place private property at sea, as well as pricate property on land, under the protection of a principle which declares, that, as war is a struggle not between private individuals but between states as such, it should not affect either private persons or property on land or sea. It cannot be successfully maintained, howerer, that such a theory is carried out at all completely in the practice regulating the seizure of private property on land, as all such properts is liable in an invaded district to requisitions, contributions and the rarages of war. While domestic trade may go on to some extent. foreign commerce is suspended wherever the invader"s arms control. For such reasons an exemption from sea cap10 Am. Naval Code, Art. 15; The Buena Ventura, 175 U. S. 384. 
ture would not equalize the perils of property on land and sea; it would rather render sea commerce the more secure of the two. The best reason, therefore, for maintaining the present condition is to be found in the fact, that, as contraband is a more inportant subject by sea than by land, a general suspension of commerce by sea cripples an enemy nore than a like suspension by land. A country may be thus distressed and the prosecution of a war rendered more difficult by the cutting off of sea commeree, whose interruption makes more inconvenient and expensice the introduction of many things, including often the necessities of life. Such "erippling of commerce" is an effective means of war." When fully carried out, an interruption of that kind amounts to a blockade of the whole enemy country, save so far as the same is modified by railroad commerce with adjacent countries, an alleviation that could not extend to island states like Great Britain and Japan. Such was the condition of the Sonthern Confederacy when, with an enemy only on its northern borders, it was practically cut off from all trade by sea; and such might be the condition of Spain in the event of a war with France. Practically it makes no difference whether private commeree is prevented by blockaders at the entrance of a harbor or by captures made on the high sea; and as blockade and eapture of private cargoes rest upon the same principle, that of weakening the enemy country, their abandomment, for lumanitarian or other reasons, must inevitably render war less hmmane by prolonging its duration. And in this connection the fact should not be overlooked, that, as it is generally more difficult to provide a naval than a military base of supplies, it very often becomes necessary for ships at sea to secure the same by captures from the enemy. In 1782 the great French admiral suffren, without a port or resourees, lived from the enemy's shipping for six months at a time; $;^{12}$ in the American civil war Captain Semmes with only two ressels succeeded to a great extent in living on the enemy; while during 1796 the British fleet was actually driven from the Mediterranean for want of ports in whish to obtain provisions and water. On long cruises, particularly in lostile waters, all flects must to some extent depend upon their own resources. Nelson's orders in the expedition in which was fought the battle of the Nile were to supply his fleet in any way at the ammon's mouth. ${ }^{13}$ 779 .

12 Mahan's Sea Pow̌er, 445. 1:3 Mahan's Nelson, 283. 
Should property taken at sea be paid for?-Convoy.-As private property when taken on land is now supposed to be paid for, the same rule should be extended to like seizure and appropriations made at sea. In point of fact, it is often provided in treaties that when such losses have been ascertained by a mixed commission they shall be paid for, as in agreements made between France and Spain in 1S23, between France and Mexico in 1865, and between the English and Dutch in 1812 when vessels captured from the latter were returned. Such efforts in the right direction may be said to represent international law in the process of formation. On some occasions practice has even gone further, as in the war of England and France with China, in the Crimean war, and in that between Italy and Austria in 1866, when the belligerents expressly or tacitly agreed on the entire exemption of pricate property at sea from capture, a rule in which France, with a stronger navy, refused to coincide when initiated by Prussia in 1870. Such instances are, howerer, beyond the present stage of international law. As yet private property of the enemy, sailing under his flag, is subject to capture; and, if compensation is allowed at all, it is onlr in the subsequent treaty of peace. Part of the contention as to neutrals-accepted in America and on the continent of Europe ${ }^{1+}$-is that when ressels sail under convoy the word of the commanding officer of the squadron should suffice,-the contention of Denmark in 1801 which made British victory at Copenhagen possible. ${ }^{15}$ The most formidable obstacle to the establishment of the rule of convoy is to be found in the fact that the present extent of merchant shipping makes it practically impossible to supply sufficient warships to escort it.

\$548. Rules defining enemy property at sea. Actual ownership; suum cuique.-Admitting that private property of the enemy at sea is liable to capture, an attempt must be made to define, with special reference to cargoes, what enems property on the sea really is. Does the flag of the ship or the actual ownership of the goods control? While such is not yet the rule, and while historically the practice has been far different, the present tendency perhaps is to make the nationality of the vessel conclusice as to the cargo, that is, to make the flag, except

14 Am. Naval Code, Art. 30. 15 Mahan's Nelson, 457. Geffcken thinks that the exemption of private property must be established, if at all, rather through treaties than discussion. Heffter, $\S 139$, note. 
in cases of deception, cover the goods on board. As the question whether property is enemy property vel non is the crucial one in capture, and the one most difficult of solution, special consideration must be given here to four different systems or theories touching the subject which have prevailed at different times and in different countries. For the first we must look to the Consolato del Mare, a code said to have been compiled at Barcelona in the latter part of the fourteenth century (or at Pisa, according to Azuni) in which is contained the earliest collection of the laws and customs of the sea in time of war. ${ }^{1:}$ In that sonrce is expressed the natural riew that the ownership of the ship determines the right of its capture, and that the ownership of the goods determines the right of their capture. Although either may be captured if belonging to the enemy, neither shall be captured if belonging to a neutral. In that way the goods and the rehicle are separately considered, and neither affects the other. Hostile goods, for instance, may be taken out of a neutral merchant shi], which is released. ${ }^{17}$ This principle of suum cuique, which Chief Justice Marshall considers to be the original law of nations on the subject of captures, has been called the common law of the sea. Its origin may be traced even back of the Consolato, as it was the basis of a compact between Arles and Pisa in 1221. Spreading with other customs of the Mediterranean to the western and northern seas, by the fifteenth century it had become the general rule of the civilized world, and still prevails in Great Britain and the United States. ${ }^{18}$ In one respect, however, the English differs from American practice,-the former regarding it as a departure from neutrality if the goods are laden on an armed enemy vessel, the latter holding that fact to be immaterial.19 The presumption that the goods are of the same nationality as the ship-res in hostium navibus prosumuntur esse hostium donec probetur-can be overcome by papers on board at the time of the visit. ${ }^{20}$ In no event can enemy property be seized in neutral waters or on public ships of a neutral,

16 Consolato, ch. 273; Twiss, Law of Nations, War, $\S 76$; The Venus, 8 Cranch, 253; 2 Azuni, II, ch. III, Art. 1.

17 Bynkershoek, Quaest. Jur. $P u b .$, ch. XIV.

18 The Nereide, 9 Cranch, 388, 418; Kent's Commentaries, 124. 129; Wheaton's Elements, IV., ch.
III, § 19; Jefferson to Genet, July 24, 1793, 4 Works, 24.

19 Twiss, Law of Nations, War, § 77; The Fanny, 1 Dodson, 443;

The Nereide, 9 Cranch, 388; The Atalanta, 3 Wheaton, 409. 20 The London Packet, 5 Wheat. 132. 
who, as he has the right to remain on friendly terms with both belligerents, can carry his goods, and ship in their vessels just as in time of peace. The liability such as it is, is ex re, not $e x$ delicto, ${ }^{21}$ and the res hostis alone suffers. The belligerent's right to take the cargo must be exercised so as not to conflict with the neutral's right to earn freight by carrying it. If, therefore, one belligerent takes the goods of the other out of a neutral ship, it must be without damage to the ship; he must pay the ressel, not pro rata itineris, as Zouch argues, but the whole freight which it would have earned by completing the royage, capture being equivalent to delivery. ${ }^{22}$ The measure of the freight to be paid is that of peace, as a belligerent does not have to pay the war premium caused by fear of the very capture which he has the right to make. ${ }^{23}$ The case is entirely altered, however, if the neutral endearors to cover the property from lawful belligerent seizure, because in that way he identifies himself with the opposite belligerent;24 and if enemy property is fraudulently blended in the same claim with neutral, all must be condemned. ${ }^{25}$ While the captor must pay the freight due on the enemy goods taken out, he is not liable for freight on neutral goods which happen also to be on the ship, nor for damages or losses caused by delay or otherwise. Such are the misfortunes of the neutral, ${ }^{26}$ and like many others resulting from war must be borne where they fall.

$\$ 549$. Doctrine of the Consolato first changed by the French. Hostile infection.-The rule in question, called the "common law of the sea," was first changed by the French, who introduced the doctrine of hostile infection under which the carriage of a hostile cargo rendered the ship also liable to capture, and the loading of a neutral cargo on a hostile ship rendered both liable. A règlement of Francis I, of 1543, introducing this new principle, was followed by another of similar nature in 1584. No matter whether Sir Leoline Jenkins is right or wrong in supposing that such ordinances were passed merely in terrorem, to put an end to neutral frauds, the prin-

211 Kent Comm. 124, 126; The Atlas, 3 Rob. 304, n.; Am. Naval Laws, Art. 2.

22 The Copenhagen, 1 Rob. 245 (Am.).

23 The Twilling Riget, 5 Robinson, 82; The Antonia Johanna, 1 Wheaton, 159; Vattel, Droit des Gens, III, ch. 7 , § 115 .
$2+$ Schwartz v. Ins. Co., 3 Wash. C. C. 117; The Hart, 3 Wall. 559; The Rugen, 1 Wheat. 61.

25 The St. Nicholas, 1 Wheat. 417.

26 The Antonia Johanna, 1 Wheat. 159. See the Ann Green, 1 Gallison, 274. 
ciple of infection contained in them became a part of the Ordonnance de la Marine of Lonis XIV, ${ }^{27}$ and continued to be French practice down to the Declaration of Paris. The result of the innovation has been embodied in the formula:

$$
\begin{aligned}
& \text { Enemy ship-enemy goods, } \\
& \text { Enemy goods-enemy ship. }
\end{aligned}
$$

Although Grotius states the Dutch law to be otherwise, Bynkershoek says the rule thus formulated obtained in his day. He contends that the fact that goods are found on an enemy ressel should raise only a removable presumptiou of hostile ownership. ${ }^{29}$

$\$ 550$. Further variations established by the Dutch. Nationality of ship.-The Dutch established the further variation that the nationality of the ship controls that of the cargo, a rule embodied in the formula:

Free ship-free goods,

Enemy ship-enemy groods,

which, after having been adopted by Turkey as early as $\mathbf{1 6 0 4}$ in a treaty with Henry IV of France, rrevailed during the greater part of the eighteenth century. The two propositions embodied in the respective phrases of the above formula are, however, severable; and they have been so treated in the United States, where only the first is insisted on. The second, as a departure from the original common law of the sea, has found less general acceptance ${ }^{29}$ Grotins was only willing to accept the principle involved in it as a rehuttable presumption. ${ }^{30}$ Bynkershoek properly excepted from the operation of the first contraband of war on its way to the enemy. ${ }^{31}$

$\S 551$. Declaration of Paris, 1856. Free ships-free goods.The Declaration of Paris of 18.5 i substantially adopts the first half of the Duth valliation of the eommon law of the sea in these words: "Neutral flagr covers enemy cargo, except contraband of war." 32 This final acceptance pro tanto of the principle declared by Russia and the other parties to the Armed Neu-

${ }_{27}$ Twiss, Law of Nations, War, $\$ 84$; Grotius, De Jure Belli ac $\S 83$.

Pacis, III, ch. 6, title 6; Azuni, 2 2s Bynkershoek, Quacst. Jur. Maritime Law, 163. $P u b$., ch. XIII, XIV.

31 Bynkershoek, Quaest. Jur. 29 The Nereide, 9 Cranch, 388, Pub., XIV; 2 Azuni, II, ch. III, 418. Art. IV.

${ }^{30}$ Twiss, Law of Nations, War, ${ }^{32}$ Martens (N. R.), XV, p. 792. 
tralities, and long contended for by the United States, grew immediately out of its provisional adoption by France and England during the Crimean War.33 While the executive department of the United States from Jefferson's presidency, if not earlier, has strenuously insisted that the rule-free ships, free goods-not only ought to be but actually is international law, the judicial department from the time of Marshall has as resolutely followed Lord Stowell to the contrary. When in 1780 and 1800 two concerts of continental Europe organized armed opposition to several features in the practice of Great Britain, she managed, by her superiority at sea, either to break up these alliances or otherwise to neutralize their effects. And yet in the end the right has so far triumphed that all the civilized world, exeept Spain and the United States, have now adopted the declaration of free ship, free goods. In point of fact both of these countries do act upon this part of the Declaration, although they opposed other portions; and during the American civil war both sections virtually accepted it. In 1861, when the United States offered to give its formal adhesion to the Declaration, Great Britain declared "that Her Majesty does not intend thereby to undertake any engagement which shall have any bearing, direct or indirect, on the intermal differences now prevailing in the United States." The answer made was "that the United States must accede to the Declaration of the Congress of Paris on the same terms with all the other parties to it, or that they do not accede to it at all." The British and French governments through their consuls in Charleston arranged with the Southern Confederacy that it should respect all the articles of the Declaration except that as to privateers, ${ }^{34}$ but the United States, refusing to recognize a qualification suggested from abroad, took no further steps in the matter. It must be noted here that the correlative French principle of enemy ship, enemy goods was not adopted at Paris. As to neutral cargoes in enemy ships, therefore, the common law still prevails and such goods are exempt from capture. The principle of protection by flag now applies to all goods, not contraband, under the neutral flag. The terms of the Declaration on that subject are: "Neutral goods, with the exception of contraband of war, are not liable to capture under the enemy's flag."

33 Ib. III, p. 158; 1 Kent Comm. 126; Wharton, Int. Law Dig., §

34 Wharton, Int. Law Dig. $\S 342$. 342 . 
$\$ 552$. Nationality of vessel; change of ownership.-From a commercial point of view, property at sea is either vessel or argo. As to the first, nationality generally appears from the flag, while ownership of the vessel itself is shown by the ship's falers, of which the certificate of registry best proves the nationality and owner, passport, muster roll or erew list, and $\log$ book being also of value. The charter party will be found useful only when the ressel is hired. ${ }^{35}$ A bona fide sale of a ship to a neutral, even churing war, is recognized in Engrland and America, although reesalrded with suspicion, but the purehase of an enemy ressel which has taken refuge in a neutral port has been disregaldede ${ }^{36}$ Liens are not upheld, except such obvious ones as the lien of a ship on the cargo for freight. On the continent of Europe, especially in France and Russia, a sale during war is disregarded. ${ }^{37}$

\$553. Cargo; questions as to consignments.-The difficulty of determining the true ownership of property at sea is greatest as to cargoes, the nicest questions arising perhaps out of consignments. Generally goods are shipped by a seller in one country to a buyer in another. Sometimes they are paid for before shipment, but oftener not. Upon aipture of the vessel in mill-ocean, to whom do the goods belong? The generally accepted rule of law is that if shipped under order and on accomnt of and at the risk of the consignee, they are his; but not if any interest is left in the consignor, or election to accept is given to the consignee. Under such conditions a complete title cannot be said to have passed. Delivery to the carrier is delivery to the buyer only when made without conditions.38 Usage and special agreement may alter the rule as betweon the parties, but not as regards a captor. The consignor is often, perlanes generally, a neutral, and, if he could save the goods by assuming risks, he would always do so, and thus captures at sea would practically ecase. For the same reason

35 The American naval code calls for register, crew and passenger list, log book, bill of health, manifest of cargo, charter party, invoices and bills of lading as generally expected (Article 23 ). Hübner reckons eleven papers, but Galliani, Lampredi, and Azuni are content with five. 2 Azuni, II, ch. III, Art. IV.
36 The Minerva, 6 Rob. 396; The Ga., 7 Wall. 32; The Soglasie, 2 Spinks, 101.

37 Sorenson v. Reg., 11 Moore Priv. C. C. 119 ; Heffter, $\S 124$, G. n. 1 .

3. The Mariana, $6 \mathrm{Ch}$. Robinson, 24. 
no change of ownership pending the royage is recognized, except in case of stoppage in transitu for insolvency of the consignee; or a transfer made bona fide before war is declared. ${ }^{39}$ If a transfer or other contract is made in contemplation of impending war, it is roid, as defrauding a belligerent of his right of capture. ${ }^{40}$ Bills of lading, invoices and all other papers throwing light on the question of ownership are to be consulted, as cargoes are often documented as neutral in order to avoid capture. For that reason in every case the papers, which are strictly construed, must show definitely who the real owner is. As a consignment to the order of the shipper does not divest him of the title, the goods remain liable to capture, if he be an enemy.

$\S 554$. What constitutes capture at sea.-Passing from the question of liability to capture to capture itself, it may be said that captureat sea consistsina belligerent's taking firm possession of the enemy's property, which is then called prize. As such property is necessarily either a ressel or a cargo or other property upon a ressel, its capture is often confounded with surrender of the crew manning the ship. Surrender, as heretofore defined, consists of an offer to submit on the one side, generally signified by hoisting a white flag, and of its acceptance on the other, by receiving the commander's sword or otherwise assuming control. And yet, although almost invariably preceding its capture, surrender of the crew is not essential to capture of the property they control. It is conceivabie that victors might take possession of a ship covered with dead or wounded without the flag having been struck; and it not infrequently happens that a ship is abandoned to the enemy by its crew when they are able to escape. The Consolato, following the Roman rule in land war, required the property to be taken to port or other safe place, infra prosidia, before it could be recognized as a complete prize. While in later times capture has on the continent of Europe been considered incomplete until after possession of a night, or of twenty-four hours, the generally accepted rule of British and

39 The Frances, 8 Cranch, 183; The Francis \& Cargo, 1 Gallison, 445; 'The St. Jose Indians, 1 Wheat. 208; The Josephine, 4 Ch. Robinson, $25 ; 3$ Phillimore Int. Law, 610 , 612; Service Afloat, 483; Halleck, Int. Law, 474; The Frances, $1 \mathrm{Gal}$ - lison, 448, 8 Cranch, 354; The Vrow Margaretha, 1 Ch. Rob. 337; The Packet de Bilboa, 2 Ch. Rob. 133.

40 The Rendsborg, $4 \mathrm{Ch}$. Rob. 121; The Jan Frederick, $5 \mathrm{Ch}$. Rob. 133; The Bernon, 1 Ch. Rob. 102. 
American courts now is that capture becomes complete upon firm possession taken, just as on land, except that in sea captures recognition by a prize court is also necessary to validate the otherwise perfect act. The captor is not bound to leave the crew on the ship, nor are they bound to navigate her, although after possession taken prisoners left on board on parole are not at liberty to escape. Possession is usually consummated by sending a prize crew on board, or by some equivalent act manifesting intention to scize and hold. ${ }^{41}$ One man, as prize master, is sufficient if he talies complete control. In fact, as Lord stowell has decided, no one at all need be sent if the ship follows the orders of her captors, as when she has been compelled to steer in a prescribed direction. ${ }^{2}$ The essential element, therefore, is change of control from one belligerent to the other, which, when effected to the satisfaction of a prize court, changes the ownership from the one to the other. Lord Stowell properly regarded as mere chimeras the views of those publicists who maintain on theoretical grounds that a capture at sea, like an appropriation of realty, can be validated only by a treaty of peace. ${ }^{43} \mathrm{As}$ in the nature of things there must be a distinction in the treatment of realty and personalty, it can hardly be doubted that the present practice is well grounded and essentially right.

§55. Naval capture on land.-The prize jurisdiction is exercised in cases of belligerent naval capture on land just as in cases of belligerent capture on the high seas, whether the capture be by the naval force alone or in conjunction with the army.4 As unarmed transports not commanded by government officers are not war ressels, they do not make land captures prize. ${ }^{5}$ Pine timber, which at low tide rests in the mud at one end, is property on land and if taken is land and not naval prize. 4 ship seized at anchor in a conquered port is a droit of the admiralty. ${ }^{47}$

41 The Grotius, 9 Cranch, 368; Goss v. Withers, 2 Burr. 683; Valin sur l'Ordonnance, III, tit. 9, Art. 8.

42 The George, 1 Mason 24; 'The Hercules, 2 Dodson 368; The Edward \& Mary, $3 \mathrm{Ch}$. Rob. 306; The Grotius, 9 Cranch, 370; Halleck, Int. Law, 727, 730 n.; Mauran v. Ins. Co., 6 Wall. 10.

43 Martens, Ueber Caper, § 40 ,
45; Heffter, § 192 . See also Linguet and Jouffroy, passim.

44 Le Caux v. Eden, Douglas Rep. 594; Lindo v. Rodney, Douglas Rep. 620; Camden v. Home, 4 Term R. 382; Smart v. Wolff, 3 Term R. 323; The Cape, 2 Rob. 216.

45 U. S. v. Bales of Cotton, 1 Woolw. 236, 257.

46 Brown v. U. S., 9 Cranch, 139. 47 The Foltina, 1 Dods. 450. 
\$56. Joint capture.-As constructive assistance is recognized in captures, each war vessel in sight is held to participate, because she may have contributed by intimidating the enemy. ${ }^{48}$ A privateer, revenue cutter, or other armed vessel not bound to participate must, however, in order to share show some actual participation, the same being presumed of a public ressel, even when the actual capture is made by a privateer. ${ }^{49}$ Transports are not held to participate as joint captors, although their presence with men of war may in fact. intimidate the enemy; and the same is true of a ship's boats in sight at the time of capture but not actually aiding. ${ }^{50}$ Where a boat, dispatched from a ship makes the capture, it enures to the benefit of the whole ship and not to the boat's crew alone. In the absence of statute the proceeds of the prize are distributed among joint captors in proportion to their respective force. It is not universally agreed, however, how far such force depend on the guns and how far on the men. The simpler rule, applicable at least to privateers, estimates not according to the instrument, but to the men behind the guns, who make them effective.51 Land forces are not held to share in a capture unless they actually co-operate. ${ }^{52}$ When Wellington's army captured Oporto and English ressels there were thus released, the army was given salvage for the English ships, but not for those of their allies, the Portuguese. No antecedent or subsequent services will per se enable one to share as a joint captor. In America, a joint capture enures to the United States only, as there is no law covering prize money in such. a case. ${ }^{53}$

\section{$\S 557$. Bringing prize in for adjudication. Destruction.-} When a captor takes possession of a prize there are four or five courses open to him. His general duty is to bring or send the ressel into the nearest suitable port for adjudication by a

48 La Flore, 5 Ch. Rob. 268; The Virginia, $5 \mathrm{Ch}$. Rob. 126; The Galen, 2 Dodson, 19; The Arthur, 1 Dods. 423.

49 L'Amitié, 6 Ch. Rob. 267; The Virginie, 5 Ch. Rob. 124; The Santa Brigada, 3 Ch. Rob. 52; The Bellona, Edw. 65; La Flore, 5 Ch. Rob. 270; The William \& Mary, 4 Rob. 312 (Am.).
50 The Cape of Good Hope, $2 \mathrm{Ch}$. Rob. 216; The Odin, $4 \mathrm{Ch}$. Rob. 327 ; U. S. v. Bales of Cotton, 1 Woolw. 236, 257.

51 Roberts v. Hartley, 3 Douglas, 311; Duckworth v. Tucker, 2 Taunton, 7; The Dispatch, 2 Gall, 2.

52 The Dordrecht, 2 Rob. 53 (Am.) ; Oakes v. U. S., 174 U. S. 778.

53 The Siren, 13 Wall. 389. 
prize court.54 The prize should be delivered to the court as nearly as possible in the condition in which she was at the time of seizure, and to this end her papers should be carefully sealed at the time of seizure and kept in the custody of the prize master for delivery to the court. All witnesses whose testimony is necessary to the adjudication of the prize should be detained and sent in with her, and if circumstances permit, it is preferable that the officer making the search should act as prize master. If bringing in is difficult, from unseaworthiness, disease, lack of men, or other cause, the captor may appraise and sell the prize, if he can find a purehaser; he may destroy it, saving of course the persons on board; he may release it on a ransom bond; or he may use it as a tender to his own ship, putting some of his own crew aboard under his commission. 55 The course last named was pursued in the case of the Federal bark Conrad, captured by the Alabama and converted into the Confederate war vessel, Tuskaloosa, afterwards seized by the British at Cape Town with the view of restoring her to the original owners. Because the seiming government concluded that they could not go back of her commission, an order was finally made directing her return to the Confederate authorities, the commission of any de facto government being sufficient to authorize captures. ${ }^{56}$ During the war of 1812 the Americans systematically burned their prizes in order to cripple British commerce, although ports and courts were open to them. Capt. Semmes of the cruiser Alabama burned most of his eaptures during the civil war, for the reason that the Federal navy had blockaded all Confederate ports, and England, France and other neutral nations refused to permit prizes to be brought into their own. Unless le ransomed them, as he did whenever neutral goods were aboard, there was no other course but destruction. Bluntschli, who opposes that remedy except in cases of necessity (or force majeure, as Geffcken expresses it), denies that even blockade of the lome ports is a ground for burning.57 If, however, the blockade is general, covering all home ports, and nentral harbors are closed, it is difficult to imagine a better reason. When under such cir-

54 The Anna, 5 Ch. Rob. 373, 384.

55 Wharton, Int. Law Dig., § 328;

Am. Naval Code, Arts. 46-50.

56 Service Afloat, 627, 743; Mauran v. Ins. Co., 6 Wall. 1 ; Dole v. N. Eng. Co., 6 Allen, 373; Fifield v.
Ins. Co., $47 \mathrm{~Pa}$. St. 166; Dole v. Merch. Co., 51 Me. 464.

57 Mlod. Völkerrecht, § 672; Semmes, Service Afloat, 141. Geffcken approves such destruction; Heffter, § 138 , n. 5 . 
eumstances the Russians burned ships in the Black Sea in 1877 their right was fully recognized by the Institute of International Law at Turin, 18s2. In 1870 the Desaix burned two German ships because there were too many prisoners for the French to spare prize crews. It is generally agreed that a neutral prize should never be burned. The American rule is that whenever captured ressels, arms, munitions of war, or other material are destroyed or taken for the use of the belligerent before coming into the custody of a prize court, they shall be surveyed, appraised, and inventoried by persons as competent and impartial as can be obtained; and the surver, appraisement, and inventory shall be sent to the prize court where proceedings are to be held. ${ }^{58}$

\$58. Ransom; hostage.-The right to take a ransom or a ransom bond (billet de rancon), not exceeding the value of ship and cargo, exists from the moment of capture, and applies to property of a neutral as well as to that of an enemy. ${ }^{59}$ The ransom bond or bill is usually in duplicate, one being liept by the captor and the other by the master of the prize, to whom it serves as a pass against all enemy cruisers. Unless the course prescribed as well as other conditions are followed so far as possible, the ressel is liable to a second capture. While that event would discharge the bond, the second captors must out of the proceeds of their prize pay the amount of it to the first captors. The loss of the vessel by perils of the sea does not discharge the bond; and in a suit upon it is presumed that the capture was justifiable. Ransom is sometimes described as a repurchase, by which a new property is acquired, ${ }^{60}$ and the bill is valid even when given to a pirate. As a stronger assurance, a hostage is often given in addition to the bond. If a captor vessel is herself captured with bill and hostage, with the hostage only, or with bill alone, if there is no hostage, the ransom is discharged; 61 but not if both are safe elsewhere. When a bill of exchange has been given, the rule is different, if it has

58 Am. Naval Code, Art. 14.

59 Maissonnaire v. Keating, 2 Gallison, 337; The Gratitudine, 3 Ch. Rob. 258; Hall, Int. Law, 479; Halleck, Int. Law, 672; 1 Kent Comm. 105.

60 Valin, Traité des Prises, ch.11, $\S \S 1-3 ; 2$ Azuni, II, ch. IV, Art. VI; Miller v. Resolution, 2 Dallas, 15; Cornu v. Blackburne, 2 Douglas,
650 , etc.; Yates v. Hall, 1 Term R. 73; The Resolution, 6 Ch. Rob. 23; 1 Kent Commentaries, 105; Maisonnaire v. Keating, 2 Gall. 325 ; Calvo, Droit Int. II, 277; Ricord v. Bettenham, 3 Burr. 1734.

61 Emerigon, Traité des Assurances. ch. 12 , sec. $23, \S 8$ (combating Valin); Calvo, Droit Int., II, 280 . 
been negotiated, for the reason that the bona fide purchaser for value must be protected. Though it is not necessary to take a hostage, he is useful, for he can sue the master and owner in their own country to compel performance of the ransom contract, which, in England, an enemy captor could not do. The hostage himself has a claim for expenses. ${ }^{62}$ The escape or death of the hostage, who is merely a collateral security, does not aroid the bond, nor does the loss of the ransomed slip by stress of weather. In France a ressel ransomed by giving hostages is seized by the admiralty immediately on her arrival in order to compel the more expeditious performance of the contract. ${ }^{63}$ The practice of giring hostages has, however, everywhere fallen into desuetude.

\section{$\$ 559$. How captor's rights may be lost. Recapture and post-} liminy.-Property acquired by capture may be lost by recapture, abandonment, escape, rescue by the captured crew, and of course by discharge. Although abandonment cannot be passed on by neutrals, salvage on an abandoned ressel will be allowed by a neutral court. In such a court, however, the captor's rights will not be adjudged forfeited by abandonment, ${ }^{64}$ and no contractual lien can operate to cut them off. ${ }^{65}$ Recapture gires rise to the doctrine of postliminy. While the capture is complete as between the two belligerent states when the captor takes possession, such possession must be firm enough to stand the scrutiny of a prize court. If the prize be lost, the owner has an equity as against third parties upon rescue or recapture (recuperalio, reconsse, reprise, wiedernahme, recolro, ricupero), by ships of his own country, unless, according to the American doctrine, this be after condemnation by a prize court. Upon recapture arise the rights of postliming, which do not apply if the enemy obtained possession in any other way than by force. Thus, the right has been denied when the master fraudulently sold the ressel to the enemy, and also when the possession was under a wrongful condemnation before the war for violation of revenue laws. ${ }^{66}$ The rule dates back to the Consolato and is derived from the Roman law as to a citizen,- -antequam in presidia perducalur

62 The Hoop, 1 Ch. Rob. 20; 1 Kent Commentaries, 107; 2 Azuni, II, ch. IV, Art. VI.

63 Azuni, 2 Droit Maritime, ch. 4, Art. VI, § 5 ; Calvo, Droit Int. II, 279-280.
64 McDonough v. Dannery, 3 Dallas 188 .

65 See ante, notes 37 and 39.

66 Oakes v. U. S., 174 U. S. 778;

The Jeune Voyageur, 5 C. Rob. 1. 
hostium manet civis. From the Institutes we also learn that postliminium fingit eum qui captus est in civitate semper fuisse. Asto ships nottakeninto port or other property not reduced to firm possession, Bynkershoek observes, it is not so much postliminy as incomplete capture. ${ }^{67}$ According to the theories of medieval Europe the right of postliminy npon recapture was to be recognized upon the owner's allowing compensation, called salrage, for the rescue, ${ }^{68}$ provided the claim was made before the prize was brought infra prasidia, as to the main fleet or dock; and provided, according to the Grotian rule heretofore noted, such claim was set up before twent $y$-four hours' possession in the recaptor cut it off. As the Digest (I, 3, 20) truly says non omnium qua a majoribus constituta sunt ratio reddi potest, the latter rule, for want of a better origin, is derived from the Lombard custom limiting the right of the hunter to recover the animal which he had wounded to twenty-four hours. The present rule is that capture is complete when the article is brought to a safe place. ${ }^{9}$ Althongh recapture is generally effected by a third ressel, postliminy also results when the original crew recapture the ship, because a rescue is not part of their duty ${ }^{70} \Lambda$ neutral master, however, violates the laws of war if he attempt a rescue. ${ }^{71}$ The rescue of an attacked ship by the approach of a superior force has the same result as its recapture after surrender. ${ }^{22}$ Rescue and safe return to port terminate the rights of the captor. ${ }^{73}$ For that reason when the British ship Emily St. Pierre, captured by the Federals during the American civil war, was rescued by her crew, the British government declined to refmin her to the captors. A similar incident had occmred in 1800, the United States then declining to surrender the Experience, a rescued ship. ${ }^{74}$ Abandonment by captors does not revive the title of the original owner. ${ }^{75}$

67 Consolato del Mare, ch. 295 (290); Digest XLIX, tit. XV, c. 5, § 1; Bynkershoek, Quaest. Jur. Pub., ch. V.; Grotius, De Jure Belli ac Pacis, III, ch. 6, § III, 1; The Ceylon, 1 Dodson, 116.

68 Consolato, c. 287, \$§ 1136, 1138. 69 The Santa Cruz, 1 Robinson, 60 ; Hall, Int. Law, 473; Bynkershoek, Quacst. Jur. Pub. ch. V.

70 The Two Friends, 1 Rob. 241; The Short Staple v. U. S., 9 Cr. 55; 2 Azuni, II, ch. IV, Art. V, n.
71 The Short Staple, 9 Cr. 55; Dederer v. Del. Ins. Co., 2 Wash. 61; The Catherine Elizabeth, $5 \mathrm{Ch}$. Rob. 206.

72 The Ann Green, 1 Gallison, 274.

733 Opin. Attys. Gen. 377.

74 Heffter, § 192 G. n. 3; The Emily St. Pierre, Snow Cas. 361-3; 3 Whart., Int. Law Dig. § 328.

75 The Mary Ford, 3 Dallas, 188, 198. 
Salvage.-The rate of salvage is by no means uniform, vary. ing in Great Britain, for instance, since the act of 1692, from one-eighth to one-fourth, according to danger, while France and Prussia allow one-third. ${ }^{i 6}$ In Europe it is sometimes estimated on the net value, in the United States on the gross value of the ship.it It is to be noted that salvage applies to prize at sea only, property recaptured on land reverting to the owner without cost when it can be identified. An army may, however, earn and receive salvage if it compels a naval surrender. If the original arew are the recaptors, they sometimes receive salvage, as in France in the ease of the Sainte Anne. ${ }^{78}$ As a rule, salvage is not allowed on neutral property retaken. ${ }^{79}$

$\$ 560$. Exceptions to postliminy.-If the captured vessel is "set forth" by the enemy, that is, has been employed with or without a commissions ${ }^{\mathrm{s}}$ in his public military service, whether. regular or privateer, it becomes the property of the enemy state and the right of the original owner generally ceases for all purposes. ${ }^{\$ 1}$ If, after condemmation, a neutral has bought the ressel, there is no postliminy; and the extension of the right does not necessirily cover neutral ships when rescued. Both English and American laws and courts so extend it only when the neutral state in question does so; and the French so extend it according to Portalis (in the Statira' only when the enemy state grants a similar extension. As stated by Hautefeuille, recapture does not literally apply to the case of neutrals; for, as it is presumed the eapture will not be sustained by the courts, the recapture also is unlawful. ${ }^{82} \mathrm{~A}$ recapture by an ally, not having a less favorable rule himself, is subject to postliminy in faror of the original owner, unless a privateer be the recaptor, because allies stand in the position

76 Naval Prize Act, $1864,27 \&$ 28 Vict. cap. $25, \S 40$; Heffter, § 192 , G. n. 4 .

77 Act Mar. 3, 1800, ch. 14, § 1 ( 2 Stat. L. 16) ; Act June 30, 1864 (13 Stat. L. 314 ); The Adeline, 9 Cranch, 244; The Star, 3 Wheat. 78.

is The Two Friends, I Rob. 241; The Short Staple v. U. S. 9 Cr. 55; 2 Azuni, II, ch. IV, art. V, n. 79 The Carlotta, 5 Ch. Rob. 55. 80 The Ceylon, 1 Dods. 105. 81 Nostra Signora, 3 Ch. Rob. 10;
The Ceylon, 1 Dodson, 105; The Georgiana, 1 Dodson, 401; L'Actif, Edwards, 186; The Horatio, $6 \mathrm{Ch}$. Rob. 320.

82 The Star, 3 Wheaton, 92; Talbot v. Suman, 1 Cranch, 1; The Adeline and cargo, 9 Cranch, 244, 288; The Carlotta, 5 Rob. 54; 2 Azuni, II, ch. IV, Art. V. The rules of several states are given in Twiss, Law of Nations, War, $\S$ 175. See 1 Kent Commentaries, 112; Hantefeuille, III, p. 352; Heffter, $\S 192$, G. n. 3 . 
of one's own state for purposes of the war. Such is the application in this connection of the rule of reciprocity. ${ }^{83}$

$\$$ 561. Ownership of the prize. Rule as to privateers.-Because the rights of making war and of granting commissions are royal prerogatives, the power to dispose of the acquisitions of war belongs to the state. "Prize," declares Lord Stowell, "is altogether a creature of the crown." ${ }^{*}$ Parta bello cedunt reipulice. It may, as in case of seizure on land, retain all, or waive its rights in whole or part. Before the statute of Anne (6 Anne, ch. 1:3) resting the prize, after adjudication, in the captors, captures under commissions belouged to the crown, those without commissions to the admiral. Since then the subject has received much attention, each state for itself regulating the amount of prize money to which captors are entitled, and its distribution among them according to rank. In Great Britain the Act of 27 and 28 Vict., c. 25, controls; in United States the act of 1864, c. 174. (R. S. 4613-4652). ${ }^{85}$ While domestic courts will thus distribute the proceeds according to the local municipal law, foreign courts consider the property and possession as that of the captor'is sovereigns so The captor has right in and to his prize, insurable and valuable, from the moment of taking possession; but it is a defeasible right,

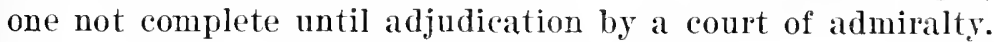
A prize can be released by the government only before condemnation. The right of prize is superiol to contractual liens such as mortgages. ${ }^{87}$ In the case of privateers captures enure to the captors themselves, who have thus a greater interest in prizes because of the special right to make them granted by such states as have not yet assented to the abolition of privateering itself.

§562. Damages for wrongful capture-Every marine capture must be made at the peril of the seizing belligerent; unless he can show grounds for force, the captor is liable for damages. $^{\text {ss }}$ The right of seizure is dependent upon the lawful

83 Vattel, Droit des Gens, III, ch. 14, § 207; The Santa Cruz, I Rob. 50. So between France and Spain, 1780, etc.; 2 Azuni, II, ch. IV, 510 Art. V.

s4 The Elsebe, 5 Ch. Rob. 184; 1 Kent Commentaries, 100; Home v. Earl Camden, 2 H. Blacks. 533; Bluntschli, 165 (655), 173 (673);
Halleck, 727, $730 \mathrm{n}$; The Dos Hermanos, 10 Wheat. 306.

85 See Dewey v. U. S., 178 U. S. 86 The Santissima Trinidad, 7 Wheaton, 283; The Florida, $101 \mathrm{U}$. S. 37 .

87 The Hampton, 5 Wall. 372. 88 The Resolution, 2 Dall. 1; 
use of the war power by the captors. 89 If the grounds of capture are good, the ship is condemned and the captors receive their shire of the proceeds of sale as prize money. On the other hand, if there was not probable cause, the captor may be made to pay costs and damages. Where there were grounds of suspicion, cleared up only in court, the vessel is released, in whole or in part at the expense of the owner, according to circumstances.90 The measure of damages for an unlawful capture by a privateer, as against the owners, is the full value of the property injured or destroyed. ${ }^{91}$ The commander of a United States ship of war, if he seizes a ressel on the high seas without probable cause, may be held liable to make restitution in value, with damages and costs, notwithstanding the vessel is afterwards taken out of his possession by a superior force. ${ }^{92}$ Where the captor transcends his powers and rights, he becomes guilty of a marine trespass, and is amenable in damages for the injury sustained; and where the ressel has been lost in consequence of such illegal acts, the value of the vessel, the prime cost of the cargo, with all the charges and the premium of insurance, are to be allowed in ascertaining the damages. ${ }^{93}$ While in case of an illegal seizure, if there be gross and wanton outrage, the actual wrongdoers may be made responsible beyond the loss actually sustained. The owners of a privateer, who are only constructively liable, are not bound to the extent of vindictive damages. ${ }^{94}$ Freight is a proper item for allowance in estimating the damages arising from an illegal capture, where the cargo has been lost, or the vessel been unliceried; but it is not to be allowed where the ressel has been restored with the cargo on board,

The Grand Sachem, 3 Dall. 333; The Charming Betsy, 2 Cranch, 64; The Thompson, 3 Wall. 155; Hollingsworth v. The Betsy, 2 Pet. Adm. 330.

89 The Jane Campbell, Blatchf. Pr. Cas. 101; The Anna, 5 Ch. Rob. 373.

90 The Nayade, Newb. Adm. 366; The Olinde Rodrigues, 174 U. S. 510; The Joseph, 8 Cranch, 451; The Liverpool Packet, 1 Gall. 513; The Rover, 2 Gall. 240; Maisonnaire v. Keating, 2 Gall. 325; The Charming Betsy, 2 Cranch, 64; Maley v. Shattuck, 3 Cranch, 458;
The Venus, 5 Wheat. 127; The Thompson, 3 Wall. 155; The Springbok, 5 Wall. 1; The Dashing Wave, 5 Wall. 170; The Peel, 5 Wall. 517; The Teresita, 5 Wall. 180; The Jenny, 5 Wall. 183.

91 The Grand Sachem, 3 Dall. 333.

92 The Charming Betsy, 2 Cranch, 64; Maley v. Shattuck, 3 Cranch, 458.

93 The Anna Maria, 2 Wheat. 327; Heffter, $\S 138$, G. n. 2.

94 The Amiable Nancy, 3 Wheat. 546. 
and in such a condition as to be capable of performing the voyage. ${ }^{95}$ If captors wantonly injure the captured crew, a prize court will award damages for personal ill usage. Misconduct on the part of the captors, such as wrongful spoliation of property on board a prize, or separation of the officers or crew frow her, may even destroy the legality of the capture, and subject the captors personally to punishment for infringement of the laws of maritime warfare. As the condemnation is not a criminal proceeding, the President cannot remit forfeitures in captures made jure belli. ${ }^{96}$

\$563. Prize courts.-Although firm possession constitutes capture, it must be recognized as adequate by the prize court,- - such adjudication or condemnation, as it is called, being necessary to complete the inchoate right acquired by capture of private property at sea. The title to property seized as prizes is changed only by the decision rendered by the prize court. ${ }^{1}$ No decree of admiralty is necessary, however, to validate in any way the capture or destruction of the enemy's war vessels, that being an act of war which, like all others of its class, is subject only to the regulations of the political department of the government and not to those of the judicial. The rule is different only when neutral or private enemy property is concerned. As mail and telegraphic communications make the military commander practically present every where, all questions of booty and capture on land can be decided summarily; and such was formerly the case at sea when the cruise 'was made by a fleet under the admiral, who satisfied himself by a summary examination of persons and papers, after the prize was taken alongside his ship. ${ }^{2}$ The prevalence of privateering and later the overhauling of neutral trade made such inquiry always necessary in order to prevent the abuse of commissions, and to avoid war with other states. Finally, after the admiral was stripped of his judicial powers, commissions to adjudicate on land became as common as commissions to make captures at sea; and they apply to captures of private property by regular ships of war as well as to those by privateers. Out of such beginnings has grown

95 The Lively, 1 Gall. 315.

9610 Opinions Attys. Gen. 452; 11 Id. 484; The Grey Jacket, 5 Wall. 342; The Hampton, 5 Wall. 372.

1 Am. Naval Code, Art. 49.

24 Rymer's Foedera, 14 (1357);
Twiss, Law of Nations, War, $\S 186$; The Santa Cruz, 1 Ch. Rob. 65; Camden v. Home, 4 Term R. 382; Lindo v. Rodney, 3 Term R. 613. Semmes held a kind of admiralty court aboard the Alabama; Service Afloat, 483 . 
a regular practice as to prize,-in France since the institution of an admiral in 1373, in Eugland since 1414 .

$\S 564$. Prize jurisdiction, its nature and extent.-Prize jurisdiction, bestowed by special commissions or instructions in Great Britain, and except for a short time in France, is in the United states a part of the admiralty law administered by the district courts, which possess both instance and prize jurisdiction. ${ }^{3}$ The tribunal must belong to the captor's country, and for its acts the state creating or permitting it is responsible." "Where the responsibility of the captor ceases," says Wheaton, "that of the state begins." A neutral court of admiralty will pass on a belligrerent capture only when it comes before it incidentally as a part of its rightful jurisdiction, as when an abandoned prize is liable for salvage and the question of ownership of surplus comes up between captor and original owner. ${ }^{5}$ The only exception to the rule of direct noninterference by neutral courts is where a capture is made under circumstances affecting the neutrality of the nation in question, as when made within the neutral's territorial waters, or by a ressel equipped in violation of neutral rules, and the like. Jurisdiction is then taken in order to vindicate violated neutrality. ${ }^{6}$

$\$ 565$. Where prize courts should be held.-A prize court, as declared by Lord stowell in a famous case already quoted, and even more clearly by Sir James Mackintosh, is not municipal, but emphatically a court by virtue of the law of nations. ${ }^{7}$ The mandate of that law is that it must be held in the captor's country; neither the decree of her consul or of any other court in a neutral country need be recognized. ${ }^{8}$ When complaint

3 Glass v. The Betsy, 3 Dall. 6. The reinstitution of the council of prizes in France in 1800 will always be associated with the name of Portalis, the public attorney, some of whose opinions, as in the case of the American ship Statira, are classic. See above pp.

${ }^{4}$ Halleck Int. Law, 750, 752; 2 Rutherforth Inst. 595, 596 (Cambr. ed.); Wharton, Int. Law Dig. § 329 .

5 The Schr. Adeline, 9 Cranch, 191; 11 Opin. Attys. Gen. 445. As to the origin of English admiralty jurisdiction and its transfer to America, see Origin and
Growth of the Eng. Const., vol. 1, 547-551.

63 Phillimore,479; La Satanique v. L'Ary et Maria, 1 De Pist. et Duver., 191.

7 Mackintosh in The Erin, and in The Minerva, 2 Life Mackintosh, 317. "The seat of judicial authority," says Lord Stowell (in the Maria, $1 \mathrm{Ch}$. Robinson 350), "is, indeed, locally here, in the belligerent country, according to the known law and practice of nations; but the law itself has no locality."

8 The Flad Oyen, 1 Ch. Rob. 135. 
was made by Great Britain that Genet was attempting to establish such courts in the United States, President Washington insisted on his removal by France, as the toleration of such courts would have been a breach of neutrality.9 While it is unusual to have such a court in an ally's country, such a course has been defended on the principle that allies make up one nation for purposes of the war,-unam constituunt civitatem, as Bynkershoek has it in anotler connection. ${ }^{10} \mathrm{~A}$ court of admiralty is merely an arm of the government and the sovereign is responsible in damages for its wrong decision. As such responsibility could not be assumed for the courts of an ally, any more than for the army of an ally, the employment of foreign admiralty courts is subject to the objection that either the captor country would be without responsibility for a wrong capture, or would have to defend a judicial act of another nation, either of which is opposed to international principles. The vessel itself, however, need not be brought into the captor's yort. It is sufficient if it be secured in a harbor of an ally or of a neutral; and even if destroyed at sea, or sold, or ransomed, the cause is nevertheless heard.1 Neutral nations generally prohibit the bringing in of prizes, on the ground of public policy, but for that reason no doubt a greater number of them are destroyed at sea. ${ }^{2}$

566. Procedure in prize cases.-The prize proceeding is summary, in rem, and in the first instance turns largely upon the ship's papers, - an order for further proof being made always with extreme caution, and only when the ends of justice clearly require it. Spoliation of papers at the time of

Marshall as secretary of state recognized such consular decrees of the French in Spain but held that state responsible. Whart., Int. Law Dig., § 329.

91 Pres. Messages, 146; Wharton, Int. Law Dig., $\$ \S 399-400,329 ; 4$ Jefferson Wks. 39. So Geffcken in Heffter, $\S 138$ n. 6 ; 3 Phillimore, 581; Martens, $\S 37$; Wheaton, Elements, $\S 15$; Wheelwright v. Depeyster, 1 Johns. R. 481; Glass v. The Betsy, 3 Dall. 6.

10 The Christopher, $2 \mathrm{Ch}$. Rob. 209; The Flad Oyen, $1 \mathrm{Ch}$. Rob. 146; The Divina Pastora, 4 Wheat- on, 52; 1 Kent Comm. 103; Bynkershoek, Quaest. Jur. Pub., ch. $\mathrm{XV}$.

11 Hudson v. Guesteer, 4 Cranch, 293; The Invincible, 2 Gall. 29; Smart v. Wolff, 3 Term R. 329 ; The Herstelder, 1 Rob. 100; The Hendrick \& Maria, 5 Rob. 35; Rose v. Himely, 4 Cranch, 241.

12 Semmes' Service Afloat, passim; Crawford v. Lucena, 3 B. \& P. Exch. 269; Le Cras v. Hughes, East 22 G. III; Boehm v. Tell, 8 T. R. 154; The Nemesis, Edw. 50; The Josefa Segunda, 5 Wheat. 338 . 
capture therefore warrants the most unfavorable inferences. ${ }^{\mathbf{1 4}}$ The practice applies to recapture as well as original capture, ${ }^{15}$ and in America proceedings should be begun in the name of the United States. ${ }^{16}$ The three questions to be settled are these: (1) Was the subject of capture lawful prize; (2) was the captor inpressed with military character; (3) were the place and mode of capture and detention legal? ${ }^{17}$ The burden of proving neutrality rests on the claimant, and that beyond a reasonable doubt. ${ }^{8}$ The court will not go behind the commission of the ship. ${ }^{19}$ When made, a decree of condemuation orerrides all existing liens, ${ }^{-0}$ and affects the title as of the begimning of the voyage; the transfer or incumbrance of a ressel at sea being invalid as against the captor. ${ }^{21}$ The judgment of condemmation should state or be accompanied with a statement of the grounds on which it is based.22

$\$ 567$. Finality of decree.-The decree of a court of admiralty as to the question of title,- - the sale of a ship, for instance, under a regular proceeding,- is in rem and valid, whether the decision itself be right or wrong. If wrong, the government responsible for the court should, by treaty or otherwise, provide an indemnity, as frequently happens. No question can

14 The Zavalla, Blatchf. Prize Cases, 173; The Jane Campbell, Ib. 101; The George, 1 Wheat. 408; The Dos Hermanos, 2 Wheat. 76; The Pizarro, 2 Id. 227; The Grey Jacket, 5 Wall. 542; The Ann Green, 1 Gallison, 274. The English practice is given in the letter of Sir John Nicholl and Sir Wm. Scott of 1794 to John Jay, the American envoy, in the appendix to $1 \mathrm{Ch}$. Robinson, edition of Little, Brown \& Co., 1853. The standing interrogatories in prize cases in the English courts are to be found in the same appendix.

15 The Bermuda, 3 Wall. 514; The Adeline, 9 Cranch, 244, 286.

16 The Palmyra, 12 Wheat. 1; Jecker v. Montgomery, 18 How. 110.

17 Field's Int. Code, $\S 895$. The English practice is given in Wharton, Int. Law Dig., $\S 330$.

18 The Amiable Isabella, 6
Wheat. 1, 78; 2 Azuni, II, ch. III, Art. IV; U. S. v. Hayward, 2 Gall. 485.

10 The Sant. Trinidad, 7 Wheat. 283; La Nereyda, 8 Wheat. 108.

20 McDonnough v. Dannery, 3 Dall. 188; L'Invincible, 1 Wheaton, 238.

21 The Battle, 6 Wallace 498; The Sally Magee, 3 Wallace, 451; The Marianna, $6 \mathrm{Ch}$. Rob. 24; The Tobago, 5 Ch. Rob. 218; The Ariel, 11 Moore, P. C. 119.

22 Hobbs v. Henning, 17 C. B. (N. S.) 791; Field's Int. Code, $\S 898$, and citations. The courts of admiralty for several countries are given in Heffter, $\S 138$, Geffcken n. 3 ; Wharton, Int. Law Dig., $\S \S$ 399, 329; The Estrella, 4 Wheat. 298; La Amistad, 5 Wheat. 365. The Sant. Trinidad, 7 Wheat. 283; Brig Alberta v. Moran, 9 Cranch, 359. 
ever be raised, however, as to the validity of titles and acts under the decree where the court had jurisdiction. ${ }^{23}$ Such a reëxamination of British decrees as I'russia undertook in 1753, international law can recognize only as a means by which the dissatisfied sovereign can determine whether to demand damages or not. In 1794, a joint commission was organized by Great Britain and the United States with authority to pass on American claims for wrongful captures by British cruisers, and there have been many such mixed commissions since. A foreign admiralty decree is not examinable elsewhere, as was declared in the case of French condemnation under the Milan decree as to trading with England,-a decree declared by Congress a violation of international law. ${ }^{24}$ As the Confederate States were not recognized as a government by their opponents, the proceedings of a Confederate prize court are of no validity in the United States and convey no right or title. ${ }^{25}$

23 Wharton, Int. Law Dig., § $329 \mathrm{a}$.

24 Williams v. Armroyd, 7
25 The Lilla, 2 Sprague 177;

Oakes v. U. S., 174 U. S. 794.

Cranch, 423. 


\section{CHAPTER IX.}

\section{MILITARY OCCUPATION AND ADMINISTRATION.}

\$568. Ancient theory of substituted sovereignty.-The subject involved in this chapter has been reserved for special treatment in this place because military oceupation and administration by a conquering army is, as a general rule, the prelude to the termination of war by al treaty of peace, or other means converting occupation, a momentary possession of territory, into conquest, a definitive and final appropriation of it. Or to state the matter in another form, conquest in the military sense, which takes place when the army of one belligerent state drives that of the other out of a certain territory and holds it by force, does not ripen into conquest in the legal sense until the victorious state permanently assumes sorereignty over such territory by some adequate diplomatic act indicating its purpose to remain and govern it as a part of its dominions. Thus it appears that the right of mere military oceupation (occupatio bellica) falls far short of the right of complete conquest (debellatio, ultima victoria). Obvious and well defined as the distinction now is between these two essentially different conditions, it was so entirely overlooked in the formative period of modern international law that it was then assumed that as an invader entering a lostile country drives before him the forces of the owner he is dothed with the rights of full sovereignty by the bare fact of military possession, regardless of his intention or power to convert such possession into a definitive applopriation. This ancient theory of substituted sovereignty rested on the rule of Roman law which provided that all property, including territory, after it had become res nullins by passing out of the hands of its owner in war, belonged to any person able to seize it for so long as he could retain it. ${ }^{1}$ In accordance with that doctrine the occupying sovereign, no matter how transient or precarious his possession might be, could deal with the occupied territory as his own, and with its inhabitants as their legitimate ruler so long as he could hold on to it. As such ruler he could require such. inhabitants not only to renounce their fealty to their legitimate sorereign, but to acknowledge him either by the promise

1 See above, p. 128. 
of fidelity and obedience, or more often by the taking of an oath of allegiance. ${ }^{2}$ In logical accord with that premise was the further contention that such inhabitants were bound to render to the invader all other serviees due to their former sovereign, including, as Frederick II claimed, the right to bring his army up to its full strength by forcible recruiting in the enemy country; "if the local authorities are willing to hand over recruits, so much the better, if not, they are taken by force." 3 With equal consistency it was also claimed that, while the final issue of hostilities was still in doubt, the captor of the res nullius could transfer his title to a third power, as in the case of the Swedish province of Bremen conquered by the king of Denmark in 1712, and sold by him three years later, along with Verden, to the Elector of Hanorer. ${ }^{4}$

$\$ 569$. Modern theory of quasi sovereignty of belligerent occupant.-The fact that the ancient doctrine of substituted sovereignty had been very seriously diseredited by the middle of the eighteenth century is put beyond all question by Vattel from whom we learn that "a third party cannot safely purchase a conquered town or province till the sorereign from whom it was taken has renounced it by a treaty of peace, $\mathrm{or}^{*}$ has been irretrievably subdued, and has lost his sovereignty: for, while the war continues,-while the sovereign has still hopes of recovering his possessions by arms,-is a neutral prince to come and deprive him of the opportunity by purchasing that town or province from the conqueror? The original proprietor cannot forfeit his rights by the act of a third person; and if the purchaser be determined to maintain his purchase, he will find himself involved in the war. Thus, the king of Prussia became a party with the enemies of Sweden, by receiving Stettin from the hands of the king of Poland and the Czar, nuder the title of sequestration." After the close of the Seven Year's' War the distinction between the right of control over hostile territory incident to mere military occupation, and the right of sovereignty incident to completed

2 "In the seventeenth century express renunciation of fealty to the legitimate sovereign was sometimes exacted." Hall, p. 482, note 1. See also Martens, Prícis, $\$ 280$; Heffter, § 132; Moser, Versuch, ix, i, 231, 280, and ix, ii, 27; Memorial of the Elector of Hanover to the
Diet of the Empire, Entick, Hist. of the Late War, ii, 425 .

3 Oeuvres de Fred. II, xxviii, 91. See also Moser, Versuch, ix, i, $296,389$.

4 Stanhope, Hist. of Eng., ch. vii.

5 By the treaty of Schwedt, Octo- 
conquest became so clearly defined that the continuing sovereignty of the original owner became generally recognized for certain purposes, while the intruder was supposed to supersede him temporarily for certain other purposes. Thus the idea dereloped that although the national character of the soil and its inhabitants remained unchanged, the invader was clothed with such a quasi-sovereignty over both as authorized hin to do everything necessary to bring the war to a successful conclusion, provided he neither recruited his army nor disturbed the permanent institutions of the country. During the period in which the onsted owner retains a kind "of latent title," ${ }^{6}$ as Klüber has expressed it, those of his subjects to whom he can no longer guarantee protection "pass under a temporary or qualified allegiance to the conqueror." 7 Or in the words of Mr. Justice Story: "The capture and possession by the British was not an absolute change of the allegiance of the captured inhabitants. They owed allegiance, indeed, to the conquerors during their occupation; but it was a temporary allegiance, which did not destroy, but only suspended their former allegiance. It did not annihilate their allegiance to the state of Sonth Carolina and make them de facto aliens." \& In 1808 , after the beginning of the Spanish insurrection against France, Great Britain, then at war with Spain, issued a proclamation commanding that all hostilities against that country should immediately cease. Shortly thereafter, when a Spanish. ship, captured on a voyage to Santander, a port still occupied by the French, was brought in for condemnation Lord Stowell remarked that "under these public declarations of the state establishing this general peace and anity, I do not know that it would be in the power of the court to condemn Spanish property, though belonging to persons resident in those parts of Spain which are at the present moment under French control, except under such circumstances as would justify the confiscation of neutral property." 9 During the military occupation of Catalonia by the French in the summer of 1811 Vilber 6, 1713. Droit des Gens, III, the enemy certain rights over it, c. xiii, $\S 197$.

' Europäisches Völkerr., \$ 256. See also Manning, ch. 5.

7 "The general doctrine may be stated thus: firm possession by the enemy in war suspends the power and right to exercise sovereignty over the occupied places, and gives of a temporary character, which all nations recognize, and to which loyal citizens may submit." Dana's Wheaton, p. 421, note 162 .

8 Shanks v. Dupont, 3 Peters, p. 246.

9 Edwards, 182. 
lasseque, a Frenchman, was tried and convicted of the murder in that province of a Catalan by the Court of Assizes of the Pyrenées Orientales. On appeal, after the prosecution had contended that because Catalonia was occupied by French troops, and governed by French anthorities, it must be considered French territory, the Court of Cassation ( $\Lambda$ rrêt du 22 Janvier, 1818), quashed the conviction on the ground that the courts of the territory had exclusive jurisdiction: "This oecupation and this administration by French troops and French authorities," it was said, "had not communicated to the inhabitants of Catalonia the title of Frenchmen, nor to their territory the quality of French territory; this communication could result only from an act of union emanating from the public authority, which had never been carried out." 10

\$70. Military authority over hostile territory as limited by Hague Conference.-During recent years the tendency has been to escape from certain inconsistencies inherent in the law of occupation as redefined early in the last century through the adoption of the simple principle that the invader is only permitted to perform within the occupied territory such acts as are the natural incidents of hostilities, - the legal relations of the population to the invader remaining unchanged, and the rights of the sovereign surviving intact. While the great military powers cannot be said to have expressly assented to such a doctrine, unanimously supported by the smaller ones at the Conference at Brussels, they permitted the Declaration to be drawn in a form that certainly implied it.11 Since then the whole subject has been regulated by Section III of The Hague Second Convention, "On Military Authority orer Hostile Territory," which clearly defines the extent to which the invader may subject the inhabitants of the occupied territory and its resources to the necessities of war. In the expositions heretofore made of the laws of war as to enemy persons, and enemy property on land, ${ }^{12}$ it became necessary to refer to all of the provisions contained in that section, except the following: (Art. XLII.) "Territory is considered occupied when it is actually placed under the authority of the hostile army. The occupation applies only to the territory where such authority is

10 Ortolan, Diplomatie de la Mer, II, ch. xiii; Heffter, § 131; Campbell v. Hall, 1 Cowp. 204; Kampt, Literatur des Völkerrechts, § 307. 11 Calvo, § 1877; Rolin Jacquemyns, La Guerre actuelle dans ses
Rapports avec le Droit International, p. 29. See also Bluntschli, § 539-40 and 545; Heffter, § 131.

12 See above pp. 527, 528, 541, $542,545,547,549,550$. 
established, and in a position to assert itself. (Art. XLIII.) The authority of the legitimate power having actually passed into the hands of the occupant, the latter shall take all steps in his power to reëstablish and insure, as far as possible, public order and safety, while respecting, unless absolutely prevented, the laws in force in the country. (Art. XLIV.) Any compulsion of the population of occupied territory to take part in military operations against its own country is prohibited. (Art. XLV.) Any pressure on the population of oceupied territory to take the oath of allegiance to the hostile power is prohibited. (Art. L.) No general penalty, pecuniary or otherwise, ean be inflicted on the population on account of the acts of individuals for which it cammot be regarded as collectively responsible. (Art. LIV.) The plant of railways coming from neutral states, whether the property of those states, or of companies, or of private persons, shall be sent back to them as soon as possible. (Art. LV.) The occupying state shall only be regarded as administrator and usufructuary of the public buildings, real property, forests, and agrieultural works belonging to the hostile state, and situated in the occupied country. It must protect the capital of these properties, and administer it according to the rules of trusteeship."

$\S 571$. When military occupation begins and ends. Contention of smaller states.- $\mathrm{C}_{\mathrm{P}}$ to a certain point it is not difficult to determine when military occupation actually begins and ends in a given area of territory. According to the American Regulations (\$8) occupation of territory (occupatio bellica) occurs when the regular authority of the old state has ceased, and the invading forces find themselves able to maintain order. There can be no doubt of such ability within the actual outposts of an army, and along its lines of communication so long as they are kept open, that is within the limits of the hostile army's actual as distinguished from its constructive possession. The limits of that lind of possession are always difficult to define no matter whether the question arises as to the boundaries of real property in litigation between private owners, or as to the area within which a hostile army may claim authority in an invaded country only partially subdued. The less powerful states, whose interests prompt them to resist every extension of the doctrine of constructive military possession, contend, that, as all rights over territory acquired by invasion rest upon mere force, they should appear with it. disappear with it, and cease to exist in the meantime. They claim that such pos- 
session to be effective must, as in the analogous case of blockade, be maintained at all points by a sufficient force; that the rights of the invader extend over the hostile territory only so far as the inhabitants are vanquished or reduced to actual submission to him. "To extend the rights of military occupation, or the limits of conquest, by mere intention, implication, or proclamation, would be establishing a paper conquest infinitely more objectionable in its character than a paper blockade." 13 Or, as Wildman has stated it, "the constructive occupation of the owner is defeated by actual occupation, so far as it extends. Thus it is said by Celsus, if an enemy enter a territory by force of arms, it is in possession of so much only as it occupies. When lie speaks of force, he supposes resistance ou behalf of the sovereign, in defense of his possession. An army only possesses a country so far as it compels the enemy forces to retire. $* * *$ Upon these principles, the extent of hostile possession may be distinctly defined. If an army be in possession of a principal town of a province, it is not thereby in possession of the towns and forts within the same, which hold out for the enemy. Forcible possession extends so far only as there is an absence of resistance. The occupation of part by right of conquest, with intent to appropriate the whole, gives possession of the whole, if the enemy maintain military possession of no portion of the residue. Under such circumstances, military possession of a capital would be possession of a whole kingdom. But if any part hold out, so much only is possessed as is actually conquered." 14 Such principles are in perfect accord with Lord Coke's declaration in Calvin's case ${ }^{15}$ that "certain it is, whilst King Henry VI had both England and the heart and greatest part of France under his actual legiance and obedience (for he was crowned king of France in Paris) that they that were then born in those parts of France that were under actual legiance and obedience, were no aliens, but capable of, and heritable to, lands in England. Those born in parts of France not under actual legiance and obedience, and prior to King Henry's recognition and coronation, were regarded as antenati, and received letters patent of denization, as in the case of Reynel." Or, as Chief Justice Taney has stated it: "By the laws and usages of nations, conquest is a. valid title, while the victor maintains the exclusive possession of the conquered country." 16

13 Halleck, Int. Law, ii (Baker ed.) 434 .

14 Int. Law, i, pp. 163-64.
157 Rep. 28 a.

16 Fleming et al. v. Page, $9 \mathrm{How}$. 615 . 


\section{$\$ 572$. Contention of the great military states. Conclusions} reached at Brussels and The Hague.-On the other hand certain great military powors have for a long time contended that, unless military resistance is maintained by duly organized national troops, the invader may establish a constructive occupation through the whole of a district forming an administrative unit so soon as notice of such occupation is given by placard or otherwise. Such was the practice of the Germans in France in 1870 where the eanton, of an average size of about seventy-two square miles, was adopted as the administrative unit to be affected by notice of occupation given at any spot within it. Some idea of the extent of the constructive possession thus maintained by the invaders, without the present military power to enforce their authority, may be drawn from the statement of $\mathrm{Mr}$. Edwards, who says, in his "Germans in France," "I once traveled from St. Germain to Louviers, a distance of fifty miles along a road oceupied theoretically by the Prussians, without seeing a Prussian soldier. From the outskirts of Rouen to Dieppe, nearly fifty miles, I met, here and there, and at one place found a post of prihaps half a dozen men. At Dieppe, l'russian proclamations on the walls and the local cannons spiked or otherwise spoiled; the police and firemen disarmed; the telegraph in every direction cut, the postal service stopped; but nowhere a Prussian or a German soldier." According to this theory occupation once established does not cease by the absence of the invading force; and thus the inhabitants remain liable to penalties for disobedience to order's when no means for enforcing them exist, and for subsequent resistance to invading bodies too weak to overcome it. While the hostile occupation ceases if the invader be expelled by the regular forces of the country, it is not extinguished by a temporary disposition which is the result of a popular movement, even when the national govermment has been reëstablished. The most extreme form which this theory has assumed is embodied in the pretension that such a constructive oecupation as will subject the inhabitants to penalties for disobedience of orders may be established even by a flying column passing through the district. ${ }^{17}$ In order to set limits to such

17 Cf. Gen. Von Voigts Rhetz on flying columns and temporarily successful insurrections, Parl. Papers, Miscell., i, 1875, p. 65; Bluntschli, \& 544. As to Napoleon's practice with respect to fly.

ing columns, illustrated in an order issued in 1806 to Marshal Lannes before the French army passed the Oder, see Corresp. xiii, 467. Hall, p. 501, note 1. 
extravagant claims it was provided in the project of Declaration formulated at Brussels that "a territory is considered as occupied when it finds itself placed in fact under the authority of the hostile army. The occupation extends only to territories where this authority is established and in condition to be exercised." When delegates of some of the smaller powers contended that there is such a close analogy between such occupation and blockade as now understood as to compel the maintenance of an immediately effective force in order to render it valid, a view likewise maintained by England, Germany denied the assumption. ${ }^{18}$ In the next year, however, the Institute of International Law in examining the project accepted the definition "that a territory is considered as occupied from such a time, and so long as the state of which it forms a part is prevented by the cessation of local resistance from publicly exercising there its sovereign authority." 19 Finally the definition of occupation in the amended form (Art. I), approved at Brussels, was incorporated into The Hague Second Convention (Art. XLII) without even a verbal alteration.

$\S 5$ 573. Legal relation of subdued inhabitants to occupying state. Suspended sovereignty of prior owner.-As observed heretofore when a state is compelled to yield a portion of its territory to the superior force of an enemy, it loses for a time its claim to the perfect allegiance of the inhabitants whom it is no longer able to protect. As a necessary consequence they must give a temporary or qualified allegiance to the military occupant whose possession so far suspends the authority of the former owner as to deprive him of the power to alienate any part of his territory so long as it remains in the possession of the conqueror, or his allies.20 It is even a question whether such owner can make a valid transfer of it to a neutral while his possession continues, if such transfer is made after a declaration of war, and as a means of depriving his adrersary of the opportunity of acquiring it by conquest. As the general right

18 Parl. Papers, Miscell., i, 1875, p. 64 .

19 See Rolin Jacquemyns' Second Essai, p. 34.

20 The grantor can not make a perfect title unless he possesses at once the jus ad rem (the possession of) and the jus in rc (the right to) the thing conveyed. During military occupation these rights coexist neither in the original owner nor occupant. Grotius, De Jure Belli ac Pacis, II, c. vi, § 1; Puffendorf, iv, c. ix, $\S 8$; The Foltina, 1 Dod. 450; The Fama, 5 Rob. 97. 
of neutrals to purchase the property of belligerents, fagrante bello, is universally conceded, provided the sale is bona fide, it can hardly be doubted that such a transfer of title, coupled with a formal delivery of possession to the neutral grantee, would be unassailable unless the transaction is evidently mala fide, a conclusion to be established or rebutted by the special (ircumstances of each particular case.21 During the suspension of the sovereignty of the former owner the inhabitants owe no such legal or moral duty to the occupant as deprives them of the right to rise in insurrection against him, provided they are prepared to brave the perils such an enterprise involves. The right of insurrection in war is supposed to rest upon the same principle as the right of revolution against an established government in time of peace; and history abounds in notable instances of its exercise, followed often by executions and confiscations, where such attempts have been unsuccessful. When during the Italian campaign of 1796 the inhabitants of Paria rose against the French troops and made them prisoners, Napoleon, after Lamnes had routed a portion of the insurgents and burned the village of Brescia, returned himself to the revolted eity, shot the leaders of the insurrection, and delivered up the place to plunder, a "terrible example," we are told, that "erushed the insurrection over the whole of Lombardy." 22 Despite the fact that when inhabitants thus throw off the implied obligation of submission to the authority of the conqueror, he is entitled to exercise the extreme and severe rights over life and property conferred by the laws of war, involving death and confiscation, such extreme rights should be limited in their application by the laws of humanity forbidding cruel and unsual punishments. In modern warfare, while the leaders and instigators of military insurrections are usually punished by death, the main body of the common people controlled by them are more leniently dealt with.

$\S 574$. Legal relation of inhabitants of occupied territory to third states.- $A$ s to third states territory in the military occupation of a conquered state is, together with its inhabitants, regarded as a part of the oceupying country, although such country may treat it as hostile in relation to itself. As Chief

"1 Heffter, § 131; Duer, On Ins., i, pp. 437-38; Opinions of Attys. Genl. U. S. vi, p. 638; Halleck (Baker ed.), ii, pp. 459-60.

22 Napier, Hist. Peninsular War, ii, p. 451. See also Jomini, Des Guerres de la Révolution, ch. lxxiii; Napoleon, Mćmoires, iii, p. 195; iv, p. 149; Alison, Hist. of Europe, i, pp. 405, 468. 
Justice Marshall said in a notable case: "Although acquisitions made during war are not considered as permanent until confirmed by treaty, yet to every commercial and belligerent purpose they are considered as a part of the domain of the conqueror, so long as he retains the possession and government of them. The island of Santa Cruz, after its calpitulation, remained a British island until it was restored to Denmark." 23 When, during the war of 1812, the British occupied Castine, Maine, it became as to the United States a foreign port, and so remained until its evacuation after the treaty of peace. "Castine was, therefore, during this period, so far as respected our revenue laws, to be deemed a foreign port; and goods imported into it by the inhabitants were subject to such duties only as the British govermment chose to require. Such goods were in no correct sense imported into the United States. The subsequent evacuation by the enemy, and resumption of authority by the United States, did not, and could not, change the character of the previous transactions. The doctrines respecting the jus postliminii are wholly inapplicable to the case." 24 And so after the American troops occupied Tampico in November, 1846, and established a custom house there, a vessel trading thence to Philadelphia was held to be engaged in foreign as distinguished from coasting trade; and in that way liable to pay, so long as the military occupation of the United States continued, all customs duties imposed upon goods imported in foreign ships. ${ }^{25}$ The doctrine that enemy character is impressed upon all persons and things connected with enemy territory has been carried so far that a vessel owned by merchants residing at the Cape of Good Hope and captured on a royage begun from Batavia to Holland, before the conquest of the Cape by the English, was condemned by Lord Stowell because the capture took place after that event. The reason giren was that the ship "having sailed as a Dutch ship, her character during the voyage could not be changed." 26 In the same way an English vessel was condemned during the American civil war for having attempted to violate a public blockade of the city of New Orleans in defiance of "a well established principle of prize law, as administered by the courts, both of the United States and

23 Thirty Hogsheads of Sugar v. Boyle et al. 9 Cranch, 195.

24 United States v. Rice, 4 Wheat. 255; U. S. v. Hayward, 2 Gall. 435.
25 Fleming et al. v. Page, 9 How. 603.

26 The Danckebaar African, 1 
Great Britain, that sailing from a neutral port with intent to enter a blockaded port, and with knowledge of the existence of the blockade, subjects the vessel, and in most cases its cargo, to capture and condemnation." In answer to the contention that the blockading belligerent had ended the public blockade by occupying the city itself, it was said that "only the city was occupied, not the port; much less the district of country commercially dependent upon it, and blockaded by its blockade. Even the city had been occupied only three days. It was yet hostile; the rebel army was in the neighborhood; the occupation, limited and recent, was subject to all the vicissitudes of war." 27

\section{$\$ 575$. When territory may possess at same moment a neutral} and belligerent character.-Such a condition of things can arise only when subject states are united to a central authority whose sovereignty or overlordship is of so limited or shadowy a character that the over-sovereign may be at war with another belligerent without actually involving all of his dependencies in hostilities, or vice versa. While the Germanic Confederation still survived we were told that "the states which are under the sceptre of the head of the house of HapsburgLorraine may be divided into Germanic and non-Germanic states. The Germanic states form part of the territory of the Germanic Confederation; they at the same time form part of the Austrian Empire, and their twofold national eharacter has been the subject of international recognition. In a sinilar manner the Germanic states of the head of the house of Hohenzollern form part of the territory of the Germanic Confederation, and at the same time form part of the Prussian Monarchy." 2s When such relations existed those parts of the empire which were Austrian or Prussian were always in a donble or anbiguous position when either was at war. As an illustration, reference may be made to the Austro-Sardinian war of 1848, during which an Austrian fleet sought shelter in the fortified port of Trieste under the dominion both of Austria and the Confederation. Regardless of the nentral position of the latter, the Italians declared a blockade against

27 Hunter v. United States (the British steamer Circassian), 2 Wall. p. 135. Compensation for wrongful capture was subsequently awarded by a mixed commission on British and American claims.
Parl. Papers, North Am., No. 2, 1874, p. 124.

$2 \times$ Twiss, Peace, $\S 39$. As to the legal relations existing between Turkey as overlord and certain of her dependent principalities, see 
Trieste, not only because it had been made a refuge for the Austrian fleet, but because, as they claimed, it had been fortified and garrisoned and fire directed by its batteries against the Sardinian fleet. After consuls of the various German states had protested against such blockade the Italian admiral consented to recognize the place as belonging to the Confederation when the Austrian should be supplanted by the German flag; and subsequently, with the authority of his government, agreed to permit vessels both Austrian and foreign to go in and out provided they did not carry soldiers, arms or munitions of war or articles of contraband for naval forces,it being declared that such vessels would not be permited to go in or come out except by day, subject to the right of visit. Against the blockade thus maintained in principle but abandoned in substance the minister of foreign affairs of the Confederation, after denying that Trieste had been used as a base of offensire operations, presented a protest, ${ }^{29}$ claiming in substance that the neutrality of the Confederation, no matter how shadowy its overlordship, impressed itself upon the territory in question regardless of the fact that it had been employed as a refuge for a worsted squadron, and as a place in which munitions of war and other supplies could be obtained. Such a contention necessarily implied, of course, the converse proposition that the belligerency of the over-sovereign would impress itself upon each portion of its subject territory regardless of the fact that its governing authorities were really neutral. Both assumptions are clearly untenable. The only reasonable and practicable rule to be observed under such circumstances las been stated by an eminent publicist as follows: "The belligerency or neutrality of territory subject to. a double sovereignty must be determined for external purposes, upon the analogy of territory under military occupation, by the belligerent or nentral character of the state de facto exercising permanent military control within it. * * * Where sovereignty is double or ambiguous a belligerent must be permitted to fix his attention upon the crude fact of the exercise of power. He must be allowed to deal his enemy blows wherever he finds him in actual military possession, unless that possession has been given him for a specific purpose, such as that of securing interual tranquillity, which does not carry with it a right to use the territory for his military Holtzendorff's Handbuch, ii, $§ 57$ (1887).

${ }^{29}$ Martens (N. R. G.) xii, 497506. 
objects. On the other hand, where a scintilla of sovereignty is possessed by a belligerent state orer territory where it has no real control, an enemy of the state, still fixing lis attention on facts, must respect the neutrality with which the territory is practically invested." 30

$\S 576$. Duty of occupant to govern. Nature and extent of his authority.-The duty of an occupant to govern the territory of which he is in military possession is correlative to his right to possess himself of it as conqueror, and as such to end all forms of preexisting authority. The right of a belligerent to so occupy and govern is one of the incidents of war flowing directly from the laws of war as recognized by usage and as embodied in the laws of nations. From a theoretical point of view it may be said that the conqueror is armed with the right to substitute his arbitrary will for all preëxisting forms of government, legislative, executive and judicial. From the standpoint of actual practice such arbitrary will is restrained by that provision of the law of nations which compels the conqueror to continue local laws and institutions so far as military necessity will permit. All occupied districts become ipso facto and without proclamation, subject to martial law, the law of military necessity which is administered by the general of the army. ${ }^{31}$ As the Duke of Wellington once expressed it, "martial law is neither more nor less than the will of the general who commands the army. In fact, martial law means no law at all; therefore the general who declares martial law, and commands that it shall be carried into execution, is bound to lay down distinctly the rules and regulations and limits according to which his will is to be carried out. Now, I have in another country carried out martial law; that is to say, I have governed a large proportion of a country by my own will. But then, what did I do? I declared that the country should be governed according to its own national law; and I carried into execution that my so declared will." 32 A much clearer recognition of the fact that the arbitrary will of the general should be limited in its practical exercise by a recognition of local laws and institutions was made by Count Bismark Bohlen, who, on assuming the government of Alsace in 1870, declared that "le maintien des lois existantes, le rétablissement d'un ordre de choses régulier, la remise en activité de 30 Hall, p. 532. 180; Field's Int. Code, § 718; Mar-

31 Maine, Int. Law, pp. 127, tin v. Mott, 12 Wheat., p. 19. 32 Hansard, 3d Series, cxv, 881. 
toutes les branches de l'administration, roila où tendront les efforts de mon gouvernement dans la limite des nécessités imposées par les operations militaires. La religion des habitants, les institutions, et les usuges du pays, la vie et la propriété des habitants jouiront d'une entière protection."33 When, in 1806, Napoleon occupied the greater part of Prussia, he continued the existing administration under the general direction of a French official $;^{34}$ and in the same way when the Duke of Wellington invaded France he authorized the local authorities to continue the exercise of their functions, apparently without the superrision of any English superior. ${ }^{35}$ On the other hand, when, in 1870, the Germans invaded France they appointed, certainly in Alsace and Lorraine, their own ofticials in every department of the administration, and of every rank. ${ }^{36}$ The retiring sorereign of the invaded territory may withdraw with him its functionaries and even its police, as was done in Austria in 1866; or, if le leaves such officials behind him, he may forbid them to serve the invader. If, however, such functionaries consent to serve him, the occupant may continue the existing administration as a whole, subject to supervision of the military anthorities or of superior civil authorities appointed by him. Such officials as thus consent to serve may be required to take an oath binding themselves to obey the orders of the invader during his occupation and not to do anything to his detriment. The occupant cannot, however, demand that local officers shall exercise their functions in his name. When, in 1870, the Germans in France attempted to violate that rule, by ordering, after the fall of the Emperor Napoleon, the courts at Nancy to administer justice in the name of the "High German Powers occupying Alsace and Lorraine," upon the ground that the exercise of their power's in the name of the French people and government was at least an implied recognition of the republic, the courts refused to obey and suspended their sittings. ${ }^{37}$

$\$ 577$. Punishment of crimes in occupied territory.-Neither the civil nor criminal jurisdiction of the invading state is considered in international law to extend over conquered territory

33 Proclam. of Aug. 30, D'Angeberg, No. 371.

${ }^{34}$ Lanfrey, Hist. de Nap., i, iv, 25.

35 Wellington Despatches, $x i$, 307.
36 Calvo, § 1896; Hall, pp. 489-90, 495 and notes.

37 Cf. Calvo, $\$ 1891$; Bluntschli, $\S \S 540,541,547,551$; Am. Instruct., Art. 26. For the oath taken in 1806 by the Prussian officials who 
during military oecupation of it. As explained heretofore in connection with the case of Villasseque ${ }^{38}$ such eriminal jurisdiction does not so extend until therehas been some official and final act of incorporation. The criminal jurisdiction established by the invader in the occupied territory finds its source neither in the laws of the conquering or conquered state,-it is drawn entirely from the law martial as defined in the usages of nations. ${ }^{39}$ The authority thus derived can be asserted either through special tribunals whose authority and procedure is defined in the military code of the conquering state, or through the ordinary courts and authorities of the oceupied district. During the war between the United States and the republic of Mexico, when it was found that the rules and articles of war of the former failed to provide for many eases, eivil and criminal, between its citizens and between such citizens and foreigners in Mexican territory occupied by its troops, but beyond the jurisdiction of its ordinary courts, all such cases of a criminal character arising within the limits occupied by the "main army" of General scott were referred by him to "military commissions" as special tribunals constituted for that purpose. While in California a few such special tribunals were likewise organized for particular cases, as a general rule the punishment for all criminal offenses was left to the decision of the ordinary tribunals of the country. ${ }^{40}$ In either event the martial law of the conqueror, as limited by the laws of war, is the basis of authority, ${ }^{41}$ the special or civil tribunal the mere instrument through which it is exercised. By reason of certain provisions in the Constitution of the United States, military commissions organized during the civil war in states not invaded and not in a state of revolt, and in which the ordinary Federal courts were unobstructed in the

continued their functions during the French occupation, see Alison, Hist. of Europe, v. p. 855.

38 See above, p. 587.

39 "The proclamation of martial law renders every man liable to be treated as a soldier. The instant the necessity ceases, that instant the state of soldiership ought to cease, and the rights with the relations of civil life to be restored." Lord Brougham, Debate on the trial of the Rev. John Smith by court-martial, Parl. Debates, 1824.
40 Scott, General Orders, No. 20, Feb. 19, 1847; Marcy to Scott, Feb. 15, 1847; Cong. Doc. No. 60, 30th Cong., 1st sess. H. of R., p. 874 ; Cushing, Opinions of Attys. General, pp. 365 seq.; Gardner, Inst. of Am. Int. Law, p. 208; Halleck (Baker ed.), ii, p. 441.

41 As to the offences and persons over which courts-martial have jurisdiction, see $R e$ Davison, 22 Blatch. 475; Re Bogart, 2 Sawy. 402-3. 
exercise of their judicial functions, were without jurisdiction to try, convict, or sentence for any criminal offense, a citizen who was neither a resident of a revolted state, a prisoner of war, nor a person in the military or naval service. For a like reason the suspension of the privilege of habcas corpus does not suspend the writ itself. ${ }^{2}$

$\S 578$. Suspension of political and continuance of municipal laws.- While political laws are as a general rule suspended during the military occupation of a conquered territory,-as heretofore explained in the chapter devoted to the laws of war as to enemy property on land,-the municipal laws of such territory, that is the laws regulating private rights, are generally continued in full force during the military occupation, except so far as they are changed or suspended by acts of the conqueror. As he possesses all the powers of a de facto government he can, of course, establish an entirely new civil code or make such changes in the old as he sees fit. As the conqueror has no interest or necessity requiring an abolition of the municipal laws of the country, important changes in them are seldom made. Such as are made are usually of a temporary eharacter and end with the authority of the government making them. Unless some restriction is expressly imposed by the conqueror, as an exception to the general rule of public law recognizing the right of alienation as incident to ownership, the right of private individuals to transfer their property continues unimpaired during the military occupation in the same manner and to the same extent to which it existed prior to its beginning. A municipal or private corporation, like a natural person, has an equal right to dispose of its property during war, and all such transfers are prima facie as valid as if made in time of peace. ${ }^{43}$ And yet despite the general rule as to the binding force of municipal laws, not expressly altered or suspended by the conqueror, the rule that the lex loci rei sitae governs in all things connected with title, tenure and transfer of real estate may be superseded, if the occupant sees fit to introduce a different usage or custom, even without a special decree to that effect. Such a change

42 Ex parte Milligan, 4 Wall. 2142; see also Geoffroy's Case in France, Forsyth, Cases and Opinions, 483; Phillips v. Eyre, L. R., 6 Q. B. 1.

43 KentComm.i, p. 92; Cobraz v.
Raisin, 3 Cal. 445; Welch v. Sullivan, 8 Cal. 165; Hart v. Burnett, 15 Cal. 559; Riquelme, Derecho Pub. Int. lib. i, tit. i, ch. xii; Kamptz, Literatur, etc., $\S 307$. 
took place during the military oceupation of California by the forces of the United States through the establishment of the custom of transferring real estate in that department by the simple deeds of conveyance commonly used in the United States, which seldom conformed either to the usual requirements of Mexican mnnicipal law, or to the Mexican revenue regulations requiring such transfers to be made on stamped paper. Transfers of many millions of property there made in accordance with that usage, which continued after the restoration of peace and until the enactment of other laws by the govermment established after the organization of California as a state, were upheld as valid and sufficient.4t "In the first place, the law requiring the use of stamped paper was a law for levenue, and, consequently, was suspended, with other political laws, ipso facto by the conquest, and completely abrogated by the cession. In the second place, the lex loci rei sitae, with respect to the forms and execution of conveyances of real property, was also suspended in its operation, by the introduction of a different usage with the government of the conquerors, and, from the nature of the case, the inhabitants of California could hardly be considered as remitted to this law by the restoration of peace." 45

\$57. Military occupation under Constitution of the United States.-The legal relation of the inhabitants of an occupied district to the invading state depends largely upon the character of the constitution of such state. As defined in the English constitution, conquest means one thing; as defined in the constitution and laws of the United States it means quite another. In contemplation of the former, a country subdued by British arms becomes immediately a part of the king's dominions in right of his crown, and its inhabitants, so soon as they pass under the king's protection, cease to be enemies $0 r^{\circ}$ aliens and become subjects. In a word, foreign territory becomes a part of the British Empire and its inhabitants British subjects, both as to the conquering state and foreign nations, ipso facto, by the conquest itself, without any enabling or confirming legislation upon the part of the Imperial Parliament. As Lord Coke declared in Calvin's case, "they that were born in those part of France that were under actual legiance and obedience were no aliens, but capable of, and heritable to,

4 Cross v. Harrison, 16 How. 45 Halleck (Baker ed.), ii, p. 449. 164. 
lands in England." 46 In contemplation of the latter, hostile territory subdued by the armies of the United States does not pass under the dominion either of its constitution or its laws, neither do its inhabitants become citizens or subjects of the same, for the reason that neither the President as Commanderin-chief nor the military officers under his control can enlare the boundaries of the Union without enabling legislation from Congress itself. As explained heretofore, until the status of territory so occupied and that of its inhabitants has been altered by adequate legislation, such territory does not cease to be foreign, nor do its inhabitants cease to be aliens, in the sense in which those words are used in the laws of the United States. ${ }^{47}$ While such conquered territory is under the sovereignty of the United States, it is no part of the Union, ${ }^{48}$ and its inhabitants have none of the rights, immunities or privileges guaranteed by law to eitizens thereof. Both the territory and its inhabitants are, while in this condition, subject to martial law as limited by the usage of nations. ${ }^{49}$ When territory is thus acquired by the United states by conquest its holding is a mere military occupation until by a treaty of peace the acquisition is confirmed. ${ }^{50}$ While war continues it is the military duty of the President as commanderin-chief to provide for the security of persons and property, and for the administration of justice. ${ }^{51}$ Such govermment may be carried on under an entirely new code made by the authority of the commander-in-chief, or, by the same authority, the native laws of the conquered territory may be continued in full force. ${ }^{52}$ No constitutional difficulty can stand in the way of such a regime until the ceded territory is drawn within the circle of the constitutional guarantees which apply, in their entirety, to states only. ${ }^{53}$

467 Rep. 1, Broom's Const. Law, 2 d ed., pp. 19, 48, 49, 50, 51, 60; Elphinstone v. Bedreechund, 1 Knapp, P. C. C. 338; Campbell v. Hall, 23 State Trials, 322; Fabrigas v. Moslyn, 1 Cowp. 165; Callet v. Lord Keith, 2 East, 260; Blankard v. Galdy, Salk. 411, 412.

47 Fleming v. Page, 9 How. 603; Cross v. Harrison, 16 How. 164.

48 See above, p. 593 .
49 In re Kemp, 16 Wis. 359; Ex parte Milligan, 4 Wall. 2; see also Anonymous, 9 Opin. Atty. Gen. 518. 50 American Ins. Co. v. Canter, 1 Peters, 542.

51 The Grape Shot, 9 Wall. 129. 52 Scott v. Billgerry, 40 Miss. 119.

53 First Natl. Bk. of Brunswick v. Yankton, 101 U. S. 129. See Appendix, page 793 . 


\section{CHAPTER $\mathrm{X}$.}

\section{TERMINATION OF WAR.}

$\$ 580$. How war may be terminated.- $\Lambda$ war may be terminated (1) by a simple cessation of hostilities with no accompanying agreement; ( 2$)$ by conquest and absorption of one belligerent by the other; (3) by a treaty of peace. While the first two methods are by no means unknown to history, war is usually terminated by a peace treaty negotiated between the belligerents, endiugr hostilities and fixing their relations for the future. A treaty may be of stalus quo ante bellum, uti possi. detis, cession, or indemnity,-any or all combined,-involving the consideration of the treaty-making power and the interpretation of the terms of the instrument itself. The termination of war often presents also the question of the resumption of rights and property abandoned by the enemy upon the return of peace and not covered by the terms of the treaty, if there is one. The term postliminy or postliminium is generally employed to express the fact that the rights of an owner - suspended, not destroyed, by occupation or capture-revive when the suspending conditions cease to be operative. Every treaty of peace, unless the contrary is expressly stipulated, rests upon the principle of keeping what one has, uti possidetis.

$\S 581$. General principles affecting treaties of peace.-Although war may be compared in a general way to a lawsuit, there is at least one clear distinction. At law the plaintiff can recover no more than he claims at the beginning, with costs; in war the victor is entitled not only to collect his claim and expenses but also to inflict such terms as will prevent his opponent from setting up a similar claim in future. Beyond that he should not go. Even admitting that Mr. Day's statement made at the American-Spanish Conference of 1899, to the effect that conquerors impose what terms they please, contained much of truth, the rictor who demands more than damages and security transcends the legitimate bounds of his opportunity. ${ }^{1}$ Despite the fact that a treaty of peace is the result of armed force, it cannot be invalidated upon the ground of duress, if the negotiators themselves are at the time free agents. ${ }^{2}$ After such a treaty is concluded, it cannot be

1 Cic. De Off. i, c. ii.

2 Heffter, § 180. See above, p. 385. 
abrogated, however, without mutual consent. When Russia sought to take advantage of the Franco-Prussian war and violate the Treaty of Paris, she was checked by a conference of the powers, which declared it to be a principle of international law that no state can liberate itself from a treaty except by the consent of the other contracting power. ${ }^{3}$ Such has been the uniform practice as illustrated by history. If the whole enemy country is annexed, there is, of course, no one to make a treaty in its behalf; and there is no necessity for such a treaty, as conquest is a valid title while the victor maintains exclusive possession. ${ }^{4}$ In such a case the victor's title must ever depend upon his firm and continuous possession, military or otherwise. ${ }^{5}$ The close of the American civil war was indicated by peace proclamations, varying for the different states to which they applied. ${ }^{6}$ So far as litigation was concerned, Federal courts were sometimes opened before the making of such proclamations, and loyal citizens were allowed to sue others at once. ${ }^{7}$ It is the province of peace treaties not only to settle disputed questions, but to open up new fields of development to the conqueror. Every peace is a new epoch. ${ }^{8}$

$\S 582$. Effect of peace on pre-existing treaties.-Important as the effect of a declaration of war on preëxisting treaties really is, the effect of a succeeding peace on such treaties is even greater. During war all treaties must perforce stand suspended except those for the regulation of war itself, as there is then no other than hostile intercourse. When peace is restored the difficult question which at once arises is this: How many of the preëxisting treaties revive with it? To remove all doubt on that subject it is not unusual in a treaty of peace to stipulate for the revival of all treaties not expressly abrogated by its terms. Should a few only be mentioned, as after the Franco-Prussian war, the doubt as to all others is thereby intensified. If the result of the war is a complete annihilation and absorption of one of the contesting states, there is, of course, an end of all treaties by reason of the non-existence of

3 Maine, Int. Law, 220; Vattel, III, ch. 4, §54; IV, ch. $4, \S 37$.

4 Vattel, III, c. $13, \S 20$; Fleming v. Page, 9 How. 613; Halleck, 780.

5 Semble, Lamar v. Browne, 92 U. S. 178.

6 The Protector, 12 Wall. 700; Brown v. Hiatts, 15 Wall. 177; Ad- ger v. Alston, 15 Wall. 355; Batesville Inst. v. Kauffman, 18 Wall. 151.

7 Masterson v. Howard, 18 Wall. 99.

8 Bluntschli, Mod. $K r ., \quad \S 27$ (536); Vattel, III, ch. 9, § 190; Heffter, § 181 . 
the opposite contracting party. Even then there may be a question of private international law as to the survival of treaties affecting private persons, in the erent the extinct state was simply a trustee, as international equity can hardly permit a trust to fail for want of such a functionary. Leaving out of view instances of absolute conquest, and of treaties expressly reviced or aroided, a perplexing field of doubt still remains as to the effect of war (1) on treaties to which other powers beside the belligerents are parties; (2) on treaties to which the belligerents only are parties. The following table, prepared by Lawrence, 9 to dininisl, to some extent at least, the difficulties incident to this intricate subject, is sufficiently helpful to warrant its reproduction:

TABLE SHOWING THE EFFECT OF WAR ON TREATIES TO WHIOH THE BELLIGERENTS ARE PARTIES.

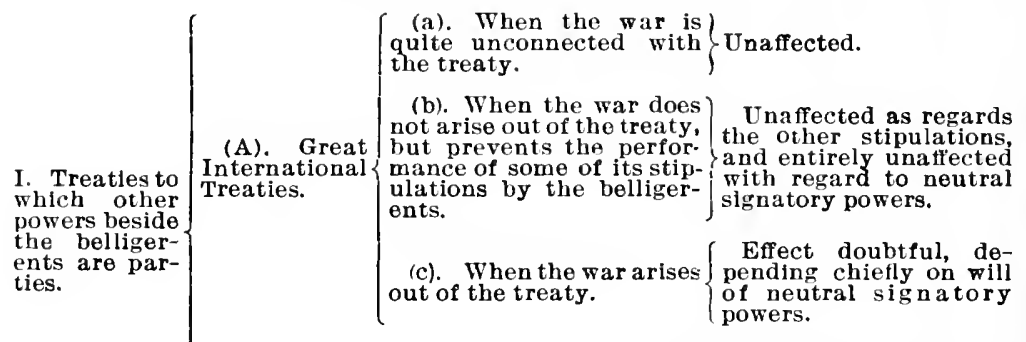

(B) (Effect depends upon subject(B). Ordinary Treaties to which matter. Generally suspended one or more powers beside the bel- or abrogated with regard to ligerents are parties. regard to third parties.

(a). Pacta Transitoria. ..........Unaffected.

(b). Treaties of Alliance.......... Abrogated.

II. Treaties to which the belligerents only are parties.

(c). Treaties for regulating or-) Effect doubtful. Generally dinary social and commercial the treaty of peace deals with intercourse, such as postal and such matters; if not, it is best commercial treaties, conventions to take the stipulations as about property, etc. merely suspended during war.

(d). Treaties regulating the conduct of signatory powers towards Brought into operation by each other as belligerents or as
belligerent and neutral.

The effect of the War of 1812 on the Treaty of 1783 has been fully considered already. ${ }^{10}$

583. Usual bases of peace : status quo; uti possidetis; amnesty. -When there is no contrary stipulation the conclusion of every peace is based on the assumption that each combatant will remain in the same position (status quo) as the close of war finds him, with the same possessions and rights. ${ }^{11}$ The usual

- Principles Int. Law, 313.

10 See above, pp. 367-68, and also

Foster Century Am. Dipl. 254.
11 Bluntschli, Mod. $K r ., \S 216$ (715) ; 1 Kent Comm. 173; Heffter, $\S 181$. 
Greek formula is $\dot{x} \chi 0 v \tau \varepsilon s \dot{\alpha} \dot{\varepsilon} \chi o v \sigma \iota v$, the Latin, uti possidetis. All military operations cease, and everything connected therewith. Prisoners are released, punishments suspended, and friendly relations resumed. ${ }^{12}$ Thus, contributions and requisitions cease, and, although Vattel holds that those previonsly promised are debts which may be enforced, ${ }^{13}$ the modern view avoids even an uncollected lery. Prisoners' debts, however, ransom contracts, and other private obligations designed to lessen or exclude the ravages of war, and the like, are not released by conclusion of peace, for they amounted pro tanto to a restoration of peaceful relations when they were made. While prisoners of war are not freed ipso facto by peace, they must be released as soon as proper arrangements can be made therefor, including generally payment of their debts. ${ }^{14}$ When after the treaty of Ghent American soldiers confined at Dartmoor, who had become restless or insubordinate at their detention, were fired on by British troops, seven being killed and sixty wounded, the British government apologized for the affair and offered compensation, ${ }^{15}$ the last of which the government of the United States declined to accept. If territors is in question, the rule is status quo ante bellum, so far as the provisions of the treaty do not otherwise determine. ${ }^{16}$ Excepting such as are unsanctioned by municipal or international law, peace works an ammesty for all acts of war, not including offenses or obligations arising before the war. ${ }^{17}$ If a provision to that effect, usually embodied in treaties of peace, is omitted, the existence of the principle is implied; and also in the event there is no formal treaty at all. By treaty stipulation any offense may be excepted from the amnesty, as in the case of the peace treaty between Germany and France, 1871, excluding from its benefits French prisoners who had been condemned during their captivity for breaches of discipline regarded by their captors as ordinary crimes. ${ }^{18}$

$\$ 584$. Cessation of hostilities.-Peace sometimes results from a mere cessation of hostilities without ans accompanying agreement. Until the treaty of Kutschauk-Kainardji, 1774, such was the usual practice of the Turks, as the Koran did

12 Id. $\S \S 217$ ( 716 ), etc.

13 Vattel, Droit des Gens, IV, ch.

3, § 29; Davis, Int. Law, 258.

14 Heffter, $\S 180$ and note 6 .

15 Whart., Int. Law Dig., $\S \S 315 \mathrm{c}$,
16 Heffter, \& 181, G. n. 2.

1 i Bluntschli, §§ 211 (710); 213

(712), etc.

18 Calvo, § 1303; Heffter, \& 180, G. n. 4 . $348 \mathrm{c}$. 
not admit of peace with infidels. The British possession of Lower Burmah was based upon a similar condition, the Burmese king declining to enter into any treaty whatever. As examples of like procedures between Christian countries, reference may be made to a Franco-Spanish war which died in 1702 of inanition; and to a war between Poland and Sweden which came to an end in the same way in 1716 , the peace treaty not being signed until ten years thereafter. In 1801 Paul simply ceased hostilities which Catharine had begun against Persia; and not until 1881 did France, and in 1901 Austria, renew with Mexico diplomatic relations broken off at the death of Maximilian. The Central and South American Republics offer in their revolts from Spain even more striking illustrations. Although hostilities ceased about 1825, Spain refused intercourse with some Central American states until 1840, and did not acknowledge Venezuela until 1850. It is doubtful, however, whether such a state of things can recur among civilized powers, as the world is too fast becoming a family of nations for countries to remain long out of touch with each other.

$\S 585$. Conquest and its effects.-The second mode of ending war is by conquest. As explained heretofore, modern practice, unlike the ancient, makes a distinction between military occupation and provisional administration during war (occupatio bellica) and complete conquest, consummated and legalized by the close of the war (debellatio, ultima victoria). While the oath exacted of inhabitants during a mere military occupation is necessarily of a temporary nature, it may be otherwise when conquest is intended. In the latter case all official acts are in the name of the conqueror, and from the time he declares his intention to assume sovereignty he may treat the inhabitants as subjects. ${ }^{19}$ Such is the explanation often given of the oath enforced by Gustarus Adolphus in Germany, an explanation which probably applies also to the oath required by General Roberts in the Orange Free State. Although conquest, which gives plenum dominium et utile, may become complete by possession, it is usual to validate it by cession, as in the treaty of Frankfort in 1871 between France and Germany. Such a cession has the ex post facto effect of relating back to the day of actual occupation and validating all that the conqueror has done in the meantime. Until such cession is made,

19 Heffter, $\S 186$ and notes; John- Campbell v. Hall, 1 Cowp. 208. son v. McIntosh, 8 Wheaton, 588; 
the occupation is technically called Usurpation. ${ }^{20}$ If territory marked out for conquest is alienated by the owner before occupancy is taken by the invader, the alienation stands, as mere intention to conquer confers no right whatever. ${ }^{21}$ As conquest by Great Britain converts the occupied district into a dependency of the crown withont an act of parliament, the sovereign can rary the rights of his new subjects in any way that does not give them more privileges than Britons as a class. $^{22}$ By virtue of that anthority Charles II changed the government of New Netherland, when conquered from the Dutch, by letters patent to the Duke of York. On the other hand, conquests of American armies remain only military occupations until an act of Congress makes some other disposition of them. Citizenship does not necessarily follow the flag. ${ }^{23} \mathrm{As}$ a general rule it is permissible for the inhabitants to retain their old citizenship, provided they emigrate permanently from the ceded territory. If they remain, their consent to a transfer of allegiance will be presumed. ${ }^{24}$ Such right of election, first recognized in 1763 in the treaty of Hubertsburg, is now guaranteed as a general rule. ${ }^{24}$ As an exception to that rule may be mentioned the treaty of cession of Nice and of Savoy to France in 1860 giving to the inhabitants a time to manifest their intention to preserve their Italian nationality without a change of residence. ${ }^{25}$ While the Treaty of Frankfort, 18:1, provided that natives of Alsace and Lorraine desiring to remain French should emigrate, they were permitted to remain owners of their lands. On the other hand, after Count Platen had emigrated in 1866 to Vienna with his expelled sovereign, the king of Hanover, he was subsequently tried for treason as a Prussian subject, a procedure which cannot be justified. Despite the stipulation by the United States, on the acquisition of Florida, that the inhabitants shonld be incorporated into the Union as soon as practicable, and admitted to all rights, privileges and immunities of citizens, it was held that they were not endowed with political rights until, in accordance with American precedents, the territory should be admitted as a state. Private property and titles are to be protected, subject to the institution of commissions to investigate

20 Calvo, Droit Int. II, 292, 300; Halleck, XXXIII, 19; Heffter, § 185; Am. Ins. Co. v. Canter, 1 Pet. 511.

21 Calvo, Droit Int. II, 293.

22 Ib. 292, 304 . See above, p. 600.
23 See the Insular Cases, decided by U. S. Sup. Ct. in May, 1901.

24 Halleck (Baker ed.) ii, 472.

25 Calvo, II, 301, 303; Heffter, 182, G. n. 2. 
and determine which of them are sufficiently complete to be recognized or confirmed. Such was the uniform practice followed by the United States after the acquisitions of Louisiana, Florida and California, and also by France as to the nuncupative titles in Algeria. ${ }^{26}$ That intermediate alienations and other acts of governments de facto or by conquest are valid was clearly recognized by the Treaties of Paris and Vienna, of 1814 and 1815. The Elector of Hesse violated the rule, however, and the Congress of Viemna declined to restrain its creature even when he interfered with his own courts in order to prevent their recognition of the validity of alienations made by Napoleon and Jerome in his "absence." The wrong was redressed pro tanto by the eminent authorities who, in passing upon the question of the existence of debts originally due the elector but collected by the conqueror of the country, justly decided that they were by reason of such collection paid and extinguished. Although the principle involved was the same, ${ }^{27}$ the elector never surrendered the lands of which he had forcibly repossessed himself. The rule of conquest requires the new possessor to assume the whole, or a portion, as the case may be, of the lawful public debt of the country or province. ${ }^{28}$

$\S 586$. Public property after conquest.-When there is no treaty, or one containing no contrary provision, public property passes by conquest itself to the conqueror. By that right Alexander, after he had acquired through the capture of Thebes the eridence of indebtedness of his Thessalian allies to Thebes, remitted the 1,000 talents due thereon. On doubtful authority it is said that the Thebans presented the validity of that act to the judgment of the Amphictyonic Council, and that that body decided adversely to them. ${ }^{29}$ In reference to property of the late Confederate States it was held that a debt due to a seceded State was a lawful subject of conquest by the United States; ${ }^{30}$ and that land conveyed to the Confed. erate States passed in like manner without any procedure of forfeiture or condemmation. ${ }^{31}$ Rulings made on the same subject in Europe have recognized distinctions worthy of consideration. In France, after the American civil war, the

${ }^{26}$ Calvo, Droit Int., II, 306 ; U. S. See authorities cited in Heffter, $\S$ v. Morino, 1 Wall. 400 ; U. S. v. 134 , n. 4.

Reynes, 9 How. 127.

27 Ib. $308,310$.

28 Calvo, II, 309; Heffter, § 182.

29 Quintilian, Inst. Or. V, 10, 111.
30 United States v. Smith, 1 Hughes, 347 .

31 United States v. Tract of Land, 1 Woods, 475. 
United States sued to recover the money paid by the Confederate government to builders of vessels who had been compelled, by reason of the discovery of the contract, to sell them to Prussia and other powers. The suit was dismissed under the empire, and, on appeal, nnder the republic, because, amongst other reasons, no United States funds conld be traced into the ships. So far as the violation of neutrality was considered, it was held to be a matter only for the French govern. ment and in no event could confer rights on the injured foreign state. $^{32}$ In England, in 1866, the United States exhibited a bill in equity against Colin J. McRae, a Confederate agent, who was supposed to have funds of the late government in his possession or under his control, Sir Roundell Palmer appear. ing as solicitor for the complainant and Judah P. Benjamin for the defendant. The court, speaking through Sir W. M. James, V. C., decided that a government suppressing a rebellion could reclaim all public property originally belonging to it which had been seized by the insurgent authorities; and, by right of succession or representation, could claim all public property of the late government, however acquired. It was further held that the conquering power could force an accounting with an agent only by standing in the shoes of the insurgent government, subject to a liability to pay any balance that might appear to be due such agent, if the accounting should result in his favor. As the complainant declined to accept a decree in any form which would recognize the authority of the belligerent states, or involve any payment to their agent, and as the proof failed to show that McRae possessed anything belonging originally to the United States, the suit was dismissed with costs. ${ }^{33}$

$\S 587$. Effects of conquest on laws, municipal and political.Private or municipal laws of a conquered country, says Lord Mansfield, remain in force until changed by the conqueror; political laws yield, ipso facto, to martial rule upon occupation taken. The American president, for instance, as commanderin-chief, can frame a government for conquered territory and administer it so long as the military retain control,- the question when such control shall cease being a constitutional and not an international one. Even when the criminal and political procedure of the conqueror is introduced, it is usual to retain

32 Bigelow's France and Confederate Navy, 94 .

33 U. S. v. McRae, L. R. 8 Equity, 69. 
the civil law of the conquered prorince under which all prirate rights shall be preserved inviolate. That rule, recognized after the British conquest of Canada from the French, and of Cape Town from the Dutch, is the general rule of international law as to cessions and conquests alike. ${ }^{34}$ If a hostile state or province is entirely destroyed, and its people absorbed by the conqueror, political arrangements may be entirely remodeled, without a violation of established usage. And yet even in that extreme case policy should dictate gradual and not radical changes, no matter whether the territory in question is annexed by force or cession. When in 1809 the whole of Finland was ceded to Russia, Alexander I, after convoling the diet at Borgo, issued a manifesto in which he declared his purpose to preserve the religion, laws and liberties of the country, a pledge under which Finland long remained perhaps the freest and best governed part of the Russian Empire.

$\S 588$. Private property, unaffected by change of sovereignty. - Private property should not be affected by change of sorereigns. "The people change their allegiance; their relation to their ancient sovereign is dissolved; but their relations to each other, and their rights of property remain undisturbed. * * * A cession of territory is never understood to be a cession of the property belonging to its inhabitants. The king cedes that only which belonged to him." 35 Conquest or cession passes the sorereignty only, and even that is limited to such of the old inhabitants as change their allegiance. If, however, a property owner prefers to depart with the old flag, he forfeits his property to the new sovereign, except so far as there may be treaty stipulations to the contrary. As the Supreme Court of the United States has expressed it, in a notable case, ${ }^{36}$ "the conqueror who has obtained permanent possession of the enemy's country has the right to forbid the departure of his new subjects or citizens from it, and to exercise his sovereign authority over them. Hence the stipulation in the capitulation and treaties of cession providing for the emigration of those inhabitants who desire to adhere to their ancient allegiance, usually fixing a limited period within which to leave the country, and frequently extending to them

${ }^{34}$ Twiss, Law of Nations, War, $\S 66$; U. S. v. Percheman, 7 Peters, 51; Strother v. Lucas, 12 Peters, 410; Am. Ins. Co. v. 356 Bales of Cotton, 1 Pet. 511, 542.
35 United States v. Percheman, 7 Peters, 51, 87 (Marshall).

36 United States v. Repentigny, 5 Wall. 211. 
the privilege, in the meantime, of selling their property, collecting their debts, and carrying with them their effects."

$\$ 589$. Suppression of a rebellion.--Should a rebellion against an established government be concluded by a treaty as in the case of states recognizing each other, there would be a confusion of ideas, and a confusion of terms. The word "rebellion" cannot be applied to a condition of things necessarily involving the recognition of a new state. For that reason a rebellion can be logically suppressed only upon the theory of conquest. After a return to original conditions, there is generally some kind of penalty inflicted upon the leaders of a rebellion, who may be punished for high treason unless the terms of their surrender forbid. ${ }^{37}$ Thus, when after the close of the American civil war General Lee was threatened with arrest, General Grant successfully urged the sacredness of his parole. Mr. Jefferson Davis was, at the same time, actually arraigned on the charge of treason, but after long imprisonment the prosecution was abandoned because the de facto existence of the Confederate government was so pronounced and notorious as to render the theory of the charge absurd.

$\S 590$. Treaty of peace.-The third and most common method of terminating a war is by treaty of peace, which is usually preceded by an armistice and preliminary agreement made by commissioners or through the mediation of a friendly power. After M. Cambon, the French minister at Washington, had negotiated such a provisional treaty, called a protocol, as the basis of peace between Spain and the United States, a joint commission from the two powers met at Paris and settled the final or definitive treaty. The general rules applicable to the making of other treaties apply, with certain modifications, to treaties of peace, due consideration being given in each case to the treaty-making power, the form of which differs in different constitutions. Although in the United States that power is vested in the President and Senate, the annexations of Texas and Hawaii were effected by joint resolutions of a majority of each house of Congress. A treaty legally executed binds the whole nation; and when its performance requires the payment of money, it is morally obligatory upon that branch of the government whose duty it is to originate the necessary law. A refusal to perform such a duty would constitute a breach of public faith. ${ }^{38}$ When private rights are 
sacrificed by treaty for national purposes, as by alienation, the government is bound to make compensation. ${ }^{39}$ But no such obligation arises when, as in the case of the revolt of Vermont from New York, the injury proceeds not from the voluntary act of the state, but from refusal of a revolutionary government to recognize old grants. ${ }^{40} \lambda$ treaty is effective from its ratification by the treaty-making powers, not from its signature by the envoys. ${ }^{41}$ If there is no one left to conclude a treaty, the silence of the defeated nation is really a tacit consent. While a captive sovereign may negotiate peace, it is not binding until ratified by the nation. ${ }^{2}$ Napoleon III declined to treat at all during his captivity after Sedan.

$\S 591$. Interpretation.-When doubts arise as to the meaning of a treaty of peace, the construction of its terms is against the victor, contra proferentem, because as the dictator of the treaty he will be held to have expressed the full extent of his rights. The names of places and things are to be understood according to intelligent usage; and, unless otherwise expressed, the treaty relates only to the war just ended.43 If restitution is provided for, it must be of the thing in the condition it was when taken,- - except so far as otherwise expressly agreed, or unless the amnesty clause permits surrender in the then existing condition. Improvements added during possession may be removed, however, by the party surrendering. ${ }^{44}$

\$592. Indemnity and guarantees.-It has become usual to claim indemnity from the conquered state, nominally for expenses and pensions, but of ten really for gain or in order to cripple the enemy. The habit of exacting money contributions from districts during invasion and from the whole country at the conclusion of peace, infrequent before the wars of the French Revolution, has, to use Calvo's expression, been erected since that time into a system. Napoleon of ten enforcerl such demands, and the allies, after his fall in 1815, imposed an indemnity on France of seren million francs, payable in installments running over fire years. All precedents sink into insignificance, however, beside Germany's exaction of five billion francs (one billion dollars) of France in 1871, also pay-

Peggy, 1 Cranch, 103; Ware v. Hylton, 3 Dallas, 199, 245.

39 Vattel, Droit des Gens, VI, ch.

$2, \S 12$.

401 Kent Comm. 178.

41 Halleck, Int. Law, 855.
42 Vattel, Droit des Gens, VI, ch. $2, \S 11$.

43 Vattel, Droit des Gens, IV, ch. $3, \S 32-4$. See ante chapter II of this part.

44 Heffter, § 182. 
able in five years. If France established such a method of punishment, she has certainly been the greatest sufferer from it. To the honor of the government of the United States it may be said that instead of enforcing such exactions, it actually paid Mexico and Spain for the territories taken from them in war. As a guaranty for the payment of indemnity, or fulfilment of other stipulations, territory of the conquered state, of greater or less extent, is often retained by the conqueror. Such a requirement was made of France, after the fall of Napoleon, and also after the Franco-German war of 1870-1. As an occupation of that character, although military, is not an act of war, all war measures, such as requisitions and contributions, cease entirely during its continuance. ${ }^{45}$

$\S 593$. Cession perfected by delivery of possession.-According to the rule observed in conveyances between individuals, delivery of possession is necessary to perfect the cession of territory between states, the signature and even ratification of a treaty not being sufficient. Until possession is taken, the agreement is only executory and the sovereignty is not changed. ${ }^{46}$ Possession of Louisiana, ceded by France to Spain in 1762 , was not taken until 1766 ; and, although retroceded in 1800 , France did not take possession until 1803, and then only to transfer it in thirty days to the United States, to whom she had sold it. In each instance the old flag, officials and laws remained in the interim. ${ }^{47}$ Unless otherwise provided by treaty, the transfer of the country ipso facto changes the allegiance of such of the inhabitants as elect to remain; but, as in the case of conquest, there is no change of the relations of such inhabitants to each other. ${ }^{48}$ Even political rights remain the same, provided they are not inconsistent with the new order of things; or, in the case of previous occupation, have not been changed by the conqueror. Some modern publicists maintain that the consent of the inhabitants of the ceded territory is necessary in order to validate its transfer, after the manner of the plebiscite employed by France on the annexation or "reunion" of Savoy and Nice. Such a proceeding cannot, howerer, be more than a form when cession is the

45 Heffter, § 184, G. n. 3.

46 The Fama, 5 Ch. Rob. 113; The Bolletta, Edwards 173.

472 Gayarré La., 92, 131; 3 Id. 445,620 . In fact, Ulloa's possession was but momentary and the real
Spanish occupation was under O'Reilly in 1769.

4sAm. Ins. Co. v. Canter, 1 Peters 542; U. S. v. Percheman, 7 Peters 87. 
result of war. Not even Bluntschli's modified demand for assent of the annexed province is practicable, as the ceding gorernment is a unit and acts in making a cession, as in everything else, as the sovereign. Cession by the defeated to the conquering state is a finality so far as the war it closes is concerned, no matter what its victims think of it. Bluntschli attempted to rest the accurisition of Alsace and Lorraine upon mace conditions. a contention certainly not true as to the latter province; but Geffeken frankly admitted that it was an act of force, necessary for military reasons. ${ }^{49}$

$\$ 594$. Violation of treaty.-Unless otherwise stipulated, the violation of any material provision may be treated as a breach of the whole treaty. ${ }^{50}$ While the carrying on of hostilities in ignorance of the ending of the war does not constitute such a violation, their fruits must be restored, whether the eapture of a ship or city has resulted therefrom..$^{51}$ If a ship is taken under such circumstances, the alct is not criminal, and the commander of the squadron, unless a participant, is not liable. Only the immediate captor is liable civiliter, and, if he is innocent, his government should reimburse him. ${ }^{52}$ If a capture is made with knowledge of the treaty, but before the time fixed for cessation of hostilities at the particular place, it is null and void, provided such knowledge is positive and official. Information derived from the enemy was disregarded by the French privateer Bellona in 1802, and her capture of the Swineherd under such circumstances was sustained by the French Prize court. ${ }^{3}$ When General Jackson after the battle of Fort Bowyer was notified by the British naval commander of the conclusion of peace at Ghent, he promptly declined to act on it. In that case, however, military operations did not result in any further change of conditions before authentic information reached the American general from his own goverument.

49 Heffter, $\S 18$ and notes. See Stoerk's "Option und Plebiscit bei Eroberungen," etc., 1879.

50 Grotius De Jure Belli ac Pacis, III, c. 19, § 14; Vattel, Droit des Gens, ch. 4, § 47 .

51 Vattel, Droit des Gens, IV, ch. 3, § 24; Bluntschli, Mod. Kr., § 210 (709); 2 Dallas 40; Hylton v.
Brown, 1 Wash. Cir. Rep. 311-12, $342,351$.

52 The Mentor, 1 Rob. 151; Grotius, De Jure Belli ac Pacis, III, c. $21, \S \S 5,20$; Heffter, $\S 183$ and notes.

53 Cited in 1 Kent Comm. 172, note; The Legal Tender, Wheaton's Dig., 302; The Sophie, 6 Rob. 175. 
$\S 595$. Postliminy as applied to states or provinces.-The principle of postliminy (postliminium),- - heretofore considered as to certain property recaptured from an enemy by the state to which it originally belonged,-likewise restores upon the return of peace the status of whole states and provinces and their governments which have passed for a time, during the progress of a war, under the control of an enemy. From the Roman law of postliminy, applying almost exclusively to private rights, has been drawn that principle of public law, ${ }^{5 *}$ which provides that a state or other govermmental entity, upon the removal of a foreign military force, resumes its old place, with its rights and duties substantially unimpaired, except that taxes paid or other duties discharged during the foreign occupancy cannot be reclaimed or questioned. Such political resurrection is the result of a law analogous to that which enables elastic bodies to regain their original shape upon the removal of external force,-and subject to the same exception in case of absolute crushing of the whole fibre and content. Where there has been such political reconstruction, however, even a successful revolution, or independence given by a third state, does not without more restore the original status. There is not then postliminy, but a new creature, which may assume a new form as readily as the old. When the occupation and the abandonment have been each an incident of the same war, postliminy applies, even though the occupant has acted as conqueror and for the time substituted his own sovereignty. Whether exactly the same forms of government must be restored depends upon the circumstances of each case and the constitutional powers of the restored sovereign. While past acts (faits accomplis) of the occupant cannot be disturbed, and civil rights, public or private, growing out of them cannot be impaired, there is no reason for their continuance. Taxes released or collected cannot be re-collected, but no future exemption will be recognized nor unfulfilled contracts regarded. Alienation of domains, income and other property by the occupant must nevertheless be respected, at least so far as they would have been lawful if made by the legitimate

54 Digest 49,15 , de captivis et postliminio reversis; Codex $\bullet 8,51$, de postliminio reversis; Cocceji De Jure Postliminii, 1683, De Postliminio in Pace et Amnestia, 1752.
For modern views, Grotius, III, 9; Vattel, III, 14; Phillimore III, 853; Calvo IV, 2977; Hall 416; Heffter, $\S 187$ et seq. 
sorereign. ${ }^{55}$ As to lands the rule is therefore reasonably clear, but as to movable or personal property, there is more dispute. Roman law excluded all such, except munitions of war, from postliminy on the idea that capture changed the title,- crerything becoming booty under a rule which does not now obtain.

${ }_{55}$ New Orleans v. S. S. Co., 20 Wall. 387; Oakes v. U. S., 174 U. S. 778,792 . 


\section{PAFT $V$.}

\section{RIGHTS AND DUTIES OF Neutral States.}

\section{CHAPTER I.}

ORIGIN AND GROWTH OF THE LAW OF NEUTRALITY.

\$596. Dim conceptions of neutrality in Greek and Roman world.-While the sweeping assertion usually made that the nations of classical antiquity possessed no words which expressed what is now understood by the English terms, neutral and neutrality, is literally and technically true, it must not be accepted as conclusive of the fact that the idea itself did not exist in any form whaterer. ${ }^{1}$ Recent researches into the system-highly developed in certain particulars-of international relations existing between Greek city commonwealths have revealed the fact that although the prevalence of confederations rendered perfect neutrality practically impossible between state and state, there did exist a clearly defined idea that a state standing in a friendly relation to two belligerents violated its intermational duty if it gave to one military aid or succor withheld from the other. Such was the contention of the Corcyraeans who, when pleading before the assembly at Athens for such an alliance as would protect them against the Corinthians, said: "You should either stop their mercenaries drawn from your conntry, or send succor to us also, in what manner you may be persuaded is the most expedient; but it were best of all to receive us openly and assist us." 2

Dim as the conception of neutrality, as between state and state, may have been, there is definite and satisfactory evidence

1 Calvo reproduces the over-statement usually made when he says: Il n'existait anciennement dans le droit international ancune notion de l'état de neutralitê. $\$ 1011$.

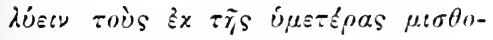

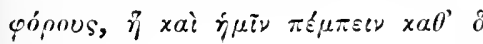

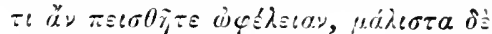

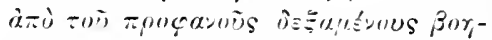
$\theta$ siv.-Thuc. I. 35 . Rererring to Grotius's citation of this passage, Walker says: "And he quotes with approval the declaration of the Corcyrreans to the Athenians that, if they would really be neuters, they should either forbid the Corinthi- 
of the fact that the Greek law of nations provided as carefully for the neutralization during war of the person and property of a certain official known as a $\pi$ pószon as the Red Cross conrentions now provide for the neutralization of the medical staff, with their equipages and instruments. deroted to the care of the wounded during actual hostilities. Prof. H. Brougham Leech, ${ }^{3}$ after defining the rights of ambassadors as recognized in the Greek law of nations, sars that "akin to the subject which has been under discussion is the institution called rpošcur. This system, widely adopted among Hellenic communities, was in many respects analogous to the modern system of consular agency. *** The proxenus was the person who, in his native city, represented the interests of another community. The word is defined

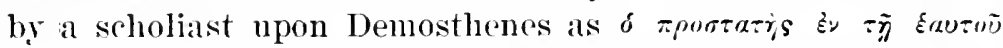

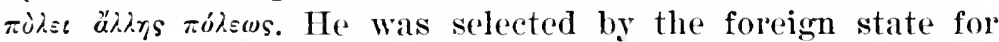
the purpose of watching over its general interests, and protecting its subjects, in his own city. * * * The proxenus, whose position has been discussed, enjoged peculiar privileges in the ease of a war between his own city and the one which he represented. Many of the inscriptions which record the bestowil of this dignity guarantee the inviolability of his person and property in time of war and peace, by land and sea.* If taken prisoner in battle, he was entitled to be released without ransom: if his city was stormed and sacked, his house was privileged to remain uninjured. On this point there is historical evidence in support of the inscriptions. Polybius relates that an Achaean admiral, making a descent on the territory of Naupaktus, took captive one Kleonikus, 'who, as he was a proxenus of the Achaeans, was not sold forthwith, but set free without ransom after a time." 5 The fact that

ans to raise levies in Attica, or suffer the Corcyræans to do the like." Science of Int. Law, p. 378. Such a liberal rendering, which would be very important if defensible, goes not only beyond the text of Thucydides, but beyond that of Grotius, who correctly translates him when he says: Concyrenses apud Thucyidem Arheniensium officii èse ajunt, si extra partes esse velint, aut Corinthios prohibere ne ex agro Attico militem conducant, aut idem sibi permittere. De Jure Belli ac Pacis, III, c. $17, \S 3$. A Greek orator had no words with which to say, if you "would really be neuters."

3 Essay on Ancient Int. Law, pp. $49,64$.

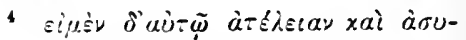

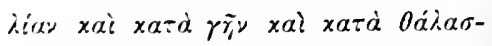
$\sigma \ll \%$ (Corpus Inscriptionum. 1052.)

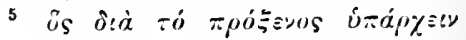

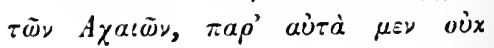


Professor Leech has thus convinced us, quite unconsciously, that such a thing as a neutralized person during war was known to Greek diplomacy, while employing the proof of it in connection with another subject, renders what he says only the more convincing. There is nothing, however, roing to show that the Romans had any elearly defined idea eren of a neutralized person during war. The terms neutralis, neutralitas, barbarisms used by certain modern writers, are not to be found in any classical author. The Latin language contained no substantive whatever corresponding to neutrality. The nearest approach ever made by the Roman historians and civilians in their efforts to describe those we now call neutrals was embodied in such inadequate expressions as amici, medii, pacati, socii. ${ }^{6}$

\section{$\S 597$. Neutrality incompatible with theory of Medieval} Empire.-The idea of neutrality as now understood is the outcome of the creation of a family of nations composed of coequal and sorereign states whose only common superior is that body of rules which Grotius was the first to place upon the throne made vacant by the collapse of the Medieval Empire as an international power. ${ }^{7}$ So long as that strange creation, resting upon the theory of a vast Christian monarchy whose sway was absolutely universal, endured, there was no place for the idea of a state standing as an impartial spectator in war's in which every member of the confederation was directly interested, no matter whether they were waged by one member of the association against the other, or by the corporate person of the entire church militant against Saracens and

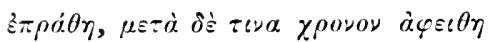

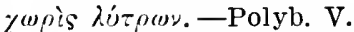

The Athenians put to death a certain Antipater, who had slain their proxenus during an uprising. ('Tit. ' $A \theta r^{\prime} \nu$ V.)

"Grotius, regarding neutrals as "middle men," termed them medii in bello. De Jure Belli ac Pacis, III, 17, De his qui in bello medii sunt. As to those who are not parties to a war, and yet supply aid to the combatants, see III, 1 , § 5. Bynkershoek, expressing the idea negatively, used the term non hostes. Non hostes appello, qui neutrarum partium sunt, nec ex foedere his illisve quicquam debent; si quid debeant, federati sunt, non simpliciter amici.Quaest. Jur. Pub. I. c. 9, De statu belli inter non hostes. As to Vattel's use of the terms neutre and neutralite, see Droit des Gens (III, ch. vii), published in 1758 . In the next year Hübner, a Danish civilian, published at The Hague his De la Sáisie des Batimes neutres. From that time the words, neutral and neutrality, became technical terms in international law.

ז See above, p. 78 . 
Infidels. According to medieral ideas no Christian could stand neutral in the struggle of orthodoxy against heresy, a struggle which intensified the application of the scriptural precept that, "he that is not with us is against us." While a crusader, under exceptional circumstances, might make a truce with the Saracen, no peace could be made with the Infidel, against whom all wars carried on by Christians were, according to Conrad Brunus, just, provided they were undertaken to recover dominions that might be made nseful to all Christendom. ${ }^{8}$ Under the aegis of that principle Chivalry marshaled its hosts, embracing such religious orders of knighthood as the Tentonic Knights and Knights of the Sword-offsprings of the Crusades-whose territorial aequisitions were so considerable. ${ }^{9}$ The same antagonism to the principle of neutrality likewise inspired that sehool of lay thinkers which, at the close of the Middle I ges, revived the study of the science of polities. Machiavelli, as its mouthpiece, advised his ideal prince never to stand nentral in wars between his neighbors, because it is always more advantageous in the end to enlist on one side or the other. When there is danger to be feared from the conqueror, whoerer he may be, it is wise to take up arms on one side or the other, because, if you do not, "you are certain to become the prey of the victor, to the satisfaction and delight of the ranquished." If neither party is powerful enough to put you in fear, "it is all the more prudent for you to take a side, for you will then be ruining one with the help of the other, who, were he wise, would endeavor to save him. If he whom you help conquers, he remains in your power, and with your aid he cannot but conquer." I0 Machiavelli's teachings found favor with his contemporaries,-the Borgias, while hesitating as to their part in the Franco-Spanish struggle, gave leave to both parties to enlist levies at Rome. ${ }^{11}$

598. Absence of rule as to neutral duty in sixteenth century.-Thronghout the sixteenth century there was such an absence from the common law of nations of any recognized rule denying to a state the right to commit, or to permit its

8 See above, p. 56 . As to Ayala's contrary view, see note 8 .

a Freeman, Historical Geography, pp. 512, seq.; Schmauss, Corpus Juris Gent. Academ., II, p. 2162 ; Walker, Science of Int. Law, p. 375 ,
10 The Prince, ch. xxi. See trans. by N. H. T., published by Kegan, Paul \& Co.

11 Guicciardini, The Hist. of Italy, iii, p. 223. Godard's trans. 
subjects to commit, acts of open hostility against other states with which it was nominally at peace, that neither usage nor moral opinion was ontraged if a nentral state permitted an enemy or its ally to enlist levies within its territories, or eren if it should lend him money or ships of war, or should supply him, directly or through its subjects, with munitions of war. If any recognized rule had then existed forbiddingr such unneutral acts there would have been no occasion for the series of treaties entered into during that and the preceding epoch expressly stipulating for nentrality in such a way as to prevent the contracting parties from assisting the enemies of the other, either publicly with subsidies or auxiliary forces, or privately by indirect means. The state thus binding itself to be nentral generally undertook at the same time to prevent its subjects from doing like acts. Fair examples of such stipulations, couched sometimes in general, and sometimes in very specific terms, may be found in treaties entered into, in 1502, between Henry VII. and Maximilian, King of the Romans; and, in 1505, between Henry VII. and the Elector of Saxony. In the first it was agreed "quod nullus dictorum principum movebit aut faciet etc. guerram etc. nec dabit auxilium, consilium, rel favorem, publice vel occulte, ut hujusmodi guerra moveatur vel excitetur quovismodo." In the second it was corenanted that neither of the contracting parties, "patrias, dominia, etc. alterius a suis subditis invadi aut expugnari permittet, sed expresse et cum effectu prohibebit et impediet," and neither of them "alicui alteri patrias, dominia etc. alterius invadenti etc. consilium, auxilium, favorem, subsidiun, naves, pecunias, gentes armorum, victualia aut aliam assistentiam quamcunque publice vel occulte dabit, aut praestari consentiet, sed palam et expresse prohibebit et impediet." 12

599. Growth of the principle of neutrality in seventeenth century. Grotius. - That the right to resist and resent the performance of acts of war within its lands or waters was vested, in theory at least, in a sorereign state, at the beginning of the seventeenth century, is manifest from the proclamation issued by James I. in 1604 directing that "all officers and subjects by sea and land shall rescue and succour all such merchants and others as shall fall within danger of such as wait

12 Quoted by Hall, Int. Law, p. 599, citing Dumont's Corps Uni versel Diplomatique. 
the coasts." And yet the non-existence of any well defined rule covering the entire subject is manifest from the short and unsatisfactory chapter ("De his qui in bello medii sunt"), in which Grotius went no farther than to say that "it is the duty of those that are not engaged in war, to sit still and do nothing that may strengthen him that prosecutes an ill canse, or hinder the motions of him that hath justice on his side; and, in a dubions case, to behave themselves alike to both parties, as in suffering them to pass through their country to smpply them with provisions, and not to relieve the besieged." 13 In had previously admitted, however, that "it is not inconsistent with an alliance that those who are attacked by one of the parties to it shall be defonded by the other, peace being maintained in other respects." 14

The vamue and incoherent doctrine of nentrality thus put forth by the "father of the law of nations," at the end of the first quarter of the serenteenth century, was of a piece with the practice prevailing about that time, from which it clearly appears that such doctrine as did then exist had not adranced beyond the stage of theory. "In 1627, the English captured a French ship in Intch waters; in 1631, the Spaniards attacked the Dutch in a Danish port; in 1639, the Dutch were in turn the agrressors, and attacked the Spanish fleet in English waters; again in 1666;, they captured Engrish ressels in the Elbe, and in spite of the remonstrances of Hambura and of several other German states did not restore them; in 1665, an English fleet endearored to seize the Dutch East India squadron in the harbour of Bergen, but were beaten off with the help of the forts; finally, in 1693, the French attempted to cut some Dutch ships out of Lisbon, and on being prevented by the guns of the place from carrying them off, burnt them in the river." 15 And yet the learned anthor from whose pages that extract is taken concludes that "by the latter half of the seventcenth century it was no longer necessary to stipulate for neutrality in precise language. The neutrality article dwindled into a promise of mutual friendship. But it would be a mistake to infer from this that international practice conformed to the more stringent provisions of former treaties." 16

13 De Jure Belli ac Pacis, III, c. xvii.

14 Ibid., II, c. xvi.

15 Hall, Int. Law, pp. 604-5.
16 Ibid., p. 600. "The Peace of the Pyrenees (1659) has merely the general words, 'Les Roys, etc., eviteront de bonne foy tant qu'il 
$\S 600$. Theory of neutrality as defined by publicists of eighteenth century. Bynkershoek. - On the threshold of the eighteenth century we are met by one of the most important of the early publicists, Bynkershoek, whose De Dominio Maris, which appeared in 1702 , was followed in 1721 by his De For Legatorum, and in $\mathbf{1 7 3 7}$ by his Questiones Juris Publici. In the latter he says: "I call those non-enemies (non hostes) who are of neither party in a war, and who owe nothing by treaty to one side or to the other. If they are under any such obligation they are not mere friends, but allies. *** Thrir duty is to use all care not to meddle in the war. *** If I am neutral, I camnot advantage one party, lest I injure the other. * * * The enemies of our friends may be looked at in two lights, either as our friends or as the enemies of our friends. If they are regarded as om friends, we are right in helping them with our counsel, our resources, our arms, and everything which is of avail in war. But in so far as they are the enemies of our friends, we are barred from such conduct, because by it we should give a preference to one party orer the other, inconsistent with that equality in friemdship which is above all things to be studied. It is more essential to remain in amity with both than to favor the hostilities of one at the cost of a tacit renunciation of the friendship of the other." Again he says: "What if I have promised help to an ally, and he goes to war with my friend? I think I ought to stand by my promise, and that I can do so properly." If, however, the war has been undertaken unjustly on the part of the ally the neutral may abstain; and after it has begm no new engagements must in any event be entered into. As to levies in a neutral state, apart from treaty, Bynkershoek says: "I think that the purchase of soldiers among a friendly people is as lawful as munitions of war." 17

Wolf.-From Wolf, whose Jus Gentium appeared in 1749, we learn that those are called neutrals "who adhere to the side of neither belligerent, and consequently do not mix themselves up in the war." 18 As such neutrals are in a state of amity

leur sera possible le dommage l'un de l'autre.' Dumont, vi, ii, 265. Like language is found in the Treaty of Breda, between England and France, in 1667 (Dumont, vii, i, 41 ) ; in the Peace of Lisbon, between Spain and Portugal, in 1668 (Dumont, vii, i, 73); in the Treaty of Nymeguen, in 1678 (Dumont. vii, i, 357); and the Peace of Ryswick, in 1697 (Dumont, vii, ii, $389)$." Note 1 on p. 600 .

17 Quaest. Jur. Pub., I, cc. ix; xxii.

18 Jus Gentium, § 672. 
with both parties and owe to each whaterer is due in time of general peace, belligerents hare the right of unimpeded aceess to their territory, and of purchasing there such things as they may require. That right is modified, however, by the condition that it shall be exercised only for a causa justa, but as war is a causa justa the passage of troops is therefore to be permitted.

Vattel. - Vattel, whose Droit des Gens appeared in 1758, tells us that "is long as a neutral nation wishes securely to enjoy the advantages of her nentrality, she must in all things show a strict impartiality towards the belligerent powers: for, should she favor one of the parties to the prejudice of the other, she camot complain of being treated by him as an adherent and confederate of his enemy. Her nentrality would be a fraudulent neutrality, of which no nation will consent to be the dupe. *** Let us therefore examine in what consists that impartiality which a neutral nation ought to observe. It solely relates to war, and includes two articles: 1 . To give no assistance when there is no obligation to give it,-nor voluntarily to furnish troops, arms, ammunition, or anything of direct use in war. I do not say, 'to give assistance equally,' but 'to give no assistance,' for it would be absurd that a state should at one and the same time assist two nations at war with each other; and, besides, it would be impossible to do it with equality. The same things, the like number of troops, the like quantity of arms, of stores, etc., furnished in different circumstances, are no longer equivalent succours. 2. In whaterer does not relate to war, a neutral and impartial nation must not refuse to one of the parties, on account of his present quarrel, what she grants to the other. This does not deprive her of the liberty to make the advantage of the state still serve as her rule of conduct in her negotiations, her friendly connections and her commerce. *** When a war breaks out between two nations, all other states that are not bound by treaties are free to remain nenter; and, if either of the beligerent powers attempted to fores them to a junction with him, le would do them an injury, inasmuch as he would be guilty of an infringement on their independency in a very essential point. To themselves alone it belongs to determine whether any reason exists to induce them to join in the contest; and there are two points which claim their consider. ation: 1. The justice of the canse. If that be evident, injustice is not to be countenanced: on the contrary, it is generous 
and praiseworthy to succour oppressed innocence, when we possess the ability. If the case be dubious, the other nations may suspend their judgment, and not engage in a foreign quarrel. 2. When convinced whicl party has justice on his side, they have still to consider whother it be for the adrantage of the state to concern themselves in this affair, and to embark in the war." 19

A little later on $V$ attel qualifies his general statement of the duties imposed by neutrality by saying that without a violation of his duty a neutral may make a loan of money at interest to one of two belligerents, while refusing a like loan to the other, provided the transaction between the states is of a purely business character. "If the sovereign, or his subjects, lend money to my enemy on that footing, and refuse it to me because they have not the same confidence in me, this is no breach of nentrality. They lodge their property where they think it safest. ** * But if the loan were eridently gr: nted for the purpose of enabling an enemy to attack me, this would be concurring in the war against me."20

G. F. de Martens.-Thirty years later21 Martens, a successor of Vattel, who followed closely in his footsteps, maintained that a state in order to preserve entire neutrality must (1) abstain from all participation in military operations, and ( 2$)$ bear itself with absolute impartiality in all that can be useful or necessary to the belligerent powers, granting or refusing to the one what it grants or refuses to the othere, or continuing the same conduct in respect of each which it observed in time of peace. 22 "Strietly speaking," he says, "a belligerent power" has a right to treat as his enemies all the powers who lend military assistance to the enemy, from whaterer motive or in consequence of whatever treaty. However, policy has induced the powers of Europe to depart from this vigorous principle. They now admit (1) that not only a sovereign who furnishas but a body of troops in virtue of a simple treaty of subsidy does not thereby become the enemy of the power against which those troops act, and that the troops alone can be

19 Droit des Gens, III, c. vii, §§ $104,106$. 110.

20 Droit des Gens, III, c. vii, §

21 The Précis du Droit des Gens Moderne de l'Europe was published at Göttingen in 1788, and translated by the author into German in 1796. In 1795 it was translated into English by W. Cobbett, Philadelphia. A fifth edition, in French, with notes by Pinheiro-Ferreira and Vergé, appeared in 1855.

22 Cf. Bk. viii, ch. vi, "Of Neutrality." 
treated hostilely; but (2) that an auxiliary power, who contents himself by sending to the defence of his ally no more than the number: of troops, ete., stipulated for in the general treaty of defensive alliance made before the war without taking any direct part in it, ought not to be looked upon as the enemy of the power against which his troops make war, and that the treaties concluded with the power are not broken. This is more especially the case when the aid of an auxiliary is the consequence of a treaty of general defensive alliance concluded before the beginning of the war.". 23 Walker, therefore, concludes that, "in accordance with these principles, a sovereign may maintain an unbroken neutrality while lending assistance in the struggle to one or the other belligerent; provided that such assistance (1) be granted under a treaty made before the rupture, (2) do not exceed the stipulated amount, (3) do not involve the whole or nearly the whole strength of the auxiliary power, or (4) be not the main cause of the continuation of the war." "2t In harmony with that conclusion is Hall's statement ${ }^{25}$ that, under the practice of the eighteenth century, "it was clearly open to a state, without abandoningr its position of neutrality, to supply troops to a belligerent under a treaty between the two powers, either for mutual help, or for succour to be given by one only to the other in the event of a war which might be in contemplation by an intending belligerent at the very moment of concluding the treaty. A greements of this kind were often made, and were sometimes guarded against by express stipulations."

$\S 601$. Sweden's protest against succour furnished by Denmark to Russia in 1788. - It appears that not until 1788, upon the outbreak of war between Russia and Sweden, was the right of a neutral state to give succour to a belligerent under a pre-existing treaty called serionsly into question. Prior to that time it was deemed necessary to prevent the exercise of that right by express contract, as in the treaties concluded between Great Britain and Demmark in 1780; and in that conchuded between the United states and Prussia in 1785, wherein it was agreed that "neither" one nor the other of the two states would let for hire, or lend, or give any part of its naval or military forces to the enemy of the other to help it or to enable it to act offensively or defensively against the bellig-

23 Bk. viii, ch. v, sec. 9, “Of the rights of a belligerent power with respect to the allies of the enemy."
24 Science of Int. Law, p. 382.

2.5 Int. Law, pp. 608-9. 
erent party" to the treaty. ${ }^{27}$ It is not, therefore, strange that when Russia called upon Denmark for an auxiliary contingent of troops and vessels stipulated for in treaties of 1768,1769 and 1781 that the Danes should have felt in honor bound to supply them. ${ }^{28}$ In doing so, Count Bernstorf said that "His Danish Majesty has ordered the undersigned to declare, that although he complies with the treaty between the Courts of Petersburg and Copenhagen, in furnishing the former with the number of ships and troops stipulated by sereral treaties, and particularly that of 17S1, he yet considers himself in perfect amity and peace with His Swedish Majesty; which friendship shall not be interrupted, although the Swedish arms should prove victorious, either in repulsing, defeating or taking prisoner's the Danish troops now in the Swedish territories, acting as Russian auxiliaries, under Russian flags. Nor does he conceive that His Swedish Majesty has the least ground to complain, so long as the Danish ships and troops now acting against Sweden do not exceed the number stipulated by treaty; and it is his earnest desire that all friendly and commercial intercourse between the two nations, and the good understanding between the Courts of Stockholm and Copenhagen, remain inviolably as heretofore." In her counterdeclaration Sweden said, through Ker minister at Copenhagen, that "the declaratory note delivered by the Count Bernstorf to the undersigned, in which his Danish Majesty conceives that his Swedish Majesty cannot have any ground of complaint, as long as the Danish ships and troops merely act as auxiliaries to Russia, is a doctrine which His Swedish Majesty cannot altogether reconcile with the law of nations and rights of sovereigns, and against which His Majesty has ordered the undersigned to protest."29 By reason of her nilitary weakness, Sweden, after making that protest, deemed it politic to preserve her general peaceful relations with Denmark, by limiting hostilities to the auxiliary forces. Even that cause of offence was removed, however, by the withdrawal of such forces, with the consent of Russia, when Great Britain, Prussia and Holland intervened in behalf of the Swedes with the demand that the Danes should maintain an unlimited and per-

27 Elliot, American Diplomatic Code, i, 347; Chalmers, Collection of Treaties, i. 97.

28 Martens, Causes Célíbres, iii, p. 506 .
29 Annual Register (1788), vol. XXX, pp. 292-3. Quoted by Phillimore, iii, p. 206, 207. 
feet neutrality. ${ }^{30}$ Although general opinion seems to have been against his contention, Count Bernstorf firmly maintained to the last that the grant of auxiliary forces, under existing treaties, was in nowise inconsistent even with such a strict neutrality as the three powers had exacted. ${ }^{31}$

$\S 602$. Conflict between Great Britain and Spain in 1804.The same question again arose when on the rupture between Napoleon and Great Britain in 180:3 Spain was called upon for the military and naval contingent due under the offensive and defensive alliance of San Ildefonso entered into between France and Spain three years before. The attempt made by Spain to placate Great Britain through the substitution of a money payment in lieu of the promised forces was met, at first, by an indication from the latter power that she would not regard a subsidy as a casus belli, so long as the former neither furnished more than the stipulated amount of aid nor permitted the entrance of French troops into Spanish territory. That conditional acquiescence upon the part of Great Britain was abandoned, however, when Napoleon gained "an useful tributary for a burdensome ally" through Spain's contribution to France of $6,000,000$ livres per month. The failure upon the part of Spain to give a satisfactory explanation of the preparation of armaments at Ferrol and of other suspicious movements within her territory finally provoked the issuance of orders to British commanders for the detention of all ships laden with treasure for Spain and of all Spanish ressels carrying military or naval stores, and for the prevention of the sailing of Spanish men-of-war to and from Ferrol. When in October, 1804, Spanish frigates were attacked and captured under such orders, the strong ties of friendship uniting the two countries were not strong enough to prevent their drifting into war. ${ }^{32}$ In the face of such opposition the right of $A$ to give military assistance to $\mathrm{B}$ while the latter is at war with $\mathrm{C}$ gradually came to be considered essentially an unneutral act, which cannot be explained away by the fact that $\Lambda$ was under a pre-existing contract to commit such an illegality. ${ }^{33}$ Thus

30 See ultimatum of the Court of Sweden, Oct. 5, 1788; letter of the three Ministers Plenipotentiary of Great Britain, Prussia and Holland to Count Bernstorf, July 6, 1789.

31 Declaration of Count Bern- storf, July 9, 1789. Causes Célibres, III, pp. 514, 524.

32 Papers relating to the Discussion with Spain in 1802, 1803 and 1804 , pp. $81,189,247-262,300,380$. 33 F. E. Smith's Int. Law, p. 132. 
was finally established the principle now generally admitted that it is incumbent upon neutrals non se interponere bello.

$\S 603$. Struggle for the freedom of neutral commerce.According to the Consolato del Mare the customs of the sea dominant in the western Mediterranean during the Middle Ages decreed the condemnation of enemy goods found under the neutral flag on the high seas, and the release of neutral goods found on a captured belligerent vessel, ${ }^{34}$ in obedience to the precept- "confiscate the goods of your enemy; respect the property of your friend." That the later and more artificial doctrine which has invested a neutral vessel with the power to protect enemy goods had no existence in early maritime usage is evident from the declaration of Louis XI., who, in writing to the King of Sicily, said that it is a. "usus in hoc occidentali mari indelebiliter observatus, res hostium et bona, etiamsi infra amicorum aut confoederatorum triremes seu naves positae sint, nisi obstiterit securitas specialiter super hoc concessa, impune et licite jure bellorum capi posse."35 The French Ordinances of 1538, 1543 and 1584 even went so far as to confiscate not only the hostile goods, but the ship in which they were embarked, ${ }^{36}$-a harsh rule to whose principle Grotius, despite the efforts of the French courts not to enforce it to its full extent, gave his sanction when he said "neque amicorum naves in praedam reniunt ob res hostiles, nisi ex consensu id factum sit dominorum naris." 37 The first serious effort to establish the rights of neutral commerce came from the north, from the merchants of the Hanse Towns, whose trading leagues extended throughout northern Europe; $; 8$ and from the sturdy and heroic burghers of Holland after they had triumphed in their glorious struggle for independence. These people of the sea, who were carriers rather than producers of merchandise, became, in response to the touch of self-interest, the champions of the principle that such a freedom should be given to neutral commerce as would enable the neutral trader to keep up intercourse with any customer in time of war as in time of peace. The Dutch were the earliest people to stipulate for the freedom of enemy cargo in

34 In either event there was an equitable settlement of the question of freight. Consolato del Mare, c. 273. For a translation of the text of the Consolato, see Ortolan, Dip. de la Mer, ii, 68.
35 Quoted by Heffter, § 163.

36 Valin, Ord. de la Marine, III, tit. ix, art. 7 .

37 De Jure Belli ac Pacis, III, c. vi, § vi note.

38 See above, p. 40 . 
neutral ships in a treaty concluded in $1650^{39}$ between Spain and the United Provinces in which it was agreed that the goods of the enemies of either party should be free from capture when on board the ships of the other party, the latter being neutral; and during the fifty years that followed that event they were able to have that privilege either granted or confirmed in eleren treaties entered into with Great Britain, France, Sweden and Portugal. ${ }^{40}$ And yet despite such efforts upon the part of the Dutch the new principle of free ships, free goods made but little real progress down to the end of the serenteenth century. The treaties made by France in $1646^{41}$ with the United l'rovinces, and in 1655 with the Hanse Towns, ${ }^{42}$ pointing in the same direction, had been given by the former an extreme construction against the right; while Great Britain, except when she had agreed to the contrary in an express convention, ${ }^{43}$ asserted her right, under the rules of the Consolato, to confiscate enemy goods in neutral bottoms, a right confirmed by her in several treaties. ${ }^{44}$ Not until near the middle of the eighteenth century did France resolve to espouse the new Dutch principle by departing from the harsh rule established by the reglement of 1704 , which intensified the hardships of the older practice by declaring liable to confiscation the raw or manufactured produce of hostile soil, when the property of a nentral, except when it was in the course of transportation direct from the enemy country to the port of the nentral state to which its owner belonged. Not until 1744 did France concede that neutral ressels carrying enemy goods were free from confiscation; and not until 177s was the freedom of the goods themselves conceded by the règlement of that year. ${ }^{45}$ While spain occasionally recognized the freedom of enemy goods by treaty, she did not adopt the

39 Dumont, vi, i, 571.

40 Portugal, 1661 (Dumont, vi, ii, 369); France, 1661 (ib. 346); France, 1662 (ib. 415); Great Britain, 1667 (ib. vii, 1, 49); Sweden, 1667 (ib. 38) ; Great Britain, 1674 (ib. 283) ; Sweden, 1675 (ib. 317); France, 1678 (ib. 359 ); Sweden, 1679 (ib. 440) ; Great Britain, 1689 (ib. ii, 236); France, 1697 (ib. 389) 317.
42 Dumont, vi, ii, 103.

43 Such conventions were made with Holland in 1667 and 1674; and with France in 1677, 1713 and 1786. Cf. Martens (R) II, 693; Jenkinson, Discourse, pp. 67-9.

44 With Sweden and Denmark in 1654 and 1661 ; and with Denmark in 1670 , Dumont, vi, ii, 80, 92, 387,346 ; ib. vii. i, 128.

45 Valin, Ord. de la Marine, iii, tit. ix, art. 7 ; Pistoye and Duverdy, i, 344,360 . 
new policy of France in its fullness until 1780, when her prirate rules for the first time exempted both enemy goods in neutral ressels, as well as the vessels themselves, from confiscation. ${ }^{46}$ From this new policy Great Britain, jealous of her belligerent rights as a great sea power, stood firmly aloof. She pledged herself in treaties with only a few states not to follow the old practice of seizing neutral goods, and neutral ships, too, subject to release upon the payment of freight. Such special treaty arrangements she regarded simply as exceptions to the old rule and not as recognitions of its abrogation. As Pitt well expressed it: "I must observe that the honorable gentleman has fallen into the same error which constitutes the great fallacy in the reasoning of the advocates of the northern powers; namely, that every exception from the general law by a particular treaty proves the law to be as it is stated in that treaty; whereas the very circumstance of making an exception by treaty proves what the general law of nations would be if no such treaty were made to modify or alter it."47

$\$ 604$. Rule of war of 1756. - After the European states had established colonies in newly discovered lands each claimed as the legitimate reward of its efforts the right to exclude foreign ships from the trade with such colonies, just as states still deny to strangers the right to engage in the coasting trade from one port to the other of the home country. When in 1756 the French, under the pressure of Great Britain's superiority at sea, opened the trade between the mother-country and its colonies to the Dutch, excluding all other neutrals, the question arose whether an enemy of the state thus opening its close trade had the right to deny to a favored neutral or to all neutrals the enjoyment of the adrantages thus accruing to them. While the Dutch and other northern neutrals, eager to reap advantage out of the crippled naval condition of France, were eager to maintain such an enlargement of their rights, Great Britain, whose interests were the other way, finally declared, through Lord Mulgrave, "that a neutral power had no right to a commerce with the colonies of an enemy in time of war which it had not in time of peace, and that every extension of it in the former state, bejond the limit of the latter, was due to the concession of Great Britain, not to the right of the neutral power." 4 s By

46 Martens (R), iv, 270.

47 Speeches, iii, 227-8.
48 In a dispatch to Mr. Madison, Aug. 20, 1805, Mr. Monroe states 
virtue of her maritime supremacy Great Britain was able to uphold that view under which Dutch ships, with their cargoes, were captured and condemned as a part of the commercial nary of France, upon the ground that they had adopted the commerce and eharacter of the enemy. The property involved was considered, pro hac vice, as enemy property, in obedience to that principle which decrees that where a nentral is encraged in a trade, confined so exclusively to the subjects of nuy comtry, in peace and war, and so interdicted to all others that it cannot be earried on in the name of a foreigner, it must be considered so entirely national as to follow the hostile situation of the country. ${ }^{49}$ This "Rule of War of 1756," originally founded on that principle, after lying dormant during the American Revolution, was given a wider extension at the commencement of the war against France in 1793 in order to meet conditions arising out of the opening to neutrals by that country of her coasting as well as her colonial trade. As a counter-blast to that permission Great Britain issued in Norember, 1793, and in January, 1794, 50 instructions to her naval commanders which not only denied to nentrals the right to carry French goods between the mother-country and her colonies, and to engage in her coasting trade, but also exposed them to penalties for conveying neutral goods from their own ports to those of a belligerent colony, or from any one port to another belonging to the belligerent country. The reasons for these extreme measures, rendered still more severe by what was known as the doctrine of continnous royage, although ably expounded by Lord Stowell in his great judgments, ${ }^{51}$ were as earnestly combated by the statesmen and jurists of

that the British position was thus declared by Lord Mulgrave. See also $3 \mathrm{Am}$. St. Papers, 105; (For. Rel.), 118; and President Jefferson's Special Message, Jan'y 17, 1806. Under the rule as laid down by the British Courts, "neutrals are not permitted to engage in a trade with the colonies of a bellig. erent during war which is not permitted to foreigners in time of peace." Manning, Bk. v, ch. v; The Juliana, 4 Rob. Admr., 328. For the views of Gessner and Bluntschli, who repudiated the rule, see Le Droit des Neutres, pp. 266, 275;

\section{Le Droit International Codifé, $\$$} 799,800 .

49 The Pincessa, 2 Rob. Admr., 52; the Anna Catharina, 4 Ibid., 118; The Rendsborg, Ibid., 121; The Vrow Anna Catharina, 5 Ibid., 150; 2 Wheat. Appendix, 26; Dana's Wheaton, p. 666 .

50 The Orders in Council of Nov. 6,1793 , and Jan'y 8, 1794, were followed by the Order of Jan. 25. 1798, finally merged in the retal. iatory Orders in Council of $1806-7$

:1 See The Emmanuel, 2 Rob. Admr., p. 199. 
the United States. Madison declared "that the principle is of modern date; that it is maintained, as is believed, by no other nation but Great Britain, and that it was assumed by her under the auspices of a maritime ascendeney which rendered such a principle subservient to her particular interest;" "52 and to that Jefferson added: "Under this new law of the ocean, our trade to the Mediterranean las been swept away by seizures and condemnations, and that in other seas has been threatened with the same fate." 53

$\$ 605$. First Armed Neutrality League of 1780.-The natural ontcome of England's effort to enforce the ancient rule as to belligerent rights in the face of the attempt of the northern powers to establish the freedom of neutral commerce was the union of all the hostile elements in an armed confederacy against her. As France was aiding the revolted colonies in the American Revolution then pending, England, in order to prevent munitions of war from reaching them, was forced to assert her naval power to the utmost against enemies and neutrals alike, just at the time when Catherine II. was upbuilding the commerce of Russia, and the other neutral states of the Baltic were learning to look to that growing empire for advice and moral support. It is not, therefore, strange that the French Ambassador Vergennes should have been behind the first more made in 1778 when Sweden and Denmark approached the Empress with formal proposals for the organization of a combined fleet for the protection of the neutral trade of the north against all attack. ${ }^{54}$ The outcome was the presentation by Catherine, early in 1780, to the three belligerent courts of London, Versailles and Madrid of a Declaration $^{55}$ setting forth in five articles the propositions as to neutrality which she proposed to adopt and defend. These articles, which became the basis of the First Armed Neutrality, embodied four principles which may be briefly stated as follows: First, freedom of the coasting trade of states at war; second, that the neutral flag should cover all goods not contraband; third, that contraband should be limited to essentially warlike stores; and, fourth, that a blockade to be effective

$52 \mathrm{Mr}$. Madison, Sec. of State, to Mr. Monroe, April 12, 1805, 3 Am. St. Papers (For. Rel.), 101.

53 Message of October 27, 1807;3 Am. St. Papers (For. Rel.), 5.
54 Cf. Diaries and Correspondence of the Earl of Malmesbury, i, p. 219.

55 Martens (R), ii, pp. 74, 75. 
must be one dangerous to pass. 56 The Empress did "not hesitate to declare that to maintain these principles and protect the honor of her flag and the security of the trade and navigation of her subjects she hat prepared the greatest part of her maritime forces;" that she would continue a strict neutrality "so long as she was not provoked and forced to break the bounds of moderation and perfect impartiality;" that in such an extremity her fleet had "order's to go wherever honor, interest and need might require." 57 In the presence of such a menace Great Britain, strugghing as she was with her revolted colonies, and with her ancient enemies, France and Spain, replied with firmess and dignity that, as to the general law, she had acted "conformably to the clearest principles generally acknowledged as the law of nations, being the only law between powers where no treaties subsist. * * * That precise orders had been giren respecting the flag and commerce of Russia, according to the laws of nations and the tenor of our treaty of commerce." 5 s The replies of the courts of Versailles and Madrid were made in April, 1780,59 and, before that year ended, Denmark and Sweden had united with Russia in forming the league known as the First Armed Neutrality. In the next year it was joined by France, Spain, Holland, Prussia, Austria and the United States; in 1782 by Portngal, and in $1783 \mathrm{by}$ the two Sicilies. No settlement of this controversy, thus championed on the one hand by Great Britain and on the other by Russia, had been reached when

56 (1) "Que les vaisseaux neutres puissent naviguer librement de port en port et sur les côtes des nations en guerre.

(2) "Que les effects appertenans aux sujets des dites Puissances en guerre, soient libres sur les vaisseaux neutres à l'exception des marchandises de contrabande.

(3) "Que pour déterminer ce qui caractérise un port bloqué, on n'accorde cette dénomination qu' a celui, où il y a par la disposition de la Puissance, qui l'attaque avec des vaisseaux arrêtés et suffisamment proches, un danger évident d'entrer.

(4) "Que les vaisseaux neutres ne peuvent être arrêtés que sur justes causes et faits évidens; qu'ils soient jugés sans retard; que la procédure soit toujours uniforme, prompte et légale, et que chaque fois, outre les dédommagemens, qu'on accorde à ceux qui ont fait des pertes sans avoir été $€ n$ faute, il soit rendu une satis. faction complette pour l'insulte fait au pavillon." Convention between Russia and Denmark, July 9, 1780. Martens (R) ii, 103-107; Walker, 304-5.

57 For Declaration of the Empress, sēe 2 Azuni, p. 373.

5s Annual Register for 1780, (115).

59 Martens (R), iv, pp. 346-348, $348 \cdot 350$. 
the treaties of peace, concluded at Versailles in 1783 between Great Britain, France and spain, revived and confirmed the treaties of Utrecht, establishing between such contracting powers the principle of free ships, free goods, ${ }^{60}$ - a principle which, under the lead of France, rapidly advanced down to the time when the movement in faror of neutral rights was checked by the outbreak of the wars of the French Revolution.

\section{$\S 606$. Second Armed Neutrality League of 1800.-As} early as 1653 the question was first mooted whether neutral merchant ressels are bound to suffer a visit while sailing under convoy of ships of war of their own nation. In that year Queen Christinal of Sweden issued, during the war between England and the United I'rovinces, a Declatation in which, after reciting that the goods of ler subjects were plundered by privateers, she gave orders to her ships of war eonvoying such ressels as desired protection "in all possible ways to decline that they or any of those that belong to them be searched."61 Not, however, until the American War of Independence was the right seriously urged, the Dutch government ordering in 1780 "that a certain number of men-of-war should be ready for the future to conroy naval stores to the ports of France," and that the commander of the conroying force should resist the visit and search of the vessels so laden. ${ }^{62}$ Great Britain, nevertheless, maintained her right in that case, and in another arising in the next year with Sweden, who, upon an appeal to Russia, drew from that power a declaration that it considered the principle of the immunity of convoyed ressels as emblaced in the principles of the Armed Nentralities. Undaunted by that declaration, and by the affirmance of the immunity in the six treaties made before the end of the century between the Baltic powers, and in one between Holland and the United States, ${ }^{63}$ England in 1798 brought in tor adjudication a, Swedish convoy, which was condemned by the

60 The two maxims were again associated when the confirmation was again reiterated in the commercial treaty of 1786 between France and Great Britain. As there was no armed conflict with the power last named, the First Armed Neutrality can only be regarded as a concert of action for the for- mal announcement of certain clearly defined principles.

61 Thurloe's State Papers, i, 424. 62 Stanhope, Hist. of England, vii, 44; Martens, Nouvelles Causes Cćlibres, i, 165.

63 Martens (R), III, 437, 475, 571; iv, 43, 212, 238, 328; Hall, pp. 747 , seq. 
British prize-court on the ground of resistance. ${ }^{64}$ In December, 1799, a conflict occurred between an English squadron and a Danish convoy in the straits of Gibraltar, when the Danish commander, acting under instructions, fired upon the English search party. ${ }^{65}$ While that affair was still unsettled, the British and Danish navies came again into collision in the British Chamnel in July, 1800, when the captain of the Danish frigate, "Freya," convoying six merchantmen, was, after refusal at the cannon's mouth to permit the search of his charge, breught in with his convoy to the Downs. ${ }^{66}$ The attitude thus assumed by England as to the rights of neutral convoy was the direct and moving cause which impelled Demmark, Sweden, Prussia and Russia to unite in the Second Armed Neutrality Leagne of December, 1800 . In order to understand the entire purport of the new agreement it must be remembered that in 179:3 the British govermment had issued orders to its commander's directing that all neutral ships sailing for any port "declared" by the British to be blockaded should be liable to condemnation. ${ }^{67}$ To meet such conditions the programme upon which the Second League was based, after repeating the four principles embodied in the First, simply added to them two further rules,-the one recognizing the protection for neutral convoy demanded by Denmark and Sweden, the other declaring the necessity for actual direct notice by the blockading squadron as a preliminary to the eapture of a blockade-runner. ${ }^{68}$ The prelude to the armed con-

64 The Maria, 1 Rob. Admr., 340.

65 Martens, Supplément, II, 347, 350. Correspondence between $\mathrm{Mr}$. Merry and Count Bernstoff, April 10 and 19,1800 .

$66 \mathrm{As}$ to the lively controversy that ensued, see Martens, Suppliment, II, 353, seq.; Memoirs and Correspondence of the Marquess Wellesley, II, 116. For the convention embodying a temporary settlement of the question, see Martens ( $R$ ), vii, 426. Walker, 311-12.

67 For the views of the government of the United States as to this order preventing neutral corn ships from entering unblockaded ports, sec Mr. Jefferson. Sec. of
State, to Mr. Pinckney, May 7, 1793. MSS. Inst. Ministers.

68 The five articles agreed upon by the four powers in conventions between Russia and Sweden, Russia and Denmark and Russia and Prussia (Dec., 1800) are as follows: (1) "Que tout vaisseau peut naviguer librement de port en port, et sur les côtes des nations en guerre.

(2) "Que les effects appertenans aux sujets des dites puissances en guerre soient libres sur les vaisseaux neutres, à l'exception des marchandises de contrebande.

(3) "Que pour' déterminer ce qui caractérise un port bloqué, on n'accorde cette dénomination qu' a 
fict which soon followed was a war of embargoes into which the emperor, Paul, who had sneceeded Catherine, entered with special zeal by reason of the conduct of Great Britinin in retaining the island of Malta in violation of what he claimed to be his rights as the Grand Master of the Knights of st. John. ${ }^{69} \Lambda$ s a response to that fresh threat against her commercial supremacy England dispatched her fleet to the north under Parker and Nelson, forced the passage of the Sound and, on April 2, 1801, while the Russians were still ice-bound, crushed the naval power of the Danes in the bloody battle of Copenhagen. ${ }^{70}$ That trimplh, soon followed by the murder of Paul, opened the way for the settlement of differences embodied in the maritime convention ${ }^{71}$ signed at St. Petersburg in June between the government of George III. and the new emperor, Alexander. Under the terms of that compromise Great Britain,-after vindicating against the Armed Neutralities the right to search merchantmen under convoy as exercised by men-of-war, and establishing the liability to seizure by a hostile captor of goods actually the property of the subject of a belligerent laden under the neutral flag,agreed, while confirming the definition of contraband contained in her last treaty of commerce with Russia, expressly to

celui, où il y a, par la disposition de la puissance qui l'attaque avec des vaisseaux arrêtés et suffisamment proches, un danger évident d'entrer et que tout bâtiment naviguant ver's un port bloqué ne pourra être regardé d'avoir contrevenu à la presenté convention, que losqu' après avoir été averti par le commandant du blocus de l'état du port, il tâchera d'y pénétrer en employment la force ou la ruse.

(4) "Que les vaisseaux neutres ne peuvent être arrêtés que sur de justes causes et faits évidents, qu' ils soient jugés sans retard, que la procédure soit toujours uniforme, prompte et légale, et que chaque fois, outre les dédommagemens qu' on accorde à ceux qui out fait des pertes, sans avoir été en contrevention, il soit rendu une satisfaction complette pour l'in- sulte faite an pavillon de leurs Majestés.

(5) "Que la déclaration de l' officier, commandant le vaisseau ou les vaisseaux de la Marine Royale ou Impériale, qui accompagneront le convoi d'un ou de plusieurs bâtimens merchands, que son convoi n'a à bord aucune marchandise de contrebande, doit suffire pour qu'il n'y ait lieu à aucune visite sur son bord ni à celui des bâtimens de son convoi." Martens, Suppléments, II, 393, 402, 409.

69 Paul not only laid an embargo on all British property within his dominions, but ordered one British vessel to be burned because another had escaped. Martens (R), vii, 155 .

7o Mahan's Nelson, ch. xiv.

i1 Martens, Supplément, II, p. 476 . 
adopt the three principles by virtue of which the League maintained that neutrals lave the right to navigate freely between the ports and on the coasts of nations at war, that blockade to be binding must be effective, and that belligerents in their dealings with neutrals must administer speedy and uniform justice. In the following October additional explanatory articles were adopted limiting the general permission given to neutral trade by the declaration that in no event was the direct conveyance by a neutral carrier of belligerent merchandise and produce between the belligerent and the mother country to be permitted. On that basis Denmark acceded to the arrangement in October, 1801, and Sweden in March, 1802.72 Although neutral commerce had yet to strugrgle with British Orders and French Edicts during the wars of the French Revolution,-whose exigencies forced the signatories of the Armed Neutralities to trample as belligerents upon principles they had championed as neutrals, and England and France to vie with each other in the commission of illegalities and severities which each justified as measures of retaliation for acts committed by the other,--the fact remains that the Leagues of 1780 and 1800 , by their efforts to establish the rule of free ships, free goods, without the corollary of enemy ships, enemy goods, pared the way for the triumph of that principle in the time to come.

\section{$\$ 607$. Neutral territorial rights vindicated by United} States. Proclamation of April 22, 1793.-During the latter part of the eighteenth century,-while publicists like Galiani, Lampredi and Azuni ${ }^{73}$ were giving scientific form to the growingr conceptions of the rights and duties of nentrals considered as a definite part of the international code, and while the Baltic powers were insisting upon the practical enforcement of such rights and duties at the cannon's mouth, - the young republic beyond the sea was suddenly called upon to restate with precision and force the very imperfect rules by which the law of mations then attempted to protect the sanctity of

72 Martens (R), vii, 260-281.

73 Galiani's Dei doveri dei Principi Neutrali verso $i$ Principi Guerreggianti e di questo verso $i$ Principi Neutrali was published at Naples in 1782; Lampredi's Del Commercio dei Popoli Neutrali in tempo di Guerra, at Florence in
1788; and a second edition of Azuni's Sistema Universale dei principi del Diritto Marittimo dell' Europa, the second volume of which considers the relative rights and duties of belligerents and neutrals, at Trieste in 1796-97. 
neutral territory. The loose practice of the seventeenth century heretofore referred to, ${ }^{74}$ under which acts of war were so often committed with impunity npon neutral lands and waters, - after being improved during the latter part of the eighteenth in a series of treaties binding the contracting parties not to permit hostilities between belligerents within a marine leagne of their coasts, and not to attack within a like distance of neutral shores, ${ }^{75}$-relapsed during the wars of the French Revolution into a condition worse than the first. In 1793 even the government of Great Britain refused to restore a French frigate captured in the port of Genoa by two English men-of-war ${ }^{76}$ and in 1806 Murat, when he came into violent collision with Danish forces while pursuing a corps of Prussians under Blizcher across the Danish frontier, informed the Danish commander that French troops would follow their enemies wherever they found them, ${ }^{77}-\mathrm{a}$ lule to which $\mathrm{Na}$ poleon and his marshals ruthlessly adhered.78 In the presence of such flagrant breaches of neutral right and duty in the Old World, Washington, as the embodiment of the spirit of legality in the New, said to Congress in his fourth annual address of 1792: "I particularly lecommend to your" consideration the means of preventing those aggressions by our citizens on the territory of other nations, and other infraction of the law of nations, which, furnishing just subject of complaint, might endanger our peace with them."79 On April 20, 179:3, Jefferson, then Secretary of State, wrote to Pinckney: "You may on every occasion give assurances, which cannot go beyond the real desires of this country, to preserve a fair neutrality in the present war, on condition that the rights of neutral nations are respected in us as they have been settled in modern times either by the express declarations of the powers of Europe, or their adoption of them on particular occasions." 80 Two days later President Washington issued his famous neutrality proclamation in which,-after stating that "it appears that a state of war exists between Austria, Prussia, Sardinia, Great Britain and the United Netherlands of

74 See above, p. 622 .

75 Martens (R) II, 704; III, 16, $45,57,118$; iv, 21 ; vi, 380 ; vii, 148 .

76 Heffter (Geffcken). $\$ 147$, note.

$77 \mathrm{Mr}$. Garlike to Viscount Howick, Nov. 11, 1806, Papers respecting Austria, Denmark, ete., 1808, pp. 483-5. Walker, p. 430. is Napoleon could quote Frederick's declaration "that there are no neutrals when there is war."

79 Messages and Papers of the Presidents, vol. i, p. 128.

80 MSS. Inst., Ministers. 
the one part and France on the other, and the duty and interest of the United States require that they should with sineerity and good faith adopt and pursue a conduct friendly and impartial toward the belligerent powers,"-he declared "that whosoever of the citizens of the Cnited States shall render himself liable to punishment or forfeiture under the law of nations by committing, aiding or abetting hostilities against any of said powers, or by carrying to them those articles which are deened contraband by the modern usages of war, will not receive the protection of the United States against such punishment or forfeiture; and, further, that I have given instructions to those officers to whom it belongs to cause prosecutions to be instituted agaiust all persons who shall, within the connizance of the courts of the Inited States, violate the laws of nations with respect to the powers at war, or any of them." 1

$\$ 608$. Illegal acts of the French minister Genet. Executive orders of June 5th and August 4th, 1793.-Two weeks before the issuance of the proclamation in question M. Genet, accredited as minister plenipotentiary of France, arrived at Charleston intent upon involving this country in war with England by making its territory the base of belligerent operations. As a justification of his acts he appealed to the Treaty of Commerce, of 1778 , made by the United states with France in order to secure her ajd in the strugrole for independence, the seventeenth article of which provided that public ships or privateers of France could take their prizes into American ports without restriction as to time or cause. While the legality of the captures thus made conld not be inquired into, the United States were bound to close their ports a arainst prizes made from the French by nations at war with France, except as ports of refuge in stress of weather, and in such case to require their departure at the earliest practicable moment. By the twenty-second article of the same treaty privateers of a nation at war with France were to be prohibited, in ports of the United states, from fitting themselves and from selling their prizes or procuring stores beyond what should be necessary to take them to the nearest port of their own country. Sustained by such treaty provisions and bya public sentiment, grateful to France for her timely aid and sympathetic with her democratic iustitutions, M. Genet, instead of proceeding

81 Messages and Papers of the Presidents, vol. i, pp. 156-7.
82 Treaties and Conventions, 1889 , p. 296 . 
directly to the capital, undertook at Charleston to offer commissions to citizens of the United States to cruise in the service of France against Great Britain, to fit out privateers, to set up French consular prize-courts, so that prizes brought in could be condemmed in American ports, and otherwise to employ the territory of this country for belligerent purposes. The embarrassments of such a situation were greatly increased by the fact that neither in the mother-country nor in the infant. republic had any statutes ever been passed to aid either the executive or the courts in enforcing the legal obligations of neutral duty. ${ }^{83}$ Tashington and his cabinet were thus forced to rely upon executive orders and the conmon law as supplemented by the law of nations. When on May 2 the British Minister ${ }^{84}$ complained to Jefferson of the capture on April 25 in Delaware Bay of the British ship Grange, brought into Philadelphia by the French frigate Ambuscade, the American cabinet, after declaring that such capture was a clear violation of the sorereignty of the United States and of the laws of nations, ordered her restoration. ${ }^{85} \Lambda \mathrm{few}$ days later the British representative complained of the fitting out at Charleston under French commissions of two privateers to cruise against British commerce; of the condemuation of British prizes by a prize-comrt set up by the French Consul at that port, and of the sale of a large quantity of arms and military accoutrements to a French agent at New York. After due consideration the President held that the equipping and commissioning of ressels in American ports to cruise against any belligerent was reprehensible and wonld be prevented, and that the setting up of the French consular prize-court was not only unwarranted by the law of nations or by the treaty relations of the United States with France, but was a mark of special dispespect because all judicial functions must be exercised in this country by its courts only. ${ }^{86}$ As to the third ground of complaint, involving a distinction between commercial dealings with belligerents in materials of war and the fitting out of vessels, enlisting of men and commissioning of officers here for hostile operations, a different answer was given. Mr. Jefferson, in his notable letter of May 15, 1793, after condemning

83 Am. State Papers, i, p. 44.

$84 \mathrm{Mr}$. G. Hammond to Mr. Jefferson, May 2, 1793. Appendix to the case of Great Britain, v, pp. 238-239. s5 Mr. Jefferson to Mr. Ternant, May 3, 1793; Randolph, Correspondence of Jefferson, iii, p. 234. s; Mr. Jefferson to Mr. Hammond, May 15, 1793; Ibid., iii, p. 234. 
the latter, wrote to $\mathrm{Mr}$. Hammond that "our citizens have been always free to make, vend and export arms. It is the constant occupation and livelihood of some of them. To suppress their calling, the only means perhaps of their subsistence, because a war exists in foreign and distant countries, in which we have no concern, would scarcely be expected. It would be hard in principle and impossible in practice. The law of nations, therefore, respecting the rights of those at peace, does not require from them such an internal derangement of their occupations." 87 Such was the prelude to Mr. Genet's arrival at Philadelphia and reception by the President on May 17th. On June 5 a further reply was made to Mr. Hammond, finally disposing of the question involved in fitting out of prirateer's at Charleston, in a letter from Jefferson declaring "that the granting of military commissions within the United States by any other authority than their own is an infringement on their sorereignty, and particularly so when granted to their own citizens to lead them to acts contrary to the duties they owe their own country; that the departure of vessels thus illegally equipped from the ports of the United States will be but an acknowledgment of respect analogons to the breach of it, while it is necessary on their part, as an evidence of their faithful neutrality." 8 While $\mathbf{X}$. Hammond was thus obtaining from Jefferson executive definitions of neutral duty farorable to England, M. Genet demanded reparation for the capture by the British of French property under the American neutral merchant flag. To that complaint Jefferson could only answer that "I believe it cannot be doubted but that by the general law of nations the goods of a friend found in the ressel of an enemy are free, and the goods of an enemy found in the ressel of a friend are lawful prize. Upon this principle, I presume, the British armed ressels have taken the property of French citizens found in our ressels, in the cases above mentioned, and I confess I should be at a loss on what principle to reclaim it." ${ }^{\prime}$ In the midst of such difficulties the American

$87 \mathrm{Mr}$. Jefferson, Sec. of State, to Minister of Great Britain, May 15, 1793; 3 Jefferson's Works, 558. See 1 Am. St. Papers (For. Rel.), 69,147 . A like note was addressed on the same day to the Minister of France, 3 Jefferson's Works, 560.

$88 \mathrm{Mr}$. Jefferson, Sec. of State, to the Minister of Great Britain,
June 5, 1793, Correspondence of Thomas Jefferson, iii, p. 243. The decision was at the same time communicated to the Minister of France, 1 Am. St. Papers (For. Rel.), 150.

s9 Mr. Jefferson to M. Genet, July 24, 1793. 1 Am. St. Papers (For. Rel.), 166. 
cabinet resolved that the despatch of June 5th should be followed by a circular directed on August 4 th to the collectors of customs throughout the United States for the guidance of the revenue officers in their efforts to prevent the arming and equipping of ressels by belligerents in our ports; ${ }^{90}$ and on August ith Jefferson wrote M. Genet that the President considered this gorernment bound to restore all prizes which had been captured by privateers fitted out in the United States, and brought into port after June 5th, or make compensation therefor;91 and that the President would, therefore, expect the minister of France to deliver up all prizes taken by such ressels after that date. Before that point was reached, however, Washington had resolved to demand the recall of Genet, 92 who was superseded by $\mathrm{Mr}$. Fauchet, instructed to disarow the acts of his predecessor, to disarm the privateers fitted out in the United States and to remove such consuls as had acted in violation of the proclamation, circular and despatches of the President. ${ }^{93}$

$\S 609$. Trial of Gideon Henfield, July, 1793.-While the executive power was thus doing its utmost to uphold the nentrality of the United States its courts were making ineffectual efforts in the same direction. The case of the William, captured May 3, 1793, off Cape Henry by the Citoyen Genet, in which the District Court of Pennsylvania declared its inability to decree restitution of the ressel, ${ }^{9+}$ was the prelude to the trial in the Circuit Court of Philadelphia of Gideon Henfield, which began on July 22. Tlie two cases were in fact but different phases of the same transaction, as Henfield, a Massachusetts sailor, was indicted at common law for serving on board the Citoyen Genet in riolation of the treaties of the United States. It appeared that the defendant had shipped on the French

90 For the cabinet resolution of August 3, 1793, see 10 Washington's Writings, by Sparks, 546. It appears also as an appendage to Hamilton's Treasury circular of Aug. 4. See $1 \mathrm{Am}$. St. Papers (Fol. Rel.), 140.

011 Wait's St. Papers, 167; 1 Am. St. Papers (For. Rel.), 136.

92 Sparks, Life and Writings of General Washington, x, p. 547.

${ }^{93}$ On Feb. 24, 1794, the new minister addressed a letter to $\mathrm{Mr}$.
Randolph, Sec. of State, "communicating the order of the Executive Provisoly Council of the French Republic to demand the arrest of M. Genet and all the other agents who may have participated in his faults and sentiments." See Mr. Randolph to Mr. Fauchet, Feb. 27, 1794 (MSS. Notes For. Leg.), declining to make the arrest.

94 Mr. Hammond to Mr. Randolph, June 18. 1794, Case of Great Britain, Appendix V, pp. 248, 279. 
privateer at Charleston on the understanding that he should be given the position of prize-master on board the first prize captured, which turned out to be the William. In that capacity he amived at Philadelphia. The administration took an active interest in the frosecution of Henfield, whose defence was as wamly espoused by M. Genet, who claimed that he had not committed any indictable offence because it appeared that he had enlisted before the proclamation and in ignorance of the law. Althourh the court charged, upon such evidence, that, as the United States was in a condition of nentrality as to the contest between Great Britain and France, the acts of hostility committed by Henfield constituted a crimo, the jury, after prolonged consideration, returned a verdiet of not guilty 95 -a result hailed as a triumph by M. Genet and his followers, casting, as it did, upon the administration "the obloquy of having attempted a measure which the laws would not justify." ${ }^{6}$

\$610. American Foreign Enlistment Acts of 1794 and 1818.-Upon the opening of Congress in December, 1793, Washington, after commmicating the proclamation, dispatches and circulars mnder which he had ineffectually attempted to enforce all of our nentral duties, appealed to that body for such legislation as was necessary to supply the deficiency. The response was the first American Foreign Enlistment Act of June 5, 1794, ${ }^{97}$ generally called at the time the Nentrality Act, which, as it was enacted in the first instance for only two years, was continued for a like term by the Act of March 2, 1797, and made perpetual by the Act of April 24, 1800. Despite the fact that an act was also passed, June 14th, $\mathbf{1 7 9 7}$, to prevent citizens from privateering against nations in amity with the United States, Portugal was compelled, in $1816,{ }^{98}$ to suggest additions to our neutrality laws of a preventive character by reason of special damage she had suffered in that regard. In response to that suggestion was passed the temporary Act of March 3, 1817, incorporated before its expiration in the Act of $A$ pril 20,1818 , which, after repealing all other acts upon the subject, consolidated thrir contents in a definite code, so designed as to prevent or punish every infraction of neutral duty which could be committed by the issuance

95 Wharton, State Trials of the

U. S., pp. 49-89.

96 Marshall's Life of Washington,
9 т U. S. Laws, i, 381.

$98 \mathrm{M}$. J. Correa de Serra to Mr.

ii, p. 273 . 
of foreign commissions or by the enlistment of land or sea forces within the territorial limits of the United States. The first conviction which occurred under the act of June 5th, 1794, was in the case against John Etienne Guinet and John Baptiste le Maitre, indicted in the Cireuit Court at Philadelphia, ${ }^{1}$ May 11, 1795, for a misdemeanor in fitting out and arming a ressel called Les Jumeaux in that port, to be enployed in the service of the Republic of France against Great Britain, both powers being at peace with the United States. After Justice Patterson had charged the jury that "converting a ship from her original destination, with intent to commit hostilities, or, in other words, converting a merchant ship into a ressel of war, must be deemed an original outfit; for the act would, otherwise, become nugatory and inoperative. It is the conversion from the peaceful use to the warlike purpose that constitutes the offence,"-a rerdict of guilty was rendered against Guinet; the only party apprehended. The subsequent history of the neutrality laws of the United States,--put to a severe test in their application to the conditions arising out of the successive insurrectionary movements in the American possessions of Spain and Portugal, and to the prevention of attempts to organize military expeditions against the Sandwich Islands, Cuba, Mexico and Nicaragua,-must be drawn from the judicial decisions ${ }^{2}$ and the state papers in which it is recorded. No higher tribute to the character of such laws, as standards for imitation, could be desired than that contained in Canning's speech delivered in 18.3, in which he said: "If I wished for a guide in a system of neutrality I should take that laid down by America in the days of the presidency of Washington and the secretaryship of Jefferson. In 1793 complaints were made to the American Government that French ships were allowed to fit out and arm in American ports for

1 U. S. v. Guinet, Wharton's State Trials of the U. S., 93-101. See also U. S. v. Peters, 3 Dallas, 121.

2 For the judicial history of the subject see The Betsey, Bee, 67; The Brothers, Ibid., 76; The Nancy, Ibid., 73; The Betsey Cathcart, Ibid., 292; The Sloop Betsey, 3 Dallas, 6; The Magdalena (Talbot v. Jansen), Ibid., 133; The Alfred, Ibid., 307; The Phoebe Ann, Ibid.,
319; The Exchange, 7 Cranch, 116; Santissima Trinidad, 1 Brockenbrough (Marshall's Circuit decisions) 470; The Alerta, 9 Cranch, 359; The Invincible, 1 Wheat., 238; The Estrella, 4 Wheat., 298; La Amislad de Rues, 5 Wheat., 385; La Conception, 6 Wheat., 235; Bello Corrunes, Ibid., 152; Santissima Trinidad, 7 Wheat., 283; Gran Para, Ibid., 471; Arrogante Barcelones, Ibid., 496; Nereyda, 8 
the purpose of attacking British vessels, in direct opposition to the laws of neutrality. Immediately upon this representation the American Government held that such a fitting out was contrary to the laws of neutrality, and orders were issued prohibiting the arming of any French vessels in American ports. It New York a French vessel fitting out was seized, delivered over to the tribunals and condenned. Upon that occasion the American Government held that such fitting out of French ships in American ports for the purpose of cruising against English ressels was incompatible with the sovereinnty of the United States, and tended to interrupt the peace and good understanding which subsisted between that country and Great Britain." 3

\$611. British Foreign Enlistment Acts of 1819 and 1870. -Canning had been an advocate of the Foreign Enlistment Act carried through parliament, in the face of strong opposition, in 1819,4-a reproduction, as all the world knew, of the

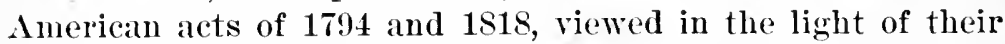
diplomatic and judicial history. "While statutes had been passed prior to that time prohibiting enlistments in England in the service of recognized foreign governments, the $A$ ct of 1819 must be regarded as the first in aid of British neutrality considered as a complete system. Although drawn, in other particulars, almost in the terms of the American act of 1818 , it differed seriously from it in the omission of its tenth and eleventh sections, in which were embodied the preventive powers under which security could be demanded of the owners or consignees of armed vessels about to sail from the United States, owned in whole or in part by citizens thereof, that the sime shall not be employed by them in hostilities against any state with which the United States is at peace, and revenue officers anthorized to detain any vessel, manifestly built for warlike purposes, whose cargo shall consist chiefly of munitions of war, when the circumstances render it probable that she is intended to be used in hostilities against any state with which the United States is at peace. During the Civil War in the United States the complaints made against the British government for its failure to perform its neutral duty by the Wheat., 108; The Fanny, 9 Wheat., 658; U. S. v. Quincy, 6 Peters, 445 ; Kenneth v. Chambers, 14 Howard, 38. See also Title (lxvii), "Neutrality," in Revised Statutes of the U. S. 51.

3 Canning's Speeches, v, pp. 50,

4 Alison, Hist. of Europe, i, pp. 401, seq.; il, p. 53. 
prevention of the building and selling in its ports of ressels designed for use against a friendly power revealed the fact that the Foreign Enlistment Act of 1819 was fatally defective in that respect. As Chicf Baron Pollock said in the case of the Alexandra: "Building ships is not prohibited, even building ships for war is not prohibited, provided they be not 'equipped, furnished, fitted out or armed' in our ports with either of the intents stated in the serenth section. $* * *$ I told the jury, in substance, that the sale of a ship was, in my judgment, perfectly lawful, even of a ship so constructed as to be convertible into a ship of war; that the sale of arms and ammunition and every lind of warlike implement was not forbidden by any law, either intermational or municipal, and that I thought that a ship capable of being used for war might be made and sold, as well as sold (if made) provided she did not leave a port of this country either armed or equipped, or furnished or fitted out within the meaning of the statute; that is to say, with intent or in order to cruise or commit lostilities against a state $\mathrm{or}^{2}$ power with whom Her Majesty was not at war." Under a statute thus construed it was perfectly possible for an unarmed vessel to be built or purchased in a neutral port and then dispatched to some place far beyond the neutral jurisdiction, there to meet arms and men sent from some other neutral port with the express purpose of completing her equipment as an engine of war. In such a case the difficulty was to ascertain the criminal intent with which the elements were prepared prior to the final combination revealing such intent. With that defect in the act of 1819 clearly in view, a Royal Commission was appointed in $1867 \mathrm{for}^{\circ}$ the purpose of recommending such changes in its prorisions as would give it increased efficiency and bring its provisions into full conformity with British international obligations as then understood. The result was the Foreign Enlistment Act of $1870,{ }^{6}$ which deals specifically and in detail with such violations of neutral duty on the part of British subjects as are involved in illegal enlistments, in the preparation of hostile expeditions, in the augmentation of warlike forces and with the offence of illegal ship-building within Her Majesty's dominions. When the offence last named is charged the onus

5 Judgment in the Court of Exchequer, Jan. 11, 1864. Appendix to the case of Great Britain at Geneva, iii, p. 60 .
6 Stat. 33 and 34 Vict., c. 90 . See Report of the Neutrality Law Commission appointcd Jan. 30, 1867. 
of proving an innocent intent is cast upon the ship-builder by Section 9, which provides that "when any ship is built by order of or on behalf of any foreign state when at war with a friendly state, or is delivered to or to the order of such foreign state, or to any person who, to the knowledge of the person building, is an agent of such foreign state, or is paid for by such state or such agent, and is employed in the military or naval service of such foreign state, such ship shall, until the contrary is proved, be deemed to have been built with a view to being so employed, and the burden shall lie on the builder of such ship of proving that he did not know that the ship was intended to be so employed in the military or naval service of such foreign state." By sec. 14 the Court of Admiralty is empowered to deal with all questions arising out of illegal prize of every lind whatsoever when he who brings it in has linowledge that the same was captured as a prize of war either within British territorial jurisdiction, or by a ressel built, equipped, commissioned, despatched or having had her warlike fore augmented contrary to the provisions of the law in question.

\$612. Law of neutrality as between state and state.The growth of the law of neutrality, whose several stages of development have now been briefly outlined, has resulted in the definition of two vitally important principles which should never be confused with each other. At the outset international law contemplated no other relations than those of peace and war. Upon the breaking out of the latter every state not an ally was supposed to be an enemy. The pext step was taken when a state, unwilling to participate in hostilities to the full extent, assumed a position of partial nentality in which it could permit the enemy of its ally to levy troops within its dominions, or supply such an enemy with money, ships of war or munitions of war without a violation of its duties to the state with which it was nominally at peace. Gradually the special stipulations contained in innumerable treaties to the effect that the contracting parties would not thus assist the enemies of the other, either publicly with aluxiliary forces or subsidies, or privately by indirect means, grew into a general rule which required neutrals not merely to extend impartial treatment to the opposing belligerents, but to abstain entirely from any assistance whatever to either party to the contest. As Bluntschli has expressed it: Les états neutres sont reux qui ne sont pas parties belligérantes 
et qui ne prennent part aux operations militaires, ni en faveur de l'un des belligérantes, ni au detriment de l'autre.7 Before the end was reached, however, that principle, which compelled a neutral state simply to refrain from helping either of two belligerents, was supplemented by another requiring it to take care to a reasonable extent that neither shall be injured by acts over which it is supposed to exereise control. Thus were finally developed these canous of international law which now define the reciprocal duties of a neutral towards belligerent states, and of a belligerent towards neutral states. As such duties are due from each to the other in its corporate capacity as a sovereign, the breach of any one of them constitutes an international wrong which can be righted only through the application of an international remedy,-a subject to which the two following chapters will be specially devoted.

$\$ 613$. Law of neutrality as between states and individuals. -Long before the doctrine defined in the preceding section was firmly established, traders, who undertook during the Middle Ages to build up certain rights in faror of neutral commerce as against the claim of belligerent states to restrain and limit it, were often brought under the direct action of law administered by such states in their own tribunals. The claim of such belligerents was that they had the right summarily to inflict in their own prize-courts penalties for the infraction of rules they were permitted to enforce, without a prior appeal to the neutral sovereigns to which the wrong-doers belonged. Such sorereignties were thus forced either to accept responsibility for all acts committed by their subjects beyond the limits of their territorial jurisdiction, or to submit to their punishment in the courts of the belligerents by whom their persons and properties were seized. The exercise of the right last named was finally acquiesced in because, as Lord Broughams has expressed it, "no power cam exercise such an effective control over the actions of each of its subjects as to prevent them from yielding to the temptations of gain at a distance from its territory. No power can, therefore, be effectually responsible for the conduct of all its subjects on the high seas; and it has been found more convenient to entrust the party injured by such aggressions with the power of

${ }^{7}$ Le Droit International Codifie, $\quad$ s Works, viii, 386 (Ed. 1857). $\S 742$, 
checking them. This arrangement seems beneficial to all parties, for it answers the chief end of the law of nations,checking injustice without the necessity of war." Neutral sorereigns, while thus conceding to foreign tribunals the right to aljudge whether or no one or more of their subjects have infringed the privileges of the belligerent state, have reserved the right of interference only when such state exceeds the bounds set by the law of mations. The enforcement, on that principle, of the law of nentrality as between belligerent states and nentral individuals will be examined in detail in the following chapters dexoted to the consideration of "Legitjmate nentral eommeree;" to "Contraband " to "Nentral services, lawful and mlawful"; to "Blockade" and to the "Right of visit and capture." No other branch of international law is so precise and definite because its rules have been elaborated by trained jurists, acting to some extent under the direction of their own govermments, and at the same time under the jealous scrutiny of foreign states ready to demand reparation for any act committed or decree rendered beyond the limits of their recognized authority. 


\section{CHAPTER II.}

\section{DUTIES OF NEUTRAL TOWARDS BELLIGERENT STATES.}

$\S 614$. General scope of neutral duties defined. - In the preceding chapter the conclusion was reached that the principle compelling a neutral state sinply to refrain from helping either of two belligerents was finally supplemented by another requiring it to take care, to a reasonable extent, that neither shall be injured by acts over which it is supposed to exercise control. Neutrality (medius in bello), a condition in which any state has a perfect right to remain, ${ }^{1}$ consists in the continuance of all the rights of peace, with friendly impartiality towards both contestants. ${ }^{2}$ It is in effect a state of friendship maintained by a nation at peace towards two or more nations at war,-a continuation of the state of peace, with certain limitations and responsibilities growing out of the fact of dealing with two or more states belligerent as to each other. ${ }^{3}$ How modern the doctrine, in its fully developed form, really is appear's from the preceding outline of its growth which concluded with emphasizing the fact that, not until the time of Washington and Jefferson, was that part of the doctrine requiring a neutral actively to prohibit within its limits acts injurious to a belligerent fully and frankly recognized. Not until that point was reached was the general scope of neutrality, as a condition involving both rights and responsibilities, clearly defined. Not until then was there a clear comprehension of the fact that a neutral is in duty bound to vindicate his neutrality; that lie is armed with certain powers and privileges to be exercised primarily in his own interest, secondarily in that of the family of nations considered as a whole. As Lord Bowen well expressed it in a pamphlet published in 1868 on the Alabama claims: "The rights violated are those of the neutral only. May not the neutral do what he pleases with his own? If this were excellent learning it would be indifferent sense. In spite of local jurisconsults, America will still be of the opinion that she was rery closely concerned with the uninterrupted equipment in English ports

1 Bourrienne, ch. vi; 2 Azuni, I, - 2 Heffter, $\$ 144$ and notes. 14.

32 Azuni, ch. I, art. III. 
of cruiser's like the Alabama." 4 When the government of the United States informed M. Genet ${ }^{5}$ and others that it considered itself "as bound * * * in conformity to the laws of neutrality, to effectuate the restoration of, or to make compensation for, prizes which shall hare been made of any of the parties at war with France subsequent to the 5th day of June last by privatecrs fitted out of our ports"; * * * that "besides taking efficacions measures to prevent the future fitting out of privateers in the ports of the United States, they will not give asylum therein to any which shall have been at any time so fitted out, and will cause restitution of all such prizes as shall hereafter be brought within their ports by any of the said privateers"; * * * "that if the Cnited States have a right to refuse permission to arm vessels and raise men within their ports and territories, they are bound by the laws of neutrality to exercise that right, and to prohibit such armaments and enlistments,"-the outlines were drawn of that chapter in international law as to neutral responsibility whose progress towards completion was so materially advanced by the treaty of Washington of 1871 and the Genera Arbitration of that year.

$\$ 615$. Standards of neutral duty prior to 1871. - That the two states, which deemed it wise to submit the gravest question of neutral responsibility that ever arose to an arbitral tribunal, felt compelled to agree beforehand upon the rules by which such responsibility was to be measured in that case is certainly persuasive of the fact that no generally recognized standard had then been established by the consensus of nations. Prior to the wars of the French Revolution it cannot be said that anything more existed than a growing sense of state responsibility in regard to neutrality which was prompting law-Ioving nations to demand that a scrupulous respect for their sovereign rights should be the return made by belligrents for the olscrvamce of an absolute impartiality between them. Croglanhinal position prompted the United States to leald that advance." As IIall has expressed it: "The policy of the Cnited states in 1793 constitutes an epoch in the development of the usages of nentrality. There can be no doubt that it was intended and believed to give effect to the obliga-

4 See Law Quarterly Review for July, 1894 , p. 214.

$5 \mathrm{Mr}$. Jefferson to M. Genet, Aug. 7, 1793. Correspondence of Thomas
Jefferson, iii, p. 270. See also Am. State Papers, i, 116, 136.

6 2 Azuni, II, ch. I, art. V. 
tions then incumbent upon nentrals. But it represented by far the most advanced existing opinions as to what those obligations were; and in some points it even went further tham anthoritative international custom has up to the present time advanced. In the main, howerer, it is identical with the standard of conduct which is now adopted by the community of nations." 7 In order to enable the executive government of the United States to enforce its ideals the Foreign Enlistment Acts ${ }^{8}$ were passed, whose application to the fitting out, arming and equipping of belligerent ships in neutral waters gave rise to a long line of judicial decisions whose central idea is that the character of the acts inrolved in such fitting ont, arming and equipping depends upon the intent with which they are performed,--the animus belligerandi being guilty, the animus vendendi being innocent. After carefully reviewing such decisions Dana concludes: (1) "As to the preparing of ressels within our jurisdiction for subsequent hostile operations, the test we have applied has not been the extent and character of the preparations, but the intent with which the particular acts are done. If any person does any act, or attempts to do any act, towards such preparation, with the intent that the ressel shall be employed in hostile operations, he is guilty, without reference to the completion of the preparations; * * * (2) An American merchant may build and fully arm a vessel, and supply her with stores, and offer her for sale in our own market. * * * He may, without violating our law, send out such a vessel, so equipped, under the flag and papers of his own country with no more force of crew than is suitable for navigation, with no right to resist search or seizure, and to take the chances of capture as contraband merchandise, of blockade, and of a market in a belligerent port. In such calse, the extent and character of the equipments is as immaterial as in the other class of cases. The intent is all." 9 On the other hand the British Foreign Enlistment Act of 1819, drawn on the American model, escaped judicial interpretation until proceedings for forfeiture were taken under it in the case of the Alexandra, designated by the American minister as a vessel in course of constrnction at Liverpool for the Confederate Government. As heretofore explained the English judges held in that case, in harmony with the American judges, that the act was directed not against the

7 Int. Law, p. 616.

9 Dana's Wheaton, pp. 562-63.

8 See above, p. 644 . 
animus vendendi but against the animus belligerandi. The result of such interpretation was that unless a ship suitable for war went away from a neutral port so equipped as to commence hostilities the moment she crossed the line dividing the territorial waters from the high seas, she was merely an article of contraband trade, and as such subject to its vicissitudes. Conscious that a statute so construed did not enible the government to discharge, with due diligence, the full measure of neutral duty then imposed by international law parliament enacted the Foreign Enlistment Let of $1870{ }^{10}$

Codes of France, Italy, the Netherlands, Austria, Spain, Portugal and Denmark. - Great Britain and the United States have, by the terms of their Foreign Enlistment Acts, gone farther than the other nations who have linited their prohibitions to ressels fitted solely for fighting purposes. France leaves the punishments of those who violate such prohibitions to certain general provisions of her Penal code 11 to which special attention is called upon the outbreak of hostilities, as in the proclamation of neutrality issued in 1861 , on the ontbreak of the American Civil War, referring to such articles, and prohibiting all French subjects from "assisting in any way the equipment or armament of a vessel of war or privateer of either of the two parties." 12 In 1864 Italy, prompted by the Danish war, adopted a like rule; and in 186i6 the government of the Notherlands for the first time "nndertook to see that the equipment of ressels intended for the belligerent parties should not take place in the ports of the Netherlands." The codes of spain, Austria, Denmark and Portugal also contain prohibitions against the procuring of arms, numitions of war, or ressels for the service of a foreign power,-terms which could be so extended no doubt as to restrain the construction of any vessel intended for belligerent use. ${ }^{13}$

$\$ 616$. The Three Rules of the Treaty of Washington, 1871. - Such were the antecedents of the Treaty of Washington ${ }^{14}$ whose sixth article prorides that, "in deciding the matters submitted to the arbitrators, they shall be governed by the

10 See above, p. 646.

11 Code Pénal, arts. 84 and 85.

12 Under that proclamation six vessels then in the course of construction for the Confederate States in French ports were arrested.
13 See Neut. Laws Commissioners' Rep., Appendix, iv; Rev. de Droit Int., vi, 502; Hall, Int. Law, p. 638 .

14 Treaties and Conventions, 1889 , p. 478 . 
following three rules, which are agreed npon by the High Contracting Parties as rules to be taken as applicable to the casc, and by such principles of international law not inconsistent therewith as the Arbitrators shall determine to have been applicable to the case.

\section{RULES.}

\section{A NEUTRAL GOVERNMENT IS BOUND-}

First, to use due diligence to prevent the fitting out, arming, or equipping within its jurisdiction, of any ressel which it has reasonable ground to believe is intended to cruise or to carry on war against a power with which it is at peace; and also to use like diligence to prevent the departure from its jurisdiction of any ressel intended to cruise or carry on war as above, such ressel having been specially adapted, in whole or in part, within snch jurisdiction to warlike use.

Secondly, not to permit or suffer either belligerent to make use of its ports or waters as the base of naval operations against the other, or for the purpose of the renewal or augmentation of military supplies or arms, or the recruitment of men.

Thirdly, to exercise due diligence in its own ports and waters, and, as to all persons within its jurisdiction, to prevent any violation of the foregoing obligations and duties.

Her Britannic Majesty has commanded her High Commissioners and Plenipotentiaries to declare that Her Majesty's gorernment cannot assent to the foregoing rules as a statement of principles of international law which were in force at the time when the claims mentioned in Article I. arose; but that Her Majesty's government, in order to evince its desire of strengthening the friendly relations between the two countries and of making satisfactory provisions for the future, agrees that, in deciding the questions between the two comtries arising out of these claims, the arbitrators should assume that Her Majesty's Government had undertaken to act upon the principles set forth in these rules. And the High Contracting Parties agree to observe these rules as between themselves in future, and to bring them to the knowledge of other maritime powers, and to invite them to accede to them." 15

$15 \mathrm{As}$ to the relation of these rules to pre-existing international law see Calvo's article in Rev. de

Droit Int., 1874, p. 529. 


\section{As construed by the counsel of the United States.-As} article VII. of the treaty provided that the tribunal should first determine as to each ressel separately, whether Great Britain had, by any act or omission, failed to fulfill any of the duties defined in the three rules, or recognized by the principles of international law not inconsistent therewith, and certify the fact as to each ressel,-the question of questions presented for solntion, upon the very threshold of the controrersy, was that involved in the construction of the phrase, "due diligence," contained in the first and third of the rules. As to the precise scope and meaning of that phrase,-certainly intended to indicate in some form the degree of care that can be justly demanded by a belligerent from a neutral government in matters concerning the enforcement of neutral duty, - the advocates of the contesting states differed widely. The counsel for the United States,-after claiming, " 1 . That it is the duty of a neutral to preserve strict and impartial neutrality as to both belligerents during hostilities.

2. That this obligation is independent of municipal law.

3. That a nentral is bound to enforce its municipal laws and its executive proclamation; and that a belligerent has the right to ask it to do so,"- undertook to define certain conditions under which "due diligence" can always be exacted of a neutral power. ${ }^{16}$ Thus the statement was made, "9. That when a neutral fails to use all the means in its power to prevent a breach of the neutrality of its soil or waters, in any of the foregoing respects, the neutral should make compensation for the injury resulting therefrom.

10. That this obligation is not discharged or arrested by the change of the offending vessel into a public man-of-war.

11. That this obligation is not discharged by a fraudulent

16 " 4 . That a neutral is bound to use due diligence to prevent the fitting out, arming or equipping, within its jurisdiction, of any vessel which it has reasonable ground to believe is intended to cruise or to carry on war against a power with which it is at peace. 5. That a neutral is bound to use like diligence to prevent the construction of such a vessel. 6. That a neutral is bound to use like diligence to prevent the departure from its jurisdiction of any vessel intended to cruise or carry on war against any power with which it is at peace; such vessel having been specially adapted, in whole or in part, within its jurisdiction, to warlike use. 7. That a neutral may not permit or suffer either belligerent to make use of its ports or waters as the base of naval operations against the other. 8. That a neutral is bound to use due diligence in its ports and waters to prevent either belligerent from obtaining there a renewal 
attempt of the offending vessel to evade the provisions of a local municipal law.

12. That the offence will not be deposited so as to release the liability of the neutral even by the entry of the offending vessel in a port of the belligerent, and there becoming a millof-war, if any part of the original fraud continues to hang about the ressel." 17 The essence of the American contention was that the "due diligence" required by the rules in question was a diligence "commensurate with the emergency, or with the magnitude of the results of negligence." In applying that language to the construction and sale of a warship by a neutral builder it was said that "while the subjects or citizens of either" country have been left by law free to manufacture or sell muskets or gunpowder, or to export them at their own risk, even if known to be for the use of a belligerent, the legislatures, the executives, and the judiciaries of both Great Britain and the United States have joined the civilized world in saying that a vessel of war, intended for the use of a belligerent, is not an article in which the individual subject or citizen of a neutral state may deal, subject to the liability to capture as contraband by the other belligerent. Such a ressel has been and is regarded as organized war."

As construed by the counsel of Great Britain.-The counsel for Great Britain,-after excepting certain cases from the operation of the rule of "due diligence," and declaring that "public ships of war in the service of a belligerent, entering the ports or waters of a neutral are, by the practice of nations, exempt from the jurisdiction of a neutral power,-" declared that "9. Due diligence on the part of a sorereign gorernment signifies that measure of care which the government is under an international obligation to use for a given purpose. This measure, where it has not been defined by international usage or agreement, is to be deduced from the nature of the obligation itself, and from those considerations of justice, equity, and general expediency on which the law of nations is founded.

10. The measure of care which a government is bound to use in order to prevent within its jurisdiction certain classes of acts, from which harm might accrue to foreign states or their citizens, must always (unless specifically determined by usage or agreement) be dependent, more or less, on the sur-

or augmentation of military supplies, or arms for belligerent vessels, or the recruiting of men."
17 Papers relating to the Treaty of Washington, I, pp. 87-88. 
rounding circumstances, and cannot be defined with precision in the form of a general rule. It would commonly, however, be unreasonable and impracticable to require that it should exceed that which the governments of civilized states are accustomed to employ in matters concerning their own security or that of their own citizens. That even this measure of obligation has not been recognized in practice might be clearly shown by reference to the laws in force in the principal countries of Europe and America. It would be enough, indeed, to refer to the history of some of these countries during recent periods, for proof that great and enlightened states have not deemed themselves bound to exert the same vigilance and employ the same means of repression, when enterprises prepared within their own territories endangered the safety of neighboring states, as they would probably have exerted and employed had their own security been similarly imperilled.

11. In every country where the executive is subject to the laws, foreign states have a right to expect-(a) That the laws be such as in the exercise of ordinary foresight might reasonably be deemed adequate for the repression of all acts which the govermment is under an international obligation to repress; (b) That, so far as may be necessary for this purpose, the laws be enforced and the legal powers of the government exercised." In applying these general principles to the case of an armed ship it was said that "the case of a vessel which is despatched from a neutral port to or for the use of a belligerent, after having been prepared within the neutral teritory for warlike use, is one which may be regarded from different points of view, and may fall within the operation of different principles. The ship herself may be regarded merely as an implement or engine of war, sold or manufactured to order within neutral territory, and afterwards transported therefrom, and the whole transaction as falling within the scope of the principles applicable to the sale, manufacture, shipment, and transportation of artieles contraband of war; or, on the other hand, the preparation and dispatch of the ship may be viewed as being really and in effect the preparation and commencement of a hostile expedition. The circumstances of each case can alone determine from which of thes two points of riew it may most fitly be regarded, and to which class the transaction ought to be assigned." 18

18 Case of Great Britain, Part III, pp. 23-25. Papers relating to the Treaty of Washington, I, p. 229. 
As construed by the arbitral court.-The United States demanded judgment, on the submission made under the rules, against Great Britain for damages resulting from the acts of the Alabama and her tender, the Tuscaloosa; from the acts of the Florida and her tenders, Clarance, Tacony and Archer; from the acts of the Shenandoah, Sumpter, Nashville, Retribution, Georgia, Tallahassee and Chickamauga. The court, by a unanimous vote in the case of the Alabama, by a vote of four to one in the case of the Florida, and by a rote of three to two in the case of Shenandoah fixed the responsibility for such acts on Great Britain, except as to such acts of the Shenandoah as were committed prior to her departure from Melbourne on Feb. 18th, 1865. It was further decreed "that such tenders or auxiliary vessels, being properly regarded as accessories, must necessarily follow the lot of their principals, and be submitted to the same decision which applies to them respectively." Great Britain was acquitted of all responsilility for the acts of the Sumpter, Retribution, Georgia, Nashville, Tallahassee, and Chickamauga. As the claim for indirect losses presented by the United States was rejected, the responsibility of Great Britain was limited to such direct losses as had resulted from the destruction of vessels and their cargoes by the cruisers in question, and to national expenditures incurred in their pursuit. The essence of the decree, so far as the definition of principles is concerned, is as follows: * * * "the 'due diligence' referred to in the first and third of the said rules ought to be exercised by neutral governments in exact proportion to the risks to which either of the belligerents may be exposed, from a failure to fulfil the obligations of neutrality on their part. * * * the effects of a violation of neutrality committed by means of the construction, equipment, and armament of a vessel are not done away with by any commission which the government of the belligerent power, benefited by the violation of neutralitr, may afterwards have granted to that vessel; and the ultimate step, by which the offence is completed, cannot be admissible as a ground for the absolution of the offender, nor can the consummation of his fraud become the means of establishing his innocence. * * * the privilege of exterritoriality accorded to vessels of war has been admitted into the law of nations, not as an absolute right, but solely as a proceeding founded on the principle of rourtesy and mutual deference between nations, and therefore can 
never be appealed to for the protection of acts done in violation of neutrality." 19

Criticisms of arbitral definition of "due diligence."-Strange, indeed, it would have been if this first tentative effort to solve the mighty problem involved in neutral responsibility had resulted in a judge-made rule at once so clear, comprehensive, precise and adaptable to every possible condition as to eliminate all future controversy upon the subject. Nothing more conld have been reasonably expected than a substantial advance in the direction of a rule,- to be hereafter perfected through the further reflection of publicists and growing experience of nations, - whose application to new conditions must erer be attended with certain difficulties which human wisdom has so far been unable to remove from the domain of jurisprudence. A gainst the definition giren by the arbitrators to the phrase, "due diligence," the sererest criticism has naturally been directed. One English publicist of great acmmen, after condemning the construction given to "due diligence" by the counsel for both of the contesting states, concludes that the comrt itself made a fatal mistake in accepting and embodying in their award "the principle of a changing standard." "In the second of their recitals they laid down the propo. sition that 'due diligence' onght to be exercised by neutral states 'in exact proportion to the risks to which either of the belligerents may be exposed from a failure to fulfill the obligations of nentrality on their part.' This is the least happy of all the attempts to discover a standard of nentral obligation. It imposes different degrees of responsibility upon different neutrals in the same war, and even upon the same nentral in respect of different belligerents in the same war, and thus destroys that impartiality which is the essence of nentral duty." 20 On the other hand, another English publicist of the highest reputation, declares that "with this award it is, under the peculiar conditions of the reference, well nigh impossible to quarrel. Opinions may well differ as to the valne of eertain of the legal propositions adranced by the majority of the arbitrators, but under no reasonable interpretation of language could Great Britain hope to secure aeguittal from a tribunal sitting under and guided by the Three Rules of

19 See the "Decision and Award" printed in Moore's International Arbitrations as a part of an excel- lent statement of the case as a whole; vol. 1, pp. 495-682.

20 Lawrence, Principles of Int. Law, pp. 53s-539. 
the Treaty of Washington. The British Government did not, it must be confessed, show 'due'-that is, a reasonably sufficient-diligence in the fulfilment of its neutral duty. Whether 'due diligence' be or be not the diligence contended for by the American Counsel and demanded by the majority of the Geneva Tribunal, due diligence must be alert, prompt and fearless. The British Government, however well meaning, was in no true sense alert in the protection of its neutrality. The British Foreign Enlistment Act was in terms reasonably adequate for its purpose, but the British officials were not duly alert in the detection of attempted fraudulent evasions of the law. The British authorities evinced a marked disposition to believe the best of all men, to wait for, rather than to seek out, eridence, and to trust to the initiative of the United States Minister and his active subordinates. In a word, they displayed a fatal lack of appreciation of the preventive duty of a gocernment." 21 Into that declaration is condensed the essence of the whole matter, because it admits that, according to the new conception of neutrality which has developed since the end of the eighteenth century, Great Britain had not exercised that degree of diligence as to the arming and equipping of belligerent ships in neutral waters which the quickened sense of neutral duty now demands. The arbitral tribunal, while fully and frankly recognizing the existence of a new and stricter rule, failed to give to it that logical, and generally satisfactory definition which must precede its incorporation into the law of nations. ${ }^{22}$

Intent as the test of guilt.-The difficulty attending the construction of such a rule, in its application to the arming and equipping of belligerent ships in neutral waters, arises out of the fact that the dividing line between acts which the neutral government is bound to restrain, and those which its subjects are permitted to engage in at their' peril "may often be scarcely

21 Walker, Science of Int. Law, pp. $493-494$.

22 Instructive discussions of the several questions involved in the arbitration and award may be found in Rolin Jaequemyns' article (severity criticising the arbitral definition of "due diligence") in the Rev. de Droit Int., 1874, p. 567; in Pradier-Fodéré, La Ques. tion de l'Alabama et le Droit des Gens; in Rivier, L'Affaire de l'Ala. bama et le Tribunal Arbitral de Genève; in Kamarowski Le Tribu. nal International, 214; in Rouard de Card, Les Destinées de l'Arbitrâge International, 75; in Fiore, Nouveau Droit Int. Public, I. 130, 135; III, 464; in Neumann, Droit des Gens Moderne, 139. 
traceable." 23 The difficulty in each particular case is to determine whether the vessel, considered in reference to the cir. cumstances under which it is equipped and sold, constitutes an "expedition," whose departure the neutral gorernment is bound to prevent; or merely an article of contraband, liable to capture and confiscation by the belligerent against whom she is to be used, without any responsibility whatever upon the part of the neutral state from whose waters it departs. On the one hand, the Supreme Court of the United States, speaking through Story, J., in the case of the Santissima Trinidad, ${ }^{24}$ said that "there is nothing in our laws, or in the law of nations, that forbids our citizens from sending armed ressels, as well as munitions of war, to foreign ports for sale. It is a commercial adventure which no nation is bound to prohibit; and which only exposes the persons engaged to the penalty of confiscation." On the other, the same court, speaking through Marshall, C. J., in the case of the Gran Para, ${ }^{25}$ decreed the next day the restitution of captured property brought within the jurisdiction of the United States, on the ground that the ressel by which it was brought "was purchased, and that she sailed out of the port of Baltimore, armed and manned as a ressel of war, for the purpose of being employed as a cruiser against a nation with whom the United States were at peace. * * * The ressel was constructed for war, and not for commerce. There was no cargo on board but what was adapted to the purposes of war. The crew was too numerous for a merchantman, and was sufficient for a privateer. These circumstances demonstrate the intent with which the Irresistible sailed out of the port of Baltimore." As explained heretofore the line of American cases in question rests upon the cardinal principle that in the event of a fitting out, and arming of a ressel in neutral waters the intent of the parties engaged in the enterprise is all in all. ${ }^{26}$

The character of the ship as the test.-Because of the difficulty of applying intent as the crucial test of guilt, Hall has suggested that it be superseded by another making the claracter of the ship the criterion of illegality. That great publicist was, however, too acute.not to perceive the worthlessness of his own suggestion. While he claims that "experts are perfectly able to distinguish vessels built primarily for warlike

23 Dana's Wheaton, p. 563 , note. 247 Wheat., 341.
25 Ibid., 486.

26 See above, p. 653. 
use," he at the same time admits that "it is otherwise with many vessels primarily fitted for commerce. * * * Mail steamers of large size are fitted by their strength and build to receive, without much special adaptation, one or two guns of sufficient calibre to render the ships carrying them dangerous cruisers against merchantmen. These vessels, though of distinct character in their more marked forms,-melt insensibly into other types, and it would be impossible to lay down a rule under which they could be prevented from being sold to a belligerent and transformed into constituent parts of an expedition immediately outside neutral waters without paralyzing the whole ship-building and ship-selling trade of the neutral country." 27 The perfect facility with which certain "mail steamers of large size" were quickly adapted to hostile purposes during the recent Spanish-American war demonstrates beyond question, if demonstration is necessary, that no expert could possibly determine "almost from the laying of the keel the difference between the two classes of ships." The fact that such ressels, fitted primarily for commerce, may be suddenly converted into ideal commerce destroyers should remore the suggestion of the character of the ship, as a sole and exclusive test, from serious eonsideration. Unless "the whole ship-building and ship-selling trade of the neutral country" is to be paralyzed the question whether or not a particular ressel constitutes an "expedition," or is merely an article of contraband, must ever depend upon the intent of the parties by whom she is itted out and equipped. The only practical question is as to the best method of remoring the difficulties attending the proof of such intent. A most intelligent move in that direction was made by the framers of the British Foreign Enlistment Act of 1870, which, in dealing with the offence of illegal ship-building, provides (Sec. 8) that any person who, within British dominions and without license (1) builds, agrees to build or causes to be built, (2) issues or delivers a commission to, (3) equips, or (4) despatches, or causes or allows to be despatched, any ship with intent or knowledge or having reasonable cause to believe that the same shall or will be employed in the military or naval service of any foreign state at war with any state with which Great Britain is at peace, is declared thereby to offend against her laws. ${ }^{28}$ And

27 Int. Law, p. 640.

28 The way is then pointed out in which a person who, within
British dominions, builds, causes to be built or equips a vessel for a belligerent power, in pursuance of 
if (See. 9) "any ship is built by order or on behalf of any foreign state when at war with a friendly state *** or is paid for by such foreign state or such agent, and is employed in the military or llaval service of such foreign state, such ship, shall, until the contrary is proved, be deemed to have been built with a view to being so employed, and the burden shall lie on the builder of such ship of proving that he did not know that the ship was intended to be so employed in the military or naval service of such foreign state." Could the new rule as to neutral duty be so formulated, through international concert, as to require each state to cast the onus of proof, according to the British Act of 1870 , upon those engagred in suspected trafice, it is more than likely that the greater part of the existing difliculties as to the proof of guilty intent would soon disappear.

Practical value of arbitral decree. - No matter to what extent the jurists ${ }^{29}$ who construed the three rules in the arbitral court at Geneva may have failed in the effort to provide a canon so complete as to command immediate and general acceptance, as a final expression of the new and stricter conception of neratial duty, the fact remains that what they did accomplish, while moving in the right direction, is of the highest practical value. In the first place, the result of the decree rendered "mphasized the truth, as it had never been emphasized before, that the municipal laws of a sovereign state are not the measure of its international obligations so far as neutral duties are concerned. The only standard by which such obligittions can be measured is an international one. In the particular ease before the court a conventional standard had been agreed npon beforehand by which the adequacy of the municipal law of Great Britain was tested and found wanting. By that great object-lesson the world has been convinced that a standard of general application must soon be set up through surh an international concert as will give to it the moral power to bind any minority that may attempt to resist it. When such a standard is once clearly defined no neutral can escape respensibility by pleading that it has satisfied all the requirements of its cown law. On the other hand, no belligerent can

a contract made before the outbreak of war, may avoid the penal. ties of illegal shipbuilding.

29 The court was composed of Mr. Charles Francis Adams (Unit- ed States), Sir Alexander J. E. Cockburn (Great Britain), Count Sclopis (Italy), M. Stämpfli (Switzerlan(l), and Viscount d'Itajubá (Brazil). 
complain if a neutral does not comply fully with its own law, provided it performs all that it is required to do by the common law of nations. Even in the absence of such a generally recognized standard the authorities of every well governed state have been aroused by the Geneva award to a livelier sense of neutral responsibility which they are preparing to discharge. In the second place, while the award did not deny that a commission emanating from a recognized government protected a ressel bearing it from all subsequent proceedings against her by a neutral whose neutrality she had violated, it did declare that "the effects of a violation of neutrality committed by means of the construction, equipment, and armament of a vessel, are not done away with by any commission which the government of the belligerent power, benefited by the violation of neutrality, may have afterwards granted to that vessel." In the third place, the award has put all neutral states on notice that while a ship of war may still be built and armed for a belligerent, and delivered to him outside neutral territory ready to receive a fighting crew; or may be delivered to him within such territory, and issue therefrom as belligerent property, provided it is neither commissioned nor so manned as to be able to commit immediate hostilities, and provided there is no good reason to believe that an intention exists to make a fraudulent use of such territory in the particulars indicated,-every belligerent injured by the issuance of such a ressel, under such circumstances, will expect the neutral state to prove its innocence under the common law of nations. The only real difficulty which still remains is that involved in the making of proof as to guilty intention.

$\S 617$. Declarations of neutrality. - As neutrality is presumed unless a state declares otherwise, there is no legal necessity for a formal manifesto or proclamation announcing the fact to the world. And yet as it has been the custom for such declarations to be made, since the new conception of neutral duty began to develop, they stand forth as important and reliable expositions of its history. The First Armed Neutrality League of 1780 grew out of a declaration of neutral rights ${ }^{30}$ issued in that year by Russia to which Sweden and Denmark immediately adhered. Then followed the famous proclamation issued by Washington in $1793,{ }^{31}$ said to have had a greater influence in molding international law than any 
single document of the last hundred years. Among the important declarations made since that time should be noted the Neutrality Ordinance of Austria of $1803 ;^{32}$ the neutrality proclamations of Great Britain and France at the outbreak of the American Civil War in 1861; and that issued by Great Britain in 1870.33

$\S 618$. Neither armed assistance nor other aid to be granted under preexisting treaty. $-A$ s explained heretofore the idea that a neutral state could supply military assistance to an ally under a treaty made before the war, without a breach of neutrality, ceased to influence practice after the end of the eighteenth century."34 And yet despite the fact that during the nineteenth century no nation while professing to be neutral has actually given such assistance, the right to give it has been maintained down to our own time by writers of high reputation. In 1797 the Supreme Court of Pennsylvania assumed the right to be unquestioned when it said that, "if two nations are at war, a neutral power shall not do any act in favor of the commercial or military operations of one of them; or, in other words, it shall not, by treaty, afford a succor, or grant a privilege, which was not stipulated for previously to the commencement of hostilities." 35 In 1836 Wheaton stated that "the neutral may be bound by treaty, previous to the war, to furnish one of the belligerent parties with limited succor in money, troops, ships, or munitions of war, or to open his ports to the armed vessels of his ally, with their prizes. The fulfilment of such an obligation does not necessarily forfeit his neutral character, nor render him the enemy of the other belligerent nation, because it does not render him the general associate of its enemy." 36 Manning, whose work appeared in 1839, while admitting that the custom is "directly at variance with the true basis of neutrality" says, "it has now been established by the habitual and concurrent practice of states, and is at the present day an undisputed principle of the European law of nations," 37 a doctrine reasserted in a work so very

32 Martens (R.) viii, III.

3. See Bigelow's France and the Confederate Navy, p. 20, note; Wharton, Int. Law Dig., $\S 402$; Hansard, 3d series, vol. cciil, 1098.

${ }^{34}$ See above p. 626 seq.

35 Vasse v. Ball, 2 Dallas, p. 275.

36 Dana's Wheaton, p. 517. See also Kent (Comm. I, lect. vi), who says that "neutral duty does not extend so far as to prohibit the fulfilment of antecedent engagements, which may be kept consistently, with exact neutrality, unless they go so far as to require the neutral nation to become an associate in war."

37 Comm. Law of Nations, p. 225. 
recent as that of M. Bluntschli.3s The answer to such assumptions is that, no matter how high the standing on the publicists in question may be, they all rely upon no later precedent than that growing ont of the demand made by Russia on the ontbreak of war with Sweden in 1788, for certain ships and troops stipulated for in a treaty made in 1781,-a precedent which, when correctly interpreted, really marks the end of the old system." The protest of Sweden against "a doctrine which his Swedish Majesty cannot reconcile with the law of nations and rights of sovereigns" was the first strong expression of that new-born sense of neutral duty that compelled even Washington to falter when called upon to carry out the embarrassing provisions contained in the treaty of 1778 whose non-fulfilment occasioned for a time a rupture with France. The result, however, of the negotiations that followed was the convention of 1800 , from which the objectionable stipulations of the treaty of 1778 were omitted. From that time it may be said that the right of a neutral to give succor under a preëxisting treaty ceased to be recognized by the common law of nations. Since then it has not been upheld by continuous usage; and it cannot be successfully maintained that an agreement, contrary to existing usage, although made prior to a war, can in any way affect the character of unneutral acts with reference to a non-consenting third party having the right to rely upon such usage. ${ }^{40}$

\$619. No levying of soldiers in neutral territory.-During the seventeenth century it was deemed no riolation of neutrality for a state to give permission to recruit to its neighbors engaged in war. Often the right of recruiting was stipulated for in treaties like that entered into in 1656 between Great Britain and Sweden providing that it should be "lawful for" either of the contracting parties to raise soldiers and seamen by beat of drum within the kingdoms, countries and cities of the other, and to hire men of war and ships of burden." 41 Although Bynkershoek says, "I think that the purchase of soldiers among a friendly people is as lawful as the purchase of munitions of war," 42 certainly during the eighteenth century there was a great deal of doubt on the subject. Despite the fact that his country was a favorite recruiting-ground

38 Völkerr, \& 759.

39 See above, p. 627. 40 Such is the view of Philli- 125. more, iii, § cxxxviii; Heffter, § 117;
Calvo, § 2322; Hall, pp. 618-619. 41 Dumont, vi, ii, III, and vi, ii,

42 Quaest. Jur. Pub., I, c. xxii. 
Vattel says: "The Switzers, as we have already observed, grant levies of troops to whom they please; and no power has hitherto thought fit to quarrel with them on that account. It must, however, be owned, that, if those levies were considerable, and constituted the principal strength of my enemy, while, without any substantial reason being alleged, I were absolutely refused all levies whatever,-I should have just cause to consirler that nation as leagued with my enemy; and, in this case, the care of my own safety would authorize me to treat her as sucll." Just before he had said that "when it is the custom of a nation, for the purpose of employing and training her subjects, to permit levies of troops in favor of a particular power to whom she thinks proper to intrust them,- the enemy of that power cannot look upon such permissions as arts of hostility, unless they are given with a view to the invasion of his territories, or the support of an odious and evidently unjust cause." ${ }^{43}$ After the rising tide of public opinion as to neutral duty had settled the fact that the right of a belligerent to lery troops in other states was extinct, and that a neutral state permitting such a levy was guilty of a breach of neutrality, Switzerland continued the practice under treaties called capitulations. The troops thus furnished were simply mercenaries engaged for a stated period in foreign service, for stipulated pay and allowances, and absolutely subject to the power employing them. The result of a mutiny that resulted in the death of several hundred Swiss soldiers belonging to regiments, composed entirely of Swiss, hired to the Neapolitan government under a capitulation that ended in June, 1859, added to complications arising in the same year out of the employment of Swiss troops in other foreign states, especially in Italy, prompted Great Britain and other powers to induce the Confederation to pass a law destroying the entire system by making it a penal offense for foreigners to enroll Swiss citizens, and forbidding such citizens to enroll themselves as soldiers to a foreign state, without the permission of the govermments of their respective cantons. ${ }^{44}$ The practice thus extinguished was not only in conflict with existing ideas of neutral duty but inconsistent with the peculiar status of Switzerland as a neutralized power. It is not to be understood,

43 Droit des Gens, III, § 110.

44 Halleck (Baker ed.), II, 8, note 1; Bury, La Neutralité de la Suisse, in the Rev. de Droit Int., vol. ii, pp. 636-642; Manning, Law of Nations, Bk. V, Ch. I; Dana's Wheaton, p. 356, note 145 . 
however, that a neutral state is obliged to exercise such care as to prevent a man here and there from erossing its frontier to take service with a belligerent. Such incidents fall under the de minimis non curat lex maxim of international law. ${ }^{45}$ It is only expected that precautions will be taken to prevent anything like the migration in considerable bodies, or in a continuous stream, of neutral citizens to swell the ranks of either combatant. All such movements can be easily detected, and should be promptly suppressed. Express prohibitions against them are often embodied in neutrality proclamations.

\section{\$620. No passing of belligerent troops through neutral} territory. - The right of passage through nentral territory was gradually extinguished by the same sentiment that forbade recruiting. Grotius was simply describing the practice of the seventeenth century when he said that the right of passage not only existed but could be taken by force when denied unjustly. ${ }^{46}$ In the eighteenth century the right had become so limited that Vattel says, "an innocent passage is due to all nations with whom a state is at peace; and this duty extends to troops as well as to individuals. But it rests with the sovereign of the country to judge whether the passage be innocent; and it is very difficult for that of an army to be entirely so. * * * He who desires to march his troops throngh a neutral country, must apply for the sovereign's permission. To enter his territory without his consent, is a violation of his rights of sovereignty and supreme dominion. ${ }^{47}$ He admits, however, that there is an exception in the case of extreme necessity. "When, therefore, an army find themselves exposed to immineni destruction, or unable to return to their own country, unless they pass through neutral territories, they have a right to pass in spite of the sovereign, and to force their way, sword in hand." To that he adds: "If the nentral state grants or refuses a passage to one of the parties at war, she ought, in like manner, to grant or refuse it to the other, unless a change of circumstances affords her substantial reasons for acting otherwise." A refusal without such reasons was supposed to constitute "a departure from the line of strict neutrality." 48 The idea that a neutral state could thus grant a passage

45 Calvo, § 2321; Heffter, § 145. 126. Pando ( $\$$ cxci) maintains 46 De Jure Belli ac Pacis, II, ii, with Vattel that a belligerent may 13, and III, xvii, 2.

47 Droit des Gens, III, $\$ 119$. 4s Droit des Gens, III, $\S 122$, sity. force a passage against the will of a neutral in case of extreme neces- 
through its territory to a belligerent army, withont a violation of its neutrality, certainly in the event it was granted impartially to both belligerents, was upheld by leading publicists down to the earlier part of the present century. ${ }^{49}$ It has not been exercised, however, since 1815, when the allies forced the Federal Council of switzerland to grant permission for the passage of troops across its territory on their way to invade the southeastern portion of France. ${ }^{50}$ The opinion of recent publicists ${ }^{51}$ that the right no longer exists has been fully vindicated by recent practice. In 1870 the government of Switzerland refused to permit bodies of Alsatians enlisted for the French army to cross her frontiers, although they were traveling without arms or miforms. ${ }^{52}$ In the same year Belgium thwarted an attempt of the Germans to send their wounded home over her railways, even when the privilege was asked in the name of humanity. The application was made because after the battle of Serdan the victorious army found it difficult to remove to Germany over the rontes then open the masses of womded by which it was enemmered. It was pefused because, if the Germans had been permitted thus to relieve the congestion of the lines of eommunication with their own country, their ability would have been increased to reinforce and support their armies then invading France.53 Although France's earnest protest was sustained by Belgium, after consultation with Great Britain, her representative at the Brussels Conference assented to the Article 55 of the Military Code then drawn up, providing that "the neutral state may authorize the transport across its territory of the wounded and sick belonging to the belligerent armies, provided that the trains which convey them do not arry either the personnel or the material of war." 54 In 1875 when the troops of Diaz. after defeating and routing their adversaries on Mexican soil, pursued them into Texas, where they amain attacked and dispersed them, the government of Mexico was told that "while it is deemed hardly probable that this unjustifiable invasion of

49 Martens, Précis, \$ 310 ; Klüber, $\S 284$; Kent, lect. vi: Manning, p. 245; Dana's Wheaton, $\$ 427$.

50 Heffter, $\$ 147$; Bluntschli, $\S 770$; Calvo, $\$ 2345$; Negrin, p. 173; Hall, p. 624 .

$51 \mathrm{As}$ to the special circumstances under which the permission was extorted see Martens
(N. R.) II, p. 170; Dana's Wheaton, $\S+19$.

52 Bluntschli, $\$ 770$.

53 Cf. Rolin Jaequemyns in the Rev. de Droit Int., vol. ii, pp. 708 . 709 (La Guerre Actuelle).

54 British State Papers, Miscell., No. 1 (1875), p. 324 . 
American soil was made in obedience to any specific orders from the Mexican capital, it is, nevertheless, a grave violation of international law, which cannot for a moment be overlooked. You are instructed to call the attention of the officers of the de facto government with whom you are holding unofficial intercourse to this case, and to say that the government of the United States will confidently expect a prompt disarowal of the act, with reparation for its consequences, and the punishment of its perpetrators." 55 In the year in which the United States was thus emphasizing the new conception of neutral duty a step backward was apparently taken by the making of a convention between the Russian and Roumanian gorernments, just before the beginning of hostilities between Russia and Turkey, in which permission was given to the former to pass its troops through Roumania while on the march to the Danube for the purpose of invading European Turkey. The Russian commanders who were responsible for the good order of their troops, and who were to pay for all supplies taken from the country, were to have the use of all railways, roads, and telegraphs, provided they neither passed through the Roumanian capital, nor interfered with the internal affairs of the state. Under that agreement at least half a million Russian troops are said to have passed during the war across the Danube into Fulgaria. ${ }^{56}$ In this transaction may be found a typical illustration of the principles involved in a condition of double sovereignty, a condition in which it is possible for a state to possess at the same moment a belligerent and a neutral character. ${ }^{57}$ As Turkey was the nominal suzerain of Roumania its territory was technically a part of the Turkish Empire. Therefore the entry of Russian troops into such territory was, in theory at least, an invasion of Turkey. In fact, the subjection of the self-gorerning state of Roumania to Turkey was so slight that it was practically an independent power. As such it assumed to sever its connection with its nominal orer-lord, first by giving free passage to the troops of Russia through its territory; and then by joining that country in the war with its entire army.

$\$ 621$. Internment of belligerent soldiers in neutral territory.-The prohibition which denies to a neutral the right to

$55 \mathrm{Mr}$. Evarts, Sec. of State, to 497; Lawrence, Principles, pp. 526Mr. Foster, June 21, 1877. MSS. 528.

Inst., Mex., For. Rel., 1877.

57 See above, pp. 594-96.

56 Fyffe, Modern Europe, iii, p. 
lend his territory to either belligerent for the purposes of war does not deprive him of the right to extend hospitality and asylum to a beaten army or to individual fugitives seeking refuge from a pursuing enemy. Modern practice, which ignores Bynkershoek's contention that tying troops may be followed into a neutral state, imposes mon such a state the duty of receiving them under such conditions as will deprive them of the power to start again from its soil in order to renew hostilities. To secure that end, and at the same time to satisfy the elaims of hmmanity, belligerent troops are disarmed so soon as they cross the nentral frontier 59 and detained in honorable confinement until the end of the war. While thus detained they are said to be interned,-a condition which they must not resist, and the expense of which their government is in honor bonnd to bear. When in 1871 the wreck of Bourbaki's army, consisting of eighty-five thonsand starving French troops, sought permission, in the last days of the Franco-Prussian War, to cross the Swiss frontier, it was given by a special convention made between their commander, General clinckant, and the Swiss General Herzog, ${ }^{60}$ providing for their immediate disarmament. At the conclusion of peace they were permitted to return to France under an agreement providing for the payment by that country of a stipulated sum to defray the cost of their maintenance by the Swiss during their detention. ${ }^{61}$ The Hague Conference substantially confirmed the preëxisting practice by declaring that a neutral state that receives into its territory troops belonging to a belligerent army shall intern them, so far as possible, at a distance from the theatre of war. It can guard then in camps and even in fortresses or other places appropriated to that purpose. It may leave officers at liberty on their giving their parole not to quit the neutral territory withont permission. Unless there shall be some other special convention made, the neutral state shall supply those thus interned with the food, clothing and relief required by humanity, and upon the return of peace remuneration shall be made by the state

ss Quaest. Jur. Pub., I, 8.

$\therefore 9$ The neutral who fails to perform that duty justifies the other belligerent in attacking such refugees within such territory, which can no longer be regarded as neutral. Heffter, § 149 ; Klüber, $\S 208$;
Ortolan, Dip. de la Mer, iii, ch. viii; Hautefeuille, Des Nations Neutres, vi, ch. ii; Halleck (Baker ed.), ii, p. 152.

60 Martens (N. R. G.), xix, 639. 61 Calvo, § 2336; Fyffe, Modern Europe, iii, 462 . 
interested for the expenses incurred during the internment.62 §622. Neither gifts nor loans of money to be made by neutral to belligerent states. - Neither reason nor authority can be opposed to the statement that it is a grave breach of duty for a neutral state to give or lend money to a belligerent one. When Kent says that "even a loan of money to one of the belligerent parties is considered to be a violation of neutrality, he emphasizes the fact that he is referring to public loans by citing Pickering's instructions of March 2, 1798, to Messrs. Pinckney, Marshall, and Gerry as to a proposed loan from the political representatives of a neutral state to a belligerent one. ${ }^{63}$ Under such instructions the American envoys declined to consider the application of the Directory for a loan of thirty-two millions of Dutch florins to France, then at war with England. ${ }^{64} A$ neutral power has no right to guarantee a loan issued by its belligerent friend.

§623. Neutral individuals may lend money to belligerent states. - Usage has entirely discredited those publicists who have attempted to give an unreasonable and impracticable extension to the foregoing rule by denying, directly or by implication, to individuals composing a neutral community the exercise of a right withlield for obvious reasons from the state as such. Bluntschli ${ }^{65}$ claims in direct terms not only that a state must abstain from the making of loans for war purposes, but that the rule is equally applicable to loans negotiated by private individuals. Phillimore, after criticising Vattel, opposes both classes of loans as "a manifest frittering away of the important duties of the neutral," ${ }^{6}$ a conclusion to which Halleck ${ }^{67}$ definitely subscribes. Calvo, ${ }^{68}$ while admitting that all loans made during war are illicit, holds that as the neutral

62 Second Hague Convention, sec. iv. "On the detention of belligerents and the care of the wounded in neutral countries." Arts. LVII and LVIII.

63 Comm. I, p. 116, note (b). Wharton (Int. Law Dig., § 390) says "the loan proposed in this case was to be from the political representatives of a neutral state to a belligerent." Hall (p. 620, note 1) overlooked that fact when he wrote: "Kent merely says that 'a loan of money to one of the belligerent parties is considered to be a violation of neutrality,' but it does not appear whether this language is intended to include private as well as public loans."

64 The loan was asked, in addition to fifty thousand pounds sterling, as a "douceur" to the Directory.

65 Volkerr, \$ 768 .

6i Int. Law, iii, § CLII. Vattel, III, $\$ 110$.

163.

fi Int. Law (Baker ed.), ii, p.

68 Droit Int., § 2331. 
state cannot control the acts of individuals in certain commercial transactions it cannot be held responsible for their consequences. Phillimore and Halleck rest their contention mainly upon the dictum of Lord Chief Justice Best, who expressed the opinion in De Wurtz v. Hendrick ${ }^{69}$ that it is "contrary to the law of nations for persons residing in this country, to enter into engagements to raise money, by way of loan, for the purpose of supporting subjects' of a foreign state in arms against a government in alliance with our own." The statement then follows that a like case had recently been decided "in which the Lord Chancellor entertained the same opinion as myself, and in which he is stated to have said, that English courts of justice will not take notice of, or afford any assistance to persons who set about raising loans for subjects of the king of Spain, to enable them to prosecute a war against that sovereign; or, at all events, that such loans could not be raised without the license of the crown." The rule thus laid down by the English courts declaring it to be illegal for individuals to raise money by way of loan to assist subjects of a foreign state, so as to enable them to prosecute a war against their own government, while the latter is in amity with that of the lenders, has been expressly aftirmed by the Supreme Court of the United States. ${ }^{70}$ And yet the fact that moner is an article of commerce, whose transmission can be so manipulated by private individuals as to baffle all attempts upon the part of governments to control it, has made necessary the rule exempting them from the neutral duty of interference when the transaction is merely a commercial one, providing for the bona fide payment of reasonable interest. Vattel, clearly perceiving the real difficulty, even in his day, drew the distinction between a case in which money is loaned in the ordinary course of business "for the sake of gaining an interest upon it," and a case in which a loan is made with a definitely hostile purpose. As he has expressed it, "if the loan were evidently granted for the purpose of enabling an enemy to attack me this would be concurring in the war against me." 71 And so when Canning, in 18³, called upon the British law officers (including Copley, afterwards Lord Lyndhurst) for advice as to the legality of loans and subscriptions "for the use of one of two belligerent states by individual subjects of

69 9 Moore's Common Pleas Reports, ix, p. 587 . io Kennett v. Chambers, 14

Howard, p. 38.

:1 Droit des Gens, III, § 110 . 
a nation professing and maintaining a strict nentrality between them," the reply was made that, while voluntary subscriptions of the kind in question were inconsistent with neutrality, "loans, if entered into merely with commercial views, we think, according to the opinions of witers on the law of nations, and tlee practice that has prevailed, that they would not be an infringement of neutrality." 72 In accordance with that unquestionably sound view Mr. Webster declared in 1842 that "as to adrances and loans made by individuals to the government of Texas or its citizens, the Mexican government hardly needs to be informed that there is nothing unlawful in this, so long as Texas is at peace with the United States, and that these are things which no government undertakes to restrain." 73 Upon that basis the bourses of the world are open to the traffic in money as merchandise. During the Franco-Prussian war the French Morgan Loan and a part of the German Confederation Loan were issued in England; ${ }^{\mathbf{4}}$ and during the American Civil War the loan of the Confederate States was taken without interference in London, Frankfort, Paris and Amsterdam. ${ }^{75}$ Such bonds, secured by cotton, ranked higher for a time than those of the United States.

\$624. Neither arms nor instruments of war can be furnished by a neutral to belligerent state. An exception.-The same reason that denies to a neutral state the right to supply a belligerent with money and military contingents, denies to it the right to supply arms, ships and other instruments and materials of war. No matter whether the transfer is gratuitous or for a consideration, a neutral state has no right to engage, under ordinary conditions, in transactions with the agents of belligerent powers which must result in arming their principals with the means of injuring a friend. And yet an exception is made to that wholesome and necessary rule in favor of the right of a neutral government to continue the ordinary sales of old arms and stores from its arsenals, even though it knows that agents of belligerent powers will avail themselves of the opportunity to buy. The Congress of the United States having, by the act of 1868 , directed the Secretary of War to dispose of

72 See the two opinions of the British law officers printed in Halleck (Baker ed.), ii, pp. 164-165.

$73 \mathrm{Mr}$. Webster to Mr. Thompson, Ex. Doc., 27th Congress, 1841-1842. ¿* Wharton, Int. Law Dig., $\$ 390$.
75 The remonstrances of Mr. Adams, the American minister, against the acts of private bankers and buyers were disregarded by the British Govt. Cf. Adams's Life of C. F. Adams, p. 346. 
such arms and stores as were unsuitable for use, sales of them began before the commencement of the war between France and Germany. Perels $i 6$ says that the government of the United States sold in October, 1870, at public auction 500,000 muskets, 163 carbines, 35,000 revolvers, 40,000 sabers, 20,000 horse trappings, and 50 batteries with ammunition; and that the export from New York to France from september to the middle of December of that year included 378,000 muskets, $45,000,000$ patronen, 55 cannon, and 2,000 pistols, which were paid for througl a French consul. When early in 1872 complaints were made to the senate that certain "sales of ordnance stores" had been made by the government, during the preceding fiscal year, to parties who were agents of the French gorernment, and that the same had been used in the war then pending with Germany, a committee was appointed to investigate the subject. That committee said in its report that "Congress having, by the act of 1868 , directed the Secretary of War to dispose of these arms and stores, and the government being engaged in such sales prior to the war between France and Germany, had a right to continue the same during the war, and might, in the city of Washington, have sold and delivered any amount of such stores to Frederick William or Louis Napoleon in person, without violating the obligations of neutrality, providing such sales were made in good faith, not for the purpose of influencing the strife, but in the execution of the lawful purpose of the government. to sell its surplus arms and stores." 77 While it cannot be denied that the government of the United States was clearly within its legal rights, it is certain that under such circumstances the neutral state should do all in its power to remore any just cause of complaint. In 1825 Sweden, in order to reduce its nary, offered six frigates for sale to Spain; and after she had refused to buy, three of them were sold to an English commercial firm, who were afterwards suspected of acting in the matter as agents of Mexico, then in revolt against the mother country. When the vessels were about to be handed over to the recognized agent of Mexico in England Sweden, after an earnest remonstrance from Spain, rescinded the contract at considerable pecuniary loss to herself, although the ships had been sold in ignorance of their ultimate destination.78 In the same spirit the British government, when it 
found out that an old and unserviceable gunboat, called the Victor, sold to a private firm, had been resold to agents of the Confederate government, gave orders that no more ships of the royal nary should be disposed of until after the end of the civil war then pending. ${ }^{79}$

\$625. Neutral individuals may supply instruments and materials of war to belligerent state.-The same mercantile considerations which permit loans of money by neutral individuals to belligerent states, permit such individuals to supply, at their peril, instruments and materials of war. President Pierce correctly interpreted the law of nations when he said: "In pursuance of this policy, the laws of the United States do not forbid their citizens to sell to either of the belligerent powers articles contraband of war, or take munitions of war or soldiers on board their private slips for transportation, and although in so doing the individual citizen exposes his property or person to some of the hazards of war, his acts do not involve any breach of national neutrality, nor of themselves implicate the government. Thus, during the progress of the present war in Europe, our citizens liave, without national responsibility therefor, sold gunpowder and arms to all buyers, regardless of the destination of those articles." so

Sale of Warships.-As heretofore explained an American merchant may build and fully arm a ressel, supply her with stores, and offer her for sale in our own market; or he may, without a violation of law, send out a vessel so equipped, under the flag and papers of his own country, with no more crew than is necessary for navigation, and then take the chances of capture as coutraband merchandise, of blockade, and of a market in belligerent port,-provided he performs such acts without the guilty intent involved in an arrangement or understanding with a belligerent that she shall be employed in hostilities when sold. ${ }^{81}$ In other words, such a vessel, regarded as a mere implement of war, may be sold or manufactured to order within neutral territory, and afterwards transported therefrom, under such circumstances as will place the entire transaction within the scope of the principles applicable to the sale, manufacture, shipment, and transportation of articles contraband of war. A different result will follow, however, if

79 British State Papers, North Am., No. 2 (1873), pp. 104-105.

so Second Annual Message, 1854.
Adopted by Sir W. Harcourt, in Historicus, 132.

81 See above, pp. 661-62. 
the preparation and dispateh of such a ship is coupled with such an intent as will convert them into the commencement of a hostile expedition.

$\$ 626$. Neutral territory not to be used as base of operations for warlike expeditions, military or naval.-A neutral state cammot permit its territory to be used as a base of operations in the technical semse, from which a force, military or naval "draws its resonrees and reinforcements, that from which it sets forth on an offensive expedition, and in which it finds refuge at need." $s 2$ As such expeditions have their inceptions, as a general rule, in secret acts, not involving force, whose real significance camnot be understood until their completion at a subsequent time, and in some place remote from the neutral territory, it is difficult to define the degree of diligence which the neutral must amploy under such circumstances. The starting point of any effort to ascertain what kind of incipient acts a neutral is expected to prevent must begin, however, with an understanding of what a warlike expedition really is. The leading case usually cited to illustrate its simplest form is that of the Twee Gebroeder's ${ }^{83}$ in which Lord Stowell released several Dutch merchantmen,-captured in 1800 just outside the limits of nentral jurisdiction by boats sent out by an English ship lying in neutral Prussian waters, - on the ground that no fruit could be reaped from proximate acts of war originating in neutral territory. More complicated conditions were involved in what is known as the Terceira affair, which grew out of the civil war originating in Portugal in 1828 between the partisans of the youthful Donna Maria and those of her uncle, Don lliguel. When a body of troops in the service of the former, which had taken shelter in England, endeavored to organize an expedition there in favor of their mistress, the British government warned them that it would not permit the execution of such a design. After declaring that their only object was to send unarmed lortuguese and Brazilian subjects in merchant ressels to Brazil, the refugees embarked at l'lymouth in 1829 about seven hundred men under Count Saldanha in four unarmed ressels for Terceira, one of the Azores that lad remained faithful to Donna Maria's cause. While off Port Praya in Tercein... to which place the necessary arms had been shipped as merchandise for its use, this expedition, marmed, but under military command, was intercepted by

\$2 Jomini, Prícis de l'Art de la

833 C. Rob. Admr., p. 162.

Guerre Ire partie, ch. iii, art. 18. 
the British ship Ranger, dispatched to prevent a landing at the real destination. When the Portuguese commander, who was told that he might go where he would outside of the Azores, refused to yield to anything but force, his vessels were conducted within a few miles of the English Clannel, from which they proceeded to Brest. ${ }^{84}$ The fact that the British government made a mistake in arresting this expedition in Portuguese waters and on the high seas, where it really had no jurisdiction, instead of preventing its departure from the English waters, where its right to deal with it was complete, does not impair the ralue of the incident as an assertion of the principle that a warlike expedition fitted out within neutral territory is illegal, even when its individual members are unarmed, provided they are organized as soldiers and placed under military command. That a hostile expedition does not exist, in contemplation of international law, without such organization and leadership, was maintained by the gorernment of the United States at the outbreak of the Franco-Prussian war, when large numbers of Germans and Frenchmen resident here returned in order to discharge their military obligations to their respective countries. When the attention of Secretary Fish was called to the embarkation at New York of nearly twelve hundred Frenchmen in two French ships, laden with a cargo of rifles and ammunition, he held that the vessels could not be regarded as a warlike expedition against Germany, because the arms and ammunition were subjects of legitimate commerce, and the unarmed and unofficered Frenchmen on board without any kind of organized military discipline. ${ }^{85}$ That riew Hall declared to be undoubtedly correct as "it was impossible for the men and arms to be so combined on shipboard, or soon after their arriral in France, as to be capable of offensive use. It would have been a different matter if the men had previously received such military training as would have rendered them fit for closely proximate employment." s6 From these precedents the conclusion may be drawn that a warlike expedition, as that term is now understood, is one which is organized with a view to proximate acts of war, and which goes forth, under military or naval command, with a present purpose of engaging in hostilities. It

84 Annual Register for 1829, vol. 738-781, and xxiv, 126-214; Phillimore, iii, §§ CLIX, CLX, Bulwer's Life of Lord Palmerston, i, 301-2.
85 Mr. Thornton to Lord Granville, Aug. 26, 1870; State Papers, 1871, 1xxi, 128.

s6 Int. Law, p. 631. 
is not necessary, however, that the members of such an expedition should take with them the arms they expect to use; they need not be in a position to begin fighting the moment they cross the nentral frontier. A mere preparation or plan to violate nentral territory does not constitute an expedition without orert acts. "If the means provided were procured to be used on the occurrence of a future contingent event, no liability is incurred under the statute. If, also, the intention is that the means provided shall only be used at a time and under circumstances when they could be used without a violation of law, no criminality attaches to the act."sz Angmentations of warlike forces, military or naval, within nentral territory are as clear a violation of such territory as original equipments.

527. Warlike expeditions organized outside of neutral territory from elements issuing separately from it.-It is not grencrally understood, perhaps, that Captain semmes of the Alabama, who was the guiding and directing force in the fitting out of the expeditions whose destructive work resulted in the claims "generically known as the Alabama Claims," was one of the most astute and accomplished lawyers of his time. $88 \mathrm{As}$ his notable work shows he was perfectly familiar with the infirmities of the British Foreign Enlistment Act of 1819 with whose prohibitions he was called upon to deal. He fells us that "the Mlabama had been built in perfect good faith by the Lairds. When she was contracted for, no question had been raised as to the right of a neutral to bnild, and sell to a belligerent such a ship. $* * *$ Notwithstanding this practice of good faith, on our part, and our entire innocence of any breach of the laws of nations, or of the British Foreign Enlistment Act, Lord John Russell had been intimidated to such an extent, that the ship came within an ace of being detained. But for the little ruse which was practiced, of going cn a trial-trip, with a party of ladies, and the customs officers, mentioned by Mr. Laird, on board, and not returning, but sending our guests back in a tug, there is no doubt that the Alabama would have been tied up, as the Oreto or Florida had been, in ronrt. She must have been finally released, it is true, but the delay itself would have been of serieus detriment

${ }_{87}$ U. S. v. Lumsden, 1 Bond, 5, War he practiced for many years construing sec. 6 of the neutrality act of 1818 (Rev. Stat., $\$ 5286$ ).

ss After the close of the Civil causes, civil and criminal. 
to us." 89 Captain Semmes clearly understood that the framers of the British Foreign Enlistment Aet of 1819 had not possessed sufficient foresight to provide for the prevention of warlike expeditions organized ontside of neutral teritory by the combination of elenents issuing separately from it. Is an English publicist has recently stated the matter: "Who may know the intent of a erafty and secret mind? I thousand tricks and devices may be employed to disam suspicion. An unarmed vessel may be dispatched from a neutral port, arms and men from another, and the intent with which these elements were prepared and gathered together may only become apparent on their combination at some spot far beyond the bounds of the neutral jurisdiction. May the neutral monarch suffer his laws thus to be rendered futile? If otherwise, when do well-grounded suspicions amount to reasonable ground for active action, and circumstantial detiils constitute legal proof?" 90 In the case as made before the arbitral tribunal at Geneva it appeared that the Alabama, wholly unarmed, left Liverpool in July, 1862, and afterwards received her guns and ammunition at Terceira, partly from a vessel which cleared two weeks later from Liverpool for Nassan, and partly from another ressel which cleared from London for Demarara. The Georgia, built near Glasgow, after clearing from that port in March, 1863, under the name of the Japan, on a pretended voyage to China, received her arms and ammunition off the French coast from the steamer Alar, which had sailed from Newharen in Sussex. Upon that state of facts the United States claimed that those two ressels were, in contemplation of law, "armed within British jurisdiction." The great unsettled question which the Geneva tribunal has left for future solution is that involving the duty of a neutral state to vindicate its nentrality by preventing the departure from its jurisdiction of the elements ont of whose combination, outside of its limits, an hostile expedition may be formed. "When do well-grounded suspicions amount to reasonable ground for active action, and circumstantial details constitute legal proof?" No more satisfactory answer has so far been made than that of Dana, who says that "the intent covers all cases, and furnishes the test. It must be immaterial where the combination is to take place, whether here or elsewhere, if the acts done in our territory-whether acts of building, fitting, arm-

s9 Service Afloat, pp. 401-2.

so Walker, Science of Int. Law, p. 500 . 
ing, or of procuring materials for these acts-be done as part of a plan by which a ressel is to be sent out with intent that she shall be employed to cruise." 91

\section{$\$ 628$. Neutral states should prevent acceptance of letters} of marque by their citizens. - It is evident that the states who signed the Declaration of Paris, abolishing privateering, cannot offer privatecring commissions in the form of letters of marque to neutral seamen. The fact is that the right to offer such letters to such seamen has, for more than a century, been forbidden by the common law of nations, and neutral govermments have accepted the correlative duty of prohibiting the acceptance of such eommissions by their citizens. ${ }^{22} A$ disposition has sometimes been shown to regard as pirates persons taking letters of marque from one of two belligerents, their own state being at peace with the other. When France was at war with Mexico in 1839 Admiral Baudin, commanding the fleet of the former, gave notice that every privateer sailing undel the Mexican flag, of which the captain and two-thirds of the crew were not Mexican subjects by birth, would be regarded as piratical and treated as such; and during the war between Mexico and the United States, which began in 1846, the government of the latter declared that it could not "recognize the lawful existence of Mexican privateers in the Mediterranean. $* * *$ These corsairs take to the seas, under color of commissions issued in blank and filled up in a Spanish port by some inferior agent, from whom they have purchased the privilege to plunder American ressels. * * * Our vessels of war in the Mediterranean will be ordered to seize and send home for trial as pirates, under the treaty of 1795 and the act of March 3,1847, all Spanish subjects who have accepted and acted under such Mexican commissions." 93 In obedience to that growing public sentiment, before which the older usage has practically disappeared, the United States, the most important of the powers that failed to sign the Declaration of Paris, las manifested its disposition in no uncertain way to treat as piracy the capture of vessels belonging to one belligerent by nentral privateers in the service of the other. By the Lets of June 14, 1797, and of April 24, 1816, eitizens of the 563.

91 Dana's Wheaton, Note 215, p.

92 Report of Neutrality Law Commissioners, 1868, Appendix, iv. $93 \mathrm{Mr}$. Buchanan, Sec. of State, to Mr. Saunders, June 13, 1847. MSS. Inst., Spain. See also Ortolan, Dip. de la Mer, II, ch. xi, and Annexe $\mathrm{H}$. 
United States were forbidden to take part in the equipment or manning of privateers to act against nations at peace with it; and in treaties made with France, the Netherlands, Sweden, Prussia, Great Britain, Spain, Central America, Brazil, Chile, Venezuela, Peru, Bolivia, Ecuador, Guatemala and San Salvador, those powers were asked to declare that they would consider as piracy the acceptance of letters of marque by the subjects of a state from one foreign country against the other. ${ }^{94}$ While some of those treaties have been abrogated enough survive to rebut the presumption that there is any purpose to depart from the general line of policy they were intended to embody.

$\$ 629$. Power of neutral state to prevent infractions of its neutrality. - Whenever a belligerent attempts to violate the reasonable regulations made by a neutral for the protection of its neutrality, or the general rules prorided by the law of nations for that purpose, such neutral may resort to remedies, diplomatic, administrative or judicial. If there is no urgent reason for immediate action remonstrance should be made through the ordinary diplomatic channel so that the offending state may have the opportunity spontaneously to offer adequate redress. There is no reason, howerer, for such a preliminary when it is necessary for the neutral to prevent the completion of a wrong, or to inflict exemplary punishment upon the wrongdoer, by the prompt and summary application of its administrative machinery. If a belligerent ship undertakes to make a capture in a neutral port the local authorities may employ all necessary force to thwart the attempt, regardless of any consequent damage they may inflict upon the aggressor, who can only blame himself for such a result. Publicists of the highest reputation have rightfully maintained that when it becomes necessary for a state to vindicate its neutrality it may pursue the peceant ship into the open sea and arrest it there just as it would have the right to do in the event of an infraction of its municipal laws. ${ }^{95}$ Lawrence's

94 Martens (R), ii, 597; Ibid., iii, 447; Ibid., 576; Ibid., iv, 45; Ibid., v. 678 ; (N.R.) vi, 836 ; Ibid., ix, 24 , 447; Ibid., xiii, 564, vi, 122 ; (N. R. G.) iv, 317; Ibid., xiv, 318; Ibid., $\mathrm{xv}, 77$. Wharton, Int. Law Dig., § 385; Hall, pp. 273-4.

95 Bluntschli, Droit Int. Codifié,
§ 342; Woolsey, Int. Law; § 58; Hall, Int. Law, § 227. As to the right in the event of a breach of municipal laws see Hudson v. Guestier, 6 Cranch, 284; overruling Rose v. Himely, 4 Cranch, 276. See also The Marianna Flora, 11 Wheaton, p. 42. 
(armest contention"6 that such a right cannot be justified on principle is rery much weakened by the fact that the eighth of the articles adopted at Paris, in March, 1894, by the Institut de Droit International, on the subject of territorial waters, declares that the territorial state may continue on the high seas a pursuit commenced in its waters,- - the right so to follow and capture to cease in the event the flying vessel gains a port of its own country or of a third power. ${ }^{97}$ No matter whether property captured in violation of neutrality remains from the first in neutral waters where it has been illegally taken, or is brought back to them some time after the capture, the neutral sorereign must assume the duty of undoing the wrongful act of the belligerent. "In a case in which a captured ressel be brought, or voluntarily comes, infra presidia, the neutral nation extends its examination so far as to ascertain whether a trespass has been committed on its own neutrality by the ressel which has made the capture." 98 Such jurisdiction extends even to a case in which a capturing ves. sel, after having received its original warlike equipment or a subsequent aummentation of its warlike force within neutral territorial waters, returns with a prize to the port whose neutrality it has violated. The leading case in the line in which that doctrine has been maintained is that of the Santissima Trinidad, ${ }^{99}$ in which Judge Story declared that while captures made during the same cruise are infected with the character of torts, and must be restored to the original owner when the property is brought within our jurisdiction, an augmentation of force, or illegal outfit, does not affect any capture made after the original cruise, for which such angmentation or outfit was made, is terminated. Despite the fact that restoration in all such cases may be made by administrative act, it is generally

96 Principles of Int. Law, p. 555.

$9 \pi$ Annuaire de linstitut de Droit International, 1894-95, p. 330.

98 The Estrella, 4 Wheaton, p. 309. See also The Betsey Cathcart, Bee. 282; Talbot v. Janson, 3 Dallas, 157; La Amistad de Rues, 5 Wheaton, 385; Ortolan, Dip. de la Mer, ii, 298; Phillimore, iii, $\S \S$ clvii-viii, cccxxvii; Pando, III, sect. vii, $\$ 192$. According to Calvo ( $\$ 2843$ ) the right of the neutral sovereign is limited to cases of cap. ture within his jurisdiction.
997 Wheaton, 285. If the captured property is carried into the jurisdiction of the belligerent whose subjects are the wrongdoers. courts of such belligerents must do justice to the neutral state when application is made to them. Twee Gebroeders, 3 C. Rob., Admr., 162; La Nostra Señora del Carmel contre la Vénus de Médecis; Pis. toze et Duverdy, Traité des prises Maritimes, i, 106; Ortolan, ii, 298; Hall, pp. 645-6. 
adrisable to hand over such controversies to the neutral prize court for authoritative adjudication.

$\S 630$. Reparation by neutral state for failure to perform its obligations as such. - When the rights of a neutral sovereign were so lightly regarded that either belligerent dared to defy them and set them aside whenerer he possessed the necessary physical force, it was held that the other belligerent had no claim upon the neutral for redress, as the latter was not a free agent under such circumstances. Not until the stricter conception of neutral duty had so far dereloped as to suggest the necessity for arming the neutral state with certain large powers and privileges was the corollary established that the possession of them compelled the neutral so to assert them as to vindicate its neutrality. When that point was reached it was not difficult to formulate the rule under which a neutral state is now required to make reparation to a belligerent who has been seriously and specifically injured by its failure to perform its neutral obligations. The fact that such a rule is a part of modern international law has not been an open question since the meeting of the arbitral court at Geneva, whose very existence was the strongest possible affirmation of it. Under the terms of the rule as now understood the neutral state is expected not only to procure redress for injuries inflicted upon a belligerent within its territory, but also to respond directly for any serious and specific damages suffered by a belligerent through such violations of its neutrality as it can rightfully be expected to prevent. The degree of diligence which the neutral is required to exercise in the vindication of its neutrality has been fully considered already. When the liability of the neutral to the belligerent has once accrued by reason of the lack of reasonable rigilance, negligence, or willful omission upon its part, the exact nature and extent of the reparation cannot be determined by any fixed rule. It can only be settled by negotiation between the powers concerned in reference to the special facts and circumstances of the particular case. When a neutral state undertakes to procure redress for injuries done to a belligerent within its territory, it should act just as if its own dignity and interest were involved, and demand that the wrongdoer restore, as far as possible, the matter or thing affected to the condition in which he found it. In 1864 the government of Brazil demanded immediate reparation from the cabinet at Washington for the wrongful seizure in the harbor of Bahia of the Confederate cruiser Florida by the United 
States steamer Wachusett. As exact reparation was impossible by reason of the fact that the Florida had foundered at Hampton Roads, the American government did what it could by surrendering the crew, and by offering special satisfaction to the violated sovereignty of Brazil by dismissing the consul at Bahia, by sending the captain of the Wachusett before a court-martial, and by saluting the flar of the Enpire at the spot where the offence occurred. A year before, after the passenger boat Chesapeake, plying between Portland and New York, had been captured on its royage by a small band of Confederates, she was pursued by an armed ressel of the United states and seized in British waters. For that violation of the territorial rights of Great Isritain, of which its officers had been snilty, the Enited States not only apologized, but surrendered the ressel with the two eaptors found on her, and a third taken out of an English ship lying alongside. ${ }^{1}$

1 For more complete statements, see Dana's Wheaton, notes 207 and 209; Wharton, Int. Law Dig., $\$ \S 27$, 399; Calvo, $\S 1032,1033,1079$. As to the right of a neutral state to demand the return of property taken within its limits, see the French cases of La Christiana Colbiornsen and Le Daniel Fred- erick. Merlin, Rép. XIII, pp. 111114. The first was restored as being within neutral territory at the time of capture; the second was condemned as having been $\grave{a}$ plus d'une double porté du canon from the neutral coast at the time of capture. 


\section{CHAPTER III.}

\section{DUTIES OF BELLIGERENT TOWARDS NEUTRAL STATES.}

$\S 631$. Notice to neutrals of commencement of war.-While it is undoubtedly true, as heretofore explained, that there is no necessity as between belligerents for notice of the fact that war has actually begun, or about to begin, as between a belligerent and neutral, there is a necessity for such notice for the reason that as there is no privity between the parties last naned, neither duties nor liabilities can be imposed upon the neutral until the fact of the existence of war had been brought home to him. It cannot be claimed, however, that the law of nations requires a belligerent to give to a neutral express and formal notice of the fact that war has begun,--he can be held to the performance of neutral duties from the time when adequate orert acts should convince him of its existence. As war often breaks out before the issuance of a manifesto, in consequence of unforeseen events, or from the execution of conditional orders given to a military force, its beginning as between the belligerents themselves may date from the conlmission of any act which either may elect to consider hostile. But such an election does not bind the neutral; he can only be required to perform neutral duties from the time when it can be claimed that he has receired adequate notice, actual or constructive, of the existence of hostilities. The issuance of a formal manifesto upon the part of a belligerent informing all the world of the commencement of war is not, therefore, a mere act of courtesy which he owes to neutrals, but a prudential act in his own interest enabling him to prove beyond question that, from its date, all third powers must obey the laws of neutrality so far as he is concerned. What has thus been said "as to the moment from which states, and therefore their" subjects, become affected by the consequences of non-neutral action does not apply to cases in which neutral persons are engaged knowingly or even ignorantly in carrying out a naval or military operation for an intending belligerent." 2

$\S 632$. Hostilities not to be carried on in neutral territory. - The duty of a belligerent not to carry on hostilities in neutral territory is reciprocal to that which compels the neutral him-

1 See above, p. 454 .

2 Hall, Int. Law, p. 597, note 1. 
self so to vindicate his neutrality, by armed force if necessary, as to prevent a belligerent from infringing it. These correlative duties were the outgrowth of a common idea and matured side by side. The only legitimate fields for hostilities are territories of either belligerent, the high seas, or territory belonging to no one. The boundaries with which international law incloses the domain of a neutral state, whether consisting of land or water, must not be crossed by either belligerent without the neutral's consent, or in certain exceptional cases under the pressure of irresistible necessity. The aneient contention of Bynkersloek ${ }^{3}$ that a belligerent has a right to pursue an enemy's ressel into neutral waters and complete her capture there, dum fervet opus, has not received the general sanction and approval necessary to make it a part of the law of nations. One of the most generally recognized exceptions to the rule protecting neutral territory against invasion is that which concedes the right of a belligerent to cross the boundaries of a neutral for the purpose of self-defense when the necessity for the same is "instant, overwhelming, leaving no choice of means, and no moment for deliberation." The best illustration of that exception is to be found in the case of the Caroline heretofore (ited for other purposes. ${ }^{4}$ In that case the commander of a British force in Canada suddenly crossed the frontier of the Cnited States in order to arrest and destroy a hostile expedition then being fitted out upon American soil for the purpose of invading Canadian territory. The government of the United states admitted that such invasions are defensible when the necessity for self-defense is instant and overwhelming. And yet eren after the British cabinet had demonstrated the existence of such a necessity, it felt called upon to apologize for the action of its military commander for which it assumed official responsibility.

$\$ 633$. No direct preparation for hostile acts to be made in neutral territory.-Before the present conception of neutral duty reached its maturity the rule which denies to a belligerent the right to carry on actual hostilities in neutral territory was so enlarged as to compel him to abstain from making in such territory direct preparation for acts of hostility. The essence of the prohibition last named has been already considered in what has been said in reference to the duty of a neutral to forbid the fitting out within its limits of hostile expeditions,

3 Quaest. Jur. Pub., I, 8.

4 See above, pp. 171, 405 . 
whether such expeditions consist of the equipment of land forces under organized military command or of a ship or ships of war prepared in neutral ports for actual hostilities the moment they pass the neutral boundary. ${ }^{5}$ It is, therefore, unnecessary to say more on those subjects than that the belligerent is in duty bound to abstain from doing whatever the neutral is required to prevent. The prohibition in question assumes its greatest importance so far as it relates to the conduct of belligerent warships in neutral waters to be specially considered hereafter.

$\$ 634$. All reasonable regulations for protection of neutrality to be respected.-The restrictions to which a belligerent is subject in neutral territory are either those fixed and permanent regulations embodied in the law of nations of general application, or such as are contained in the municipal law of the neutral, depending entirely upon his will, which may be made or unmade, strengthened or relaxed at his pleasure. Of the latter no state has a right to complain so long as they are reasonable in themselves and are applied with absolute impartiality to both combatants. Such regulations must be faithfully observed either by land forces crossing a neutral frontier under circumstances subjecting them to internment or by belligerent warships seeking an asylum in a neutral port for the purpose of obtaining provisions or supplies. If they are not so observed, the neutral is armed with the present coercive power to enforce them, and also with the right to demand reparation for their infraction.

$\S$ 635. Belligerent warships in neutral waters. Hospitality and asylum. - The rule forbidding the land forces of belligerents to enter neutral territory is greatly relaxed in its application to the entry of warships into neutral ports. Chief Justice Marshall has thus expressed it in the notable case in which the present status of warships in neutral waters was first authoritatively defined: "But the rule which is applicable to armies does not appear to be equally applicable to ships of war entering the ports of a friendly power. The injury inseparable from the march of an army through an inhabited country, and the dangers often, indeed generally, attending it, do not ensue from admitting a ship of war, without special license, into a friendly port. A different rule, therefore, with respect to this species of military force has been generally

5 See above, p. 678 . 
adopted. If, for reasons of state, the ports of a nation generally, or any particular ports be closed against ressels of war generally, or the ressels of any particular nation, notice is usually given of such determination. If there be no prohibition, the ports of a friendly nation are considered as open to the public ships of all powers with whom it is at peace, and they are supposed to enter such ports and to remain in them while allowed to remain, under the protection of the govern. ment of the place." Only in the event such a ressel is driven by stress of weather, or by unseaworthiness to seek shelter, can it demand, as a matter of strict law, the right of asylum and hospitality in a neutral port. Under all circumstances the neutral can couple the enjoyment of such privileges with reasonable restraints which the visitor must not refuse to obey. In addition to the observance of all quarantine rules, local revenue and harbor regulations, ${ }^{7}$ the belligerent ship must respect all prohibitions designed to prevent the use of the neutral port for purposes other than those of immediate necessity. While the fighting force of such a ship may not be reinforced or recruited in such a port, nor supplies of arms and warlike stores or other equipments of direct use for war obtained, such supplies and equipments may be purchased as are necessary to sustain life or carry on navigation. If she is in need of repairs she may procure whatever is needful to put her in a seaworthy condition, including masts, spars and cordage. But she cannot make such structural changes as will increase her efficacy as a fighting machine, either of offense or defense. She may take in such provisions as she needs; and, if a steamer, she may purchase enough coal to enable her to reach the nearest port of her own country.

Substance of Azuni's rules. - The duties of warships in neutral ports have been summarized in the following rules, which are substantially those given by Azuni, ${ }^{8}$ as of long practice in Europe: (1) All vessels of war, including privateers, must, during such stay, live in the greatest peace and tranquillity with all persons, and especially with the subjects and ressels of their enemies, though privateers or ships of war. (2) They are not allowed to receive on board, for the purpose of aug-

6 The Exchange v. McFaddon, 7 Cranch, p. 141.

7 See above, p. 305.

82 Maritime Law, ch. V, art. I, \& 7. As to the treatment of ves- sels of the revolted American colonies in Dutch ports, and protests of the British government, see 1 Martens, N. Causes Célibres, 113. See also 2 Ib., pp. 183, 332. 
menting the number of their crews, any mariner of any nation whatever, not even those of their own country, who might happen to be enrolled for the military service. (3) They cannot increase either the number or size of their guns, nor the quantity of their warlike stores. Any capture on the same eruise after a violation of this rule is unlawful. (4) They ought not to keep watch in the port, nor endeavor to gain information of ressels of their enemy, which are expected to arrive there. In case they discover any ressel of an enemy, they cannot go out of the port to attack it. If they do so the artillery and vessels of the port may be employed to compel them to return. (5) They cannot set sail as soon as an enemy's ship has weighed anchor. Twenty-four hours, at least, ought to intervene between the departure of the one and that of the other. Where that time has elapsed, if the enemy-ressel be still in sight of the port, their departure ought to be delayed, until the ressel is out of sight, and it is unknown what course she has steered. (6) They cannot lie in wait in bays or gulfs nor conceal themselves behind capes, headlands or the small islands belonging to the neutral territory, to be on the look-out and ready to chase the vessels of their enemy. They ought not, in any manner, to hinder the approach of vessels of any nation whatever to the ports and shores of neutral powers. (7) While they are within the ports or in the territorial sea of a neutral power they can employ neither force nor stratagem in order to recover prizes in the possession of their enemies, nor to deliver their countrymen who are prisoners. (8) Except in cases of necessity they can neither sell, nor ransom prizes made by them, before a legal sentence has been pronounced on the validity of the capture, ${ }^{9}$ although probable prizes may be repaired so as to be able to make the voyage to the prize port. To these may be added the rule which during the recent war with Spain drove Cervera from the Cape Verde Islands and Dewey from Hong Kong. (9) They can lie in such port only long enough to complete repairs or to procure supplies, including coal to last them to a home port or nearer destination, and they can revisit the same harbor only after a reasonable interval, to be declared by the neutral state, and generally fixed at from one to three months. (10) When not otherwise directed they may land their prisoners, but these thereupon become free. So long as prisoners are kept on board, however, the port authorities will

9 See the case of the Chesapeake, miralty court. As to repairs, 2 before the Nova Scotia vice-ad- Opin. Atty. Gen. 86. 
not interfere, and the fact that they are in friendly waters does not release them. ${ }^{10}$

Negrin's rules.-Negrin ${ }^{11}$ has summarized the conditions upon which belligerent ressels are now admitted into neutral ports as follows: (1) The greatest harmony must be observed and the perfect peace of the port kept even with one's enemies; (2) there must be no recruiting to increase or complete the crews; (3) there must be no increase in the caliber of the artillery, and there must be no taking on of arms and munitions of war by war ships or privateers; (4) the place of asylum must not be used for the purposes of watching enemy ships or for obtaining information as to their future movements; (5) the port must not be abandoned until twenty-four hours after the departure of the squadron or ship of the enemy, mercantile or warlike, found therein; (6) no aid must be given, eitler by force or stratagem, to prizes found in the port; $(\bar{\tau})$ and no attempt must be made to sell those brought there until they have been declared legitimate by a competent tribunal. It may be added that while it is within the right of a nation to prohibit the entry of warships of another, such an act is generally regarded as an affront. The British government so regarded the action of President Jefferson when, after the affair of the Leopard and Chesapeake, he issued a proclamation excluding British ships of war from American ports. ${ }^{12}$

\$636. The twenty-four hours' rule. Nashville and Tuscarora.-One subject embraced in the foregoing rules is so important as to require more extended consideration. The old rule permitting a ressel of war to enjoy the security of neutral waters for as long a time as seemed good to her began to be limited in the last half of the eighteenth century by the establishment of regulations fixing hours of sojourn of belligerent ressels within such places, and interposing definite intervals between the sailings of such eraft as were likely to come into hostile contact with each other. ${ }^{13}$ While commanders of vessels of war were generally permitted to relieve themselves of the inconvenience of the last requirement by giving their word

10 Vattel, III, c. $7, \S 132 ; 1$ Kent Commentaries, 109; But see Vattel, III, c. $7, \S 109$, note; Halleck, Int. Law, p. 870 .

11 Derecho International Maritimo. p. 180.

12 See Mr. Canning to Mr. Mon- roe, Sep. 23, 1807. 3 Am. St. Papers (For. Rel.), 200.

13 For the rules laid down by Spain in 1759 , see Ortolan, Dip. de la Mer, ii, 257; for those laid down by the Grand Duke of Tuscany, in 1778 , see Martens (R), iii, 25. As 
not to attack any ressel issuing from a neutral port shortly. before them, commanders of privateers, who were often entirely excluded by reason of the disfavor in which they were held, were required to submit to a detention of twenty-four hours. ${ }^{14}$ That rule has been extended to public ships of war by Great Britain, France, the United States, Italy and Holland. How near the new rule had approached to general acceptance at the outbreak of the American Ciril War may be inferred from the following statement of Mr. Bernard, made not long thereafter: "The rule that when hostile ships meet in a neutral harbor, the local authority may prevent one from sailing simultineously with or immediately after the other, will not be found in all books on international law. It is, however, a convenient and reasonable rule; it has gained, I think, sufficient foundation in usage, and the interval of twenty-four hours adopted during the last century in a few treaties and in some marine ordinances has been commonly accepted as a reasonable and convenient interval." 15 In 1861 France undertook to redefine and affirm both aspects of the rule by providing that a belligerent vessel should neither be permitted to remain in a port of that country for more than twenty-four hours, except in case of exhaustion of necessary provisions, injuries or stress of weather, nor to sail therefor until the lapse of twenty-four hours after the sailing of a possible opponent. ${ }^{16}$ Like regulations were afterwards adopted by Great Britain, Spain and Brazil.17 ${ }^{7}$ The practical difficulties incident to the execution of such a policy without special regu-

to the rules of the Genoese and Venetians, see Ibid., 80.

14 Pistoye et Duverdy, i, 108.

15 Hist. Acc. of the Neutrality of Great Britain, p. 273. See also Bluntschli, § 776; Hall, pp. 651-52. After quoting Bluntschli's statement that "in strict law a ship of war cannot quit a neutral port for four-and-twenty hours after the departure of an enemy's vessel," Hall says, that "even if the twentyfour hours' rule becomes hardened by far longer practice than now sanctions it, the right of a neutral to vary his own port regulations can never be ousted. The rule can never be more than one to the enforcement of which a belligerent may trust in the absence of notice to the contrary."

$16 \mathrm{M}$. Hautefeuille, in his Quelques Questions au Droit International Maritime, 1861, contended that certain of the prohibitions contained in the French order of June 10,1861 , were in conflict with previous treaties with the United States. Woolsey concludes that such order "was perfectly legal and just," because Hautefeuille "fails in his foundation of fact." Int. Law, p. 274. See also U. S. Diplomatic Correspondence, 1864, Pt. 3, p. 48 .

17 Case of Great Britain, Appendix III, pp. 19, seq. 
lations became apparent to the power first named when its govermment was called upon to deal with the virtual blockades of the Nashville at Southampton, and the Sumter at Gibraltar. At the close of 1861, while the Confederate cruiser Nashville was in dock for repairs at the port first named, the United States ship of war Tuscarora arrived for the purpose, as it afterwards appeared, of preventing her exit. By keeping up steam and having her eables so arranged that she conld slip them at a moment's notice, the Tuscarora claimed the right to precede the Nashville whenever she attempted to depart; and thus, by moving and returning within twenty-four hours, actually blockaded the latter in a British port. To terminate such a condition of things the British government, in the exereise of its clear nentral duty, ordered one of its warships to conduct the Nashville out to sea, at the same time forbidding her antagonist to leave the port until the lapse of twenty-four hours. ${ }^{18}$ In order to prevent the repetition of such acts Great Britain adopted a series of neutrality regulations, more stringent than any hitherto published, providing, among other things, that while hostilities continued, any war vessel of either belligerent entering a British port "should be required to depart and to put to sea within twenty-four hours after her entrance into such port, except in case of stress of weather, or of requiring provisions, or things necessary for the subsistence of the crew, or repairs." In either of such contingencies the authorities of the port were commanded "to require her to put to sea as soon as possible after the expiration of such period of twenty-four hours." It was further provided that no ship of war of either belligerent should be permitted to leare a British port from which a ship of war or neutral ressel of the other belligerent had previously departed, until after the lapse of at least twenty-four hours after such departure. Although such regulations permitted the purchase of provisions and all other things necessary for the subsistence of the crews of such ressels, their supplies of coal were limited to the amounts necessary to take them to the nearest port of their own country, no two supplies of the same to be obtained in British waters within three months of each other. ${ }^{19}$ Not long thereafter the French government, in its dealings with the American belligerents, fixed the limits of neutral hospitality in a

18 British State Papers, North America, No. 2 (1873), pp. 242-44. 19 Order in Council of January
31, 1862; British State Papers, Report of the Neutrality Laws Com. missioners, pp. 77, 78 . 
rule which clearly drew the line between the necessary supplies furnished a belligerent vessel for the strengthening of her fighting qualities as distinguished from her "navigability."20 The restrictions upon belligerent ressels in neutral waters, thus adopted by the leading European powers at the time in question, were repeated by the United States at the outbreak of the war between France and Germany ${ }^{21}$ and since that time by other powers, either wholly or in part, to such an extent that they are beginning to be regarded as rules of international law.

\section{$\S 637$. Sale of a belligerent warship in a neutral port.} Case of the Sumter.-In January, 1862, the Sumter arrived at Gibraltar in need of repairs, coal and other supplies, and before the middle of the next month her commander was complaining that he had "made every effort to procure a supply of coal withont success. The British and other merchants of Gibraltar, instigated, I learn, by the United States consul, have entered into the unneutral combination of declining to supply the Sumter with coal on any terms. Under these circumstances I trust the government of Her Majesty will find no difficulty in supplying me."22 The application was, however, refused, after reference to the law-officers of the crown, and in the meantime the arrival of three United States men-of-war at Gibraltar resulted in the blockade of the Sumter in that port. Her sale at public auction in the following December gave rise to a correspondence between the American minister, $\mathrm{Mr}$. Adams, and Earl Russell, in which the latter said: "The neutral and belligerent have distinct rights in the matter: the neutral has a right to acquire such property offered to him for purchase, but the belligerent may, in the particular circumstances of the case, not recognize the transfer of such property, as being that of his enemy, only parted with to the neutral in order to protect it from capture on the high seas. The prize court of the belligerent, when property so circumstanced is brought before it, decides whether the transfer is fair or fraudulent." 23 In harmony with that declaration the Supreme Court of the United States held in the case of the

20 Papers relating to the Treaty 1870. Wharton, Int. Law Dig., of Washington, II, p. 44; U. S. $\S 402$.

Diplomatic Correspondence, 1863 , p. 715 .

21 President Grant's proclamation of Oct. 8, 1870. For. Rel.,
22 Service Afloat, p. 331

23 Earl Russell to Mr. Adams, April 10, 1863. U. S. Diplomatic Correspondence, 1883 , pp. 26, seq. 
Georgia ${ }^{24}$ that a bona fide purchase for a commercial purpose by a neutral, in his own home port, of a ship-of-war of a belligerent that had fled to such port in order to escape from enemy ressels in pursuit, but which was bona fide dismantled prior to the sale, and afterwards fitted up for the merchant service, does not pass a title above the right of capture by the other belligerent. Such a vessel may be afterwards captured as a prize of war. The sumter, however, was never captured. She escaped the rigilance of the blockading squadron, reached Liverpool in February, 186;3, and after "being put under the English flag as a merchant ship, made one voyage to the coast of the Confederate States as a blockade-rumner, entering the port of Charleston. Her new owner changed her name to the Gibraltar. She was lost afterwards in the North Sea, and her bones lie interred not far from those of the Alabama."25

Buying and selling of merchant vessels in time of war.After a declaration of war, according to English and American practice, a neutral citizen may buy a merchant vessel of a belligerent, provided the sale is absolute. A conditional sale, as with right of repurchase, is not considered bona fide. Many purchases of American ships were made by British subjects during the careers of the Confederate cruisers, and like purchases were made of Chinese vessels by Americans during the Franco-Chinese war. It is not a violation of neutrality to sell a belligerent a ressel suited for privateering if its equipment, although warlike, is that frequently used by merchant ships. The case is otherwise if a war vessel, partially finished here, is taken abroad by one of our citizens and then sold to a bellig. erent. ${ }^{26}$

$\$ 638$. Belligerent's right to hold captured persons in neutral territory.-In the case of Sommersett, Lord Mansfield said that "the state of slavery is of such a nature, that it is incapable of being introduced on any reasons, moral or political, but only by the positive law, which preserves its force long after the reasons, occasion and time itself from whence it was created, are erased from memory. It is so odious that nothing

247 Wallace, p. 32.

25 Service Afloat, p. 345.

267 Opinions Attys.-General, 538; The Sechs Geschwister, 4 C. Rob., Admr., 100; Moodie v. The Alfred, 3 Dallas, 307 , "If such a ship is subsequently employed in trade with the enemy, very slight indicia of fraud would cause her condemnation." Halleck (Baker ed.) II, p. 135. See also The Vigilantia, 1 Rob., Admr., 13; The Bernon, Ibid., 102; The Georgia, 7 Wallace, 32 ; The Georgia, 1 Lowell, 96. 
can be suffered to support it but positive law."27 Because the positive law of England did not support the captivity of sommersett, while confined on board a merchant slip lying in the Thames and bound for Jamaica, he was delivered on habeas corpus. On that general principle all captured persons on board belligerent ships must be delivered when they come within the territory of a neutral, if they once touch the soil,that is, if they ever come within limits in which the positive law upholding their captivity does not operate. ${ }^{28}$ When in 1588 a large number of Turkish and Barbary captives escaped from one of the galleys of the Spanish Armada wrecked near Calais, they regained their liberty, and were sent back to Constantinople by the council of the French ling, regardless of the claims of the Spanish ambassador. ${ }^{29}$ In order to prevent that result in every case, nations by comity admit that the positive law of the enslaving state may be permitted to operate in neutral territory, so long as captured persons are kept on board a commissioned ship of a belligerent power, even though it be a privateer. ${ }^{30}$ That concession is made in accordanee with the general principle of exterritoriality which respects the internal economy of ships of war independent, as a generil rule, from the local jurisdiction of the state in whose waters they may happen to be. When, however, a captive passes beyond the ship and touches the soil he is a prisoner no longer. ${ }^{31}$

$\S 639$. Belligerent's right to deal with prizes in neutral ports. - The right of a belligerent to bring a prize into a neutral port and deal with it there depends upon the same general rule of comity that tolerates the detention of captured persons while confined within ships of war. The extent of the neutral's right to control the matter is best illustrated by the fact that it is now becoming usual for the neutral state to deny to a belligerent the right to bring prizes into its harbors, except in cases of danger or want of provisions, and then only for as

2720 St. Tr. 79; 1 Evans, Decis. of Lord Mansfield, 95.

28 Vattel, III, § 132; Bluntschli,

§ 785; Twee Gebroeders, 3 Rob., Admr., 165.

29 Martin, Hist. de France, X, 93. Austria's Neutrality Ordinance of 1803 expressly provided: "Il ne sera pas permis aux Puissances belligérantes de mettre à terre dans nos ports, etc., aucun individu comme prisonnier de guerre.

$30 \mathrm{As}$ to the status of a privateer regularly commissioned see L'Invincible, 1 Wheaton, 238.

31 As to the privileges of ships of war in territorial waters, so far as imprisoned persons are concerned, see Sir J. F. Stephen, Hist. of the Crim. Law, vol. ii, p. 49 , seq. 
short an interval as the circumstances of the case will allow. Under the older practice free entry was permitted, and prizes were sometimes adjudicated upon and sold, while lying in neutral waters, when it was not expedient to take them into the ports of the captor's country. As Phillimore has expressed it: "In attentive review of all the cases decided in the courts of England and the North American United States, during the last war (1793-1815), leads to the conclusion that the condemnation of a capture by a regular prize court, sitting in the country of the belligerent, of a prize lying at the time of the sentence in a neutral port, is irregular, but clearly valid."32 Not until a belligerent has perfeeted his right to captured property by a definitive appropriation, ${ }^{33}$ or by a valid judicial condemnation, does he acquire such a title as the neutral is bound to respect. For instance, while the taking as booty by one belligerent of what unquestionably belongs to another confers title upon the captor, as between the belligerents them. selves, so soon as the seizure is effected by being brought within the captor's lines, ${ }^{34}$ as to a neutral, the title is not complete mless there has been a deposit in a safe place or possession for twenty-four hours before neutral territory is entered. ${ }^{35}$ In the same way title to the property of a neutral trader seized as contraband, or for breach of blockade, is not complete until after judgment by a prize tribunal. Therefore, under the old rule, the belligerent was permitted to bring his prize into a neutral harbor and keep it there until a suit for its condemnation in the proper court could be terminated. Then, under the usage as recognized by most writers, he had the right to sell the prize in the neutral port by virtue of such condemmation. ${ }^{36}$ The transition from the older to the existing practice began as

32 Int. Law, iii, ccclxxix, citing The Henrick and Maria, 4 Rob., Admr., p. 43; The Christopher, 2 Ibid., p. 207; The Victoria, Edwards, p. 97; Hudson v. Guestier, 4 Cranch, p. 293 , and 6 Cranch. p. 281; The Arrabella and Madeira, 2 Gallison, p. 368. Phillimore then adds that "it appears to be the inclination of the English Prize Court, during the present war, to limit to cases of necessity the condemnation of vessels lying in a neutral port," citing The Polka, 1 Spink's Eccles. \& Admr. Rep.
(1854), pp. 447-8. See also Dana's Wheaton, p. 479.

$33 \mathrm{As}$ to the probable origin of the rule see above p. 575 .

34 Ayala, De Jur. et Off. Bell., I, c. ii, § 37; Gentilis, De Jure Belli, III, c. 17; Pardessus, Col. de Lois Maritimes, ii, 338-9.

35 "When the capture is completed, and the booty absolutely in the enemy's power, no inquiry is made how he came by such effects, and he may dispose of them in a neutral country." Vattel, III, § 132. 36 Ortolan, Dip. de la Mer, ii, 303, 
early as 1823, when Denmark inaugurated a morement, advanced by Great Britain, France, the United States, Prussia, Italy, Sweden, Holland, Spain, Portugal and the Hanseatic Towns, resulting in a set of regulations under which some powers admit prizes into some ports and exclude them from all the rest, while others either exclude them altogether or admit them only when taken by ships of war as distinguished from privateers. The one prohibition common to all such regulations is that forbidding the sale of a prize, however captured, in a neutral port. ${ }^{37}$ The outcome of the movenent thus made by neutral maritime states in the direction of total exclusion, which has been greatly accelerated by regulations issued during the conflicts of the middle of the present century, including the American Civil War, is the new rule which denies to belligerents the right to bring prizes into neutral ports except in cases justifying an entry under the right of asylum. If that rule has not ret become an obligatory part of international law, it is moving rapidly in that direction.

$\$ 640$. Attack of one belligerent upon another in neutral waters. - Prior to and during the wars arising out of the French Revolution the violation of neutral waters by acts of war was so common that no great commotion was made when a cruiser, continuing its pursuit of a ressel into neutral territory, completed its capture there; or even when ressels of one belligerent were cut out of a neutral port by a boat expedition from the war ships of the other. When in 1759 Admiral Boscawen pursued the French fleet to the very shores of Portugal, near Cape St. Vincent, and captured or destroyed French ressels there, Great Britain apologized, but refused the earnest demands of Portugal for restitution or indemnification by which she could satisfy the claims of France upon her. ${ }^{35}$ The failure of Portugal, helpless as she was, to enforce her demands against Great Britain, France alleged as one of the grounds of justification for her subsequent invasion. When in 1793 the French frigate Ambuscade captured the George, a British merchant ressel, in Delaware Bay and took her to

306, 310; Bynkershoek, I, c. 15; Martens, Précis, viii, ch. vi, sect. 6; 1 Kent Comm., p. 124; Manning, 387; Heffter, § 147; Bluntschli, $\S \S 777,857$; Hopner v. Appleby, 5 Mason, 77.

37 British State Papers, Report of the Neutrality Laws Commissioners, pp. 39-79; Calvo, § 2379; Hall, pp. 472, 642, 643; Lawrence, Principles Int. Law, p. 512.

38 Mahan, Influence of Sea Power, p. 299. 
Charleston as a prize, the govermment of the United States, upon the complaint of Great Britain, brought the matter to the attention of the minister of France, who ordered the ressel's restitution. ${ }^{39}$ In the next year, howerer, when a flagrant violation of neutrality was committed by the capture of the French frigate Modeste in the harbor of Genoa by two English men-of-war, Great Britain neither restored the ship nor apologized for the violation of Genoese territory ${ }^{40}$

Effect of resistance to unlawful attack in neutral waters. Case of the Gen. Armstrong. - From the foregoing incidents it is evident that when one belligerent attacks another in neutral waters the primary wrong is a gainst the neutral whose sovereignty is violated. The primary duty, therefore, devolves upon the nentral to protect his guest, to seek indemnity from the wrongdoer, or to respond in damages for any failure upon his part to discharge such neutral obligations. If a belligerent, when attacked in neutral territory, elects to defend himself, instead of appealing for protection to his host, does his own riolation of the nentral sovereignty free the neutral from all responsibility? During the war of 1812-1815 the American privateer, the General Armstrong, was found at anchor in the Portuguese harbor of Fayal by a British squadron. When a boat detached from the latter approached the privateer it was fired upon. The next dar, after a ressel of the squadron had taken a position near the General Armstrong for the purpose of attacking her, her crew, who found themselves unable to resist, abandoned and destroved her. The demand made by the United states against Portugal for large compensation for the owners of the privateer, which rested upon the assumption that the Portugnese gorernor had failed to discharge his duty as a neutral, was finally submitted to the arbitration of Louis Napoleon, then President of the French Republic. While his award recognized the fact that neutral territory had been violated, he refused indemnification because the privateer, instead of demanding protection from the Portuguese anthorities at the time, elected to resist by battle the unjust British assault. He held that the prirateer should have applied

$39 \mathrm{Mr}$. Jefferson to Mr. Ternant, May 15, 1793; opinion of Atty.Genl., May 14, 1793; and reply of M. Genet, of May 27, 1793. Waite's Am. State Papers, i, 69-80; 1 Opinions Attys.-Gen., 32. As to the return in 1805 of an American vessel captured near the mouth of the Mississippi by a British privateer, and taken to England as a prize or suspicion of unneutral character, see The Anna, 5 Rob., Admr., 373. 40 Azuni, II, ch. V, p. 331 . 
"from the beginning for the interrention of the neutral sovereign." Instead of that he said resort had been had to force by her captain on his own account, and in that way he had "failed to respect the neutrality of the foreign sovereign, and released that sovereign from the obligation in which he was, to afford him protection by any other means than that of pacific intervention." +1 That doctrine, which has been approved in certain quarters without qualification, should certainly be modified in one particular. There can be no doubt that when a belligerent is attacked by another in neutral territory his primary duty is to appeal to the neutral sovereign for protection and to rely upon him for it, provided time suffices, and such sorereign has the will and power to respond to it effectively. If either of those conditions are wanting the unjustly assaulted belligerent should be permitted to exercise his natural right of self-defense without freeing the neutral from responsibility. In the case of The Anne, ${ }^{42}$ Judge Story clearly recognized that right when he said that "while the ship was lying in neutral waters, she was bound to abstain from all hostilities, except in self-defense." That qualification is supported inferentially by Dana, and with great cogency by Lawrence.

\$641. Belligerent right of angary.-From what has been said heretofore it appears that the persons and property of neutral individuals residing in a belligerent state are, duringr the progress of hostilities, subject to all such exceptional measures as the exigencies of war render necessary, provided that no unjust discrimination is made in their application between subjects and foreigners. ${ }^{43}$ Is resident neutrals are thus assimilated with the mass of the population of the state in which they live, so far as its gorernment is concerned, it is not entirely unreasonable that, to a certain extent at least, they should be dealt with in the same general way by an occupying belligerent. And yet as such neutrals are subjects of a friendly state and cannot be presumed to be personally hostile to such belligerent until the contrary appears, there are cogent reasons why neutral property, accidentally or temporarily

41 For the text of the President's award see Ortolan, Dip. de la Mer, ii, 547. For the leading accounts of the case see Dana's Wheaton, note 208, p. 526; Wharton, Int. Law Dig., §§ 27, 228, 399, 401; Cal- vo, Droit International, \& 2359 ; Hall, § 228; Lawrence, Principles, $\S 260$.

423 Wheaton, 447.

43 See above p. 554. 
within belligerent territory, should be exempted from the indisputable general principle that nentral property, associated either permanently or for a considerable time with such territory, must suffer all the vicissitudes to which the property of subjects is liable. As a recognition of the fact that neutral property, accidentally or temporarily within the theater of war, is entitled to special consideration, occupyind belligerents have recognized the duty of making just compensation for its appropriation. The right of a belligerent to use such property or even to destroy it when necessary, subject to liability for just compensation, is called le droit d'angarie or angaria, a term which has been anglicized into angary. Phillimore says, "it is an act of the state, by which foreign as well as private domestic ressels which happen to be within the jurisdiction of the state, are seized upon, and compelled to transport soldiers, ammunition or other instruments of war; in other words, to become parties against their will to carrying on direct hostilities against a power with whom they are at peace. The owners of these ressels receive payment of freight beforehand. Such a measure is not without the sanction of practice and usage, and the approbation of many good writers upon international law. *** At all events, justice demands that the owners of such goods and ressels be indemnified for all damages caused by the interruption of their lawful gains, and for the possible destruction of the thing themselves, though so high an authority as M. Massé says that usage has not hitherto gone that length." 4 It appears that a considerable portion of the French expedition to Egrpt in 1798 was carried in neutral vessels seized in the ports of France. ${ }^{45}$ Less than ten years before Martens had said in his Précis (\$ 269) that "it is doubtful whether the common law of nations gives to a belligerent, except in cases of extreme necessity, the right of seizing neutral vessels lying in his ports at the outbreak of war, in order to meet the requirements of his fleet, on payment of their services. Usage has introduced the exercise of this right, but a number of treaties have abolished it." About the same time, however, Azuni, treating the right as existing in all cases of "necessity of public utility," declared that any vessel attempting to avoid it is liable to confiscation. ${ }^{46}$ At a later day both Heffter (s 150)

44 Int. Law, iii, § xxix.

45 Martens (R.), vii, 163. 46 1 Droit Maritime, Part 1, ch. ing the vessel of a friend is derived
III, art. 5. In art. VI he says:

"The right of stopping or detain. 
and Bluntschli (\$795) hare recognized the existence of the right, with more or less reserve; and Dana,-after reviewing the leading authorities and certain provisions upon the subject contained in treaties between the United States, Prussia and Venezuela,-concludes that "these treaties certainly seem to recognize this angaria as a right, or at least as a practice of nations, and only seek to regulate its exercise." 47 Halleck says, "by virtue of this right, nentral vessels may be appropriated by a belligerent, on payment of a reasonable price for compensation. It is akin to the right of prestation by which neutral vessels may be hired by a belligerent, on payment of freight beforehand, and to embargo or arrest of princes." 48

Right of angary as exercised during the Franco-Prussian War of 1870-1871. - The most recent examples of the exercise of the right of angary occurred during the Franco-Prussian War, when it was invoked as a justification for the appropriation of personal property belonging to Swiss, Austrian and British subjects. Between six and seren hundred railway carriages belonging to the Central Swiss Railway, in addition to a considerable quantity of A ustrian rolling stock, were seized for military purposes by the German authorities of Alsace, who appear to have retained the property so seized for some time. A clearer and more important application of the right grew ont of the seizure, almost at the same moment, of six British merchant ressels by the German general commanding at Rouen, who sunk them in the Seine at Duclair to prevent French gumboats from running up the river in order to cut off communication between the German corps operating. on both banks. When the German military authorities failed to make agreements with the captains of the ressels to sink them, after the remoral of their cargoes and the payment of their value, the refnsal of the captains to enter into such an arrangement was "considered to be an infraction of neutrality," which was followed by the sinking of ressels by firing upon them while some members of their crews appear to have been still on board. Count Bismarck, in defending this proceeding. maintained that "the measure in question, howerer exceptional

from the same source as that of impressing ships. * * * This detention is made upon the payment, to the vessels retained in such circumstances, of a reasonable freight, equal to what they might iave otherwise earned."
See also Molloy, De Jure Maritimo, I, ch. 6; Loccenius, De Jure Marit., I, c. v., § 3; Massé, Droit Commercial, I, 1, ii, tit. 1, c. $2, \S 7$.

47 Dana's Wheaton, note 152, p. 373.

48 Int. Law (Baker ed.), i, p. 485. 
in its nature, did not orerstep the bounds of international warlike usage," because he said that "the report shows that a pressing danger was at hand, and every other means of meeting it was wanting; the case was, therefore, one of necessity, which even in time of parce may render the employment or destruction of foreign property admissible under the reservation of indemnification." 4: 'The british government evidently accepted that statement as a corpect exposition of the international rule upon the subject. as it only demanded that the persons whose property hald been destroged shonld receive just compensation.

$\$ 642$. Reparation to neutral state for violation of its neutrality.-The conclusion has been reached already that a belligerent state which violates the neutrality of another must malie prompt and adequate reparation. As there is no precise international rule defining the form in which or the extent to which such leparation should be made, it must be fixed in aarh case according to its special facts and circumstances, through diplomatic negotiation. When property is illegally captured by a belligerent within neutral territory it must be restored with such expressions of regret, or, may be, with such additional compensation, as the nature of the offence shall warrant. A typical illustration of the proper procedure in the event of the illegal capture of a ressel of one belligerent by that of another in neutral jurisdiction is to be found in the alse of the Florian, seized in Brazilian waters by the Wachusett, a warship of the Enited States. When Brazil demanded reparation, the Inited states, mable to restore the Florida, which had been accidentally sunk in Hampton Roads, sent the commander of the Wachusett to a cont-martial, dismissed the consul who had advised the attack, and saluted the Brazilian flag at the place where the capture was made. When the Chesalpeake was illegally scized in British waters, under cir"umstances cqually indefensible, the govermment of the United States vindicated its dignity and self-respect by promptly surrendering the vessel and the men found on board, with an ample alpology for the violation of neutral territory of which its

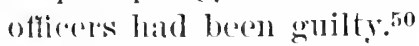

49 D'Angeberg. Nos. 914, 920, 250; Ann. Reg., for 1870, p. 110; 957; State Papers, 1871, 1xxxi. c. Hall, pp. 765-67.

50 See above, p. 686 . 


\section{CHAPTER IV.}

\section{LEGITIMATE NEUTRAL COMMERCE.}

$\$ 643$. Belligerent states and neutral individuals. - In the three preceding chapters an attempt has been made to outline the growth of the law of neutrality, and to illustrate its application to the reciprocal duties of a neutral towards belligerent states and of a belligerent towards neutral states considered as corporate persons. From what has thus been said of the law of neutrality as between state and state it appears that it is only an element in that body of rules known as international public law, slowly evolved out of the experience of civilized nations, whose breach constitutes an international wrong which can be righted only through the application of an international remedy. It is scarcely necessary to remark that, so far as definiteness and precision are concerned, the law of neutrality regulating the relations of state with state is in nowise distinguishable from the main body of law, if law it can be called, appertaining to that subject. In the five following chapters consideration will be given to the action of belligerent states dealing directly with neutral individuals through the application to them of a system of law more definite and precise in its nature, because formulated and administered, as a general rule, by trained publicists or jurists sitting in prize courts, after full forensic discussion and mature deliberation.

$\$ 644$. Conflict between neutral and belligerent interests. - The rights now enjoyed by legitimate neutral commerce are the final outcome of centuries of struggle carried on, on the one hand, by neutral individuals striving to trade unhindered by war; and, on the other, by belligerents striving to weaken their opponents by depriving them of the benefits of maritime commerce, whether carried on in their own ships or in those of neutrals. While it is impossible to assign an exact date to the beginning of the struggle for the freedom of neutral commerce it must have been in progress long before the compilation of the Consolato del Mare, generally regarded as a gradual collection of the maritime customs of the commercial cities of the Mediterranean made between the twelfth and fourteenth centuries. As stated heretofore the compilation was probably called Consolato because it embodied the rules according to 
which the judge-consuls established in the maritime cities of Spain determined the controversies brought before them. ${ }^{1}$ The fact that the Consolato contains a definite and comprehensive rule based upon the principle that you should confiscate the goods of your enemy and protect those of your friend proves conclusively that, prior to its promulgation, there was a usage to that effect authoritative, at least, in the Western Mediterranean. The rule of the Consolato, based upon the character of the goods, may therefore be justly regarded as the first recorded compromise between conflicting neutral and belligerent interests. The first assault made upon that rule came from the French, who resolved to forbid, if possible, all intercourse between neutrals and an enemy through the introduction of the doctrine of hostile infection, under which the carriage of a hostile cargo rendered the ship also liable to capture, and the loading of a neutral cargo on a hostile ship rendered both liable. The counter-blast against this retrograde morement upon the part of France came from the Dutch, who, as carriers rather than producers of merchandise, naturally became the champions of the principle that such a freedom should be given to neutral commerce as would enable the neutral trader to keep up intercourse with any customer in time of war as in time of peace. The result of this conflict between the French and the Dutch was to place in juxtaposition two maxims embodying two essentially distinct propositions of law: Free ships-free goods, Enemy ships-enemy goods. The existing freedom of neutral commerce is the outcome of the compromise embodied in the Declaration of Paris through which the parts of each system most favorable to neutrals were blended in a working rule which, if not yet authoritative international law binding upon all maritime states, is likely soon to be so. The real nature of the rule in question,- - referring to belligerent goods carried in neutral vessels, and to neutral goods in belligerent ressels,-can only be fully understood after an examination of each progressive stage of the prolonged conflict out of which it finally arose.

$\$ 645$. Rule of the Consolato-ownership of goods as the test. -There can be no doubt that the rule of the Consolato had to struggle for existence against an earlier and harsher practice, which so lightly regarded the rights of the neutral carrier that the Genoese and Venetians, when at war, searched the ships of the neutral Greeks and made prisoners of the subjects of

1 See above, p. 355 , note 48 . 
their opponents hidden on board. ${ }^{2}$ The fact that the rule thus established maintained itself in the Europe of the Renaissance and the Reformation down to the days of Henry IV. of France and of Dutch Independence is persuasive at least of its intrinsic justice, providing as it did for the safety of the property of a friend found under a hostile flag while condemning that of an enemy when taken in a neutral bottom. In either case the question of freight was equitably regulated. If an enemy cargo was found on a neutral vessel the captor could compel it to carry the goods to a place of safety only upon the payment of the freight it would have received from the original owners. If a neutral cargo was found on an enemy ship the owners of the former had the right to ransom the latter from the captor and proceed upon the voyage. If such owners refused to exercise that right the captor was authorized to send the ship to a port of his own country, and there require them to pay the freight contracted for in the first instance. If the captor refused to permit the owners of the cargo to enter into such an arrangement, he not only forfeited his claim to freight, but subjected himself to liability for damages. ${ }^{3}$ such was the nature and application of the rule which Grotius approved in a general way when he said that the vessel of a friend did not become lawful prize because an enemy's goods were laden thereon, unless such lading took place with the consent of the ship-owner. And to that he added that when neutral goods were found on an enemy's ship their situation should do no more than raise a presumption of their hostile character rebutable by proof that they were really neutral.4 Gentilis, ${ }^{5}$ while admitting that enemy goods found under a neutral flag were subject to seizure, asserted the liability of the captor to pay freight, a view reaffirmed with emphasis by Vattel, ${ }^{6}$ who says, "if we find an enemy's effects on board a neutral ship, we seize them by the rights of war; but we are naturally bound to pay the freight to the master of the vessel, who is not to suffer by such seizure. The effects of neutrals,

2 Grotius, De Jure Belli ac Pacis, III, c. vi, note 6 . Jenkinson's Discourse on the Conduct of the Gov't of Great Britain, pp. 30-31.

3 Consolato del Mare, c. 273 ; Pardessus, Us et Coutumes de la Mer. ii, 304; Manning, Law of Nations, 280 ; Ward, Maritime Law, pp. 3031.
4 Neque amicorum naves in praedam veniunt ob res hostiles, nisi ex consensu id factum sit dominorum navis. De Jure Belli ac Pacis, III, c. vi, $\S 6$, note. See also Ibid., III, c. i, $\S 5$, note 4 .

5 De Advocatione Hispanica I, c. 28.

${ }_{6}^{6}$ Droit des Gens, III, §§ 115, 116. 
found in an enemy's ship, are to be restored to the owners, against whom there is no right of confiscation,-but without any allowance for detainer, decay, etc. The loss sustained by the neutrals on this occasion is an accident to which they expose themselves by embarking their property in an enemy's ship." It may be inferred that an early usage, substantially the same as that eridenced by the Consolato, protected neutral goods in enemy ships in the northern seas from the fact that during the war with Luibeck and other Hanse Towns, the Hollander's, in 1438, ordered that neutral goods found in enemy ships should not be made prize; and, it is said, that France observed a like rule down to the middle of the sixteenth century. ${ }^{8}$ Such, in general terms, was the origin and nature of the rule of the Consolato, whose distinguishing feature was embodied in the principle that the ownership of the goods and not the character of the vehicle determined their liability to capture. On that ground this primitive law of capture at sea, which exempted the goods of a neutral found in the vessel of an enemy, as freely subjected the goods of an enemy when found under the flag of a neutral.

$\S 646$. French invention of hostile infection.-The first serious assault upon that part of the rule of the Consolato exempting the goods of a neutral found in the ressel of an enemy seems to have been embodied in the French ordinances of 1538,1543 and 1584 , the last of which provided that "if the ships of our subjects make a prize in time of war of enemy ships, in which are persons, merchandise, or other goods of our said subjects or allies, the whole shall be declared good prize as if the whole belonged to our said enemies."' The momentary return made by France to the earlier practice in the royal declaration of 1650 , recognizing the freedom of neutral goods in enemy ressels, was abandoned, if ever actually enforced, by the reassertion of the right to confiscate neutral goods contained in the ordinances of $1681,1704,1744$ and 1788 . On the French regulations in force at their respective dates were modeled the Spanish ordinances of 1702,1718 and $1779 .{ }^{10}$ The French rule was also embodied in a series of treaties extending down to the First Armed Neutrality, which generally contained express stipulations authorizing the confiscation of neu-

8 Hübner, Ire partie, ch. i, § 8; ix, art. 7; Ortolan, Dip. de la Mer, Ortolan, Ib., 100.

- Valin, Ord. de la Marine, iii, tit. i, 101 .

10 Ortolan, Dip. de la Mer, ii, 108. 
tral goods when found in enemy ressels. ${ }^{11}$ In 1681 a complete statement of the doctrine of infection was embodied in the maxim, "la robe enuemie confisque la marchandise et le vaisseau ami," - a maxim under which the conjunction of enemy and nentral property on the high seas involved both in a like condemnation. That stringent rule confiscated not only enemy goods under a neutral flag, but neutral goods under an enemy flag, as well as the ressel of a neutral carrier of enemy merchandise. ${ }^{12}$ Valin and Pothier ${ }^{13}$ rest their defence of that invention of their nation upon the contention that those who favor the commerce of the enemy by embarking their goods upon his ships should be made to suffer their fate, the former asking, "how can it be that the goods of friends and allies, found in an enemy ship, should not be liable to confiscation, whilst even those of subjects are liable to it?" Ortolan, rather in a spirit of apology than defence, so construes the ordinance of 1681 as to give plausibility at least to the contention that it was intended to apply only to allies in a common war, and not to neutrals, despite the fact that it was so administered as actually to embrace both. ${ }^{14}$

$\$ 647$. Dutch rule-nature of the vehicle as the test.While France, in the days of her maritime greatness, was thus upholding, both by her treaties and ordinances, the strictest exercise of belligerent rights, the Dutch, in response to the tonch of self-interest, espoused the canse of the neutral carrier. After having enforced from time to time a policy hostile to neutral vessels, engaged either in the carrying of Spanish goods to Flanders or in the carrying of provisions or any other merchandise into the Peninsula, ${ }^{15}$ the Dutch, in 1646, made a convention ${ }^{16}$ with France providing for the suspension for four years of the ordinance of 1584 , asserting the rule that "la robe d'ennemi confisque celle d'ami." As the suspending treaty provided that the ships of the Dutch "should free their cargo, notwithstanding the presence in it of merchandise, and even of grain and regetables belonging to enemies, excepting always articles contraband of war," 17 the Dutch negotiators concluded

11 Hall, p. 742.

12 Naval Ordonnance of 1681 , Title ix.

${ }_{13}$ Comm., liv., iii, tit. 9 ; Des Prises, art. 7; Traité de Proprieté, No. 96.

14 Dip. de la Mer, ii, 104.

15 Camden, Annales. Anno 1576;
Grotius, De Jure Belli ac Pacis, III, c. i, $\S 5$, note 6 ; Hist., 8,15 , pp. 639,829 ; Ward, Maritime Law, p. 51; Jenkinson, Discourse, pp. 33-34. 16 Ortolan, Dip. de la Mer, ii, 110.

17 "En telle sorte que les navires qui trafiqueraient avec la patente 
that they had secured a concession of the prineiple that the neutral flag covered the cargo, excepting only contraband of war. When, however, loreel, the ambassador of the United I'rovinces, attempted to enter into a permanent convention with France, after the expiration of the provisional one, that illusion vanished in the presence of the discovery that the French commissioner's so construed the agreement of 1646 as to exempt from condemnation only the ressel of the neutral carrier of enemy goods. That the French had no idea of eonceding the principle of free ships, free goods, is evident from the letter of Boreel who wrote to the Grand Pensionary, De Witt: "I have obtained the abrogation of that pretended French law, that enemies' property involves in confiscation the property of friends; so that, if henceforward any goods belonging to the enemies of France be found in a neutral Dutch vessel, these goods alone will be liable to condemnation; and the vessel will be released, together with all the other property on board. But I find it impossible to obtain the object of the twenty-fourth article of my instructions, which says that the immunity of the vessel shall extend to the cargo, even if cnemics property." 18 Despite that momentary failure the Dutch, between 1646 and the end of the seventeenth century, succeeded in securing from Spain, Portugal, France, England and sweden the recognition in twelve treaties, of the rule of free ships, free goods, coupled with the concession of enemy ships, enemy groods. ${ }^{19}$ The only like treaty of that century to which neither the Dutch nor French were parties was that concluded between England and Portugal in 1652.0 And here let the fact be emphasized that down to the beginning of the eighteenth century, the principle of free ships, free goods, with the corollary, was simply an exception to a general rule which prevailed in the absence of an express convention to

de l'amiral des Provinces-Unies, seront libres et rendront aussi toute leur charge libre, bien qu'il y eut dedans de la marchandise, même des grains et légumes, appartenant aux ennemis; sauf et excepté toutefois les marchandises de contrebande de guerre." Art. I.

18 Vattel, III, § 115, note.

19 Treaty with Spain, 1650 (Dumont, vi, i, 571); with Portugal, 1661 (Ib., ii, 369); with France,
1661 (Ib., 346) ; with France, 1662 (Ib., 415); with England, 1667 (Ib., vii, i, 49) ; with Sweden, 1667 (Ib., 38) ; with England, 1674 (Ib., 283) ; with Sweden, 1675 (Ib., 317 ) ; with France, 1678 (Ib., 359); with Sweden, 1679 (Ib., 440); with England, 1689 (Ib., ii, 236); with France, 1697 (Ib., 389). Cf. Dana's Wheaton, p. 583; Hall, p. 712 and notes.

20 Dumont, vi, ii, 84. 
the contrary. While France stipulated in favor of the exception in many treaties, she reasserted in her regulations of 1704 , 1744 and $1788^{21}$ the doctrine that neutral goods become enemy under an enemy's flag, a doctrine embodied in the Spanish ordinances of 1702,1718 and $1779 .{ }^{22}$ According to a computation made by Ward and adopted by Phillimore 23 thirty-four treaties were entered into between 1713 and 1780 in which no mention whaterer was made of the principles free ships, free goods; enemy ships, enemy goods. In the face of such conditions the Dutch, as neutral carriers intent upon securing the immunity of their flag, began by buying the privilege in particular cases in treaties conceding to others the right to confiscate their merchandise when found in a belligerent ship. The problem to be worked out involves the process through which the doctrine of free ships, free goods,- - first established as an exception to a contrary general rule in a treaty made between Spain and the United Provinces in 1650,24-has received such universal acceptance as to make it the governing rule of the civilized world.

$\S 648$. British theory and practice.-The doctrine of the Consolato denying the liability to capture of neutral goods in enemy bottoms,--a doctrine reaffirmed by Gentilis in his declaration that property which does not belong to an eneny is nowhere confiscable, ${ }^{25}$-was recognized from the outset by Great Britain, subject to the limitation authorizing a belligerent to take enemy goods from a neutral vessel on the high seas, provided he released it with payment of freight. The first treaty in which she ever surrendered that belligerent right was that made with Portugal in 1652, a treaty recognizing the rule of free ships, free goods, which, after confirmation in 1661 and 1703, was abandoned by the treaty of Rio Janeiro in 1810. ${ }^{26}$ Great Britain also recognized the principle of free ships, free goods in treaties entered into at the Peace of Utrecht, 1713, with France and the United Provinces, and also with Spain. ${ }^{27}$

$21 \mathrm{As}$ to the modifications made in the Réglements of 1774 and 1778, see Walker, Science of Int. Law, pp. 296-7. See also Valin, Ord. de la Marine, iii, tit. ix, art. 7; Pistoze et Duverdy, i, 344 and 360; Ortolan, Dip. de la Mer., ii, 108.

22 Not until 1780 did the private rules of Spain exempt either enemy goods or the neutral vessel from confiscation. Martens (R), iv, 270 .

23 Int. Law, iii, § clxxxii.

24 Manning, Law of Nations (Amos's ed.), bk. v. ch. vi.

25 Res non hostium non bene capitur ullibi. De Jure Belli, II, c. 22.

26 Hansard, cxlii, 491.

27 Dumont, viii, i, 348, 379, 409. 
It was then stipulated, as between the parties in question, that the ships of each shall be free to carry goods not contraband, and persons not military, ${ }^{28}$ pertaining to enemies of the other, a principle sanctioned in a commereial treaty of the sime date between France and Holland.99 The few exceptions thus made to the general rule British statesmen and jurists claimed in nowise hindered its enforcement, through the seizure of enemy goods in neutral bottoms, in any case in which their country was not bound by treaty stipulations to the contrary. Such statesmen and jurists were, therefore, quick to respond when in 1752 the Prussian government attempted to justify its confiscation of the interests of English creditors in the silesian loan by asserting that "Prussian ressels, although laden with property belonging to the enemies of England, were a neutral place, whence it follows that it is exactly the same thing to have taken such property ont of the said vessels as to lave taken it upon nentral territory." 30 The English reply to the Prussian claim that the confiscation in question was justifiable,-a reply characterized by Montesquieu" as a veritable "Réponse sans réplique,"demonstrated that the contention of the Prussian jurists that, by the common law of nations as it then stood, the goods of enemies found on neutral vessels were not liable to seizure and condemnation was as untenable as their assertion that stock in the public debt held by subjects of the offending country could be lawfully seized by way of reprisal. ${ }^{32}$ Three years after that controversy had been settled by the compromise embodied in the Treaty of Westminster, 1756, the Danish civilian, Huibner, published at The Hague the treatise in which he reiterated the Prussian view in the statement that "it is universally agreed that a belligerent cannot attack an enemy in a neutral place, nor capture his property there. Neutral As to the subsequent confirmations of the principles in the treaties of 1721 and 1739 between Great Britain and Spain, in the treaty of Aix-la-Chapelle, in 1748, and in that of Paris in 1763, between Great Britain, France and Spain, see Wheaton's Hist. Law of Nations, 120-125.

2s The commercial treaty of Utrecht between France and Great Britain (Dumont, viii, i, 345) provided that the liberty granted to goods on a free or neutral ship "shall be extended to persons sailing on the same, in such wise that, though they be enemies of one or both the parties, they shall not be taken from the free ship, unless they be military persons, actually in the service of the enemy." 29 Ibid., viii, i, 366.

30 Martens, Causes Célibres, ii, 117.

31 OEuvres, vi. p. 445.

32 See above, p. 442. 
ressels are unquestionably neutral places. Consequently when they are laden with enemy's goods a belligerent has no riglit to molest them because of their cargoes." 33 Unfortunately the conclusion thus reached that the goods of an enemy could not be seized in a neutral bottom rested upon the assumption of the exterritoriality of a merchant ressel which had no real existence either in theory or in fact. Nevertheless that conclusion received the earnest support of the Northern powers; and, when Great Britain persisted in resisting it by the enforcement of the old practice of seizing enemy goods in neutral vessels, those powers drew together for its defence in the First Armed Neutrality League of 1780.

$\S 649$. Armed Neutralities of 1780 and 1800 . - In the outline heretofore drawn of the history of those leagues the statements were made (1) that one of the four principles which became the basis of the First Armed Neutrality was that the neutral flag should cover all goods not contraband; (2) that before the clain thus set up had been determined, peace was concluded at Versailles in 1783 between Great Britain, France and Spain, reviving and confirming the treaties of Utrecht which had established between such contracting powers the principle of free ships, free goods; (3) that the programme upon which the Second Armed Neutrality of 1800 was based repeated the four principles embodied in the First; (t) that in the convention signed at St.' Petersburg in June, 1801, between the government of George III. and the Emperor Alexander, Great Britain finally vindicated against the leagues not only the right of search of merchantmen under convoy as exercised by men-ofwar, but also the liability to seizure by a hostile captor of goods actually the property of the subject of a belligerent laden under a neutral flag. ${ }^{34}$

$\S 650$. American theory and practice.-At this point some account should be given of the support rendered to the cause of the neutral carrier by the gorernment of the United States. Prior to the Revolution which severed the English colonies in America from the parent state, Great Britain had made exceptions to the general rule of the Consolato in the treaty made with Portugal in 1652, in which for the first time she adopted the combined rule of free ships, free goods; enemy ships, enemy

33 De la Saisie des Bâtimens neutres, ou du droit qu' ont les nations belligérantes d'arrêter les navires des peuples amis (La Haye, 1759), I, ptie ii, ch. ii, $\S 6$.

34 See above, p. 633-38, . 
groods; in the treaties made with Holland in 1667 and 1674 ; and in the treaties of Utrecht of 1713 , subsequently confirmed by those of 1721 and 1739, between Great Britain and Spain, by the treaty of $\mathrm{Aix}$-la-Chapelle, in 1748 , and by that of Paris in 1763 , between Great Britain, France, and Spain. ${ }^{35}$ While a concentional law thus united the two maxims in certain notable treaties, no ambiguity existed in the minds of English jurists as to the consuctudinary law upon the subject in the absence of treaties. According to the declaration made in 175:3 by four experts, ${ }^{36}$ including Murray, subsequently Lord Mansfield, "the law of nations has established:

That the groods of an enemy, on board the ship of a friend, may be taken.

That the lawful goods of a friend, on board the ship of an enemy, ought to be restored.

That contraband goods going to the enemy, though the property of a friend, may be taken as prizes; because supplying the enemy with what enables him better to carry on the war "is a departure from neutrality." 37 Moving on the old lines the Uniced states in making its first treaty of amity and commerce with France stipulated for free ships, free goods; enemy ships, enemy goods, as an exception to the general maritime law of nations regulating the intercourse of European states, ${ }^{38}$ a law recognized by the United States as binding upon them during the War of the Revolution. ${ }^{39}$ American prize courts accepted from the beginning the principle that exempted neutral property in an enemy's vessel from confiscation while consigning

35 See above, p. 711.

$36 \mathrm{Sir}$ G. Lee, then judge of the prerogative court; Dr. Paul, advocate-general; Sir D. Rider, attorney-general; and Mr. Murray.

37 An extract from the opinion of the experts in question was delivered to Mr. Jay in 1794 by Sir W. Scott (Lord Stowell) and Sir J. Nicholas as the best "statement of the general principles of proceeding in prize causes in British courts of admiralty, and of the measures proper to be taken when a ship and cargo are brought in as prize within their jurisdiction." See Am. St. Papers (For. Rel.), $494 \mathrm{ff}$; Wharton, Int. Law Dig., $\S \S$ 330,342 .
38 In Sec. 23 of the Commercial Treaty of 1778 it was agreed that as between the parties free ships were to make free goods, except contraband of war, of which a limited list was appended. The principle was set aside, however, by France during her war with England in 1796-97. Mr. Pickering, Sec. of State, to Mr. Pinckney, Jan. 16, 1797, 1 Am. St. Papers (For. Rel.), 559. The United States also embodied the new doctrine in the treaty of 1782 with the Dutch and in the treaty of 1783 with Sweden. Treaties of the United States, pp. 301, 303, 326, 752, 1044, 1046.

39 See above, p. 136. 
enemy property in neutral ressels to that fate. No effort was made to depart from that principle until the issuance of the ordinance of 1780 in which Congress recognized the programme of the Armed Neutrality of that year upon condition that it should be reciprocally recognized by the other belligerent states. $^{40}$ And yet despite that move in faror of a new rule that conld claim only a conventional basis American statesmen, after the adoption of the present constitution, espoused anew the old doctrine as it had existed in the mother country when the Revolution began. As Jefferson declared in his letter to Genet of July 24, 1793: "I believe it cannot be doubted but that br the general law of nations the goods of a friend found in the ressel of an enemy are free, and the goods of an enemy found in the ressel of a friend are lawful prize. $* *$ It is true that sundry nations, desirous of aroiding the inconreniences of haring their vessels stopped at sea, ransacked, carried into port, and detained, under pretense of having enemy's goods on board, have, in many instances, introduced, by their special treaties, another principle between them, that enemy bottoms shall make enemy goods, and friendly bottoms friendly goods; a principle much less embarrassing to commerce, and equal to all parties in point of gain and loss. But this is altogether the effect of particular treaty, controlling in special cases the general principle of the law of nations, and therefore taking effect between such nations only as have so agreed to control it." 41 The subsequent departure of the executive department of the government of the United States from that clear and unmistakable declaration was the afterthought of a later time. ${ }^{42}$

Rule of the Consolato adopted by the American judiciary.The judiciary of the United States never warered in their adherence to the rule of the Consolato so long recognized by the European nations. In the words of Marshall, C. J., "the rule that the goods of an enemy found in the ressel of a friend are prize of war, and that the goods of a friend found in the

40 Dana's Wheaton, p. 587.

411 Am. St. Papers (For. Rel.), 166; 1 Wait's St. Papers, 134.

42 For the lame attempt to show that Mr. Jefferson's expression of opinion to Mr. Genet, in July, 1793, was not intended to be absolute, because he used the phrase, "I believe it cannot be doubted," see 6 ,
J. Q. Adams's Mem., 162 (July 7, 1823) ; Wharton, Int. Law Dig., § 342. See also Phillimore (iii ( 3 ed.), $315 \mathrm{ff}$ ), who maintains that the United States did admit that the rule, free ships, free goods, was not a part of the law of nations at the outbreak of the war of the first French Revolution. 
ressel of an enemy are to be restored, is believed to be a part of the original law of nations, as generally, perhaps universally acknowledged. Certainly it has been fully and unequivocally recognized by the United States. This rule is founded on the simple and intelligible principle that war gives a full right to capture the goods of an enemy, but gives no right to capture the goods of a friend. In the practical application of this principle, so as to form the rule, the propositions that the neutral flag constitutes no protection to enemy property, and that the belligerent flag communicates no hostile character to neutral property, are necessarily admitted. The character of the property, taken distinctly and separately from all other considerations, depends in no degree upon the character of the velicle in which it is found." 43 During the war which began between Great Britain and the United States in 1812 the prize courts of the latter uniformly enforced the rule that enemy groods in neutral vessels are liable to condemnation, except in cases in which the executive government had established the contrary rule of free ships, free goods by express treaty stipulation.

An Exception. - The only essential difference between the judge-made law of England and the United States upon this subject arose out of the refusal of the courts of the latter to recognize the distinction drawn by Lord Stowell in the case of the Fanny ${ }^{4+}$ to the detriment of neutral goods transported in an armed ship of a belligerent. In that case it was said that "a neutral subject is at liberty to put his goods on board a merchant vessel, though belonging to a belligerent, subject nevertheless to the rights of the enemy who may capture the vessel, but who has no right, according to the modern practice of eivilized states, to condemn the neutral property. Neither will the goods of the neutral be subject to condemnation, although a rescue should be attempted by the crew of the captured vessel, for that is an event which the merchant could not have foreseen. But if he puts his goods on board a ship of force, which he hais every reason to presume will be defended against the enemy by that force, the case then becomes very different. He betrays an intention to resist visitation and search, which he could not do by putting them on board a mere merchant vessel, and, in so far as he does this, he adheres

43 The Nereide, 9 Cranch, p. 441 Dodson, 443.

418. See also El Telegrapho,

Newb., 386. 
to the belligerent; he withdraws himself from his protection of neutrality, and resorts to another mode of defence; and I take it to be quite clear, that if a party acts in association with a hostile force, and relies upon that force for protection, he is, pro hac vice, to be considered as an enemy." In the case of the Nereide that doctrine was expressly repudiated by the Supreme Court of the United States in a judgment declaring that "a neutral may lawfully employ an armed belligerent vessel to transport his goods, and such goods do not lose their neutral character by the armament, nor by the resistance made by such vessel, provided the neutral does not aid in such armament or resistance, although he charter the whole vessel, and be on board at the time of the resistance." 45

Conventional law as to free ships, free goods.-While expressly confirming the rule of the Consolato, as "the original law of nations," American jurists and statesmen held from the outset that states have a perfect right to change it by convention between themselves whenever it is to their advantage to do so. At an early day the fact was recognized that the maxims, free ships, free goods; enemy ships, enemy goods, embody entirely distinct propositions; and that the stipulation in a treaty that free ships shall make free goods, does not imply the converse proposition that enemy ships shall make enemy goods. "Do the United States understand this subject differently from other nations? It is certainly not from our treaties that this opinion can be sustained. The United States lave in some treaties stipulated for both principles, in some for one of them only, in some that neutral bottoms shall make neutral goods and that friendly goods shall be safe in the bottom of an enemy. It is therefore clearly understood in the United States, so far as an opinion can be formed on their treaties, that the one principle is totally independent from the other. They have stipulated expressly for their separation, and they have sometimes stipulated for the one without the other." 46 A typical illustration of such a

459 Cranch, 388, head note. Three years later that doctrine was affirmed in The Atalanta, 3 Wheaton, p. 409.

46 The Nereide, 9 Cranch, p. 421. In that case the court was called upon to construe Art. 15 of the treaty of 1795 between the United
States and Spain, which "stipulated that free ships shall also give freedom to goods," without any provision, express or implied, that enemy ships shall make enemy goods. The court therefore held, as a matter of judicial construction, that the existence of the right 
severance may be found in article twelve of the treaty made in 17S5 between the United States and Prussia in which the principle of free ships, free goods was agreed upon without the correlative maxim of enemy ships, enemy goods. ${ }^{4 \pi}$ When, however, that treaty expired by its own limitation in 1796 the American plenipotentiary was directed to suggest to the Prussian government, during the subsequent negotiation for its renewal, that the clause in question be omitted from the new treaty because the United States had learned from experience that such special stipulations were of little or no avail in the absence of a general recognition of the new rule by the maritime nations. "It is possible," said Mr. Pickering at the time, "that in the pending negotiations for peace (July, 1797, between Great Britain and France) this principle of free ships making free goods may be adopted by all the great maritime powers; in which case the United States will be among the first of the other powers to accede to it and to observe it as a universal rule." 48 In a reply made by Mr. J. Q. Adams, minister at Berlin, in the following October, he stated that "the principle of making free slips protect enemy's property has always been cherished by the maritime powers who have not had large navies, though stipulations to that effect have been in all wars more or less violated. In the present war, indeed, they have been less respected than usual, because Great Britain has held more uncontrolled the command of the sea, and has been less disposed than ever to concede the principle." 49 In article seventeen of the treaty made between Great Britain and the United States in $1794^{50}$ it was provided that vessels, captured on suspicion of having on board enemy property or contraband of war, should be carried to the nearest port for adjudication; and, after that part of the cargo only which consisted of enemy property or contraband for an enemy's use had been made prize, such ressels should be permitted to proceed with the remainder of their cargoes. When in 179s France complained ${ }^{51}$ that such a stipulation was in conflict with the prior

last named could not be implied from an express grant of the former.

47 Treaties of the United States, p. 899.

$48 \mathrm{Mr}$. Pickering, Sec. of State, to Mr. J. Q. Adams, July 17, 1797;

2 Am. St. Papers (For. Rel.), 250 .
492 Am. St. Papers (For. Rel.), 251.

50 Treaties of the United States, p. 379 .

51 Ward, p. 167. The essence of the complaint was that as the United States was bound to treat France as the most favored nation, it was also bound not to permit 
agreements entered into with her in the treaties of 1778 and 1780 , Pinckney said in a note to Washington that "the complaints of the French had reference, amongst other things, to the abandonment by the Americans of their neutral rights, in not maintaining the pretended principles of the modern law of nations, that free ships make free goods; and that timber and naval stores are not contraband of war. The necessity, however, for the strong and express stipulations of the Armed Neutrality itself by all the various powers which joined it, showed that those maxims were not in themselves law, but merely the stipulations of compact; that, by the real law, belligerents had a right to seize the property of enemies on board the ships of friends; that treaties alone could oblige them to renounce it; and that America, therefore, could not be accused of partiality to Great Britain, because she did not compel her to renounce it." 52 If the United States took a step backward in the treaty of $\mathbf{1 7 9 4}$ with Great Britain providing that enemy property in a neutral vessel was good prize of war, the loss was made up in the next year in the treaty with Spain, in which it was stipulated that free ships should make free goods, without the correlative provision that enemy ships should make enemy goods.53 When the negotiation between the United States and Prussia was finally concluded in $\mathbf{1 7 9 9}$ a far less decided result was embodied in the article in which,-after a declaration that experience had "proved that the principle adopted in the twelfth article of the treaty of 1785 , according to which free ships make free goods, has not been sufficiently respected during the last two wars, and especially in that which still continues,--" it was agreed that if "either of the contracting parties should be engaged in war, to which the other should remain neutral, the ships of war and privateers of the belligerent power shall conduct themselves toward the merchant vessels of the neutral power, as favorably as the course of the war then existing may permit; observing the principles and rules of the law of nations generally acknowledged." In the next year the doctrine of free ships, free goods; enemy ships, enemy goods, was

French property on board American ships to be seized by British cruisers, while it prevented the seizure of British property in the same situation by the French. Cf. Phillimore, iii, § cxcviii.

525 Am. St. Papers, 281, 286.
53 See above, p. 717.

54 On the expiration of the treaty of 1799 , the twelfth article of the original treaty of 1785 was revived by article twelve of the treaty of 1828. Treaties of the United States, p. 916. 
embodied in the treaty then made between France and the United States. ${ }^{55}$ As stated heretofore, during the war begun between Great Britain and the United States in 1812, the prize courts of the latter firmly enforced seizures and confiscations against enemy goods in neutral bottoms, except as to those powers with whom then existing treaties had established the contrary rule of free ships, free goods. ${ }^{56}$ And yet despite sucll enforcement by Anerican prize courts of the old rule, there was a continual longing for the substitution of the new. In $1816 \mathrm{Mr}$. Monroe wrote to Mr. Adams: "It is also desirable to stipulate with the British government that free ships shall make free goods, though it is proper to remark that the importance of this rule is much diminished to the United States by their growth as a maritime power, and the capacity and practice of their merchants to become the owners of the merchandise carried in our vessels. It is nevertheless still important to them, in common with all neutral nations, as it would prevent vexatious seizures by belligerent cruisers, and unjust condemnations by their tribunals from which the United States have sustained such heavy losses." 57 Looking to the ultimate abolition of that condition of things the United States in their earlier negotiations with the South American republics proposed the establishment, throughout these continents, of the principle of free slips, free goods, limited, however, by the proviso that a belligerent may justly refuse that benefit to a neutral, unless extended to such neutral by the opposing bolligerent. A typical illustration of such a proviso was embodied in the treaty of 1846 between the United States and New Granada, in which it was stipulated that the rule of free ships, free goods, should be understood "as applying to those powers only, who recognize this principle, but if either of the two contracting parties shall be at war with a third, and the other remiins neutral, the flag of the neutral shall cover the property of enemies whose governments acknowledge this principle and not of others." 58 In 1823 the United States sub-

55 Treaties of the United States, divided, in 1831, into three indep. 322 , Arts. XIV, XV.

56 Sec above, p. 716.

$57 \mathrm{Mr}$. Monroe, Sec. of State, to Mr. Adams, May 21, 1816. MSS. Inst., Ministers.

58 Treaties of the United States, p. 195, Art. 15. The Republic of Colombia, established in 1819 , was pendent republics, New Granada, Venezuela, and Ecuador. In 1862 its name was changed to the United States of Colombia, and in 1886 the states were abolished and the country became the Republic of Colombia. 
mitted to all the leading European nations a proposal to abolish by treaty private war at sea, and to restrict contraband. "The tenth article of the draft proposes the adoption of the principle that free ships make free goods and persons, and also that neutral property shall be free, though laden in a vessel of the enemy. The government of the United States wishes for the universal establishment of this principle as a step towards the attainment of the other, the total abrogation of private maritime war." 59 "The principle upon which the government of the United States now offers this proposal to the civilized world is, that the same precepts of justice, of charity, and of peace, under the influence of which Christian nations have, by common consent, exempted private property on shore from the destruction or depredation of war, require the same exemption in faror of private property upon the sea." 60

$\$ 651$. Declaration of Paris, 1856.-From what has now been said it appears that the concerted efforts in favor of the principle of free ships, free goods, as defined in the programme of the Armed Neutralities, were finally frustrated by Great Britain who rose triumphant from the conflict with the clear and definite admissions of the maritime convention of St. Petersburg, 1801, not only of the right of search of merchantmen under convoy, but of the right of a belligerent to seize and confiscate the goods of an enemy when found in a neutral bottom. ${ }^{61}$ From that time down to the Congress of Vienna the disorganized forces of the neutral trader, so far from advancing the cause for which they had contended, seriously compromised it by trampling "as belligerents upon the doctrines they had championed as neutrals; while Great Britain and France vied with one another in attacks upon innocent commerce, each justifying its severities on the plea that they were adopted in retaliation for illegal acts committed by the other. At the end of the struggle no definite code of maritime capture had received universal acceptance." ${ }^{2}$ Clearly perceiving that force had utterly failed to attain the end in view the government of the United States, in the midst of the period of peace that divides the great settlement of 1815 from the beginning of the Crimean War, resolved to appeal

$59 \mathrm{Mr}$. Adams, Sec. of State, to Inst., Ministers. Wharton, Int. Mr. Rush, July 28, 1823. MSS. Law Dig., § 342.

Inst., Ministers.

$60 \mathrm{Mr}$. Adams, Sec. of State, to Mr. Middleton, Aug. 13, 1823. MSS. Law, p. 567.
61 See above, p. 637.

62 Lawrence, Principles of Int. 
to the maritine nations to mite in the establishment of a conventional law having for its ultimate object not only the establishment of the principle of free ships, free goods, but "the total abrogation of private maritime war." That farreaching proposal was, however, so far in advance of the times that it never became binding even on the United States, except in cases of special treaty stipulation. After all the resorrees of force and persuasion had thus failed to compel or persuade the maritime states to emancipate neutral commerce, the end came at last as an accidental result of the alliance of Great Britain and France in the war begun in 1854 for the defence of the Turk against Russia. To remove the inconvenience that would have resulted from the conflicting policies of two allies-one claiming the right to capture enemy goods in neutral ressels, and the other the right to capture neitral goods in enemy ressels, - Great Britain agreed to admit, during the war, the freedom of enemy property, not contraband, found under a neutral flag, while France suspended npon her part her old claim of enemy ships, enemy goods. In ordel to emphasize the fact that such concession was special and temporary, the former was careful to declare that "to preserve the commerce of neutrals, Her Majesty is willing, for the present, to waive a part of the belligerent rights appertaining to her by the law of nations. * * * Her Majesty will waive the right of seizing enemy's property, laden on board a neutral vessel, unless it be contraband of war." ${ }^{\prime} 3$ That temporary surrender of the rule of the Consolato by the greatest of the maritime powers in favor of the new rule, which the interests of her own world-wide commerce demanded, was made final on April 16, 1556, when Great Britain, France, Austria, Prussia, Russia, Sardinia, and Turkey subscribed to the Declaration of Paris, whose second and third articles provide that "the neutral flag covers enemy's goods with the exception of contraband of war. Neutral goods, with the exception of contraband of war, are not liable to capture under the enemy's flag." 64 The signatories also bound themselves "to bring the present Declaration to the knowledge of the states which have not taken part in the Congress of Paris, and to invite them to accede to it." That invitation has since been accepted by substantially all of the family of nations with the notable ex-

63 See the agreement of the two powers resulting in the concurrent declarations of England and
France, under date of March 28-29, 1854. Cf. Manning (2nd ed.), 249. fit Martens (N. R. G.), xv, 791. 
ceptions of the United States, Spain, Mexico, China, and Venezuela. The refusal of the United States arose out of the failure of the Declaration completely to embody the aspiration expressed in its notable appeal of 1823 . This republic proposed, in what is called the Marcy or American Amendment, to accede to the Declaration, if an article should be added protecting all private property not contraband from capture at sea. When that proposal, farored by Russia, France, Prussia, Italy and the Netherlands, was defeated, probably by reason of the opposition of Great Britain, it was in the next year formally withdrawn. ${ }^{65}$ Nerertheless the conduct of the United States since that time has been substantially the same as it would hare been if it had actually signed the Declaration. During the war with Mexico no letters of marque were issued; and during the Civil War the President, although armed by Congress with the power to issue such letters, did not exercise it. ${ }^{66}$ In the Spanish-American war, although neither combatant was a signatory of the Declaration, both were careful to observe its principles. Thus while it is true that the Great Charter of neutral commerce has not jet received the formal ratification of all, or substantially all of the family of nations, it has receired the actual ratification of substantially all, and is fast becoming, if it is not already, a recognized part of the law of nations. If Captain Mahan is right in believing that "the principle that the flag corers the cargo is forever secure," 67 then the capture of private property at sea, not contraband, must be limited in future to enemy property in enemy vessels.

$\S 652$. Effect of the final clause of the Declaration.-And yet the fact cannot be ignored that the final clause provides that "the present Declaration is not and shall not be binding, except between those powers who have acceded, or shall accede to it." Certainly a neutral who has observed the rule of free ships, free goods, although a non-signatory power, has a clear moral right to be treated as such by all belligerents who are parties to the agreement. Acting upon that theory both combatants in the Franco-Prussian war of 1870-71 extended the protection of its principles to the property of American and

$65 \mathrm{Mr}$. Marcy, Sec. of State, to Mr. Sartiges, July 28, 1856, MSS. Notes, France; same to Mr. Seibels, July 14, 1856, MSS. Inst., Belgium; President Pierce, Fourth
Annual Message, 1856; 144 Edinb. Rev., 353.

66 Dana's Wheaton, Note 173.

67 Influence of Sea Power, ch. I, p. 84 . 
Spanish citizens, although the states of neither had formally adopted its provisions. If the question be asked whether or no a belligerent, who has signed the Declaration, is bound in a war with another, who has not, to recognize its rules in dealings with neutrals whose governments have acceded to it, the answer must be given that practice favors the idea that he is bound. In 1860 when China, a non-signatory power, was at war with Great Britain and France, both applied the second and third articles of the Declaration to neutral trade; and that course was repeated by Chili and Peru when they were allied against Spain, a non-signatory power, in 1885. As a further illustration of the tendency in that direction reference may be made to the fact that during the war which began between China, a non-signatory power, and Japan, a signatory power, in 1894, the former made no attempt to capture Japanese goods under a neutral flag or neutral goods under a Japanese flag, while Japan manifested no disposition whatever to ignore the principles of the Declaration because China had not acceded to it. ${ }^{68}$

68 Twiss, Belligerent Right on Principles of Int. Law, pp. 569-70. the High Seas, p. 8; Lawrence, 


\section{CHAPTER V.}

CONTRABAND TRADE.

\$653. Ancient and medieval history of contraband.-The statement has been made heretofore that the final emancipation of legitimate neutral commerce was the outcome of centuries of struggle carried on, on the one hand, by neutral individuals striving to trade unhindered by war, and, on the other, by belligerents striving to weaken their opponents by depriving them of the benefits of maritime commerce, whether carried on in their own ships or in those of nentrals. ${ }^{1}$ From the very beginning of that struggle it was understood that such emancipation should never extend to the illegitimate neutral commerce involved in the transport of such commodities as are capable of being immediately used by one belligerent in the prosecution of hostilities against another. That self-erident principle of self-preservation so far antedated the birth of modern international law that several Roman emperors imposed heavy penalties upon the sale of arms, iron or other necessities to the barbarians; and as a perpetuation of that idea, the popes in their time, by edict or interdict (Latin, lannum, Italian, bando) put under the ban of the church such Christian traders as trafficked with infidels in weapons and munitions of war. ${ }^{2}$ In that way the term contraband (contrabannum) came to be applied to the commerce in prohibited articles described in medieval Latin as merces banno interdictce. And here let the fact be emphasized that, long before there was any consensus of opinion between nations as to what articles should be considered contraband, the power to define their character was admitted to reside in the sovereign of the country prohibiting their importation or exportation.

\$654. Grotian definition of contraband.-By the first quarter of the seventeenth century ideas upon the subject of contraband had so far crystallized that Grotius was able to distinguish between those things which are useful only for the purposes of war, those which are not so, and those which are susceptible of indiscriminate nse in peace and war. "There are some things," he says, "which are of use in war alone, as

1 See above, p. 605 .

cken), II, § 158; Gessner, Le Droit

2 Cod. iv, 41, 1, Heffter (Geff- des Neutres, p. 71. 
arms; there are others which are useless in war, and which serve only for the purposes of luxury; and there are others which can be employed both in war and in peace, as money, provisions, ships, and articles of naval equipment. Of the first lind it is true, as Amalasuintha said to Justinian, that he is on the side of the enemy who supplies him with the necessaries of war. The second class of objects gives rise to no dispute. With regard to the third class, embracing objects of ambiguous use (ancipitis usus), the state of the war must be considered. If seizure is necessary for defence, the necessity confers a right of arresting the goods, under the condition, however, that they shall be restored unless some sufficient reason interferes." 3 No higher tribute to the comprehensiveness or permanency of Grotius's classification can be found than that embodied in the fact of its substantial reproduction by the Supreme Court of the United States, in 1866, in the following form: "The classification of goods as contraband or not contraband has much perplexed textwriters and jurists. A strictly accurate and satisfactory classification is perhaps impracticable; but that which is best supported by American and English decisions may be said to divide all merchandise into three classes. Of these classes, the first consists of articles manufactured and primarily and ordinarily used for military purposes in time of war; the second, of articles which may be and are used for purposes of war or peace, according to circumstances; and the third, of articles exclusively used for peaceful purposes. Lawrence's Wheat., 772, 776, note; The Commercen, 1 Wheat., 382; Dana, Wheat., 629, note; Par's. Mar. Law, 93, 94. Merchandise of the first class, destined to a belligerent country or places occupied by the army or navy of a belligerent, is always contraband; merchandise of the second class is contraband only when actually destined to the military or naral use of a belligerent; while merchandise of the third class is not contraband at all, though liable to seizure and condemmation for violation of the blockade or siege." As there can be no real controversy as to articles used exclusively for peaceful purposes. the prolonged and inconsistent contentions carried on for centuries as to what articles do or do not constitute contraband have been confined in the main. first, to articles manufactured and primarily and ordinarily used for military purposes in time of war: second, to articles

${ }^{3}$ De Jure Belli ac Pacis, III, c. i, ${ }^{4}$ The Peterhoff v. United States, $\S 5$. 5 Wallace 28-62. 
which may be and are used for purposes of peace or war, according to circumstances.

$\S 655$. Articles absolutely contraband-Arms and munitions of war.-After the whole field has been examined, and due allowince nlade for the changes constantly going on in the materials which enter into the manufacture of arms and munitions of war, there is really no great divergence of opinion as to what they really are. As Chancellor Kent has expressed it, "it is the usus bellici which determine an article to be contraband, and as articles come into use as implements of war, which were before innocent, there is truth in the remark, that as the means of war vary and shift from time to time, the law shifts with them; not, indeed, by the change of principles, but by a change in the application of them to new arses, and in order to meet the varying uses of war." ${ }_{5}$ In a treaty made between Great Britain and Russia in 1781 it was declared that contraband of war shall consist of the following articles only: "Saltpeter, sulphur, cuirasses, pikes, swords, sword-belts, linapsacks, saddles and bridles, cannon, mortars, firearms, pistols, bombs, greuades, bullets, firelocks, flints, matches and gunpowder'; excepting, however, the quantity of the said articles which may be necessary for the defense or use of the ship and those who compose the crew;" 6 and in another treaty entered into between the same parties in 1800 articles, which by common consent are regarded as contraband were declared to be, "cannons, mortars, firearms, pistols, bombs, grenades, bullets, balls, muskets, flints, matches, powder, saltpeter, sulphur, cuirasses, pikes, swords, belts, cartouch-boxes, saddles and bridles, beyond the quantity necessary for the use of the ship." As an illustration of American practice, reference may be made to the treaty entered into between the United States of North America and the Republic of New Granada, in 1846, in which it was declared that "under this name of contraband, or prohibited goods, shall be compreheuded:

First-Cannons, mortars, howitzers, swivels, blunderbusses, muskets, rifles, carbines, pistols, pikes, swords, sabres, lances, spears, halberts; and grenades, bombs, powder, matches, balls, and ail other things belonging to the use of these arms.

Second-Bucklers, helmets, breast plates, coats of mail,

5 International Law (Ed. Abdy.), ch. ix, p. 359 .

6 Cf. Wharton, Int. Law. Dig., $\S 368$. 
infantry belts, and clothes made up in the form and for the military use.

Third-Cavalry belts and horses with their furniture.

Fourth-And generally all kinds of arms and instruments of iron, steel, brass, and copper, or of any other materials manufactured, prepared and formed, expressly to make war by sea or land.

Fifth-Irovisions that are imported into a besieged or blockaded place."7

In the instructions given by the government of France to its naval officers during the Crimean War (March, 1854) the articles enumerated as contraband are "bouches et armes à feu, armes blanches, projectiles, poudre, saltpêtre, soufre, objets d'équipment, de campement et de harnachement militaires, et tous instruments quelconques fabriqués à l'usages de la guerre." In the Manual of Naval Prize Law, drawn up for the British Admiralty by Professor Holland, in 1888, goods absolutely contraband were said to embrace not only arms of all kinds and the machinery for their manufacture, ammunition and the materials of which it is made, gun cotton and clothing for soldiers, but also military and naval stores, including in the latter marine engines and their component parts, such as cylinders, shafts, boilers and fire-bars. The American Naval War Code declares that articles of the first class are such as "are primarily and ordinarily used for military purposes in time of war, such as arms and munitions of war, military material, vessels of war, or instruments made for the immediate manufacture of munitions of war." These articles, when "destined for ports of the enemy or places occupied by his forces, are always contraband of war."s

$\$ 656$. Articles which may or may not be contraband-Res ancipitis usus.-Almost from the outset the fact was recognized that contraband cannot be limited to arms and munitions of war, that it must be so extended as to embrace a larger list of articles which may or may not be contraband according to the greater or less intimacy of their association with warlike operations. In that way a wide field for controversy was opened up between two sets of disputants, each prompted by motives of self-interest to insist upon an expansion or contraction of the list of contraband, according as the one or the other plan best served their own purposes. Great

7 Treaties and Conventions of the 8 Art. 34 .

U. S., p. 195. 
Britain, as the possessor of the greatest sea power, has naturally stood forth as the representative of the idea which favors not only a long list of contraband goods, but also a policy of severity in dealing with those who attempt to traffic in prohibited articles. Against that policy, upheld in the main by English jurists and statesmen, has been arrayed the Continental publicists who have advocated a short list of contraband articles and a lenient method of dealing with those who 'offend in doubtful cases. ${ }^{9}$ Between the two stand the statesmen and the publicists of America who, in the drafting of treaties and state papers, have inclined as much to Continental models as, in the making of judicial decisions, they have inclined to English precedents. Nothing, however, like uniformity in practice or consistency in principle can be attributed to any one of the disputants in the prolonged and selfish wrangle whose outcome has been only weariness and uncertainty. The conflicts between publicists as to the application of the principles involved have not been more marked than the inconsistent practices under which the same state has not only enforced one policy at one time and another at another, but has actually placed conflicting lists of contraband articles in different treaties almost at the same moment. Nothing like order can be extracted from such chaos except through examinations of particular controversies carried on between leading states as to certain controverted groups of articles.

$\S 657$. Materials and machinery for manufacture of arms and munitions of war.-If arms and munitions of war are contraband by the common consent of nations, it is no extreme extension of principle to associate with them the materials out of which and the machinery by which they are fabricated. While such is not the accepted usage of all nations, it is certainly the general practice of Great Britain and the United States so to regard them. Bynkershoek, who earnestly contended that the materials out of which contraband articles may be made are not themselves contraband,--because such an extension of the rule to all materials out of which something fit for war might be made would render the catalogue of contraband interminable,-qualified his general statement by an exception which admitted that materials for the build-

9 Cf. Gessner, Le Droit des Neu- Bluntschli, \& 805; Geffcken, in tres, 92-6, 109, 160; Kleen, Contre- Holtzendorff's Handbuch (1889), bande de Guerre, 30-37, 43; Or- v, 719-24.

tolan, Dip. de la Mer. II, 190; 
ing of ships might be properly prohibited, if the enemy is in great need of them and cannot well carry on the war without them. ${ }^{10}$ On the same general principle saltpeter and sulphur have generally been included in the contraband list; and in the same category must be placed the materials necessary in the manufacture of the other various linds of explosives created of late by the ingenious hand of modern invention. The British Admiralty Manual of Prize Law treats as absolutely contraband machinery for manufacturing arms, ammunition and materials for ammunition, including lead, sulphate of potash, muriate of potash, chlorate of potash, and nitrate of soda; gunpowder and its materials, saltpeter and brimstone, also guncotton. The American Naval Code declares absolutely contraband ammunition and explosives of all kinds and their component parts; machinery for the manufacture of arms and munitions of war, including saltpeter.

$\$ 658$. Materials for naval construction.--In some of the treaties of the seventeenth century articles of naval construction were expressly included, while in others they were expressly excluded. In the absence of express treaty stipulation such articles were not then contraband under the general law of nations, according to Sir Leoline Jenkins, who, in reporting to King Charles II, in 1674, upon a case in which English tar and pitch, carried in a Swedish vessel and the produce of Sweden, had been captured and taken into Ostend for adjudication, said: "There is not any pretense to make the pitch and tar belonging to your Majesty's subjects to be contraband; these commodities not being enumerated in the twenty-fourth article of the treaty made between your Majesty and the crown of Spain, in the sear 1667 , are consequently declared not to be contraband in the article next following. * * * These goods, therefore, if they be not male unfree by being found in an unfree bottom, can not be judged by any other law than by the general law of nations; and then I am humbly of opinion, that nothing ought to be judged contraband by that law in this case, except it be in the case of besieged places, or of a general notification made by Spain to all the world, that they will condemn all the pitch and tar they meet with."11 In the last

10 Quandoque tamen accidit. ut et gerere haud possit. Quaest. Jur. navium materia prohibeatur, si Pub.. I, c. 10 . hostis eâ quam maxime indigeat, et absque eâ commode bellum Jenkins. ii. 751. The written opin- 
clause is contained a declaration by a great authority on interuational law that, at that date, each state possessed the right, upon the outbreak of war, to draw up a list of such articles as it resolved to consider as contraband during its continuance. Upon that theory the United Provinces, during the war with England in 165\%, and with P'ortugal in 1657, issued edicts placing naval stores in the list of contraband,edicts so enlarged in $\mathbf{1 6 8 9}$ as to embrace grain and provisions of every kind. ${ }^{2}$ In 1799 we find Lord Stowell departing wideIy from the opinion of Sir Leoline Jenkins, when, in deciding the case of the Swedish convoy, determined in the English court of admiralty in that year, he said "that tar, pitch, and hemp, going to the enemy's use, are liable to be seized as contraband in their own nature, can not, I conceive, be doubted under the modern law of nations; though formerly, when the hostilities of Europe were less naval than they have since become, they were of a disputable nature, and perhaps continued so at the time of the making of the treaty, or at least at the time of making that treaty which is the basis of it, I mean the treaty in which Whitlock was employed in 1656; for I conceive that Valin expresses the truth of this matter when he says: 'De droit ces choses (speaking of naval stores) sont de contrabande aujourd'hui et depuis le commencement de ce siècle, ce qui n'etoit pas autrefois néanmoins;-and Vattel, the best writer upon these matters, explicitly admits amongst positive contraband, 'les bois, et tout ce qui cert $\grave{a}$ la construction et à l'armement de vaisseaux de guerre." "13 The foregoing opinion was delivered by the great English admiralty judge near the close of the mighty struggle between Great Britain and the powers united in the Armed Neutrality Leagues, a struggle terminated at last by the convention concluded between Great Britain and Russia in 1801, and subsequently acceded to by Sweden and Denmark. By the third article of that treaty it was declared, "that, in order to avoid all ambiguity in what ought to be considered as contraband of war, His Imperial Majesty of all the Russias and His Britannic Majesty declare, conformably to the eleventh article of the

ions delivered by that eminent civilian, Judge of the High Court of Admiralty in the reign of Charies II, in answer to questions submitted to him by the King or by the Privy Council, relating to prize cases, were published as an Appendix to Wynne's Life.

12 Bynkershoek, Quaest. Jur. Pub., I, c. $\mathbf{x}$.

31 The Maria, 1 Rob. Adm., 372. 
treaty of commerce, concluded between the two crowns on the 10th (21st) February, 1797, that they acknowledge as such only the following articles, namely, cannons, mortars, firearms, pistols, bombs, grenades, balls, bullets, firelocks, flints, matches, powder, saltpeter, sulphur, helmets, pikes, swords, sword-belts, saddles and bridles; excepting, however, the quantity of the said articles which may be necessary for the defense of the ship and those who compose the crew; and all other articles whatever, not enumerated here, shall not be considered warlike and naval ammunition, nor be subject to confiscation, and of course shall pass freely, without being subject to the smallest difficulty, unless they be considered as enemy's property in the above settled sense."14 To that rule, excluding naval stores from the list of contraband, France has adhered with consistency. ${ }^{15}$ On the other hand, the United States and Great Britain hare distinctly repudiated it. In 1797 , in the course of a dispute with Spain, the governiment of the former declared that "ship timber and naval stores are by the law of nations contraband of war,"16 and the decisions of its prize courts have been in the same direction, while the British Admiralty Manual of Prize Law now classes as articles absolutely contraband naval stores, such as masts, spars, rudders, and ship timber, hemp and cordage, sail cloth, pitch and tar.

$\$ 659$. Horses as contraband.-Sharply as Great Britain and France have disagreed as to naval stores they have united in regarding loorses as contraband. In the Ordonnance de la Marine of 1681, in which French law on the subject was distinctly declared, it was provided that "arms, powder, bullets, and other munitions of war, with horses and their harness, in course of transport for the service of our enemies, shall be confiscated;" 17 and, as a general rule, horses have been included in all Englisl treaties with other powers, excepting a few contracted with Russia. ${ }^{18}$ It is nevertheless a fact that in the

14 Martens (R.), vii, 150-281.

15 Pistoye et Duverdy, I, 445; Il Volante, ib. 409; La Minerve, ib. 410.

16 In the treaty of 1794 , between Great Britain and the United States, in which several kinds of naval stores were declared contraband, it was added that "generally whatever may serve directly to the equipment of vessels, unwrought iron and fir planks only excepted," shall partake of that quality. See Kent, Con. 1, p. 138.

17 Valin, Ord. de la Marine, II, 264.

18 Manning say that "all the principal powers have so looked upon them at different times, with the exception of Russia." p. 355 . 
British Manual of Prize Law horses are placed in the list of conditional contraband. That concession may be the outcome of the contention now made by certain publicists that horses and all other beasts of burden should be regarded as contraband or not according to the purpose for which they are intended. The United States and other American countries, accepting that idea, seem to limit the prohibition only to such horses as are intended for cavalry mounts. ${ }^{19}$ It is difficult, however, to explain why horses imported for that purpose are less noxious than those destined for transport or artillery service. $^{20}$ As horses and other beasts of burden are seldom purchased during war for agricultural purposes every state should have the right to presume that they are destined for military use unless there is the most convincing proof to the contrary. Horses are included in an Austrian ordinance of 1864, limiting contraband in other respects to munitions, etc., saltpeter and sulphur; and in 1870 Count Bismarck complained that the "export of horses from England under existing circumstances provided the enemy of Prussia with the means of carrying on a war with a power in amity with Great Britain."11

$\S 660$. Coal as contraband.-Although the introduction of the use of coal into vessels of war began early in the last century, the Crimean War was the first maritime struggle of importance in which such ressels were propelled by steam power. Thus confronted by new conditions Great Britain, after stopping coals on the way to a Russian port, applied to them, as an article ancipitis usus, her doctrine of conditional contraband. When the question again arose in 1859 in the war between Austria on the one hand and France and Piedmont on the other the Foreign Office warned British merchants that "it appears, however, to her Majesty's Government, that, having regard to the present state of naval armaments, coal may, in many cases, be rightly held to be contraband of war,

19 See treaties made by United States with Brazil, 1828; with Colombia, 1846, and with Bolivia, 1858. Treaties and Conventions, pp. $105,195,90$. As to that limitation, considered as an international rule, see Bluntschli, $\S 805$.

20 The contraband character of horses is maintained by Vattel, III, § 112; Kent, Lect., vii; Manning,
355; Calvo, §§ 2451, 2461, 2293. 21 State Papers, No. 3, 1870 , Franco-Prussian War. Hall well says that "under the mere light of common sense the possibility of looking upon horses as contraband seems hardly open to argument. They may no doubt be imported during war-time for agricultural purposes, as powder may be used 
and therefore that all who engage in the traffic must do so at a risk, from which Her Majesty's Government cannot relieve them." 22 When the royal nentrality proclamation, issued upon the outbreak of the American Civil War, came under discussion in the House of Lords Earl Granville, after referring to articles elearly contraband, said "there are certain other articles the character of which can be determined only" by the eircumstances of the case,"-a remark made more definite by a declaration by Lord Brougham that coal might be contraband, "if furnished to one belligerent to be used in warfare against the other," and by a still more precise statement from Lord Kingsdown, who said that "if coals are sent to a port where there are war steamers, with a view of supplying them, they become contraband."'23 In accordance with such ideas coal was naturally listed in the British Admiralty Manual of Prize Law as conditional contraband. The same conclusion has been reached by the gorernment of the United States despite the fact that in 1859 Mr. Cass declared that "the attempt to enable belligerent nations to prevent all trade in this most raluable accessory to mechanical power has no just claim for support in the law of nations; and the United States arow their determination to oppose it so far as their ressels are concerned." 24 The American Naral War Code declares coal conditionally contraband "when destined for a naval station, a port of call, or a ship or ships of the enemy." The Cnited States enjoyed the benefit of the English rule in the matter of the Geneva award in which Count Sclopis ${ }^{26}$ said that "if an excessive supply of coal is connected with the other circumstances which show that it was used as a reritable res hostilis, then there is an infraction of the second article of the treaty. *** Thus, for example, when I see the Flor. ida and the Shenandoah choose for their fields of action, the one the stretch of sea between the Bahama Archipelago and Bermuda, to eruise there at its ease. and the other Melbourne and Hobson's Bay for the purpose, immediately carried out, of going to the Aretic Seas, there to attack the whaling ressels,

for fireworks; but the presumption is certainly not in this direction." p. 683 .

22 Jurist, 1859 , v, 203.

23 Hansard, 3d series, vol. clxii, 2084 and 2087. Dana's Wheaton, p. 632 .
$2+$ Mr. Cass, Sec. of State, to Mr. Mason, June 27, 1859. MSS. Inst., France.

25 Art. 36.

26 In the Geneva award. See Whart. Dig., § 369 . 
I cannot but regard the supplies of coal in quantities sufficient for such services infraction of the second rule of Article VI." Germany, going even farther than Great Britain and the United States, maintained during the war of 1870 that the English government should not only regard as contraband all cargoes of eoal bound for the French fleet in the North Sea, but that all export of coal to French ports should be prohibited.27 On the other hand, many of the Continental states have from the outset assumed a contrary position. In 1859 France declared that coal was not contraband, and that assertion she repeated in 1870 . Among those who uphold her in that contention are numbered not only the greater part of the secondary states, but Russia herself, who, during the West African Conference of 18s4, vigorously protested against the inclusion of coal amongst articles contraband of war, declaring at the same time that she would "categorically refuse her consent to any articles in any treaty, convention, or instrument whatever which would imply its recognition"2s as contraband.

\$661. Provisions as contraband.-From the founding of international law the opinion has prevailed that while provisions are not in themselves contraband, they may become so when their withholding offers a prospect of reducing the enemy by famine. The general views on that subject, expressed by Grotius and upheld by Bynkershoek, ${ }^{29}$ received a more explicit statement from Vattel, who said that "commodities particularly useful in war, and the importation of which to an enemy is prohibited, are called contraband goods. Such are arms, ammunition, timber for ship-building, every kind of naval stores, horses,-and even provisions, in certain junctures, when we have hopes of reducing the enemy by famine. * * King Demetrius hanged up the master and pilot of a vessel carrying provisions to Athens at the time when he was on the point of reducing that eity by famine. In the long and 27 State Papers, Franco-German
War, 1870, No. 3; Calvo, § 2460 ; Bluntschli, § 805 .

2. Parl. Papers, Africa, No. iv, $1885,132$.

${ }_{29}$ De Jure Belli ac Pacis, II, c. ii, $\$ 6$; III, c. xvii, § 1 ; Quaest. Jur. Pub., I, c. 9. Rutherforth, in commenting on Grotius's declaration (III, c. i, §5) as to the right of seizing provisions on the ground of necessity, supposes his meaning to be that such seizure would not be justifiable "unless the exigency of affairs is such that we cannot possibly do without them." Inst. II, b. ii, ch. 9, § 19. It thus appears that the opinion of Grotius did not proceed upon the idea of contraband, but upon the 
bloody wal carried on by the United Prorinces against Spain for the recovery of their liberties, they would not suffer the English to carry groods to Dunkirk, before which the Dutch fleet lay." And from the same author we learn that "in 1597 Queen Elizabeth would not allow the Poles and Danes to furnish spain with provisions, much less with arms, alleging that "aceording to the rules of war, it is lawful to reduce an enemy by famine, with the view of obliging him to sue for peace.' "3o Under the shadow of such precedents the English government in 1793 and 1795 seized all ressels laden with provisions bound to French ports, alleging as justification that there was a prospect of reducing the enemy by famine, and that the British nation was threatened by a scarcity of the articles directed to be seized. After the instructions of June, 1793, had been revoled, a treaty was concluded between Great Britain and the United States, November 19th, 1794, in which it was provided that "whereas the difficulty of agreeing on the precise cases, in which alone provisions and other articles, not generally contraband, may be regarded as such, renders it expedient to provide against the inconveniences and misunderstandings which might thence arise; it is further agreed, that whenever any such articles so becoming contraband according to the existing law of nations, shall for that reason be seized, the same shall not be confiscated; but the owners thereof shall be speedily and completely indemnified."31 Before the treaty in question could be ratified an Order in Council was issued in April, 1795, instructing British cruisers to stop and detain all vessels, laden wholly or in part, with corn, flour and other articles of provisions, bound to any port in France, and to send them to such ports as might be most con. venient, in order that such provisions might be purchased on behalf of the govermment. When the legality of the proceedings was challenged by the United States, the issue was trans. ferred to a mixed commission which awarded, under the seventh article of the treaty of 1794 , to the owners of the vessels and cargoes seized under the Orders in Council full indemnity as well for the loss of a market as for the other consequences of their detention. The vital question of law,the question involving a definition of the circumstances under

assumption of pure necessity upon the part of the capturing bellig. erent.
30 Droit des Gens, III, §§ 112, 117, and note to $\S 112$.

31 Treaties and Conventions, p. 379. 
which provisions and other articles, not generally contraband, might be regarded as such,-was, however, left undetermined. A judicial answer to that question was first given by Lord Stowell in the case of the Jonge Margaretha, ${ }^{32}$ in which cheeses sent by a Papenberg merchant from Amsterdam to Brest, where a considerable French fleet was stationed, were condemned as contraband. After declaring that "I take the modern established rule to be this, that generally provisions are not contraband, but may become so under circumstances arising out of the particular situation of the war, or the condition of the parties engaged in it," the judge proceeded to enumerate three causes of exception tending to protect provisions from condemnation as contraband. The first was that they are the growth of the country which exports them; the second, that they are in their native and unmanufactured state; the third, that they are intended for the ordinary uses of life, and not for military use. "As it is impossible to ascertain the final use of an anticle ancipitis usus, it is not an ininjurious rule, which deduces the final use from the immediate destination; and the presumption of a hostile use, founded on its destination to a military port, is very much inflamed, if, at the time when the articles were going, a considerable armament was notoriously preparing, to which a supply of those articles would be eminently useful."'32a In the case of the Commercen ${ }^{33}$ the rules laid down in the Jonge Margaretha were accepted and restated by the Supreme Court of the United States. Despite the suggestion made by Lord Stowell in the Ranger, ${ }^{34}$ that a claim might legally be made to condemn all provisions, whether intended for military consumption or not, the sounder view undoubtedly is that prorisions can only be contraband when intended for military use, or when sent to ports actually besieged or blockaded. Regardless of her usual devotion to a limited list of contraband articles France, during her hostilities with China in 1885, assumed an extreme position in an opposite direction by declaring shipments of rice destined for any port north of Canton to be contraband of war, by reason of "the importance of rice in the feeding of the Chinese population," as well as in the feeding of the Chinese armies. ${ }^{35}$ The unjustifiable attempt

321 Rob. Adm., 189.

s2a Kent, Com. 1, p. 140.

331 Wheaton, 387. See also Maiscnnaire v. Keating, 2 Gallison, 325 .
346 Rob. Adm., 125. See also the Edward, 4 Rob. Adm., 69.

35 Mr. Kasson, then U. S. minister at Vienna, writing on the sub- 
thus made by France to oppress the non-combatant population of China, as Great Britain had attempted to oppress the noncombatant population of France in 1793 and 1795, was met by a declaration from Lord Granville that the decision of no prize court attempting to give effect to the doctrine put forward by France would be respected. ${ }^{36}$ Notwithstanding such recent action upon her part in the right direction Great Britain nevertheless attempted during the Boer War, by the seizures of the liundesrath, the Her'og and the General in African waters, ${ }^{37}$ to carry out a policy defensible, if at all, on the ground that by no other means could the legitimate rights of a belligerent be enforeed in cases in which the only approach to an enemy's country from the sea is through neutral ports.

\$662. Money, metals, cotton, and clothing.-Such articles, although not in themselves contraband, mas become so under circumstances substantially the same as those that impart to provisions a noxious character. ${ }^{38}$. While money may be lawfully sent to a belligerent country for the purchase of groods or for the payment of debts, its consignment for the purpose of assisting belligerent operations authorizes its treatment as contraband. Upon that ground the Supreme Court of the United States held that the general commanding at New Orleans during the Civil War was justified in ordering the removal from a Prussian vessel, outward bound, of silver plate and bullion believed to be intended for the promotion abroad of the interests of the Southern Confederacy. ${ }^{39}$ During that contest it was also held that cotton was contraband because it took the place of money. As Mr. Bayard expressed it: "Cotton was useful as collateral security for loans negrotiated abroad by the Confederate States Government, or, as in the present ease, was sold by it for cash to meet current expenses, or to purchase arms and munitions of war. Its use for such purposes was publicly proclaimed by the Confederacy, and its

ject of the declaration of France to the Sec. of State, said, "the real principle involved goes to this extent, that everything the want of which will increase the distress of the civil population of the belligerent country may be declared contraband of war. The entire trade of neutrals with belligerents may be thus destroyed without the establishment of an effective block- 520 . ade of ports. War itself would become more fatal to neutral states than to belligerent interests."

36 Parl. Papeis, France, No. 1, 1885. See Geffeken's comments in Holtzendorff's Handbuch (1889), iv, 723 .

37 Blue-book, Africa, 1900, No. 1. 38 Cf. Manning Int. Law, p. 358.

39 U. S. v. Diekelman, 92 U. S. 
sale interdicted, except under regulations established by, or contract with, the Confederate government. Cotton was thus officially classed among war supplies, and as such, was liable to be destroyed, when found by the Federal troops, or turned to any use which the exigencies of war might dictate. *** Cotton in fact was to the Confederacy as much munitions of war as powder and ball, for it furnished the chief means of obtaining those indispensables of warfare." 40 As to clothing and the materials from which it is made, there can scarcely be a doubt as to their contraband character when the fact appears that they are intended for military uses. In the Peterhoff ${ }^{41}$ case "men's army bluchers, artillery boots and government regulation gray blankets" were said to belong to the first class of contraband articles because "destined directly to the rebel military service."

$\S 663$. Power to declare what is contraband. Conditional contraband. - At the beginning of this chapter the fact was emphasized that long before there was any consensus of opinion between nations as to what articles should be considered contraband, the power to define their character was admitted to reside in the sovereign of the country prohibiting their importation. Only the admitted tendency upon the part of English statesmen and jurists to cling to ancient forms, long after their vitality has departed, can account for the statement contained in the British Admiralty Manual of Prize Law that "it is a part of the prerogative of the crown during. the war to extend or reduce the lists of articles to be held absolutely or conditionally contraband." Certainly nothing can be farther from the truth than the assumption that the sovereign of the British Empire or any other now possesses the power to enlarge the list of contraband articles regardless of the assent of other nations. While it is undoubtedly true that no general or precise agreement exists regulating the details of the entire subject, there does exist, first, a general understanding that arms and munitions of war, and the materials from which they are made, are in their nature contraband, and as such liable to seizure and condemnation when found on the way to an enemy's destination; second, that there are other articles not contraband in their own nature which may be treated as such when about to be applied to

$40 \mathrm{Mr}$. Bayard, Sec. of State to Mr. Muruaga, June 28, 1886. MSS.

415 Wallace, 28.

Notes, Spain. 
warlike purposes as distinguished from the needs of a noncombatant population. In order to give scientific form to the latter classification English publicists invented the doctrine of occasional or conditional contraband which has been fully accepted in the United States. Despite the efforts of certain Continental jurists to deny the existence of such a doctrine the leaders among them have made such admissions as concede at least a limited application of the principle involved in it. Klüber, for instance, admits its existence in doubtful cases to be governed by surrounding circumstances, ${ }^{42}$ while Ortolan maintains that res ancipitis usus may be treated as contraband under very exceptional conditions. ${ }^{43}$ To such conces. sions may be added Bluntschli's declaration (\$ \$05) that such things as engines, horses and coal may be treated as contraband if it can be proven that they are destined for warlike uses,- -articles classed by Heffter as prohibited goods when their transport to a belligerent by a neutral gires assistance manifestly hostile in its nature. ${ }^{44}$ "These opinions concede," as Lawrence well says, "all that is essential in the British position." ${ }^{\prime 5}$ It may, therefore, be confidently maintained that the power once vested in each sovereign to prescribe for himself a list of contraband articles, to be expanded or contracted at his pleasure, has been merged long ago in the primacy of overlordship rested in the family of nations as a whole. Certainly no extension of the contraband list can now be made by any one sovereign to the detriment of the interests of all the rest without their consent.

$\S 664$. State responsibility for individual action. Lord Westbury said that "in the view of international law the commerce of nations is perfectly free and unrestricted. The subjects of each nation have a right to interchange the products of labor with the inhabitants of every other country. If hostilities occur between two nations, and they become belligerents, neither belligerent has a right to impose, or to require

42 Droit des Gens Moderne de l'Europe, § 288.

43 Dip. de la Mer, II., 179. Ortolan excepts from this exception provisions and other objects of first necessity.

44 "C'est seulement dans le cas où, par leur transport vers l'un des belligérants, le commerce neutre prend le caractère manifestement hostile, que l'autre belligérant a le droit d'empêcher de fait." $\$ 160$.

45 Principles on Int. Law, p. 609. See M. Kleen's criticism upon the English doctrine in his Contrebande de Guerre (1893), pp. 30-37. 
a neutral government to impose any restrictions on the commerce of its subjects." 46 In time of war as in time of peace neutral merchants may trade even in arms and munitions of war at their peril. Such peril arises out of the right of a belligerent to intercept the transport to his enemy of such commodities as are capable of being immediately used in the prosecution of hostilities against himself. The infraction of law arises ont of the act of the neutral individual whenever such act conflicts with the privilege of the belligerent. As Ortolan has expressed it: "Il ne s'agit pas d'actes d'un gourernement qui romprait la neutralite, mais d'actes de particuliers qui exercent leur traffic." 47 $O r$ in the words of Lord Stowell "upon the breaking out of a war, it is the right of neutrals to carry on their accustomed trade, with an exception of the particulir cases of a trade to blockaded places, or in contraband articles (in both which cases their property is liable to be condemned), and of their ships being liable to visitation and search." 4 As the neutral government to which such traders belong is not bound to restrain them from dealing in forbidden goods, neither is it permitted to interfere in their belalf if the articles in which they traflic are seized by one belligerent while on the way to the other. When war occurs all that a neutral government is required to do is to warn its subjects, generally in a proclamation of neutrality, of the risks they run as carriers of contraband goods, with an admonition that those who disregard such warning may not expect when calamity overtakes them to be sheltered by state protection. As the offense of transporting contraband is not com.

${ }_{46} E x$ parte Chavasse, re Grazebrook, 34 L. J. N. S. 17. In that case was cited and approved the following passage from Kent (1 Com., 142): "It was contended on the part of the French nation in 1796 , that neutral governments were bound to restrain their subjects from selling or exporting articles contraband of war to the belligerent powers. But it was successfully shown, on the part of the United States, that neutrals may lawfully sell at home to a bellig. erent purchaser, or carry them. selves to the belligerent powers, contraband articles subject to the right of seizure in transitu. This right has been explicitly declared by the judicial authorities of this country (Richardson v. Ins. Co., 6 Mass. 113; the Santissima Trinidad, 7 Wheat. 283). The right of the neutral to transport, and of the hostile party to seize, are conflicting rights, and neither party can charge the other with a criminal act." See Mr. Abdy's criticism on Kent's position in Abdy's Kent (ed. 1878), p. 301.

47 Dip. de la Mer, II., 199.

4s The Immanuel, 2 Rob. Adm., 198. 
plete until the quitting of nentral territory on a belligerent destination, a neutral gorermment is not required by the law of nations to prohibit the sale of arms and munitions of war to belligerent agents within such territory. When, in 1793 , the government of the United States was called upon by that of Great Britain to prevent the sale of arms and accoutrements to an agent of France, Jefferson, then Secretary of State, replied that American citizens "have been always free to make, vend and export arms. It is the constant occupation and livelihood of some of them. To suppress their callings, the only means perhaps, of their subsistence, because a war exists in foreign and distant countries, in which we have no concern, would scarcely be expected. It would be hard in principle and impossible in practice. The law of nations, therefore, respecting the rights of those at peace, does not require from them such an internal derangement of their occupations. It is satisfied with the external penalty pronounced in the President's proclamation, that of confiscation of such portion of these arms as shall fall into the hands of the belligerent powers on the way to the ports of their enemies. To this penalty our citizens are warned that they will be abandoned." 49 In accordance with that incontestable doctrine the Geneva Tribunal gave no damages against Great Britain because its gorernment had refused to prohibit the trade in contraband goods carried on by English merchants with the ports of the Southern Confederacy. ${ }^{50}$ Credit can not be given to the few publicists who claim that justice and equity demand that neutral states are bound to prohibit the sale of arms and other instruments of war within their territory to belligerent agents, especially when such traffic involves large transactions. ${ }^{51}$ After a neutral government has prevented the departure of armed expeditions from its shores, and has interdicted the supply of fighting outfits to belligerent vessels in its ports, it can consign with a warning the individual neutral trader who takes his fate in his own hands to the jurisdiction of the prize court of the offended belligerent, subject only to the obligation of securing to him there a trial according to the recognized principles of international law. ${ }^{\mathbf{2 2}}$

49 Randolph, Correspondence of Phillimore, III., $\S$ ccxxx.; BluntJefferson, III., 234. schli, § 76 .

50 See American Case, Pt. iv.; 52 Only the commerce actif is British Counter Case, Pt. iv. punishable under Bynkershoek's 51 Hautefeuille, II., tit. viii., § 3 ; rule, non recte vehamus, sine 
\$665. Belligerent destination. Deposit. - From what has been said it appears that no offense can be committed by the sale or transport of contraband goods within neutral territory. The offense is not complete until after such goods lave been sent, by land or sea, across the frontier with a belligerent destination. ${ }^{22 a}$ And as a destination is presumed to be belligerent if it is not manifestly friendly, a vessel is not to leave her course open to circumstances, and to make her destination dependent on contingencies. As she is liable to capture if in any contingency she may touch at a hostile port, she can only sare herself by proving that the contingent intention was definitely abandoned. ${ }^{53}$ As the offense is complete when a neutral vessel leaves port with a belligerent destination and a contraband carge, so when the destination is reached and the cargo delivered, in technical language, "deposited," criminality ceases, because the goods are seizable on account of their noxious qualities, and not by reason of the act of the person carrying them. Therefore the penalty can only be inflicted before deposit terminates the liability. As Lord Stowell has expressed it in the case of the Imina just cited, "the articles must be taken in deticto, in the actual prosecution of a royage to an enemy's port. Under the present understanding of the law of nations you cannot generally take the proceeds on the return voyage." The leading exception to that general rule, as laid down by the same judge in the case of the Nancy, ${ }^{54}$ declares that the return voyage will not be regarded as a separate and innocent expedition when the outward and homeward voyage are really but parts of one trans. action, planned and conducted from the beginning by the same persons as one adventure, especially in a case in which the presumption of guilt is increased by the carrying on the outward royage of contraband goods and fraudulent papers. That extreme extension of belligerent rights, condemned by Continental and American publicists, ${ }^{55}$ is modified certainly by implication in the provision of the British Admiralty

fraude tamen vendimus. Quaest. these last decisions may well be Jur. $P u b .$, I., c. 22.

52a See above, p. 741 . questioned (The Rosalie and

53 The Imina, 3 Rob. Adm., 167; 343. The Nancy, ib. iii., 122); Trende Sostre, cited in the Lisette, for, in order to sustain the pen6 ib., $390 \mathrm{n}$.

543 Rob. Adm., 126. alty, there must be, on principle,

5.5 Cf. Ortolan, Dip. de la Mer, ure." Dana's Wheaton, p. 649. III., ch. vi. "The soundness of 
Manual of Prize Law, ${ }^{56}$ which only requires that a commander shall detain a ressel returning under such circumstances.

$\$ 666$. Penalty for carrying contraband. - Before the principle was settled that the damage to a belligerent from contraband trade results from the nature of the goods conveyed and not from the fact of transport, it was the ancient practice to confiscate both ship and cargo. ${ }^{57}$ The milder modern practice of confiseating the contraband goods only is one of the notable developments of international trade in the seventeenth century. A relic of the earlier practice survives, however, in the rule which still condemns the ressel if the contraband eargo belongs to its owner. If the owner of the contraband articles is part owner of the ship his share in her is also forfeited upon the principle that "when a man is concerned in an illegal transaction, the whole of his property embarked in the transaction is liable to confiscation." 58 Thus it may happen that a neutral who may carry the contraband goods of another neutral with no other penalty than the loss of freight, may suffer as the penalty of carrying his own contraband goods the loss of his vessel. If a neutral vessel is bound by a treaty of its own country to abstain from the act in question, the ressel is condemned for the act, although the cargo be not the property of its owner.59 If there is a resort to fraudulent devices, such as false papers and false destination, for the purpose of defeating the right of search, or deceiving the searching officers, the vessel becomes subject to confiscation as well as the contraband cargo. The extreme contention of certain writers ${ }^{60}$ that mere knowledge on the part of the owner of a vessel of her employment in the carrying of contraband involves the ship in the penalty imposed upon the noxious goods is certainly weakened by the absence of such a rule from Lord Stowell's statement made as early as 1798 , that "the carrying of contraband articles is attended only with the loss of freight and expenses, except when the ship belongs to the owner of the contraband cargo, or when the simple misconduct of carrying a contraband cargo has

56 Holland, 23, 24. Lawrence, Kent's Com., I., 146; Bynkershoek, Principles, 616.

57 Such was the ancient practice, except in France, where, until 1681, goods were only seized on payment of their value. The Neutralitet, 3 Quaest. Jur. Pub., ch. 12-14.

5s Jonge Tobias, 1 Rob. Adm., 330 .

59 Dana's Wheaton, p. 663.

${ }^{60}$ E.g., Bynkershoek, Quaest. Jur.

Rob. Adm., 295; Jonge Tobias, Pub., I., c. 12.

I., ib. 330; Atalanta, 6 ib. 440; 
been connected with other malignant and aggravating circumstances." 61 In the absence of any such "malignant and aggravating circumstances" the modern rule undoubtedly is that the vessel carrying contraband goods is visited with no other penalty than loss of time, freight, and expenses. The penalty of confiscation which falls upon contraband goods extends itself, however, to innocent goods on the same ship, provided they belong to the same owner. As Lord Stowell has expressed it: "The law of nations in my opinion is, that to escape the contagion of contraband, the innocent articles must be the property of a different owner." 62

Modifications by treaty. The fact should here be emphasized that the growing interests of modern commerce are continually suggesting mitigations of existing penalties through treaty stipulations. A few exceptional treaties, such for instance as that made between the United States and Prussia in 1785,63 impose temporary detention as the only penalty for the carrying of contraband. The treaty in question, after declaring that there shall be no "confiscation or condemnation and a loss of property" in such cases, provides that "it shall be lawful to stop such ressels and articles, and to detain them for such length of time as the captors may think necessary to prevent the inconvenience or damage that might ensue from their proceeding," etc. Another attempt to remove the great inconvenience to commerce resulting from the detention of ressels is embodied in that class of treaties which provide that a neutral ressel has the right to purchase the free continuation of her royage by abandoning to the belligerent whatever contraband goods she has on board, provided they are not greater in quantity than the captor can conveniently accommodate. ${ }^{64}$ Some authorities go so far as to claim that such a right exists even in the absence of treaty.

61 Ringende Jacob, 1 Rob. Adm., note 2 . In the scheme of the In91. stitut de Droit International for 62 The Staadt Embden, 1 Rob. a Règlement des Prises Maritimes, Adm., 31. it is provided that "le navire ar-

${ }_{63}$ Treaties and Conventions of U. rêté pour cause de contreband de S., 907. guerre peut continuer sa route, si

64 Such provisions are contained sa cargaison ne se compose pas in the treaties between Russia and exclusivement, ou en majeure parDenmark, 1782 (Martens, R. iii., tie, de contrebande de guerre, et $476)$; the United States and Swe- que le patron soit prêt à livrer den, 1783 (ib. 571); Austria and celle-ci au navire du belligérant et Russia, 1785 (ib. iv., 78), and in que le déchargement puisse avoir other treaties cited by Hall, 692, lieu sans obstacle selon l'avis du 
Although a practice, presupposing such a right, was followed by the Confederate States during the American Civil War, it can not be said to rest upon any generally recognized canon of international law. And it is not likely to be recognized as such, becanse as Dana has expressed it, "as the captor must still take the cargo into port, and submit it to adjudication, and as the neutral can not bind the owner of the supposed contraband cargo not to claim it in court, the captor is entitled, for his protection, to the usual evidence of the ship's papers, and whatever other evidence induced him to make the capture, as well as to the examination on oath of the master and supercargo of the vessel. It may not be possible or convenient to detach all these papers, and deliver them to the captor; and certainly the testimony of the persons on board cannot be taken at sea in the manner required by law. * * Indeed, a strong argument might be made for these considerations, that the article in the treaty can only be applied to a case where there is the capacity in the neutral vessel to insure the captor against a claim on the goods." 65

Pre-emption. In the event the goods seized are undoubtedly contraband there can be no question that the belligerent captor maly elect, from motives of policy, to acquire a title by purchase rather than through a judicial condem. nation. Such a relaxation of the severe right of war was first made in favor of the products of the owner's comtry as in the ease of the concession made at the end of the last century in faror of pitch and tar by Great Britain, who preferred to pay for them rather than seize them as lawful prize. "No unfair compromise," Lord Stowell said, "between the belligerent's rights, founded on the necessities of self-defense, and the claims of the neutral to export his native commodities, though immediately subservient to the purposes of lostility." 66 As a perpetuation of that principle the British Admiralty Manual of Prize Law provides that "the carriage of goods conditionally contraband, and of such absolutely contraband goods as are in an nmmanufactured state and are the produce of the country exporting them, is usually followed only by the pre-emption of such goods by the British Government, which then pays freight to the vessel carrying the

commandant du croiseur." Ann. "66 Sarah Christina, 1 Rob. Adm., de IIInstitut, $1883,218$. 241.

65 Dana's Wheaton, 665. 
goods." "67 The real difficulty arises when an attempt is made to pre-empt goods not liable to confiscation as contraband of war. In that event the claim of pre-emption must rest (1) either upon the assumption that the right exercised by governments during the Middle Ages of seizing grain or other necessary articles found in the hands of foreigners in their ports, on promise of compensation, still survives; 68 or (2) on the necessity which may compel any government to take at its cost property from subjects or foreigners whenever selfpreservation requires it. ${ }^{69}$ Modern practice, which declines to recognize either claim in that extreme form, confines the right to times of war, and limits it to certain kinds of neutral goods bound to an enemy's port. "I have never understood," said Lord Stowell, "that, on the side of the belligerent, this claim [of pre-emption] goes beyond the case of cargoes avowedly bound for enemy's ports, or suspected on just grounds to have a concealed destination of that kind."7o When a neutral and belligerent government cannot agree upon the fact whether or no certain captured goods are or are not contraband of war, they may agree by treaty on the right of pre-emption in order to escape "the difficulty of agreeing on the precise cases, in which alone provisions and other articles, not generally contraband, may be regarded as such." On that basis, as explained heretofore, compensation was granted to American owners of vessels and cargoes seized under the obnoxious British Orders in Council of 1793 and 1795 by the mixed commission appointed under the seventh article of the treaty of $1794 .^{71}$

67 Holland, p. 24. British Courts of Admiralty usually give "the original price actually paid by the exporter" (case of the Haabet, 2 Rob. Adm., 183), plus his expenses and a reasonable profit, generally calculated at ten per cent on the first cost. See Phillimore. III., $\S \S$ cclxviii.-1xx.; Heffter, $\S 161 ; \quad 71$ See above, p. 736.
Calvo, §§ 2517-8; Ortolan, II,, 220230; Bluntschli, §§ 806 and 811 ; Lawrence, Principles, 620-22. 68 Manning (Amos ed.), Bk. V., ch. viii. 69 See above, p. 554. 70 The Haabet, 2 Rob. Adm., 174-185. 


\section{CHAPTER VI.}

NEUTRAL SERVICES, LAWFUL AND UNLAWFUL.

$\S 667$. Distinction between unneutral service and the carrying of contraband. The same gencral line of demalcation that divides legitimate neutral commerce from contraband trade divides certain services that may be lawfully rendered by a neutral to a belligerent from others that are unlawful and therefore unneutral. There was once a tendency to assimilate too closely umentral service with the carrying of contraband goods, a tendency evidenced by the statement issued by the Russian goverument in 1877 of the rules that were to regulate its conduct in the war with Turkey in which it was said that "le transport de dépêches et de la correspondence de l'emneni est assimilé à la contrebandé de guerre;"l and by Article thirty-four of the scheme for a Reglement des Prises Maritimes of the Institut de Droit International, in which such service is associated with contraband trade under the title of Des trunsports Interdits durant la Guerre." The same confusion appears in the royal proclamation issued at the beginning of the Civil War in the United States, ${ }^{3}$ in which British subjects were warned against "carrying officers, soldiers, despatches, arms, military stores $* *$ for the use of either of the contending parties." It cannot justly be said that Hall failed to perceive with perfect clearness the distinction which must always be maintained between unneutral services and the carriage of contraband, because, while he uses the title "Analogues of Contraband," he expressly declares that such services "differ from it in some cases by involving an intimacy of connection with the belligerent which caunot be inferred from the mere transport of contraband of war, and in others by implying a purely accidental and almost involuntary association with him. They are invariably something distinctly more or something distinctly less than the transport of contraband amounts to *** The real analogy between carriage of contraband and acts of the lind in question lies not in the nature of the acts, but in the nature of the remedy applicable in respect of them." t The distinction

1 Journal de St. Pétersbourg, 14-

$26 \mathrm{Mai}, 1877$.

2 Tableau Gćnćral, pp. 201, 202.
3 May 13th, 1861.

* Int. Law, pp. 697-98. Lawrence goes too far in the opposite direc- 
is more sharply drawn, however, by Dana, who says that unneutral service is a topic which "requires a separate treatment from that of contraband, by reason of the actual state of the practice of nations, although logically it may seem to come within the same principle. * * The subject now under consideration is of a different character. It does not present cases of property or trade, in which such interests are involved, and to which such considerations apply, but simply cases of personal overt acts done by a neutral in aid of a belligerent."5

$\S 668$. Lawful neutral service. Carriage of private, diplomatic and consular correspondence.-The same considerations which permit a neutral to car'ry goods not contraband permit him to carry a certain class of mail matter, provided he has no good reason to believe, after the exercise of reasonable care, that it is of a noxious character. As a letter or despatch is not necessarily noxious, the bearer of it is not necessarily exposed to a penalty, because, in the words of Lord Justice Brown, a despatch is not like fire,-a neutral may carry it about without being bound to suppose that it is likely to do an injury. ${ }^{6}$ In the case of the Rapid, ${ }^{7}$ Lord Stowell disclaimed any intention to prescribe a rule that would deter a neutral master from taking private letters. In that case papers in an envelope addressed to a private citizen in Tonningen were given by a Dutch gentleman in New York to the master of an American ressel bound to Tonningen, a free port, from New York. The packet itself bore no evidence of a hostile official character, and the sender of it was not such an officer as required recognition by the government of the United States. When, therefore, it turned out that the packet contained letter's with important information addressed to the Dutch government, which the receiver in Tonningen was to forward, the ship was released after the captain had made affidarit of his ignorance of the official character of the packet, and of its hostile destination. ${ }^{8}$ Speaking of the diligence the

tion when he says: "In truth between the carrying of contraband and the performance of what we may call unneutral service, there is a great gulf fixed." Principles, p. 624 .

5 Dana's Wheaton, pp. 637-38.

${ }^{6}$ Emmens v. Pottle, xvi, Q. B. D., p. 358 .
7 Edwards, Adm. Repts., 228.

8 In the case of the Susan it was held, however, that ignorance of the nature of the despatches, unaccompanied by caution, was not suficient to authorize the release of the vessel. The cases of the Constantia, Susan and Hope, all decided in 1808 , are described in 
captain was required to exercise, the learned judge said: "His caution must be proportioned to the circumstances under which such papers are received. * * If he is taking his departure from a port in a hostile country, and, still more, if the letters are addressed to persons resident in a hostile country, he is called upon to exercise the utmost jealousy. On the other hand, when the commencement of the royage is in a neutral country, and is to terminate in a neutral country * * there is less to excite his vigilance." Even from official despatches, which are of course forbidden when their real character is lnown, are excepted those sent from accredited diplomatic or consular agents residing in a neutral country to their govermment at home, or inversely, because it is presumed that ther are not witten with a belligerent object. In the case of the Caroline, ${ }^{9}$ an American ressel captured by a British cruiser in 1808 when on a royage from New York to Bordeaux,- - having on board a cargo of cotton, and also consular and diplomatic despatches from the French minister at Washington and a French consul in America for the government at home,-Lord Stowell, after declaring that, as a general rule, the carrying of despatches for the enemy by a neutral is illegal, excepted this case from its operation on account of the character of the person from whom the communication came. "He is not an executive officer of the government, acting simply in the conduct of its own affairs within its own territories, but an ambassador resident in a neutral state, for the purpose of supporting an amicable relation with it." It was further said that "the neutral country has a right to preserve its relations with the enemy, and you are not to conclude that any communication between them can partake, in any degree, of the nature of hostility against you." In the subsequent case of the Madison ${ }^{10}$ (1810), an American vessel from Dieppe (held to be a hostile port) to Baltimore, having on board consular despatches only as distinguished from diplomatic, it was held that the neutral could carry them with impunity.

Should postal vessels and mail bags be exempt from search? The fact that the neutral carrier is permitted to convey certain classes of mail matter does not deprive the belligerent

a note by the reporter ( 6 Rob. tempting to reproduce the lanAdm., 440) who gives the sub- guage of the judge. stance of the decisions without at $\quad 96$ Rob. Adm., 464-70.

10 Edwards, Adm. Repts., 224. 
of the right to search his mail bags in order to ascertain whether or no he is engaged in the transport of noxious despatches. The ever-increasing importance to the world of regular and secret postal communication, and the serious inconvenience to a multitude of interests resulting from its interruption, long ago suggested the possibility of some arrangement under which mail steamers could be exempted from search, except under circumstances of grave suspicion. As steps in that direction may be noted the stipulation in the treaty of $1848^{11}$ between the United States and Great Britain providing that in the event of war between them the mail packets shall be unmolested for six weeks after notice by either government that the service is to be discontinued, in which case they shall have safe conduct to return; and the rule adopted by the gorernment of the United States during the Ciril War that "public mails of any friendly or neutral power, duly certified or authenticated as such," found on board captured vessels, "shall not be searched or opened, but be put, as speedily as may be convenient, on the way to their destination. This instruction, howerer, will not be deemed to protect simulated mails rerified by forged certificates or counterfeited seals." 12 In the prize case of the Peterhoff, ${ }^{13}$ when the court ordered the mails found on board to be opened in the presence of the British consul, who was requested to select such letters as appeared to him to relate to the cargo and its destination, and then to forward the remainder, he refused to comply upon the ground that the entire mail should be forwarded unopened. After the United States Attorney at New York had been directed to pursue that course, notwithstanding the fact that there was reason to believe that there were some letters in the pouches containing evidence as to the cargo, Mr. Seward wrote to Mr. Adams"t that "the President believes it is not less desirable to Great Britain than it is to the United States, and other maritime powers, to arrive at some regulation that will at once save the mails of neutrals from unnecessary interruption and exposure, and, at the same time, prevent them from being made use of as auxiliaries to unlawful designs of irresponsible persons seeking to embroil friendly states in the calamities of war." A

11 U. S. Laws, ix, 965.

12 Instructions from Sec. of State to Sec. of the Navy, Oct. 31, 1862. See Dipl. Corr., 1863, Part I, p. 402.
135 Wallace, 28.

14 April 21, 1863. Dana's Wheaton, pp. 660-61; Bernard's Neut. of Great Britain, 319-23. 
genuine desire to hasten such a result was manifested in 1870 in the direction given by the gorernment of France to its officers that "when a ressel subjected to visit is a packetboat engaged in postal serrice, and with a government agent on board belonging to the state of which the vessel carries the flag, the word of the agent may be taken as to the character of the letter's and despatches on board."15 The question for future solution is this: Can belligerents afford to give up absolutely the right to intercept correspondence between the hostile country and its colonies, or a distant expedition sent out by it, upon a mere verbal or even written assurance from the agent of the neutral state which has no power to guilrantee the innocence of the contents of mail bags of which it is ignorant. Hall believes, with good reason, that nothing better can be done than to concede such immunity to mail bags, as a general rule, subject to the right of the belligerent "to examine the bags upon reasonable grounds of suspicion being specifically stated in writing."16

$\S 669$. Transport of diplomatic agents. The Trent affair.The rule that permits a neutral ressel to be the bearer of diplomatic despatches passing between a belligerent government and its diplomatic agents in a neutral country, also permits such a ressel to transport diplomatic agents themselres. If that plain and simple rule had been applied to the taking of Messi's. Mason and Slidell from the British mailsteamer Trent, in 1861, unconfused by the illogical attempt to prove that the Confederate Commissioners and their suite were contraband of war, the question at issue could hare been solved without the slightest difficulty. If the distinction between unneutral service and the carrying of contraband hatd been as sharply defined then as now, such confusion could hardly have occurred. Messrs. Mason and Slidell had been appointed by the gorernment of the Confederate States as its diplomatic agents at the Courts of St. James and the Tuileries, each with a secretary, after such government had been recognized as a belligerent power but not as a sovereign

${ }^{15}$ Rev. de Droit Int., xi, 582. by the respective governments In a series of postal conventions should be so treated; and, finally, between France and Great Britain that lines subsidized by them it has been agreed, first, that pack- should have the same privileges. ets owned by the state should be Martens (N. R.), xiii, 107; (N. R. treated as vessels of war in the G.) v, 183; Hertslet's Treaties, $x$, ports of the two countries; second, 10 S. that vessels freighted as packets 16 Int. Law, p. 704. 
state. While the commissioner's stood in that status, after running the blockade to Harana, they took passage there, on their way to Europe, in the British mail-steamer Trent, bound from Havana to Nassau, from which latter port a regular line of steamers, connecting with the Trent, ran to England. Before the Trent reached Nassau, Captain Wilkes of the United States war steamer San Jacinto, after visit and search, took from her, on the high seas, the Confederate Commissioners, and then permitted her to proceed upon her voyage. Not until after the release of the prisoners,-upon the admission by the government of the United States that they should not have been taken out of the ressel, but should have been brought in, with the rehicle which carried them, for adjudication in a prize court,--did the discussion of the legal merits of the case really begin. In the despatch in which $\mathrm{Mr}$. Seward, as Secretary of State, agreed to restore the commissioners to British custody he declared that "whatever disputes have existed concerning a right of visitation or search in times of peace, none, it is supposed, has existed in modern times about the right of a belligerent in times of war to capture contraband in neutral and even friendly merchant vessels." From the bog in which he thus involved himself, in the hopeless attempt to apply the principles of law applicable to contraband to a case of neutral service, Mr. Seward was never able to extricate himself for the simple reason, to use the words of Mr. Bernard, that "it is incorrect to speak of the conveyance of persons in the military or ciril employment of a belligerent as if it were the same thing as the conveyance of contraband of war, or as if the same rules were applicable to it. It is a different thing, and the rules applicable to it are different." The real and primary question was whether or no the captured persons, as the accredited diplomatic agents of a government which had only reached the stage of belligerent recognition, were entitled to that free transport admitted to belong to the representatives of regularly organized sorereignties. After contending that they were, Earl Russel said that "it appears to Her Majesty's government to be a necessary and certain deduction from these principles, that the conveyance of public agents of this character on their way to Great Britain and France, and of their credentials and despatches (if any), was not, and could not be, a violation of the duties of neutrality." If, however, the contention of Earl Russell was unsound in that regard, as it may hare been, 
the fact remains that Messis. Mason and Slidell were private persons, and as such clearly entitled to transport as ordinary passengers in the mail packet of a neutral. Their seiz. ure in that capacity was certainly illegal. The great practical danger of the fallacious reasonings of $\mathrm{Mr}$. Seward, on the theory that the persons in question could be treated as contraband, was clearly demonstrated by Historicus, ${ }^{17}$ when he said "that they would serve to justify, and may be taken to encourage, the captain of the Tuscarora to seize the Dorer packet-boat and carry her into New York for adjudication, in case Messis. Mason and Slidell should take a through ticket for Paris."

$\$ 670$. Unlawful neutral service. Transmission of signals or messages for a belligerent.-No overt act could be performed by a neutral in aid of a belligerent more clearly unlaw. ful than the transmission of signals or the carrying of messages between two portions of a fleet engaged in concert in hostile operations, and not in sight of each other. It makes no difference whether such fleets or squadrons are in ports of their own country, in neutral ports, or on the high seas, or whether such signals are transmitted by the neutral directly or through a repeating neutral vessel. No matter whether such communications be rerbal or written, important or unimportant to the general results of the war, as the criminality of the act depends alone upon the nature of the service in which the neutral is engaged. The same principle extends to signalling or bearing of messages between a land force and a fleet, or to the laring of a cable to be used chiefly or exclusively for hostile purposes. ${ }^{18}$

$\$ 671$. Carrying of prohibited despatches or persons for a belligerent. - As stated heretofore the carrying of despatches

17 Letters on Int. Law, p. 192. The best statements of the matter, pro and con, may be found in Montague Bernard, Neutrality of Great Britain in the American Civil War, ch. ix; Wharton, Int. Law Dig., $\S \S 325,328,329,374$; Dana's Wheaton, note 228 , on the "Carrying of Hostile Persons and Papers;" Hall, pp. 705-8; Lawrence, Principles, pp. 638-36; Walker, Science of Int. Law, pp. 131-34; and Marquardsen, Der Trentfall.
In the work last named the entire subject of the transport by neutrals of belligerent persons and papers is ably discussed.

18 "The national character of places at which the illegal service begins and ends is also immaterial. If the message is to be carried from Portsmouth to Hong-Kong by stages, the neutral that carries it on its way between neutral ports, by agreement with the belligerent government, is violating the duties 
(excepting such as are diplomatic and consular) for the enemy by a neutral is illegal,-Despatches being defined by Lord Stowell to be "official communications of official persons, on the public affairs of the govermment. ${ }^{19}$ After the proper subtraction has been made, prohibited despatches may be defined to be such as are military or naval, or such as pass between the belligerent government and the officials of its colonies and dependencies. In the case of the Atalanta, ${ }^{20}$-a Bremen ship detained at the Isle of France by the French governor in order that she might carry despatches from him to the Minister of Marine at Paris, despatehes so concealed by the supercargo that they were only discovered by the British captor accidentally,-the ressel was held responsible for the act of the supercargo. The learned judge said, "how is the intercourse between the mother country and the colonies kept up in time of peace? By ships of war or by packets on the service of the state. If a war intervenes, and the other belligerent prevails to interrupt that communication, any person stepping in to lend himself to effect the same purpose, under the privilege of an ostensible neutral character, does in fact place himself in the service of the enemy state. ** In the transmission of despatches may be conveyed the entire plan of campaign, that may defeat all the projects of the other belligerent in that quarter of the world." The same principle which denies to a neutral the right to bear noxions despatches for a belligerent likewise prohibits the transport of certain classes of persons in his service. While no penalty attaches to a neutral who receives on a regular packet-boat indiriduals who come on board as ordinary passengers and pay for their berths as such, even should it transpire that they are officers of either the one or the other of the combatants, ${ }^{21}$ military or naval persons coming on board as such, and travelling at the expense of a belligerent power, must be carried by a neutral at the peril of seizure and confiscation.

$\$ 672$. Neutral vessels engaged as transports in service of a belligerent. - When neutral ressels are regularly hired as

of neutrality as much as any other parties to the transaction." Dana's Wheaton, p. 638 .

19 The Caroline, 6 Rob. Adm., 464-470.

206 Rob. Adm., 440.

21 Such was the opinion of Lord
Stowell, who said in the case of the Friendship (6 Rob. Adm., 420) that "if he were going merely as an ordinary passenger, as other passengers do, at his own expense, the question would present itself in a different form. Neither this court 
transports in the service of a belligerent there can be no doubt that they are engaged in unneutral service, such transports being defined to be "ressels hired by the government to do such acts as shall be imposed upon them, in the military service of the country.", 22 In that case an American vessel made a contract, concealed or destroyed, with the agent of the French government in the United States, to carry to France about eighty French officers and seamen, survivors of the crews of wrecked French ressels constituting a part of the French naval marine. As it appeared that the compensation for the use of the vessel was paid by the French government, that she was to take no cargo, and that while on board the men were to be under military control and supervision, it was held that "their military claracter travelled with them," and that the ressel was "a transport engaged in the inmediate military service of the enemy." In the same year was decided the case of the Orozembo, ${ }^{23}$ a neutral American vessel condemned by an English prize court because the owner or his agents had agreed with the government of Holland, then at war with Great Britain, to go from Rotterdam to Lisbon, in order to take in three Dutch military officers of distinction destined to Batavia. As it appeared from the contract produced that the ressel was to take no cargo, and was to receive one thousand dollars per month for the employment, regardless of the number on board, it was held that she had been let as a transport to the Dutch government to convey military and other persons on their way from the home state to a distant dependency, ${ }^{24}$ a conclusion strengthened by the fact that she held out a false destination to Macao. In the earlier case of the Carolina, ${ }^{25}$ - a Swedish ressel engaged as one of the fleet of French transports between Italy and Egypt and employed under the direction and control of French military and naral ofticers, - it was held that the ressel was good prize, despite the fact that the master set up that the ressel was so employed against his consent, by force and fraud. While he doubted that fact, Lord stowell held in effect that when a neutral vessel is found in the transport service of the enemy

nor any other British tribunal has ever laid down the principle to that extent."

22 The Friendship, 6 Rob. Adm., 425.

236 Rob. Adm., 430 .
24 Such the court held to be the real contract, despite the fact that the one produced purported to have been made with a private citizen at Lisbon.

254 Rob. Adm., 256. 
she should be condemned, no matter whether the enemy obtained her by force or fraud, or by voluntary contract. It is not necessary, however, that it should appear that any special contract or agreement was made by the neutral captain or owner to place a vessel in the service of a belligerent, if she be seized while actually giving him assistance. Under such circumstances the vessel will not be saved from condemnation if it appears, in the event of capture, that those controlling her knowingly performed an unlawful or unneutral act. Guilty knowledge upon their part is the gravamen of the question; and as the presumption is that they possessed it, the burden is upon them to prove ignorance. And as excusable ignorance constitutes the only ground for leniency, it is necessary that they should prove that they took all reasonable precautions to avoid error. Ignorance pure and simple will not avail to prevent forfeiture. ${ }^{26}$

\section{$\$ 673$. Penalty for the performance of unneutral service.-} From what has now been said the distinction clearly appears between the carrying of contraband goods-merely a commercial venture whose injuriousness to a belligerent results from the nature of the goods conveyed and not from the fact of transport-and the performance of unneutral service which consists of hostile overt acts performed by a neutral in aid of a belligerent. In the first case, a belligerent destination and a contraband cargo must co-exist in order to constitute the offense; in the second, the destination of the neutral vessel is of no importance whatever. As the nature of the service in which she is engaged is the real criterion of guilt, she may be seized and condemned for the performance of such service, if unlawful, while sailing between two neutral ports. The real bond that unites two offenses so dissimilar in character is the common principle upon which the seizure is made and the penalty inflicted. In either case the injured belligerent, without appealing to the sovereignty to which the offender belongs, stops the contraband trade, or interrupts the unneutral act by force, and then inflicts the penalty directly upon the guilty individual. In the case of unneutral service the penalty is generally more severe because the acts involved are more positively hostile. The liability of a vessel engaged

26 Whether a vessel not in the be pro hac vice enemy property, enemy's service, but doing hostile see the case of the Tulip, 3 Washacts for his benefit, can be held to ington's Repts., 181. 
in such service to capture and condemnation, which begins with the commencement of its performance, does not end until she has deposited the forbidden persons, delivered the noxious despatches or concluded other forbidden acts. If taken in delicto, the despatches are seized, the persons become prisoners of war, and the peccant ship is confiscated, with any part of the cargo which may belong to her owner.27

$\because$ The Caroline, 4 Rob. Adm., 1 Wheaton, 391; Ortolan, Dip. de la 256; the Friendship. 6 ib. 420 ; the Mer, II, 234; Phillimore, III, § Orozembo, ib. 430 ; the Commercen, cclxxii. 


\section{CHAPTER VII.}

\section{BLOCKADE.}

$\$ 674$. Blockades as compromises between belligerent and neutral interests.-As the primary purpose of blockade is to force the enemy to surrender by cutting off his supplies of every kind, it is not strange that the belligerent practice of prohibiting all trade with the enemy should be as ancient as war itself. From the records of the thirteenth and fourteenth centuries it seems to have been usual for belligerent states to issue proclamations, on the outbreak of war, warning all persons not to attempt to import victuals or merchandise into enemy territory under penalty of seizure and confiscation. ${ }^{1}$ In the early days of modern international law it was a question whether powerful nations would permit neutrals during war to trade at all with their enemies,-they often assumed that the mere issuance of proclamations to the effect that enemy ports were blockaded suspended neutral trade, even when such proclamations were supported by a notoriously insufficient force. So well settled were such ideas in the first quarter of the seventeenth century that Grotius declares that "if the supplies sent hinder the execution of my design, and the sender might have known as much, as if I had besieged a town or blocked up a port, and thereupon I presently expect a surrender or a peace, that sender is obliged to make me satisfaction for the damage that I suffer on his account, as much as he that shall take a person out of custody that was committed for a just debt, or help him to make his escape, in order to cheat me; and proportionally to my loss I may seize his goods, and take them as my own, for recovering what he owes me." 2 And then speaking with special reference to the introduction of supplies into a blockaded place, he adds that "if my enemy's injustice towards me be evident, the neutral who aids him in his unjust war will be guilty not only of a civil, but of a criminal offense, and may be punished accordingly."3 A little more than a century later Bynkershoek said that "to

1 See Proclamation of Henry III, 1223; letter of Edward II to Philip $\mathrm{V}$ of France. Foedera, I, p. 440 , ib.

2 De Jure Belli ac Pacis, III, c. 1., $\S 53$. III, p. 880 .

3 Ibid, III, c. i., § v. 3. 
carry supplies to a besieged enemy has been always a capital offense in friends, equally as in subjects, after notice giren to them, and sometimes even without notice; and further, that if the supplies be intercepted by the belligerent, he may not only confiscate them, but inflict corporal, if not capital, punishment upon those who scek to introduce them."4 Twenty year's thereafter Vattel wrote that "all conmerce with a besieged town is absolutely prohibited. If I lay siege to a place, or even simply blockade it, I have a right to hinder anyone from enter. ing it, and to treat as an enemy whosoever attempts to enter the place, or carry anything to the besieged parties, without my leave; for he opposes my undertaking, and may contribute to the miscarriage of it, and thus involve me in all the misfortures of an unsuccessful war." 5 The counter movement, which had for its object a modification of such extreme claims in favor of the rights of neutral traders, may be said to date from the Ordinance of June 26, 1630, issued by the States General of the United Provinces on the advice of their courts of admiralty, for the purpose of regulating the blockade of the ports of Flanders, then in the possession of the Spanish crown. The necessity for such regulation grew out of the fact that "their High Miglitinesses keep the said ports continually blockaded by their vessels of war at an excessive charge to the state, in order to hinder all transport to and commerce with the enemy; and because those ports and places are reputed to be besieged, which has been from all time an ancient usage after the example of all lings, princes, powers, and other republics, which have exercised the same right on similar occasions." Not however until the latter half of the eighteenth century was there any decided and concerted action to establish the principle that the right of a neutral to trade with blockaded territory can not be cut off unless, (1) a blockade exists de facto; (2) that there is reputation of its existence; (3) that there has been an undoubted intention to violate it.

Armed neutralities and Declaration of Paris. $-\mathrm{A}$ notable effort in the right direction was made when the First Armed Neutrality of 1780 embodied in its Declaration the statement that "in order to determine what characterizes a blockaded port, that term shall only be applied to a port where, from

* Quaest. Jur. Pub., I, c. II.

5 Droit des Gens, III, § 117.

- Robinson's Collectanea Mari. tima, p. 158, and note to the Hurtige Hane, 3 Rob. Adm., p. 327; Twiss, War, pp. 189-95. 
the arrangement made by the attacking power with ressels stationed off the port and sufficiently near, there is evident danger in entering the port."7 In the case of the Betsey, decided in December, 1798, Lord Stowell declared that "on the question of blockade three things must be proved; 1st, the existence of an actual blockade; $2 \mathrm{nd}$, the knowledge of the party; 3rd, some act of violation either by going in or coming out with a cargo laden after the commencement of the blockade." In that definition of the elements which must enter into an actual blockade was embodied the compromise finally made between belligerents and neutral interests. By that compromise the fact was recognized that "the right of blockade is founded not on any general unlimited riglit to cripple the enemy's commerce with neutrals by all means effectual for that purpose, for it is admitted on all hands that a neutral has a right to carry on with each of the belligerents during war all the trade which was open to him in time of peace, subject to the exceptions of trade in contraband goods and trade with blockaded ports. Both these exceptions seem founded on the same reason, viz., that a neutral has no right to interfere with the military operations of a belligerent either by supplying his enemy with the materials of war; or by holding intercourse with a place which he has besieged or blockaded. ${ }^{9}$ The provisions of the First Armed Neutrality of $\mathbf{1 7 8 0 ,}$ which contained the inadmissible principle that the blockading vessels must be stationary, were repeated in the second of 1800 , which contained the further restriction that no lawful capture could occur unless an attempt was made by the peccant vessel to enter after notice had been given by the commander of the blockading squadron. ${ }^{10}$ Against such extreme statements in favor of neutral rights were directed the counterblasts embodied in the British Orders in Council of 1806 and $\mathbf{1 8 0 7}$, and the Berlin and Milan decrees of Napoleon, unwarrantably reviving the restrictions

7 Que pour déterminer ce qui see Martens, Précis, Bk. viii, ch. caractérise un port bloqué, on n'ac. cord cette dénomination qu' à celui, où il y a, par la disposition de la Puissance qui l'attaque avec des vaisseaux arrêtés et suffisamment proches, un danger évident d'entrer. See above, p. 634 .

81 Rob. Adm., p. 93. vi.; 2 Azuni, ch. ii.

${ }^{10}$ Et que tout bâtiment naviguant vers un port bloqué ne pourra être regardé d'avoir contrevenu à la présente Convention, que lorsqu' après avoir été averti par le commandant du blocus de l'état du port, il tâchera d'y pénétrer en

๑ For an elaboration of that idea, employant la force ou la ruse. 
of blockade in all their ancient severity. At that time it was that France declared the British Isles to be in a state of blockade, despite the fact that she dared not send a single squadron to sea for fear of capture by the British navy; and Great Britain placed in the position of blocliaded ports all places from which her commercial flag was excluded.1 ${ }^{11}$ During that period of violence and confusion it was that a general dispegard by belligerents of the rights of nentral commerce, apart from the matter of blockade, produced the irritation which culminated in the war of 1812 between Great Iiritain and the United States. Not until the period of ealm that followed the great settlement of 1815 did passions so far subside as to make possible the final and definitive settlement of 1856 . At the outbreak of the war with Russia in 1854 Great Britain and France declared their intention "to maintain the right of a belligerent to prevent neutrals from breaking any effective blockade, which may be established with an adequate force against the enemy's ports, harbors, or coasts;" and at its close they joined with the other leading maritime states in declaring that "blockades, in order to be binding, must be effective, that is to say, magntained by a force sufficient really to prevent access to the coast of the enemy."12

$\$ 675$. Classification of blockades-Strategic, commercial and pacific. - From what has now been said as to the origin of blockade it appears that, in its inception, it was a military expedient of the greatest strategic value in time of war for the ultimate reduction of some vitally important place in the possession of the enemy. Unlike siege, blockade implies no intention to get possession of the blockaded place, simply a purpose to reduce it by obstructing access to it. ${ }^{13}$ While in the wider meaning of the term blockade implies obstruction of a passage to or from a place by land or sea, it is usually confined to the obstruction interposed by naral forces to communication by water. ${ }^{14}$ An effective blockade as now understood is one "maintained by a force sufficient really to prerent access to the coast of the enemy." A great enlargement of the original idea of a military or strategic blockade, carried

11 Manning (Amos ed.) Bk. v., ment l'accès du littoral de l'ench. vi. nemi. Martens (N. R. G.) XV, p.

12 Les blocus, pour être obligatoires, doivent être effectifs, c'està-dire, maintenus par une force suffisante pour interdire réelle792.

13 Woolsey, Int. Law, § 202.

14 Pitt-Cobbett, Cas. Int. Law, p. 301; Davis, Int. Law, p. 366. 
on for the purpose of reducing the particular place blockaded, was made when the process of obstruction was extended far beyond the scene of warlike operations in order to weaken the resources of the enemy generally by cutting off his extermal trade. Such a condition of things would occur if Great Britain, in the event of war with the United States, should blockade the entire western coast of this republic, while military operations were confined to the $A$ tlantic seaboard and the Canadian frontier.15 When the legality of such blockades, known as commercial blockades, was still debatable, upon the ground that the harm they inflict upon neutrals is greater than the advantage they give to belligerents, the statesmen of the United States expressed themselves more or less positively against them. At the beginning of the last century Marshall, as Secretary of State, said that "on principle it might well be questioned, whether this rule can be applied to a place not completely invested by land as well as by sea. If we examine the reasoning on which is founded the right to intercept and confiscate supplies designed for a blockaded town, it will be difficult to resist the conviction that its extension to towns invested by sea only is an unjustifiable encroachment on the rights of neutrals."16 And in 1859, on the outbreak of the Italian war, Mr. Cass, then Secretary of State, issued a circular to American representatives in Europe in which it was declared that "the blockade of a coast or of commercial positions along it, without any regard to ulterior military operations, and with the real design of carrying on a war against trade, and from its very nature against the trade of peaceable and friendly powers, instead of a war against armed men, is a proceeding which it is difficult to reconcile with reason or with the opinions of modern times. To watch every creek and river and harbor upon an ocean frontier, in order to seize and confiscate every vessel with its cargo attempting to enter or go out, without any direct effect upon the true objects of war, is a mode of conducting hostilities which would find few advocates if now first presented for consideration. Unfortunately, however, the right to do this has been long recognized by the law of nations, accompanied indeed with precautionary conditions, intended to prevent abuse, but which experience has shown to be lamentably inoperative."1 7 Regardless, bowever.

16 Mr. Marshall to Mr. King, Sep. Mason, June 27, 1859; 3 Wharton, 20, $1800 ; 3$ Wheaton, Appendix.

Int. Law. Dig., § 361 . 
of its inconveniences and imperfections the government of the United States, after the outbreak of the Civil War, instituted along the entire coast of the Southern Confederacy the most extensive commercial blockade the world has ever seen, a blockade which finally assumed serious military importance in so far as it promoted a scheme of conquest materially adranced by the cutting off of supplies from every side. In the light of that precedent the right to institute a commercial blockade, often questioned prior to that time, may be said to be undisputed at the present day. Entirely apart from blockades in time of war, which may be either strategic or commercial, stand pacific blockades heretofore described as one of the means of forcible restraint or redress short of actual hostilities. ${ }^{18}$

\$676. Law of blockade as construed by two distinct schools. - As the largest experience in the actual conduct of blockades during the last century fell to the lot of Great Britain and the United States, a certain practical value slould attach to a set of principles recognized by both as necessary for the maintenance of a practice which refuses to shackle belligerents with too serere and impracticable restrictions. In opposition to the English and American school, whose views on some points are accepted by Prussia and Denmark, stands a group of Continental powers, with France at their head, which firmly adheres to a stricter construction of the law of blockade in favor of nentral interests. The leading subjects as to which the opposing schools disagree are those involving (1) the circumstances under which a neutral becomes affected with knowledge of a blockade; (2) the rule with regard to the proper maintenance of a blockade; (3) as to the warning necessary to ressels in a blockaded port; (4) as to the acts constituting a breach of blockade. From the same data of fact in any one of the enumerated cases a different conclusion may be reached according as the theory of one school or the other is accepted as the major proposition in the syllogism. In what follows British and American theory, as embodied in what may be called for convenience the British rule, will be accepted as the basis of the running contrast to be made with Continental theory embodied in what may be called for convenience the French rule.

\section{$\S 677$. By what authority and within what limits blockades}

18 See above, p. 444. 
may be instituted.-As blockade is not a necessary consequence of a state of war, it must be specially instituted as an act of war under the express or implied authority of the sovereignty responsible for it. While general iustructions given to the commander of a belligerent force do not necessarily imply competent orders, his implied powers are supposed to invest him with such sovereign authority as will enable him, when operating far from lome, to cope with the contingencies of the service in which he is engaged. Subordinate officers are not authorized to create or vary a blockade at their will; and when an officer not armed with the proper authority has assumed the right to institute a blockade, captures effected under it can only be validated retrospectively by a subsequent adoption of his act by his state. ${ }^{19}$ According to English and American theory blockade is not confined to a seaport, but may be extended to any arenue of communication such as a river, bay or other portion of the enemy's coast, and to any necessary portion of the high seas outside of the threemile limit. Such a rule conflicts, of course, with the ideas of the Continental publicists who claim that as blockade is simply the displacement by a belligerent of the territorial jurisdiction of his blockaded enemy, it cannot be carried on beyond the limits of territorial waters. ${ }^{20}$

Access to contiguous territory. - The blockade of enemy ports can not, however, be permitted to obstruct access to the contiguous possessions of a neutral state, as in the case of the blockade of rivers forming the boundary between enemy and neutral territory, or in the event of the blockade of a river the upper portion of whose navigable course is beyond the frontiers of the hostile state. Under such circumstances a belligerent can maintain only such a blockade as will permit the neutral to have free access to his own ports or territory, and at the same time permit other neutrals to communicate freely with him. It was therefore held that a blockade of Holland was not broken by a destination to Antwerp;21 and during the American Civil War the trade to Matamoros, on the Mexican shore of the Rio Grande, was conceded to be perfectly lawful

19 The Hendrick and Maria, 1 Rob. Adm., p. 148; The Juffrow Maria Schrœder, 3 ib., p. 154; The Rolla, 6 ib., p. 365; The Franciska, $\mathrm{X}$ Moore, p. 46; 3 Phillimore, § cclxxxviii; Calvo, § 2555.
20 Hautefeuille, Droits des $\mathrm{Na}$ tions Neutres, tit. ix., ch. I, § 1; Ortolan, Diplomatie de la Mer, II., ch. ix.; Calvo, § 2567.

21 The Frau Ilsabe, 4 Rob. Admr., p. 64. 
by the courts of the United States. The rule was then laid down that it was a duty incumbent on ressels with a neutral destination to keep south of the dividing line between Texan and Mexican territory; and in the case of ressels captured for being north of that line, the judges refused, while restoring them, to allow them costs and expenses. ${ }^{22} \mathrm{~A}$ blockade cannot extend beyond the area controlled by the operations of the forces maintaining it. Internal means of transport by canals, through which ships may gain access to the sea at a point which is not blockaded, may therefore be used with impunity. For that reasou, during a blockade of Holland, a vessel and cargo sent to Embden, in neutral territory, and issuing from that port were not condemned.23

$\$ 678$. Blockades to be binding must be effective.-The assault made upon "paper blockades" by the First Armed Neutrality of 1780 was embodied in the provision that blockades to be effective must be maintained by vessels stationary and sufficiently near to produce evident danger in entering; and, in the second of 1800 , that definition was repeated with the additional statement that no lawful capture could be made, unless the peccant ressel attempted to enter after notice from the commander of the blockading squadron. ${ }^{24}$ After a long interval followed the Declaration of Paris of 1856 , providing that "blockades, in order to be binding, must be effective, that is to say, maintained by a force sufficient really to prevent access to the coast of the enemy." Lord Russell, writing in 1863 as to the meaning of that Declaration, said that it "was in truth directed against what were once termed 'paper blockades'; that is, blockades not sustained by any actual force, or sustained by a notoriously inadequate naval force, such as an occasional appearance of a man-of-war in the offing, or the like. * * The interpretation, therefore, placed by Her Majesty's government on the Declaration was, that a blockade, in order to be respected by neutrals, must be practically effective."25 The most satisfactory definition perhaps of the difficult term "practically effective," generally approved by English and American judges and text writers, is to be found in the case of the Franciska, where it was said that in order to maintain a proper blockade a place must be "watched by a force sufficient

22 The Peterhoff, 5 Wallace, $p$. 54; The Dashing Wave, ib. 170; The Science, ib. 178; The Volant, ib. 179.
23 The Stert, 4 Rob. Adm., p. 65. 24 See above, p 761.

25 Lord Russell to Mr. Mason, Feb. 10, 1863, ap. Bernard, 293. 
to render the egress or ingress dangerous; or, in other words, save under peculiar circumstances, as fogs, violent winds, and some necesșary absences, sufficient to render the capture of ressels attempting to go in or come out most probable."26 Under that rule the government of Great Britain naturally accepted the contention of that of the United States, made during the American Civil War, to the effect that the legal efficiency of the blockade of Charleston,- - usually maintained by one ship lying off the bar between the two principal channels, with two or three others cruising outside within signalling distance,-was not destroyed by the absence of the Niagara, a blockading vessel whose withdrawal, in the attempt to intercept a cargo of arms expected at another part of the coast, left the harbor open for at least five days. It was admitted under the British rule that there was no cessation of the Charleston blockade despite the fact that a large number of vessels succeeded in passing it, owing to the peculiar nature of the coast. ${ }^{27}$ As there is no rule requiring the blockading squadron to remain within a certain distance of the place blockaded, provided access is really interdicted, Buenos Ayres was held to have been sufficiently blockaded by vessels stationed in the vicinity of Monte Video; and, in like manner, the blockade of Riga was maintained, during the Russian war in 1854, at a distance of one hundred and twenty miles from the town by a ship in the Lyser Ort, a channel three miles wide, forming the only navigable entrance to the gulf. ${ }^{28}$

Opinions of continental publicists. - A majority of the modern Continental publicists so construe the principle embodied in the Declaration of Paris as to revive that contained in the First Armed Neutrality of 1780 . The substance of their contention is that the immediate entrance to a port must be so guarded by stationary vessels as to render ingress practically impossible, or at least to expose any ship attempting to pass to a cross fire from the guns of two of them. Under that view a vessel is justified in attempting to enter whenever any accidental circumstance puts an end temporarily to the blockade. While Heffter (\$155) does not hold that temporary absence involves a cessation of blockade he requires that ressels shall

26 Spinks, Prize Cas., p. 115; $\mathrm{x}$ ain, chs. $\mathrm{X}$ and XII; Glass, Marine Moore, Privy Council Cases, p. 58; Phillimore, III, § ccxciii-iv; Bluntschli, § 829 .

Int. Law, p. 91.

28 The Franciska, Spinks, 115; Hall, pp. 726-27.

27 Bernard, Neut. of Great Brit- 
be "stationnés en permanence et en assez grand nombre pour empecher toute espece de communieation aree la place ou le port investi." And in the same vein Ortolan ${ }^{29}$ claims that a blockade is not effective unless "toutes les passes ou avenues qui y conduisent sont tellement gardées par des forces narales permanentes, que tout batiment qui chereherait à s'y intro. duire ne puisse le faire sans etre apereu et sans en etre détourne." The proposed Règlement des Prises Maritimes, adopted by the Institut de Droit International, declares in a more conservative spirit, that a blockade is to be considered effective "lorsqu'il existe un danger imminent pour l'entrée ou la sortie du port bloqué. à cause d'un nombre suffisant de navires de guerre stationnés ou ne s'écartant que momentanément de leur station," with the proviso that "si les navires bloquants s" eloignent de leur station pour un motif autre que le maurais temps constaté, le blocus est considéé comme. leve. $" 30$

$\S 679$. How knowledge of blockade must be communicated to neutrals. - According to the British rule, recognized by Prussia and Denmark ${ }^{31}$ as well as by the United States, a belligerent may be justified in seizing the property of a neutral who attempts to violate a blockade, even when no official or formal notice of its existence has been served upon him, provided he sails for the blockaded port from a place at which the fact of blockade is so notorious that ignorance of its existence is practically impossible. It was said in a notable case that "if a blockade de facto be good in law without noti. fieation, and a wilful violation of a legal blockade be punishable with confiscation, propositions which are free from doubt, the mode in which knowledge has been acquired by the offender, if it be elearly proved, can not be of importance."32 And yet while, under the letter of the law, a vessel sailing for a blockaded port from one in which the fact of blockade is so notorious that ignorance of its existence is really impossible may be seized and confiscated without further warning, such a proceeding is looked upon with disfavor. As Dr. Lushington expressed it, in passing in the first instance on the case of the Franciska, "unless the notoriety of the blockade be so

29 Dip. de la Mer, II, p. 328.

30 Ann. de linstitut, 1883 , p. 218

31 As to the Prussian and Danish

Prize regulations, see Bulmerincq,
Le Droit des Prises Maritimes, Rev. de Droit Int., x. pp. 240, 212. 32 The Franciska, x Moore, p. 46. 
great, that according to the ordinary course of human affairs the knowledge thereof must have reached all engaged in the trade between the ports so blockaded, a warning to each ressel approaching is indispensably requisite." Under that rule knowledge of the fact can not be presumed when ressels sail before the official notice of a blockade is proclaimed; or when they approach a port closed by a merely de facto blockade, instituted on the authority of an officer commanding in neighboring seas, whose existence had not become notorious before their departure for such port. Under such circumstances, in which a guilty knowledge can not be presumed, ressels are simply turned back with such a notice endorsed on their papers as the French practice requires. ${ }^{33}$ And, despite the assumption that a neutral who sails for a port with full knowledge that it is blockaded when his royage is begun ought to expect to find it in the same state when he arrives, a mitigation is made in faror of a ressel that sails with such full knowledge from a place far distant from the blockaded port. And so it was held during the wars at the beginning of the last century that a vessel sailing for Europe from America did not become liable to capture simply because she was destined to a blockaded port, the presumption in favor of the continuance of blockade being necessarily weakened by the lapse of time sufficient for a long voyage. It was further held, however, that inquiry as to the continued existence or suspension of blockade, justifiable under such circumstances, ought to be made, not at the blockaded port, but at intermediate places where fraud is less likely to be the motive of it. ${ }^{34}$ With the growing application of steam to maritime navigation and the consequent shortening of royages, and with the rapid dissemination of news through newspapers and the electric telegraph, the rule, under which sailing from a neutral port with intent to enter a blockaded port and with knowledge of the existence of the blockade subjects a vessel to condemnation,

33 Vrow Judith, 1 Rob. Adm., p. 151; The Neptunus, 2 ib. p. 114; British Admiralty Manual of Prize Law, p. 34. If, however, the vessel sails to a blockaded port, at a time later than that at which the general notification is matter of public knowledge, it may be seized without special warning. The Columbia, 1 Rob. Adm., p. 156; The
Vrow Johanna, 2 ib., p. 109; Mr. Justice Story in the Nereide, 9 Cranch, p. 440.

34 The Betsy, 1 Rob. Adm., p. 334. The rule is different, however, when a vessel sails with the intention of inquiring whether a blockade de facto is continued or not. Naylor v. Taylor, 4 Manning \& Ryland, 531. 
becomes every day more reasonable. As Chief Justice Chase expressed in the case of the Circassian, "we are entirely satisfied with this rule. It was established, with some hesitation, when sailing vessels were the only vehicles of ocean commerce; but now when steam and electricity have made all nations neighbors, and blockade-running from neutral ports seems to have been organized as a business, and almost raised to a profession, it is clearly seen to be indispensable to the efficient exercise of belligerent rights." 35 Formal and official notice of the existence of blockades is nevertheless a recognized part of British and American practice, both by proclamation announcing the date upon which the designated place will be blockaded, and also by warning vessels, when they approach, of the existence of the blockade. Whenever blockade is instituted under the direct authority of either government, the fact is always communicated to foreign states, and through them to their subjects. The mandate contained in Mr. Lincoln's proclamation of April 19, 1861, that ressels should be individually warned, was so construed by Commo. dore Pendergrast, in notifying the actual commencement of the blockade of the Virginia coast in July of that year, that only "those coming from abroad, and ignorant of the blockade, will be warned off." 36

French theory and practice.-Under the French rule, followed by Italy, Spain and Sweden, ${ }^{37}$ the neutral is not injuriously affected by any information gained previous to his arrival at the blockaded place. Even if he has received information through his own government he is not bound by it,he still has the right to proceed to the entrance of the block. aded port and there ascertain personally whether or no blockade exists at that moment. While it is the practice of France, and of other states sharing her views, to issue proclamations announcing the existence of blockades, they are regarded simply as acts of courtesy, as the subjects of neutral

352 Wallace, p. 151.

36 In the case of The Hiawatha (2 Black, 675) it was insisted that "according to the President's Proclamation of the 19th of April, the Hiawatha was not liable to capture, until 'the commander of one of the blockading vessels' had 'duly warned' her, indorsed 'on her register the date and fact of such warning,' and she had again attempted 'to leave the blockaded port." "The court answered that "it would be absurd to warn parties who had full previous knowledge."

37 Bulmerincq, Le Droit des Prises Maritimes, Rev. de Droit Int., X, pp. 220, 400, 441; Negrin, p. 213 . 
nations are not deemed to be prejudiced by them. According to the French rule, which Calvo ${ }^{38}$ thinks should be accepted as the rule of law, especial notification is necessary, in addi. tion to the diplomatic announcenent which ought also to be given. Where that view prevails the neutral trader is only liable to seizure and confiscation for an attempt to enter a blockaded port, after he has been individually warned by one of the blockading squadron, ${ }^{39}$ with the fact of such warning endorsed on the ship's papers with mention of the date and place of notification. In harmony with that practice is the contention of those Continental writers who claim that the neutral trader who sails for a blockaded port in the hope of flnding a free entry through the chances of war, the effects of the weather, or through any other cause, is not to be punished, if perchance his hope fails to be justified by conditions actually existing at the time of his arrival. ${ }^{40}$

$\$ 680$. What acts constitute a breach of blockade. English and American rule.-As English and American practice bases the liability to seizure on knowledge of the fact of the existence of blockade, coupled with the presumption that under ordinal'y circumstances it will continue, the neutral trader, as a general rule, subjects his property to confiscation from the time he sails with a clear destination to a blockaded port. As the test of criminality is intention, in the event of doubt, all acts performed from the commencement of the royage may be looked to as evidence of it. If it thus appears that the trader, although anxious to enter the prolibited place, resolved to inquire on the way as to the existence of blockade, in order that he might desist from his purpose in the event of an affirmative answer to his inquiry, his property is not subject to condemnation. In all such cases it is incumbent upon the trader to show that an intention to inquire really existed, because acts of a doubtful character, in the absence of full explanation, will be interpreted against him.41 As a precaution against fraud the rule has been laid down that inquiries, which should be made at points sufficiently distant from the blockaded harbor, must not be withheld until its very entrance is reached. "The neutral merchant is not to

38 Droit Int., $\$ 2581$. See, also, tice upon the approaching neutral. Pistoye and Duverdy, I, p. 370; Hautefeuille, tit. ix, ch. ii, § 2 .

39 A vessel not engaged in the blockade can not serve a valid no-

${ }^{40}$ Ortolan, Dip. de la Mer, II, pp. 334-411.

41 The Despatch, 1 Acton, 163. 
speculate on the greater or less probability of the termination of a blockide, to send his vessels to the very mouth of the river, and say: 'If you do not meet with the blockading force, enter. If rou do, ask a warning and proceed elsewhere.' Who does not perceive the frauds to which such a rule would be introductory.42" "If approach for inquiry were permissible, it will be readily seen that the greatest facilities would be afforded to elude the blockade.43" A breach of blockade may be committed even when the peceant ship does not actually cross the forbidden line, as in the case of vessels lying outside, and receiving their cargoes from lighters or other craft issuing from the blockaded port. ${ }^{4}$

Case of the Circassian.-In his comments on the application of the general rule now under consideration Hall says that "during the American Civil War the courts of the United States strained and denaturalized the principles of English blockade law to cover doctrines of unfortunate riolence. A ressel sailing from Bordeaux to Havana, with an ulterior destination to New Orleans, or in case that port was inaccessible, to such other place as might be indicated at Havana, was condemned on the inference that her owner intended the ship to violate the blockade if possible, notwithstanding that the design might have been abandoned on the information received at the neutral port." 45 That the rule laid down by the Supreme Court of the United States in the case in question rested upon an entirely different data of fact is erident from its opinion which declares that "we agree, that if the ship had been going to Havana with an honest intent to ascertain whether the blockade at New Orleans yet remained in force, and with no design to proceed further if such should prove to be the case, neither ship nor cargo would have been subject to lawful seizure. Int it is manifest that such was not the intent. The existence of the blockade was known at the inception of the voyage, and its discontinuance was not ex-

42 The Irene, 5 Rob. Adm., p. 80.

$43 \mathrm{Mr}$. Justice Field in the Cheshire, 3 Wallace, p. 235 . See, also, the Hurtige Hane, 2 Rob. Adm'r, p. 127; The Charlotte Christine, 6 ib., p. 101; The James Cook, Edwards, 264; Ortolan, Dip. de la Mer., 349 and 353 .

44 The Maria, 6 Rob. Adm., p. 201; Charlotte Sophia, ib. 202n.
"Of course a vessel taking on board cargo, at a port not under blockade, which has arrived from a blockaded port by canal or lagoon navigation, does not commit an infraction of the blockade; and conversely a vessel so delivering cargo is not liable to capture." Hall, p. 735 , note 3 . 
pected. The ressel was chartered and her cargo shipped with the purpose of forcing the blockade. The destination to Havana was merely colorable. It proves nothing beyond a mere purpose to tonch at that port, perhaps and probably, with the expectation of getting information which would facilitate the success of the unlawful undertaking." $t 6$ The force of the criticism of the eminent English publicist is broken of course the moment it appears that the data of fact on which it was based had no real existence.

French rule.-The logical result of French requirements as to the kind of evidence necessary to bring knowledge home to the neutral trader as to the existence of blockade, in the absence of presumption as to its continuance, is the rule that no condemnation is justifiable until, after special notification, an actual attempt has been made, by force or fraud, to pass into or out of the blockaded place. ${ }^{47}$ If however a vessel, which has received in the course of her voyage a regular notification from a belligerent cruiser of the blockading country of the existence of the blockade, is seized while prosecuting hel original design, but before an actual attempt to enter the blockaded place, the French rule permits an inference of intention to commit a breach of blockade. ${ }^{48}$

$\$ 681$. Right of ingress and egress to and from a blockaded port.-The usage is generally respected which permits neutral ressels, lying in belligerent ports when blockade begins, to come out with cargoes bought and shipped, bona fide, prior to its commencement. ${ }^{9}$ The authorities of the blockaded place are usually notified of the institution of the blockade, with a designation of the time within which nentral vessels will be permitted to go out. According to the practice of most nations no further notice is given; and, as it is a reasonable assumption, after the blockade has existed for a time, that

46 Hunter v. U. S. ("The Circassian"), 2 Wallace, p. 135.

${ }_{47}$ Que pour que le blocus devienne légalement obligatoire avec toutes ces conséquences, il faut que la notification diplomatique, considérée avec raison comme toujours utile, soit dans chaque cas particulier complétée, corroborée par une notification spéciale aux neutres qui se présentent sur la ligne $\mathrm{du}$ blocus. Calvo, $\S 1152$.

48 Ibid, 1176.
49 The Juno, 2 Rob. Adm., p. 119. In such cases the time of shipment is a most material fact. The Betsy, 1 Rob. Adm., p. 93. The privilege is extended to cases where there has been a delivery of goods on board ship, or in lighters, but not to shipments from warehouses. The Rolla, 6 Rob. Adm., p. 371. To take on board cargo, after the blockade has begun, is a fraudulent violation of it. The Vrow Judith. 1 Rob. Adm.. p. 152; The Nep- 
"it is impossible for those within to be ignorant of the forcible suspension of their commerce," warning to each ship, even in the absence of general notice, is deemed superfluous under such circumstances. ${ }^{50}$ While the British rule provides that "prima facie every vessel whatsoever, laden with a cargo, quitting a blockaded port, is liable to condemmation on that account, and must satisfactorily establish her exception to the general rule, ${ }^{51}$ the French practice probably extends the privilege of special warning to ressels issuing from a blockaded port with cargo laden after the commencement of blockade.52 As the privilege of refuge in a blockaded port can not be denied to a neutral ship in distress, from stress of weather, want of provisions or the like, she must be permitted to pass out when her needs have been satisfied, provided her eargo remains intact; ${ }^{53}$ and a like indulgence should be extended to a ressel employed exclusively by a minister of a neutral state for the transport of distressed marines to his own country, ${ }^{54}$ to a neutral ressel which has legally entered with a cargo found to be unsalable, ${ }^{55}$ and to a neutral vessel permitted to pass the blockade, after coming to the port in ignorance of its existence. In the case last named, however, the privilege is not extended to a cargo taken on board in the blockaded port. ${ }^{56}$ Although, strictly speaking, access to such a port is forbidden to ships of war as well as to merchant ressels, it is usual as a matter of courtesy to permit such ships of a neutral state to pass in and out subject to proper and necessary restrictions. ${ }^{57}$

tunus, ib., 171; the Juno, ib., p. notwithstanding the blockade." 119; the Hiawatha, Blatchford, Bluntschli, § 838 .

Prize Cases, p. 19.

50 The Vrow Judith, 1 Rob. p. 58.

Adm., p. 152. Knowledge of a re- ${ }_{55}^{5}$ The Potsdam, 4 Rob. Adm., cently established blockade may be p. 89 .

inferred from facts. The Herald, 3 Wallace, p. 231.

51 The Otto and Olaf, Spinks, p. 259; the Frederick Molke, 1 Rob. Adm., 88.

52 The Eliza Cornish, Pistoye et Duverdy, 1, p. 387.

53 The Charlotta, Edwards, 252; the Hurtige Hane, 2 Rob. Adm. 127. Sucl neutral ships must, however, "respect the regulations preserved by the maritime power that gives them authority to pass

56 The Juffrow Maria Schroeder, 3 Rob. Adm., 160. As to the contrary usage of Prussia and Denmark in reference to the coming out of vessels from a blockaded port with cargoes shipped after its commencement, see Rev. de Droit Int., X, 212, 239.

57 Ortolan, Dip. de la Mer, II, p. 329. The same privilege has been extended in some recent wars to mail steamers, with a guarantee 
Period usually allowed for exit.-The period of fifteen days is usually designated as the minimum time within which the exit of neutral ressels from a blockaded port is permitted. Such was the rule adopted by England and France during the Crimean war; by the United States during the American Civil war; by France in the war of 1870 ; and by Denmark in 1848 and 1864. That limit is often extended, however, for special reasons, as much as three times that number of days. After the institution of the blockade at New Orleans in 1861 , the commander of the blockading squadron extended the time in favor of vessels of deep draught as the water on the bar of the Mississippi was then unusially low; and in 1838 France, in establishing the blockade of Buenos Ayres, fixed the time within which neutral vessels could go out at forty-two days. ${ }^{58}$

Licenses. - In the case of the Franciska, ${ }^{59}$ Dr. Lushington said that by the law of nations "a belligerent may not concede to another belligerent, or take for himself, the right of carrying on commercial intercourse prohibited to neutral nations; and therefore no blockade can be legitimate that admits to either belligerent a freedom of commerce denied to the subjects of states not engaged in war. The foundation of this principle is clear, and rooted in justice; for interference with neutral commerce at all is only justified by the right which war confers of molesting the enemy, all the relations in the nature of trade being by war itself suspended." The Lords of Appeal in applying that doetrine to the British Orders in Council issued at the commencement of the war with Russia, under which free ingress into Russian ports was granted for a certain time to Russian vessels sailing from ports in the British dominions, and free egress from Russian ports for a certain time to Russian vessels bound with cargoes to British ports,-held that during the interval covered by such orders no valid blockade of the Russian ports in the Baltic could be maintained by the British fleet.60 When a license is granted

that the immunity would not be abused as a cloak for forbidden trade. Glass, Marine International Law, p. 102.

58 Consul Mure to Lord John Russell, June 6, 1861, ap. Bernard, p. 242; Martens ( N. R.) xv, p. 503 ; Hall, p. 733 ; Dana's Wheaton. Note 235; the Prize Cases, 2 Black, 676.

\section{Spinks, p. 135.}

$60 \times$ Moore, P. C. p. 56. The Lords of Appeal said in that case that "no doubt ships of one belligerent at the outbreak of war, found in the ports of another, into which they have entered for peaceful purposes, with the expectation of the continuance of peace, form an exceptional class which has a strong 
in a particular case on special grounds, although there is no express provision in it $0 r^{\circ}$ in a blockading order to that effect, if it appears to have been the intention of the sovereign granting it that the permission given by it should not be suspended by an order of blockide, it is not affected thereby. Thus in the case of the Hoffnung61 it was held that when a license had been granted to certain vessels, pursuant to a power given to the king in council by an act of parliament, to import Spanish wool from ports of Holland, it operated to protect the parties acting under it from the effects of a blockade, which had been notified on the same day on which the license was granted. "I think," Lord Stowell said, "that I am bound to presume that it was intended the parties should have the full benefit of importing these articles without molestation from a blockade, which could not be unknown to the great Personage, under whose authority, and in whose name the license issued."

$\S 682$. Effect of the cessation of blockade.-English and French theories are at one as to the principle that the restrictions imposed upon neutral commerce by blockade depend for their validity solely upon the fact that a blockade really exists at a given time. The conflict in the application of that principle arises out of diverging opinions as to the circumstances under which a blockade may cease to exist. It is admitted, however, on all hands that the right of the belligerent to subject a neutral to penalties ceases from the time when the blockade is no longer effectively maintained. ${ }^{62}$ For that reason the contention put forward by the government of the United States in 1861, that a blockade

claim to an indulgent exercise of the right of capture; and an express permission to such ship to enter their port of destination, though blockaded, might perhaps not affect the validity of the blockade."

612 Rob. Adm., p. 162. In the case of the Orion (Stewart's Reports, p. 506) Sir Alexander Grant held that the opinion of Lord Stowell in case of the Hoffnung remained untouched by his subsequent dictum in the Byfield (Edwards, p. 188). In the case of the Orion Sir A. Croke held that a license to an enemy protected him in egress from a port subsequently blockaded, as the nature of the trade afforded a presumption of such being the intention of the license. Twiss, War, 227 seq.

62 The Nancy, 1 Acton, p. 58; the Rolla, 6 Rob. Admr. p. 372. As to the manner in which a blockade once discontinued or abandoned may be renewed, see the Hoffnung, 6 Rob. Admr. p. 120; the Hare, 1 Acton's Reports of Cases before the High Court of Appeal, p. 261; Phillimore, III, p. 389. 
tstablished by proclamation continues in effect until notice of its relinquishment is given in the same way, has been justly criticised, ${ }^{63}$ as the failure of a belligerent state to give notice of discontinuance can not prolong the life of a blockade which has in fact ceased to be because the port is no longer effectively watched. If the belligerent state which has formally notified the world of the commencement of a blockade fails to give prompt and equal publicity to its discontinuance, certainly no principle of justice can authorize the confiscation of a ressel seized while approaching a port between the actual cessation of the blockade and the public and formal proclamation of the fact. Nothing more can be required of a vessel captured under such circumstances than proof of the special state of facts upon which she relies, facts which may have exempted her from a penalty incurred at the outset of the voyage through an actual intention to violate the blockade. As in the case of a de facto blockade, or the resumption of a blockade, the burden of proof is cast always upon the captor, so in the case of a regularly notified blockade the court will assume its continued existence until that presumption is overcome by evidence. ${ }^{64}$

$\S 683$. Doctrine of continuous voyages as applied to breach of blockade.-An account has heretofore been given of the origin and nature of the rule of war of 1756, under which a neutral was not permitted to engage in trade with the enemy during a war from which he had been shut out during peace; and of the extension, in 1793 , of that rule by Great Britain in such a way as to meet the conditions arising out of the opening by France to all neutrals of her coasting as well as her colonial trade. The merchants of the United States, who were heavy sufferers, often attempted to evade the prohibition by sailing from a French colonial port to an American port, and thence to Europe, as trade between the enemy's colonies and America, and between America and Europe was permitted by the British authorities. The British counterblast to that practical argument was a rule of judicial construction, embodied in the doctrine of continuous voyages, under which two voyages of the character indicated are treated as one, when a forbidden

$63 \mathrm{Mr}$. Seward to Lord Lyons, 67; the Neptunus (1798) $1 \mathrm{ib.,} \mathrm{171;}$ May 27, 1861; ap. Bernard, 238; the Circassian, 2 Wallace, p. 150; Hall, p. 731 .

the Baigorry, ib., p. 480 ; Philli64 The Triheten, 6 Rob. Adm., p. more, III, p. 401. 
cargo is carried to a forbidden destination. ${ }^{65}$ In short a continuous royage is one in which goods are finally carried to a hostile destination, after the vessel has touched at an intermediate neutral port in which she unloads and reloads before sailing for the forbidden port. ${ }^{66}$ During the American Civil War that doctrine, which had been previously applied both to blockade and contraband, and which is undoubtedly sound in principle, was given a new and dangerous extension that has received from the publicists of the world, outside of the United States, general and emphatic condemuation. ${ }^{67}$ The essence of that extension was embodied in the claim that nentral ships captured on a voyage to a neutral port could be condemned, not only when there was good reason to believe. that the ressels themselves were intended to proceed further and to make an attempt to enter a blockaded Confederate port, but also when there was reason to suspect that their cargoes were to be transferred in the neutral port to other steamers and to be thus conreyed through the blockading squadron. In the case of the Bermuda, a ressel captured while she claimed to be en route between two neutral ports, it was held that "it makes no difference whether the destination to the rebel port was ulterior or direct; nor conld the question of destination be affected by transhipment at Nassau, if transhipment was intended, for that could not break the continuity of the transportation of the cargo. ** $*$ A transportation from one point to another remains continuous, so long as intent remains unchanged, no matter what stoppages or transhipments intervene."6s In the subsequent case of the Springbok, the Supreme Conrt of the United States, after reaftirming the doctrine laid down in the case of the Bermuda, -that "where goods, destined ultimately for a belligerent port, are being conveyed between two neutral ports by a neutral ship, under a charter mide in good faith for that voyage, and withont any fraudulent connection on the part of her owners with the ulterior destination of the goods, that the ship, though liable to seizure in order to the confiscation of

65 See above, pp. 631-33.

66 The William, 5 Rob. Adm. p. 385; the Maria, ib., p. 365 . In the first case, a cargo taken on board at La Guayra was brought to Marblehead, Massachusetts, landed there, and re-embarked in the same vessel with the addition of some sugar from Havana. Within a week of its arrival it was despatched to Bilboa. Phillimore, III, p. 309 seq. 67 See above, p. 72 . 683 Wallace, 514. 
the goods, is not liable to condemnation as prize,"-condemned the cargo because a majority of the judges believed that the owners of it intended it to be sent on from Nassau to some blockaded Confederate port in some other vessel. The Court said that "upon the whole case we can not doubt that the cargo was originally shipped with intent to violate the blockade; that the owners of the cargo intended that it should be transhipped at Nassau into some vessel more likely to succeed in reaching safely a blockaded port, than the Springbok; that the royage from London to the blockaded port was, as to cargo, both in law and in the intent of the parties, one voyage; and that the liability to condemnation, if captured during any part of that voyage, attached to the cargo from the time of sailing."69 The outery against such a rule of law, admitting that the facts were as they were assumed to be by the court, rests upon the well-grounded objection that "if a belligerent may capture a neutral vessel honestly intended for a neutral port, and condemn her cargo because he vaguely suspects it will be transferred to some ressel unknown to him, and sent on to some hostile destination also unknown to him, a new disability has been imposed upon neutral commerce. States at war will in future be able to establish what has well been called a blockade by interpretation of any neutral port situated near the coast of an enemy."7o

$\S 684$. Penalty for breach or attempted breach of blockade. - The penalty for a breach or attempted breach of blockade, in the event of capture, is the forfeiture of both ship and cargo, provided they belong to the same owner. If their owners are different, the ressel may be condemned and the cargo restored, when the person to whom it belongs is ignorant at the time of shipment that the port of destination is blockaded, or in case the ressel deviates from her legitimate course in order to enter a blockaded harbor. If, however, such deviation is made to a port, the blockade of which was known before the ressel sailed, the complicity of the owner of the cargo is assumed upon the theory that the change was prompted by his interests. ${ }^{71}$

605 Wallace, pp. 1-28.

70 Lawrence, Principles, p. 597.

71 The Comet, Edwards, p. 32; the Columbia, 1 Rob. Adm., p. 154; the Alexander, 4 ib., p. 93 ; the
Adonis, 5 ib., p. 258; the Marianna Flora, 11 Wheaton, p. 57; the Panaghia Rhomba, xii Moore, P. C. p. 180; the Vrow Judith, 1 Rob. Adm., 150. 


\section{CHAPTER VIII.}

\section{RIGHT OF VISIT AND CAPTURE.}

$\$ 685$. Visit and capture in time of peace.-Apart from treaty, there is no right to visit a ship without a right to axmine first her papers, and then, if they are not satisfactory, the cargo, in order that the actor may thus determine whether or no he will assume the responsibility of detaining the ship itself. The substantive right involved is the right of eapture to which the right of visit and search is merely ancillary. ${ }^{2}$ To justify the exercise of the substantive right the inquiring state must employ it to enforce some kind of jurisdiction lawfully belonging to it. From what has been said already it appears that even in time of peace the right may be exercised in the execution of revenue laws within the territorial waters of the offended state; in the case of ressels suspected of being piratical, provided it is asserted in good faith, on the high seas or in the territorial waters of the state to which the risiting ressel belongs; and in a proper case of self. defense. $^{3}$ A review has also been made of the history of the right of visit in time of peace as a means of ascertaining the real nationality of ressels suspected of being engaged in the slave trade, the claim to which right Great Britain really abaudoned in 1858.4

$\S 686$. Visit and capture, in time of war. Nature and scope of the right.-Subject to the foregoing exceptions it may be said that the right of visit and capture "is strictly a belligerent right, allowed by the general consent of nations in time of war, and limited to those occasions." It is the process through which a belligerent gives effect to his rights over neutral property at sea which has become noxious to him by reason of some breach of the law of neutrality. By means of

1 The Louis, 2 Dodson's Adm., III, § cccxxvi; Webster's Works, vi, p. 238; the Antelope, 10 Wheaton, pp. 335, 339; Requelme, Derecho pp. 122, 123; the Marianna Flora, Pub. Int., I tit. ii, ch. vii; Bello, 11 Wheaton, pp. 39,40 .

Derecho Int., pt. II, ch. viii, $\$ 10$;

2 As to the British attempt to Wheaton, Hist. Law of Nations, pp. draw a distinction between the 706 seq.

right of visit and the right of search, see British Foreign State Papers, xxx, p. 1165; Phillimore,

3 See above, pp. 310-11.

4 See above, pp. 238-40.

5 Judge Story in the Marianna 
the visit he ascertains whether a merchant vessel carrying the flag of a neutral state is really such, and whether she has been guilty of any breach of the law; by means of the capture he puts himself in a position to inflict the proper penalty. As this right of a belligerent to control the intercourse between neutrals and his enemy is an incident of war, which can be waged only by or under the authority of a state, its exercise is limited to ressels plovided with commissions by the sovereign power. ${ }^{6}$ The claim that the right of visit and capture may be enforced against neutral men-of-war having" ended with the beginning of the last century when it was disarowed by Great Britain in the case of the Chesapeake and Leopard, 7 it may now be said that only the private ressels of the neutral state are subjects of this belligerent privilege. Against them it can be asserted on the higl seas and within the territorial waters of the belligerent or his enemy. In the" words of Lord Stowell, "the right of risiting and searching" merchant ships upon the high seas, whatever be the ships, whatever be the cargoes, whatever be the destination, is an uncontestable right of the lawfully commissioned cruisers of a belligerent nation. I say, be the ships, the cargoes, and the destination what they may, because, till they are visited and searched, it does not appear what the ships, or the cargoes, or the destination are; and it is for the purpose of ascertainiug these facts that the necessity of this right of visitation and search exists. * * The right must unquestionably be exercised with as little of personal harshness and of rexation in the mode as possible, but soften it as much as you can, it is still a right of force, though of lawful force in something of the nature of civil process when force is employed, but a lawful force which cannot be lawfully resisted."'s

$\$ 687$. Formalities of visit.- While it is generally conceded that the right of visit must be attended with certain formalities, it has been held that a lack of conformity to the forms of risit, and of attention to the eridences of nationality, prescribed by the regulations of the state to which the visiting

Flora, 11 Wheaton, p. 1: "It is founded upon necessity, and is strictly and exclusively a war right, and does not exist in time of peace." Kent. 1 Com. p. 153.

6 It must be exercised by the public ships of state-the regular navy-or by private vessels com- missioned for the purposes of the particular war, called privateers. Phillimore, III, \& cccxxx.

7 See above, p. 302 , and also Wharton, Int. Law Dig., $\S 3315 \mathrm{~b}$, $319,331$.

s The Maria, 1 Rob. Adm., p. 359. 
ship belongs, will not invalidate the eapture, if the fact be proved before the prize conrt that a good cause for it really existed. ${ }^{9}$ There is nevertheless a general disposition to observe certain formalities incident to the right of visit which are fairly well understood, despite the fact that no regulations. as to all details have received universal assent. The usual method of approach for the purpose of visit and search is for the visiting ship, when at a reasonable distance, to hoist the national ensign and to fire a blank charge, known as the semonce or affirming gun. ${ }^{10}$ It then becomes the duty of the neutral vessel to obey such summons by heaving to, to permit boarding, ${ }^{11}$ and at the same time to display her national colors. According to the Naval War Code of the United States (Mrt. 32), prepared by a professional sailor," "the following mode of procedure, subject to any special treaty stipulations, is to be followed by the boarding vessel, whose colors must be displayed at the time: The ressel is brought to by firing a gun with a blank charge. If this is not sufficient to cause her to lie to, a shot is fired across the bows, and in case of tlight or resistance force can be used to compel the ressel to surrender. The boarding ressel should then send one of its smaller boats alongside, with an officer in charge wearing side arms, to conduct the search. Arms may be carried in the boat, but not upon the persons of the men. When the officer goes on board of the ressel he may be accompanied by not more than two men, unarmed, and he should at first examine the ressel's papers to ascertain her nationality, the nature of the cargo. and the ports of departure and destination. If the papers

9 La Tri-Swiatitela, Dalloy, Jurisp. Gén. Ann. 1855, III, p. 73.

10 Heffter, § 169; Hautefeuille, Des Droits des Nations Neutres, III, pp. 438-39. "We are not disposed to admit that there exists any such universal rule or obligation of an affirming gun, as has been suggested at the bar." Judge Story in the Marianna Flora, 11 Wheaton, pp. 48-50. See also Dahlgren, Mar. Int. Law, p. 103.

11 In the absence of treaty stipulations, which were once over precise, the distance which the boarding vessel should maintain is unfixed by custom. As the old claim of cannon shot distance can no longer prevail, nothing more can be said than that the distance should be a convenient one. According to modern usage the mas. ter of the merchantman may be summoned on board the cruiser with his papers. The Eleanor, 2 Wheaton, p. 262. The regulations of the German and Danish navies recognize that right. Rev, de Droit Int., $\mathrm{x}$, pp. 214, 238. For the contrary view, see Pistoye et Duverdy, 1, p. 237.

12 Capt. Charles H. Stockton, U. S. N. Ortolan, who was himself a naval officer, complains that such 
show contraband, an offense in respect of blockade, or enemy service, the ressel should be seized; otherwise she should be released, unless suspicious circumstances justify a further search. If the vessel be released, an entry in the log book to that effect should be made by the boarding officer."

$\S 688$. Examination of ship's papers.-Notwithstanding the fact that the number and form of such papers differ, according to the laws of the various maritime countries, it is generally admitted that they should always be sufficiently definite to determine the nationality of the ship, her destination, and the ownership of ressel and cargo. There should be (1) the register, vouching the nationality of the vessel, and specifying tho owner, the name and size of the ship, and all other particulars necessary for identification; (2) the passport or sea letter issued by the neutral state; (3) the muster roll, containing names and other particulars concerning the crew; $(4)$ the logbook; (5) the charter party, or other contract under which the ship is let for the current royage; (6) invoices and bills of lading, and the duplicate of the bill of lading, or acknowledgment from the master of the receipt of the goods specified therein, and promise to deliver them to the consignee or his order. $^{13}$ In the hope of bringing about uniformity in the character and extent of such documents, the Institut de Droit International has proposed as a matter of international rule that every vessel shall be required to possess the following: (1) Les documents relatifs à la propriété du navire; (2) Le connaissement; (3) le rôle d'équipage, avec l'indication de la nationalité du patron et de l'équipage; (4) le certificat de nationalité, si les documents mentionnés sous le chiffre $3 \mathrm{n} y$ suppléent; (5) le journal de bord. ${ }^{14}$ Absence of papers, as well as false papers, or gross irregularities, omissions or inconsistence in such as are produced, will justify detention

regulations are often open to criticism because "they have not been drawn by sailors." Dip. de la Mer, II, 256 .

13 A list of the papers required by the law of each civilized state will be found in the Manuals of Prize Law issued by the naval authorities of such of them as are maritime. "The papers generally expected to be on board of a vessel are: (1) The Register; (2) The crew and passenger list; (3) The $\log$ book; (4) A bill of health; (5) The manifesto of cargo; (6) A charter party, if the vessel is chartered; (7) Invoices and bills of lading." Naval War Code of U. S., Art. 33. For the lists of the more important maritime nations, ses Holland's Admiralty Manual of Naval Prize Law, pp. 52-9; Halleck (Baker ed.) ii, pp. 98-105.

14 Ann. de l'Inst., 1883, p. 217. 
by a belligerent cruiser which has the right to expect information from documents in the usual and legitimate form. ${ }^{\mathbf{1 5}}$ After the visiting officer has questioned the master of the ressel and examined her papers, if circumstances of suspicion are thus revealed, but not otherwise, he has the right to call his boat's crew on board in order that they may make a thorough search of the ship. ${ }^{16}$

$\S 689$. Effect of resisting visit and search. Conflicting English and American rules. $-A$ s it is the duty of the neutral to submit to search, an obligation lies on the neutral ship to make no resistance. Any resistance, therefore, or attempt to escape, or to avoid the search and its consequences, by force or fraud, if such measures do not involve the destruction of the ressel at the time, may involve her, together with her cargo, in seizure and subsequent confiscation. When resistance is made by the master of the ressel, the question arises as to the effect of such resistance upon cargo, owned perchance by persons powerless to control his conduct. Notwithstanding that fact, however, English and American courts agree that in case of such resistance by a neutral master, both vessel and cargo become subject to confiscation. ${ }^{17}$ Only in case the neutral goods are placed on board a belligerent merchantman are they exempt from confiscation in the event of capture after resistance by the master, because, while such master has a right to protect the belligerent goods of his cargo, the neutral shipper is not supposed to know when he makes the shipment that such resistance to search will occur. ${ }^{18}$ If, however, the neutral places his goods on a belligerent ship of force, he is presumed to know that there is an intention to resist risit and search, and that force will be relied on to protect his goods. In that event, according to the rule of the English courts, confiscation will follow, because the neutral then "betrays an intention to resist visitation and search, which he could not do by putting them on board a mere merchant vessel, and, in so far as he does this, he adheres to the bellig-

15 Un des principes du droit des gens est, que tout navire droit être muni de pièces de bord, qui permittent de constater son identité, et de reconnaître sa nationalité. Tout navire neutre qui, en temps de paix, navigue armé sans pièces de bord, s' expose à être traité comme pirate. Pistoye et Duverdy, Rob. Adm. p. 232.
Traité des Prises. I, p. 416.

16 Ortolan, Dip. de la Mer, III, ch. vii.

1i The Maria, 1 Rob. Adm., p. 377; the Franklin, 2 Acton, p. 106; Holland's Manual of Prize Law, pp. 43-44.

18 The Catherina Elizabeth, 5 
erent. * * If a party acts in association with a hostile force, and relies on that force for protection, he is pro hac vice to be considered an enemy." 19 As heretofore pointed out, ${ }^{20}$ the Supreme Court of the United States, in a judgment from which Mr. Justice Story earnestly dissented, repudiated the English rule in that respect, and declared that a neutral may lawfully employ an armed belligerent vessel for the transport of his goods, without the loss of their neutral character, either by the armament, or by the resistance made by such vessel, although he charter the whole ressel and is on board at the time, provided he does not aid in such armament or resistance. $^{21}$

\$690. Other grounds justifying capture.-Apart from the causes already discussed, a vessel may become liable to capture (1) when there is reasonable ground to believe, from evidence obtained by the visit, that it is engaged in an illicit act, or that its cargo is liable to confiscation; (2) when the vessel is in possession of false documents, or when there has been a concealment, destruction, or defacement of documents. Under the first head may be ranged all offenses arising out of the carriage of contraband, including cases in which the owner of the ship is privy to their carriage, and all such offences as arise out of the performance of unneutral services or out of breach or attempted breach of blockade. Under the second head stands first the offence arising out of the possession of false documents which is invariably held to be a sufficient reason for bringing in a vessel for adjudication. While some countries, notably Russia and Spain, hold that the possession of false or double papers of any kind, renders both ship and cargo liable to confiscation, Great Britain and the United States adopt the more lenient riew that the possession of such papers does not necessarily involve it. $B y$ the states last named such fictitions papers are only considered noxious, when they relate to the voyage in which the capture is made, and when there is reason to believe that they were prepared with the express intention to deceive the belligerent making the capture, or that they would operate as a fraud on the

19 The Fanny, 1 Dodson, pp.448-9. now completed it, and never in 20 See above, p. 716.

21 The Nereide, 9 Cranch, p. 441. my whole life was I more entirely "I have been lately engaged in in their juthent" Story's drawing up my dissenting opinion I, p. 256. in the case of the Nereide. I have 
rights of the captors, if admitted as genuine.22 Even the destruction or "spoliation of papers," which is regarded as a more serious offence than concealment, does not necessarily involve confiscation. The severity of the French rule, which declared to be good prize all ressels with their cargoes on simple proof of the fact that their papers had been destroyed, regardless of their cliaracter, ${ }^{23}$ has been tempered in English and American practice by a qualification which admits explanation even of a circumstance apparently so incriminating. If such explanation be frank and satisfactory the ressel will not be condemned for that offence alone. If, however, the destruction took place under circumstances indicating that the intent of the act was to conceal the real character of the papers, condemnation would no doubt follow. ${ }^{24}$

$\$ 691$. Duties and liabilities of a captor.-After conducting his visit and capture with as much consideration for persons, and for the safety of property as the necessities of the ease will admit, it is the duty of the eaptor to bring in, with all convenient speed, the captured property for adjudication in the most accessible prize court of his own state. If he takes his prize unnecessarily to an inconrenient port for adjudication he may be justly mulcted in demurrage, costs and dam. ages. ${ }^{25}$ If the ressel is destroyed, full compensation must be given to the neutral with damages and costs, beeause the destruction of a neutral ship is a punishable wroug,--if it can not be brought in for adjudication, it can and ought to be released. ${ }^{26}$ If the captured ressel is not capable of reaching

22 The Eliza and Katy, 6 Rob. treme application of the rule, see Adm., p. 192; the St. Nicholas, 1 the case of the Apollos, Ibid. p. 81. Wheaton, p. 417; Blaze v. N. Y. Ins. Co., 1 Caines Rept., p. 565; Phoenix Ins. Co. v. Pratt, 2 Binney Rept., 308; the Mars, 6 Rob. Adm., p. 79; Negrin, p. 251; Rev. de Droit Int., x, p. 611; Halleck (Baker ed.) II, p. $271 \mathrm{seq}$; Duer on Ins., 1, p. 738 .

23 The severity of the French rule was there so modified in practice as to require that the destroyed papers should be proven to be such as would in themselves involve confiscation. Pistoye et Duverdy, II, p. 73, citing the case of La Fortuna. For a more ex-

24 Bernardi v. Motteaux, Doug. las, Rept., 581; the Rising Sun, 2 Rob. Adm., p. 106; the Hunter, 1 Dodson, p. 487; Livingston v. the Maryland Ins. Co., 7 Cranch, p. 544; the Commercen, 1 Wheaton. p. 386 ; the Pizarro, 2 Ibid. 241; Kent. Com., p. 158.

25 The Anna, 5 Rob. Adm. p. 385; the Wilhemsberg, ib., p. 143; the Catherina Elizabeth, 1 Acton, p. 309.

26. The Felicity, 2 Dodson. p. 383; the Zee Star, 4 Rob. Adm., p. 71; the Lucade, Spinks, p. 221. 
the port in which the adjudication is to take place, but can be safely taken to a neutral port, she should be taken thither and kept there, provided the local authorities will consent to receive her. In that event the ship's papers, the witnesses, and the necessary affidavits must be sent in charge of an officer to the nearest port of the captor in which a prize court sits. While the captured property is being brought in the captor must exercise due care in the preservation of both vessel and cargo; and, excepting the perils of the sea, he is liable for the results of his negligence. The prize master is regarded in the light of a bailee, and as such is held to a strict accountability in the event of the loss of the captured property. ${ }^{27}$

$\$ 692$. Burden on captor in prize court.-Immediately upon his arrival in port, it is the duty of the prize master to institute proceedings for adjudication of his prize in the proper court, to which he should deliver the proper papers and furnish the necessary evidence for its examination. While the captor may detain persons as witnesses, he can not treat them as prisoners of war, nor can he exact pledges with respect to their future conduct as a condition of their release. If he maltreats them the court will decree damages. ${ }^{2 s}$ As the property in a neutral ressel or cargo does not vest in the belligerent upon the completion of the capture, he can acquire title only through a decree of condemnation pronounced by a competent court at the conclusion of proceedings conducted according to law. ${ }^{29}$ Although the prize court in which such a decree is rendered sits ordinarily in the territory of the belligerent, the law which it administers upon his initiative is international law. ${ }^{30}$ Under that law the neutral, in the absence of proof that he has rendered himself liable to penalties, has the benefit of the presumptions that flow from his professed neutrality. His goods being prima facie free from liability to seizure and confiscation, the burden is upon the

27 Der Mohr, 4 Rob. Adm. p. 314: Die Fire Damer, 5 ib., p. 357 ; the Palmyra, 12 Wheaton, p. 1; Locke v. The U. S., 7 Cranch, p. 339 ; Jecker v. Montgomery, 13 Howard, p. 505; the George, 1 Mason, p. 24. 28 The Vrow Johanna, 4 Rob. Adm.p.351; the San Juan Raptista, 5 ib., p. 23; Rev. de Droit Int., $\mathrm{x}$, p. 239; the Anna Maria, 2 Wheat., p. 332 .

29 For an answer to the question, to whose benefit does the capture enure, see The Ships Taken at Genoa, 4 Rob. Adm., p. 403; the French Guiana, 2 Dodson, p. 157; Phillimore, III, § ccclvi.

30 See above, p. 42. 
captor to satisfy the court by competent and sufficient evidence that he has committed such acts as should subject them to such penalties. ${ }^{31}$

\section{$\S 693$. Can convoyed ships be visited? Continental practice.-} In the account heretofore given of the origin and scope of the Second Armed Neutrality League of 1800 the fact was emphasized that as early as $\mathbf{1 6 5 3}$ Sweden, after complaining that the goods of her subjects were plundered by privateers, gave orders to her ships of war convoying merchant vessels "to decline that they or any of those that belong to them br searched;" and in the next year, when some Dutch merchant ressels under convoy of a man-of-war were searched by the English, the states-General, while declining to make complaint, declared that they were "persuaded that such visitation and search tended to an inconveniency of trade." Not, however, until the American War of Independence was the right of neutral states to protect their carrying trade by convoy seriously urged. Then it was that the Dutch stood forth as its defender, and to their side were soon drawn that group of maritime states known as the Baltic powers. The unyielding opposition set up by Great Britain to the attempt thus made to curtail the belligerent right of search really induced Denmark, Sweden, Prussia and Russia to unite in the Second Armed Neutrality League of 1800 which, after repeating the four principles embodied in the first, added another, declaring in effect that the statement of an officer in command of a neutral ship of war that there is nothing contraband on board the ressels convoyed by him should cut off further inquiry by the belligerent. The temporary concession made by Great Britain in the treaties concluded with Russia, Sweden and Denmark in 1801 and $1802,3^{32}$ whereby she agreed as a part of the compromise then entered into that the right to search merchant vessels under convoy should be subjected to certain limitations, was so far withdrawn by the treaties concluded between the same parties in 1812 and 1814 as to leave Great Britain, on the one hand, and the Baltic powers, on the other, free to maintain their original contentions. ${ }^{33}$

31 Hall, pp. 761-2.

32 See above, pp. 635-38.

33 Martens (N. R.) 1, pp. 481 and 666 , and III, p. 227 . Les traités de paix conclus en 1812 et en 1814 entre de l'Angleterre, la Russie, la Suède et le Danèmark rétablirent les relations commerciales entre ces quatre quissances sur le pied des traités de la fin du XVIIIe siècle, 
Since that time the Baltic powers, France, Germany, Austria, Spain and Italy, have given empliasis to the principle that merchant vessels under convoy are exempt from the right of search by providing in their naval regulations that the declaration of the convoying officer shall be accepted as final. The Continental jurists, with but few dissenting voices, have united in the conclusion that the practice thus settled by a large group of nations has resulted in the establishment of the exemption from search of merchant vessels under convoy as a canon of international law. ${ }^{35}$

English and American practice.-While the Continental nations have been thus uniting in support of an expedient which certainly curtails the advantage of a belligerent state armed with a great sea power, Great Britain has firmly maintained her right to resort to the ancient practice upon which she has always acted, and which is now embodied in her Admiralty Manual of Prize Law. ${ }^{36}$ So far as the judge-made law of the United States is concerned English and American jurists and text writers are in perfect accord. In the case of the Nereide Judge Story said, in his dissenting opinion, that "the law proceeds yet farther and deems the sailing under convoy as an act per se inconsistent with neutrality, as a premeditated attempt to oppose, if practicable, the right of search, and therefore attributes to such preliminary act the full effect of actual resistance." That conclusion was prefaced by the statement that in relation to his commerce the neutral "is bound to submit to the belligerent right of search, and he can not lawfully adopt ans measures whose direct object is to withdraw that commerce from the most liberal and accurate search without the application on the part of the belligerent of superior force." 37 Kent expresses the same view when he says that "every belligerent power, who is no party to the agreement, has a right to insist on the only security known to the law of nations on this subject, independent of any special covenant, and that is the right of personal visitation and search, to be exercised by those who have an interest in making it. **A merchant vessel has no right to say for itself,

sans faire revivre les principes transactionnels proclamés en 1801. Calvo, \& 1219 .

34 For the announcement made by Prussia, Austria and Denmark during the war of 1864 that they would not visit vessels under convoy, see Martens (N. R. G.) xv, p. 113.

35 Cf. Calvo, § 1220.

36 Holland, p. 2.

379 Cranch, pp. 439-40. 
and an armed vessel has no right to say for it, that it will not submit to visitation and search, or to be carried into a proximate court for judicial inquiry."3s The American publicist thus pointedly denies, in the latter part of his statement, the contention upon which the immunity of a convoyed merchantman is fombled, and that is that the immunity from visit possessed by a ship of war extends itself to all vessels under its control. ${ }^{39}$ The common law right to search vessels under conroy, thus asserted by American judges and text writers, has, howerer, often been surrendered by the political department of the government of the United States in treaties entered into, as a general rule, only with states in this hemispluele..$^{40}$ And, in the Naval Tar Code issued in 1!900, a very close approach to Continental practice has certainly been made in the article (30) which declares that "convoys of neutral merchant ressels, under escort of vessels of war of their own state, are exempt from the right of search, upon froper assurances, based on thorough examination, from the commander of the convoy."

Controversy between United States and Denmark as to convoy. - The controversy in question grew out of the application by Demmark of the general principle that resistance to visit and search by a neutral master furnishes a good ground for capture to the following state of facts. It seems that latrge numbers of American vessels, after receiving cargoes of naval stores in Russia, were in the labit of assembling on the coasts of sweden where they placed themselves under the convoy of British men-of-war until they were out of danger. To meet such conditions Denmark, then at war with England, issued in 1810 an ordinance relating to captures, which declares as good and lawful prize "such ressels as, notwithstanding their flay is considered neutral, as well with regard to Great Britain as the powers at war with the same nation, still, either in the Atlantic or Baltic, have made use of English convoy." It is

381 Com., p. 154.

39 Ortolan, Dip. de la Mer, II, p. 271.

40 The notable exceptions are the treaty with Sweden, 1816 (N. R., iv, p. 258), and that with Italy, 1871 (Treaties and Conventions, U. S., p. 581). Art. XIX of the last named provides that "the visiting and examining of a vessel shall apply only to those which sail without a convoy; and when said vessels shall be under convoy the verbal declaration of the commander of the convoy, on his word of honor, that the vessels under his protection belong to the nation whose flag he carries, and, when bound to an enemy's port, that they have no contraband goods on board shall be sufficient." 
un reasonable to suppose that in issuing such instructions to its cruisers, in the hope of breaking up a traftic which the nature of the cargoes involved certainly rendered suspicious, Denmark intended to do more than to lay down for the guidance of its tribunals such principles as that government understood to be just principles of law. After several stragglers had been captured, without actual resistance being mate, they were condemned by the Danish prize courts on the ground that mere intention to resist, manifested by the simple fact of joining the convoy, was sufficient to involve confiscation. "The principle laid down in the ordinance, as interpreted by the Danish tribunals, was, that the fact of having navigated under enemy's convoy is, per se, a justifiable cause, not of capture merely, but of condemnation in the courts of the other belligerent; and that, without inquiring into the proofs of proprietary interest, or the circumstances and motives under which the captured ressel had joined the convoy, or into the legality of the voyage, or the innocence of her conduct in other respects." The protest of the government of the United States against that extreme position led to a negotiation in the course of which the American negotiator, the famous Wheaton, contended that "being found in company with an enemy's convoy might, indeed, furnish a presumplion that the captured ressel and cargo belonged to the enemy, in the same manner as goods taken in an enemy's vessel are presumed to be enemy's property until the contrary is proved; but this presumption is not of that class of presumptions called presumptiones juris et de jure, which are held to be conclusive upon the party, and which he is not at liberty to coutrovert. It is a slight presumption only, which will readily yield to countervailing proof." ${ }^{41}$ The final outcome was a

41 Dana's Wheaton, pp. 699-708. courts did not violate any estabAs Mr. Wheaton was the negotia- lished rule of international law. tor of the treaty made with Den- Manning (p. 369) and Wildman mark in 1830 for the settlement of (ii, 126) and Woolsey (§ 193) are the question at issue, special in- of that opinion. Hautefeuille terest attaches to his very full account of the matter from his point of view. Dana says, however, at the conclusion of note 245 , that "there seems little doubt that, in condemning these vessels, as the practice in respect to convoys then stood, and in the relations of Denmark with France, the Danish (tom. iii, p. 162-64) gives the arguments, but no opinion. Ortolan seems to doubt the soundness of the American position (tom. i, p. $245)$. Halleck gives the arguments and no opinion (pp. 617-619)." Hall evidently opposes Wheaton's views, p. 759 , note 1 . 
treaty ${ }^{42}$ signed between the United States and Denmark in 1830 in which the latter agreed to pay a sum en bloc by way of indemnity to the American citizens whose property had been seized, coupled with the declaration that the convention, having no other object than the termination of all the claims, "can never hereafter be invoked, by one party or the other, as a precedent or rule for the future."

42 Treaties and Conventions of U. S., p. 235. Elliot's Am. Dip. Code, 1, p. 453. 


\title{
APPENDIX.
}

\author{
"INSULAR TARIFF CASES."
}

\section{(Referring to last clause on page 601.)}

53 Since the text was printed the Supreme Court of the United States has delivered weighty judgments in the cases of De Lima v. Bidwell; Dooley v. U. S.; Downes v. Bidwell; Armstrong v. U. S.; Goetze v. U. S.; and Crossman v. U. S., now known as the "Insular Tariff Cases," to be reported in 182 U. S. After a careful study of the prevailing opinions the author can discover no material departure from the following propositions, which he assumed to be settled and fundamental when the text was written: (1) That when territory is subdued by the armies of the United States, it passes under the despotic war power of the President, as commander-in-chief, who, in the exercise of that power, is unrestrained by the constitution and the laws of the United States; (2) that when territory is thus acquired by the United States by conquest, its holding is a mere military occupation until, by a treaty of peace, the acquisition is confirmed; (3) that when the new acquisition passes into a territorial condition the despotic war power vested in the President as commander-in-chief is superseded by the power of Congress which is equally unlimited, except as to such constitutional "prohibitions as go to the very root of the power of Congress to act at all, irrespective of time or place;" (4) that until the ceded territory is admitted as a state, it is not drawn within the circle of the constitutional guarantees which apply, in their entirety, to states only.

In the case of De Lima v. Bidwell the leading facts were these: The invasion of Porto Rico, begun in July, 1898, by the military forces of the United States, was suspended on August 12th by a protocol entered into between the Secretary of State and the French Ambassador on the part of Spain, providing for a suspension of hostilities, the cession of the island, and the conclusion of a treaty of peace. On October 18th Porto Rico was evacuated by the Spanish forces, and, on December 10th, a treaty was signed at Paris, under which Spain ceded the island to the United States. Such treaty was ratified by the President and Senate February 6th, 1899, and by the Queen Regent of Spain, March 19th. On March 2nd, an act was passed making an appropriation to carry out the obligations of the treaty; and, on April 11 th, the ratifications were exchanged and the treaty proclaimed at Washington. De Lima \& Company sued the Collector of the Port of New York to recover duties alleged to have been illegally exacted and paid under protest upon certain importations of sugar from San Juan, in the island of Porto Rico, during the autumn of 1899 , and subsequent 
to the cession of the island to the United States. The duties in question were exacted under the tariff aet of July 24th, 1897, commonly known as the Dingley Act, which declares that "there shall be levied, colleeted, and paid upon all articles imported from foreign countries" certain duties therein specified. Unless Porto Rico was a "foreign country," within the meaning of the tariff laws, at the time these duties were levied, it was admitted that their exaction was illegal. As Congress had not acted in any manner in regard to Porto Rico, prior to the exaction of the duties in question, the isfand certainly remained a "foreign country" as to the United States, unless it had been transformed into domestic territory solely through the force of the treatymaking power, unaided by Congressional legislation. Prior to the announcement of the judgment in the De Lima case, the author assumed it to be settled by the decisions of the Supreme Court that, until the status of territory so oceupied, and that of its inhabitants has been altered by adequate congressional legislation, such territory does not cease to be foreign, nor do its inhabitants cease to be aliens, in the sense in which those words are used in the laws of the United States. That conclusion was based in the main upon the pointed deelarations made in U. S. v. Rice, 4 Wheat. 246, and in Fleming v. Page, 9 How. 603. The result of the effort of Justice Brown to reverse the rule thus settled can hardly be permanent, unless he has been able to overthrow the authority of Fleming v. Page,-first, by the assumption that the gravamen of that decision is mere dicfum; second, by the assumption that a contrary rule was really announced in the subsequent case of Cross v. Harrison, 16 How. 164. Justice Gray expressed himself with sententious foree, as to the first assumption, when he dissented from the conclusion announced by Justice Brown upon the ground that it appeared to him "irreconcilable with the unanimous opinion of this court in Fleming v. Page, 9 How. 603, 13 L. ed. 276, and with the opinions of the majority of the justices in the case, this day decided, of Downes v. Bidwell, 181 U. S." As to the second assumption, it is hard to understand how the conclusion reached in Fleming v. Page could be weakened by that announced in Cross v. Harrison, in view of the fact, as stated by Justice White in the ease of Downes v. Bidwell, that the opinion in the latter case "pointedly referred to a letter of the Secretary of the Treasury directing the enforcement of the tariff laws of the United States, upon the express ground that Congress had enacted laws which recognized the treaty of cession. Besides, the decision was expressly placed upon the conditions of the treaty, and it was stated, in so many words, that a different rule would have been applied had the stipulations in the treaty been of a different character." The dominant idea which seems to have driven Justice Brown to the conclusion reached in the De Lima case, as stated by himself, was that "we are unable to acquiesce in this assumption that a territory may be at the same time both foreign and domestic." Such a seruple certainly has no foundation in the general eanons of international law which even go so far as to recognize the principle that the same territory may possess, at the same moment, a belligerent and a neutral character. (See above, p. 594.) The most eogent reason, however, for the re-establishment of the rule, 
supposed, for so long a time, to have been settled in Fleming v. Page, is to be found in the fact that the admission of a new community into our customs union is purely a political function that should belong exclusively to the federal legislature. To bring about such a ehange in the application of statute law, through judieial construetion merely, is a dangerous extension of the power of judicial legislation.

The vacuum existing in the De Lima case, by reason of the lack of Congressional action, was filled by the enactment, on April 12th, 1900, of the aet known as the Foraker Aet, to provide temporary revenues and a civil government for Porto Rico, which took effeet May 1st, 1900. The case brought by Downes against the Collector of the Port of New York was to recover certain duties, paid under protest, upon certain merchandise brought thither from San Juan, in the island of Porto Rico, during the month of November, 1900, imposed under the authority of the Foraker Act. The plaintiff assailed the constitutionality of that act on the ground that it conflicts with Art. 1, $\$ 8$, of the constitution of the United States, which provides that "all duties, imposts and excises shall be uniform throughout the United States." The question thus presented was this: To what extent does the federal constitution apply to a territory of the United States? The prolonged controversy on that subject, extending from the makins of the present constitution, reached a decided stage when the Supreme Court declared, in 1879, without a dissenting voice, in the case of First National Bank of Brunswick v. County of Yankton, 101 U. S.. 129 , that "the territories are but political subdivisions of the outlyin" dominion of the United States. They bear much the same relation to the general government that counties do to the states, and Congress may legislate for them as states do for their respective municipal organizations. The organie law of a territory takes the place of a constitution, as the fundamental law of the local government. It is obligatory on, and binds the territorial authorities; but Congress is supreme and, for the purposes of this department of its governmental authority, has all the powers of the people of the United States, except such as have been expressly, or by implication, reserved in the pro. hibitions of the constitution." In Church of Jesus Christ of L. D. S. v. United States, 136 U. S., 1, the Supreme Court, speaking througb Justice Bradley, said, in holding that Congress had power to repeal the charter of the church, that "the power of Congress over the territories of the United States is general and plenary, arising from and incidental to the right to aequire the territory itself, and from the power given by the constitution to make all needful rules and regulations respecting the territory or other property belonging to the United States. *** Doubtless Congress, in legislating for the territories, would be subject to those fundamental limitations in favor of personal rights which are formulated in the constitution and its amendments; but these limitations would exist rather by inference and the general spirit of the constitution, from which Congress derives all its powers, than by any express and direet application of its provisions." In the case of Downes v. Bidwell a bare majority of the Supreme Court, speaking through the weighty words of Justice Brown, reiterated that historic and unassailable doctrine in the declaration 
"that the power over the territories is vested in Congress without limitation, and that this power has been considered the foundation upon which the territorial governments rest, was also asserted by Chief Justice Marshall in M'Culloch v. Maryland, 4 Wheat. 316, 422, 4 L. ed. 579, 605, and in United States v. Gratiot, 14 Pet. 526, 10 L. ed. 573." So far from attempting to enlarge the power of Congress over the territories, as defined in the earlier cases, Justice Brown, in announcing the prevailing opinion in the case in question, manifested a decided inclination to narrow it, when he said: "To sustain the judgment in the case under consideration it by no means becomes necessary to show that none of the articles of the constitution apply to the island of Porto Rico. There is a clear distinction between such prohibitions as go to the very root of the power of Congress to act at all, irrespective of time or place, and such as are operative only 'throughout the United States' or among the several states. Thus when the constitution declares that 'no bill of attainder or ex post facto law shall be passed,' and that 'no title of nobility shall be granted by the United States,' it goes to the competency of Congress to pass a bill of that description. * * * Whatever may be finally decided by the American people as to the status of these islands and their inhabitants, - whether they shall be introduced into the sisterhood of states, or be permitted to form independent governments, -it does not follow that, in the meantime, awaiting that decision, the people are in the matter of personal rights unprotected by the provisions of our constitution, and subject to the merely arbitrary control of Congress." While the court was thus emphasizing the fact that the personal rights of inhabitants of territories are guarded, to some extent at least, by such constitutional limitations "as go to the very root of the power of Congress to act at all, irrespective of time or place," it was careful to say that such provisions of the constitution as are operative only "throughout the United States" or among the several states, are applicable to the territories acquired by purchase or conquest, only when Congress shall so direct. An incontrovertible historical fact is recognized by the statement that the existing federal constitution was made for the "United States, by which term we understand the states whose people united to form the constitution, and such as have since been admitted to the Union upon an equality with them." The court therefore concluded that "the island of Porto Rico is a territory appurtenant and belonging to the United States, but not a part of the United States within the revenue clauses of the constitution; that the Foraker Act is constitutional, so far as it imposes duties upon imports from such island, and that the plaintiff cannot recover back the duties exacted in this case." 


\section{INDEX.}

[THE REFERENCES ARE TO THE PAGES.]

ABANDONMENT, of enemy property at sea, 574 .

ABDY, MR.

criticises Kent's position, that neutrals may sell and transport contraband subject to seizure in transitu, $741 n$.

ABERDEEN, LORD

right of sovereignty over disputed territory pending settlement, 134 . cited, 133.

ABSORPTION OF A STATE,

how a state may be extinguished through, 199.

cases of Poland, the Netherlands, New Spain, Republic of Valais,

Neuchatel and Texas, 200, 201.

ACCRETIONS,

title to, 273.

effect of formation of islands off coast, 273 .

Lord Stowell's opinion in case of the Anna, 274.

right to new formations when rivers are boundaries, 274 .

decision in State of Alabama v. State of Georgia, 275n.

title to bed of lake which overflows into another state, 275.

ACHAIAN LEAGUE,

purpose of, 15.

existence of treaty system for maintenance of balance of power, 16 . supremacy of federal head as to relations to other states, 16. classed by Mr. Freeman among composite states, 167.

ACTIONS AT LAW,

right to prescribe conditions on which they may be commenced, 206.

how far citizens abroad are amenable to local jurisdiction, 233, 242. see Comity; Criminal Offenses.

ADAMS, CHAS. F.

on Great Britain's recognition of Southern Confederacy, 190.

effect of concession of belligerent rights to Confederate States, $192 n$.

remonstrance against loan by private bankers to same, $675 n$.

ADAMS, JOHN QUINCY

protest against Russia's claim to Bering Sea as mare clausum, $44 n$. position respecting unsettled boundaries in northwest, 144 .

author of doctrine that American continents are not open to further colonization by European countries, 145.

right of insurgent state to demand acknowledgment of its independence, 193.

justification of recognition of South American republics, 194, 412. right of search is for pirates in peace, and for enemies in war, 310 . freeing of slaves not legitimate act of war, 476 .

effort to induce England, France and Russia to adopt principle of exemption of private property from capture at sea, 561, 721. on provisions for free ships, free goods, in conventions, 718 .

ADAMS, PRESIDENT JOHN

conditional offer to receive minister must not attempt to prescribe qualifications, 328 . 
ADMIRALTY, BRITISH COURT OF

booty within jurisdiction of, 541 .

ADMIRALTY MANUAL OF PRIZE LAW, see British Admiralty Manual of Prize Law.

AFRICA,

treaties for spheres of influence in, 272.

status of native African tribes in international law, 273.

status of different colonies, 268.

extent of interior occupations how determined, $272 n$.

freedom of navigation of rivers Congo and Niger, 287.

AGENTS OF A S'TATE,

state bound, in international relations, to inform itself as to au-

thority of agents with whom it deals, 158.

see Diplomatic Agents.

AIX-LA-CHAPELLE,

peace of, 1668, between France and Spain, 102.

peace of, 1748, between France, Great Britain and Holland, 108, $370,372,374$.

congress of, 1818,320 .

ALABAMA, CASE OF THE

statement of the case, 681 .

questions submitted to arbitral tribunal at Geneva, 43, 656 .

three rules of the treaty of Washington, 654 .

as construed by counsel for United States, 656 .

as construed by counsel for Great Britain, 657.

judgment of the court of arbitration, 43, 659 .

criticisms of arbitral definition of "due diligence," 660 . practical value of arbitral decree, 664 .

discussions of questions involved in arbitration of, $661 n$.

Lord Bowen on equipment of the Alabama in English ports, 651. some inside history of, 680 .

escape of Captain Semmes to British pleasure yacht, 501, 505.

ALASKA,

claim of House of Representatives as to right of approval or disapproval of treaty for purchase of, 392 .

claims of United States under treaty for purchase of, 44.

\section{ALIENATION,}

of income and other property during occupation, 545, 615 .

of territory during military occupation, $591,615$.

before occupancy is taken by invader is good, 607 .

see Property, Private; Property, Public.

\section{ALIENS,}

status of, in ancient Greek commonwealths, 11, 246.

conventions for mixed tribunals for, $12,362,375$.

position of foreign colony in Rome, 22, 246.

treatment of, in middle ages, 247.

special policies of England, Germany and France, 247.

rights of, under treaty between France and United States, $248 n$.

their relations to international law, 210 et seq.

how domicil is acquired, 249.

may acquire national character by virtue of domicil, 211, $5 \mathrm{~s} . \mathrm{.}$ citizenship of children born of alien parents, 218, 219.

effect of marriage to, 221 .

owe temporary allegiance during residence, $217,251,467$.

immunities and disabilities of traveling sovereigns, 228 .

rights and liabilities of mere travelers or sojourners, 249.

naturalization of, 225 et seq.

letters of denization in England, 252.

jurisdiction of; basis of state jurisdiction in relation to, 206 . maxims of Huber, 206, 208. 
[THE REFERENCES ARE TO THE PAGES.]

ALIENS-Continued.

legal fiction of exterritoriality, 207.

how far amenable to local jurisdiction, 233, 251.

subject to laws of the land for criminal offenses, 233, 253.

can demand only fair trial under local law, 242.

exceptions to general rule of state's exclusive territorial juris-

diction, $233,240,251$.

jurisdiction in cases of piracy, 234.

liability for offenses committed in foreign countries, 240, 251. Cutting's case, 241.

state jurisdiction in such cases defined by Institut de Iroit International, 72 .

offenses comitted by, under authority of government, 171.

rights of naturalized citizens as affected by treaties, 227 .

protection of ; domiciled, entitled to protection of laws, 246, 251, 467.

and against acts of foreign governments, 212, 251.

Koszta's case, 212, 251.

Hall's criticism of Marcy's contention in that case, $212 n$.

latter's position sustained by U. S. Supreme Court, $212 n$. duty of states to protect, from mob violence, 261 .

liability for injuries inflicted upon, by mob violence, 171, 261.

position of United States as to such liability, 170, 171, 261.

insufficient authority of United States government as to reparation in such cases, 170,171 .

case of the Dows, 171.

case of McLeod, 171.

when injured, should resort to local courts, $260,261,432$.

jurisdiction of offenses against, in United States, 170, 171.

jurisdiction of federal courts as to writ of habeas corpus in

cases affecting, 172.

states not responsible for judicial decisions affecting, 260.

redress of, upon failure to obtain justice in courts, 260, 261. responsibility for non-execution of laws during civil war, 261.

effect of war upon resident enemies, 461.

right of state to imprison, held by Grotius and Kent, 461.

Vattel's view the prevailing one, 461.

enemy soldiers an exception to general rule, 462 .

detention or expulsion of, when justifiable, 462, 467.

entitled to safe conduct when expelled, 462.

confiscation of property of resident enemies, 462 .

liability of, to military service, 467 .

declaration of Lord Lyons on this question, 468.

withdrawal of French subjects at New Orleans, 467.

President Lincoln's proclamation as to liability, 467.

admission of Great Britain during American Civil war, 468 . Hall's just criticism of this admission, 468 .

rule correctly stated by Bluntschli, 468.

cannot be compelled to serve against old sovereign, 494.

reception of; right of state to receive or expel foreigners, 231.

against this right is claim to right of intercourse, $231 n$.

right early claimed by United States, 231.

Institut de Droit International on right of expulsion. 72. 233. right to exclude obnoxious foreigners defined, $232,252$.

United States' “Act to Regulate Immigration," 232.

legislation for removal of aliens in Great Britain, 232.

passports required of immigrants during American Civil war, 232.

effect upon a state of excluding all foreigners, 246.

see Allegiance; Citizens; Nationality.

ALISON,

cited, $353,412,486,592,598$. 


\section{ALLEGIANCE,}

basis of citizen's right to state protection abroad, 213, 216, 217, 223 . definition of, $214,217$.

natural, originally perpetual, 214 .

early American doctrine of expatriation, 214n, 217, 225.

cases of Prussian subjects naturalized in United States, 225. departure in declaration of Mr. Cass, 226.

rule now repudiated in England and United States, 217, 227.

English and American expatriation acts, 217, 227.

right of expatriation necessary to change of, 223 .

right of state to settle question of expatriation for itself, 227.

rights of English subjects in American colonies, 215.

federal citizenship created by fourteenth amendment, 216 .

relation of, to citizenship, 217 .

how British and American citizenship acquired, 218.

different kinds of, 217.

as affected by naturalization, 215, 223, 224 .

temporary and local, due from domiciled aliens, 251.

temporary or qualified, during military occupation, 586, 591. pressure upon inhabitants of occupied territory to change, 588 .

effect of conquest upon, 607, 610, 793.

effect of cession upon, of inhabitants who elect to remain, 613. see Citizens; Conquest; Sovereignty.

ALLIANCE,

Triple, 1668, 102.

Grand, 1689, 103.

Grand, 1701, 106.

Holy, 1815, 116.

Quadruple, 1834, 118, 413.

\section{ALLIANCE, TREATIES OF}

may be either offensive or defensive, or both, 369 .

nature of offensive alliance, 369 .

nature of defensive alliance, 370 .

ally not concluded by declaration of war, 464 .

entitled to determine whether casus foederis has taken place, 464.

not bound if war is obviously unjust, 464 .

when casus foederis arises in defensive alliance, 370, 464.

conflicting views of Great Britain and Holland as to construction of treaties of, 370,464 .

need furnish only such assistance as is possible at time, 466 . inaction of powers when Russia attacked Turkey in 1871, 466.

conflict between France and United States as to treaty of 1778,

464.

ground upon which binding force of treaty was denied, 465 . position of United States shown untenable by Madison, 465 . Madison's view in accord with Vattel, 465.

ground on which release might have been claimed, 466 .

warlike, made after outbreak of war, 466 .

when making is tantamount to declaration of war, 466 .

Great Britain so regarded alliance between France and North American colonies, 466 .

difference between, and one of limited succor and subsidy, 371 .

former reliance of Great Britain and France upon treaties of subsidy for troops, $371 n$.

\section{ALTERNAT,}

use of the, 394 .

AMAZON,

treaty with Peru as to navigation of, 287.

finally opened to all nations by decree of 1867, 287 . 
AMBASSADORS,

only class of diplomatic agents possessing the representative character, $318,319,320$.

relative rank of, and ministers settled at Vienna and Aix-laChapelle, 115, 319.

right to personal audience with sovereign, 320 .

right of solemn entry now practically obsolete, 321 .

significance of royal honors, 323 .

letters of credence and additional full powers, 329.

ceremonials of arrival and reception, 334 .

beginning of functions, 334 .

ceremonial lex loci, 334 .

inviolability of despatches of neutral, in time of war, 333 .

immunities, are not unlimited, 334 .

their duration and extent, 335, 350n.

cannot be compelled to appear as witness, 338 .

privilege may properly be waived, $338 n$.

rule for representatives of United States, $338 n$.

exemption from civil jurisdiction, 338 .

opinion of Grotius as to such exemption, 339 .

how personal effects of, may be subjected, 340 .

tacit hypothecation not enforceable, 341.

case of $\mathrm{Mr}$. Wheaton, 341 .

distress for rent will not lie against goods of, 342 .

how civil immunity may end, 341 .

immunity of hotel and grounds, 342 .

when hotel may be subject to local law, 342, 344 .

must not harbor criminals not of suite, 343 .

right of asylum for political refugees in certain countries, 343.

immunity of residence defined, 344 .

freedom of religious worship, 344 .

immunity of servants, 346 .

practice not uniform, 346 .

contentious jurisdiction no longer exists, 347 .

extent of voluntary jurisdiction, 347 .

how accused servants should be dealt with, 348 .

offenses punishable by, in certain countries, 246 .

termination of mission; with or without formal recall, 348 .

in case of death or abdication of envoy's sovereign, 349.

Calvo's opinion that new letter of credence is necessary in such case, $349 n$.

functions of, from republics not interrupted by change of presidents, 349.

in what cases termination of mission is absolute. 349 .

whether new letter of credence is necessary in case of change of government throngh revolution, $349 n$.

ceremonial attending recall, 349.

dismissal before recall, 350 .

should not be capriciously sent away, 350 .

whether recall is necessary when envoy unacceptable, 351.

position taken by United States, $351 n$.

notable cases of recall or dismissal, $351,353,354$.

termination of mission by death of envoy, 354 .

immunities accorded to widow, family and servants, 354 .

see Diplomatic Agents.

AMBULANCES,

neutralization of, with attendants, under Geneva convention, 536.

AMELIA ISLAND,

attack upon, by United States, 412.

AMERICAN ARMY REGULATIONS,

when quarter may be refused, 488 . 
[THE REFERENCES ARE TO THE PAGES.]

AMERICAN ARMY REGULATIONS-Continued.

exemptions of all not directly promoting objects of war, 525 .

deatl penalty allowable for breach of parole, 533 .

when military occupation begins, 588 .

freedom of fugitive and captive slaves on invasion, 551.

cited. $461,482,484,485,489,490,491,492,493,514,515,517,525$, $527,529,530,532,535,536,541,543,547,548,611$.

AMERICAN CIVIL WAR,

judicial determination as to beginning of. 458 .

Great Britain's recognition of Southern Confederacy, 190. her regulations for warships in her ports, 694.

French order of 1861 , redefining twenty-four hours rule, 693.

negotiations for loan to Confederate States in Europe, 675 .

indirect recognition of belligerency of Confederacy by parent state, 186.

Confederacy as a de facto govermment in decisions of federal courts, 459.

President's proclamation blockading southern ports, 190, 458.

validity of blockade upheld by United States Supreme Court, 187. this precedent establishes validity of commercial blockades, 764 . efficiency of Charleston blockade admitted by Great Britain, 767. cotton and other articles, without military character, treated as constructive contraband, 555, 738 .

purchase of free continuation of voyage by carriers of contraband, practiced by Confederate States, 746 .

dangerous extension of doctrine of continuous voyage as applied to breach of blockade, 778 . cases of the Bermuda and the Bark Springbok, 778. condemnation of decisions in these cases, 72,779 .

Confiscation Acts, 551, 555n.

confiscation of debts between individuals of belligerents, 552 . of slaves, 551 .

distinction in federal legislation between rebel and loyal private property, 556 .

acts of pillage committed. 546 .

rule as to mails of neutrals found on board captured vessels, 751 .

AMERICAN NAVAL WAR CODE,

special objects of maritime war, 495 .

who comprise armed naval forces of a state, 496 .

area of maritime warfare, 499.

rules in regard to capture of enemy vessels, $559 \mathrm{n}$.

capture of merchant vessels afloat at declaration of war, 561 .

proof of nationality of vessel, $568 \mathrm{n}$.

of neutral vessels sailing under convoy, 563, 790 .

who regarded as prisoners at sea, 502 .

treatment of personnel and passenger's of merchant ships, 502 .

articles designated in, as contraband, 728 .

lists coal as conditional contraband, 734 .

rules for formality of visitation and search. 782 .

procedure in cases of destruction of prize, 573 .

bombardment of unfortified towns or buildings forbidden, 500 .

when reprisals may be resorted to at sea, 505 .

disposition of sick, wounded or shipwrecked of belligerent when rescued by nentral, 505 .

cited, 500, 501, 541, 559, 579.

AMNESTY,

peace works, for all acts of war, 605 .

offenses excepted from, in peace between Germany and France, 605.

AMPHICTYONIC COUNCIL, result of desire among Greek city-states for union, 13.

therein germs of international comity and morality first appear, 7 . 
[THE REFERENCES ARE To THE PAGES.]

AMPHICTYONIC COUNCIL-Continued.

primary purpose purely religious; political action incidental, 13. of the nature of a diplomatic congress, 14 . the Amphictyonic oath, $14 n$.

ANDORRA, REPUBLIC OF status of, in international law, 175.

ANGARY, belligerent right of, 701 .

Phillimore's statement of the rule, 702.

views of Martens, Azuni, Bluntschli, Dana and Halleck, 703. right of, as exercised during Franco-Prussian war, 703 . basis of the right, $702 n$. vessels attempting to avoid, liable to confiscation, 702 . liability of belligerent for freight, 702, 703 .

ANNE, case of the, 701 .

\section{ARBITRATION,}

standing of courts of, as sources of international law, 43 . growing popularity of treaties of, 376 .

whether political unions of Greece had tribunals for settlement of international controversies, 377 .

suggested by Gerohus for settlement of international controversies, 377 .

pope and emperor proposed by Leibnitz as public arbitrators, 377 . St. Pierre's project to secure perpetual peace, 377 .

Bentham's scheme, 63,378 .

essay touching perpetual peace by Immanuel Kant, 378 .

proposals of New York Peace Society, 1838, 378.

plan of James Mill for creation of an arbitral court, 378 .

David Dudley Field's "Outlines of an International Code," 378.

Dr. Goldschmidt's code of rules for international tribunals of, 378 .

Institut de Droit International adopts scheme of arbitral procedure, $1875,72,378$.

number of international arbitrations during present century, 378 . illustrations of advance made in international arbitrations, 43 .

case of the Alabama, 43.

Bering Sea controversy, 43.

Delagoa Bay case, 44.

Venezuelan boundary dispute, 44.

constitution and procedure of arbitral courts in general, 379 .

hindrances to practical application of, 49,380 .

permanent court of, provided by The Hague Conference, 380 .

organization of the permanent court, 49,381 .

International Bureau and Permanent Administrative Council of, 382 .

rules of procedure for, 49,382 .

authorized to determine its own jurisdiction, 49,382 .

how arbitral tribunal shall be constituted, $49,381$.

resort to permanent court of, not compulsory, 49,381 .

signatory powers may be reminded that permanent court is open to them, 382 .

when arbitral decision or award may be disregarded, 379 .

rejection of award by United States in arbitration of northeastern boundary dispute, $133 n$.

when rehearing may be allowed, 383 .

remarks upon, by President de Staal at Peace Conference, 51.

remarks on action of Peace Conference by Holls and Setl Low, 49.

ARCHIVES,

must be protected by occupying army, 545 .

ARGENTINE REPUBLIC,

blockade of La Plata by France, 1838, and by France and England, $1845,444$. 
ARGUELLES

case of, 255 .

ARISTOTLE, advocated war for purpose of acquiring slaves, 526 . cited, 2.

ARMED NEUTRALITIES,

first league of $1780,633,713$. declaration of, 633 .

second league of $1800,635,713,788$. declaration of, $636 n$. declaration as to blockades, 766 .

Great Britain's effort to vindicate her position against, 637, 788 . recognition of program of, by United States, 715 .

influence in advaucing principle, free ships, free goods, 738.

influence in securing exemption of ships under convoy from right of search, 788 .

inadmissible principles respecting blockade, 761 .

ARMISTICE,

authority to conclude, 514 .

period of operation, 514 .

what acts permissible during, 514 .

effect of intentional breach, 514 .

to be construed liberally, 515 .

revictualing a besieged place during, 515 .

Bismarck's refusal to allow admission of supplies to Parls, 516 .

rules of The Hague Peace Conference regulating, 521.

ARMSTRONG, GENERAL

case of the, 700 .

ARMY,

development of idea of standing armies, 472 .

who constitute the regular forces of a state, 472 .

regular forces governed by military law, 470, 473 .

pickets and sentinels not exempt from fire, 482 .

ART, WORKS OF

generally exempt from seizure as booty, 543 .

practice of different powers, 543 .

rule of American regulations, 543.

Asgill's case, $490 n$.

ASSASSINATION,

never permissible in war, 491.

putting price on enemy's head forbidden, 491.

offense not purged by safe return to camp, 536 .

ASYLUM,

for political refugees in hotel of ministers, 343 .

and on board public vessels of foreign state, 306 .

old and new rules as to local jurisdiction of public vessels, $303,304$.

remedy when commander of vessel refuses to surrender political refugees or ordinary criminal, 307 .

no right of, in merchant vessels, 314 . cases of Sotelo and Gomez, 314 .

for belligerent war ships in neutral ports, 689 .

must observe regulations for protection of neutrality, 305, 689 . case of The Exchange v. McFaddon, 689.

ATHENIAN ALLIANCE,

primary purpose of, 14 .

nature of, 15 .

AUGSBURG,

League of, $1686,103$. 
[THE REFERENCES ARE TO THE PAGES.]

AUGUSTINE,

considered use of fraud against an enemy innocent, 490.

AUSTIN,

excludes international law from domain of positive law, 82 .

definition of international law, 83 .

AUSTRIA,

declaration of Louis XV. in favor of Elector of Bavaria in 1741, 372 .

effect of peace of Westphalia upon, 97.

territorial limits after congress of Vienna, 1815, 115.

nature of political constitution, 159 .

enforces domestic criminal law against subjects committing offenses abroad, 243.

articles designated by, as contraband, 733 .

AYALA,

declared war against infidels as such unjustifiable, $56 n, 127$.

cited, 55, 698 .

AZUNI,

rules in respect to duties of war ships in neutral ports, 690 .

vessels attempting to avoid belligerent right of angary liable to confiscation, 702 .

cited, 559, 560, 564, 566, 568, 573, 575, 576, 577, 582, 634, 651, 700.

BALANCE OF POWER,

Greek treaty system for maintenance of, 16, 363 .

first recognized as de facto system in Peace of Utrecht, 425.

to preserve, in Europe, the primary purpose of Peace of Westphalia, 1648, 95, 99.

as related to the primacy of more powerful states, 98 .

definition of, by von Gentz, 98 .

suggests four conditions as necessary basis of, 99 .

christendom a kind of universal republic, says Fénelon, 99.

duty of members to oppose member who might overthrow, 99 .

system of, not obsolete, 100 .

development of, since Peace of Westphalia, 98 .

continuance of system then laid down to present time, 99 .

maintenance of, primary purpose of modern international system, 425 .

intervention as a means of preserving, 425 .

preservation of, in Eastern Europe, the primary purpose of Crimean war, 119.

system established by Congress of Vienna disturbed by rise of Prussia and reorganization of Germany, 126.

latest readjustment of, 126 .

overlordship of United States in New World, 140, 417.

its correspondence to concert of Europe, 418, 426.

termination of France's intervention in affairs of Mexico, 149. see Monroe Doctrine.

concert of Europe; the basis of its authority, 98 .

successor to Holy Roman Empire as international director, 98.

fact of, recognized in European diplomacy today, 100.

knowledge of history of European treaties since Peace of Westphalia necessary to understanding of, 100.

treaties aggrandizing France and Sweden at expense of Spain and the Empire, 100.

effect of treaties of Breda, 1667, 101.

of triple alliance between England, Holland and Sweden, $1668,102$.

of Peace of Nimeguen, 1678-79, 102.

of Grand Alliance, $1689,103$.

of Peace of Ryswick, 1697, 103. 
BALANCE OF POWER-Continued.

of Grand Alliance, 1701, 106.

of Peace of Utrecht, 1713-14, 106.

introduction of new elements with advent of eighteenth century, 107.

effect of Peace of Nystadt, 1721, 108.

of Peace of Aix-la-Chapelle, 174S, 108.

of Peace of Paris, 1763, 109

violation of basic principle in partition of Poland, 1772, 110. effect of intervention of great powers in affairs of France, 111. of treaties at Versailles, 17\$3, 111.

ancient diplomatic fabric of Europe shattered by wars of Napoleon, 112.

secret treaty of allied powers for disposal of territories surrendered by France, $1814,114 n$.

defeat of plan through influence of Talleyrand, $115 n$.

effect of Holy Alliance, 116.

intervention of powers to secure independence of Greece, 118. effect of Peace of Paris, 1856, 119.

independence of Ottoman Empire guaranteed, 120.

effect of rise of Prussia, 121.

of Peace of Prague, 122.

of Congress of Berlin, 1878, 125.

its assumption of jurisdiction over the Eastern question, $179 n$. emancipation of Christian principalities of Ottoman Empire, 179.

intervention for protection of Christian peoples subject to Turkey, 430 .

guarantees sovereignty of Roumania and Servia, 180.

its influence in the emancipation of Montenegro, 181.

action of in relation to Bulgaria. 182 .

capture of Constantinople by Mehemit Ali prevented by Russia, 182

Peace of the Levant secured by cession of Syria to Mehemit Ali, 182.

revolt of Arabi Pasha, 1882, crushed by Great Britain, 183.

administration of Egypt given to Mehemit Ali, 183.

appointment of controllers-general for Egypt by France and Great Britain, 183.

control over administration of justice in Egypt, 184.

neutralization of Suez Canal, 184.

\section{BALLOONS,}

launching of projectiles and explosives from, 479 .

use of, for reconnoissance, recognized as legitimate by conference at 'The Hague, 494.

BALTIC SEA,

territorial reasons why should be considered a mare clausum, 291.

BANCROFT,

cited, 215.

BANDITTI,

employment of, in war, 476 .

BARBARY STATES,

recognized as states for many purposes, 449.

naval demonstration by United States, 442 .

control over persons and property of Christians in Morocco, 359. citizens of United States when in Morocco, required to obtain cer-

tificate of protection from consul, 359 .

BAVARIA,

devastation of, by Marlborough, 482.

BAYARD, CHEVALIER

regarded firearms an unfair innovation, 480 . 
[THE REFERENCES ARE TO THE PAGES.]

BAYARD, SECRETARY OF STATE

power of United States to afford reparation for wrongs inflicted upon aliens, 170.

on right of Mexico to administer punishment in Cutting's case, 241. position of United States in respect to taxation of property of ministers, 345 .

cited, 242, 260, 329, 739.

\section{BAYS}

whether regarded as territorial, 278.

jurisdiction over land-locked, extending beyond three mile zone, $138,278$.

BEACONSFIELD, LORD

powers of English parliament in relation to treaties, 163.

cited, 163.

\section{BEHRING SEA,}

see Bering Sea Controversy.

\section{BELGIUM,}

intervention of great powers to compose revolution, $45,118,414$. constituted an independent and neutral state, 119, 200, 373.

only a part-sovereign state, 174.

refused passage to wounded German troops during Franco-Prussian war, 670 .

Great Britain's defense of neutrality of, 119.

BELLIGERENT COMMUNITIES,

internal and external sovereignty of, contrasted, 184.

a civil war is a public war, 459 .

recognition of belligerency and its effects, 185,457 .

benefits accruing from recognition, 191.

general question involved in recognition, $186 n$.

Canning's reply to Turkey's remonstrance against recognition of provisional government of Greece, 189.

discussion between Mr. Chas. F. Adams, minister to Great Britain, and Earl Russell, 190.

necessary conditions preceding recognition, 185, 186.

relations of parent and foreign states to recognition, 186.

recognition of, does not extend to independence, 457.

indirect recognition, $186,458$.

of American colonies by Great Britain, 186.

decision of Supreme Court as to Southern Confederacy, 187.

when recognition should be made by foreign states, 188, 457.

duty of foreign state when recognition is demanded, 187.

revolutionary governments have only a moral claim to, 187. custom as to recognition of, in cases of land war, 189.

reasons for prompt recognition in case of maritime war, 189. premature, by foreign state, an act of intervention, 192.

notable recognitions of belligerency, 189 .

of provisional government of Greece in 1825, 189 .

of American colonies by France and Holland, 190.

considered by Wheaton "an unjustifiable aggression," $193 n$.

of South American colonies by United States and Great Britain, 190, 194.

of Texas by United States during civil war with Mexico, 190.

of Southern Confederacy by Great Britain, 458.

formality; recognition of, should be formal, 191.

is irrevocable, except by agreement, while situation is unchanged, 191.

recognition of, as affecting acts of piracy, 234.

BELLIGERENT OCCUPATION,

see Military Occupation and Administration. 
[THE References are to the PAges.]

\section{BELLIGERENT RIGHTS AND DUTIES,}

during hostilities on land, 470 , et seq.

evolution of military codes, 471.

convention of The Hague conference, 1899, as to manuals to armed forces, 471.

rule of reciprocity, 474,488 .

extent to which force is allowable in war, 470 .

practice of the ancient world, 470 .

views of different publicists, 470 .

combatants lawful and unlawful, 471.

who comprise regular forces of a state, 472 .

irregular forces, 473.

employment of savages now condemned, 474.

arming of slaves by United States during Civil war, 475

were refused quarter by Confederates, 489 .

employment of guerrillas and banditti, 476 .

volunteers from abroad, 477 .

rules of Brussels Conference confirmed at The Hague

Peace Conference, 477.

status of levies en masse as defined by Brussels Project and The Hague Convention, 478.

weapons; only such, as will disable enemy without unnecessary suffering permitted, 47,479 .

see Weapons.

methods of warfare; no exemption for crowned heads and officers in actual battle, 482 .

whether pickets and sentinels should be fired on, 482 .

devastation as a means of offense, 482 .

as a means of defense, 483 .

lawful methods for reducing besieged towns, 484 .

bombardments, 484 .

what buildings should be spared, 485 .

storming and sacking of towns unlawful, 485 .

unjustifiable resistance, 486.

when quarter should be given, 487 .

retaliation and reprisals, 488 .

how far deceit may be used against enemy, 490 .

assassination or treachery never permissible, 491.

bribery of soldier's or people of enemy unlawful, 492.

services of traitors may be accepted when tendered, 492 .

instigating or aiding rebellion in enemy state authorized by usage, 492 .

guides; enemy inhabitant compelled to act as guide, 492.

punishment of guides for intentionally misleading, 492.

spies; who may be regarded as spies, 492, 493.

rule of The Hague Conference as to punishment of, 492. reconnoitering in balloons, 493.

deserters; from enemy, may be accepted and enlisted, 494 . unlawful to incite enemy's soldiers to desert, 494.

punishment of deserters, 494.

inhabitants of enemy country cannot be compelled to serve against their sovereign, 494.

enemy persons; rules respecting enemy persons, 523 et seq. see Enemy Persons.

enemy property; rules respecting enemy property, 539 et seq. see Property, Enemy.

during hostilities at sea; rules of land war observed at sea, so

far as applicable, 495 .

what ships may give battle at sea, 496 .

rights of private vessels without commission, 497.

have no right of search and capture as to neutrals, 497.

rules governing privateers, 497 .

privileges in neutral ports, 498 . 
[THE REFERENCES ARE TO THE PAGES.]

BELLIGERENT RIGHTS AND DUTIES-Continued.

area of maritime warfare, 499.

position of Bynkershoek as to pursuit of vessel begun outside territorial limits, 499.

rules governing conduct of naval engagements, 500 .

bombardment from sea not limited to fortified places, 499 . when artifice is permissible at sea, 500 .

Nelson's declaration for annihilation before Trafalgar, 501. surrender at sea, 501.

humane spirit of American forces in battle off Santiago, 502.

who are to be regarded as prisoners, 502.

see Prisoners.

extension of Red Cross rules to warfare at sea, 502.

religious, medical and hospital staffs inviolable, 503.

hospital ships exempt from capture, 503.

rules affecting such vessels, 504 .

effect of rescue of wounded or shipwrecked by neutral, 504 . refusal of Great Britain to surrender Captain Semmes to United States, 501, 505.

naval reprisals, 505 .

duties toward neutral states, 687, et seq.

legitimate fields for hostilities, 688 .

direct preparation for hostile acts, in neutral territory, 688 .

all reasonable regulations of neutrality, to be respected, 689 .

landing of prisoners in neutral states, 691.

rules affecting belligerent warships in neutral waters, 689 .

twenty-four hours' rule, 692 .

cases of the Nashville and Tuscarora, 694.

right to hold captured persons, in neutral territory, 696.

right to deal with prize in neutral ports, 697 .

attack made in neutral waters, 699 .

right of angary, 701 .

in dealings with neutrals, must administer speedy and uni-

form justice, 638 .

how non-hostile relations are established, 506 .

rules respecting the termination of war, 602 et seq.

province of cartels, and their binding character, 506 .

flags of truce, 507.

political conferences under protection of, 508 .

suspensions of arms, armistices and truces, 513, 518.

acts lawful and unlawful during truce, 514 .

revictualing besieged place, 515 .

capitulations, see Capitulations.

rights and duties incident to military occupation, see Military Occupation and Administration.

see Contraband; Neutrals; Projectiles; Property; Visitation and

Search; War.

BENTHAM, JEREMY

author of the phrase "international law," 86 .

scheme to secure universal and perpetual peace, $63,378$.

BERING SEA CONTROVERSY,

claim made by United States to certain portions of open sea, 44. submission of claim to arbitration, 44.

substitution of claim to jurisdictional right of control, 293.

judgment of arbitral court against United States, 44.

BERLIN,

decree of Napoleon, 761 .

Congress of, $1879,44$.

Conference, $1884-85$, to regulate affairs of West Africa, 46.

BERNARD, MONTAGUE

lack of protection to ambassadors in medieval world, 316. 
[THE REFERENCES ARE TO THE PAGES.]

BERNARD, MONTAGUE-Continued.

criticism of $\mathrm{Mr}$. Seward's classification of diplomatic agents with contraband, 753 .

cited, 186, 191, 751, 754, 766, 767, 775, 777.

BERNE,

treaty of, 1874,374 .

BISMARCK, PRINCE

his conception of customary law of nations, $272 n$.

remarks on purpose of Berlin Conference, 399 .

defense of sinking British merchant vessels in Seine, 703 .

complaint of, as to export of horses from England during Franco-

Prussian war, 733 .

refusal to spare public buildings at siege of Paris, 485.

refused admission of supplies to Paris during armistice, 516.

BLACK SEA,

Turkey compelled by Russia to open, to merchant vessels, $120 \mathrm{n}$.

"ancient rule of Ottoman Empire" as to exclusion of ships of war

from, recognized by European powers, $120 \mathrm{n}$.

provisions of treaty of Paris, 1856, as to neutralization of, 120 .

abrogation of these provisions by Conference of London, 1871, 124 . convention between Russia and Turkey as to armed vessels in, 124 .

BLAINE, SECRETARY OF STATE

instructions concerning case of Bermuda, 315 .

BLOCKADE,

history of, a compromise between belligerent and neutral interests, 759 .

views of Grotius, Bynkershoek and Vattel, 759, 760 .

Lord Stowell's definition of elements constituting an actual, in case of Betsey, 761.

inadmissible principles of armed neutralities, 761 .

rule of Crimean war, 762 .

classification of, 762 .

military or strategic, 762 .

law of, as construed by two distinct schools, 764 .

must be specially instituted as an act of war, 765 .

by what authority and within what limits may be instituted, 765 .

English and American theory, 765 .

access to contiguous territory, 765 .

trade with Matamoras, during American Civil war, 765.

continental theory, confined to territorial waters, 765 .

effective; state at war cannot close ports in hostile occupation, except by effective, 459 .

provisions of Armed Neutralities as to effective, 638, 766 . under Declaration of Paris, to be binding, must be effective, 121, 513, 762, 766 .

British and American definition of effective, 766 .

case of the Franciska, 766 .

Great Britain's acceptance of efficiency of Charleston blockade, 767 .

construction of principles of Declaration of Paris by Continental publicists, 767 .

notice of; how communicated to neutrals, 768 .

case of the Circassian, 770,772 .

when knowledge of, cannot be presumed, 769 .

vessel sailing with knowledge of, from distant port, 769 . sailing to blockaded port after general notification, $769 n$.

or with intention of making inquiry, $769 n$.

formal and official notice, by proclamation and warning, 770 .

case of the Hiawatha, $770 n$. 
[THE REFERENCES ARE TO THE PAGES.]

BLOCKADE-Continued.

vessel not engaged in, cannot serve notice, $771 n$.

French theory and practice, 770.

logical result of French rule, 773 .

breach of; what acts constitute breach of; English and American rule, 771.

intention, the test of criminality, 771.

sailing with knowledge of, and with intent to enter, 769 .

vessels lying outside, but receiving cargoes from craft

issuing from blockaded port, 772 .

ingress and egress to and from blockaded port, 773 .

difference between English and French rules, 774 .

knowledge of recently established blockade may be inferred from facts, $774 n$.

period usually allowed for exit, 775 .

doctrine of continuous voyage as applied to breach of, 777 .

dangerous extension of doctrine during American Civil war, 72,778 .

case of the Bermuda, 778.

case of the Springbok, 72, 778, 779 .

penalty for breach or attempted breach of, 779 .

licenses; effect of licenses on validity of, 775 .

case of the Hoffnung, 776 .

termination; effect of the cessation of, 776 .

contention of United States as to continuance of, when established by proclamation, 776 .

presumption of regularly notified, must be overcome by evidence, 777.

right of parent state as to, of its own ports, upon recognition of belligerency of insurgent state, 191.

by either belligerent in civil war, 459 .

President Lincoln's proclamation as to ports of Soutbern states, $190,458$.

principle recognized by United States in Columbian Civil war, $1885,459$.

closing of ports of New Granada, 459.

commercial; criticisms of, by Mr. Marshall and Mr. Cass, 763 .

of entire coast of Southern Confederacy, 458, 764 .

validity of, upheld by United States Supreme Court, 187.

right of commercial, now undisputed, 764 .

pacific; as a positive remedy for obtaining redress, $431,444$.

when tantamount to declaration of war, 446 .

has become part of international law, 445 .

should not disturb neutral commerce, 445.

confiscation not allowable in connection with, 445 .

originated in nineteenth century, 444.

summary of those in nineteenth century, 444.

bombardment of arsenal of Foo Chow and Formosa by France, $1884,445$.

condemned by Institut de Droit International, 445.

BLUNTSCHLI, JOHANN KASPAR

definition of international law, 81.

exposition of subject of state responsibility, 259 .

grounds for avoiding an arbitral decision, 280 .

effect of refusal to ratify a treaty, 388 .

right of state to repudiate treaty if incompatible with its development, 400 .

rule as to liability of resident aliens to military service, 468 .

claims right of state to intervene in civil war in behalf of estab-

lished government, 424 .

modified assent of inhabitants to cession of territory, 614 .

attempt to rest acquisition of Alsace and Lorraine upon race con. ditions, 614 . 
BLUNTSCHLI, JOHANN KASPAR-Continued.

definition of war, 448 .

just causes of war, 451 .

uniform a matter of discipline, not of international law, 477.

views on seizure of Prussian ships by Great Britain, 442.

on treatment of levies en masse in rear of army, 478.

implied agreement that exchanged soldiers shall not serve, 533 .

origin of effort to neutralize persons and things engaged in relief of wounded, $536 \& n$.

opposes destruction of prize, 572 .

duty of neutrals to belligerents, 648 .

views upon neutral aid under pre-existing treaties, 667.

denies that neutral individuals may make loans to belligerents, 673.

recognizes belligerent right of angary, 703 .

frequently cited, for example, 131, 262, 544, 733 .

BOER WAR,

beginning of, by conditional ultimatum, 457 .

expulsion of British from Transvaal at beginning of, 461 .

attempted starvation of garrison at Ladysmith not unlawful, 484 .

rights of private property respected in, 542 .

Great Britain's seizure of the Bundesrath, Herzog and the General, 738 .

BOMBARDMENT,

to what extent allowable, 484 .

when notice of, is necessary, 484.

retirement of non-combatants, 484.

right denied at siege of Paris, 484, 485.

truce of several days allowed at Santiago, 484 .

expulsion of non-combatants, 485 .

buildings dedicated to religion, art, science or benevolence, hospitals and public buildings not in military use to be spared, 485 . exempt buildings must be designated by besieged, 485 .

from the sea, not limited to fortified places, 499 .

of Valparaiso, 500 .

of Copenhagen, 500 .

provisions of American Naval Code, 500.

of undefended towns, habitations and buildings probibited by The Hague Conference, 484.

BOOTY,

when title to personal property captured on land passes, 539.

generally becomes property of state or army as organism, 541 .

exception to this rule in favor of individual captors, 541.

what state personal property subject to seizure as, 540 .

exemption of public securities from seizure as, 542 .

exemption of works of art, and of libraries and museums, 543. respect due to private property, 547, 552 .

declaration of The Hague Conference concerning, 547.

within jurisdiction of British Admiralty Court, 511.

BOROUGHS, SIR JOHN

cited, 292.

\section{BOSPHORUS, STRAITS OF THE}

provision of treaty of Paris, 1856, as to passage of ships of war, 120.

effect of new convention, 1871, between Russia and Turkey, 124.

BOUNDARIES,

general rules as to, of states, 298.

burden of proof in cases of dispute, 299 .

questions as to, determined by political department in United

States, 299. 
[THE REFERENCES ARE TO THE PAgES.]

BOUNDARIES-Continued.

general rules as to area appropriated by an act of occupation, 130 . rule as to lateral boundaries, 131 .

conflict between United States and Spain as to western boundary of Louisiana, 132.

dispute between United States and Great Britain as to northeastern boundary, 133.

dispute as to northwestern boundary of United States, 134. respective claims of Great Britain and United States, 134, 135. claims of Russia to Alaskan territory, 44, 144.

effect of formation of islands off coast, 273 .

effect of new formations in livers, 274 .

BOURRIENNE,

cited, 534, 535, 538, 542, 651 .

BRAZIL,

Rio de Janeiro blockaded by England, 1862, 444.

BRIBERY, generally unlawful agaiust enemy, 492.

BRITISH ADMIRALTY MANUAL OF PRIZE LAW, articles designated in, as contraband, 732 .

horses and coal listed as conditional contraband, 733, 734 . pre-emption of goods conditionally contraband, 746 .

requires only detention of carrier of contraband on guilty return voyage, 743 .

on punishment of individuals for breaches of neutrality, 649 .

coal as contraband, 734 .

cited, 507,769 .

BROWN, LORD JUSTICE

on carriage of despatches by neutrals to belligerents, 749 .

BROWN, MR. JUSTICE

on nationality of married women, 222 .

BRUSSELS,

Conference, 1874, to discuss laws of warfare on land, 46, 47.

project for military code promulgated by conference, 471, 481 . same approved by Institut de Droit International, 483.

rule of, as to regular forces of state, 477.

as to treatment of irregular forces in war, 477. concerning status of levies en masse, 478 .

code of, adopted by The Hague Conference, 471, 477.

Conference, 1890; Final Act for suppression of African slave trade, 46.

BRYCE, JAMES

the two great ideas bequeathed by antiquity to future ages, 30 .

effect of Roman dominion and Christianity on Greek exclusiveness, 362 .

cited, 52, 160, 166, 169, 269, 322.

BUCHANAN, SECRETARY OF STATE

cited, $255,344,682$.

BULGARIA,

division of, by treaty of Berlin, 1878. 125.

its relations to the Ottoman Empire, 125, 181.

consolidation of Eastern Roumelia with, in 1885, 182.

BULLETS,

see Projectiles, 479.

BULMERINCQ, DR.

his definition of international law, 3, 84 .

cited, 768,770 .

BULWER, MR.

his dismissal as British minister to Spain, 354 . 
BURKE, EDMUND

on title by prescription, 264 .

slaying of prisoners, 528 .

BURLAMAQUI, JEAN J.

distinguishes declaration of war from manifesto, $457 n$.

by state of war that of society is abolished, $470 \mathrm{n}$.

cited, 252.

BYNKERSHOEK, CORNELIUS VAN

held international law to be derived from reason and usage, 61 .

influence upon rules as to territorial waters, 71 .

admitted portions of sea susceptible of exclusive dominion, 61 .

reduced statement of extent of state jurisdiction over adjacent sea

to usable basis, 294 .

on extent of territorial waters of a state, 499.

discredited permanent diplomatic missions, 317 .

privilege of inviolability of ambassadors how far operative, 331 . suit against envoy of Duke of Holstein, 341.

goods of foreign ministers not subject to seizure under distress or pledge, 342 .

question, "Are ambassadors sent to harbor thieves?" 343.

criticises Wicquefort's condemnation of refusal of princes to ratify acts of ministers in concluding treaties, $387 n$.

definition of war, 448 .

declared everything lawful against an enemy except perfidy, 470 . promises to an enemy must be kept, 490 .

cruel to punish an enemy for his courage, 487.

area of maritime warfare, 499.

pursuit of vessel begun outside marine league may be continued within limit, 499,688 .

effect of bringing prisoners of war into neutral port, 530 .

excepts contraband from principle of "flee ships, free goods," 566 . distinction between postliminy and recapture, 575 .

his terms to describe neutrals, 619 .

views upon the subject of neutrality, 623 .

purchase of soldiers in neutral territory lawful, 667 .

flying troops may be followed into neutral states, 672 .

on immunities of public vessels in foreign ports, 303 .

views on early law of blockade, 759 .

frequently cited, for example, 230, 539, 731, 744 .

CALHOUN, JOHN C.

criminal jurisdiction of states, 240 .

on suggestion of Canning for joint declaration with Great Britain against European interference in South America, 142.

what will justify invasion of neutral territory, 406 .

cited, 130 .

CALVIN,

case of, 600 .

CALVO, M. CARLOS

definition of international law, 84 .

classification of treaties, 366 .

relation of three rules of treaty of Washington to pre-existing international law, $655 n$.

ambassador needs new letter of credence upon abdication or death of his sovereign, $349 n$.

state bound to recall envoy who has become unacceptable, 351. regards invasion of state in self-defense as imperfect war, $405 n$. confines right of intervention to narrower limits than other-authorities, 426.

intervention permissible to end crimes and slaughter, 429.

some solemn act necessary to begin any war not of defense, 454 . war cannot silence conscience, 488 . 
[THE REFERENCES ARE to THE PAges.]

CALVO, M. CARLOS-Continued.

right of state to detain resident enemy soldiers, 462.

his division of combatants, $472 n$.

classes horses among contraband of war, $733 n$.

favors continental theory of individual notice of blockade, 771.

loans made by individuals to belligerents, 673 .

rights of neutral as to illegal captures in his jurisdiction, $684 n$. frequently cited, for example, $253,346,587,597,686$.

CAMPBELL, LORD

ambassadors' privilege from liability to civil jurisdiction, $3 \cdot 10$.

CANADA,

status of, in relation to international law, 176 .

CANNING,

an advocate of universal right of self-government, 141.

tribute to neutrality laws of the United States, 145.

proposed joint declaration by Great Britain and United States

against European intervention in South American republics, 111 .

reply to 'Turkey's complaint of England's recognition of belligerent

rights of Greece, 189.

cited, 192, 646, 692 .

CANON LAW,

basis of papal authority in international affairs, 34 .

CAPITULATION,

terms of, 516.

destruction of stores, 517.

when surrender is complete, 517.

sponsions and their ratification, $518,519 n$.

of El Arish in 1800, 519.

of Gen. Joseph E. Johnston in 1865, 520.

surrender at sea, 501 .

The Hague Conference rules regulating, 521.

CAPTURE,

what constitutes, at sea, 569 .

when complete, $569,575,698$.

acts necessary to change of possession, 570 .

when complete as to neutrals, 698 .

what is a good, of personal property on land, 539, 540.

when title passes, 539 .

ownership of captured personal property, 541 .

joint, 571.

of evidences of debt, 542 .

co-operation of land forces, 571.

in United States inures to benefit of government, 571.

disposition of prize, 571 .

ransom of prize, 573 .

hostages, 573 .

how captors' rights may be lost, 574 .

recapture and postliminy, 575 .

how terminated by rescue, 575 .

salvage, 575,576 .

exceptions to postliminy, 576 .

ownership of prize, 577.

rule as to privateers, 577 .

procedure in prize cases, 581.

validity; damages for wrongful, 577.

effect of misconduct on part of captors, 579 .

destruction of enemy's war vessels, 579.

effect of, after termination of hostilities, 614 .

right of neutrals to prevent, in their territory, 683 .

pursuit of vessel into neutral territory to effect, 699 .

of French fleet by Boscawen to shores of Portugal, 699. 
[THE REFERENCES ARE TO THE PAGES.]

CAPTURE-Continued.

capture of British ship Grange in Delaware Bay, 499.

case of the George, 699

Bynkershoek's contention that, may be completed in neutral waters, 688 .

reparation for, made by belligerent in neutral territory, 704 .

made on high seas, not affected by previous passage over neu-

tral waters, 281.

property liable to, at sea, 558 , et seq.

rule of American Naval Code, $559 n$.

private property of enemy, sailing under his flag, 563 .

whether private property taken at sea should be paid for, 563 .

property exempt from, 543 et seq.

property exempt from, for humanity's sake, 558 .

fishing boats generally exempt, 558 .

exception to this rule, 559.

vessels engaged in scientific expeditions, 559.

mail packets exempt, 560 .

as to vessels in distress, 560 .

merchant vessels afloat at declaration of war, 560 .

tendency to exempt all private property at sea, not contraband, 561 .

rule of the Consolato del Mare, 564.

French doctrine of hostile infection, 565 .

Dutch rule that nationality of ship controls cargo, 566 .

adoption of principle of free ships, free goods in Declaration of Paris, 566.

second part of formula not accepted by United States, 566 . neutral cargoes in enemy ships exempt from seizure, 567. right of, as affected by ownership of cargo, 568 .

disposition of personnel of captured merchant vessel, 502.

treatment of women and children on same, 502.

procuring naval supplies by, of enemy private property, at sea, 562 .

naval, on land, 570 .

see Neutrals; Visitation and Search.

\section{CARTELS,}

purpose of such agreements, 506 .

power to conclude, 518 .

are not treaties within constitution of United States, 506.

what vessels may be employed as cartel ships, 507 .

restrictions upon use of, 507 .

when protected from capture, 507, 558.

rule of American Naval Code, $559 n$.

CASS, SEC. OF STATE

effect of naturalization on allegiance, 226 .

jurisdiction of crimes of naturalized citizens, 226 .

criticism of commercial blockades, 763 .

criticism of attempt to make coal contraband, 734 .

cited, 734 .

CASTLEREAGH, LORD

right of intervention where security of state endangered, 422 .

suggested disarmament on great lakes, 443 .

CATACAZY, MR.

demand of United States for recall of, as Russian minister, 353.

CEMETERIES,

of enemy, must be protected by army of occupation, 546 .

CEREMONIAL,

questions of. subject to state regulation within territorial jurisdiction, 323. 
CESSION,

[THE REFERENCES ARE TO THE PAGES.]

right of state to dispose of territory by gift, sale or exchange, 275 .

instances of, as manifestation of good will, 276 .

for valuable consideration, 113,276 .

as the result of war, 276,614 .

new policy inangurated by United States, 277.

stipulations for apportionment of public debt and as to rights of inhabitants, 277.

for retention of nationality of inhabitants, $277 n$.

delivery of possession necessary to perfect, $389 n, 613$

effect upon existing order of things, 613.

whether consent of inhabitants of ceded territory is necessary, 613 . status of territory ceded to United States before admission as state, 793 .

see Military Occupation and Administration.

rules for construction and interpretation of, $276 \mathrm{n}$.

effect of treaty of partition between mother state and new one born of it, 133 .

claims of United States under boundary treaty with Spain, 1819, as to northwest territory, 135 .

CHARGE D'AFFAIRES,

must be accredited to sovereign to be included in third class, 321 . ad hoc, and ad interim, 321.

letters of credence, 329 .

double political capacity of consul appointed as, 360 .

CHARTERED COMPANIES.

why they are subjects of international law, 268 .

CHASE, CHIEF JUS'TICE

on notice of blockade to neutral vessels, 770 .

CHAUDORDY, M. DE

revictualing besieged places during armistice, 516 .

cited, 514.

CHESAPEAKE, CASE OF THE, 686, 691n, 704.

CHILI,

pacific blockade of, by Bolivia, 1879, 445.

CHINA,

qualified extension to, of international law, 91.

CHURCHES,

must be protected by occupying army, 546 .

\section{CICERO}

on identity of jus gentium and jus naturae, 23.

acts preceding beginning of war by Romans, 24 .

definition of war, 448 .

cited, 460 .

\section{CITIZENS,}

have no jural relations with other states, 211.

status more important than citizenship in international law, 211. Koszta's case, $212,251$.

fact of citizenship a question of municipal law, 211.

Huber's maxims as to who are subjects, 206.

classes of persons composing every state, 212.

how to become; feudal rule of citizenship, and reaction against it, 218.

political privileges not essential to citizenship, 218 .

how British and American citizenship acquired, 218.

citizenship of children born of alien parents, $218,219,220$.

election by children born of alien parents, 219 .

nationality of married women, 221, 222.

federal and state citizenship distinct in United States, 216.

federal, created by fourteenth amendment, 216 . 
[THE REFERENCES ARE TO THE PAGES.]

CITIZENS-Continued.

citizenship by naturalization in United States, 223.

interstate citizenship, 215.

effect of British naturalization acts, 1870, 214, 218, 224. case of Bourgoise, 224.

protection of; who are entitled to state's protection, 211.

right of state to protect, abroad, 213.

Calvin's case, 213.

protection to, of United States by fourteenth amendment, 216 . naturalized, may be protected by adopted country in land of nativity, 226 .

relation of allegiance to citizenship, 217.

natural allegiance originally perpetual, $214,217$.

status of American colonists, 214, 215.

early American doctrine of expatriation, 214, 225. cases with Prussia, 1840, 1853, 225.

rule repudiated by Act of Congress, 1868, 217, 227.

effect of conquest upon citizenship, 214, 607. 793, 794.

tendency to regard inhabitants of protected state as, of protecting state, 271.

customary to provide for rights of, in treaties of cession, 277.

as diplomatic representatives of foreign states, 327.

see Aliens; Allegiance; Domicil; Naturalization.

CIVIL, WAR,

to what contests term may be applied, 453 .

characteristics of, 453 .

is a public war, 459 .

when will be officially noticed by foreign powers, 457 .

authority of parent government in states in rebellion, 459 .

effect of, upon treaties of parent state, $198 n$.

Hall's view as to test of continuance of identity of parent state, $198 n$.

effect upon rights and obligations of the state, 198.

power of revolutionary government to alienate public domain, 199. effect of transfer of public property to new government upon private property, 199.

recognition of belligerency, see Belligerent Communities.

CLAY, SEC. OF STATE

construction of most favored nation clause in treaties, 375 .

objection of United States to occupation of Cuba and Porto Rico by any other European power than Spain, 419.

liability of reprisals to result in war, 438 .

redress by foreigners in courts, 260 .

CLAYTON-BULWER TREATY,

an exception to Monroe doctrine, 147.

provisions of, 147.

why avoidable by one of the contracting parties, 148 .

CLAYTON, SEC. OF STATE

privilege of asylum to political refugees, 344 .

CLEVELAND, PRESIDENT

completed definition of Monroe doctrine, 150.

message to Congress respecting application of Monroe doctrine to

Venezuelan boundary dispute, 417.

primacy of United States on American continent, 417.

place of Monroe doctrine in international law, 417.

refusal to cancel Mr. Keiley's appointment as minister to Austria, $329 n$.

intervention in behalf of Cuba as a contingent necessity, 420,421 .

COAL,

right of belligerent warship to purchase in neutral port, 690,691 . 
[THE REFERENCES ARE TO THE PAGES.]

COAL-Continued.

doctrine of conditional contraband applied to, by Great Britain during Crimean war, 733.

listed as conditional contraband in British Admiralty Manual of Prize Law and American Naval War Code, 734.

contrary position of France, Russia and other countries, 735 .

rule laid down by Germany during Franco-Prussian war, 735.

COCKBURN, SIR ALEXANDER

on relation of Great Britain to system of international law, 88 .

reasons for dissenting from award of Tribunal of Arbitration at Geneva, 259.

CODE NAPOLEON

affirmed principle of actual detention as determining title to personal property captured on land, 540 .

\section{COKE}

commended Henry VII. for opposition to permanent embassies, 317 . liability of envoy to punishment for crime under local laws, 318 .

limits of military occupation, 589.

COLERIDGE, LORD

definition of international law, 84 .

on testimony of publicists, $53 n$.

how states may give assent to rule of international law, 89.

COLLEGIUM FETIALIUM

origin of, $363 n$.

its composition and duties, 24, 363.

COLONIES,

see Chartered Companies; Occupation.

COMITY,

basis of international private law, 207.

surrender of fugitive criminals dependent upon, in absence of express compact, 252, 256.

exemption of coastwise fishing boats from capture during war originally based on, 559 .

exemption from capture of ships and cargo wrecked on enemy coast, rests upon, 560 .

privilege of exterritoriality accorded to vessels of war based on, 305 .

maxims of Huber, 206, 208.

COMMERCIAL BLOCKADE, see Blockade.

COMMERCIAL, CONVENTIONS,

for regulation of conditions of reciprocal trade, and defining rights and duties of commercial intercourse, 374 .

COMMISSION,

right of insurgent state to commission cruisers at sea on recognition of its belligerency, 191.

COMMISSIONS OF INQUIRY,

as preliminary means of settlement of international controversies, 384.

COMMON LAW OF NATIONS,

its place in international law, 364,365 .

principle of suum cuique called the common law of the sea, 564 . COMPACT, FAMILY, OF 1761, 109.

COMTE, AUGUSTE

founder of science of society, 4 .

on method of study of social organization, 4 .

CONFEDERATIONS,

distinction between personal and real unions, 159 .

federalism prior to second constitution of United States, 163. 
CONFEDERATIONS-Continued.

fundamental principle of, the requisition system, 163.

how federal unions are classified, 165.

characteristics of confederated state or staatenbund, 165.

Swiss and German confederations originally of this class, 165.

when Swiss confederation became sovereign state, 165 .

right of cantons to make separate treaties, 166 .

new constitutions of 1848 and 1874, 168 .

of the Rhine, 112 .

Germanic confederation; constitutions of, under Peace of Westphalia and Congress of Vienna, $160,166$.

withdrawal of Austria from, 122, 168.

North German confederation; constitution of, 168 . reorganization of, into Empire of Germany in $1871,169$. technically a staatenbund, but really a bundesstaat, 169 .

United States: first constitution a confederation on old plan, 164. path-breaking idea embodied in second constitution, 164 .

nature of Union under second constitution, 165 .

unique federal creation of 1787 a bundesstaat, 166.

its effect upon other state systems, 167.

defect in present constitution of United States 170 .

no federal control over states in certain cases, 170 .

case of McLeod, 171.

Central and South America; entire state system of, formed upon

North American plan, 168.

whether Achaian League may be classed as composite state, 167.

CONFERENCE,

see Congress and Conference.

CONFISCATION,

general principle affecting public and private property in enemy country, 539.

enforced only as a supposed military necessity, 547, 552.

distinguished from sequestration, 552 .

confined almost exclusively to civil wars, 552 .

limits of modern practice, 463.

of private property; of resident enemies, 198, 462.

held by United States Supreme Court to be a war right, but not effective without legislation, $198 n, 462,551$.

legislation of American Congress during Civil war, 551, 555n. under these acts property or stocks, as well as freeing of slaves, within war right of, 551 .

act of Confederate Congress, 1861, 463.

removal of enemy property after outbreak of war, 463, 554 .

as a right of the crown in Great Britain, 463.

attempt in that country to distinguish between debts and other property, 463.

of private property of Elector of Hesse by Napoleon, 267.

of interest of English creditors in Silesian loan, 442, 712.

of debts between individuals of belligerent states, 552 . when an excuse from second payment, 552 .

never justified as means of extinguishing title to real property, but income is subject to, 552 .

right of. as affected by owner's domicil, 552 .

matter of the Laurents, 553 .

rule so extended as to make citizen enemy of his country, 553 . so extended as to cotton owners during Civil war, 553 .

on continent of Europe nationality of owner controls, 553 .

right of, as affected by situs of property, 554 .

reason for liability of property so situated, 554 .

of enemy ships in port at outbreak of war, 463 .

of enemy property in neutral territory, 553, 554 .

Great Britain's maintenance of right of, as to enemy goods in neutral vessels, 637,721 . 
[THE REFERENCES ARE TO THE PAGES.]

CONFISCATION-Continued.

effect of hostile use of neutral property, 554 .

merchant vessels captured under enemy convoy, 554, 790 .

of vessel engaged in unneutral service, 758.

as penalty for carrying contraband, 744 .

of vessel attempting to avoid belligerent right of angary, 702 .

of vessel for possession of false documents or for destruction of papers, 785 .

not allowable in counection with pacific blockade, 445 .

by occupying army; right as to state property, 539, 545.

exemption in favor of holder of public securities, 542.

works of art, libraries and museums exempt from, 543.

rule of The Hague Conference as to property of religious, char-

itable and educational institutions, 547.

private property of enemy persons not subject to, 547 .

of cotton and other articles during American civil war, 555. criticism of action of United States, 556.

of slaves; decision of Czar of Russia as arbitrator between

Great Britain and United States, 551.

rule of American Regulations, 551.

emancipation proclamation of President Lincoln, 551.

see Conquest; Contraband; Neutrals; Property, Enemy.

CONFLICT OF LATVS,

relation of subject to public international law, 153.

reasons for preferring title, international private law, 153.

see Comity; International Private Law.

CONGO FREE STATE,

extension to, of international law, 90.

CONGRESS AND CONFERENCE,

assemblies of nations for purpose of quasi legislation, 44.

difference between a congress and a conference, 44 .

limited full powers to envoys, 330 .

instructions to envoys, 330 .

immunities accorded to envoys assembled in, 332 .

political, under flags of truce in time of war, 508.

notable congresses: Westphalia, 1648; Nimeguen, 1678; Ryswick, 1697; Utrecht, 1712; Rastadt, 1797-99; Vienna, 1815; Verona, 1823; Paris, 1856, and Berlin, 1879, 44.

Rastadt, abolished Rhine tolls, 283.

Vienna, undertook reconstruction of ancient diplomatic fabric of Europe, 45 .

and confirmed free navigation of Rhine, 283.

navigation of other rivers opened and regulated, 283.

settled questions of precedence between classes of diplomatic agents, 319 .

fragments of work that survive in international law, 45.

Aix-la-Chapelle, 1818, France became party to Holy Alliance, 116.

Troppau, 1820, declaration of Holy Alliance of right to intervene to prevent "crime" of revolt, 116.

Verona, 1822, circular letter of Holy Alliance declaring intention "to repel the maxim of rebellion," 116 .

secret treaty to put end to representative government and liberty of press, 117.

Paris, declaration of new maritime rules, 46.

Berlin, modified treaty of San Stefano, 125 .

conferences; St. Petersburg, 1825, paved way for independence of

Greece, 45 .

London, 1831, arranged separation of Belgium from Holland, 45.

Geneva, 1864, gave direction to first European effort for greater humanity in rules and practices of war, $45,46$. 
CONGRESS AND CONFERENCE-Continued.

Geneva, 1868, provided for neutralization of hospital ships, 46 .

St. Petersburg, 1868, declaration in regard to projectiles, and stating object of use of weapons in war, $46,479,481$.

London, 1871, modified treaty of Paris, 46.

Brussels, 1874 , to promote adoption of common code for regulation of warfare on land, $46,47$.

see Brussels Conference.

Constantinople, 1877, endeavored to secure from Porte guaranantees for better government of Christian subjects, 46 .

Berlin, 1S\$4-85. for regulation of affairs of West Africa, 46, 270.

Washington, 1889, 46.

Brussels, 1890, resulted in a final act for suppression of African slave trade, 46,270 .

The Hague, 47, 4S, 49, 50, 51, 384 . see Peace Conference of The Hague.

\section{CONQUEST,}

subjugation of a state forbidden by common law of nations, ex-

cept when necessary to general security, 364 .

ancient theory of substituted sovereignty, 584 .

law of occupation as drawn from Roman sources, 128.

how rights of native infidel inhabitants of New World were regarded, 127.

effect of former mistaken view of military occupation, 584,585 .

modern theory of quasi sovereignty of belligerent occupant, 585 . military authority over hostile territory as limited by The Hague Conference, 587.

in military sense, distinguished from, in legal sense, 266, 584, 606. in legal sense, when complete, 266, 584.

may be, by possession, but usually validated by cession, 606 , 613.

until cession, occupation is technically called usurpation, 607 . whether consent of inhabitants to cession is necessary, 613 . its effects, 606 .

alienation of territory pending mere intention to conquer, 607 . effect of, by Great Britain, 607 .

effect of, by armies of United States, 267, 607, 793. construction of stipulation on acquisition of Florida, 607. decisions of Supreme Court in Insular Tariff Cases, 793. oath of allegiance exacted during military occupation when complete, is intended, 606 .

right of election between emigration and transfer of allegiance usually guaranteed inhabitants, 607, 610 .

when consent to transfer of allegiance presumed, 607 .

effect of, on title to public property, 608 .

validity of alienations by de facto government, 266, 608 . case of the Electorate of Hesse-Cassel, 267, 608 .

debts due Confederate States held lawful subject of, 608 . case of United States against builders of vessels in France, 609.

case of McRae, 609 .

effect on laws, municipal and political, 609 .

private property unaffected by change of sovereignty, 607, 610 .

suppression of a rebellion by, 611 .

exaction of indemnity and guarantees, 612 .

practice of United States, 613.

postliminy as applied to states or provinces, 615 .

when alienation of domain, income and other property by occupant must be respected, 615 .

disagreement as to rule affecting personal property, 616 . see Military Occupation and Administration. 
CONSOLATO DEL MARE,

earliest collection of laws and customs of sea in time of war, 564 .

its origin and nature, 41, 564, 705, 708 .

rule of, ownership of goods the test, 564, 706 .

its application to neutral goods, 564, 565, 707, 708 .

equitable adjustment of freight under, $565,629 n, 707$.

rule of, adopted by American judiciary, 715 .

French doctrine of hostile infection, first assault upon, 565, 629, 709.

further variations established by the Dutch, 566, 629, 709 .

finally supplanted by doctrine of free ships, free goods, 566, 721. cited, 575.

CONSPIRACY,

minister forfeits personal and local immunities in case of, 336,342 . cases of Gyllenborg and Cellamare, 336.

CONSTANTINOPLE,

conference, 1877, to obtain from Porte guarantees for better government of Christian subjects, 46 .

CONSTITUTION, CASE OF THE, 305n.

CONSTRUCTION AND INTERPRETATION OF TREATIES,

distinction between construction and interpretation, 394 .

foundation for existing system of rules of interpretation laid by Grotius, $395 n$.

general rules of, 395 .

instrument must be taken as a whole, 395 .

meaning can be drawn only from words used, 396 .

spirit rather than letter should govern, 396 .

treaty must be so construed as to exclude fraud, 396 .

when general terms are obscure or equivocal, 396.

extent to which matters aliunde may be considered, 395, 396 .

when term has special meaning in each of several states, 396 .

technical terms, how construed, 397.

when recourse must be had to general spirit and purpose, 397 . construction most favorable to execution of treaty as designed by parties preferred, $397 n$.

clauses in favor of justice and humanity, 397.

presumption favors state's retention of sovereignty and property, 397, 401.

incidents of substantive rights and obligations, 397.

rules regulating certain preferences, 398 .

where two meanings are admissible, 398. use of interpretation clause, 398 .

special rules, 398 .

general permission overcome or limited by imperative provision, 398 .

special permission overcomes general imperative provision, 398 .

precedence between conflicting prohibitive provisions, 398 .

when stipulations are so identical that no priority can be assigned, 399 .

when most recent of two treaties takes precedence, 399 . exception to this rule, 399 .

prior treaty prevails over subsequent one in conflict, 399 . exception to this rule, 402 .

rules laid down by Supreme Court for, of treaties of cession, $276 n$.

CONSULS,

Greek system of proxenia analogous to modern system of consular agency, 618 .

quasi-international character of, 355 .

fiction of exterritoriality does not extend to, $456 n$.

their duties, 356.

consular organization as a whole, 357 .

possess neither diplomatic character nor its immunities, 355. 357, 
[THE REFERENCES ARE TO THE PAGES.]

CONSULS-Continued.

exemptions from local and political obligations through comity, 357.

their privileges, $357,358$.

their local obligations, 358 .

consequences of political misconduct, 358 .

privilege does not extend to mercantile transactions outside offcial business, $358 n$.

in United States, have privilege of being sued only in federal courts, $358 n$.

not affected by political changes, 358 .

citizen commissioned by foreign state as consul, 358.

sometimes clothed with judicial and diplomatic functions by treaty, $359,376$.

certain treaties enlarging privileges and duties of, $359 n$.

extension of judicial side of consular office, 312,360 .

offenses punishable by, of United States in certain states, 246 .

cases of the Sally and the Newton, 312.

consular courts in Egypt, 360.

consuls à l'étranger, 355 .

CONTINUOUS VOYAGE,

definition of, 778 .

original application of doctrine, 777 .

doctrine of, as applied to breach of blockade, 777 .

dangerous extension of doctrine during American Civil war, 778. just criticism of such extension, 779 .

case of the Bermuda, 778.

case of the Springbok, 778 .

decision condemned by Institut de Droit International, 72.

CONTRABAND,

proposal of United States to European nations to restrict, 721.

emancipation of neutral commerce, never intended to include, $121,725$.

penalties imposed by Roman emperors and popes upon traders in, 725 .

origin of term, 725 .

Grotian definition of, 725 .

substantial reproduction of Grotian definition by Supreme Court of United States, 726.

principal points of contention in controversy as to what is, 726 . power to declare what is, 725,739 .

articles considered absolutely, 727 .

the usus bellici test of contraband character, 727 .

articles designated as, in treaties, 727 .

by France in instructions to naval officers during Crimean war, 728 .

in Prof. Holland's Manual of Naval Prize Law, 728.

in American Naval War Code, 728.

articles which may or may not be contraband, 728 .

policy of Great Britain to extend list, and to deal severely with those engaged in traffic, 729 .

opposition of continental publicists to English position, 729.

materials and machinery for manufacture of arms and munitions of war, 729 .

Bynkershoek's position as to materials out of which, may be made, 729 .

saltpeter, sulphur and other materials used in manufacture of explosives, 730 .

materials for naval construction, 730 .

Lord Stowell's opinion in case of the Maria, 731.

expressly excepted from list of, in convention of St. Petersburg, 1801, 731 . 
[THE REFERENCES ARE TO THE PAGES.]

CONTRABAND-Continued.

rule of this convention adhered to by France, but repudiated by Great Britain, United States and Spain, 732. horses, 732 .

limit of prohibition in United States and other American countries, 733 .

coal, 733 .

doctrine of conditional, applied by Great Britain to coal during Crimean war, 733.

same, under certain circumstances by American Naval War Code, 734.

English rule enjoyed by United States in Geneva award, 734.

position of Germany during Franco-Prussian war, 735.

contrary position of other continental states, 735 .

provisions may become, 735 .

views of Grotius, Bynkershoek and Vattel, 735 .

practice of Great Britain, 736 .

Lord Stowell's opinion in the Jonge Margaretha, 737.

Lord Stowell's rules accepted and restated by United States Supreme Court in case of the Commercen, 737.

rice destined for Chinese ports declared, by France, 739 .

Great Britain's seizure of the Bundesrath, Herzog and the General during Boer war, 738.

money, metals, cotton and clothing may be, 738 .

cotton and similar articles treated as constructive, during American Civil war, 555, 738.

criticism of American position, 556 .

Mr. Bayard's statement why cotton was so regarded, 738.

case of the Peterhoff, 739 .

conditional, English doctrine of, 740 .

acceptance of doctrine by United States, 734, 740.

existence of, denied by continental publicists, 740 .

rights and liabilities of neutrals in respect to, 741 .

state responsibility for individual action, 740 .

not required to prohibit sale of, to belligerent agents, $\mathbf{7 4 2}$.

offense of transporting, when complete, 741, 743 .

belligerent destination and contraband cargo must co-exist to constitute offense, 757 .

presumption as to belligerent destination, 743 .

penalty can only be inflicted before deposit, 743 .

liability of vessel to capture upon reasonable grounds of belief that cargo is liable to confiscation, 785 .

when return voyage will not be regarded by Great Britain as

a separate and innocent expedition, 743 .

English position condemned by continental and American publicists, 743 .

modification of rule in British Admiralty Manual of Prize Law, 743 .

doctrine of continuous voyage applied to carrying of, 777 .

dangerous extension of doctrine by United States, 778. just criticism of such extension, 779 .

cases of the Bermuda and the Springbok, 778 .

- decision in Springbok case condemned, 72.

penalty for carrying, 744 .

rule laid down by Lord Stowell, 744.

modifications of existing penalties by treaty, 745 .

whether right to purchase free continuation of voyage exists

in absence of treaty, 745 .

pre-emption as a means of acquiring title to, 746 .

provisions of British Admiralty Manual of Prize Law, 746.

of neutral goods not liable to confiscation as, 747 .

distinction between unneutral service and carrying of, 748 . 
[THE REFERENCES ARE TO THE PAGES.]

CONTRABAND-Continued.

carriage of diplomatic and consular correspondence, 749 .

vain attempt of Mr. Seward to class diplomatic agents as, 753 . carrying prohibited despatches or persons, 754 .

CONTRACTS,

when governed by lex domicilii, 209 .

effect of war upon, 459 .

views of Heffter and Sir Wm. Scott, 460.

ransom bills and the like are enforceable, 460 .

made under license to trade with enemy are enforceable, 510.

authentication of, by diplomatic agents, 347 .

CONTRIBUTIONS,

distinction between, and requisitions, 549 .

levied by Gustavus Adolphus, 549 .

rules of Brussels and The Hague Conferences on, 550 .

levy must be on authority of commander-in-chief, 550 .

receipt must be given to person paying, 550 .

levies made by United States during Mexican war, 551.

people giving shelter to wounded exempt from, 538 .

CONVENTIONS,

distinction between, and treaties, 394 .

term "transitory," as used to describe perpetual treaties, discarded in this work, 367 .

of Pilnitz, 1791, 112.

of Kutayeh, 1833, ceded whole of Syria to Mehemit Ali, 182.

of Gastein, 1865, 122.

of Nikolsburg, 1866, 122.

see Treaties.

CONVOY,

right of ships under, to freedom from search first asserted by Sweden, 1653, 635 .

insistance of Great Britain to right of search, moving cause of Second Armed Neutrality, 635, 636 .

Great Britain's vindication of her right of search in convention of St. Petersburg, 1801, 637, 721.

whether convoyed ships may be visited, 788 .

continental practice, 563,789 .

English and American practice, 789. case of the Nereide, 789.

continental rule now accepted by United States, 563.

controversy between United States and Denmark as to, 790 .

opinions of publicists concerning American position, $791 n$.

difficulty of establishing rule of, 563 .

CORPUS JURIS CIVILIS,

origin of, 19.

COURTS,

treaties establishing special tribunals, 375 .

Greek international conventions providing for administration of justice to resident foreigners, 12,375 .

jurisdiction of Roman praetor peregrinus, $21,376 n$.

jurisdiction of consular, 359,376 .

see Arbitration; Prize Courts.

CRACOW,

former status in international law, 177.

CREOLE, CASE OF THE, 311 .

CRETE,

blockade of, by great powers, 1897,445 .

CRIMEAN WAR,

motive for intervention which resulted in, 119, 430 .

freedom of trade permitted to neutrals during, 513, 563.

terminated by treaty of Paris, 1856, 119. 
[THE REFERENCES ARE TO THE PAGES.]

CRIMINAL OFFENSES,

exceptions to rule that territory and jurisdiction are co-extensive in respect to crimes, 233 .

territoriality of, disputed by many nations, 240 .

Cutting's case, 241.

jurisdiction of, committed within three mile zone, 138.

domiciled aliens subject to local criminal law, 251.

foreigner can demand only fair trial under local law, 242.

jurisdiction of, not completed before expatriation, 226 .

treaties of United States as to jurisdiction of offenses of naturalized citizens, 227.

committed on shore by crew of foreign public vessel within juris-

diction of local tribunals, 307.

committed abroad, right of state to punish its citizens for, 243 .

general rule in Great Britain and United States that crimes are territorial, 244.

legislative departures from this rule, 244, 245 .

British Foreign Enlistment Acts, 244.

legislation in different countries against slave trade, 236. declared piratical in United States and Great Britain, $236,237$.

judicial interpretation of these statutes, 236 .

jurisdiction of, committed on high seas against laws of United States, 245.

entire jurisdiction of, committed beyond limits of several states vested in federal government, 245.

criminal jurisdiction of United States purely statutory, 245 .

jurisdiction of, during military occupation, 587.

punishment of, in occupied territory, 597.

offenses punishable by United States ministers and consuls in cer-

tain countries, $246,359,376$.

proper course where envoy's country claims exclusive juris-

diction to try, 343 .

envoy must not harbor criminals not of his suite, 343 .

envoy's contentious jurisdiction no longer exists, 347.

immunity of diplomatic agents from local jurisdiction, 336, 337.

when envoy may be arrested and expelled for crime, 336 .

cases of Gyllenbor'g and Cellamare, 336.

when an envoy may be punished by a local tribunal, 337 .

of diplomatic agents does not include mere visitors, 337 .

Sa's case, 337 .

immunities of minister's servants, 346 .

liability of consuls to local criminal jurisdiction, 357 .

immunity of traveling sovereigns, 228 .

of foreign army in friendly state, 230 .

CUBA,

transfer of, by Spain, opposed by United States, 146, 419.

intervention of United States in, as a contingent necessity, 420 .

devastation of, under Gen. Weyler, 483.

intervention of United States in, precipitated by destruction of the Maine, 420.

forcible intervention in behalf of, advised by President McKinley, 421.

grounds of intervention as defined by President McKinley, 421.

intervention of United States in, justified by general principles of international law, 422 .

CUSHING, ATTY.-GEN.

foreign ship of war in port of friendly power exempt from local jurisdiction, 304 .

privilege accorded diplomatic representative from foreign state not recognized by United States, 332 .

cited, 598. 
CYPRUS,

Island of, acquired by Great Britain from Turkey at Congress of Berlin, 1878, 126.

\section{DAMAGES,}

for wrongful capture, 577.

see Reparation.

DAMM,

judgments of, $40 \mathrm{n}$.

DANA, JR., RICHARD HENRY

contention as to condemnation of the Amedie, 237.

view that legislation extending limit of territorial waters for certain purposes is invalid, 295.

fishing rights in British possessions were by treaty, 1818, guaranteed to United States on basis of contract, $297 n$.

on grounds for dismissal or demand for recall of minister, 351.

rules established by judicial decisions under foreign enlistment acts of United States, 653.

exercise of sovereignty during military occupation, $586 \mathrm{n}$.

recognizes belligerent right of angary, 703 .

test of neutral liability for fitting out of hostile expedition within its territory, 681 .

register of foreign nation as proof of nationality of vessel, 409 .

right of self defense, when vessel attacked in neutral waters, 701. purchase of free continuation of voyage in absence of treaty, 745 .

obstacles to such right becoming a recognized canon of international law, 746 .

Denmark's condemnation of American vessels under English convoy authorized, $791 n$.

frequently cited, for example, 213, 686, 701, 723, 754, 775.

DANUBE RIVER,

excepted from regulations made by Congress of Vienna, 1815, 115.

by Peace of Paris included in those regulations, $115 n, 120$.

Russia deprived of command of mouth of, by Peace of Paris, 120. commercial use of, $120,284$.

DARDANELLES,

recognition of ancient custom of the Porte in respect to exclusion of ships of other powers from, $120 \mathrm{n}$.

provisions of treaty of Paris, as to passage of ships of war, 120. modification of principle of closure, 124.

DAVIS, J. C. BANCROFT

cited, 194, 410 .

\section{DEBTS,}

of a state; not affected by change in ruler or of internal organization of government, 198 .

effect of extinction of sovereignty, 201, 205.

necessary to distinguish between general, of state, and such as are special and local, 201, 205.

Hall on difference between effect of acquisition by cession and by absorption of an entire state, $201 n$.

where state is absorbed by another, 201, 205.

where two entirely new and distinct states are created out of one annihilated, 201, 205.

opinions of Grotius, Kent, Phillimore, Hall and Heffter, $201,202$.

case of the Netherlands, 201, 202.

custom to provide in treaties of cession for proportionate share of public, to follow ceded territory, 277.

effect of dismemberment, 202 .

in case of acquisition of part of state by conquest, 202,608 . cases of such unions, 203. 
[THE REFERENCES ARE TO THE PAGES.]

DEBTS-Continued.

due confederate states, held subject of conquest, 608 . actions by United States in France and Great Britain

for recovery of moneys due Confederacy, 608 . payment of guaranteed loans, 203.

when severed territory becomes distinct community, 203. new state liable for local obligations, 204.

effect of war upon payment of public, 542, 548 . public, not the subject of reprisal, 442,542 .

confiscation of interests in Silesian loan, 442.

capture of evidence of public, without complete conquest, 542.

refusal to settle, sufficient cause for withdrawal of diplomatic agents, 432 .

see Loans.

private; confiscation of, when between individuals of belligerent states, 552 .

.rhen an excuse for second payment, 552 .

confined almost exclusively to civil wars, 552.

of prisoners, paid on release after conclusion of peace, 605 .

see Ambassadors; Diplomatic Agents.

DECEIT,

to what extent permitted against enemy, 490 .

Roman practice, 490 .

use of false uniforms or flags, 490 .

rule as to negotiations, 490 .

when artifice is permissible at sea, 500 .

DECLARATION OF PARIS,

abolished privateering, 121.

that blockades to be binding must be effective, $121,513,766$.

that neutral flag covers enemy goods, and neutral goods not liable to capture under enemy's flag, 120, 513, 566, 722.

invitation to accept, refused by United States, Spain, Mexico, China and Venezuela, 567, 722.

American amendment defeated by Great Britain, 723 .

reasons for refusal of United States, 723 .

observed by United States during Mexican and Civil Wars, and ly both combatants in Spanish-American War, 567, 723.

effect of provision that same shall not be binding except between signatory powers or those acceding thereto, 723 .

whether belligerent who has signed same is bound thereby in war with state not signing or acceding thereto, 724 .

DECLARATION OF ST. PETERSBURG,

assisted in development of modern military code, 471 .

convention as to projectiles, $46,479$.

DECLARATION OF WAR,

formal declaration made by civilized nations of antiquity before commencing hostilities, 24.

how made by the Greeks, 24.

by the Romans, 24 .

in the Middle Ages, $24 n, 455$.

under Roman law function belonged to collegium fetialium, 24 .

from what power must proceed, 457.

United States and Great Britain reproached by Calvo and Hautefeuille for beginning hostilities without, 454 .

by conditional ultimatum, 457 .

when making of warlike alliance is tantamount to, 466 .

DELAGOA BAY,

controversy between Great Britain and Portugal in relation to, submitted to arbitration, 44. 
[THE REFERENCES ARE TO THE PAGES.]

DEMONSTRATIONS, see Military and Naval Demonstrations.

DENMARK,

nature of international relations of, 160 .

led the way in prohibition of slave trade, 236.

exacts dues for passage of vessels through two Belts, 280 .

treaties with, for free passage through two Belts, 280 .

sale of conquered Swedish provinces by, to elector of Hanover, 585 . relation to armed neutralities, 634,636 .

conflicts with Great Britain in regard to right of convoy, 636 . battle of Copenhagen, 637 .

seizure of Danish fleet by Great Britain as permissible measure of self-preservation, 411.

controversy with United States as to condemnation of American ships taken under British convoy, 790 .

Danish position justified by Dana, 791n.

loss of territory by peace of Nimeguen, 1678.79, 102.

treaty of Fontainebleau, 1679, 103.

treaty of Lund, $1679,103$.

intervention of Prussia in affairs of, 414 .

loss of Schleswig, Holstein and Lanenburg by peace of Vienna, 1864, 121.

DERBY, LORD

duty of enforcing collective guaranty of neutrality, 373 .

DESERTERS,

punishment of, 494 .

not protected by flag of truce, 508 .

reception of, during armistice, 514 .

inciting enemy's soldiers to desert unlawful, 494.

raising of Hungarian regiments against Austria by France and Prussia, 494.

DESPATCHES,

carrying of, by neutral for belligerent, 749, 750, 755 .

prohibited, defined, 755 .

case of the Atalanta, 755 .

consular and diplomatic, 749, 750, 755.

case of the Caroline, 750, 755 .

case of the Madison, 750 .

DESTRUCTION OF STORES, when lawful, 517.

DEVASTATION,

as a means of offense, 482 .

as a means of defense, 483 .

DICEY,

domicil of dependent persons under laws of Great Britain, 221.

cited, 208, 209, 214, 249, 250, 251.

DIPLOMATIC AGENTS,

lack of protection afforded, in ancient and medieval times, 316, 618 . slaughter of Persian envoys by Athenians and Spartans, 316 .

Turkey's disregard of general usage as to treatment of, 316 . growth of immunities, 318 .

classes; not divided into classes or orders in ancient times, 316. the several classes of, 317,319 .

disputes as to precedence between several classes, 318 .

relative rank of several classes, 318 .

distinctive character of ministers plenipotentiary, 318.

questions of precedence, see Diplomatic Intercourse.

right of personal audience with sovereign, 320 .

letters of credence and additional full powers, 329 .

effort of Great Britain to simplify ceremonial of, $329 n$. 
[THE REFERENCES ARE TO THE PAGES.]

\section{DIPLOMATIC AGENTS-Continued.}

limited full powers, 330 .

instructions to envoys, 330 .

general full powers rare, if not obsolete, 330 n.

whether new leiter of credence is necessary in cases of successful revolution, $349 n$.

right of innocent passage, 330 .

right of third state to prescribe route, 331.

Mr. Soulé's case, 331.

necessity for safe conduct in time of war, 332 .

Belleisle's case, 332 .

ceremonials of arrival and reception, 334 .

beginning of functions, 334 .

ceremonial lex loci, 334 .

inviolability of despatches of neutral envoy in time of war, 333 . immunities are not unlimited, 334 .

their duration and extent, $325,335$.

when envoy may be arrested and expelled, 336 . cases of Gyllenborg and Cellamare, 336 .

ordinary cases of violation of criminal laws by, 337.

immunity from local criminal process, 337 . state represented may waive immunity, 337 . Wicquefort's case, 337 .

what persons included in this immunity, 337.

Sa's case, 337 .

immunity of, when citizens of states to which sent, 328 . commissioners for special purposes not entitled to, 354 . exemption from local civil jurisdiction, 338 .

purpose of legislation exempting them from, 339.

privilege not forfeited by trading, 339 .

case of Taylor v. Best, 339.

Magdalena Steam Navigation Co. v. Martin, 340.

proper course for collection of debts of, 339 .

how envoy's personal effects may be subjected, 340 .

tacit hypothecation not enforceable, 341 .

case of Mr. Wheaton, 341.

minister cannot be compelled to appear as witness, 338 . proper course in such case, $338 n$.

how civil immunity may end, 341 .

immunity of minister's hotel and grounds, 342.

envoy must not harbor criminals not of his suite, 343 .

remedy when demand of local authorities for surrender

of criminal is refused, 343 .

case of Mr. Guidekens, 343.

where envoy's country claims exclusive jurisdiction, 343.

whether refusal to deliver criminal justifies forcible entry and seizure, $342,343,346$.

case of Duke of Ripperda, $343 n$.

right of asylum for political refugees, 343 .

immunity of envoy's residence defined, 344 .

immunities continue after termination of mission, until return

to their own country, $350 n$.

exemption from general taxes, $345,357$.

exceptions to this rule; 345 .

views of Wheaton and Phillimore, $345 n$.

liability for local dues, 345 .

exemption from custom dues, 346 .

freedom of religious worship, 344 .

immunities of envoy's servants, 346 .

practice in Great Britain in respect to servants, 346.

how accused servants should be dealt with, 348 .

envoy's contentious jurisdiction no longer exists, 347 . 
DIPLOMATIC AGENTS-Continued.

extent of envoy's voluntary jurisdiction, 347 .

offenses punishable by United States ministers and consuls in cer-

tain countries, 246.

termination of mission; grounds for recall, 338,343 .

may terminate, with or without formal recall, 348 .

in what cases termination of mission is absolute, 349 .

dismissal of envoy before recall, 350 .

case of Mr. Genet, 351,643 .

should not be capriciously sent away, 350 .

engaging in enlistment of troops for his government subject to summary dismissal, 352 .

position of United States in case of delay in recall, 353.

procedure when mission is terminated by death of envoy, 354 . quasi-international character of consuls, 355 .

judge consuls, 355 .

consuls à l'etranger, 355.

DIPLOMATIC INTERCOURSE,

conditions of, in ancient times, 316 .

effort to establish permanent embassies, 316 .

views of Grotius, Bynkershoek and Vattel as to right of, 317.

growth of diplomatic immunities, 318 .

precedence of agents as settled at Vienna and Aix-la-Chapelle, 319.

how diplomatic rank is usually determined, 321.

theory of equality between sovereign states, 322 .

precedence of Pope and Emperor, 322.

significance of royal honors, 323 .

right of every state to regulate ceremonials, 323 .

courtesy on high seas, 323 .

right to send and duty to receive envoys, 324 .

difficulties incident to contests for sovereignty, 324 .

reception of agents of Confederate government by France and

Great Britain, $325 n$.

effect of revolutionary changes after reception of envoy, 325 .

right of legation in favor of part-sovereign states, 326.

right to reject envoy, 327 .

inquiry in advance as to acceptability unusual, $327 n$.

conditional reception of, 328 .

offer to conditionally receive, must not pretend to prescribe qualifications, 328 .

Mr. Keiley's case, 328 .

once received unconditionally entitled to immunities, 329.

control of foreign affairs of United States in federal government, 326.

carriage of official dispatches, 750,755 .

severance of, as a negative remedy for obtaining redress, 431.

how business may be transacted during suspension of, 432 .

refusal to settle just claims sufficient cause for, 432 .

with Naples, by France and England, because of inhumanity

of government, 429 .

withdrawal of American chargé from Rio Janeiro, 1827, 432.

suspension of, with Mexico, 1858, 432.

withdrawal of American minister at Paris, 1834, 432.

suspension of, between Great Britain and Venezuela, 432.

transport of diplomatic agents, 752 .

the Trent affair, 752 .

\section{DISCOVERY,}

early conflicts as to boundaries in new world, 127.

principle established in Europe in respect to title by, 127, 129.

necessary that settlement follow, to perfect title, 128.

rights of infidel inhabitants, 127, 129.

Roman law supporting title by, 128 . 
[THE REFERENCES ARE TO THE PAGES.]

DíSCOVERY-Continued.

title to newly discovered lands under English constitution, 129.

defect in old doctrine of discovery and settlement exposed, 130, 268 . an insufficient ground of proprietary right, $268 n$.

confers for a reasonable time exclusive right of occupancy, 268. see Occupation.

DIVORCE,

law of domicil controls in cases of, 209.

DOCUMENTS,

liability of vessel to capture for possession of false, or for destruction of papers, 785 .

\section{DOMICIL,}

governs the civil status of persons, 209 .

all rights in movables governed by law of, 209 .

effect of, on national character of individual, $211,212,523$.

locality, not nationality, all-important test of character, 212.

$\mathrm{Mr}$. Marcy on relation of domicil to national character, 212. position controverted by Hall, $212 n$.

what necessary to constitute, $249,523$.

kinds of, and their continuance, 250.

of minors and married women, 220, 250 .

as affected by question of legitimacy, 220, $250 \mathrm{n}$.

of child born in United States of foreign father, and taken abroad, 220.

that of envoy continues in his own country, $345 n$.

different domicils for different purposes, 251 .

when it ceases, 524 .

effect of, in enemy's country, 523, 554 .

effect of such domicil on private property, $212 n, 525$.

see Aliens; Allegiance; Enemy Persons.

DUMDUM BULLETS,

originally manufactured for British Army in India, 479.

declaration of The Hague Peace Conference against use of, 479 .

declaration not signed by Great Britain and United States, 479.

DUMONT,

cited, 36, 94, 96, 97, 101, 102, 103, 104, 105, 107, 108, 623, 630, 667, $710,711$.

DURESS,

treaties of peace cannot be invalidated upon ground of, 385,602 . but force and intimidation may vitiate agreements, 385 .

DWARRIS,

cited, $394,395$.

EGYPT,

military successes of Mehemit Ali, 182.

administration of, given to Mehemit Ali and his descendents, 183. government under direction and advice of Great Britain, 183.

revolt of Arabi Pasha crushed by Great Britain, 183.

appointment of controllers-general for, by France and Great Britain, 183.

European control of administration of justice in, 184 .

reformed tribunals of 1875,360 .

progress of consular courts in, 360 .

neutralization of Suez canal, 184.

right of, to negotiate commercial and postal conventions with fureign powers, $326 n$.

ELBE, THE

free navigation of, established, 283.

ELIZABETH, QUEEN

refusal to receive nuncio of Pius IV., 327.

position of, as to freedom of sea, 291. 
[THE REFERENCES ARE TO THE PAGEs.]

ELLENBOROUGH, LORD

decision as to invalidity of Danish sequestrations, 463.

enemy trader under license cannot sue in his own name, $510 n$.

EMBARGO,

as a positive remedy for obtaining redress, 431 .

different forms of, 433 .

domestic, of United States, 1794, and non-intercourse act of 1809 , 434.

principal decisions of United States under embargo laws, $433 n$. same under non-intercourse laws, $434 n$.

upon shipping of Two Sicilies by England, 1839, 434.

ENCLAVE,

right of, denied to soldicrs occupying American apartments during occupation of Paris, 469.

ENEMY PERSONS,

effect of domicil in enemy's country in determining national character, 523, 524 .

effect of domiciled enemy putting himself in motion to leave permanently, 524 .

effect of war upon resident enemies, 461.

right of state to imprison, upheld by Grotius and Kent, 461.

Vattel's view the prevailing one, 461 .

enemy soldiers an exception to general rule, 462.

detention or expulsion of, justifiable only for military reasons, $462,467$.

entitled to safe conduct when expelled, 462 .

imprisonment of German merchant seamen by France, 525 .

modern rule as to protection due non-combatants, 485,525 .

rule of American regulations, 525 .

cannot be compelled to serve against their old sovereign, 494 .

confiscation of private property of, 462 .

see Confiscation.

treatment of prisoners, 528 .

see Prisoners.

detention of suspected persons justifiable, 536 .

punishment of military offenses by martial law, 535 .

care of wounded, 536 .

neutralization of persons and things contributing to physical and spiritual needs of combatants, 536 .

requisitions of labor for military purposes, 548 .

in besieged towns, to be respected if non-combatants, 485 .

ENEMY PROPERTY,

see Property, Enemy.

ENEMY TERRITORY,

how district may be internationalized, 556 .

ENLISTMENT,

American Foreign Act, 67, 644, 653.

British Foreign Acts, 646, 653.

of soldiers in neutral state, 468.

of prisoners of war, 530 .

ENVOY,

see Ambassadors; Diplomatic Agents.

EUROPE,

reconstruction of European states by Congress of Vienna, 114.

EUROPEAN CONCERT,

see Balance of Power.

EVARTS, SEC. OF STATE

note to Swiss government on adherence to doctrine of perpetual allegiance, 227.

liability of state for damages done to resident aliens, 171. 
[THE REFERENCES ARE TO THE PAGES.]

EVARTS, SEC. OF STATE-Continued.

how child of alien parents may abjure American nationality, 220 . right of person born here, and taken abroad, to elect nationality, 220.

right of children of naturalized parents to passport to return to this country, 220.

on freedom of fishing rights of United States, from local regulations of New Foundland under treaty of Washington, 298.

cited, 261, 328, 671 .

EVIDENCE,

of domicil, 523 .

in prize cases, 581 .

burden on captor in prize court, 787 .

presumptions arising from professed neutrality, 787.

how neutrality and ownership of vessel may be established, 568 .

ownership of cargo as affecting right of capture, 568.

EXPATRIATION,

right of, necessary to change of allegiance by naturalization, 223 . early American doctrine of, 225 .

cases of Prussian subjects naturalized in United States, 225.

act of United States, 1868, 217, 227.

right of every state to settle question of, for itself, 227.

EXPERIENCE, CASE OF THE, 575.

EXTERRITORIALITY,

of envoys, 334 et seq.

extension of, pertains only to positive law of nations, $335 n$.

legal fiction of, 207.

how far citizens abroad are amenable to local jurisdiction, 233.

immunities and disabilities of sovereigns traveling abroad, 228 . their jurisdiction over subjects in foreign territory, 229 .

foreign army in friendly state exempt from its jurisdiction, 230 .

of what non-territorial property of state consists, 301 .

state jurisdiction over such property, 301 .

immunities of public vessels, 302 .

state's jurisdiction over merchant vessels on high seas, 307 .

immunity of private vessels in territorial waters, 311 . goods of citizens embarked in ships of foreign state, 315.

see Jurisdiction; Property; Vessels.

EXTRADITION,

nature and origin of existing system, 252.

existing system of, regulated by treaty, 252 .

United States and England hold obligation to surrender fugitive

criminal is not absolute in absence of treaty, 253, 255 .

conceded through comity in absence of treaty, 257. case of Argüelles, 255.

treaties between Great Britain and France and United States, 253.

demand for, should be limited to treaty offenses, 257.

crimes committed before date of treaty, 257 .

where fugitive is in custody for offense committed in state on which demand is made, 258.

state may impose conditions for surrender, 256.

fugitive must be tried only for offense specified, 257.

position of United States as to trial for other crimes, 254.

cases of Winslow and Rauscher, 254.

crimes committed in third independent state, 257.

political offenses distinguished from ordinary crimes, 258. case of Castioni, 258.

FENELON,

definition of system of balance of power, 99 .

FEUDALISM,

principle of territorial sovereignty the outcome of, 27, 157.

feudal rule of citizenship, and reaction against it, 218 . 
[THE References are to the pages.]

\section{FIELD, DAVID DUDLEY}

definition of war, 448 .

his "Outlines of an International Code," $69,378$.

divisions of international law, $154 n$.

right of navigation on rivers flowing through foreign state, 287 . classification of reprisals, 436 .

advocates death rather than barbarity in retaliation, 490 .

cited, $331,439,451,473,490,493,532,533,535,540,582,596$.

FIORE, PASQUALE

when state may regard treaty as null, 402 .

intervention permissible to put an end to crimes and slaughter, 429 . cited, $230,240,252,259,380,395,397,404$.

FIRE ARMS, see Weapons.

FISH, SEC. OF STATE

on nature of policy involved in Monroe doctrine, 149.

intervention of United States in behalf of Cuba, 420 .

power to expel obnoxious foreigners incident to sovereignty, 232 . inviolability of despatches of neutral envoy in time of war, 333 . cited, 171, 261, 353, 393, 420 .

\section{FISHERIES,}

state owning shore has exclusive right within marine league, 296.

right to fish in high seas and on banks and shoal places, 296 .

conflicts between Great Britain and United States as to, 296.

construction of treaty of $1818,297$.

case of the schooner Washington, $297 n$.

readjustment of subject of northeastern, by treaty of 1854, 297 .

free trade provisions of treaty of Washington, 1871, 298.

contention of United States as to effect of provincial legislation, 298.

return in 1885 to basis of treaty of 1818,298 .

French rights of fishery on coasts of Newfoundland, 111.

FISHING BOATS,

with crews and appurtenances, generally exempt from capture, 558 . exemption not extended to whaling vessels and those engaged in deep sea fisheries, 559 .

British destruction of, in sea of Azof, 559 .

FLAGS,

when national colors should be displayed in naval warfare, 500 .

use of false colors, 500 .

The Hague rules as to hospital ships, 504.

subject to seizure as booty, 541 .

offer to surrender by pulling down flag, or hoisting white one, 517 .

flags of truce; rules governing, 507 .

political conferences under, 508 .

care of wounded under, 536 .

FOEDERA,

nature of, $363 n$.

FOELIX,

Traité du droit international privé, 66.

powers of state as to persons and property in its territory, 206. cited, 240, 253, 305.

FORCES OF A STATE,

military; in ancient times comprised whole male population, 472. development of standing armies, 472.

regular forces; conduct of hostilities confined to regular army and navy, 472, 473.

who comprise regular forces of a state in time of war, 472. persons not in military and naval forces passive enemies, 473. 
[THE REFERENCES ARE TO THE PAges.]

FORCES OF STATE-Continued.

regular forces governed by military law, 473 .

irregular forces, 473.

employment of savages now condemned, except as against their kind, 474.

use of Indians as allies by United States, 473 .

use of natives in Africa and India by Great Britain, 474. use of Yellow Flags in Tonquin by France, 474.

employment of slaves against their masters by United States in Civil war, 475.

stationing of Indian troops at Malta by Great Britain, 475 . whether guerrillas and banditti may be legitimately employed, 476.

description of guerrillas and banditti in manual for $\mathrm{U}$. S. armies in the field, 476 .

rules of Brussels and Hague conferences in regard to irregular troops, 477.

employment of volunteers from abroad lawful, 477 .

status of levies en masse, 478.

naval; who comprise the, 496 .

right to give battle confined to ships with commissions, 496 .

development of English navy, 496.

original composition of navy of Holland, 497.

rules affecting ships without commissions, 497.

rules governing privateers, 497.

FOREIGN ENLISTMENT ACTS, see Enlistment.

FOREIGNERS;

see Aliens; Citizens; Domicil; Naturalization.

FORESTS,

must be guarded and administered by occupying army, 545 .

sale of right to cut from, during German occupation of France, 546.

FORSYTH, SEC. OF STATE

policy of United States as to recognition of independence, 195. cited, 196, 405.

FRANCE,

prime object of policy of Louis XIV, 100, 102 .

designs on United Provinces frustrated, 102.

results of long struggle between, and rest of Europe under Louis XIV, 103.

intervention in favor of Catholic party, by Austria and Spain, 413. intervention of allied powers in affairs of, 111, 413.

the wars of Napoleon, 112.

becomes a member of the Holy Alliance, 1818, 116.

intervention by, and England in affairs of Turkey, resulting in Crimean war, $100,414$.

former reliance upon treaties of subsidy for troops, $371 n$.

acquisition of territory under Peace of Pyrenees, 100.

treaty of Breda, 101.

peace of Nimeguen, 102.

treaty of Fontainebleau, 103.

peace of Paris, 114.

forced to retire from North America, 109.

her influence at Congress of Vienna, 114.

territorial limits after Congress of Vienna, 115.

second treaty of Paris, $115 n$.

convention with Spain for establishment of special courts, 376 .

reception of Count Pozzo di Borgo and Count de Bray as diplo-

matic representatives of Russia and Bavaria, $328 n$.

refusal to allow Mr. Soulé to sojourn in Paris, 331.

case of Marechal de Belleisle, 332.

arrest of Cellamare, the ambassador of Spain, 336 . 
[THE REFERENCES ARE TO THE PAGES.]

FRANCE-Continued.

conflict between, and United States as to alliance of 1778,464 .

disavows the acts of $\mathrm{Mr}$. Genet in United States, 643.

recall of Mr. Genet as minister to United States, 351,643 .

controversy with United States as to treaty of 1831,390 .

position in respect to juriscliction over bays and gulfs, 278 .

claims whole of oyster beds in bay of Cancale, 278 .

treatment of aliens in, 247 .

treaty with United States as to property rights of aliens, $248 n$.

trial of Frenchman for murder by French ambassador at London. 347 .

claimed pardon of, by James I, unauthorized, $347 n$.

refusal to surrender Russian subject charged with commission of

criminal offense in Russian embassy at Paris, 348.

attitude towards principle of free ships, free goods, 630 et seq.

changed doctrine of Consolato by introduction of principle of hostile infection, 565, 708 .

granted freedom of trade to neutrals during Crimean war, 513. treaties with Spain and Mexico for payment for private property of enemy taken at sea, 563 .

adheres to list of contraband set forth in convention of St. Petersburg, 1801, 732 .

includes horses in list of contraband, 732.

coal not included, 735 .

declared shipments of rice destined for ports nortin of Canton contraband, in war with China, 737 .

marine ordinance of Louis XIV as to procedure in prize cases, 151. proclamation of neutrality at outbreak of American Civil war, 666 . arrest of six vessels in ports of, in course of construction for Confederate States, $654 n$.

attempt of, to redefine twenty-four hours' rule in $1861,693$.

theory of the law of blockade, 764 .

treated as piratical, privateers manned by Mexican subjects during

war with Mexico, 682.

Franco-Prussian war, 123.

permitted German soldiers to retire on breaking out of, 462 . see Franco-Prussian war.

employment of Yellow Flags in Tonquin against native Black Flags, 474.

FRANCO-PRUSSIAN WAR,

declaration of, how made, 455 .

German soldiers permitted to retire from France, 462.

entire exemption of private property from capture at sea initiated

by Prussia, but not agreed to by France, 563 .

coal listed as contraband by Germany, but not by France, 735 .

German protest against exports of coal and horses to France from

England, 733, 735.

treatment as banditti of Franc-tireurs and "garde national mobile"

by Germany, 476 .

punishment of Berlin banker for dealing in French securities, 464. requisitions made by Germans at Versailles, 549 .

seizure of railways under right of angary, 703 .

payment of prisoners, 530 .

acts of pillage committed, 542 .

murder of women and children by Germans near Sedan, 486.

German bombardment of twenty-two protected cities, 484 .

unlawful use of hostages by Germany, 534 .

refusal to allow entrance of supplies to Paris during armistice, 516. unusual administration of affairs during occupation of French territory, 590, 597.

attempt to compel courts at Nancy to administer justice in name of "High German Powers," 597.

siege of Paris, 124, 485. 
[THE REFERENCES ARE TO THE PAGES.]

FRANCO-PRUSSIAN WAR-Continued.

indemnity exacted by Germany, 124, 612 .

guarantee required for payment of, 613 .

cession of Alsace and part of Lorraine to Germany by treaty of Frankfort, 124, 277, 614.

FRANKLIN, BENJAMIN

efforts to establish principle, that private property, not contraband, is exempt from capture at sea, 561 .

FREE SHIPS-FREE GOODS

illustration how special stipulation may become general rule, 93 .

rule that nationality of ship controls that of cargo established by

Dutch, 566, 709 .

to beginning of eighteenth century was simply an exception to contrary general rule, $710,711,714$.

formula, free ships-free goods, enemy ships-enemy goods, accounted for, $566,706,711$.

do these maxims embody distinct propositions, 566, 717 .

so regarded in United States from its early history, 566, 717. second part of formula, not accepted by United States, 566 .

British theory and practice in respect to, 711 .

armed neutrality leagues paved the way for triumph of, 638, 713 .

American theory and practice in respect to, 713 .

rule not recognized by prize courts of United States during war of $1812,716,720$.

conventional law with reference to, 709, 710, 713, 717 et seq. according to Ward, no mention of principle in thirty-four treaties made between 1713 and 1780,711 .

doctrine embodied in treaty between France and United States, 1786,719 .

proposal of United States that principle of, be established throughout American continents, 720 .

like proposal made to European nations, and that neutral property shall be free in enemy's vessel, 721 .

rule substantially adopted in Declaration of Paris, 566, 721.

contraband excepted from operation of principle, 566, 725 .

FREEMAN, EDWARD A.

nature of Amphictyonic Council, 14.

classes Achaian League among composite states, 167.

history must be rewritten in light of new revelation of science of society, 4.

views as to when titles Rex Francorum and Rex Francial came into use, 28.

cited, 10, 30, 161, 163, 165, 620 .

FREIGHT,

payment of, under rule of the Consolato, $629 n, 707$.

liability for, on enemy property taken from neutral ship, 565 .

effect of endeavor to cover property from lawful belligerent seizure, 565.

as an element of damage for illegal capture, 578 .

liability of belligerent for, upon seizure of vessel under right of angary, 702, 703 .

lien on cargo for, 568 .

when loss of, part of penalty for carrying contraband, 744, 745 .

paid for by captor when title to conditional contraband is acquired by pre-emption, $74 \hat{\mathrm{u}}$.

FRELINGHUYSEN, SEC. OF STATE

child born in United States to alien father, when taken abroad acquires his domicil and nationality, 220.

cited, 327.

FULL POWERS,

general, $329,330 n$. 
[THE REFERENCES ARE TO THE PAGES.]

FULL POWERS-Continued.

limited, 330.

additional, 329,330 .

GASES,

convention of The Hague conference in regard to diffusion of asphyxiating, by projectiles, 479.

GEFFCKEN, DR. F. HEINRICH

he who makes war unavoidable is the cause of it, 453 .

approval of seizure of interests in Silesian loan, 442 .

admits acquisition of Alsace and Lorraine was an act of force, 614 .

prisoners released on parole should remain neutral, 532.

exemption of private property at sea from capture dependent on treaty, $563 n$.

approves destruction of prize, $572 n$.

frequently cited, for example, 433, 447, 458, 533, 556.

GENET, CASE OF M., 351, 640, 700.

GENEVA AWARD,

see Alabama, case of the.

GENEVA CONVENTION,

conference, 1864 , to introduce greater humanity into rules and practices of war, 45 .

conference of 1868,46 .

influence of, upon neutralization of persons and things engaged in relieving wounded, 536 .

inadequate to new conditions, 538.

call for revision of, at The Hague Peace conference, 538.

GENTILIS, ALBERICUS

his De Jure Belli commentatio prima, 54.

regarded by some as real founder of modern international law, 54 . applied jus natural to questions arising out of relations of modern states, 54.

liability of captor of enemy goods under neutral flag for freight, 707.

property not belonging to enemy not subject to confiscation, 711 . cited, 698 .

GEORGIA, CASE OF THE, 659, 681, 696.

\section{GERMANY,}

how affected by peace of Westphalia, 96, 423 .

intervention in internal affairs of, by France and Sweden, 412.

confederation of the Rhine, 112.

nature of international relations of Germanic Confederation, 160 . territorial limits after congress of Vienna, 1815, 115.

rise of Prussia, 121.

Schleswig-Holstein question, 121.

constitution of North German Confederation, 122, 160.

right of states in, to make separate treaties, 166.

constitution of German Empire, 168, 169.

jurisdiction of foreign affairs of empire vested in imperial government, 169.

Bavaria, Wurtemberg and Baden admitted to confederation under constitution of 1871,169 .

Empire of, a complete sovereign state as to international relations, 173.

some states of, enforce criminal laws against subjects committing offenses abroad, 243.

treatment of aliens in, 247.

position in respect to jurisdiction over bays and gulfs, 278 .

unlawful use of hostages in Franco-Prussian war, 534.

unusual administration of affairs during occupation of French territory, 597. 
[THE References are to THE PAges.]

GERMANY-Continued.

complaint in regard to export of horses to France from England, 733 .

demand that England should prohibit export of coal to French ports, 735 .

exercise of the right of angary, 703 .

refused entrance of supplies to Paris during armistice, 516.

indemnity exacted of France, 612 .

GLADSTONE, MR.

cited, 163.

GOOD OFFICES, see Mediation.

GRANT, PRESIDENT

proclamation in regard to restrictions on belligerent vessels in ports of United States, 695.

intervention in behalf of Cuba as a contingent necessity, 420 .

when recognition of belligerency should be made, $457 n$.

liability of Virginius to visitation and detention on high seas, 407 . insisted on parole of General Lee, 611.

cited, 521.

GRANT, SIR ALEXANDER

effort to create international rule that slave-trade is prima fiacie illegal jure gentium, 237.

GRANVILLE, LORD

on articles considered contraband, 734 .

declaration as to decisions of prize courts, attempting to give effect

to French doctrine, that rice is contraband of war, 738 .

GREAT BRITAIN,

her relation to system of international law, 88 .

incorporate union embodied in British empire, 161.

government of colonial system, 162 .

treaty making power of, vested in crown, 162, 391.

powers of parliament in relation to treaties, $163,391$.

act of parliament unnecessary to title by conquest, 607 .

diplomatic history of, dates from formation of Triple Alliance,

$1668,102 n$.

her relation to the Holy Alliance, 117.

controversy with Holland as to treaties of alliance, 370.

protestant succession to throne of, guaranteed by Dutch, 372 .

intervention in favor of Catholic party of, by Austria and Spain, 413.

union with France in prosecution of Crimean war, 99.

conventions with Spain and Portugal for special courts, 375.

territorial claims; position as to territoriality of sea, 290, 292.

claims of, in respect to inclosed parts of sea, 278 .

denial of right of United States to navigate lower waters of St.

Lawrence, 285 .

controversies with United States as to fisheries, 296.

development of English navy, 496.

former doctrine in respect to local sovereignty over public vessels of other states, 304.

neutrality and neutral trade; conflict between, and Spain in 1804, because of alleged breach of neutrality, 628 .

refusal to restore French frigate captured at Genoa, 639.

her action in the Terceira affair, 678.

violation of Genoese territory in capture of frigate Modest, 699.

capture of French fleet within Portuguese waters, 699.

proclamation of, at outbreak of American civil war, 666 .

regulations of, 1862 , in respect to twenty-four hours' rule, 694 .

cases of Nashville and Tuscarora, 694 .

Foreign Enlistment Acts of 1819 and 1870, 646 . 
[THE REFERENCES ARE TO THE PAGES.]

GREAT BRITAIN-Continued.

opposition to principle of free ships-free goods, 567,630 .

promulgation of rule of war of 1756,631 .

position as to right of visit and capture of merchant vessels under convoy, $788,789$.

controversies with Sweden, Holland and Russia in respect of right of visit of ships under convoy, 635 .

armed neutralities of 1780 and $1800,443$.

seizure of Danish fleet as a permissible measure of self-preservation, 411.

her frustration of the principle of free ships-free goods in convention of St. Petersburg, 1S01, 721.

final acceptance of principles of armed neutrality, 637 .

first recognition of principle-free ships-free goods, in treaty with Portugal, 1652, 713.

subsequent recognition of rule in treaties with Holland, France and Spain, 714.

granted freedom of trade to neutrals during Crimean war, 512.

blockade; theory of the law of blockade, 764 .

contraband; repudiation of list of contraband as set forth in convention of St. Petersburg, 1801, 732.

articles designated as, in Admiralty Manual of Prize Law, 732. articles designated as, in treaty with United States, $732 n$.

attitude in respect to horses as contraband, 732 .

doctrine of conditional, applied to coal during Crimean war, 733.

coal listed as conditional, in British Admiralty Manual, 734.

practice of, in treating provisions as contraband, 736 .

Orders in Council, that vessels laden with provisions and bound to any port in France, be detained 736 .

rules when provisions may be regarded as contraband 737 .

refusal to concede legality of French declaration of rice as contraband, 738 .

seizure of vessels, Bundesrath, Herzog and General, during Boer war, 738.

war; former reliance upon treaties of subsidy for troops, $371 n$.

British manual on objects of war, 452 .

reproached by Calyo and Hautefeuille for beginning wars before formal declaration, 454.

captured New York, 1664, before declaration of, 455 .

employs natives in African and Indian wars, 474.

stationing of Indian troops at Malta in 1878, 475.

excuse for British severity in South Africa, 476.

opposed declaration of The Hague as to explosive bullets, 479 .

also that in regard to diffusion of deleterious gases by projectiles, 479 .

British Manual on relation of war to citizens and private property, 450 .

attempt to distinguish between debts and other private property of resident aliens, 463 .

ordered destruction of Capital at Washington in 1814, 545 .

effect of war of 1812 upon property rights of British subjects in America, 368.

invasion of United States by British subjects, 1838, 405.

slave trade; legislation with reference to slave trade, 236.

claimed right of visit to enforce statutes against same, 238.

aliens; her treatment of aliens, 247.

criminal jurisdiction: refusal to take jurisdiction of crime com.

mitted at sea within three mile zone, 88 .

general rule in, that crimes are territorial, 244.

legislative departure from this rule, 244.

conditions sought to be imposed in extradition of forger Winslow to United States, 254. 
[THE REFERENCES ARE TO THE PAGES.]

GREAT BRITAIN-Continued.

Monroe doctrine; agrees not to exercise dominion over any part of Central America, 146.

relinquishes protectorate over Mosquito coast, 147.

controversy with Venezuela over boundary, 416.

disputes existence of Monroe doctrine as a principle of international law, 417.

diplomatic intercourse; opposition to establishment of permanent embassies, 317.

effort to simplify credentials of diplomatic agents, $329 n$.

case of Lesley, Bishop of Ross, 336n.

legislation exempting diplomatic agents from civil jurisdiction, 338 .

does not extend privilege of exterritoriality to crimes of ministers' servants, 346 .

dismissal of Spanish minister in retaliation for Spain's dismissal of Mr. Bulwer, 354 .

recall of Mr. Jackson as minister to United States, 356.

recognition of Southern Confederacy, 458.

appointed consuls to South American Republics before recognition, $359 n$.

judicial powers vested in British consuls in Eastern countries, 360 .

\section{GREECE,}

Greek state-system, what it was, 7 .

affords earliest illustration of ancient conception of state as city-commonwealth, 8.

Greek city-state an aggregation of village communities, 8 .

Grecian conception of the city-commonwealth, 9 .

varied character of city-commonwealths, 9 .

state-system as outlined by Aristotle, 9 .

futile efforts of Greeks to establish political unity, 13.

desire for unity first manifested in religious leagues, 13.

purpose of Amphictyonic council, 13.

the Athenian Alliance, 14.

the Achaian League, 15.

why independent cities never merged into a single state, 15.

primitive conceptions of international law held by ancient, 14, 16 .

recognized no duties to each other without express compact, 362 .

had fully matured treaty system, 362 .

what conventions embraced in, 375 .

whether political unions of had tribunals for arbitration of international disputes, 377.

dim conceptions of neutrality, 617 .

Prof. H. Brougham Leech on institution of the proxenia, 619. contributions to federalism, 16.

Greek ideas as to proper relations of states impressed on Roman law, 8.

why she produced no complete system of jurisprudence, 17.

extreme cruelty of laws of war, $10,11 n$.

persons protected in time of war, 14 .

buried those who died in battle, 14 .

modern; belligerent rights of provisional government of, recognized by England, 1825, 189.

independence of, made possible by conference of St. Petersburg, 1825,45 .

and finally secured through intervention of Great Britain, Russia and France, 1827, 118, 413, 422.

independence guaranteed by treaty, 372.

Ionian Islands annexed to, by treaty of the powers, 375 .

concessions of Sultan to, at Congress of Berlin, 1878, 126.

blockaded by England, 1850, 444 .

blockaded by great powers, 1886,445 . 
GREEN, JOHN RICHARD

cited, $35,327,545 n$.

GREY, EARL

on maintenance of balance of power, 99 .

GREYTOWN,

bombardment of, by United States, 1854.

GROTIUS, HUGO (Huig van Groot).

the father of modern international law, 60 .

held that natural law and jus gentium are identical, 2.

his De Jure Belli ac Pacis, 54.

method and arrangement largely drawn from Gentilis, 55.

author of many humane rules now basis of belligerent theory and practice, 71 .

establishment of a "divine and human law," his substitute for overlordship of Holy Roman Empire, 73.

not first to perceive need of substitute for international power of Holy Roman Empire, 73.

fundamental conceptions upon which merits of his work rest, 75 . his law of nature, 78 .

voluntary law, as an alternative to jus naturae, the basis on which he rested his law of nations, 78 .

profited from the work of his Spanish and Italian predecessors, 78 . authority of Grotian system of international law, 79.

alternative proposition of, the basis of modern system of international law, 84.

on title by occupation, 129 .

finds authority for title by prescription in Roman law, 264 .

his Mare Liberum, 291.

doctrine of free navigation of the seas, 291, 293.

view as to state jurisdiction over adjacent sea, 294.

advocated alliances to preserve balance of power, 452 .

when casus foederis of a defensive alliance arises, 370 .

rules for construction of treaties, 396 .

diplomatic intercourse; right of state to reject permanent diplomatic missions, 317 .

inviolability of ambassadors, 331 .

fiction of exterritoriality in respect to envoys, $335 n$.

exemption of ambassadors from civil jurisdiction, 339 .

goods of foreign ministers not subject to seizure under distress or pledge, 342 .

rules as to safe-conducts and passports attributed to, $509 n$.

war; his definition of war, 448 .

all law, divine and human, is abandoned in war, 526 .

an injury received, the only reasonable cause of war $_{2} 451$.

humane rules of war advocated by, 470 .

right of passage through neutral territory absolute, 284 .

right of state to imprison resident enemies. 461.

pleaded against injustice of ancient practice of considering conquered enemy without rights, 524.

tolerates devastation as a means of offense, 482 .

appropriation of private property by occupying army, 547 .

definition of contraband, 725 .

views on early law of blockade, 759 .

neutrals; accepted principle of enemy ships-enemy goods only

as a rebuttable presumption, 566 .

his terms describing neutrals, 619 .

unsatisfactory treatment of sulject of neutrality, 622 .

frequently cited, for example, $199,252,289,324,366,575$.

GUARANTEE,

treaties of, mutual and unilateral, 371.

illustrations of these classes, 372 .

to be strictly construed, 373 . 
GUARANTEE-Continued.

when guarantor may intervene in such case, 372 .

beneficiary not entitled to indemnity if assistance prove insufficient, 372.

limited to rights and possession existing at time of making, 372.

action of Louis XV under treaty of Vienna as to Austrian succession, 372 .

treaty of alliance between United States and France, 465.

ground upon which United States claimed release unten. able, 465 .

views of Washington, Hamilton and Madison, 465.

legal ground upon which release might have been claimed, 466 .

collective, to secure a common interest, 373 .

duty by enforcing collective, of neutrality, 373 . views of Bluntschli and Lord Derby, 373.

Hall on purpose of collective, $374 n$.

agreements in which guarantee may be embodied, 374 .

for payment of indemnity, 613 .

GUERRILLAS, employment of, in war, 476.

GUIDEKENS, BRITISH AMBASSADOR. case of, 343 .

GUIDES, rules concerning, 492 .

GUIZOT, FRANCOIS P. G.

defense of French government's refusal to ratify treaty, 1841, for suppression of slave trade, 388 .

\section{GULFS,}

when included in territorial property of state, 263, 278.

GUSTAVUS ADOLPHUS,

pioneer in caring for soldiers, 537.

burned villages of German peasants who mutilated stragglers, 476 .

HABEAS CORPUS

jurisdiction of federal courts as to, in cases of aliens, 172.

whether writ may issue against commander of public vessel of another state, $303 n$.

HALL, W. E.

his definition of international law, 83 .

on relation of non-christian nations to international law, $127 n$. discovery an insufficient ground of proprietary right, $268 n$.

how protected state may preserve an international existence, 176.

difference between protected state and one under suzerainty of another, $179 n$.

on recognition of independence of belligerent state after same act by parent state, $192 n$.

how long identity of state continues, $198 n$.

difference between effect of acquisition by cession and that by absorption of entire state on liability for obligations, $201 n$.

relation of domicil to national character, $212 n$.

right of protecting subjects abroad, $213 n$.

on boundary line of Cuba, 274.

whether right of military passage now exists, 300 .

on doctrine that a ship is "a floating part of the nation." $301 n$. presumption in favor of innocence of public vessel acting piratically, $302 n$.

when immunity of minister's hotel ceases, 343 .

states reasonable rule as to dismissal of diplomatic agents, 351 . contradicts statements of Calvo and Lawrence as to seizure of consular property in England, $357 n$. 
HALL, W. E.-Continued.

purpose of collective guarantee, $374 n$.

when breach of condition by one party will render treaiy voidable at instance of other party, 403.

capture of Virginius not regarded as improper by Great Britain, $411 n$.

latest occasions of intervention to enforce treaty granting reversion to another dynasty, $427 n$.

his just exception to Great Britain's admission as to liability of resident aliens to military service, 468 .

how belligerency or neutrality of territory subject to double sovereignty must be determined, 595 .

on effect of treaties for aid in time of war upon neutrality of states in the 18 th century, 626 .

influence of policy of United States in 1793 on development of law of neutrality, 652 .

suggests making character of ship the criterion of guilt as to vessels equipped in neutral waters for use against belligerent, 662 .

on refusal of United States to interfere with embarkation of Frenchmen during Franco-Prussian war, 679.

comment on twenty-four hours' rule, $693 \mathrm{n}$.

propriety of classification of horses as contraband, $733 n$.

on distinction between unneutral service and carrying of contraband, 748 .

receiving cargo from blockaded port, through port not under blockade, not an infraction of blockade, $772 n$.

frequently cited, for example, 134, 192, 273, 590, 687, 791.

HALLECK, HENRY W.

effect, on state obligations, of severed territory becoming distinct state, 204.

right of commercial navigation of rivers subject to safety and convenience of states interested, 282.

state is bound to recall envoy who has become unacceptable, 350 .

obligation of aliens to submit to martial law, 262 .

regards invasion of state's territory in self defense as "imperfect war," $405 n$.

invitation to intervene from one only of parties to civil conflict confers no rights against other party, 424 .

officer unable to control his soldiers unfit to command, 486 .

deceit not allowable in negotiations between hostile forces, 490 .

on constructive military occupation, 589.

opposes loans by either neutral states or individuals to belligerents, 673.

recognizes belligerent right of angary, 703 .

often cited, for example, 134, 227, 304, 548, 668, 783.

HAMILTON, ALEXANDER

right of protection and security to enemy property, 462 .

views on release of United States from treaty of alliance with France, 465.

cited, 196,552 .

HARBORS,

regulations of, must be respected by public vessels of foreign state, 305,690 .

HARCOUR'T, SIR WM. VERNON

intervention not within domain of international law, $428 n$.

cited, 677.

HAUTEFEUILLE, L. B.

views as to the source of international law, 81 .

some solemn act necessary to begin any war not of defense, 454. first summons to stop in conflict at sea should be fired under national colors, 490 . 
[THE REFERENCES ARE TO THE PAGES.]

HAUTEFEUILLE, L. B.-Continued.

claims privateers are exempt from search, 498.

criticism of French order, 1861, as to twenty-four hours rule, $693 n$. cited, $305,576,672,742,765,771,782,791$.

HEFFTER, AUGUST W.

apportionment of state obligations in case of cession or alienation of portion of state territory, 203 .

no step can be taken against an ambassador that cannot be taken against absent stranger, 340 .

right of contentious jurisdiction not now conceded to ambassadors at Christian courts, 347 .

right of state to repudiate a treaty, 402 .

confines right of intervention to narrower limits than other author-

ities, $426 n$.

state may intervene in civil conflict in behalf of either party, 424. intervention not permissible for repression of tyranny, 429 .

definition of war, 448 .

injury received or threatened, a cause for war, 451.

denies that war suspends trade, 460 .

on growth of modern methods of war, 470 .

war against hordes and bands necessarily lawless, 474 .

classification of those beyond protection of laws of war, 535 .

recognizes belligerent right of angary, 702 .

views of effective blockade, 767 .

often cited, for example, 161, 203, 231, 535, 629, 782 .

HERTSLET, SIR EDWARD

cited, $197,285,286,287,318,320,391,394,401$.

HOBBES, THOMAS

erroneous view of, that government originated in social contract, 1. his divisions of natural law, 62 .

natural state of men and nations is that of war, 62 .

his creed of perpetual war mitigated by admission that reason suggests agreements for peace, 62 .

HOLLAND,

see The Netherlands.

HOLLAND, PROF. T. E.

definition of international law, 7,83 .

on distinction between international law and ordinary law and morals, 82 .

European concert in respect to disintegration of Turkey, $179 n$. classification of servitudes, 299.

articles designated as contraband in Manual of Prize Law, 728 .

cited, $153,155,182,183,184,210,276,284,301,389,399,401,7+4$, 747,789 .

HOLLS, FREDERICK W.

on Peace Conference at The Hague, 49.

his error in translating contributions as taxes in account of The Hague Conference, $550 \mathrm{n}$.

cited, $478,479,480$.

HOLY ALLIANCE,

history of, reviewed, 140 .

suggested by successful intervention of allied powers in internal affairs of France, 413.

its purposes defined, 116, 413.

Congress at Verona, and circular declaring intention of allies, 116.

circular denouncing military reform effected by revolt, 116.

enlargement of its designs at Congress of Trappau, 1820, 116.

secret treaty of, at Verona, 1\$22, 117.

determination to put an end to representative government, and to destroy liberty of the press, 117. 
HOLY ALLIANCE-Continued.

extension of policy to New World opposed by United States, 117. see Monroe Doctrine.

HOLY ROMAN EMIPIRE,

medieval state-system, what it was, 7 .

theory of, 30 .

pope and emperor as chiefs of the world monarchy, 30 .

effects of this dual sovereignty, 31 .

impracticable character of such a union demonstrated, 32.

belief that empire was to be eternal, 31 .

wherein theory of, failed, 32 .

limits of the actual authority of the medieval empire, 32 .

the pope as an international judge, 33 .

his authority recognized by the canon law, 34 .

attempt to make emperor an international judge, 34 .

conception of, held Europe together until Reformation, 35.

effect of Reformation upon, 35 .

relation of, to international law, 35 .

sovereignty of Rome formally abrogated by Peace of Westphalia, 36.

finally dissolved in $1806,112$.

\section{HORSES,}

may be appropriated from enemy soldiers, 541 .

countries listing them as contraband, 732 .

HOSPITALS,

military, neutralized by convention of Geneva, $1864,46,536$.

convention the outgrowth of "Souvenir de Solferino" by Genevan physician Dunant, 536.

may be retained, with equipment, by captors; but not ambulances

and their equipment, 537.

spared in bombardment, if designated as such, 485 .

hospital staff of captured ship inviolable, 503.

HOSPITAL SHIPS,

exempt from capture, 558.

rule of American Naval Code, $559 n$.

convention of The Hague Conference in regard to, 503.

not on same footing as men-of-war in neutral port, 503 .

are subject to direction and control of belligerents, 504 .

HOSTAGES,

as pledges for fulfillment of belligerent agreements or as security

for payment of indemnity, 534 .

treatment of, 534 .

unlawful use of in Franco-Prussian war, 534.

given in cases of prize, 573 .

as security for performance of treaty, 374 .

exaction of, now practically obsolete, 535,574 .

HOSTILE INFECTION,

effect of French doctrine of, upon rule of the Consolato, 565, 706.

HUBER, ULRIC

maxims in relation to laws of a state, 206, 208.

HUBNER, MARTIN VON

words neutral and neutrality became technical terms in international law from his time, $919 n$.

belligerent cannot attack enemy, nor capture his property, in neutral place, 712 . cited, 708.

IMMIGRATION, see Aliens.

INDEMNITY,

exaction of, from conquered state, 612 .

unprecedented, exacted of France after Franco-Prussian war, 613. practice of United States, 613. 
INDEPENDENCE,

of belligerent states; principles that govern recognition, 192, 424 . premature recognition of, by foreign state, 192.

recognition of, in order to keep open channels of intercourse with state having de facto existence, 193.

notable cases of recognition of, 192 .

recognition of, according to Lord Liverpool, not warranted while contest is going on, 195 .

Mr. Adams' justification of action of United States in case of South American republics, 194.

policy of United States to regard, of other nations as a question of fact merely, 195.

all must finally recognize governments le facto, 196.

recognition of, in cases of Greece and Belgium, illustrations of forcible intervention, 197.

treaty becoming a menace to, of state becomes voidable, 397,400 . presumption against surrender of, in treaty, 397, 400 .

INDIA,

status of, in relation to international law, 176 .

INDIANS,

status of, in United States in relation to international law, 175.

INFIDELS,

formerly excluded by Christian states from family of nations, 91 .

INSTITUT DE DROIT INTERNATIONAL,

authority of rules promulgated by, 72 .

resolutions as to right of expulsion of aliens, $72,233 n$.

on right of state to punish foreigners for acts done outside its jurisdiction, 72 .

proposed Riglement des Prises Maritimes, 72.

resolution as to extension of three-mile limit, 72, 294 .

declarations on inviolability of private property at sea, 72 .

resolutions on the duties of neutrals, 72 .

on pursuit by neutral, on high seas, of vessel committing breach of its neutrality, 684 .

proposal to charge neutral governments with duty of preventing shipments of contraband, 72 .

declaration as to pacific blockade, $72,445$.

on what shall constitute an effective blockade, 768 .

condemnation of decision in Springbok case, 72 .

assent to Manuel des Lois de la Guerre sur Terre, 72.

military code adopted by, in $1880,47,471$.

scheme of arbitral procedure, 1875, 72, 378 .

INSURANCE,

of cargo carried under license to trade, 512 .

on cargo from enemy country cannot be collected, 464 .

captor has insurable interest in prize, 577.

INSURRECTION,

right of, during military occupation, 592.

INTERNATIONAL LAW,

growth of, explained through record of its development, 3 .

germs of, first appear in clearly developed form in Delphic

Amphictyony, 7, 13, 14.

religious leagues the first movement toward, 362 .

fully matured treaty system in Greece, 16, 17, 362.

Collegium Fetialum at Rome, 24, 363.

apart from compact, no positive international code in ancient

times, 364 .

modern, foundations how laid, 70 .

formative period not ended, 72,86 .

Gentilis regarded by some as the founder of, 54 .

limits of its original sphere, 87 . 
[THE REFERENCES ARE TO THE PAGES.]

INTERNATIONAL LAW-Continued.

all dealings with infidels once deemed unlawful, 91.

sphere widened by admission of states, new and old, 89. when first asserted in England to be part of municipal law, 137.

extension of international system to New World, 127.

acceptance of, by United States, 136.

qualified extension of, to non-Christian states, 91 .

such states not bound to utmost rigor of, 91 .

status of native African races, 273.

operation of; Mr. Webster on obligation of new states to respect, 137.

how state may assent to an international rule, 88.

operates only upon states as such, 210.

deals with them as corporate persons, 210.

and solely with their external relations, 158.

relation of belligerent communities to, 184 .

definition of, according to historical school, 2.

by Dr. Bulmerincq, 3,84 .

by Holland, 7,83 .

by Austin, Lawrence and Hall, 83 .

by Cairns, Calvo, Coleridge and Twiss, 84 .

by John J. Moser, 59.

author's definition of, $86,157,364$.

origin of the phrase, 86 .

current classifications and definitions not final, 83 .

basis of; Roman jurisprudence the philosophic basis of, 20 .

jus gentium, 21.

relation of jus gentium to jus naturae, 22 .

mistake of Wheaton and others in confounding jus fetiale with jus gentium, 25.

jus fetiale only branch of Roman law that corresponds to modern conception of, 24 .

why it should be re-examined by historical method, 5 .

why several types of state organization must be examined in study of, 158 .

basis on which Grotius rested his law of nations, 2, 79.

development of idea that it is based upon natural law, 2.

claimed by Vattel to be originally Law of Nature applied to nations, 65 .

derived from reason and usage according to Bynkershoek, 61 . useful purpose of the natural law theory, 79 .

Selden in accord with Grotius as to basic principle of, 62.

principle on which it is founded according to Talleyrand and Montesquieu, 447.

modern, based upon alternative proposition of Grotius, 84.

substitute for primary assumption of Grotius as to transcendental source of, 85 .

based upon consent of sovereign states, 3 .

territorial sovereignty the basis of all international relations, 157.

presupposes equality between states affected, 446 .

equality between sovereign states the cornerstone, 322 .

based on reciprocity, even of evil, 474, 488 .

regarded as positive law by transcendental school, 79.

views of Puffendorf, Vattel, Hautefeuille, Phillimore and Bluntschli, 80 .

is not positive law-views of Austin, Holland and Wilson, 81, 430 .

no positive international code apart from compact, 364 .

sources of, 39 .

purely conventional in ancient times, 362 .

rested upon positive compacts or conventions, 364 . 
[THE REFERENCES ARE TO THE PAGES.]

INTERNATIONAL LAW-Continued.

division of international compacts by Roman lawyers, 363 .

relation of Holy Roman Empire to, 35 .

effect of Reformation upon, 35 .

true science of, made realizable by Peace of Westphalia, 37 .

decisions of prize courts the earliest sources of, 43 .

marine ordinance of Louis XIV., 151.

recommendations of Institut de Droit International, 72.

relation to, of works of publicists, 53 .

publicists as creators of, 71 .

treaties as solurces of, 93.

conventional law, upon which rests primacy or overlordship

of few great states, 98 .

instructions for guidance of state courts and officers, 151.

history of diplomatic intercourse, 152.

pactiones, sponsiones and foedera, $363 n$.

INTERNATIONAL PRIVATE LAW,

its relation to international public law, 153, 209.

connection between the two, 209 .

comity the basis of, 207, 208.

maxims of Huber, 206, 208.

result of strict enforcement of lex loci, 208 .

limited to regulation of rights in movables, 209 .

rights in immovables, as a general rule, regulated by lex situs, 209.

Savigny and Lord Westbury on civil status of persons, 209.

INTERVENTION,

origin and growth of right of, 110 et seq.

security of intervening states as alleged ground for partition of Poland, 110.

threatened danger to monarchial institutions made a ground for, during French revolution, 111. 116.

of Austria to suppress Neapolitan revolution in Italy, 117.

of France to overthrow Spanish constitution and restore absolutism in Spain, 117.

proposed, of Holy Alliance for purpose of terminating revolutionary governments in Spanish America, 117.

of Quadruple Alliance in affairs of Portugal, 117.

of Great Britain, Russia and France to secure independence of Greece from Ottoman Empire, 118.

treaty of, between Great Britain, Russia and France, 1827, 118. of powers to dissolve union of Belgium with Holland, 118.

protection of Christian peoples subject to Turkey one object of Crimean war, 119.

recognition of independence of Greece and Belgium illustrations of forcible, 197.

conflict with right of independence; right of every state to manage

its own affairs, internal and external, 198.

when recognition of independence is an act of, 192 .

difficulty of defining term, 412 .

defined in light of authoritative precedents, 424 .

is an hostile act, 424 .

burden assumed by intervening power, 424 .

difficulty of reconciling, with right of independence, 425.

claimed by Lord Harcourt and others not to belong to domain of international law, $428 n$.

grounds of; humanitarian, to prevent cruelty and tyranny, 428.

conflicting opinions as to right of, on moral grounds, 429 .

notable cases of, on religious grounds, 412 .

to end religious persecutions in the Orient, 429 .

notable cases of, on political grounds, 413.

of France, Great Britain and Spain in Mexico, 414. 
[TIE REFERENCES ARE TO THE PAGES.]

INTERVENTION-Continued.

to prevent or terminate illegal intervention of another state, 416,427 .

of United States in affairs of Mexico, 427.

of United States in affairs of Venezuela, 416.

primacy of United States as defined by President Cleveland and Prof. Lawrence, 417.

of United States in affairs of Cuba, 419. community of interests, 419.

as a contingent necessity, 420 .

views of Presidents Grant and Cleveland, 420.

precipitated by destruction of the Maine, 420 .

grounds of, as defined by President McKinley, 421.

justified by general principles of international law, 422.

self-defense; whether self-defense may involve necessity of, 422.

under contract of guarantee, $423,427$.

right of, upheld by Martens, Klüber and Heffter, $423 n$.

disputed by Hall, Twiss and Halleck, $423 n$.

case of Belgium during Franco-Prussian war, 427.

when asked by both parties to a conflict, or by only one, 423.

as a means of preserving balance of power, 425 .

claim that it has fallen into disrepute, refuted, 426 .

for protection of indirect interests not too remote, 426 .

limit to this rule, 426 .

to ward off an imminent danger, 427.

right of, confined to narrower limits by Vattel, Heffter and Calvo than by other authorities, $426 n$.

IONIAN ISLANDS,

their international status as a protected state, 176.

added to territory of Greece by treaty, 1864, 118.

IRREGULAR WARFARE,

see Forces of a State; War.

ISOPOLITY,

conventions granting it to resident foreigners in Greece, 12,363 .

ITALY,

Italian city-state system, 7, 18.

the gens the unit of organization, 18.

independent city-state idea did not reach same completeness in, as in Greece, 18.

ancient history of, that of confederations rather than of single cities, 18.

Rome the exception to this general rule, 18 .

resemblance between Greek and Latin city-states, 18.

intervention of Austria to suppress Neapolitan revolution, 117.

enforces domestic criminal law against subjects conmitting of fenses abroad, 243.

see Rome; Holy Roman Empire.

JACKSON, BRITISH AMBASSADOR

demand of United States for his recall, 352 .

JACKSON, PRESIDENT

suggested reprisal against France, 436.

on recognition of independence of Texas, 195.

his temporary expllsion, as general in war of 1812, of foreigners

from City of New Orleans, 467 .

cited, $261,437$.

JAPAN,

qualified extension of international law to, 91.

naval demonstration by United States, 1852, 442. 
[THE REFERENCES ARE TO THE PAGES.]

JEFFERSON, THOMAS

on obligation of United States to respect law of nations, 137.

letter to Mr. Pinckney on neutrality of United States, 639.

criticism of Great Britain's interference with neutral trade with enemy's colonies, 633 .

views upon the duties of neutrals, 641,642 .

reply to demand of Great Britain that United States prevent sale of arms to France in 1793, 742 .

proclamation, excluding British ships of war from American ports, 692.

position that rule of Consolato was general law of nations, 715 .

letters of marque and reprisal have advantage over formal war, 438.

on acquisition of Cuba by United States, 419.

his famous letter to Monroe, 141.

cited, 249, 257, 357, 564, 581, 632, 636, 652, 700 .

JENKINS, SIR LEOLINE

opinion that tar and pitch are not contraband, 730 .

cited, 497.

JENKS, EDWARD.

modern conception of state, at close of middle ages, $29 n$.

definition of a state, 210 .

JUDGE-CONSULS,

nature and origin of office, 355 .

their relation to the Consolato del Mare, 706 .

JURISDICTION,

source of present law of, 71 .

territory and, co-extensive, 197, 206.

an attribute of sovereignty, 197, 206.

maxims of Huber, 206, 208.

exterritorial, of states, 197.

legal fiction of exterritoriality, 207, 308.

exterritorial effect given to laws based on comity, 207.

of state in relation to persons, 206 et seq.

immunities and disabilities of traveling sovereigns, 228.

of foreign army in friendly state, 230 .

how far citizens abroad are amenable to local, 233.

over citizens of Christian states in non-Christian countries, 92.

of civil controversies between American citizens in nonChristian countries, 92.

territoriality of crime disputed by many nations, 240 .

Mr. Calhoun on criminal jurisdiction of states, 240.

Cutting's case, 241.

case of Diblassi, $241 n$.

of crimes during military occupation, 587.

right of state to punish for crimes committed abroad, 243.

British and American legislation upon the subject, 243, et seq.

offenses punishable by United States ministers and consuls in certain countries, 246.

in relation to property, 263 et seq.

how limited or qualified, 263.

over territorial waters of a state, 263,277 et seq.

where ownership is claimed of entire river forming boundary between states, 288 .

over non-territorial property, 301 et seq.

see Property, Private; Property, Public; Sovereignty; States;

Territorial Waters; Vessels.

JURISPRUDENCE,

analytical and historical methods of exposition contrasted, 1. 


\section{JURISPRUDENCE-Continued.}

[THE REFERENCES ARE TO THE PAQES.]

analytical method responsible for misconceptions as to development of law, 1 .

Roman theory of a determinable law of nature, 2.

what international law really is, 2 .

growth of law explained through record of its development, 3.

law of growth and decay in the physical world applicable to societies, 3.

Comte as founder of science of society, 4 .

failure of Greeks to produce any complete system of, 17.

science of, a Roman creation, 19.

development of Roman, 19.

impressed with Greek ideas as to proper relations of states, 8. origin of the Corpus Juris Civilis, 19.

the philosophic basis of international law, 20 .

the jus civile, 21.

comparative, beginnings of, in Roman administration of law to foreigners, 21 .

the jus gentium, 21.

relation of jus gentium to jus naturae, 22 .

jus fetiale, only branch of Roman law that corresponds to modern conception of law of nations, 24 .

revival of study of, 52 .

foundations of public law relaid at Congress of Vienna, 1815, 114.

JUS CIVILE,

of what it consisted, 21 .

administration of the, 21 .

JUS FETIALE,

only branch of Roman law that corresponds to modern conception

of law of nations, 24.

confounded by Wheaton with jus gentium, 25 .

see also Calvo and Sir Sherston Baker, 25.

JUS GENTIUM,

development of, 21 .

held by Cicero, Grotius and others identical with natural law, $2,23$.

process by which it was blended with the jus naturae, 22, 76 .

result of this union, 23,76 .

effort to give to blended product a strained construction, 23, 77. properly viewed by Gaius, 23.

use of, by Ayala, Gentilis, Oldendorp and Grotius to sustain authority of law of nations, $2,23,76$.

improper use of phrase, 77.

had nothing to do with the conduct of war, 25 .

JUS NATURAE,

as viewed by Ulpian, 23.

by Gaius, 23 .

identity of, with the jus gentium, 23.

effect of, upon Roman jurisprudence, 22.

KANT, IMMANUEL

essay touching perpetual peace, 378 .

KEILEY, MR.

refusal of Austria-Hungary to receive him as minister, 328.

KENT, CHANCELLOR

on divisions of international law, 153.

where state is divided, its obligations must be fulfilled by all parts in common, 202.

right of United States to extension of maritime jurisdiction, 279. advocated alliances to preserve balance of power, 452 .

upon neutral aid under pre-existing treaties, $666 n$.

loan of money to belligerent state a violation of neutrality, 673 . 
[THE REFERENCES ARE TO THE PAGes.]

KENT, CHANCELLOR-Continued.

right of state to imprison resident enemies, 461.

right of neutral to sell contraband to belligerent state, $741 n$.

on determination of contraband character of goods, 727 .

classes horses among contraband of war, $733 n$.

right of visit and capture of merchant vessels under convoy, 789 .

often cited, for instance, $134,252,369,560,611,732$.

KLUBER, J. L.

temporary allegiance due to conqueror during military occupation, 586.

interpretation of servitudes, 369 .

often cited, for instance, 161, 173, 229, 252, 323, 342, 369, 670.

KOSZTA'S CASE, 251.

LAKES,

neutralization of great, 443 .

agreement for disarmament of, 444 .

LAWRENCE, PROF. T. J.

why Boer Republic cannot be said to possess full rights of independence, 174 .

annexation and settlement inseparable elements of international occupation, $268 n$.

sovereignty of chartered companies, $270 n$.

conditions justifying avoidance of treaty, a question of morality rather than of law, $403 n$.

primacy of United States on American continent, 418.

intervention for preservation of balance of power fallen into disrepute, 426 .

test of political offenses in matter of extradition, 259.

definition of war, 448 .

table showing effect of war on treaties between billigerents, 604 .

criticism of arbitral definition of "due diligence" in case of the Alabama, 660 .

criticism of principle, that neutral may pursue and arrest belligerent vessel attempting capture within its territory, 683 .

on vessel's right of self-defense in neutral waters, 701 .

distinction between unneutral service and carrying of contraband, $748 n$.

criticism of extension of doctrine of continuous voyage by United States Supreme Court, 779 .

cited, 173, 184, 186, 228, 235, 259, 272, 425, 513, 560, 671, 699, 721, $724,744,747$.

LAWRENCE, WILLIAM BEACH

cited, 212, 254, 357 .

LEAGUES,

religious, the first movement toward political fellowship betweeu alien peoples, 362 .

first armed neutrality, of 1780,633 .

second armed neutrality, of 1800,635 .

of the Rhine, 40.

Swabian League, 40.

Hanseatic League, 40, $41 n$.

LEECH, PROF. H. BROUGHAM

relations of states comprising Greek federal leagues, $15 n$.

allusions to an international positive law in Greece found in pages of Thucydides, $17 n$.

on classes of treaties in Greek diplomacy, 93.

origin of the Collegium Fetialium, 363 .

statements as to cruelty of Greeks in war exaggerations, $11 n$. on institution called proxenia in Greece, 618.

cited, 93 . 
[THE REFERENCES ARE TO THE PAGES.]

LEIBNITZ, GOTTFRIED WILHELM

proposed pope and emperor as joint public arbitrators, 377 .

LESLEY, BISHOP OF ROSS, CASE OF, 336n.

L.ETTERS OF CREDENCE,

see Ambassadors; Diplomatic Agents.

LIBERIA, REPUBLIC OF

extension to, of international law, 90 .

LIBRARIES,

generally exempt from seizure as booty, 543 .

contrary rule of American Regulations, 543.

LICENSES TO TRADE,

defined, 510 .

general and special, 510 .

by what authority granted, 510 .

invalid if obtained through misrepresentation, 510 .

how to be construed, 511 .

not transferable unless made negotiable, 511.

may be sold when general in terms, and not granted to specific individual, $511 n$.

national character of vessel in which goods are to be transported, 511.

correspondence between cargo and terms of license, 511.

course of voyage, 512 .

limitations as to time, 512 .

must be on board at time of visitation, 512 .

are becoming obsolete, 513 .

LIEBER, DR. FRANCIS

first to attempt codification of rules of war, 47.

his Manual for United States Army in the Field, 152n, 471.

too severe in some particulars, 471 .

many principles of, found in Swedish Army Regulations of

Gustavus Adolphus, 471.

combatant committing flagrant breach of laws of war not entitled to quarter, 488.

cited, 395 .

LIEN,

on cargo for freight, 568 .

contractual, inferior to right of prize, 577 .

LINCOLN, PRESIDENT

proclamation blockading ports of Confederate States, 190, 458.

proclamation, 1863 , as to liability of aliens to military service, 467 . proclamation that vessels be individually warned of blockade, 770 .

LIVERPOOL, LORD

recognition of independence of insurgent state, 195 .

conduct of Great Britain in respect to neutrals, $370 \mathrm{n}$.

construction of treaties of alliance between Great Britain and

Holland, 371.

LIVINGSTON, SEC. OF STATE

construction of most favored nation clause, 375 .

LIVY,

cited, 447, 456, 491, 514 .

LOANS,

right of insurgent state to negotiate, upon recognition of its belligerency, 191.

what are guaranteed loans, 203.

payment of, in case of cession or alienation of part of state territory, 203. 
LOANS-Continued.

decisions of English and American courts upon question of, by neutral individuals to belligerent states, 674 .

views of Vattel on same question, 625 .

LONDON,

conference, 1831, 45.

conference, 1871, 46, 124.

LOUISIANA,

cession of, by France to Spain, 276.

cession of, to United States, 113.

LOW, SETH

on Peace Conference at The Hague, 49.

LUSHINGTON, DR.

on necessity of notice of blockade to neutrals, 768 .

opinion in case of the Franciska, 768, 775.

on issue of licenses to trade by belligerents, 775 .

LYONS, LORD

on liability of resident aliens to serve in militia or police, 468 .

MACHIAVELLI, NICCOLO

modern study of politics begins with, 52 .

the "Prince" regarded as a veiled satire by Gentilis, 52 .

his advice against neutrality, 620 .

MACINTOSH, SIR JAMES

constitutions are not made; they grow, 48.

on distinction between recognition of independence by parent state and by foreign one, $192 n$.

criticism of British destruction of state property at Washington, 545.

nature of prize courts, 580 .

MADISON, PRESIDENT

nature of treaties, 93 .

on varieties of treaties, 93.

treaties considered as positive law of nations, 93 .

favored suggestion of Canning for joint declaration with England against European interference in South America, 142.

ground on which United States claimed release from treaty of alliance with France untenable, 465.

criticism of Great Britain's interference with neutral trade with enemy's colonies, 633 .

MAGNA CHARTA,

provisions of, as to resident enemies in time of war, 461 .

MAHAN, CAP'T.

principle that neutral flag covers cargo, forever secure, 723 . cited, 412, 439, 481, 501, 502, 508, 517, 519, 562, 563, 637, 699.

MAILS,

mail packets exempt from capture until notification, 560 .

whether mail bags should be exempt from search, 750 .

treaty between United States and Great Britain, i848, for exemption of, 751.

see Contraband; Neutrals.

\section{MAINE, SIR HENRY}

assent of Europe to blended product of jus gentium and jus naturae, 77.

habit of identifying Roman law with law of nature in Europe, 85. cited, $152 n, 197,474,478,481,482,486,508,509,526,532,533,538$, $542,545,547,552,596,603$, 
[THE REFERENCES ARE TO THE PAGES.]

MAINE, THE BATTLESHIP,

sent to Havana harbor to protect American interests during Cuban insurrection, 443.

destruction of, precipitated intervention of United States in Cuba, 420 .

MANNING, WILLIAM OKE

on neutral aid under pre-existing treaties, 666 .

Denmark's condemnation of American vessels under English convoy legal, $791 n$.

horses as contraband, $732 n$.

cited, $630,668,670,699,707,711,722,733,738,747,762$.

MANSFIELD, LORD

effect of conquest on laws, municipal and political, 609.

declaration that Consolato del Mare is part of existing law of nations, 714 .

opinion in case of Sommersett, 696 .

MANUAL FOR UNITED STATES ARMIES IN THE FIELD,

Calvo's designation of, 471 .

many principles of, found in Swedish Army Regulations of Gustavus Adolphus, 471.

is too severe in some particulars, 471.

description of guerrillas and banditti, 476 .

cited, $459,472,478,597$.

MARCY, SECY. OF STATE

relation of domicil to national character, 212.

on right of state to determine who shall compose its members, 231. urged incorporation in Declaration of Paris of principle of exemption of private property from capture at sea, 561 . cited, $234,260,723$.

MARE CLAUSUM, doctrine of, 290 .

contention of Selden, 292.

gradual extinction of doctrine, 292.

claim of United States in Bering Sea, 44.

see Sea; Territorial Waters.

MARINE LEAGUE,

see Sea; Territorial Waters.

MARITIME FORCES OF A STATE, see Forces of a State.

MARITIME LAW,

only operative so far as adopted, when not part of international law, 137.

rubrics relating to ships and shipping in Roman civil law the starting point of other compilations, 41 .

Laws of Oléron, 40.

Laws of Wisbuy, 40.

judgments of Damm, 40 .

the Consolato del Mare, 41, 564, 705.

collection of maritime laws by Pardessus, 41 .

Guidon de la Mer, 41.

sources of British, 41.

Ordonnance de la Marine of Louis XIV., 41.

state jurisdiction over its marginal waters, 263 et seq.

emancipation of high seas, 289 et seq.

gradual extinction of doctrine of mare clausum, 292.

Grotius' Mare Liberum, 291.

the marine league, 293.

state jurisdiction over merchant vessels on high seas, 307 et seq, Marine Conference at Washington, 1889, 46.

rights of war vessels in territorial waters, 281. 
[THE REFERENCES ARE TO THE PAGES.]

MARITIME LAW-Continued.

rules of Congress of Paris as to privateering, blockades and seizure of goods at sea, 46 .

laws of war as to enemy property at sea, 558 et seq.

convention of The Hague Conference for adaptation to maritime warfare of principles of Geneva Convention, 1864, 50, 51.

see American Naval War Code; Belligerent Rights and Duties; Consolato del Mare; Declaration of Paris; Neutrals; Neutral Trade; Sea; Vessels.

MARQUE,

meaning of term, 437.

letters of, 437.

see Privateers; Reprisals.

MARRIAGE,

solemnized by diplomatic agent between members of suite, 348 . whether authority extends to subjects of state not of his suite, 348 . valid when each party has capacity to contract according to law of his domicil, 209.

MARSHALL, CHIEF JUSTICE

on law established by European nations for regulation of title by discovery, 129.

status of Indians in United States in international law, 176.

jurisdiction of state in own territory exclusive and absolute, 206. views as to immunity of private vessels in territorial waters, 311. foreign war vessel in port of friendly power exempt from local jurisdiction, 304 .

right of asylum for belligerent war ships in neutral waters, 689 . African slave trade not piracy by law of nations, 238 .

occupied territory considered part of domain of conqueror, 593.

confiscation of private property a war right, but not effective without legislation, 462 .

as to what places right of commercial blockade exists, 763 .

considered suum cuique original law of nations on subject of captures, 564,715 .

right of visitation and search does not exist in time of peace, 238 . recognized consular decrees in prize cases, $581 n$.

on circumstances demonstrating intent with which vessels are fitted out in neutral ports for use against belligerent, 662 . cited, 228, 644 .

MARTENS, BARON CH. DE

his Guide Diplomatique and Causes célèbres du droit des gens. cited, $190,193,283,284,285,302,317,326,328,332,334,336,348$, $350,386,526,635,636,676,712,732$.

MARTENS, FEDOR FEDOROVITCH

his Les Consulats et la Jurisdiction Consulaire ex Orient, 70.

La Conflict entre la Chine et la Russie, 70.

Traitś de Droit International, 70.

collection of treaties and conventions concluded by Russia, 70 . cited, 203.

MARTENS, GEORGE FREDERICK VON

his Précis du Droit des Gens Moderne de l'Europe, 59.

Recueil des Principaux Traités de Paix, d'Alliance, etc., 59.

in accord with Wolf and Vattel as to theory of sources of positive law of nations, 59 .

classification of treaties, 366 .

law of exterritoriality susceptible of modification by treaty or usage, $335 n$.

views on subject of neutrality, 625 .

European construction of neutrality, with respect to treaties for aid in time of war, 625 . 
[THE REFERENCES ARE TO THE PAGES.]

MARTENS, GEORGE FREDERICK VON-Continued. on belligerent right of angary, 702 .

frequently cited, for instance, $173,367,389,401,480,585,627,637$.

MARTIAL LAW,

Duke of Wellington on nature of, 596.

offences and persons over which its jurisdiction extends, $598 n$. effect of proclamation of, $598 n$.

its administration in Mexico by General Scott, 598 .

conquered territory occupied by United States' forces is subject to, $601,793$.

punishment of military offenses by, 535, 536 .

MASSE, M. G.

his Le Droit Commercial Dans les Rapports Avec les Droits des Gens et le Droit Civil, 66.

usage as to compensation for vessels seized under belligerent right of angary, 702 . cited, 240,703 .

MCKINLEY, PRESIDENT

message to Congress advising forcible intervention in Cuba, 421.

MCLEOD, CASE OF, 171.

MEDIATION,

as means of adjusting international controversies, 383,384 .

MEDICAL STAFF,

of captured ship is inviolable, 503.

belligerent must guarantee salary of, falling into its hands, 503. see Hospitals; Hospital Ships.

MEDIEVAI STATE-SYSTEM, see Rome; Holy Roman Empire.

MEXICO,

invasion of, by United States troops, 1836, 405.

pacific blockade of, by France, 1838, 444.

treaty of Guadalupe Hidalgo, 1848, with United States, $277 n$.

intervention of Great Britain, France and Spain in internal affairs of, $1861,414$.

ultimate motive of Napoleon, 414.

his instructions to Gen. Forey, $415 n$.

agreement to furnish military aid to Maximilian, 415.

further co-operation refused by Great Britain and Spain at Conference at Orizaba, 415.

intervention of United States to terminate intervention of France in, $149,416,427$.

invasion of Texas by Mexican troops, 1877, 670 .

case of $\mathrm{Mr}$. Cutting, 241.

MILAN DECREE, 583, 761.

MILITARY AND NAVAL DEMONSTRATIONS,

as a forcible means of redress, 431.

instances of, by United States, 442 .

armed neutralities of 1780 and 1800,443 .

counter demonstrations, 443.

MILITARY COMMISSIONS,

as special tribunals for trial of criminal cases in occupied territory, 598.

MILITARY FORCES OF A STATE, see Forces of a State.

MILITARY LAW, operations of army in field regulated by, 470 .

rules governing regular and irregular forces, 472 et seq.

retaliation and reprisals, 488 .

suspension and conclusion of hostilities, 508 et seq. 
[THE REFERENCES ARE TO THE PAGES.]

MILITARY LAW-Continued.

laws of war as to enemy property on land, 539 et seq.

military occupation and administration, 584 et seq.

duties of belligerents toward neutral states, $687 \mathrm{et}$ seq.

Lieber's Manual for United States Army in the Field, 47, 152, 471.

project for military code by Brussels Conference, 1874, 46, 471 .

approved by Institut de Droit International, 47, 483.

conventions of The Hague Peace Conference, 51.

see American Army Regulations; Belligerent Rights and Duties;

Capture; Confiscation; War.

MILITARY OCCUPATION AND ADMINISTRATION,

ancient theory of substituted sovereignty, 584 .

modern theory of quasi sovereignty of, 585 .

only temporary allegiance due conquerer, 586 .

military authority over hostile territory as limited by Hague Con-

ference, 587 .

when it begins and ends, 588 .

contention of smaller states, 589 .

views of Halleck, Wildman, Lord Coke and Chief Justice

Taney, 589.

contention of greater military states, 590 .

German, during Franco-Prussian war, 590.

constructive occupation by flying column, 590 .

conclusions reached at Brussels and The Hague, 590.

legal relation of subdued inhabitants to occupying state, 591 .

transfer of territory to neutral during, 591 .

right of insurrection by inhabitants of occupied territory, 592 .

legal relation of inhabitants to third states, 592 .

when territory may possess both neutral and belligerent character 594 .

how to deal with territory under such circumstances, 595. effect of, under constitution of England, 600 .

conquered territory passes under despotic power of President as commander-in-chief, 601, 793.

constitution and laws of United States not extended to occupied territory, 601, 793, et seq.

inhabitants do not cease to be aliens, 601, 793 .

holding is mere military occupation until acquisition is confirmed by treaty of peace, 601,793 .

decisions of Supreme Court in Insular Tariff Cases, 793 et seq. effect of, under constitution of United States, 600 .

administration; duty of occupant to govern, 596 .

nature and extent of his authority, 596 .

German attempt to compel courts at Nancy to administer justice in name of "High German Powers," 597.

effect of proclamation of martial law, $598 n$.

basis of authority of officials in occupied territory, 598 .

punishment of crime in occupied territory, 597.

by military commissions under Gen. Scott in Mexico, 598.

suspension of political and continuance of municipal laws, 599 .

right of alienation of private property unimpaired, 599 . authority of conqueror in this regard, 599 .

action of United States forces during occupation of California, 600 .

as guarantee for payment of indemnity, 613 .

right of occupying army to use state property, 545 .

injury or destruction of same prohibited, 545 .

rule of The Hague Conference, 545 .

sale of right to cut in public forests near Nancy during German occupation, 546 .

rule as to churches, cemeteries and the like, 546 .

declaration of The Hague Conference concerning, 547. 
MILITARY OCCUPATION AND ADMINISTRATION-Continued. respect due to private property and individual rights, 547 . requisitions, 548 . see Belligerent Rights and Duties; Conquest.

MILITARY OFFENSES, Heffter's classification of, 535 .

punishment of, by martial law, 535 . punishment of, not affected by sex, 536 .

MILITARY SERVICE,

treaties of United States as to requirement of, of naturalized citi. zens, 227.

\section{MILITIA,}

liability of resident aliens to service in, 467 .

admission of Great Britain in regard to, 468 .

declaration of Lord Lyons as to liability of, 468 .

rule correctly stated by Bluntschli, 468 .

when treated same as regular army in war, under rule of The Hague Conference, 477. see Forces of a State.

MILL, JAMES

plan for arbitral court composed of delegates from the several governments, 378 .

\section{MINISTERS,}

see Ambassadors; Diplomatic Agents.

MISSISSIPPI RIVER,

right to exclusive use of, claimed by United States, 277.

free navigation of, opened to ships of foreign states, subject to control of United States, 278.

navigation as regulated by treaties of Paris and San Lorenzo, 284.

MONACO,

status of, in international law, 178.

MONEY,

when state, may be appropriated by occupying army, 548 .

not subject to appropriation from enemy soldiers unless dead, 541 . when considered contraband of war, 738 .

MONROE DOCTRINE,

events which led to declaration, 140 .

correspondence of John Quincy Adams as to further European colonization on American continent, 144.

correctness of American position denied by Great Britain, $144 n$. Jefferson's famous letter to Monroe, 141.

President Monroe's message of Dec. 2, 1823, 142.

meaning of phrase, "future colonization," 143, 145.

extension of, by President Polk, 146.

controversy as to Oregon territory, 146.

protest against transfer of Yucatan, $146 n$.

opposition of United States to transfer of Cuba based upon, 146. Clayton-Bulwer treaty an exception to, 147.

agreement of Great Britain not to exercise dominion over any part of Central America, 146, 147.

declaration of Mr. Cass as to European protectorates over independent states on American continent, $147 \mathrm{n}$.

termination of intervention of France in affairs of Mexico, 149.

Mr. Fish on nature of policy, 149 .

Venezuelan boundary dispute, 150, 416.

applicability of doctrine to cases of forcible extension of boundaries of European states, 417.

its existence as principle of international law disputed by Great Britain, 417.

definition of, completed by President Cleveland, 150, 417. 
[THE REFERENCES ARE TO THE PAGES.]

MONROE DOCTRINE-Continued.

primacy of United States on American continent as defined by President Cleveland, 417.

as defined by Prof. Lawrence, 418.

is a continuous growth, 151 .

place of, in international law, 151.

acquiescence in, by France and Great Britain, 152.

when may become part of public law of nations, 152 .

MONROE, PRESIDENT

message to Congress containing statement of Monroe doctrine, 142. on recognition of South American republics, 194.

as Secretary of State, proposed disarmament on great lakes, 444. desirability of conventions for freedom of neutral commerce, 720 . cited, $355,412$.

MONTENEGRO,

emancipation of, from Turkey, 181.

independence of, recognized by Congress of Berlin, 1878, 181.

MONTESQUIEU, BARON CHARLES DE

principle on which international law is founded, 447.

comment on reply of English jurists to threat of Frederick II. to confiscate Silesian loan, 442, 712 .

MONUMENTS,

must be protected by occupying army, 545 .

MOORE, PROF. JOHN BASSETT

on exceptions taken by Russia and England to Monroe doctrine, $145 n$.

cited, $242,379$.

MOSER, JOHANN J.

his Versuch des Neuesten Europäischen Völkerrechts in Friedens. und Kriegszeiten, 59.

definition of international law, 59 .

called the father of positive school, 59 .

cited, 332, 585.

MUIRHEAD, JAMES

administration of jus gentium, 22 .

cited, 247, 264.

MUSEUMS,

generally exempt from seizure as booty, 543 .

contrary rule of American Regulations, 543.

NAPLES,

diplomatic relations with, suspended by France and Great Britain, 429.

treaty of, 1759, 109.

NAPOLEON BONAPARTE,

practice to make war pay for itself while in enemy's country, 450. accumulation of art treasures of Europe in the Louvre, 543 .

shot Venetian revolutionists who killed French wounded, 478.

debated propriety of poisoning wounded in Syria rather than leave them to mercy of enemy, 538 .

his punishment of insurrectionists of Pavia, 478, 592.

treatment of prisoners at Jaffa, 528, 533.

practice with respect to flying columns, $590 \mathrm{n}$.

Milan decrees, 583, 761 .

his contemplated overthrow of European concert crushed by inter-

vention of great powers, 112 .

efforts to break coalition against him, 113.

notified by Mr. Fox of projected attempt upon his life, 491.

abdication of, 114 .

his detention at St. Helena, 527. 
[THE REFERENCES ARE TO THE PAGES.]

NAPOLEON BONAPARTE-Continued.

treatment of, criticised by Lord Roseberry, $527 n$.

decision in case of the General Armstrong, 700 .

cited, 592, 639 .

NASHVILLE, CASE OF THE, 694.

NATIONALITY,

status more important than citizenship in international law, 211.

for many purposes is determined by domicil, 523 .

national character of aliens may be acquired by domicil, 211.

determination of, purely matter of municipal law, 223 .

doctrine of English law as to nationality by birth, 214, 217.

of English subjects in America, 215.

how British, may be lost, 221 .

effect of naturalization in a foreign state, 218, 221.

of children, 217 et seq.

of legitimate, 220 .

of illegitimate, 220 .

of children of naturalized parents, 220 .

of naturalized parents born abroad under British naturalization act, 224 .

of naturalized aliens in United States, 224.

by election, $219,220,221$.

of married women, 221 .

effect of cession upon, of inhabitants, $277 n, 613$.

of vessels, how determined, $310,408,568$.

see Aliens; Allegiance; Citizens; Naturalization.

NATURALIZATION,

is subject to control of international law, 223.

state jurisdiction over naturalized citizens, 212, 216, 218, 226.

tendency of legislation upon, that husband is political representa-

tive of family, 222.

laws in relation to, in United States, 216, 223.

early American doctrine of expatriation, 225.

cases of Prussian subjects naturalized in United States, 225.

Mr. Cass on effect of, upon allegiance, 226 .

right of adopted country to protect naturalized citizen in land of nativity, 226 .

declaration of United States as to right of expatriation, 227.

treaties as to jurisdiction of offenses and military service of naturalized citizens, 227.

British Act of 1870, 224.

effect of, upon allegiance and citizenship, 214, 218.

limitation upon privileges of naturalized citizens, 224 .

the case of Bourgoise, 224.

see Aliens; Allegiance; Citizens.

NAVAL FORCES OF A STATE,

see Forces of a State.

NAVAL WAR CODE,

absence of international, 495.

The Hague Convention for adaptation of Geneva Convention, 1864,

to maritime war, 495 .

see American Naval War Code; Belligerent Rights and Duties;

War.

NAVIGATION,

of great rivers of Europe, except Danube, regulated by Congress of

Vienna, 1815, 115.

regulations extended to Danube by treaty of Paris, 1856, 115.

see Gulfs; Lakes; Rivers; Sea.

NEGRIN, DON IGNACIO DE

his Estudios Sobre el Derecho Internacional Maritimo, 55. 
[THE REFERENCES ARE TO THE PAGES.]

NEGRIN, DON IGNACIO DE-Continued.

rules for admission of belligerent vessels to neutral ports, 692 . cited, $670,770,786$.

NETHERLANDS, THE, sovereignty of United Provinces recognized by Spain in Peace of Münster, 1648, 97. treaty of Breda, 1667, 101. acquisition of Surinam and Isle of Polaroon, 101. Peace of Nimeguen, 1678-79, 102. territorial limits after Congress of Vienna, 1815, 115.

controversy between Holland and Great Britain as to construction of certain treaties of alliance, 370 .

intervention of great powers to dissolve union of Belgium with, $118,414$.

pacific blockade of Holland by France and Great Britain, 1833, 444 . navy originally composed of private ships, 497.

Dutch efforts for freedom of neutral commerce, 629, 706 . conflicts with Great Britain in regard to right of convoy, 635 . Wicquefort's case, 337.

refusal of minister of, to United States to appear as witness in homicide case, 338 .

NEUCHATEL, PRINCIPALITY OF admitted to Helvetic Confederation, 201.

NEUTRALITY, growth of law; dim conceptions of in Greek and Roman worlds, 617.

Latin language contains no substantive corresponding to, 619 . incompatible with theory of Medieval Empire, 619.

absence of rule as to neutral duty in sixteenth century, 620 . growth of principle of, in seventeenth century, 621 .

unsatisfactory doctrine put forth by Grotius, 65,622 .

theory of, as defined by publicists of eighteenth century, 623 . positions of Bynkershoek and Wolf, 623 .

influence of Vattel in advancing law of, 66, 624 .

rules laid down by G. F. de Martens, 625 .

effect of treaties for aid in time of war in eighteenth century, 625 . Sweden's protest against succor furnished by Denmark to Russia in 1788,626 .

conflict over similar question between Great Britain and Spain, in 1804,628 .

contributions to law of, by American publicists, 67, 153.

standards of neutral duty as set forth in Jefferson's letter to M. Genet and in the Treaty of Washington, 1871, 652 .

President Washington's proclamation of, 465, 639.

Jefferson's letters to Mr. Hammond, 641, 642, 643.

executive orders of June 5 th and August 4th, 1793, 640.

American Foreign Enlistment Acts of 1794 and 1818, 644.

British Foreign Enlistment Acts of 1819 and 1870, 646.

neutral duties defined, general scope of, 651 .

law of, as between state and state, 648 .

law of, as between states and individuals, 649 .

standards of neutral duty prior to 1871,652 .

rules established by judicial decisions under Foreign Enlistment Acts of United States, 653.

codes of France, Italy, the Netherlands, Austria, Spain, Portugal and Denmark, 654.

three rules of the Treaty of Washington, 1871, 654 .

relation of, to pre-existing international law, $655 n$. as construed by counsel for United States, 656 .

construction of, by counsel for Great Britain, 657 . as construed by arbitral court, 659 .

criticisms of arbitral definition of "due-diligence," 660 . 
[THE REFERENCES ARE TO THE PAGES.]

NEUTRALITY-Continued.

intent as the test of guilt, 661 .

opinions of Marshall and Story, 662 .

character of the ship as a test of illegality, 662 .

provisions of British Foreign Enlistment Act on proof of such intent, 663 .

practical value of arbitral decree, 664 .

resolutions of Institut de Droit International on neutral duty, 72,684 .

declarations of, 665 .

penalty for violations of state neutrality statutes, 704 .

in France left to general provisions of Penal Code, 654 .

arrest of six ressels, in French ports, in course of construc-

tion for Confederate States, $654 n$.

reparation; to neutral for violation of neutrality, 704 .

by neutral, for failure to perform its obligations as such, 685 . seizure of Confederate cruiser Florida, 685 .

seizure of the Chesapeake, 686 .

neutralization of great lakes, 443 .

duty of enforcing collective guaranty of, 373 .

of Belgium, protected by Great Britain in $1870,119,427$.

NEUTRALS,

rights and duties; territorial, vindicated by United States, 638 .

diligence required of, $655,659,660,661$.

power of state to prevent infractions of its neutrality, 683 .

right to pursue belligerent vessel into open sea, 683 .

declaration of Institut de Droit International, 684.

in cases of property returned to neutral territory sometime after illegal belligerent capture, 684 .

case of the Santissima Trinidad, 684 .

purchase of belligerent territory after declaration of war, 591 .

right of ingress and egress to and from blockaded port, 773 .

rights of parent state in respect to neutral commerce upon recognition of belligerency of insurgent state, 191 .

duties of, towards belligerent states, 651 .

Mr. Jefferson's views upon, 641, 642.

armed assistance or other aid under pre-existing treaty, 666 .

levying of soldiers in neutral territory, 667 .

practice of, finally abolished, 668 .

passage of belligerent troops through neutral territory, 669 . in cases of "extreme necessity," 669.

opinion of recent publicists that right no longer exists, 670 .

passage of Alsatians enlisted for French army refused by

Switzerland in 1870,670 .

passage for German wounded refused by Belgium, 670 .

passage of belligerent sick and wounded authorized by Brussels Conference, 670.

invasion of United States by Mexican troops in 1877, 670. convention of 1877 for passage of Russian troops through Roumania, 671.

internment of belligerent soldiers in neutral territory, 671 . practice confirmed by The Hague Conference, 672 .

gifts or loans of money, cannot be made to belligerents, 673 . but loans may be made by neutral individuals, 673,675 . contrary view of Bluntschli, Phillimore and Halleck, 673.

decisions of English and American courts, 674. views of Canning and Webster, 674, 675 .

arms and instruments of war; furnishing of, unlawful, 675 . exception to this rule, 676 .

may be supplied by neutral individuals, 677 .

vessels; sale of war-ships by, to belligerents, 653, 676, 677 . 
NEUTRALS-Continued.

application of American and English Foreign Enlistment Acts to such transactions, 653 .

intent of fitting out as the test of legality, $653,661,663$.

proof of intent, 663,665 .

character of ship as the test, 661 .

codes of France, Italy, the Netherlands, Austria, Spain,

Portugal and Denmark, 654.

case of the Alabama, 43, 680, 681 .

three rules of Treaty of Washington, see Neutrality.

effect of decree in Alabama case upon right of sale, 665 .

buying and selling of merchant vessels by, in time of war, 696.

when sale to neutral upheld by England and America, 555,568 .

when recognized by France and Russia, 555 .

purchase of enemy vessel in neutral port, 568,695 .

case of the Sumter, 695 .

warlike expeditions; use of territory of, as base of operations

for warlike expeditions, military or naval, 678 .

what constitutes a warlike expedition, 679 .

illegal acts of French minister Genet, 640 .

case of the Grange, 641 .

embarkation of unarmed expedition of Frenchmen from

United States during Franco-Prussian war, 679.

case of the Twee Gebroeders, 678.

the Terceira affair, 678.

augmentations of warlike forces, 680 .

warlike expeditions organized outside neutral territory

from elements issuing separately from within it, 680 .

should prevent acceptance of letters of marque, by citizens, 682 .

United States Acts of 1797 and 1816, 682.

state responsibility for individual action, 740 .

proclamations of neutrality, 741 .

not required to prohibit carrying of contraband, 741 .

proposal of Institut de Droit International to charge, with

duty of preventing shipments of contraband, 72 .

duty of neutral vessels rescuing sick, wounded or shipwrecked

of belligerents under American Naval Code, 505 .

services of; distinction between unneutral service and carrying of contraband, 748,757 .

rules announced by Russia, to regulate war with Turkey, 748 .

proclamation of Great Britain at beginning of American Civil war, 748.

lawful neutral service; carriage of private diplomatic and consular correspondence, 749 .

whether ignorance of official character and hostile destination will authorize release of carrier, $749 n$.

cases of the Rapid and the Caroline, 749, 750 .

should postal vessels and mails be exempt from search, 750 . practice of United States during Civil war, 751 . case of the Peterhoff, 751 .

practice of France, 752 .

transport of diplomatic agents, 752 .

the Trent affair, 752 .

unlawful neutral service; transmission of signals or messages for belligerents, 754 .

carrying prohibited despatches or persons, 754 .

neutral vessels engaged as transports by belligerents, 755 . opinion of Lord Stowell in case of the Friendship, 755. cases of the Carolina and the Orozembo, 756 .

penalty for performing unneutral service, 757 . 


\section{NEUTRALS-Continued.}

duties of belligerents toward; notice of commencement of war, 687 . must not enlist soldiers in neutral territory, 468 .

but military service of individuals, may be accepted, 468 . belligerent warships in neutral waters, 689 .

hospitality and asylum, 689 .

observance of quarantine rules, local revenue and harbor regulations, 690 .

rules in regard to repairs, provisions, coal, etc., 690 .

substance of Azuni's rules, 690.

Negrin's rules, 692.

exclusion of warships from ports of, 692 .

twenty-four hours' rule, 692 .

restatement of rule by France in $1861,693$.

cases of the Nashville and Tuscarora, 694 .

usually prohibit bringing in of prizes, 581, 697 .

when prizes may be taken to neutral port, 698, 786 .

moder'n practice of designating ports for, 699 .

sale of prize prohibited in ports of, 699 .

enemy property not subject to seizure in neutral waters, 564 . neutral waters not to be violated by naval combats, 498,688 .

attack of one belligerent upon another in neutral waters, 699. effect of resistance to unlawful attack, in such case, 700 . right of self-defense when vessel is thus attacked, 701 .

restrictions upon belligerent vessels regarded as rules of international law, 695 .

see Belligerent Rights and Duties.

neutral individuals; effect of domicil in enemy country, 553 .

residing in belligerent state, are subject to measures rendered necessary by exigencies of war, 554,701 .

how they may become de facto citizens of belligerent state, 468 . soldiers billeted in American apartments by Germans during occupation of Paris, 1871, 468 .

belligerent right of angary, 701 .

right of, as exercised during Franco-Prussiar war, 703.

NEUTRAL TRADE,

right of neutrals to trade with belligerents, 741,761 .

suspended by war in early international law, 759 .

licenses to trade, 510 et seq.

vessel under enemy's license liable to capture, 512.

struggle for freedom of neutral commerce, 629 .

rule of the Consolato del Mare, 565, 629, 705, 706. ownership of goods the test, 706 .

French doctrine of hostile infection, 565, 629, 708 .

French rule in treaties down to first armed neutrality, 708 . defense of French rule by Valin, Pothier and Ortolan, 709.

Dutch movement for neutral rights, 629, 706, 708. treaties of seventeenth century with Spain, Great Britain, France, Sweden and Portugal, 630, 709 .

nationality of vessel as the test, 566, 709 .

rule of war of 1756,631 .

British theory and practice, 630, 631, 632, 711 .

armed neutralities of 1780 and $1800,633,635,713$.

situation under Peace of Versailles, 1783, and convention of

St. Petersburg, 1801, 635, 637, 713.

American theory and practice, 567, 713. rule of Consolato accepted by prize courts, 714 . treaty between United States and France, 1788, 714n. similar treaties with Dutch, 1782 , and Sweden, 1783, 714n. conditional recognition of armed neutrality, 715 . position of Mr. Jefferson that rule of Consolato was part of law of nations, 715 . 
NEUTRAL TRADE-Continued.

rule adopted by American judiciary, 567, 715 .

criticism of United States for its departure from declaration of Jefferson, $715 n$.

during war of 1812 enforced seizures and confiscations against enemy goods in neutral bottoms, 716, 720 .

exception made by English courts to rule of Consolato, 716. opposing opinion by courts of United States, 716.

conventional law as to free ships-free goods, 717 et seq.

do maxims, free ships, free goods; enemy ships, enemy goods, embody distinct propositions? 717 .

theory of United States as disclosed in treaties, 717.

negotiations of United States with South American republics as to principle of free ships, free goods, 720 .

proposal to European nations to abolish private war at sea, 721 .

attacks upon, by Great Britain and France in early part of nineteenth century, 721 .

efforts in favor of free ships, free goods finally frustrated by Great Britain, 637, 721.

freedom of trade allowed during Crimean war, 513, 721, 722. Declaration of Paris; existing freedom of, the outcome of, 706, 722. as to maritime rights of neutrals, $120,513,566,722$.

effect of final clause of Declaration, 723 .

countries refusing invitation to accept, $567,722$.

American amendment defeated by Great Britain, 567, 723.

reasons for refusal of United States to sign Declaration, 723.

provisions observed by nations not signing, 567, 723 .

as to neutral cargoes in enemy ships common law rule still prevails, 567.

contraband; struggle for the emancipation of, never intended to include contraband, 725 .

questions as to consignments, 568 .

penalty for carrying contraband, 741, 744 .

capture of property at sea; rules concerning, 563, 743 .

tendency to make nationality of vessel conclusive as to cargo, 563,568 ,

vessel sailing under convoy, word of commanding officer should suffice, 563 .

principle of surm cuique, 563 .

effect of endeavor to cover enemy property from lawful belligerent seizure, 565 .

liability of belligerent for freight on enemy property taken from neutral ships, 565 .

loading of goods on armed enemy vessel regarded by Great Britain as departure from neutrality, 564 .

citizen residing in neutral state may trade with country at war with his native country, 524 .

right of ingress and egress to and from blockaded port, 773 .

no legal blockade by neutrals except in war, 444.

see Blockade; Contraband; Free Ships, Free Goods; Freight.

NEWFOUNDLAND,

reservation of, to France in Peace of Utrecht, 1713-14, 106, 109.

controversies as to fisheries off coasts of, between Great Britain

and United States, 296 et seq.

NEW GRANADA,

pacific blockade of, by England, 1836, 444.

closing of ports by government of, to foreign ships, 459.

NICARAGUA,

seizure of port of Corinto by Great Britain, 441. 
NIMEGUEN,

Congress of, 1678, 44.

NON-COMBATANTS,

modern war a relation of states, and not of individuals, 449 .

effect of war on private citizens, 459,461 .

proclamation of Wilhelm that he would protect French citizens, 451.

private property of, 462 .

Napoleon's practice to make war pay for itself while in enemy's country, 450 .

persons not in military and naval forces considered passive enemies, 473.

their right to notice of bombardment to enable them to retire, 484 . permitted to retire at siege of Strasburg, 485 .

may be expelled during siege, 485 .

persons and property of, to be respected after taking besieged town, 485 .

murder of women and children in Franco-Prussian war, 486.

how far private rights respected by conquering army, 524.

see Belligerent Rights and Duties; Confiscation; Enemy Persons;

Property; War.

NON-INTERCOURSE,

as a positive remedy for obtaining ređress, 431 .

United States Act, 1809, against Great Britain, 434.

principal decisions under, laws of United States, $434 n$.

see Embargo.

NOOTKA SOUND CONVENTION, 135.

NORTHWEST BOUNDARY OF UNITED STATES, controversy between United States and Great Britain in relation to, 134.

claims of Russia in northwest territory, 144.

correspondence of John Quincy Adams in relation to, 144.

NORWAY,

Union of, and Sweden constitutes them a single sovereign state as to international relations, 173.

enforces its domestic criminal law against subjects who have committed offenses abroad, 243.

NOTICE,

to neutrals of commencement of war, 687 .

of the closing of particular ports against vessels of war, 690 .

of blockade; to neutrals, 768 et seq.

of siege, to non-combatants, 449.

NUNCIOS,

representative character of, 319,320 .

OBLIGATIONS OF A STATE,

see Debts; Loans.

OCCUPATION,

source of present law of, 71,127 .

law of, as drawn from Roman sources, 128 .

title to newly discovered lands under English constitution, 129.

basis of title of English settlers on American continent, 129.

charter to London and Plymouth companies the title deed of

English settlers in America, 130.

international validity of charters to English settlers questioned by England, 130 .

effect of settlement on coasts of continent, 130 .

general rules as to area appropriated by act of occupation,

Oregon boundary dispute, 130, 135.

defect in old doctrine of discovery and settlement, 130, 268, 
[THE ReFERENCES ARe TO THE PAGEs.]

OCCUPATION-Continued.

extent of England's claim under settlements on coasts of

American continent, 130.

rule that finally prevailed as to rights of coast settlement, 131 . effect of settlements upon islands, 131.

possession of Louisiade Archipelago and Marshall Islands by

Great Britain and Germany, 131.

rule as to lateral boundaries, 131 .

its application to boundary line between Spain and United

States in Gulf of Mexico, $131 n$.

basins of great rivers and their tributaries, 131.

contention of Mr. Rush and Mr. Gallatin at London Conferference, $1827,131 n$.

authority for settlement, 132 .

effect of subsequent ratification of unauthorized settlement, 132 .

conflict between United States and Spain as to western boundary

of Louisiana, 132.

basis of Spain's claim, 132.

claims of United States based on acts of LaSalle, 132.

effect of discovery and occupation of line of sea coast on title to interior country, 133.

conflict with Great Britain as to northeastern boundary, 133 . same as to northwestern boundary, 134.

conflicting claims as to prior discovery and settlement of Columbia River basin, 134.

settlement and annexation two inseparable elements of effective international, 268.

chartered companies as colonizing agents, 268 .

protectorates over appropriated and uncivilized regions, 270.

conventions for "spheres of influence" employed in Africa, 271.

extent of interior occupations in Africa, how determined, $272 n$.

see Boundaries; Discovery.

military occupation, see Military Occupation and Administration.

OLERON,

laws of, 40 .

ORDERS IN COUNCIL, BRITISH,

freedom of trade to neutrals during Crimean war, 513.

for detention of vessels laden with provisions and bound for any port in France, 736.

revival of ancient severity in law of blockade, 761 .

neutrality regulations adopted during American Civil war, 694. cited, 632 .

ORDONANCE DE LA MARINE,

of Louis XIV., model of marine legislation, 41.

articles designated in, as contraband, 732 .

OREGON,

London Conference, 1826-27, for settlement of boundaries of, 130 . conflict with Great Britain as to northwestern boundary, and treaty of $1846,134,136$.

dispute over, an occasion for extending Monroe doctrine, 146.

ORTOLAN, LEON FELICITE THEODORE

his Régles Internationales et Diplomatie de la Mer, 66.

views as to effective blockade, 768 .

frequently cited, for instance, $294,302,324,587,629,684,701,782$.

OTTOMAN EMPIRE,

independence and territorial integrity of, guaranteed by treaty of

Paris, 1856, 119.

special treaty between Great Britain, France and Austria to insure

independence and integrity of, $121 \mathrm{n}$.

see Turkey. 
PACIFIC BLOCKADE,

[THE REFERENCES ARE TO THE PAges.] see Blockade.

PARIS. treaty of, $1856,119$.

siege of, during Franco-Prussian war, 485. see Declaration of Paris; Treaties.

PARKS, must be protected and administered by occupying army, 545 .

\section{PAROLE,}

in cases of capitulation, 516 .

its obligations, 532 .

of wounded soldiers, 537.

rules of The Hague Peace Conference concerning, 532.

PARTITION TREATIES, 104, 106.

PASSAGE, INNOCENT,

meaning of phrase, 281 .

growing pressure for, through all territorial waters, 280, 281, 287. exaction of "Sound dues" by Denmark in two Belts, 280.

when right of, extends to vessels of war in territorial waters, 281. customary servitudes for, through territorial waters, 299.

whether right of, for military forces, exists, $300,669,670$.

for diplomatic agents, 330 .

\section{PASSPORTS,}

theory of, $356 n$.

nature of document, 509 .

difference between, and safe conduct, 509 .

may be implied from circumstances, 509 .

persons and places to which they extend, 509 .

practice in respect to, 356 .

PEACE,

general principles affecting treaties of, 602 .

effect on pre-existing treaties, 603 .

usual basis of, 604 .

by cessation of hostilities, 605 .

treaty of, as method of terminating war, 611 .

treaty of, effective only from time of ratification, 612 .

interpretation of treaties of, 612 .

violation of any material provision of treaty may be treated as breach of whole, 614 .

treaties of; Westphalia, 1648, 36, 95, 365, 423.

religious, of Augsburg, 413.

Pyrenees, 1659, 100.

Aix-la-Chapelle, 1668, 102.

Nimeguen, 1678-79, 102.

Ryswick, 1697, 104.

Carlowitz, 1699, 107.

Utrecht, 1713-14, 97, 106, 111, 300, 371, 372, 423, 462, 635, 711.

Nystadt, 1721. 107.

Breslau, 1742; Berlin, 1742; and Dresden, 1745, 108.

Hubertsburg, 1763, 110.

Paris, 1763, 109, 372.

Versailles, 1783, 713.

Paris, 1783, 111.

Basel, 1795, and Tilsit, 1807, 113.

Paris, 1814, 114.

Paris, 1856, 119.

Vienna, 1864, and Prague, 1866, 122,

Frankfort, 1871, 124.

see Treaties. 
[THE REFERENCES ARE TO THE PAGES.]

PEACE CONFERENCE AT THE HAGUE,

its basic principle, 48 .

calling of conference; circular letter of Count Mouravieff, 50.

its composition; results of, 51,95 .

convention for peaceful adjustment of international differences,

$47,48,51$.

convention as to laws and customs of war on land, 49, 51.

convention for adaptation to maritime warfare of principles of

Geneva Convention, 1864, 49. 51.

permanent court of arbitration provided by, 380 .

invigorated preliminary means of settlement, 384 .

see Arbitration; Mediation.

instructions or manuals to armed forces of signatory powers, 471.

treatment of irregular forces employed in war, 477.

declaration in regard to projectiles, 479 .

diffusion of asphyxiating gases by projectiles, 479 .

bombardment of towns, habitations and buildings, 484 .

prohibits sacking of towns, 486 .

who may be considered spies, 492 .

must be given trial before punishment, 492 .

use of balloons for reconnoissance legitimate, 494 .

application of Red Cross conventions to wounded at sea, 502 .

neutral vessel rescuing sick, wounded or shipwrecked of bel-

ligerents not liable to capture, 504 .

revision of Geneva Convention to meet new conditions, 538.

rules as to treatment of prisoners, 528, 529 .

bureau of information and relief societies, 530 .

parole of prisoners of war, 532.

prohibits pillage, 542 .

rules regulating capitulations and armistices, 521.

respect due to private rights of non-combatants, 525 .

occupation; relation of occupying army to state property, 545 .

private rights and property to be respected, 547 .

property of municipalities, and that of religious, charitable and educational institutions, 547.

military authority over hostile territory, 550, 587.

on internment of belligerent troops in neutral territory, 672 .

cited, 472, 478, 484, 485, 486, 490,491, 494, 528, 529.

PERSIA,

qualified extension to, of international law, 91.

PERSONAL TREATIES.

not subjects of international law, 365 .

PHILLIMORE, SIR ROBERT

his Commentaries on International Law, 63.

on testimony of publicists, 53 .

on American contributions to law of neutrality, 67.

views as to sources of international law, 81 .

on union between Norway and Sweden, $161 n$.

inviolability of ambassadors in transit through third state, $330 n$.

fiction of exterritoriality not applicable to immovable possessions of ministers, $345 n$.

right of self-defense may involve necessity of intervention in affairs of another state, 422 .

intervention on invitation of one party to a civil conflict, 424 .

effect of partition of state upon state obligations, 202.

opposes loans by neutral states or individuals to belligerents, 673 .

condemnations by prize court of belligerent while prize is lying

in neutral port, 698 .

on belligerent right of angary, 702 .

admission of United States that rule, free ships, free goods, was not part of law of nations during French revolution, $715 \mathrm{n}$.

frequently cited, for instance, $2,131,181,229,369,533,615,765$. 
[THE REFERENCES ARE TO THE PAGES.]

PIERCE, PRESIDENT

right of neutral individuals to supply instruments and materials of war to belligerents, 677 .

PILLAGE,

modern instances of, 541, 486.

its employment always questionable, 486 .

Napoleon's opinion as to effects of, 542 .

acts of, during Franco-Prussian war, 542.

committed during international expeditions into China, 1900, 542. of persons on board captured merchant vessel punishable under American Naval Code, 502.

prohibited by The Hague Peace Conference, 542.

PINCKNEY, MR.

on French criticism of treaty between United States and Great Britain, 1794, 719.

PIRACY, practiced by ancient Greeks, 11.

interfered with freedom of high seas in former times, 290.

piratical leagues of the Mediterranean, $290 \mathrm{n}$.

rich vessel never secure from attack in thirteenth and fourteenth centuries, $290 n$.

tolls exacted by Venice of vessels in Adriatic for ridding gulf of pirates and Saracens, $290 n$.

what constitutes offense of, jure gentium, 234.

acts of insurgents committed without authority of any recognized political community, 234.

case of the Shenandoah, $235 n$.

case of the Huascar, 235.

acts declared, by statute, which are not so by law of nations, 236 . jurisdiction in cases of, 234, 244, 245.

in cases of statutory piracy, 236 .

punishment of, 246.535 .

presumption in favor of innocence of public vessel, $302 n$.

right of visitation and search on suspicion of, 310 .

see Privateers; Slave-trade.

PISTOYE AND DUVERDY.

cited, $630,693,711,732,771,782$.

PITT, WILLIAM

admitted United States not liable for losses to British loyalists

through casualties of Revolutionary war, 262.

effect of exceptions to general international law in treaties, 631.

POLAND,

losses under treaty of Oliva, $1660,101$.

opposition to establishment of permanent embassies, 317.

three partitions of, $1772,1793,1795,99,110$.

ostensible ground for intervention of the powers, $413,426$.

failure in reconstruction of, at Congress of Vienna, 1815, 115.

POLK, PRESIDENT

extended application of Monroe doctrine, 146.

on transfer of Yucatan to any European power, $146 n$.

POLLOCK, CHIEF BARON

construction of British foreign enlistment act, 1819, 647.

POPE. THE

relation to medieval empire, 30 .

conflict for supremacy between pope and emperor, 32 .

claimed jurisdiction to settle international disputes, 33 .

canon law the basis of papal authority in international affairs, 34 . precedence still given to his nuncios in Catholic countries, 322 .

refusal to receive Prince $\cdot$ Hohenlohe as ambassador, 327.

election of new pope causes no interruption in functions of diplomatic agents, 349 . 
PORTUGAL,

independence of, acknowledged by treaty of Lisbon, 1668, 102 .

conflicts as to boundaries in New World between, and Spain, 127. intervention of Great Britain in internal affairs of, 117, 413. pacific blockade of the 'Tagus by France, 1831, 444.

controversy with Great Britain in relation to Delagoa Bay, 44.

POSTAL CONVENTIONS.

Universal Postal Union of 1874, 374.

POSTLIMINY,

origin of the rule, 574 .

theories of medieval Europe, 575 .

when right of, accrues under present rule, 574,575 .

cases of the Experience and Emily St. Pierre, 575.

recapture by ally is subject to, 576 .

question of salvage, 576 .

exceptions to rule. 576 .

emancipated slaves are beyond, under American regulations, 551. as applied to states or provinces, 615 .

POSTOFFICES,

may be seized by enemy in time of war, and mails opened, 541 .

see Mails.

PRE-EMPTION,

as a means of acquiring title to contraband, 746 .

authorized by British Admiralty Manual of Prize Law, 746.

whether right of, exists as to goods of neutrals not contraband, 747 .

treaty between Great Britain and United States, 1794, with reference to right of, $736,747$.

PRESCRIPTION,

title by, founded on Roman law, 264.

its application to possessions of states, 264 .

Vattel on necessity of, in law of nations, 264 .

views of Burke upon, 264.

narrow sense in which term is used in English law, 264n.

international application of, 265.

case of Poland, 265.

time necessary to establish international, 266.

existence of international, denied by Mamiani, $265 n$.

has no place in law of nations according to Lampredi, Martens and Klüber, 265.

annexation of Alsace and Lorraine, 265.

the basis of customary servitudes, 299 .

PRESTATION, purposes for which right may be invoked, 703 .

see Angary.

PRESUMPTIONS,

in favor of state's retention of sovereignty and property, 397, 401.

\section{PRISONERS,}

who are, of war, 527.

non-combatants generally not liable to be made, 525 .

imprisonment of German merchant seamen by France, 525 .

rule of American Regulations, 525.

force offering to surrender are not, if offer not accepted, 518 .

crew of sinking ship after offer to surrender, may escape to

neutral ship before acceptance, 501.

who are to be regarded as, at sea, 502, 503.

repatriation of wounded, taken at sea, 503 .

killing and enslaving of, 525 .

practice among Greeks, 11, 526.

Roman oustom of killing captives, 525 . 
[THE REFERENCES ARE TO THE PAgEs.]

PRISONERS-Continued.

practice during middle ages, 526 .

ransom of, 526,527 .

whether they can rightfully be slain, 528 .

practice of Henry V., Napoleon and Charles XII., 528.

treatment of, 502,528 .

rules of The Hague Peace Conference, 528, 529, 530.

provisions of American Naval Code on treatment of personnel of captured vessels, 502 .

employment of, 529 .

pay for labor of, 529 .

burial of, 529 .

wills of, 529,530 .

exiled to Siberia by Peter the Great, 530 .

practice during Franco-Prussian war, 530.

bureau of information and relief societies, 530 .

escape of, 530,697 .

effect of taking prisoners into neutral waters, 530, 691.

brought into neutral port, are free on escaping to shore, 697.

enlistment of, 530 .

parole and its obligations, 531 .

exchange of. 533 .

offense of cruelty to, 536 .

cartels for exchange of, 506,518 .

cartel ships, see Cartels.

\section{PRIVATEERS,}

origin of word privateer, $438 n$.

what a privateer is, 438 .

age of practice, 438 .

privateering distinguished from piracy, 497.

attempts of Great Britain and United States to treat it as piracy, 498,682 .

whether resort to, by neutrals would be piracy, 439,682 .

duty of neutral states to prevent acceptance of letters of marque by their citizens, 682 .

position of United States on fitting out of, in neutral ports, $641,643,652$.

conventions between United States and various countries as to acceptance of letters of marque by neutrals, 683 .

declaration of France that it would be so treated during war with Mexico, 1839,682 .

offers of Mexico in 1845, and Confederate States, 1861, to grant letters of marque to neutrals, 439.

rules concerning, 497 .

existing rules compiled by Jenkins, 438.

where captures may be made, 497 .

privateer must have authorization of sovereign and bring his captures into court, 438.

treaties of fifteenth century provide for exacting sureties of mas-

ters or owners of privateers, 438 .

commission and bond required, 439.

rules affecting commission, 439 .

enemy commissioned to act against his own country, 439.

British law requires privateers to carry special jack, 439.

privileges and duties of privateers in neutral ports, 498, 690 . status of regularly commissioned privateer, $697 n$.

captures inure to benefit of captors, 577 .

rules affecting validity of capture, 439 .

measure of damages for unlawful capture, 578 .

bond limits liability of sureties, but not of owner, 440 .

owners severally liable, 440.

damages not limited to ship and freight, 440 , 
[THE REFERENCES ARE TO THE PAGES.]

PRIVATEERS-Continued.

efforts of United States to suppress, 682.

efforts of Sweden, Holland and United States to secure abolition of, 440,721 .

abolished by Declaration of Paris, 1856, 46, 95, 121, 440.

attitude of United States and Spain during Civil and SpanishAmerican wars, 441.

objection of France to Prussian volunteer navy as privateers, 441. use of volunteer navies by other states, 441 .

PRIZE,

infuence of Consolato del Mare upon principles of prize law, 41. Ordonnance de la Marine of Louis XIV. as to procedure in prize cases, 41, 151.

when capture at sea becomes prize of war, $569,574,575$.

naval captures on land may be, 570 .

joint capture of, 571 .

bringing in for adjudication, 571 .

need not be brought into captor's port, 581 .

destruction of 571 .

remedy opposed by Bluntschli, 572 .

rule of American Naval Code, 573.

taking of ransom, 573 .

advantage in taking hostages, 572 .

not now generally practiced, 574 .

how captor's rights may be lost, 574 .

ownership of, $577,579$.

right of, superior to contractual liens, 577.

rule as to privateers, 577 .

duties and liabilities of captor, 786 .

belligerent right to deal with, in neutral ports, 580, 697, 786 . repair of, in neutral port, 691 .

enemy cannot use force or stratagem to recover, 691.

when may be sold or ransomed, 691 .

trial of, by neutral when brought into her ports, 305 .

salvage on abandoned vessel allowed by neutral court, 574 . duty of neutral to ascertain if trespass has been committed against its neutrality, 684 .

case of the Santissima Trinidad, 684 .

departure from old rule since 1823, 699 .

sale of, now forbidden by all regulations, 699 .

only right of asylum now recognized, 581, 699 .

see Capture; Postliminy; Salvage.

\section{PRIZE COURTS,}

their position as international tribunals, $39,42$.

originated with reprisals, 437 .

decrees of, as sources of international law, 42.

Lord Stowell on administration of prize law, 42, 787.

necessity of adjudication in cases of prize, 579 .

development of practice as to prize, 579.

nature and extent of prize jurisdiction, 580 .

jurisdiction of British Court of Admiralty, 580, 648.

in cases of belligerent naval capture on land, 570 .

where they should be held, 580 .

attempt of French minister to establish, in United States, 581.

procedure in prize cases, 581 .

questions for settlement, 582 .

when burden of proof is on captor, 787 .

burden of proving neutrality on claimant, 582 .

finality of decrees, 582 .

joint commissions for investigation of clalms for wrongful captures, 583.

decrees of Confederate, of no validity in United States, 583. 
PROJECTILES,

what are lawful, 479, 480.

St. Petersburg Convention in relation to, 479 .

dumdum bullets, 479 .

declaration of Peace Conference at The Hague, 479.

reasons of British and American delegates for not signing, 479.

launching of, from balloons unlawful, 479 .

convention in regard to asphyxiating or deleterious gases, 479 .

proposal of Capt. Crozier, 479.

\section{PROPERTY, ENEMY}

laws of war as to, on land, 539 et seq.

war implies primarily direct exercise of force against, 539 .

how far, public and private, may be appropriated in war, 539 . distinction between public and private property, 540 .

ownership of captured personal property, 541 .

when title passes, 539 .

dangers of pillage and its abolition, 486, 541, 542 .

what personal property is subject to seizure as booty, 540 .

rule as to money and effects of enemy soldiers, 541 .

evidences of public debt exempt, 542 .

works of art, libraries and museums exempt, 485, 543.

contrary rule of American Regulations, 543.

practice of different powers, 543,545 .

state property, light of occupying army to use, 545 .

use of churches, cemeteries and the like, 546 .

destruction of Capitol at Washington by British, 545.

rule of The Hague Conference, 545, 547.

sale of right to cut from public forests near Nancy, 546 .

alienation of lands and other property in hands of, 546 .

private property; extent to which exempt from seizure, 547.

practice among Greeks and Romans, 547.

declaration of The Hague Conference, 547 .

requisitions, 548,549 .

contributions, 549 .

confiscation and sequestration, 551 .

right of seizure as affected by domicil, $212 n, 552$.

as affected by situs of property, 554 .

confiscation of, not favored, 462 .

a war right in United States and Great Britain, 462. of debts and other property by France in 1814, 463 .

attempt of Great Britain to distinguish debts from other property, 463.

of Danish property in British ports in $1807,463$.

when cotton and other articles may be constructive contraband, 555 .

American extension of doctrine criticised, 556.

severity of Dr. Lieber's manual, 471.

how a district may be internationalized, 556 .

military authority over, as limited by The Hague Con-

ference, 587 .

of non-combatants, after taking of besieged town, 485 .

modern practice in respect to private property, 463 .

laws of war as to, at sea, 558 et seq.

what liable to capture at sea, 558 .

private property; tendency to exempt all not contraband, 561, 563.

declarations of Institut de Droit International on inviola. bility of, 72 .

history of struggle for freedom of, in neutral vessels, 629 et seq.

influence of armed neutralities in promotion of principle, "free ships-free goods," 713. 
PROPERTY, ENEMY-Continued.

French doctrine of hostile infection, 565, 708 .

American theory and practice, 713 .

Declaration of Paris that neutral flag covers enemy's goods, except contraband, $121,513,566,721$.

refusal of United States, Spain and Mexico to sign same, 94,723 .

effect of final clause of Declaration, 723 .

rules defining enemy property at sea, 563 .

whether nationality of vessel conclusive as to cargo, 563 .

Dutch rule that nationality of ship controls cargo, 566.

how nationality and ownership of vessel are shown, 568 . how presumption that goods are same as nationality of ship may be overcome, 564 .

ownership of cargo as affecting right of capture, 568 .

how enemy character may attach to that of nelitrals, 315 . seizure in neutral waters or on public ships of neutral, 564 .

effect of neutral's endeavor to cover, from lawful seizure, 565 . property exempt from capture for humanity's sake, 558.

hospital and cartel ships and fishing boats, 558 .

vessels engaged in whaling and deep sea fisheries an exception, 559.

vessels engaged in scientific expeditions, 559 .

rule as to ships in port, 463,560 .

capture of merchant vessels afloat at declaration of war, 560 . capture of vessels in distress, 560 .

rule of American Naval Code, $559 n$.

whether private property taken at sea should be paid for, 563 . liability of belligerent for freight on, when taken from neutral ship, 565 .

damages for wrongful capture, 577.

see Blockade; Capture; Contraband.

\section{PROPERTY, NEUTRAL}

neutralization of property in Greek Law of Nations, 618.

confiscation of, when situated in enemy country, 551, 553 .

right of, as affected by situs, 554, 555, 701 .

effect of hostile use of neutral property, 554, 702, 758, 790 .

belligerent right of angary, 701 .

defense of sinking of British merchant vessels in Seine, during Franco-Prussian war, 703.

struggle for freedom of neutral commerce, 629 et seq., 707, 721.

rights of parent state as to neutral commerce upon recognition of belligerency of insurgents, 191.

Declaration of Paris as to maritime rights of neutrals, 121, 566, 721.

neutral cargoes in enemy ships under common law rule, 567.

see Contraband; Declaration of Paris; Neutral Trade.

protection afforded house of consul of neutral state, 357.

?ROPERTY, PRIVATE,

jurisdiction of, when beyond territorial limits of state, 207 .

all rights in immovables generally regulated by lex situs, 209.

movables governed by law of domicil. 209 .

jurisdiction over merchant vessels on high seas, 307 .

goods of citizens of one state embarked in ships of another, 315 . transfer of, during military occupation, 599 .

confiscation of, by dominant party during revolution, 198.

of resident enemies, $198,462,551$.

of enemy persons, not subject to confiscation by occupying army, 547, 551, 555 .

how affected by transfer of public property to revolutionary government, 198.

effect of war of 1812 upon, in Great Britain and United States, 368. 
PROPERTY, PRIVATE-Continued.

unaffected by change of sovereignty, 610 .

except where inhabitants choose to emigrate, 610 .

see Booty; Capture; Confiscation; Contraband; Debts; Property, Enemy; Property, neutral.

\section{PROPERTY, PUBLIC}

territorial, of what it consists, 263.

jurisdiction and territory co-extensive, 197.

basis of legal title to, 263 .

rights of, on erection of new state out of old, 204.

fisheries dispute between United States and Great Britain, 204.

effect of revolution upon, 198.

state may dispose of, by gift, sale or exchange, 275 .

alienation of public domain by revolutionary government, 199.

suspension of power to alienate, during military occupation, 591 .

servitudes, $263,299$.

title by prescription, 264 .

its application to possessions of states, 264 .

case of Poland, 265 .

title by conquest, 266 .

case of electorate of Hesse-Cassel, 267.

what passes by conquest, 608 .

questions arising out of American Civil war, 608. see Conquest.

prior discovery as a basis of title, 127 .

early conflicts as to boundaries, 127 .

effect of recent experience in Africa, 268.

title to newly discovered lands under English constitution, 129.

see Discovery.

title by occupation, $128,267$.

elements of effective international occupation, 268.

chartered companies as colonizing agents, 268.

see Occupation.

protectorates, 270 .

spheres of influence, 271.

title by accretion, 273 .

right to new formations when rivers are boundaries, 274 .

ownership of entire river forming boundary between two states, 288, 289.

title by cession, 275 .

see Cession.

territorial waters, 277.

bays, gulfs or recesses in coast line, 278 .

straits only six miles wide regarded wholly within territory of state, 279.

waters connecting parts of high seas, 280 .

emancipation of high seas, 289.

doctrine of Mare Clausum, 290.

claims of Spain and Portugal to newly discovered seas, 291.

Grotius' Mare Liberum, 291.

Selden's Mare Clausum, 292.

gradual extinction of the doctrine, 292.

the marine league, 293.

necessity for widening zone, 294. see Territorial Waters.

non-territorial, classes of, 301 .

of what it consists, 263. 
[THE REFERENCES ARE to the pages.]

PROPERTY, PUBLIC-Continued.

fiction of exterritoriality, 301.

basis of state's jurisdiction over, 301 .

immunities of public vessels, 302 .

exposition of earlier doctrine, 303 .

new doctrine as defined by Marshall, Cushing and Ortolan, 304. papers and archives of consulate generally exempt from seiz-

ure or detention, 357.

see Exterritoriality; Vessels.

PROTECTORATES.

extent of internal control and external obligation, 270.

difference between, and colonies, 270 .

tendency to regard inhabitants of protected districts as subjects of protecting state, 271.

jurisdiction over territorial waters of protected state, 271.

PROTOCOLS,

use of, 393 .

PROVISIONS,

when considered contraband, see Contraband.

PRUSSIA,

growth of, promoted by Peace of Westphalia, 97 .

Peace of Breslau, 1742, 108.

participation in partition of Poland, 110.

Conventions of Pilnitz for intervention in favor of monarchial government in France, 112.

as member of Holy Alliance, 116 et seq.

territorial limits after Congress of Vienna, 1815, 115.

war with Denmark for possession of Schleswig and Holstein, 121.

effect of rise of, on balance of power in Europe, 121.

Peace of Prague, 1866, 122.

confiscation of English interests in Silesian loan, 442, 712.

claim under cession of entire river Netze, 289.

king assumes title of German Emperor, 123.

gains Alsace and Lorraine by Peace of Frankfort, 1871, 124.

attempted enforcement of its conscription laws against natural-

ized citizens of United States of Prussian birth, 225, 226.

see Franco-Prussian War; Germany.

\section{PUBLICISTS,}

familiarity with, important to student of international law, 53 . as creators of international rules, 71.

their testimony as experts, 53.

Sir Robert Phillimore on testimony of, 53.

Lord Coleridge on same, $53 n$.

dicta of, given greater weight than judgments of prize courts on Continent, 53.

tendency in England and America in opposite direction, 54. theories of Hobbes and Bentham, 62, 63 .

review of works of publicists of different countries, 54 et seq.

list of authorities cited in this work, xlvii.

PUFFENDORF, SAMUEL VON

views as to source of international law, 80 .

maintained law of nature and that of nations are identical, 57 .

nature of personal and of real treaties, 366 .

review of his works on international law, 56 .

cited, 252, 282, 284, 288, 386, 395, 591 .

QUADRUPLE ALLIANCE, 413.

QUARANTINE,

rules for, must be respected by public vessels in foreign ports, $305 ; 690$. 
QUARTER, when enemy is entitled to, 487. exceptions to general rule, 488 . instances of refusal of quarter, 488. refused by Confederates to slaves armed by Federal forces in American Civil war, 489.

can seldom be properly refused except by way of retaliation, 488 .

RAILROADS,

subject to seizure in time of war, 540 .

seizure of, and rolling stock, during Franco-Prussian war under right of angary, 703 .

rules of The Hague Conference, concerning, 588 .

RANSOM,

of prize, 573.

right of, as to neutral cargo found on enemy ship, 707.

of prisoners of war, 526 .

in what cases now permitted, 527 .

\section{RASTADT,}

Congress of, 1797-1799, 44.

RATIFICATION OF TREATIES,

necessity of; right of, usually reserved, 388 .

when required by state constitution, express ratification necessary, 386 .

old and new rules as to, when no right of rejection is reserved, 386 .

when concluded by negotiations in name of another, 387 .

when treaty is concluded by sovereign in person, $387 n$.

necessary to make treaty effective, 389,612 .

convention for pacification of the Levant an exception to this rule, 389 .

refusal to ratify; treaty must not be rejected capriciously, 387 .

Bluntschli on effect of refusal to ratify, 388 .

express, how made, 388 .

including new condition or explanatory clause in, $388 n$.

tacit, as to informal agreements between negotiators, 388 .

under constitutions like that of United States, $389 n$.

effect of stipulations to be performed between signature and ratification, 389 .

of acts performed in interim in contravention of treaty, $390 \mathrm{n}$.

\section{REBELLION,}

suppression of, 611 .

when leaders may be punished for high treason, 611 .

abandonment of prosecution of Jefferson Davis, 611. see Revolution.

RECAPTURE, see Postliminy.

RECIPROCITY,

international law based upon, 474,488 .

treaties based upon principle of, 374 .

RECOGNITION OF STATES, see Belligerent Communities; Independence.

RED CROSS,

Geneva Convention, 1864, on neutralizing persons and things employed in service of sick and womded if under sign of, 46 .

conventions of 1864,1868 , furthered development of modern laws of war, 471.

neutralization of all who minister to physical and spiritual needs of combatants, 537.

application of conventions of, to wounded at sea, 502 .

flag of, used by besieged towns to designate public buildings, 485 . 
REFORMATION, THE

effects of, on Holy Roman Empire, 35.

cleared the field for growth of modern international law, 35 .

principle of territorial religion adopted by Lutheran states, 35 .

REGISTRY OF VESSELS,

how nationality of merchant vessels may be established, 308 .

merchant, must show papers when nationality is challenged, 309 .

only prima facie evidence of nationality, 309, 310, 408.

Mr. Dana on, as proof of national character, 409 .

respect due to, as evidence of nationality, 408 .

case of the Virginius, 406.

when non-registered vessels entitled to protection of United States, 309.

REPARATION,

with Romans, demand for, preceded declaration of war, 24 .

liability of states for damages done to resident aliens, 171 .

power to afford, in such cases disclaimed by United States, 170.

to neutral state for violation of its neutrality, 704 .

by neutral state for failure to perform its obligation as such, 685 .

extent of, not to be determined by any fixed rule, 685 .

case of the Wachusett, 686 .

case of the Alabama, $43,680,681$.

see Aliens; Damages; Reprisal.

REPATRIATION,

of wounded prisoners taken at sea, 503 .

REPRISAL,

as a positive remedy for obtaining redress, 431 .

classification of, 435 .

origin and growth of, 436 .

only resorted to in case of palpable denial of justice, 436 .

seizure of French ships by Cromwell, 436.

propriety of, recognized by treaties up to last century, 437.

right of, after unjust prize adjudication, 437 .

division into public and private, 437,438 .

private, known to the Greeks and in Middle Ages, 437.

authorization to commit must proceed from sovereign, 437 .

reprisals committed without letters of marque, 437.

capture without letters of, good against enemy, 437.

duty of neutral states to prevent acceptance of letters of marque and reprisal by their citizens, 682 .

neutrals, accepting letters of, regarded as pirates, 682 .

see Privateers.

survival of public, 441 .

views of Jefferson and Clay as to expediency of, 438 .

not allowable for injuries done to third nation not an ally, 438 .

seizure of port of Corinto by Great Britain, 441.

public debt not the subject of, 442 .

threat of Frederick II. to confiscate English interests in Silesian loan, 442.

when justifiable in war, 489 .

British threat to try for treason naturalized Irishmen captured in American ressels, 489.

in conflicts between countries of different civilizations, 489 .

on prisoners, most cruel and objectionable form of, 489.

treatment of persons seized by way of, 530 .

when resort to, permitted under American Naval Code, 505. see Quarter; Reparation; Retaliation.

REPUTATION,

right of a state to, 199.

REQUISITIONS,

origin of term, 550 . 
REQUISITIONS-Continued.

of food, animals, transportation, labor and money may be made

when a military necessity, 548 .

payment for, 548,549 .

Mexican and Crimean wars exceptions to general rule that they are made without compensation, 548.

views of Heffter, Bluntschli, De Garden and Calvo, 548.

declaration of The Hague Conference, 548.

must be on authority of commander, 549 .

by Germans at Versailles, 549 .

as guarantee for payment of indemnity, 613 .

distinction between, and contributions, 549 .

RESCUE,

of captured vessel by crew or by approach of superior force, 575 . cases of the Experience and Emily St. Pierre, 575.

by neutral, in violation of laws of war, 575 .

RETALIATION,

when justifiable in war, 488 .

destruction of Corinth, 489.

in kind for unlawful acts of war not justifiable, 545.

imprisonment of British in France, by Napoleon, because of British seizure of French ships, 461.

sequestration of debts due British subjects by Denmark, 1807, 463. sacking and burning of emperor's palace in China unjustifiable, 490 .

threat of President Lincoln to execute Confederate prisoners, 489. see Reprisal.

RETORSIONS,

as a positive remedy for obtaining redress, 431 .

different forms of. 434 .

restricted use of term suggested, 435.

REVENUE LAWS,

public and private vessels in foreign port must observe local, 305 .

REVOLUTION,

effect of internal, upon sovereignty of a state, 198.

upon public domain, 199.

upon individual property, 198.

upon relations of diplomatic agents, 325 .

see Belligerent Communities; Rebellion.

RHINE, THE,

free navigation of, secured by Congress of Rastadt, 1804, 283.

league of, 40 .

confederation of, 112 .

RIGHTS AND DUTIES OF STATES,

see Belligerent Communities; Belligerent Rights and Duties; Sovereignty; States.

RIVERS,

territorial rights of states in respect to, 263,277 .

jurisdiction over territorial waters of protected states, 271.

right to new formations in, when boundaries, 274,288 .

exclusive right to use great, when entirely within borders of a state, $277,281 n, 288 n$.

varying views as to right of free navigation of, when separating or passing through different states, $281,282 n$.

how great European rivers were emancipated, 282.

right of navigation of, made subject of convention at beginning of modern international law, 283.

closing of Scheldt against Spanish Netherlands, 283.

subsequent arrangements for free navigation of, $283 n$.

free navigation of Rhine secured by congresses of Rastadt and Vienna, 283. 
RIVERS-Continued.

final act of Vienna Congress respecting the Neckar, Moselle, Main, Scheldt and Meuse, 115, 283.

real intention of treaties of Paris and Vienna as to freedom of river navigation, $283 n$.

Danube brought under general system established by Congress of Vienna by treaty of Paris, 1856, 115, 284.

navigation of Mississippi as regulated by treaties of Paris and

San Lorenzo, 284.

of St. Lawrence as regulated by treaties of 1854, 1871, 285.

opening of South American, 286.

opening of Alaskan and African, 287.

incidental right to use river banks, 287.

title to navigable, forming boundary between states, 274, 289.

construction of cession of entire river Oder, 288.

cession of entire river Netze by Poland to Prussia, 289.

burden of proof on state claiming to own entire stream to show title, 289.

polluting and poisoning of, unlawful, 484.

ROME,

principle of incorporation as developed by, 18 .

illustrates ancient conception of state as city-commonwealth, 19.

franchise of, only exercised within her walls, 19 .

Greek ideas as to proper relations of states to each other im. pressed on Roman law, 8 .

development of Roman law, 19.

Roman jurisprudence the basis of international law, 20.

jus civile, 21 .

jus fetiale only branch of Roman law that corresponds to modern conception of law of nations, 24,363 .

division of international compacts by Roman lawers, 363 .

had no positive international code apart from compact, 364 .

Roman ideas of citizenship, 218.

treatment of foreigners, $22,23,247$.

practice of Romans in beginning war, 455 .

had no clearly defined idea of neutralized person in war, 78, 619. sovereignty of, formally abrogated by Peace of Westphalia, 36 . see Italy; Holy Roman Empire.

\section{ROUMANIA,}

independence of, acknowledged by treaty of Berlin, 126, 180.

European guarantee substituted for that of Russia, 180.

convention with Russia for passage of Russian troops, 671.

ROUMELIA,

constituted a province under authority of Sultan by treaty of Berlin, 1878, 125, 182.

consolidation of, with Bulgaria, 182.

ROSEBERRY, LORD

arraignment of English government for treatment of Napoleon at St. Helena, $527 n$.

RUSSELL, LORD

on Great Britain's recognition of Southern Confederacy, 190.

closing of rebellious ports by New Granada during civil war contrary to international law, 459.

interpretation of Declaration of Paris that blockades to be binding must be effective, 766 . cited, 695 .

RUSSIA,

acquisitions of territory by Peace of Nystadt, 1721, 108.

intervention in affairs of Poland, 413.

her connection with Holy Alliance, 116, 413.

relation to Armed Neutralities, 633, 635, 637, 713, 788. 
RUSSIA-Continued.

convention with Great Britain, 1801, in settlement of demands of Armed Neutralities, 713, 731 .

controversies with United States and Great Britain as to rights in northwestern part of American continent, 44, 144.

motives for intervention of France and Great Britain resulting in Crimean war, $119,430$.

granted freedom of trade to neutrals during Crimean war, 513 .

how affected by treaty of Paris, $1856,108$.

repudiation of vital provisions of treaty of Paris, 1856, 124, 400. sent Circassians into Hungary, 1848, and Bashi Bazooks into Bulgaria in 1877,475 .

regains sovereignty over Black Sea and its coasts, 125.

opposition of Great Britain to treaty of San Stefano, 125.

settlement effected by Congress of Berlin, 125 .

conference of Brussels, 1874, convened at invitation of Czar, 47.

conference of St. Petersburg, 1868, called by Czar, 481.

calling of Peace Conference at The Hague by Emperor of, 50 .

recall of Mr. Catacazy as minister to United States, 353.

does not consider coal as contraband, 735 .

enforces its domestic criminal law against subjects who commit offenses abroad, 243.

permitted French court to try subject charged with criminal offense in Russian embassy, 348.

RUTHERFORTH, THOMAS

his Institutes of Natural Law, 62.

cited, $252,264,324,335,395,519,735$.

RYSWICK,

congress at, 1697, 44.

SA, DON PANTALEON

case of, 337 .

SACKVILLE, BRITISH AMBASSADOR,

dismissal of, by United States, 353 .

cited, 264.

SAFEGUARDS, 509.

ST. LAWRENCE RIVER, navigation of, as regulated by treaties of 1854, 1871, 285 .

ST. PETERSBURG,

declaration of, in relation to weapons and projectiles, $46,479,481$. convention of, 1801, in settlement of demands of Armed Neutralities, 713,731 .

\section{SALVAGE,}

applies to prize at sea only, 575 .

army may receive, if it compels naval surrender, 576 .

in cases of second capture after ransom, 573.

on abandoned vessel, 574 .

right of postliminy upon recapture, in medieval Europe, dependent upon allowance of, by owner, 575 .

rate of, in different countries, and basis for estimating, 576 .

statutes of Great Britain and United States in relation to prize money, 577.

apportionment of, in cases of joint capture, 571 .

SAN MARINO, REPUBLIC OF

status of, in international law, 175.

SATISFACTION FOR WRONGFUL ACTS,

should not be refused by state in the wrong, 445 .

how to be made, 445 .

various instances of, 445 . 
SAVAGES,

employment of, in war, now condemned, except against their kind, $473,474$.

SAVANNAH, CASE OF THE, 498.

SAVIGNY, FREDERICK KARL VON

civil status of persons, 209.

on development of international private law, 208.

cited, $209,221,395$.

SCIENTIFIC EXPEDITIONS,

vessels engaged in, exempt from capture, 559 .

SEA,

history of customary laws, 39.

effect of piracy on high seas in ancient times, 290 .

emancipation of high seas, 289.

doctrine of mare clausum, 290.

considered incapable of appropriation under Roman law, 289, 291.

Selden's Mare Clausum, 62, 292.

basis of former claim of right to exact tolls and dues, 290 .

claims of Spain and Portugal to newly discovered seas, 291.

Russia's claim to North Pacific as a mare clausum, 44.

declaration of Mr. Adams concerning Pacific Ocean, 144.

claims asserted by United States in Bering Sea, 44, 293.

Grotius' Mare Libernum, 291, 293.

treaty for acquisition of proprietary rights over, contrary to common law of nations, 365 .

the marine league, 293.

basis of state jurisdiction over marine league, 293.

decision of Lord Ch. Justice Cockburn in Queen v. Keyn, 88.

Territorial Waters Jurisdiction Act of Great Britain, 89.

limit of territorial waters, 498, 499.

adoption by United States of rule extending jurisdiction of nation over littoral seas, 137.

assertion of jurisdiction by United States over land-locked waters without regard to three mile zone, 138.

claims of United States as to seaward boundary of three-mile zone on eastern coast of North America, 138.

effect of formation of islands off coast upon territorial jurisdiction, 273 case of the Anna, 273.

right of innocent passage through territorial waters connecting parts of high seas, 280,300 .

necessity for widening zone, $138,294$.

whether state may, of its own motion, extend territorial jurisdiction beyond three-mile zone, 138.

recommendations of Institut de Droit International, 72. validity of state legislation extending limit for health and revenue purposes, 294.

right to fish within marine league, See Fisheries.

jurisdiction over territorial waters of protected state, 271.

state jurisdiction over public and merchant vessels on high seas,

See Vessels.

right of visit on high seas, See Visitation and Search.

hostilities at sea, See Belligerent Rights and Duties.

see Blockade; Declaration of Paris; Maritime Law; Neutrals;

Straits.

SEARCH,

see Visitation and Search.

SELDEN, JOHN

in accord with Grotius as to basic principle of international law, 62 .

his Mare Clausum, 62, 292.

cited, 290. 
[THE REFERENCES ARE TO THE PAGES.]

\section{SELF-PRESERVATION,}

defensive forms of, 405 .

when state may send troops across border to check invasion, 405 . invasion of Mexico by United States troops, 1836, 405.

invasion of United States by British subjects, 1838, 405.

when state may defend itself in its own or in non-territorial waters, 406.

case of the Virginius, 406.

its liability to capture, though register was lawful, 409.

position of Great Britain on legality of, 410.

Woolsey on right of, as authority for visit and capture of vessel on high seas, 409 .

exercise of right of, subject to limitations imposed by international law, 410.

Great Britain's seizure of Danish fleet as permissible measure of, 411.

attack by the United States upon Amelia Island, 412.

right of, as a ground for intervention, 422 .

SEQUESTRATION,

as a positive remedy for obtaining redress, 431 .

in what respect differs from confiscation, 552 .

income of real property liable to, by occupying army, 552 .

purchase of conquered territory during military occupation, 585 . transfer of Stetin to Prussia, under title of, 585.

SERVIA,

its emancipation from Turkey, 180.

sovereignty of, placed under guarantee of all the powers, 180 .

independence of acknowledged by treaty of Berlin, 126, 180.

SERVITUDES,

signification of term, 263, 299, 369 .

classification of, $263,299$.

examples of customary, 299.

illustrations of negative, 300 .

how negative, may be terminated, 301 .

suspended during war, but revived with return of peace, 369 .

how converted into a right, 369 .

as embodied in contracts of guarantee, 423 .

SEWARD, SEC. OF STATE,

reasons for extradition of Argüelles to Spain, 256.

policy of United States as to agents of revolutionary parties, 325 . refusal of Christian nations to allow government of Morocco any

control over persons or property of Christians, 359 .

protest against intervention of France in affairs of Mexico, 416. agreement for withdrawal of French troops from Mexico, 416. claim concerning surrender of Captain Semmes, 501.

cited, 262, 360, 777 .

SHENANDOAH, CASE OF THE, 659.

SIAM,

qualified extension to, of international law, 91.

SICILY,

blockaded by Sardinia and revolutionists of Naples, 1860, 444.

SIEGE,

means allowed for reducing garrison, 484.

extent to which bombardment is lawful, 484 .

bombardment of undefended towns, villages, habitations or build-

ings prohibited by The Hague Conference, 484 .

notice to non-combatants, 484 .

storming and sacking of towns 485 .

unjustifiable resistance, 486 . 
SILESIAN LOAN, threat of Frederick II to confiscate English interests in, 442.

SITKA, CASE OF THE, 304.

SLAVES,

prisoners of war regarded as, by Greeks, 526 .

effect of military occupation upon status of, 551 .

freeing of, as war right under acts of United States Congress, 551. emancipation proclamation by President Lincoln, 551.

freedom of, as matter of war policy now permissible, 476.

giving asylum to fugitive, on board British ships of war, 306 .

SLAVE-TRADE,

no international rule justifying interference with it, 236 .

compact for establishment of, void, 365 .

prohibited by Denmark after 1802, 236 .

and by United States after 1807, 236.

declared abolished by congress of Vienna, 1815, 45.

treaties providing for its abolition, 236 .

unsuccessful efforts of United States to have it declared piracy by law of nations, 236.

statutes of United States and Great Britain declaring it to be piracy, 236, 236.

attempts to have it pronounced illegal by law of nations through judicial interpretation unsuccessful, 237.

cases of the Amedie, Fortuna, Diana, Louis and Antelope, 237.

treaties conceding mutual right of search for enforcement of laws against, 239.

suppression of, under Final Act of Brussels Conference, 1890, 46, $90,240$.

SOULE, MR.

sojourn in France while en route to post as minister to Spain refused by French government, 331 .

SOUND DUES,

imposed by Denmark upon vessels passing through two Belts, 280 . basis upon which such exactions were formally justified, 290 .

SOUTH AFRICAN REPUBLICS,

see Boer War; Transvaal Republic.

SOUTH AMERICA,

belligerency of colonies recognized by United States, 190.

constitutions of republics of, framed after pattern of United

States Constitution of $1789,168$.

opening of rivers of, 286.

SOVEREIGNS,

no right to enter foreign territory without permission, 228.

their immunities and disabilities while in foreign states, 228.

relation to visiting state while in its military service or while traveling incognito, 229.

position of, when sovereign in one state and subject in another, 229.

jurisdiction of property of, in foreign states, 230 .

effect of entering courts of foreign state voluntarily, 230 .

may be treated as prisoners, 527 .

SOVEREIGNTY,

domination of entire world by single power contrary to common

law of nations, 365 .

territorial, the basis of all international relations, 157.

upon such basis rests modern conception of state as a nation, 157 . internal and external sovereignty contrasted, 184.

choice of constitution by state an inherent right of, 259.

self-preservation the foremost attribute of, 200 .

relinquishment of part, by treaty, 427 . 
[THE REFERENCES ARE TO THE PAGES.]

SOVEREIGNTY-Continued.

partial surrender of, by treaties of guarantee, 423.

defects in, of United States, 170.

presumption in favor of states originally independent, 178, 397, 401.

as to states gradually acquiring limited independence, 179.

in relation to property of state, 157 et seq, 263 .

legal fiction of exterritoriality, 207.

how state may limit or qualify its, over its jurisdictional property, $263,299$.

of state in relation to persons, 206 et seq.

in case of military occupation, 584 .

effect of internal revolution upon, 198.

change of, does not affect private property, 610 .

see Conquest; Military Occupation and Administration; States.

SPAIN,

maintained disciplined standing army in fifteenth century, 472.

relation to Peace of Westphalia, 96.

treaties aggrandizing France and Sweden at expense of, 100 .

acknowledged independence of Portugal, in treaty of Lisbon, 102. restoration of Franche Comté by treaty of Aix-la-Chapelle, 102.

changes in territory under Peace of Nimeguen, 102.

Spanish succession and partition treaties of 1698, 1700, 104 .

Peace of Utrecht, 1713-14, 106.

cession of Florida to Great Britain by Peace of Paris, 110.

Florida restored to, under treaty of Versailles, 1783, 111.

intervention of France to overthrow constitution of the cortes, and restore absolutism in, 117, 140.

intervention in affairs of Portugal in behalf absolutist pretender

Dom Miguel, 117.

conflicts with Portugal as to boundaries in New World, 127.

arrest of its ambassador, Prince Cellamare, in France, 336.

recall of Yrojo as minister to United States, 352.

dismissal of Mr. Bulwer as British ambassador, 354.

controversy with United States as to western boundary of Louisiana, 132 .

insurrections in South American colonies, 194.

revolutionary governments recognized by United States and Great Britain, 194.

controversy with United States as to capture of Virginius, 406, 408. attack by United States upon Amelia Island, 412.

conflict with Great Britain, 1804, because of alleged breach of neutrality, 628 .

practice in respect to neutral trade on high seas, $711 n$.

claim of special jurisdiction over waters surrounding Cuba, 292. transfer of Cuba by, opposed by United States, 146, 149.

insurrections in Cuba, 420.

devastation of Cuba under General Weyler, 483 .

destruction of battleship Maine in Havana harbor, 420 .

intervention of United States in behalf of Cuba, 420.

SPANISH-AMERICAN WAR,

proclamation of President McKinley warning resident Spaniards, 461.

parties to, observed principles of Declaration of Paris as to neutral trade, 723 .

time allowed foreigners to retire at siege of Santiago, 484 .

rule under which Spanish and American fleets were forced to leave neutral ports, 691 .

see Cuba.

SPHERES OF INFLUENCE,

prevention of conflicts as to boundaries through establishment of, 271. 
[THE RETERENCES ARE TO THE PAGES.]

SPHERES OF INFLUENCE-Continued.

rights incident to, 271.

foundations of new system outlined at West African Conference at Berlin, 1885, 272 .

treaties in respect to, 272.

new rule may develop into positive canon of international law, 273.

SPIES,

who may be considered as, 492 .

soldiers reconnoitering in balloons are not, 493 .

when bearer of flag of truce is liable to be treated as spy, 508 .

rules affecting, 492 .

punishment of, 535 .

offense extinguished by successful return to camp, 536 .

SPONSIONS,

nature of, $363 n, 518$.

ratification necessary, 518 .

duty of state repudiating act of agent, 519 .

\section{STATES,}

normal international person a state, 7 .

historical study of, necessary to clear understanding of international law, 5 .

status and not contract the basis of primitive society, 1 .

law of growth and decay in the physical world applicable to societies, 3.

sociological study of, given impulse by French Revolution, 3 . history of, must be rewritten in light of social science founded by Comte, 4.

existing aggregate of states viewed as result of their historical antecedents, 7 et seq.

Ancient; Greek, Roman and medieval state-systems, 7 et seq. unit of organization in all Aryan nations, 8.

city-commonwealth the ancient conception of the state, 19.

Greek state-system as outlined by Aristotle, 9.

elements of federation contained in Greek political system, 16 . Rome and the principle of incorporation, 18.

see Greece; Holy Roman Empire; Rome.

modern state a Teutonic creation, 26 .

resultant of union of Teutonic tribes was a nation, 26 .

based upon principles of territorial sovereignty, 157 .

territorial sovereignty the basis of international relations, 157. means by which transition to territorial organization of, was accomplished, $27,75,157$.

origin of state system of modern Europe, 28.

not until Reformation did modern state-system assume its present form, 5 .

definitions of Aristotle and Cicero inadequate to describe modern, 157.

equality of, and idea that territory and jurisdiction are coextensive, the outgrowth of principle of territorial sovereignty, 157 . independence of each, the primary contention of Grotius, 76 . equality of, cornerstone of existing international system, 322 . equality of, under Peace of Westphalia qualified by subsequent growth of primacy of greater states, 98 . reconstruction of European, by Congress of Vienna, 114, 115.

divisions of sovereign, 158.

why several types of state organization must be examined, 158 . those united in personal union, 159.

those united in real union, 159.

examples of Gesammtstaats. 160, 161.

incorporate union embodied in British empire, 161.

government of colonial system of Great Britain, 162. 
STATES-Continued.

federalism prior to second constitution of United States, 163. classification of federal unions, 165 . see Confederations.

part-sovereign states, 172.

staatenbund, an example of, 173.

when may become fully sovereign, 173.

neutralized states only part sovereign, 174 .

protected, that retain an international existence as partsovereign, $175,270$.

are not persons in international law, 174 .

illustrations of protected, $175,176$.

extent of internal control and external obligation of protectorates, 176,270 .

presumption in favor of, originally independent, 178 .

does not obtain where limited independence has been gradually acquired, 179.

emancipation of Roumania and Servia, 179.

relations of Bulgaria to Ottoman Empire, 181.

suzerainty of Porte over Egypt, 182.

internal and external sovereignty contrasted, 184.

three factors of independent states, 376 .

attributes of sovereign, as moral persons, 197, 210, 365 .

right to manage internal affairs without intervention from other states, 158, 198.

choice of constitution an inherent right of sovereignty, 259.

each supreme within its territorial limits, 158.

each bound by acts of authorized government agents, 158 .

in international relations, must ascertain authority of agents with whom they contract, 158 .

how a state may assent to an international rule, 88 .

non-Christian, not bound to utmost rigor of international law, 91 . extension to, of international law, qualified onty, 91.

effect of temporary suspension of state life, 197, 198.

effect of recognition of belligerency, 185 .

see Belligerent Communities.

jurisdiction in relation to persons, 206 et seq.

who are entitled to state's protection, 211.

classes of persons composing every state, 212 . see Aliens; Citizens.

sovereignty of, in relation to property, 206, 263.

basis of title to territorial property of, 263 .

of what territorial property of, consists, 263 .

of what non-territorial property of, consists, 263 .

title by conquest, 266 .

see Conquest; Property, Public.

territorial waters, 277.

see Bays; Gulfs; Rivers; Sea; Straits; Territorial Waters.

jurisdiction over public and private vessels in foreign ports and on high seas, 301 et seq.

see Jurisdiction; Sovereignty; Vessels.

general rules as to boundaries, 298.

see Boundaries.

self-preservation the foremost attribute of sovereignty, 200 .

how states may be extinguished through absorption, division or merger, 200.

how they may limit or qualify sovereignty over territorial property, 263, 299.

chartered companies as colonizing agents of, 268 .

status of African colonies, 268.

spheres of influence, 271 .

duty of, to prevent invasion of neighboring state, 405 . 
[THE REFERENCES ARE TO TIIE PAGES.]

STATES-Continued.

when state may defend itself in its own or in non-territorial waters, 406 .

forcible means of redress short of actual war, 431.

methods of adjusting international controversies, 383 .

withdrawal of diplomatic agents, 432 .

embargo and non-intercourse. 432.

retorsions, 434.

duty of state in wrong to give satisfaction, 445 .

see Blockade; Military and Naval Demonstrations; Reprisals.

STEPHEN, SIR J. F.

test of political offense in matter of extradition, 259.

exception to rule as to asylum to fugitive slave on ship of war, 306 .

privileges of ships of war in neutral waters as to imprisoned persons, $697 n$.

cited, 245, 253, 254, 259, 301, 305, 360 .

STOCKTON, CAPT. CHAS. H.

naval war code prescribed for use of United States navy, 495.

cited, 782.

STORY, JOSEPH

his treatise, The Conflict of Laws, 68.

contributions to international law as prize court judge, 68 .

expatriation not an individual right, 225 .

temporary allegiance to conquerer during military occupation, 586 . confiscation of private property war right without legislation, 462. confiscation of private debts valid, 552 .

dissenting opinion in case of the Nereide, $785 \mathrm{n}$.

on right of neutrals to send armed vessels to belligerent ports for sale, 662 .

duty of belligerent vessels in neutral waters, 700 .

right of visitation and search strictly a war right, 311, 780 .

visit and capture of merchant vessels under convoy, 789 .

obligation of an affirming gun before visit not universal, $782 n$.

cited, 154, 215, 221.

STOWELL, LORD

on administration of prize law, 42 .

administration of international law and of King's orders in coun-

cil by same tribunal, 43 .

relation of Ottoman Empire to international law, 91.

proof of domicil, 523 .

when domicil ceases, 524 .

how slave trade might become piracy, 237.

opinion in the case of the Anna, 274.

arrest of British subject on board British ship of war in Spanish port, 304 .

declaration of war an empty form, 456.

nature of prize courts, 580 .

what constitutes capture at sea, 570 .

fishing boats exempt from seizure only by comity, 557 .

exercise of sovereignty during military occupation, 586 .

judgments under rule of war of 1756,632 .

opinion that tar, pitch and hemp are contraband, 731 .

conditions under which provisions may become contraband, 737 .

condemnation of provisions legal, whether intended for military consumption or not, 737 .

when return voyage will not be regarded as separate and innocent expedition, 743 .

proceeds of contraband not subject to seizure on return voyage, 743.

penalty for carrying contraband, 744 .

on pre-emption of goods of neutrals not contraband, 747 . 
STOWELL, LORD-Continued.

opinion in case of the Rapid, 749.

when carriage of despatches by neutrals for enemy lawful, $\mathbf{7 5 0}$. carrying of prohibited despatches, 755 .

neutrals may carry military or naval persons as ordinary passengers at their own expense, $755 n$.

neutral vessel found in transport service of enemy, liable to condemnation, 756.

proof necessary in question of blockade, 761 .

representations in applications for licenses to trade, 510.

that license to import Spanish wool from Holland protected licensee from effects of blockade, 776 .

right of visitation and search purely belligerent right, 238 .

right of visit of merchant ships of neutrals on high seas, 781 .

cited, 479 .

STRAITS,

territorial rights in respect to, 279 .

what are included in territorial property of a state, 263.

subject to free passage when connecting parts of high seas, $2 S 0$.

Denmark's sound dues, 280.

treaties for free passage through two Belts, 280 .

settlement of boundary line in Strait of Fuca, 279.

see Bosphorus; Dardanelles.

SUBJECTS,

see Citizens.

SUMTER, CASE OF THE, 695.

SUPPLIES,

right of belligerent to purchase, in neutral ports, $690,691,694$, 695.

revictualing of besieged place during armistice, 515 .

SURRENDER,

what constitutes, at sea, 569 .

see Capitulations.

SUUM CUIQUE,

principle of, called common law of the sea, 564 .

principle still prevails in Great Britain and Unitel States, 564.

difference between English and American practice, 564 .

SWABIAN LEAGUE, 40.

SWEDEN,

territory recovered by Peace of Nimeguen, 1678, and treaty of Lund, 103.

changes in territory under Peace of Nystadt, 1721, 108.

conflicts with Great Britain, in regard to right of convoy, 635 .

protest against succor furnished by Denmark to Russia, 626 .

territorial limits after Congress of Vienna, 1815, 115.

union of, with Norway, constitutes single sovereign state as to international relations, 173.

arrest of its ambassador, Count Gyllenborg, in Great Britain, 336. asylum given by Mr. Guidekens, British ambassador, to merchant charged with crime, 343.

\section{SWITZERLAND,}

independence of, recognized by Peace of Westphalia, 97.

nature of union of cantons prior to treaty of Westphalia, 165.

right of cantons to make separate treaties, 166.

practice of furnishing troops to belligerents, 668 .

Swiss confederation reorganized by Congress of Vienna, 1815, 115.

by new constitution of 1847 became composite state, 168 .

as neutralized state, is only part sovereign, 174 .

refused Alsatians, enlisted in French army, permission to cross

frontier, 670 . 
[THE REFERENCES ARE TO THE PAGES.]

SWITZERLAND-Continued.

internment of Bourbaki's army during Franco-Prussian war, 672. some cantons enforce domestic criminal law against citizens committing offenses abroad, 243.

\section{SYRIA,}

cession of, by convention of Kutayeh, 1833, to Mehemit Ali, 182.

TACITUS, CAIUS CORNELIUS

observations upon the social and political organization of Teutonic race, 26 .

cited, 506, 526 .

TALLEYRAND,

principle on which international law is founded, 447.

on formation of permanent balance of power after Peace of Paris, $1814,114$.

war does not extend to private persons or property, 450 .

TANEY, CHIEF JUSTICE

exclusive possession necessary to title by conquest, 589 . cited, 130.

TAXES,

collection and use of, by enemy, in time of war, 541 .

must be first applied to administration of government, 541 .

fiction of exterritoriality not applicable to immovables, $345 n$.

liability of diplomatic agents for, see Diplomatic Agents.

TELEGRAPHS,

subject to seizure as booty, 540, 541 .

TEMPEST, CASE OF THE, 313.

TERCEIRA AFFAIR, 678.

TERRITORY,

of what territorial property of state consists, 263 .

territorial waters, 277 et seq.

non-territorial property, 301 et seq.

jurisdiction and, coextensive, 197, 206.

exceptions to rule that territory and jurisdiction are coextensive, 234.

alienation of public domain by revolutionary government, 199 .

see Jurisdiction; Property; Sovereignty; States.

TERRITORIAL WATERS,

what included in, 263, 277.

bays, gulfs or recesses in coast line, whether included in, 278 .

England's claims in respect to inclosed parts of sea, 278 .

position of Germany and France, 278.

former disposition of United States, 278.

Chesapeake and Delaware bays still considered parts of, by

United States, 279.

tendency to curtailment of unreasonable claims, 279 .

straits; rule in regard to, 279 .

when connecting parts of high seas, 280 .

Denmark's Sound dues, 280.

settlement of northwest boundary line of United States

through Strait of Fuca, 279.

rivers; exclusive right to use great rivers, 277.

claims of United States in respect to use of Mississippi, 277.

progress of free navigation of rivers separating or passing

through different states, 281.

see Danube; Mississippi; Rhine; Rivers.

Sea; emancipation of high seas, 289.

gradual extinction of doctrine of mare clausum, 292.

see Maritime Law; Sea.

marine league, a creation of international law, 293.

decision in Queen v. Keyn, 88. 
[THE REFERENCES ARE TO THE PAGES.]

TERRITORIAL WATERS-Continued.

basis of state jurisdiction, 293.

positions of Grotius, Vattel and Bynkershoek, as to, 293.

early adoption of rule by United States, 137, $138 n$.

seaward boundary of, on eastern coast of North America, 138.

necessity for widening zone, 294.

whether state may of its own motion extend limits of its jurisdiction, 138, 294, 295.

state legislation extending limit for health and revenue purposes, 294.

validity of such legislation, 295 .

right to fish within marine league, see Fisheries.

rules for determination of state boundaries, 298 .

right to arrest persons for crimes committed within, 138. see Criminal Offenses; Jurisdiction.

jurisdiction as to public and private vessels in, 281, 302, 308, 311 . does not extend to ships using ocean as highway, and not bound for any port, 138 .

see Belligerent Rights and Duties; Neutrals; Vessels.

TEUTONIC KNIGHTS, organization of, the outgrowth of siege of Acre, 537.

TEUTONIC RACE,

had no common name in its own tongue by which to describe race as a whole, 26.

complete political isolation of each of its tribes, 26 . transition from tribal to territorial organization, 27.

TEXAS,

belligerency of, recognized by United States, 190 .

independence of, recognized, 195.

admitted as a state to American Union, 201.

THEATRE OF WAR, territory to which it is limited, 472.

TORPEDO,

its introduction and final recognition in warfare, 481.

TRADE,

duty of states to keep open channels of intercourse with every state having de facto existence, 193.

effects of war upon, 459.

opposing views of Heffter and Sir Wm. Scott, 460 .

war suspends, between citizens of belligerent states, 464 .

but does not affect intercourse with neutrals, 464 .

Berlin banker punished for dealing in French securities during Franco-Prussian war, 464. see Neutral Trade.

TRANSPORTS, unarmed, are not war vessels, 570 .

do not become joint captors by presence at time of capture, 571 .

TRANSVAAL REPUBLIC,

independence of, recognized, $174 n$.

sovereignty of, impaired by convention, 1884, with Great Britain, 174.

see Boer War.

TREASON,

domiciled alien may be guilty of, 251 .

resident aliens volunteering against their old sovereign, 494 .

British threat to try naturalized Irishmen captured in American vessels for, 489 .

leaders in rebellion may be punished for high, 536, 611 .

case of General Lee, 536.

triable as civil offense, 535 . 


\section{TREATIES,}

ancient international law conventional, 362 .

terms used by Greek diplomacy to express different kinds, 93.

definition of, in their narrowest aspect, 93.

as sources of international law; special stipulations in, may become

general rule, 93 .

those declaring new general rules or modifying old ones, 94 .

Examples; Declaration of Paris, 1856; treaty of Washington, 1871; Final act of Brussels Conference, 1890;

Peace Conference at The Hague, 1899, 95.

those forming basis for concerted action for maintenance of balance of power, 95 .

Peace of Westphalia basis of public law of Europe down to French revolution, 96 et seq.

position of, in modern international law, 364 .

classifications of, by Vattel, Martens and Calvo, 366 .

all real, divisible into two classes, 367 .

nature of executed and executory conventions, 367 .

executed conventions; as defined by Master of the Rolls, 368 .

as defined by Supreme Court of United States, 368 .

executory conventions; of alliance, offensive and defensive, 369.

conflicting views of Great Britain and Holland as to certain, of alliance, 370 .

difference between treaty of general alliance and one of limited succor, 371 . see Alliance.

of guarantee, mutual and unilateral, 371 et seq. operation and construction of, 372 .

collective guarantee to secure a common interest, 373 . agreements in which guarantees are embodied, 374 . see Guarantee.

commercial conventions, 374 . construction of most favored nation clause, 375 .

for establishing special tribunals, 375 .

of arbitration, 376 .

history of conventions for settlement of international controversies, 377 et seq.

see Arbitration; Courts.

power of state to contract, 385 .

in whom power is usually vested, 385 .

state must inform itself as to authority of agents, 158.

signing or receiving declarations by agents in negotiation of, $389 n$.

consent; only limited freedom of consent required, 385 .

when may be avoided for want of freedom of consent, 385 .

ratification, necessary when required by state constitution, 386 .

when no right of rejection is reserved; old and new rules, 386 . unnecessary when concluded by sovereign in person, 387 .

express and tacit ratifications, 388 .

see Ratification of Treaties.

when they become effective, 389,612 .

binding upon whole nation when legally executed, 390, 611 . when auxiliary legislation is required, $390,391$.

duty of legislature in such case, 390 .

refusal of French Chamber of Deputies to make appropriations to carry out, 390 .

rejection by English Parliament of legislation necessary to give effect to, 391 .

claim of United States House of Representatives as to consent to purchase of Alaska. 392.

as to northwest boundary. submitted by United States to states of Maine and Massachusetts, $134 n$. 
[The References are to the Pages.]

TREATIES-Continued.

form; may be verbal or written, 393.

language employed in, 393.

use of the alternat in execution of, 394.

confirmation of, by solemn oaths obsolete, 374 .

use of protocols, 393.

distinction between, and conventions, 394 .

construction and interpretation of, 394 et seq.

rules of United States Supreme Court, $276 n$.

when most recent of two treaties takes precedence, 399.

prior treaty prevails over subsequent one in conflict, 399.

exception to this rule, 402 .

see Construction and Interpretation of Treaties.

validity; must accord with common law of nations, 364, 365 .

principles by which validity is tested, 365 .

agreements and, not subject to international law, 365 .

when voidable; concluded under false impressions produced by

fraud, 386.

may become voidable through subsequent events, 400 .

Russia's contention as to treaty of Paris, 1856, 124, 400.

Declaration of Conference of London, 1871, that consent is necessary to terminate or modify, $124 n$.

effect of changes in internal life of state, 198, 401.

Wheaton's position that those relating to national objects continue during life of state, $198 n$.

Swiss exception to this rule, $198 n$.

dangerous contentions of Heffter and Fiore, 402.

when breach by one party will render treaty voidable at instance of other party, 402 .

other circumstances by which a treaty may be avoided, 403 .

Lawrence's position that conditions justifying avoidance of, is a question of morality, $403 n$.

how extended or renewed, 404.

difference between extension and renewal, 404 .

effect of war upon, general rules as to, $369 n, 460,461$.

position of Great Britain, $369 n$.

on treaties of 1783 and 1794 between Great Britain and United States, 296, 367, 368, 604 .

of peace, as a means of terminating war, 602 .

effect of peace on preexisting, 603 .

revival of permanent servitudes, 369 .

customary stipulations in treaties of cession, 277.

enlarging privileges and duties of consuls, $359 n, 376$.

principal treaties; Verdun, $843,28$.

Passau, 1552; Augsburg, 1555, 96, 413.

Westphalia, $1648,36,44,96,99,365,423$.

Oliva, 1660; Copenhagen, 1660, 101.

Breda, 1667; Triple Alliance, 1668, 101.

Lisbon, 1668, 102.

Lund, 1679; Fontainbleau, 1679; Augsburg, 1686; Grand Alliance, 1689, 103.

Grand Alliance, 1701, 106.

Barrier treaties, 1709, 1713, 1715, 107.

Utrecht, 1713-1715, 106.

Vienna, 1738, 108.

Naples, 1759; Family Compact, 1761; for secret cession of Louisiana, $1762,109$.

Partition treaties, 1772, 1793, 1795, 105, 110.

of alliance, 1778 between United States and France, 640 .

between Great Britain and Russia, 1781, 727.

Paris, 1783, between Great Britain and United States, 111.

Versailles, 1783, 111, 285. 
[THE REFERENCES ARE TO THE PAGES.]

TREATIES-Continued.

between United States and Prussia, 1785, 93, 745.

between Great Britain and United States, 1794, 718, ${ }^{7} 32 n$.

St. Idlefonso, 1796, 113.

Luneville, 1801; Presburg, 1805; Vienna, 1809, 113.

Paris, 1814, 283, 301.

Second, of Paris, 1815, 115n.

between Great Britain and United States, 1818, 297.

Quadruple, of London, 1840, 183.

between United States and Great Britain, 1846, in respect to settlement of northwest boundary, 279.

between United States and New Granada, 1846, 727.

Guadalupe Hidalgo, 1848, $277 n$.

reciprocity, between Great Britain and United States, 1854, 297. Paris, 1856, 46, 119, 124.

between powers and Denmark as to throne of Greece, 1863, 118. between United States and Russia, 1867, 44.

between United States and Great Britain, 1871, in respect to northwest boundary, 279.

Washington, $1871,43,95,286,287,298,654$.

Berne, 1874, 374.

San Stefano, $1878,125$.

fishing treaty between Great Britain and United States, 1885, 298.

see Congress and Conference; Peace.

TRENT, CASE OF THE, 752.

TRUCE,

scope of term, 513.

authority to conclude, 514,518 . sponsions, 518 .

period of operation, 514.

what acts permissible during, 514 .

to be construed liberally, 515 .

private trade pending, between opponents, 515 .

revictualing besieged place, 515 .

Bismark's refusal to allow admission of supplies to Paris, 516 .

violation of, may be prevented by force without renewal of hostilities, 514 .

responsibility for breach of, 514 .

effect of international breach, 514 .

liability for injury inflicted by breach of, 515 .

flags of truce, See Flags.

TURKEY,

first diplomatic relations with, 91 .

disregard of general usage as to treatment of diplomatic agents, 316.

status of Christian principalities of, in international law, 179.

emancipation of Roumania and Servia, 179.

emancipation of Montenegro, 181.

Bulgaria still dependent, 181 .

intervention of Great Britain, Russia and France to secure independence of Greece, 118.

Crimean war, 119, 120, 430 .

treaty of San Stefano, 1878, 125.

admitted to family of nations by Peace of Paris, 1856, 120.

intervention of Great Britain and France in affairs of, to preserve balance of power, 414 .

pacific blockade of Greek provinces of, by Great Britain, France and Russia, 1827, 444.

suzerainty of Porte over Egypt, 182.

capture of Constantinople threatened by Mehemit Ali, 182.

cession of Syria to Mehemit Ali by convention of Kutayeh, 182. 
[THE REFERENCES ARE TO THE PAGES.]

TURKEY-Continued.

Sultan's nominal control over foreign affairs of Egypt, 183.

pacific blockade of Dulcigno by the powers, 1880,445 .

see Ottoman Empire.

TUSCARORA, CASE OF THE, 694.

TWISS, SIR TRAVERS

his "Law of Nations Considered as Independent Political Communities," 63 .

his "Rights and Duties of Nations in Time of War," 63.

definition of international law, 84.

personal treaties an exception to rule as to continuance of real ones, $198 n$.

position of Great Britain as to effect of war upon treaties, 369 .

on union between Norway and Sweden, $161 n$.

distinguishes between right of empire or jurisdiction, and right of dominion or property, $206 n$.

ministers exempt from general taxes, but not from local dues, 345 .

frequently cited, for instance, $130,173,198,276,294,330,359,566$.

UNITED PROVINCES,

sovereignty recognized by Peace of Münster, 1648, 97.

edicts 1652,1657 and 1689 placing naval stores, grain and provisions in list of contraband, 731 .

see Netherlands.

UNITED STATES,

belligerency of colonies recognized by Great Britain, 186. recognition by France and Holland, 190.

independence of, recognized by treaty of Paris, 1783, 111.

opinion of Supreme Court as to when, became sovereign state, 185.

constitution; first, produced confederation upon old plan, 164 . path breaking idea embodied in second constitution, 164. nature of government under second constitution, 165. constitution of 1789 a unique federal creation, 166 .

relation to international law; extension of international law to, 91 . acceptance of law of nations, 136.

Ordinance of 1781 concerning marine captures, 136.

treaties made supreme law of land by second constitution, 136, 390.

equivalent to acts of congress after ratification, 136 .

common law of nations binding on federal courts, 136.

decisions of federal government in respect to foreign relations binding upon all citizens, 137.

adoption of rule as to jurisdiction over three-mile zone, 137.

assertion of jurisdiction over land-locked waters without regard to three-mile zone, 138.

foreign affairs; entire control of, in federal government, 326 .

duty of the congress when legislation is necessary to carry treaty into effect, 390 .

claim of House of Representatives as to treaty for purchase of Alaska, 392.

jurisdiction; former disposition to claim dominion over wide ex-

tent of adjacent ocean, 278 .

claims of, in Bering Sea, 44, 293.

see Bering Sea.

former doctrine as to local sovereignty over public vessels, 303 .

immunity of private vessels in territorial waters, 311 .

general rule that crimes are territorial, 244.

legislative departures from this rule, 245 .

legislation with reference to slave trade, 236 .

emancipation proclamation of President Lincoln, 551.

citizenship of; interstate citizenship, 215. 
[THE REFERENCES ARE TO THE PAGES.]

UNITED STATES-Continued.

effect of fourteenth amendment upon citizenship, 216, 218.

citizens of, entitled to protection of federal government when on high seas or within foreign jurisdiction, 216 .

controversy with Prussia as to conscription laws, 226.

resistance to Mexico's claim of right to punish for libel committed in United States, 241.

aliens; right of sovereign state to determine whether it will receive or expel visitors, early asserted by, 231.

British threat to try for treason naturalized Irishmen captured in American vessels, 489.

treaty with France as to property rights of aliens, $248 n$.

position in respect to liability for injuries to aliens, 261.

defect in constitution of, in respect to responsibility of executive in such cases, 169 .

federal government without power to control states in certain cases, 170.

such offenses cognizable only by authorities of state in which injury is inflicted, 171.

extradition; controversy with Great Britain as to, of Winslow, 254. position in respect to trial of offenders for crimes other than those for which they are extradited, 254.

recognizes no obligation to surrender alien offenders on extradition in absence of treaty, 255.

case of Argüelles, 255.

diplomatic intercourse; conditional offer to accept minister, 328 . Mr. Keiley's case, 328 .

citizens as diplomatic agents of foreign states, $328 n$.

official intercourse with agents of revolutionary parties, 325 .

rule governing diplomatic representative of foreign state not yet recognized by, 332 .

practice in respect to recognition of insurgent states, 195. recognition of South American republics, 193.

controversy with Great Britain because of latter's recog. nition of Confederate States, 190.

authority of agents to sign or receive declarations or other notes in connection with treaty, $389 n$.

Germany's recognition of inviolability of despatches of minister of, to France during siege of Paris, 333 .

legislation respecting exemption of diplomatic agents from civil process, 338 .

recall of Dutch minister demanded by, because of refusal to testify in case of homicide, 338 .

rule for representatives of United States when asked to testify in criminal case, $338 n$.

denial of right to seize minister's goods on tacit hypothecation, 342 .

case of $\mathrm{Mr}$. Wheaton, 341 .

position as to right of asylum in certain countries, 343 .

rule in respect to taxation of property of ministers, 345 .

arrest of servant of American minister at London, 346.

change of President causes no interruption in functions of diplomatic agents of, 349 .

sanctions views of Halleck, Calvo and Dana as to obligation of state to recall unacceptable minister, $351 n$.

request of, for recall of $\mathrm{Mr}$. Genet, 351 .

demand for recall of Spanish minister Yrujo, 352.

for recall of British minister Jackson, 352 .

minister engaging in enlistment of troops for his govern. ment, subject to summary dismissal, 352 .

request for recall of Russian minister Catacazy, 353.

claims right to give minister his passports in case of delay in obtaining recall, 353 . 
[THE REFERENCES ARE TO THE PAGES.]

UNITED STATES-Continued.

dismissal of British minister, Lord Sackville, 353.

trial of British commissioner for offense against local laws, 355.

ministers and consuls given jurisdiction to punish offenses of its citizens in certain countries, 246 .

international incidents; claim against Denmark for delivery of prizes to Great Britain during revolution, 186.

conflict with France as to alliance of $1778,464$.

resisted Great Britain's claim to right of visit, 238 .

effect of war of 1812 upon trcaty of peace, 1783, with Great Britain, 368, 604 .

conflict with Spain as to western boundary of Lonisiana, 132. conflict with Great Britain as to northeastern boundary, 133.

controversy with Great Britain as to northwest boundary, 134 . conflict with Russia as to same, 144 .

controversy with France as to payment of spoliation claims, $390,436$.

invasion of, by British subjects, 1838, 405 .

American invasion of Mexico, 1836, 405.

attack upon Amelia Island, 412.

controversy with Spain in respect to Virginius affair, 406, 408. assumed to be sole judge of validity of ship's papers, 309 .

demand upon Great Britain to prevent attack on frontier by Sitting Bull, 261.

controversies with Great Britain as to fisheries, 296 et seq. neutrality; early action of, in vindication of neutral territorial rights, 638 .

Washington's neutrality proclamation of 1793,639 .

illegal acts of French minister, Genet, 581, 640.

case of Gideon Henfield, 643.

foreign Enlistment Acts, 1794, 1819, 644.

tribute of Mr. Canning to neutrality laws of, 645

influence upon development of law of neutrality, 651 .

proclamation of President Grant in regard to restrictions on belligerent vessels in ports of, 695 .

refusal to interfere with embarkation of unarmed expedition of Frenchmen during Franco-Prussian war, 679.

demand against Portugal in case of the General Armstrong, 700 .

controversy with Great Britain respecting case of the Alabama, see Alabama, Case of the; Arbitration.

neutral trade; theory and practice of, in respect to rule of Consolato del Mare, 713.

does not accept rule of enemy ships, enemy goods, 566 .

confiscations of enemy goods in neutral vessels enforced by prize courts during war of $1812,716,720$.

treaty with France embodying principle, free ships-free goods, enemy ships-enemy goods, $714 n$.

similar treaties with Holland, 1782, and Sweden, 1783, 714n. conditional recognition of armed neutrality of 1780,715 . position as to right of visit of vessels under convoy, 789 . controversy with Denmark as to convoy, 790 .

adoption of rule of Consolato by judiciary, 715 .

criticism of departure from declaration of Mr. Jefferson, $715 n$. doctrine embodied in treaty with France, 1786, 719.

treaty with Great Britain, 1794, 718 .

French criticism of this treaty, and reply of Mr. Pickering, $718,719$.

proposal that principle, free ships, free goods, be established throughout American continents, 720 . 
[THE REFERENCES ARE TO THE PAGES.]

UNITED STATES-Continued.

proposal to European nations for adoption of principle, 720 .

refusal to give formal acceptance to Declaration of Paris, 567. reasons for such refusal, 723 .

contraband; repudiation of list of contraband, excluding naval stores, in convention of St. Petersburg, 1801, 732.

reply to Great Britain's demand that sale of arms and accoutrements to agents of France be prevented, 742 .

articles designated as, in treaty with Great Britain, 1794, 732n. attitude respecting horses, 733 .

coal listed as conditional, in American Naval War Code, 734. protest against British Orders in Council as to provisions, $7 \lesssim 6$. decision of Supreme Court as to provisions in case of the Commercen, 737 .

held silver plate and bullion, cotton and clothing to be contraband during Civil war, 738.

blockade; theory of law of, 764 .

of entire coast of Confederate States in Civil war, 190, 458, 764 . contention as to continuance of blockade established by proclamation, 776 .

dangerous extension of doctrine of continuous voyage as applied to breach of blockade during Civil war, 778 .

just criticism of such extension, 779 .

rules of war; reproached by Calvo and Hautefeuille for beginning wars before formal declaration, 454.

war begun against Mexico without declaration, 454.

Civil war begun by President's proclamation of blockade, 454 . regulations in respect to citizens and private property, 450.

instructions for guidance of armies in the field, 152 .

Manual for United States Armies in the Field, 471.

employment of Indians as allies in Indian wars, 473. of slaves against their masters in Civil war, 475 .

requires military service of aliens who have assumed rights of citizens, 467 .

confiscation as war right affirmed by congress and Supreme Court, 551.

military occupation under constitution and laws of, 600, 793 . contributions levied by, during Mexican war, 551.

treatment of leaders in war of rebellion, 611.

opposed convention of The Hague in regard to diffusion of gases by projectiles, 479 .

also declaration in regard to use of explosive bullets, 479 .

conquest; position of, as to title by, 267 .

effect of military occupation under laws of United States, 793.

territory acquired by conquest or ceded to, cannot remain foreign for any purpose. 793 .

status of inhabitants of such territory, 793.

powers of congress over territory not admitted as state under decisions in lnsular Tariff cases, 793, 795.

primacy of, in New World, 417.

as defined by President Cleveland, 417.

as defined by Prof. Lawrence, 417.

intervention of, in affairs of Mexico, 427.

intervention in Mexico to terminate intervention of France, 416.

intervention in affairs of Venezuela, 417.

intervention in affairs of Cuba, 419.

see Cuba; Spanish-American War.

UNITED STATES SUPREME COURT,

fishing boats exempt flom capture. 559 .

refusal to recognize principle, free ships, free goods, as rule of

international law, 567 .

definition of contraband, 726 . 
[THE REFERENCES ARE TO THE PAGES.]

UNITED STATES SUPREME COURT-Continued.

justified seizure of silver plate and bullion as contraband, 738 . circumstances under which provisions may be contraband, 737 . dangerous extension of doctrine of continuous voyage as applied to blockade, 778 . just criticism of such extension, 779 .

UNNEUTRAL SERVICE, see Neutrals.

USURPATION, conquest without cession, 606 .

UTRECHT, TREATY OF its leading stipulations, 106.

articles of, as to Dunkirk abrogated by treaty of Versailles, 111. guaranteed protestant succession to throne of England, 372, 423. and that crowns of France and Spain should never be united on same head, 423.

principle of free ships, free goods, established between contracting powers, $711,712 n, 713$.

VALIN, RENE J.

cited, 436, 570, 573, 629, 630, 708, 711, 732 .

VATTEL, EMERIC de

disciple of Leibnitz, and interpreter of Wolf, 64 .

law of nations originally law of nature applied to nations, 65 .

divided law of nations into voluntary, conventional and customary, 65.

views as to sources of international law, 80 .

on acquisition of sovereignty over islands or other lands in desert state, $131 n$.

title by prescription, part of law of nations, 264 .

view as to extent of state jurisdiction over adjacent sea, 294 .

on classes of diplomatic agents, 317 .

right of envoy to passage through friendly third state, 331.

right of minister to freedom of religious worship, $344 n$.

classification of treaties, 366 .

difference between extension and renewal of treaties, 404 .

of alliance, not affected by change in form of government, 465 . confines right of intervention to narrower limits than other authorities, $426 n$.

permissible for succor of people oppressed by sovereign, 429 . obligation of states to fortify, 200 .

definition of war, 448 .

advocated alliances to preserve balance of power, 452 .

nature of civil war, 453 .

implied right of resident enemies to leave country with their property on breaking out of hostilities, 461 .

advocated humane rules of war, 470 .

deceit not allowable in negotiations between hostile forces, 490 . purchase of conquered territory before sovereignty has been renounced by treaty of peace, 585 .

contributions and requisitions promised previous to peace are debts, 605 .

his use of terms Neutre and Neutralite, 619.

views on subject of neutrality, 624 .

influence upon growth of law of, 65,71 .

levying of troops in neutral territory, 668 .

right of passage of troops through neutral territory, 669 .

belligerent seizing enemy goods in neutral ship bound to pay freight, 707 .

articles designated as contraband, include horses and provisions, $733 n, 735$. 
[THE REFERENCES ARE TO THE PAGES.]

VATTEL, EMERIC de-Continued.

views on early law of blockade, 760 .

frequently cited, for example, 198, 247, 288, 324, 373, 577, 673, 710 .

VENEZUELA,

interventiou of United States in affairs of, 416.

arbitration of boundary dispute between, and Great Britain, 44.

VERSAILLES, treaty of, $1783,111,285,713$.

VESSELS,

public; term "public vessel" defined, 301.

unarmed transports are not war vessels, 570 .

evidence of nationality, 302 .

state jurisdiction, on high seas and in foreign ports, 301.

immunities of, 302 .

rights in territorial waters, 281.

right to enter ports of friendly powers, 303 .

slow growth of immunities, 303 .

new doctrine as defined by Marshall, Cushing and Ortolan, 304.

cases of the Exchange and Sitka, 304.

arbitral tribunal at Geneva on privilege of exterritoriality accorded to, 305 .

duties and exemptions of public vessels defined, 305 .

must observe health regulations, local revenue laws and administrative rules of port, 305,690 .

exempt from all forms of process in private suits, 305 . case of United States frigate Constitution, $305 n$.

primary object of immunities, 305 .

must not harbor criminals and fugitive slaves, 306 . immunities attach to, as complete organisms only, 307 .

remedy of state if aggrieved by action of, 305 . when diplomatic appeal must be made, 307 . when expulsion of vessel allowable, 307 .

ceremonial regulated by each state within territorial jurisdiction, 323 .

courtesy on high seas, 323 .

uniform standard for salutes through international agreement, 324 .

of belligerents; origin of permanent fleets, 496 .

sale of, by neutral to belligerent, 677 .

of enemy in port, at commencement of war, not liable to confiscation, 463.

right to give battle confined to ships with commissions of war, 496 .

rules affecting those without commissions, 497. have no right of search as to neutrals, 497 .

rules governing privateers, see Privateers.

duties and liabilities of captor of prize, see Capture; Prize.

rescue of sick, wounded or shipwrecked belligerents by neutral, see Capture; Wounded.

hospital ships, see Hospital Ships.

cartel ships, see Cartels.

mail packets exempt from capture by convention between France and Great Britain, 560.

see Belligerent Rights and Duties; Capture; Visitation and Search.

same in neutral waters; right of asylum, 689.

must respect regulations for protection of neutrality, 690 .

purchase of supplies and coal, 690 .

substance of Azuni's rules, 690 .

Negrin's rules, 692 . 
[THE References are to the Pages.]

VESSELS-Continued.

exclusion of, from neutral ports, 692 .

twenty-four hours' rule, 692 .

views of Bermard and Hall, 693.

attempt of France, to redefine rule in 1861, 693 .

cases of the Nashville, and Tuscarora, 694 .

Great Britain's neutrality regulations during American Civil war, 694 .

restrictions imposed by Great Britain and France adopted by United States, 695 .

fitting out of belligerent vessels in neutral ports, sec Alabama, Case of the; Neutrals.

bona fide sale of vessel to neutral valid in England and United States, but not on Continent, 555, 568, 695 . cases of the Sumter and Georgia, 695, 696 .

belligerent right of angary, 701 . sinking of British merchant, in Seine, during FrancoPrussian war, 703.

right to hold captured persons in neutral territory, 696 . release of Barbary captives wrecked near Calais, 697. application of principle of exterritoriality, 697 .

bringing of prizes into neutral port, 697 . see Prize.

attack by belligerent in neutral waters, 498,699 . effect of resistance to unlawful attack, 700 . see Belligerent Rights and Duties; Neutrals.

private; how nationality may be established, 308, 568 .

when must show papers, 309.

register only prima facie evidence of nationality, 408.

state having right to inquire into, not concluded by flags or

papers, 309 .

position of United States in case of the Virginius, 309, 408. buying and selling of, in time of war, 696 .

jurisdiction of state on high seas complete.

corresponding responsibility for hostile acts of, 308 .

fiction of exterritoriality scarcely exists as to, 308 .

immunity of, in territorial waters, 311.

in foreign port are subject to local law, if not exempted by treaty, 312 .

attempt to regulate subject by conventions, 312,314 . cases of the Sally and Newton, 312 .

case of Jally, 313 .

case of WVildenhus, 313.

no right of asylum in merchant vessels, 314 . cases of Sotelo and Gomez, 314.

right of ingless and egress to and from blockaded port, 773 . see Blockade.

right of visitation in time of peace, $310,409,780$.

exceptions in favor of right, 310 .

right of visit in time of war, 780 et seq.

see Visitation and Search.

capture of; subject to seizure in time of war as booty, 540 .

fishing boats exempt from capture, 558 .

exceptions to this rule. 559 .

engaged in scientific expeditions exempt. 559.

rule of American naval code, $559 n, 561$.

rule as to vessels in distress, 560 .

afloat at declaration of war generally exempt, 560 .

register of neutral power will not exempt on high seas

when necessary to self defense, 409.

neutral engaged as transport in service of belligerent, 755 . cases of the Carolina and Orozembo, 756 . 
[The References are to the Pages.]

VESSELS-Continued.

struggle for freedom of neutral commerce, 629 .

see Armed Neutralities; Capture; Contraband; Declaration of Paris; Free Ships, Free Goods; Neutrals.

VIENNA, CONGRESS OF

see Congress and Conference.

VIRGINIUS, CASE OF THE,

statement of case, 407 .

position of United States respecting right to determine validity of register, 408.

contrary position taken by Mr. Dana, 409.

capture not regarded as improper by Great Britain, 411.

Mr. George T. Curtis on legality of seizure, 409.

right of American and British citizens on board to lawful trial, 409 .

VISITATION AND SEARCH,

purposes for which right may exist in time of peace, 310,780 .

in case of piracy, 234, 310 .

when probable ground to believe that flag is assumed for

piratical purposes, $302 n$.

when necessary to self defense, 406, 409.

distinction between; British attempt to distinguish between right of visit and right of search, 238, $780 \mathrm{n}$.

Mr. Webster on absence of such distinction, 238.

why negotiations for settlement of dispute as to, between

United States and Great Britain, were unsuccessful, 292.

slave trade; right of, held not to exist against vessels engaged in, 238.

assertion of right by Great Britain in such cases, 238.

reluctance of France and United States to concede right for such purpose, 239.

treaties mutually conceding right of, 239.

right ended when Great Britain abandoned it in $1858,310 \mathrm{n}$.

as war right; primarily belongs to belligerents only, 238, 311, 780 . nature and scope of right, 780 .

only private vessels of neutrals subject to, 302,781 .

limited to vessels provided with commissions of war, 497, 781 .

rules as to formalities of visit, 781 .

rules of American Naval War Code as to formalities, 782. validity of capture not affected by failure to observe, 781 . examination of ship's papers, 783 .

when right of search arises, 784 .

conflicting British and American rules as to effect of resistance, 784 .

privateers may be visited but not searched, 498 .

whether nostal vessels and mail-bags should be exempt, 750 . practice of United States, 751.

treaty between United States and Great Britain, 1848, 751.

whether vessels under convoy may be visited, 788 .

Continental practice, 788 .

declaration of second Armed Neutrality League of 1800, 635 .

English and American practice, 789.

rule of American Naval War Code, 790.

Great Britain's maintenance of right of, in convention of St.

Petersburg, 1801, 637, 721.

controversy between United States and Denmark as to, 790 .

WALKER, THOMAS A.

his "Science of International Law," 64 .

on effect of treaties for aid in time of war upon neutrality, 626 .

criticism of arbitral definition of "due diligence" in case of the

Alabama, 661 . 
[THE REFERENCES ARE TO THE PAGES.]

WALKER, THOMAS A.-Continued.

on neutral action to prevent fitting out of hostile expedition, 681 . cited, 186, 197, 225, 247, 256, 258, 278, 290, 337, 620,634, 711, 754.

WAR,

primary object in, 447.

only to be resorted to when all other means of redress exhausted, 431.

logical division of laws of, 447.

state of, defined by various authorities, 448 .

meaning of, in its broader sense, 449.

modern definition of, 449 .

how far a relation of states, and not of individuals, 449 .

can be made only by supreme power of state, 449 .

but state need not have fixed territory, 449.

just causes of, 451.

objects of, political and military, 452 .

classification; how wars are classified, 452.

when it may be said to be defensive, 453,464 .

conflict of views between Great Britain and Holland, 1756, $369,464$.

conflict between France and United States as to alliance of 1778,464 .

defensive in principle, though offensive in operation, $370 n$. he who makes it unavoidable is cause of, 453 . civil war, a public war, 459 .

declaration; whether formal declaration of, is necessary, 454. see Declaration of War.

effects of; upon treaties, $368,369,460$.

position of Great Britain that it puts an end to all, $369 n$. see Treaties.

on allies, see Alliance.

on private citizens, 459 .

effect of domicil in enemy's country, 461, 523.

Grotius and Kent on right to imprison resident enemies, 461.

Vattel's view the prevailing one, 461 .

right to detain enemy soldiers maintained by Calvo, 462 . liability of domiciled aliens to military service, 467. rule correctly stated by Bluntschli, 468 .

when neutrals become de facto citizens of belligerent state, 468.

see Aliens.

upon private property, 462.

see Confiscation; Property, Private.

effect on trade, 463 .

opposing views of Heffter and Sir Wm. Scott, 460.

see Blockade; Contraband; Licenses to Trade; Neutral Trade.

upon occupied territory and its inhabitants, see Military Occu-

pation and Administration.

rights of neutrals; notice to, of commencement of war, 687 .

belligerent right of angary, see Angary.

hostilities not to be carried on in neutral territory, 687.

nor direct preparation made for hostile acts, 688 .

passing of belligerent troops through, not permitted, 669 .

internment of belligerent soldiers in, 671 .

captures in neutral territory, 683.

when territory may possess both neutral and belligerent char-

acter, 594.

see Neutrality; Neutrals.

usages called laws of, 447 .

method of in earlier ages, 470. 
WAR-Continued.

extreme cruelty of Greek laws of, 11.

death or slavery expected by the conquered, 11, 362 .

protected persons in wars of Greek states, 14.

burial of those who died in battle, 14.

conduct considered contrary to laws of, by Sallust, 470 .

against infidels, as such, condemned by Ayala, 127.

general principle underlying modern methods of, 470.

methods advocated by Bynkershoek and Wolf, 470.

humane rules advocated by Grotius and Vattel, 470 .

extent to which force is permissible in, 470 .

evolution of military codes, 471.

convention of The Hague Conference with respect to laws and customs of, on land, 51.

as to instructions or manuals to armed forces of signatory powers, 471.

see Brussels, Conference of; Military Law; Peace Conference of The Hague.

maritime rules of Congress of Paris, 1856, 46.

convention of The Hague Conference adapting principles of Geneva convention, 1864, to maritime warfare, 51.

theatre of, 472 .

area of maritime warfare, 499.

combatants, lawful and unlawful, 471.

respective modes of dealing with them, 472.

see Forces of a State.

weapons; what are lawful, see Weapons.

exemptions; none for crowned heads and officers in battle, 482 . pickets and sentinels not exempt from fire, 482 .

devastation as a means of offense, 482 .

as a means of defense, 483 .

sieges and bombardments, 484 .

see Bombardment; Siege.

quarter; the giving of, See Quarter.

retaliation and reprisals, See Reprisal; Retaliation.

deceit and treachery; how far deceit may be used, 490 .

gaining admission within enemy's lines by false pretenses or disguises forbidden, 491.

assassination or injury by treachery never permissible, 491. employment of balloons, 479, 493, 494 .

aiding and instigating rebellion in enemy state, 492.

guides; rules affecting, 492 .

spies; rules affecting, see Spies.

deserters; rules concerning, see Deserters.

wounded; care of, see Wounded.

who are prisoners of, 527.

see Prisoners.

giving of hostages, 534 .

military offenses; punishment of military offenses, 535.

enemy property; laws of war as to, on land, 539 et seq.

laws of war as to, at sea, 558 et seq.

see Belligerent Rights and Duties; Property, Enemy.

termination of; how it may be terminated, 602 .

how non-hostile relations are established, 506 .

flags of truce, 507 .

safe-conducts and passports, 509.

suspension of arms, armistices and truces, 513 .

general principles affecting treaties of peace, 602 .

indemnity and guarantees, 612 .

fruits of hostilities conducted after termination of war, 614 .

postliminy as applied to states or provinces, 615 .

see Capitulations; Cartels; Postliminy; Surrender. 
[THE REFERENCES ARE to the PAgES.]

WARD, ROBERT PLUMER

his "Enquiry into Foundation and History of Law of Nations in Europe," 70 .

no mention of principle, free ships-free goods, in thirty-four treaties made between 1713 and 1780,711 . cited, 317, 336, 337, 33\$, 347, 374, 707, 709, 718.

WARLIKE EXPEDITIONS,

use of neutral territory as base of operations for, 678 .

what constitutes such expedition, 679 .

illegal acts of French minister Genet, 640, 700 .

organized outside of neutral territory from elements issuing separately from within it, 680 .

case of the Alabama, 654, 681 .

unarmed expeditions, 679 .

invasion of state to prevent acts which may lead to war, how regarded, 406.

WASHINGTON, PRESIDENT

message to congress recommending legislation to prevent violations of neutrality, 639,644 .

his neutrality proclamation of April 22, 1793, 639 .

influence of same upon international law, 465 .

action in case of Mr. Genet, 640 .

assent of House of Representatives not necessary to validity of treaties, 390 .

origin of term, requisition, attributed to him, as general, 550 . cited, 533.

WASHINGTON, TREATY OF, 286, 287, 654 .

WEAPONS,

object of use of, 47,479 .

what are lawful, 479.

use of balloons for launching of projectiles, 479 .

what are unlawful, 480 .

declaration of conference of St. Petersburg, 1868, 46, 481.

convention of The Hague conference, 479.

reasons of British and American delegates for not signing, 479.

introduction of firearms, and opposition to their use, 480 .

appropriation of, from enemy soldiers, 541 .

cannot be furnished by neutral to belligerent states, 675 .

sale of, to belligerents by neutral individuals, 677 .

WEBSTER, DANIEL

obligation of United States to respect law of nations, 137.

binding force of international law upon civilized governments, 491.

public act under authority of government not a private trespass, 172.

declaration concerning opinion of court in McLeod case, 172n.

no distinction between right of visit and right of search, 238 .

merchant vessel on high seas under protection of her nation, 307 .

immunity of private vessels in territorial waters, 311 .

on loans by neutral individuals to belligerents, 675 .

cited, $134,137,242,251,252,312,406,529,780$.

WEBSTER, NOAH

on giving federal government power to execute laws directly on individuals, 164.

WEBSTER, PELATIAH

on giving federal government power to execute laws directly on individuals, 164 .

WELLINGTON, DUKE OF

what martial law is, 596 .

treatment of guerrillas, 476 . 
[THa REFERENCES ARE to THE PAGES.]

WELLINGTON, DUKE OF-Continued.

employed the Ordenanza of Portugal in 1810, 477.

constantly employed spies in Spain, 493.

defenders of stormed fortress no right to quarter, 487.

seizure of works of art contrary to civilized warfare, 543 .

cited, 597.

WESTBURY, LORD

civil status of persons, 209.

on freedom of neutral commerce, 740 .

WESTLAKE, JOHN

his "Treatise on Private International Law," 63.

cited, 209, 221, 250, 471.

WESTPHALIA, PEACE OF, 36, 44, 96, 365, 423.

WHARTON, DR. FRANCIS

his "Conflict of Laws" and "Digest of International Law of United States," 69.

when visitation and search is excusable, $302 n$

frequently cited, for example, 190, 235, 305, 392, 439, 476, 572, 763.

\section{WHEATON, HENRY}

his "Elements of International Law" and "History of Law of

Nations in Europe and America," 68, 71.

confounds jus gentium with jus fetiale, 25.

whole international code founded on reciprocity, 488.

hotel of minister subject to taxation, 345 .

on union between Norway and Sweden, $161 n$.

recognition of independence of United States by France in 1778 an

unjustifiable aggression, $193 n$.

views on default of French government under treaty of 1831, 391.

on continuance of treaty obligations, $198 n$.

on naturalization without right of expatriation, 225 .

war may be defensive in principle, though offensive in operation, $370 n$.

his application of term, reprisal, confusing, 431 .

upon neutral aid under pre-existing treaties, 666 .

questions soundness of decision in case of the Nancy, $743 n$.

presumption arising from merchant vessel being found in enemy's convoy, is rebuttable, 791 .

frequently cited, for example, $160,192,226,249,338,384,670,744$

WICQUEFORT, CASE OF, 337.

WILDMAN, RICHARD

his "Institutes of International Law," 63.

limits of military occupation, 589.

Denmark's condemnation of American vessels under English con. voy legal, $791 n$.

cited, $234,395,515$.

WILLS,

as to movables, governed by law of testator's domicil, 209 .

law governing validity of envoy's testament, 354 .

of prisoners of war, 529,530 .

authentication of, by diplomatic agents, 347 .

WILSON, WOODROW

on province of international law, 83 .

cited, 160, 161, 165, 168.

WISBUY, LAWS OF, 40.

WOLF, CHRISTIAN F. von

his "Institutiones Juris Naturae et Gentium" and "Jus Gentium Methodo Scientifica Pertractatum," 58.

advocates methods of earlier ages in war, 470 . 
[THE REFERENCES ARE TO THE PAGES.]

WOLF, CHRISTIAN F. von-Continued.

views upon subject of neutrality, 623 .

cited, 198, 206, 264, 288, 480 .

WOMEN AND CHILDREN,

American Naval Code on disposition of, on captured merchant vessel, 502 .

WOOLSEY, DR. THEODORE D.

his "Introduction to Study of International Law," 69.

Denmark's condemnation of American vessels under English convoy legal, $791 n$.

view of pacific blockades, 445 .

advocates employment of spies in war, 493.

opinion of French order of 1861 as to twenty-four hours' rule, $693 n$.

right of self-defense may authorize visit on high seas, 409.

cited, $191,199,240,242,243,256,311,340,341,492,494,683,764$.

WOUNDED,

care of, 536 .

neutralization of persons and things contributing to physical and spiritual needs of, 536 .

rule for paroling them proven unwise, 537 .

surrender of, to belligerent when rescued by neutral, $5 J 5$.

Geneva Convention inadequate to new conditions, 537.

application of Red Cross Conventions to, at sea, 502 .

ships of belligerents not in use must give relief and assistance to, 504 .

rules as to sick and wounded captured at sea, 538 .

YRUJO, SPANISH MINISTER

demand of United States for his recall, 352. 




JAN 231975 
